\title{
Why Jamaica wants to protect Champagne: intellectual property protection in EU bilateral trade agreements
}

Citation for published version (APA):

Moerland, A. (2013). Why Jamaica wants to protect Champagne: intellectual property protection in EU bilateral trade agreements. [Doctoral Thesis, Maastricht University]. Wolf Legal Publishers. https://doi.org/10.26481/dis.20131004am

Document status and date:

Published: 01/01/2013

DOI:

10.26481/dis.20131004am

Document Version:

Publisher's PDF, also known as Version of record

Please check the document version of this publication:

- A submitted manuscript is the version of the article upon submission and before peer-review. There can be important differences between the submitted version and the official published version of record.

People interested in the research are advised to contact the author for the final version of the publication, or visit the DOI to the publisher's website.

- The final author version and the galley proof are versions of the publication after peer review.

- The final published version features the final layout of the paper including the volume, issue and page numbers.

Link to publication

\footnotetext{
General rights rights.

- You may freely distribute the URL identifying the publication in the public portal. please follow below link for the End User Agreement:

www.umlib.nl/taverne-license

Take down policy

If you believe that this document breaches copyright please contact us at:

repository@maastrichtuniversity.nl

providing details and we will investigate your claim.
}

Copyright and moral rights for the publications made accessible in the public portal are retained by the authors and/or other copyright owners and it is a condition of accessing publications that users recognise and abide by the legal requirements associated with these

- Users may download and print one copy of any publication from the public portal for the purpose of private study or research.

- You may not further distribute the material or use it for any profit-making activity or commercial gain

If the publication is distributed under the terms of Article $25 \mathrm{fa}$ of the Dutch Copyright Act, indicated by the "Taverne" license above, 


\section{Why Jamaica Wants to Protect Champagne:}

International Property Protection in EU Bilateral Trade Agreements 


\title{
Why Jamaica Wants to Protect Champagne: Intellectual Property Protection in EU Bilateral Trade Agreements
} Anke Moerland

ISBN: 978-94-6240-040-5

Layout by Marina Jodogne

Cover Design by Wolf Legal Publishers

\author{
Wolf Legal Publishers (WLP) \\ Postbus 313 \\ 5060 AH Oisterwijk \\ info@wolfpublishers.nl \\ www.wolfpublishers.com
}

\begin{abstract}
Alle rechten voorbehouden. Behoudens de door de Auteurswet 1912 gestelde uitzonderingen, mag niets uit deze uitgave worden verveelvoudigd (waaronder begrepen het opslaan in een geautomatiseerd gegevensbestand) of openbaar gemaakt, op welke wijze dan ook, zonder voorafgaande schriftelijke toestemming van de uitgever. De bij toepassing van artikel 16B en 17 Auteurswet 1912 wettelijk verschuldigde vergoedingen wegens fotokopiëren, dienen te worden voldaan aan de Stichting Reprorecht. Voor het overnemen van een gedeelte van deze uitgave in bloemlezingen, readers en andere compilatiewerken op grond van artikel 16 Auteurswet 1912 dient men zich tevoren tot de uitgever te wenden. Hoewel aan de totstandkoming van deze uitgave de uiterste zorg is besteed, aanvaarden de auteur(s), redacteur(en) en uitgever geen aansprakelijkheid voor eventuele fouten of onvolkomenheden.
\end{abstract}

(C) 2013 A. Moerland 


\title{
Why Jamaica Wants to Protect Champagne: \\ Intellectual Property Protection in EU Bilateral Trade Agreements
}

\author{
DISSERTATION \\ to obtain the degree of Doctor \\ at the Maastricht University, \\ on the authority of the Rector Magnificus, \\ Prof. Dr. L.L.G. Soete \\ in accordance with the decision of the Board of Deans, \\ to be defended in public \\ on Friday 4 October 2013, at 10.00 hours
}

by

Anke Moerland 
Supervisors

Prof. dr. Anselm Kamperman-Sanders

Prof. dr. Peter Van den Bossche

Prof. dr. Dirk De Bièvre

\author{
Assessment Committee \\ Prof. Dr. Michael G. Faure \\ Prof. Dr. Thomas Christiansen \\ Dr. Christopher Heath
}




\section{Acknowledgements}

Writing a $\mathrm{PhD}$ is a long, sometimes tiresome and frustrating, often lonely and definitely a struggling exercise. However, it is above all an exciting opportunity to discover, in depth, a topic that you are enthusiastic about and which has become a part of your life. I am now, more than ever before, grateful for this opportunity. This is the reason why I would like express my gratitude to some people that have made this time so special for me.

The journey to writing a $\mathrm{PhD}$ started in Macao, China of all places. In 2006, I participated in the summer school on 'Intellectual Property Law', a programme that was offered together with the summer school on 'International Trade Law', which at that point was the reason why I signed up. But it turned out to be different than I thought: Dr. Christopher Heath and Prof. Anselm Kamperman-Sanders taught the subject of intellectual property law in such an engaging way that I became fascinated by many aspects of that area of law. For this, I would like to thank both of them.

On Anselm's initiative, and with the support of Prof. Peter Van den Bossche, I was offered the opportunity to further discover this new and exciting field of intellectual property law by writing a $\mathrm{PhD}$ proposal, which was accepted by the WeCie. Certainly in view of the recent changes at the Law Faculty with regard to the scope and extent of $\mathrm{PhD}$ proposals and the available budget, I am especially grateful for having had the privileged position of undertaking research that involved several trips to far-away destinations, the possibility to follow additional courses, to attend several conferences and even to study Dutch Law. I therefore would like to express a big thank you to the Faculty of Law.

My supervisors Anselm and Peter deserve a special thank you-note. The trust they have put in me and my work has been contagious: it has encouraged me to explore my topic in any way that I thought worthwhile and to do what I truly wanted. Even though not always hands-on at times, your mentorship allowed me to develop important skills and gave me the self-confidence to pull off this research independently. Peter, you have been a teacher and mentor to me even before I started my $\mathrm{PhD}$ thesis. While being your research assistant and at the same time following your classes, you infected me with your dedication and passion for your topic, the world of international trade law. You have taught me how to do proper research, how to build a convincing argument and how to write with the necessary sense for precision and perfectionism. I truly appreciate that you have treated me from the very beginning as a scholar, on an equal footing. I owe you a lot for this support.

This research project would not have been possible without the support of Prof. Dirk De Bièvre, who has become my co-promotor in November 2012 only. Nevertheless, you have been a third promotor to me from the moment that we met in early 2009. Our in-depth discussions in Antwerp provided me with a lot of food for thought and, more importantly, the trust that I am on the right track. Your year-long support, during which I could turn to you whenever I needed it, is exceptional and I wish to express my utmost gratitude for that. I would also like to thank the members of my assessment Committee, Prof. Michael Faure, Prof. Thomas Christiansen and Dr. Christopher 
Heath, as well as my fellow scholar Pedro Roffe, for taking the time to read my manuscript and for giving me comments to help improve my book.

For the case-study, I have heavily relied on data that I was able to collect through the collaboration of many state and non-state actors in Jamaica, Barbados, Geneva and Brussels. I very much appreciate that all interviewees took the time to answer my questions during the interview, and sometimes also in follow-up emails. I hope that you feel that your input in this project has been worthwhile, also for you. In particular, I would like to thank Beverley Pereira and Nathalie Courtesy, who have helped me contacting relevant people in Jamaica and who have made my stay in Jamaica very pleasant.

Maastricht has become my home. Not only do I love the city - I have met wonderful people here who have become dear friends and a second family. Aimee, Livina, Mariska, Gaston, Elce and Martijn, you have made integration into Dutch society a lot easier and a lot of fun. With you Carol, Eliza, Jennifer, Laura and Martin, Marco, Kees, Mariolina, Michal, Bram, Mieke and Dyebo, life at the faculty and outside of it has been filled with much laughter, joy, gossips, great dinners and above all friendship. Also you, Sylvia and Nina, deserve a special thank you for your continuous friendship beyond borders and the hours we have spent talking and discussing PhD-related, and more importantly, PhD-unrelated things.

All the help and support I received during my $\mathrm{PhD}$ would have been useless without the necessary backpack. My confidence, values and the ability to persevere have been nourished by my parents. I am privileged to have parents that strove for the best education of their children, without making compromises according to their own wishes. Your support in the choices I have made enabled me to pursue my career in this way. I am who I am because of you. And also because of my sister Ina, who has taught me so many other important things during the last thirty years. Even though some $700 \mathrm{~km}$ apart from each other, we are as close as we could be when living in the same city. Ina, I am so glad that also your dream has come true.

Finally, I would like to thank Roland whom I met at the very beginning of my $\mathrm{PhD}$ and who turned out to be the love of my life. You have taught me to accept that some things take more time than others and that in the end they will turn out to be just fine. I truly appreciate your enthusiasm, which affects many areas of our life. And of course, it is needless to say that I admire you for being a wonderful father to our daughter Isabel, who makes our lives just perfect.

The manuscript of this book was completed in October 2012. Consequently, later developments have not been taken into account in this analysis.

Maastricht, November 2012 


\section{Table of Contents}

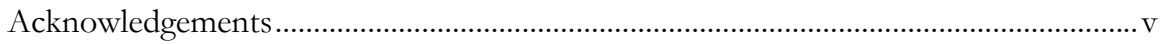

List of Abbreviations ..................................................................................................

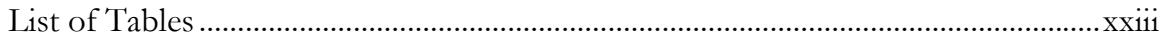

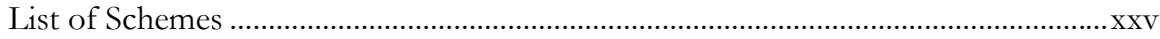

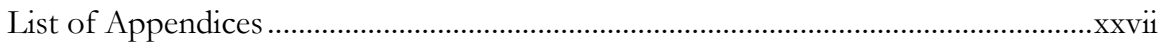

\section{PART A: INTRODUCTION}

Introduction 1

\section{PART B: GLOBAL TRENDS IN PROTECTING INTELLECTUAL PROPERTY: MULTILATERAL, BILATERAL AND UNILATERAL APPROACHES}

Chapter 1

The International System of Protecting Intellectual Property pre-TRIPS.

1.1. Introduction

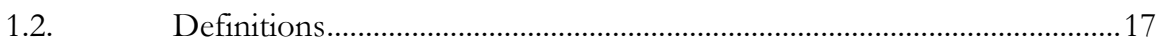

1.3. The Territorial Protection of Intellectual Property.....................................21

1.4. From Bilateral to Multilateral Protection of Intellectual Property............22

1.5. Multilateral System of Protecting Intellectual Property .............................24

1.5.1. The Paris Convention ..................................................................................24

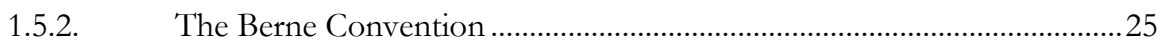

1.5.3. The establishment of the BIRPI and the WIPO......................................26

1.5.4. Multilateral Treaties Administered by WIPO .............................................26

1.5.5. Multilateral Treaties outside WIPO .............................................................28

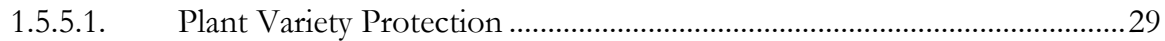

1.5.5.2. Copyright Protection ....................................................................................... 30

1.5.6. The Regulation of Intellectual Property under the General Agreement

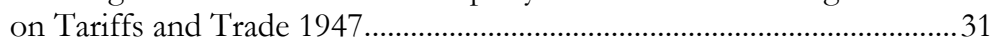

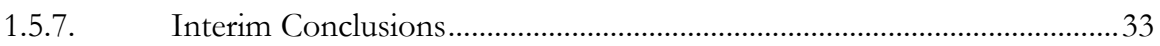

1.6. From Bilateral and Unilateral to Global Protection of Intellectual

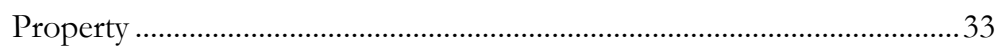

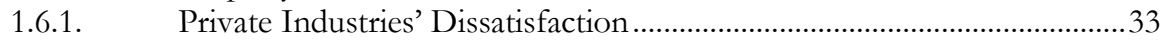

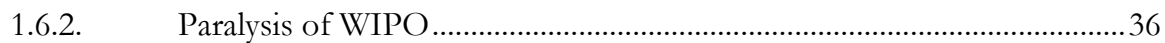

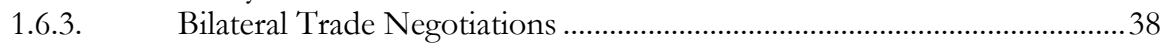

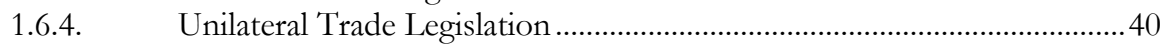

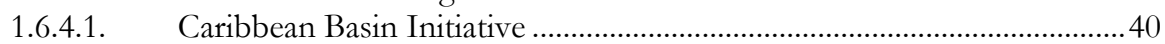

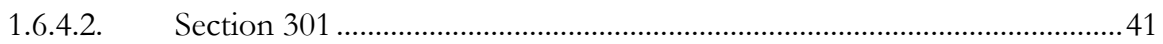

1.6.4.3. Generalized System of Preferences.............................................................. 44 
1.6.5. Multilateral Regulation: Incorporating the Protection of Intellectual Property into the GATT Framework …………….........................................46

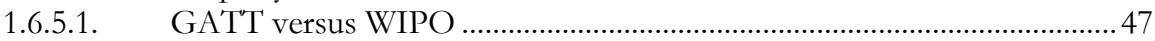

1.6.5.2. Shifting the Forum from WIPO to GATT ………....................................... 48

1.6.6. Business Support for a GATT-based Approach to Protecting Intellectual Property................................................................................. 50

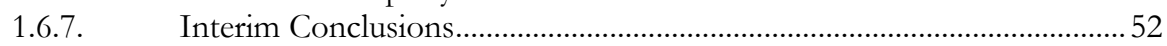

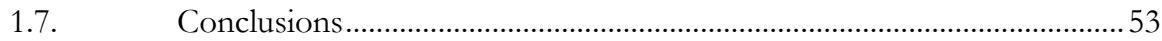

\section{Chapter 2}

The TRIPS Agreement: A Global IP Regime.............................................................. 55

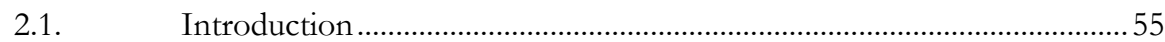

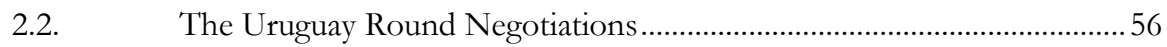

2.2.1. The "Preparation and Fact-finding Phase"...............................................57

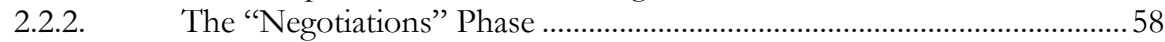

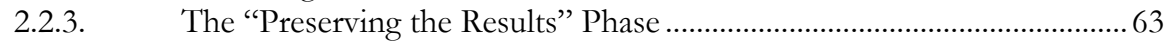

2.2.4. The Input of Developing Countries in the Negotiations ...........................64

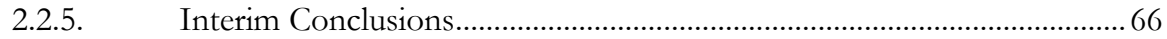

2.3. Substantive Provisions of the TRIPS Agreement ............................................66

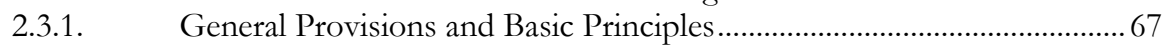

2.3.2. Substantive Provisions of Intellectual Property ...........................................68

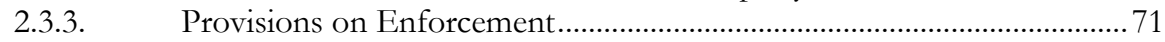

2.3.4. Provisions on Acquisition and Maintenance ............................................... 72

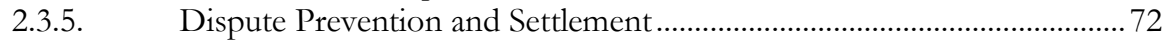

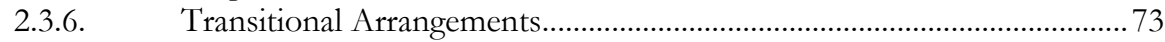

2.3.7. Institutional Arrangements and Final Provisions ....................................... 75

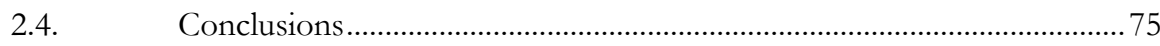

\section{Chapter 3}

The International System of Protecting Intellectual Property post-TRIPS.............. 77

3.1. Sources of TRIPS-plus Provisions............................................................... 79

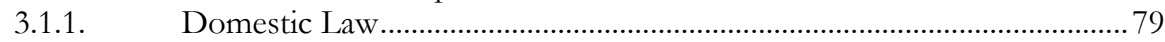

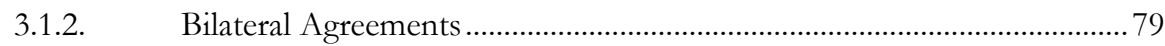

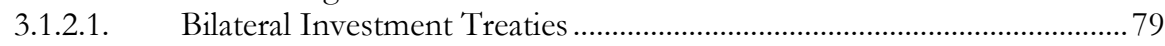

3.1.2.2. Bilateral Intellectual Property Agreements ................................................. 85

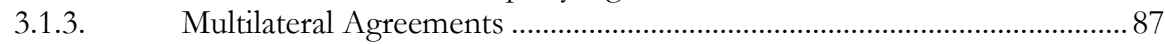

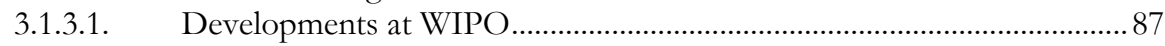

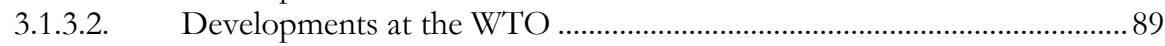

3.1.4. The Anti-Counterfeiting Trade Agreement: A Plurilateral Agreement... 90

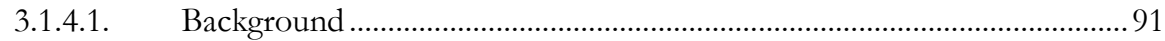

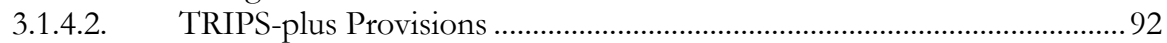

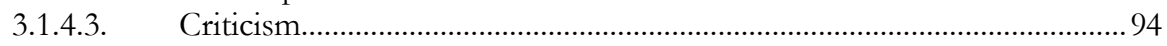

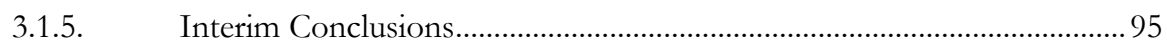

3.2. Free Trade Agreements Concluded by the United States.......................... 96

3.2.1. Legal Method ................................................................................................ 98 


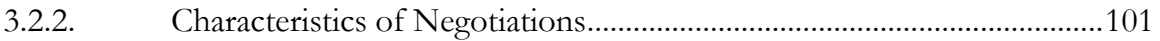

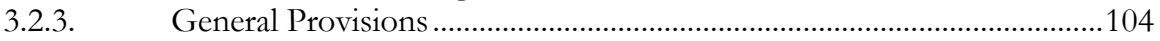

3.2.4. Provisions Related to Public Health .........................................................108

3.2.4.1. The pProtection of Undisclosed Information.........................................109

3.2.4.2. Linkage between Drug Registration and Patent Protection ....................111

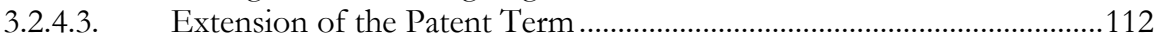

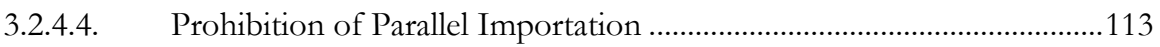

3.2.4.5. Restrictions on Compulsory Licensing....................................................114

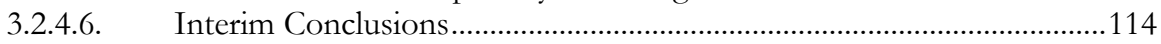

3.2.5. Provisions Relating to the Access to Information in the Digital

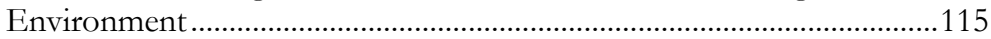

3.2.5.1. Prohibition of Temporary Storage in Electronic Form ..........................115

3.2.5.2. Extension of the Copyright Term.......................................................116

3.2.5.3. Prohibition of the Circumvention of Technological Measures...............117

3.2.5.4. Protection of Digital Rights Management Information...........................118

3.2.5.5. Protection of Programme-carrying Signals that are Transmitted by

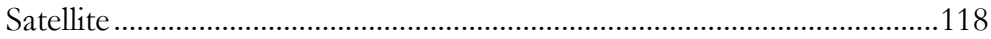

3.2.5.6. Administration and Management of Domain Names .............................119

3.2.5.7. Interim Conclusions .................................................................................... 120

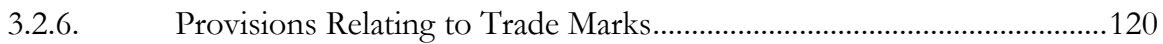

3.2.6.1. Eligible Types of Marks for Registration ................................................120

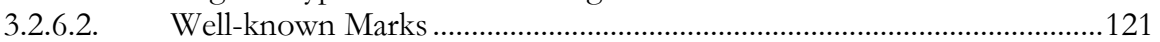

3.2.6.3. Period of Trade Mark Protection.................................................................122

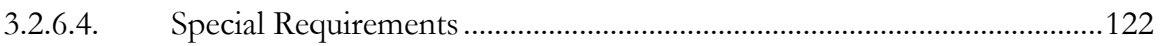

3.2.6.5. Interim Conclusions................................................................................... 123

3.2.7. Provisions Relating to the Protection of Life Forms ...............................123

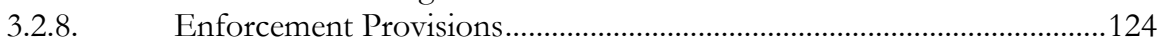

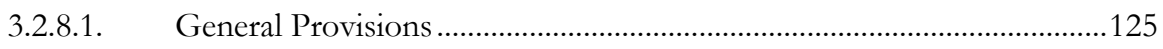

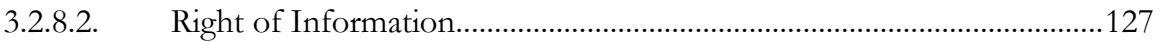

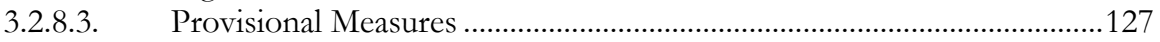

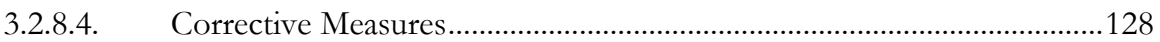

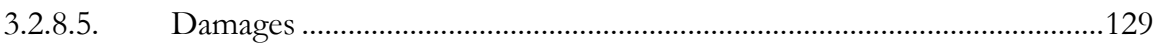

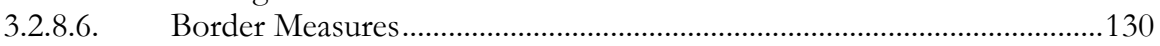

3.2.8.7. Criminal Procedures and Remedies .........................................................132

3.2.8.8. Limitations on the Liability of Internet Service Providers.......................133

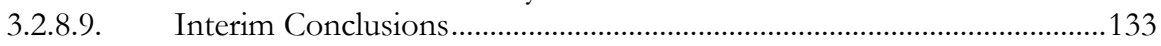

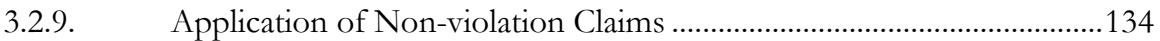

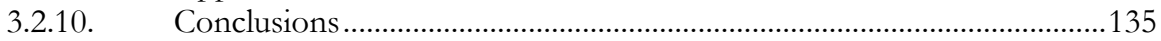

3.3. Bilateral Trade Agreements Concluded by the European Union up

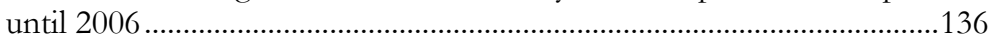

3.3.1. Categorization of European Union Bilateral Trade Agreements.............137

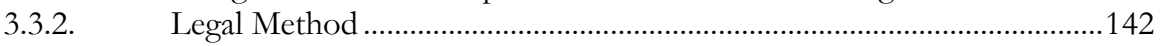

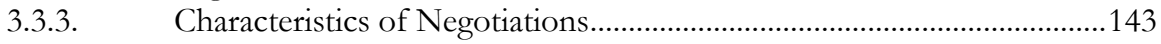

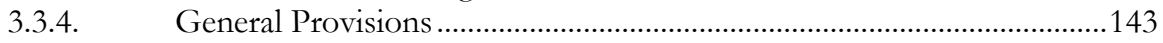

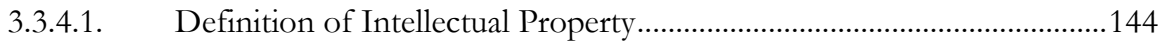

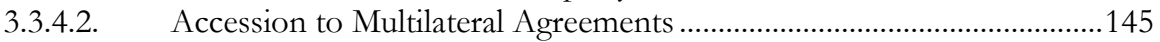

3.3.4.3. Most-favoured-nation Treatment Obligation............................................150

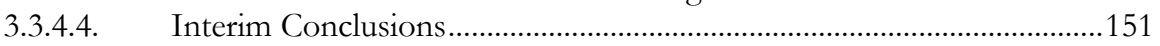

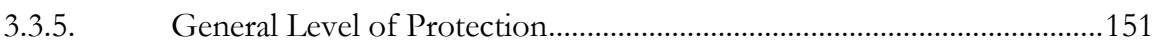


3.3.6. Provisions Relating to Geographical Indications.......................................154

3.3.6.1. Scope, Structure and Definition of Geographical Indications ................. 155

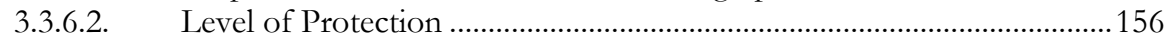

3.3.6.3. The Relationship with Trade Marks ............................................................ 160

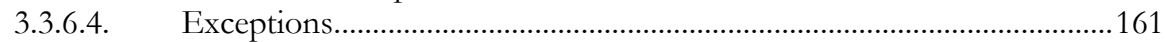

3.3.6.5. Invoking TRIPS Exceptions in a Dispute before Arbitrators

Established under the EC-Australia Wine Agreement.................................163

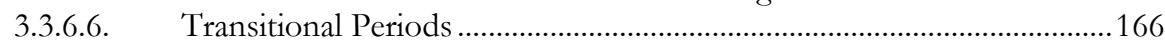

3.3.6.7. Protection of Traditional Expressions ........................................................ 168

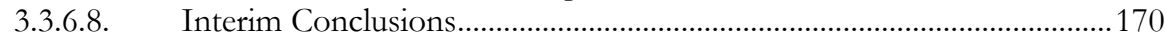

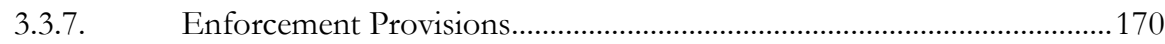

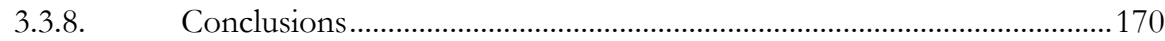

3.4. Free Trade Agreements Concluded by Others ….....................................171

3.4.1. Free Trade Agreements by EFTA States ..................................................171

3.4.2. Free Trade Agreements Concluded by Japan............................................176

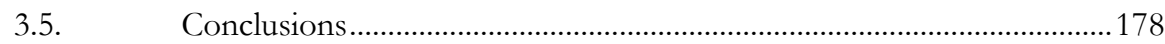

PART C: THE EUROPEAN UNION'S INTELLECTUAL PROPERTY POLICY TOWARDS THIRD COUNTRIES THROUGH BILATERAL TRADE AGREEMENTS

\section{Chapter 4}

The European Union's Intellectual Property Policy in Third Countries since the TRIPS Agreement: A Shift towards a Tough Approach ..................................... 185

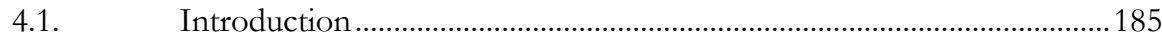

4.2. External Competence of the EU in Intellectual Property Matters.........186

4.2.1. Exclusive External Competence ................................................................187

4.2.1.1. Broad Concept of Commercial Aspects of Intellectual Property ...........189

4.2.1.2. Dynamic Concept of Commercial Aspects of Intellectual Property.....192

4.2.1.3. Lack of a Reference to Non-commercial Aspects of Intellectual

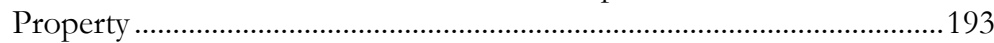

4.2.1.4. Pure IP Treaties or "Non-commercial Aspects of IP” '............................194

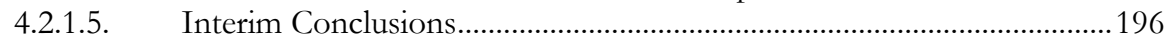

4.2.2. Coherence with Development Objectives .................................................197

4.2.3. Decision-making Regarding the Negotiation and Conclusion of Trade Agreements .................................................................................... 198

4.2.4. Role of the European Parliament............................................................... 201

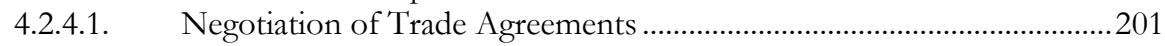

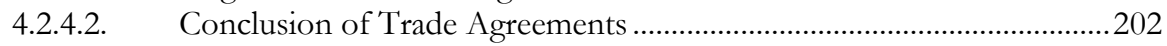

4.2.4.3. Implementation of Trade Agreements ......................................................203

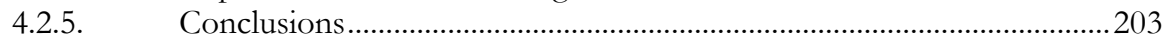

4.3. Shift from Multilateral to Bilateral Regulation of IP with Third

4.3.1. Prioritization of Multilateralism under Pascal Lamy ................................205

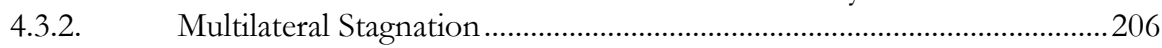


4.3.3. End of Moratorium for Negotiating New Bilateral Trade

Agreements.

4.3.4. Intellectual Property Chapters in Future Bilateral Agreements a

Priority

4.3.5. Comprehensive Bilateral Trade Agreements ...

4.4. Shift in the Legal Approach to Protecting IP in Bilateral Trade Agreements.

4.4.1. The EU's Approach of Protecting IP in Third Countries before the Launch of "Global Europe"

4.4.2. The EU's Approach of IP Protection in Third Countries after the Launch of "Global Europe"

4.4.2.1. Identical Levels of IP Protection ................................................................2. 217

4.4.2.2. Definition of Highest International Standards of IP................................220

4.5. Prioritized Partner Countries .....................................................................221

4.6. Development Concerns in EU's External IP Policy ................................225

4.6.1. Strong Concern for Development under "Managed Globalization" ....225

4.6.2. Little Concern for Development since "Global Europe" .......................226

4.7. Conclusions.

\section{Chapter 5}

Legal Analysis of the CARIFORUM-EC Economic Partnership Agreement.......233

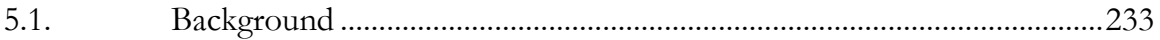

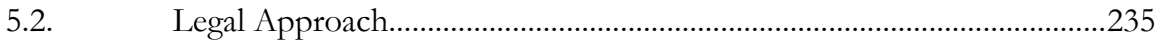

5.3. Chapter 2 on Innovation and Intellectual Property ..................................235

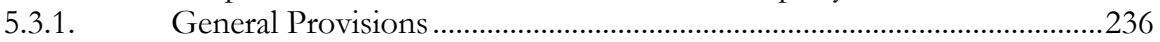

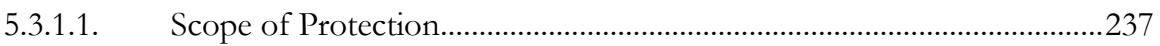

5.3.1.2. Definition of Intellectual Property.........................................................238

5.3.1.3. Principle of Minimum Protection and Freedom of Implementation....239

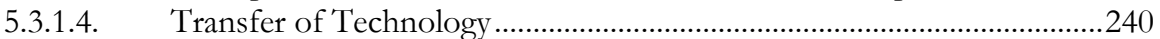

5.3.1.4.1 Article 142: Transfer of Technology .......................................................240

5.3.1.4.2 Context for Interpreting Article 142 ......................................................241

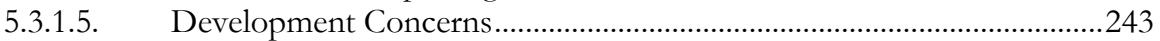

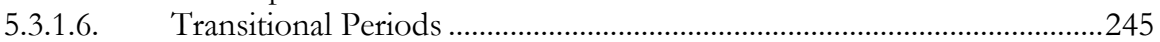

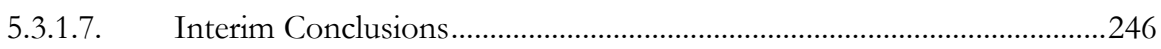

5.3.2. Individual Intellectual Property Provisions..............................................246

5.3.2.1. Provisions Relating to Access to Information in the Digital

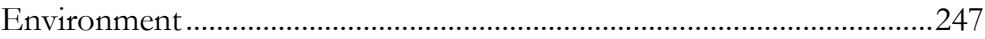

5.3.2.2. Provisions Relating to Trade Marks..........................................................248

5.3.2.3. Provisions Relating to Geographical Indications ......................................251

5.3.2.3.1 Scope of Protection, Transitional Periods and Term of Protection......251

5.3.2.3.2 Level of Protection.......................................................................................252

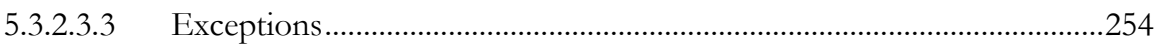

5.3.2.3.4 Invoking TRIPS Exceptions before an EPA Panel.................................256

5.3.2.3.5 Relationship between Geographical Indications and Trade Marks .......260

5.3.2.3.6 WIPO Joint Recommendation Concerning the Protection of Marks and Signs on the Internet 


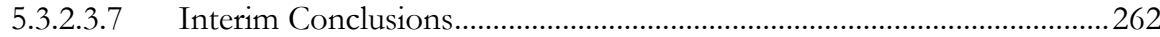

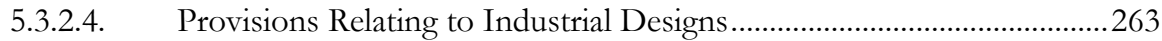

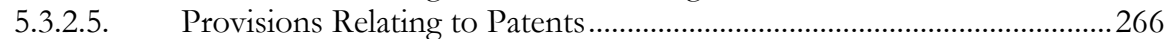

5.3.2.6. Provisions Relating to Utility Models ...........................................................269

5.3.2.7. Provisions Relating to Plant Varieties ......................................................271

5.3.2.8. Provisions Relating to Genetic Resources and Traditional Knowledge273

5.3.2.9. Interim Conclusions................................................................................. 276

5.3.3. Enforcement Provisions.......................................................................... 277

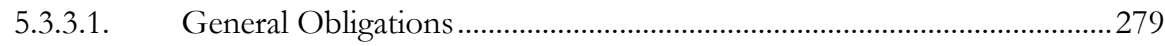

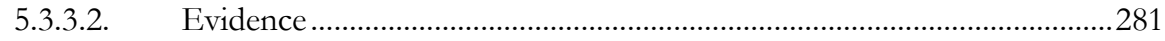

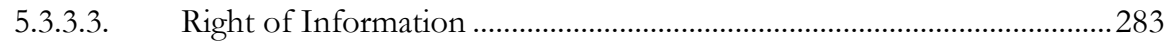

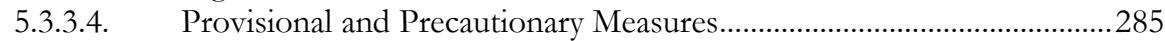

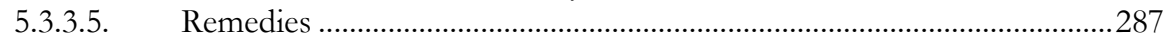

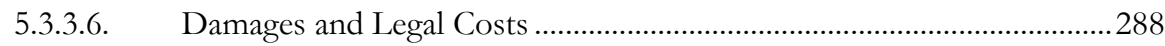

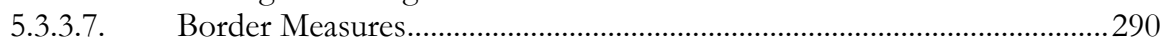

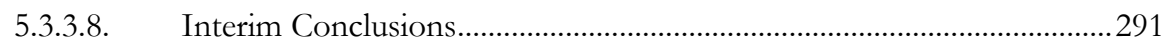

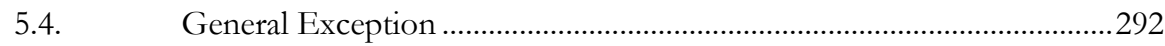

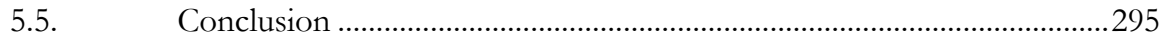

\section{Chapter 6}

Legal Analysis of the Draft India-EU Broad-based Trade and Investment

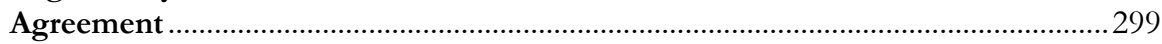

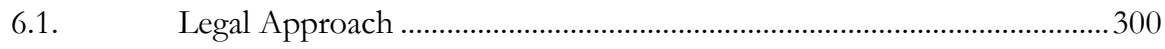

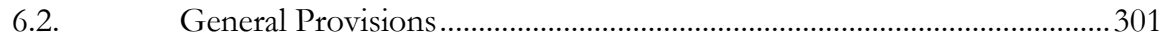

6.2.1. Context and Definition of Intellectual Property ………….........................301

6.2.2. Objectives and Scope of Protection .............................................................. 302

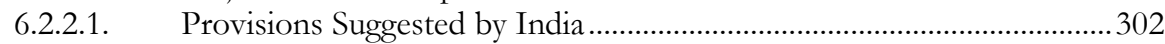

6.2.2.2. Provisions Suggested by the European Union............................................. 304

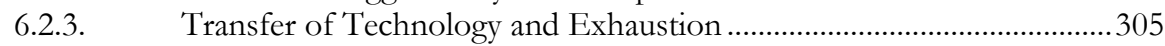

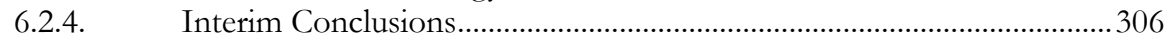

6.3. Individual Intellectual Property Provisions .................................................306

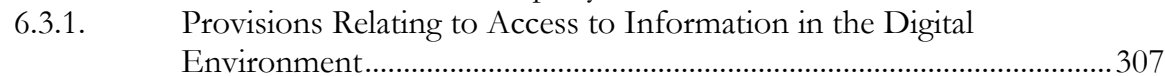

6.3.1.1. Compliance with International Treaties .................................................... 307

6.3.1.2. The Protection of Technical Protection Measures and Rights

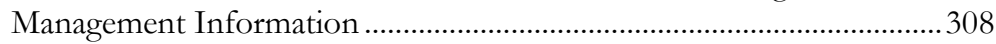

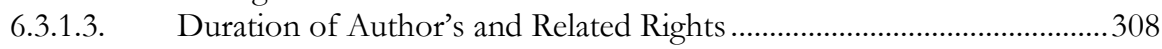

6.3.1.4. Cooperation on the Collective Management of Rights............................310

6.3.1.5. Particular Rights and Exceptions ………................................................... 310

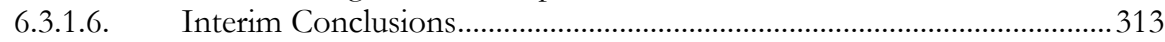

6.3.2. Provisions Relating to Trade Marks ........................................................... 314

6.3.2.1. Compliance with International Agreements ..............................................314

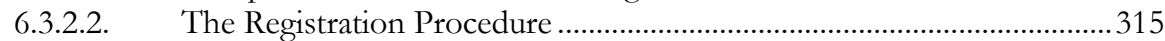

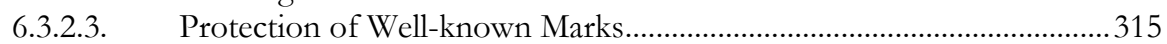

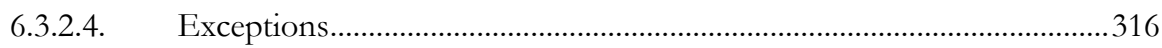

6.3.2.5. Interim Conclusions................................................................................. 317

6.3.3. Provisions Relating to Geographical Indications........................................ 317 
6.3.3.1. Recognition of Geographical Indications .....................................................

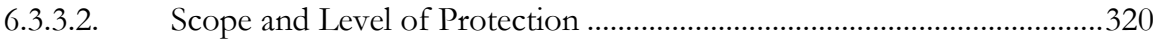

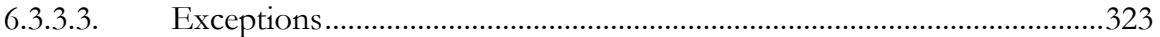

6.3.3.4. The Relationship with Trade Marks.............................................................326

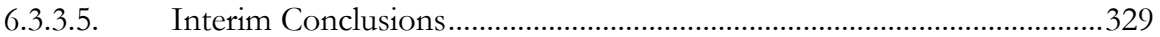

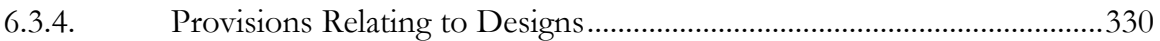

6.3.4.1. Accession to the Geneva Act of the Hague Agreement and Definition of

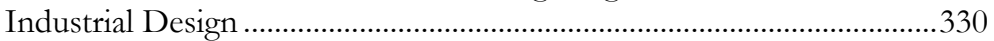

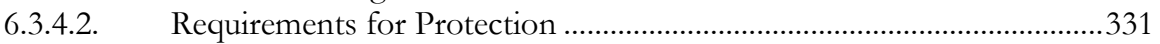

6.3.4.3. Rights Conferred and Term of Protection..................................................... 333

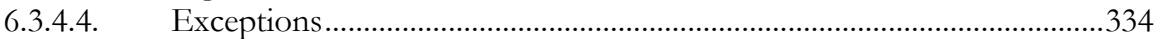

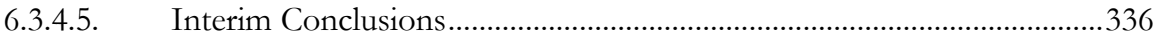

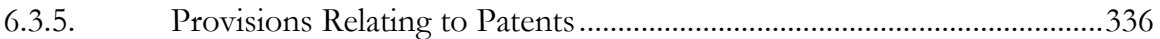

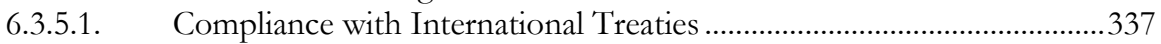

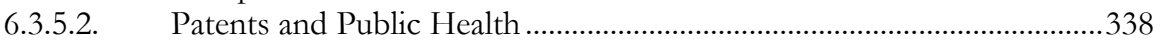

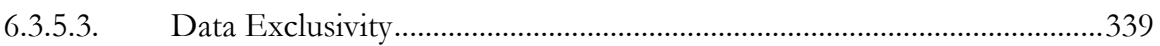

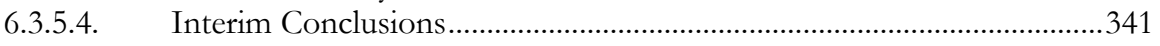

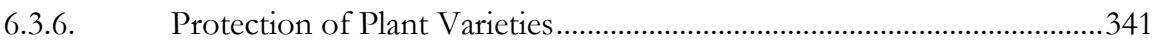

6.3.7. Provisions Relating to Genetic Resources and Traditional

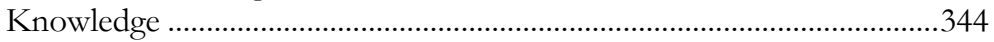

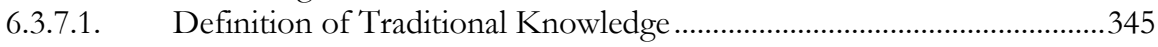

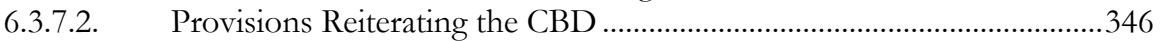

6.3.7.3. New Commitments with Regard to Disclosure, Prior Informed

Consent, Sharing of Benefits and the Related Consequences of

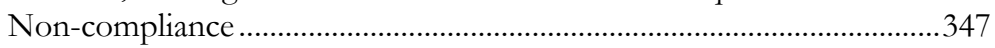

6.3.7.4. Procedural Commitments by Patent Offices.............................................348

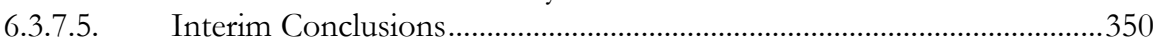

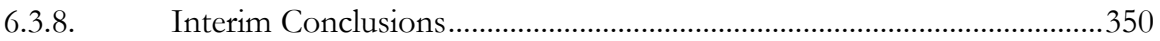

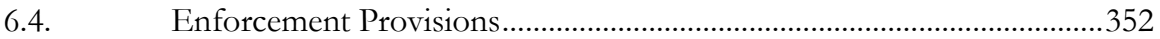

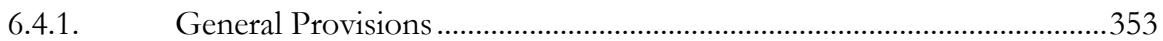

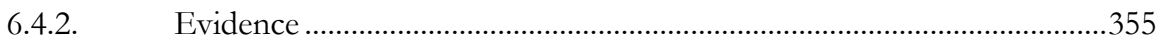

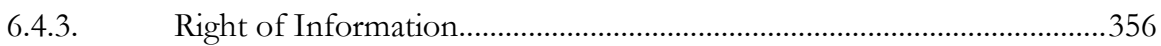

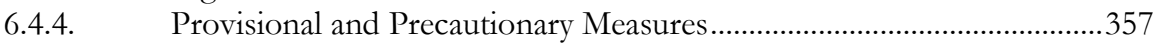

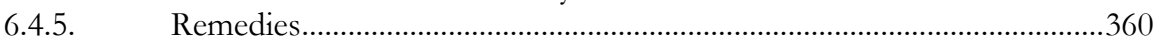

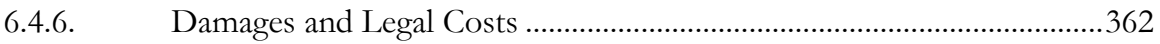

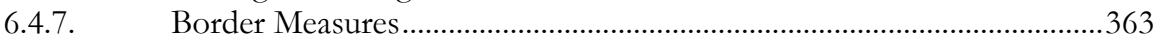

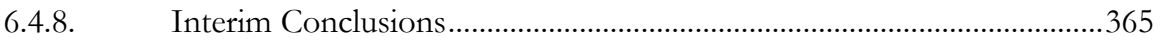

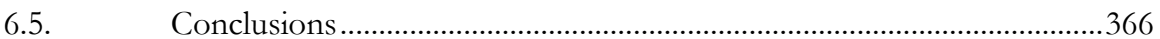

\section{Chapter 7}

Legal Comparison of the CARIFORUM-EC EPA with the India-EU BTIA ........369

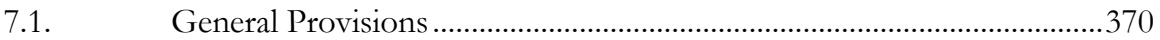

7.2. Copyright Protection in the Digital Environment ...................................373

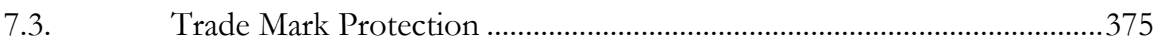

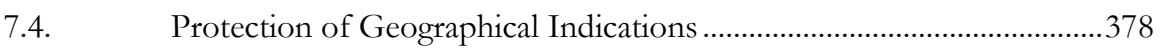

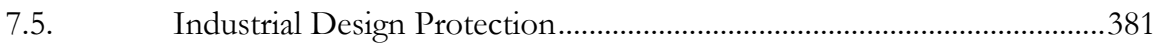




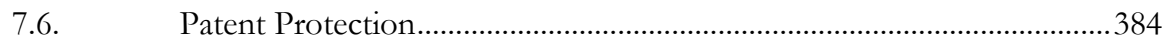

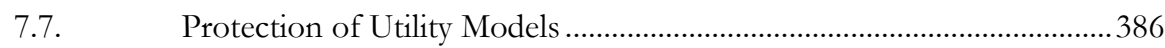

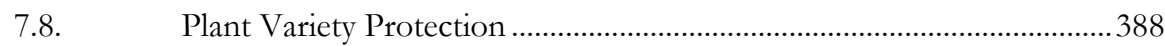

7.9. Protection of Genetic Resources and Traditional Knowledge ................390

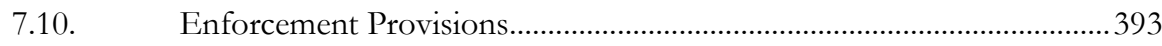

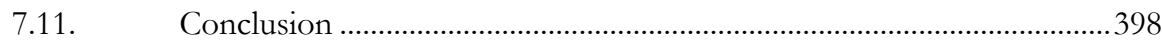

PART D: CASE STUDY JAMAICA: AN ANALYSIS OF THE

PREFERENCES AND INFLUENCE OF NON-STATE ACTORS ON

THE IP POLICY POSITION OF JAMAICA AND THE CARIFORUM

REGION

Chapter 8

Research Design: Methodology and Theoretical Framework .................................405

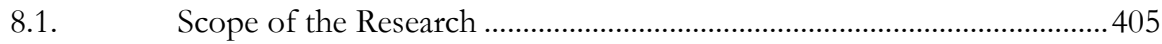

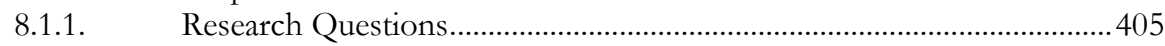

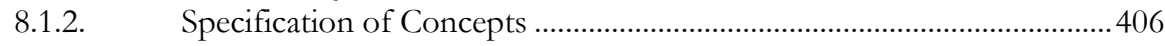

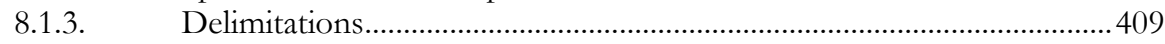

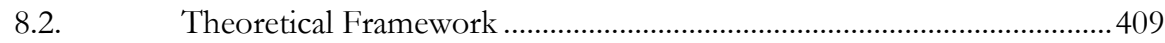

8.2.1. Liberal Theories of International Relations .............................................410

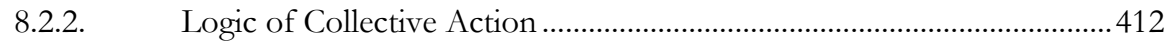

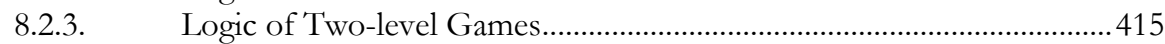

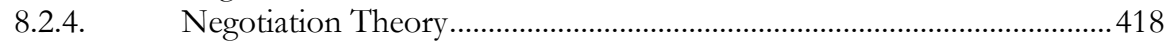

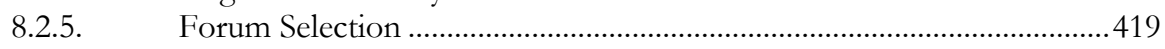

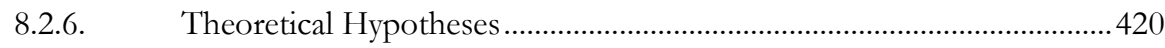

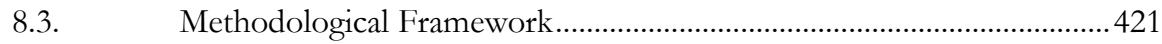

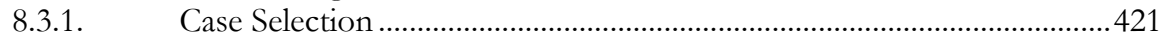

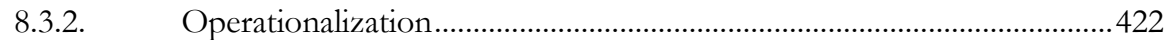

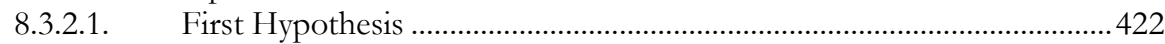

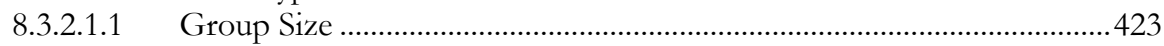

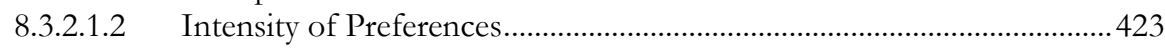

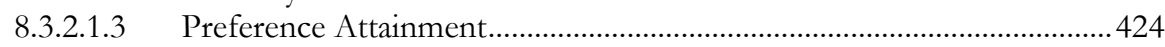

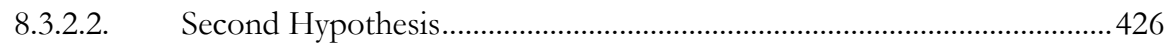

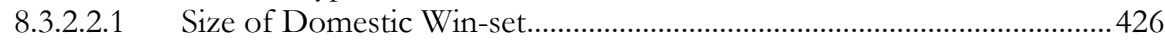

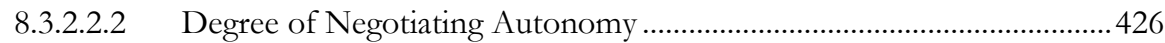

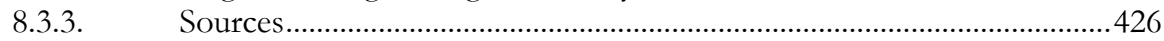

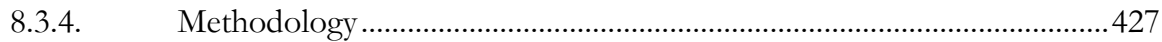

8.3.5. Limitations of the Research ....................................................................429

Chapter 9

Jamaica's Economic Development and Intellectual Property Legislation ............. 431

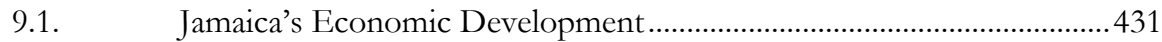

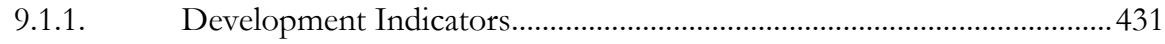

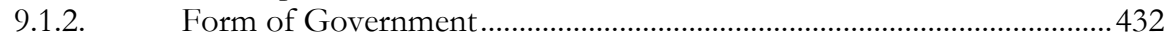




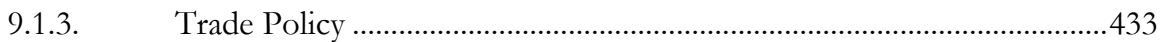

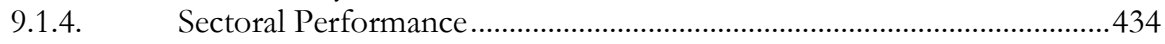

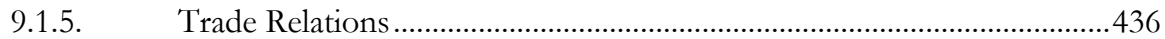

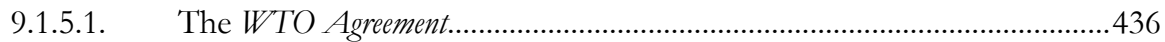

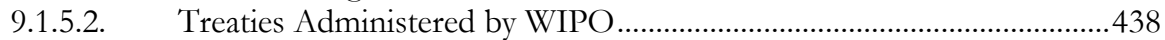

9.1.5.3. The Caribbean Community and the Caribbean Forum ...........................439

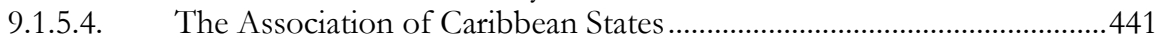

9.1.5.5. Bilateral Trade Agreements with Latin American Countries......................441

9.1.5.6. CARICOM - Canada Free Trade Negotiations.........................................442

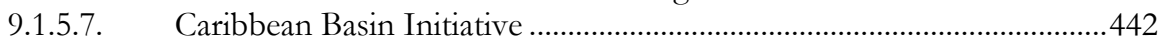

9.1.5.8. The COTONOU AGREEMENT and the ECONOMIC PARTNERSHIP

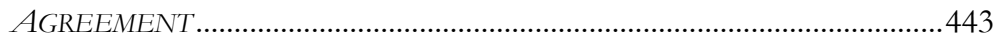

9.2. Jamaican Intellectual Property Legislation before and after the

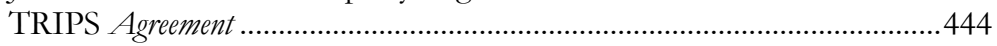

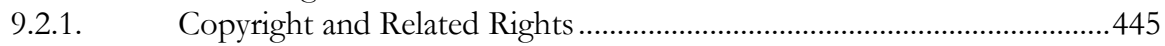

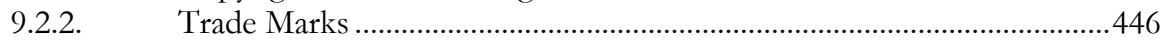

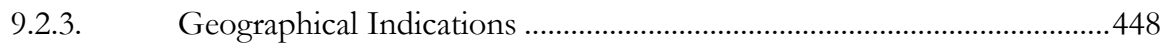

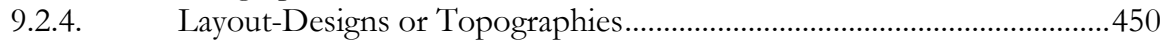

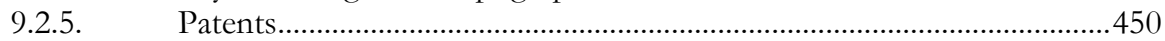

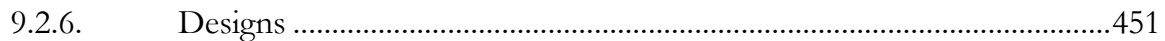

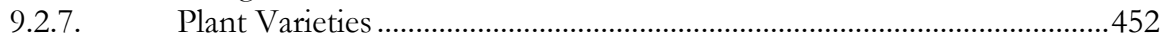

9.2.8. Protection of Genetic Resources and Traditional Knowledge................454

Chapter 10

Policy-making Processes on Intellectual Property Matters in CARIFORUM, in

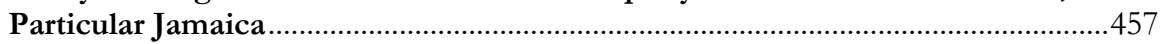

10.1. State Actors Involved in Policy-making and International Negotiations on Intellectual Property Matters in CARIFORUM, in Particular Jamaica

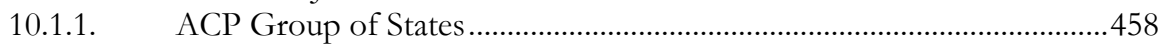

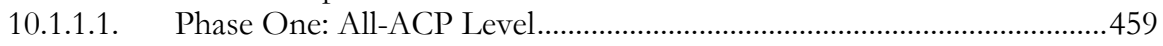

10.1.1.2. Phase Two: Regional Phase ………..............................................................459

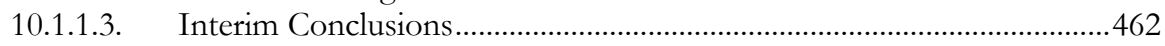

10.1.2. The CARIFORUM-EC EPA Negotiations: Political Hhases..................463

10.1.2.1. Phase One: April 2004-November 2004 ……….......................................463

10.1.2.2. Phase Two: November 2004-September 2005 ............................................. 464

10.1.2.3. Phase Three: September 2005-November 2006........................................466

10.1.2.4. Phase Four: December 2006-December 2007 ...........................................468

10.1.3. Caribbean Forum of African, Caribbean and Pacific States (CARIFORUM): Regional State Actors ....................................................469

10.1.3.1. Methodology …………………….............................................................. 470

10.1.3.2. The EPA College of Negotiators: Conduct of Technical
Negotiations ……........................................................................................ 470

10.1.3.3. CARIFORUM Council of Ministers: Political Direction of the
Negotiations ............................................................................................4 472

10.1.3.4. Caribbean Regional Negotiation Machinery (CRNM): Coordination of Technical Negotiations .............................................................................473

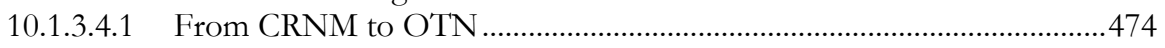




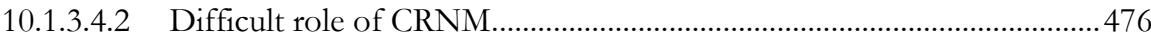

10.1.3.5. Technical Working Group (TWGs): Formulation of Negotiating Positions

10.1.3.6. The Regional Preparatory Task Force (RPTF) .........................................479

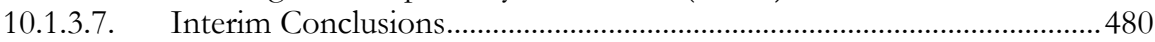

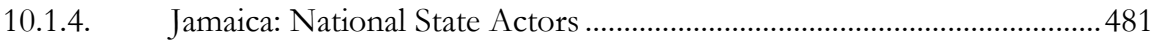

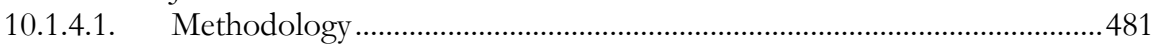

10.1.4.2. Jamaican Parliament.................................................................................. 482

10.1.4.3. Ministry of Foreign Affairs and Foreign Trade (MoFAFT) .................... 485

10.1.4.4. Jamaica Intellectual Property Office (JIPO) ...............................................487

10.1.4.5. Jamaica Promotions Corporation (JAMPRO) ...............................................48

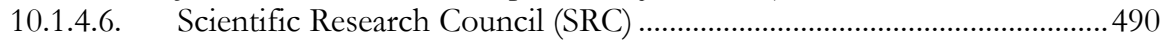

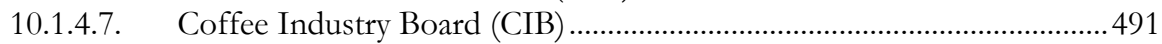

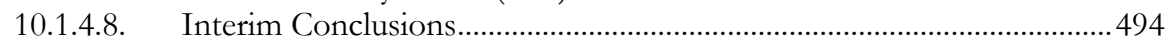

10.1.5. Differences between EPA Negotiations and Multilateral

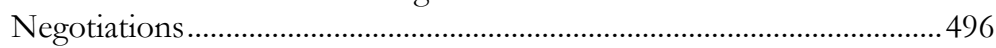

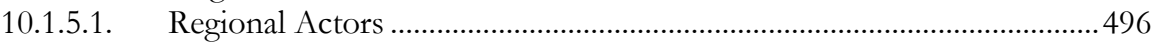

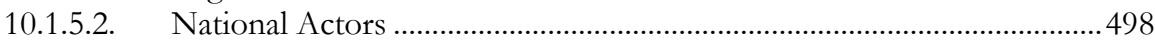

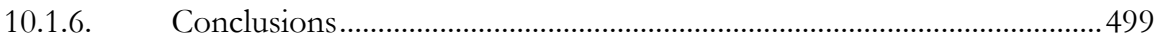

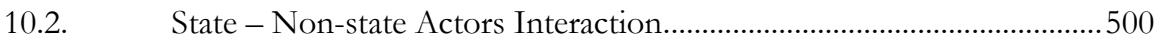

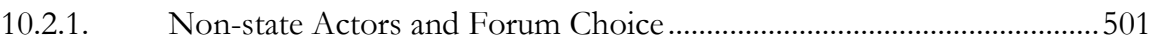

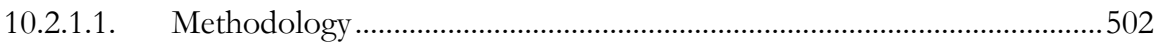

10.2.1.1.1 Regional Non-state Actors.......................................................................... 502

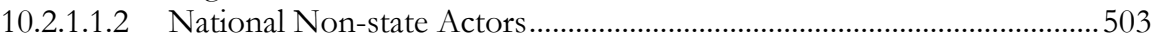

10.2.1.2. Business/industry Associations and Producers ........................................504

10.2.1.2.1 West Indies Rum \& Spirits Producers' Association Inc. (WIRSPA) ....505

10.2.1.2.2 West Indies Central Sugar Cane Breeding Station (WICSCBS)...............506

10.2.1.2.3 The Private Sector Organization of Jamaica (PSOJ) ................................508

10.2.1.2.4 The Jamaica Chamber of Commerce (JCC) ……......................................510

10.2.1.2.5 The Competitiveness Company Limited (CC) ......................................... 511

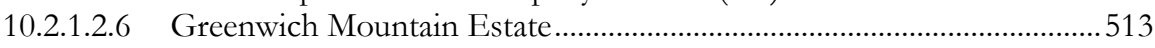

10.2.1.2.7 Jamaica Standard Products Company (JSP)............................................... 514

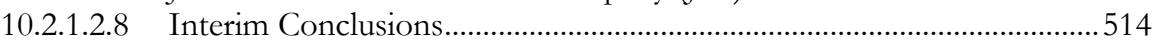

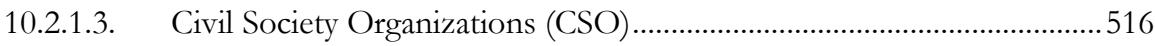

10.2.1.3.1 Caribbean Policy Development Centre (CPDC) ......................................517

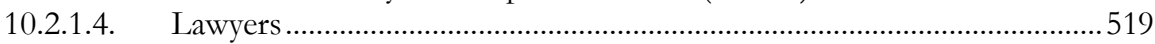

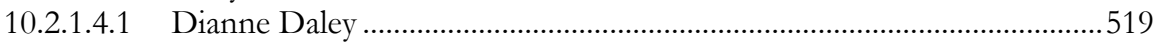

10.2.1.4.2 Peter Goldson, Myers, Fletcher \& Gordon................................................. 522

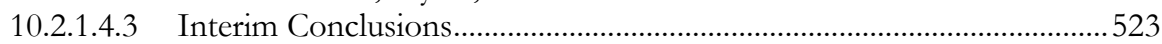

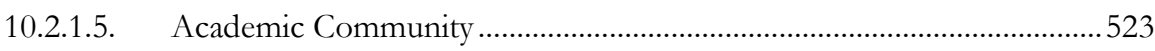

10.2.1.5.1 Norman Girvan, University of the West Indies St. Augustine,

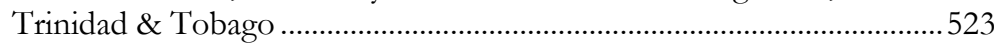

10.2.1.5.2 Beverley Pereira, UWI Mona Campus Jamaica ..........................................5 525

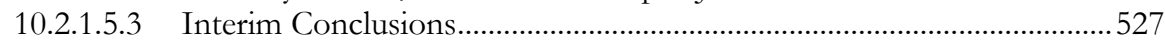

10.2.1.6. International Non-state and Para-state Actors........................................527

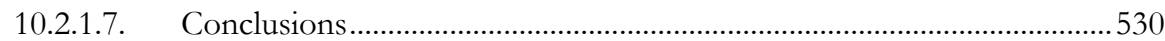

10.2.2. Regional Consultative Processes, Organized by CRNM .........................5 534

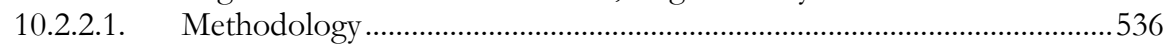

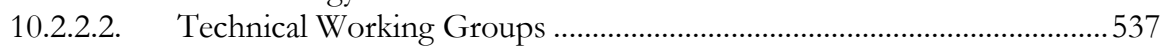


10.2.2.3. Private Sector Outreach Programme (PSOP) ….........................................538

10.2.2.4. Regional Consultations with Non-State Actors (NSAs) ...........................539

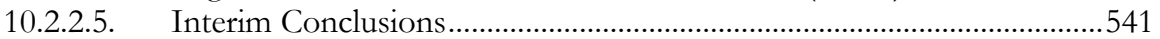

10.2.3. National Consultative Processes: Jamaica ...................................................542

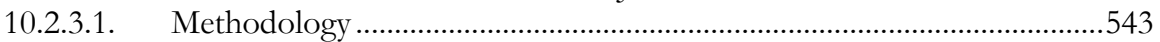

10.2.3.2. Jamaica Trade Adjustment Team (JTAT) …………..................................54

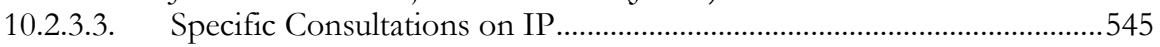

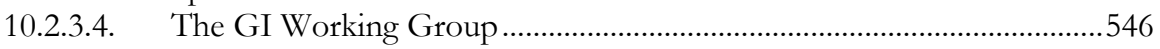

10.2.3.5. Involvement during the Implementation Phase.........................................548

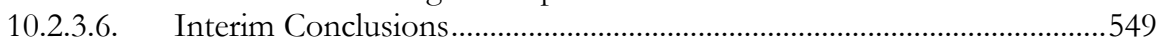

10.2.4. Differences between EPA Negotiations and Multilateral

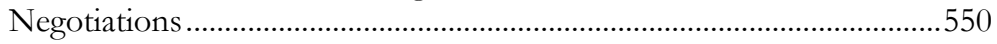

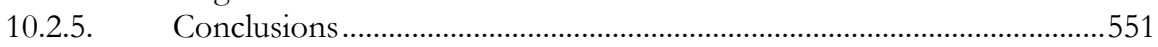

\section{Chapter 11}

Influence of Non-state Actors on the IP Policy Position during the EPA

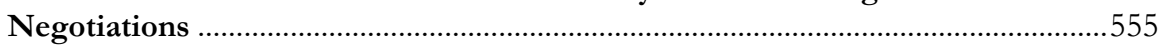

11.1. Final Policy Positions in the Area of IP Protection..................................555

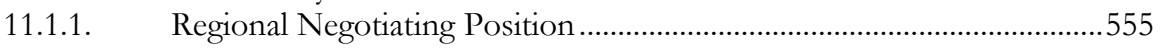

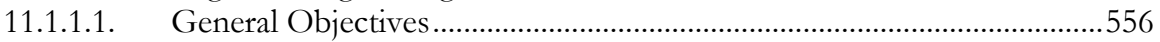

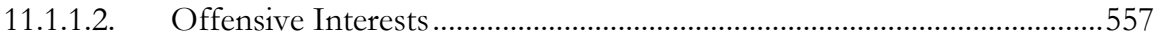

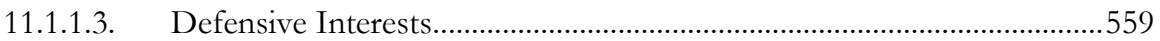

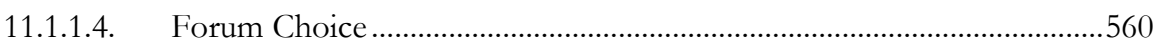

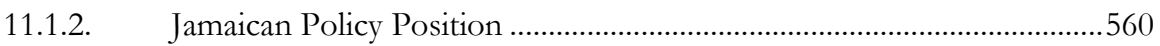

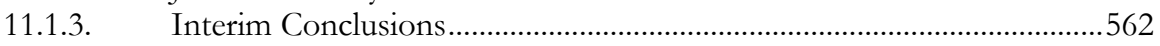

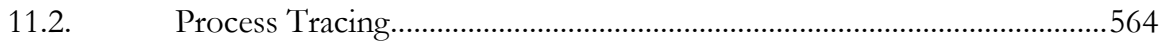

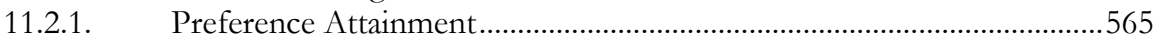

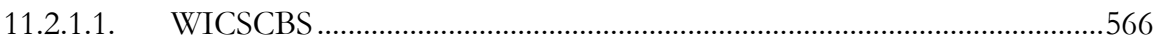

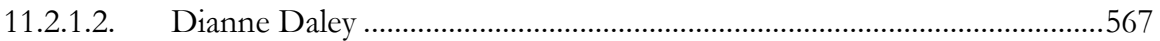

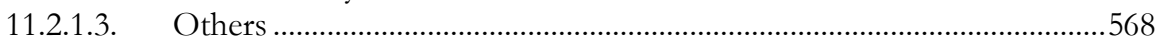

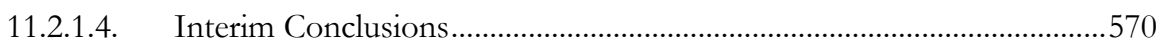

11.2.2. Self and Peer Assessment ...........................................................................5 570

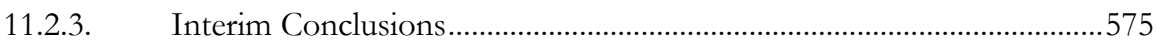

11.3. Role of CRNM and the Technical Negotiator on IP .............................575

11.3.1. Asymmetrical Distribution of Knowledge .................................................576

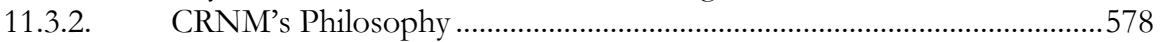

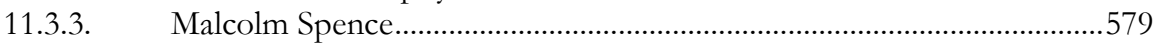

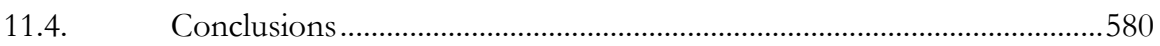

Chapter 12

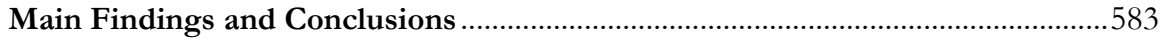

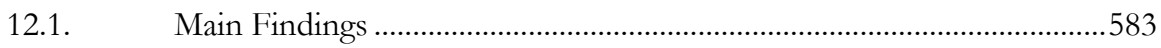

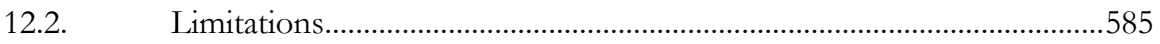

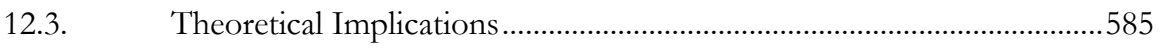

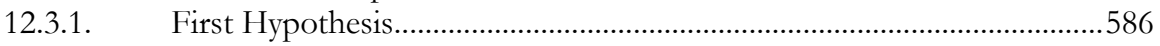




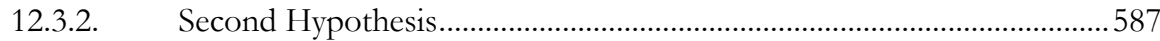

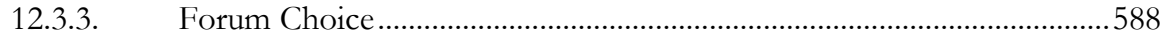

PART E: CONCLUSIONS AND SUMMARY

\section{Chapter 13}

Conclusions and Summary

13.1. The International System of Intellectual Property Protection pre-TRIPS

13.2. The International System of Intellectual Property Protection post-TRIPS .................................................................................................. 592

13.3. The EU's Intellectual Property Policy towards Third Countries ............594

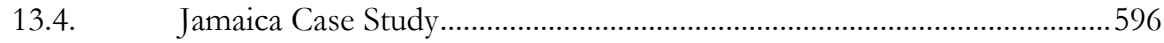

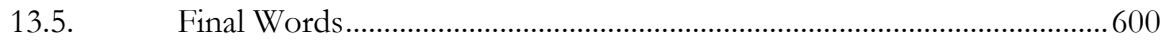

\section{Chapter 14}

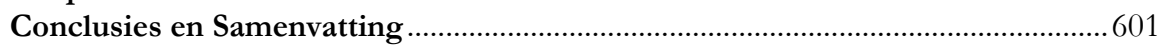

14.1. Het internationaal systeem van IE bescherming pre-TRIPS ..................601

14.2. Het internationaal systeem van IE bescherming post-TRIPS.................602

14.3. Het beleid van de EU betreffende de bescherming van intellectueel eigendom in derde landen .........................................................................604

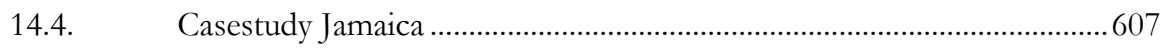

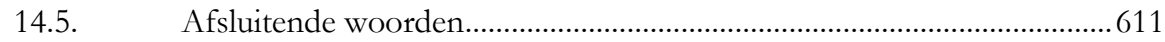

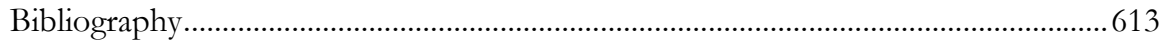

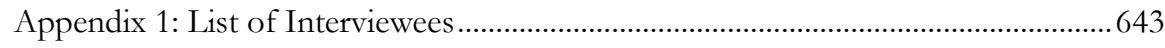

Appendix 2: Interview guide used for state actors .........................................................645

Appendix 3: Interview guide used for non-state actors................................................649

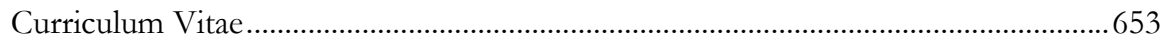




\section{List of Abbreviations}

\begin{tabular}{|c|c|}
\hline AA & Association Agreement \\
\hline ACP & African, Caribbean and Pacific States \\
\hline ACTA & Anti-Counterfeiting Trade Agreement \\
\hline ACTN & Advisory Committee on Trade Negotiations \\
\hline ASEAN & Association of Southeast Asian Nations \\
\hline ASSINSEL & $\begin{array}{l}\text { International Association of Plant Breeders for the } \\
\text { Protection of Plant Varieties }\end{array}$ \\
\hline BIT & Bilateral Investment Treaty \\
\hline BTA & Bilateral Trade Agreement \\
\hline BIP & Bilateral Intellectual Property Agreement \\
\hline BIRPI & $\begin{array}{l}\text { Bureaux Internationaux Réunis pour la Protection de la } \\
\text { Propriété Intellectuelle, French acronym for United } \\
\text { International Bureau for the Protection of Intellectual } \\
\text { Property }\end{array}$ \\
\hline BTIA & Broad-based Trade and Investment Agreement \\
\hline $\mathrm{CA}$ & Cooperation Agreement \\
\hline CARICOM & Caribbean Common Market \\
\hline CARIFORUM & Caribbean Forum \\
\hline CBD & Convention on Biological Diversity \\
\hline CBI & Caribbean Basin Initiative \\
\hline CC & Competitiveness Company \\
\hline CETA & Comprehensive Economic and Trade Agreement \\
\hline $\mathrm{CIB}$ & Coffee Industry Board \\
\hline CJEU & Court of Justice of the European Union \\
\hline COTED & $\begin{array}{l}\text { CARICOM Council of Trade and Economic } \\
\text { Development }\end{array}$ \\
\hline CPDC & Caribbean Policy Development Centre \\
\hline CRNM & Caribbean Regional Negotiation Machinery \\
\hline CSME & Caricom Single Market and Economy \\
\hline $\mathrm{CSO}$ & Civil Society Organization \\
\hline DG & Directorate General \\
\hline DMCA & Digital Millennium Copyright Act \\
\hline DRM & Digital Rights Management \\
\hline DSB & Dispute Settlement System \\
\hline DSU & Dispute Settlement Understanding \\
\hline EC & European Community \\
\hline ECJ & European Court of Justice \\
\hline EFTA & European Free Trade Association \\
\hline EMEA & European Medicines Agency \\
\hline EP & European Parliament \\
\hline EPA & Economic Partnership Agreement \\
\hline ERTA & European Road Transport Agreement \\
\hline EU & European Union \\
\hline FP7 & Framework Programme 7 \\
\hline FTA & Free Trade Agreement \\
\hline FTAA & Free Trade Area of the Americas \\
\hline FYROM & Former Yugoslav Republic of Macedonia \\
\hline
\end{tabular}




\begin{tabular}{|c|c|}
\hline GA & Global Agreement \\
\hline GATS & General Agreement on Trade in Services \\
\hline GATT & General Agreement on Tariffs and Trade \\
\hline GI & Geographical indications \\
\hline GSP & Generalized System of Preferences \\
\hline ICANN & Internet Cooperation of Assigned Names and Numbers \\
\hline ICSID & $\begin{array}{l}\text { International Centre for Settlement of Investment } \\
\text { Disputes }\end{array}$ \\
\hline IIPA & International Intellectual Property Alliance \\
\hline I.L.M. & $\begin{array}{l}\text { International Legal Material of the American Society of } \\
\text { International Law }\end{array}$ \\
\hline INTA & International Trade Committee \\
\hline IP & Intellectual property \\
\hline IPC & International Property Committee \\
\hline IPI & Institute of Intellectual Property \\
\hline IPIC & Intellectual Property in Respect of Integrated Circuits \\
\hline JAMPRO & Jamaican Promotions Corporation \\
\hline JCC & Jamaica Chamber of Commerce \\
\hline JIPO & Jamaican Intellectual Property Office \\
\hline JSP & Jamaica Standard Products Company \\
\hline JTAT & Jamaica Trade Adjustment Team \\
\hline $\mathrm{LDCs}$ & Least-Developed Countries \\
\hline MERCOSUR & Southern Common Market \\
\hline $\mathrm{MFN}$ & Most-Favoured-Nation \\
\hline MoFAFT & Ministry of Foreign Affairs and Foreign Trade \\
\hline NAFTA & North American Free Trade Agreement \\
\hline NBA & National Biodiversity Authority \\
\hline NRCA & Natural Resources Conservation Authority \\
\hline NSA & Non-state actor \\
\hline OTN & Office of Trade Negotiations \\
\hline PCA & Partnership and Cooperation Agreement \\
\hline РCТ & Patent Cooperation Treaty \\
\hline PLT & Patent Law Treaty \\
\hline PMSC & Prime Ministerial Sub-Committee \\
\hline P'TA & Preferential Trade Agreement \\
\hline PSOJ & Private Sector Organization Jamaica \\
\hline PSOP & Private Sector Outreach Programme \\
\hline QUAD & Quadrilateral \\
\hline RPTF & Regional Preparatory Task Force \\
\hline RTA & Regional Trade Agreement \\
\hline SAA & Stabilization and Association Agreement \\
\hline S\&D treatment & Special and Differential treatment \\
\hline SPLT & Substantive Patent Law Treaty \\
\hline SRC & Scientific Research Council \\
\hline SVE & Small and Vulnerable Countries \\
\hline TDC & Trade and Development Committee \\
\hline TDCA & Trade, Development and Cooperation Agreement \\
\hline TEC & Treaty Establishing the European Community \\
\hline TEU & Treaty on the European Union \\
\hline TFEU & Treaty on the Functioning of the European Union \\
\hline
\end{tabular}


TK

TKDL

TLD

TPM

TPR

TRIPS

TWG

UCC

UDRP

UNESCO

U.N.T.S.

UNCTAD

UNDP

UPOV

U.S.T.

USTR

UWI

WCT

WIPO

WIRSPA

WPPT

WTO
Traditional Knowledge

Traditional Knowledge Digital Library

Top Level Domain

Technological protection measure

Trade Policy Review

Trade-related Aspects of Intellectual Property Rights

Technical Working Group

Universal Copyright Convention

Uniform Domain-Name Dispute-Resolution Policy

United Nations Economic, Social and Cultural

Organization

United Nations Treaty Series

United Nations Conference on Trade and Development

United Nations Development Programme

International Union for the Protection of New Varieties of Plants

United States Treaties

United States Trade Representative

University of the West Indies

WIPO Copyright Treaty

World Intellectual Property Organization

West Indies Rum \& Spirits Producers' Association Inc.

WIPO Performances and Phonograms Treaty

World Trade Organization 



\section{List of Tables}

TABLE 1: TREATIES ADMINISTERED BY WIPO ACCORDING TO AREA OF IP AND

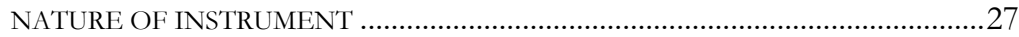

TABLE 2: UNITED STATES FREE TRADE AGREEMENTS FROM MID-2000 UNTIL

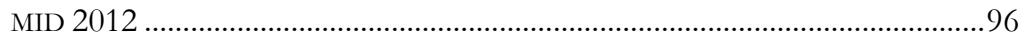

TABLE 3: MULTILATERAL TREATIES LISTED IN EU BILATERAL AGREEMENTS WITH CANDIDATES, POTENTIAL CANDIDATES FOR ACCESSION AND NEIGHBOURING COUNTRIES .......................................................................146

TABLE 4: MULTILATERAL TREATIES LISTED IN EU BILATERAL AGREEMENTS WITH PARTICULAR DEVELOPING COUNTRIES ...........................................148

TABLE 5: EFTA FTAS ALREADY CONCLUDED OR UNDER NEGOTIATIONS UNTIL

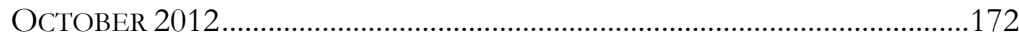

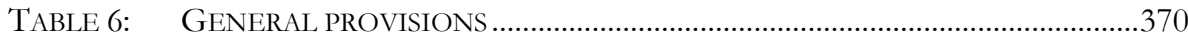

TABle 7: COPYRIght PROTECTION IN THE DigitAl ENVIRONMENT.......................373

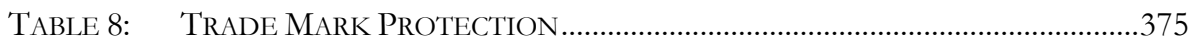

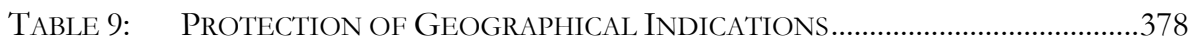

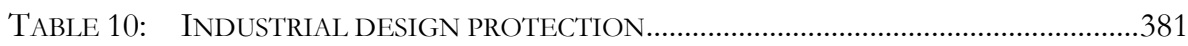

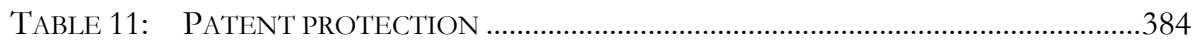

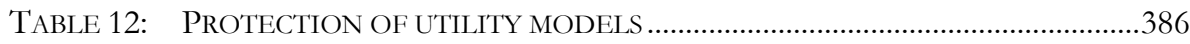

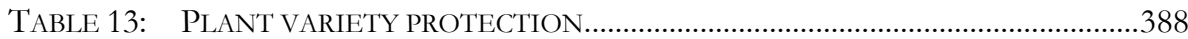

TABLE 14: PROTECTION OF GENETIC RESOURCES AND TRADITIONAL

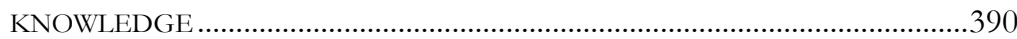

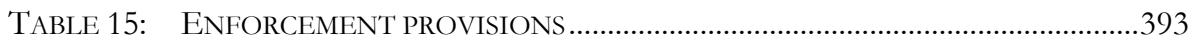

TABLE 16: SCHEDULE FOR NEGOTIATIONS ON THE CARIFORUM-EC EPA..........463

TABLE 17: NON-STATE ACTORS' PREFERENCES AND INVOLVEMENT IN IP POLICY MAKING DURING EPA NEGOTIATIONS.......................................................531 



\section{List of Schemes}

SCHEME 1: EFFECTS OF REDUCING WIN-SET SIZE .........................................................416

SCHEME 2: CARIFORUM-EC EPA CONFIGURATION AND OVERLAPPING REGIONAL AND SUB-REGIONAL ECONOMIC INTEGRATION GROUPINGS. .440

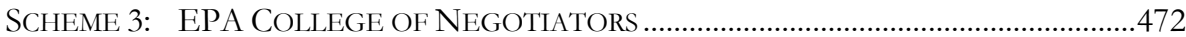

SCHEME 4: GOVERNANCE STRUCTURE OF CRNM DURING THE EPA

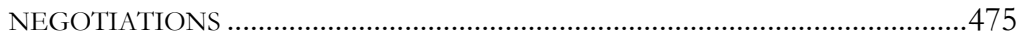

SCHEME 5: JAMAICAN STATE ACTORS INVOLVED IN POLICY-FORMULATION ...............486 SCHEME 6: CARIFORUM NEGOTIATING STRUCTURE UPDATE 0801 .536 



\section{List of Appendices}

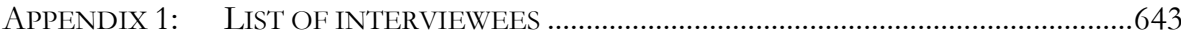

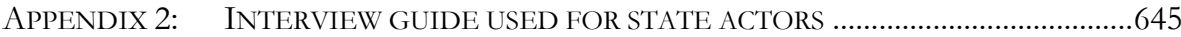

APPENDIX 3: INTERVIEW GUIDE USED FOR NON-STATE ACTORS................................649 

PART A: INTRODUCTION 



\section{Introduction}

Ever more developing countries participate in bilateral trade negotiations. In the case that developing countries negotiate with a developed country, such as the United States or the European Union, the trade areas under negotiations always cover the protection and enforcement of intellectual property (IP). Countries such as Colombia, Peru, Costa Rica, Nicaragua, Barbados, Jamaica, and India are confronted with requests by the United States or the European Union to accept intellectual property protection that, in many areas, goes beyond the standard of protection agreed upon in the Agreement on Trade-Related Aspects of Intellectual Property Rights (TRIPS Agreement). ${ }^{1}$ TRIPS-plus provisions require parties to bilateral trade agreements (BTAs) to increase the protection for right holders of IP and to limit access to the products and services protected by IP for competitors and consumers. These requirements do not always seem to be in the best interest of contracting parties that do not yet have the level of development and capacity to undertake innovative research and development which would allow them to take full advantage of the benefits that strong IP protection and enforcement offers in the various areas. ${ }^{2}$

Situations of bilateral trade negotiations involving a developing and a developed country have become increasingly more common. During the last fifteen years, bilateral trade agreements have proliferated at a pace and geographical coverage that so far has been unprecedented. Approximately 350 new preferential trade agreements have entered into force since the establishment of the World Trade Organization (WTO) in January 1995, the vast majority of which are bilateral trade agreements. ${ }^{3}$ At the same time, concluding multilateral trade agreements has become very difficult. Pascal Lamy, Director-General of the WTO, noted in a recent speech in Geneva that: "Multilateralism is struggling in almost all spheres of global co-operation." 4 This is

1 Agreement on Trade-Related Aspects of Intellectual Property Rights, Annex 1C of the Marrakesh Agreement Establishing the World Trade Organization, signed on 15 April 1994, 33 I.L.M. 1197 (1994) [hereinafter TRIPS Agreement].

2 Several authors have conducted empirical research into the economic effects of strong intellectual property protection for developed and developing countries. See Y.K. Kim et al., "Appropriate Intellectual Property Protection and Economic Growth in Countries at Different Levels of Development” Research Policy, 2012, Vol. 41 (2), 358375; Commission on Intellectual Property Rights (ed.), Integrating Intellectual Property Rights and Development Policy (3rd edn, CIPR, London, 2003), p. 22; C. Fink and C.A. Primo Braga, "How Stronger Protection of Intellectual Property Rights Affects International Trade Flows" in C. Fink and K.E. Maskus (eds.), Intellectual Property and Development: Lessons from Recent Economic Research (World Bank and Oxford University Press, New York, 2005) 19-40, p. 34; W.G. Park and D.C. Lippoldt, Technology Transfer and the Economic Implications of the Strengthening of Intellectual Property Rights in Developing Countries (OECD Trade Policy Working Papers, No. 62, 2008), p. 25; D. Greenbaum, "Determining Optimal Levels of Intellectual Property Protection in Developing Nations: Is Less really More? Is More really Less?” Current Science, 2009, Vol. 97 (11), 1604-1620; W.G. Park, "Intellectual Property Rights and International Innovation" in K.E. Maskus (ed.), Frontiers of Economics and Globalization, Intellectual Property, Growth and Trade (Elsevier, The Hague, 2008) 289-327, p. 322f.

3 See WTO Secretariat, World Trade Report 2011 (Geneva, 2011), p. 61.

4 Speech by P. Lamy (Geneva, 24 September 2012), Multilateralism is struggeling, available at <http://www.wto.org/english/news_e/sppl_e/sppl244_e.htm> accessed on 27.09.2012. 
particularly true for the Doha Development Round negotiations which have been stalled for several years. Also the Director General of the World Intellectual Property Organization (WIPO), Francis Gurry, emphasized in a speech in December 2010 that there is a crisis in multilateralism and that the international community's capacity to reach agreements has been reduced. ${ }^{5}$ An example of a failure to reach multilateral agreement at WIPO is the draft Substantive Patent Law Treaty. Negotiations thereon were put on hold in $2006 .^{6}$

Setting intellectual property standards primarily at the bilateral level has important consequences for the international system of intellectual property protection and its constituting members. First, the standards of protection included in bilateral trade agreements become de facto global rules. Members of the WTO are under an obligation to accord the same IP treatment granted to nationals of any other country "immediately and unconditionally" to the nationals of all W'TO Members. ${ }^{7}$ In the TRIPS Agreement, preferential treatment agreed upon in BTAs is not exempted from the most-favoured-nation (MFN) treatment obligation, contrary to the exceptions provided for in Article XXIV of the General Agreement on Tariffs and Trade 1994 (GATT 1994) ${ }^{8}$ and in Article V of the General Agreement on Trade in Services (GATS). ${ }^{9}$ Because of the lack of such a regional integration exception in the TRIPS Agreement, the MFN treatment obligation applies in full to bilateral trade agreements. In other words, WTO Members that accept TRIPS-plus standards in BTAs have to extend the same standards of protection to the entire group of WTO Members. With currently 157 Members, the WTO brings together the vast majority of countries involved in international trade. In view of the territorial expansion of bilateral trade agreements, TRIPS-plus provisions become the de facto global standard.

Second, the de facto global rules on intellectual property protection are set at the bilateral level. They are not adopted in a global/multilateral forum, such as the WTO or the WIPO. When the multilateral venue is circumvented, new international standards of intellectual property protection are set outside of the institutional structures and without the procedural rules that the multilateral framework offers. While policy-making at the WTO or at the WIPO is far from perfect, it is subject to certain requirements regarding the access to documents, participation of civil society groups and institutional safeguards. Such rules are entirely missing in negotiations launched and carried out ad hoc outside of any institutional structures. Furthermore, bilateral standard setting deprives developing countries from building multilateral coalitions. With a large number of countries involved in negotiations, developing countries can increase their bargaining power through allying with like-minded

5 See W. New, "WIPO's Gurry Says 'Crisis in Multilateralism' Bringing Changes to IP”, Intellectual Property Watch (17 December 2010). See WIPO, WIPO-Administered Treaties (2012), available at <http://www.wipo.int/treaties/en/> accessed on 21.11.2012.

7 See the most-favoured-nation treatment obligation in Article 4 of the TRIPS Agreement.

8 General Agreement on Tariffs and Trade 1994, Annex 1A to the Marrakesh Agreement Establishing the World Trade Organization, signed on 15 April 1994, entered into force on 1 January 1995, 33 I.L.M. 1167 (1994) [hereinafter GATT 1994].

9 General Agreement on Trade in Services, Annex 1B to the Marrakesh Agreement Establishing the World Trade Organization, signed on 15 April 1994, entered into force on 1 January 1995, 33 I.L.M. 1167 (1994) [hereinafter GATS]. 
countries vis-à-vis powerful countries such as the United States or the European Union. This possibility does not exist at the bilateral level.

The recent development of including strong TRIPS-plus provisions in bilateral trade agreements was started by the United States, which signed the first free trade agreement containing TRIPS-plus provisions on 24 October 2000 with Jordan. The United States was not only the first major actor to require high standards of IP protection; the scope and nature of these obligations in their free trade agreements has also put the US approach at the centre of attention of academic scholars. ${ }^{10}$ For the purpose of innovative research, it was appropriate to direct the focus of the research for this thesis to another major actor that sets TRIPS-plus provisions through bilateral trade agreements. The European Union has only recently started to introduce TRIPS-plus provisions into its BTAs, including those signed with developing countries. So far, a comprehensive analysis of the recent shift in the European Union IP policy towards third countries, as well as the concrete obligations contained in its bilateral trade agreements, is still missing. This thesis aims at providing a timely contribution to the debate on the European Union's role in international IP policy-making.

10 See F.M. Abbott, The Doha Declaration on the TRIPS Agreement and Public Health and the Contradictory Trend in Bilateral and Regional Free Trade Agreements (QUNO, Geneva, 2004) [Occasional Paper No. 14]; E.T. Biadgleng and V. Muñoz Tellez, The Changing Structure and Governance of Intellectual Property Enforcement (South Centre, Research Papers 15, Geneva, 2008); A. Christie, S. Waller and K. Weatherall, "Exporting the DMCA through Free Trade Agreements" in C. Heath and A. Kamperman Sanders (eds.), Intellectual Property in Free Trade Agreements (Institute of European Studies of Macau Intellectual Property, Hart Publishing, Oxford, 2007) 211-243; C. Fink and P. Reichenmiller, Tightening TRIPS: The Intellectual Property Provisions of Recent US Free Trade Agreements (Trade Note 20 of The World Bank Group, 07 February 2005); J. Kuanpoth, "TRIPS-Plus Rules under Free Trade Agreements: An Asian Perspective" in C. Heath and A. Kamperman Sanders (eds.), Intellectual Property in Free Trade Agreements (Institute of European Studies of Macau Intellectual Property, Hart Publishing, Oxford, 2007) 28-45; B. Mercurio, "TRIPS-Plus Provisions in FTAs: Recent Trends" in L. Bartels and F. Ortino (eds.), Regional Trade Agreements and the WTO Legal System (Oxford University Press, Oxford, 2006) 215-237; J.-F. Morin, "Tripping up TRIPs Debates: IP and Health in Bilateral Agreements" International Journal of Intellectual Property Management, 2006, Vol. 1-2, 37-53; Oxfam America, Make Trade Fair for Central America: Agriculture, Investment and Intellectual Property: Three Reasons to Say No to CAFTA (2003) [Oxfam America Briefing Note 2]; M.P. Pugatch, "The International Regulation of IPRs in a TRIPs and TRIPs-plus Worlds" Journal of World Investment and Trade, 2005, Vol. 6, 231265; R. Rajkumar, "The Central American Free Trade Agreement: An End Run around the DOHA Declaration on TRIPS and Public Health" Albany Law Journal of Science \&o Technology, 2004, Vol. 15, 433-475; P. Roffe, Bilateral agreements and a TRIPS-plus world: the Chile-USA Free Trade Agreement (Quaker International Affairs Programme, TRIPS Issues Papers No 4, Ottawa, 2004); F. Rossi, "Free Trade Agreements and TRIPS-plus Measures" International Journal of Intellectual Property Management, 2006, Vol. 1 (1/2), 150172; S.K. Sell, “TRIPS-plus Free Trade Agreements and Access to Medicines” Liverpool Law Review, 2007, Vol. 28, 41-75; D. Vivas-Eugui, Regional and bilateral agreements and a TRIPS-plus world: the Free Trade Area of the Americas (FTAA) (TRIPS Issues Papers 1, Quaker United Nations Office, Geneva, 2003); P. Xiong, "Patents in TRIPS-Plus Provisions and the Approaches to Interpretation of Free Trade Agremeents and TRIPS: Do They Affect Public Health?" Journal of World Trade, 2012, Vol. 46 (1), 155186. 
While a solid legal assessment of the TRIPS-plus provisions included in recent BTAs is crucial to understanding their effects on the citizens of the negotiating parties, it is only one side of the coin. Being trained in both legal analysis of international economic law as well as theories of international relations, I find it crucial to provide a deeper analysis of the policy-making process that is at the heart of policy choices made in the context of bilateral trade negotiations on intellectual property protection. Developing countries are parties to bilateral agreements that include TRIPS-plus provisions; they have negotiated and accepted them during the negotiation process. These decisions, as diverse as the context for different developing countries may be, have in common that they are the result of a domestic decision-making process. The outcome of this process is the position that the developing country's chief negotiator adopts in international trade negotiations. In other words, in order to investigate why a certain policy position is chosen by a developing country partner in bilateral or multilateral negotiations, one needs to examine the 'structure of domestic preferences'.

This book presents one of the first assessments of the domestic preferences of a developing country that negotiated intellectual property protection in a bilateral trade agreement with the European Union. This country is Jamaica, and more generally, the CARIFORUM region. ${ }^{11}$ Until now, a lacuna exists in political scientific literature that addresses the domestic politics in developing countries that are involved in international negotiations of intellectual property protection, whether at the bilateral or multilateral level. ${ }^{12}$ One study has addressed the domestic politics involved in the negotiations of intellectual property protection as part of the US-Colombia and USPeru free trade agreements; ${ }^{13}$ no other analysis of developing countries' domestic politics that are parties to bilateral negotiations on IP protection with any other major actor could be identified.

The present analysis examines the preferences of non-state actors in Jamaica and the CARIFORUM region in relevant fields of intellectual property protection under negotiation in the CARIFORUM-EC Economic Partnership Agreement. ${ }^{14}$ At the centre of

11 CARIFORUM stands for the Caribbean Forum of African Caribbean and Pacific states and includes the following fifteen countries: Antigua and Barbuda, the Bahamas, Barbados, Belize, Dominica, the Dominican Republic, Grenada, Guyana, Haiti, Jamaica, Saint Lucia, Saint Vincent and the Grenadines, Saint Christopher and Nevis, Suriname, and Trinidad and Tobago. It consists of the CARICOM Common Market (minus the British dependent territory Montserrat) and the Dominican Republic.

Most studies focus on developed countries, and in particular on the United States and the European Union. See T. Heron and G. Siles-Brügge, "Competitive Liberalization and the 'Global Europe' Services and Investment Agenda: Locating the Commercial Drivers of the EU-ACP Economic Partnership Agreements" Journal of Common Market Studies, 2012, Vol. 50 (2), 250-266; D. Robinson and C. Gibson, "Governing Knowledge: Discourses and Tactics of the European Union in Trade-Related Intellectual Property Negotiations" Antipode, 2011, Vol. 43 (5), 1883-1910. See J. Von Braun, The Domestic Politics of Negotiating International Trade: Intellectual Property Rights in US-Colombia and US-Peru Free Trade Agreements (Routledge Research in International Economic Law, Taylor and Francis, London, 2011). October 2008 (OJ L 289/I of 30.10.2008, p. 3) [hereinafter CARIFORUM-EC EPA]. The CARIFORUM-EC EPA has been provisionally applied as from 29 December 
attention are the preferences of non-state actors in protecting the intellectual property in agricultural and food products, through geographical indications, trade marks, plant varieties, traditional knowledge and genetic resources. Three reasons have prompted me to focus the research on the protection of agricultural and food products. First, non-state actors and scholars have not dedicated as much attention to the impact of intellectual property protection on food security as on its impact on a) access to medicines and b) access to knowledge. ${ }^{15}$ This relative neglect makes it necessary to focus research and non-state actors' attention on the protection of intellectual property in agricultural and food products. Second, many developing countries, among which Jamaica and the CARIFORUM States, are important exporters of food products; the protection of the relevant IP aspects also abroad is a crucial condition for the success of their products. Third, the European Union has also shown a keen interest in protecting forms of IP that are relevant for their agricultural products and foodstuffs, for example geographical indications.

When assessing non-state actors' preferences with regard to protecting the intellectual property of agricultural and food products, particular attention is paid to the question as to whether or not they have a preference for bilateral IP rule-making as opposed to, or in addition to, multilateral IP rule-making. The coexistence of the recent proliferation of bilateral trade agreements regulating IP protection and the deadlock of multilateral negotiations on IP proffers the question whether this preference for bilateral IP rule-making is also reflected in the preferences of domestic non-state actors in developing countries. The literature has not sufficiently addressed that question either. Only one contribution, the edited volume of Ann Capling and Patrick Low, which assembles case studies of eight developing countries, has tried to assess non-state actors' preferences on forum choice and whether these actors try to influence government choices. ${ }^{16}$

\section{Broader Relevance of Research}

Increasing the protection of intellectual property in various areas has an effect on the social and economic welfare of a country and its citizens. International agreements dealing with intellectual property protection set detailed standards of protection, with which national legislation needs to comply. The rights and obligations set out in national laws are directly applicable to countries' citizens and affect various aspects of their lives. While most developed countries' societies already dispose of a comprehensive system of intellectual property protection, the obligations in such

2008. See European Commission, Notice concerning the provisional application of the CARIFORUM-EC Economic Partnership Agreement (OJ L 352 of 31.12.2008). Mary Intellectual Property Research Institute, London, 2006), p. 9.

They themselves are not aware of any other empirical studies that have investigated the question of forum selection. See A. Capling and P. Low (eds.), Governments, Non-State Actors and Trade Policy-Making: Negotiating Preferentially or Multilaterally? (Cambridge University Press, Cambridge, 2010), p. 326. They also refer to a journal article authored by Edward Mansfield and Helen Milner from 1999, which points out that there is a lack of empirical evidence of "which domestic groups support regional trade agreements, whose interests these agreements serve, and why particular groups prefer regional to multilateral liberalization." E. Mansfield and H. Milner, "The New Wave of Regionalism” International Organization, 1999, Vol. 53 (3), 589-627, p. 604. 
agreements often are new for the citizens of developing countries. It is therefore crucial 1) to assess and explain in detail the concrete IP obligations contained in recent bilateral trade agreements to which developing countries are partners, and 2) to examine whether all interests in society were reflected in the policy-making process that informed the developing countries' decisions to accept TRIPS-plus provisions in bilateral negotiations.

Also in terms of theoretical relevance, this research is innovative. First, the study is truly interdisciplinary in combining the insights from a legal assessment of the TRIPS-plus provisions in recent European bilateral trade agreements with a politicalscientific analysis of the preferences of developing countries' non-state actors in IP protection and their regulation through a bilateral trade agreement. Intellectual property protection through international agreements has rarely been the subject of an interdisciplinary approach of 1) assessing in detail the rights and obligations, and 2) examining the preferences that have informed the policy choices. ${ }^{17}$ In particular the preferences of developing countries' non-state actors have so far not been analyzed sufficiently by political scientists. Second, the theoretical framework, which has been formed through a combination of the logic of collective action, the logic of two-level games and negotiating theory, is applied to a new empirical domain. So far, no study has applied these theories to the domestic preferences of developing countries' non-state actors on the international regulation of intellectual property. The research results contribute to the research community's knowledge about the degree of these theories' general character. ${ }^{18}$

\section{Research Questions, Scope and Organization of the Research}

At the outset of the research for this thesis, I was driven by the rather broad research question: Why do developing countries accept TRIPS-plus obligations in bilateral trade agreements with major actors such as the United States and the European Union? Realizing that it was impossible for me to conduct research within four years that would be able to provide a satisfactory answer to this question, I started to narrow down this research question. In view of the interdisciplinary nature of the research, it was necessary to develop several research questions which would steer the analysis for each part of the research.

Part B of this book provides a general, historical and legal assessment of how the international system of intellectual property protection has developed. The analysis

17 Some of the few analyses of the policy-making process of international IP protection are the following works, which in fact focus on international policy-making rather than domestic policy making. See A.K. Menescal, "Those behind the TRIPS Agreement: The Influence of the ICC and the AIPPI on International Intellectual Property Decisions" Intellectual Property Quarterly, 2005, Vol. 2, 155-182; P. Drahos, "Developing Countries and International Intellectual Property Standard Setting" Journal of World Intellectual Property, 2002, Vol. 5 (5), 765-789, p. 26ff; S.K. Sell and A. Prakash, "Using Ideas Strategically: The Contest Between Business and NGO Networks in Intellectual Property Rights" International Studies Quarterly, 2004, Vol. 48, 143-175.

18 See M. Lehnert, B. Miller and A. Wonka, "Increasing the Relevance of Research Questions: Considerations on Theoretical and Social Relevance in Political Sience" in T. Gschwend and F. Schimmelfennig (eds.), Research Design in Political Science: How to Practice What They Preach (Palgrave MacMillan, New York, 2007) 21-38, p. 25. 
was guided by the question of how states have regulated the international protection of intellectual property in the past and whether the recent proliferation of bilateral agreements addressing IP protection is a new phenomenon in the international system of IP regulation. To this end, Chapter 1 introduces the international system of protecting intellectual property as it existed before the TRIPS Agreement entered into force. Chapter 2 addresses the negotiations and the substantive provisions of the TRIPS Agreement. Chapter 3 examines the different sources of TRIPS-plus provisions in international agreements. In particular, it presents a detailed legal assessment of the standards of protection included in recent free trade agreements concluded by the United States and in the bilateral agreements concluded by the European Union before 2006. A short overview is given of the obligations contained in free trade agreements concluded by EFTA States and Japan.

Part C of this thesis is dedicated to the European Union's intellectual property policy towards third countries, in particular developing countries. The research aimed at answering two research questions. First, how and why has a shift occurred in the approach followed by the European Union since the entering into force of the TRIPS Agreement? Second, how is the 'new approach' reflected in the recent bilateral trade agreements concluded by the European Union, in particular in the CARIFORUMEC EPA and the draft IP chapter of the India-EU Broad-based Trade and Investment Agreement ${ }^{19}$ Can differences in the legal obligations be identified which reflect the interests of the developing country partners? In a quest to answer these questions, Chapter 4 analyses the EU's intellectual property policy towards third countries at a policy level as well as on the basis of the provisions included in recent BTAs. Chapter 5 and 6 provide precise legal assessments of the nature and scope of the intellectual property provisions included in the CARIFORUM-EC EPA and the draft IP chapter of the India-EU BTLA. Chapter 7 offers a legal comparison of the provisions analyzed in both agreements and provides a summary table.

Part D presents the other side to the European Union's approach of protecting intellectual property in developing country partners. It addresses the preferences and influence of non-state actors in Jamaica and the CARIFORUM region with regard to the international regulation of intellectual property, in particular through the CARIFORUM-EC EPA. The case study tries to answer the following research questions. What influence can domestic non-state actors have on the final IP policy position adopted by a developing country in bilateral trade negotiations through participation in consultative processes? In particular, do they influence the country's policy choice to engage in bilateral negotiations instead of or in addition to multilateral negotiations on matters of intellectual property protection? Chapter 8 specifies the methodology and theoretical framework used. Chapter 9 is a background chapter about the economic development of Jamaica and its intellectual property legislation. Chapter 10 illustrates the policy-making processes on intellectual property matters in the region CARIFORUM and Jamaica. It provides an assessment of the role different state actors, involved in the processes play, which non-state

19 Broad-based Trade and Investment Agreement between the European Union and India, July 2010 [hereinafter draft India-EU BTIA], see M. Aisola, "New Release of IPR Chapter of India-EU Free Trade Agreement" The Centre for Internet \& Society, 2011, available at <http://cis-india.org/advocacy/ipr/blog/july-2010-ipr-india-eu-fta $>$ accessed on 01.10 .2012 . 
actors in the region and Jamaica have some interest in the regulation of intellectual property, and which mechanisms are in place for non-state actors to influence the national and regional policy positions on IP matters. Chapter 11 assesses whether any of the analyzed non-state actors were able to influence the final IP policy position adopted by the region and Jamaica during the EPA negotiations. Chapter 12 offers the main findings and conclusions for the case study.

Part E contains the conclusions and the summary of the research.

\section{Sources, Approaches and Methodology}

This research did not employ one methodology. In contrast, I used different types of sources, approaches and methods depending on the type of assessment carried out.

Part B reflects a historical and legal assessment of how the international system of intellectual property protection developed. I mainly relied on primary sources (national legislation) and secondary sources, such as monographs, journal articles and edited volumes, to illustrate the intellectual property system before the TRIPS Agreement entered into force. The provisions of the TRIPS Agreement were analyzed by using both primary sources (the TRIPS Agreement, relevant jurisprudence by the WTO Dispute Settlement Body) and secondary sources (legal commentaries on the TRIPS Agreement, official documents, monographs, journal articles, edited volumes). The analysis was guided by the aim of highlighting the most important principles, standards of obligations and minimum and maximum ceilings, which are particularly relevant for developing countries and/or which have been subject to intense debate during the negotiations. The examination of the post-TRIPS developments in the international system of IP protection required the consultation of sources from various jurisdictions (international organizations, the United States, the European Union, EFTA and Japan). I analyzed the provisions of international post-TRIPS agreements on the basis of primary sources (the international treaties, European and national legislation) and secondary sources (official documents, official websites of the international organizations and governments, monographs, journal articles, edited volumes). In a comparative legal assessment, the differences with the TRIPS Agreement and with other post-TRIPS agreements were examined.

Part C contains two types of analysis, a policy-analysis and a legal assessment. For the policy-analysis of the intellectual property policy employed by the European Union towards third countries, I examined the European Union's major official strategy documents, plans and programmes as well as its practices. As a second type of analysis, I carried out a detailed legal assessment of the IP provisions of the CARIFORUM-EC EPA and the draft IP chapter of the India-EU BTIA. The sources used for the legal assessment involved primary sources (international treaties, European and national legislation, WTO jurisprudence) and secondary sources (official documents, official websites of the international organizations and governments, interview data, monographs, journal articles, edited volumes). The analysis was guided by a comparative approach of identifying the differences with the TRIPS Agreement and other recent European bilateral trade agreements. In addition, the research aimed at providing an indication in how far the negotiating partners of the European Union were able to preserve domestic policy space in order to take development concerns into account. 
The methodology used in Part D is explained in detail in Chapter 8 of this book. The case study of non-state actors' preferences in Jamaica and the CARIFORUM region has been based on a theoretical framework that combines the logic of two-level games, the logic of collective action and negotiation theory. The main hypotheses derived are the following two. First, the size of groups and the intensity of their preferences determine whether their preferences are reflected in the outcome. Second, the size of the domestic win-set determines the negotiating autonomy of the negotiator. The data on which the analysis is based was collected mainly through semi-structured interviews with approximately thirty state and non-state actors in the Caribbean region.

\section{Limitations}

A vigorous debate is reflected in the literature about the question as to whether bilateral trade agreements are a 'stumbling block' or a 'building block' of the multilateral system. ${ }^{20}$ Arguments in support of bilateral trade agreements, and therefore reflecting the original intention of including a regional integration exception in the GATT 1947, emphasize their role in facilitating more liberalization between its partners. Such liberalization at the bilateral level would create spin-offs for the multilateral system in the long run through the so-called principle of 'competitive liberalization'. However, during the last years, arguments against this belief have become dominant. When observing the increasing number of BTAs that are concluded while the Doha Development Round is deadlocked, it seems that the failing trade talks at the multilateral level spur talks at the bilateral level, and not vice versa. ${ }^{21}$ However, this contribution will not focus on the question of benefits and disadvantages of bilateral trade agreements for multilateral negotiations. ${ }^{22}$ Instead, it will address the underlying preferences of non-state actors in the partner countries of bilateral trade agreements. An attempt is made to discover whether the choice for bilateral over, or in addition to, multilateral IP protection is reflected in the preferences of developing countries' societies, which would give these choices more legitimacy.

In spite of dealing with policy choices by the policy makers of developing countries, this book does not presume to judge whether choices by policy makers were right or

20 See P. Sutherland, The Future of the WTO - Addressing Institutional Challenges in the New Millennium (WTO, Report by the Consultative Board to the Director-General Supachai Panitchpakdi, Geneva, 2004), p. 19; R. Bhala, "Competitive Liberalization, Competitive Imperialism, and Intellectual Property" Liverpool Law Review, 2007, Vol. 28, 77-105; J. Bhagwati, Termites in the Trading System: How Preferential Agreements Undermine Free Trade (Oxford University Press, New York, 2008); Sutherland, The Future of the WTO, p. 81ff.; F.M. Abbott, "A New Dominant Trade Species Emerges: Is Bilateralism a Threat?" Journal of International Economic Law, 2007, Vol. 10 (3), 571-583; M. Khor, Bilateral and Regional Free Trade Agreements (Third World Network, Penang, 2008), pp. 3ff; N. Limão, "Are Preferential Trade Agreements with Non-trade Objectives a Stumbling Block for Multilateral Liberalization?" Review of Economic Studies, 2007, Vol. 74, 821-855; K. Heydon and S. Woolcock (eds.), The Rise of Bilateralism: Comparing American, European, and Asian Approaches to Preferential Trade Agreements (United Nations University Press, Tokyo, 2009).

21 See Bhala, "Competitive Liberalization", p. 82.

22 See L. Crump, "Global Trade Policy Development in a Two-Track System" Journal of International Economic Law, 2006, Vol. 9 (2), 487-510. 
wrong for their societies. This book has not carried out a comprehensive economic impact assessment that can support particular choices over others. A cost-benefit analysis of this nature is very complex and goes well beyond the scope of this book. What this study does emphasize are 1) the preferences of non-state actors in developing countries with respect to the TRIPS-plus obligations under negotiation in a bilateral trade agreement and 2) how these preferences have been able to influence the policy-making process during the negotiations. Hence, the research focuses on the process rather than the content of policy choices made.

\section{Definitions}

Throughout this book, I use the term 'European Union' rather than the 'European Community' or the 'European Communities' in order to refer to the regional integration form of twenty-seven Member States. ${ }^{23}$ Since the entering into force of the Treaty of Lisbon ${ }^{24}$ on 1 December 2009, the European Community has ceased to exist and the European Union has become its successor. The previous 'pillar structure', which divided the competences internally between the European Union on the one hand and the European Community on the other hand, has been abolished. Even though some of the negotiating processes analyzed in this book took place before the entering into force of the Treaty of Lisbon, I will refer to the European Union as the relevant actor for conformity purposes. Only if the official name of an international treaty refers to the European Community as the negotiating party, the term 'European Community' has been used. One other exception is the reference to the European Union in the WTO context. Before the entering into force of the Treaty of Lisbon, not the European Union but the 'European Communities' and all Member States of the European Union were Members of the WTO. ${ }^{25}$ Where official documents of the W'TO Secretariat or jurisprudence of the WTO Dispute Settlement Body refer to the European Union as the 'European Communities', the latter term is used.

This book puts a spotlight on the IP preferences of "developing countries". The concept of developing countries is not very precise, yet commonly used by scholars and the international community. It encompasses a huge diversity of countries and insufficiently determines which stage of the vast spectrum of levels of development a country is currently at. For these reasons, the concept has become shallow. Nevertheless, I have chosen to use it due to a lack of better terminology and because of its wide use. When I refer to developing countries, I use the concept as a proxy for needy countries that have a rather small market size and have less political and

On 1 July 2013, Croatia will become its thirteenth Member State.

Treaty of Lisbon amending the Treaty on European Union and the Treaty Establishing the European Community, signed on 13 December 2007 in Lisbon, entered into force on 1 December 2009 (OJ C 306 of 17.12.2007, p. 1) [hereinafter Treaty of Lisbon].

25 See Art. XI of the Marrakesh Agreement Establishing the World Trade Organization, signed on 15 April 1994, entered into force on 1 January 1995, 33. I.L.M. 1144 (1994) [hereinafter WTO Agreement. At the time of the negotiations of the WTO Agreement, it was unclear whether the European Community had the necessary competence to conclude the WTO Agreement, or whether the other two Communities (Treaty establishing the European Coal and Steel Community, signed in Paris on 18 April 1961 and the Treaty establishing the European Atomic Energy Community, concluded in Brussels on 25 March 1957) had to be included. 
economic power in bilateral negotiations than their negotiating partner. In addition, countries with still developing economies cannot yet take advantage of all the benefits of a strong intellectual property system. Therefore, even though countries such as Brazil, Russia, India or China cannot be classified as needy in all aspects of their economy, important sectors of their economies do not yet benefit from strong IP protection. 

PART B: GLOBAL TRENDS IN

PROTECTING INTELLECTUAL

PROPERTY: MULTILATERAL, BILATERAL AND UNILATERAL APPROACHES 



\section{Chapter 1 : The International System of Protecting Intellectual Property pre-TRIPS}

\subsection{INTRODUCTION}

Over the last fifteen years, there has been a considerable rise in bilateral and regional trade agreements (RTAs). ${ }^{1}$ The main actor driving this development has been the United States, with other countries following suit. ${ }^{2}$ This proliferation ${ }^{3}$ of bilateral and regional trade agreements has not only taken place in areas concerning trade issues, such as trade in goods and services, but also in fields such as investment, trade facilitation, government procurement, environmental and labour standards, competition policy and, in particular, protecting intellectual property. ${ }^{4}$ In the 2006 update on the regional trade agreements notified to the WTO, staff members of the Trade Policies Review Division of the WTO Secretariat describe the increasing number of RTAs as a prominent feature of the multilateral trading system and as an important trade policy tool for virtually all WTO Members. ${ }^{5}$

The number of regional trade agreements notified before the establishment of the WTO and after its establishment confirms the claimed proliferation of regional trade agreements: during the years under the General Agreement on Tariffs and Trade 1947, ${ }^{6}$ 124 RTAs were notified, while during the WTO years (up until December 2006) 243 RTAs were registered. ${ }^{7}$ The most recent update of regional trade agreements in force

1 See WTO Secretariat, World Trade Report 2011, p. 61; M. Wilson, "Friend or Foe? Regional Trade Agreements and the WTO" ICTSD BRIDGES Monthly Review, 2008, Vol. 12 (1), 19-20, p. 19; S. Lester and B. Mercurio (eds.), Bilateral and Regional Trade Agreements: Case Studies (Cambridge University Press, Cambridge, 2009); Bhagwati, Termites in the Trading System; Abbott, "A New Dominant Trade Species Emerges", p. 571; M. Schaefer, "Ensuring That Regional Trade Agreements Complement The WTO System: US Unilateralism a Supplement to WTO Initiatives?" Journal of International Economic Law, 2007, Vol. 10 (3), 585-603, p. 585; H. Gao and C.L. Lim, "Saving the WTO From the Risk of Irrelevance: The WTO Dispute Settlement Mechanism as a 'Common Good' for RTA Disputes" Journal of International Economic Law, 2008, Vol. 11 (4), 899-925, p. 899.

2 The European Union, the European Free Trade Association and Japan have concluded several bilateral trade agreements lately. See sections 3.3 and 3.4.

3 See R.V. Fiorentino, L. Verdeja and C. Toqueboeuf, The Changing Landscape of Regional Trade Agreements: 2006 Update (WTO, Geneva, 2007) [Discussion Paper No. 12], p. 2.

$4 \quad$ See Wilson, "Friend or Foe?", p. 19.

$5 \quad$ RTAs notified to the WTO include free trade agreements, customs unions or partial scope agreements in the areas of goods and services. They include the notifications made under Art. XXIV of the GATT 1994, Art. V of the GATS, the Enabling Clause, as well as accessions to existing RTAs. However, these agreements are not limited to the areas of goods and services but also contain, in the majority of cases, rules for the protection of IPRs. Eighty-four percent of the notified RTAs in force as of December 2006 are FTAs. According to the authors of the report, this reflects the fact that FTAs do respond best to the needs of trading partners nowadays, being the clearly preferred option. See Fiorentino, Verdeja and Toqueboeuf, The Changing Landscape of Regional Trade Agreements, p. $1 \mathrm{ff}$.

6 General Agreement on Tariffs and Trade, signed on 30 October 1947, 55 U.N.T.S. 184 [hereinafter GATT 1947].

7 See Fiorentino, Verdeja and Toqueboeuf, The Changing Landscape of Regional Trade Agreements, p. 4. 
shows that between January 2007 and September 2012, another hundred regional trade agreements have been notified to the WTO. ${ }^{8}$ This amounts to an annual average of twenty notifications for the WTO years (from 1995 until September 2012) and less than three regional trade agreements notifications per year during the fortyseven years of the GATT 1947 regime (from 1947 until 1994). On average, each WTO Member participates in over twelve regional trade agreements. ${ }^{9}$ Furthermore, the World Trade Report 2011 suggests that the regional trade agreements, particularly those still at a proposal stage, reflect a significant increase in bilateral RTAs (compared with plurilateral) as well as in cross-regional RTAs (compared with intraregional). ${ }^{10}$ In other words, we can observe a

"shift from the traditional concept of regional integration among neighbouring countries to partnerships driven by strategic (political and economic) considerations that are not necessarily related to regional dynamics." 11

When looking at the type of partners involved in such regional trade agreements, it is evident that the majority of the regional trade agreements in force are among developing countries. Two-thirds of all regional trade agreements are South-South agreements, while the agreements concluded between a developing and a developed country amount to one-quarter. ${ }^{12}$ Most recent North-South agreements include references to W'TO-plus issues, including the protection of intellectual property. ${ }^{13}$

While the proliferation of bilateral agreements has been significant in recent years, efforts to conclude multilateral trade agreements have become increasingly difficult at various forums, prominently at the WTO. ${ }^{14}$ This could prompt the conclusion that WTO Members currently prefer to regulate their trade relations at the bilateral level, opposed to the multilateral level. However, such periods of preference for one level, in the present case the bilateral, instead of another level, the multilateral, are not new. In fact, 'regime shifting' is an important strategy that Laurence Helfer defines as an

"attempt to alter the status quo ante by moving treaty negotiations, lawmaking initiatives, or standard setting activities from one international venue to another."15

See WTO Secretariat, Regional Trade Agreements Information System (2012), available at $<$ http://rtais.wto.org/UI/PublicMaintainRTAHome.aspx> accessed on 27.09.2012. See WTO Secretariat, World Trade Report 2011, p. 55.

See ibid., p. 59 and 61.

Ibid., p. 61.

See ibid., p. 56.

See ibid., p. 62; Fiorentino, Verdeja and Toqueboeuf, The Changing Landscape of Regional Trade Agreements, p. 13.

The DOHA Development Agenda, which began in 2001, has been stalled since July 2008. See WTO Secretariat, "Day 9: Talks collapse despite progress on a list of issues" WTO 2008 News Items (Geneva, 29 July 2008). The Director-General of the WTO, Pascal Lamy, has referred to the struggle of multilateralism in all spheres of global cooperation in his opening speech of the WTO's Public Forum 2012 on 24 September 2012. See Speech by Lamy, Multilateralism is struggeling.

5 L.R. Helfer, "Regime Shifting: The TRIPs Agreement and New Dynamics of International Intellectual Property Lawmaking" The Yale Journal of International Law, 2004, Vol. 29 (1), 1-83, p. 14. For further discussion of forum shifting in the area of IP, 
States make use of this strategy of regime-shifting (or elsewhere commonly referred to as forum shifting $)^{16}$ when they are seeking to enhance their bargaining power. ${ }^{17}$

In the following, the development of the international protection of intellectual property ${ }^{18}$ will be analyzed. It illustrates the various shifts of forums that have taken place in order to regulate the protection of intellectual property. Starting with the territorial protection of intellectual property (section 1.3), I identify a phase of bilateral protection (section 1.4), followed by a phase of multilateral protection (section 1.5). With the conclusion of the TRIPS Agreement and after a short phase of bilateral and unilateral protection in between, that multilateral phase has developed into a global regime $^{19}$ of protecting intellectual property (section 1.6). Before elaborating each phase in detail, a few definitions are defined first.

\subsection{DEFINITIONS}

In the preceding paragraph the term 'regional' has been used in order to describe different kinds of agreements concluded between two or more parties. There are two factors according to which these agreements can be distinguished: 1) the number of countries involved in the agreement; and 2) the location of countries in the same region. First, the term 'regional' does not specify how many actors are parties to the agreement; it can be two or more parties. Second, the term regional classically implies the notion of geographical proximity. The definition by the Oxford English Dictionary confirms that the crucial element of the meaning is "pertaining to, connected with, a particular region or district." The general definition of the concept 'regional trade agreements' used by the WTO Secretariat, however, is defined much broader. It refers to agreements between countries "not necessarily belong[ing] to the same geographical region." 20 In other words, RTAs in the context of the WTO can either be concluded between two or more parties in one region or between parties

see also J. Braithwaite and P. Drahos, Global Business Regulation (Cambridge University Press, Cambridge, 2000), p. 564-71; Mercurio, "TRIPS-Plus Provisions in FTAs". available at <www.grain.org> accessed on 15.11.2012; Braithwaite and Drahos, Global Business Regulation.

17 See P. Yu, "Currents and Crosscurrents in the International Intellectual Property Regime" Loyola of Los Angeles Law Review, 2004, Vol. 38, 323-443, p. 412.

18 The term "intellectual property protection" used in the remainder of this book covers a broad variety of rights, such as the protection of copyright, the sui generis protection of databases, the protection of geographical indications, industrial designs, layout designs of integrated circuits, plant varieties, uitility models trade secrets, undisclosed information and unfair competition. The historical distinction between literary and artistic property versus industrial property is not followed in this book. For a discussion on this distinction, see J. Chasen Ross and J. Wasserman, "Trade-Related Aspects of Intellectual Property Rights" in T.P. Stewart (ed.), The GATT Uruguay Round: A Negotiating History (1986-1992), Vol 2 (Kluwer Law and Taxation Publishers, Deventer, The Netherlands, 1993), 2241-2335, p. 2246; Yu, "Currents and Crosscurrents in the International Intellectual Property Regime", p. 324, footnote 2.

19 For an explanation why the most recent phase is called global, see section 2.1.

20 See WTO Secretariat, Scope of RTAs (2012), available at <http://www.wto.org/english/tratop_e/region_e/scope_rta_e.htm> accessed on 09.05.2012. 
from different regions. The definition of regional trade agreement used by the WTO is overly broad with regard to both factors for the purpose of this thesis. ${ }^{21}$

I propose to use a narrow definition of regional trade agreements which only includes agreements that are concluded by more than two parties located in the same region. ${ }^{22}$ Examples are the classic regional integration agreements, such as the constituting treaties establishing the European Economic Community ${ }^{23}$ and the European Union, ${ }^{24}$ the North American Free Trade Agreement ${ }^{5}$ (NAFTA), the Association of Southeast Asian Nations ${ }^{26}$ (ASEAN) and the Southern Common Market $^{27}$ (MERCOSUR). ${ }^{28}$ Following this proposition, the term 'regional trade agreement' reflects the notions of plurality of actors and geographical proximity.

Throughout this book, I will refer to bilateral, plurilateral and multilateral trade agreements. These terms make a clear distinction between agreements involving two actors, more than two actors and a great many actors. The choice for this terminology has been made for two reasons. First, the concepts used emphasize the criterion of how many actors are parties to an agreement. Since this research aims at assessing choices made by countries between bilateral forums and multilateral forums, the number of actors is crucial. Second, in the context of most trade agreements that are dealt with in this research, the parties are not located in the same region. Therefore, the term 'regional' is not deemed appropriate. Even in cases where the European Union concludes agreements with another form of regional integration, which consists of a number of countries, these agreements would still be characterized as bilateral agreements. The two forms of regional integration are each a party to the agreement. The fact that in certain agreements the members of the regional integration form are also parties to an international agreement (the Member

21 Surely, the meaning of a term can change over time. However, also including crossregional relations into the meaning of the term "regional" seems to deprive the term of a meaningful definition.

Arguably, the first element of the narrow definition of regional trade agreements, namely that there are more than two parties to the agreement, should be dealt with in a flexible manner. Also an agreement between two countries could be a regional agreement. However, the majority of regional integration agreements exceed the number of two parties to the agreement. Treaty establishing the European Economic Community, signed in Rome on 25 March 1957, entered into force on 1 January 1958, 298 U.N.T.S. 3. Treaty on European Union, signed in Maastricht on 7 February 1992, entered into force on 1 November 1993, (OJ C 191 of 29 July 1992), 31 I.L.M. 253 (1992).

North American Free Trade Agreement, signed on 17 December 1992 and entered into force on 1 January 1994 between the United States, Canada and Mexico, 32 I.L.M 289 (1993) and 32 I.L.M 612 [hereinafter NAFTA].

Treaty of Amity and Cooperation on Southeast Asia, signed on 24 February 1976 in Bali, entered into force on 21 June 1976, see Association of Southeast Asian Nations, Treaty of Amity and Cooperation in Southeast Asia (1976), available at <http://www.aseansec.org/5047.htm> accessed on 04.10.2012.

Treaty establishing a Common Market between the Argentine Republic the Federative Republic of Brazil, the Republic of Paraguay and the Eastern Republic of Uruguay, adopted at Asunción on 26 March 1991, entered into force on 29 November 1991, 2140 U.N.T.S. I-37341.

These regional integration forms are not analyzed in this book. The focus rather lies on recent agreements that are concluded between mostly two parties and who are not situated in the same region. 
States of the European Union, together with the European Union and/or the European Community, are parties to the so-called 'mixed agreements' ${ }^{29}$ ) does not affect the inherently bilateral nature of the agreement.

Many of the issues covered in bilateral trade agreements are WTO-plus provisions. ${ }^{30}$ The term WTO-plus is used to describe provisions that differ from the nature and level of WTO rules in one of the following two ways: 1) WTO Members have not agreed to negotiate or have not concluded multilateral rules in a particular issue area in the framework of the WTO, and hence the rules contained in a bilateral or regional trade agreement deal with a new issue; or 2) the BTA imposes obligations that go beyond existing WTO rules in a certain issue area. The first category of provisions mainly concerns areas of economic relations for which the WTO framework does not yet provide general multilateral rules, ${ }^{31}$ such as on investment, public procurement, environmental and labour standards, competition, finance, insurances. These types of rules so far have not been regulated in the WTO framework. When looking at the latter category of WTO-plus rules, one type of such rules are the rights and obligations in the area of protecting intellectual property rights. The WTO already deals with IP rules in the TRIPS Agreement, which is a multilateral agreement annexed to the Agreement Establishing the World Trade Organization [hereinafter the WTO Agreement. ${ }^{32}$ To the extent that the provisions included in bilateral trade agreements go beyond the standard set in the TRIPS Agreement, they are called TRIPS-plus provisions.

While most commentators generally refer to TRIPS-plus provisions, ${ }^{33}$ Peter Yu has suggested making a distinction between three different types of provisions: TRIPSplus, TRIPS-extra and TRIPS-restrictive. ${ }^{34}$ Accordingly, TRIPS-plus provisions are more extensive standards of intellectual property protection and enforcement than contained in the TRIPS Agreement (e.g. extended period of copyright protection). TRIPS-extra provisions describe commitments in a new area of intellectual property rights not yet dealt with in the TRIPS Agreement (e.g. the protection of the content of databases). TRIPS-restrictive provisions do not increase the level of protection or add a new area of IP; they restrict the interpretation of existing TRIPS-rules, usually by eliminating a flexibility foreseen in the TRIPS Agreement (e.g. the obligation to

29 For an explanation of the concept "mixed agreements", see section 4.2.1.1 of this book.

$30 \quad$ See Wilson, "Friend or Foe?", p. 19.

31 The WTO framework contains two plurilateral agreements, one on trade in civil aircraft and another one on public procurement. These agreements are only binding on those WTO members that are party to these agreements. As they are not part of the body of WTO law that is multilaterally accepted, they are also not recognized as WTO rules for the matter of WTO-plus rules. Agreement Establishing the World Trade Organization, signed on 15 April 1994, 33 I.L.M 1144 (1004) [hereinafter WTO Agreement].

33 See Peter Drahos in P. Drahos, "BITs and BIPs - Bilateralism in Intellectual Property" Journal of World Intellectual Property, 2001, Vol. 4 (6), 791-808, p. 792/3; and Mohammed El Said in M. El-Said, "The European TRIPS-plus Model and the Arab World: From Co-operation to Association - A New Era in the Global IPRs Regime" Liverpool Law Review, 2007, Vol. 27, 143-174, p. 158.

34 See P. Yu, “The International Enclosure Movement” Indiana Law Journal, 2007, Vol. 82, 827-907, p. 867. 
become a party to the UPOV Convention, Act 1991)..$^{35}$ Even though it is useful to conceptualize TRIPS-plus provisions according to these three distinctions (and most scholars have done so by integrating them in their definitions of TRIPS-plus provisions), ${ }^{36}$ in the remainder of this book, the term TRIPS-plus provision is used in its broad sense, defined as covering the three elements highlighted by Peter Yu.

The term TRIPS-plus is often exclusively used in the context of bilateral trade agreements. However, TRIPS-plus provisions have not only occurred at the bilateral level, but also at the multilateral, plurilateral and unilateral level. As adjustments of intellectual property protection to the technological developments continue to take place, they are likely to result in stricter rules compared to the TRIPS Agreement, which was adopted in 1994. Examples of such adjustments are the WIPO Copyright Treaty (WCT) and the WIPO Performances and Phonograms Treaty (WPPT), adopted in Geneva on 20 December 1996 under the administration of the World Intellectual Property Organization (WIPO).37 The so-called 1996 WIPO Internet Treaties updated the international intellectual property regime by extending the multilateral system of protecting intellectual property to the Internet and new digital developments. ${ }^{38}$ However, the phenomenon of TRIPS-plus provisions is most apparent in recent bilateral trade agreements.

Parallel (even though with a slight time-lag) to the development of inserting TRIPSplus provisions in bilateral trade agreements, ever more BTA provisions also broaden the flexibilities provided for in the TRIPS Agreement. Examples of such provisions are the farmers' privilege ${ }^{39}$ in Article 149.1 of the CARIFORUM-EC EPA and the general exception in Article 224 of the CARIFORUM-EC EPA ${ }^{40}$ An example from the EU-Colombia-Peru FTA $A^{41}$ is Article 201 which emphasizes development-friendly

35 International Convention for the Protection of New Varieties of Plants, adopted in Paris on 2 December 1961, as revised in Geneva on 10 November 1972, on 23 October 1978, and on 19 March 1991, 815 U.N.T.S. 89 [hereinafter UPOV Convention, Act 1991]. See Mercurio, "TRIPS-Plus Provisions in FTAs", p. 219; R. Kampf, "TRIPS and FTAs: A World of Preferential or Detrimental Relations" in C. Heath and A. Kamperman Sanders (eds.), Intellectual Property in Free Trade Agreements (Institute of European Studies of Macau Intellectual Property, Hart Publishing, Oxford, 2007) 87125, p. 102; Vivas-Eugui, The Free Trade Area of the Americas, p. 4. The WIPO Copyright Treaty entered into force on 6 March 2002, 36 I.L.M. 65 (1997) [hereinafter WCT]. The WIPO Performances and Phonograms Treaty entered into force on 20 May 2002, 36 I.L.M. 76 (1997) [hereinafter WPPT]. An example of such new rights is Article 8 of the WCT and Article 15.4 of the WPPT. They grant right holders the right to authorize the digital transmission of their work as it falls under the concept of "communications to the public". This exception to the exclusive rights granted to plant breeders allows farmers to save, use and exchange protected farm-saved seed or propagating material. For further analysis, see section 5.3.2.7 of this book. The general exception is applicable to all chapters of the CARIFORUM-EC EPA (including the chapter on "Innovation and intellectual property"). See section 5.4 of this book.

The Trade Agreement between the European Union and its Member States and Colombia and Peru, [hereinafter EU-Colombia-Peru FTA] was initialled on 24 March 2011, see European Commission, "Press Release: Negotiators initial trade agreement between the EU, Colombia and Peru" (Brussels, 24 March 2011). The text used for this analysis is the initialled text from March 2011, see European Commission, Trade Agreement between the 
aspects of the protection of traditional knowledge, such as the obligation for patent applicants to submit a declaration of origin or source of the genetic resource. These exceptions go beyond the TRIPS Agreement in the sense of providing broader and more far reaching flexibilities. They have not been included in the terminology TRIPS-plus in order to avoid any confusion between rules that impose stricter rules and those that provide more flexibility compared to the TRIPS Agreement. So far, no new term has been introduced to refer to the latter type of provisions that broaden the flexibilities of the TRIPS Agreement.

\subsection{The Territorial Protection of Intellectual Property}

The first forms of intellectual property protection that come close to our current intellectual property system can be traced back to the system of royal privileges in the fifteenth century. It was the Venetian Republic that developed the first patent law, followed by England, France and later the United States. ${ }^{42}$ Also the development of copyright law had its early origins in Venice in the late fifteenth century. ${ }^{43}$ This system of privileges in the field of copyright law developed into two systems of modern copyright law in different parts of Europe. These different approaches to copyright law were the copyright system in the United Kingdom (and other Commonwealth countries), which was based on an economic approach, and the authors' right system in Continental Europe, in which the concept of a right was linked to the author's personality. The first codifications of these approaches were found, for the copyright system, in the English Statute of Anne in the early eighteenth century, ${ }^{44}$ and for the author's right system in the French Laws of 1791 and $1793 .{ }^{45}$

The main difference between the copyright system and the author's right system was developed in the French jurisprudence which created two categories of rights for authors: economic rights (i.e. the rights to control commercial or other forms of exploitation of works) and moral rights (i.e. the rights associated with the author's personality and integrity of his or her work). ${ }^{46}$ The English copyright system lacked the latter concept of moral rights as it was designed to enable authors to control and

European Union and Colombia and Peru (2011), available at <http://trade.ec.europa.$\mathrm{eu} / \mathrm{doclib} / \mathrm{press} /$ index.cfm?id=691> accessed on 15.11.2012.

For an overview of the origins of intellectual property law, see C. May, "The Venetian Moment: New Technologies, Legal Innovation and the Institutional Origins of Intellectual Property" Prometheus, 2002, Vol. 20 (2), 159-179; P.S. Ladas, Patents, Trademarks, and Related Rights: National and International Protection (Harvard University Press, Cambridge, 1975); P.S. Ladas, The International Protection of Literary and Artistic Property (Harvard studies in international law, Macmillan, New York, 1938); F.D. Prager, "A History of Intellectual Property from 1545 to 1787" Journal of the Patent Office Society, 1944, Vol. 26, 711-760.

43 Most authors trace copyright back to the patent granted to Johann Speyer for his printing press in 1469. See J. Feather, Publishing, Piracy and Politics: An Historical Study of Copyright in Britain (Mansell, London, 1994).

$44 \quad$ See Act 8 Ann., c. 19 (1710).

45 See Loi des 13/19 janvier 1791 relative aux spectacles, Loi des 19/24 juillet 1793 relative aux droits de propriété des auteurs d'écrits en tout genre, des compositeurs de musique, des peintres et des dessinateurs.

46 See J. Sterling, World Copyright Law: Protection of Authors' Works, Performances, Phonograms, Films, Video, Broadcasts and Published Editions in National, International and Regional Law (Sweet \& Maxwell, London, 1998), p. 12. 
make money out of the exploitation of their work, rather than protecting the integrity of their work.$^{47}$ Notwithstanding, these early forms of protecting intellectual property were very different from today's complex systems. The protection of intellectual property did not become a major issue until the nineteenth century.

The nineteenth century saw the proliferation of laws in the different intellectual property areas, such as the laws of patent, trade mark, copyright and design protection. This development took place primarily in Europe, with much borrowing and cross-pollination between states. These laws also made their way into the legal systems of European colonies, such as those in Africa ${ }^{48}$ and Australia. ${ }^{49}$ The protection granted through these laws was limited to the territory of each of them.

The territorial protection of intellectual property is based on the principle of territoriality, a principle that is still today fully respected. This principle stipulates that

"intellectual property rights do not extend beyond the territory of the sovereign that granted the rights". ${ }^{0}$

Thus, if state A granted protection to authors and inventors in its own territory, these rights did not have any effect in state B. Such a system on rights that would not regulate the protection of foreign right holders proved to be inadequate to the new reality of the industrial revolution: rapid improvements in transportation and communication and an accelerated production of knowledge-intensive goods, such as books. ${ }^{51} \mathrm{It}$ is in the late nineteenth century that the need for international cooperation between countries arose in order to create common rules which apply to the protection of intellectual property.

\subsection{From Bilateral to Multilateral Protection of INTELLECTUAL PROPERTY}

The increasing interest in international cooperation expressed itself first through bilateral agreements between major European countries. In the area of copyright, typical features of such agreements were the reciprocity provisions. These provisions assured that each party to the agreement protected the creative efforts and works of the nationals of both parties. By the late nineteenth century, a comprehensive network of bilateral copyright conventions had developed between European and Latin American states. ${ }^{52}$ In addition to bilateral copyright agreements, national acts were enacted that granted copyright protection to foreign works. For example, the

\footnotetext{
$47 \quad$ See ibid., p. 15.

48 See R. Roberts and K. Mann, "Law in Colonial Africa" in R. Roberts and K. Mann (eds.), Law in Colonial Africa (Heinemann, Portsmouth, 1991), p. 3-58.

$49 \quad$ See Braithwaite and Drahos, Global Business Regulation, p. 58.

$50 \quad$ See ibid., p. 58.

51 See Ladas, Patents, Trademarks, and Related Rights: National and International Protection, p. 12.

52 See S. Ricketson, "The Birth of the Berne Union" Columbia-VLA Journal of Law and the Arts, 1986, Vol. 11, 9-32, p. 15.
} 
United Kingdom passed the International Copyright Act of 1838 and 1844,53 which protected works first published outside the United Kingdom on the basis of reciprocity. ${ }^{54}$ An exception to the reciprocity requirement was the French International Copyright Act of 1852,55 which granted copyright protection to foreign works and foreign authors without the requirement of reciprocity. ${ }^{56}$ Some authors have noted that this decree has accelerated considerably the movement towards a multilateral copyright system..$^{7}$

The manner of protecting copyright chosen by the United States was somehow different from that pursued by European states. The United States denied protection to foreigners and, in essence, made it possible for its own nationals to free ride on the protection for foreign authors granted by European states. The U.S. Copyright Act of $1790^{58}$ stipulated copyright protection only for citizens and residents of the United States. Much of the pirating that countries, such as the United Kingdom, were trying to combat was taking place in the United States. ${ }^{59}$

In contrast to its reluctance to cooperate internationally in the field of copyright protection, the United States was one of the driving forces of international cooperation in the field of industrial property. Similarly to the bilateral copyright treaties, European states started cooperating with each other through bilateral treaties that regulated industrial property. By 1883, there were at least sixty-nine bilateral agreements, the majority of which dealt with trade marks and designs or models. ${ }^{60}$ The international protection of patents however remained inadequate. Overall, the network of bilateral treaties in the field of copyright and industrial property and its lack of uniformity led to the common understanding of states to create multilateral pillars for regulating the protection of intellectual property.

53 International Copyright Act of 1838, 1 \& 2 Vict. c.59 and International Copyright Act of 1844, 7 \& 8 Vict., c.12, available at <http://www.copyrighthistory.org/> accessed on 28.11.2012.

$54 \quad$ See Braithwaite and Drahos, Global Business Regulation, p. 59.

55 See Rapport et Décret sur la Contrefacon d'Ouvrages étrangers, available at <http://www.copyrighthistory.org/> accessed on 28.12.2012.

56 For an examination of the reasons for the promulgation of this decree, see P. Yu, "The Copyright Divide" Cardozo Law Review, 2003, Vol. 25, 331-445, p. 347.

57 See Yu, "Currents and Crosscurrents in the International Intellectual Property Regime", p. 336; B.A. Ringer, "The Role of the United States in International Copyright - Past, Present, and Future" Georgetown Law Journal, 1968, Vol. 56, 10501079, p. 1052.

58 U.S. Copyright Act 1790, An Act for the Encouragement of Learning, by securing copies of maps, charts, and books, to the authors and proprietors of such copies, during the times therein mentioned, 1 Stat. 124 (1790), available at <www.copyrighthistory.org/> accessed on 28.11.2012.

59 See B. Sherman, "Remembering and Forgetting: The Birth of Modern Copyright Law" in D. Nelken (ed.), Comparing Legal Cultures (Dartmouth, Aldershot, 1997) 237-266, p. 240.

60 See Ladas, Patents, Trademarks, and Related Rights: National and International Protection, p. 43 ff. 


\subsection{Multilateral System of Protecting Intellectual Property}

The development of a multilateral system of protecting intellectual property was initiated by the adoption of the Paris Convention for the Protection of Industrial Property of 1883 [hereinafter Paris Convention] ${ }^{61}$ and the Berne Convention for the Protection of Literary and Artistic Works of 1886 (hereinafter Berne Convention). ${ }^{62}$ These two multilateral pillars were further formalized by the creation of the United International Bureau for the Protection of Intellectual Property (BIRPI), the predecessor of the World Intellectual Property Organization (hereinafter WIPO). It was primarily under the framework of this International Bureau, and later the WIPO, that the twentieth century saw the proliferation of multilateral treaties in the field of intellectual property protection. The intellectual property regime developed in areas such as trade marks, designs, patents, micro-organisms, indications of origins, performance, audiovisual works and the Internet. Outside the WIPO framework, the intellectual property regime expanded to areas such as the protection of plant varieties, copyright protection and the protection of biological diversity.

\subsubsection{The Paris Convention}

The Paris Convention for the Protection of Industrial Property was initiated by an international exposition of inventions which was planned to be held in Vienna in 1873. Foreign inventors were reluctant to participate in the exposition because there was no international system in place that would protect their innovations from being copied. They feared that the Austrian public would benefit tremendously from this exposition, with no benefits for the foreign inventors. It was the American Foreign Ministry that requested a special law from the Austrian Foreign Office to temporarily protect inventions, trade marks and patents or models. ${ }^{63}$ This request gave rise to the Congress for Patent Reform in 1873 before the exposition. Although limited to the area of patent protection, the Congress laid down the major principles that would achieve a uniform patent legislation in all countries. ${ }^{64}$ The Congress' work was taken up in two conferences in 1878 and 1880 and the scope was expanded to include matters beyond patents, such as trade marks, designs and models, photographic work, trade names and industrial rewards. ${ }^{65}$ Also, it was suggested that the conference should create a union that would establish the general principles for securing the protection of industrial property. ${ }^{66}$ After some heated discussions, the delegates

61 Paris Convention for the Protection of Industrial Property, adopted in Paris on 20 March 1880, entered into force on 7 July 1884; last revised at the Stockholm Revision Conference, adopted in Stockholm on 14 July 1967 and entered into force 26 April 1970, 828 U.N.T.S. 305 [hereinafter Paris Convention].

Berne Convention for the Protection of Literary and Artistic Works, adopted in Paris on 24 July 1971, as amended on 28 September 1979, Stockholm Treaty Doc. No. 99-27 (1986) [The 1979 amended version does not appear in U.N.T.S. or I.L.M.] [hereinafter Berne Convention]. See Ladas, Patents, Trademarks, and Related Rights: National and International Protection, p. 60.

64 See ibid., p. 60.

65 This list is very similar to the one finally incorporated into the Paris Convention, Article 1.2: patents, trademarks, industrial designs, trade names, appellations of origin, and utility models.

66 See Ladas, Patents, Trademarks, and Related Rights: National and International Protection, p. 61 and 63 . 
adopted the draft Convention in 1880; in 1883, the Paris Convention was finally approved and entered into force on 8 July 1884.

The main goals of the Paris Convention can be summarized in the following features. ${ }^{67}$ First, it created a union that was independent from its membership. Second, instead of the principle of reciprocity, the Convention was built on the principle of nondiscrimination, in particular the national treatment obligation. Third, it recognized the priority of rights, which enabled inventors to rely on the date of application in their home countries when applying for patents in foreign countries. Fourth, the Convention circumvented some difficult issues by affirming the independence of the patents doctrine, which acknowledged that patents granted in one country are independent in time and validity from patents granted in other countries. ${ }^{68}$ Since it entered into force, the Paris Convention has been subject to six revisions that clarified and expanded the Convention's scope. The revisions took place in 1900, 1911, 1925, 1934, 1958, and the last in 1967 in Stockholm.

\subsubsection{The Berne Convention}

The Berne Convention for the Protection of Literary and Artistic Works was the result of several intergovernmental conferences held by the International Literary Association in the beginning of the 1880 s. This association was made up of different literary societies and authors as well as artists. On the proposal of a member of the German Publishers Association to create a union, a conference was convened in September 1883 in Berne. ${ }^{69}$ The conference produced a draft convention of ten articles, which formed the basis of discussions for the conferences that would take place over the following three years. Eventually, at the conference on 6 September 1886, the Berne Convention was signed. It entered into force on 5 December 1887.

The Convention constituted the first truly multilateral copyright treaty in history. ${ }^{70} \mathrm{It}$ contains principles similar to those adopted in the Paris Convention. For example, the Berne Convention also created a union independent from its membership and chose the principle of national treatment instead of the principle of reciprocity. A difference with the Paris Convention is that Article 20 of the Berne Convention clearly establishes the principle of minimum protection, leaving member states free to seek more extensive protection through special agreements. In contrast, Article 19 of the Paris Convention, the counterpart to Article 20 of the Berne Convention, makes no reference to the principle of minimum protection. It merely stipulates the right of member states to enter into special agreements for the protection of industrial property, insofar as they do not contravene the Convention.

As was the case with the Paris Convention, the Berne Convention also faced major substantial revisions in the years 1908, 1928, 1948 and in 1971. The final revision

67 For a comprehensive discussion of the Paris Convention, see ibid.

68 See $\mathrm{Yu}$, "Currents and Crosscurrents in the International Intellectual Property Regime”, p. 352.

69 See Ricketson, "The Birth of the Berne Union”, p. 19.

70 See Ringer, "The Role of the United States in International Copyright", p. 1053. For a comprehensive discussion of the Berne Convention, see generally S. Ricketson, The Berne Convention for the Protection of Literary and Artistic Works: 1886-1986 (Kluwer, London, 1987). 
conference in 1971 took place in Paris and was based on the Stockholm Act, which was the outcome of the conference four years before, in 1967. ${ }^{71}$ The Stockholm Act was never ratified because of diverging interests between developed and developing countries and the strong reflection of developing countries' interests in the final act. The Paris Act, however, revised the demands of developing countries significantly and therefore made the rest of the Stockholm Act acceptable to developed countries.

\subsubsection{The establishment of the BIRPI and the WIPO}

When the Paris and the Berne Union came into existence, each Union established separate secretariats in order to carry out the administrative tasks of the Unions, such as organizing the meetings of the Member States. In 1893, the two secretariats were united to form what has been referred to as BIRPI, the French acronym for United International Burean for the Protection of Intellectual Property. BIRPI was placed under the authority of the government of the Swiss Confederation and based in Berne. ${ }^{72}$ It can be described as the predecessor of the World Intellectual Property Organization, which replaced BIRPI in 1967. With the establishment of the new organization WIPO, mainly structural and administrative reforms were initiated. ${ }^{73}$ Importantly, WIPO acquired a secretariat that was answerable to the Member States.

BIRPI had already moved to Geneva in 1960 to be closer to the United Nations and other international organizations. The close link between WIPO and the United Nations was formalized in 1974, when WIPO became a specialized agency of the United Nations. Its mandate became to administer international treaties on intellectual property, recognized by the Member States of the United Nations, to provide assistance to signatories in promulgating intellectual property laws, and to seek harmonization of national laws. The rise of the international organizations (BIRPI and WIPO) was accompanied by the rise of multilateral treaty-making. Since the establishment of the BIRPI, more than twenty multilateral treaties dealing with the protection of intellectual property have come into force and are now administered by the International Bureau of WIPO. These treaties deal with matters of industrial property as well as copyright.

\subsubsection{Multilateral Treaties Administered by WIPO}

WIPO currently administers twenty-five treaties, including the Convention Establishing the World Intellectual Property Organization (hereinafter WIPO Convention). ${ }^{74}$ The other twenty-four treaties deal with the protection of industrial property on the one hand, and with the protection of copyright and related rights on the other hand. Another categorization of these treaties can be made according to what these treaties try to

71 The Stockholm conference will be of importance again in a later context. See section 1.6.2 of this book on the paralysis of WIPO.

72 This was in accordance with the practice of the 1880 s, see E.M. Braderman, "The World Intellectual Property Organization and the Administrative Reorganization of BIRPI" Patent, Trademark and Copyright Journal of Research and Education, 1968, Vol. 12, 673-689, p. 674.

73 For a comprehensive discussion of the main reforms introduced by the Convention Establishing the World Intellectual Property Organization, see ibid., p. $677 \mathrm{ff}$.

$74 \quad$ Convention Establishing the World Intellectual Property Organization, adopted in Stockholm on 14 July 1967, entered into force on 26 April 1970, amended on 28 September 1979, 828 U.N.T.S. 3 [hereinafter WIPO Convention]. 
regulate in a particular area of intellectual property. There are three categories of instruments: 1) standard-setting instruments, 2) registration instruments, and 3) classification instruments. In the area of copyright and related rights, one finds only standard-setting instruments; there are no copyright treaties that have established systems of registration or classification. However, for the different types of industrial property, one can find standard-setting, registration and classification instruments. Table 1 gives an overview of the treaties listed according to these categories.

Table 1: Treaties administered by WIPO according to area of IP and nature of instrument

\begin{tabular}{|c|c|c|c|}
\hline & Standard-setting & Registration & Classification \\
\hline \multirow[t]{8}{*}{ Copyright } & $\begin{array}{l}\text { Berne Convention for the Protection of } \\
\text { Literary and Artistic Works (1886) }\end{array}$ & & \\
\hline & $\begin{array}{l}\text { Rome Convention for the Protection of } \\
\text { Performers, Producers of Phonograms and } \\
\text { Broadcasting Organizations (1961) } \\
\text { [hereinafter Rome Convention] }\end{array}$ & & \\
\hline & $\begin{array}{l}\text { Geneva Convention for the Protection of } \\
\text { Producers of Phonograms against } \\
\text { Unauthorized Duplication of Their } \\
\text { Phonograms (1971) [hereinafter Geneva } \\
\text { Convention] }\end{array}$ & & \\
\hline & \begin{tabular}{|l|} 
Brussels Convention Relating to the \\
Distribution of Programme-Carrying Signals \\
Transmitted by Satellite (1974) \\
[hereinafter Brussels Convention] \\
\end{tabular} & & \\
\hline & WIPO Copyright Treaty (WCT) (1996) & & \\
\hline & $\begin{array}{l}\text { WIPO Performances and Phonograms } \\
\text { Treaty (WPPT) (1996) }\end{array}$ & & \\
\hline & $\begin{array}{l}\text { Treaty on the International Registration of } \\
\text { Audiovisual Works (1989) }\end{array}$ & & \\
\hline & $\begin{array}{l}\text { Beijing Treaty on Audiovisual Performances } \\
(2012)\end{array}$ & & \\
\hline $\begin{array}{l}\text { Industrial } \\
\text { Property } \\
\end{array}$ & $\begin{array}{l}\text { Paris Convention for the Protection of } \\
\text { Industrial Property (1883) }\end{array}$ & & \\
\hline \multirow[t]{2}{*}{ Patents } & Patent Law Treaty (PLT) (2000) & \begin{tabular}{|l|} 
Patent Cooperation Treaty (PCT) \\
$(1970)$
\end{tabular} & $\begin{array}{l}\text { Strasbourg Agreement } \\
\text { Concerning the International } \\
\text { Patent Classification (1971) } \\
\text { [hereinafter Strasbourg } \\
\text { Agreement] }\end{array}$ \\
\hline & & $\begin{array}{l}\text { Budapest Treaty on the } \\
\text { International Recognition of the } \\
\text { Deposit of Microorganisms for the } \\
\text { Purposes of Patent Procedure } \\
\text { (hereinafter Budapest Treaty) } \\
\text { (1977) }\end{array}$ & \\
\hline \multirow[t]{2}{*}{$\begin{array}{l}\text { Trade } \\
\text { marks }\end{array}$} & Trademark Law Treaty (TLT) (1994) & $\begin{array}{l}\text { Madrid Agreement Concerning } \\
\text { the International Registration of } \\
\text { Marks (1891) [hereinafter } \\
\text { Madrid Agreement] }\end{array}$ & $\begin{array}{l}\text { Nice Agreement Concerning } \\
\text { the International } \\
\text { Classification of Goods and } \\
\text { Services for the Purposes of the } \\
\text { Registration of Marks (1957) } \\
\text { [hereinafter Nice } \\
\text { Agreement] }\end{array}$ \\
\hline & $\begin{array}{l}\text { Singapore Treaty on the Law of Trademarks } \\
\text { (2006) [hereinafter Singapore Treaty] }\end{array}$ & $\begin{array}{l}\text { Protocol Relating to the Madrid } \\
\text { Agreement Concerning the } \\
\text { International Registration of } \\
\text { Marks (1989) [hereinafter } \\
\text { Madrid Protoco] }\end{array}$ & \begin{tabular}{|l|} 
Vienna Agreement \\
Establishing an International \\
Classification of the Figurative \\
Elements of Marks (1973) \\
[hereinafter Vienna \\
Agreement]
\end{tabular} \\
\hline $\begin{array}{l}\text { Industrial } \\
\text { Designs }\end{array}$ & & $\begin{array}{l}\text { Hague Agreement Concerning the } \\
\text { International Deposit of Industriat } \\
\text { Designs (1925) [hereinafter } \\
\text { Hague Agreement] }\end{array}$ & $\begin{array}{l}\text { Locarno Agreement } \\
\text { Establishing an International } \\
\text { Classification for Industrial } \\
\text { Designs (1968) [hereinafter } \\
\text { Locarno Agreement }\end{array}$ \\
\hline
\end{tabular}




\begin{tabular}{|l|l|l|l|}
\hline $\begin{array}{l}\text { Geographical } \\
\text { Indications }\end{array}$ & $\begin{array}{l}\text { Madrid Agreement for the Repression of } \\
\text { Foods or Deceptive Indications of Source on }\end{array}$ & $\begin{array}{l}\text { Lisbon Agreement for the } \\
\text { Protection of Appellations of } \\
\text { Origin and their International } \\
\text { Registration }(1958) \text { [hereinafter } \\
\text { Lisbon Agreement }\end{array}$ & \\
\hline Others & $\begin{array}{l}\text { Nairobi Treaty on the Protection of the } \\
\text { Olympic Symbol (1981) }\end{array}$ & & \\
\cline { 2 - 4 } & $\begin{array}{l}\text { Treaty on Intellectual Property in Respect of } \\
\text { Integrated Circuits }(1989)^{75} \text { [hereinafter } \\
\text { Washington Treaty or IPIC Treaty] }\end{array}$ & & \\
\hline
\end{tabular}

Source: WIPO website, WIPO-Administered Treaties (2012) ${ }^{76}$

\subsubsection{Multilateral Treaties outside WIPO}

WIPO was not the only forum in which the intellectual property regime developed. Outside the framework of WIPO, important multilateral instruments were created that dealt with particular areas of intellectual property protection (plant variety protection and copyright protection - addressed in the remainder of this section) as well as with areas that are only related to intellectual property protection. IP protection is relevant to many other international regimes. Laurence Helfer distinguishes four international regimes where IP-lawmaking has taken place: biodiversity, plant genetic resources for food and agriculture, public health and human rights. ${ }^{77}$ However, the protection of intellectual property only received attention in these regimes after the TRIPS Agreement came into force. Before that, there was little concern about the relationship between biodiversity, plant genetic resources, public health and human rights on the one hand and intellectual property rights on the other.

After the entering into force of the TRIPS Agreement, new treaties or non-binding instruments were newly created or re-interpreted in order to set out their relationship with the instruments that protect intellectual property. The forums in which these developments have taken place include the following: the Convention on Biological Diversity $^{78}$ (CBD) in the area of biodiversity, the Food and Agriculture Organization

Note that this Treaty has not entered into force. It was opposed by the United States and Japan, the world's two largest producers of semiconductors, because of developing countries' insistence on a mechanism to issue non-voluntary licenses, because of concerns of the lack of compensation for innocent infringement and dissatisfaction with the dispute settlement mechanisms. The IPIC Treaty, however, is still of relevance as most of its substantive provisions were incorporated into the TRIPS Agreement in 1995 (see Article 35 of the TRIPS Agreement). Its partial incorporation into the TRIPS Agreement seems to have been acceptable to the United States and Japan because compulsory licensing provisions in the IPIC Treaty were left out. See generally C.A. Kukkonen, "The Need to Abolish Registration for Integrated Circuit Topographies under TRIPS" IDEA The Journal of Law and Technology, 1997, Vol. 38 (1), 105-137, p. 128-131. 
in the area of plant genetic resources, the World Health Organization in the public health regime and the United Nations ${ }^{79}$ in the field of Human Rights. ${ }^{80}$

\subsubsection{Plant Variety Protection}

The protection of plant varieties is one area in which international cooperation has been established outside of the WIPO framework. In the 1940s and 1950s, European countries adopted a wide range of approaches to protecting plant varieties. Britain and Denmark denied any protection; Italy, France and Belgium allowed patents on plant varieties; other countries, such as the Netherlands, Austria and Germany, created specific systems of protection. ${ }^{81}$ In 1961, the International Convention for the Protection of New Varieties of Plants (hereinafter UPOV Convention) ${ }^{82}$ was adopted by Germany, the Netherlands and the United Kingdom. Mainly two international nongovernmental organizations promoted its adoption: the International Association for the Protection of Intellectual Property and the International Association of Plant Breeders for the Protection of Plant Varieties (ASSINSEL).

These two organizations shared the view that the protection of plant varieties should be regulated internationally. Two reasons appear to have been determinative in pursuing the harmonization of plant variety legislation: 1) relatively homogeneous climatic and agronomic conditions in Europe, and 2) postwar moves towards enhanced integration of West European countries. ${ }^{83}$ On the request of ASSINSEL, an International Conference for the Protection of New Varieties of Plants was organized by the French Government in May 1957 in Paris. A Committee of Experts was set up to determine various problems, among others whether the Plant Breeders' Rights system should be established under the framework of the Paris Convention, or whether it was necessary to have a separate convention. ${ }^{84}$ Eventually, the Committee of Experts decided in favour of a separate convention. At the second meeting of the International Conference for the Protection of New Varieties of Plants in November 1961, the UPOV Convention was adopted in 1961 and entered into force in 1968. The

Within the United Nations, different forums address the protection of intellectual property, such as the Commission on Human Rights, the UN High Commissioner for Human Rights or Special Rapporteurs. For an in-depth analysis of the various legal instruments and their relationship to intellectual property protection in the different international regimes, see Helfer, "Regime Shifting", p. 26 ff.

81 See G. Dutfield, Intellectual Property Rights and the Life Science Industries: A 20th Century History (Ashgate Publishing Limited, Hampshire, 2003), p. 184-185.

82 International Convention for the Protection of New Varieties of Plants, adopted in Paris on 2 December 1961, as revised in Geneva on 10 November 1972, on 23 October 1978, and on 19 March 1991, 815 U.N.T.S. 89 [hereinafter UPOV Convention]. See Dutfield, Intellectual Property Rights and the Life Science Industries: A 20th Century History, p. 185.

Interesting to note is that the revision conference of the Paris Convention in 1958 did not address the question of plant variety protection despite the efforts of the International Association for the Protection of Intellectual Property and the International Chamber of Commerce to include the matter into the scope of the Paris Convention. Arguably, the contracting parties of the Paris Convention did not want to include plant variety protection into the framework of the Paris Convention because of continued skepticism among patent office representatives whether the plant variety protection would fit into the patent framework. See ibid., footnote 12. 
Convention is administered by the International Union for the Protection of New Varieties of Plants (UPOV), an intergovernmental organization which has its headquarters in Geneva. The Secretary-General of UPOV is also Director-General of WIPO, which illustrates the close link between the two organizations.

\subsubsection{Copyright Protection}

Another forum in which international intellectual property protection was and continues to be addressed is the United Nations Economic, Social and Cultural Organization (UNESCO). UNESCO was established in 1945 and has as its major purpose the advancement of common welfare and international peace through the means of educational, scientific and cultural relations between the peoples. ${ }^{85}$ This newly established organization was regarded as particularly suited to regulate policies related to copyright and information flow. ${ }^{86}$ In September 1952, a new international copyright treaty, the Universal Copyright Convention (UCC), was adopted by UNESCO. ${ }^{87}$ The question why another international copyright instrument was necessary in addition to the Berne Convention must be answered in the context of the role of the United States.

Since the end of World War II, the United States had become a major exporter of copyright products. ${ }^{88}$ As mentioned before, the United States had not joined the Berne Union in 1886 and still had not done so in the early 1950's. However, the international community was eager to include the United States in the international copyright system and for that purpose was willing to create a new international copyright instrument that "had been designed as a sort of junior Berne Convention". 89 The major goal of the UCC was to set a minimum standard of copyright protection throughout the entire world, which differed from the Berne Convention in several aspects. The Berne Convention grants copyright protection for a single term without the need to register. The UCC, on the other hand, provided for fixed, renewable terms of protection and required registrations with the Copyright Office. In other words, the obligations of the UCC were more in line with the already existing copyright law of the United States than the Berne Convention.

The further destiny of the UCC was again related to the United States policies. With the emergence of the knowledge-based society and the ever growing political influence of intellectual property owners, the United States gained an interest in joining the Berne Convention, due to its strong authorial protection..$^{90}$ Before the United

85

See the Preamble of the Constitution of the United Nations Economic, Social and Cultural Organization, signed on 16 November 1945 and entered into force on 4 November 1946, 4 U.N.T.S. 275 (1945).

See R. Okediji, "The International Relations of Intellectual Property: Narratives of Developing Country Participations in the Global Intellectual Property System" Singapore Journal of International \& Comparative Law, 2003, Vol. 7, 315-385, p. 332.

Universal Copyright Convention, signed in Geneva on 6 September 1952, entered into force on 16 September 1952, revised in Paris on 14 July 1971, 216 U.N.T.S. 132 (1952) [hereinafter UCC].

See Ringer, "The Role of the United States in International Copyright", p. 1060.

See P. Jaszi, "A Garland of Reflections on Three International Copyright Topics" Cardozo Arts \& Entertainment Law Journal, 1989, Vol. 8 (1), 47-72, p. 53.

See Okediji, “The International Relations of Intellectual Property”, p. 332. 
States joined the Berne Convention in 1988, ${ }^{91}$ it had abandoned UNESCO in 1984, mainly for three reasons. First, in the view of the US, UNESCO had extraneously politicized North-South problems. Second, the United States clearly opposed the 'New World Information and Communication Order', ${ }^{22}$ which dominated UNESCO at the time. Third, according to the US, UNESCO had a careless management. The United States' accession to the Berne Convention and its withdrawal from UNESCO were important factors for incorporating the substantive provisions of the Berne Convention into the TRIPS Agreement rather than those of the UCC. Although the Universal Copyright Convention formally continues to exist, it has been relegated to the periphery of international copyright protection.

\title{
1.5.6. The Regulation of Intellectual Property under the General Agreement on Tariffs and Trade 1947
}

Even though not a treaty that intends to deal with intellectual property protection comprehensively, some provisions on intellectual property issues have found their way into the GATT 1947. There are two Articles in the GATT 1947 that expressly refer to the protection of intellectual property: 1) Article IX:6 of the GATT 1947, and 2) Article XX(d) of the GATT $1947 . .^{93}$

First, Article IX:6 of the GATT 1947 concerns marks of origin and relates to the area of intellectual property that deals with the protection of geographical indications. The Article set out an obligation to

\begin{abstract}
"co-operate with each other with a view to preventing the use of trade names in such manner as to misrepresent the true origin of a product, to the detriment of such distinctive regional or geographical names of products of the territory of a contracting party as are protected by its legislation"
\end{abstract}

This provision was once assessed by a GATT Panel which gave this obligation a restrictive interpretation. It clarified that fulfilling the requirements of the Madrid Agreement Concerning the International Registration of Marks ${ }^{94}$ is evidence enough for meeting its obligations under this Article. ${ }^{95}$

Second, Article XX(d) is one of the general exceptions under the GATT 1947 that concerns, among others, the protection of patents, trade marks, copyright and the prevention of deceptive practices. This provision could be used to justify a breach of a GATT obligation. A realistic example of a possible breach would have been a ban of counterfeiting products. Legislation to that effect would not comply with the

91 See Berne Convention Implementation Act of 1988, Pub. L. No. 100-568, 102 Stat. 2853.

92 The Order addresses issues such as the media representations of the developing world in UNESCO, media coverage of the developing world and the unbalanced flows of mass media.

93 The relevant provisions have been incorporated by reference into the General Agreement on Tariffs and Trade 1994 and therefore are still applicable today.

94 Madrid Agreement Concerning the International Registration of Marks, adopted on 14 April 1891, as last revised and amended on 28 September 1979, 828 U.N.T.S 389 [hereinafter Madrid Agreement].

95 Japan - Customs Duties, Taxes and Labelling Practices on Imported Wines and Alcoholic Beverages [BISD 34S/83] (GATT Panel Report, 10 November 1987). 
national treatment obligation for internal regulation in Article III:4 of the GATT 1947 and therefore is in need of a justification under Article XX(d) of the GATT 1947. The latter Article reads as follows:

\begin{abstract}
"Subject to the requirement that such measures are not applied in a manner which would constitute a means of arbitrary or unjustifiable discrimination between countries where the same conditions prevail, or a disguised restriction on international trade, nothing in this Agreement shall be construed to prevent the adoption or enforcement by any contracting party of measures:

(a) $[\ldots]$

(d) necessary to secure compliance with laws or regulations which are not inconsistent with the provisions of this Agreement, including those relating to $[\ldots]$, the protection of patents, trade marks and copyrights, and the prevention of deceptive practices;"
\end{abstract}

There were several requirements that must be fulfilled in order to use this justification: 1) the specific exception of paragraph (d) must apply; 2) the condition of "necessary" must be met; and 3) the requirements of the chapeau must be fulfilled. In the following, I will focus on the first element, which is most relevant to this section. ${ }^{96}$ The specific exception of paragraph (d) justified the breach of a GATT 1947 obligation in order to comply with domestic patent law, trade mark law, copyright law or domestic law designed to prevent deceptive practices. A precondition is, however, that these domestic laws are GATT-consistent. In the first patent infringement case in GATT history, the GATT Panel had to decide whether the United States could invoke Article XX(d) of the GATT 1947 to justify an exclusion order against automotive spring assemblies which had been found to infringe a United States patent. The Panel found that

"the exclusion order issued [...] under Section 337 of the United States Tariff Act of 1930 was 'necessary' in the sense of Article XX(d) to prevent the importation and sale of automotive spring assemblies infringing the patent, thus protecting the patent holder's rights and securing compliance with United States patent law." 97

Therefore, in cases where foreign products infringe a domestic patent, GATT contracting parties were able to justify the breach of GATT obligations by using the specific exception Article XX(d) of the GATT 1947. The term "deceptive practices" refers to the false marking of the geographical origin. ${ }^{98}$ Furthermore, the disciplines of the national treatment obligation in Article III:4 of the GATT 1947 establish conditions that any kind of intellectual property regulation needs to fulfill, also today. A scheme of compulsory licensing ${ }^{99}$ or, as was at issue in the EC - Trademarks and

For a comprehensive elaboration on the second and third requirement, see P. Van den Bossche, The Law and Policy of the World Trade Organization: Text, Cases and Materials (2nd edn, Cambridge Publishers, Cambridge, 2008), p. 616 ff.

See United States - Imports of Certain Automotive Spring Assemblies [BISD 30S/107] (GATT Panel Report, 26 May 1983), paragraph 60.

See A. Porges, Guide to GATT Law and Practice: Analytical Index (6th edn, World Trade Organization, Geneva, 1995), p. 583.

See D.J. Gervais, The TRIPS Agreement: Drafting History and Analysis (2nd edn, Sweet \& Maxwell, London, 1998), paragraph 1.08. 
Geographical Indications WTO Panel Report, the conditions under which products protected by a geographical indication are imported, have to meet the requirements of Article III:4 of the GATT 1994. ${ }^{100}$

To sum up, intellectual property protection was not a major issue in the GATT 1947 before the TRIPS Agreement was established. To the contrary, the drafters of the GATT 1947 included these few provisions on the protection of intellectual property to accommodate what they perceived to be an "accepted obstacle" to free trade, at least until the Tokyo Round. ${ }^{101}$ In the years to come, the relative non-involvement of the GATT 1947 in intellectual property issues would change considerably.

\subsubsection{Interim Conclusions}

The adoption of the Paris Convention and Berne Convention in 1883 and 1886 marked the beginning of the first multilateral phase. Multilateral IP treaties continued to proliferate in the following years, importantly under the framework of WIPO, but also in other forums, such as the UPOV Union, UNESCO and the GATT 1947. Even though these treaties were concluded throughout the twentieth century, European countries and the United States also resorted to bilateral (investment) treaties and unilateral protection of intellectual property before achieving a global system of intellectual property protection.

\subsection{From Bilateral and Unilateral to Global Protection of INTELLECTUAL PROPERTY}

The abandoning of WIPO for bilateral and unilateral protection of intellectual property, and ultimately for a system of global IP protection, was initiated by the efforts of private industry and governments, whose ultimate goal was to incorporate the protection of intellectual property into the GATT 1947 framework. United States businesses and the US Government employed a strategy that consisted of fomenting the link between substantive standards of intellectual property protection and trade in different forums and at different levels. ${ }^{102}$ The different levels, where the linkage was pursued, included the national, bilateral, regional and multilateral level. Before analyzing these complementing efforts at various forums in detail, the most important reasons for this development are illustrated.

\subsubsection{Private Industries' Dissatisfaction}

Despite the multitude of multilateral agreements in the different areas of intellectual property protection, the international IP system remained incomplete. States had agreed to basic principles, the most important one being the national treatment obligation. However, many substantive technical rules were not harmonized and states had full discretion about whether to have a first-to-invent or a first-to-file

100 See EC - Trademarks and Geographical Indications [DS174] (WTO Panel Report, 15 March 2005), paragraphs 7.272 and 7.342 .

101 The Tokyo Round took place between 1973 and 1979. In those years, trade in counterfeit goods had already emerged as a serious issue. See Gervais, The TRIPS Agreement: Drafting History and Analysis, paragraph 1.08.

102 Section 1.6.6 deals with the question as to how the strategy of linking intellectual property and trade developed and who the driving forces behind this development were. 
patent system, whether or not to protect moral rights in copyright or whether to allow for patenting of chemical compounds. ${ }^{103}$ Overall, the international system of intellectual property protection remained highly fragmented and incomplete.

At the same time, the need of private industries for better protection of intellectual property increased in many developed countries, foremost the United States. After World War II, industries depending on information and creativity became much stronger and their share in the gross domestic product of many developed countries had increased substantially. ${ }^{104}$ These industries could be found primarily in the entertainment sector, such as film and music industries. In order to make optimal profit out of creative works, industries were eager to seek proper protection of their products. In other words, they wanted to exploit as much as possible their newly found comparative advantage in informational goods; ${ }^{105}$ what they needed was a stronger protection of intellectual property. Ruth Okediji observes:

"The more vital role of the trade context for intellectual property was the consolidation of a domestic reconditioning of the basis of comparative advantage in order to exploit both factor endowments and to adjust to the new division of labour evident in the global economy." 106

In the 1970s and 1980s, many industries in the United States reported significant losses to their government due to counterfeit and piracy of intellectual property which took place in domestic and foreign markets. ${ }^{107}$ According to a United States Congress report, the overall loss in 1984 of different industries in the automotive, agricultural chemical, video and apparel sectors caused by counterfeit and piracy amounted to tens of billions of dollars. ${ }^{108}$ Another report, which was submitted by the International Intellectual Property Alliance (IIPA) in 1985, stated that the main copyright-reliant industries, represented by the Alliance, had lost 1.3 billion US dollars annually due to ineffective intellectual property protection in the selected countries of the study. ${ }^{109}$ Furthermore, according to a report by the US Office of Technology Assessment, new information and communication technologies caused

See Braithwaite and Drahos, Global Business Regulation, p. 60.

See $\mathrm{Yu}$, "Currents and Crosscurrents in the International Intellectual Property Regime", p. 356.

Prior to making profit out of knowledge-intensive goods, the comparative advantage of the United States was still primarily in the productive factor labour. With the new division of labour in the world, industries quickly adapted to make the most out of their new comparative advantage, being information.

R. Okediji, "Back to Bilateralism? Pendulum Swings in International Intellectual Property Protection" University of Ottawa Law \& Technology Journal, 2003, Vol. 1, 125147, p. 135.

See United States Congress, Unfair Foreign Trade Practices, Stealing American Intellectual Property: Imitation is not Flattery (Washington) [Committee print 98-V], p. 2.

Ibid., p. 1.

See International Intellectual Property Alliance, Piracy of U.S. Counterfeited Works in Ten Selected Countries (IIPA, Washington, 1985), paragraph i. The ten countries selected for the study were: Brazil, Egypt, Indonesia, Korea, Malaysia, Nigeria, Philippines, Singapore, Taiwan, and Thailand. 
difficulties for the existing international intellectual property system, which needed to be solved. ${ }^{110}$

These developments eventually led to the formation of coalitions among the private industry actors in order to increase the protection against counterfeit goods. One such coalition was the Anti-Counterfeiting Coalition which consisted of a hundred multinational corporations on a global scale. The aim of this alliance was to encourage national governments to increase protection against counterfeit trade marked goods. ${ }^{111}$ The group was very active, particularly in providing input to the drafting of an anti-counterfeiting code that was to be included into the GATT framework. Although no agreement on the code could be reached at the end of the Tokyo Round (1973-1979), the Coalition supported the United States and the European Union (at the time the European Community) in continuing their efforts, and eventually resulted in a proposed draft code entitled "Agreement on Measures to Discourage the Importation of Counterfeit Goods". 112

The Coalition's efforts eventually paid off: a revised version of the draft code, although limited, was submitted to the 1982 GATT Ministerial Meeting and formed the basis for discussions on the GATT work program for the following trade round, the Uruguay Round. ${ }^{113}$ In particular, it authorized the Director-General of the GATT to discuss the legal and institutional issues with its counterpart at the WIPO. ${ }^{114}$ Thus, the protection of intellectual property was included into the GATT framework, the negotiations of which finally led to the adoption of the TRIPS Agreement.

Another business group influencing public policy in the field of copyright protection was the Publishers' Association, representing the interests of the book publishers in Great Britain. Already in 1978, this association sought international cooperation with other countries in order to develop a coordinated strategy that would counter copyright infringement. ${ }^{115}$ In addition to starting an infringement procedure in Singapore against a publisher, the association also sent a delegation to the Deputy United States Trade Representative (USTR) to take action against infringement worldwide. ${ }^{116}$ Although at that time the United States policy makers did not endorse the association's efforts, many United States companies copied its strategy shortly after. An example is the agricultural chemicals producers, such as Monsanto Agricultural Company, FMC Corporation and Stauffer, that urged the United States

110 The Office of Technology Assessment assisted the United States Congress between 1972 and 1995. See Office of Technology Assessment, Intellectual Property Rights in an Age of Electronics and Information (United States Congress, Washington DC, 1986) [OTACIT-302], p. 213.

111 See Chasen Ross and Wasserman, "Trade-Related Aspects of Intellectual Property Rights", p. 2259, footnote 83.

112 See Agreement on Measures to Discourage the Importation of Counterfeit Goods, GATT Doc. No. L/4817 (July 31, 1979). For a summary of the content of the Agreement, see ibid., p. 2260.

113 See D. Matthews, Globalising Intellectual Property Rights: The TRIPs Agreement (Routledge, New York, 2002), p. 9.

114 See J. Watal, Intellectual Property Rights in the WTO and Developing Countries (Kluwer Law International, The Hague, 2001), p. 15.

115 See Matthews, Globalising Intellectual Property Rights, p. 13.

116 See ibid., p. 13. 
Government in the late 1970s and beginning 1980s to seek bilateral consultations with Hungary, Taiwan, Korea, United Mexican States (hereinafter Mexico) and Singapore about the piracy of agricultural chemicals in their countries. ${ }^{117}$

While each of the industry groups by then had pursued their efforts on an individual basis, in the early 1980s, the agricultural chemical producers, the Anti-Counterfeiting Coalition and newly established Copyright Alliance joined forces in order to change the United States policy on intellectual property protection. ${ }^{118}$ Their economic leverage convinced the United States Government to convert its "previous piecemeal treatment of intellectual property"119 into a comprehensive strategy of putting intellectual property protection high on the international agenda. ${ }^{120}$

\subsubsection{Paralysis of WIPO}

The strategy of linking substantive standards of intellectual property protection with trade issues arose at a time when the international system of intellectual property protection was paralyzed due to polarized positions of developed countries on the one hand, and developing countries on the other hand. After World War II, the former colonies had gradually been integrated into the international system, including the intellectual property regime. As Peter Drahos and John Braithwaite put it,

"the Paris and Berne Conventions ceased to be Western clubs and, under the principle of one-state-one-vote Western states could be outvoted by a coalition of developing countries." 121

Over the efforts to revise the Paris Convention in the early 1980s, a blockade of the multilateral IP system, which was administered by WIPO, arose. Two coalitions of countries had opposing views. On the one hand, developed countries were unsatisfied with two major flaws of the Paris Convention and the Berne Convention: the lack of detailed rules for enforcement of rights before national judicial authorities, and the absence of an effective and binding dispute settlement system. ${ }^{122}$ Already in the 1970s, the United States, Canada and Western European countries had insisted on strengthening the international treaties administered by WIPO, arguing that the lack of enforcement encouraged piracy and counterfeit. ${ }^{123}$

On the other hand, developing countries were particularly motivated to seek changes in the international system that would respond to their stage of economic development. More access to technology that had been locked through patents was the most important demand developing countries put forward. ${ }^{124}$ Their engagement was mainly based on two factors. First, the previous success of revising the Berne

See S.K. Sell, Power and Ideas: North-South Politics of Intellectual Property and Antitrust (State University of New York Press, New York, 1998), p. 132.

See Matthews, Globalising Intellectual Property Rights, p. 13.

Sell, Power and Ideas, p. 133.

See section 1.6.6.

Braithwaite and Drahos, Global Business Regulation, p. 61.

See Gervais, The TRIPS Agreement: Drafting History and Analysis, p. 9-10.

See United States General Accounting Office, International Trade: Strengthening Worldwide Protection of Intellectual Property Rights (Washington) [NSIAD-87-65], p. 8.

See Braithwaite and Drahos, Global Business Regulation, p. 61. 
Convention gave developing countries reason to demand similar adjustments in the Paris Convention. The Berne Convention had been modified in Stockholm in 1967 in order to address the needs of developing countries. However, the changes in the Stockholm Protocol, which limited the rights of authors and publishers, were too controversial; many developed countries failed to ratify the Protocol and the Berne Convention was again revised in 1971. The 1971 Paris Revisions incorporated an Appendix into the Berne Convention that described the "Special Provisions Regarding Developing Countries". The Appendix was much less radical than the Stockholm Protocol and designed to facilitate access to copyrighted work by a system of compulsory licensing. ${ }^{125}$ However, as Ruth Okedijj notes:

"the appendix is generally acknowledged as a failure in terms of its utility to and by developing countries". ${ }^{126}$

Even though the appendix did not achieve what it was meant to, it set a precedent for special and differential treatment at WIPO which developing countries tried to achieve also in the context of the revision of the Paris Convention.

The second factor that encouraged developing countries to seek reduced obligations under the Paris Convention was two studies conducted by the United Nations Conference on Trade and Development (UNCTAD) from 1974 and 1975. The studies sharply criticized the international system of patent protection and urged reforms to improve the situation of developing countries. ${ }^{127}$ The studies helped to mobilize developing countries' opinions into a united front and resulted in a powerful negotiating position of developing countries in the revision conferences of the Paris Convention. ${ }^{128}$ Their main goal was to make patent holders work their patents in developing countries by retaining the use of compulsory licenses as a sanction mechanism for the non-working of a patent. ${ }^{129}$

Given these polarized views of the Group 77, which was made up of developing countries, and the Group B, which consisted of developed countries, the first three revision conferences in Geneva (1980), Nairobi (1981) and Geneva (1982) were unsuccessful. In 1984, the parties to the Paris Convention met once again in Geneva in an attempt to agree upon revisions. Yet, positions had hardened on both sides and negotiations broke down. A fifth session was postponed to a later stage, but delegations must have lost interest since such a meeting was not scheduled again. ${ }^{130}$ Consequently, the Paris Convention remains as it was last revised in Stockholm in 1967, the moment when the Berne Convention was also revised.

See Ringer, "The Role of the United States in International Copyright", p. 1050.

Okediji, "The International Relations of Intellectual Property", p. 328.

See UNCTAD, The Role of the Patent System in the Transfer of Technology to Developing Countries (United Nations, Geneva, 1974) [TD/B/AC.11/19] and UNCTAD, The International Patent System as an Instrument for National Development (United Nations, Geneva, 1975) [TD/B/C.6/AC.2/3].

See Sell, Power and Ideas, p. 117.

See ibid., p. 120.

See ibid., p. 130. Clearly, the need to revise the Paris Convention was reduced the by the adoption of the TRIPS Agreement, which updated the intellectual property framework. 
The deadlock at WIPO and the huge losses of various industries from piracy and counterfeit were the main causes for industries in developed countries and their governments, in particular the United States, to pursue the strategy of linking substantive standards of intellectual property protection with trade issues at various forums. The various efforts will be examined in the following sections.

\subsubsection{Bilateral Trade Negotiations}

Effective protection of intellectual property was, among others, sought through bilateral agreements. One form of bilateral agreement was the bilateral investment treaty (BIT). Generally, these treaties regulate the conditions of entry, treatment, protection and exit of investments between two countries. In particular, the definition of investment in these agreements often includes intellectual and industrial property rights. Hence, BITs allow countries to protect intellectual property through the protection granted to investment. Bilateral investment treaties have first been used in the late 1950s by European countries; ${ }^{131}$ during the 1970s, they became very popular. Already those agreements addressed, among other things, the protection of intellectual property as one form of investment, although not in detail. ${ }^{132}$

The United States, in contrast, did not start using bilateral investment treaties until the early eighties. ${ }^{133}$ For more than two hundred years, US treaties of Friendship, Commerce, and Navigation had served the purpose of regulating its relations with other countries. ${ }^{134}$ However, the general language of Friendship, Commerce, and Navigation treaties and the increased need to address specific investment issues in detail induced the United States to develop an instrument that was more adequate to the regulation of investment. ${ }^{135}$ For these reasons, on 13 January 1982, the United States Trade Representative first announced the formulation of a prototype bilateral investment treaty. ${ }^{136}$ It is interesting to note that the United States prototype BIT was based on the basic European bilateral investment agreement; however, it expanded its scope. ${ }^{137}$

131 The first BIT was signed between Germany and Pakistan in 1959 and entered into force in 1962. See UNCTAD, Bilateral Investment Treaties: 1959-1999 (United Nations, New York and Geneva, 2000), p. 57.

132 For two examples, see Article 1(a)(iv) of the Agreement for the Promotion and Protection of Investments, United Kingdom of Great Britain and Northern Ireland and Singapore, signed at Singapore on 22 July 1975 (United Nations Treaty Series, Vol. 1018, No. 14935), p. 175; see Article 1.1(d) of Treaty concerning the promotion and reciprocal protection of investments, Federal Republic of Germany and Singapore, signed at Singapore on 3 October 1973 (United Nations Treaty Series, Vol. 1008, No. 14792), p. 229.

See M.S. Bergman, "Bilateral Investment Protection Treaties: An Examination of the Evolution and Significance of the U.S. Prototype Treaty" New York. University Journal of International Law \& Policy, 1983, Vol. 16 (1), 1-43, p. 3. See K. Kunzer, "Recent Development: Developing a Model Bilateral Investment Treaty" Law and Policy in International Business, 1983, Vol. 15, 273-A214, p. 276. See ibid., p. 277.

See S. Gudgeon, "United States Bilateral Investment Treaties: Comments on their Origin, Purposes, and General Treaty Standards" Berkeley Journal of International Law, 1986, Vol. 4 (1), 105-135, p. 106, footnote 4. 
The United States model prototype of 1983 specifies in Article I(c)(iv) that the definition of investment includes

"intellectual and industrial property rights, including rights with respect to copyrights, patents, trademarks, trade names, industrial designs, trade secrets and know-how, and goodwill." 138

The agreement grants foreign investors, e.g. foreign intellectual property holders, 1) either national or most-favoured-nation treatment, whichever is most favorable; ${ }^{139} 2$ ) adequate compensation in the event of expropriation or nationalization; ${ }^{140} 3$ ) the ability to transfer capital and profits relating to their investments to other countries; ${ }^{141}$ and 4) the right to rely on arbitration according to the principles of international law for investment disputes. ${ }^{142}$

It can be argued that the use of bilateral investment treaties constituted an important element in the United States strategy to increase global intellectual property protection. First, the number of BITs signed by the United States increased drastically during the Uruguay Round. Until the end of the Uruguay Round in April 1994, the United States had signed twenty-eight bilateral investment treaties with different countries. ${ }^{143}$ Compared to zero investment agreements in 1980, this is a considerable increase. Second, while European countries also signed BITs, the protection of intellectual property is dealt with in far greater detail in BITs signed by the United States than in treaties signed by European countries. ${ }^{144}$ Third, the level of detail with which the intellectual property provisions were drafted increased rapidly over the years. ${ }^{145}$ This emphasis on stronger intellectual property provisions in BITs to the end of the Uruguay Round leads to the conclusion that BITs formed part of the United States strategy to achieve enhanced protection of intellectual property. ${ }^{146}$

While the use of bilateral investment treaties in the form of the United States prototype was most prevalent, the United States also led bilateral negotiations with countries where the protection of intellectual property was found to be insufficient. Consultations were initiated with Taiwan in 1983 about the lack of patent protection for chemical compounds and inadequate copyright protection, and with Singapore in

Treaty Between The United States of America and (negotiating partner) Concerning the Reciprocal Encouragement and Protection of Investment, reprinted in Kunzer, "Developing a Model Bilateral Investment Treaty", A-2 [hereinafter Model BIT]. Note that this model is the third draft of the original prototype announced in January 1982. Minor changes have been incorporated into the prototype as a result of negotiating experiences with Egypt and Panama. See Kunzer, "Developing a Model Bilateral Investment Treaty", footnote 1.

139 See Article II (1), Model BIT, supra note 138.

140 See Article III (1), Model BIT, supra note 138.

$141 \quad$ See Article IV (1), Model BIT, supra note 138.

142 See Article VIII (2), Model BIT, supra note 138.

143 See UNCTAD, Bilateral Investment Treaties, p. 117-118.

144 See Kunzer, "Developing a Model Bilateral Investment Treaty", p. 285.

145 See Okediji, "Back to Bilateralism?”, p. 138.

146 See F.M. Abbott, "Protecting First World Assets in the Third World: Intellectual Property Negotiations in the GATT Multilateral Framework" Vanderbilt Journal of Transnational Law, 1989, Vol. 22 (4), 689-745, p. 710, footnote 71. 
1984 about copyright improvements, in particular for tapes and records. ${ }^{147}$ In 1985, Singapore was identified as the world's largest producer of works that copy the products of United States copyright industries. ${ }^{148}$ As to the results of the negotiations, Taiwan amended both its trade mark and copyright law and Singapore also passed an improved copyright law in 1987.149

The success of the United States in convincing developing countries in bilateral negotiations to improve the protection of intellectual property must also be understood in the context of the threat posed by unilateral mechanisms available to the Untied States, in particular the Section 301 process. A failure to enter into good faith negotiations or not to make enough progress in bilateral negotiations was likely to lead to the use of the Section 301 mechanism.

\subsubsection{Unilateral Trade Legislation}

The pressure by a number of private sector interest groups in the United States to increase the protection of intellectual property also affected the national legislation of the United States. ${ }^{150}$ Three initiatives introduced by the United States illustrate how the protection of intellectual property has been integrated in national legislation: 1) the Caribbean Basin Initiative; 2) the amendments to Section 301 of the United States Trade Act of 1974; and 3) the conditions for Generalized System of Preferences (GSP) benefits. The United States stands alone in the scope and extent of the measures; other countries have not enacted similar types of legislation that address the protection of intellectual property specifically and would form part of a general strategy to increase that protection globally. ${ }^{151}$

\subsubsection{Caribbean Basin Initiative}

To start with, one of the first measures taken by the United States to incorporate the protection of intellectual property in their unilateral trade policies was the signing into law of the Caribbean Basin Economic Recovery Act in August 1983 (hereinafter 'Caribbean Basin Initiative'). ${ }^{152}$ This act offers preferential treatment to goods from Caribbean countries when the President of the United States designates them as beneficiary countries. One of the factors negating eligibility as a beneficiary country in that Act were actions that

See United States General Accounting Office, International Trade: Strengthening Worldwide Protection of Intellectual Property Rights, p. 50-51.

See International Intellectual Property Alliance, Piracy of U.S. Counterfeited Works in Ten Selected Countries, paragraph i.

See United States General Accounting Office, International Trade: Strengthening Worldwide Protection of Intellectual Property Rights, p. 51-52.

See J.R. Enyart, "A GATT Intellectual Property Code" Les Nouvelles, Journal of the Licensing Executives Society International, 1990, Vol. 25 (2), 53-56, p. 54; Chasen Ross and Wasserman, "Trade-Related Aspects of Intellectual Property Rights", p. 2255.

The European Union in fact enacted a Regulation that is similar to Section 301 of the United States Trade and Tariff Act of 1974. However, the European Union did not seek to follow an explicit strategy at that time, as explained in section 1.6.4.2.

Caribbean Basin Economic Recovery Act (Title II of Pub. L. No. 98-67 of 1983), codified as amended at 19 U.S.C. \$S 2701-2706 (2006). 
"repudiate or nullify any existing contract or agreement with any patent, trademark or other intellectual property." 153

Furthermore, in deciding whether to grant benefits to a particular country, the President of the US also had to consider whether the beneficiary government

"violates intellectual property laws by broadcasting materials of American copyright owners without their consent." 154

These conditions were integrated into the legislation addressing the Caribbean countries because the film industry in the United States was worried about piracy of their movies in the Caribbean. ${ }^{155}$ The success of this initiative paved the way for the following changes effectuated in trade legislation of the United States.

\subsubsection{Section 301}

The second initiative of the United States was to incorporate the protection of intellectual property into the Section 301 process. Before describing the amendments to the trade policy instrument of Section 301, it is useful to explain shortly its context. While Section 337 of the Tariff Act of $1930^{156}$ allows protecting United States intellectual property rights inside the United States from foreign infringements, the equivalent provision that protected United States intellectual property rights outside the United States in foreign countries did not exist until the 1984 amendment of Section 301 of the Trade Act of $1974 .{ }^{157}$ Before the amendment, companies located in the United States were unsatisfied with the reach of the measures available under Section 337 of the Tariff Act of 1930. They were not able to prevent counterfeit goods from being sold on markets outside of the United States. ${ }^{158}$

In addition, the then existing Section 301 of the Trade Act of 1974 did not explicitly address the protection of intellectual property rights in foreign markets. Section 301 was and is a means for United States exporters to gain access to foreign markets. By filing a petition with the USTR, United States exporters can request that action is taken with regard to any act, policy, or practice of a foreign country (including those addressing intellectual property protection) that 1) denies rights, 2) violates provisions

See Section 212(b)(2) of the Caribbean Basin Economic Recovery Act (1983), cited in M.C. Dypski, "The Caribbean Basin Initiative: An Examination of Structural Dependency, Good Neighbor Relations, and American Investment" Journal of Transnational Law and Policy, 2002, Vol. 12, 95-136, p. 103. The wording of the Statute today is very similar, see 19 U.S.C. $\$ 2702$ (b)(2)(B)(ii) (2006).

See Section 212(b)(5) of the Caribbean Basin Economic Recovery Act (1983), cited in ibid., p. 103. The wording of the Statute today is very similar, see 19 U.S.C. $\ 2702$ (c)(10) (2006). Note that the Statute today also refers to adequate and effective enforcement mechanisms in 19 U.S.C. $\$ 2702$ (c)(9) (2006). See Braithwaite and Drahos, Global Business Regulation, p. 62.

156 Tariff Act of 1930 (Chapter 497, Section 337, 46 Stat. 703), codified as amended at 19 U.S.C. $\int 1337(\mathrm{~d})(\mathrm{e})(2006)$.

157 Trade Act of 1974 (Pub. L. No. 93-618, 88 Stat. 2011), codified as amended at 19 U.S.C. SS 2111-2487 (2006).

158 See G.E. Evans, "Intellectual Property as a Trade Issue: The making of the Agreement on Trade-Related Aspects of Intellectual Property Rights" World Competition, 1994, Vol. 18 (2), 137-180, p. 151. 
under a United States trade agreement or 3) unjustifiably burdens or restricts United States commerce. ${ }^{159}$ Back then, the United States President had the power to take all appropriate and feasible action to enforce United States rights under trade agreements or to eliminate such act, policy or practice. Today, it is the USTR that determines whether one of the three situations applies, and if so, it shall take action authorized in subsection (c) of $\int 2411$, including the suspension of benefits of the trade agreement concessions, the imposition of duties and the withdrawal of dutyfree treatment. ${ }^{160}$

Even though this process could also be used to challenge intellectual property acts, policies or practices, it did not deal with the protection of intellectual property abroad specifically. For these reasons, in 1984, the United States Congress amended ${ }^{161}$ Section 301 of the Trade Act of 1974. With the amendment, two major changes were introduced: first, the amended act explicitly included the failure to adequately protect intellectual property as actionable. The amendments clarified under which circumstances trade practices relating to the protection of intellectual property are "unjustifiable or unreasonable" and thus can be eliminated or phased out. ${ }^{162}$ The second major change introduced by the 1984 amendment ${ }^{163}$ of Section 301 was that the USTR could initiate cases on its own motion. Hence, it was no longer necessary to wait for a petition by industries, trade associations or individual companies in the United States to investigate an action taken by foreign governments. ${ }^{164}$ Section 301 cases were first brought against South Korea and against Brazil in 1985, both of which proved to be successful in terms of achieving better protection for US intellectual property rights abroad. ${ }^{165}$

Encouraged by the perceived success of Section 301 and motivated by industry lobbying, the United States sought to strengthen Section 301 further in 1988, ${ }^{166}$ two

See 19 U.S.C. \2412(a) (2006) and \2411(a)(1) (2006).

See 19 U.S.C. $\$ 2411(\mathrm{a})(1)$ and (c)(2006). Note that the USTR is not required to take action in any case in which the Dispute Settlement Body has adopted a report, or a ruling that the rights of the United Sates under a trade agreement are not being denied or that the relevant act or policy is not a violation of the rights of the United States or does not deny benefits to the United States. See 19 U.S.C. $\$ 2411$ (2)(A) (2006).

Section 301 was amended by the Trade and Tariff Act of 1984 (Pub. L. 98-573, 98 Stat. 2948).

According to \$2411, "unjustifiable" conduct would include any act, policy, or practice that denies "protection of intellectual property rights". "Unreasonable" conduct was defined to include "any act, policy, or practice $[\ldots]$ which denies $[\ldots]$ adequate and effective protection of intellectual property rights." See U.S.C. \2411(d)(3)(B)(i)(II) (2006). It is important to note that the difference between these two forms of conduct is that unjustifiable conduct constitutes a violation of international legal rights of the United States, whereas this is not necessarily the case for unreasonable conduct. Respectively, unjustifiable conduct has as a consequence that the USTR is obliged to take retaliatory action. See U.S.C. \2411(a) (2006). For the three alternative retaliatory actions permitted by the law, see $\$ 2411$ (c) (2006). In the case of unreasonable conduct, the USTR has the discretion to take action under Section 301.

See Trade and Tariff Act of 1984 (Pub. L. 98-573, 98 Stat. 2948).

See A. Zalik, "Implementing the Trade-Tariff Act" Les Nouvelles, Journal of the Licensing Executives Society International, 1986, Vol. XXI (4), 199-202, p. 200.

See Matthews, Globalising Intellectual Property Rights, p. 15-16.

See Sell, Power and Ideas, p. 134. 
years after the Uruguay Round had commenced. This renewed focus on Section 301 was interpreted as a clear sign by the United States that it would make use of this process in case the multilateral negotiations in the Uruguay Round would not deliver the expected results. ${ }^{167}$ The Omnibus Trade and Competitiveness Act of $1988^{168}$ provided an overall strategy to increase the United States' ability to be economically competitive and, in particular, to ensure adequate and effective protection of intellectual property rights. ${ }^{169}$ The amendment of Section 301 in 1988 had three major consequences. First, the role of the USTR's office was enhanced by transferring substantial authority from the United States President to the USTR. Vesting more powers in the USTR was intended to decrease the possibility of trade policy priorities being exchanged for foreign policy or defense considerations. ${ }^{170}$

Second, the 'Special 301' process was added to the Regular 301 process. According to Special 301, the USTR must produce an annual report entitled National Trade Estimate, ${ }^{171}$ which identifies and analyzes

"acts, policies, or practices of each foreign country which constitute significant barriers to $[\ldots]$ United States exports of goods or services," 172

including property protected by intellectual property rights. Part of the report is also an estimate of the trade-distorting impact that these trade barriers have on United States commerce. ${ }^{173}$ The report is submitted to the President, Senate Finance Committee, and appropriate House committees. ${ }^{174}$ Thirty days after its issuance, the USTR must identify so-called 'priority foreign countries' that deny adequate and effective protection of intellectual property rights. ${ }^{175}$ 'Priority foreign countries' are those countries that fulfill the following three factors: 1) countries that have the most onerous or egregious acts, policies, or practices; 2) countries whose acts, policies, or practices have the greatest adverse impact on United States' products; and 3) countries that are not entering into good faith negotiations or are not making significant progress in bilateral or multilateral negotiations. ${ }^{176}$ Being listed as a priority foreign country has severe consequences. Not does it only shame a country, it also triggers the newly added 'Super 301' process, being the third change brought about by the 1988 amendment of Section 301.

See M. Getlan, "TRIPs and the Future of Section 301: A Comparative Study in Trade Dispute Resolution" Columbia Journal of Transnational Law, 1996, Vol. 34, 173-218, p. 184; see Chasen Ross and Wasserman, "Trade-Related Aspects of Intellectual Property Rights”, p. 2257; see Matthews, Globalising Intellectual Property Rights, p. 26. Omnibus Trade and Competitive Act of 1988 (Pub. L. No. 100-418, 102 Stat. 1107), codified as amended at 19 U.S.C. SS 2411-19 (2006). Effectiveness of Intellectual Property Protection in Foreign Countries" Transnational Law, 1988, Vol. 1, 421-447, p. 425-426.

170 See Sell, Power and Ideas, p. 134.

171 19 U.S.C. $\$ 2241$ (2006).

17219 U.S.C. $\int 2241$ (a)(1)(A) (2006).

17319 U.S.C. $\$ 2241$ (a)(1)(B) (2006).

17419 U.S.C. \$ 2241(b)(1) (2006).

17519 U.S.C. \$2242(a)(1) (2006).

17619 U.S.C. \ 2242(b)(1) (2006). 
According to the 'Super 301' process, the USTR must initiate a Section 301 investigation once a priority foreign country is listed in the annual report, unless such an investigation would be detrimental to the economic interests of the United States. ${ }^{177}$ The USTR generally has only six months to conclude the investigation. ${ }^{178}$ If the foreign country's practices continue to exist at the end of the investigation, the USTR may impose trade sanctions in the form of suspended benefits of trade agreement concessions, increased tariff duties or import restrictions or by entering into a binding agreement with the foreign country. ${ }^{179}$

The European Union (then European Community) introduced a similar instrument to Section 301 of the Trade Act of 1974 in 1984: the EEC Regulation 2641/84. ${ }^{180}$ Being partly a response to the enactment of Section 301, it provides for similar procedures. ${ }^{181}$ On a closer look, however, there are remarkable differences with regard to both their procedural and substantive law. ${ }^{182}$ One example of a difference is that EEC Regulation $2641 / 84$ does not provide for a procedure specifically concerned with intellectual property violations. ${ }^{183}$ Private parties have made use of the procedure established by the Regulation in three cases. ${ }^{184}$ In all cases, the European Commission did not press for retaliatory measures. ${ }^{185}$ Therefore, it can be claimed that the procedure offered by EEC Regulation 2641/84 has not served the purpose of promoting increased global protection of intellectual property.

\subsubsection{Generalized System of Preferences}

A third initiative in US policy regarding intellectual property protection, which complemented the strengthening of Section 301, was the revision of the conditions of eligibility under the United States Generalized System of Preferences (GSP). ${ }^{186}$ The revision formed part of the Trade Act of 1974 and introduced the protection of

17719 U.S.C. $\$ 2412$ (b)(2)(B) (2006).

17819 U.S.C. $\$ 2414(\mathrm{a})(3)(\mathrm{A})-(\mathrm{B})(2006)$.

179 U.S.C. $\$ 2411$ (c)(1) (2006).

180 EEC Council Regulation 2641/84 of 17 September 1984 on the Strengthening of the Common Commercial Policy with Regard in Particular to Protection Against Illicit Commercial Practices (OJ L 252 of 20.09.1984), 1 [hereinafter EEC Regulation 2641/84].

See D. Rose, "The E.U. Trade Barrier Regulation: An Effective Instrument for Promoting Global Harmonisation of Intellectual Property Rights?” European Intellectual Property Review, 1999, Vol. 21 (6), 313-320, p. 313.

See W.W. Leirer, "Retaliatory Action in United States and European Union Trade Law: A Comparison of Section 301 of the Trade Act of 1074 and Council Regulation 2641/84" North Carolina Journal of International Law and Commercial Regulation, 1994, Vol. 20, 41-96, p. 90.

See T.C. Bickham, "Protecting U.S. Intellectual Property Rights Abroad with Special 301” AIPLA Quarterly Journal, 1995, Vol. 23 (2), 195-220, p. 203.

See Rose, "The E.U. Trade Barrier Regulation", p. 313. In fact, only five complaints have been formally examined by the Commission during the ten years of the EC Regulation's existence. Leirer's study suggests that the high admissibility standards for private complaints under the Regulation and the lack of the Commission's right to selfinitiate the examination procedure explain the low number of actual use. See Leirer, "Retaliatory Action in United States and European Union Trade Law", p. 95. See Rose, “The E.U. Trade Barrier Regulation”, p. 313.

The Generalized System of Preferences is a scheme that allows the head of a country to waive tariffs on many imports from developing countries declared as GSP beneficiaries on a non-reciprocal basis. 
intellectual property rights as a new criterion for the elimination of tariff privileges for imports into the United States. ${ }^{187}$ When making a decision whether to eliminate tariff preferences for imports from a particular country, the President must consider whether this country provides adequate means for securing and enforcing intellectual property rights, the extent of their statutory protection, the remedies for enforcement, their willingness to enforce on behalf of foreign nationals and the ability of foreign nationals to enforce their rights on their own behalf. 188

It is interesting to note that the revision of the terms of eligibility came about at a time when bilateral talks with Taiwan and Singapore on piracy issues in June 1984 had disappointed industry associations. ${ }^{189}$ Particularly the International Intellectual Property Alliance (IIPA), ${ }^{190}$ representing the main copyright-reliant industries, saw the withdrawal of GSP benefits as "an attractive trump card"191 to achieve effective protection of intellectual property in GSP beneficiary countries, such as Taiwan and Singapore. Because of the pressure exerted by the copyright industries, the factor of adequate protection of intellectual property was added to the terms of assessment when granting GSP benefits under the Trade Act of 1974.

Also the European Union made the scheme of generalized tariff preferences contingent upon the adequate protection of intellectual property. In December 1987, the EU suspended the application of tariff preferences to the Republic of Korea for discriminating against EU products and in favour of American products through its industrial property protection. ${ }^{192}$ Compared to the United States GSP system, the European scheme does not mention the lack of adequate intellectual property protection as an explicit criterion for suspending tariff preferences to particular countries. ${ }^{193}$ It can be argued that the European Union did not pursue a similarly strong strategy of raising global protection of intellectual property as the United States.

The reformed Section 301 process and the conditionality of GSP benefits on effective protection of intellectual property have been and continue to be crucial elements in the United States trade policy. As the then United States Trade Representative Charlene Barshefsky stated on 1 May 1998: "Special 301 is one of the

\footnotetext{
$187 \quad 19$ U.S.C. $\$ 2462(a)(5)$ (2006).

188 See Chasen Ross and Wasserman, "Trade-Related Aspects of Intellectual Property Rights", p. 2256, footnote 60.

189 See section 1.6.3.

190 See section 1.6.1.

191 Sell, Power and Ideas, p. 135.

192 See EEC Council Regulation 4257/88 of 19 December 1988 applying generalized tariff preferences for 1989 in respect of certain industrial products originating in developing countries (OJ L 375 of 31.12.1988), p. 3.

193 The protection of intellectual property was never mentioned in any of the Council Regulations applying a scheme of generalized tariff preferences. See the latest EC Council Regulation 980/2005 of 27 June 2005 applying a scheme of generalized tariff preferences that sets out the scheme of generalized tariff preferences for the years 2006-2015. See also D. Demiray, "Intellectual Property and the External Power of the European Community: The New Extension" Michigan Journal of International Law, 1995, Vol. 16, 187-239, p. 205.
} 
most effective instruments in our trade policy arsenal." 194 This also became apparent during the negotiations of the Uruguay Round. The Special 301 process was successfully employed against a number of countries, including the developing countries that were leading the opposition towards the discussion of intellectual property issues in the Uruguay Round, such as Brazil, India, Argentina and Thailand. ${ }^{195}$

The first Special 301 Report, released in May 1989, did not list any priority foreign country. However, the United States made use of placing countries on the so-called 'Priority Watch List' and the 'Watch List', two weaker forms of scrutinizing foreign countries' efforts of protecting intellectual property. Twenty-five countries were listed on each of them. ${ }^{196}$ Among others, Brazil, India and Thailand were listed on the Priority Watch List and Argentina on the Watch List. ${ }^{197}$ The first countries to be designated as priority foreign countries in 1991 were India, the People's Republic of China and Thailand, and in 1992 India, Taiwan and Thailand. ${ }^{198}$ In most cases, the investigations did not have to be brought to an end as the listed priority foreign countries proposed improvements of the particular laws in question shortly after they had been placed on the list. The strategic use of the trade sanctions, however, isolated hardliner opposition countries in the Uruguay Round negotiations and ultimately divided the less developed countries, some of which changed their position and agreed to the United States' position. ${ }^{199}$ Having persuaded enough countries at the bilateral level, the United States was able to secure itself less resistance in the negotiations on the TRIPS Agreement at the multilateral level. ${ }^{200}$

\subsubsection{Multilateral Regulation: Incorporating the Protection of Intellectual Property into the GATT Framework}

While alternative ways of increasing the protection of intellectual property - the Caribbean Basin Initiative, the Section 301 processes and the GSP program - served particular industries in relation to certain countries, the United States was convinced that the multilateral regulation of intellectual property would be the best way to achieve effective protection. ${ }^{201}$ However, it was clear to the United States and other developed countries that WIPO was not the adequate forum to introduce higher

194 Office of the United States Trade Representative, "Press Release: USTR Announces Results of Special 301 Annual Review" (1 May 1998).

195 See Watal, Intellectual Property Rights in the WTO and Developing Countries, p. $24 \mathrm{ff}$.

196 These countries were Argentina, Indonesia, Portugal, Canada, Italy, Spain, Chile, Japan, Turkey, Columbia, Malaysia, Venezuela, Egypt, Pakistan, Yugoslavia, Greece, the Philippines, Brazil, India, Korea, Mexico, the People's Republic of China, Saudi Arabia, Taiwan and Thailand. See A.S. Gutterman, "International Intellectual Property: A Summary of Recent Developments and Issues for the Coming Decade" Santa Clara Computer \& High Technology Law Journal, 1992, Vol. 8, 335-405, p. 341-342. See ibid., p. 341-342.

See Chasen Ross and Wasserman, "Trade-Related Aspects of Intellectual Property Rights", p. 2258-2259.

See Yu, "Currents and Crosscurrents in the International Intellectual Property Regime", p. 361-362.

See Braithwaite and Drahos, Global Business Regulation, p. 63.

See Chasen Ross and Wasserman, "Trade-Related Aspects of Intellectual Property Rights", p. 2259. 
protection of intellectual property. ${ }^{202}$ Instead, in those countries' view, GATT was an alternative that offered a number of advantages compared to WIPO.

\subsubsection{GATT versus WIPO}

First, the United States and the European Union (at the time the European Community) felt that they could increase their leverage in a forum such as GATT. WIPO Member States are United Nations Members, which at that time amounted to about 150 countries. Compared to ninety states that were parties to GATT, the influence of the United States and the European Union was greater in a forum with less members. Furthermore, the decision-making procedure under the GATT 1947 was more favourable for developed countries compared to the procedure in WIPO. Even though decisions in both forums were made by consensus in practice, gaining consensus under the GATT 1947 was easier because once consensus was achieved among the US, the EU, Canada and Japan, general consensus became more likely. The United States and the European Union were prepared to use the principle of consensus to "force" weaker states to disclose their preferences and support the initiatives proposed by the former. ${ }^{203}$ On the other hand, the WIPO Convention formally foresees decision-making according to the one-country-one-vote rule, ${ }^{204}$ under which developing countries would be able to outnumber developed countries. ${ }^{205}$ In brief, from developed countries' point of view, GATT offered benefits in terms of composition and rule-making.

Second, the GATT framework allows countries to use other fields of international trade as bargaining leverage. In WIPO, the protection of intellectual property is isolated from other trade issues. This precludes countries from negotiating the terms of an agreement on intellectual property by giving and taking from other areas of trade. By contrast, the GATT framework allows for cross-sector concessions. In particular, during the TRIPS negotiations, improved access to the textiles and agricultural markets of developed nations was determinative for developing countries to accept adherence to an enhanced level of intellectual property protection. ${ }^{206}$

Third, the GATT 1947 disposed of a dispute settlement system. Although dispute settlement under the GATT 1947 was far from perfect, it was used often and presented a much more effective system than the mechanisms for reviewing states'

202 The opposing views of developed and developing countries on the protection of intellectual property had caused a deadlock of the WIPO in 1984. See above section 1.6.2.

203 See Braithwaite and Drahos, Global Business Regulation, p. 570. In this respect, consensus decision making allows instrumentalizing power asymmetries while the outcome is legitimized on the basis of the principle of sovereign equality. See R.H. Steinberg, "In the Shadow of Law or Power? Consensus-Based Bargaining and Outcomes in the GATT/WTO” International Organization, 2002, Vol. 56 (2), 339-374, p. 365.

204 See Article 6.3 of the WIPO Convention.

205 See $\mathrm{Yu}$, "Currents and Crosscurrents in the International Intellectual Property Regime", p. 357.

206 See Helfer, "Regime Shifting", p. 22-23. 
compliance with the WIPO-administered conventions. ${ }^{207}$ In fact, WIPO lacked an effective and simple system of dispute settlement; ${ }^{208}$ it was cumbersome in theory and never used in practice. ${ }^{209}$ The dispute settlement system offered by GATT therefore was highly appreciated by developed countries.

The fourth and last factor that made GAT'T an attractive alternative for developed countries were the standards of effective enforcement. ${ }^{210}$ The rules on enforcement of rights before national judicial administrative authorities, which had been developed for trade disputes, were easily applicable for disputes regarding intellectual property rights. ${ }^{211}$ As WIPO did not dispose of a system that would guarantee effective enforcement, the GATT was also favourable in that respect.

\subsubsection{Shifting the Forum from WIPO to GATT}

Due to these advantages of the GATT institutional framework, the United States and the European Union (then European Community) were eager to shift the forum of discussing intellectual property protection from WIPO to the GATT framework. The first time that the GATT 1947 was addressed for issues of intellectual property had already taken place in the late 1970s. Back then, the United States and the EU had tried to include an Anti-Counterfeiting Code in the Tokyo Round. ${ }^{212}$ This attempt was unsuccessful due to the lack of good empirical evidence on the trade implications of counterfeit; however, the revised draft made it to the 1982 Ministerial Meeting in the form of the 'Agreement on Measures to Discourage the Importation of Counterfeit Goods'. ${ }^{213}$ The United States wanted to negotiate that agreement further; however, it did not receive the support of other delegations. In particular, India and Brazil strongly contested the appropriateness of GATT as the competent forum. ${ }^{214}$

The next chance to discuss the incorporation of intellectual property matters into GATT was in 1985 when the GATT Preparatory Committee met. The Committee was mandated to determine the work programme for the forthcoming trade round. ${ }^{215}$ Notably, the scope of its mandate was broad enough to include the protection of

The most important flaw of the GATT dispute settlement system concerned the fact that losing parties could block the adoption of panel reports. This has been changed with the improvement of the system through the Uruguay Round amendments.

See T. Cottier, "The Agreement on Trade-Related Aspects of Intellectual Property Rights" in P.F.J. Macrory, A.E. Appleton and M.G. Plummer (eds.), The World Trade Organization: Legal, Economic and Political Analysis (Springer, New York, 2005) 1041-1120, p. 1050 .

See F. Emmert, "Intellectual Property in the Uruguay Round: Negotiating Strategies of the Western Industrialized Countries" Michigan Journal of International Law, 1990, Vol. 11 (4), 1317-1399, p. 1343.

See Gervais, The TRIPS Agreement: Drafting History and Analysis, p. 10.

The enforcement of benefits recurring from trade or intellectual property rules requires a similar set of enforcement mechanisms.

See M. Blakeney, Trade Related Aspects of Intellectual Property Rights: A Concise Guide to the TRIPs Agreement (Sweet and Maxwell, London, 1996), p. 1.

See section 1.6.1.

See Chasen Ross and Wasserman, "Trade-Related Aspects of Intellectual Property Rights", p. 2261.

See GATT Council, Decision of 28 November 1985 on Establishment of the Preparatory Committee [Doc. No. L/5925]. 
intellectual property in the next GATT round. ${ }^{216}$ All delegations were encouraged to submit their proposals by 31 July 1986. The United States was the first to submit its proposal, which included all intellectual property rights rather than just trade marked goods. ${ }^{217}$ Including all intellectual property fields went too far for most countries, especially those that still did not accept the competence of GATT to deal with these matters. These were foremost the Group of Ten, including Brazil and India. 218 Notably, not all developing countries were opposed to the inclusion of intellectual property into GATT; South East Asian countries generally saw the need to provide effective protection of intellectual property and accepted GATT as the appropriate forum. ${ }^{219}$ In an attempt to reconcile the opposing views, the Swiss and Columbian delegations produced a compromise proposal. Although it did not receive full support by all delegations, it represented the views of forty delegations. ${ }^{220}$ It was ultimately this compromise proposal that was forwarded to the ministers as the basis of their considerations in Punta del Este. ${ }^{221}$

As a side note, the idea of linking intellectual property with trade issues was not completely new. In fact, there is an inherent link between intellectual property and trade. The link arises when national IP legislation constitutes a restriction on trade, such as a ban on counterfeit products (as already addressed by the GATT 1947), ${ }^{222}$ or when there is a lack of intellectual property protection that results in a trade barrier (not yet regulated by the GATT 1947). The latter example is known as a third generation trade barrier, which used to be dealt with primarily by domestic law addressing the protection of intellectual property. ${ }^{223}$ Only lately, international trade law has touched upon a variety of domestic economic affairs, among others the regulation of intellectual property law, and tried to develop global rules in these areas. ${ }^{224}$ To sum up, the relationship between substantive standards of intellectual property and trade law has only recently (approximately for twenty years) been dealt with at the international level.

216 See Chasen Ross and Wasserman, "Trade-Related Aspects of Intellectual Property Rights", p. 2262.

217 See ibid., p. 2263.

218 See Matthews, Globalising Intellectual Property Rights, p. 17.

219 See ibid., p. 17.

$220 \quad$ See A.J. Bradley, "Intellectual Property Rights, Investment and Trade in Services in the Uruguay Round: Laying the Foundations" Standford Journal of International Law, 1987, Vol. 23, 57-98, p. 83.

221 Note that in total three proposals were submitted by the Preparatory Committee: the compromise proposal by the Swiss and Columbian delegations, a proposal by Brazil and a proposal by Argentina. See ibid., p. 84 .

222 See section 1.5.6.

223 According to Thomas Cottier, a trade barrier created by the lack of intellectual property protection classifies as a third generation barrier. Third generation barriers are foremost part of domestic legal systems and not directly related to border measures and classical international trade relations. See Cottier, "The Agreement on TradeRelated Aspects of Intellectual Property Rights”, p. 1053.

224 It is interesting to note that the first linkage between trade negotiations and intellectual property issues dates back to the mid-nineteenth century when France agreed to a commercial treaty with Belgium only after it agreed to institute copyright protection. See Ricketson, The Berne Convention for the Protection of Literary and Artistic Works: 1886-1986, p. 35-36. 


\subsubsection{Business Support for a GATT-based Approach to Protecting Intellectual Property}

The efforts of developed countries' delegations, in particular the United States, to include the protection of intellectual property into the GATT framework would not have been successful if business groups in the United States, European countries and Japan had not supported, or better-said promoted this initiative. Private interest groups' engagement and support were crucial for the adoption of the TRIPS Agreement under the framework of the new World Trade Organization. Business groups initiated governments' actions at the multilateral level, in particular under the GATT 1947.225 While US businesses were the first to lobby the US Government, the private sector in Europe and Japan followed suit shortly after.

The idea of linking substantive protection of intellectual property to trade was first launched during the early eighties by a small group of Washington-based lobbyists, lawyers and consultants.226 Among the strongest proponents of the trade-based approach to protecting intellectual property were the executives of Pfizer. ${ }^{227}$ For pharmaceutical companies like Pfizer, patent protection was the backbone of their industries. Pfizer had invested in developing countries and it wanted to produce in those markets without generic manufacturers posing a threat to its business activities. ${ }^{228}$ In 1979, the chief executive officer of Pfizer, Edmund Pratt, had become a member of the Advisory Committee on Trade Negotiations (ACTN), an influential private sector advisory committee with direct access to USTR. ${ }^{229}$ In 1981, he was appointed chairman of this committee. With the chief executive officers of IBM and Du Pont Corporation serving as members of ACTN, the ACTN became crucial in the evolution of the trade-based strategy of linking the protection of intellectual property and trade. ${ }^{230}$

The Committee established a Task Force on Intellectual Property that consisted of eight members of United States IP-related industries. ${ }^{231}$ The key message of the Task Force to the United States Government was to pull as many levers as possible to link substantive standards of intellectual property with trade. Bilateral and unilateral efforts were only the interim strategy; the final goal was to integrate intellectual property in the GATT framework. ${ }^{232}$ Soon, it became clear to Edmund Pratt and the chairman of IBM, John Opel, that the ACTN alone would not be able to achieve the long-term goal of linking intellectual property standards to the GATT 1947; they needed the support of different business organizations, in the United States as well as in other countries, in particular the "Quadrilaterals" or "QUAD" countries (United States, European Union, Japan and Canada). 233 The need to focus on these four contracting parties to the GATT 1947 became obvious in the preparations of the

See M.P. Ryan, Knowledge Diplomacy: Global Competition and the Politics of Intellectual Property (Brookings Institution Press, Washington, 1998), p. 8.

The most influential people were Eric Smith, Elery Simon and Jacques Gorlin. See Braithwaite and Drahos, Global Business Regulation, p. 61.

See Drahos, Expanding Intellectual Property's Empire, p. 3.

See ibid., p. 3.

See ibid., p. 4.

See Braithwaite and Drahos, Global Business Regulation, p. 61.

See Matthews, Globalising Intellectual Property Rights, p. 19.

See Braithwaite and Drahos, Global Business Regulation, p. 62.

See Drahos, Expanding Intellectual Property's Empire, p. 5. 
forthcoming trade round. In the early eighties, different views existed between Europe and the United States on the desirability of an intellectual property agreement in the GATT. Only the support of the four most important GATT contracting parties would secure an inclusion of intellectual property in the trade round. ${ }^{234}$

Edmund Pratt and John Opel focused their efforts first on the United States. In March 1986, they founded a new business organization, the International Property Committee (IPC). In fact, "the IPC grew out of the work of the ACTN."235 Previously disparate industry groups of patent-reliant industries in the United States were brought together, resulting ultimately in thirteen founding members. ${ }^{236}$ Under the leadership of Jacques Gorlin, IPC worked effectively and was well managed, staffed, and funded.237 IPC's agenda reflected one issue only, that of linking intellectual property standards to the GATT framework.

Another important organization that played a major role in the trade-based approach to intellectual property in the United States is the above-mentioned International Intellectual Property Alliance (IIPA). ${ }^{238}$ This alliance represents the interests of the copyright-reliant industries, in particular eight trade associations. ${ }^{239}$ In contrast to the IPC, IIPA initially was not convinced that the multilateral GATT-based approach to copyright protection would be useful. Instead, it regarded bilateral trade negotiations and the sanctions under the Section 301 processes as most flexible and useful. ${ }^{240}$ Its main purpose of lobbying the USTR was to educate policy makers in the field of intellectual property where, according to IIPA, the latter's knowledge was still limited. ${ }^{241}$ Following continuous discussions with USTR policy makers about the long-term benefits of a TRIPS Agreement, IIPA reluctantly agreed to support the GATT-based strategy. ${ }^{242}$

\footnotetext{
$234 \quad$ See ibid., p. 5.

235 Braithwaite and Drahos, Global Business Regulation, p. 71.

236 The companies part of the founding team were Bristol-Meyers, DuPont, FMC Corporation, General Electric, General Motors, Hewlett-Packard, IBM, Johnson and Johnson, Merck, Monsanto, Pfizer, Rockwell International and Warner Communications. See Matthews, Globalising Intellectual Property Rights, p. 20. See Ryan, Knowledge Diplomacy: Global Competition and the Politics of Intellectual Property, p. 9.

238 See sections 1.6.1 and 1.6.4.3 on the role of the IIPA in bringing the problem of piracy to the attention of the US Government and in amending the eligibility criteria for the GSP scheme in the United States.

These associations are the Association of American Publishers, the Association of Data Processing Service Organisations, the Computer and Business Equipment Manufacturers Association, the Film Marketing Association, the International Anticounterfeiting Coalition, the Motion Picture Association of America, the National Music Publishers Association, and the Recording Industry Association of America. See Matthews, Globalising Intellectual Property Rights, p. 21. See Ryan, Knowledge Diplomacy: Global Competition and the Politics of Intellectual Property, p. 70.

241 See ibid., p. 70.

242 See Matthews, Globalising Intellectual Property Rights, p. 22.
} 
After having gotten IIPA on board, the next task of IPC was to form alliances with its counterparts in Europe and Japan. ${ }^{243}$ It established intensive contacts with the Union of Industrial and Employers' Confederation of Europe, which represented thirty-three national business federations at the European level, and with the Japanese Federation of Economic Organizations (Keidranen), which represented all business sectors in Japan. ${ }^{244}$ These organizations needed to be convinced to put pressure on their governments in order to include intellectual property in the trade agenda. According to Duncan Matthews, the European and Japanese trade associations were willing to cooperate with IPC and supported its initiative; ${ }^{245}$ his findings are in contrast with those of some US scholars. ${ }^{246}$ Duncan Matthews showed that European pharmaceutical and book-publishing industries had strong business interests in intellectual property protection; also Japanese companies producing consumer electronics and software relied heavily on intellectual property protection. ${ }^{247}$ In 1988, the three big business organizations IPC, the Union of Industrial and Employers' Confederation of Europe and Keidranen produced a joint statement of views, which they presented to the GATT Secretariat. ${ }^{248}$ This document was later known as the White Book and some of its provisions are reflected in the final TRIPS Agreement. ${ }^{29}$ In summary, private business networks in the United States, Europe and Japan were convinced of the need to link substantive intellectual property standards to the GATT framework, in particular to the Uruguay Round, and were highly successful in promoting their views with their governments.

\subsubsection{Interim Conclusions}

By the early 1980s, various US industry groups had become ever more dissatisfied with the level of intellectual property protection available at the global level. They formed alliances to lobby the US policy makers to pursue a comprehensive strategy of putting intellectual property protection high on the international agenda. The ultimate goal of the US strategy was to establish a link between substantive standards of intellectual property protection and trade matters, in particular by integrating intellectual property protection into the GATT 1947. That objective was pursued through initiatives at different levels: unilateral mechanisms (the Caribbean Basin Initiative, the Section 301 processes and the GSP scheme), bilateral investment treaties and an effort to shift the multilateral forum for IP protection.

The shift away from WIPO to the GATT framework was deemed necessary because the polarized views between developed and developing countries had produced a

The IPC did not address business groups in Canada, the fourth QUAD country. Despite its membership to QUAD, Canada was not such an important player. See Drahos, Expanding Intellectual Property's Empire, p. 6. See Matthews, Globalising Intellectual Property Rights, p. 22. See ibid., p. 23.

The view taken by some scholars in the United States was that European and Japanese associations have been rather reluctant to support the initiative and were never as committed as United States associations. See Ryan, Knowledge Diplomacy: Global Competition and the Politics of Intellectual Property, p. 107. Property”, see Drahos, Expanding Intellectual Property's Empire, p. 6, footnote 14. 
deadlock at the World Intellectual Property Organization. In addition, the GATT 1947 offered advantages in terms of composition, rule-making, scope of issues and enforcement rules. While it was the United States Government that pursued this overall strategy, it would not have been successful without the continued efforts of a group of influential US businessmen: they managed to get most intellectual propertyreliant industries in the Unites States, Europe and Japan on board. This international support for the link between IP standards and trade was determinative for the adoption of the TRIPS Agreement as part of the new World Trade Organization.

\subsection{CONCLUSIONS}

The first form of international protection of intellectual property was a comprehensive network of bilateral copyright conventions among European and Latin American countries. Also in the field of industrial property, European states started cooperating internationally through bilateral treaties. However, the network of bilateral treaties in the field of copyright and industrial property, and its lack of uniformity, led to the common understanding of states that multilateral pillars for regulating the protection of intellectual property needed to be created.

The Paris Convention and the Berne Convention marked the first multilateral phase. Many further initiatives of regulating intellectual property at the multilateral level took place in the framework of the Secretariat administering the Paris and Berne Conventions, and later within the context of the World Intellectual Property Organization. Despite these multilateral efforts, different industries, in particular the IP-reliant industries in the United States were not satisfied with the still fragmented international system of IP protection. In addition, the deadlock at WIPO increased the need for alternative venues of regulating intellectual property protection..$^{250}$

As a remedy for this dissatisfaction and as an element of a broader strategy, European states and the United States started using bilateral investment treaties and unilateral legislation to achieve a higher level of intellectual property protection in particular countries. Their ultimate goal, however, was to establish a link between the protection of intellectual property through substantive standards and trade matters, in particular by integrating intellectual property protection into the GATT 1947. They pursued that objective successfully with the continued support of various industry alliances in the United States, Europe and Japan. The establishment of the TRIPS Agreement within the new WTO initiated a new phase, the global phase.

Overall, the development of the international protection of intellectual property can be described as a dialectic one. In other words, bilateral phases have been followed by multilateral phases and the other way around. The recent proliferation of bilateral trade agreements seems to fit into this dialectic of forum shifting history in the international regime of protecting intellectual property. ${ }^{251}$ Peter Drahos refers to this phenomenon as waves of bilateral agreements that are followed by occasional

$250 \quad$ See Okediji, "Back to Bilateralism?", p. 138.

251 See section 3.5 on an assessment as to whether or not the recent proliferation indeed is only one phase in this dialectic development or whether it must be classified as exceptional. 
multilateral standard setting. ${ }^{252} \mathrm{He}$ does not only observe the reoccurring shifts of forums, but he also recognizes that each wave of bilateral agreements or multilateral agreements never derogates from existing standards, and that they even go beyond those standards by creating new standards. This is known as the global intellectual property ratchet where each wave of bilateralism and multilateralism is used to expand global intellectual property protection consistently. 253

252 See Drahos, Expanding Intellectual Property's Empire, p. 8.

253 For a more detailed assessment of the global intellectual property ratchet, see introduction to Chapter 1: The International System of Protecting Intellectual Property pre-TRIPS. 


\section{Chapter 2 : The TRIPS Agreement: A Global IP Regime}

\subsection{INTRODUCTION}

The TRIPS Agreement represents the beginning of the global regime of intellectual property protection. There are several reasons why I, as well as other authors, ${ }^{1}$ describe the recent phase as a global one. First, the TRIPS Agreement represents the first clear linkage between substantive standards of intellectual property protection and the trade framework. With the TRIPS Agreement, the protection of intellectual property has become a prominent pillar of the WTO framework. It introduces mandatory substantive IP obligations for all existing and future Members of the WTO. With currently 157 Members, ${ }^{2}$ the WTO is a truly global organization.

Second, all WTO Members are under an obligation to adhere to the entire TRIPS Agreement. While states were able to make reservations to intellectual property conventions and treaties in the past, the TRIPS Agreement is binding in its entirety. Third, by reference, the TRIPS Agreement incorporates various other intellectual property conventions. ${ }^{3}$ It obliges states to implement a "common and enlarged set of intellectual property standards". ${ }^{4}$ Even those international standards of intellectual property from which states used to be able to opt out have become mandatory.

Fourth, the recent proliferation of bilateral trade agreements enlarges the group of states that adhere to this common set of standards. ${ }^{5}$ The scope of common standards is further broadened through so-called TRIPS-plus provisions contained in bilateral agreements. Because the TRIPS Agreement lacks a regional integration exception similar to those included in Article XXIV of the GATT 1994 and in Article V of the GATS, the most-favoured-nation treatment obligation in Article 4 of the TRIPS Agreement applies in full to bilateral trade agreements. In other words, WTO Members that accept TRIPS-plus standards in bilateral trade agreements must accord the same treatment "immediately and unconditionally to the nationals of all other members" 6 of the WTO.

Fifth, as Christopher May notes, a truly global legal regime for intellectual property has existed only since the TRIPS Agreement because the international IP regime lacked

$1 \quad$ See C. May, "Why IPRs are a Global Political Issue” EIPR, 2003, Vol. 25 (1), 1-5, p. 1 ff; Braithwaite and Drahos, Global Business Regulation, p. 61; Drahos, Expanding Intellectual Property's Empire, p. 6 ff; Cottier, "The Agreement on Trade-Related Aspects of Intellectual Property Rights", p. 1050.

2 This is the number of WTO Members on 16 October 2012.

$3 \quad$ See Article 9 for the Berne Convention; Article 2 for the Paris Convention, and Article 35 for the Treaty on Intellectual Property in Respect of Integrated Circuits (the IPIC Treaty). The TRIPS Agreement contains some references to certain provisions of the International Convention for the Protection of Performers, Producers of Phonograms and Broadcasting Organizations (the Rome Convention). However, there is no general obligation to comply with the substantive provisions of that Convention.

$4 \quad$ See Braithwaite and Drahos, Global Business Regulation, p. 63.

5 This is the case if bilateral trade agreements involve non-WTO Members. An example is the CARIFORUM-EC EPA, which has as a party the Bahamas, a country that is not yet a Member of the WTO.

6 Article 4 of the TRIPS Agreement. 
a strong enforcement mechanism and therefore had no teeth. ${ }^{7}$ The possibility of enforcing the TRIPS standards through the effective dispute settlement system of the WTO increases the actual rate at which countries comply with their international obligations. This used to be a major criticism of the international conventions which could not be enforced effectively before the entering into force of the TRIPS Agreement.

Due to the importance and wide application of the TRIPS Agreement, it is worthwhile to shed some light on 1) the negotiating history and 2) the main substantive provisions of the TRIPS Agreement. During the negotiations of the TRIPS Agreement, conflicting positions between developed and developing countries had occurred. The views defended on both sides are still relevant today when members of those groups face each other in bilateral trade negotiations. Also the main TRIPS obligations are often referred to in the context of bilateral trade negotiations: many standards included in the bilateral agreements are based on the TRIPS standards and often go beyond the level of protection foreseen in the TRIPS Agreement.

\subsection{The URuguay Round Negotiations}

The negotiations of the Uruguay Round were of crucial importance for the future of the international system of intellectual property protection. The efforts of industry networks had helped to put intellectual property on the trade agenda. Now it was up to the delegations of the contracting parties to the GATT 1947 to negotiate what form, scope and content the protection of intellectual property should take within the GATT framework. The negotiations, especially in the beginning, were marked by conflicting positions on North-South issues, i.e. issue areas where opinions between developed and developing countries were polarized. Towards the end of the negotiations, conflicts arose also on North-North issues, i.e. those areas that created conflict among different developed countries. The negotiating history grants important insights into the process of establishing the TRIPS Agreement. According to Daniel Gervais, between the initiating Ministerial Conference of Punta del Este in September 1986 and the concluding Ministerial Conference of Marrakesh in April 1994 ,

\footnotetext{
"the broadest and most extensive multilateral agreement in the field of intellectual property [was created], covering basically the entire area and adding enforcement, acquisition and most-favoured nation obligations to new and existing rules."
}

The negotiating history of the TRIPS Agreement has been analyzed extensively by a number of scholars. ${ }^{9}$ It is beyond the scope of this book to give a detailed account of the negotiations. However, it is useful to point out the major yardsticks of the process in order to demonstrate how controversial it was to establish rules on the

$7 \quad$ See May, "Why IPRs are a Global Political Issue", p. 2.

$8 \quad$ See Gervais, The TRIPS Agreement: Drafting History and Analysis, paragraph 1.12.

9 For some comprehensive accounts of the TRIPS drafting history, see T.P. Stewart (ed.), The GATT Uruguay Round: A Negotiating History: 1986-1992 Vol. 2 (Kluwer Law and Taxation Publishers, Deventer, 1993); Chasen Ross and Wasserman, "TradeRelated Aspects of Intellectual Property Rights"; Gervais, The TRIPS Agreement: Drafting History and Analysis; Watal, Intellectual Property Rights in the WTO and Developing Countries; and Matthews, Globalising Intellectual Property Rights. 
protection of intellectual property that would finally apply to all WTO Members. It also provides a point of reference for the negotiation processes of the IP chapters in recent bilateral trade agreements. In the following, the negotiating history of the TRIPS Agreement will be discussed shortly according to three phases: 1) "preparation and fact-finding" phase, 2) "negotiation" phase, and 3) the "preserving the results" phase. In addition to that, a short discussion of the input of developing countries in the negotiations will follow.

\title{
2.2.1. The "Preparation and Fact-finding Phase"
}

The first phase lasted from the launch of the Uruguay Round at the Punta del Este Ministerial Conference in September 1986 until the mid-term review in December 1988 in Montreal. It was primarily marked by defining the negotiating mandate, several initial proposals of which areas of intellectual property should be covered and more specifically the disagreement over the competence of the GATT to negotiate substantive intellectual property rules. The Punta del Este Ministerial Declaration contained many different subjects for negotiation, one of them addressing the TradeRelated Aspects of Intellectual Property Rights. That paragraph was based on the Swiss-Colombian proposal submitted to the GATT Preparatory Committee in 1985. ${ }^{10}$ In the relevant part, it reads:

\begin{abstract}
"In order to reduce the distortions and impediments to international trade, and taking into account the need to promote effective and adequate protection of intellectual property rights, and to ensure that measures and procedures to enforce intellectual property rights do not themselves become barriers to legitimate trade, the negotiations shall aim to clarify GATT provisions and elaborate as appropriate new rules and disciplines. [...]" [emphasis added]. ${ }^{11}$
\end{abstract}

In fact, the entire TRIPS Agreement, except for the enforcement provisions, rests on the final words of this first paragraph. ${ }^{12}$ This statement clearly shows that the final TRIPS Agreement developed into a far-reaching agreement when compared to the initial mandate.

One out of the fourteen negotiating groups established under the Group of Negotiation on Goods 13 dedicated itself to the "Trade-Related Aspects of Intellectual Property, Including Trade in Counterfeit Goods". This group was chaired by the Ambassador of Sweden, Lars Anell. Three tendencies can be observed in the work of the negotiating group from early 1987 until late 1988. First, considerable information was still lacking on the scope of and the problems with intellectual property protection. ${ }^{14}$ This insight induced contracting parties to gather more information and start a process of mutual learning on the relevant subject matters. Second, participants of the group were free to make any suggestions as to how the negotiating

$10 \quad$ See section 1.6.5.2.

11 GATT, Ministerial Declaration on the Uruguay Round (Punta del Este, 20 September 1986) [MIN.DEC], part D. Subjects for Negotiation.

12 See Gervais, The TRIPS Agreement: Drafting History and Analysis, paragraph 1.12.

13 In the hierarchy, this Group reported to the highest body charged to oversee the negotiations, the Trade Negotiations Committee. See ibid., paragraph. 1.13.

14 See ibid., paragraph 1.13. 
mandate could be achieved; in addition, draft texts could be tabled later on. ${ }^{15}$ This liberal approach allowed all contracting parties to present any suggestions as to which aspects of intellectual property should be included. Proposals were submitted by the United States, the European Union (at the time European Community), Switzerland and Japan in the second half of $1987 .{ }^{16}$ These four proposals were comprehensive in scope and addressed most possible aspects of intellectual property.

Third, a major disagreement existed between developing and developed countries with regard to the competence of the GATT to negotiate substantive intellectual property standards. ${ }^{17}$ According to Duncan Matthews, this was the main reason why negotiating attempts in the beginning of the Round were not successful. ${ }^{18}$ In particular, India and Brazil stressed the role of WIPO as the appropriate forum for the regulation of intellectual property. ${ }^{19}$ The proposal presented by Brazil in July 1986 illustrates various issues that developing countries sought to achieve, among others the disputed jurisdictional adequacy of the GATT. ${ }^{20}$ The fundamental disagreement in the "North-South debate"21 became obvious at the Ministerial Meeting of December 1988 in Montreal. ${ }^{22}$ Together with agricultural reforms, the question of the appropriate forum was the main reason why no formal agreement on the framework of the TRIPS Agreement and on specific substantive standards could be reached. ${ }^{23}$ In conclusion, the first phase of the Uruguay Round in the field of intellectual property revealed that the positions of contracting parties were far from homogeneous and that negotiations would be very difficult.

\subsubsection{The "Negotiations" Phase}

The second phase of the negotiations started with the Geneva Ministerial Meeting in April 1989 and lasted until the Draft Final Act which was presented in December 1991. The main characteristics of this phase were the typical negotiating processes, with different proposals being presented, compromise texts being sought, breakdowns over particular issues, and finally a solution that could be accepted by all parties involved. What is striking about this phase is the process of how developing countries have changed their position from bitter opposition in the first phase to

15 See ibid., paragraph 1.13.

16 See Chasen Ross and Wasserman, "Trade-Related Aspects of Intellectual Property Rights", p. 2266-2267.

17 See J. Gorlin, An Analysis of the Pharmaceutical-related Provisions of the WTO TRIPs (Intellectual Property) Agreement (Intellectual Property Institute, London, 1998), p. 2.

18 See Matthews, Globalising Intellectual Property Rights, p. 31.

19 See M. Blakeney, "Intellectual Property in World Trade" International Trade Law and Regulation, 1995, Vol. 1 (3), 76-81, p. 79.

See GATT Preparatory Committee, Draft Ministerial Declaration, Revision (16 July 1986) [PREP.COM(86)W/41/Rev.1], paragraph 7. The proposal stresses that the liberalization of trade, in particular in all areas of trade in goods, should be addressed in strict observance of GATT jurisdiction.

21 See Chasen Ross and Wasserman, "Trade-Related Aspects of Intellectual Property Rights", p. 2287.

22 See GATT Trade Negotiations Committee, Meeting at Ministerial Level (Montreal, 9 December 1988) [MTN.TNC/7(MIN)].

23 See Chasen Ross and Wasserman, "Trade-Related Aspects of Intellectual Property Rights”, p. 2268. 
accepting the position of industrialized countries by the end of the second phase. This development has been described as a 'sea-change'. ${ }^{24}$

The beginning of the second phase was marked by an agreement on the scope of future intellectual property negotiations which was reached on the Mid-Term Meeting in Geneva in April 1989.25 The GATT parties agreed to include substantive standards, effective means of enforcement and effective dispute settlement mechanisms in the negotiations; the contentious issue of choosing the appropriate forum was left aside. ${ }^{26}$ This outcome can be described as a victory for developed countries. They managed to get a text that allowed all substantive aspects to be discussed legitimately, along with enforcement and dispute settlement issues, whereas developing countries failed to bargain for concrete assurances on the forum question or transitional periods. ${ }^{27}$

Following the agreement on the framework of negotiations, submissions were made by developed and developing countries. ${ }^{28}$ While developed countries' submissions mainly followed the United States position, India rejected the inclusion of all aspects of intellectual property, emphasizing that only those practices that distorted international trade should be subject to negotiation. ${ }^{29}$

These submissions were followed by a round of tabling draft texts. In early 1990, the European Union was the first to submit a written proposal in treaty language. ${ }^{30}$ Quickly, proposals by the United States, fourteen developing countries, Switzerland and Japan followed. ${ }^{31}$ The EU proposal covered all aspects of intellectual property

24 See Watal, Intellectual Property Rights in the WTO and Developing Countries, p. 37.

25 See GATT Trade Negotiations Committee, Mid-Term Meeting (Geneva, 21 April 1989) [MTN.TNC/11].

26 See Matthews, Globalising Intellectual Property Rights, p. 34.

27 See Gervais, The TRIPS Agreement: Drafting History and Analysis, paragraph 1.16; Watal, Intellectual Property Rights in the WTO and Developing Countries, p. 27.

28 The developed countries that submitted proposals were Australia, the Nordic countries, Switzerland, Austria and Hong Kong. Among the developing countries, India, the Republic of Korea, Peru and Brazil issued submissions, arguing among others for the permission for compulsory licences. See Chasen Ross and Wasserman, "Trade-Related Aspects of Intellectual Property Rights", p. 2273; Gervais, The TRIPS Agreement: Drafting History and Analysis, paragraph 1.17.

29 See GATT Delegation of India, Standards and Principles Concerning the Availability Scope and Use of Trade-Related Intellectual Property Rights, Communication from India (10 July 1989) [MTN.GNG/NG11/W/37], p. 1.

30 See GATT Delegation of the European Community, Draft Agreement on Trade-Related Aspects of Intellectual Property Rights, Communication from the European Community (29 March 1990) [MTN.GNG/NG11/W68] [hereinafter EU proposal].

31 See GATT Delegation of the United States, Draft Agreement on the Trade-Related Aspects of Intellectual Property Rights, Communication from the United States (11 May 1990) [MTN.GNG/NG11/W70] [hereinafter United States proposal; WTO Secretariat, Communication from Argentina, Brazil, Chile, China, Colombia, Cuba, Egypt, India, Nigeria, Peru, Tanzania and Uruguay (Geneva, 14 May 1990) [MTN.GNG/NG11/W71] [hereinafter developing countries' proposal W/71]; GATT Delegation of Switzerland, Draft Amendment to the General Agreement on Tariffs and Trade on the Protection of Trade-Related Intellectual Property Rights, Communication from Switzerland (14 May 1990) [MTN.GNG/NG11/W73]; GATT Delegation of Japan, Main Elements of a Legal Text 
rights as well as enforcement provisions, and the application of the basic GATT principles. The United States proposal was very similar in structure and content to the EU proposal and it was suggested that transatlantic consultation had taken place beforehand. ${ }^{32}$ Overall, developed countries' proposals supported a comprehensive agreement on IP protection; they were divided on issues that later would receive more prominence as the "North-North issues". 33 In contrast, the developing countries" proposal $W / 71$ unequivocally separated the discussion of trade in counterfeit and pirated goods from other intellectual property issues and made clear that they did not view intellectual property as a property right, but as a matter of public policy. ${ }^{34}$ Also the form of the proposal substantially differed from those presented by the European Union and the United States: it was of a more general nature and not yet in treaty language. ${ }^{35}$

Despite the multitude of different proposals, or maybe because of that, negotiations were largely stalled by the end of $1990 .{ }^{36}$ This time, it was the chairman Lars Anell who was described as the "hero of the hour" 37 and consolidated the different viewpoints in one compromise text. The July 1990 Chairman's Report ${ }^{38}$ contained agreed issues in unbracketed language, and issues where agreement was still lacking in bracketed language. In addition, he presented two versions: the approach favoured by developed countries in 'version $A$ ' and the approach favoured by developing countries in 'version B'. Approach A represented a single agreement covering all intellectual property rights, their acquisition, enforcement provisions and the applicability of GATT 1947 principles. Approach B allowed for a separation into two agreements, one part on trade in counterfeit and pirated goods and the second part on other intellectual property standards and principles. ${ }^{39}$ Although the July 1990 Chairman's Report was a "negotiating masterstroke," 40 it was also criticized for having

for TRIPs, Communication from Japan (15 May 1990) [MTN.GNG/NG11/W74]. Note that the developing countries' proposal W/71 was joined by Pakistan and Zimbabwe later.

See Gervais, The TRIPS Agreement: Drafting History and Analysis, paragraph 1.18; T. Dreier, "TRIPs and the Enforcement of Intellectual Property Rights" in F.-K. Beier and G. Schreiker (eds.), From GATT to TRIPs: the Agreement on Trade-Related Aspects of Intellectual Property Rights (International Review of Industrial Property and Copyright Law, VCH, Weinheim, 1996), 248-277, p. 257.

For a detailed account on the differences between developed countries' proposals, see Chasen Ross and Wasserman, "Trade-Related Aspects of Intellectual Property Rights", p. 2273.

See WTO Secretariat, Communication from Argentina, Brazil, Chile, China, Colombia, Cuba, Egypt, India, Nigeria, Peru, Tanzania and Uruguay, p. 2. See Watal, Intellectual Property Rights in the WTO and Developing Countries, p. 31. See Chasen Ross and Wasserman, "Trade-Related Aspects of Intellectual Property Rights", p. 2274.

37 See Matthews, Globalising Intellectual Property Rights, p. 36.

38 See Chairman Lars Anell, Status of Work in the Negotiating Group, Chairman's Report to the GNG (23 July 1990) [MTN.GNG/NG11/W/76] [hereinafter July 1990 Chairman's Report].

39 See ibid., p. 1.

40 See Matthews, Globalising Intellectual Property Rights, p. 36. 
adopted the structure of the EU and the United States proposals too closely. ${ }^{41}$ Ultimately, the text was largely accepted as the basis for further discussions.

Over the following months, the July 1990 Chairman's Report developed into the Brussels Draft which eventually was presented to the Ministers on the Brussels Ministerial Meeting in December 1990.42 In this period, the pace and style of the negotiations had changed and the significance of informal meetings increased. Chairman Anell assembled the key players regularly in informal sessions which took place next to formal meetings. ${ }^{43}$ In contrast to the formal meetings, informal sessions stayed off the official records. This style of negotiation proved to be so efficient that to the end of the negotiations, the "ten-plus-ten" informal drafting group was introduced. It consisted of the most active and most skilled negotiators from ten developed and ten developing countries, or other formations for different issues. ${ }^{44}$ The result of the negotiations by December 1990 was so advanced that it would have been possible to finish the TRIPS Agreement, had the other areas under negotiation been sufficiently close to agreement. ${ }^{45}$ Yet, the Brussels ministerial negotiations were dissolved due to continuing disagreement on agricultural issues. ${ }^{46}$

Nevertheless, the Brussels Draft became the basis for the negotiations that continued after the breakdown of the Brussels Ministerial Meeting. This draft contained provisions in all fields of intellectual property; ${ }^{47}$ furthermore, it was noted that these standards were minimum requirements. ${ }^{48}$ Yet, many issues were still unresolved and left for discussion in the TRIPS negotiation group. Controversial issues included the protection of pharmaceutical products by patents, the role of dispute settlement procedures, the nature and duration of transitional arrangements for developing countries, the protection of geographical indications and the status of moral rights relating to copyright. ${ }^{49}$

The TRIPS negotiation group was not affected by the general reorganization of the negotiating groups; $; 0$ it therefore could preserve its working method that had been employed between July and December 1990. In particular, the informal drafting

See Gervais, The TRIPS Agreement: Drafting History and Analysis, paragraph 1.23. See GATT Trade Negotiations Committee, Agreement on Trade Related Aspects of Intellectual Property Rights, including Trade in Counterfeit Goods, Draft Final Act Embodying the Results of the Uruguay Round of Multilateral Trade Negotiations (3 December 1990) [MTN.TNC/W/35/Rev.1] [hereinafter Brussels Draft, p. 260.

See Gervais, The TRIPS Agreement: Drafting History and Analysis, paragraph 1.23.

See Matthews, Globalising Intellectual Property Rights, p. 38; Watal, Intellectual Property Rights in the WTO and Developing Countries, p. 32.

See Gervais, The TRIPS Agreement: Drafting History and Analysis, paragraph 1.25.

See Chasen Ross and Wasserman, "Trade-Related Aspects of Intellectual Property Rights", p. 2276.

See Articles 9-43 of the Brussels Draft.

See Chairman Lars Anell, Status of Work in the Negotiating Group (1 October 1990) [Ref. No. 2341], p. 3.

See Matthews, Globalising Intellectual Property Rights, p. 37.

The fifteen existing groups were replaced by seven negotiating groups. Due to the technical nature of intellectual property protection, one of the seven groups remained solely dedicated to TRIPS. See Gervais, The TRIPS Agreement: Drafting History and Analysis, paragraph 1.28 . 
group "ten-plus-ten" continued its work. One procedural innovation was implemented in February 1991: it was primarily the Chairman that put forward draft texts; before, parties involved in the "Green Room" process narrowed down options in a lengthy process in order to arrive at a compromise text. ${ }^{51}$ The group focused on specific issues ${ }^{52}$ rather than on the well-known politically sensitive problems, which could not be solved at the level of negotiators.

Together with the Chairman of the TRIPS negotiating group, the Director-General Arthur Dunkel, presented another draft text in December 1991. The text had abolished all forms of 'options'. ${ }^{53}$ The so-called Dunkel Draft therefore was an "all-ornothing" agreement which the Chairman and the GATT Secretariat believed to be acceptable to all participants. They had chosen for the following solutions of the contentious issues: ${ }^{54}$

- inclusion of national treatment and most-favoured-nation treatment; 55

- exclusion of moral rights (taking account of the United States position); ${ }^{56}$

- right of authors to allow rental rights (Japanese position); ${ }^{57}$

- protection of "new or original" industrial designs, ${ }^{58}$

- "additional protection" of geographical indications for wines and spirits (European position); 59

- patent protection of twenty years (practice in most countries); ${ }^{60}$

- possible exclusion of plants and animals from patentability (developing countries' and the European position); ${ }^{61}$ and

$51 \quad$ See Matthews, Globalising Intellectual Property Rights, p. 38.

52 For a detailed account of the issues discusses, see Chasen Ross and Wasserman, “Trade-Related Aspects of Intellectual Property Rights", p. 2277-2279; Gervais, The TRIPS Agreement: Drafting History and Analysis, paragraph 1.29.

53 See GATT Trade Negotiations Committee, Agreement on Trade Related Aspects of Intellectual Property Rights, Including Trade in Counterfeit Goods (Annex III), Draft Final Act Embodying the Resultus of the Uruguay Round of Multilateral Trade Negotiations (20 December 1991) [MTN.TNC/W/FA] [hereinafter Dunkel Draft.

For a detailed discussion of the issues listed, see Gervais, The TRIPS Agreement: Drafting History and Analysis, paragraph 1.30; Chasen Ross and Wasserman, "Trade-Related Aspects of Intellectual Property Rights", p. 2282-2284.

$55 \quad$ See Articles 3 and 4 of the Dunkel Draft. See also sections 3.1.2.1 and 3.2.3 for a more detailed analysis of the two non-discrimination obligations in the TRIPS Agreement.

56 See Article 9.1 of the Dunkel Draft and section 1.3 for a brief account of the concept of moral rights.

57 See Article 11 of the Dunkel Draft. See also section 2.3.2 of this book on substantive provisions of the TRIPS Agreement.

See Article 25 of the Dunkel Draft and section 6.3.4.2 on the requirements for design protection in the draft IP chapter of the India-EU BTIA. In particular, see footnote 186 in section 6.3.4.2 of this book.

See Article 23 of the Dunkel Draft and section 3.3.6.2 for a detailed analysis of the additional protection for geographical indications granted in the TRIPS Agreement and in the CARIFORUM-EC EPA.

See Article 33 of the Dunkel Draft and section 2.3.2 of this book on substantive provisions of the TRIPS Agreement.

61 See Article 27.3 of the Dunkel Draft and section 2.3.2 of this book on substantive provisions of the TRIPS Agreement. 
- transitional periods of five years after the coming into force of the Agreement, including another five years for least-developed countries (developing countries' position). ${ }^{62}$

The Dunkel Draft gave most parties something considered to be of importance to them. For that reason, the majority of countries were willing to accept the package presented by the Dunkel Draft, except for India and the United States. They proposed further revisions during the last phase of the negotiations. The Dunkel Draft marked the end of phase two; it was hardly changed before becoming the final TRIPS Agreement. ${ }^{63}$

\subsubsection{The "Preserving the Results" Phase}

The final phase lasted from the beginning of 1992 until the end of the Uruguay Round in April 1994. This phase can be identified by two developments in the Round: first, a predominance of other issues than intellectual property protection, and second, a specific focus on North-North issues in the intellectual property discussions. In 1992, negotiating parties were preoccupied with a disagreement between the United States and the European Union on issues in agriculture. Only after an agreement was achieved between these two parties in November 1992, the discussions in the TRIPS negotiating group continued. ${ }^{64}$ While most parties were prepared to move forward with the "up-or-down" package that the Dunkel Draft presented, India and the United States added further proposals to the discussions in late 1992.

India proposed to omit the exclusive right to market patented products and to require right holders to "work" a patent locally. ${ }^{65}$ The United States asked for "pipeline" protection for patented drugs that have not been marketed in foreign countries and a change of the exceptions to Article 3 on the national treatment obligation. ${ }^{66}$ Besides efforts to agree on these issues, the major focus of the final stages was to solve outstanding issues between the United States, the European Union and Japan. ${ }^{67}$ However, it was clear that the potential gains of the TRIPS Agreement for developed countries far outweighed the remaining differences. This situation already secured a successful outcome in the area of intellectual property. ${ }^{68}$

62 See Articles 65 and 66 of the Dunkel Draft and section 2.3.6 of this book on transitional arrangements.

63 See Gervais, The TRIPS Agreement: Drafting History and Analysis, paragraph 2.01.

64 See Chasen Ross and Wasserman, "Trade-Related Aspects of Intellectual Property Rights", p. 2286.

65 See ibid., p. 2286-2287. See also section 2.3.2 of this book on substantive provisions of the TRIPS Agreement.

66 For a more detailed explanation of "pipeline" protection, see section 2.3.2 of this book on substantive provisions of the TRIPS Agreement. See also Matthews, Globalising Intellectual Property Rights, p. 40-41. For more information on the alleged discrimination under the video levy system of Western European countries allowed under Article 3, see Chasen Ross and Wasserman, "Trade-Related Aspects of Intellectual Property Rights", p. 2286.

67 For a detailed discussion of the main areas of disagreement, see Chasen Ross and Wasserman, "Trade-Related Aspects of Intellectual Property Rights", p. 2287 ff. See Matthews, Globalising Intellectual Property Rights, p. 42. 
Ultimately, the Dunkel Draft became the final TRIPS Agreement, only minor amendments were added. It was adopted at the conclusion of the Uruguay Round in Marrakesh 12-15 April 1994 and was included in Annex 1C to the WTO Agreement. The Agreement on Trade-Related Aspects of Intellectual Property Rights, together with the WTO Agreement, entered into force on 1 January 1995.

\subsubsection{The Input of Developing Countries in the Negotiations}

The input of developing countries during the negotiations of the TRIPS Agreement has been subject to a scholarly debate which is reflected in the literature. The academic community seems to be divided on the question as to whether or not developing countries were able to participate in the negotiations and defend their interests adequately. Drawn from the accounts given by John Braithwaite, Julie Chasen Ross and Jessica Wasserman, Thomas Cottier, Peter Drahos, Daniel Gervais, Jacques Gorlin, Duncan Matthews, Susan Sell, Terence Stewart, and Jayashree Watal, the perspectives on the issue differ.

To start with, in his work 'The TRIPS Agreement: Drafting History and Analysis', Daniel Gervais does not take a particular view as to how much input developing countries had in the negotiations of the TRIPS Agreement. He analyses the negotiations without discussing the question of participation. Similarly, Julie Chasen Ross and Jessica Wasserman in 'Trade-related Aspects of Intellectual Property Rights' do not address developing countries' participation in detail. However, they note that

\footnotetext{
"Pressure by the United States through its domestic law remedies (section 301, special 301) resulted in movement in fact by a number of developing countries both reducing the factual basis for some countries objecting to a multilateral consensus and encouraging other countries to be amenable to a multilaterally agreed set of principles to restrict the U.S.'s unilateral actions." ${ }^{69}$
}

Accordingly, the United States' usage of their unilateral trade regulation in respect of many developing countries clearly has influenced the positions taken by these countries within the multilateral negotiations. They became more amenable to agree to the standards offered at the multilateral level as a means to avoiding further unilateral actions by the United States. Also other authors point out that the Section 301 processes have played a pivotal role for developing countries to give up their resistance to the TRIPS proposal. ${ }^{70}$ Peter Drahos shows in his article 'Developing Countries and International Intellectual Property Standard Setting' that out of the ten developing countries that were most active in their opposition to the United States' intellectual property agenda during the Uruguay Round, five countries found themselves listed on either the Priority Watch List or the Watch List. ${ }^{71}$ Therefore, the United States' threat of using unilateral sanctions seems to be the most important

Chasen Ross and Wasserman, "Trade-Related Aspects of Intellectual Property Rights", p. 2313.

See Braithwaite and Drahos, Global Business Regulation, p. 63; see also Matthews, Globalising Intellectual Property Rights, p. 44.

71 See Drahos, "Developing Countries and International Intellectual Property Standard Setting", p. 773-774. See also the table on page 775 in which Drahos shows the 301 process being strategically employed against the developing countries that were resisting the United States intellectual property agenda. 
factor that made developing countries change their positions in the course of the negotiations.

Another factor that several authors have noted to have played an important role was the lack of representation and expertise of developing countries. ${ }^{72}$ Jacques Gorlin suggests that only about ten countries had sent actual intellectual property experts to the TRIPS negotiations; in most cases, developing countries' delegations consisted of officials from the trade ministries and/or officials from national patent offices that were not necessarily aware of the impact that the TRIPS Agreement could have for their national industries. ${ }^{73}$

In addition to the lack of expertise, Peter Drahos points out that on the face, developing countries might have been properly represented; however, representation of interests also entails the idea of not being excluded from negotiations. ${ }^{74}$ In the case of the TRIPS negotiations, not only the traditional process of the "Green Room" negotiations excluded developing countries from negotiations; also other informal groups, which were established according to specific issues, did so. ${ }^{75}$ The most important negotiating groups consisted of the United States, the European Union, Japan and Canada (QUAD countries); they really mattered in the TRIPS negotiations. ${ }^{76}$ This in fact prevented developing countries from being properly represented and from receiving full information. Most authors conclude that because of these circumstances, effective negotiation on behalf of developing countries was not possible.

In contrast to these opinions, Thomas Cottier in 'Agreement on Trade-Related Aspects of Intellectual Property Rights' takes another view. According to him, complaints that developing countries could not fully understand the content of the provisions are not well founded:
"perhaps with the exception of complaints from some African States that were not prepared or able to make the necessary resources available during the negotiations. But there was a strong group of countries, including Brazil and India, which resolutely defended their interests $[\ldots] .{ }^{\prime}{ }^{77}$

To conclude the different accounts presented above, it seems fair to say that developing countries faced obvious constraints and problems in preserving their interests in the TRIPS negotiations adequately. The problems identified can explain the change of their positions during the negotiations, namely the move from strong

72 See Watal, Intellectual Property Rights in the WTO and Developing Countries, p. 44; Matthews, Globalising Intellectual Property Rights, p. 44; S.K. Sell, Private Power, Public Law: The Globalization of Intellectual Property Rights (Cambridge Studies in International Relations (No. 88), Cambridge University Press, Cambridge, 2003), p. 139-140.

73 See Gorlin, Pharmacentical-related Provisions, p. 6.

74 See Drahos, "Developing Countries and International Intellectual Property Standard Setting", p. 770.

75 See ibid., p. 771

76 See ibid., p. 772.

77 Cottier, "The Agreement on Trade-Related Aspects of Intellectual Property Rights", p. 1056. 
opposition at the beginning of the negotiations to accepting most developed countries' propositions at the end.

\subsubsection{Interim Conclusions}

The negotiations of the TRIPS Agreement were marked by conflicting views on whether the GATT was the appropriate forum for the negotiations to take place and what the scope and extent of a future agreement should be. While the first phase clearly reflected a sphere of opposition between developed and developing countries, the second phase showed a remarkable development: step by step, developing countries came closer to the positions of developed countries. All countries finally agreed to the Dunkel Draft, a proposal of IP standards that included substantive, minimum intellectual property standards in all aspects of intellectual property protection, combined with the GATT principles of non-discrimination and enforcement mechanisms. This result has been achieved through a negotiation process that relied heavily on informal drafting groups which brought together the main actors from developed and developing countries. It also reflects a remarkable change in positions on behalf of developing countries which can partly be explained by the threat that the Section 301 process posed on developing countries, their limited expertise and a partial exclusion from the negotiating table.

\subsection{Substantive Provisions of the TRIPS AGREEMENT}

This paragraph does not provide a detailed account of all provisions contained in the TRIPS Agreement; other scholars have done so already. ${ }^{78}$ However, it is an attempt to illustrate the major characteristics and novelties compared to the international system of protecting intellectual property before the TRIPS Agreement was adopted. The TRIPS Agreement has been described by several authors as a milestone in the development of intellectual property. ${ }^{79}$ It is a milestone because of the breadth of subject matters that are comprised in the Agreement and because of the minimum standards that apply to them. The obligation of all WTO Members to guarantee specific enforcement procedures and to accept cross-sectoral trade sanctions imposed by duly constituted international bodies is also unprecedented. ${ }^{80}$

78 To just mention a few, see Gervais, The TRIPS Agreement: Drafting History and Analysis, paragraph 2.01 ff; C.M. Correa, Trade Related Aspects of Intellectual Property Rights: A Commentary on the TRIPS Agreement (Oxford University Press, Oxford, 2007); Blakeney, Trade Related Aspects of Intellectual Property Rights; Cottier, "The Agreement on TradeRelated Aspects of Intellectual Property Rights", p. 1057-1115; Matthews, Globalising Intellectual Property Rights, p. 46-77.

See S. Ricketson, "The Future of Traditional Intellectual Property Conventions in the Brave New World of Trade-Related Intellectual Property Rights" Intellectual Review of Industrial Property and Copyright Law, 1995, Vol. 25, 872-899, p. 883; Stewart (ed.), The GATT Uruguay Round: The End Game, p. 576; Gervais, The TRIPS Agreement: Drafting History and Analysis, paragraph 1.01; Watal, Intellectual Property Rights in the WTO and Developing Countries, p. 2.

80 See J.H. Reichman, "Compliance with the TRIPS Agreement: Introduction to a Scholarly Debate" Vanderbilt Journal of Transnational Law, 1996, Vol. 29, 363-390, p. 366367. 


\subsubsection{General Provisions and Basic Principles}

The structure of the TRIPS Agreement consists of seven parts. ${ }^{81}$ Part I deals with the general provisions and basic principles. It includes the principle of minimum standards in Article 1.1 of the TRIPS Agreement, the GATT principles of nondiscrimination, being the national treatment obligation and the most-favoured-nation treatment obligation (Articles 3 and 4). ${ }^{82}$ It also contains in Article 6 the stipulation that the Agreement does not address the issue of exhaustion of intellectual property rights. ${ }^{83}$

Articles 7 and 8 of Part I define the object and purpose of the Agreement and therefore provide the context for the interpretation and implementation of the rights and obligations under the Agreement. Article 7 was based on the developing countries' proposa ${ }^{\beta 4}$ and strikes a balance between the positions of developed and developing countries, noting the importance of intellectual property protection for innovation as well as the necessity to promote the transfer and dissemination of technology 85 Furthermore, it stipulates that the social and economic welfare and the balance of rights and obligations should be taken into account.

Article 8 allows WTO Members to take any measures that they deem necessary to protect public health and nutrition and other public interests in sectors of vital importance to development; however, such measures must be consistent with the provisions of the Agreement. 86 The importance of these "development-friendly safeguard provisions" 87 has been singled out in paragraph 19 of the Doha Ministerial Declaration. ${ }^{8}$ Arguably, this has increased their significance for interpreting provisions of the TRIPS Agreement. Nevertheless, WTO jurisprudence indicates that its interpretative force is limited to the already "negotiated" balance exhibited in the

81 Part I addresses the general provisions and basic principles. Part II deals with standards concerning the availability, scope and use of intellectual property rights. Part III elaborates the provisions on enforcement of intellectual property rights. Part IV is entitled "Acquisition and Maintenance of Intellectual Property Rights and related Interpartes procedures" Part V deals with dispute prevention and settlement and Part VI with transitional arrangements. Part VII concludes the agreement with institutional arrangements and final provisions.

82 See sections 3.1.2.1 and 3.2.3 for a more detailed analysis of the two nondiscrimination obligations in the TRIPS Agreement.

83 See section 3.2.4.4 on the provisions addressing exhaustion in United States' FTAs and for a detailed analysis of the TRIPS rule.

84 See WTO Secretariat, Communication from Argentina, Brazil, Chile, China, Colombia, Cuba, Egypt, India, Nigeria, Peru, Tanzania and Uruguay.

85 For a further analysis of the elements of Articles 7 and 8 of the TRIPS Agreement, see section 5.3.1.5 on the development concerns in the CARIFORUM-EC EPA, and section 6.2.2.1 on the provisions on objectives suggested by India in the negotiations on the India-EU BTIA.

86 See Article 8.1 of the TRIPS Agreement.

$87 \mathrm{Yu}$, "Currents and Crosscurrents in the International Intellectual Property Regime", p. 365.

88 See WTO Ministerial Conference, Doha Ministerial Declaration (Doha, 20 November 2001) [WT/MIN(01)/DEC/1] [hereinafter Doba Ministerial Declaration]. 
substantive provisions of the TRIPS Agreement. ${ }^{89}$ In particular, the CanadaPharmaceuticals Panel stated that the balancing required by Article 8.1 is already exemplified by Article 30 of the TRIPS Agreement, a provision that sets out the conditions for exceptions to patent protection. ${ }^{90}$ The role that Article 8 could still play in that case was to inform the interpretation of Article 30.

\subsubsection{Substantive Provisions of Intellectual Property}

Part II of the TRIPS Agreement is divided into eight sections that contain international minimum standards in different categories of intellectual property. These sections address copyright and related rights, ${ }^{91}$ trade marks, ${ }^{92}$ geographical indications, ${ }^{93}$ industrial designs, ${ }^{94}$ patents and plant variety protection, ${ }^{95}$ layout designs of integrated circuits, ${ }^{96}$ and undisclosed information. ${ }^{97}$ The TRIPS Agreement created several new obligations and rights under existing categories. For example, computer software received copyright protection because the TRIPS Agreement recognized it as "literary work" under the Berne Convention; ${ }^{98}$ rental rights were created in relation to computer programmes and cinematographic works; ${ }^{99}$ geographical indications for wines and spirits received "additional protection"; 100 and judicial authorities obtained the power to order the reversal of proof for process patents, i.e.

"the defendant $[\ldots]$ [must] prove that the process to obtain an identical product is different from the patented process." 101

With regard to patents, another three issues were of great importance in the last phase of the negotiations, in particular during the negotiations that took place after the Dunkel Draft had been presented and before the final TRIPS Agreement was adopted. The first issue concerned the protection of plant varieties. Indian farmers were opposed to the language of the Dunkel Draft which required plant varieties to be protected, either through patents or through a sui generis system. ${ }^{102}$ They feared that they would have to pay high royalties to monopolistic, multinational seed companies without appreciating the fact that it was Indian farmers that had perfected the varieties for decades. ${ }^{103}$ Eventually, the Indian Government was able to convince its

See Canada - Patent Protection of Pharmaceutical Products [WT/DS114/R] (WTO Panel Report, 7 April 2000), paragraph 7.26 [hereinafter Canada-Pharmaceuticals Pane].

For a particularly positive assessment of the force of Articles 7 and 8 of the TRIPS Agreement in supporting social and economic development, see A. Slade, "Articles 7 and 8 of the TRIPS Agreement: A Force for Convergence within the International IP System" Journal of World Intellectual Property, 2011, Vol. 14 (6), 413-440.

See Articles 9-14 of the TRIPS Agreement.

See Articles 15-21 of the TRIPS Agreement.

See Articles 22-24 of the TRIPS Agreement.

See Articles 25-26 of the TRIPS Agreement.

See Articles 27-34 of the TRIPS Agreement.

See Articles 35-38 of the TRIPS Agreement.

See Article 39 of the TRIPS Agreement.

See Article 10.1 of the TRIPS Agreement.

See Article 11 of the TRIPS Agreement.

See Article 23 of the TRIPS Agreement.

Article 34.1 of the TRIPS Agreement.

See Article 27.3(b) of the Dunkel Draft.

See Stewart (ed.), The GATT Uruguay Round: The End Game, p. 531. 
farmers that their interests would also be protected under the text of the Dunkel Draft. accordingly, the right to replant and exchange seeds was retained and parties would be allowed to establish a sui generis system. ${ }^{104}$ The then Director-General of the GATT Peter Sutherland assured the Indian Government that a sui generis system would have to fulfill certain minimum standards, being those of the UPOV Convention, Act 1978, not the UPOV Convention, Act 1991. ${ }^{105}$ It is however unclear whether WTO Panels would also consider the UPOV Convention of 1978 for guidance in assessing a sui generis system. As a result, the obligations set out in Article 27.3(b) of the TRIPS Agreement are the same as already contained in the Dunkel Draft. The article requires plant varieties to be protected, either through patent protection or through a sui generis system.

The second issue that was a matter of discussion until the end of the Uruguay Round revolved around Article 27 of the Dunkel Draft and its requirement that "any invention, whether product or processes, in all fields of technology" must be patentable. This obligation was especially contentious for inventions concerning pharmaceuticals and agricultural chemicals. Various countries did not provide patent protection for these kinds of inventions and their pharmaceutical companies made a living out of producing generic drugs. For that reason, pharmaceutical industries from India, Canada, Egypt and thirteen Latin American countries opposed any patent protection for pharmaceuticals. ${ }^{106}$

On the other hand, pharmaceutical industries from the United States were very unhappy with the fact that the TRIPS Agreement did not provide for more protection, in particular, 'pipeline' protection for pharmaceuticals. 'Pipeline' protection already protects pharmaceuticals that are patented but not yet developed or marketed. The issue became relevant in the context of Article 65.4 of the Dunkel Draft which grants developing countries the right to delay the application of product patent protection for a period of ten years. This right only applies to patent applications made in those areas of technology that were not protected in developing countries before the application of the TRIPS Agreement. For the area of pharmaceuticals and agricultural chemicals, this was the case for most developing countries.

The right to delay patent protection in these areas was balanced by a two-fold obligation. First, according to Article 70.8 of the TRIPS Agreement, the countries that are allowed to delay the grant of such patents in the field of pharmaceuticals and agricultural chemical products must make available a means by which applications for such patents can be filed as from the date of entry into force of the WTO Agreement (generally 1 January 1995). ${ }^{107}$ The filed applications must be assessed according to the

$104 \quad$ See ibid., p. 532

105 See "Seeds of Doubt: Assurance on 'Farmers' Privilege" India Times (15 March 1994), p. 16. The differences between the 1991 Act of the UPOV Convention and the 1978 version are quite substantial. The most important change is that the revised version of the Convention requires farmers to obtain the breeders' permission in order to produce propagating material for commercial or farmer use. See Article 5 of UPOV Convention, Act 1991. For an account of the most important changes, see Stewart (ed.), The GATT Uruguay Round: The End Game, p. 530.

106 See F. Williams, “Bio-piracy' Under New Fire” Financial Times (30 November 1993), p. 6.

107 See Article 70.8(a) of the TRIPS Agreement. 
criteria for patentability and priority established under the TRIPS Agreement and the term of protection will be counted from the date of filing under the filing system. ${ }^{108}$ In other words, if a patent application is filed 1 January 1998 and a country has made use of the transitional period, the patent will expire on 1 January 2018, which is twenty years after the filing date. ${ }^{109}$

The second obligation in Article 70.9 of the TRIPS Agreement requires exclusive marketing rights to be granted to products that 1) have been filed under Article 70.8, 2) for which a patent has been granted in another WTO Member and 3) for which marketing approval was obtained in that other country. ${ }^{110}$ These exclusive marketing rights must last for five years after obtaining marketing approval in the other WTO Member.

Next to the protection of plant varieties and product patents for pharmaceuticals, the compulsory licensing provisions for semiconductor technology have been an important issue of discussion until the final days of the negotiations. Under the Dunkel Draft, the United States Semiconductor Industry Association was concerned that foreign countries could use compulsory licensing as a tool to create their own chip industry. ${ }^{111}$ If a foreign government was able to force companies to reveal their chip design and pay them remuneration in return, the foreign government could use this information to build up its own industry and leave the companies worse off. For that reason, United States' negotiators submitted a request in November 1993 to limit the use of compulsory licensing for semiconductor chips. ${ }^{112}$ Their efforts were successful and an exemption for semiconductor technology was added to Article 31(c) of the TRIPS Agreement, which reads as follows:

"Article 31

Where the law of a Member allows for other use of the subject matter of a patent without the authorization of the right holder, including use by the government or third parties authorized by the government, the following provisions shall be respected:

[...] c) the scope and duration of such use shall be limited to the purpose for which it was authorized, and in the case of the semi-conductor technology shall only be for public noncommercial use or to remedy a practice determined after judicial or administrative process to be anticompetitive; [emphasis added]"

The part in italics was added to the Dunkel Draft. It specifies that compulsory licenses for semiconductor chips can only be granted for public non-commercial use or to remedy an anti-competitive practice which has been established through due process. This effectively prevented foreign countries from making commercial profit out of compulsory licenses.

\footnotetext{
108 See Article 70.8 (b) and (c) of the TRIPS Agreement.

109 See Cottier, "The Agreement on Trade-Related Aspects of Intellectual Property Rights", p. 1098.

110 See Article 70.9 of the TRIPS Agreement.

111 See Stewart (ed.), The GATT Uruguay Round: The End Game, p. 535-536.

112 See United States General Accounting Office, GATT: Uruguay Round Final Act Should Produce Overall U.S. Economic Gains (Geneva, 29 July 1994) [GAO/GGD-94-83b], p. 93.
} 


\subsubsection{Provisions on Enforcement}

Part III of the TRIPS Agreement concerns the enforcement of intellectual property rights. The detailed rules on enforcement have been recognized as an important strength of the TRIPS Agreement which other multilateral IP agreements were lacking. ${ }^{13}$ They form a harmonized body of common standards for civil and administrative procedures while room is left for WTO Members to opt for alternative solutions. The scope and applicability of the enforcement provisions differs according to the type of intellectual property right at issue. For example, civil and administrative procedures apply to all types of intellectual property rights covered under the TRIPS Agreement, whereas border measures and criminal sanctions only apply to certain types of intellectual property rights. Footnote 14 of Article 51 of the TRIPS Agreement clarifies that Articles 51 to 61 apply only to "counterfeit trade mark or pirated copyright goods".

Most provisions are not mandatory but grant WTO Members discretion as to whether to grant judicial and administrative authorities the power to take certain measures. ${ }^{114}$ One of the mandatory provisions is Article 41 which requires enforcement procedures to be available under national law and to allow effective action against infringements of intellectual property rights. ${ }^{115}$ Article 41 further stipulates a number of fundamental principles that apply in general and, in particular, to the subsequent sections. Two of the most important principles mentioned in Article 41.3 are the right to reasoned decision making and the right to be heard.

There are four types of enforcement measures dealt with in the TRIPS Agreement: civil and administrative procedures and remedies (Articles 42-49), provisional measures (Article 50), special requirements related to border measures (Articles 51-60) and criminal procedures (Article 61). The section on civil and administrative procedures and remedies reflects general rules of civil judicial procedures, such as rules on fair and equitable procedures (Article 42), evidence (Article 43), injunctions (Article 44), damages (Article 45), other remedies (Article 46), the right of information (Article 47), indemnification of the defendant (Article 48), and the application of the above guidelines to administrative procedures (Article 49). Article 50 is concerned with provisional measures. They are an essential tool of national authorities to avoid that irreparable harm is caused to the right holder and can be ordered even before an infringement has been found. Judicial authorities have the power to order prompt and effective provisional measures, even without having heard the other party (inaudita altera parte). ${ }^{116}$ This power, however, is limited by a number of procedural safeguards that aim at avoiding the abuse of provisional measures. ${ }^{117}$

The special requirements related to border measures also present a powerful instrument to enforce intellectual property rights. Border measures intercept

113 Treaties administered by WIPO, such as the Berne and Paris Convention, lacked effective enforcement requirements. See above sections 1.5.1 and 1.5.2.

114 See Cottier, "The Agreement on Trade-Related Aspects of Intellectual Property Rights", p. 1103.

115 See Article 41.1 of the TRIPS Agreement.

116 See Article 50.2 of the TRIPS Agreement.

117 See Articles 50.3, 50.6 and 50.7 of the TRIPS Agreement. For a detailed analysis of the TRIPS provision, see section 5.3.3.4 on the CARIFORUM-EC EPA. 
counterfeit and pirated goods at the point of importation. This has the advantage of preventing goods from entering into the channels of distribution, at which state law enforcement becomes more difficult and burdensome. ${ }^{118}$ As noted above, the rules contained in this section apply only to counterfeit trade mark goods and pirated copyright goods; ${ }^{119}$ no obligation exists to provide right holders of other intellectual property rights contained in the TRIPS Agreement with a possibility to apply for border measures. However, WTO Members can choose to make border measures also available for other forms of IP infringement. The rules that govern the use of border measures concern, for example, the suspension of release by customs authorities (Article 51), the application for such procedures (Article 52), and a security or equivalent assurance (Article 53). ${ }^{120}$

The last set of enforcement procedures regards criminal procedures in Article 61 of the TRIPS Agreement. It is the first generation of penal provisions in the WTO system. ${ }^{121}$ Also this part gives Members a certain amount of flexibility: Article 61 obliges Members to provide criminal procedures and penalties at least in cases of willful trade mark counterfeiting or copyright piracy on a commercial scale; however, in other cases of intellectual property rights infringement, Members may choose to provide for criminal procedures and penalties.

\subsubsection{Provisions on Acquisition and Maintenance}

Part IV of the TRIPS Agreement deals with the acquisition and maintenance of intellectual property rights and related inter-partes procedures. The rules contained therein intend to prevent disguised restrictions when protecting intellectual property rights. Article 62 deals with reasonable procedures and formalities. In particular, intellectual property rights must be registered in a reasonable period of time. ${ }^{122}$ Interpartes procedures, i.e. procedures of opposition, revocation and cancellation, shall be subject to review by a judicial or quasi-judicial authority ${ }^{123}$ and must be governed by the general principles set out in paragraph 2 and 3 of Article 41. ${ }^{124}$

\subsubsection{Dispute Prevention and Settlement}

Part V concerns the dispute prevention and settlement. According to Article 64.1 of the TRIPS Agreement, the WTO Dispute Settlement Understanding ${ }^{125}$ (DSU) applies in full

See Cottier, "The Agreement on Trade-Related Aspects of Intellectual Property Rights", p. 1107.

See Article 51 of the TRIPS Agreement.

Other rules concerning border measures address the notice of suspension (Article 54), the duration of suspension (Article 55), indemnification of the importer and of the owner of the goods (Article 56), the right of inspection and information (Article 57), ex officio action (Article 58), remedies (Article 59) and de minimis imports (Article 60).

See Cottier, "The Agreement on Trade-Related Aspects of Intellectual Property Rights", p. 1109.

See Article 62.2 of the TRIPS Agreement.

See Article 62.5 of the TRIPS Agreement.

See Article 62.4 of the TRIPS Agreement.

Understanding on Rules and Procedures Governing the Settlement of Disputes, Annex 2 of the Marrakesh Agreement Establishing the World Trade Organization, signed on 15 April 1994, entered into force on 1 January 1995, 33 ILM 1226 (1994) [hereinafter Dispute Settlement Understanding]. 
to the TRIPS Agreement, subject to initial restrictions on non-violation complaints set out in Article 64.2 of the TRIPS Agreement. For the first time, the international intellectual property system was given tools and instruments that allowed interpreting and enforcing international standards of intellectual property protection between states. The rules specified by the DSU apply to complaints with respect to violations of the TRIPS Agreement.

The TRIPS Agreement also foresees the possibility to make complaints with respect to measures that do not violate specific rights and obligations, but which still nullify or impair a benefit under the TRIPS Agreement (the so-called non-violation complaints). ${ }^{126}$ However, in the very final stages of the negotiations, India and Canada feared that non-violation complaints could be used against them. ${ }^{127}$ For that reason, paragraph 2 and 3 of Article 64 of the TRIPS Agreement were added to the Dunkel Draft and granted a five year "moratorium" (i.e. a temporary agreement not to file "non-violation" complaints), with the possibility of prolongation. ${ }^{128}$ WTO Members seem to be reluctant to allow this form of complaints for the area of intellectual property protection. As part of the Doha Mandate, the Cancún Ministerial Conference in 2003 was mandated to determine the future of non-violation complaints in the TRIPS Agreement; ${ }^{129}$ these efforts failed. Since then, the moratorium has been prolonged continuously. ${ }^{130}$

\subsubsection{Transitional Arrangements}

Part VI of the TRIPS Agreement contains two important issues that developing countries insisted on during the TRIPS negotiations: 1) the transitional provisions for lesser and least developed countries and 2) the obligation of developed countries to transfer technology to least-developed countries (LDCs).

The transitional provisions contained in Article 65 specify that no Member is obliged to apply TRIPS provisions before the expiry of a period of one year. Developing countries, and under certain circumstances economies in transition, may delay the application for another four years. ${ }^{131}$ LDCs are granted most flexibility since they are not required to apply the TRIPS Agreement for a period of ten years from the date of application of the Agreement. ${ }^{132}$

Special rules apply to product patents granted in areas of technology that were not protected in developing countries before the application of the TRIPS Agreement.133

See Article XXIII:1(b) and (c) of the GATT 1994.

See Stewart (ed.), The GATT Uruguay Round: The End Game, p. 538.

See Article 64.3 of the TRIPS Agreement.

See WTO Ministerial Conference, Implementation-Related Issues and Concerns, Decision of November 2001 (Doha, 20 November 2001) [WT/MIN(01)/17], paragraph 11.1.

See WTO Secretariat, Non-violation complaints (Article 64.2): Background and the current situation (2012), available at <http://www.wto.org/english/tratop_e/trips_e/nonviolation_background_e.htm $>$ accessed on 23.11.2012.

See Article 65.1, 65.2 and 65.3 of the TRIPS Agreement.

See Article 66.1 of the TRIPS Agreement. The basic principles of non-discrimination have been excluded from the transition period and must be applied in these countries as of the entry into force of the Agreement.

See Article 65.4 of the TRIPS Agreement. 
Examples of such areas are the technologies relevant to pharmaceutical and agricultural chemical products. The special obligations of establishing a filing system and granting exclusive marketing rights are explained above. ${ }^{134}$ According to the Doha Declaration on TRIPS and Public Health, least-developed countries do not have to implement, apply or enforce the obligations regarding patents on pharmaceutical products in the TRIPS Agreement until the year 2016.135

The provision on transfer of technology was a centerpiece of developing countries' achievements during the TRIPS negotiations. As the WTO website notes,

"developing countries, in particular, see technology transfer as part of the bargain in which they have agreed to protect intellectual property rights."136

Article 66.2 of the TRIPS Agreement establishes a positive legal obligation on the part of developed countries to

"provide incentives to enterprises and institutions in their territories for the purpose of promoting and encouraging technology transfer to least-developed country Members in order to enable them to create a sound and viable technological base."

The mandatory nature of the obligation has been reaffirmed in the Doha Decision on Implementation-Related Issues and Concerns ${ }^{137}$ and the Doba Declaration on TRIPS and Public Health. ${ }^{138}$ Governments are not obliged to carry out technology transfer themselves, but rather to provide incentives to their enterprises and institutions to encourage technology flows to LDCs. Nevertheless, the requirement has hardly been put into effect by developed countries. In order to remedy the problem, the TRIPS Council adopted a decision in 2003 that requires developed country Members to submit annual reports on actions taken or planned in relation to their commitments under Article 66.2.139 Nevertheless, according to two studies carried out on the basis of these self-evaluation reports, the obligation in Article $66.2 \mathrm{had}$ a rather limited impact on the creation of incentives for developed countries' enterprises to transfer technology. ${ }^{140}$

See section 2.3.2.

See WTO Ministerial Conference, Declaration on the TRIPS Agreement and Public Health (Doha, 20 November 2001) [WT/MIN(01)/DEC/2], paragraph 7 [hereinafter Doha Declaration on TRIPS and Public Health].

See WTO Secretariat, Technology transfer (2012), available at

$<$ http://www.wto.org/english/tratop_e/trips_e/techtransfer_e.htm> accessed on 15.06.2012.

See WTO Ministerial Conference, Implementation-Related Issues and Concerns, paragraph 11.2.

See WTO Ministerial Conference, Doba Declaration on Public Health, paragraph 7.

See Council for Trade-Related Aspects of Intellectual Property Rights, Decision of the Council of TRIPS of 19 February 2003 on the Implementation of Article 66.2 of the TRIPS Agreement (Geneva, 20 February 2003) [IP/C/28], paragraph 1.

See S. Moon, Does TRIPS Art. 66.2 Encourage Technology Tranfer to LDCs? (UNCTAD ICTSD Project on IPRs and Sustainable Development, Geneva, 2008), p. 6; C.M. Correa, Intellectual Property in LDCs: Strategies for Enbancing Technology Transfer and Dissemination (UNCTAD, The Least Developed Countries Report, 2007) [Background Paper No. 4], p. 25. 


\subsubsection{Institutional Arrangements and Final Provisions}

The seventh and last part of the TRIPS Agreement concerns institutional arrangements and final provisions. In particular, it sets out rules on the functions of the TRIPS Council (Article 68), on exchange of information and international cooperation between customs authorities (Article 69), on the protection of existing subject matter (Article 70), on the duty of the TRIPS Council to review and to propose amendments (Article 71), on reservations (Article 72) and on security exceptions concerning essential security interests of Members such as traffic in arms or circumstances of war (Article 73).

\subsection{CONCLUSIONS}

After eight years of very difficult and controversial negotiations, a comprehensive agreement on the protection of intellectual property was born. It went far beyond what earlier international agreements on intellectual property had covered. The TRIPS Agreement contains provisions on principles and objectives, on individual areas of intellectual property protection, dispute settlement, enforcement measures, transitional periods and on technology transfer. Being part of the WTO framework, the TRIPS Agreement incorporated the protection of intellectual property into the multilateral trade regime. This multilateral agreement reached an unprecedented scope of substantive intellectual property protection, membership and level of enforcement. However, immediately after the conclusion of this significant agreement, a new bilateral phase started with the recent proliferation of bilateral trade agreements, which often include TRIPS-plus provisions. 



\section{Chapter 3 : The International System of Protecting Intellectual Property post-TRIPS}

The final outcome of the TRIPS Agreement marked a watershed, particularly in view of the development that took place in the position defended by developing countries. Two important reasons can explain why developing countries have accepted the present scope and extent of TRIPS provisions. ${ }^{1}$ First, they received access to the textiles and agricultural markets of the United States and other industrialized countries. Second, they believed that this multilateral agreement would ultimately put an end to the unilateral and bilateral efforts of developed countries, in particular the United States, to increase the protection of intellectual property further. ${ }^{2}$ This latter conviction on the part of developing countries proved to be wrong. Industrialized countries did not regard the TRIPS Agreement as the end of the road; they rather saw it as "another step in the pyramid of global IPRs regulation." 3 The propositions made by developed countries during the negotiations of the TRIPS Agreement already indicated that they were pursuing higher standards than those finally adopted in the Agreement. It quickly became clear that if they could not get the level of IP protection they wanted at the WTO, they would make use of their, by then wellestablished, strategy of forum shifting in order to achieve higher standards in forums that were more favourable to them.

The recent tremendous rise of bilateral agreements, which also cover the protection of intellectual property, represents the latest shift of forum. ${ }^{4}$ These agreements mainly exist between developed countries and developing countries, even though an increasing number of bilateral agreements, which also deal with intellectual property protection, are concluded among developing countries only. ${ }^{5}$ However, it is the agreements signed primarily by the United States and the European Union with developing countries that assign intellectual property a key role and increase the

1 See section 2.2.4 on the input of developing countries in the TRIPS negotiations and reasons that can explain the change of position by developing countries.

2 See C.M. Correa, "Bilateralism in Intellectual Property: Defeating the WTO System for Access to Medicines" Case Western Reserve Journal of International Law, 2004, Vol. 36, 7994, p. 79.

3 M. El-Said, "Editorial: Free Trade, Intellectual Property and TRIPS-plus World" Liverpool Law Review, 2007, Vol. 28, 1-9, p. 7.

4 See A. Endeshaw, "Free Trade Agreements as Surrogates for TRIPs-Plus" EIPR, 2006, Vol. 28 (7), 374-380, p. 374; M. El-Said, “The Road from TRIPS-Minus, to TRIPS, to TRIPS-Plus: Implications of IPRs for the Arab World" Journal of World Intellectual Property, 2005, Vol. 8 (1), 53-65, p. 57.

5 In general, the number of South-South agreements that set out specific rules on the protection of intellectual property is limited. See Kampf, "TRIPS and FTAs: A World of Preferential or Detrimental Relations", p. 105. Only one out of thirteen intra-Asian South-South free trade agreements includes a chapter on intellectual property protection but is limited to cooperation provisions. That is Chapter 11 of the IndiaSingapore Comprehensive Economic Cooperation Agreement, signed 29 June 2005 and entered into force 1 August 2005. For the list of agreements analyzed, see T. Takahashi, SouthSouth Trade in Asia: the Role of Regional Trade Agreements (UNCTAD Secretariat, Japan External Trade Organization, Geneva, 2008) [UNCTAD/DITC/TAB/MISC/2008/2]. 
standard of protection considerably beyond the level established by the TRIPS Agreement, ${ }^{6}$ the so-called TRIPS-plus provisions. ${ }^{7}$

In the context of the recent proliferation of TRIPS-plus provisions in bilateral trade agreements, the TRIPS Agreement may be seen as merely one element in a larger cycle of protection that alternates between unilateralism, bilateralism and multilateralism, and is evident since the beginning of the international system of intellectual property protection. ${ }^{8}$ This has been described by Peter Drahos as the global intellectual property ratchet. The ratchet builds upon bilateral and regional agreements that increase the standards of intellectual property protection and are eventually taken to the higher, multilateral level to become global standards. ${ }^{9}$ Ruth Okediji has classified this ratchet as an ongoing explicit strategy by the United States and the European Union to use bilateral trade agreements in order to expand global intellectual property rights. ${ }^{10}$

The standards adopted in the TRIPS Agreement build upon the intellectual property obligations established in the North American Free Trade Agreement (NAFTA) ${ }^{11}$ from 1993; similarly, recent bilateral agreements, which contain TRIPS-plus provisions, will set the stage for future multilateral agreements addressing intellectual property. Peter Drahos found the following three factors to be essential for the ratchet to work: 1) a process of forum shifting that allows countries to choose the forum where they will encounter least resistance to their intellectual property agenda; 2) co-ordinated bilateral and multilateral intellectual property strategies that are adapted to the situations faced at the respective forum; and 3) the principle of minimum standards which is included in every agreement and preserves the option to establish higher standards in future agreements. ${ }^{12}$

The following section will address the recent proliferation of TRIPS-plus provisions. In particular, different sources of TRIPS-plus developments are examined at the domestic, bilateral, multilateral and plurilateral level. Against this background, a detailed analysis of the bilateral trade agreements concluded or negotiated by the main demandeurs of TRIPS-plus standards is carried out. The main actors under examination are the United States, the European Union, EFTA States and Japan. Their legal approaches to the IP chapters in the bilateral trade agreements, the characteristics of negotiations and the substantive provisions usually contained in recent agreements are analyzed and compared with each other.

See Rajkumar, "The Central American Free Trade Agreement: an end run around the DOHA Declaration on TRIPS and Public Health", p. 446; Endeshaw, "Free Trade Agreements as Surrogates for TRIPs-Plus", p. 374. 7. 


\subsection{SOURCES OF TRIPS-PLUS PROVISIONS}

\subsubsection{Domestic Law}

A very common source of TRIPS-plus standards are domestic laws, in particular those of developed countries. Countries that ask for increased intellectual property protection at the international level usually already provide for higher standards than those contained in the TRIPS Agreement in their national law and would like other countries to adjust their own legislation to these higher standards. One major example is the United States Digital Millennium Copyright Act ${ }^{3}$ (hereinafter DMCA) which became part of the United States copyright law in 1998. Since the US-Chile Free Trade Agreement ${ }^{4}$ (hereinafter US-Chile FTA), DMCA-like provisions appear in all intellectual property chapters of the free trade agreements (FTAs) concluded by the United States. Another example is the European Union's approach to the protection of geographical indications (GIs). The European standards of GI protection go beyond the level of the TRIPS Agreement. It is those standards that the EU tries to get accepted in bilateral and multilateral forums. TRIPS-plus provisions in domestic law generally do not provoke much debate internationally as it is a legitimate choice of every country to adapt their intellectual property protection to the level that they see fit the domestic situation. The international protection of intellectual property is affected where these standards become part of international agreements.

\subsubsection{Bilateral Agreements}

TRIPS-plus provisions prominently appear in a variety of bilateral agreements. The most common examples are bilateral trade agreements (BTAs), such as free trade agreements, which will be analyzed in greater detail below. ${ }^{15}$ However, TRIPS-plus provisions are not only included in BTAs but also in bilateral investment treaties (BITs) and bilateral intellectual property agreements (BIPs).

\subsubsection{Bilateral Investment Treaties}

Bilateral investment treaties concern the regulation of investment and not intellectual property as such; therefore they also do not include detailed chapters on the regulation of intellectual property. However, the definition of investment in these agreements is based on the concept of assets; intellectual property rights are generally

13 See To amend title 17, United States Code, to implement the World Intellectual Property Organization Copyright Treaty and Performances and Phonograms Treaty, and for other purposes, (Digital Millennium Copyright Act), Pub. L. No. 105-304, 112 Stat. 2860, 28 October 1998 [hereinafter $D M C A]$.

14 United States - Chile Free Trade Agreement signed on 6 June 2003, entered into force on 1 January 2004, 42 I.L.M. 1026 (2003) [hereinafter US-Chile FTA].

15 For the purpose of this book, the term bilateral trade agreement refers to bilateral agreements that focus on economic cooperation. Although especially the agreements concluded by the European Union also pay particular attention to other areas of cooperation, it is the part dealing with trade matters that is of importance for the following analysis. Different actors have attributed different names to such trade agreements. Examples are free trade agreements, trade promotion agreements, association agreements, partnership and cooperation agreements, economic partnership agreements, political coordination and cooperation agreements and trade, development and cooperation agreements. 
included as investment assets that are protected. The guarantees afforded to investors under BITs potentially also apply to intellectual property rights and can be of a TRIPS-plus nature.

The extent to which an investor's intellectual property is protected depends on the way it is included in the definition of investment and how intellectual property itself is defined. One important definition is that used by the United States in its model bilateral investment treaty of $2012,{ }^{16}$ which reads as follows:

\begin{abstract}
“'investment' means every asset that an investor owns or controls, directly or indirectly, that has the characteristics of an investment, including such characteristics as the commitment of capital or other resources, the expectation of gain or profit, or the assumption of risk. Forms that an investment may take include:

(f) intellectual property rights;"'17
\end{abstract}

As evident from the definition of investment, the term "intellectual property rights" is not further specified; the same is true for the Canadian Model BIT of 2003. ${ }^{18}$ This kind of definition does not make clear what exactly is covered when reference is made to intellectual property as a generic term. For example, it is not obvious whether the definition is limited to the forms of intellectual property that are covered by the TRIPS Agreement or whether it goes beyond that. ${ }^{19}$ If the latter is true, there could be a TRIPS-plus implication of the investment treaty.

Some of the most important provisions that are usually included in BITs and can protect forms of intellectual property are: ${ }^{20}$ 1) national and most-favoured-nation

16 The United States develops a model bilateral investment treaty [hereinafter United States Model BIT of 2012] that is used systematically as the basis for negotiations with other countries. The United States Model BIT of 2012 followed the Model BIT of 2004 and 1994.

See USTR, Bilateral Investment Treaties and Related Agreements (2012), available at <http://www.state.gov/e/eb/ifd/bit/index.htm> accessed on 21.11.2012. The definition is the same as used in the US Model BIT 2004.

See Foreign Affairs and International Trade Canada, Canada's Foreign Investment Promotion and Protection Agreements (FIPAs) (2003), available at <http://www.international.gc.ca/trade-agreements-accords-commerciaux/agracc/fipa-apie/index.aspx?view $=\mathrm{d}>$ accessed on 15.112012 [hereinafter Canadian Model BIT of 2003]. Note that other bilateral investment treaties include a specific definition of intellectual property rights, such as Article 1.1(d) of the German Federal Ministry of Economics and Technology, Treaty between the Federal Republic of Germany and the Federal Democratic Republic of Ethiopia concerning the Encouragement and Reciprocal Protection of Investments, signed in Bonn on 17 January 2004, entered into force on 4 May 2006 (Bundesgesetzblatt 2005 Teil II Nr. 17 of 3 August 2005, p. 743-750) [hereinafter Germany-Ethiopia BIT].

19 See South Centre, Intellectual property in investment agreements: The TRIPS-plus implications for developing countries (Geneva, 2005) [SC/TADP/AN/IP/5, SC/TADP/AN/INV/2], p. 11.

20 The following analysis is not a comprehensive study of all potential TRIPS-plus implications that different BITs could have. It rather aims at highlighting the most 
treatment, 2) fair and equitable treatment, 3) prohibition of expropriation, 4) limited capacity to impose performance requirements and 5) investor-state dispute settlement mechanism.

First, the national treatment principle contained in some bilateral investment agreements differs slightly from the definition contained in the TRIPS Agreement. ${ }^{21}$ The definition of national treatment in Article 3 of the TRIPS Agreement requires members to accord treatment "no less favourable than" that accorded to their own nationals with regard to the "protection" of intellectual property. Bilateral investment agreements, however, ask for treatment in the "same manner" or "as favourable as" the treatment given to national investment; some require national treatment for foreign investors, others also for the investment itself.22 Differences in defining the national treatment principle have the potential of extending the protection required in a BIT above the level of protection required by the TRIPS Agreement.

Another difference in defining the national treatment principle is often found with respect to the term "protection" of intellectual property in Article 3 of the TRIPS Agreement, which is defined in footnote 3 as including "the availability, acquisition, scope, maintenance and enforcement of intellectual property", as well as matters affecting the use of intellectual property. In contrast, the United States Model BIT of 2012 as well as some European BITs provide national treatment with respect to "the establishment, acquisition, expansion, management, conduct, operation, and sale or other disposition" of investment. ${ }^{23}$ In these cases, the proprietary interest to be protected as intellectual property is wider than that recognized under the TRIPS Agreement.

In addition to the potentially expanded protection of proprietary interest, the exceptions and limitations to national treatment and most-favoured-nation treatment available under the TRIPS Agreement are reduced under certain BITs. This is the case for the BITs signed by the United States until 2000. ${ }^{24}$ All of these BITs do not recognize the exceptions to national treatment and most-favoured-nation treatment

important and potentially contentious issues. For a detailed account of the potential TRIPS-plus provisions in BITs, see C.M. Correa, Bilateral Investment Agreements: Agents of New Global Standards for the Protection of Intellectual Property Rights? (GRAIN, Barcelona, 2004), available at <www.grain.org> accessed on 15.11.2012; South Centre, Intellectual Property in Investment Agreements; E.T. Biadgleng, IP Rights Under Investment Agreements: The TRIPS-plus Implications for Enforcement and Protection of Public Interest (GRAIN, Barcelona, 2006) [Research Paper No. 8]; UNCTAD, Intellectual Property Provisions in International Investment Arrangements (UNCTAD, Geneva, 2007) [UNCTAD/WEB/ITE/IIA/2007/1].

21 According to South Centre, Intellectual Property in Investment Agreements, agreements that contain a slightly different national treatment obligation than the TRIPS Agreement are the Unified Agreement for the Investment of Arab Capital in the Arab States, Article 6, UNCTAD (1996), Vol. II, op. cite. 36, p. 214; UK-China BIT (1986) Article 3.3.

22 See ibid., p. 14.

23 See Article 3.1 of the US Model BIT of 2012; see ibid., p. 15.

24 According to ibid., p. 16, the BITs concerned are those concluded between the United States and Honduras (1995), Azerbaijan (1997), Bahrain (1999), Bolivia (1998), Costa Rica (1996), Georgia (1994), Trinidad and Tobago (1995) and Vietnam (2000). 
under the TRIPS Agreement. ${ }^{25}$ In contrast, the current Model BIT by the United States and that of Canada include an explicit provision that preserves the exceptions provided in Article 3, 4 and 5 of the TRIPS Agreement. ${ }^{26}$

Second, the fair and equitable treatment requirement included in different BITs is a novelty in terms of rules contained in international instruments that address the protection of intellectual property. ${ }^{27}$ While investment treaties generally have this standard, the TRIPS Agreement or other multilateral agreements governing the protection of intellectual property do not refer to such a principle of fair and equitable treatment. ${ }^{28}$ Hence, it represents a TRIPS-plus requirement. Fair and equitable treatment is, contrary to the non-discrimination principles, an absolute standard that requires a certain level of protection. The non-discrimination principle is a relative standard insofar as it requires no less favourable treatment than that accorded to nationals; however, it does not specify the substantive level of protection.

There is no single international interpretation of fair and equitable treatment. Generally, it provides a rule against which the national rules of a country are judged. The fair and equitable treatment standard included in recent BITs suggests that it is synonymous with the concept of international minimum standards applied in international law. ${ }^{29}$ As David Vivas-Eugui remarks, this approach starts from the assumption that customary international law recognizes a certain level of treatment (e.g. a minimum standard) that foreign investors are entitled to and that the failure to grant such treatment gives rise to liability on the part of the state. ${ }^{30}$ However, such an internationally recognized standard of treatment does not exist.

The United States has specified in its Model BIT of 2012 what it understands under fair and equitable treatment. Article 5.2 mentions

\footnotetext{
"the obligation not to deny justice in criminal, civil, or administrative adjudicatory proceedings in accordance with the principle of due process embodied in the principal legal systems of the world."
}

The Article also requires the parties to provide the level of police protection as required under customary international law. Furthermore, according to its Article 5.4, fair and equitable treatment covers the non-discriminatory treatment with regard to measures that are adopted in relation to losses suffered because of armed conflict or

See Articles 3 and 4 of the TRIPS Agreement.

See Article 14.4 of the United States Model BIT of 2012; see Article 9.4 of the Canadian Model BIT of 2003. Article 5 of the TRIPS Agreement concerns the procedures for acquisition or maintenance of intellectual property under WIPOadministered agreements and exempts them from the application of the national treatment and the most-favoured-nation treatment obligation of Article 3 and 4 of the TRIPS Agreement.

See Article 5 of the US Model BIT of 2012.

Note that the TRIPS Agreement does specify in the section on enforcement that the principle of fairness and equity shall be safeguarded in enforcement procedures. See footnote 33 of this section of this book.

See South Centre, Intellectual Property in Investment Agreements, p. 12.

See Vivas-Eugui, The Free Trade Area of the Americas, p. 8. 
civil strife. A final obligation in relation to fair and equitable treatment regards the obligation to provide restitution and compensation of investment that was destroyed by authorities of the host state. ${ }^{31}$

The obligations listed in the US Model BIT of 2012 require fairness and equity particularly in relation to enforcement. The TRIPS Agreement has similar obligations with regard to the enforcement of intellectual property. Although WTO Members are free to determine the appropriate method of implementing the agreement according to their own legal system, ${ }^{32}$ the TRIPS Agreement requires national procedures concerning the enforcement of intellectual property to be fair and equitable, not unnecessarily complicated or costly, or entail unreasonable time-limits. ${ }^{33}$ An international minimum standard of fair and equitable treatment as required by the US Model BIT of 2012 eliminates the TRIPS flexibility with respect to the method of implementation and could be interpreted to refer to the harmonization process at WIPO or other international forums. ${ }^{34}$ The standard therefore potentially has TRIPSplus consequences.

Third, most BITs prohibit the expropriation or nationalization of investment. ${ }^{35}$ As investment covers intellectual property rights, the issuance of a compulsory license for the use of a patent could arguably amount to an act of expropriation. A compulsory license is an authorization by the government given to a third party to use a patent without the consent of the patent holder. ${ }^{36}$ The TRIPS Agreement, however, allows WTO Members to use compulsory licenses only under specific conditions listed in Article 31 of the TRIPS Agreement. If a bilateral investment agreement prohibits expropriation without providing an exception for compulsory licenses issued in accordance with the conditions of Article 31 of the TRIPS Agreement, it would constitute a TRIPS-plus provision in the investment agreement. While the United States Model BIT of 2012 and the Canadian Model BIT of 2003 exclude compulsory licenses that are in conformity with Article 31 of the TRIPS Agreement as a form of expropriation, other agreements, such as the Germany-Ethiopia BIT, do not. ${ }^{37}$

The fourth important feature often contained in BITs is the prohibition to impose performance requirements on investment activities. ${ }^{38}$ Such a prohibition is not found in the TRIPS Agreement and therefore potentially represents a TRIPS-plus obligation. Among the requirements that the United States and the Canadian Model BIT of 2012, 2003 respectively, prohibit is the commitment

31 See Article 5.5 of the United States Model BIT of 2004.

32 See Article 1.1 of the TRIPS Agreement.

33 See Article 41.2 of the TRIPS Agreement and section 2.3.3 on the enforcement provisions of the TRIPS Agreement.

34 See South Centre, Intellectual Property in Investment Agreements, p. 13.

35 See Article 6.1 of the United States Model BIT of 2004; Article 13.1 of the Canadian Model BIT of 2003; see Article 4.2 of the Germany-Ethiopia BIT.

36 See Correa, Bilateral Investment Agreements, p. 14.

37 See Article 6.5 of the United States Model BIT of 2012; Article 13.5 of the Canadian Model BIT of 2003; see Article 4 of the Germany-Ethiopia BIT.

38 See Article 8 of the United States Model BIT of 2012; Article 7 of the Canadian Model BIT of 2003. The Germany-Ethiopia BIT does not contain a prohibition of performance requirements. 
"to transfer a particular technology, a production process, or other proprietary knowledge to a person in its territory." 39

Governments of developing countries, however, make use of the possibility to impose restrictions on the way foreign companies exploit their technology in order to achieve greater technology transfer. Technology transfer, as explained above, ${ }^{40}$ is recognized by the TRIPS Agreement in Article 8.2 and 66.2.41 It has to be noted that the Model BITs of the United States and Canada allow the use of performance requirements in certain cases. ${ }^{42}$ However, even if exceptions are included, the options available under the TRIPS Agreement are still reduced and could therefore constitute TRIPS-plus obligations.

The fifth main characteristic of BITs concerns the availability of an investor-state dispute settlement between the foreign investor and the state in which the investment has taken place. For example, Article 27 of the United States Model BIT of 2012 opens up the possibility to resort to investor-state procedures that are based on binding arbitration. The US Model BIT specifies the International Centre for Settlement of Investment Disputes (ICSID), established by the International Bank for Reconstruction and Development (the World Bank), the United Nations Commission on International Trade Law (UNCITRAL) or any other arbitration institution as forums where to seek arbitration. ${ }^{43}$

The option of an alternative dispute settlement mechanism other than the WTO dispute settlement system has been described as one of the most powerful legal tools available to foreign investors. ${ }^{44}$ Under the WTO dispute settlement, private parties such as intellectual property holders cannot sue states; only states can bring claims against each other. The investor-state dispute settlement foreseen in BITs, however, allows investors to sue states directly, but states are not allowed to sue investors. The alternative system of dispute settlement under a BIT has the following characteristics: it is separate from the WTO dispute settlement, it enables access of private parties, it works under different procedural rules, ${ }^{45}$ it may impose damages under the applicable investment agreement, and it has the competence to adjudicate on the provisions contained in the BIT only.

See Article 8.1(f) of the United States Model BIT of 2012. See Article 7.1(f) of the Canadian Model BIT of 2003 for a very similar provision.

See section 2.3.7 of this book.

Examples of performance requirements that promote technology transfer are to be found in Vivas-Eugui, The Free Trade Area of the Americas, p. 8.

See Article 8.3(a),(b),(c) and (e) of the United States Model BIT of 2012; Article 7.1(f), 7.2., 7.4. and 7.6(b) of the Canadian Model BIT of 2003. Although Article 8.3.(b)(i) makes reference to the TRIPS Agreement, it only excepts performance requirements in the cases of Article 31 and Article 39. This does not leave all options available under the TRIPS Agreement as a country could also apply a measure on the basis of the exception contained in Article 30 of the TRIPS Agreement.

See Article 24.4 of the United States Model BIT of 2012. Similar rules can be found in Article 27.1 of the Canadian Model BIT of 2003 and in Article 11.2 of the GermanyEthiopia BIT.

See Vivas-Eugui, The Free Trade Area of the Americas, p. 8.

See Correa, Bilateral Investment Agreements, p. 27. 
By creating such a system, no TRIPS-plus provision in the strict sense is created. However, there appear to be two major problems. The first issue regards the coexistence of alternative dispute settlement systems which are dealing with similar subject matters. Even if WTO rules are not directly applicable in an investment dispute under a BIT, they are part of their interpretative context according to Article 31.3(c) of the Vienna Convention on the Law of Treaties. ${ }^{46}$ A likely outcome of this situation is that investors will go "forum-shopping" and the different decisions from the different forums may conflict with each other. ${ }^{47}$ For example, in an ICISD procedure, an intellectual property right holder, as an investor, can seek direct reparation of damages from the State that allegedly failed to recognize his rights under the TRIPS Agreement. For that, the arbitrator would have to interpret relevant provisions of the TRIPS Agreement. Such interpretations can potentially conflict with those of WTO dispute settlement bodies.

The second problem relates to the activity of regulatory authorities to implement policies in areas of public interest. The resort to a direct investor-state dispute settlement mechanism could increase the number of disputes ${ }^{48}$ and, in addition, opens up the possibility of damage-claims. As a consequence, regulatory authorities have a disincentive to make use of their ability to address public health, nutritional or environmental problems. ${ }^{49}$ This clearly can have negative consequences for society, particularly in the case of developing countries.

To sum up, bilateral investment treaties are important sources of TRIPS-plus provisions since intellectual property is covered under the definition of "investment". IP right holders are regarded as investors and can also seek the protection of their rights in relevant BITs. The most relevant Model BITs are those of the United States and Canada which have been identified as containing TRIPS-plus features regarding the scope of the non-discrimination obligations, the application of the standard of fair and equitable treatment to intellectual property and the imposition of performance requirements. Since most BITs provide for the additional and attractive investor-state dispute settlement mechanism, intellectual property right holders are likely to see the benefit of also pursuing the enforcement of their rights under BITs.

\subsubsection{Bilateral Intellectual Property Agreements}

Another category of bilateral agreements that mostly include TRIPS-plus provisions are the bilateral intellectual property agreements. BIPs have generally been concluded between industrialized and developing countries. They often were part of a greater package of trade concessions, for example in the form of other bilateral agreements. Such other agreements could take the form of BITs, science and technology

\footnotetext{
46 See Vienna Convention on the Law of Treaties, done at Vienna on 23 May 1969, entered into force on 27 January 1980, 1155 U.N.T.S. 331.

47 See also Correa, Bilateral Investment Agreements, p. 27-28.

48 It has been established that the number of cases brought to the ICSID under BITs and NAFTA has increased considerably between the foundation in 1966 until 2001. See CIEL, "Foreign Investment and Sustainable Development: Issue Brief for the World Summit on Sustainable Development 26 August-4 September 2002" 2002, available at $<$ http://www.ciel.org/Publications/investment.pdf $>$ accessed on 15.11.2012, p. 2. 
cooperation agreements or economic or aid assistance. ${ }^{50}$ It was common for industrialized countries to specifically ask for upgraded intellectual property legislation and enforcement measures through BIPs until the end of the 1990s; since then, strong rules on the protection of intellectual property are commonly pursued in the context of free trade agreements. ${ }^{51}$ To date, the United States has signed eighteen agreements addressing intellectual property rights in the form of understandings, memoranda of understanding, in the context of the WTO accession of a developing country or in the form of IPR agreements. ${ }^{52}$

One of the agreements concluded by the United States is the Intellectual Property Rights Agreement with Nicaragua ${ }^{53}$ which was adopted in 1998. It contains various TRIPSplus features, among others in the field of plant variety protection, the protection of life and with regard to the use of the international classification system for trade marks. ${ }^{54}$ The US-Nicaragua IPR Agreement was concluded in the context of signing a bilateral investment treaty between the United States and Nicaragua. ${ }^{55}$ The United States insisted on the back-to-back signing of the US-Nicaragua IPR Agreement in exchange for the BIT which Nicaragua wanted to have. Furthermore, in order to speed up negotiations on the IPR Agreement, the United States placed Nicaragua on the 'Other Observations' List of the Special 301 Report in April 1997..5

The European Union has concluded specific bilateral agreements that importantly achieve a stronger protection of geographical indications for wines and spirits than provided for in the TRIPS Agreement. To date, the European Union has entered into eight agreements that protect either the designations for wines, spirit drinks or both. ${ }^{57}$ In the case of Chile, the Agreements on Trade in Wine and on Trade in Spirit Drinks and Aromatized Drinks are included as Annex V and VI to an overall Association Agreement between the European Community and Chile. ${ }^{58}$ The agreements concluded

$50 \quad$ See ibid., p. 9.

51 See bilaterals.org, IPR agreements (2012), available at <http://www.bilaterals.org/spip.php?rubrique60\&lang=en $>$ accessed on 12.11.2012.

52 See ibid.

53 Agreement between the Government of the United States of America and the Government of the Republic of Nicaragua concerning the Protection of Intellectual Property Rights, adopted on 7 January 1998 in Managua, entered into force on 1 July 1999, Trade Compliance Center, Nicaragua Intellectual Property Rights Agreement (2012), available at <http://tcc.export.gov/Trade_Agreements/All_Trade_Agreements/exp_005869.asp> accessed on 21.11.2012 [hereinafter US-Nicaragua IPR Agreement].

$54 \quad$ See Article 1.2 (d), Article 7.2 and Article 5.7 of the US-Nicaragua IPR Agreement.

55 Treaty between the Government of the United States of America and the Government of the Republic of Nicaragua concerning the Encouragement and Reciprocal Protection of Investment, signed in Denver on 1 July 1995, not yet ratified by the United States, see United States Senate, Investment Treaty with Nicaragua (Washington, 26 June 2000) [Treaty Doc. 106-33]. See J. Love, 1997 USTR Special 301 Annual Report (2009), available at <http://www.keionline.org/ustr/1997special301> accessed on 16.11.2012. The "other observations" list is another category of lists such as the Priority Watch List. Agreements have been concluded with Australia, Canada, Chile, Mexico, South Africa (two agreements), Switzerland and the United States. See European Commission, Bilateral agreements (2012), available at <http://ec.europa.eu/agriculture/markets/wine/third/index_en.htm> accessed on 15.11.2012. See also section 3.3.1 of this book. See EC Council Decision 2002/979/EC of 18 November 2002 on the signature and provisional application of certain provisions of an Agreement establisbing an association between the European 
with the other countries are not part of general bilateral trade agreements. All of them contain TRIPS-plus provisions; in particular, the Wine Agreement signed with South Africa contains a list of names, the use of which is exclusively reserved for the products originating in the party to which they apply and only under the conditions laid down in the laws of that party. ${ }^{59}$ This seems to go beyond the TRIPS Agreement as the exceptions otherwise available in Article 24.4 and Article 24.6 of the TRIPS Agreement are abolished with regard to the geographical indications listed. Article 24.4 of the TRIPS Agreement allows the continuous and similar use of a geographical indication if it has been used in a continuous manner. Article 24.6 of the TRIPS Agreement permits the use of a geographical indication for products, the customary name of which is identical to the relevant indication.

\subsubsection{Multilateral Agreements}

In addition to unilateral and bilateral measures, multilateral agreements can also be a source of TRIPS-plus provisions. Different international forums are involved in the process of setting new standards concerning the protection of intellectual property, including enforcement. These standards go beyond the protection granted by the TRIPS Agreement. In the following, the developments at two important international forums will be illustrated. These are WIPO and the WTO. ${ }^{60}$

\subsubsection{Developments at WIPO}

WIPO has been active in two fields of intellectual property law in which TRIPS-plus standards are being discussed: first, the WIPO Digital Agenda, which mainly involves the promotion of the two WIPO Internet Treaties, and second, the WIPO Patent Agenda, which represents a new initiative that aims at the future development of an international patent system.

First, the WIPO Digital Agenda was launched by the Director General of WIPO in September 1999 with a view to increase the number of developing countries participating in the access to intellectual property information and to promote the adjustment of the international system of intellectual property protection to ecommerce. ${ }^{61}$ Part of this agenda is the encouragement of Members to join the WIPO Copyright Treaty and the WIPO Performances and Phonograms Treaty which were adopted

Community and its Members States, of the one part, and the Republic of Chile, of the other part (OJ L 352 of 30.12.2002) [hereinafter EC-Chile AA].

$59 \quad$ See Articles 7 and 8 of the Agreement between the European Community and the Republic of South Africa on trade in wine (OJ L 28 of 30.01.2002) [hereinafter EC-South Africa Wine Agreement.

60 It must be noted that the process of standard setting in the field of intellectual property touches upon a variety of policy fields and therefore different international organizations, such as the Food Agricultural Organization, the Convention on Biological Diversity, the World Customs Organization, and the United Nations, are involved (see section 1.5.5). Rules that have an impact on the regulation of intellectual property are created continuously in an ongoing process that takes place at different forums. An overview of all developments currently taking place extends the scope of this book.

61 See S.F. Musungu and G. Dutfield, Multilateral Agreements and a TRIPS-plus World: The World Intellectual Property Organization (WIPO) (Quakers United Nations Office, TRIPS Issues Papers 3, Geneva, 2003), p. 15. 
in 1996 and entered into force in 2002. Both treaties grant right holders a level of protection that goes beyond the standards foreseen by the TRIPS Agreement and the Berne Convention. Prominent examples of TRIPS-plus standards are 1) the right to authorize digital transmission, 2) the requirement to provide legal protection against circumvention technologies, and 3) the obligation to provide legal remedies against the alteration of digital rights management information.

In the WCT and WPPT, digital transmission is interpreted to come under the concept of "communication to the public" set out in the Berne Convention. ${ }^{62}$ The WCT and WPPT enlarge the scope of rights of right holders by adding the right to authorize the digital transmission of a copyrighted work. ${ }^{63}$ Neither the Berne Convention nor the TRIPS Agreement includes digital transmissions in the concept of "communication to the public"; hence, the provision is of a TRIPS-plus nature. Another example is the requirement to provide adequate and effective legal protection and legal remedies against circumvention technologies and services. ${ }^{64}$ The WCT and WPPT set out obligations with regard to protecting technological protection measures (TPMs) which are designed to deny unlawful users access to and/or the copying of a copyrighted work contained on a digital medium such as a DVD. ${ }^{65}$ The protection of TPM's are not addressed in the Berne Convention or the TRIPS Agreement and therefore constitute a TRIPS-plus provision. A last main feature of the WCT is that it introduces an obligation to provide adequate and effective legal remedies against the alteration of digital rights management (DRM) information (e.g. information that identifies the work, the author, etc.). ${ }^{66}$ There is no obligation concerning DRM information in the Berne Convention or the TRIPS Agreement.

The initiative to create the WIPO Internet Treaties came from the United States, where a national working group was eager to promote strong rights for copyright holders operating in the online environment and, eventually, to globalize their agenda. ${ }^{67}$ Although a strong resistance movement countered the agenda of copyright holders at the Diplomatic Conference on Certain Copyright and Neighbouring Rights Questions in December 1996, the two treaties were adopted and grant strong protection to copyright holders. ${ }^{68}$ With an international obligation to implement these two treaties in national law, United States copyright holders were successful in creating the highly controversial Digital Millennium Copyright Act ${ }^{69}$ which implements the above mentioned international treaties into US law and arguably goes beyond that.

The right of "communication to the public" can be found in different articles of the Berne Convention, depending on the type of work under protection. For literary works, see Article 11 ter of the Berne Convention. For dramatic and musical works, see Article 11 of the Berne Convention. For broadcast, see Article 11 bis of the Berne Convention.

63 See Article 8 of the WCT. The same is true for performers and producers of phonograms, see Article 15.4 of the WPPT.

64 See Article 11 of the WCT; Article 18 of the WPPT.

65 See also section 3.2.5.3 for an analysis of the protection granted by United States FTAs.

66 See Article 12 of the WCT; Article 19 of the WPPT.

67 See Braithwaite and Drahos, Global Business Regulation, p. 64.

68 See Musungu and Dutfield, Multilateral Agreements and a TRIPS-plus World, p. 15-16.

69 See footnote 13 in section 3.1.1 on domestic sources of TRIPS-plus provisions. 
The second initiative at WIPO regards the WIPO Patent Agenda. It encompasses three main activities: 1) the ratification of the Patent Law Treaty (PLT),$^{70}$ 2) the reform of the Patent Cooperation Treaty (PCT), ${ }^{71}$ and 3) negotiations on the draft Substantive Patent Law Treaty (SPLT). While the PLT and PCT are concerned with harmonization and simplification of the formal requirements of patent procedures, the efforts to establish a draft Substantive Patent Law Treaty seem to be the most far-reaching. The draft SPLT aims at harmonizing substantive patent law standards such as priority art, novelty, utility, inventiveness, requirements relating to sufficient disclosure and the drafting of patent claims. ${ }^{72}$ Harmonizing substantive concepts of patent law is likely to result in TRIPS-plus provisions. The TRIPS Agreement leaves WTO Members the flexibility to interpret and implement substantive patent concepts in accordance with their local preferences. If the draft SPLT gives clear definitions of the concepts concerned, this flexibility is significantly reduced.

Another problem of harmonizing substantive patent law standards outside of the TRIPS Agreement may arise where amendments of the TRIPS Agreement are sought that are not in line with the draft SPLT. ${ }^{73}$ An example is the requirement to disclose genetic resources and traditional knowledge (TK) when applying for a patent, which has been discussed as a possible amendment to the TRIPS Agreement. ${ }^{74}$ Adding such a requirement through an amendment to the TRIPS Agreement might contradict the requirements that the draft SPLT stipulates for patent applications. The negotiations on the draft SPLT started in May 2001 but were put on hold for three years in 2006 due to polarized views among WIPO Member States. In June 2008, the WIPO Standing Committee on the Law of Patents met for the first time again after the collapse. ${ }^{75}$ However, the discussions at the Committee no longer focus on the draft SPLT but on building a technical and legal resource base from which informed discussions on a work program are held. ${ }^{76}$

\subsubsection{Developments at the WTO}

Major sources of TRIPS-plus provisions are the protocols of accession to the WTO. Newly acceding Members have to go through a lengthy process of negotiating the

70 Patent Law Treaty, signed in Geneva on 1 June 2000, entered into force on 28 April 2005, 39 I.L.M. 1047 (2000) [hereinafter PLT].

71 Patent Cooperation Treaty, adopted on 19 June 1970, amended on 28 September 1979, modified on 3 February 1984 and 3 October 2001, entered into force on 24 January 1978, 9 I.L.M. 978 (1970) [hereinafter PCT].

72 See Musungu and Dutfield, Multilateral Agreements and a TRIPS-plus World, p. 12.

73 See ibid., p. 12.

74 Such an amendment has been under discussion at the WTO as part of the Doha Development Round and is referred to as Article 29bis of the TRIPS Agreement. See WTO General Council, Trade Negotiations Committee and Council for Trade-Related Aspects of Intellectual Property Rights, Doha Work Programme - The Outstanding Implementation Issue on the Relationship Between the TRIPS Agreement and the Convention on Biological Diversity, Communication from Brazil, China, Colombia, Cuba, India, Pakistan, Peru, Thailand and Tanzania (Geneva, 5 July 2006) [IP/C/W/474], p. 2. See also section 5.3.2.8 of this book.

75 See T. Balasubramaniam, WIPO Patent Committee Embarks on Positive Agenda (2008), available at $<\mathrm{http}: / /$ keionline.org/node/75> accessed on 12.11.2012.

76 See WIPO, Draft Substantive Patent Law Treaty (2012), available at <http://www.wipo.int/patent-law/en/harmonization.htm> accessed on 20.11.2012. 
terms of accession with the countries that are already Members of the WTO. During these negotiations, WTO Members ask for market access commitments and concessions in the different areas of trade, including the protection of intellectual property rights. The countries that have most recently acceded to the WTO have made commitments regarding the protection of intellectual property that go beyond the standards of the TRIPS Agreement. ${ }^{77}$ An example of such a TRIPS-plus standard is the commitment not to grant marketing approval for a generic drug that relies on the test data submitted in support of the original patented drug for at least five years. ${ }^{78}$ The TRIPS Agreement in Article 39.3 merely requires the protection of undisclosed information against unfair commercial use; it does not specify a period of time of protection nor does it ask for data exclusivity as such. ${ }^{79}$

Another commitment made by Cambodia, Saudi Arabia, Viet Nam, Tonga and Ukraine in their accession protocols is the link made between the approval for marketing a generic drug and the patented drug: as long as the patent has not expired, the generic drug will not be granted marketing approval, unless the patent holder agrees to such approval. ${ }^{80}$ This requirement is often referred to as "patent linkage" and cannot be found in the TRIPS Agreement. However, the United States have inserted an identical requirement in their free trade agreements. ${ }^{81}$ In addition, the analyzed countries have agreed not to have recourse to any transitional period and to apply the commitments described above from the date of entering into force of the WTO Agreement including its annexed agreements. ${ }^{82}$

\subsubsection{The Anti-Counterfeiting Trade Agreement: A Plurilateral Agreement}

Different from the two forums described in the previous section, the negotiations of the Anti-Counterfeiting Trade Agreement (ACTA) have not taken place in the framework

The countries analyzed here are Cambodia, Saudi Arabia, Viet Nam, Tonga and Ukraine. They have acceded to the WTO between October 2004 and May 2008.

See WTO Secretariat, Report of the Working Party on the Accession of Tonga to the World Trade Organization (Hong Kong, 2 December 2005) [WT/ACC/TON/17], paragraph 159; WTO Secretariat, Report of the Working Party on the Accession of the Kingdom of Saudi Arabia to the World Trade Organization (Geneva, 1 November 2005) [WT/ACC/SAU/61], paragraph 261; WTO Secretariat, Report of the Working Party on the Accession of Cambodia (Geneva, 15 August 2003) [WT/ACC/KHM/21], paragraph 205; WTO Secretariat, Report of the Working Party on the Accession of Viet Nam (Geneva, 2006) [WT/ACC/VNM/48], paragraph 437; WTO Secretariat, Report of the Working Party on the Accession of Ukraine to the World Trade Organization (Geneva, 25 January 2008) [W'T/ACC/UKR/152], paragraph 433.

See section 3.2.4 on the protection of data as foreseen by the free trade agreements concluded by the United States.

See WTO Secretariat, Working Party Report Tonga, paragraph 159; WTO Secretariat, Working Party Report Saudi Arabia, paragraph 261; WTO Secretariat, Working Party Report Cambodia, paragraph 205; WTO Secretariat, Working Party Report Viet Nam, paragraph 437; WTO Secretariat, Working Party Report Ukraine, paragraph 433.

See section 3.2.4 on the protection of data as foreseen by the free trade agreements concluded by the United States.

See WTO Secretariat, Working Party Report Tonga, paragraph 167 and 169; WTO Secretariat, Working Party Report Saudi Arabia, paragraph 272; WTO Secretariat, Working Party Report Cambodia, paragraph 206; WTO Secretariat, Working Party Report Viet Nam, paragraph 471; WTO Secretariat, Working Party Report Ukraine, paragraph 470. 
of an international multilateral organization. Because of this fundamental difference of institutional linkage, ACTA cannot be referred to as a multilateral agreement but is classified as a plurilateral agreement of "like-minded" countries. These so-called "country-clubs" have become a new vehicle for countries to discuss matters of common interest and to move forward.

\subsubsection{Background}

The idea for ACTA seems to have first been launched in 2004 at the Global Congress on Combating Counterfeiting, ${ }^{83}$ a Congress that was hosted by the World Customs Organization and Interpol and sponsored by an interest group that represents multinational copyright and trade mark owners. ${ }^{84}$ The proposal was quickly taken up by G8 members at the 2005 G8 Summit in Gleneagles and led to the adoption of a document that envisaged "Reducing IPR Piracy and Counterfeiting through more Effective Enforcement". 85 On the basis of these efforts, the United States, the European Union, Japan and Switzerland initiated negotiations in October 2007 with the aim of setting

"a new, higher benchmark for enforcement that countries can join on a voluntary basis. The negotiations represent a cooperative effort by the governments involved, and will not be conducted as part of any international organization." 86

After eleven rounds of negotiations, Australia, Canada, the European Union and its Member States, ${ }^{87}$ Japan, the Republic of Korea, Mexico, Morocco, New Zealand, Singapore, Switzerland and the United States have concluded negotiations in October 2010.88 As of October 2012, all countries but Switzerland have signed the treaty; the ratification procedure is still ongoing in all participating countries, except for Japan which has already ratified the treaty. The Agreement will enter into force thirty days after the sixth signatory has deposited the instrument of ratification. ${ }^{89}$ Following the

83 See Australian Department of Foreign Affairs and Trade, An International Proposal for a Plurilateral Anti-Counterfeiting Trade Agreement (ACTA) (Canberra, 13 November 2007), available at <www.dfat.gov.au/trade/acta/discussion-paper.html> accessed on 13.11.2008.

84 This interest group is Global Business Leaders' Alliance Against Counterfeiting.

85 See G8, Reducing IPR Piracy and Counterfeiting Through More Effective Enforcement (2005), available at <www.g7.utoronto.ca/summit/2005gleneagles/ipr_piracy.pdf> accessed on 18.10.2012.

86 See USTR, "Press Release: Ambassador Schwab Announces US Will Seek New Trade Agreement to Fight Fakes" (12 June 2009), available at <www.ustr.gov/ambassadorschwab-announces-us-will-seek-new-trade-agreement-fight-fakes $>$ accessed on 18.10.2012.

87 Since the European Union shares competence with the Member States on the subject matters addressed in the agreement, both the Union and its Member States have to sign and ratify the treaty for it to enter into force. See section 4.2.1.1 of this book.

88 The text of the agreement can be found in Council of the European Union, AntiCounterfeiting Trade Agreement (Brussels, 23 August 2011) [2011/0166 (NLE)].

$89 \quad$ See Article 40.1 the ACTA. 
rejection of ACTA by the European Parliament, ${ }^{00}$ the future of ACTA for the European Union remains uncertain.

While many controversial elements of ACTA, which were discussed during the negotiations, ${ }^{91}$ did not make it into the final agreement, ACTA still contains a number of TRIPS-plus provisions. These are 1) the omission of exceptions and flexibilities foreseen by the TRIPS Agreement, 2) the protection of the digital environment, 3) the disclosure of information on the identity of subscribers' data, 4) border measures and 5) criminal enforcement measures.

\subsubsection{TRIPS-plus Provisions}

First, ACTA cannot be read without filling the gaps left in ACTA with relevant provisions of the TRIPS Agreement. The legal basis for this is Article 1 of ACTA:

"Nothing in this Agreement shall derogate from any obligation of a Party with respect to any other Party under existing agreements, including the WTO Agreement on Trade-Related Aspects of Intellectual Property Rights.”

It happens that ACTA mainly leaves gaps where relevant safeguards or limits on right holder action are concerned; these exceptions and flexibilities must be filled by the TRIPS Agreement. However, it may be argued that only mandatory safeguards in the TRIPS Agreement are not modified by ACTA;22 voluntary flexibilities can be compromised by ACTA obligations. An example is Article 47 of the TRIPS Agreement, which allows WTO Members to grant judicial bodies the authority to order the infringer to inform the right holder of the identity of third persons involved in the production and distribution of infringing goods. According to Article 47, such an authority is limited by a proportionality test regarding the seriousness of the infringement. Article 11 of ACTA, in contrast, requires ACTA parties to grant this authority to judicial bodies but does not provide for the same proportionality test. Since the TRIPS provision is merely a voluntary one, the ACTA obligation could compromise WTO Members' ability to provide for a proportionality safeguard. Therefore, Article 11 of ACTA can be regarded as a TRIPS-plus provision, unless provided for in their domestic laws.

90 See Pinsent Masons, "ACTA rejected by European Parliament" Out-Law, 2012, available at <http://www.out-law.com/en/articles/2012/july/acta-rejected-byeuropean-parliament/> accessed on 20.11.2012.

See R. Gross, IP Justice White Paper on the Proposed Anti-Counterfeiting Trade Agreement (ACTA) (2008), available at <http://ipjustice.org/wp/2008/03/25/ipj-white-paperacta-2008/> accessed on 18.10.2012, p. 6 and 7; A. Shaw, "The Problem with the AntiCounterfeiting Trade Agreement (and what to do about it)" Knowledge Ecology Studies, 2008, Vol. 2, 1-9, p. 2.

Examples of mandatory safeguards are Article 56 of the TRIPS Agreement concerning compensation in cases of wrongful detentions, Article 53.2 on the importer's right to the release of his allegedly infringing and suspended goods if no provisional relief was granted and the importer posts an adequate security, and Article 55 on the mandatory limits to the duration of the initial detention of goods suspected of infringement, within which proceedings leading to a decision on the merits have to be initiated or otherwise the goods must be released. 
Second, ACTA reinforces the use of "Digital Rights Management" (DRM) technologies and "Technological Protection Measures' (TPM). ${ }^{93}$ Articles 27.5 and 27.7 of ACTA set out in detail in how far state parties must provide adequate legal protection and effective legal remedies against the circumvention of TPMs and DRM technologies. These technologies prevent access to and/or the reproduction of optical discs, such as DVDs. The protection of DRM technologies is included in the WCT and the WPPT, ${ }^{94}$ however not in the TRIPS Agreement. The cited ACTA Article does not only contain TRIPS-plus provisions but also goes beyond the protection foreseen in the WCT and the WPPT. ${ }^{95}$

A third main element contained in ACTA concerns the disclosure of subscriber's data information by intermediaries. Article 27.4 stipulates that ACTA parties may provide their competent authorities with the authority to order online service providers to disclose expeditiously subscribers' identities in case that their accounts have been used for infringing behaviour. The TRIPS norm contained in Article 47 of the TRIPS Agreement does not require the same obligation from any intermediary, but from infringing intermediaries only.

Fourth, according to ACTA, border measures have to be applied to 1) imports and exports of goods that 2) infringe any type of IP right covered by the TRIPS Agreement, with the exception of patents and the protection of undisclosed information. ${ }^{96}$ The TRIPS Agreement, on the other hand, merely requires their application to 1) the importation of 2) counterfeit trade mark or pirated copyright goods. Both the applicable customs procedures as well as the scope of the IP rights covered have been considerably expanded.

A fifth and final TRIPS-plus issue is set out in Article 23.1 of ACTA. Accordingly, criminal procedures shall be applied at least in cases of willful trade mark counterfeiting or copyright or related rights piracy on a commercial scale. This obligation is in conformity with Article 61 of the TRIPS Agreement. The provision in ACTA, however, also defines the concept of "commercial scale" as including at least those acts

"carried out as commercial activities for direct or indirect economic or commercial advantage."

Article 61 of the TRIPS Agreement itself does not provide a definition of the concept. Nevertheless, in the 2009 Panel Report China - Measures Affecting the Protection and

93 These two concepts are often used for referring to devices that control the access to and copying of copyrighted works. However, there are small differences to be aware of: DRM technologies in principle only refer to digital works and to all sorts of technologies that manage works, including copy control. TPMs may include works that are not digital and describe technological means with which the use and/or access to works can be restricted. See also section 3.1.3.1 of this book for an account of how the WCT and WPPT deal with these measures.

94 See Article 12 of the WCT and Article 19 of the WPPT.

95 See European Academics, Opinion of European Academics on Anti-Counterfeiting Trade Agreement (2011), available at <http://www.iri.uni-hannover.de/tl_files/pdf/ACTA_opinion_200111_2.pdf> accessed on 15.11.2012, paragraph 15.

96 See footnote 6 of ACTA. 
Enforcement of Intellectual Property Rights, ${ }^{97}$ the Panel stated that the threshold for criminal enforcement covering activities on a commercial scale is set at

"counterfeiting or piracy carried on at the magnitude or extent of typical or usual commercial activity with respect to a given product in a given market." 98

A study produced for the European Parliament concludes that the ACTA norm of "indirect economic or commercial advantage" focuses on the intent of the alleged counterfeiter or pirate rather than on assessing the adverse effects on the market. ${ }^{99}$ Therefore, Article 23.1 of ACTA goes beyond the standard required in the TRIPS Agreement and might even conflict with the above-mentioned WTO Panel decision.

\subsubsection{Criticism}

Not surprisingly, the ACTA negotiations have received much criticism. One of the major criticisms was the secrecy that surrounded these negotiations. Almost no information was available about the content of such an agreement during the negotiations. Public interest organizations were excluded from the process. Developing countries and main IP-infringing nations such as India, China and Brazil were not involved in the negotiations. ${ }^{100}$ As Kimberlee Weatherall notes,

"the veil surrounding the negotiations is generating a certain amount of paranoia and speculation regarding the possible contents of the agreement." 101

In addition, the approach to this agreement has been criticized. The wealthiest countries coming together and only inviting like-minded countries as well as right holders and trading partners has been described as a "blatant disregard for global consensus and the needs of developing regions." 102 This plurilateral approach outside existing international frameworks allows developed countries to evade all accountability structures ${ }^{103}$ and set the standards that they want without having to compromise the final outcome.

A third concern regards the conclusion of a plurilateral agreement outside of any international organization. ${ }^{104}$ It creates a new layer of global governance on top of the diverse, already existing, multilateral, regional and bilateral forums between which states have been shifting until now. A new layer has been added to the forum-shifting strategy, that of creating new forums instead of shifting between the already existing

97 China - Measures Affecting the Protection and Enforcement of Intellectual Property Rights [WT/DS362/R] (WTO Panel Report, 26 January 2009) [hereinafter Panel Report China - Intellectual Property Rights].

$98 \quad$ Ibid., paragraph. 7.577.

99 See A. Kamperman-Sanders et al., The Anti-Counterfeiting Trade Agreement (ACTA): An Assessment (Directorate-General for External Policies of the Union, Brussels, 11 July 2011) [EXPO/B/INTA/FWC/2009-01/Lot7/12], p. 23.

100 See Gross, IP Justice White Paper, p. 5.

101 See K. Weatherall, The Anti-Counterfeiting Trade Agreement: What's it all about? (2008), available at <http://works.bepress.com/kimweatherall/18> accessed on 18.10.2012, p. 3.

104 See Shaw, "The Problem with the Anti-Counterfeiting Trade Agreement", p. 2. 
forums. Fourth, the new responsibilities under ACTA are vested with public institutions such as local and national law enforcement bodies, border agencies, customs controls and local courts. ${ }^{105}$ However, under many legal systems, intellectual property rights are private rights and the burden of enforcing those rights lies with the right holders. Public enforcement means that the public will have to pay the majority of the enforcement costs. As resources are scarce in developing countries, the money spent on IP enforcement cannot be invested in other public benefit projects.

In conclusion, even though many controversial topics under discussion during the negotiations have not been included in the final ACTA text, there are still a considerable number of TRIPS-plus features that are likely to impact the international system of regulating intellectual property. With an expected number of thirty-six initial signatories, the Agreement is mainly relevant for developed countries and emerging economies. Main IP-infringing nations such as India, China and Brazil are currently not parties to the Agreement. Whether future free trade agreements will contain an obligation to accede to or comply with the standards of ACTA is rather unlikely since the scope of the Agreement stays well behind the standards set in relevant provisions of recent bilateral trade agreements concluded by the United States and the European Union. ${ }^{106}$

\subsubsection{Interim Conclusions}

TRIPS-plus provisions are widespread, at various levels and in different forums. Since the establishment of the TRIPS Agreement, particularly developed countries have sought to include TRIPS-plus provisions in bilateral, plurilateral and multilateral treaties. These treaties are to be found within international organizations, such as WIPO and the WTO, as well as outside of pre-established institutional structures, for example ACTA. The diversity of treaties as well as the institutional structures make it difficult to maintain an overview of important sources of TRIPS-plus provisions.

Some efforts to set TRIPS-plus standards through bilateral, multilateral and plurilateral agreements have been more successful than others. Bilateral investment treaties, even though now often incorporated in free trade agreements, have been an important source of TRIPS-plus protection for IP right holders. Very successful examples of multilateral standard setting beyond the TRIPS level are the WIPO Internet Treaties, which have been widely adopted by WIPO Members. WIPO's efforts to harmonize substantive patent law, on the other hand, seem to have failed in view of the fact that discussions in the relevant committee have not focused on the draft Substantive Patent Law Treaty for several years. The future of ACTA is still uncertain, as protests by citizens continue to jeopardize the domestic ratification processes in European and other signatory parties.

The most recent developments around ACTA show that the public has become ever more suspicious and worried about the content of international IP agreements which might ultimately result in the death of ACTA overall. Like-minded countries seem to

105 See Gross, IP Justice White Paper, p. 6.

106 See sections 3.2.8 and 6.4 of this book for a detailed assessment of the enforcement provisions in US FTAs and recent European bilateral trade agreements. 
have difficulties convincing their own populations of the use of higher IP enforcement standards where privacy rights, procedural safeguards and criminal enforcement measures are at issue. It remains to be seen whether the faith in this plurilateral agreement will also affect that in recently concluded and future bilateral agreements which, in fact, contain higher standards of IP protection and enforcement than the final ACTA text.

\subsection{Free Trade AgreEments ConCluded By the United States}

After having provided an overview of TRIPS-plus developments in national laws, bilateral investment and intellectual property treaties, multilateral and plurilateral treaties, particular attention is paid to the TRIPS-plus provisions contained in bilateral trade agreements. The agreements analyzed are those concluded or negotiated by the main TRIPS-plus demandeurs with developing countries or emerging economies. Bilateral trade agreements or free trade agreements ${ }^{107}$ currently are the most dominant form of international treaties that include obligations on intellectual property protection. As elaborated below, these bilateral trade agreements contain the most far-reaching IP provisions among international IP treaties. The main actors analyzed are the United States, the European Union, EFTA States and Japan.

The United States currently is the actor that has concluded more bilateral trade agreements containing intellectual property provisions than any other actor. Not only the number of concluded agreements is impressive, also the scope of the IP chapter, the level of detail with which the different areas are set out and the nature of the obligations are without comparison. The following Table 2 presents an overview of the free trade agreements concluded by the United States between 2000 and 2012. The negotiations of free trade agreements that have been launched in the past but were suspended or for which no rounds of negotiations have been scheduled, are not listed in the table. ${ }^{108}$

Table 2: United States free trade agreements from mid-2000 until mid 2012

\begin{tabular}{|l|l|l|l|}
\hline Agreement & Date of signature & Date of entry into force & $\begin{array}{l}\text { Starting date of negotiations that } \\
\text { have not yet been concluded }\end{array}$ \\
\hline US-Jordan FTA & 24 October 2000 & 17 December 2001 & \\
\hline $\begin{array}{l}\text { US-Singapore } \\
\text { FTA }\end{array}$ & 6 May 2003 & 1 January 2004 & \\
\hline US-Chile FTA & 6 June 2003 & 1 January 2004 & \\
\hline $\begin{array}{l}\text { US-Australia } \\
\text { FTA }\end{array}$ & 18 May 2004 & 1 January 2005 & \\
\hline US-Morocco FTA & 15 June 2004 & 1 January 2006 & \\
\hline
\end{tabular}

107 As mentioned above, the terminology used for bilateral trade agreements varies according to the actor involved. The United States has generally included its TRIPSplus provisions in free trade agreements. See footnote 15 of section 3.1.2 of this book. Free trade negotiations have been officially suspended with the Southern African Customs Union (2006), Thailand (2006), and Qatar (2006). There is a wish to start negotiations with the Middle East Free Trade Area and the European Union; however, up until mid October 2012, this has not yet happened. The fifth round of talks with the United Arab Emirates had yet to be scheduled. 


\begin{tabular}{|c|c|c|c|}
\hline $\begin{array}{l}\text { US-CAFTA- } \\
D^{109}\end{array}$ & 5 August 2004 & \begin{tabular}{ll|}
- & 28 July 2005 (United \\
& States) \\
- & 1 March 2006 (El \\
& Salvador) \\
- & 1 April 2006 (Honduras \\
& and Nicaragua) \\
- & 1 July 2006 (Guatemala) \\
- & 1 March 2007 (Dominican \\
& Republic) \\
- & 1 January 2009 (Costa \\
& Rica)
\end{tabular} & \\
\hline US-Babrain FTA & 14 September 2004 & 11 January 2006 & \\
\hline US-Oman FTA & 19 January 2006 & 1 January 2009 & \\
\hline US-Peru TP $A^{110}$ & 12 April 2006 & 1 February 2009 & \\
\hline $\begin{array}{l}\text { US-Columbia } \\
\text { TPA }\end{array}$ & 22 November 2006 & 15 May 2012 & \\
\hline US-Panama TPA & 28 June 2007 & 21 October $2011^{111}$ & \\
\hline $\begin{array}{l}\text { US-South Korea } \\
\text { FTA }\end{array}$ & 30 June 2007 & 15 March 2012 & \\
\hline TPP & & & $\begin{array}{ll}\text { - } & \text { February } 2008 \text { (United States) } \\
\text { - } & \text { November 2008 (Australia, } \\
\text { - } & \text { Peru, Vietnam) } \\
\text { - } & \text { October } 2010 \text { (Malaysia) } \\
\text { - } & \text { Noveme } 2012 \text { (Canada) } \\
& \text { joined as observer) }\end{array}$ \\
\hline
\end{tabular}

Source: USTR website, Free Trade Agreements (2012) ${ }^{112}$

The United States has signed twelve free trade agreements, one of which (the USCAFTA-DR) involves five developing countries. The Trans-Pacific-Partnership Agreement (TPP) is currently being negotiated among the four original parties ${ }^{113}$ and another six countries, ${ }^{114}$ one of them being the United States. The basis of the following analysis are the texts of the concluded agreements as well as the draft IP chapter of the TPP from February $2011 .{ }^{115}$ The purpose of this section is to show how aggressive a) the legal method used by the United States in the IP chapters of its FTAs, b) the characteristics of the FTA negotiations, and c) the TRIPS-plus provisions contained in US FTAs are. "Aggressive" in this context must be understood as an approach which is merely focused on US preferences, without

The agreement encompasses the Central American countries Costa Rica, El Salvador, Guatemala, Honduras and Nicaragua, as well as the Dominican Republic.

110 The agreements with Peru, Colombia and Panama are called "Trade Promotion Agreement" rather than "Free Trade Agreement". They have the same effect.

111 Note that the agreement entered into force for the United States on 31 October 2012.

112 The data collected here was obtained from the USTR website, USTR, Free Trade Agreements (2012), available at <http://www.ustr.gov/trade-agreements/free-tradeagreements $>$ accessed on 21.11.2012.

113 The negotiations on the Trans-Pacific Partnership Agreement build upon the Trans-Pacific Strategic Economic Partnership Agreement (P4) between Brunei Darussalam, Chile, New Zealand and Singapore. The latter was signed on 3 June 2005 and entered into force among the four contracting parties on 28 May 2008.

114 These are the United States, Australia, Peru, Vietnam, Malaysia and Canada.

115 See Keionline, Draft Intellectual Property Rights Chapter of the Trans-Pacific Partnership (10 February 2011), available at <http://keionline.org/sites/default/files/tpp-10feb2011us-text-ipr-chapter.pdf $>$ accessed on 16.11.2012 [hereinafter draft TPP of February 2011]. 
considerations for the preferences of its negotiating partners, and which is unique in the combination of the tools used. These tools are each of a "value-claiming" nature, ${ }^{116}$ hence placing little or no emphasis on joint gains, but promoting the United States' preferences without compromises. The analysis provided here will be used as a reference point for the section dealing with European Union bilateral trade agreements before 2006, but, most importantly, for the EU agreements concluded after 2006 which reflect to a large extent similar legal methods and substantive provisions. ${ }^{117}$ Before turning to the detailed examination of the substantive intellectual property provisions contained in United States FTAs, the following two sections will give an overview of the legal method used by the United States when concluding free trade agreements and the characteristics of such negotiations.

\subsubsection{Legal Method}

The United States uses certain techniques in each FTA negotiation on intellectual property issues. Three features are described here as part of the US legal method which is unique to the United States, even though some aspects have been copied by other major players. One of the most striking features of the free trade agreements concluded by the United States is the level of detail and extensiveness that the chapter dealing with the protection of intellectual property characterizes. The table drafted by Andrew Christie, Sophie Waller and Kimberlee Weatherall contains a list of all agreements concluded by the United States until June 2007, including the number of pages and number of words the respective intellectual property chapters contain. ${ }^{118}$ The number of pages has increased from eight pages in the US-Jordan FT $A^{119}$ to a maximum of thirty-seven pages in the US-Morocco FT $A ;{ }^{120}$ the number of words expanded from 2,438 in the US-Jordan FTA to 12,908 in the latest US-South Korea FTA. ${ }^{121}$ These numbers exclude the side letters often incorporated in the agreements, which can amount to another nineteen pages in some cases.

Despite the fact that the number of pages and words has increased over time, the structure of the agreement and the content of its provisions have stayed rather constant since the US-Chile FT $A^{122}$ from June 2003. In fact, the United States uses a prototype agreement that serves as the basis for negotiations with each country. It uses a certain template that is always asked for and developed further with each FTA. Provisions are scaled up with every new agreement negotiated, and standards that

See section 8.2.4 of this book.

See Chapter 5 : Legal Analysis of the CARIFORUM-EC Economic Partnership Agreement and Chapter 6: Legal Analysis of the Draft India-EU Broad-based Trade and Investment Agreement of this book.

See Christie, Waller and Weatherall, "Exporting the DMCA through Free Trade Agreements", p. 212-213.

Agreement Between the United States of America and the Hashemite Kingdom of Jordan on the Establishment of a Free Trade Area, signed on 24 October 2000, entered into force on 17 December 2001, 41 I.L.M. 63 (2002) [hereinafter US-Jordan FTA].

United States - Morocco Free Trade Agreement, signed on 15 June 2004, entered into force on 1 January 2006, 44 I.L.M. 544 (2005) [hereinafter US-Morocco FTA].

Free Trade Agreement between the United States of America and the Republic of Korea, signed on 30 June 2007, entered into force on 15 March 2012, see USTR, Free Trade Agreements [hereinafter US-South Korea FTA].

United States - Chile Free Trade Agreement, signed on 6 June 2003, entered into force on 1 January 2004, 42 I.L.M. 1026 (2003) [hereinafter US-Chile FTA]. 
have already been obtained in a previous agreement are rarely downgraded to lower standards. ${ }^{123}$ A good example is the US-Australia FTA: ${ }^{124}$ it included a standard of protection for undisclosed information ${ }^{125}$ with which Australia complied already before the FTA was negotiated. Effectively, there was no need to include the data exclusivity provision; however, from the point of view of the United States' policymaker, its inclusion made sense because the US-Australia FTA would form the basis for future negotiations with Bahrain, Peru or Thailand. ${ }^{126}$

The intellectual property chapters are not only very detailed and extensive; they also prescribe a specific "to-do list". This has been described as the "nanny approach". ${ }^{127}$ In contrast to provisions of a more general nature, which would leave some flexibility in implementation, the provisions contained in the intellectual property chapters of US FTAs set out detailed pieces of legislation. For example, the copyright provisions are almost identical to United States' copyright law, the Digital Millennium Copyright Act. ${ }^{128}$ While DMCA-like provisions cannot yet be found in the US-Jordan FTA from 2000, they first appeared in the US-Chile FTA from 2003, where still some scope of discretion was left to the implementing country. Later FTAs, such as those with Singapore and Australia, include DMCA-like provisions that do not leave any room for countries to take local preferences into account; ${ }^{129}$ the provisions usually are transferred into national law as they are. This specificity is not only symptomatic for copyright protection but can also be found in other areas, such as data exclusivity.

The reason for exporting one's own legislation is twofold in the case of the United States: first, the United States' Trade Act of 2002 prescribes that

"the provisions of any multilateral or bilateral trade agreement governing intellectual property rights that is entered into by the United States [must] reflect a standard of protection similar to that found in United States law."130

According to the so-called Trade Promotion Authority, FTA provisions on intellectual property must not deviate from the standard guaranteed by United States law. In order to comply with its national law, the USTR asks for "legislation-like" provisions in FTA negotiations. The second reason for using a prototype as the basis for negotiation of each FTA is a very practical one: the United States Congress must

See also Biadgleng and Muñoz Tellez, The Changing Structure and Governance of Intellectual Property Enforcement, p. 30.

United States - Australia Free Trade Agreement, signed on 18 May 2004, entered into force on 1 January 2005, 43 I.L.M. 1248 (2004) [hereinafter US-Australia FTA].

See section 3.2.4.1 of this book.

See Kuanpoth, "TRIPS-Plus Rules under Free Trade Agreements", p. 28. Note that there is another added value of including a provision in a bilateral agreement even if national legislation already provides the protection specified: Australia will be prevented from changing its legislation in the future as it has to comply with the international binding obligation in the free trade agreement.

See Pugatch, "The International Regulation of IPRs in a TRIPs and TRIPs-plus Worlds", p. 10.

See Christie, Waller and Weatherall, "Exporting the DMCA through Free Trade Agreements", p. 215.

See ibid.

See Trade Act of 2002 \$2102(4)(A)(II), 19 U.S.C. \$3802(b)(4)(A)(i)(II) (2002). 
pass legislation that approves an FTA before it can enter into force. In order to guarantee a realistic chance of obtaining congressional approval, the intellectual property chapters follow the same prototype. Congressional approval is even more likely if the prototype copy-pastes parts of United States intellectual property law: also Congress will assess whether the standard of the Trade Promotion Authority is met. Once that model agreement has been approved by Congress, later agreements are not expected to face substantial problems in receiving approval. ${ }^{131}$ Furthermore, different advisory committees are involved in the process of approval of a trade agreement. In particular, the Industry Advisory Committees are known for drawing very explicit comparisons with prior FTAs. ${ }^{132}$

"Provisions that are seen to be less IP-protective than provisions in past FTAs attract negative comment." 133

Such negative comment could endanger congressional approval and is therefore avoided.

A third element of the US approach is the "certification" process that takes place after negotiations have been finished and the agreement has been concluded. In the implementation phase, negotiating partners of the United States have to undergo a "process of scrutiny and vetting"134 of their implementing laws. This process is based on the implementation bills passed by Congress regarding the entry into force of the respective FTA. ${ }^{135}$ The executive branch determines whether the laws are satisfactory in order for them to enter into force. For example, Peru was obliged to pass different legislative acts and to amend previous ones because they did not conform to the expectations of the USA. ${ }^{136}$ In essence, already concluded FTAs are renegotiated in the implementation phase and allow the United States to have an even greater impact on the actual laws that will apply in the partner country. This process is based on a unilateral act on which the partner country has no influence whatsoever.

To sum up, the legal method used by the United States in the negotiations of the IP chapter contained in its FTAs contains aggressive features. First, all IP chapters of FTAs are based on a detailed and extensive prototype which is offered to each new negotiating partner and from which the United States rarely departs. Second, the

See R. Mayne, Regionalism, Bilateralism, and "TRIP Plus" Agreements: The Threat to Developing Countries (United Nations Development Programme, Human Development Report, New York, 2005) [Occasional Paper No. 2005/18], p. 3.

The reports of the Industry Functional Advisory Committee or the Industry Trade Advisory Committee can be found on the website of the USTR under each agreement concluded, see USTR, Free Trade Agreements. Christie, Waller and Weatherall, "Exporting the DMCA through Free Trade Agreements", p. 220. Email correspondence with Pedro Roffe, Senior Associate of ICTSD, 18 October 2012 (available on request).

135 For the example of the US-CAFTA, see To implement the Dominican Republic - Central America- United States Free Trade Agreement, Pub. L 109-53, 119 Stat. 462, 2 August 2005, Section 101(b).

136 See A. Villarreal, US-Peru Economic Relations and the US-Peru Trade Promotion Agreement (US Congress, Congressional Research Service, 27 July 2007) [Order Code RL34108], p. 2. 
language used in the IP provisions is highly prescriptive and hardly leaves room for making choices in the implementation of these obligations. In fact, the United States demands its partners to transplant parts of US legislation into their domestic laws. Foreign transplants can create all sorts of problems which are difficult to handle, especially for developing countries. Third, the United States preserves the right for itself to assess the implementing legislation of its trading partners; only if it satisfies the expectation of Congress and the US Executive, the agreement can enter into force. This assessment stage in the implementation phase has not been agreed upon by both parties in the FTA negotiation, but is imposed by the United States unilaterally.

\subsubsection{Characteristics of Negotiations}

Many of the United States' trading partners have accepted the same model intellectual property chapter with merely minor deviations. ${ }^{137}$ This proffers the question as to how the United States successfully persuades its trading partners. Its style of negotiating with trading partners is certainly one part of the explanation. First, the United States is aware of the fact that most developing country partners do not set their priorities in safeguarding flexibilities for their intellectual property policies, but rather in accessing core markets of the United States. These are typically the markets of trade in agricultural goods and textiles. Duncan Matthews found in his analysis of the TRIPS negotiations that developing countries were

"offered trade advantages and market access in key areas, such as agriculture, in return for agreeing"138

to more stringent provisions on intellectual property rights. The same seems to be true for most bilaterally-negotiated agreements between developing countries and the United States, ${ }^{139}$ such as the US-CAFTA-DR. ${ }^{140}$

Second, the lack of available information on the content of the FTA IP chapter makes it almost impossible for negotiating partners to receive relevant information and advice from third parties in order to adjust their negotiating strategy. Official information is either not made public at all or merely in summary version just before or after the agreement has been signed. In the case of the US-CAFTA-DR, even on

137 It must be pointed out that only those countries that have finally concluded an agreement with the United States accept the provisions of the model intellectual property chapter without major deviations. This does not mean that all countries negotiating with the United States accept the chapter; negotiations can get stuck along the way or are suspended for an indefinite period of time.

138 D. Matthews, "WTO Decision on Implementation of Paragraph 6 of the DOHA Declaration on the TRIPS Agreement and Public Health: A Solution to the Access to Essential Medicines Problem?” Journal of International Economic Law, 2004, Vol. 7 (1), 73 107, p. 85.

139 See generally for FTAs, Kuanpoth, "TRIPS-Plus Rules under Free Trade Agreements", p. 28; for the US-CAFTA-DR, see Rajkumar, "The Central American Free Trade Agreement: an end run around the DOHA Declaration on TRIPS and Public Health", p. 460.

140 The Dominican Republic - Central America - United States Free Trade Agreement, signed on 5 August 2004, entered into force on 28 July 2005, 43 I.L.M. 514 (2004) [hereinafter USCAFTA-DR]. 
demands by civil society organizations, the draft texts were not made public. ${ }^{141}$ Costa Rican negotiators had to sign a confidentiality agreement which prevented them from disclosing meeting agendas or substantive information about the agreement to the public. ${ }^{142}$ In the case of the US-Chile FTA, the Chilean Government made brief summaries available just before the agreement was signed. ${ }^{143}$ Although it is true that most developing countries which face the United States in bilateral negotiations can now learn from earlier experiences of other countries, the lack of official information leaves a lot of room for speculation which often does not increase the support for the FTA.

Third, since FTA negotiations take place outside institutional structures (like those of the W'TO or WIPO), rules on a balanced involvement of interest groups or transparency considerations are lacking. In the negotiations of the US-Thailand FTA, ${ }^{144}$ the Thai Government had not conducted consultations across the Thai community; hence, the public did not know which legal obligations were contained in the proposed FTA. ${ }^{145}$ Only private sector interest groups are likely to be involved when key decisions are made; civil society organizations are not invited. The Thai Government was heavily criticized for deepening inequalities between different interest groups. "Business people" were given privileged access and therefore could decide the main issues together with "bureaucrats". ${ }^{146}$ The negotiations between the United States and CAFTA States took

\footnotetext{
"place in closed quarters, with a side room available for selected interested parties. [...] The business sector has privileged access to the negotiating process but civil society organizations have limited or no access."147
}

Also the US-Chile FTA negotiations were criticized for the limited participation of interest groups. ${ }^{148}$ One of the few ways civil society can be involved in the negotiations of free trade agreements is through public protests. ${ }^{149}$

A fourth feature of negotiations is the undemocratic manner in which US FTAs are put in place. Free trade agreements negotiated by the United States encompass a large variety of areas which are sought to be liberalized. The content of FTAs undoubtedly has an enormous impact on the lives of people in the countries involved. The decision to participate in such agreements should therefore have democratic legitimacy. In the case of negotiations between Thailand and the United States, the agreement was not put before the Thai Parliament for its approval. According to the Thai Government, approval by parliament was not required as Section 224 of the

See Oxfam America, Make Trade Fair for Central America, p. 7

See Rajkumar, "The Central American Free Trade Agreement: an end run around the DOHA Declaration on TRIPS and Public Health", p. 465.

See Vivas-Eugui, The Free Trade Area of the Americas, p. 15.

The negotiations on the US-Thailand FTA have been on hold since the 2006 Thai coup d'état.

See Kuanpoth, "TRIPS-Plus Rules under Free Trade Agreements”, p. 29.

See ibid., p. 29.

Oxfam America, Make Trade Fair for Central America, p. 6.

See Vivas-Eugui, The Free Trade Area of the Americas, p. 15.

See below the section on public protests. 
Constitution of the Kingdom of Thailand of 1997150 limited the necessity of having parliamentary approval to treaties that require the enactment of legislation to implement the agreement. ${ }^{151}$ The Thai Government argued that this was not the case. ${ }^{152}$ Even though the political decision to seek approval by the national parliament of developing countries is not taken by the United States, developed countries need to consider whether it is in their interest to negotiate and conclude an agreement with a partner country that hardly respects the principles of democratic legitimacy.

In addition, the theory of democratic bargaining adds another dimension to the debate. Peter Drahos and John Braithwaite argue in their book 'Information Feudalism' that decision making

"in relation to property rights should take place under conditions of democratic bargaining. Democratic bargaining matters crucially to the definition of property rights because of the consequences of property rules for all individuals within a society. Property rights confer authority over resources. When authority is granted to the few over resources on which the many depend, the few gain power over the goals of the many." 153

In order to comply with the theory of democratic bargaining, three conditions have to be fulfilled to ensure that property rights are efficiently defined: 1) all relevant interests have to be represented in the negotiating process, 2) all those involved in the negotiation must have full information about the consequences of various possible outcomes, and 3) one party must not coerce the others. ${ }^{154}$ It is doubtful whether all three conditions are fulfilled in FTA negotiations conducted by the United States. ${ }^{155}$

A last characteristic that United States FTA negotiations have in common is that they are accompanied by public protests. The negotiations with CAFTA countries, especially Ecuador and Costa Rica, prompted huge social and political mobilizations

150 Section 224 reads as follows: "A treaty which provides for a change in the Thai territories or the jurisdiction of the State or requires the enactment of an Act for its implementation must be approved by the National Assembly". See Constitution of the Kingdom of Thailand, enacted on 11 October 1997 and abrogated by military coup on 19 September 2006, published in the Government Gazette Vol. 114, Part 55a.

151 See D. Laohapakakul, "United States - Thailand Free Trade Agreement Negotiations: Potential Effects on Pharmaceutical Patent Protection in Thailand" Legal Electronic Document Archive, 2006.

152 See BIOTHAI, "Fighting FTAs: The Experience in Thailand" in bilaterals.org, BIOTHAI and GRAIN (eds.), Fighting FTAs: The growing resistance to bilateral free trade investment agreements (2008) 36-43, p. 38.

153 P. Drahos and J. Braithwaite, Information Feudalism (Earthscan Publications Ltd., London, 2002), p. 12-13.

154 See ibid., p. 15.

155 It can be argued that most national laws and international treaties of any country will not meet the three conditions outlines. However, this reality does not make it more acceptable to conclude agreements in a non-transparent, non-inclusive and illegitimate manner. 
in protest. In Thailand, 15,000-20,000 people besieged the hotel that served as the venue for the sixth round of FTA negotiations. ${ }^{156}$

In brief, the way in which the United States negotiates the IP chapters with developing countries contains a number of aggressive features. First, knowing that intellectual property protection is not a priority for many developing countries, the United States uses this insight strategically to push for the highest intellectual property standards currently found in international agreements. ${ }^{157}$ Second, the United States effectively uses the by now well-known strategy of secrecy. By requiring its negotiating partners to keep all information secret until the free trade agreement is signed, developing country partners are precluded from obtaining necessary and relevant advice from civil society organizations, international and regional organizations and business groups. Finally, bilateral negotiations are carried out outside of pre-established institutional structures where rules on the respect of transparency and participatory democracy are lacking. As a consequence, the United States is not under an obligation to adjust certain provisions immediately during the negotiations in order to balance different interests.

After having pointed out the aggressive aspects of the legal method and the negotiating process used by the United States, particular attention will be paid to the TRIPS-plus provisions contained in US FTAs concluded since the year 2000. I include in this assessment the draft IP chapter of the TPP of February 2011 which presents the most recent agreement that is currently being negotiated. The analysis does not only indicate the various TRIPS-plus provisions, it also assesses how far these obligations go beyond the TRIPS Agreement. This is done by examining the development of the level of protection that has taken place in a number of areas. In addition, the FTA standards of protection are compared with the equivalent provisions in pluri- or multilateral treaties other than the TRIPS Agreement, such as the WIPO Copyright Treaty, the WIPO Performances and Phonograms Treaty and ACTA. In view of the criticism that ACTA has incurred worldwide, and particularly in Europe, the aggressive nature of the IP chapters in US FTAs becomes particularly evident as the provisions contained in the FTAs are even more restrictive than those included in ACTA.

\subsubsection{General Provisions}

The intellectual property chapters of United States FTAs follow a particular structure. The structure can be subdivided into four sections: 1) general matters, 2) individual intellectual property regimes and matters that interface with intellectual property regimes, 3) enforcement matters and 4) the application of non-violation complaints. ${ }^{158}$ All of these provisions strongly relate to the TRIPS Agreement. They do so by either repeating provisions of the TRIPS Agreement, by elaborating on the provisions or by going beyond the standard of the TRIPS Agreement. Particular focus

See BIOTHAI, "Fighting FTAs: The Experience in Thailand", p. 36.

This general observation is true for most areas dealt with in US FTAs. In the area of geographical indications, however, it is the European Union that has introduced the highest international standards. See section 3.2.3 of this book for a detailed analysis of the substantive provisions in US FTAs.

See also Christie, Waller and Weatherall, "Exporting the DMCA through Free Trade Agreements", p. 214. 
is paid to the last type of provisions. To start with, there are four general matters relevant to intellectual property protection dealt with in US FTAs: a) the ratification of international treaties, b) the entitlement to provide for more extensive protection, c) the national treatment principle, and d) the integration of investment chapters into the FTA.

The first general provision, which is commonly contained in the intellectual property chapters of United States FTAs, regards the accession to multilateral treaties relating to the protection of intellectual property. ${ }^{159}$ This obligation can take one of the two forms: either an obligation to accede to multilateral IP treaties by a specific date, or an obligation to "make best efforts" to accede to international IP agreements without a time indication. Among the treaties to which accession is required are:

- the Patent Cooperation Treaty;

- the Convention Relating to the Distribution of Programme-Carrying Signals Transmitted by Satellite ${ }^{160}$ [hereinafter Brussels Convention] (1974);

- the Budapest Treaty; ${ }^{161}$

- the UPOV Convention, Act 1991;

- $\quad$ the Trademark Law Treaty ${ }^{162}$ (or Singapore Treaty); $;^{163}$

- the WIPO Copyright Treaty; and

- the WIPO Performances and Phonograms Treaty.

Best efforts have to be made to accede to the following treaties:

- the Patent Law Treaty;

- the Geneva Act of the Hague Agreement; ${ }^{164}$ and

- $\quad$ the Madrid Protocol. ${ }^{165}$

It can be observed that the agreements listed in both sections (the hard obligation to ratify or accede to the treaty and the soft obligation of making best efforts to accede

159 See Article 1.3 and 1.5 of the draft IP chapter of the TPP of February 2011; Article 14.1.2 and 14.2.3 of the US-Babrain FTA; Article 17.1.2, 17.1.3 and 17.1.4 of the USChile FTA; Article 4.2 of the US-Jordan FTA.

160 Convention Relating to the Distribution of Programme-Carrying Signals Transmitted, done in Brussels on 21 May 1974, entered into force on 25 August 1979, 1144 U.N.T.S. 3 (1979) [hereinafter Brussels Convention].

161 Budapest Treaty on the International Recognition of the Deposit of Microorganisms for the Purposes of Patent Procedure, signed in Budapest on 28 April 1977, entered into force 9 August 1980, 1861 U.N.T.S. 361 (1977).

162 Trademark Law Treaty, signed in Geneva on 27 October 1994, entered into force on 1 August 1996, 2037 U.N.T.S. 35 (1994).

163 Singapore Treaty on the Law of Trademarks, signed at Singapore on 27 March 2006, entered into force on 16 March 2009. As of 1 July 2012, the treaty has twenty-seven contracting parties. See WIPO, WIPO-Administered Treaties.

164 Geneva Act of the Hague Agreement Concerning the International Deposit of Industrial Designs, signed in Geneva on 2 July 1999, entered into force on 23 December 2003, 2279 U.N.T.S. 156 (1999). There are currently three Acts of the Hague Agreement in force: the 1999 Act, the 1960 Act and the 1934 Act.

165 Protocol relating to the Madrid agreement concerning the international registration of marks, done in Madrid on 27 June 1989, entered into force 1 December 1995. 
to the treaty) show a development to stricter obligations. For example the Madrid Protocol has moved in a number of agreements to the hard obligation of ratifying or acceding to the Protocol, rather than making reasonable efforts to do so. ${ }^{166}$ Also, the addition of the Singapore Treaty to the list of international agreements shows a gradual increase in the level of protection. ${ }^{167}$ The TRIPS Agreement does not require the accession to, the ratification of, or the compliance with, any of these multilateral agreements.

A second general feature is the right of contracting parties to provide for more extensive protection. ${ }^{168}$ This is either contained in a separate provision or included in the provision on minimum standards. It is important to note that the minimum standards provision resembles word-for-word that of the TRIPS Agreement. ${ }^{169}$ What FTAs do not include is a right that the TRIPS Agreement grants in this respect: the freedom to determine the appropriate method of implementation. The effect of dropping this right has the same effect as the above-mentioned observation that many provisions are "legislation-like": United States free trade agreements do not leave much discretion to their negotiating partners to implement the provisions of the IP chapter according to their national preferences. Making more extensive protection elsewhere possible is the basis for the global intellectual property ratchet to work: the standards of protection included in one international agreement are built upon in each following agreement in order to expand global intellectual property protection consistently. ${ }^{170}$

Another general matter dealt with in United States FTAs regards the adherence to the national treatment obligation. ${ }^{171}$ Generally speaking, the national treatment principle, as defined in the TRIPS Agreement, ${ }^{172}$ requires WTO Members to grant no less favourable treatment to foreign nationals than it accords to its own nationals with regard to the "protection" of intellectual property rights. Footnote 3 of the TRIPS Agreement defines the concept of "protection" in the TRIPS context. ${ }^{173}$ The same

See Article 1.3(e) of the draft IP chapter of the TPP of February 2011; Article 18.1.3(e) of the US-South Korea FTA; Article 14.1.2(c) of the US-Babrain FTA; Article 15.1.2(c) of the US-Morocco FTA and Article 17.1.2(c) of the US-Australia FTA. For other deviations from the general rule, see Kampf, "TRIPS and FTAs: A World of Preferential or Detrimental Relations”, p. 107-111.

Only the draft IP chapter of the TPP of February 2011 requires parties to ratify or accede to the Singapore Treaty by the date of entry into force of the TPP. See Article 1.3(h) of the draft IP chapter of the TPP of February 2011. The US-South Korea FTA demands its negotiating parties to make all reasonable efforts to ratify or accede to the treaty. See Article 18.1.4(c) of the US-South Korea FTA.

See Article 18.1.5 of the US-South Korea FTA; Article 14.1.4 of the US-Babrain FTA; Article 15.1.4 of the US-Morocco FTA; Article 17.1.1 of the US-Chile FTA and of the US-Australia FTA. The draft IP chapter of the TPP of February 2011 has preserved a section for this provision but has not filled it in yet. See Article 1.1 of the TRIPS Agreement. See section 1.1 of this book. See Article 18.1.6 of the US-South Korea FTA; Article 17.1.6 of the US-Australia FTA; Article 17.1.6 of the US-Chile FTA; Article 16.1.3 of the US-Singapore FTA. See Article 3.1 of the TRIPS Agreement.

173 Footnote 3 of the TRIPS Agreement reads as follows: "For the purposes of Articles 3 and 4, 'protection' shall include matters affecting the availability, acquisition, scope, maintenance and enforcement of intellectual property rights as well as those matters 
definition is also taken up in the FTAs, however with certain amendments. ${ }^{174}$ The FTA definition of "protection" also includes the prohibition on the circumvention of effective technological measures and rights management information, ${ }^{175}$ a matter not addressed by the TRIPS Agreement but on which US FTAs provide rules. It is in this respect that the national treatment obligation contained in the FTA goes beyond the TRIPS rule. The obligation to adhere to the national treatment principle is accompanied by certain exceptions. ${ }^{176}$ These are almost textually drawn from the TRIPS Agreement ${ }^{177}$ and deal with judicial and administrative procedures, and multilateral agreements concerning the acquisition or maintenance of intellectual property rights.

A last issue of a general nature is the inclusion of investment chapters into FTAs. Its rules are also relevant for intellectual property right holders since IP rights are protected as an asset of investment. Except for Jordan and Bahrain, ${ }^{178}$ all FTAs contain a chapter on investment. ${ }^{179}$ The issues dealt with in these chapters are not different from those stipulated in bilateral investment treaties concluded by the United States and have been discussed above. ${ }^{180}$ Two matters deserve further attention: first, all investment chapters exempt compulsory licenses that are in compliance with the TRIPS Agreement from the application of expropriation rules. ${ }^{181}$ Second, all agreements, except for the US-Australia FTA, establish an investor-state dispute settlement mechanism which co-exists with the regular state-to-state dispute settlement mechanism provided for in the FTA chapters on dispute settlement. ${ }^{182}$

affecting the use of intellectual property rights specifically addressed in this Agreement."

174 It is interesting to note that FTAs do not only refer to protection, but also to the "enjoyment" of such rights and "to any benefit derived from such rights". Arguably, this amended scope of protection does not expand the issues covered by protection. For a discussion of this matter see Roffe, Bilateral Agreements and a TRIPS-plus World: The Chile-US A Free Trade Agreement, p. 17. See footnote 2 of the draft IP chapter of the TPP of February 2011; footnote 2 of the US-Babrain FTA; footnote 4 of the US-Panama TPA, the US-Peru TPA and the USCAFTA-DR. See Article 18.1.7 and 18.1.8 of the US-South Korea FTA; Article 14.1.6 and 14.1.7 of the US-Babrain FTA; Article 16.1.9 and 16.1.10 of the US-Panama TPA; Article 15.1.9 and 15.1 .10 of the US-CAFTA-DR. See Articles 3.2 and 5 of the TRIPS Agreement.

178 These two countries have concluded BITs with the United States, which basically provide for the same rights and obligations as the chapters included in the FTAs. Also the TPP seems to contain an investment chapter, a draft of which was leaked on 13 June 2012. See "Press Release: Conroversial Trade Pact Text Leaked, Shows U.S. Trade Officials Have Agreed to Terms That Undermine Obama Domestic Agenda" Public Citizen (Washington), available at <http://citizen.typepad.com/eyesontrade/2012/06/controversial-trade-pact-text-leaked-shows-us-trade-officials-have-agreed-toterms-that-undermine-ob.html> accessed on 12.11.2012.

180 See section 3.1.2.1 on bilateral investment treaties.

181 See Article 12.12.5 of the draft IP chapter of the TPP of February 2011; Article 11.6.5 of the US-South Korea FTA; Article 10.7.5 of the US-Panama FTA, US-Colombia TPA, US-Peru TPA, US-CAFTA-DR; Article 10.6.5 of the US-Oman FTA and US-Morocco FTA; Article 10.9.5 of the US-Chile FTA; Article 15.6.5 of the US-Singapore FTA; Article 11.7 .5 of the US-Australia FTA.

182 See Section B, including Article 12.16bis until 12.29, of the draft IP chapter of the TPP of February 2011; Section B, including Article 11.15-11.27, of the US-South Korea FTA; 
Hence, investors can choose whether to pursue the direct investor-state mechanism or seek diplomatic protection of their home state before the state-to-state dispute settlement mechanism. By providing an additional set of rights to IP right holders by regarding them as investors, US FTAs introduce TRIPS-plus provisions.

To conclude, the four issues addressed above are general matters in US FTAs that go beyond the TRIPS standard. Contracting parties are required to a) ratify or accede to, or b) make best efforts to accede to a number of international agreements. Some agreements have been moved from the best effort section to the hard obligation section, and others were added newly to the lists. These obligations have become stricter and therefore more aggressive. Also the principle of more extensive protection without providing the TRIPS safeguard of freedom of implementation leaves contracting parties hardly any room to choose the appropriate method of implementing the FTA provisions in their own legal systems. Finally, covering technological protection measures and rights management information, as well as new rights stemming from the investment chapter, they impose additional obligations on contracting parties compared to the TRIPS Agreement which require resources specifically scarce in developing countries.

After having set out the most important general IP-related matters featured in United States FTAs, the analysis will now focus on the substantive TRIPS-plus provisions contained therein. These address a) provisions related to public health, b) provisions related to access to information in the digital environment, c) provisions related to trade marks and d) provisions relating to the protection of life forms. It is important to note that not all matters discussed under these titles concern individual intellectual property regimes but are also matters that interface with such intellectual property regimes. Examples of the latter are the regulations concerning the marketing of regulated products (interface with patent regime), the circumvention rules of technological protection measures (interface with copyright regime), the protection of programme-carrying signals transmitted by satellite (interface with copyright regime) and the management of domain names (interface with copyright and trade mark regime).

\subsubsection{Provisions Related to Public Health}

It is fair to say that the FTA provisions related to public health have been criticized most. The issues that these provisions deal with are far-reaching and have been analyzed in detail by different scholars. ${ }^{183}$ Five issues will be illustrated below: a) the protection of undisclosed information, b) the linkage between the drug registration and patent protection, c) the extension of the patent term for pharmaceutical and

Article 11.16 of the US-Australia FTA and the US-South Korea FTA; Article 10.16 of the US-Peru TPA, US-Colombia TPA, US-Panama TPA, US-CAFTA-DR; Article 10.15 of the US-Oman FTA; Article 15.15 of the US-Singapore FTA.

183 Abbott, The Doha Declaration on the TRIPS Agreement and Public Health; Sell, "TRIPS-plus Free Trade Agreements and Access to Medicines"; Morin, "Tripping up TRIPs debates: IP and Health in Bilateral Agreements"; Rossi, "Free Trade Agreements and TRIPS-plus Measures"; Fink and Reichenmiller, Tigbtening TRIPS; Mercurio, "TRIPSPlus Provisions in FTAs", p. 224-235; Pugatch, "The International Regulation of IPRs in a TRIPs and TRIPs-plus Worlds", p. 13-20; Kuanpoth, “TRIPS-Plus Rules under Free Trade Agreements", p. 32-41. 
chemical patents, d) restrictions on parallel imports and e) restrictions on compulsory licenses.

\subsubsection{The pProtection of Undisclosed Information}

Probably the most contentious requirement among the public health provisions is the protection of undisclosed information. United States FTAs drastically increase the protection of undisclosed information that is submitted by a patent applicant to a regulatory agency for marketing approval of his pharmaceutical product. The data exclusivity requirements have been described as

"another form of monopoly [...] [that is granted in United States FTAs] in ways the TRIPS Agreement does not require."'184

Consequently,

"brand name pharmaceutical companies, in effect, have acquired a new form of intellectual property right in their test data." 185

Data exclusivity provisions intend to protect the information submitted by a pharmaceutical company which proves the safety and efficacy of a new chemical entity (drug). This data is submitted to regulatory authorities and is kept undisclosed. The question arises in how far third parties, in particular generic pharmaceutical producers, can rely on that same data in order to apply for marketing approval for their generic version of the original pharmaceutical. Relying on that data submitted by the originator is essential for generic producers as it is very expensive to produce test data.

In order to protect the data of originators, the TRIPS Agreement requires in Article 39.3 that WTO Members must protect undisclosed test data on pharmaceutical products against unfair competition. The rationale behind this provision is the protection against unfair commercial use, not against any use by third parties. That is, however, how United States FTAs have interpreted this provision of the TRIPS Agreement. The core prohibition required by United States FTAs is that generic producers of new pharmaceutical products cannot rely on the undisclosed data submitted by the originator for a period of five years from the date of marketing approval in that country, unless the consent of the originator is given. ${ }^{186}$ In this prohibition, no reference is made to protecting the data against unfair commercial use; it rather introduces exclusivity for the originator for at least five years. This means, a Member that wishes to register a generic drug for public non-commercial use in clinics will not be able to rely on the data submitted by the originator, without his consent, for marketing approval during the five-year period of market exclusivity.

184 Abbott, The Doha Declaration on the TRIPS Agreement and Public Health, p. 7.

185 Sell, "TRIPS-plus Free Trade Agreements and Access to Medicines”, p. 60.

186 See Article 18.9.1(a) of the US-South Korea FTA; Article 15.10(1)(a) of the US-CAFTADR; Article 15.10.1 of the US-Morocco FTA; Article 14.9.1(a) of the US-Babrain FTA. Note that a provision on the same matter is foreseen in Article 9.2 of the draft IP chapter of the TPP of February 2011. However, it is not filled in yet. 
Another difference with the TRIPS Agreement is contained in the definition of "new pharmaceutical product" which is included in United States FTAs. That definition reads:

"A new product is one that does not contain a chemical entity that has been previously approved in the territory of the Party."187

This definition differs from the "new chemical product" in Article 39.3 of the TRIPS Agreement. According to US FTAs, a product that contains a chemical entity which has not yet been approved, but is actually quite old and well known, is still regarded as a new product and its undisclosed data must be protected. Article 39.3 of the TRIPS Agreement, in contrast, only requires that the undisclosed information of new chemical entities is protected; it does not specify whether a new chemical entity must be understood as one that has not yet been approved or that is genuinely new. The former interpretation allows covering more chemical entities under the concept of "new product" than the latter, and therefore is broader. By requiring the broader definition to apply to both negotiating partners, the FTA provision reduces the flexibility granted in the TRIPS Agreement to limit the protection of undisclosed information to a narrower range of new pharmaceutical products. Interestingly, the data exclusivity requirements are not contained in the latest FTAs concluded by the United States with Peru, Colombia and Panama. ${ }^{188}$ The provisions therein reflect the rationale of Article 39.3 of the TRIPS Agreement: they refer to unfair commercial use, require a "reasonable period of time" for protecting undisclosed information (instead of five years of data exclusivity) and contain the concept of "new chemical entity" instead of new pharmaceutical product (allowing for a narrow interpretation). ${ }^{189}$

In addition to the prohibition of the use of the data submitted for marketing approval in one country for five years, earlier US FTAs still contain another provision. ${ }^{190}$ Generic producers are also prohibited from relying on the data of a marketing approval procedure in another country for at least five years. ${ }^{191}$ This obligation implies that before a generic producer in country A can rely on the data submitted by the originator in country $\mathrm{B}$, the originator needs to request marketing approval in country A for his drug. US FTAs grant the originator a period of five

Article 15.10.1(c) of the US-CAFTA-DR. See for the same definition Article 18.9.1(c) of the US-South Korea FTA; Article 14.9.1(c) of the US-Babrain FTA; Article 17.10.1(d) of the US-Australia FTA. Note that a provision on the same matter is foreseen in Article 9.5 of the draft IP chapter of the TPP of February 2011. However, it is not filled in yet.

Note that the US-South Korea FTA constitutes an exception to the approach shown in the latest agreements. The obligations on data exclusivity are still the same as in earlier FTAs.

See Article 16.10.2 of the US-Peru TPA and the US-Colombia TPA; Article 15.10.2 of the US-Panama TPA.

190 These are the US-Babrain FTA, the US-CAFTA-DR, the US-Singapore FTA and the USMorocco FTA. Even though the US-Chile FTA sets out the previous obligations on data exclusivity, it does not contain the same prohibition for other countries. FTA; Article 15.10.1(b) of the US-CAFTA-DR; Article 16.8.2 of the US-Singapore FTA; Article 15.10 .1 of the US-Morocco FTA. 
years to do so. ${ }^{192}$ An originator can thus protect his undisclosed information for a maximum of ten years before generic producers in country A can use his information. In other words, the originator can make use of the full five year period of protection in country B before (s)he requests marketing approval in country A. Once this has been done, the originator still enjoys a five year period of data exclusivity in country A. The TRIPS Agreement does not recognize the protection of undisclosed information submitted for marketing approval in another country.

Next to protecting information on safety and efficacy required in the marketing approval, some United States FTAs also protect "new clinical information" that is required in order to receive marketing approval for the new use of a drug that has been previously approved for another use. ${ }^{193}$ Originators of such new clinical information can exclusively use this information for a period of three years. The same protection is also granted to new clinical information submitted in another territory. In total, the established protection adds up to the five years data exclusivity granted for the information on safety and efficacy first submitted and allows originators to receive another monopoly right on the data of a drug of which a new use was discovered. The TRIPS Agreement does not provide for such protection.

The relevant rule in the TRIPS Agreement, on which the different obligations in US FTAs are based, has been interpreted by US FTAs far beyond its actual meaning. These provisions clearly prolong the period in which generic producers of pharmaceutical products cannot receive marketing approval. Without competition from generic producers, patented originator drugs can be sold at high(er) prices due to their monopoly position. This extended period of market exclusivity leads to high(er), unaffordable drug prices for patients in developing countries for an even longer period of time.

\subsubsection{Linkage between Drug Registration and Patent Protection}

Related to the protection of undisclosed information is the issue concerning the linkage between the drug registration and patent protection. A link is created by making the marketing approval for a generic drug dependant on the expiry of the patent for the original drug. The TRIPS Agreement does not provide any rules on this linkage. United States FTAs require that state parties prevent the marketing of a generic drug that relies on the information on safety and efficacy submitted by the originator of the patented drug, unless the patent owner has given his consent. ${ }^{194}$ This provision effectively extends the term of data protection to the full term of a patent, rather than the five years referred to above. ${ }^{195}$ However, the difference with

See Article 15.10.1(b) of the US-CAFTA-DR; Article 16.8.2 of the US-Singapore FTA; Article 15.10 .1 of the US-Morocco FTA.

193 See Article 18.9.2(a)+(b) of the US-South Korea FTA; Article 14.9.2(a)+(b) of the USBabrain FTA; Article 17.10.2 of the US-Australia FTA; Article 15.10.2 of the US-Morocco FTA.

194 See Article 15.10.2(a) of the US-CAFTA-DR; Article 15.10.4(a) of the US-Morocco FTA; Article 16.8.4(c) of the US-Singapore FTA; Article 17.10.2(c) of the US-Chile FTA; Article 15.10.4 of the US-Panama TPA. Note that a provision on the same matter is foreseen in Article 9.3 of the draft IP chapter of the TPP of February 2011. However, it is not filled in yet.

See Abbott, The Doha Declaration on the TRIPS Agreement and Public Health, p. 8. 
the data exclusivity provision is that one can only get data protection for the full patent term if a patent is granted; the five years of data exclusivity is also granted to drugs that finally do not receive patent protection. An additional requirement is to notify the patent owner of the identity of the third party that requests marketing approval during the term of his patent. ${ }^{196}$

These provisions not only restrict the marketing of a generic drug during the term of a patent, they also restrict the use of compulsory licenses or government use. A drug can only receive marketing approval if the patent owner consents. In essence, although a compulsory license has been granted to the generic producer, (s)he will not be able to market the product on regulatory grounds, unless (s)he gathers her/his own test data. This is very expensive and almost prohibitive for generic producers.

\subsubsection{Extension of the Patent Term}

The third issue dealt with in the public health provisions of the IP chapters of United States FTAs is the extension of the patent term. The patent term recognized by the TRIPS Agreement lasts for twenty years. ${ }^{197}$ This is the nominal term of protection that foresees twenty years of protection regardless of delays in the patent examination procedure or the marketing approval procedure. ${ }^{198}$ United States FTAs, in contrast, require an effective term of protection that takes into account delays in these procedures. In fact, there are two possibilities for patent holders to receive a prolongation of the nominal patent term: 1) by receiving compensation for unreasonable delays in granting the patent, and 2) by receiving compensation for unreasonable curtailment as a result of the marketing approval procedure.

Concerning delays in the granting procedure, unreasonable delay is defined by some FTAs as a delay of four years from the date of filing of the application or two years after a request for examination has been made, whichever is later. ${ }^{199}$ Other FTAs have stipulated that unreasonable delays in the granting procedure are delays of more than five years from the filing date and three years after the request for examination was made. ${ }^{200}$ These rules specify under which conditions unreasonable delay exists

196 See Article 17.10.4(b) of the US-Australia FTA; Article 14.9.4(b) of the US-Babrain FTA; Article 4.23(b) of the US-Jordan FTA.

197 See Article 33 of the TRIPS Agreement.

198 Note that Article 62.2 of the TRIPS Agreement requires Members to ensure that these procedures permit the grant or approval within a reasonable period of time so as to avoid the unwarranted curtailment of the period of protection. The Article does not specify further what a reasonable period of time is and what compensation a patent holder should get in case of unwarranted curtailment.

See Article 14.7.6(a) of the US-Babrain FTA; Article 16.7.7 of the US-Singapore FTA; Article 15.9.7 of the US-Morocco FTA; Article 17.9.8(a) of the US-Australia FTA. Note that a provision on the same matter is foreseen in Article 9.4 of the draft IP chapter of the TPP of February 2011. However, it is not filled in yet.

200 See Article 15.9.6(a) of the US-CAFTA-DR; Article 17.9.6 of the US-Chile FTA. The most recently concluded FTAs between the United States and Panama, Peru and Colombia do not apply this compensation rule for pharmaceutical patents, see Article 15.9.6(b) of the US-Panama TPA; Article 16.9.6(b) of the US-Peru TPA and the USColombia TPA. However, the US-South Korea FTA does contain an almost identical rule, requiring compensation for a delay of more than four years from the filing date and 
which needs to be compensated; however, they do not define how much compensation needs to be granted to the patent applicant.

The second possibility of prolonging the term of a patent is through receiving compensation for unwarranted curtailment of the effective patent term as a result of the marketing approval procedure. ${ }^{201}$ It has not been further specified what an unwarranted curtailment is, neither how long the effective patent term is nor how much of the curtailment will be compensated. ${ }^{202}$

By prolonging the patent term, the monopoly that the original makers of a patented drug hold is also extended. Competitors and generic producers are therefore prohibited from producing, making, using, offering for sale, selling or importing that drug for an even longer period of time. The beneficial effects of competition on drug prices are therefore also postponed and leave citizens of developing countries even longer without affordable drugs.

\subsubsection{Prohibition of Parallel Importation}

The fourth public health issue dealt with in United States FTAs concerns the prohibition of parallel importation. The TRIPS Agreement refers to parallel importation of intellectual property goods indirectly by stating that nothing in the Agreement addresses the issue of the exhaustion of intellectual property rights. ${ }^{203} \mathrm{In}$ other words, WTO Members are free to adopt the exhaustion principle they prefer, be it the national exhaustion principle, therefore preventing parallel imports, or the principle of international exhaustion, which allows parallel imports to the country where, for example, a patent has been granted. Some United States FTAs do not leave this choice to Members but require that patent owners shall have the exclusive right to prevent the importation of the patented product; this right also shall not be limited by the sale or distribution of that product outside its territory. ${ }^{204}$ In other words, parallel importation of the patent product can be prevented by the patent owner and therefore amounts to the imposition of the national exhaustion regime. To sum up, by prohibiting parallel imports, it will not be possible for country A to allow imports of the same drug that have also been marketed in country B. Therefore, this prohibition prevents competitive prices and the affordability of essential medicines for citizens of developing countries.

three years after the request for examination was made, see Article 18.8.6 of the USSouth Korea FTA.

201 See Article 18.8.6(b) of the US-South Korea FTA; Article 15.10.3 of the US-Morocco FTA; Article 16.8.4(a) of the US-Singapore FTA; Article 4.23(a) of the US-Jordan FTA; Article 16.9.6(c) of the US-Peru TPA and the US-Colombia TPA.

202 Note that the latest FTAs specify that the compensation should be the restoration of the patent term or patent rights; see Article 18.8.6(b) of the US-South Korea FTA; Article 16.9.6(c) of the US-Peru TPA and the US-Colombia TPA.

203 See Article 6 of the TRIPS Agreement.

204 See Article 15.9.4 of the US-Morocco FTA; Article 17.9.4 of the US-Australia FTA. Article 16.7.2 of the US-Singapore FTA provides the same obligation in a slightly different form. 


\subsubsection{Restrictions on Compulsory Licensing}

The last issue discussed in the context of public health provisions in United States FTAs regards the restrictions on compulsory licensing. A compulsory license is an authorization that the government gives to a third party in order to use the patented invention without the consent of the patent holder. The TRIPS Agreement allows granting compulsory licenses under certain conditions specified in Article 31. United States FTAs restrict the use of compulsory licenses beyond these numerous conditions. They do so in two manners: first, the use of compulsory licenses is restricted by the linkage between drug registration and patent protection. Hence, a generic producer who has received a compulsory license still needs the consent of the originator in order to rely on the originator's test data for receiving marketing approval of his generic drug. ${ }^{205} \mathrm{~A}$ second and more direct restriction is the limitation of the grounds on which compulsory licenses can be issued. In contrast to the TRIPS Agreement, certain United States FTAs restrict the use of compulsory licenses to specified cases. ${ }^{206}$ The grounds on which these FTAs restrict the use of compulsory licenses are anti-competitive practice, public non-commercial use, national emergency, other circumstances of extreme urgency and the failure to meet working requirements. Article 31 of the TRIPS Agreement, however, does not contain an exhaustive list of grounds.

Other FTAs with Chile, Central American countries and the Dominican Republic, Bahrain, Morocco, Peru, Colombia, Panama, South Korea and the prospective TPP do not contain these restrictions. This seems to reflect the United States' deference to the Doha Declaration on the TRIPS Agreement and Public Health, which grants all WTO Members the right to determine for themselves the grounds upon which compulsory licenses can be granted. ${ }^{207}$ Compulsory licenses are an important exception with which the rights of a patent holder, as stipulated in Article 28 of the TRIPS Agreement, can be set aside for the promotion of a public interest. This exception is one of the most important tools for developing countries to fight their public health crisis. Generic producers are granted a license to produce and market a certain patented drug at lower prices. By restricting the grounds for granting compulsory licenses to an exhaustive list, a crucial flexibility, emphasized by the Doha Declaration on the TRIPS Agreement and Public Health, for developing countries is curtailed. The fact that the United States revised its FTA policy in this regard supports the interpretation that the earlier FTA provisions contradict the TRIPS Agreement as interpreted by the latter Declaration.

\subsubsection{Interim Conclusions}

The public health provisions in US FTAs have been criticized by many because of its effects on generic producers. They prolong the period in which generic producers of essential drugs cannot receive marketing approval, link drug registration to patent protection, prolong the patent term and limit the grounds on which compulsory licenses can be granted. These provisions prevent competitive drug pricing and the affordability of essential medicines for citizens of developing countries. From a legal

See section 3.2.4.2 of this book.

206 See Article 17.9.7 of the US-Australia FTA; Article 4.20 of the US-Jordan FTA; Article 16.7.6 of the US-Singapore FTA. 
perspective, the rules described go far beyond the TRIPS standard; in the case of restricting the grounds of compulsory licensing, they even contradict Article 31 of the TRIPS Agreement as interpreted by the Doha Declaration on the TRIPS Agreement and Public Health.

\subsubsection{Provisions Relating to the Access to Information in the Digital Environment}

The protection of works in the digital environment takes an important place in FTAs concluded by the United States. As mentioned above, the United States started to export its own legislation (the Digital Millennium Copyright Act) into its FTAs. ${ }^{208}$ The first time that DMCA-like provisions appeared in an FTA was in the US-Chile FTA. The provisions included therein still leave some room for implementation, whereas the provisions in the later FTAs have become more specific with almost no discretion left for interpretation. ${ }^{209}$ In the following, six issues will be discussed that go beyond the protection foreseen in the TRIPS Agreement and, in certain cases, even beyond the protection granted in the WIPO Copyright Treaty and the WIPO Performers and Phonograms Treaty. These issues concern a) the prohibition of temporary storage in electronic form, b) the extension of the copyright term, c) the prohibition of the circumvention of technological measures, d) the protection of digital rights management information, e) the protection of program carrying satellite signals, and f) the regulation of Internet domain names.

\subsubsection{Prohibition of Temporary Storage in Electronic Form}

The first and one of the most use-restrictive issues regards the prohibition of storing temporarily copyright data. The Berne Convention, and therefore the TRIPS Agreement, recognize the right of authors of literary and artistic works to authorize or prohibit all reproductions of their works in any form or manner. ${ }^{210}$ The WIPO Copyright Treaty, in connection with its Agreed Statement concerning Article 1.4 of the WCT, provides that the right of reproduction recognized in the Berne Convention

"fully appl[ies] in the digital environment [...]. It is understood that the storage of a protected work in digital form in an electronic medium constitutes a reproduction within the meaning of Article 9 of the Berne Convention."

The TRIPS Agreement, the Berne Convention and the WCT do not specify what types of storage in digital form fall under the reproduction of a protected work. In fact, during the negotiations of the WCT, the question whether "temporary storage" in electronic form, and therefore the temporary copies made in the RAM memory of a computer, would also be covered by the concept "storage" was discussed extensively, however not included into the final text. ${ }^{211}$ United States FTAs, in contrast, have included the

See section 3.2.1 of this book. The provisions exported from the DMCA regard the FTA provisions on the prohibition of the circumvention of technological measures and of the devices made for such circumvention, the liability of Internet service providers and the protection against satellite signal theft.

209 See Christie, Waller and Weatherall, 'Exporting the DMCA through Free Trade Agreements", p. 215.

$210 \quad$ See Article 9.1 of the Berne Convention.

211 See Roffe, Bilateral Agreements and a TRIPS-plus World: The Cbile-USA Free Trade Agreement, p. 27. 
temporary storage in the concept of reproduction of a protected work. ${ }^{212}$ A person that surfs the Internet and uses an Internet browser will breach the copyright of protected works posted online if the browser requires a few seconds of storage in the RAM memory. ${ }^{213}$ Copyright infringement, however, will only take place if the temporary reproduction cannot be justified.

The FTAs include the traditional "three-step test" 214 which provides for the possibility of justifying certain breaches of copyright through national exceptions. Accordingly, national exceptions have to meet three conditions: 1) they are confined to certain special cases, 2) they do not conflict with the normal exploitation of the work and 3) they do not unreasonably prejudice the legitimate interests of the right holder. ${ }^{215}$ Some FTAs also include footnotes in which exceptions for temporary reproductions 216 and exceptions recognized under the Berne Convention ${ }^{217}$ are given as examples for possible exceptions. Other agreements do not include such footnotes. However, in both cases, a contracting party first has to enact such exceptions (which meet the three-step test) into its national law before a citizen can invoke them. If a state has not done so, temporary storage will ultimately lead to a copyright infringement. Including the temporary storage in digital form under the concept of reproduction of a work does not only go beyond the TRIPS Agreement but also beyond the WIPO Copyright Treaty.

\subsubsection{Extension of the Copyright Term}

United States FTAs require its trading partners to protect copyright protection for the life of the author plus seventy years after his death. ${ }^{218}$ This is an increase of twenty years of copyright protection compared with the Berne Convention and therefore also the TRIPS Agreement which both require protection for the life of the author plus fifty years after his death. ${ }^{219}$ This TRIPS-plus provision reflects United States law which was changed in this respect in 1998. The increase of copyright protection in United States law was a result of an intense lobbying effort by a United States copyright owner group; of particular importance was the expiration of the Mickey Mouse character that was due in $2003 .{ }^{220}$ Increasing copyright protection by twenty years has significant effects for users of protected works: materials protected by

212 See Article 4.1 of the draft IP chapter of the TPP of February 2011; Article 18.4.1, including footnote 11, of the US-South Korea FTA; Article 15.5.1, including footnote 12, of the US-CAFTA-DR; Article 17.5.1 for copyright and Article 17.6.1 for related rights of the US-Chile FTA; Article 16.4.1, including footnote 17, of the US-Singapore FTA; Article 14.4.1 of the US-Babrain FTA; Article 15.5.1, including footnote 13, of the USPanama TPA.

See Kuanpoth, "TRIPS-Plus Rules under Free Trade Agreements”, p. 44.

See Article 13 of the TRIPS Agreement.

See footnote 11 of the US-South Korea FTA; Article 17.4.10(a) of the US-Australia FTA; Article 15.5.11(a) of the US-Morocco FTA; Article 16.7.8 of the US-Peru TPA.

See footnote 17 of the US-Cbile FTA; footnote 12 of the US-CAFTA-DR; footnote 17 of the US-Singapore FTA; footnote 13 of the US-Panama TPA.

See Articles 9.2, 10 and 10bis of the Berne Convention.

See Article 4.5(a) of the draft IP chapter of the TPP of February 2011; Article 18.4.4(a) of the US-South Korea FTA; Article 16.4.4(a) of the US-Singapore FTA; Article 15.5.4(a) of the US-CAFTA-DR; Article 15.4.5(a) of the US-Morocco FTA.

See Article 7.1 of the Berne Convention.

See Kuanpoth, “TRIPS-Plus Rules under Free Trade Agreements”, p. 42. 
copyright (including teaching materials) will enter the public domain twenty years later and therefore require additional royalty payments of a considerable amount.

\subsubsection{Prohibition of the Circumvention of Technological Measures}

The third issue discussed concerns the anti-circumvention provisions included in all FTAs since the US-Chile FTA. These rules deal with technological protection measures (TPMs), which must not be circumvented. TPMs are certain technologies or devices that control the access to and the copying of digital works, as defined in United States FTAs. In essence, the provisions require parties to

"provide adequate legal protection and effective legal remedies against the circumvention of effective technological measures $[\ldots]$ that restrict unauthorized acts." 221

While the TRIPS Agreement does not contain rules on that matter, the FTA obligations are very similar to those contained in Article 11 of the WCT and Article 18 of the WPPT. ${ }^{22}$ The provisions of the FTA, however, go beyond what is required in the WCT and WPPT in at least two ways. First, not only the circumvention of effective technological measures is prohibited, but also the manufacture or distribution of devices that can be used to circumvent these measures is not allowed. ${ }^{223}$ Second, US FTAs stipulate very detailed rules on how the provisions must be implemented and whether to apply civil or criminal sanctions to infringers. In particular, specific civil remedies are required in cases of infringement, and if the infringement is willful and for commercial purposes, criminal procedures and penalties must be applied, unless the infringer is a nonprofit library, archive, educational institution, or public non-commercial broadcasting entity.224

United States FTAs provide for limited exemptions for particular types of infringements, such as reverse engineering to achieve interoperability between computer programs, or the prevention of access by minors to inappropriate online content. ${ }^{225}$ However, even with these exceptions, the provisions on TPMs in US FTAs impede non-infringing and therefore lawful uses of works, such as private noncommercial use or use for teaching purposes.22 Also, the principle of "fair use" is narrowed down as users will have to pay for access to the information in any case, no

221 Article 15.5.7(a) of the US-CAFTA-DR. See also Article 5.9(a) of the draft IP chapter of the TPP of February 2011; Article 18.4.7(a) of the US-South Korea FTA; Article 16.7.4 of the US-Peru TPA; Article 17.4.7(a) of the US-Australia FTA.

222 See section 3.1.3.1 of this book.

223 See Article 4.9(a)(ii) of the draft IP chapter of the TPP of February 2011; Article 18.4.7(a)(ii) of the US-South Korea FTA; Article 15.4.8(a)(ii) of the US-Morocco FTA; Article 17.7.5(b) of the US-Chile FTA; Article 15.5.7(a)(ii) of the US-Panama TPA. See Article 4.9(a) of the draft IP chapter of the TPP of February 2011; Article 18.4.7(a) of the US-South Korea FTA; Article 15.5.7(a) of the US-Panama TPA; Article 14.4.7(a) of the US-Babrain FTA; Article 17.4.7(a) of the US-Australia FTA.

225 See Article 4.9(d) of the draft IP chapter of the TPP of February 2011; Article 18.4.7(d) of the US-South Korea FTA; Article 15.5.7(d) of the US-Panama TPA; Article 14.4.7(e) of the US-Babrain FTA; Article 17.4.7(e) of the US-Australia FTA.

226 See Roffe, Bilateral Agreements and a TRIPS-plus World: The Cbile-USA Free Trade Agreement, p. 33. 
matter what the user's purpose is. ${ }^{227}$ In addition, TPMs enable owners to control access to works that have fallen into the public domain and should therefore be freely accessible to consumers. ${ }^{228}$

\subsubsection{Protection of Digital Rights Management Information}

Digital rights management (DRM) information identifies the work and the author of a digital work. Its protection is already provided for in the WCT and WPPT. ${ }^{229}$ According to US FTAs, state parties are under an obligation to provide adequate and effective legal remedies to protect DRM information from being removed or altered. This rule is very similar to Article 12 of the WCT and Article 19 of the WPPT. However, US FTAs go beyond that obligation by requiring civil and criminal sanctions for prohibited acts that are done willfully and for commercial advantage. ${ }^{230}$ The TRIPS Agreement does not require the protection of DRM information.

\subsubsection{Protection of Programme-carrying Signals that are Transmitted by Satellite}

According to United States FTAs, all state parties must accede to the Brussels Convention 231 on the distribution of programme-carrying signals transmitted by satellite. ${ }^{232}$ According to this Convention, parties must take adequate measures to prevent the unauthorized distribution of programme-carrying signals transmitted by satellite. ${ }^{233}$ FTAs go beyond the level of protection set out in the Convention by requiring specific enforcement measures. First, the manufacture, modification or distribution of a device that can decode an encrypted programme-carrying satellite signal must be made a criminal offence. Second, the reception or further distribution of a signal, knowing that it has been decoded without authorization, must be made a criminal offence. Third, any person injured must be able to get civil remedies, including compensatory damages. ${ }^{234}$ The TRIPS Agreement does not provide any rules on these matters. Requiring specific enforcement procedures for these types of infringement, in particular criminal sanctions, goes far beyond the standard applied by the TRIPS Agreement for the imposition of criminal sanctions. ${ }^{235}$ Such requirements also contradict the TRIPS principle of not creating any obligation with respect to the distribution of resources as between enforcement of IP rights and the enforcement of law in general. ${ }^{236}$ These obligations de facto affect the capacity of parties to enforce their law in general as they are very resource intensive. Where

See Kuanpoth, “TRIPS-Plus Rules under Free Trade Agreements”, p. 43.

See ibid., p. 43.

See section 3.1.3.1 of this book.

See Article 4.10(a) of the draft IP chapter of the TPP of February 2011; Article 16.4.8(a) of the US-Singapore FTA; Article 17.7.6(a) of the US-Chile FTA; Article 15.5.9(a) of the US-Morocco FTA.

See footnote 160 of section 3.2 .3 of this book.

See section 3.2.3 of this book.

See Article 2.1 of the Brussels Convention.

See Article 7 of the draft IP chapter of the TPP of February 2011; Article 18.7 of the US-South Korea FTA; Article 16.8 of the US-Peru TPA; Article 15.8 of the US-CAFTADR; Article 16.6 of the US-Singapore FTA. Note that in the US-Chile FTA, a choice is left to the contracting parties to make the infringements referred to above a civil or criminal offence, see Article 17.8 of the US-Chile FTA.

See Article 61 of the TRIPS Agreement and section 3.2.8.7 of this book.

See Article 41.5 of the TRIPS Agreement. See also section 3.2.8.1 of this book. 
resources are scarce, states may not have any choice than to use them for the enforcement of these IP rights rather than for the enforcement of their law in general.

\subsubsection{Administration and Management of Domain Names}

United States FTAs contain rules on the administration and management of domain names; the TRIPS Agreement, on the other hand, does not deal with domain names at all. A domain name such as <www.tripsplus.org> consists of two parts which are separated by a dot: the main name that describes the page and a suffix which is also called Top Level Domain (TLD). TLDs exist in two forms: they can either be generic (gTLD), such as .com, .org, .net, or they can be country specific (ccTLDs), such as .us, .ca, .nl. The management of the ccTLDs is carried out by so-called local Network Information Centers, under the supervision of the Internet Cooperation of Assigned Names and Numbers (ICANN). There are mainly two obligations in United States FTAs that these local Network Information Centers need to comply with.

First, the management of the ccTLDs must provide for appropriate procedures for the settlement of disputes based on the principles established in the Uniform DomainName Dispute-Resolution Policy ${ }^{237}$ (UDRP). ${ }^{238}$ UDRP presents a set of rules that were established by ICANN. The obligation in US FTAs does not require parties to apply the specific rules of UDRP which elaborate when, where and how complaints should be made. It rather obliges parties to apply the principles of UDRP. It has been argued that this obligation includes the conditions under which administrative proceedings must be made available and what kind of remedies should be available. ${ }^{239}$ Hence, FTAs leave discretion to the parties as to whether to apply either UDRP itself or a local dispute resolution policy which is based on the UDRP-principles. ${ }^{240}$ In any case, establishing one of the dispute resolution policies is costly, knowledge- and timeconsuming. Such resources are notoriously scarce in developing countries.

Second, state parties to US FTAs are required to make an online public database available which is reliable and accurate and contains the contact information of domain-name registrants. ${ }^{241}$ This requirement prompts the question as to how the personal data contained therein is protected. Only the FTAs with Chile and CAFTA stipulate that the personal data is to be protected in accordance with each party's

237 See ICANN, Uniform Domain-Name Dispute-Resolution Policy (adopted on 24 August 1999, accepted on 26 October 1999), available at <http://www.icann.org/en/help/dndr/udrp/policy> accessed on 28.06.2012.

See Article 3.1 of the draft IP chapter of the TPP of February 2011; Article 18.3.1 of the US-South Korea FTA; Article 15.4.1 of the US-Panama TPA; Article 14.3.1 of the US-Babrain FTA; Article 17.3.1 of the US-Australia FTA. See Roffe, Bilateral Agreements and a TRIPS-plus World: The Chile-USA Free Trade Agreement, p. 36.

240 While all FTAs leave this option, the US-Singapore FTA requires the parties to participate in the ICANN and makes participation in UDRP mandatory. See Article 16.3.1 of the US-Singapore FTA.

241 See Article 3.2 of the draft IP chapter of the TPP of February 2011; Article 18.3.2 of the US-South Korea FTA; Article 15.4.2 of the US-CAFTA-DR and the US-Morocco FTA; Article 17.3.2 of the US-Chile FTA; Article 16.3.2 of the US-Singapore FTA. 
laws; ${ }^{242}$ other FTAs concluded by the United States do not address the protection of personal data at all. Requiring the setting up of a database that contains private information without stipulating privacy provisions does not take into account the situation in some developing countries where consumer protection and privacy laws are not as developed as in industrialized countries.

\subsubsection{Interim Conclusions}

The IP provisions contained in US FTAs that affect access to digital works also contain aggressive features. They have become stricter and more specific with time and do not take into account the situation in (developing) country partners. The protection of technological protection measures, digital rights management information and the protection against satellite signal theft have been added to the obligations in US FTAs in 2003. They strongly affect access to digital works. The provisions on TPMs in US FTAs impede non-infringing and therefore lawful uses of works, such as private non-commercial use or use for teaching purposes. Requiring specific enforcement procedures for RMI infringements and satellite theft de facto affects the capacity of parties to enforce their other laws. Where resources are scarce, states may not have any other choice than to use them for the very resource-intensive enforcement procedures required for these IP rights rather than for the enforcement of their law in general. Also the establishment of resolution policies for domain name disputes is costly, knowledge- and time-consuming. The same is true for the setting up of a database that contains private information on domain name registrants. Moreover, the lack of privacy provisions for these databases does not take into account the situation in some developing countries where consumer protection and privacy laws are rather weak.

\subsubsection{Provisions Relating to Trade Marks}

The provisions relating to public health and to access to information in the digital environment are by far the most important and relevant parts of the free trade agreements concluded by the United States. It is in those parts that the most controversial TRIPS-plus provisions can be found. Nevertheless, some additional issues are included in the FTAs that potentially are of a TRIPS-plus nature. With regard to the protection of trade marks, four provisions are relevant: a) the expansion of types of marks that must be eligible for trade mark registration, b) strengthened protection of well-known marks, c) extension of the period of trade mark registration, and d) further restrictions on the prohibition to unjustifiably encumber trade marks through special requirements.

\subsubsection{Eligible Types of Marks for Registration}

To start with, FTAs concluded by the United States require parties to make available trade mark protection for collective, certification, sound and scent marks, and geographical indications. In some agreements, the protection of scent marks and geographical indications is not mandatory, ${ }^{243}$ while in most other agreements all agreements constitute that the protection of personal data is left to each Party's law. 15.2.1 of the US-CAFTA-DR; Article 15.2.1 of the US-Panama TPA. 
subject matters mentioned must be made eligible for trade mark protection. ${ }^{244}$ In order for a geographical indication to enjoy trade mark protection, it must consist of a sign that is capable of identifying a good or service as originating in the territory of a party. ${ }^{245}$ These provisions in FTAs concluded by the United States go beyond the TRIPS Agreement in three aspects.

First, the IP chapter of US FTAs makes the protection of certification marks mandatory, which is not required in the TRIPS Agreement. ${ }^{246}$ Second, FTAs concluded by the United States oblige countries to grant trade mark protection to sounds and scents, with the exception of some FTAs. ${ }^{247}$ Article 15.1 of the TRIPS Agreement provides a broad definition of the protectable subject matter; however, it does not include scents and sounds explicitly. As Article 15.1 does not constitute an exhaustive list, it might cover scents and sounds. Indeed, a number of countries have chosen to accept these subject matters as trade marks; this decision should however be made by each country domestically, rather than through an international agreement. Third, many FTAs oblige parties to protect geographical indications as trade marks. The TRIPS Agreement does not contain such an obligation and allows for the protection of geographical indications under a sui generis system. By requiring trade mark law to apply to geographical indications, the FTAs go beyond the standard contained in the TRIPS Agreement.

The latter obligation can create a legal conflict for a contracting partner that also has concluded or decides to conclude a bilateral trade agreement with the European Union. In contrast to providing protection of geographical indications through trade mark law, the European Union obliges its trade partners to establish a sui generis system of protection. ${ }^{248}$ In order to comply with the obligations from both agreements, they would have to establish two systems of protecting GIs, an effort that is costly and highly unpractical.

\subsubsection{Well-known Marks}

US FTAs grant specific protection to well-known marks. Well-known marks of goods are protected under Article 6bis of the Paris Convention. According to this Article, state parties must refuse the registration of a trade mark or prohibit its use if it is liable to create confusion with a mark that is considered to be well known and

$244 \quad$ See Article 2.1 and 2.2 of the draft IP chapter of the TPP of February 2011; Article 18.2.1 and 18.2.2 of the US-South Korea FTA; Article 17.2.1 and 17.2.2 of the USAustralia FTA; Article 14.2.1 and 14.2.2 of the US-Babrain FTA; Article 16.2.1 and 16.2.2 of the US-Peru TPA. Note that the US-Morocco FTA provides for a separate subchapter on the protection of geographical indications and does not require that geographical indications must be eligible for trade mark protection. See Article 15.3 of the US-Morocco FTA.

245 See footnote 4 of the draft IP chapter of the TPP of February 2011; footnote 5 of the US-South Korea FTA; footnote 3 of the US-Chile FTA; footnote 17-5 of the USAustralia FTA; Article 15.2.1 of the US-Panama TPA.

246 See Roffe, Bilateral Agreements and a TRIPS-plus World: The Chile-USA Free Trade Agreement, p. 37.

247 See footnote 243 of section 3.2.6.1 of this book.

248 See section 3.3.6 and section 5.3.2.3 on the obligations in the CARIFORUM-EC EPA and section 6.3 .3 on the obligations in the draft chapter of the India-EU BTLA. 
that is used for identical or similar goods. The TRIPS Agreement expands this protection to 1) trade marks for services that are similar or identical, and 2) to goods and services that are not similar to those in respect of which a trade mark is registered. ${ }^{249}$ The free trade agreements concluded by the United States take this protection even further in two aspects: first, the FTAs require that protection is also granted to non-registered well-known marks. ${ }^{250}$ Hence, a larger number of wellknown marks can benefit from this protection.

The second issue concerns the determination of what a well-known trade mark is. The TRIPS Agreement specifies that Members, when determining whether a trade mark is well known, shall take into account the knowledge of the trade mark in the relevant sector of the public. ${ }^{251}$ United States FTAs specify this obligation by defining the concept of "sector of the public" precisely: state parties may not require that the reputation of the trade mark must extend beyond the sector of the public that normally deals with the relevant goods or services. ${ }^{252}$ Such an interpretation has the effect that more trade marks can benefit from the protection granted to well-known marks and therefore increasing the protection available to right holders. Interpreting a concept of the TRIPS Agreement in a particular way limits FTA partners' discretion as to how to implement the TRIPS Agreement.

\subsubsection{Period of Trade Mark Protection}

Article 18 of the TRIPS Agreement provides that the initial registration and each renewal of that registration shall be for a term of no less than seven years. The more recent FTAs, since the United States FTA with Australia, require this period to be no less than ten years. ${ }^{253}$ This obligation clearly is of a TRIPS-plus nature as it extends the mandatory minimum period of protection by three years.

\subsubsection{Special Requirements}

A fourth and last provision discussed concerns the prohibition to unjustifiably encumber the use of a trade mark through special requirements. Article 20 of the TRIPS Agreement, in this respect, is intended to prohibit the use of national measures that require a special form or use of the trade mark if this special form would be detrimental to the trade mark's capability of distinguishing its goods or services from those of other undertakings. United States FTAs elaborate this provision to apply to national measures mandating the use of a common name that is customary in

See Articles 16.2 and 16.3 of the TRIPS Agreement.

See Article 2.7 of the draft IP chapter of the TPP of February 2011; Article 18.2.6 of the US-South Korea FTA; Article 4.8 of the US-Jordan FTA; Article 17.2.6 of the USAustralia FTA; Article 16.2.6 of the US-Peru TPA.

See Article 16.2 of the TRIPS Agreement.

See Article 2.7, footnote 5 of the draft IP chapter of the TPP of February 2011; Article 18.2.7, footnote 6, of the US-South Korea FTA; Article 17.2.8 of the US-Chile FTA; Article 14.2.6, footnote 5 of the US-Babrain FTA; Article 15.2.6, footnote 4 of the USMorocco FTA.

See Article 2.12 of the draft IP chapter of the TPP of February 2011; Article 18.2.12 of the US-South Korea FTA; Article 17.2.9 of the US-Australia FTA; Article 15.2.10 of the US-Morocco FTA; Article 15.2.9 of the US-CAFTA-DR and the US-Panama TPA; Article 14.2.10 of the US-Babrain FTA; Article 16.2.11 of the US-Peru TPA. 
common language. ${ }^{254}$ This is particularly relevant for pharmaceutical products that usually carry a brand name and the name of the active ingredient. Most countries require pharmaceutical companies that hold a trade mark on a drug, to also put the common name of the drug, which is the name of the generic substance, on the package. In this respect, FTAs oblige state parties to ensure that such requirements

"do not impair the use or effectiveness of a trade mark used in relation to such products." 255

While the US-Singapore FTA 256 states in a footnote that "this provision is not intended to affect the use of common names of pharmaceutical products in prescribing medicine", ${ }^{257}$ none of the other United States FTAs examined includes this caveat. The obligation to ensure that such measures do not impair the effectiveness of a trade mark narrows down Article 20 of the TRIPS Agreement to a very specific issue and thereby insinuates that such a measure may be a case that Article 20 intends to prevent.

\subsubsection{Interim Conclusions}

The protection granted to trade marks in US FTAs has developed into ever more right holder friendly regulations. Not only has the scope of eligible subject matters been broadened to include sounds, scents and geographical indications, the protection for well-known trade marks and the term of protection also provide right holders with additional rights. Even though the effects of stronger trade mark protection may not have severe effects on (developing) partner countries, they require law amendments and training for employees of the registry and judges, all of which cost time, money and human resources, which cannot be used for other public interest purposes.

\subsubsection{Provisions Relating to the Protection of Life Forms}

Another very important obligation, which US FTAs provide for, concerns the protection of plants and animals. Offering patent protection for technical or mechanical inventions is a very obvious thing to do; doing so in other fields of science, such as chemistry and biotechnology, has also become ever more common. However, during the last decades, a lively debate has been going on in many countries as to whether one should be able to patent life forms, such as plants or animals. The TRIPS Agreement allows WTO Members to exclude plants and animals from the list of eligible subject matters for patent protection, together with a number of other exceptions. ${ }^{258}$ Hence, WTO Members can decide domestically whether they prefer plants and animals to be non-patentable, or whether patent protection should

254 See Article 2.3 of the draft IP chapter of the TPP of February 2011; Article 18.2.4 of the US-South Korea FTA; Article 15.2.3 of the US-Morocco FTA; Article 16.2.6 of the US-Singapore FTA; Article 15.2.2 of the US-Panama TPA.

255 Article 14.2.3 of the US-Babrain FTA. See also Article 16.2.6 of the US-Singapore FTA; Article 16.2.3 of the US-Peru TPA.

256 United States - Singapore Free Trade Agreement, signed on 6 May 2003, entered into force on 1 January 2004, 42 I.L.M. 1026 (2003) [hereinafter US-Singapore FTA].

257 Footnote 16-7 of the US-Singapore FTA.

258 See Article 27.3(b) of the TRIPS Agreement. Other exceptions can be found in Article 27.2 and 3(a) of the TRIPS Agreement. 
be available for all fields of science, including inventions concerning life forms. Free trade agreements concluded by the United States take this option away from state parties, 1) by explicitly requiring patent protection for plants and animals, ${ }^{259} 2$ ) by requesting that reasonable efforts are undertaken to provide patent protection for plants, ${ }^{260}$ or 3) by not explicitly providing for the possibility of exempting plants and animals from patent protection. ${ }^{261}$

Where an exemption for plants and animals from patent protection is absent from US FTAs, it could be argued that the list of exemptions incorporated in the FTAs is non-exhaustive and therefore allows for other exemptions, such as those provided for in the TRIPS Agreement, to also be applied in the FTA context because both negotiating parties are also WTO Members. ${ }^{262}$ Such an exemption for plants and animals is reflected in Article 27.3(b) of the TRIPS Agreement. However, the USAustralia FTA provision seems to limit the exemptions available in the chapeau by stating that

"Each Party may only exclude from patentability:

$[\ldots] ;$ and

$[\ldots]]^{\prime 263}[$ emphasis added]

To conclude, all three options contained in US FTAs, except for the US-Jordan FTA, go beyond the TRIPS Agreement since state parties' flexibilities guaranteed by the TRIPS Agreement are taken away from them. Even the soft obligation to make best efforts and the absence of the relevant exemption create obligations not incorporated in the TRIPS Agreement. Patent protection for plants or animals touches upon moral questions and should be answered by each country in accordance with its preferences. Prescribing this choice for negotiating partners constitutes an aggressive feature of US FTAs.

\subsubsection{Enforcement Provisions}

The IP enforcement provisions in the free trade agreements signed by the United States are extremely detailed and present an essential part of the IP chapter. They incorporate stronger rules compared to the enforcement standards in the TRIPS Agreement and even compared to ACTA on various issues. The characteristics of these

See Article 8.2(a) of the draft IP chapter of the TPP of February 2011 and Article 15.9.2 of the US-Morocco FTA. Article 14.8.2 of the US-Babrain FTA requires that patent protection is made available for plant inventions, leaving out animals from this obligation.

See Article 15.9.2 of the US-CAFTA-DR and of the US-Panama TPA; Article 17.9.2 of the US-Chile FTA; Article 16.9.2 of the US-Peru TPA. See Article 18.8.2 of the US-South Korea FTA; Article 16.7.1 of the US-Singapore FTA; Article 4.18 of the US-Jordan FTA; Article 17.9.2 of the US-Australia FTA. This seems to be the case for Article 4.18 of the US-Jordan FTA, which does not limit the possible exemptions to those listed.

263 See Article 17.9.2 of the US-Australia FTA. Also provision 16.7.1 of the US-Singapore FTA limits the exemptions available to only those defined in Articles 27.2 and 27.3(a) of the TRIPS Agreement. 
provisions are yet another example of the aggressive approach followed by the United States as concerns the IP provisions included in its FTAs. If a partner country does not yet provide for the same enforcement rules, it will need to dedicate more financial and human resources to securing a high level of enforcement. These resources are particularly scarce in developing countries. Increased enforcement standards therefore pose real problems to developing countries.

Some of the most important issues are included in the a) general provisions, b) civil and administrative procedures, c) border measures, d) criminal procedures and remedies, and e) limitations on the liability of Internet service providers. A common feature of these provisions is that many discretionary remedies under the TRIPS Agreement are made obligatory through the FTAs and therefore constitute TRIPSplus, and in various cases even ACTA-plus, provisions. They are also more detailed and precise, which on the one hand provides clarity and on the other hand eliminates flexibility for choosing a less restrictive or cost-intensive enforcement procedure.

\subsubsection{General Provisions}

There are four general provisions that go beyond the standard agreed upon in the TRIPS Agreement. To start with, United States free trade agreements limit the flexibility of countries to dedicate resources to the institutions they choose. WTO Members enjoy this flexibility under Article 41.5 of the TRIPS Agreement, accordingly, they are under no obligation to put in place a judicial system for the enforcement IP rights distinct from that for the enforcement of law in general. While only some free trade agreements repeat this principle literally, ${ }^{264}$ the vast majority requires that the distribution of resources cannot be used as an excuse for non-compliance with the provisions on enforcement of the FTA. ${ }^{265}$ In fact, even if the institutional flexibility principle is recognized by the FTA, it could not be invoked to justify a noncompliance with the FTA enforcement standards since the specific rule, which eliminates the distribution of resources as an excuse for non-compliance, prevails. The latter rule constitutes a TRIPS-plus provision.

A second general issue regards the omission of some general principles that are included in the TRIPS Agreement but do not appear in any of the United States FTAs. According to Article 41.2 of the TRIPS Agreement, enforcement procedures need to reflect the principles of fairness and equitability. Articles 41.1, 48.1, 50.3 and 53.1 of the TRIPS Agreement require respect for the principles of protection against abuse and the proportionality of the measure in light of the seriousness of the infringement. Omitting such principles while elaborating in detail specific enforcement obligations seems to be unbalanced and limits the safeguards incorporated into the TRIPS Agreement.

Third, United States FTAs impose additional requirements on the form and content of judicial decisions. Article 41.3 of the TRIPS Agreement stipulates the following

264 See Article 16.9.4 of the US-Singapore FTA; Article 15.11.3 of the US-Morocco FTA; Article 14.10 .3 of the US-Babrain FTA.

265 See Article 17.11.2 of the US-Cbile FTA; Article 15.11.2 of the US-CAFTA-DR; Article 16.11.4 of the US-Peru TPA; Article 15.11.2 of the US-Panama TPA. Note that the USAustralia FTA and the US-Jordan FTA do not include this provision. 
requirements with regard to form and content of decisions on the merits: they shall be in writing, reasoned and at least made available to the parties to the proceeding without undue delay. United States FTAs repeat the first two requirements and add two other requirements: the decision must state the relevant facts and reasoning or the legal basis on which the decisions are based and must be published or made publicly available. ${ }^{266}$ These additional requirements go beyond the standard contained in the TRIPS Agreement and create additional costs. While the TRIPS Agreement requires all decisions on the merits to comply with the above mentioned requirements, United States FTAs only require this for final decisions.

Fourth, also the scope of persons that are entitled to claim certain rights are expanded by United States FTAs compared to the TRIPS Agreement. According to US FTAs, entitled applicants can be 1) licensees, 2) federations and 3) associations. There is a slight difference in the wording of some US FTAs as to the type of licensee at issue: for example the US-Chile FTA specifies that the term "right holder" covers "duly authorized licensees", ${ }^{267}$ whereas the US-South Korea FTA and the draft IP chapter of the TPP of February 2011 limit the availability of rights to exclusive licensees. ${ }^{268}$ The TRIPS Agreement, on the other hand, only refers to federations and associations and does not mention licensees at all. ${ }^{269}$

In brief, the general provisions referred to are 1) costly for negotiating partners to put into effect and 2) right holder-friendly. Taking away the TRIPS safeguard of not creating an obligation as to the distribution of resources potentially requires contracting parties to invest time, money and human resources into adequate enforcement procedures, as required in the remainder of the chapter, if not yet in place. Also the additional requirements on the content of final judicial decisions require increased resources that have to be spent on the IP enforcement system. As to the omission of the procedural principles stipulated in the TRIPS Agreement and the broadened scope of entitled applicants, US FTAs appear to be unbalanced in favour of right holders' interests and against procedural safeguards. These are aggressive features. After having presented four matters of a general nature, four issues of civil and administrative enforcement procedures are also analyzed below. These are a) the right of information, b) provisional measures, c) corrective measures, and d) damages. These civil enforcement measures are followed by three other types of enforcement matters, namely e) border measures, f) criminal procedures and remedies and g) limitations on the liability of Internet service providers

See Article 11.1 of the draft IP chapter of the TPP of February 2011; Article 15.11.3 of the US-CAFTA-DR; Article 15.11.1 of the US-Morocco FTA; Article 17.11.2 of the USAustralia FTA; Article 14.10.1 of the US-Babrain FTA; Article 16.11.2 of the US-Peru TPA. Note that the US-Singapore FTA does not require relevant facts to be stated, see Article 16.9.1 and 16.9.2 of the US-Singapore FTA. The US-Chile FTA adheres to the requirements of the TRIPS Agreement and does not go beyond this, see Article 17.11.1 and 17.11.3. See Article 17.11.7, including footnote 19, of the US-Chile FTA. See Article 12.2, including footnote 17 of the draft IP chapter of the TPP of February 2011; Article 18.10.3, including footnote 27 of the US-South Korea FTA. ACTA is identical to the TRIPS standard. 


\subsubsection{Right of Information}

In judicial proceedings, national authorities are able to order the infringer to provide information on the persons involved in the infringement and the distribution channels. The right of information, as contained in US FTAs, goes beyond the equivalent TRIPS standard in three aspects. First, US FTAs expand the scope of information that can be required by competent authorities. According to Article 47 of the TRIPS Agreement, the authorities may order the infringer to inform the right holder of the identity of third persons involved in the production and distribution of infringing goods or services and their channels of distribution. US FTAs, on the other hand, demand information regarding

"any persons or entities involved in any aspect of the infringement and regarding the means of production or distribution channel of such goods or services" 270 [emphasis added].

This FTA provision contains much broader language which can be interpreted to expand the right of information to more issues than the relevant TRIPS provision.

Second, US FTAs put parties under an obligation to grant this power to their competent authorities. Article 47 of the TRIPS Agreement leaves it to WTO Members to decide whether they want to grant this power or not. ${ }^{271}$ Third, the TRIPS Agreement has inserted a proportionality test: only if the exercise of such power is in proportion to the seriousness of the infringement, the authorities can order the infringer to provide the relevant information. ${ }^{272}$ US FTAs do not provide for a similar test. It is not clear whether the proportionality test required by the TRIPS Agreement is a mandatory requirement as soon as WTO Members choose to provide their authorities with this power. In that case, the absence of the test in US FTAs does not limit WTO Members' ability to provide for such a test. The recently drafted Article 11 of ACTA has built in a number of caveats that need to be respected, such as taking into account laws governing privilege, the protection of confidentiality of information sources and personal data. However, a similar proportionality test to that contained in Article 47 of the TRIPS Agreement is absent. To conclude, the obligation on providing information in US FTAs is very right holder-friendly and provides little safeguards for the infringer.

\subsubsection{Provisional Measures}

An important issue dealt with in the civil enforcement section of US FTAs are provisional measures. They are an essential tool of national authorities to avoid that irreparable harm is caused to the right holder or that evidence is destroyed. ${ }^{273}$ In order to do so efficiently, the TRIPS Agreement provides for the possibility of adopting provisional measures without having heard the other party (inaudita altera

\footnotetext{
270 Article 12.8 of the draft IP chapter of the TPP of February 2011. See for almost identical wording Article 18.10.10 of the US-South Korea FTA; Article 15.11.12 of the US-Panama TPA.

271 See Article 12.8 of the draft IP chapter of the TPP of February 2011; Article 18.10.10 of the US-South Korea FTA; Article 17.11.13 of the US-Chile FTA.

272 See Article 47 of the TRIPS Agreement.

273 See Article 50.2 of the TRIPS Agreement.
} 
parte). This being an exception to the general rule of providing each party with an opportunity to present their claims, ${ }^{274}$ the TRIPS Agreement requires certain safeguards, such as a test of proportionality, the obligations that parties are given notice without delay and that a review mechanism is put in place. ${ }^{275}$ US FTAs do away with these safeguards and merely require that requests for provisional relief inaudita altera parte must be acted upon expeditiously. ${ }^{276}$ Some agreements even specify that generally these requests shall be executed within ten days. ${ }^{277}$ Eliminating procedural safeguards is an important characteristic of the aggressive approach of the IP chapter in US FTAs.

One type of provisional measure that has received particular attention in US FTAs is the seizure of suspected or alleged infringing goods.

\begin{abstract}
"In civil judicial proceedings concerning copyright or related rights infringement and trademark counterfeiting, each Party shall provide that its judicial authorities shall have the authority to order the seizure of alleged infringing goods, materials, and implements relevant to the act of infringement, and, at least for trademark counterfeiting, also documentary evidence relevant to the infringement."'278
\end{abstract}

The TRIPS Agreement does not allow seizures of goods in civil judicial proceedings at all. ${ }^{279}$ Seizing goods is a far reaching competence for which states should determine for themselves in which cases and under which circumstances it should be available.

\title{
3.2.8.4. Corrective Measures
}

While provisional measures are applied on goods that are suspected of infringing an intellectual property right, corrective measures prescribe the remedies available for goods that have been found to be pirated or counterfeit. The TRIPS Agreement sets out two options: first, such goods must be disposed of outside the channels of commerce, or second, they must be destroyed. 280 The second option of destruction may not be contrary to existing constitutional requirements and needs to be in proportion with the seriousness of the infringement, as well as the interests of third

See Article 42.1 of the TRIPS Agreement.

See Article 50.2 and 50.4 of the TRIPS Agreement.

See Article 13.1 of the draft IP chapter of the TPP of February 2011; Article 18.10.17 of the US-South Korea FTA; Article 14.10.17 of the US-Babrain FTA; Article 15.11.17 of the US-Morocco FTA. Note that Article 17.11 .15 of the US-Chile FTA and Article 15.11.17 of the US-Panama TPA set out that the judicial procedural rules of the party must be respected. However, no agreement specifies for which situations such measures are available.

See Article 13.1 of the draft IP chapter of the TPP of February 2011; Article 14.10.17 of the US-Babrain FTA; Article 15.11.17 of the US-Morocco FTA.

Article 18.10 .8 of the US-South Korea FTA. See also Article 12.6 of the draft IP chapter of the TPP of February 2011. Similarly, Article 17.11.11 of the US-Chile FTA requires the seizure of "suspected infringing goods", without including documentary evidence in the list of possible items that can be seized.

See Article 61 of the TRIPS Agreement.

See Article 46 of the TRIPS Agreement. 
parties. US FTAs, in contrast, require the destruction of such goods as the first and only option, without specific requirements. ${ }^{281}$

Another difference between US FTAs and the TRIPS Agreement regards the question of who takes the decision as to whether such remedies are applied. Article 46 of the TRIPS Agreement makes clear that judicial authorities shall determine the remedy. US FTAs, on the other hand, stipulate that it is at the right holder's request that these goods shall be destroyed. ${ }^{282}$ Also Article 10.1 of the ACTA allows for the right holders to request such measures.

As regards the materials and implements used in the manufacture or creation of infringing goods, US FTAs require their destruction but also create another option for exceptional cases: goods may also be disposed of outside channels of commerce. ${ }^{283}$ This rule goes beyond the TRIPS standard: Article 46 of the TRIPS Agreement only requires the disposal of goods outside the channels of commerce (not destruction) and limits this authority to materials that have been used predominantly in the creation of the infringing goods. US FTAs do not limit the scope of materials for which the corrective measures are available and do not provide for the proportionality principle that is foreseen in Article 46 of the TRIPS Agreement. In this, the relevant ACTA rule essentially follows US practice. ${ }^{284}$ To sum up, US FTAs always choose as a first (and in one case also only) remedy the destruction of goods and materials and implements, without providing for procedural safeguards or proportionality concerns.

\subsubsection{Damages}

A last issue addressed in US FTAs on civil and administrative procedures regards damages. Judicial authorities have the power to award damages to the applicant, in addition to the available remedies. According to the TRIPS Agreement, the payment of adequate damages to compensate for the injury the right holder has suffered can be ordered by judicial authorities in the case that an infringer "knowingly, or with reasonable ground to know, engaged in infringing activity." 285 United States FTAs, however, do not qualify the types of the infringement for which the payment of damages can be ordered; rather, competent authorities can impose the payment of damages in any cases of infringement, including innocent infringement. ${ }^{286}$ United

281 See Article 12.7(a) of the draft IP chapter of the TPP of February 2011; Article 18.10.9(a) of the US-South Korea FTA; Article 17.11.12(a) of the US-Cbile FTA.

282 See Article 12.7(a) of the draft IP chapter of the TPP of February 2011; Article 18.10.9(a) of the US-South Korea FTA; Article 15.11.10(a) of the US-Morocco FTA; Article 17.11.10(a) of the US-Australia FTA. Note that Article 15.11.11(a) of the USCAFTA-DR and Article 17.11.12(a) of the US-Chile FTA follow the TRIPS standard by granting the authority to order such measures to the judicial authorities.

283 See Article 12.7(b) of the draft IP chapter of the TPP of February 2011, Article 14.10.10(b) of the US-Babrain FTA, Article 15.10.11(b) of the US-Morocco FTA and Article 15.11.11(b) of the US-Panama TPA and the US-CAFTA-DR. Note that Article 18.10.9(b) of the US-South Korea FTA and Article 17.11.12(c) of the US-Cbile FTA do not provide for the option of disposal outside the channels of commerce.

284 See Article 10.2 of ACTA.

285 See Article 45.1 of the TRIPS Agreement.

286 See Article 12.3(a)(i) of the draft IP chapter of the TPP of February 2011; Article 18.10.5(a)(i) of the US-South Korea FTA; Article 4.24 of the US-Jordan FTA; Article 
States FTAs hence have chosen to make the optional right in Article 45.2 of the TRIPS Agreement mandatory regarding the damages that can be ordered where the infringer did not know.

Furthermore, free trade agreements concluded by the United States require establishing or maintaining pre-established damages ${ }^{287}$ for cases of copyright and related rights' infringement and trade mark counterfeit. ${ }^{288}$ Some recent free trade agreements even expand the scope of this provision further by requiring that such damages shall be available upon the election of the right holder, that they shall be high enough to constitute a deterrent to future infringements, and that in patent cases, authorities have the power to set pre-established damages up to triple the amount of the injury assessed. ${ }^{289}$ Not all legal systems have statutory damages for certain types of crimes as an alternative for actual damages. For that reason, Article 45.2 of the TRIPS Agreement has left it to the discretion of WTO Members to provide for pre-established damages. United States free trade agreements abolish this discretion by turning it into an obligation. Overall, the possibilities for right holders to be awarded damages are expanded considerably by US FTAs. There is a development in recent free trade agreements to expand these rights further.

\subsubsection{Border Measures}

After having assessed the most important civil and administrative enforcement procedures contained in US FTAs, another crucial tool available to enforce intellectual property rights are border measures. Border measures are applied by customs authorities at the border of their territory when goods under their supervision are suspected of infringing a form of intellectual property. Customs authorities may then suspend the release into free circulation of such suspected goods. In that regard, four TRIPS-plus standards can be identified in US FTAs. First, US FTAs require that customs authorities shall have the power to initiate border measures at their own initiative, so-called ex officio actions. ${ }^{290}$ Article 58 of the TRIPS Agreement leaves it to the discretion of countries to provide for ex officio actions or not.

Second, competent authorities receive the power to initiate border measures with respect to imported, exported and transiting goods, ${ }^{291}$ and, in most agreements, also

17.11.8(a)(i) of the US-Cbile FTA; Article 17.11.6(a)(i) of the US-Australia FTA; Article 15.11.7(a)(i) of the US-Panama TPA.

Pre-established damages are to be set out in domestic law (statutory) and do not constitute punitive damages. See Article 16.11.8, including footnote 22, of the US-Peru TPA.

See Article 12.4 of the draft IP chapter of the TPP of February 2011; Article 16.9.9 of the US-Singapore FTA; Article 15.11.8 of the US-CAFTA-DR; Article 16.11 .8 of the US-Peru TPA, Article 17.11.9 of the US-Chile FTA.

See Article 12.4 of the draft IP chapter of the TPP of February 2011. Note that Article 18.10.6 of the US-South Korea FTA also includes the two former expansions.

290 See Article 14.4 of the draft IP chapter of the TPP of February 2011 and Article 18.10.22 of the US-South Korea FTA.

291 See Article 17.11.20 of the US-Chile FTA; Article 15.11.23 of the US-Morocco FTA; Article 16.11 .23 of the US-Peru TPA. 
to merchandise in free trade zones. ${ }^{292}$ Article 51 of the TRIPS Agreement only requires border measures to be initiated with respect to imported goods, and makes it optional for countries to apply them also to goods destined for exportation. Also Article 16 of ACTA is not as broad as US FTAs; it demands ex officio actions for import and export shipments, but leaves it to the discretion of contracting parties to also allow such actions for in-transit goods. Thus, US FTAs expand the group of goods that can be subject to a border measure initiated by customs authorities compared to the TRIPS Agreement and to ACTA by broadening the included customs status.

Third, also the scope of IP rights covered by border measures is expanded by US FTAs: border measures can be applied to pirated copyright goods, counterfeit trade mark goods as well as to confusingly similar trade mark goods. ${ }^{293}$ The last category of confusingly similar trade mark goods is also taken up in ACTA, ${ }^{294}$ but not provided for in Article 51 of the TRIPS Agreement. Allowing border measures to be applied to products which may be considered to be confusingly similar has been criticized to interfere with normal business methods.

The fourth and final TRIPS-plus aspect of the border measures in US FTAs addresses the period of time that goods can be suspended from release into free circulation. According to US FTAs, this period shall not last less than one year. ${ }^{295}$ US FTAs go far beyond the TRIPS standard, which specifies that goods can be suspended for maximum of ten working days after the applicant has served notice. This period may not be exceeded if no proceedings to the merits have been initiated and all other conditions for importations and exportation are complied with. ${ }^{296}$

Altogether, US FTAs expand the group of goods that can be subject to a border measure as well as the period of time for which goods can be suspended from release into free circulation. These changes clearly benefit right holders at the expense of the broader public, whose tax payments are used to pay for the necessary adjustments, such as the enactment of laws and regulations and the training of customs officials and judges.

292 All FTAs concluded by the United States, except for the US-Australia FTA and the USJordan FTA, contain these extended groups of goods. See Article 17.11.22 of the USAustralia FTA; Article 4.26 of the US-Jordan FTA.

293 See Article 14.1 of the draft IP chapter of the TPP of February 2011; Article 18.10.19 of the US-South Korea FTA; Article 15.11.20 of the US-Panama TPA. Note that Article 17.11.17 of the US-Chile FTA follows the TRIPS standard. See Article 13 footnote 6 juncto Article 5(d)(k) of ACTA.

295 See Article 14.1 of the draft IP chapter of the TPP of February 2011; Article 18.10.19 of the US-South Korea FTA; Article 14.10.20 of the US-Bahrain FTA; Article 15.11.20 of the US-Morocco FTA; Article 17.11.19 of the US-Australia FTA. Note that Article 17.11.17 of the US-Chile FTA, Article 16.11.20 of the US-Peru TPA, Article 15.11.20 of the US-Panama TPA and the US-CAFTA-DR and Article 16.9.16 of the US-Singapore $F T A$ do not include this requirement. 


\subsubsection{Criminal Procedures and Remedies}

The criminal penalties, which are contained in free trade agreements concluded by the United States, are significantly strengthened compared with the TRIPS Agreement. According to Article 61 of the TRIPS Agreement, criminal penalties must only be applied in cases of willful trade mark counterfeiting or copyright piracy on a commercial scale. US FTAs go beyond this standard and define specifically which acts of copyright or related rights piracy are subject to criminal procedures. They include willful infringements for purposes of commercial advantage or financial gain, as well as significant willful infringements that have no motivation of financial gain. ${ }^{297}$ Sanctioning infringements without any motivation of financial gain by criminal penalties is problematic because it includes end-user piracy. Narrowing down a provision of the TRIPS Agreement to a very specific interpretation goes beyond the TRIPS Agreement.

Furthermore, the remedies available under many US FTAs include sentences of imprisonment as well as monetary fines. ${ }^{298}$ These provisions oblige state parties to impose fines, in addition to imprisonment, in order to provide a deterrent to future infringements. The TRIPS Agreement in Article 61 does not make the imposition of fines mandatory; it leaves it to WTO Members to set out the remedies imprisonment and/or fines for each crime. In addition, US FTAs do not feature the TRIPS safeguard of imposing fines "consistently with the level of penalties applied for crimes of a corresponding gravity;" 299 instead, they include an obligation to establish policies that encourage judicial authorities to impose fines. ${ }^{300}$ Such an obligation clearly derogates from the intention of the TRIPS provision. Finally, US FTAs require that competent authorities shall have the power to initiate criminal procedures at their own initiative. ${ }^{301}$ The TRIPS Agreement does not know ex officio actions for criminal procedures. To sum up, the scope of IP infringements that can be subject to criminal measures in US FTAs as well as the additional imposition of

297 See Article 15.1 of the draft IP chapter of the TPP of February 2011; Article 18.10.26 of the US-South Korea FTA; Article 16.11.21 of the US-Singapore FTA; Article 15.11.26 of the US-Morocco FTA; Article 14.10.26 of the US-Babrain FTA. Note that Article 23.1 of the ACTA allows ACTA signatories to provide criminal procedures and penalties for infringements without the intention of financial gain, but does not require it. See Article 15.5(a) of the draft IP chapter of the TPP of February 2011; Article 18.10.27(a) of the US-South Korea FTA; Article 14.10.27(a) of the US-Babrain FTA; Article 16.11.27 (a) of the US-Peru TPA; Article 15.11.26(b)(i) of the US-Morocco FTA, Article 17.11.27(a) of the US-Australia FTA and Article 16.9.21(a)(i) of the US-Singapore FTA. Note that Article 15.11.26(b)(i) of the US-Panama TPA, Article 17.11.22(b) of the US-Chile FTA, Article 15.11.26(b)(i) of the US-CAFTA-DR and Article 14.1 of the USVietnam FTA do not require the imposition of imprisonment and fines at the same time. See Article 61 of the TRIPS Agreement. 18.10.27(a) of the US-South Korea FTA; Article 15.11.26(b)(i) of the US-Panama TPA; Article 16.11.27(a) of the US-Peru TPA; Article 14.10.27(a) of the US-Bahrain FTA; Article 15.11.26(b)(i) of the US-CAFTA-DR; Article 15.11.26(b)(i) of the US-Morocco FTA. 18.10.27(f) of the US-South Korea FTA; Article 17.11.22(e) of the US-Chile FTA; Article 17.11.27(d) of the US-Australia FTA; Article 16.11.27(d) of the US-Peru TPA. 
fines hardly leaves room for contracting parties to set up a system of enforcement that corresponds with their own preferences.

\subsubsection{Limitations on the Liability of Internet Service Providers}

Internet service providers can be held liable for material that infringes copyright and that is hosted or transmitted by the service provider. US FTAs focus on the limitations of this liability for certain cases. In essence, the provisions aim at limiting the scope of remedies available against service providers for infringements that they do not control, initiate or direct and that take place through systems or networks controlled or operated by them or on their behalf. ${ }^{302}$ These limitations are constrained to the defined service providers, the functions specified (i.e. transmitting, routing, storing, caching) and detailed conditions that have to be fulfilled. ${ }^{303}$ In particular, US FTAs require that reasonable restrictions on court-ordered relief are put in place to compel or restrain certain actions (i.e. terminate accounts, remove or disable access to infringing material). The notice and take down process has received particular attention: Internet service providers will benefit from limitations if they have

"expeditiously remov[ed] or disable[ed] access to the material residing on its system or network on obtaining actual knowledge of the infringement or becoming aware of facts or circumstances from which the infringement was apparent, such as through effective notifications of claimed infringement." 304

Such effective notification must be available through an administrative or judicial procedure to copyright owners. ${ }^{305}$ The TRIPS Agreement does not stipulate any rules on the liability of Internet service providers. Neither have such rules been addressed in ACTA or in European Union bilateral trade agreements so far. To conclude, the United States FTA obligations in that regard go well beyond the current international rules and constitute aggressive features of the FTAs.

\subsubsection{Interim Conclusions}

The enforcement section of US FTAs includes the highest international standards on enforcement procedures currently contained in an international agreement. They go beyond the standards set out in the TRIPS Agreement as well as ACTA. The level of detail with which these rules are set out does not leave any room for discretion on the part of the negotiating partner. In view of the costs that (developing) partner 18.10.30(b) of the US-South Korea FTA; Article 15.11.27(b) of the US-CAFTA-DR; Article 17.11.23(ii) of the US-Chile FTA. See Article 16.3(b)(i)-(xii) of the draft IP chapter of the TPP of February 2011; Article 18.10.30(b)(i)-(xii) of the US-South Korea FTA; Article 15.11.27(b)(i)-(xii) of the USCAFTA-DR.

$304 \quad$ See Article 16.3(b)(v)(B) of the draft IP chapter of the TPP of February 2011; Article 18.10.30(b)(v)(B) of the US-South Korea FTA; Article 15.11.27(b)(v)(B) of the USCAFTA-DR.

305 Article 16.3(b)(ix) of the draft IP chapter of the TPP of February 2011; Article 18.10.30(b)(xi) of the US-South Korea FTA; Article 15.11.27(b)(xi) of the US-CAFTADR. 
countries need to incur in order to bring their enforcement system up to this standard, the US enforcement approach can be classified as aggressive.

The enforcement provisions deal with procedural matters, the right to information, provisional and corrective measures, the award of damages, border and criminal measures, and limitations on the liability of Internet service providers. All of these provisions have certain characteristics in common. First, the rights of right holders are broadly increased, to the detriment of the alleged infringer. This is particularly the case where general procedural principles and safeguards set out in the TRIPS Agreement are omitted from the FTA, with regard to the right of information, the award of damages and border measures. Second, US FTAs choose to regulate sensitive areas of enforcement. Far-reaching and precise competences on provisional, corrective and criminal measures interfere with the negotiating partner's ability to choose the actual implementation of such measures in accordance with its own preferences. Third, US FTAs set the highest international standards currently contained in international agreements. The limitations of the liability of Internet service providers as well as criminal measures provide clear examples of this.

\subsubsection{Application of Non-violation Claims}

The applicability of non-violation claims in the WTO dispute settlement system has become a controversial subject matter among WTO Member States. ${ }^{306}$ The WTO dispute settlement system establishes different grounds on which disputes can be based. In this respect, countries cannot only claim a violation of an obligation under any of the agreements annexed to the WTO Agreement, they can also claim an impairment or nullification of a benefit under any of these agreements by a measure otherwise WTO-consistent or by any other situation. ${ }^{307}$ For the time being, nonviolation claims in disputes involving intellectual property cannot be brought to the dispute settlement system, due to the moratorium in Article 64.2 of the TRIPS Agreement which has been prolonged continuously; 308 the WTO Ministerial Conference still has to take a decision on whether such complaints should be made available for TRIPS-related disputes in the future.

Free trade agreements concluded by the United States, however, impose the applicability of non-violation complaints for matters involving the protection of intellectual property, ${ }^{309}$ irrespective of any future decision by the WTO Ministerial

See section 2.3.5 of this book for an explanation and the applicability of non-violation complaints in disputes involving intellectual property rights in the WTO dispute settlement system.

See Article XXIII(b) and (c) of the GATT. One important requirement in order to rely on non-violation or situation complaints is that the WTO-consistent measure or the situation could not have been anticipated by the parties. The rationale behind nonviolation and situation complaints is to safeguard the balance of tariff negotiations; measures that would affect agreed market-access commitments are therefore prohibited.

See also section 2.3 .5 of this book for an overview of the dispute settlement provisions in the TRIPS Agreement.

309 See Article 22.2(c) juncto Annex 22.2.1 of the US-Chile FTA; Article 20.2(c) of the USMorocco FTA; Article 21.2(c) of the US-Colombia TPA. Note that Article 22.4(c) of the US-South Korea FTA provides in footnote 1 that neither party will invoke a non- 
Conference. Compared to the status quo of WTO rules to date, the applicability of non-violation complaints presents a TRIPS-plus provision. This might change in the future should the WTO Ministerial Conference decide to make non-violation complaints also applicable for TRIPS-related disputes and therefore terminate the moratorium of Article 64.2 of the TRIPS Agreement. However, for the last thirteen years, WTO Members have been hesitant to do this. An acknowledgement of this development could be seen in the adjustment made in the US-South Korea FTA where the obligation to make non-violation complaints available for intellectual property rights is limited by the agreement not to use such complaints for as long as WTO Members have not agreed to do so in the framework of the WTO. ${ }^{310}$ The WTO moratorium is only applicable to complaints brought to the WTO dispute settlement system. Therefore, the obligation in previous FTAs to make non-violation complaints available in disputes involving the impairment of IP benefits under the FTA does not conflict with the moratorium.

\subsubsection{Conclusions}

The IP chapters contained in the free trade agreements concluded by the United States can be described as aggressive in various aspects. First, the legal method used by the United States currently constitutes the most aggressive way of achieving high IP standards when compared with other major actors such as the European Union, Japan and EFTA States. The United States uses a model IP chapter that is based on domestic legislation and the most far-reaching IP chapter contained in a recent FTA. This prototype serves as the basis for future negotiations; deviations from the text hardly occur. As a result, the level of TRIPS-plus obligations contained in US FTAs is unprecedented in other international agreements.

Second, the aggressiveness is also obvious in the way the United States approaches negotiations on IP chapters. The IP negotiations of FTAs are carried out in secrecy, outside of pre-established institutional structures which could impose the respect of certain principles, such as transparency and participatory democracy. Negotiating partners, in particular developing countries, consequently lack advice from third parties and find it difficult to balance their interests during the negotiations of IP provisions. In addition, the United States uses a value-claiming strategy of achieving the highest standards of intellectual property protection in exchange for rules on access to the US markets of, for example, textiles and agriculture, which constitute absolute priorities for many developing countries.

Third, the IP chapter of US FTAs contains the highest standards of IP protection in almost all areas of IP covered by the TRIPS Agreement. ${ }^{311}$ No other international

violation complaint during the period for which WTO Members have agreed not to initiate such complaints.

310 See Article 22.4(c), footnote 1 of the US-South Korea FTA.

311 The bilateral trade agreements concluded by the European Union (both before and after 2006) impose stricter standards than the United States in the area of the protection of geographical indications. The most recent European BTAs also stipulate higher standards in the area of design protection, which US FTAs hardly address. On the protection of geographical designs, see section 3.3.6 in EU agreements on trade in wine and/or spirits, section 5.3.2.3 in the CARIFORUM-EC EPA, and section 6.3.3 in the draft IP chapter of the India-EU BTLA. On the protection of industrial designs, see 
agreements, not even ACTA or the WIPO Internet Treaties, reach this standard. The provisions relating to the protection of public health and to the access to digital works have been described as the most far-reaching obligations. But also the rules on patent protection for plants and animals and the enforcement provisions hardly leave any room for negotiating partners to choose the appropriate method of implementing the FTA provisions in their own legal systems. Moreover, obligations have become stricter, such as the list of international agreements to which negotiating partners need to accede to or make best efforts to do so. In view of the costs that need to be made in order to adjust (developing) partner countries' IP laws accordingly, the substantive provisions in various sections constitute aggressive features.

\subsection{Bilateral Trade AgreEments Concluded By the EUROPEAN UNiON UP UNTIL 2006}

The aggressive features of the IP chapter in United States FTAs are unprecedented. Nevertheless, the European Union also concludes bilateral trade agreements that address the protection of intellectual property. In fact, the European Union's approach to protecting intellectual property through bilateral trade agreements provides a very special and highly interesting example: its approach has changed significantly during the last decennium. This change occurred with the launch of the "Global Europe" strategy in 2006.312 Since the European Union's new approach is the main subject of research, it is addressed in great detail in Part C: The European Union's intellectual property policy towards third countries through bilateral trade agreements. This section, therefore, focuses on the old approach followed by the European Union up until 2006. Its legal method, the characteristics of negotiations and the substantive IP provisions contained in bilateral trade agreements concluded by the European Union between 1994 and 2006 are assessed and compared to the United States approach analyzed above.

There are significant differences between the chapters dealing with intellectual property protection in the free trade agreements concluded by the United States and the bilateral trade agreements concluded by the European Union under the old approach, as will be apparent from the following analysis. One difference of a more general nature already concerns the terminology used by these actors for the bilateral agreements. Whereas provisions on the protection of intellectual property asked for by the United States are mainly included in free trade agreements, intellectual property issues that the European Union requires are contained in a variety of agreements, the names of which depend on the partner country and its relation with the Union. They take the form of association agreements (used for candidate countries for accession, Latin American countries, agreements under the European Neighbourhood Policy), stabilization and association agreements (used for neighbouring countries), partnership and cooperation agreements (agreements under the European Neighbourhood Policy), and economic partnership agreements, socalled EPAs (used for African, Caribbean and Pacific States). Although these

section 5.3.2.4 in the CARIFORUM-EC EPA and section 6.3.4 in the draft IP chapter of the India-EU BTLA.

312 See European Commission, Global Europe: competing in the world (Brussels, 4 October 2006) [hereinafter 'Global Europe']. 
agreements differ in the comprehensiveness of issues dealt with, as a generic term, bilateral trade agreements is used throughout this book in order to refer to the bilateral agreements concluded by the European Union that contain, among other things, issues on the protection of intellectual property.

In addition to the diversity of terms used for its bilateral agreements, the European Union's approach to pursuing the protection of intellectual property in bilateral agreements stands out insofar as it has shifted in recent years. The United States has followed a consistent policy of demanding a high level of protection for intellectual property beyond the TRIPS Agreement in all its free trade agreements, with a tendency to increase that level from one agreement to the other. The European Union used to be modest in its requests from partner countries and rarely asked for standards of intellectual property protection that went beyond the level asked for in the TRIPS Agreement. As pointed out above, with the launch of the "Global Europe" strategy, a TRIPS-plus mandate has been included in the negotiations of bilateral agreements:

"The EU should seek to strengthen IPR provisions in future bilateral agreements and the enforcement of existing commitments" 313

This change in approach can be observed for the first time in the latest bilateral negotiations with one group of African, Caribbean and Pacific (APC) countries, the Caribbean Forum of African, Caribbean and Pacific States (CARIFORUM). ${ }^{314}$ An Economic Partnership Agreement was signed on 20 December 2008. Pending the completion of the ratification procedures of its signatory states, the agreement has yet to enter into force.

\subsubsection{Categorization of European Union Bilateral Trade Agreements}

It is not a straight forward task to give an overview of all bilateral trade agreements that the European Union has concluded up until 2006 and that include rules on the protection of intellectual property. The contexts in which agreements are negotiated are far more diverse than in the case of the United States FTAs. EU bilateral trade agreements, and their respective chapters on the regulation of intellectual property, vary according to the different political and commercial processes in which partner countries are related to the European Union. The relations with some countries are defined by broader frameworks, such as the "Barcelona process"; 315 some countries have particular bilateral relations with the European Union, and others find themselves in the process of integration towards accession. Therefore, a division into three different groups of countries seems most adequate in order to contrast the

313 Ibid., p. 13.

314 The Caribbean Forum of African, Caribbean and Pacific States includes the following sixteen countries: Antigua and Barbuda, the Bahamas, Barbados, Belize, Cuba, Dominica, the Dominican Republic, Grenada, Guyana, Haiti, Jamaica, Saint Lucia, Saint Vincent and the Grenadines, Saint Christopher and Nevis, Suriname, and Trinidad and Tobago. It consists of the CARICOM Common Market (minus the British dependent territory Montserrat) and the Dominican Republic. Note that Cuba is not a contracting party to the CARIFORUM-EC EPA.

315 The Barcelona Process was launched in November 1995 and forms a partnership with twelve Southern Mediterranean States, based on a number of principles. See Barcelona Declaration adopted at the Euro-Mediterranean Conference, 27 and 28 November 1995. 
slightly different rules in the area of intellectual property protection which the European Union requires from its trading partners. These groups are the following: a) candidates, potential candidates for accession and neighbouring countries, b) particular developing countries, and c) ACP States.

Candidates, potential candidates for accession and neighbouring countries have the closest relationship with the European Union. (Potential) Candidates for accession are being prepared to become Member States of the European Union. For that reason, the aim of bilateral trade agreements with these countries is a very ambitious one: their laws need to be brought into conformity with European Union law as much as possible. This is also true for the laws on the protection of intellectual property. The neighbouring countries are not prepared for membership but, also with these countries, the goal is to adapt their standards of protection as much as possible to those of the European Union. The countries included in this group are:

- candidate countries: Former Yugoslav Republic of Macedonia (FYROM), Montenegro, Serbia and Turkey;316

- potential candidates in the Balkans: Albania, Bosnia and Herzegovina, Kosovo (under resolution 1244 of the United Nations Security Council);

- neighbouring countries in the South Caucasus and Central Asia: Armenia, Azerbaijan, Georgia; Republic of Kazakhstan, Kyrgyz Republic, Republic of Moldova, Russian Federation, Ukraine and Republic of Uzbekistan; 317 and

- neighbouring Mediterranean countries: the People's Democratic Republic of Algeria, the Arab Republic of Egypt, the State of Israel, the Hashemite Kingdom of Jordan, the Republic of Lebanon, the Kingdom of Morocco, the Palestinian Authority of the West Bank and the Gaza Strip, and Tunisia.

The agreements concluded by the European Union with candidates, potential candidates and neighbouring countries are Stabilization and Association Agreements (SAAs) with the Balkan states, ${ }^{318}$ an Association Agreements (AAs) with Turkey ${ }^{319}$

316 Note that the Croatia's Treaty of Accession was signed by the Member States of the European Union and the Republic of Croatia in Brussels on 9 December 2011 and therefore is not anymore considered a candidate for accession. The treaty will enter into force when the Parliaments of the currently twenty-seven Member States of the $\mathrm{EU}$ have ratified the treaty. Accession of Croatia to the $\mathrm{EU}$ is expected to take place on 1 July 2013.

317 Bilateral agreements have been signed with the Republic of Tajikistan and Turkmenistan, however, they have not been ratified. Also with the Republic of Belarus, a Partnership and Cooperation Agreement has been concluded in 1995, which has not been ratified by the European Union due to the lack of commitment to democracy, political and civil rights.

In the following, when reference is made to one of these agreements, this will be done in the following way: EC or EU-"name of the partner country" "abbreviation for the type of agreement". An example is the EEC-Turkey AA. As of July 2012, SAAs with Croatia, FYROM, Albania and Montenegro are in force. Bosnia and Herzegovina and Serbia are parties to interim agreements. The agreements in force are published in the Official Journal: EC-Croatia SAA (OJ L 26 of 28.01.2005); EC-FYROM SAA (OJ L 84 of 20.03.2004); EC-Albania SAA (OJ L 107 of 28.04.2009); EC-Montenegro SAA (OJ L 108 of 29.04.2010, p. 3); EC-Bosnia and Herzegovina LA (OJ L 169 of 30.06.2008); ECSerbia LA (OJ L 28 of 30.01.2010, p. 2). 
and the Mediterranean countries (EuroMed AAs), ${ }^{320}$ and Partnership and Cooperation Agreements (PCAs) with the countries in the South Caucasus and Central Asia. ${ }^{321}$ The relationship between the European Union and the Mediterranean countries operates under the bilateral and regional framework of the Euro-Mediterranean Partnership, which is also referred to as the "Barcelona Process".

The second group assembles developing countries that have a special bilateral relationship the European Union. The level of intellectual property protection required from these countries is not as high as that required from (potential) candidates for accession and neighbouring countries. The European Union demands a level of protection that reflects the "highest international standards" 322 of intellectual property protection, among other things. The countries in this group are:

- the Latin American countries Mexico and Chile;

- Bangladesh; and

- South Africa.

The European Union has concluded an Economic Partnership, Political Coordination and Cooperation Agreement [hereinafter Global Agreement (GA)] with Mexico, ${ }^{323}$ and an Association Agreement with Chile. ${ }^{324}$ With Bangladesh, the European Union has concluded a Cooperation Agreement (CA), and with South Africa a Trade, Development and Cooperation Agreement (TDCA). ${ }^{325}$

The African, Caribbean and Pacific States constitute the third group of countries. The Cotonou Agreement, 326 primarily an instrument for development, governs the

319 See EEC-Turkey $A A(O J 217$ of 29.12.1964).

320 See EC-Algeria EuroMed AA (OJ L 265 of 10.10.2005); EC-Egypt EuroMed AA (OJ L 304 of 30.09.2004); EC-Lebanon EuroMed AA (OJ L 143 of 30.05.2006, p. 2); EC-Jordan EuroMed AA (OJ L 129 of 15.05.2002); EC-Israel EuroMed AA (OJ L 147 of 21.06.2000); EC-Morocco EuroMed AA (OJ L 138 of 09.06.2000); EC-Tunisia EuroMed AA (OJ L 97 of 30.03.1998); EC-Palestinian Authority EuroMed LAA (OJ L 187 of 16.07.1997, p. 3). The latter interim agreement has been concluded with the Palestine Liberation Organization for the benefit of the Palestinian Authority of the West Bank and the Gaza strip.

321 See EC-Armenia PCA (OJ L 239 of 09.09.1999); EC-Azerbaijan PCA (OJ L 246 of 17.09.1999); EC-Georgia PCA (OJ L 205 of 04.08.1999); EC-Kazakhstan PCA and ECKyrgyz Republic PCA (OJ L 196 of 28.07.1999); EC-Moldova PCA (OJ L 181 of 24.06.1998); EC-Russia PCA (OJ L 327 of 28.11.1997); EC-Ukraine PCA (OJ L 049 of 19.02.1998); and EC-Urbekistan PCA (OJ L 229 of 31.08.1999).

322 The concept of "highest international standards" will be discussed in section 3.3.5 of this book.

323 See EC-Mexico GA (OJ L 276 of 28.10.2000).

324 See EC-Chile $A A$ (OJ L 352 of 30.12.2002).

325 See EC-Bangladesh CA (OJ L 118 of 27.04.2001); EC-South Africa TDCA (OJ L 311 of 04.12.1999), amended by EC Council Decision 2006/166/EC of 21.12.2005 (OJ L 57 of 28.02.2006).

326 Partnership Agreement between the Members of the African, Caribbean and Pacific Group of States of the one part, and the European Community and its Member States, of the other part (OJ L 317 of 15.12.2000) [hereinafter Cotonou Agreement]. The Cotonou Agreement has been 
special and preferential relationship between the European Union and ACP States. The Cotonou Agreement was signed in 2000 and concluded for a period of twenty years. A WTO waiver had been granted in order to remedy the preferential trading relations contained in the agreement. However, since the waiver only lasted until 1 January 2008, the European Union needed to conclude Economic Partnership Agreements which would be based on reciprocal preferences and would therefore be WTOconsistent. The Economic Partnership Agreements set out the new non-reciprocal trading regime, whereas the revised Cotonou Agreement of June 2010 provides the basis for cooperation in the fields of regional integration, security and fragility, food security, HIV-AIDS, sustainability of fisheries, aid for trade and aid effectiveness. ${ }^{327}$ This chapter only addresses the level of intellectual property protection required by the Cotonou Agreement of 2000 before the EPAs were concluded; the only EPA so far that addresses intellectual property protection is dealt with in great detail in Chapter 5: Legal analysis of the CARIFORUM-EC Economic Partnership Agreement.

In addition to the three groups of countries that have similar provisions on intellectual property in their respective bilateral agreements with the European Union, there is another group of countries that has concluded bilateral agreements on trade in wine and/or spirits. These agreements generally provide for provisions related to the reciprocal protection of the names used for the identification of spirits and wines which originate in the territories of the contracting parties. These are: ${ }^{28}$

- $\quad$ an agreement on trade in wine with Australia from 2008;329

- an agreement on trade in wines and spirit drinks with Canada; ${ }^{330}$

- an agreement on trade in wine and an agreement on trade in spirit drinks and aromatised drinks with Chile, annexed to the general EC-Chile Association Agreement, 331

- an agreement on the mutual recognition and protection of designations for spirit drinks with Mexico; 332

- two agreements on the trade in spirits and wine with South Africa; ${ }^{333}$

amended by EC Council Decision 2005/599/EC of 21.06.2005 (OJ L 209 of 11.08.2005).

See European Commission, The Cotonou Agreement (2012), available at $<$ http://ec.europa.eu/development/geographical/cotonouintro_en.cfm $>$ accessed on 15.11.2012.

The European Union has concluded agreements that deal only with customs duties and tariff quotas for certain wines and spirits but do not address intellectual property protection at all. Such agreements are the agreements concluded between the European Community and the Republic of Bulgaria, the Republic of Hungary and Romania on reciprocal preferential trade concessions for certain wines and spirits. See EC Council Regulation 678/2001 of 26 February 2001 (OJ L 94 of 04.04.2001).

See EC-Australia Wine Agreement 2008 signed on 1 December 2008 (OJ L 28 of 30.01.2009, p. 3). The EC-Australia Wine Agreement 2008 entered into force on 1 September 2010 and replaces the EC-Australia Wine Agreement 1994 (OJ L 86 of 31.03.1994). 30.01.2002). 
- an agreement on trade in agricultural products with Switzerland, containing an Annex 7 on trade in wine-sector products and an Annex 8 on the mutual recognition and protection of names of spirit drinks and aromatised wine-based drinks; ${ }^{334}$ and

- $\quad$ an agreement on trade in wine with the United States. ${ }^{335}$

The list of wine and/or spirits agreements signed with various countries concludes the overview of groups of countries that undertake similar relations with the European Union in terms of protection of intellectual property. These groups will be used throughout this chapter in order to point out the differences in intellectual property protection between them.

Since the launch of the strategy "Global Europe" in 2006, the European Union has concluded four "new generation" bilateral trade agreements that importantly address the protection of intellectual property. These are the CARIFORUM-EC EPA, the EU-South Korea FTA, ${ }^{336}$ the EU-Colombia-Peru FTA, and the EU-Central America FTA. ${ }^{337}$ Seven other bilateral trade negotiations are ongoing. In particular, negotiations have been launched with India (launched in June 2007), ${ }^{338}$ Ukraine (launched in February 2008), ${ }^{339}$ Canada (launched in May 2009), ${ }^{340}$ Singapore (launched in March 2010), ${ }^{341}$ Malaysia (launched in October 2010), ${ }^{342}$ Mercosur (relaunched in May 2010), ${ }^{343}$ and Vietnam (launched in June 2012). ${ }^{344}$ A number of

See EC-Switzerland Agricultural Products Agreement (OJ L 114 of 30.04.2002).

See EC-US Wine Agreement (OJ L 87 of 24.03.2006).

The FTA with South Korea is provisionally applied since 1 July 2011, see Notice concerning the provisional application of the Free Trade Agreement between the European Union and its Member States, of the one part, and the Republic of Korea, of the other (OJ L 168 of 28.06.2011) [hereinafter EU-South Korea FTA].

The Agreement establishing an Association between the European Union and its Member States, on the one hand, and Central America on the other [hereinafter EU-Central America AA] has been signed in Honduras on 29 June 2012, see European Commission, "Press release: EU and Central America sign Association Agreement" (Tegucigalpa, 29 June 2012). The agreement has been concluded between the European Union and Costa Rica, El Salvador, Guatemala, Honduras, Nicaragua and Panama. The text used for this analysis is the text made public for information purposes by the European Commission on 7 August 2012, see European Commission, "Press Release: EU-Central America association agreement" (Brussels, 7 August 2012).

The last EU-India Summit took place on 10 December 2010 in Brussels, after eleven rounds of negotiation on the Broad-based Trade and Investment Agreement between the European Union and India. For an updated status of these negotiations, see European Commission, Bilateral relations (2012), available at $<$ http://ec.europa.eu/trade/creatingopportunities/bilateral-relations/> accessed on 21.08.2012.

Negotiations for an association agreement encompass a free trade agreement, which will contain rules on all trade- related aspects, including on intellectual property rights. Since February 2008, eighteen negotiation rounds have taken place.

In October 2011, the ninth round of negotiations has taken place.

Ten negotiating rounds have taken place between March 2010 and March 2012.

Since the launch of negotiations, six negotiation rounds have taken place.

In July 2012, the eighth negotiation round took place in Brazil.

See European Commission, "Press release: EU and Vietnam launch negotiations for a comprehensive Free Trade Agreement" (Brussels, 26 June 2012). 
other negotiations have been launched in the past but have not been followed up or were suspended several years ago. ${ }^{345}$

\subsubsection{Legal Method}

The chapters on the protection of intellectual property in United States free trade agreements stand out due to the level of detail and extensiveness with which the provisions are drafted. Moreover, they feature a certain prototype that is used for every FTA under negotiation. The legal approach used by the European Union in its agreements before 2006 is quite different from that. Bilateral trade agreements concluded by the European Union are much more general and shorter. The agreements signed with (potential) candidates for accession usually contain one article on the protection of intellectual property and an Annex of maximum one page. ${ }^{346}$ The same is true for the EuroMed association agreements. ${ }^{347}$ Agreements with particular developing countries and the Cotonou Agreement mostly include only one or two provisions on intellectual property protection. 348 An exception to this are the agreements on trade in wine and/or spirits. Although they only contain a few provisions on the protection of geographical indications in the agreements themselves, the Annexes specifying the terms to be protected are very long. ${ }^{349}$

Different from the United States approach, the European Union does not include "legislation-like" provisions in its agreements. European Union bilateral trade agreements specify the multilateral agreements that trading partners must accede to or comply with. In other words, the agreements do not include specific intellectual property standards themselves but they refer to multilateral agreements on the protection of intellectual property and therefore require specific intellectual property standards indirectly. The "multilateral" approach can be observed in all agreements the European Union has concluded, as analyzed below in greater detail.

Another aspect of the legal approach used by the European Union regards the type of agreements that include provisions on the protection of intellectual property. Most of these agreements are association agreements (the stabilization and association agreements, the EuroMed association agreements, the association agreements with Chile and Turkey) or partnership and cooperation agreements (the partnership and cooperation agreements, the development and cooperation agreement with South

These include negotiations for an EU-Gulf Cooperation Council FTA, an EU-Iran Trade and Cooperation Agreement, and an EU-New Zealand Wine Agreement.

346 See Article 71 and Annex VII of the EC-FYROM SAA; Article 73 and Annex V of the EC-Albania SAA; Article 42 and Annex II of the EC-Azerbaijan PCA.

See Article 38 and Annex 2 of the EC-Lebanon EuroMed AA; Article 37, joint declaration on Article 37 and Annex VI, and Annex VI of the EC-Egypt EuroMed AA.

See Articles 168-170 of the EC-Chile AA; Article 12 of the EC-Mexico Global Agreement, Article 46 of the Cotonou Agreement. The EC-Bangladesh CA and the EC-Egypt EuroMed $A A$ however contain not only a provision on intellectual property protection in the respective agreements but they include a joint declaration on the respective article and an annex. See Article 4.5, Annex I and Annex II of the EC-Bangladesh CA; Article 37 and Annex VI of the EC-Egypt EuroMed $A A$.

Annex V of the EC-US Wine Agreement contains 35 pages of names of origin for wine originating from the territory of the European Union and Annex VI includes another thirteen pages of names of origin for wine originating from the territory of the United States. 
Africa, the global agreement with Mexico). These agreements are not focused on trade exclusively but incorporate a more comprehensive agenda, including economic, political and social aspects. ${ }^{350}$ This contrasts with the United States free trade agreements which are focused on trade issues only.

To sum up, European Union bilateral trade agreements concluded before 2006 contain only a few provisions on intellectual property protection, an exception being the agreements on trade in wine and/or spirits. Instead of identifying specific obligations for different fields of intellectual property protection, European bilateral trade agreements refer to standards of protection indirectly by setting out a list of multilateral agreements with which negotiating partners need to comply or accede to. Compared with the United States, the European Union overall has integrated modest standards of IP protection in its bilateral trade agreements.

\subsubsection{Characteristics of Negotiations}

Not much research has been done so far on the way the European Union negotiates with its trading partners. Most studies have focused on negotiations led by the United States. Due to this lack of research on the characteristics of negotiations led by the European Union, this research project carries out an analysis of the process of negotiations in the Jamaica and the CARIFORUM region case study. ${ }^{351}$ In particular, it will be analyzed in how far non-state actors are involved in this process and in how far public debate has taken place. The results are relevant for bilateral trade negotiations carried out after 2006; they will not allow conclusions to be drawn for the negotiations carried out before 2006 and that are at issue in this section.

One author has addressed the way in which the European Union has negotiated bilateral agreements with Mediterranean countries. Mohammed El Said seems to indicate that, similar to the negotiation processes of the United States, the European Union also lacks transparency in its bilateral negotiations. ${ }^{352}$ According to El Said, the majority of negotiations are carried out in secrecy and details of the agreement only become public when the text has been signed. Also, there is a lack of public debate and studies on the impact of such agreements on the negotiating partners' economies. Mohammed El Said also points out that the situation in Arab countries such as Tunisia and Morocco in 2004/2005 often did not allow for civil society to make their opinion known by public protests. In brief, there is little data on the characteristics of the IP negotiations carried out by the European Union in bilateral agreements before 2006. One author indicates that similar concerns regarding transparency as those raised in the context of US negotiations have been reported in negotiations with Arab countries.

\subsubsection{General Provisions}

In contrast to United States FTAs, the intellectual property provisions in bilateral trade agreements concluded by the European Union are not based on a prototype IP chapter. Nevertheless, the provisions contained in these agreements can be structured

\footnotetext{
$350 \quad$ See El-Said, “The European TRIPS-plus Model and the Arab World”, p. 163.

351 See Part D of this book, in particular section 10.1.2 on negotiation phases and section 11.1 on the final policy positions.

352 See El-Said, "The European TRIPS-plus Model and the Arab World”, p. 170.
} 
according to a similar set-up as has been used for the analysis of the provisions in United States FTAs. Three types of matters are discussed in the following: a) general provisions, b) substantive provisions on the protection of intellectual property, and c) enforcement provisions.

In the case of United States free trade agreements, the substantive provisions were analyzed according to the individual intellectual property regimes. European Union bilateral agreements do not stipulate separate rules for the individual regimes of intellectual property protection. Instead, the general level of protection required for all areas of intellectual property covered by the bilateral agreement is examined under the part b) on substantive provisions. In contrast to United States free trade agreements, EU agreements rarely make reference to the TRIPS Agreement and they contain only a few TRIPS-plus elements. Therefore, the following analysis does not focus on TRIPS-plus elements only, but analyzes the most important provisions on the protection of intellectual property.

There are three general matters that are included in most European Union bilateral agreements: a) definition of intellectual property, b) accession to multilateral agreements, and c) MFN treatment obligation.

\subsubsection{Definition of Intellectual Property}

A definition of intellectual property is contained in the bilateral agreements concluded with particular developing countries and in the Cotonou Agreement, no such definition can be found in the agreements with (potential) candidates for accession and neighbouring countries. An example of a definition which sets out the intellectual property rights that are covered under the bilateral agreement is included in Article 169 of the EU-Chile $A$ A:

\footnotetext{
"Intellectual property rights embodies copyright - including copyright in computer programs and in databases - and related rights, the rights related to patents, industrial designs, geographical indications including appellation of origins, trademarks, layoutdesigns (topographies) of integrated circuits, as well as protection of undisclosed information and protection against unfair competition as referred to in Article 10bis of the Paris Convention for the Protection of Industrial Property (Stockholm Act, 1967)."
}

Definitions in other agreements distinguish themselves by also including service marks, ${ }^{353}$ by not providing for the protection of databases, ${ }^{354}$ by requiring the protection of undisclosed information on "know-how', 355 by including the protection of utility models and the protection of bio-technological inventions, ${ }^{356}$ and by including the protection of plant varieties or other effective sui generis systems. Some of these definitions go beyond the TRIPS standard insofar as they provide for the

\footnotetext{
353 See Article 46.5 of the Cotonou Agreement, the Joint Declaration on Article 37 and Annex VI of the EC-Egypt EuroMed AA; Annex I of the EC-Bangladesh CA; Article 46.7 of the EC-South Africa TDCA. See the Joint Declaration on Article 37 and Annex VI of the EC-Egypt EuroMed $A A$. See the Joint Declaration on Article 37 and Annex VI of the EC-Egypt EuroMed AA; Article 46.5 of the Cotonou Agreement, Article 46.7 of the EC-South Africa TDCA. 
protection of intellectual property matters that are not included in the TRIPS Agreement. This is the case for requiring the protection of databases and utility models; both subject matters are not dealt with in the TRIPS Agreement. Including databases and utility models into the definition of intellectual property has the effect of extending the protection granted in the bilateral agreement also to these forms of IP protection. However, concrete rules that only address these areas of IP protection are not contained in the agreements and therefore differ from for example the CARIFORUM-EC EPA which sets out concrete standards of protection for utility models. ${ }^{357}$

\subsubsection{Accession to Multilateral Agreements}

The second matter that all European Union bilateral trade agreements deal with is the accession to certain multilateral treaties on the protection of intellectual property. This is one of the most important elements in EU agreements because the European Union achieves the protection of specific intellectual property standards by requiring its trading partners to adhere to certain multilateral treaties. The European Union employs different manners in order to make countries comply with multilateral treaties. First, partner countries must accede to a number of agreements before a certain period of time has lapsed. This period varies between three and seven years after entry into force of the respective bilateral agreement with the trading partner. Second, contracting parties have to reaffirm the importance they attach to certain international intellectual property treaties. The purpose of such a provision seems to be that partner countries emphasize the importance of treaties they have already ratified. Third, in particular some Mediterranean countries have been asked to ratify the revisions to certain multilateral treaties.

In the following, the obligations with regard to multilateral IP treaties are set out separately for 1) (potential) candidate countries and neighbouring countries, 2) particular developing countries, and 3) ACP States. Table 3 indicates to which multilateral treaties several candidates, potential candidate countries for accession and neighbouring countries must accede or the importance of which they are required to reaffirm. 
Table 3: Multilateral treaties listed in EU bilateral agreements with candidates, potential candidates for accession and neighbouring countries

\begin{tabular}{|c|c|c|c|c|c|c|c|c|}
\hline & FYROM $^{358}$ & $\begin{array}{c}\text { Bosnia/ } \\
\text { Herzegovina }^{359}\end{array}$ & Azerbaijan $^{360}$ & Russia $^{361}$ & Algeria $^{362}$ & Israel $^{363}$ & Egypt $^{364}$ & Lebanon $^{365}$ \\
\hline $\begin{array}{c}\text { Berne } \\
\text { Convention }\end{array}$ & $\mathrm{O}$ & $\mathrm{O}$ & $\mathrm{x}$ & $\mathrm{x}$ & $<$ & $\mathrm{x}$ & $\mathrm{O}$ & + \\
\hline $\begin{array}{c}\text { Rome } \\
\text { Convention }\end{array}$ & $\mathrm{O}$ & $\mathrm{x}$ & $\mathrm{x}$ & $\mathrm{x}$ & $\mathrm{x}$ & & $\mathrm{x}$ & \\
\hline $\begin{array}{c}\text { Geneva } \\
\text { Convention }\end{array}$ & $\mathrm{O}$ & $\mathrm{x}$ & & & & & & \\
\hline $\begin{array}{c}\text { Brussels } \\
\text { Convention }\end{array}$ & & $\mathrm{O}$ & & & & & & \\
\hline WCT & & $\mathrm{x}$ & & & $\mathrm{x}$ & & & \\
\hline WPPT & & $\mathrm{x}$ & & & $\mathrm{x}$ & + & & \\
\hline $\begin{array}{c}\text { Paris } \\
\text { Convention }\end{array}$ & $\mathrm{O}$ & o & $\mathrm{O}$ & $\mathrm{O}$ & $<$ & o & o & + \\
\hline PLT & & $\mathrm{x}$ & & & & & & \\
\hline $\begin{array}{c}\text { European } \\
\text { Patent } \\
\text { Convention }^{366}\end{array}$ & & $x$ & & & $<$ & & $\mathrm{x}$ & $\mathrm{x}$ \\
\hline PCT & $\mathrm{O}$ & $\mathrm{O}$ & $\mathrm{O}$ & $\mathrm{O}$ & & $\mathrm{x}$ & & \\
\hline $\begin{array}{l}\text { Strasbourg } \\
\text { Agreement }\end{array}$ & & $\mathrm{x}$ & & & $\mathrm{x}$ & & $\mathrm{x}$ & $\mathrm{x}$ \\
\hline $\begin{array}{c}\text { Budapest } \\
\text { Treaty }\end{array}$ & $x$ & $x$ & $\mathrm{x}$ & $\mathrm{O}$ & $\mathrm{x}$ & $\mathrm{x}$ & & $\mathrm{x}$ \\
\hline TLT & & $\mathrm{x}$ & & & $<$ & & $\mathrm{O}$ & \\
\hline $\begin{array}{c}\text { Madrid } \\
\text { Agreement }\end{array}$ & $\mathrm{O}$ & O & $\mathrm{O}$ & $\mathrm{O}$ & $\mathrm{x}$ & $\mathrm{x}$ & $\mathrm{x}$ & $\mathrm{x}$ \\
\hline $\begin{array}{l}\text { Madrid } \\
\text { Protocol }\end{array}$ & $\mathrm{x}$ & $\mathrm{x}$ & $\mathrm{x}$ & o & $<$ & $\mathrm{x}$ & $\mathrm{x}$ & $\mathrm{x}$ \\
\hline $\begin{array}{c}\text { Nice } \\
\text { Agreement }\end{array}$ & $\mathrm{O}$ & $\mathrm{O}$ & $\mathrm{x}$ & o & & o & & + \\
\hline $\begin{array}{c}\text { Vienna } \\
\text { Agreement }\end{array}$ & & $x$ & & & & & & \\
\hline
\end{tabular}

See Article 71 juncto Annex VII of the EC-FYROM SAA.

See Article 38 juncto Annex VI of the EC-Bosnia Herzegovina LA. The obligations contained therein are similar to Article 40 juncto Annex VI of the EC-Serbia IA, except that Serbia is required to accede to two treaties only (the PLT and UPOV Convention, Act 1991) and confirms the importance of the other treaties. Article 75 juncto Annex VII of the EC-Montenegro $S A A$ requires Montenegro to accede to all the listed treaties. See Article 42 juncto Annex II of the EC-Azerbaijan PCA. The obligations are identical in Article 42 juncto Annex II of the EC-Armenia PCA, Article 42 juncto Annex II of the EC-Georgia PCA, Article 43 juncto Annex II of the EC-Kyrgyz Republic PCA, Article 42 juncto Annex III of the EC-Kazakhstan PCA.

See Article 54 and Annex 10 of the EC-Russia PCA.

See Article 44 juncto Annex 6 of the EC-Algeria EuroMed $A A$.

See Article 39 juncto Annex VII of the EC-Israel EuroMed $A A$.

See Article 37 juncto Annex VI of the EC-Egypt EuroMed $A A$.

See Article 38 juncto Annex 2 of the EC-Lebanon EuroMed AA.

Convention on the Grant of European Patents, adopted in Munich on 5 October 1973, entered into force on 7 October 1977, 1065 U.N.T.S. 199 [hereinafter European Patent Convention]. The European Patent Convention is a regional rather than multilateral IP treaty. 


\begin{tabular}{|c|c|c|c|c|c|c|c|c|}
\hline $\begin{array}{c}\text { Geneva Act } \\
\text { of the Hague } \\
\text { Agreement }\end{array}$ & & $\mathrm{x}$ & & & & & & \\
\hline \begin{tabular}{|c|} 
Locarno \\
Agreement \\
\end{tabular} & & $\mathrm{O}$ & & & $\mathrm{x}$ & & $\mathrm{x}$ & $x$ \\
\hline $\begin{array}{c}\text { UPOV } \\
\text { Convention, } \\
1991 \text { Act }\end{array}$ & $\mathrm{x}$ & $\mathrm{x}$ & $\mathrm{x}$ & $\mathrm{x}$ & $\mathrm{x}$ & $\mathrm{O}$ & $\mathrm{o}$ & $x$ \\
\hline $\begin{array}{c}\text { WIPO } \\
\text { Convention }\end{array}$ & & $\mathrm{O}$ & & & & & & \\
\hline $\begin{array}{c}\text { TRIPS } \\
\text { Agreement }\end{array}$ & & $\mathrm{O}$ & & & & & & \\
\hline
\end{tabular}

x: shall accede to that multilateral treaty by a particular date

$\mathrm{o}$ : confirms the importance it attaches to the obligations arising from that multilateral treaty

$<$ : continues to ensure an adequate and effective implementation of obligations arising from that agreement

+ : shall ratify the revisions of the following multilateral conventions

The table lists two (potential) candidates for accession, one country from the South Caucasian region, one from the Central Asian region and four Mediterranean countries. The rationale for choosing these countries lies in the different obligations contained in the respective agreements. While the obligations with respect to the listed multilateral treaties are relatively similar among candidates and potential candidates on the one hand, and South Caucasus and Central Asian countries on the other hand, the obligations in the category Mediterranean countries differ considerably. One explanation for these differences lies in the fact that not every country has to accede to the same multilateral treaties.

An important aspect of these provisions is the specific obligation that the partner country agreed to. The obligations "to accede to a multilateral treaty" or "to ratify its revisions" are very clear, hard obligations, mostly joined with an indication as to when they have to be met. Parties comply with this formal requirement once they have completed the relevant accession and/or ratification procedures. It is less clear what is required from contracting parties in order to comply with the obligation "to confirm the importance it attaches to the obligations arising from the multilateral treaty", or "to continue to ensure an adequate and effective implementation of the obligations". While confirming the importance of a multilateral treaty seems to be a rather soft obligation (if a country is not a party yet to that agreement, it is not under an obligation to become a contracting party), ensuring an adequate and effective implementation of a multilateral treaty potentially presents the strongest obligation because it entails a substantive evaluation. The other party (here the European Union) must assess whether the obligations stemming from the multilateral treaty have been implemented by the partner country "in an adequate and effective manner". It is far from evident under which conditions the contracting parties' laws will meet this test. The broad language creates considerable uncertainty as to how the concept will be interpreted in specific cases. In the group of (potential) candidates for accession and neighbouring countries, only Algeria has agreed to this type of obligation.

When comparing the obligations of (potential) candidate countries for accession with those of neighbouring countries, it becomes clear that a number of agreements have 
not received any attention in the agreements concluded with neighbouring countries. These are the Brussels Convention and the Geneva Convention, ${ }^{367}$ and the Vienna Agreement ${ }^{368}$ and the Geneva Act of the Hague Agreement. They seem to go beyond the level of protection envisaged for neighbouring countries but are required from (potential) candidate countries in order to approximate the level of IP protection to that of the European Union. Certain agreements have received particular attention in all agreements listed. Most (potential) candidates for accession and neighbouring countries have to accede to, affirm the importance of, continue to ensure an adequate and effective implementation of, or ratify the revisions of the following agreements:

- in the field of copyright and neighboring rights: the Berne and Rome Conventions;

- in the field of patent protection: the Paris Convention, the PCT and the Budapest Treaty;

- in the field of trade mark protection: the Madrid Agreement and Protocol and the Nice Agreement; 369 and

- $\quad$ in the field of plant varieties: the UPOV Convention, Act 1991.

Turning to particular developing countries, the picture looks slightly different.

Table 4: Multilateral treaties listed in EU bilateral agreements with particular developing countries

\begin{tabular}{|c|c|c|c|}
\hline & Chile $^{370}$ & Bangladesh $^{371}$ & South Africa ${ }^{372}$ \\
\hline Berne Convention & $<$ & $\mathrm{x}$ & $\mathrm{o}$ \\
\hline Rome Convention & $<$ & $\mathrm{x}$ & o \\
\hline Geneva Convention & $\mathrm{x}$ & & \\
\hline WCT & $\mathrm{x}$ & \# & o \\
\hline WPPT & $\mathrm{x}$ & \# & \\
\hline Paris Convention & $<$ & & $\mathrm{O}$ \\
\hline PCT & $\mathrm{x}$ & $\mathrm{x}$ & $\mathrm{O}$ \\
\hline Strasbourg Agreement & $\mathrm{x}$ & & \\
\hline Budapest Treaty & $\mathrm{x}$ & \# & o \\
\hline TLT & & $\mathrm{x}$ & \\
\hline Madrid Agreement & \# & $\mathrm{x}$ & \\
\hline Madrid Protocol & $\#$ & $\mathrm{x}$ & $\mathrm{O}$ \\
\hline Nice Agreement & $\mathrm{x}$ & $\#$ & $\mathrm{O}$ \\
\hline Vienna Agreement & $\#$ & & \\
\hline Locarno Agreement & $\mathrm{x}$ & & \\
\hline UPOV Convention, 1991 Act & $<$ & $\#$ & $\mathrm{O}$ \\
\hline TRIPS Agreement & $<$ & & \\
\hline
\end{tabular}

Geneva Convention for the Protection of Producers of Phonograms against Unauthorized Duplication of Their Phonograms, adopted in Geneva on 29 October 1971, 866 U.N.T.S. 71 [hereinafter Geneva Convention].

Vienna Agreement Establishing an International Classification of the Figurative Elements of Marks, adopted in Vienna on 12 June 1973, entered into force on 9 August 1985, 1863 U.N.T.S. 317 [hereinafter Vienna Agreement].

369 Nice Agreement Concerning the International Classification of Goods and Services for the Purposes of the Registration of Marks, as last revised at the Stockholm Revision Conference, adopted in Stockholm on 14 July 1967, amended on 28 September 1979, 550 U.N.T.S. 45 [hereinafter Nice Agreement].

370 See Article 170 of the EC-Chile AA.

371 See Article 4.5(b) and (c) juncto Annex II of the EC-Bangladesh $C A$.

372 Article 46 of the EC-South Africa TDCA. 
$\mathrm{x}$ : shall accede to that multilateral treaty by a particular date

$\mathrm{o}$ : confirms the importance it attaches to the obligations arising from that multilateral treaty

$<$ : continues to ensure an adequate and effective implementation of obligations arising from that agreement

\#: makes every effort/shall endeavour to accede or ratify and ensure an adequate and effective

implementation of obligations arising from that agreement

Table 4 lists the obligations with regard to multilateral agreements for Chile, Bangladesh and South Africa. With the exception of Mexico, these three developing countries have been partners to bilateral trade agreements with the European Union. Mexico is not listed since the EC-Mexico GA does not require Mexico's accession to any multilateral treaty. The obligations for Chile, Bangladesh and South Africa differ considerably from each other. Chile has incurred most obligations with regard to multilateral agreements. It is required to accede to eight multilateral treaties, to make every effort to ratify three treaties and to continue to ensure an adequate and effective implementation of five treaties. Not only the number of agreements covered is large, the types of obligations agreed to by Chile are also strong: Chile is the only developing country that accepted the potentially strongest language of "continuing to ensure an adequate and effective implementation of obligations". Bangladesh is under an obligation to accede to six treaties and to endeavour to ratify five treaties. For a least-developed country, these obligations are also substantial, yet less than those reflected in the EC-Chile $A A$. South Africa merely confirms the importance of nine multilateral treaties.

The following treaties have received most attention in agreements with particular developing countries:

- in the field of copyright and neighboring rights: the Berne and Rome Conventions, and the WIPO Internet Treaties;

- in the field of patent protection: the Paris Convention, the PCT and the Budapest Treaty;

- in the field of trade mark protection: the Madrid Agreement and Protocol and the Nice Agreement, and

- $\quad$ in the field of plant varieties: the UPOV Convention, Act 1991.

The treaties to which only Chile needs to accede or ratify are the Geneva Convention, the Strasbourg Agreement, ${ }^{373}$ the Vienna Agreement and the Locarno Agreement; 374 Bangladesh and South Africa did not agree to any obligation in that respect.

When comparing Table 4 with Table 3, it is noteworthy that Chile's obligations come close to those of (potential) candidates for accession. In fact, only four treaties listed for (potential) candidates for accession (the Brussels Convention, the PLT, the European Patent Convention and the TLT) do not appear on the list of multilateral treaties that Chile is required to adhere to.

373 Strasbourg Agreement Concerning the International Patent Classification, adopted in Strasbourg on 24 March 1971, entered into force on 7 October 1975 and was amended on 28 September 1979. See WIPO, WIPO-Administered Treaties.

374 Locarno Agreement Establishing an International Classification for Industrial Designs, adopted on 8 October 1968 and amended on 28 September 1979, 828 U.N.T.S. 435 [hereinafter Locarno Agreement. 
The third and final group of countries assessed in this section is the group of ACP States. The Cotonou Agreement has a much shorter list of agreements that ACP States must accede to, compared with the other particular developing countries. Article 46.3 of the Cotonou Agreement establishes an obligation to accede to all international conventions that are referred to in Part I of the TRIPS Agreement. According to Article 1.3 of the TRIPS Agreement, reference is made to the Berne Convention, the Paris Convention, the Rome Convention and the Treaty on Intellectual Property in Respect of Integrated Circuits. ${ }^{375}$ Furthermore, Article 46.2 of the Cotonou Agreement underlines the importance of adhering to the TRIPS Agreement, the WTO Agreement and the Convention on Biological Diversity (CBD). The reference to the Convention on Biological Diversity has not been included in the agreements with other developing countries, (potential) candidates for accession or neighbouring countries. Incorporating the protection of biological diversity into the same provision as the protection of intellectual property suggests that the parties of the Cotonou Agreement were eager to balance patent protection with the safeguard of biodiversity. This balance is one example of the level of intellectual property protection adopted in the Cotonon Agreement which is, also in other respects, significantly more lenient than the protection required from other country groups.

Drawing from the obligations to comply with multilateral agreements that were analyzed in the different agreements, it can be concluded that only a few provisions in that respect are of a TRIPS-plus nature. This is certainly the case for the requirements to accede to the WCT and the WPPT, as argued above. ${ }^{376}$ There is one other requirement that establishes an obligation beyond the TRIPS Agreement. This concerns the obligation to accede to the UPOV Convention, Act 1991, without leaving partner countries the option to adopt a sui generis system for the protection of plant varieties. Article 27.3(b) of the TRIPS Agreement requires parties to protect plant varieties; however, it leaves the choice to each party whether this protection is granted through patents or a sui generis system. It has been generally recognized that the protection of plant varieties granted by the UPOV Convention does fulfill the requirements of a sui generis system. However, this does not mean that only the UPOV Convention, Act 1991 complies with this standard, but arguably also the UPOV Convention, Act 1978 or sui generis systems that a country developed domestically. As the European Union did not grant the same flexibility to each partner country, the obligation to accede to the UPOV Convention, Act 1991 is of a TRIPS-plus nature.

\subsubsection{Most-favoured-nation Treatment Obligation}

The MFN treatment obligation generally requires parties to the respective agreements to grant each others' nationals treatment no less favourable than the treatment granted by them to any third country national under bilateral agreements. This obligation can be found only in the agreement with (potential) candidates for accession, South Caucasian and Central Asian countries. ${ }^{377}$ Euro-Mediterranean

375 Note that the IPIC Treaty has not entered into force. See footnote 75 of section 1.5 .4 of this book.

376 See sections 3.2.5.3 and 3.2.5.4 of this book.

377 See Article 71 juncto Annex VII paragraph 3 of the EC-FYROM SAA; Article 73 juncto Annex V paragraph 3 of the EC-Albania SAA; Article 38.2 of the EC-Bosnia Herzegovina IA; Article 54 juncto Annex 10 paragraph 4 of the EC-Russia PCA; Article 43 juncto Annex II paragraph 4 of the EC-Kyrgyz Republic PCA. 
Association Agreements do not contain a MFN treatment obligation; neither do the agreements with other particular developing countries or ACP States. The MFN treatment obligation is also contained in the TRIPS Agreement and therefore does not extend the scope of obligations beyond the level of TRIPS.

\subsubsection{Interim Conclusions}

The general provisions contained in European bilateral trade agreements contain only a few TRIPS-plus provisions. Merely the protection of databases and utility models, which are taken up in the definitions of intellectual property, go beyond the TRIPSstandard. In addition, the requirement to accede to the WCT, the WPPT and the UPOV Convention, Act 1991 is of a TRIPS-plus nature. Compared to United States general provisions, EU agreements do not require the protection of technological protection measures and rights management information beyond the standard set out in the WCT; neither do they include the principle of more extensive protection or an investment chapter. Therefore, the standard of protection sought in EU agreements concluded up until 2006 remains well behind the protection achieved through the general provisions in US FTAs.

\subsubsection{General Level of Protection}

European Union bilateral trade agreements concluded before 2006 do not deal with each intellectual property regime individually. They rather specify the level of protection required generally in all areas of intellectual property. Obligations with regard to the individual IP regimes are achieved through the "multilateral approach" of requiring the accession to a multilateral treaty. In particular, protection of information in the digital environment is achieved through the obligatory accession to the WCT and the WPPT, and the protection of trade marks by requiring the compliance with the Madrid Agreement, the Madrid Protocol and the Nice Agreement. European Union bilateral trade agreements do not contain references to multilateral agreements that require specific provisions related to public health. However, in the area of geographical indications, EU bilateral agreements require specific standards of protection which are set out in the agreements on trade in wine and/or spirits. Before addressing the protection of geographical indications, the level of protection required generally in all areas of intellectual property will be analyzed according to the groups of partner countries identified above.

The level of protection of intellectual property required by the European Union from its trading partners differs according to their relation with the EU. Not surprisingly, the general level of protection demanded from (potential) candidates for accession and neighbouring countries is the highest standard compared with particular developing countries and ACP States. An exception are the Mediterranean countries, which are required to adopt the same standard as particular developing countries. For that reason, they are assessed together with the developing countries rather than in the group of neighbouring countries.

The high standard of protection of intellectual property asked from (potential) candidates for accession and neighbouring countries is defined in the following way. First, (potential) candidates for accession 
"confirm the importance they attach to ensure adequate and effective protection and enforcement of intellectual, industrial and commercial property rights." 378

Second, they are required to take necessary measures in order to guarantee a level of protection of intellectual property rights similar to that existing in the Union, including effective means of enforcement. ${ }^{379}$ The agreements stipulate a certain period of time by which this level of protection must be reached. The term varies between three and five years after the agreement has entered into force. Third, in the field of approximation of laws or legislative cooperation, most (potential) candidates for accession recognize the importance of approximating existing and future legislation to that of the European Union; furthermore, they endeavour to ensure that their legislation will be gradually made compatible with that of the Union. ${ }^{380}$ This obligation also applies to the area of intellectual property protection. Taken together, these three obligations constitute the strongest obligation with regard to the level of protection in the field of intellectual property. Approximating laws to those of the European Union is a very clear benchmark that (potential) candidate countries must achieve. In contrast, the protection required from particular developing and Mediterranean countries and the ACP States is less concrete and interpretations of the terms used can differ.

Developing and Mediterranean countries are obliged to

"grant and ensure adequate and effective protection of intellectual, industrial and commercial property rights in accordance with the bighest international standards, including effective means of enforcing such rights." 381

378 Article 71.1 of the EC-FYROM SAA. For identical provisions, see Article 73.1 of the EC-Albania SAA; Article 38.1 of the EC-Bosnia Herzegovina LA. Except for Article 54.1 of the EC-Russia PCA, the agreements concluded with South Caucasian and Central Asian countries do not include this provision. Instead, they refer to the improvement of the protection of intellectual property rights. See Article 42.1 of the EC-Armenia PCA and EC-Georgia PCA; Article 41.1 of the EC-Urbekistan PCA; Article 49.1 of the EC-Moldova PCA.

379 See Article 71.2 of the EC-FYROM SAA; Article 73.2 of the EC-Albania SAA; Article 38.3 of the EC-Bosnia Herzegovina IA; Article 42.1 of the EC-Azerbaijan PCA; Article 54 juncto Annex 10 paragraph 1 of the of the EC-Russia PCA.

380 See Article 68.1 and 68.3 of the EC-FYROM SAA; Article 70.1 and 70.3 of the ECAlbania SAA; Article 43 of the EC-Azerbaijan PCA, EC-Armenia PCA, EC-Georgia PCA, EC-Kazakbstan PCA; Article 44 of the EC-Kyrgyz Republic PCA; Article 50 of the EC-Moldova PCA; Article 51 of the EC-Ukraine PCA; Article 42 of the EC-Uzbekistan $P C A$. Note that the interim agreements with Bosnia Herzegovina and Serbia lack a provision on the legislative cooperation or approximation of laws. Article 72.1 and 72.3 of the EC-Montenegro $S A A$ provide for the approximation of laws in the area of intellectual property, however only at a later stage. The EC-Russia PCA has a provision on the approximation of laws. However, it does not extend the scope of that provision to the area of intellectual property rights. See Article 55.1 and 55.2 of the EC-Russia PCA.

381 Article 39.1 of the EC-Israel EuroMed AA. For other Mediterranean countries, see Article 38.1 of the EC-Lebanon EuroMed AA; Article 33.1 of the EC-Palestinian Authority EuroMed LAA; Article 39.1 of the EC-Tunisia EuroMed AA; Article 56.1 of the ECJordan EuroMed $A A$. For other particular developing countries, see Article 168 of the EC-Chile AA; Article 12.1 of the EC-Mexico GA; Article 46.1 of the EC-SA TDCA. 
Two deviations from this standard obligation regard the obligation to ensure not "adequate" but "suitable" and effective protection not in "accordance" but in "conformity" with. ${ }^{382}$ A second deviation replaces "highest" international standards with "prevailing" international standards. ${ }^{383}$ With regard to the concept of "highest international standards", there has been some debate in the literature as to what standards this concept contains. International law does not have a definition of what the highest international standards are. As Carlos Correa argues, the concept of "international standards" clearly excludes national, bilateral or regional standards. ${ }^{384}$ However, this still leaves us with a very broad category of standards that have been adopted in multilateral instruments dealing with the protection of intellectual property. However, would multilateral agreements on investment also be included? There are also ambiguities on how to determine the question which agreements establish the "highest" standards in a particular area of intellectual property law. In conclusion, it is far from clear which standards are referred to by the concept of "highest international standards" and therefore it leaves ample room for interpretation.

In contrast to (potential) candidate countries and neighbouring countries, which are under an obligation to approximate their laws with those of the European Union, approximation of laws is merely an area of cooperation for Mediterranean countries. Accordingly, they shall use their best endeavours to bring their legislation closer to that of the European Union in the areas covered by the agreement. ${ }^{385}$ The approximation of laws is not touched upon in the agreements concluded with particular developing countries.

The level of intellectual property protection that the final group of countries, the ACP States, must comply with is least stringent. The formula used in Article 46 of the Cotonou Agreement refers to recognizing

"the need to ensure an adequate and effective level of protection of intellectual, industrial and commercial property rights [...], in line with the international standards."

The EC-Bangladesh CA is the only agreement concluded with a developing country that does not contain such a provision. Its Article 4.5(a) reads that Bangladesh confirms to take all necessary measures to improve the conditions for adequate and effective protection and enforcement of intellectual property rights. See Article 44.1 of the EC-Algeria EuroMed AA; Article 39.1 of the EC-Morocco EuroMed $A A$.

383 See Article 37.1 of the EC-Egypt EuroMed AA.

384 See Correa, Bilateral Investment Agreements, p. 20.

385 See Article 55 of the EC-Israel EuroMed AA; Article 49 of the EC-Lebanon EuroMed $A A$; Article 48 of the EC-Egypt EuroMed AA; Article 69 of the EC-Jordan EuroMed AA. Note that there are some deviations from this terminology. For example, one finds the following provision: "cooperation shall be aimed at helping [name of country] to bring its legislation closer to that of the Community", see Article 52 of the EC-Morocco EuroMed $A A$ and the EC-Tunisia EuroMed AA; Article 56 of the EC-Algeria EuroMed AA. A similar provision is included in Article 41 of the EC-Palestinian Authority EuroMed LAA. 
This obligation is similar to the one that particular developing and Mediterranean countries have to adhere to. However, an important difference is that protection is not required to be in line with "highest international standards" but with "international standards". Leaving "highest" out of the concept seems to indicate that the European Union does not expect ACP States to protect intellectual property rights on the highest international level but according to a lower standard. However, it is still unclear which standards are covered under the concept of "international standards", see above the discussion on "highest international standards". The same ambiguities remain as to whether the standards of all multilateral agreements are meant or a selection of these agreements. To conclude, the concept of international standards is vague and leaves some room for interpretation.

Overall, there is a clear difference between the level of protection sought from (potential) candidates for accession and neighbouring countries on the one hand, and developing countries and ACP States on the other hand. While (potential) candidates for accession and countries from the South Caucasus and Central Asia are required to provide a similar level of protection as the European Union, the other (developing) partner countries have to ensure adequate and effective protection of intellectual property in accordance with (highest) international standards. The first standard of protection is very precise as it is regulated in great detail in internal legislation of the European Union. Developing and Mediterranean countries as well as the Group of ACP States agreed to a much more flexible standard that can be interpreted by the parties in accordance with their domestic policy preferences. The general level of protection reflected in European Union bilateral trade agreements has no equivalent in US FTAs. The latter specify concrete obligations for each area of intellectual property that often go beyond the level prescribed by the TRIPS Agreement.

\subsubsection{Provisions Relating to Geographical Indications}

The only area of intellectual property protection that European Union agreements on trade in wine and/or spirits address individually is the protection of geographical indications. The protection granted to GIs goes beyond the standard foreseen in the TRIPS Agreement. It is therefore one of the few areas in EU bilateral agreements where TRIPS-plus provisions are contained and where the standards of protection are higher than those included in the United States FTAs. The European Union has concluded eight agreements with seven countries that address trade in wine and/or spirits. These countries are Australia, Canada, Chile, Mexico, South Africa, Switzerland and the United States, as listed above. 386 The agreements are very much alike in terms of structure and content. However, there are some differences with regard to whether they cover wine and/or spirits, and whether they protect only geographical indications or also traditional expressions. In the following, these agreements will be analyzed and compared with each other according to six issues: a) the scope, structure and definition of geographical indications; b) the level of protection; c) the relationship with trade marks; d) exceptions; e) transitional periods for phasing out the use of geographical indications; and f) the protection of traditional expressions. 


\subsubsection{Scope, Structure and Definition of Geographical Indications}

The scope of the agreements on trade in wine and/or spirits varies according to whether they cover a) only trade in wine, b) only trade in spirits or c) both trade in wine and spirits. The agreements with Australia and the United States deal with trade in wine only; the agreement with Mexico merely covers trade in spirits; the agreements concluded with Chile, Switzerland and Canada cover both trade in wine and spirits. South Africa has concluded two separate agreements that deal with trade in wine and trade in spirits respectively.

The structure of these agreements is generally very similar. They start off with general provisions on objectives, the scope of the agreement and definitions. The main body mostly contains seven titles: 1) the protection of wine and/or spirit names, 2) oenological practices and processes and product specifications (only for agreements also addressing trade in wine), 3) import certification requirements, 4) sanitary and phytosanitary measures, 5) mutual assistance/cooperation, 6) management of the agreement, and 7) general provisions on dispute settlement and transitional periods for phasing out. In addition, most agreements have an extensive Annex. It lists the names of wines and/or spirits of both contracting parties that have to be recognized and protected. For the protection of geographical indications, only the provisions dealing with the definition of a GI, the protection of wine and/or spirit names and transitional periods for phasing out are relevant and therefore assessed in greater detail. They set out the standard of protection that the geographical indications and traditional expressions listed in the respective Annexes enjoy.

Geographical indications are defined in most agreements. The agreements on trade in wine and spirits with South Africa and Canada, and the agreements on trade in wine with Chile and Switzerland define a geographical indication as:

“an indication, including an 'Appellation of Origin', as defined in Article 22(1) of the TRIPS Agreement." 387

The EC-Australia Wine Agreement also refers to Article 22.1 of the TRIPS Agreement, but does not explicitly include "appellations of origin". 388 The latter Article reads:

"Geographical indications are, for the purposes of this Agreement, indications which identify a good as originating in the territory of a Member, or a region or locality in that territory, where a given quality, reputation or other characteristic of the goods is essentially attributable to its geographical origin."

387 See Article 3(b) of the EC-SA Wine Agreement and the EC-SA Spirits Agreement. Very similar definitions can be found in Articles 10.1 and 11.1, and 14.1 and 15.1 of the ECCanada Wine and Spirits Agreement, in Article 3(b) of Annex V of the EC-Chile AA, and in Article 3(b) of Annex 7 of the EC-Switzerland Agricultural Products Agreement. Note that the latter agreements do not include "appellation of origin" in the definition of geographical indications.

388 See Article 3(b) of the EC-Australia Wine Agreement. The four other agreements on trade in wine and/or spirits do not contain any definition. These are the agreements on trade in spirits concluded with Mexico, Switzerland and Chile as well as the agreement on trade in wine with the United States. 
According to the TRIPS Agreement, a geographical indication describes a good, the quality or reputation of which is linked to its geographical origin. The definition of a geographical indication in European Union agreements on trade in wine and/or spirits also include appellations of origin which the TRIPS Agreement itself does not refer to. Following the definition of an appellation of origin as provided for in Article 2.1 of the Lisbon Agreement, ${ }^{389}$ it becomes clear that geographical indications cover a broader range of indications than the concept of appellation of origin. Since the bilateral definitions cover both the narrower concept of an appellation of origin and the broader TRIPS definition of a geographical indication, contracting parties to agreements on trade in wine and/or spirits can benefit from the broader range of indications covered by the TRIPS definition. Hence, the EC-Australia Wine Agreement also covers "appellations of origins" as they are included in the TRIPS definition of a geographical indication. In brief, as regards the scope and structure of the agreements on trade in wine and/or spirits, as well as the definition of geographical indications, no TRIPS-plus standards could be identified.

\subsubsection{Level of Protection}

The level of protection provided for in the agreements on trade in wine and/or spirits consists of three obligations. Parties are required to a) grant mutual or reciprocal protection to geographical indications/names of origin of names for wine and/or spirits; b) provide legal means to prevent wrongful use of GIs, and c) provide appropriate legal means to ensure "additional protection".

First, the agreements on trade in wine and/or spirits concluded by the European Union generally require their partner countries to mutually or reciprocally protect the geographical indications/names of origin listed in the Annexes to the agreements.

"Contracting Parties shall take the measures necessary [...] for the reciprocal protection of the geographical indications listed in [...], which are used for the description and presentation of wines originating in the territory of the Contracting Parties." 390

Mutual or reciprocal protection of geographical indications means that both parties must protect the geographical indications listed in the Annexes of the other party without examining the eligibility of the indication according to the requirements of Article 22.1 of the TRIPS Agreement and the exceptions of Article 24 of the TRIPS Agreement. In other words, the geographical indications listed are granted "automatic"

Article 2.1 of the Lisbon Agreement sets out that an appellation of origin is "the geographical name of a country, region, or locality, which serves to designate a product originating therein, the quality and characteristics of which are due exclusively or essentially to the geographical environment, including natural and human factors."

See Article 13.2 of the EC-Australia Wine Agreement. Very similar provisions can be found in Article 4.3 of the EC-Mexico Spirits Agreement, Article 7.1 of the EC-SA Wine Agreement, Article 5.1 of the EC-SA Spirits Agreement, Article 5.1 of Annex 7 of the ECSwitzerland Agricultural Products Agreement and Article 5.3 of Annex 8 of the ECSwitzerland Agricultural Products Agreement, Article 5.1 of Annex V of the EC-Chile AA and of Annex VI of the EC-Chile AA. Note that Article 7 of the EC-US Wine Agreement does not contain the same provision, however it also requires both parties to allow certain names to be used as names of origin. In the EC-Canada Wine and Spirits Agreement, no provision on the mutual or reciprocal protection can be found. 
protection. ${ }^{391}$ Generally, the eligibility criteria under Article 22 of the TRIPS Agreement involve a verification as to whether a geographical indication complies with the definition of Article 22.1 of the TRIPS Agreement, as cited above. One must check whether the geographical indication identifies a particular geographical area and whether there is a link between the quality, reputation or other characteristics of the product and its geographical origin. In addition, it needs to be established that none of the exceptions or safeguards of Article 24.4 to 24.9 of the TRIPS Agreement applies. ${ }^{392}$ Only after establishing the fulfillment of these eligibility requirements, a geographical indication should be granted and protected under the TRIPS Agreement. The agreements on trade in wine and/or spirits concluded by the European Union go beyond this TRIPS standard by requiring protection without verifying the eligibility of the geographical indications listed in Annexes to the agreements. Admittedly, contracting parties implicitly may have performed this test when negotiating the inclusion of certain GIs into the Annexes to the agreements.

The second type of protection granted is similar to the general protection granted to all geographical indications in Article 22 of the TRIPS Agreement. According to EU agreements on trade in wine and/or spirits, the contracting parties are under an obligation to provide the legal means for interested parties to prevent the use of a

391 See D. Vivas-Eugui and C. Spennemann, "The Evolving Regime for Geographical Indications in WTO and in Free Trade Agreements" in C.M. Correa and A. Yusuf (eds.), Intellectual Property and International Trade: The TRIPS Agreement (2nd edn, Kluwer Law International, The Hague, 2008) 163-213, p. 188.

392 Article 24.4 exempts Members from having to prevent "continued and similar use of a particular indication of another Member" where that indication has been used "in a continuous manner with regard to the same or related goods or services" in the territory of that Member for at least ten years preceding 15 April 1994, or where the continuous use has been in good faith. Article 24.5 allows a trade mark to be registered and used even if it is identical or similar to a geographical indication, provided that the trade mark has been applied for, registered or rights have been acquired through use in good faith before the date of application of the TRIPS Agreement or before the identical or similar geographical indication was protected in its country of origin. For the geographical indication involved this means that the protection granted can be limited by the concurrent use of an identical or similar trade mark. Article 24.6 deals with geographical indications that have become generic in the language of the country. If an indication is identical to the term customary in common language as the common name for a good or service, a country can deny protection for this geographical indication that has become generic. An example of a generic term is Dijon for mustard, which does not only refer to the mustard produced in Dijon but denotes a certain kind of mustard, regardless of its place of production. Related to the exception of Article 24.5 is the one provided for in Article 24.7 of the TRIPS Agreement. Article 24.7 requires any request made in relation to the use or registration of a trade mark to be presented within five years after the adverse use of the protected indication has become generally known in that Member or when it has been published. This is under the condition that the geographical indication is not used or registered in bad faith. Article 24.8 stipulates that any person shall have the right to use her/his own name or the name of the person's predecessor in business if that use does not mislead the public. In other words, a country must limit the protection granted to a geographical indication if the name of a person used in the course of trade would be prejudiced. Finally, according to Article 24.9, WTO Members are not obliged to protect a geographical indication in the case that the indication has ceased to be protected in its country of origin or that it has fallen into disuse. 
geographical indication identifying wines that do not originate in the place indicated by the GI in question. ${ }^{393}$ Thus, the parties are prohibited from using geographical indications for goods that do not originate in the place indicated. The obligation in the TRIPS Agreement is similar, yet not identical. Article 22.2(a) of the TRIPS Agreement also prohibits wrongful geographical indications but only if they are used in a manner that misleads the public as to the geographical origin of the good. An example is the protected GI champagne: if used on sparkling wine not originating from the Champagne region, the public in certain countries may not be mislead about the origin of the product since the price indicates that it is not real champagne from the Champagne region in France. Yet, under the agreements on the trade in wine and/or spirits, such use is prohibited and therefore is broader than the use protected under the TRIPS Agreement.

The third obligation regards "additional protection" for GIs and is almost identical to Article 23.1 of the TRIPS Agreement. Article 23.1 of the TRIPS Agreement reads as follows:

"Each Member shall provide the legal means for interested parties to prevent use of a geographical indication identifying wines for wines not originating in the place indicated by the geographical indication in question or identifying spirits for spirits not originating in the place indicated by the geographical indication in question, even where the true origin of the goods is indicated or the geographical indication is used in translation or accompanied by expressions such as 'kind', 'types', 'style', 'imitation' or the like." 394

Article 23.1 of the TRIPS Agreement (excluding the footnote) is repeated in the agreements on trade in wine or spirits; the provisions in the bilateral agreements have been adjusted where agreements in question deal with wine or spirits only and/or with traditional expressions. ${ }^{395}$ Differences can be found with regard to the

393 See Article 13.2 second sentence of the EC-Australia Wine Agreement. Almost identical obligations are included in Article 4.3 second sentence of the EC-Mexico Spirits Agreement, Article 5.1 second sentence of Annex 7 of the EC-Switzerland Agricultural Products Agreement, and Article 5.3 second sentence of Annex 8 of the EC-Switzerland Agricultural Products Agreement. Article 5.1 second sentence of Annex V and VI of the $E C$-Chile $A A$ specify that each Party shall make use of the appropriate legal means referred to in Article 23 of the TRIPS Agreement to ensure an effective protection and prevent wrongful GIs from being used. Note that Article 7.1 of the EC-SA Wine Agreement and Article 5.1 of the EC-SA Spirits Agreement merely require legal means to ensure effective reciprocal protection. The agreements concluded with Canada and the United States do not contain this type of protection.

Footnote 4 of the TRIPS Agreement, which is attached to this provision, allows Members to provide for enforcement by administrative action instead of what Article 42 first sentence of the TRIPS Agreement stipulates.

See Articles 13.3 and 16.2 of the EC-Australia Wine Agreement, Articles 4.3 and 5 of the EC-Mexico Spirits Agreement, Article 7.3 of the EC-SA Wine Agreement, Article 5.3 of the EC-SA Spirits Agreement, Article 5.1 and 5.3 of Annex 7 of the EC-Switzerland Agricultural Products Agreement, Articles 5.3 and 6 of Annex 8 of the EC-Switzerland Agricultural Products Agreement, Article 5.1 and 5.3 of Annex V of the EC-Chile AA; Article 5.1 and 5.3 of Annex VI of the EC-Chile AA. Note that the EC-Canada Wine and Spirits Agreement in Articles 10.2 and 11.2 for wine and in Articles 14.2 and 15.2 for spirits also denies the use of geographical indications under the conditions referred to 
enumerated examples of expressions accompanying geographical indications ("such as 'kind', 'types', 'style', 'imitation' or the like"), the use of which interested parties must prevent. For example, the term "method" is added in several agreements. ${ }^{396}$ The agreements with Switzerland and Mexico do not only add the term "method", but also the term "way" as well as "other analogous expressions, including graphic symbols which may lead to confusion." 397

Although the provisions of the bilateral agreements slightly differ from Article 23.1 of the TRIPS Agreement, the main obligation is identical to the TRIPS requirement to provide legal means in order to protect against certain uses of geographical indications. There is, however, one difference worth being mentioned. The TRIPS Agreement does not specify what legal means Members must take. This discretion is taken away from contracting parties to EU agreements on trade in wine and/or spirits. For example, Article 4.1 of the EC-Mexico Spirits Agreement stipulates that:

"1. in the United Mexican States, the protected Community names:

may not be used otherwise than under the conditions laid down in the laws and regulations of the Community".

Article 4.2 of the EC-Mexico Spirits Agreement requires the same use for protected Mexican names. ${ }^{398}$ In other words, the legal system of the country from which the geographical indication originates is exported to trading partners which must protect such geographical indications according to the rules established in the country of origin. In the case of diverging rules in both countries, such a rule may lead to conflicts. Examples are the laws that regulate the relationship with trade mark protection. According to EU law, trade marks that are identical to geographical indications on wine may not be used or may only be used until 31 December 2002.399 However, the United States, for example, gives priority to pre-existing trade marks over geographical indications. A third country that has concluded bilateral agreements with both the European Union and the United States will find itself in a conflict on how to deal with the case where a European geographical indication and a

in Article 23.1 of the TRIPS Agreement, however, the agreement with Canada does not require countries to provide the legal means to prevent this use. The EC-US Wine Agreement does not provide for an obligation such as Article 23.1 of the TRIPS Agreement at all.

396 See Article 13.3 of the EC-Australia Wine Agreement, Article 7.3(c) of the EC-SA Wine Agreement, Article 5.3(c) of the EC-SA Spirits Agreement, Article 5.3(iii) of Annex V and VI of the EC-Chile $A A$, and Article 5.3 of Annex 7 of the EC-Switzerland Agricultural Products Agreement.

397 See Article 5 of the EC-Mexico Spirits Agreement and Article 6 of Annex 8 of the ECSwitzerland Agricultural Products Agreement.

398 Similar provisions can be found in Article 7.2(b) and 7.3(b) of the EC-Australia Wine Agreement, Article 7.2(a)(ii) and 7.2(b)(ii) of the EC-SA Wine Agreement, Article 5.2(a)(ii) and 5.2(b)(ii) of the EC-SA Spirits Agreement, Article 5.2 of Annex 7 of the ECSwitzerland Agricultural Products Agreement, Article 5.1 and 5.2 of Annex 8 of the ECSwitzerland Agricultural Products Agreement, Article 5.2 of Annex V of the EC-Chile AA and Annex VI of the EC-Chile AA. Note that the EC-Canada Wine and Spirits Agreement and the EC-US Wine Agreement do not contain this obligation.

399 See EC Council Regulation 1493/1999 of 17 May 1999 on the common organization of the market for wine (OJ L 179 of 14.07.1999), Annex VII, lit. F, paragraphs 1 and 2. 
trade mark originating from the United States are similar. Protecting the GI according to EU rules requires the trade mark to expire. However, this outcome seems to be contrary to bilateral obligations on the protection of trade marks incurred by a US FTA. ${ }^{400}$

To conclude, the level of protection granted to geographical indications in the agreements on trade in wine and/or spirits concluded by the European Union goes beyond the level of protection set out in the TRIPS Agreement. Requiring automatic protection for the listed GIs does not grant parties the explicit possibility of verifying their compliance with the eligibility criteria set out in the TRIPS Agreement. Parties to the agreements on trade in wine and/or spirits are obliged to prohibit the use of geographical indications for goods that do not originate in the place indicated, even if they are not used in a manner that misleads the public as to the geographical origin of the good. Finally, requiring contracting parties to protect the listed geographical indications according to the laws of the country of origin goes beyond the TRIPS Agreement.

\subsubsection{The Relationship with Trade Marks}

The general rule providing for the relationship between geographical indications and trade marks is set out in Article 23.2 of the TRIPS Agreement. Accordingly, WTO Members must refuse or invalidate trade marks for wines or spirits that contain or consist of a geographical indication if 1) the GI identifies a wine or spirit and 2) the product in question does not have this origin. Agreements on trade in wines and/or spirits repeat this obligation, however, with some divergences. Article 7 of Annex V and VI of the EC-Chile $A A$ requires that the registration of a trade mark for wines and spirits, which is identical with, or similar to, or contains a geographical indication, must be refused. One important element that is missing in this language when compared with Article 23.2 of the TRIPS Agreement is the condition that the registration of the trade mark must only be refused with respect to wines and spirits that do not have this origin indicated by the geographical indication. This condition is lacking in the EC-Chile $A A$. In other words, protection of a trade mark must also be refused in cases where the wines and spirits, for which the trade mark has been applied, originate from the region identified by the geographical indication. This interpretation stipulates a TRIPS-plus requirement.

The EC-South Africa Wine and Spirits Agreements depart even further from the obligation contained in Article 23.2 of the TRIPS Agreement. Article 7.8(a) of the ECSouth Africa Wine Agreement and Article 5.8(a) of the EC-South Africa Spirits Agreement require the parties to eliminate the trade mark and to provide for a reasonable transitional period where coexistence is possible if:

“(i) a trademark of a product of one Party is identical with, or similar to a geographical indication or other name of the other Party protected under this Agreement, and

(ii) the use of such trademarks of a product is misleading to the public as to the true place or origin of that product;" trade marks an exclusive right to prevent third parties from using identical or similar signs in the course of trade, including subsequent geographical indications. 
Even though the wording is different, trade marks that are found to be identical or similar with a geographical indication have to be invalidated after the transitional period of coexistence has expired. Similar to the provision found in the EC-Chile $A A$, the EC-South Africa Wine and Spirits Agreements do not contain the TRIPS condition that a settlement is only necessary if the wines and spirits, for which a trade mark has been registered, do not originate from the region identified by the geographical indication. However, the EC-South Africa Wine and Spirits Agreements adds a condition not stipulated in the TRIPS Agreement which limits the scope of trade marks that need to be eliminated. Paragraph (ii) of Article 7.8(a) and Article 5.8(a), respectively, add the condition that the use of the trade mark must be misleading to the public as to the true place or origin of that product. This "misleading" character is new in the "additional protection" granted to wines and spirits under the TRIPS Agreement, it can only be found in the equivalent provision that applies to all other products, not being wines and spirits. ${ }^{401}$

Another rule included in the EC-Chile $A A$ requires Chile to cancel all trade marks listed in Appendix VI and Appendix II respectively. ${ }^{402}$ More specifically, the listed trade marks must be cancelled for the internal Chilean market within twelve years, for export purposes within five years after the agreement entered into force. The trade marks for wines and spirits of small quantities must be cancelled at the date of entry into force of the EC-Chile AA. This obligation is not included in the TRIPS Agreement and therefore constitutes a TRIPS-plus feature. To sum up, the EC-Chile $A A$ and the EC-South Africa Wine and Spirits Agreements increase the protection for geographical indications beyond the level of the TRIPS Agreement by softening the conditions under which trade marks containing identical indications have to be refused or invalidated.

\subsubsection{Exceptions}

Having dealt with the protection granted to geographical indications, the focus will now shift to the exceptions contained in bilateral agreements. As mentioned above, the exceptions or safeguards recognized by the TRIPS Agreement can be found in its Articles 24.4 to 24.9.403 They concern the grandfathering of certain geographical indications (Article 24.4), trade marks registered in good faith (Article 24.5), generic geographical indications (Article 24.6), a procedural requirement for the use or registration of a trade mark (Article 24.7), the exception on a person's name (Article 24.8) and the case where protection in the country of origin of the geographical indication has ceased (Article 24.9). Bilateral agreements on trade in wine and/or spirits relate in three different ways to these exceptions: a) they explicitly preserve TRIPS exceptions; b) they explicitly give up certain exceptions; or c) they only repeat the obligation to which the exception would apply but do not provide for the exception itself.

401 See Article 22.3 of the TRIPS Agreement, which also contains the same requirement. It is very surprising that the European bilateral agreement falls back on the stricter requirements of receiving protection for geographical indications, which apply to all other products, rather than benefiting from the less stringent threshold that exists for wines and spirits in order to receive protection of geographical indications.

402 See Article 7.2 juncto Appendix VI of Annex V of the EC-Chile AA; Article 7.3 juncto Appendix II of Annex VI of the EC-Chile AA.

403 See footnote 392 of section 3.3.6.2 of this book. 
Exceptions explicitly preserved are the exceptions of Article 24.8 and 24.9 of the TRIPS Agreement: they are repeated in all agreements, except for the EC-Switzerland Agricultural Products Agreement. 404 Also Articles 24.6 and 24.7 of the TRIPS Agreement are explicitly declared applicable under the EC-Canada Wine and Spirits Agreement. ${ }^{405}$ Another rule taken up in all bilateral agreements on trade in wines and/or spirits, even though not an exception strictly speaking, is the TRIPS rule on the protection of homonymous geographical indications. ${ }^{406}$ Homonymous indications are spelled and pronounced alike but have different meanings and identify different localities from which the products originate. 407 An example is the name "Rioja" for wine which is the name of a region in Spain and in Argentina and is applied to wines from both regions. Article 23.3 of the TRIPS Agreement requires that each homonymous indication shall be protected, under the condition that their use is not misleading or deceptive under Article 22.4 of the TRIPS Agreement. In the EC-Switzerland Agricultural Products Agreement and the EC-Chile Association Agreement, this protection is not only granted to homonymous geographical indications, but also to homonymous traditional expressions. ${ }^{408}$

Agreements that explicitly give up exceptions in the TRIPS Agreement are the agreements with Mexico and Switzerland: the respective contracting parties may not apply the exceptions specified in Articles 24.4, 24.5, 24.6, and 24.7 of the TRIPS Agreement. ${ }^{409}$ In other words, geographical indications must be protected, even in those cases that are exempted in the TRIPS Agreement.

The last category of exceptions discussed here are those that are neither explicitly preserved nor given up in some agreements on trade in wines and/or spirits. An

404 See Articles 13.8 and 13.9, and 16.6 and 16.9 of the EC-Australia Wine Agreement, Articles 7 and 8 of the EC-Mexico Spirits Agreement, Article 7.6 and 7.7 of the EC-SA Wine Agreement, Article 5.6 and 5.7 of the EC-SA Spirits Agreement, and Article 34.2 of the EC-Canada Wine and Spirits Agreement. Note that only the exception of Article 24.9 is protected in Article 5.6 of Annex V and Annex VI of the EC-Chile $A A$ and in Article 12.2 of the EC-US Wine Agreement.

See Article 34.2 of the EC-Canada Wine and Spirits Agreement. Note that Article 12 of the same agreement provides for a list of GIs that Canada must cease to deem customary in its common language by the indicated date.

406 See Article 13.6 of the EC-Australia Wine Agreement, Article 6 of the EC-Mexico Spirits Agreement, Article 7.4 of the EC-SA Wine Agreement, Article 5.4 of the EC-SA Spirits Agreement, Article 5.4 of Annex 7 and Article 7 of Annex 8 of the EC-Switzerland Agricultural Products Agreement, Article 34.2 of the EC-Canada Wine and Spirits Agreement, Article 4 of Annex V and Annex VI of the EC-Chile AA; Article 12.2 of the EC-US Wine Agreement. See M. Blakeney, "Proposals for the International Regulation of Geographical Indications" The Journal of World Intellectual Property, 2001, Vol. 4 (5), 629-652, p. 643. See Article 5.5 of Annex 7 of the EC-Switzerland Agricultural Products Agreement and Article 8.5 of Annex V of the EC-Chile AA. Note that no protection is granted to homonymous traditional expressions in the EC-Australia Wine Agreement. This might be due to the fact that the latter agreement only protects traditional expressions from the European Union. Australian traditional expressions are protected and therefore may not be homonymous with European expressions either. 
example is the exception contained in Article 24.5 of the TRIPS Agreement regarding trade marks registered in good faith. Some agreements do not stipulate the exception: they repeat the general rule of the TRIPS Agreement without providing for this exception. ${ }^{410}$ Article 23.2 of the TRIPS Agreement sets out the general rule that Members must refuse or invalidate trade marks for wines or spirits that contain or consist of a geographical indication if 1) the GI identifies a wine or spirit and 2) the product in question does not have this origin. Under the TRIPS Agreement, this obligation to refuse an identical trade mark must be derogated from if a trade mark has been applied for or registered in good faith (Article 24.5 of the TRIPS Agreement). Omitting an exception contained in the TRIPS Agreement is a TRIPS-plus feature since the exception is not immediately available anymore in the context of the agreement on trade in wines and/or spirits. The same is true for the exception regarding generic terms (Article 24.6 of the TRIPS Agreement) which has been omitted in the EC-Australia Wine Agreement, the EC-Chile AA, and the South Africa Wine and Spirits Agreements.

\subsubsection{Invoking TRIPS Exceptions in a Dispute before Arbitrators Established under the EC-Australia Wine Agreement}

The question arises whether a country that is both a party to the agreement on trade in wine and spirits and the TRIPS Agreement is able to rely on the exception laid down in Article 24.5 and 24.6 of the TRIPS Agreement in case it breaches an obligation contained in the wine or spirits agreement. Let us suppose that country A and country B are bound by the EC-Australia Wine Agreement and the TRIPS Agreement. In scenario I, producer X in country B applies for the protection of a geographical indication in country A. That GI happens to be identical to a trade mark that has been registered in good faith in country A prior to the application for a GI. Country A decides not to invalidate the trade mark on the basis that it has been registered in good faith in its territory before the application of the geographical indication. It uses Article 24.5 of the TRIPS Agreement to justify this use. In scenario II, producer Y in country B applies for the protection of a GI in country A that happens to be identical to the term customary in the common language of country $\mathrm{A}$ as the common name for the same good covered by the GI. Country A decides not to grant this geographical indication protection on the basis that the term has become generic in its territory. Article 24.6 of the TRIPS Agreement provides the legal basis for this refusal to grant the GI.

As a response, country $\mathrm{B}$ initiates consultations with country A under Article 37 of the EC-Australia Wine Agreement. They eventually submit the issue to arbitration. Country B claims that country A has not fulfilled its obligation under Article 13.5, and respectively Articles 13.1, 13.2 and 13.3, of the EC-Australia Wine Agreement.

410 For the general obligations, see Article 13.5 of the EC-Australia Wine Agreement; Article 7.1 of Annex V and VI of the EC-Chile AA; Article 7.8(a) of the EC-South Africa Wine Agreement, Article 16.2(a) of the EC-South Africa Spirits Agreement. Note that the ECAustralia Wine Agreement applies the same rule for traditional expressions, see Article 16.7 of the EC-Australia Wine Agreement. Article 16.7(a) of the EC-Australia Wine Agreement, in fact, does provide the exception for trade marks registered in good faith to GIs containing a traditional expression, however not for general geographical indications. 
Country A relies as a defense on Article 24.5 and Article 24.6 respectively, of the TRIPS Agreement.

What will the arbitrators decide? After having determined that they have jurisdiction to decide the matter before them, ${ }^{411}$ they have to answer three questions. First, are the parties to the later treaty also bound by the earlier treaty? In casu, country A and country B are parties to the EC-Australia Wine Agreement, as well as Members of the WTO. Second, do both treaties deal with the same subject matter? Treaties on the same subject matter exist if there is an overlap of the ratione materiae. This can be decided upon by undertaking an "assessment of whether the fulfillment of the obligation under one treaty affects the fulfillment of the obligation of another." 412 The rules of both treaties affect the protection of geographical indications. Therefore, the answer to this question is also affirmative. ${ }^{413}$

In that case, the panel gets to the third question: does a true legal conflict exist between the provisions in the EC-Australia Wine Agreement on the one hand, and the provisions of the TRIPS Agreement on the other hand? According to Wilfred Jenks,

\begin{abstract}
"A conflict of law-making treaties arises only where simultaneous compliance with the obligations of different instruments is impossible [...]. There is no conflict if the obligations of one instrument are stricter than, but not incompatible with, those of another, or if it is possible to comply with the obligations of one instrument by refraining from exercising a privilege or discretion accorded by another." 414 [emphasis added]
\end{abstract}

In other words, only if both treaties set out obligations with which a party cannot comply simultaneously, a true legal conflict exists. The ILC Report on the Fragmentation of International Law takes a different approach. It suggests a wide notion of conflict. Accordingly, a conflict also exists where a treaty frustrates the goals of another treaty without there being any strict incompatibility between their provisions. ${ }^{415}$ An example of a broad conflict exists where an obligation in one agreement prohibits what a right in another agreement permits. Which definition of legal conflict should prevail must be determined by the judicial body addressed.

411 Article 38.1 juncto 37.1 of the EC-Australia Wine Agreement stipulate that consultations, and following arbitration, can be requested in case a contracting party has failed to fulfill an obligation under the Agreement.

See M. Koskenniemi, Fragmentation of International Law: Difficulties Arising from the Diversification and Expansion of International Law (International Law Commission of the United Nations General Assembly, Geneva, 13 April 2006) [A/CN.4/L.682], paragraph 254.

413 This is in line with the observations made in the ICL Report: the requirement of the "same subject-matter" is already fulfilled where the two treaties point in different directions on one legal question. See ibid., paragraph 23.

See W. Jenks, "The Conflict of Law-Making Treaties" British Year Book of International Law, 1953, Vol. 30, 401-453, p. 425.

415 See Koskenniemi, Fragmentation of International Law: Difficulties Arising from the Diversification and Expansion of International Law, paragraph 24. 
Looking at the provisions at issue in scenario I and II, it is clear that Article 13.5 and respectively Articles 13.1, 13.2 and 13.3 of the EC-Australia Wine Agreement are hard obligations. Article 24.6 of the TRIPS Agreement, on the other hand, states that

"Nothing in this Section shall require a Member to apply its provisions in respect of a geographical indication $[\ldots]$ of which the relevant indication is identical with the generic term."

This means that WTO Members can protect indications that contain generic names; however, they are also allowed to deny such indications protection. Following the narrow definition of conflict, the outcome of scenario II will most likely be that country A has to disregard the possibility offered by Article 24.6 of the TRIPS Agreement and apply the protection in accordance with Articles 13.1, 13.2 and 13.3 of the EC-Australia Wine Agreement. When applying the broad definition of conflict, one would find a legal conflict nevertheless.

The outcome seems to be different for scenario I since Article 24.5 of the TRIPS Agreement on trade marks registered in good faith is not permissive but mandatory.

\begin{abstract}
"Where a trade mark has been applied for or registered in good faith [...] before the geographical indication is protected in its country of origin, measures adopted to implement this Section shall not prejudice eligibility for or the validity of the registration of a trade mark" [emphasis added].
\end{abstract}

As a consequence, compliance with both obligations is not possible as Article 24.5 of the TRIPS Agreement requires the eligibility of trade marks registered in good faith, whereas Article 13.5 of the EC-Australia Wine Agreement requires the refusal of the registration of any trade mark for wines that contains or consists of a GI. Here, under both definitions of conflict, a legal conflict clearly exists.

For scenario I, and in the case of applying the broad definition of legal conflict also for scenario II, the arbitrators will have to apply conflict rules of international law in order to decide to which of the provisions they should give effect. The first source of conflict rules are the agreements themselves. The TRIPS Agreement provides for a conflict rule in the second sentence of Article 1.1. It authorizes members to grant more extensive protection than the TRIPS Agreement requires, with the qualification that such protection "does not contravene the provisions of the Agreement." This last sub-sentence limits WTO Members' ability to introduce more extensive IP protection: TRIPS-plus rules must not contravene the TRIPS Agreement. ${ }^{416}$ Arguably, a TRIPS-plus provision can contravene the TRIPS Agreement if one can point to conflicts with a mandatory TRIPS provision instead of an optional one.

Also the EC-Australia Wine Agreement contains a rule that defines its relationship with the WTO Agreement and its Annexes. This rule provides a lex specialis to the general conflict rule in Article 1.1 of the TRIPS Agreement and therefore its result prevails

416 See H. Grosse Ruse-Khan, "The International Law Relation between TRIPS and Subsequent TRIPS-plus Free Trade Agreements: Towards Safeguarding TRIPS Flexibilities?" Journal of Intellectual Property Rights, 2011, Vol. 18 (2), 325-365, p. 346. 
over the result flowing from the application of the more general TRIPS conflict norm. ${ }^{417}$ Article 34 of the EC-Australia Wine Agreement sets out:

"This Agreement shall apply without prejudice to the rights and obligations of the Contracting Parties under the WTO Agreement."

This conflict rule seems to indicate that the provisions of the EC-Australia Wine Agreement do not change the rights and obligations between the parties stemming from the WTO Agreement, including its Annexes. Whether the term "rights" used in this provision refers to safeguards, flexibilities or exceptions contained in the latter agreements seems doubtful. ${ }^{418}$ Therefore, this conflict rule should be understood as only referring to the obligations set out in the WTO Agreement and that merely such obligations should prevail over rules incorporated in the EC-Australia Wine Agreement.

As a consequence of this latter view, the conflict rule suggests that in scenario II, if the broad notion of legal conflict was followed, parties to the EC-Australia Wine Agreement may act in a manner inconsistent with their WTO flexibilities. In other words, since Article 24.6 of the TRIPS Agreement does not constitute a WTO obligation but an optional right or a flexibility, the EC-Australia Wine Agreement may require its parties to disregard such WTO rights or flexibilities. The outcome for scenario I is different. Article 24.5 of the TRIPS Agreement is a mandatory TRIPS obligation. According to the conflict rule of Article 34 of the EC-Australia Wine Agreement, Article 24.5 of the TRIPS Agreement remains unchanged and therefore still governs the relationship between the two parties. Country A can therefore rightly rely on that article in order to justify a breach of Article 13.5 of the EC-Australia Wine Agreement.

\subsubsection{Transitional Periods}

Another issue dealt with in most bilateral agreements is the phasing out of the use of certain geographical indications. In other words, the agreements specify transitional periods for the use and marketing of wines and/or spirits using geographical indications that are not in conformity with the rules of the bilateral agreement. An important transitional period is granted to the marketing of pre-existing stocks. It applies to wines or spirits that have been produced, described and presented in accordance with domestic laws before the date of entry into force of the Agreement but that are in violation of requirements in the agreement on trade in wine and/or spirits. Wines or spirits, which are described and labelled in a manner that makes use of a geographical indication protected by the Agreement, may continue to be marketed for a certain number of years.

The period of time varies slightly in the different agreements. For example, some agreements allow wines or spirits to be marketed by wholesalers for a period of one year from the entry into force of the agreement and by retailers until stocks are exhausted. ${ }^{419}$ The majority of agreements, however, permit wholesalers to market

\footnotetext{
$417 \quad$ See ibid., p. 350.

418 For an explanation why such a view is doubtful, see ibid., p. 352.

419 See Article 19 of Annex 8 of the EC-Switzerland Agricultural Products Agreement for Spirit Drinks; Article 19 of the EC-Mexico Spirits Agreement.
} 
their wines and/or spirits for a period of three years and retailers until stocks are exhausted. ${ }^{420}$ Finally, Annex 7 of the EC-Switzerland Agricultural Product Agreement on trade in wine stipulates that wines may be sold until stocks run out. ${ }^{421}$ The TRIPS Agreement does not provide rules on the marketing of pre-existing stocks but merely grants the general transitional periods of compliance with the provisions of the TRIPS Agreement.422

Marketing of pre-existing stocks is not the only area for which phasing out provisions have been foreseen in the bilateral agreements. According to the EC-South Africa Wine Agreement (and the Agreement on Trade, Development and Cooperation between the European Union and South Africa), ${ }^{423}$ South Africa agreed to phase out the use of the terms "sherry" and "port". ${ }^{24}$ Annex X of the EC-South Africa TDCA requires the marketing of "port" and "sherry" to be phased out on the South African domestic market within twelve years, products exported to the Southern African Development Community (SADC) within eight years and exports destined to other international markets within five years. For the case of exports to the European Union, no phasing out has been provided for; hence, products carrying the names "port" and "sherry" may not be marketed on the European Union's market, as from the entry into force of the agreement. These provisions have a strong impact on the South African market where "sherry" and "port" have been used for many years in a generic manner. ${ }^{425}$ In addition, South Africa also agreed to stop using specific European denominations for spirits after five years. ${ }^{426}$ These include the denominations "Grappa", “Ouzo", “Korn", "Kornbrand”, “Jägertee”, "Jagertee”, "Jagatee” and "Pacharan", as listed in Article 6(a)(iii) of the EC-South Africa Spirits Agreement.

The same denominations have been included in the EC-Canada Wine and Spirits Agreement and must be protected by the end of the transitional period of two years. ${ }^{427}$ In exchange, the European Union obliges itself to phase out the marketing of spirit drinks using the name "rye whiskey" and do not originate in Canada. ${ }^{428}$ Furthermore, the agreement concluded with Canada contains a list of wine names that are customary in the common language of Canada and which will cease to be deemed generic under Article 24.6 of the TRIPS Agreement after a certain period of time. Transitional periods have been prescribed for each wine name listed in Article 12 of the EC-Canada Wine and Spirits Agreement, during which the names can still be used in a generic manner. The wine names Bordeaux, Chianti, Claret, Madeira, Malaga, Agreement, Article 36.1(b) of the EC-Canada Wine and Spirits Agreement, Article 34 of Annex V and Article 21 of Annex VI of the EC-Chile AA. Article 40(b)(I) of the ECAustralia Wine Agreement grants a period of five years to liqueur wines and a period of three years to other wines.

See Article 28.1 of Annex 7 of the EC-Switzerland Agricultural Products Agreement.

See Article 65 of the TRIPS Agreement.

See footnote 325 of section 3.3.1 of this book.

See Article 9 of the EC-SA Wine Agreement which refers to the transitional provisions referred to in Annex X of the EC-SA TDCA.

See Vivas-Eugui and Spennemann, "The Evolving Regime for Geographical Indications", p. 198.

See Article 7 of the EC-SA Spirits Agreement.

See Article 17.1 of the EC-Canada Wine and Spirits Agreement.

See Article 17.2 of the EC-Canada Wine and Spirits Agreement. 
Marsala, Medoc, Médoc, Mosel and Moselle must not be deemed customary in the common language of Canada after the entry into force of the Agreement; the wine names Bourgogne, Burgundy, Rhin, Rhine, Sauterne and Sauternes by 31 December 2008; and the wine names Chablis, Champagne, Port, Porto and Sherry by 31 December 2013.

Also the EC-Australia Wine Agreement prohibits Australia from using the following geographical indications for wine in Australia and third countries after the period of twelve months from the entry into force of the Agreement: Burgundy, Chablis, Champagne, Graves, Manzanilla, Marsala, Moselle, Port, Sauterne, Sherry and White Burgundy. ${ }^{429}$ The Hungarian geographical indication Tokay may be used for another ten years after entry into force of the Agreement. ${ }^{430}$ To sum up, European agreements on trade in wine and/or spirits provide detailed time schedules as to how long certain geographical indications 1) may be marketed by wholesalers and retailers, 2) may be used on the internal and export markets of the trading partner and 3) may still be deemed a generic term. These rules address specific GIs, the clear majority of which are GIs originating in the European Union. Although the TRIPS Agreement does not deal with specific geographical indications, there is a significant imbalance between the amount of protected names that originates from the EU and those originating in the trading partner's territory.

\subsubsection{Protection of Traditional Expressions}

The last issue that regards the scope of protection of some wine and/or spirits agreements concerns the protection that is granted to traditional expressions in addition to geographical indications. Traditional expressions are protected in the ECAustralia Wine Agreement, the EC-Chile Association Agreement, the EC-Switzerland Agricultural Products Agreement and the EC-US Wine Agreement. ${ }^{431}$ They are defined in a slightly different manner in the agreements with Australia and Switzerland on the one hand, and with Chile on the other hand. Article 3(c) of the EC-Australia Wine Agreement reads as follows:

“'traditional expression' shall mean a traditionally used name referring in particular to the method of production or to the quality, colour or type of a wine, which is recognized in the laws and regulations of the Community for the purpose of the description and presentation of a wine originating in the territory of the Community."

See Article 15(a) of the EC-Australia Wine Agreement.

See Article 15(b) of the EC-Australia Wine Agreement.

The EC-US Wine Agreement does not use the terminology usually found in the agreements on trade in wine and/or spirits concluded by the European Union. For that reason, one does not find any reference to traditional expressions in the EC-US Wine Agreement. However, in the list of semi-generic terms in Annex II to the Agreement, a few terms are included that in the other wine agreements are listed as traditional expressions, for example "Hock" and "Claret". In addition, according to the official website of the USTR on the EC-US Wine Agreement concluded, the terms mentioned in Appendix I, Article 1 constitute European traditional expressions that may be used for United States labels under certain conditions. The terms listed here are chateau, classic, clos, cream, crusted/crusting, fine, late bottled vintage, noble, ruby, superior, sur lie, tawny, vintage and vintage character. See US Department of the Treasury, US/EC Wine Agreement Q\&A's (2006), available at <http://www.ttb.gov/wine/itd_qas.shtml> accessed on 21.11.2012. 
This definition is essentially the same as the one found in Article 3(c) of Annex 7 of the EC-Switzerland Agricultural Products Agreement. The definition in the EC-Chile Association Agreement distinguishes itself to some extent:

“'traditional expression' means a name traditionally used to refer, in particular, to the production or ageing method or the quality, colour, type of place, or a particular event linked to the history of the product concerned of wine that is recognized by the laws and regulations of a Party for describing and presenting a product originating in that Party." 432

This last definition contained in the EC-Chile $A A$ is broader than the one in the agreements with Australia and Switzerland; it includes more characteristics that qualify as being traditional, such as the ageing method, the type of place or a particular event linked to the history of the wine.

The traditional expressions protected are listed in Annex III to the agreement with Australia, in Appendix 2 to Annex 7 to the agreement with Switzerland, in Annex III and IV to the agreement with Chile and in Appendix 1 to the agreement with the United States. The number of traditional expressions usually protected by the European Union is immense; some examples are Eiswein, Spätlese, Premier cru, Grand cru, Lagrima, Amarone, Auslese, Ruby, Tawny and Vintage. Switzerland has included terms such as Dorin, Bondola, Schiller and Landwein; Chile protects traditional expressions such as Chateau, Reserva o Reservas and Noble; Australia does not protect any traditional expression. The protection granted to the listed traditional expressions is in fact the same as the protection prescribed for geographical indications. ${ }^{433}$

The obligation to protect traditional expressions is a TRIPS-plus obligation. The TRIPS Agreement does not include any provision on the protection of traditional expressions, neither are they covered by the provisions on the protection of geographical indications. Geographical indications indicate a geographical area; traditional expressions, however, describe certain production or ageing methods. Any producer can use the traditional expression if (s)he follows the specific harvesting requirements; the location where the producer is located does not play a role. 434 European agreements were criticized for having included the protection of traditional expressions since, on the multilateral level, the international community has not yet

Article 3(c) of Annex $\mathrm{V}$ of the EC-Chile $A$ A.

433 See also Article 6 juncto Article 5 of Annex 7 of the EC-Switzerland Agricultural Products Agreement, Articles 8-10 of Annex V of the EC-Chile AA. Note that Article 16 of the EC-Australia Wine Agreement differs from the equivalent provisions in the agreements with Switzerland and Chile. Article 16.2 sets out additional protection for traditional expressions (instead of general protection). Paragraph 5 allows for the use of identical or similar traditional expressions if not misleading, the origin mentioned and not constituting unfair competition. Importantly, trade marks registered or used in good faith before the signature of the agreement may continue to be used. See paragraph 7 and 8 of Article 16.

434 See also Vivas-Eugui and Spennemann, "The Evolving Regime for Geographical Indications", p. 191. 
agreed on how to protect traditional expressions; there is no multilateral treaty that recognizes traditional expressions specifically. ${ }^{435}$

\subsubsection{Interim Conclusions}

The protection for geographical indications and traditional expressions constitutes a unique area of IP protection in European bilateral agreements. First, it is the only area that is addressed individually by bilateral agreements. The agreements on trade in wine and/or spirits mainly deal with GI protection, to the exclusion of any other area of intellectual property. Second, the level of protection granted to GIs is one of the few areas of IP protection where standards of protection have been included that go beyond the TRIPS Agreement. This is particularly so with regard to the protection granted to GIs for wines and spirits, the softened conditions for identical trade marks to be refused or invalidated, the explicit non-applicability or the lack of TRIPS exceptions and with regard to the protection for traditional expressions. Third, the geographical indications and traditional expressions originating from the European Union far outweigh those listed by its trading partners. It shows a significant imbalance between the protection received by the EU and those received by its trading partners. Overall, the approach followed by the European Union in this area can be classified as securing offensive interests of the European Union. It is the only area in pre-2006 bilateral agreements in which the European Union asked for higher standards than the United States.

\subsubsection{Enforcement Provisions}

The bilateral trade agreements concluded by the European Union before 2006 do not contain specific provisions dealing with the enforcement of intellectual property. Similar to the individual intellectual property regimes, compliance with particular standards is achieved by the multilateral approach of demanding accession to multilateral treaties. For example, the TRIPS Agreement, the WCT and the WPPT set out enforcement standards that must be applied to the areas of intellectual property protection dealt with in the respective agreement. To conclude, this absolute lack of specific enforcement provisions in European bilateral trade agreements concluded up until 2006 is not only in stark contrast with the enforcement provisions in US FTAs but maybe more importantly with the new EU policy of protecting and enforcing intellectual property in third countries. ${ }^{436}$ The enforcement of intellectual property rights has become a priority area for bilateral negotiations conducted since 2006.

\subsubsection{Conclusions}

European Union bilateral trade agreements concluded before 2006 contain only a few provisions on intellectual property protection, an exception being the agreements on trade in wine and/or spirits. Instead of identifying specific obligations for different fields of intellectual property protection, European bilateral trade agreements refer to standards of protection indirectly, by setting out a list of multilateral agreements with

435 See M. Santa Cruz, Intellectual Property Provisions in European Union Trade Agreements: Implications for Developing Countries (ICTSD Intellectual Property and Sustainable Development Series, Geneva, 2007) [Issue Paper No. 20], p. 14.

436 See Chapter 4 : The European Union's Intellectual Property Policy in Third Countries since the TRIPS Agreement: A Shift towards a Tough Approach. 
which negotiating partners need to comply or accede to. Compared with the United States, the European Union overall has integrated modest standards of IP protection in its bilateral trade agreements. There is a lack of data on the characteristics of the IP negotiations carried out by the European Union in bilateral agreements before 2006; therefore, no comparisons can be made with the way the United States negotiates its FTAs.

The general and enforcement provisions contained in European bilateral trade agreements as well as the general level of IP protection sought from trading partners mainly reflect the level of protection prescribed by the TRIPS Agreement. Some of the few TRIPS-plus provisions concern the inclusion of the protection of databases and utility models into the definition of IP, the requirement to accede to the WCT, the WPPT and the UPOV Convention, Act 1991, and the level of protection asked from (potential) candidates for accession, which must be similar to the protection guaranteed within the European Union. Therefore, the standard of protection sought in EU agreements concluded up until 2006 remains well behind the protection achieved through US FTAs. One exception is the protection for geographical indications and traditional expressions which constitutes a unique area of IP protection in European bilateral agreements. The approach followed by the European Union in this area can be classified as securing offensive interests of the European Union. It is the only area in which the European Union requires a higher level of protection than United States.

\subsection{Free Trade AgreEMENTS ConCLUded by OtHers}

In addition to the United States and the European Union, two other important actors also require a high level of intellectual property protection in the bilateral agreements that they conclude with other countries. These are the European Free Trade Association (EFTA) and Japan. It goes beyond the scope of this book to analyze these agreements to the same extent as has been done in the case of the United States and the European Union. However, the following analysis presents an overview of the countries with which EFTA States and Japan have concluded agreements and what kind of TRIPS-plus provisions they usually include.

\subsubsection{Free Trade Agreements by EFTA States}

The agreements that EFTA has concluded with its trading partners are free trade agreements, covering trade in goods, trade in services, the protection of intellectual property rights, public procurement, investment, technical assistance and institutional and procedural provisions. The following table gives an overview of the countries with which EFTA States have concluded free trade agreements up until October 2012.437

437 Note that the recently concluded EFTA-Canada FTA does not contain any provision dealing with intellectual property rights. 
Table 5: EFTA FTAs already concluded or under negotiations until October 2012

\begin{tabular}{|c|c|c|c|}
\hline Partner country & Date of signature & Date of entry into force & Starting date of negotiations \\
\hline Turkey & 10 December 1991 & 1 April 1992 & \\
\hline Israel & 17 September 1992 & 1 January 1993 & \\
\hline Morocco & 19 June 1997 & 1 December 1999 & \\
\hline $\begin{array}{l}\text { Palestinian } \\
\text { Authority }\end{array}$ & 30 November 1998 & 1 July 1999 & \\
\hline Macedonia & 19 June 2000 & 1 May 2002 & \\
\hline Mexico & 27 November 2000 & 1 July 2001 & \\
\hline Croatia & 21 June 2001 & 1 April 2002 & \\
\hline Jordan & 21 June 2001 & 1 September 2002 & \\
\hline Singapore & 26 June 2002 & 1 January 2003 & \\
\hline Chile & 26 June 2003 & 1 December 2004 & \\
\hline Lebanon & 24 June 2004 & 1 January 2007 & \\
\hline Tunisia & 17 December 2004 & 1 June 2005 & \\
\hline South Korea & 15 December 2005 & 1 September 2006 & \\
\hline SACU & 26 June 2006 & 1 May 2008 & \\
\hline Egypt & 27 January 2007 & 1 August 2007 & \\
\hline Canada & 26 January 2008 & 1 July 2009 & \\
\hline Colombia & 25 November 2008 & $\begin{array}{l}1 \text { July } 2011 \text { for Colombia, } \\
\text { Liechtenstein and Switzerland }\end{array}$ & \\
\hline $\begin{array}{l}\text { Gulf Cooperation } \\
\text { Council }\end{array}$ & 22 June 2009 & pending & \\
\hline Serbia & 17 September 2009 & $\begin{array}{l}1 \text { October } 2010 \text { for Serbia, } \\
\text { Liechtenstein and Switzerland; } \\
1 \text { June } 2011 \text { for Norway; } \\
1 \text { October } 2011 \text { for Iceland }\end{array}$ & \\
\hline Albania & 17 December 2009 & $\begin{array}{l}1 \text { November } 2010 \text { for Albania, } \\
\text { Liechtenstein and Switzerland; } \\
1 \text { August } 2011 \text { for Norway; } \\
1 \text { October } 2011 \text { for Iceland }\end{array}$ & \\
\hline Peru & 24 June 2010 & $\begin{array}{l}1 \text { July } 2011 \text { for Peru, } \\
\text { Liechtenstein and Switzerland; } \\
1 \text { July } 2012 \text { for Norway } \\
\end{array}$ & \\
\hline Ukraine & 24 June 2010 & 1 June 2012 & \\
\hline Hong Kong, China & 21 June 2011 & pending & \\
\hline Montenegro & 14 November 2011 & pending & \\
\hline India & & & 6 October 2008 \\
\hline $\begin{array}{l}\text { Russia, Belarus, } \\
\text { Kazakhstan } \\
\end{array}$ & & & 14 January 2011 \\
\hline Indonesia & & & 31 January 2011 \\
\hline $\begin{array}{l}\text { Bosnia and } \\
\text { Herzegovina }\end{array}$ & & & 28 March 2011 \\
\hline Central America & & & 2 March 2012 \\
\hline Vietnam & & & 3 July 2012 \\
\hline
\end{tabular}

Source: EFTA website, Free Trade (2012) 438

The IP provisions in the agreements concluded by EFTA follow an approach that combines the multilateral approach typical for European Union bilateral trade

438 The data collected here was obtained from the EFTA website, EFTA Secretariat, Free Trade (2012), available at <http://www.efta.int/free-trade.aspx > accessed on 15.11.2012. 
agreements with the inclusion of substantive provisions in different areas of intellectual property protection. However, the specific rules dealing with the individual areas of IP do not have the same scope and level of detail as the IP chapters contained in US FTAs. One of the more recent agreements, the EFTAColombia FTA, ${ }^{439}$ contains eighteen articles which extend over twelve pages. The general structure of EFTA agreements is similar to that used in United States FTAs. They deal with a) general matters, b) individual areas of intellectual property protection, and c) enforcement provisions.

With regard to the general provisions, all agreements contain the obligation to

"grant and ensure an adequate, effective protection and non-discriminatory protection of intellectual property rights, and provide for measures for the enforcement of such rights against infringement thereof." 440

Some agreements contain the additional element that this protection must be "in accordance with international standards." ${ }^{441}$ These requirements are very similar to what some European Union bilateral trade agreements contain. As argued above, ${ }^{442}$ such a requirement goes beyond the level of protection set out in the TRIPS Agreement.

Another general provision regards the list of multilateral agreements to which the parties to the agreement either are already parties and the obligations of which they reaffirm, or to which they shall become a party by a particular date. The contracting parties to EFTA FTAs generally reaffirm the obligations of the TRIPS Agreement, the Paris Convention, the Berne Convention and the Rome Convention.443 Furthermore, many trading partners of EFTA agree to ratify or accede to the following agreements: the WCT, the WPPT, the PCT, the Nice Agreement, the UPOV Convention (either its 1978 Act or its 1991 Act), the Budapest Treaty, the Madrid Protocol and the Geneva Act of the Hague Agreement. ${ }^{444}$ An exception to this is the FTA concluded with Hong Kong,

Free Trade Agreement between the Republic of Colombia and the EFTA States, signed on 25 November 2008 and entered into force on 1 July 2011, see ibid. See Article 6.1.1 of the EFTA-Colombia FTA and EFTA-Peru FTA. For almost identical provisions, see Article 24.1 of the EFTA-Serbia FTA; Article 5.1 of the EFTA-Ukraine FTA and EFTA-Hong Kong FTA; Article 23.1 of the EFTA-Montenegro FTA.

441 See Article 1.1.2(e) of the EFTA-Korea FTA; Article 1.2(f) of the EFTA-Singapore FTA. Note that Article 1.2(f) of the EFTA-Mexico FTA and Article 15.1 of the EFTA-PA FTA contain a reference to the "highest international standards."

442 See section 3.3.5 on the general level of protection in pre-2006 European agreements.

443 See Article 6.4.1 of the EFTA-Colombia FTA and the EFTA-Peru FTA; Article 2.1(a) of Annex VI of the EFTA-Serbia FTA. Note that previous agreements did not reaffirm the obligations of the Rome Convention, see Article 2.1 of the Annex VI of the EFTAJordan FTA and of the Annex XII of the EFTA-Singapore FTA and of the Annex V of the EFTA-Tunisia FTA. Note that Ukraine and Montenegro also reaffirm the obligations of the PCT, the Budapest Treaty, the Nice Agreement and the Madrid Protocol. See Article 2.1 of the EFTA-Ukraine FTA and the EFTA-Montenegro FTA.

444 See Article 2.2 and 2.3 of Annex V of the EFTA-Morocco FTA; Article 2.2, 2.3 and 2.4 of Annex XII of the EFTA-Chile FTA; Article 2.2 and 2.3 of Annex V of the EFTATunisia FTA; Article 2.1 and 2.3 of Annex VI of the EFTA-Serbia FTA and of the EFTA-Montenegro FTA; Article 2.1 and 2.2 of Annex XIII of the EFTA-Ukraine FTA. 
China: the contracting parties agree to comply with the substantive provisions of the Paris Convention, the Berne Convention, the Rome Convention, the WCT, the WPPT, the PCT, the Nice Agreement, the UPOV Convention (either its 1978 Act or its 1991 Act) and the Budapest Treaty. ${ }^{445}$ Thereby, EFTA States and Hong Kong, China do not undertake commitments with regard to the Madrid Protocol and the Geneva Act of the Hague Agreement.

Requiring the ratification of or the accession to the listed multilateral treaties resembles the approach followed by the European Union. It is, among others, through the adherence to the standards of protection set out in these treaties that EFTA States achieve a specific level of protection. In contrast to the European Union, the IP chapters of EFTA agreements ask for some additional commitments in individual IP areas. These areas are the protection granted to patents, to undisclosed information, designs and geographical indications. In addition, one finds provisions dealing with the acquisition and maintenance of intellectual property rights and the enforcement of intellectual property rights. Several of these provisions go beyond the standards that the TRIPS Agreement stipulates. Three examples of such TRIPS-plus provisions are addressed in the following.

The first example regards the protection of undisclosed information. As mentioned above, ${ }^{446}$ the TRIPS Agreement in its Article 39.3 does not require data exclusivity for a specified period of time but protects undisclosed data against unfair competition. ${ }^{447}$ Several agreements concluded by EFTA prevent applicants, when applying for marketing approval for their pharmaceutical products, from relying on the undisclosed data submitted by prior applicants for a period of at least five years, ${ }^{448}$ in recent agreements even eight years. ${ }^{449}$ The requirement to protect data for five years is identical to most provisions in free trade agreements concluded by the United States and is of a TRIPS-plus nature.

Second, the duration of protection for design rights is expanded considerably by EFTA free trade agreements compared to the TRIPS Agreement. Article 26.3 of the latter requires countries to protect industrial designs for at least ten years. EFTA FTAs protect design rights at least for a period of fifteen years, ${ }^{450}$ the most recent

Note that Article 6.4.4 and 6.4.5 of the EU-Colombia FTA and the EU-Peru FTA only require contracting parties to adhere as soon as possible to the Geneva Act of the Hague Agreement and the Madrid Protocol.

See Article 2.2 of Annex XII of the EFTA-Hong Kong FTA.

See section 3.2.4.1 of this book.

For a detailed analysis of the difference, see section 3.2.4.1 on US free trade agreements.

See Article 4 of Annex V of the EFTA-Tunisia FTA; Article 4.2 of Annex XII of the EFTA-Chile FTA; Article 6.11.2 of the EFTA-Colombia FTA and the EFTA-Peru FTA; Article 5.2 of Annex XIII of the EFTA-Ukraine FTA. Note that Article 4 of Annex V of the EFTA-Lebanon FTA requires data exclusivity for a period of six years.

See Article 4.2 of Annex XII of the EFTA-Hong Kong FTA; Article 5.2 of Annex VI of the EFTA-Serbia FTA; Article 6.2 of Annex VI of the EFTA-Montenegro FTA.

See Article 5 of Annex XII of the EFTA-Chile FTA; Article 4 of Annex XIII of the EFTA-Korea FTA; Article 3(a) of Annex V of the EFTA-Egypt FTA. Note that Article 5 of Annex $\mathrm{V}$ of the EFTA-Lebanon FTA requires the protection of industrial designs for twenty-five years. 
agreements even for twenty-five years. ${ }^{451}$ United States FTAs do not set out specific obligations with regard to the protection of design rights. Therefore, this kind of TRIPS-plus provision is unprecedented.

The last example of a TRIPS-plus provision relates to the protection of geographical indications. While Articles 23 and 24 of the TRIPS Agreement merely require the protection of geographical indications that identify goods, most FTAs concluded by EFTA demand the protection of geographical indications that identify both goods and services. ${ }^{452}$ In addition, the more recent FTAs concluded by EFTA also protect indications of source for goods and services. ${ }^{453}$ The concept of an indication of source is broader than a geographical indication: it does not require the indication to relate to a given quality, reputation or other characteristic of the good which is essentially attributable to its geographical origin. Indications of sources merely require that the product originates in a certain geographical area. By broadening the scope of products to which the protection of geographical indications must apply and by requiring the protection of a broader type of indications, the protection goes beyond the TRIPS standard.

The final provision assessed here addresses the protection of biodiversity and traditional knowledge (TK). It is a new feature which so far has only been included in the EFTA-Colombia FTA and the EFTA-Peru FTA. Even though the TRIPS Agreement does not provide for any rule on this subject matter, the provision is not a TRIPS-plus provision in the sense that it strengthens the protection set out therein, but rather a provision that broadens flexibilities contained in the TRIPS Agreement. 454 It is remarkable that a bilateral agreement provides for certain obligations in that regard, since the international community has not yet agreed on how to address the possible conflict between patent protection on the one hand and the protection of biodiversity and traditional knowledge on the other hand. ${ }^{455}$ Having said that, the recent agreement concluded between the European Union and Colombia and Peru also addresses this subject matter. ${ }^{456}$ The EFTA provision stands out in the sense that

451 See Article 6 of Annex XIII of the EFTA-Ukraine FTA; Article 6 of the Annex VI of the EFTA-Serbia FTA; Article 6.1 of Annex XII of the EFTA-Hong Kong FTA; Article 7 of Annex VI of the EFTA-Montenegro FTA. An exception is Article 6.10 of the EFTA-Colombia FTA and the EFTA-Peru FTA which require an adequate term of protection for designs.

452 See Article 5 of Annex XII of the EFTA-Singapore FTA; Article 3 of Annex VI of the EFTA-Jordan FTA; Article 3 of Annex V of the EFTA-Morocco FTA; Article 7.1 of Annex VI of the EFTA-Serbia FTA.

453 See Article 6.7 of the EFTA-Colombia FTA and EFTA-Peru FTA; Article 7bis of Annex XIII of the EFTA-Ukraine FTA; Article 8.1 of Annex VI of the EFTAMontenegro FTA; Article 7.1 of Annex VI of the EFTA-Serbia FTA; Article 9.1 of Annex XII of the EFTA-Hong Kong FTA. See section 1.2 of this book for a general discussion on the difference between TRIPSplus provisions and provisions that broaden flexibilities.

455 See the discussion going on in the WIPO Intergovernmental Committee on Intellectual Property and Genetic Resources, Traditional Knowledge and Folklore and the Doha Development Round. See also sections 5.3.2.8 and 6.3.7 of this book for an overview of the conflict.

456 See Article 201 of the EU-Colombia-Peru FTA. Note that the CARIFORUM-EC EPA also contains certain rules in that regard, as well as the draft IP chapter of the India-EU 
it contains more far reaching obligations than the equivalent provisions in the EUColombia-Peru FTA. Article 6.5.4 of the EFTA-Colombia FTA and the EFTA-Peru FTA requires patent applicants to submit a declaration of the origin or source of the genetic resource, of which the invention makes use. ${ }^{457}$ In addition, contracting parties must provide for administrative, civil or criminal sanctions if the inventor or patent applicant willfully makes a wrongful or misleading declaration of origin or source. ${ }^{458}$ Articles 201.7 and 201.8 of the EU-Colombia-Peru FTA, on the other hand, merely acknowledge the usefulness of requiring the disclosure of the origin or source of genetic resources and require parties to provide for applicable effects so as to support compliance with the provisions regulating access to genetic resources and associated traditional knowledge. 459

In conclusion, the IP provisions in the agreements concluded by EFTA States go beyond the TRIPS Agreement in several aspects. They combine elements usually used by the United States with the approach typically followed by the European Union in its pre-2006 bilateral trade agreements. Strong protection is required for undisclosed information, similar to that contained in US FTAs. At the same time, EFTA agreements also contain TRIPS-plus provisions in areas not addressed by United States free trade agreements, such as the protection of geographical indications and design rights. The standards of protection have become more stringent in more recent agreements, a development which has also been observed in United States FTAs and was classified as an aggressive feature. On the other hand, EFTA agreements resemble European Union bilateral trade agreements in that they set out similarly extensive lists of multilateral treaties to which contracting parties must accede. Finally, a new feature in EFTA agreements is the protection of biodiversity and traditional knowledge, which is also addressed in some recent bilateral trade agreements concluded by the European Union.

\subsubsection{Free Trade Agreements Concluded by Japan}

Another important player that so far has not been mentioned is Japan. Japan in fact has already concluded a number of agreements that include extensive intellectual property chapters. Such agreements exist above all with the countries that are Member States of the Association of Southeast Asian Nations (ASEAN). Economic Partnership Agreements have been concluded with Thailand, Singapore, Philippines, Malaysia, Indonesia and Brunei between 2005 and 2007 and most of them include a chapter on intellectual property protection. ${ }^{460}$ Next to the Member States of ASEAN, Japan has also concluded agreements with Chile, India, Mexico, Peru, Switzerland and Vietnam. Negotiations for economic partnership agreements are ongoing with

$B T L A$, as proposed by India. See Article 150 of the CARIFORUM-EC EPA and Article 10 of the draft IP chapter of the India-EU BTIA, as proposed by India.

Note that this obligation does not include the fulfillment of a prior informed consent; parties will only require a prior informed consent as far as provided for in their national legislation.

See Article 6.5.6 of the EFTA-Colombia FTA and the EFTA-Peru FTA.

See section 6.3 .7 of this book for an assessment of the provisions contained in the $E U$ Colombia-Peru FTA and the draft IP chapter of the India-EU BTLA. intellectual property, not an entire chapter. 
Australia, the Gulf Cooperation Council and Mongolia. ${ }^{461}$ While the early agreements with Chile and Mexico do not present a consistent structure of dealing with intellectual property issues, recent agreements concluded with the Member States of ASEAN, Switzerland, Vietnam, Peru and India do.

The agreements concluded with ASEAN Member States contain very similar provisions: 1) general provisions such as those addressing definitions, national treatment and most-favoured-nation treatment obligations, streamlining and harmonization of procedural matters, transparency and the promotion of public awareness; 2) provisions relating to individual intellectual property regimes, such as patents, industrial designs, copyright and related rights, trade mark for goods and services, geographical indications, new varieties of plants, the protection of undisclosed information and internet service providers; 3) unfair competition and enforcement provisions; and 4) institutional provisions on the Sub-Committee for intellectual property that is set up by the agreements. ${ }^{462}$

The TRIPS-plus provisions contained in Japanese FTAs are not abundant. The EPA concluded with Switzerland is an exception as it contains several TRIPS-plus features. ${ }^{463}$ In general, recent agreements increase the protection beyond the level set in the TRIPS Agreement in the areas plant variety protection and the liability of Internet service providers. New plant varieties must be protected according to the protection granted by the UPOV Convention, Act 1991.464 The liability of Internet service providers must be limited and right holders are entitled to obtain information on the identity of the alleged infringer. 465

In summary, Japanese agreements have gone through a noticeable development. The Japan-Mexico EPA did not yet contain any provision on the protection of intellectual property. In contrast, recent agreements with ASEAN Member States, Vietnam, Switzerland and Peru contain comprehensive chapters on the protection of intellectual property, including some TRIPS-plus features in the areas of plant variety protection and the liability of internet service providers. Future agreements are very likely to follow this development and further increase the scope and extent of

461 Note that the negotiations with South Korea have been suspended. See Ministry of Foreign Affairs of Japan, Free Trade Agreement (FTA) and Economic Partnership Agreement (EPA) (2012), available at <http://www.mofa.go.jp/policy/economy/fta/index.html> accessed on 16.11.2012.

462 Note that the Japan-India EPA does not contain provisions on the national and mostfavoured-nation treatment obligation, industrial designs, copyright and related rights, new varieties of plants, the protection of undisclosed information, internet service providers, enforcement and institutional matters.

463 For example, Article 107 contains a list of multilateral treaties with which the contracting parties must comply and a commitment to accede to or ratify the PLT, the Singapore Treaty and the Geneva Act of the Hague Agreement. In the area of design protection, Article 116.4 of the Japan-Switzerland EPA increases the duration of protection to at least twenty years. See also GRAIN, Japan Digs its Claws into Biodiversity through FTAs (GRAIN, Against the Grain, Geneva, 2007), p. 1.

464 See Article 116 of the Japan-Indonesia EPA; Article 90 of the Japan-Vietnam EPA; Article 118 of the Japan-Switzerland EPA. Note that the agreements with Peru and India do not contain any obligation with regard to the protection of plant varieties.

465 See Article 126 of the Japan-Switzerland EPA; Article 185 of the Japan-Peru EPA. 
TRIPS-plus provisions provided for. The Japan-Switzerland EPA already provides an example of more far-reaching provisions than other agreements. Still, the IP chapters of Japanese EPAs are not comparable to the provisions contained in US FTAs and even EFTA agreements which show much more aggressive features than Japanese EPAs.

\subsection{CONCLUSIONS}

Since the establishment of the TRIPS Agreement, particularly developed countries have sought to include TRIPS-plus provisions at various levels and in different forums. Both bilateral, plurilateral and multilateral treaties contain protection that goes beyond the level agreed upon in the TRIPS Agreement. Some efforts to set TRIPS-plus standards have been more successful than others. Very successful examples of multilateral standard setting beyond the TRIPS level are the WIPO Internet Treaties which have been widely adopted by WIPO Members. WIPO's efforts to harmonize substantive patent law, on the other hand, seem to have failed. The future of the plurilateral Anti-Counterfeiting Trade Agreement is still uncertain as protests by citizens and parliamentarian opposition continue to jeopardize the domestic ratification processes in the European Union as well as European and other signatory parties. Without doubt, bilateral trade agreements concluded by the main actors have been incredibly successful in setting TRIPS-plus provisions.

The United States is by far the most aggressive actor in bilateral negotiations on intellectual property protection. Not only the content of the IP chapter in its FTAs, but also its style of negotiations and the legal method used for the IP chapter are not comparable with the approach of any of the other major actors, such as the European Union, Japan and EFTA. The IP chapter contained in US FTAs sets out the highest standards of IP protection in all areas of IP covered by the TRIPS Agreement, no other international agreement, not even ACTA or the WIPO Internet Treaties, reach this standard. The provisions relating to the protection of public health and to the access to digital works have been described as the most far-reaching obligations. But also the rules on patent protection for plants and animals and the enforcement provisions hardly leave any room for choosing the appropriate method of implementing the FTA provisions in the domestic legal systems of its trading partners. Moreover, obligations have become stricter, such as the list of international agreements to which negotiating partners need to accede to or make best efforts to do so.

European Union bilateral trade agreements concluded before 2006 contain only a few provisions on intellectual property protection, an exception being the agreements on trade in wine and/or spirits. Instead of identifying specific obligations for different fields of intellectual property protection, European bilateral trade agreements refer to standards of protection indirectly by setting out a list of multilateral agreements with which negotiating partners need to comply or accede to. Compared with the United States, the European Union has integrated modest standards of IP protection into its bilateral trade agreements. One exception is the protection for geographical indications and traditional expressions, which constitutes a unique area of IP protection in European bilateral agreements. The approach followed by the European Union in this area can be classified as securing offensive interests of the 
European Union. It is the only area in which European Union agreements concluded before 2006 require a higher level of protection than the United States.

Also EFTA States and Japan emphasize the protection of intellectual property in their bilateral trade agreements. The protection sought goes beyond the TRIPS Agreement in certain aspects. However, compared with the approach followed by the United States, the IP provisions in EFTA and Japan BTAs are still relatively modest.

These findings show that the latest phase of the proliferation of bilateral trade agreements stands out, in so far as the agreements contain far-reaching standards of intellectual property protection. Particularly the protection included in US FTAs as well as the way negotiations are led contain aggressive features. It has been suggested by Peter Drahos and Ruth Okedij that the latest phase should be seen as part of the broader development of alternating phases of unilateral, bilateral, regional and multilateral protection. ${ }^{466}$ However, while it may be true that this multitude of bilateral IP obligations may be succeeded by a multilateral treaty, I would argue that the current phase would be classified better as exceptional.

First, the various IP obligations that the major actors have included in recent bilateral trade agreements are not identical. There is no uniform "TRIPS-plus" approach that could be multilateralized. The various TRIPS-plus provisions do not only differ from each other, they also create legal conflicts. An example are the rules on the protection of geographical indications in European Union agreements on trade in wine and/or spirits on the one hand, and the protection of trade marks required by United States FTAs on the other hand. In the case where a trade mark is identical to, or similar to, or contains a geographical indication, European Union agreements on trade in wine and/or spirits require contracting parties to refuse such a trade mark or to cancel out the use of trade marks already registered.467 United States free trade agreements, however, require the geographical indication to be refused if it is likely to cause confusion with a trade mark that is subject of a good faith pending application, has been used in good faith or has become well known and has a priority date that predates the protection or recognition of the geographical indication. ${ }^{468}$ Where agreements contain conflicting legal obligations, a choice has to be made as to which conflict rule should prevail. Reaching compromise on a common multilateral rule is not only difficult but would also be contrary to earlier treaty obligations stemming from the bilateral trade agreements.

Second, the geographical extent and the material scope of recently concluded bilateral or plurilateral agreements leads to the suggestion that countries are (currently) not prepared to interchange fast, tailor-made legal obligations with the countries of major importance to them for multilateral commitments. One can even speak about a race among countries, such as the European Union, the United States and major emerging economies like China, Brazil and India, to conclude free trade agreements with their

\footnotetext{
466 See section 1.1 of this book.

467 See, for example, Article 7 of Annex $\mathrm{V}$ of the EC-Chile $A$ A.

468 See, for example, Article 2.15(a) of the US-Pern TPA. For a similar provision, see Article 17.4 .10 of the US-Chile FTA.
} 
trading partners. ${ }^{469}$ With this ever growing and expanding 'spaghetti bowl' of different obligations, it seems unlikely that these very same countries are willing, and still able, to change their approach in order to find a compromise for "one" set of multilateral rules. Therefore, interpreting this phase of bilateral trade agreements as exceptional may well be the more convincing conclusion.

$469 \quad$ See T. Carpenter, "A Historical Perspective on Regionalism” in R. Baldwin and P. Low (eds.), Multilateralizing Regionalism (Cambridge University Press, Cambridge, 2009) 13-27, p. 22. Agreements are concluded among the main actors or with countries on the African continent. Email correspondence with Christian Pitschas, Lawyer at Bernzen Sonntag Attorneys-at-Law \& Tax Advisors, 4 July 2011 (available on request). 
PART C: THE EUROPEAN UNION'S INTELLECTUAL PROPERTY POLICY TOWARDS THIRD COUNTRIES THROUGH BILATERAL TRADE AGREEMENTS 

This thesis focuses on the European Union as one of the main actors in international intellectual property lawmaking. Besides the fact that I am of German, hence European, origin myself and most familiar with the European legal regime of negotiating and concluding international agreements on intellectual property rights, the choice for the European Union has been made for two main reasons. One, there is already a considerable amount of research carried out about the role of the United States as arguably the most aggressive actor in this process. ${ }^{1}$ For this thesis to be innovative, the choice was made to study a different main actor.

The second reason is that the European Union is a relatively new actor in the area of intellectual property lawmaking on the international scene. This is particularly true in respect of bilateral IP standard setting with developing countries. This thesis aims at providing a timely contribution to the debate on the European Union's role in international IP policy-making. Therefore, part C of this book provides 1) a comprehensive analysis of the new external trade policy of the European Union, including the reasons why a shift has occurred, 2) a precise legal assessment of the nature and scope of the provisions in recent bilateral trade agreements that deal with intellectual property protection, and 3) an analysis of whether priorities of the European Union as to the areas of intellectual property protection can be identified from a comparison of the IP chapters in recent bilateral trade agreements. These three research topics are addressed respectively in the following four chapters, including this one.

1 See Abbott, The Doha Declaration on the TRIPS Agreement and Public Health; Biadgleng and Muñoz Tellez, The Changing Structure and Governance of Intellectual Property Enforcement; Christie, Waller and Weatherall, "Exporting the DMCA through Free Trade Agreements"; Fink and Reichenmiller, Tightening TRIPS; Kuanpoth, "TRIPS-Plus Rules under Free Trade Agreements"; Mercurio, "TRIPS-Plus Provisions in FTAs"; Morin, "Tripping up TRIPs Debates: IP and Health in Bilateral Agreements"; Oxfam America, Make Trade Fair for Central America; Pugatch, "The International Regulation of IPRs in a TRIPs and TRIPs-plus Worlds"; Rajkumar, "The Central American Free Trade Agreement: An End Run around the DOHA Declaration on TRIPS and Public Health"; Roffe, Bilateral Agreements and a TRIPS-plus World: The Chile-USA Free Trade Agreement, Rossi, "Free Trade Agreements and TRIPS-plus Measures"; Sell, "TRIPSplus Free Trade Agreements and Access to Medicines"; Vivas-Eugui, The Free Trade Area of the Americas; Von Braun, The Domestic Politics of Negotiating International Trade: Intellectual Property Rights in US-Colombia and US-Peru Free Trade Agreements. 



\section{Chapter 4 : The European Union's Intellectual Property Policy in Third Countries since the TRIPS Agreement: A Shift towards a Tough Approach}

\subsection{INTRODUCTION}

In recent years, the European Union has seen a shift in its intellectual property policy towards third countries. The policy has changed with regard to four aspects. First, a shift has occurred from regulating intellectual property protection primarily through multilateral treaties to using the instrument of bilateral trade agreements for achieving the desired level of IP protection abroad. Second, the level of protection asked for from the Union's partner countries has increased considerably: while the TRIPS Agreement has mainly been the standard that the European Union demanded from third countries for more than ten years, the protection included in bilateral trade agreements since 2006 has developed into a TRIPS-plus nature. Third, whereas bilateral agreements concluded before 2006 differentiated the level and scope of IP protection demanded from countries according to their level of development, such adaptations are hardly included in recent agreements with emerging economies (such as China, Russia, India, Brazil and the Association of Southeast Asian Nations) on the one hand, and developing countries on the other hand (African, Caribbean and Pacific countries, Andean and Central American countries). Fourth, the role that development concerns play in the conclusion of trade agreements that also address intellectual property rights has diminished considerably.

The European Union's new external IP policy seems to follow, in many aspects, the aggressive stance taken by the United States in its free trade agreements. ${ }^{1}$ It is therefore instructive to compare the new elements of the EU external IP policy with the US approach of concluding bilateral trade agreements. In the following, the development of the EU's policy of protecting IP in third countries over the last fifteen years is analyzed for the four different aspects presented above and compared with the United States' approach (see sections 4.3-4.6). The respective shifts, as well as the underlying reasons for these changes, are demonstrated by a detailed analysis of various policy documents issued by the European Union, a comparative legal assessment of relevant provisions in various bilateral trade agreements and the insights provided by a number of academic articles. ${ }^{2}$

1 See K.E. Maskus, "Observations on the Intellectual Property Component of the European Commission's New Trade Policy” Aussenwirtschaft, 2006, Vol. 61 (4), 459469, p. 460.

2 See J. Andersson, Global Europe and Sustainable Development: Implications for Climate Change and Agriculture (Swedish Society for Nature Conservation, Stockholm, 2009); J. Drexl, "Internationales Immaterialgüterrecht" in R. Rixecker and F.J. Säcker (eds.), Münchner Kommentar zum Bürgerlichen Gesetz̧buch (5th edn, Verlag C.H. Beck, München, 2010) 1344-1491; S. Evenett, “Global Europe': An Initial Assessment of the European Commission's New Trade Policy” Aussenwirtschaft, 2006, Vol. 61 (4), 377-378; H. Grosse Ruse-Khan, Sustainable Development In International Intellectual Property Law - New Approaches From EU Economic Partnership Agreements (ICTSD, Intellectual Property and Sustainable Development Series, Issue Paper No. 29, Geneva, 2010); S. McGuire and J. Lindeque, "The Diminishing Returns to Trade Policy in the European Union" Journal of Common Market Studies, 2010, Vol. 48 (5), 1329-1349; M. Maes, The EU's Global Europe 
This chapter, addressing the policy shift in Europe's external IP policy, is complemented by chapters three (Legal Analysis of the CARIFORUM-EC EPA), four (Legal Analysis of the draft India-EU BTLA) and five (Legal Comparison) of this thesis. They provide detailed legal assessments of two important bilateral trade agreements that have been signed recently, the latter still being negotiated, as well as a legal comparison of these two agreements with other recent agreements. Those chapters will present the EU's priority areas that also contain TRIPS-plus elements.

Before addressing the development of the EU's policy of protecting IP in third countries in its four aspects (from multilateral to bilateral IP regulation, from vague to high standards of IP protection, prioritized countries and development concerns), the European Union's competence to conclude international agreements in the area of intellectual property is assessed concisely. Since the European Union's external competence in the area of common commercial policy has been subject to the recent changes set out in the Treaty of Lisbon, one could argue that, also on the competence question, a shift has occurred from an exclusive competence in practice to an explicit exclusive competence of the Union to conclude trade agreements with third countries which contain standards of intellectual property protection.

\subsection{EXTERnAl COMPETENCE OF THE EU In INTELLECTUAL Property MATTERS}

In pursuing its intellectual property policy towards third countries, the European Union concludes international agreements, both at the bilateral, plurilateral and multilateral level. This raises the question under EU law in how far the European Union is competent to conclude international agreements with third countries that contain standards of intellectual property protection (external competence). Since the entering into force of the TRIPS Agreement, the legal framework of the European Union in the area of the common commercial policy, which includes the protection of intellectual property as part of international trade agreements, has been developed further through the Treaty of Amsterdam in $1999,{ }^{3}$ the Treaty of Nice in $2003^{4}$ and the

Strategy. Where is that Strategy Today, paper presented at the conference "Building a Common Platform Between Developing Countries" in Brussels (South Centre, 4-5 December 2008); Maskus, "Observations on the Intellectual Property Component"; S. Meunier, "Managing Globalization? The EU in International Trade Negotiations" Journal of Common Market Studies, 2007, Vol. 45 (4), 905-926; X. Seuba Hernández and J.F. García, "Intellectual Property and Public Health in the EU-CAN FTA" Bridges, 2010, Vol. 3, 15-16. For an International Political Economy analysis of the shift that the EU external trade policy has seen in recent years, see Heron and Siles-Brügge, "Competitive Liberalization and the 'Global Europe' Services and Investment Agenda: Locating the Commercial Drivers of the EU-ACP Economic Partnership Agreements".

3 Treaty of Amsterdam amending the Treaty on European Union, the Treaties establishing the European Communities and certain related acts, signed on 2 October 1997 in Amsterdam, entered into force on 1 May 1999 (OJ C 340 of 10.11.1997, p. 1) [hereinafter Treaty of Amsterdam].

$4 \quad$ Treaty of Nice amending the Treaty on European Union, the Treaties Establishing the European Communities and Certain Related Acts, signed on 26 February 2001 in Nice, entered into force on 1 February 2003 (OJ C 80 of 10.03.2001) [hereinafter Treaty of Nice]. 
Treaty of Lisbon ${ }^{5}$ in 2009. Most importantly, the recent Treaty of Lisbon has clarified considerably the legal framework on the external competences of the European Union in the field of the common commercial policy. These changes have been discussed in detail by many scholars. ${ }^{6}$ This section will therefore be limited to a concise summary of the EU's external competences to conclude international trade agreements that contain intellectual property issues, as provided for in the Consolidated Version of the Treaty on the Functioning of the European Union (TFEU). ${ }^{7}$ In doing so, I will highlight the changes in law and practice brought about by the Treaty of Lisbon compared with the Treaty of Nice where deemed relevant. The argument is made that in practice not many aspects of concluding international trade agreements which include intellectual property protection have changed since the Treaty of Nice.

This section assesses the following elements of the European Union's competence to conclude international trade agreements that contain standards of intellectual property protection: 1) the exclusive competence of the Union to conclude agreements with third countries (exclusive external competence), 2) coherence with development objectives, 3) decision making regarding the negotiation and conclusion of trade agreements, and 4) role of the European Parliament.

\subsubsection{Exclusive External Competence}

With the Treaty of Lisbon, the European Union's external competence has been incorporated in Article 216.1 of the TFEU.

"The Union may conclude an agreement with one or more third countries or international organizations where the Treaties so provide [...]."

5 Treaty of Lisbon amending the Treaty on European Union and the Treaty Establishing the European Community, signed on 13 December 2007 in Lisbon, entered into force on 1 December 2009 (OJ C 306 of 17.12.2007, p. 1) [hereinafter Treaty of Lisbon].

$6 \quad$ See C. Pitschas, "The Treaty of Lisbon and the 'New' Common Commercial Policy of the European Union" International Trade Law and Regulation, 2010, Vol. 16 (2), 37-43; S. Woolcock, The Treaty of Lisbon and the European Union as an Actor in International Trade (European Centre for International Political Economy, ECIPE Working Paper, Brussels, 2010) [01/2010]; Drexl, "MünchKommBGB, IntImmGR", recitals 87-91; P. Eeckhout, EU External Relations Law (2nd edn, Oxford University Press, New York, 2011); J. Wouters, D. Coppens and B. De Meester, “The European Union's External Relations after the Lisbon Treaty" in J. Griller and J. Ziller (eds.), The Lisbon Treaty: EU Constitutionalism without a Constitutional Treaty (Springer Verlag, Wien, 2008) 143-204; M. Bungenberg, "Going Global? The EU Common Commercial Policy After Lisbon" in C. Herrmann and J.P. Terhechte (eds.), European Yearbook of International Economic Law 2010 (Springer, Heidelberg, 2010) 123-151; A. Pollet-Fort, Implications of the Lisbon Treaty on EU External Trade Policy (EU Centre, Singapore, 2010) [Background Brief No. 2]. For an assessment of the modifications brought about through the Treaty of Nice compared to the Treaty of Amsterdam, see C. Herrmann, "Common Commercial Policy after Nice: Sisyphus Would Have Done a Better Job” Common Market Law Review, 2002, Vol. 39 (1), 7-29; H. Krenzler and C. Pitschas, "Progress or Stagnation? The Common Commercial Policy after Nice" European Foreign Affairs Review, 2001, Vol. 6 (3), 291-313.

7 Consolidated Version of the Treaty on the Functioning of the European Union, signed on 13 December 2007, entered into force on 1 December 2009 (OJ C 83 of 03.03.2010, p. 47) [hereinafter TFEU]. 
Such an explicit conferral of competence can be found in the area of common commercial policy, Article 207.3, subparagraph 1 of the TFEU:
"Where agreements with one or more third countries or international organizations need to be negotiated and concluded, Article 218 shall apply, subject to the special provisions of this Article."

Therefore, the Union has treaty-making competence in the area of common commercial policy. In how far the Member States of the European Union need to be involved in the treaty making depends on the nature of the external competence.

According to Article 3.1(e) of the TFEU, the competence in the area of the common commercial policy is of an exclusive nature. Since the external competence is explicitly referred to in the common commercial policy, ${ }^{8}$ this external competence is also exclusive. The exclusive nature of the competence implies that Member States are excluded from adopting international agreements in that area. ${ }^{9}$ At the same time, the Union is the sole partner to agreements with third countries; Member States of the European Union are not involved in the negotiations as separate parties to the agreements.

The scope of the competence in the common commercial policy is further clarified in Article 207.1 of the TFEU to, among others, include the conclusion of tariff and trade agreements that contain "commercial aspects of intellectual property". ${ }^{10}$ The term "commercial aspects of intellectual property" has been taken over from Article 133.5 of the Treaty Establishing the European Community (TEC). ${ }^{11}$ Even though the term has no direct equivalent in international trade law, there is a general agreement that it refers to the "trade-related aspects of intellectual property rights" incorporated in the TRIPS Agreement. ${ }^{12}$ Hence, where an international trade agreement deals with issues

Article 207.3 subparagraph 1 of the TFEU.

See Article 2.1 of the TFEU, which generally states that in the case of exclusive competences, only the Union may legislate and adopt legally binding acts, the Members States being able to do so themselves only if so empowered by the Union or for the implementation of Union acts.

See Article 207.1 of the TFEU.

Consolidated Version of the Treaty Establishing the European Community, amended in accordance with the Treaty of Nice (OJ C 325 of 24.12.2002, p. 33) [hereinafter TEC]. The Treaty of Nice extended the scope of the common commercial policy compared to how the Court of Justice of the European Union (CJEU) had defined the area in its Opinion 1/94. In this Opinion, the CJEU had delineated the external exclusive competence of the then Community to include only those aspects of intellectual property that concern the prohibition of the release into free circulation of counterfeit goods, in other words border measures. See CJEU, Opinion of the Court of 15 November 1994, Opinion 1/94, Competence of the Community to conclude international agreements concerning services and the protection of intellectual property - Article 228 (6) of the EC Treaty [1994] ECR I-5267, paragraph 71 [hereinafter Opinion 1/94]. Note that the CJEU has been called European Court of Justice (ECJ) before the Treaty of Lisbon.

See M. Krajewski, "The Reform of the Common Commercial Policy" in A. Biondi, P. Eeckhout and S. Ripley (eds.), EU Law after Lisbon (Oxford University Press, New York, 2012) 292-311, p. 301; Herrmann, "Common Commercial Policy after Nice: Sisyphus Would Have Done a Better Job”, p. 17-18. See Drexl, "MünchKommBGB, IntImmGR", recital 89. For authors that use commercial aspects of IP and trade- 
of intellectual property protection that are also regulated in the TRIPS Agreement, the Union has the exclusive competence to conclude these agreements.

Whether this competence also covers the negotiation of international agreements containing TRIPS-plus provisions (those provisions that go beyond the protection stipulated in the TRIPS Agreement) has not yet been clarified by the Court of Justice of the European Union (CJEU). However, the following three arguments suggest that the Union is competent to negotiate TRIPS-plus provisions in trade agreements exclusively.

\subsubsection{Broad Concept of Commercial Aspects of Intellectual Property}

The concept of "commercial aspects of intellectual property" incorporated in Article 207.1 of the TFEU is so broadly formulated that it is questionable which areas of IP protection might not be covered by it. Josef Drexl interprets the concept to cover all intellectual property rights that are included in a trade agreement. ${ }^{13}$ Accordingly, if IP rights are regulated in the context of a trade agreement, they would be classified as "commercial aspects of intellectual property" and therefore would come under the exclusive competence of the European Union. ${ }^{14}$

Rather than defining "commercial aspects of intellectual property" by its context, one could and arguably should aim at defining those commercial and non-commercial aspects of IP by their substance. Generally, commercial aspects of IP address intellectual property rights that have an effect on external trade. In other words, when IP rights such as geographical indications regulated in an international agreement have an effect on trade with countries outside the European Union, they come under the concept of "commercial aspects". ${ }^{15}$ However, it is unclear which IP rights in such an agreement would not classify as commercial aspects since all IP aspects regulated in international agreements have an effect on the trade in goods protected by these IP rights between those countries. ${ }^{16}$ Therefore, it is argued that the scope of IP rights covered by Article 207 of the TFEU is very broad and hence includes intellectual property rights that go beyond the TRIPS Agreement.

related aspects of IP interchangeably, see Woolcock, The Treaty of Lisbon, p. 9; PolletFort, Implications of the Lisbon Treaty on EU External Trade Policy, p. 12; Wouters, Coppens and De Meester, "The European Union's External Relations after the Lisbon Treaty", footnote 126.

13 See section 4.2.1.4 of this book for a discussion of pure IP treaties, which do not constitute trade agreements in the sense of Article 207 of the TFEU.

14 See Drexl, "MünchKommBGB, IntImmGR", recital 89.

15 Also email correspondence with Christian Pitschas, 18 March 2012 (available on request).

16 Pedro Velasco-Martins stated that possibly criminal enforcement measures and judicial cooperation fall outside the concept of "commercial aspects of intellectual property". Email correspondence with Pedro Velasco-Martins, 23 March 2012 (available on request). However, it is argued that a distinction needs to be made between issues that from the beginning do not come under that concept and those issues that are excluded from the concept for particular reasons, such as the limitations mentioned hereafter. The author argues that criminal enforcement measures and judicial cooperation are possibly excluded from the concept due to the first (and second) limitation, as explained below. 
To classify the argument made above further, the concept of "commercial aspects of intellectual property" can be and arguably is interpreted broadly by the European Commission when concluding agreements that deal with intellectual property protection. However, this does not mean that there are no other rationales than commercial interests or effects that can explain why a certain IP right is protected. For example, obligations on states, such as criminal enforcement measures, matters of administrative procedure or judicial cooperation, would not be motivated by economic interests alone but by motivations of public order, social welfare, consumer protection or the principle of equality. To summarize, while it is argued that the concept of "commercial aspects of intellectual property" is very broad and will be interpreted to cover also TRIPS-plus provisions, this is not to say that all of these provisions are only economically motivated; rather, it is a multitude of rationales that explain their existence, among them that of economic interest. It is a matter of political economy which of these rationales are highlighted in their explanatory force. With the TRIPS Agreement, IP rights have been introduced in the trade context. This link between IP and trade has created an almost exclusive focus of policy makers, including the European Commission, on the economic rationale and effects of IP. ${ }^{17}$

The broad concept of "commercial aspects of intellectual property" is limited by the caveat of Article 207.6 of the TFEU. This provision incorporates two limitations. It highlights that the exercise of the competence in the common commercial policy

\footnotetext{
"shall not affect the delimitation of competences between the Union and the Member States, and shall not lead to harmonisation of legislative or regulatory provisions of the Member States in so far as the Treaties exclude such harmonization."
}

The first limitation in the provision is an expression of the principle of conferral. This principle requires the Union to act

"within the limits of the competences conferred upon it by the Member States in the Treaties to attain the objectives set out therein." 18

Accordingly, the European Union only has the competence to act in those areas of law that have been delegated to the Union by Member States. Where competences are shared or concurring, the Union cannot legislate without the Member States. A relevant example is the area of freedom, security and justice, which includes the criminal enforcement of intellectual property rights. ${ }^{19}$ In this area, the Union shares competences with the Member States pursuant to Article 4.2(j) of the TFEU. This issue came up during the negotiations of the Anti-Counterfeiting Trade Agreement which includes criminal enforcement measures. In this context, the European Commission stated that it excluded the following measures from its exclusive competence portfolio:

I would like to thank my supervisor Prof. Kamperman-Sanders for pointing out the original rationales of protecting intellectual property to me to inform the discussion and interpretation of Article 207 of the TFEU. Article 5.2 of the Treaty on European Union. See footnote 43 of section 4.2.1.4 of this book for full reference.

19 Judicial cooperation in civil and criminal matters also falls under this area, see Articles 81 and 82 of the TFEU. 
"the type and level of criminal penalties [...] and dispositions on penal procedural law, but not provisions on aiding and abetting" 20

With the criminal enforcement measures falling under the shared competences of the Union and the Member States, ${ }^{21}$ one would have expected these to be negotiated by the European Commission and the Member States together. However, according to Commissioner of Trade, Karel de Gucht, the criminal enforcement provisions in ACTA were negotiated only by the Presidency of the EU on behalf of the Member States.22 The ACTA negotiations are remarkable: for the first time, a clear distinction has been made between areas of exclusive Union competences and shared competences by having different actors negotiate for the EU side. In previous trade agreements, for example the agreements on trade in wine and/or spirits concluded between 1994 and 2003, certain IP issues did not obviously fall under the exclusive competences of the Union; ${ }^{23}$ nevertheless, they were negotiated by the European Commission alone. ${ }^{24}$ Following the example of ACTA, trade agreements after ACTA are concluded as so-called "mixed agreements" 25 since they incorporate areas of exclusive and shared competences (not only in the area of IP but particularly in other areas covered by FTAs). Partner countries negotiating with the European Union must therefore be prepared to negotiate some parts of the agreement with the European Commission and others with the EU Presidency.

Answer given by Mr. De Gucht on behalf of the Commission on 30 November 2010 to a question posed by Member of the European Parliament Franziska Keller P9029/2010, available at <http://www.europarl.europa.eu/sides/getDoc.do?pubRef=//EP//TEXT+WQ+P-2010-9029+0+DOC+XML+V0//EN\&language=EN $>$ accessed on 02.02.2012; again stated in Proposal for a Council Decision on the conclusion of the Anti-Counterfeiting Trade Agreement between the European Union and its Member States, Australia, Canada, Japan, the Republic of Korea, the United Mexican States, the Kingdom of Morocco, New Zealand, the Republic of Singapore, the Swiss Confederation and the United States of America (COM(2011) 380 final of 24.06.2011), paragraph 5 of explanatory memorandum [hereinafter Proposal for a Council Decision on the conclusion of the AntiCounterfeiting Trade Agreement. See ibid., paragraph 6 of explanatory memorandum.

See Answer given by Mr De Gucht on behalf of the Commission on 21 January 2011 to the written question by Maritje Schaake E-8847/10, available at $<$ http:/ / www.europarl.europa.eu/sides/getDoc.do?type=WQ\&reference=E-20108847\&language $=\mathrm{EN}>$ accessed on 02.02.2012.

The 1/94 Opinion of the CJEU made clear that not all areas of the TRIPS Agreement (except for border measures) fall under the exclusive competence of the common commercial policy. Therefore, the provisions on the protection of geographical indications included in the agreements on trade in wine and/or spirits concluded after the issuance of the 1/94 Opinion and before the amendment of former Article 133 of the TEC through the Treaty of Nice on 1 February 2003 do not obviously come under the exclusive competence of the Union according to former Article 133 of the TEC.

Email correspondence with Pedro Velasco-Martins from Directorate General Trade, European Commission, 23 March 2012.

A "mixed agreement" is an international agreement to which both the European Union and the Member States individually are parties. It is through this mechanism that the European Union concludes agreements that include areas that fall both in the exclusive competence of the Union as well as in the shared or concurring competences of the Member States. 
The second limitation is a reflection of the principle of parallelism between internal and external powers of the Union. Where harmonization of internal measures is prohibited, the Union is also not allowed to conclude trade agreements that would lead to harmonization of such measures. Harmonization is clearly prohibited in areas where the Union has merely a competence to support, coordinate or supplement actions of the Member States, listed in Article 6 of the TFEU. ${ }^{26}$ Also in the field of shared competences, the ability to harmonize is limited. Taking again the example of criminal enforcement, Article 83(2) of the TFEU requires that the approximation of criminal laws and regulations is only allowed if it is

"essential to ensure the effective implementation of a Union policy in an area which has been subject to harmonisation measures." [emphasis added]

Therefore, if the European Union was able to argue that the criminal enforcement provisions such as in ACTA were "essential" to ensure the proper functioning of, for example, the internal market (an area where harmonization measures exist), the Union would be able to negotiate and conclude agreements on criminal enforcement matters exclusively. ${ }^{27}$ If the argument is successful, there is also no problem with regard to the question as to whether the Union has been granted the necessary competence by the Member States: also in areas of shared competence, the Union has the competence to regulate if the same test is passed: harmonization must be "essential".

\subsubsection{Dynamic Concept of Commercial Aspects of Intellectual Property}

The concept of "commercial aspects of intellectual property" can be interpreted in a "dynamic" or "static" manner. The dynamic concept incorporates future changes to the TRIPS Agreement whereas the static concept merely includes those IP rights specified in the TRIPS Agreement at the time of the Treaty of Lisbon. If the concept was interpreted statically, the Union would not have exclusive competence to re-negotiate changes to the TRIPS Agreement that would go beyond the current obligations of the agreement. ${ }^{28}$ As Markus Krajewski argues, this would lead to a reduction of the scope of the common commercial policy, which was not intended by the drafters of the Treaty of Lisbon. ${ }^{29}$ Therefore, a dynamic interpretation of the concept must be favoured. Already at the time the Treaty of Nice came into force, Christian Pitschas and

Article 6 of the TFEU lists the protection and improvement of human health; industry; culture; tourism; education; vocational training; youth and sport; civil protection and administrative cooperation. Such areas do not seem highly relevant for intellectual property regulation. See Pitschas, "The Treaty of Lisbon", p. 43.

This possibility has also been noted by the Commission in the Proposal for a Council Decision on the conclusion of ACTA: "The Commission has opted not to propose that the European Union exercise its potential competence in the area of criminal enforcement pursuant to Article 83(2) TFEU.[...] The Commission's position as regards ACTA and Article 83(2) TFEU is without prejudice to the position of the Commission on future exercise by the $\mathrm{EU}$ of the shared competences foreseen by Article 83(2) TFEU." See Proposal for a Council Decision on the conclusion of the AntiCounterfeiting Agreement, paragraphs 6 and 7 of the explanatory memorandum. See Drexl, "MünchKommBGB, IntImmGR", recital 89.

29 See Krajewski, “The Reform of the Common Commercial Policy”, p. 301. 
Horst Krenzler argued for a dynamic concept ${ }^{30}$ relying on the dynamic nature of the common commercial policy as explored by the Court of Justice in Opinion 1/78. ${ }^{31} \mathrm{In}$ this Opinion, the Court ruled on the compatibility of the draft International Agreement on Natural Rubber with the Treaty establishing the European Economic Community. ${ }^{32}$ The CJEU decided that the concept of common commercial policy in the former Article 113 of the EEC Treaty (now Article 207) must be governed from a wide point of view and not only regarding traditional aspects of external trade. ${ }^{33}$

Following this reasoning, a similar argument can be made for TRIPS-plus provisions. Accordingly, also nowadays, a limitation of the exclusive external competence of the Union to merely TRIPS-like IP provisions in trade agreements would not be consistent with the dynamic nature of the common commercial policy as noted by the CJEU in Opinion 1/78. Also, the drafters of the Treaty of Lisbon were well aware of the European Commission's TRIPS-plus mandate to conclude free trade agreements that contain the "highest international standards" of intellectual property protection and enforcement, which had been launched as early as $2004 .{ }^{34}$ To conclude, the concept of "commercial aspects of intellectual property" must be interpreted in a dynamic way.

\subsubsection{Lack of a Reference to Non-commercial Aspects of Intellectual Property}

The third argument in favour of an exclusive competence of the European Union to negotiate and conclude international agreements with TRIPS-plus provisions regards the fact that the Treaty of Lisbon does not provide for an equivalent provision as Article 133.7 of the TEC. The latter provision reads:

“[...], the Council, acting unanimously on a proposal from the Commission and after consulting the European Parliament, may extend the application of paragraphs 1 to 4 to international negotiations and agreements on intellectual property in so far as they are not covered by paragraph 5."

This article of the Treaty of Nice enabled the Council, under the caveat of following a stricter decision-making procedure, ${ }^{35}$ to conclude agreements with third parties on IP aspects that were not covered by the external competence granted in Article 133.5 on the "commercial aspects of intellectual property". ${ }^{36}$ The fact that the Treaty of Lisbon

$30 \quad$ See Krenzler and Pitschas, "Progress or Stagnation? The Common Commercial Policy after Nice", p. 302.

31 CJEU, Opinion of the Court of 4 October 1979, Opinion 1/78, Opinion given pursuant to the second subparagraph of Article 228(1) of the EEC Treaty - International Agreement on Natural Rubber [1979] ECR 2871 [hereinafter Opinion 1/78], paragraph 44/45. Treaty establishing the European Economic Community, signed on 25 March 1957 in Rome; entered into force on 1 January 1958. See Opinion 1/78, paragraph 45. See European Commission, Strategy for the Enforcement of Intellectual Property Rights in Third Countries (Brussels, 10 November 2004) [OJ C 129 of 26.05.2005, p. 3], p. 5 [hereinafter 'Enforcement Strategy in Third Countries'].

35 See Herrmann, "Common Commercial Policy after Nice: Sisyphus Would Have Done a Better Job”, p. 18.

36 Even though the amendments to Article 133 of the TEC through the Treaty of Nice had introduced for a period the concept of non-exclusive common commercial policy, according to Marise Cremona, the Treaty of Lisbon has returned to the idea of the 
does not provide for an equivalent "special competence" means that commercial and non-commercial aspects of IP are not treated differently anymore. Hence, the general concept of "commercial aspects" must cover a broad and dynamic range of intellectual property rights, including TRIPS-plus provisions.

For those aspects of intellectual property that are still deemed to be of a noncommercial nature, the general competence of the European Union to conclude international agreements codified in Article 216.1 of the TFEU is applicable, as explained below. ${ }^{37}$

\subsubsection{Pure IP Treaties or "Non-commercial Aspects of IP"}

The arguments presented above favour a broad and dynamic concept of "commercial aspects of intellectual property", according to which TRIPS-plus provisions, for example, in bilateral trade agreements are also covered by the exclusive external competence of Article 207.3 subparagraph 1 of the TFEU. What this competence might not include, however, are international agreements that deal with intellectual property protection only, rather than in the context of a trade agreement. Josef Drexl argues that the concept of "commercial aspects" only includes intellectual property rights addressed in the framework of a trade agreement. ${ }^{38}$ This might be deducted from Article 207.1 of the TFEU which refers to various measures that fall under the common commercial policy, such as

"the conclusion of tariff and trade agreements relating to trade in goods and services, and the commercial aspects of intellectual property".

According to Josef Drexl, where IP issues are addressed in pure IP treaties, the competence must be drawn from another provision than Article 207.3 subparagraph 1 of the TFEU. Examples of pure IP treaties are the treaties concluded in the framework of the WIPO $;{ }^{39}$ the European Union does not seem to have concluded such treaties at the bilateral level yet.

I am sceptical as to whether or not the concept of "commercial aspects" can be defined through its context only. It seems incomplete to determine the nature of the intellectual property aspects dealt with in an international agreement according to whether they are included in a trade agreement or in a pure IP-treaty. Such a distinction also raises the question as to how to define a trade agreement. For example, would an agreement already constitute a trade agreement when it does not deal with IP issues exclusively and only a minimal part of the agreement addresses a trade context?

common commercial policy being an exclusive competence by nature. See M. Cremona, "External Relations and External Competence of the European Union: The Emergence of an Integrated Policy" in P. Craig and G. De Burca (eds.), The Evolution of EU Law (2nd edn, Oxford University Press, New York, 2011) 217-268, p. 246.

37 See section 4.2.1.4 of this book.

38 See Drexl, "MünchKommBGB, IntImmGR", recital 89.

39 See sections 1.5.1, 1.5.2 and 1.5.4 of this book for an overview of the treaties administered by WIPO. 
Rather, the concept should be defined substantively, specifying which provisions on intellectual property rights have an impact on external trade and which do not. ${ }^{40}$ Following this argument, if an agreement, whether entitled "trade" agreement or purely dealing with IP issues, includes commercial aspects of IP, the relevant legal basis would be Article 216.1 in conjunction with Article 207.3 subparagraph 1 of the TFEU. If an agreement deals with non-commercial aspects of IP, it is only Article 216.1 of the TFEU that sets out the relevant procedure.

Article 216.1 of the TFEU provides another legal basis for the competence to conclude international agreements. It codifies the ERTA doctrine, ${ }^{41}$ according to which the Union has exclusive competence where

"the conclusion of an agreement $[\ldots]$ is likely to affect common rules or alter their scope."

In other words, if the European Union has exercised an internal competence by creating internal rules, there is an implied power of the Union to act externally also.42 The nature of this competence is exclusive due to Article 3.2 of the Treaty on European Union. ${ }^{43}$ Since the European Union has regulated intellectual property protection to a far-reaching extent internally, ${ }^{44}$ this Article provides a legal basis for the exclusive external competence on a broad range of IP issues. ${ }^{45}$ If an agreement contains IP rules in areas where there are no common rules yet, the competence remains shared and the Union has to conclude the agreement as a mixed agreement together with the Member States.

Even though Josef Drexl's view has not been confirmed by other authors yet, ${ }^{46}$ it provides a possible limitation of the exclusive competence of the European Union to conclude bilateral agreements on IP protection under the common commercial policy. However, so far, no bilateral agreement concluded by the European Union

40 See section 4.2.1.1 of this book. Also in email correspondence with Christian Pitschas, 16 March 2012 (available on request).

41 See Case 22/70, Commission v. Council (ERTA) [1971] ECR 263.

42 See ibid., paragraphs 12-19.

43 Consolidated Version of the Treaty on European Union, signed on 13 December 2007, entered into force 1 December 2009 (OJ C 83 of 30.3.2010, p. 13) [hereinafter TEU].

44 It is important to note that the European Union has harmonized the main areas of intellectual property protection among all Member States of the Union. In order to complete the internal market, it was necessary to harmonize the protection of IP rights. IP rights were fundamental for European industrial policy (such as stimulating innovation) as well as for creating a market and competition in intangibles (such as technology, diversified product markets, cultural goods or services) that would otherwise not exist. Through this harmonization, IP rights are exhausted in the community rather than domestically. See CJEU Case C- 355/96 of 16 July 1998, Silhouette International Schmied GmbH \& Co. KG v Hartlaner Handelsgesellschaft mbH [ECR I-4799], which ruled that IP rights are exhausted in the Community, rather than internationally.

45 See Drexl, "MünchKommBGB, IntImmGR”, recital 91.

46 See discussion of the broad scope of "commercial aspects of intellectual property", in section 4.2.1.1 of this book. Email correspondence with Christian Pitschas, 4 July 2011. 
dealt purely with intellectual property issues, isolated from their trade context. ${ }^{47} \mathrm{~A}$ plurilateral agreement of a pure IP nature is the Anti-Counterfeiting Trade Agreement. Even though the name indicates a trade context, its content is merely about the enforcement of intellectual property rights.

Following Josef Drexl, ACTA's IP provisions that do not fall under the shared competence with Member States ${ }^{48}$ should have been negotiated and concluded under Article 216.1 of the TFEU. However, the implementing Council Decision on the conclusion of ACTA indicates that the agreement was negotiated and concluded as a trade agreement containing "commercial aspects of intellectual property", suggesting that the procedure of Article 207.4 of the TFEU was followed. ${ }^{49}$ This choice of the legal basis can either indicate that the Commission has an interest in broadening the scope of Article 207 of the TFEU. It could also suggest that the Commission regards all aspects of ACTA as "commercial aspects of intellectual property" and that the question as to whether the agreements are purely about IP or trade agreements does not matter.

The legislative procedure has been brought to a hold by the European Parliament: a vast majority of the Members of the European Parliament voted against the adoption of ACTA on 4 July $2012 . .^{\circ 0}$ Without the adoption of the agreement by the European Parliament, the treaty cannot enter into force in the European Union. In May 2012, the European Commission has requested an option from the Court of Justice of the European Union on the question whether ACTA is compatible with the Treaties and in particular with the Charter of Fundamental Rights of the European Union. ${ }^{51}$

\subsubsection{Interim Conclusions}

The regulation of intellectual property provisions, including TRIPS-plus provisions, falls under the exclusive competence of the European Union. Article 216.1, in conjunction with Article 207.3 subparagraph 1 of the TFEU, forms the legal basis of this competence in the area of the common commercial policy. Even if international agreements do not come under the scope of this Article, such as treaties that contain merely non-commercial aspects of intellectual property, Article 216.1 of the TFEU

47 An example of such a bilateral agreement could be an agreement made by the Council on the basis of Article 11.3 of the Council Directive 96/9/EC of the European Parliament and of the Council of 11 March 1996 on the legal protection of databases (OJ L 77 of 27.03.1996, p. 20). Accordingly, that agreement would extend the right provided for in Article 7 of the Directive to databases made in third countries.

48 Arguably, Member States share competences with the European Union on criminal enforcement measures.

49 The Council Decision refers to Article 207.4 in conjunction with Article 218.6(a)(v) of the TFEU for the conclusion of ACTA which is the legal basis for a trade agreement coming under the common commercial policy. See Council Decision on the conclusion of the Anti-Counterfeiting Trade Agreement between the European Union and its Member States, Australia, Canada, Japan, the Republic of Korea, the United Mexican States, the Kingdom of Morocco, New Zealand, the Republic of Singapore, the Swiss Confederation and the United States of America (2011/0167 (NLE) of 23 August 2011).

$50 \quad$ See Pinsent Masons, "ACTA rejected by European Parliament".

51 See European Commission, "Notice: European Commission officially referred ACTA to the European Court of Justice" (Brussels, 11 May 2012), available at <http://trade.ec.europa.eu/doclib/press/index.cfm?id=799> accessed on 15.11.2012. 
provides another basis of an exclusive external competence for IP standards. The Union can conclude international agreements in those areas where the TFEU grants an internal competence and where that competence has been exercised by the Union through the creation of common rules. Only for the case that no internal rules exist yet in an area of IP protection dealt with in an international agreement, the Union has no exclusive competence and will have to conclude a mixed agreement with the Member States.

While the question of competences lies at the heart of the principle of "separation of powers" in the European Union, in practice, the nature of the competence has not mattered much for the incorporation of intellectual property issues in trade agreements. Most trade agreements in the past two decades have been concluded as mixed agreements; no dispute has arisen on the nature of competences in the areas dealt with in trade agreements. This harmonious approach displays a tendency towards acceptance of non-exclusive competences. ${ }^{52}$ It is surely for political reasons that the European Commission has favoured trade agreements to be negotiated and concluded as "mixed agreements". One such advantage is that all Member States are involved in the negotiations from the beginning and that they have to sign and conclude the agreement according to their national ratification procedures. They are fully aware of the content and can therefore also be held directly responsible by their citizens. In the case of ACTA, the Commission explicitly stated that the reason for choosing to involve the Member States in the ACTA negotiations, regardless of whether the Union might have an exclusive competence in the area of criminal enforcement, was to counter fears that ACTA would modify the EU acquis by harmonising EU legislation in criminal enforcement matters through the backdoor. ${ }^{53}$

\subsection{2. $\quad$ Coherence with Development Objectives}

A new element of the Treaty of Lisbon is the integration of the common commercial policy into the Union's external action. ${ }^{54}$ Part V of the TFEU is entitled "Union's External Action" and sets out certain objectives that trade agreements concluded under the common commercial policy have to respect. The claim is made that trade agreements signed with developing countries need to comply with the objectives of development cooperation of the Union. The following two arguments support that claim.

First, the Union's external actions, among which the common commercial policy, must be guided by development concerns incorporated in Articles 21.1 and 21.2 of the TEU. Accordingly, trade agreements concluded under the common commercial policy shall foster the sustainable economic, social and environmental development of developing countries. ${ }^{55}$ It shall also encourage the integration of all countries into the world economy. ${ }^{56}$ This obligation flows from the reference to principles,

52 See Cremona, "External Relations and External Competence of the European Union", p. 247.

53 See Proposal for a Council Decision on the conclusion of the Anti-Counterfeiting Agreement, paragraph 6 of the explanatory memorandum.

54 Part V of the TFEU is entitled "The Union's External Action" and includes Title II on "Common Commercial Policy".

55 See Article 21.2(d) of the TEU.

56 See Article 21.2 (e) of the TEU. 
objectives and general provisions in Article 205 and Article 207.1 of the TFEU; ${ }^{57}$ the objectives and general provisions are codified in Articles 21.1 and 21.2 of the TEU. ${ }^{58}$

Second, when acting under the common commercial policy, the Union must ensure consistency between the different areas of external action in order not to jeopardize the principles and objectives set out in Article 21 of the TEU..$^{59}$ One of the other areas of external action incorporated in Part $\mathrm{V}^{60}$ that is important when concluding trade agreements with developing countries is the "Cooperation with Third Countries and Humanitarian Aid", and in particular its sub-section "Development Cooperation". According to its Article 208.1 subparagraph 2 of the TFEU, other policies that are likely to affect developing countries (such as the common commercial policy) need to take into account the objectives of development cooperation. One of its primary objectives is the reduction and, in the long term, the eradication of poverty.

The obligation of ensuring consistency between the common commercial policy and the objectives of development cooperation is addressed by the Commission and the Council together, assisted by the High Representative of the Union for Foreign Affairs and Security Policy. ${ }^{61}$ This consistency must be understood as the outcome of the interaction between these actors rather than a substantive benchmark. ${ }^{62}$ Nevertheless, the Council and Commission will have to explain and justify a particular trade policy measure by referring to the objectives in Article 21 of the TEU.63

\subsubsection{Decision-making Regarding the Negotiation and Conclusion of Trade Agreements}

The negotiation and conclusion of trade agreements that include intellectual property protection are subject to the specific rules of Article 207 of the TFEU and the general provisions set out in Article 218 of the TFEU. ${ }^{64}$ Accordingly, the Commission makes a recommendation to the Council to start negotiations on a trade agreement with one or more third countries. ${ }^{65}$ The Council will then open the

See Articles 205 and 207.1 of the TFEU. Note that Article 205 stipulates a clear obligation to that end.

Principles listed in Article 21.1 of the TEU refer to democracy, the rule of law, human rights and the principles of the United Nations Charter. The objectives included in Article 21.2 of the TEU include preserving peace, preventing conflicts and strengthening international security, helping to develop international measures to preserve and improve the quality of the environment, assisting populations, countries and regions confronting natural or man-made disasters and promoting an international system based on stronger multilateral cooperation and good global governance.

See Article 21.3 of the TEU.

Title III addresses the "Cooperation with Third Countries and Humanitarian Aid", Title IV deals with "Restrictive Measures", Title V is entitled "International Agreements", Title VI contains provisions on "The Union's Relations with International Organisations and Third Countries and Union Delegations" and Title VII deals with the "Solidarity Clause".

See Article 21.3 of the TEU.

See Pitschas, "The Treaty of Lisbon", p. 37.

See Krajewski, "The Reform of the Common Commercial Policy", p. 297.

See Article 207.3 subparagraph 1 of the TFEU.

See Article 207.3 subparagraph 2 of the TFEU. 
negotiations formally ${ }^{66}$ and appoint the Union's negotiator. ${ }^{67}$ In the area of the common commercial policy, the negotiator is the Commission for the areas of exclusive competence. ${ }^{68}$ When trade agreements include areas of shared competences, and therefore constitute mixed agreements, the Council can also appoint a negotiating team. ${ }^{69}$ During the negotiations of trade agreements (no matter whether mixed or not), the Commission is assisted by a special committee which is appointed by the Council and to which the latter can address directives. ${ }^{70}$ This Trade Policy Committee, which was formerly known as the 'Article 133 Committee', consists of senior trade officials from each Member State and meets every week. ${ }^{71}$ When the negotiations are finalized, and based on a proposal by the negotiator, the Council authorises the signature and conclusion of the agreement. ${ }^{72}$

All decisions that the Council takes (opening of negotiations, nomination of the Union's negotiator or negotiating team, authorization of the signature and conclusion of the agreement) are made by qualified majority..$^{73}$ Different from the Treaty of Nice, unanimity voting is not required anymore for the areas of intellectual property protection where the Union did not have exclusive competence. ${ }^{74}$ The Treaty of Lisbon still contains the obligation to use unanimity voting for areas of intellectual property protection where unanimity is also required for the adoption of internal rules. ${ }^{75}$ However, when assessing Article 118 of the TFEU, which is the only Article in the TFEU that deals with making internal rules in the area of intellectual property protection, the relevant voting rules are qualified majority voting as specified in the ordinary legislative procedure. ${ }^{76}$ One exception to the qualified majority voting is contained in Article 118 subparagraph 2 of the TFEU: when regulations establish language arrangements for European intellectual property rights, the Council shall act unanimously after consulting the European Parliament.

In conclusion, Member States no longer have a formal right to seek unanimity voting for adopting trade agreements that include intellectual property rights under any of the procedures available in the TFEU. There is one exception to this rule: in case

66 See Article 207.3 subparagraph 2 of the TFEU.

67 See Article 218.3 of the TFEU.

68 Article 207 does not speak about any negotiator other than the Commission. In practice, various Directorates General (DG) of the Commission are in charge of the different areas of intellectual property under negotiation. While DG Trade has the lead on the negotiations of IP issues, it consults other DGs depending on the IP right under negotiations. DG Internal Market and Services is consulted for matters of design and trade mark protection, DG Enterprise and Industry for patent issues, DG Taxation and Customs Union for border measures, DG Sanco/Health and Consumer for plant variety protection, DG Environment for the protection of traditional knowledge, and DG Agriculture and Rural Development for the protection of geographical indications. See Article 218.3 of the TFEU. As an example, ACTA provisions on criminal enforcement were negotiated by the EU Presidency whereas the other provisions were negotiated by the Commission.

70 See Article 207.3 subparagraph 3 of the TFEU.

71 See Woolcock, The Treaty of Lisbon, p. 12.

72 See Article 218.4 and 218.5 of the TFEU.

73 See Article 207.4 subparagraph 1 of the TFEU.

$74 \quad$ See Article 133.5 subparagraph 2 of the TEC.

75 See Article 207.4 subparagraph 2 of the TFEU.

76 See Article 294 of the TFEU. 
treaties contain provisions on language arrangements, the Council acts unanimously. Also, where mixed agreements are concerned, each Member State has to sign and ratify the agreement according to their national procedures. In fact, this grants them a veto power over the agreement. In view of the fact that most trade agreements are concluded as mixed agreements, Member States effectively are able to hold back many agreements if they do not consent to them.

While the Treaty of Lisbon has brought certain formal changes in the decision-making procedure, only little has changed in practice when compared to the situation under the Treaty of Nice. First, the Commission tends to be the negotiator for all areas under negotiation in a trade agreement, whether they fall under shared or exclusive competences. ${ }^{77}$ Member States are present in the room but do not speak, ${ }^{78}$ even when mixed agreements are negotiated. With regard to the negotiation of ACTA, however, the Trade Commissioner Karel De Gucht stated that the criminal enforcement provisions constituted shared competences and were negotiated by the EU Presidency on behalf of the Member States. ${ }^{79}$ Therefore, sensitive issues are not always negotiated by the Commission.

Second, it is primarily in the Trade Policy Committee that the substance of EU trade policy is shaped in "close interplay between the Commission and the Member States". ${ }^{80}$ The Trade Policy Committee will remain of decisive importance even though the International Trade Committee (INTA) of the European Parliament has received more importance through the Treaty of Lisbon. ${ }^{81}$ The TPC's institutional memory, technical expertise, the regularity of sessions and the long established decision-making procedure are strong indicators for a continued decisive role.

Third, voting rules in the Council have not mattered much in practice. Even though, under the Treaty of Nice, Member States were able to require unanimity for decisions on agreements containing commercial aspects of intellectual property (non-exclusive EC competences), Stephen Woolcock notes that in reality,

"the established rules of the game in trade policy have been that the Council works until an agreement is reached that all can accept." 82

De facto, decisions were not taken by voting but by consensus. This will most likely continue to be the case.

77 See Woolcock, The Treaty of Lisbon, p. 8.

78 See ibid., p. 13 and 8.

79 See footnote 22 of section 4.2.1.1 of this book. Even though the Trade Commissioner provided this answer to a question of a Member of the European Parliament, it is not clear whether the EU Presidency has indeed led the negotiations thereon.

80 S. Woolcock, "The Potential Impact of the Lisbon Treaty on European Union External Trade Policy" Swedish Institute for European Policy Studies, European Policy Analysis, 2008, Issue 8-2008, p. 2.

81 See section 4.2.4 of this book. For a more detailed discussion of the differences between the Trade Policy Committee and the INTA, see Woolcock, The Treaty of Lisbon, p. 12.

82 Ibid., p. 8. 
In conclusion, the decision-making process to a large extent still relies on the close cooperation between the Council on behalf of the Member Sates and the European Commission. This coordination primarily takes place in the Trade Policy Committee. The Member States also trust the Commission when leading the negotiations in areas of shared competence. Also, the voting rules in the Council reflect a method based on cooperation, namely consensus.

\subsubsection{Role of the European Parliament}

The role and function of the European Parliament (EP) when concluding international agreements must be distinguished according to the following three phases: 1) the negotiation of trade agreements, 2) the conclusion of trade agreements and 3) their implementation through legislative acts. In all three phases, the European Parliament has gained formal power through the Lisbon Treaty.

\subsubsection{Negotiation of Trade Agreements}

In the course of the negotiations of trade agreements, the European Parliament has the right to be informed (and the European Commission the obligation to inform the $\mathrm{EP})$ on the progress of such negotiations. ${ }^{83}$ In particular, the information shall be immediate and full at all stages of the negotiation procedure. ${ }^{84}$ This formal right to be informed is a new feature of the Treaty of Lisbon. It was not laid down in the TEC but in the Framework Agreement $2005^{85}$ between the two institutions. Even though the content and timeliness of the exchange of information were already regulated back then, ${ }^{86}$ the Framework. Agreement 2005 did not create a legally binding right for the European Parliament to receive information. ${ }^{87}$ Another new feature of the Treaty of Lisbon is the link made between the scope of this right and the way the Trade Policy Committee is briefed: the EP's International Trade Committee has the right to be informed to the same extent as the Trade Policy Committee. ${ }^{88}$ Since the latter Committee is consulted on a weekly basis, the regularity of information provided to

83 See Article 207.3 3rd subparagraph of the TFEU.

$84 \quad$ See Article 218.10 of the TFEU.

85 See Framework Agreement on relations between the European Parliament and the European Commission, done on 26.05.2005 in Brussels, (OJ C 117E of 18.05.2006, p. 125) [hereinafter Framework Agreement 2005].

86 Paragraph 19 of the Framework Agreement 2005 requires the Commission to provide early and clear information during the preparation, conduct and conclusion of international negotiations. The information must be provided early enough to give the Parliament sufficient time to express its point of view and for the Commission to take Parliament's views into account.

87 See Woolcock, The Treaty of Lisbon, p. 12; Krajewski, "The Reform of the Common Commercial Policy", p. 308. Note that the new Article 295 of the Treaty of Lisbon creates the possibility for the institutions to conclude interinstitutional agreements that will be binding on these institutions.

88 Article 207(3) subparagraph 3 last sentence of the TFEU reads: "The Commission shall report regularly to the special committee and to the European Parliament on the progress of negotiations." See also Krajewski, "The Reform of the Common Commercial Policy", p. 308. 
the EP has been enhanced considerably compared to the practice under the Treaty of Nice. ${ }^{89}$

Nevertheless, even with these changes regarding the right to be informed, the European Parliament has no right to be involved in the negotiations of international trade agreements. It did not receive the same or similar status to the Trade Policy Committee which, according to Article 207.3 third subparagraph of the TFEU, assists the Commission in conducting the negotiations. However, even though the Treaty does not confer a formal right upon the EP to have input in the negotiation process, the revised Framework Agreement 2010 specifies commitments by the European Commission to involve the European Parliament in the early phases of negotiating international agreements..$^{90}$ According to paragraph 23 of the Framework Agreement 2010, the Parliament is informed when the negotiating directives are defined. The Commission also has committed to taking the EP's views into account as far as possible. ${ }^{11}$ In other words, the Commission will have to explain whether and how the Parliament's comments were incorporated in the texts under negotiation and if not why. ${ }^{92}$ As was discussed by some authors, these specific rules could enable the INTA to impose preconditions at an early stage of the negotiations for giving its consent to the conclusion of the agreement. ${ }^{93}$

\subsubsection{Conclusion of Trade Agreements}

The role of the European Parliament during the conclusion of trade agreements has been enhanced considerably compared to the Treaty of Nice. According to Article 207.3 of the TFEU, the procedure laid down in Article 218 is applicable to agreements concluded with third countries in the field of the common commercial policy. As argued above, this includes trade agreements that contain TRIPS-plus provisions due to a dynamic concept of "commercial aspects of intellectual property". Article 218.6(a)(v) of the TFEU stipulates that the European Parliament needs to give its consent ${ }^{94}$ to agreements covering fields to which the ordinary legislative procedure applies. Since measures that implement the common commercial policy are adopted according to the ordinary legislative procedure (Article 207.2 of the TFEU), the European Parliament must give its consent before a decision on the conclusion of the trade agreement can be made by the Council.

Compared with the Treaty of Nice, the de jure veto power of the European Parliament for trade agreements is a major improvement in terms of legitimacy of these agreements. Article 300.3 of the ECT only required the consultation of the European Parliament. ${ }^{95}$ In practice, the European Parliament was asked for its assent in relation

89 See ibid., p. 308-309.

90 See Framework. Agreement on relations between the European Parliament and the European Commission, done on 20.10.2010 in Strasbourg (OJ L 204 of 20.11.2010, p. 47) [hereinafter Framework. Agreement 2010].

91 See paragraph 24 of the Framework. Agreement 2010.

92 See paragraph 4 of Annex II of the Framework. Agreement 2010.

93 See Woolcock, The Treaty of Lisbon, p. 12; Bungenberg, "Going Global?”, p. 129.

94 Article 223.1 subparagraph 2 of the TFEU specifies that the consent of the EP is given by a majority of the component Members of the Parliament.

95 Note that the assent of the European Parliament was required under Article 300.3 second subparagraph of the TEC for agreements establishing a specific institutional 
to major trade agreements recently negotiated and concluded by the European Union, such as the CARIFORUM-EC EPA or the EU-South Korea FTA. However, as Stephen Woolcock notes, even though the Parliament was able to deny its consent back then already, there was never a credible formal veto power of the EP due to its lack of legal powers and limited ability to provide close scrutiny of the Union's negotiating position. ${ }^{96}$ This is different under the Treaty of Lisbon which enables the Parliament to be briefed at all stages of the negotiation process and to have input on the content of the negotiations. ${ }^{97}$

\subsubsection{Implementation of Trade Agreements}

The European Parliament has become the co-legislator on measures that define the framework for implementing the common commercial policy. ${ }^{98}$ The Council and the Parliament will adopt such measures following the ordinary legislative procedure. The procedure allows the European Parliament to make amendments to the Commission's legislative proposals and deny its approval. ${ }^{99}$ Compared with the Treaty of Nice, the involvement of the European Parliament for adopting implementing measures has increased considerably: Article 133.2 of the TEC did not include the European Parliament in the implementation of trade agreements. ${ }^{100}$

The scope of the Parliament's power is, however, limited to measures that define the framework of implementing the common commercial policy. Accordingly, the Parliament is able to co-legislate general provisions concerning trade policy but not the implementation and application of such provisions in specific cases. ${ }^{101}$ This distinction reflects existing practice in the field of common commercial policy instruments. For example, the Parliament will be involved in modifications to the basic regulations relating to anti-dumping, countervailing duties, trade barriers and to the EU's Generalised System of Preferences. ${ }^{102}$ However, it does not encompass the adoption of specific regulations targeted at certain imports. ${ }^{103}$ In the area of intellectual property protection, no detailed implementing acts come to mind in which the European Parliament would not be involved through the ordinary legislative procedure.

\subsubsection{Conclusions}

The Treaty of Lisbon has brought major changes to the legal framework of the common commercial policy, in particular as regards intellectual property rights. These changes are primarily relevant for the competence question and the involvement of the European Parliament in the decision-making procedure of

framework, having budgetary implications or those that amend an act adopted under the ordinary legislative procedure. A prominent agreement in the area of trade agreements was the WTO Agreement.

$96 \quad$ See Woolcock, The Treaty of Lisbon, p. 8.

$97 \quad$ See section 4.2.4.1 of this book.

98 See Article 207.2 of the TFEU.

99 See Article 294 of the TFEU.

100 The Commission had to submit proposals to the Council.

101 See Eeckhout, EU External Relations Law, p. 458.

102 See ibid., p. 458.

103 See Woolcock, The Treaty of Lisbon, p. 11; Eeckhout, EU External Relations Law, p. 458. 
negotiating and concluding trade agreements. The changes in relation to the decisionmaking procedure do not seem to matter in practice.

The competence to conclude trade agreements with intellectual property rules has been clarified by the Treaty of Lisbon. According to Article 216.1 in conjunction with Article 207.3 subparagraph 1 of the TFEU, the European Union has exclusive external competence to conclude trade agreements with third countries that contain intellectual property protection. The scope of this competence has been argued to include trade agreements that contain TRIPS-plus provisions. Even though the Treaty of Lisbon provides ample room for the Union to conclude trade agreements including IP provisions exclusively, the Commission has in fact favoured mixed agreements for most bilateral trade agreements and seems to continue this trend.

With the integration of the common commercial policy into the Union's External Action, the Union is under an obligation to make trade agreements consistent with development concerns. Such concerns are sustainable economic, social and environmental development of developing countries as well as the broader objectives of the Union's development cooperation. Even though the requirement does not provide a substantive benchmark, the Council and Commission will have to motivate proposed common commercial policy measures in relation to their consistency with development concerns.

The decision-making process after the Treaty of Lisbon still also relies to a large extent on the interplay between the Council on behalf of the Member Sates and the European Commission. This is evidenced by three factors: 1) the continued importance of the Trade Policy Committee (formerly the "Article 133 Committee"), 2) the Commission still leading the negotiations even in areas of shared competence, and 3) the use of the consensus for decision making in the Council.

The changes brought about by the Treaty of Lisbon for the European Parliament arguably are most significant. The EP has received an extensive right to be informed about the negotiations of trade agreements, both through the Treaty of Lisbon as well as through the revised Framework. Agreement 2010. It also gained a credible veto power through the consent requirement of the EP for the conclusion of trade agreements. Even in the implementation of the framework of the common commercial policy, the Parliament has been promoted from no role to co-legislator.

The issues discussed in this section are primarily relevant to the European Union internally and to a certain extent also to third countries. The latter have an interest to know which entity of the European Union, the Union or the Member States or both, are competent and responsible for implementing relevant provisions of an international agreement. Even more important for third countries is the content of the European Union's external IP policy, which is dealt with in the remainder of this chapter. 


\subsection{Shift From Multilateral to Bilateral Regulation OF IP with THIRD COUNTRIES}

The European Union's external trade policy, which includes as a centrepiece the protection of intellectual property, ${ }^{104}$ has seen a clear shift in recent years. This shift has occurred in respect of the forum that the EU mainly uses for conducting trade policy with third countries. While the policy in 1999 exclusively focussed on international governance through multilateral forums, in particular the World Trade Organization (WTO), an explicit reorientation from the multilateral to the bilateral level took place in 2006.

This policy development happened in different phases, which are addressed in the following. Starting with Pascal Lamy's "globalisation maitrisée" as the core ideological cornerstone for the focus on the multilateral level, the policy shift began with the stagnation of trade policy making at the WTO. As a consequence, the European Union ended the informal moratorium of negotiating new free trade agreements and started proliferating comprehensive free trade agreements which require partner countries to grant TRIPS-plus protection to right holders of intellectual property. Strong IP protection in bilateral trade agreements has become a priority for the European Union.

\subsubsection{Prioritization of Multilateralism under Pascal Lamy}

Pascal Lamy, Trade Commissioner of the European Commission under Romano Prodi from 1999 until 2004, has influenced the European Union's external trade policy significantly during his mandate. His "ideological cornerstone"105 was the concept of "la globalisation maitrisée" (managed globalization) 106 that he introduced in a speech to the European Parliament in September 1999.107 The concept resulted from his belief that the European Union needed to live up to its moral responsibility and try to make the best of the external challenges posed by globalization. ${ }^{108} \mathrm{He}$ summarized the objectives that Europe should try to achieve in order to play a responsible role:

"The right way forward is removing obstacles to trade gradually, settling disputes peacefully, building up a body of rules which allow for fair play and transparency in world trade, and always ensuring that our policies and politics help those who are affected by the 'globally' more efficient division of labour."'109

Member States subscribed to these objectives and "managed globalization" became the official EU doctrine in trade. ${ }^{110}$ The doctrine was implemented by a number of policy strategies. ${ }^{111}$ One important strategy was to prioritize multilateralism over

\footnotetext{
104 See Maskus, “Observations on the Intellectual Property Component”, p. 461.

105 See Meunier, "Managing Globalization?”, p. 909.

106 Translation by the author, following Sophie Meunier, see ibid.

107 See ibid., p. 909.

108 See European Commission, Trade policy in the Prodi Commission 1999-2004: An assessment (Brussels, 19 November 2004), p. 3; see also Meunier, "Managing Globalization?”, p. 910 .

109 See European Commission, Trade policy in the Prodi Commission, p. 3.

110 See Meunier, "Managing Globalization?", p. 910.

111 For an excellent overview of these strategies, see ibid., p. $911 \mathrm{ff}$.
} 
bilateral agreements; the WTO became the sole institution that the European Union's trade policy focussed on. ${ }^{12}$ The underlying rationale was to subject the largest possible number of countries to an inclusive international organization with muscles and one set of rules. ${ }^{113}$ This strategy even gave birth to the well-known informal moratorium ${ }^{114}$ on negotiating new bilateral trade agreements until the end of the Doha Round in order not to jeopardize a successful conclusion of the Round.

By the end of his term in 2004, Pascal Lamy had to concede that the European Union's prioritization of the multilateral trade forum had risked the WTO's "legitimacy", both internally within the Union and in the outside world. ${ }^{115}$ He came to the following conclusion:

"I do not think that the WTO can or should remain the sole island of governance in a sea of unregulated globalization." 116

In other words, already in November 2004, the author of the doctrine "managed globalization" himself had started to re-think the adequacy of the sole focus on the WTO (to the exclusion of other forms of governance) in the European Union's external trade policy.

\subsubsection{Multilateral Stagnation}

Pascal Lamy's above-cited conclusion must be read in the light of the developments at the multilateral level that had just taken place. The Cancún Session of the Ministerial Conference in September 2003 turned out to be a dismal failure: WTO Members were not able to agree on the modalities of negotiating the so-called "Singapore issues". ${ }^{117}$ These issues were first identified at the Singapore Session of the Ministerial Conference in December 1996 and covered four possible areas of negotiation. ${ }^{118}$ They reflected a deep trade agenda, of which the European Union had been the keenest advocate. ${ }^{119}$ Developing country Members, however, opposed to

See European Commission, Trade policy in the Prodi Commission, p. 5.

See Meunier, "Managing Globalization?", p. 912.

According to Sophie Meunier, the moratorium on negotiating new bilateral trade agreements has resulted from a "convergence of views between Pascal Lamy and the Commission's trade directorate that globalization would be better managed for now by stopping the effervescence and concentrating instead on multilateralism and they had succeeded in convincing the Member States without much resistance that this was the best course of action for now." Ibid., p. 913.

See European Commission, Trade policy in the Prodi Commission, p. 5.

Ibid., p. 5.

At the Singapore Session of the WTO Ministerial Conference in December 1996, a number of possible issues were first identified for further negotiations within the WTO. These included: 1) the relationship between trade and investment, 2) the relationship between trade and competition law, 3) transparency in government procurement, and 4) trade facilitation. See Van den Bossche, The Law and Policy of the World Trade Organization, p. 91.

The four "Singapore issues" are: 1) the relationship between trade and investment, 2) the relationship between trade and competition law, 3) transparency in government procurement, and 4) trade facilitation. See ibid., p. 91.

See McGuire and Lindeque, "The Diminishing Returns to Trade Policy in the European Union", p. 1333. 
start negotiations on the "Singapore issues", which all touch upon complex regulatory areas that require significant legal and bureaucratic infrastructure. ${ }^{120}$ As a result of the failure to reach an agreement in Cancún and the consequent deadlock in the negotiations of the Doha Development Round, all but one of the Singapore issues was dropped from the envisaged negotiating agenda, keeping only trade facilitation on the agenda. ${ }^{121}$

The strong opposition by developing country Members at the Cancún Session did not only mean that the European Union failed to integrate areas of trade policy into the multilateral trade agenda that in its view could have addressed social and development objectives. ${ }^{122}$ It was also evidence of a broader tendency in the WTO, namely a shift in the level of influence from the EU to the benefit of a larger variety of actors, in particular the influential group of developing countries commonly referred to as the G-20.123 While international negotiations during the Uruguay Round $^{124}$ still catalyzed around the policy preferences of Canada, the European Union, Japan and the United States (the "QUAD" countries), the ability of the European Union to drive the agenda at the WTO after Cancún had declined considerably. ${ }^{125}$ The Doha Round, or as its alternate name Doha Development Round even better illustrates, reflected much more the interests of developing countries than those of European corporations. ${ }^{126}$ As a result, the European Union started to shift discussions on complex regulatory areas from the multilateral to the bilateral level.

\subsubsection{End of Moratorium for Negotiating New Bilateral Trade Agreements}

The first policy document that reflects a change in attitude of the European Union towards the self-imposed moratorium to negotiate new bilateral trade agreements was the mid-term review of the Lisbon Strategy published in February 2005. ${ }^{127}$ The original "Lisbon Strategy" had been launched by the European Council in March 2000 with the strategic goal of becoming

See ibid., p. 1338.

See WTO General Council, Doha Work Programme, Decision adopted by the General Council on 1 August 2004 (2 August 2004) [WT/L/579], p. 3.

See McGuire and Lindeque, "The Diminishing Returns to Trade Policy in the European Union", p. 1333.

The G-20 importantly includes countries like China, India, Indonesia, Brazil, Egypt, Argentina and South Africa. For a complete list of countries, refer to WTO Secretariat, Groups in the negotiations (2012), available at <http://www.wto.org/english/tratop_e/dda_e/negotiating_groups_e.htm> accessed on 16.02.2012.

The Uruguay Round was initiated by the Punta del Este Ministerial Declaration of 20 September 1986. See GATT, Punta del Este Ministerial Declaration.

See McGuire and Lindeque, "The Diminishing Returns to Trade Policy in the European Union", p. 1339.

See ibid., p. 1336.

See European Commission, Working together for growth and jobs: A new start for the Lisbon Strategy (Brussels, 2 February 2005) [COM(2005) 24 final] [hereinafter mid-term review of the Lisbon Strategy]. 
"the most competitive and dynamic knowledge-based economy in the world capable of sustainable economic growth with more and better jobs and greater social cohesion." 128

This goal was envisaged to be achieved by 2010. In its mid-term review, the European Commission stated that not enough progress had been made by then. ${ }^{129}$ With a view of putting the Lisbon Agenda back on track, the European Commission proposed a renewed drive and focus. Delivering stronger, lasting growth and creating more and better jobs became the two principal tasks. ${ }^{130}$

In order to make Europe a more attractive place to invest and work, the renewed Lisbon Strategy stresses the link between internal and external measures: European companies must have access to third markets so that they can generate higher growth rates. ${ }^{131}$ The European Union's external trade policy has an important role to play in this context.

"The completion of an ambitious agreement in the DOHA round, therefore, remains the fundamental objective. This should be complemented by bilateral and regional Free Trade Agreements, including with Mercosur, the Gulf Co-operation Council."132

Even though the reference to bilateral trade agreements is rather modest in its scope and detail, it does indicate new possibilities for the European Union to conclude bilateral trade agreements.

\subsubsection{Intellectual Property Chapters in Future Bilateral Agreements a Priority}

Approximately at the same time as the mid-term review of the Lisbon Strategy, the European Commission adopted the "Strategy for the Enforcement of Intellectual Property Rights in Third Countries". ${ }^{133}$ This initiative specifically focuses on enhancing the effective implementation of enforcement legislation in third countries and thereby significantly reducing the level of intellectual property rights violations abroad. While the strategy proposes to undertake various actions simultaneously, ${ }^{134}$ one important proposal regards multilateral and bilateral agreements. In this context, the strategy explicitly refers to future bilateral agreements.

European Council, Presidency Conclusions (Lisbon, 23 and 24 March 2000).

See European Commission, Working together for growth and jobs: A new start for the Lisbon Strategy, p. 7.

See ibid., p. 7.

See ibid., p. 18.

Ibid., p. 18.

See European Commission, Enforcement Strategy in Third Countries.

The "Enforcement Strategy in Third Countries" suggests eight actions that involve both hard and soft mechanisms of achieving a higher level of IP enforcement: 1) identifying the priority countries, 2) multilateral/bilateral agreements, 3) political dialogue, 4) incentives/ technical cooperation, 5) dispute settlement/sanctions, 6) creation of public-private partnerships, 7) awareness raising and 8) institutional cooperation. 
"It is also envisaged to make the enforcement clauses in future bilateral or bi-regional agreements more operational and to clearly define what the EU regards as the highest international standards in this area." 135

Not only does the strategy leave no doubt about the fact that the European Union is willing to conduct negotiations of bilateral trade agreements in the future, it even regards them as a crucial tool to improve the level of IPR enforcement in partner countries. By giving clear indications on how the revisited approach to the IPR chapters must look like, ${ }^{136}$ the strategy has become the most significant initiative of the European Union in the fight against counterfeiting and piracy. ${ }^{137}$ It has also strongly influenced the formulation of strategies followed by the European Commission when negotiating the IP chapters with partner countries, such as CARIFORUM States and India. ${ }^{138}$

\subsubsection{Comprehensive Bilateral Trade Agreements}

The inclusive new political strategy "Global Europe: competing in the world"139 eventually makes bilateral trade negotiations a priority for Europe's external trade policy. The communication was launched in 2006 and sets out an agenda of external trade measures that aim at achieving the goals defined in the renewed Lisbon strategy. ${ }^{140}$ It proposes to complement the internal agenda with external measures that can foster the competitiveness of Europe and ensure productivity, growth and job creation. ${ }^{141}$ The strategy thereby reflects the interests of large European corporations, in particular the members of the industry organization BusinessEurope, which supposedly have strongly influenced the choice of focus areas, scope of the measures and targeted countries. ${ }^{142}$

The strategy presents several external measures that are meant to create open markets and fair conditions for trade abroad. ${ }^{143}$ They cover a variety of focus areas, ${ }^{144}$

European Commission, Enforcement Strategy in Third Countries, p. 5.

The level of IP protection and enforcement foreseen by the "Enforcement Strategy in Third Countries" is further analyzed in section 4.4.2 of this book.

See D. Matthews, The Fight Against Counterfeiting and Piracy in the Bilateral Trade Agreements of the EU (European Parliament, Brussels, 2008) [EXPO/B/INTA/2008/28], p. 8.

Interview with a member of DG Trade, March 2010, Brussels (available on request).

European Commission, Global Europe.

See ibid., p. 2.

See ibid., p. 2.

See Corporate Europe Observatory, Global Europe: An Open Door Policy for Big Business Lobbyists at DG Trade (Brussels, 2008), available at <http://www.corporateeurope.org/publications/open-door-policy-big-business > accessed on 15.11.2012, p. 3. The report states that BusinessEurope had at least seven meetings on the "Global Europe" strategy with top officials at DG Trade between February 2005 and October 2006. Also interview with David Cronin, Brussels correspondent of the Inter Press Service news agency, 18 March 2010, Brussels (available on request).

See European Commission, Global Europe, p. 6.

The strategy lists three main focus areas of the future trade policy: 1) reducing nontariff barriers, such as unnecessarily trade-restrictive regulations and procedures, 2) securing access to resources such as energy, metals and raw materials, and 3) stronger rules in the new areas of growth. The last category of areas cover intellectual property protection, stronger liberalization of trade in services, improved investment conditions 
intellectual property protection being one of them. ${ }^{145}$ The tools with which the European Commission proposes to achieve the goals strongly rely upon bilateral trade agreements. Four out of the eight points of actions propose bilateral agreements with third parties as the way forward. In particular, "Global Europe" suggests 1) free trade agreements as a tool to promote openness and to address key issues that until now remain outside the WTO. ${ }^{146}$ 2) The EU seeks to develop further $c^{-}$operation with the US on areas such as IPR protection and trade security. ${ }^{147} 3$ ) Drawing upon the goals of the "Enforcement Strategy in Third Countries", IPR provisions and the enforcement clauses in future bilateral agreements need to be strengthened. $\left.{ }^{148} 4\right)$ In the area of public procurement, the EU considers substantial agreements with third countries to be the best way to open up major foreign procurement markets. ${ }^{149}$

The free trade agreements envisaged by the European Commission have been described in great detail and received the most attention in the communication. In fact, the Commission proposes a "new generation" of FTAs: ${ }^{150}$ they shall be

"comprehensive in scope, provide for liberalisation of substantially all trade and go beyond WTO disciplines." 151 [emphasis added]

As key issues to be addressed in future FTAs, the Communication specifically mentions the disciplines that currently remain outside the WTO. Accordingly, these are investment, public procurement, competition, other regulatory issues and IPR enforcement. ${ }^{152}$ The broad scope and the WTO-plus nature of issues to be included in future FTAs make them very similar to the bilateral agreements concluded by the United States. ${ }^{153}$

As to the level of commitments in these areas, the European Union aims at the "highest possible degree of trade liberalisation." In addition,

"Where our partners have signed FTAs with other countries that are competitors of the EU, we should seek full parity at least." 154

in third countries, a liberalized public procurement market and new competition rules. See ibid., p. 8.

Section 4.4.2 of this book elaborates the substantive requirements that "Global Europe" imposes for Europe's future IP policy. See European Commission, Global Europe, p. 10.

147 See ibid., p. 12.

148 See ibid., p. 13.

149 See ibid., p. 14.

See European Commission, European competitiveness (2008), available at $<$ http://ec.europa.eu/trade/creating-opportunities/trade-topics/europeancompetitiveness/index_en.htm> accessed on 15.11.2012; Council of the European Union, Council Conclusions following the Commission's Communication "Global Europe: Competing in the World" (Brussels, 13 November 2006), paragraph 9. European Commission, Global Europe, p. 10.

152 See ibid., p. 10.

153 See section 1.1 of this book. 
Even though the Communication does not further clarify which countries would qualify as competitors, this group certainly includes the big players such as the United States, China, Japan, India, Brazil and South Korea. Seeking parity with the provisions in FTAs signed by the US, including on intellectual property protection, marks a significant shift to a new generation of "competitiveness-driven FTAs". ${ }^{155}$

In light of the strong reliance on bilateral trade agreements during the last six years, ${ }^{156}$ in particular free trade agreements, the EU's stated promise that the Doha Development Agenda remains its "first priority" can only be understood as declaratory in nature. ${ }^{157}$ The commitment to the WTO as the main multilateral forum of managing trade is rather weak in the remainder of the document. The Commission states that the European Union is prepared to pay "reasonably" to keep the multilateral system thriving. ${ }^{158}$ To sum up, "Global Europe" marks an unequivocal shift away from the WTO as the exclusive and prioritized trade-policy forum. As the global economy is changing rapidly, the communication urges for the tools of EU trade policy to be adapted ${ }^{159}$ and for the use of bilateral trade agreements.

This trend is reaffirmed in the Commission's most recent communication entitled "Trade, Growth and World Affairs: Trade policy as a core component of the Europe 2020 Strategy": Europe is willing to spend a large part of its energy on delivering free trade agreements that were put forward as priorities in the "Global Europe" strategy. ${ }^{160}$ The communication published in 2010 is a key element in the external dimension of the "Europe 2020" Strategy, ${ }^{161}$ which replaces the Lisbon Strategy. The European Union therein again confirms its commitment to the Doha Development Round but also qualifies that the use of bilateral agreements does not conflict with this commitment:

"Doha remains our top priority. However, the bilateral is not the enemy of the multilateral. The opposite may hold truer: liberalisation fuels liberalisation." 162

Ibid., p. 11.

This period includes the years 2006 - 2012. It is questionable how many more bilateral agreements the European Union can conclude. For the case of the United States, it can be argued that in terms of willing partners of bilateral agreements, it has achieved everything that was possible. Now, the US moves to plurilateral agreements, such as ACTA and the Trans-Pacific Partnership negotiations. See B.K. Gordon, "Trading Up in Asia: Why the United States Needs the Trans-Pacific Partnership" Foreign Affairs, 2012, Vol. 91 (4), 17-22. It is to be seen when the European Union will reach this point. For an account of the success of the US strategy to achieve higher multilateral patent norms through bilateral FTAs, see J.-F. Morin, "Multilateralizing TRIPs-Plus Agreements: Is the US Strategy a Failure?" Journal of World Intellectual Property, 2009, Vol. 12 (3), 175-197.

See European Commission, Global Europe, p. 2.

See ibid., p. 10.

See ibid., p. 2.

See European Commission, Trade, Growth and World Affairs: Trade policy as a core component of the EU's 2020 Strategy (DG Trade, Brussels, 2010) [COM(2010)612], p. 5.

See European Commission, Europe 2020: A strategy for smart, sustainable and inclusive growth (Brussels, 3 March 2010) [COM(2010)2020].

See European Commission, Trade, Growth and World Affairs, p. 5. 
In view of the extent to which the European Commission has initiated negotiations of free trade agreements since the launch of the "Global Europe" strategy and keeping in mind the continued stagnation of progress in the Doha Development Round, the EU's priority of bilateral over multilateral governance is evident. Three sets of bilateral negotiations have already been concluded: the FTA with South Korea is provisionally applied since 1 July 2011, the EU-Colombia-Peru FTA was signed on 26 June 2012, and the EU-Central America AA was signed on 29 June 2012. Seven other bilateral negotiations are ongoing. In particular, bilateral trade negotiations have been launched with India (launched in June 2007), ${ }^{163}$ Ukraine (launched in February 2008), ${ }^{164}$ Canada (launched in May 2009), ${ }^{165}$ Singapore (launched in March 2010), ${ }^{166}$ Malaysia (launched in October 2010), ${ }^{167}$ Mercosur (re-launched in May 2010), ${ }^{168}$ and Vietnam (launched in June 2012). ${ }^{169}$ The EU-South Korea FTA is the "most comprehensive free trade agreement negotiated by the EU so far", ${ }^{170}$ which will act as a benchmark for future FTA negotiations. ${ }^{171}$

In summary, the European Union's exclusive focus on the WTO as the international governance mechanism under Commissioner for Trade Pascal Lamy came to an end with the launch of the "Global Europe" strategy. The new trade policy presents the external agenda of the Lisbon Strategy, according to which Europe should become the most competitive and dynamic knowledge-based economy in the world by 2010 . Comprehensive free trade agreements that go beyond current WTO disciplines were a crucial element of the strategy and shifted the priority from the multilateral forum to the bilateral. Intellectual property protection became a centrepiece of these agreements.

\subsection{Shift in the Legal Approach to Protecting IP in Bilateral Trade AGREEMENTS}

Although the end of the informal moratorium on concluding new bilateral trade agreements has probably been discussed most, another important shift has occurred with regard to the approach of regulating IP protection. Bilateral agreements concluded with third countries before 2006 did not focus on the protection and enforcement of intellectual property rules; ${ }^{172}$ compared to the many other areas of trade regulated therein, IP was clearly not a priority. However, in the new phase since

The last EU-India Summit took place on 10 February 2012 in New Delhi, after twelve rounds of negotiation on the draft India-EU BTIA. For an updated status of these negotiations, see European Commission, Bilateral relations.

Negotiations for an association agreement encompass a free trade agreement, which will contain rules on all trade-related aspects, including on intellectual property rights. Since February 2008, eighteen negotiation rounds have taken place. In October 2011, the ninth round of negotiations has taken place. Ten negotiating rounds have taken place between March 2010 and March 2012. Since the launch of negotiations, six negotiation rounds have taken place. In July 2012, the eighth negotiation round took place in Brazil. See European Commission, "Press release: EU and Vietnam launch negotiations for a comprehensive Free Trade Agreement".

170 See European Commission, Report on progress achieved on the Global Europe strategy, 20062010 (Brussels, 3 March 2010) [SEC(2010)1269], p. 6.

171 See ibid., p. 7.

172 See also Drexl, "MünchKommBGB, IntImmGR”, recital 115. 
2006, the European Union dedicates much attention to strong IP rules. The "Global Europe" strategy states that

"the EU should seek to strengthen IPR provisions in future bilateral agreements and the enforcement of existing commitments in order to reduce IPR violations and the production and export of fake goods." 173

The importance of the protection of IP and its enforcement for Europe's competitiveness is clearly reflected in the comprehensiveness of the IP chapters in recent bilateral trade agreements. ${ }^{174}$

While this section does not aim at providing a detailed legal assessment of all the IP provisions contained in recent European bilateral trade agreements (this is done in chapters 4, 5 and 6), it does present a comparison of the legal approaches to protecting IP in third countries used by the European Union before and after the launch of the "Global Europe" strategy, in the following referred to as "old generation" and "new generation". Where relevant, the EU's approach is also compared with United States FTAs. The analysis is presented according to two main categories: 1) the scope of the IP provisions in bilateral trade agreements and 2) the level of protection achieved. The two matters are assessed first for the agreements concluded before the launch of "Global Europe" and subsequently for agreements concluded after the launch of "Global Europe". The analysis is a synthesis of the legal assessments carried out in other chapters of this thesis, notably chapters 2,4 and 5.

\subsubsection{The EU's Approach of Protecting IP in Third Countries before the Launch of "Global Europe"}

The "old generation" agreements concluded by the European Union are diverse due to the contexts in which agreements have been negotiated. The coverage of the IP chapter included in several agreements, as well as the level of protection prescribed therein, differs according to how the partners relate to the European Union. For the analysis below, particular attention is paid to the IP chapters in bilateral trade agreements and agreements on trade in wine and/or spirits that have been concluded with particular developing countries, including ACP States. ${ }^{175}$ The group of candidate, potential candidate and neighbouring countries ${ }^{176}$ are excluded from the scope of analysis as they are not targeted by the "Global Europe" strategy.

\footnotetext{
173 See European Commission, Global Europe, p. 13.

174 See also Drexl, "MünchKommBGB, IntImmGR", recital 116.

175 This group includes Mexico, Chile, Bangladesh and South Africa. See section 3.3.1 of this book on the categorization of European bilateral trade agreements.

176 Countries of this group are the candidate countries (Croatia, FYROM, Turkey), potential candidate countries of the Balkans (Albania, Bosnia and Herzegovina, Montenegro, Serbia, Kosovo), the Mediterranean countries (Algeria, Egypt, Israel, Jordan, Lebanon, Morocco, Palestinian Authority of the West Bank, Tunisia), in the South Caucasus (Armenia, Azerbaijan, Georgia) and Central Asia (Republic of Kazakhstan, Kyrgyz Republic, Republic of Moldova, Russian Federation, Ukraine and Republic of Uzbekistan). See section 3.3.1 of this book on the categorization of European bilateral trade agreements.
} 
The scope of the provisions dealing with intellectual property protection in the "old generation" bilateral agreements with particular developing countries is very limited: they include an average of one or two articles and in some cases an additional annex. ${ }^{177}$ Those one or two provisions address all areas of intellectual property protection together; they do not distinguish between or focus on specific areas of IP. One exception to the general reference to IP are the provisions on the protection of geographical indications (including extensive annexes) contained in the agreements on trade in wine and/or spirits. ${ }^{178}$

The level of protection of IP in the "old generation" bilateral trade agreements is rather modest and generally formulated. It can be characterized by three main elements: 1) the reference to multilateral IP agreements, 2) modest obligations on IP in general, and 3) specific obligations on the protection of geographical indications for wines and spirits.

First, "old generation" European Union bilateral trade agreements do not set out specific intellectual property standards themselves, but mainly refer to multilateral IP treaties that trading partners must accede to or comply with. ${ }^{179}$ Importantly, the TRIPS Agreement is the standard that most provisions therein adhere to; only a few obligations are of a TRIPS-plus nature. It is through this indirect requirement of adhering to a multilateral treaty that substantive standards of IP are included in the agreements. This approach is referred to as the "multilateral" approach, in contrast to the "legislation-like" approach used by the US, according to which bilateral provisions are drafted in the same way as internal legislation. ${ }^{180}$

Second, in addition to specifying which multilateral agreements the trading partners need to accede to or comply with within a certain period, the bilateral agreements with particular developing countries contain modest obligations on protecting IP standards in general:

177 See Articles 168-170 of the EU-Chile AA; Article 12 of the EU-Mexico GA; Article 46 of The Partnership Agreement Between the Members of the African, Caribbean and Pacific Group of States of the One Part, and the European Community and its Member States, of the Other Part, (Cotonou Agreement), signed in Cotonou, Benin on 23 June 2000, entered into force on 1 April 2003, revised in 2005 and 2010 (OJ L 317 of 15.12.2000). The EU-Bangladesh CA contains a joint declaration on the respective article and an annex. See Article 4.5, Annex I and Annex II of the EU-Bangladesh CA.

See Articles 4-11 of the EC-Mexico Spirits Agreement, Articles 5 and 7 of the EC-South Africa Wine Agreement and of the EC-South Africa Spirits Agreement, Articles 5 and 8 of Annex V of the EC-Cbile AA; Article 5 of Annex VI of the EC-Chile AA. See section 3.3.6.2 of this book on the level of protection of geographical indications in European bilateral trade agreements.

179 See section 3.3.6.2 of this book. See also X. Seuba, Health Protection in the European and Andean Association Agreement (Health Action International, Accion Internacional para la Salud Latinoamérica \& Caribe, Amsterdam, 2009) [03-2009/02], p. 5; Drexl, "MünchKommBGB, IntImmGR", recital 115. States. 
"The Parties shall grant and ensure adequate and effective protection of intellectual property rights in accordance with the highest international standards, including effective means of enforcing such rights provided for in international treaties." 181

It is left unclear what the highest international standards are and therefore offers ample room for interpretation. ${ }^{182}$

Third, one area of IP has received particular attention. The protection of geographical indications (and traditional expressions in the case of the EC-Chile Wine Agreement $)^{183}$ has been addressed specifically in the agreements on trade in wine and/or spirits. Besides definitions of the concept of geographical indications, ${ }^{184}$ the agreements require two substantive obligations. The first obligation extends to the mutual or reciprocal protection of the geographical indications for wines and/or spirits listed in the annexes. ${ }^{185}$ The parties shall provide appropriate legal means to ensure that these names can be used for identifying names or spirits in each other's territories. The level of protection is higher than that referred to in the TRIPS Agreement in two ways. First, the agreements on trade in wine and/or spirits do not limit the available protection to those uses of the GI that mislead the public as to the geographical origin of the good. ${ }^{186}$ Second, mutual or reciprocal protection is "automatic": it does not allow parties to examine the listed GIs according to certain eligibility criteria and available exceptions before protecting them in their territory. Internationally accepted eligibility criteria and exceptions are those mentioned in Article 22.1 and 24 of the TRIPS Agreement. ${ }^{187}$

The second type of protection addressed in the agreements on trade in wine and/or spirits is referred to as "additional protection". ${ }^{188}$ This additional level of protection is also foreseen in the TRIPS Agreement. ${ }^{189}$ Parties are required to also protect the listed GIs against any use for wines or spirits that do not originate in the geographical area

181 Article 168 of the EC-Cbile $A A$. For a very similar obligation, see Article 12.1 of the EC-Mexico GA; Article 46.1 of the EC-SA TDCA. Note that Article 4.5(a) of the ECBangladesh $C A$ deviates from this sentence. In particular, it does not include a commitment to protect IP in accordance with the highest international standards. For a discussion of this concept, see section 3.3.5 of this book.

183 See Article 8 of Annex V of the EC-Chile $A A$.

184 See Article 3(b) of the EC-SA Wine Agreement and the EC-SA Spirits Agreement, Article 3(b) of Annex $\mathrm{V}$ of the EC-Chile $A A$.

185 See Article 7.1 of the EC-SA Wine Agreement, Article 5.1 of the EC-SA Spirits Agreement, Article 5.1 of Annex V and VI of the EC-Chile AA. Note that Article 4.3 of the ECMexico Spirits Agreement speaks about "the" legal means instead of "appropriate" legal means.

186 See Article 22.2(a) of the TRIPS Agreement.

187 See section 3.3.6.2 of this book on the level of protection for geographical indications in European bilateral trade agreements.

188 Note that Article 23 of the TRIPS Agreement speaks about "Additional Protection for Geographical Indications for Wines and Spirits." The protection afforded in this Article adds to the general protection offered to all geographical indications, as provided for in Article 22 of the TRIPS Agreement. The general protection involves the right to prevent the use of a geographical indication for a good which does not originate in that area if this use misleads the public as to the geographical origin of the good. See also section 3.3.6.2 of this book.

189 See Article 23.1 of the TRIPS Agreement. 
indicated, even where a) the true origin of the product is shown, b) the name in question is used as a translation or c) the name is accompanied by terms such as "kind", "type", "style", "imitation", "method" or other expressions of that sort. ${ }^{190}$

To conclude, the substantive standards of IP protection in "old generation" bilateral trade agreements with particular developing countries are introduced through references to specific multilateral treaties on the protection of intellectual property. A focus on one or more areas of IP protection cannot be identified in the bilateral trade agreements since specific IP rights are not addressed individually. An exception is the protection of geographical indications, which is contained in the agreements on trade in wine and/or spirits. That protection contains TRIPS-plus elements.

\subsubsection{The EU's Approach of IP Protection in Third Countries after the Launch of "Global Europe"}

Only a few of the features identified in the multilateral approach of protecting IP rights in "old generation" bilateral trade agreements are also used in the "new generation" bilateral trade agreements. The majority of features clearly reflect a new approach to protecting intellectual property rights, which has strong similarities with the approach taken by the United States. The changes are both reflected in policy documents as well as in recent "new generation" agreements. ${ }^{191}$ They are in line with the goal set out in the "Global Europe" strategy of using IP provisions in bilateral trade agreements to foster Europe's competitiveness.

Already the scope of the IP chapters in the "new generation" bilateral trade agreements reflects the new focus on IP issues. For the first time, bilateral agreements contain specific chapters on the protection of intellectual property (and innovation). These chapters are very detailed as they deal with each intellectual property right individually. The IP chapters consist of approximately, thirty-three articles. ${ }^{192}$ This level of detail in regulating IP in bilateral trade agreements reflects an

190 See Article 5 of the EC-Mexico Spirits Agreement, Article 7.3 of the EC-SA Wine Agreement, Article 5.3 of the EC-SA Spirits Agreement, Article 5.3 of Annex V and VI of the EC-Chile $A$ A.

191 The "new generation" agreements that form part of this analysis are: the CARIFORUM-EC EPA; the EU-South Korea FTA; the EU-Colombia-Pern FTA; the India-EU BTLA; and the draft Comprehensive Economic and Trade Agreement between the European Union and Canada [hereinafter draft EU-Canada CETA], the text used for this analysis is the leaked draft IP chapter from February 2012, posted by M. Geist, ACTA Lives: How the EU \& Canada Are Using CETA as Backdoor Mechanism To Revive ACTA (2012), available at <http://www.michaelgeist.ca/content/view/6580/135/> accessed on 16.11.2012.

192 The IP chapter of the CARIFORUM-EC EPA includes thirty-four articles. The IP chapter of the EU-South Korea FTA has sixty-nine articles, although it needs to be stated that the double amount of articles merely reflects a more detailed separation of articles. The IP chapter of the EU-Colombia-Peru FTA contains sixty articles with a similarly detailed separation of articles as in the EU-South Korea FTA. The IP chapter of the draft India-EU BTLA contains thirty-three articles and four annexes and the IP chapter of the draft EU-Canada CETA consists of thirty-two articles. 
alignment with the style used by the United States: the scope of protection contained in US FTAs is equally specific and detailed. ${ }^{193}$

The level of protection in the "new generation" agreements is achieved through a mixed approach. While the European Union continues to ask its partner countries to accede to or comply with particular multilateral IP treaties, the new IP chapters now also and even predominantly address the various areas of intellectual property individually through specific provisions. These specific obligations can be described according to two main features: 1) they are legislation-like provisions achieving identical levels of protection, and 2) define highest international standards.

\subsubsection{Identical Levels of IP Protection}

An important feature of the "new generation" bilateral trade agreements are the legislation-like provisions of the IP chapter. They prescribe identical language as used in internal EU legislation for certain areas of IP protection. Requiring partner countries, including developing countries, to provide the level of intellectual property protection that the European Union also applies internally can be classified as an aggressive feature of bilateral agreements. ${ }^{194}$ It forces partner countries to apply concrete rules of European Union legislation instead of allowing them to implement the obligations in the way most suitable to them.

The purpose of copying internal legislation is stated in the "Europe 2020" Strategy:

"In negotiating FTAs, the IPR clauses should as far as possible offer identical levels of IPR protection to that existing in the EU [...]."195

This clause resembles the United States Trade Act of 2002 which requires international agreements on intellectual property protection to reflect a standard of protection similar to that found in the United States. ${ }^{196}$ As a result of the so-called Trade Promotion Authority, the United States has used "legislation-like" provisions in its FTAs for many years. The European Union has aligned its approach with that of the US and uses identical language as in internal legislation in the following areas of IP protection: 1) the enforcement of IP rights, 2) the protection of geographical indications, 3) copyright and 4) design rights.

The enforcement of intellectual property rights has become probably the most important aspect in recent bilateral trade agreements concluded by the European Union. Already in the 2005 "Enforcement Strategy in Third Countries", the EU made clear that it will revisit the approach used in the IP chapter included in recent bilateral agreements. ${ }^{197}$ In particular, the enforcement clauses were to be clarified and

See section 3.2.1 of this book for an account of the number of pages and words used in recent free trade agreements concluded by the United States.

I have used the term "aggressive" to classify features of the EU approach which are similarly hard line as the US approach. For an overall classification of the EU approach, see section 4.7 of this book on the conclusions.

European Commission, Trade, Growth and World Affairs, p. 13.

See Trade Act of 2002 \2102.4(A)(II), 19 U.S.C. \ 3802(b)(4)(A)(i)(II) (2002). See also section 3.2.1 of this book.

See European Commission, Enforcement Strategy in Third Countries, p. 5. 
strengthened. In doing so, the Strategy proposed that the Enforcement Directive 2004/48198 and the Customs Regulation 1383/2003199

"may constitute an important source of inspiration and a useful benchmark."200

The "Global Europe" strategy reaffirmed this trend:

"FTAs should include stronger provisions for IPR [...], including for example provisions on enforcement of IP rights along the line of the Enforcement Directive 2004/48." 201

These policy documents reflect a conscious choice of drafting the enforcement provisions in future bilateral agreements in the same way as the equivalent provisions of the EU's main enforcement and customs regulation instruments.

The bilateral trade agreements concluded since 2006 are evidence of this new approach of drafting bilateral provisions. Most of the enforcement provisions included in the CARIFORUM-EC EPA, the EU-South Korea FTA, the EU-ColombiaPeru FTA, the draft India-EU BTLA (as proposed by the European Union) and the draft EU-Canada CETA (as proposed by the European Union) are literally taken from the Enforcement Directive 2004/48 and the Customs Regulation 1383/2003. ${ }^{202}$

Second, several provisions on the protection of geographical indications in certain "new generation" agreements have also been copied from relevant European Union internal legislation. The protection of geographical indications always has been a crucial area of IP protection for the European Union, unlike the United States that does not have a system of GI protection and therefore does not include it in its FTAs either. For many years, it has been the only area of IP protection that was granted specific attention by the European Union in the agreements on trade in wine and/or spirits. Also after the launch of the "Global Europe" strategy, the need for a more effective protection of geographical indications and its enforcement has been noted in two recent policy documents, namely the Communication on the External Dimension of the Lisbon Strategy for Growth and Jobs ${ }^{203}$ and the Trade component of the Europe 2020 Strategy. ${ }^{204}$

See EC Directive 204/48 of the European Parliament and of the Council of 29 April 2004 on the Enforcement of Intellectual Property Rights (OJ L 157 of 30.04.2004) [hereinafter Enforcement Directive 2004/48].

See EC Council Regulation 1383/2003 of 22 July 2003 concerning customs action against goods suspected of infringing certain intellectual property rights and the measures to be taken against goods found to have infringed such rights (OJ L 196 of 02.08.2003) [hereinafter EC Customs Regulation 1383/2003]. European Commission, Enforcement Strategy in Third Countries, p. 5. European Commission, Global Europe, p. 11. See sections 5.3.3, 6.4 and section 7.10 on the enforcement provisions in the CARIFORUM-EC EPA and the draft IP chapter of the India-EU BTLA.

See European Commission, Communication on the External Dimension of the Lisbon Strategy for Growth and Jobs (Brussels, 16 December 2008) [COM(2008)874 final], p. 8. 
In order to give effect to this goal, the EU has chosen to insert or propose identical provisions to those contained in the EC Regulation 510/2006 205 on the protection of GIs for agricultural products and foodstuffs to recent negotiating partners. In particular, the Regulation's provisions addressing the level of GI protection, ${ }^{206}$ exceptions, ${ }^{207}$ as well as the relationship with trade marks, ${ }^{208}$ have found their way into the agreements concluded with South Korea and Colombia-Peru, and those that are still being negotiated with India and Canada. 209

Provisions identical to those used in European Union legislation have also been transposed into some "new generation" bilateral trade agreements in the area of copyright protection. The Information Society Directive 210 deals with copyright protection in a digital environment; its provisions on technical protection measures (TPMs), rights management information (RMI), ${ }^{211}$ and the rights on reproduction and communication to the public ${ }^{212}$ have been copy-pasted by the EU into the IP chapter proposed to India and Canada. ${ }^{213}$

Finally, the obligations in the area of design protection in recent bilateral trade agreements also show very similar language to that used in the EC Directive 89/71 on

next to enforcement in general, the protection and enforcement of geographical indications as an essential feature of future FTAs. European Commission, Trade, Growth and World Affairs, p. 13.

EC Regulation No 510/2006 of 20 March 2006 on the protection of geographical indications and designation of origin for agricultural products and foodstuffs (OJ L 93/12 of 20 March 2006) [hereinafter EC Regulation 510/2006]. See Article 13.1 of the EC Regulation 510/2006.

207 See Article 3.2 of the EC Regulation 510/2006.

208 See Article 14 of the EC Regulation 510/2006.

209 On the level of protection, see Article 210.1 of the EU-Colombia-Peru FTA; Article 9.4 of the draft IP chapter of the India-EU BTLA, as proposed by the EU; Article 7.4.1 of the draft IP chapter of the EU-Canada CETA, as proposed by the EU. On the exception addressing GIs that are identical to the name of a plant variety or animal bread, see Article 145.C.2 of the CARIFORUM-EC EPA; Article 10.24.3 of the EUSouth Korea FTA; Article 9.3.2 of the draft IP chapter of the India-EU BTLA, as proposed by the EU; Article 7.6.3 of the draft IP chapter of the EU-Canada CETA. On the relationship with trade marks, see Article 10.21.5, 10.23.1 and 2 of the EU SouthKorea FTA; Article 211.1 of the EU-Colombia-Peru FTA; Articles 9.7.1 and 5 of the draft IP chapter of the India-EU BTLA, as proposed by the EU; and Article 7.4.4 and 7.4.5 of the draft IP chapter of the EU-Canada CETA, as proposed by the EU.

210 EC Directive 2001/29 of the European Parliament and of the Council of 22 May 2001 on the harmonization of certain aspects of copyright and related rights in the information society (OJ L 167 of 22.06.2001, p. 10) [hereinafter the Information Society Directive]. See Articles 6 and 7 of the Information Society Directive. See Articles 2 and 3 of the Information Society Directive.

213 On the protection of TPMs and RMIs, see Article 7.7 and 7.8 of the draft IP chapter of the India-EU BTLA, as proposed by the EU; Article 5.13 and 5.14 of the draft IP chapter of the EU-Canada CETA, as proposed by the EU. Note that also the EU-South Korea FTA, Article 10.12 and 10.13, contains identical provisions on TPMs and RMI, however not on the other two rights. On the right of reproduction and communication to the public, see Article 7.4bis and 7.5 of the draft IP chapter of the India-EU BTLA, as proposed by the EU; Article 5.10 and 5.11 of the draft IP chapter of the EU-Canada CETA, as proposed by the EU. 
the legal protection of designs. ${ }^{214}$ In particular, its provisions on the definition of a design, ${ }^{215}$ the definition of the constituting element "individual character", ${ }^{216}$ and the term of protection ${ }^{217}$ have informed the equivalent rules in the agreements with CARIFORUM States and Central American countries and the IP chapter proposed to India and Canada. ${ }^{218}$

\subsubsection{Definition of Highest International Standards of IP}

The "old generation" bilateral trade agreements mainly contain one general obligation that applies to all areas of intellectual property rights. Accordingly, parties to the agreements must grant and ensure adequate and effective protection of intellectual property rights in accordance with the highest international standards. ${ }^{219}$ It had not been defined what the concept of highest international standards referred to. This lack of a definition was perceived to be a problem and therefore addressed in the IP "Enforcement Strategy in Third Countries": the aim was to clearly set out what the EU regards as the highest international standards in the area of enforcement. ${ }^{220}$

From the bilateral trade agreements concluded after 2006, it is evident that the European Union has followed this goal by inserting detailed provisions on the enforcement of IP rights in virtually all "new generation" agreements. The obligations on the parties are not only specifically defined for the area of enforcement but in fact equally for all other areas of intellectual property and related areas addressed in the respective IP chapters. These include the protection of copyright, trade marks, design rights, geographical indications, plant varieties, patents, the protection of traditional knowledge and genetic resources and utility models (at least in the case of the CARIFORUM-EC EPA). In many of these areas, the trading partners of the European Union are asked to adopt several TRIPS-plus elements, as specified in Chapter 5: Legal analysis of the CARIFORUM-EC Economic Partnership Agreement, Chapter 6 : Legal Analysis of the Draft India-EU Broad-based Trade and Investment Agreement and Chapter 7 : Legal Comparison of the CARIFORUM-EC EPA with the India-EU BTLA of this book.

In conclusion, the way in which "old generation" and "new generation" bilateral trade agreements concluded by the European Union deal with intellectual property protection differs significantly, in particular with regard to the scope and level of protection prescribed. Whereas the "old generation" agreements only modestly addressed IP protection in general and adhered to the TRIPS standard, a detailed and TRIPS-plus approach can be observed in the "new generation" agreements. The latter approach demands partner countries to grant identical levels of IP protection to

EC Directive 89/71 of the European Parliament and of the Council of 13 October 1998 on the legal protection of designs (OJ L 289 of 28.10.1998) [hereinafter EC Directive 89/71]. See Article 1(a) of the EC Directive 89/71. See Article 5.1 of the EC Directive 89/71.

See Article 10 of the EC Directive 89/71.

See Article 146.B.3 and 146.E.1 of the CARIFORUM-EC EPA; Article 8.5 of the EUCentral America FTA; Articles 8.2.1 and 8.6.1 of the draft IP chapter of the EU-Canada $C E T A$, as proposed by the EU; Article 12.2 of the draft IP chapter of the India-EU BTIA. 
those existing in the European Union. It also prescribes in detail what the EU regards as the highest standards of intellectual property protection. Overall, the new approach follows that of the United States.

\subsection{PRIORITIZED PARTNER COUNTRIES}

The countries that are approached to negotiate bilateral trade agreements are now clearly defined according to certain criteria. Focussing on particular countries, also in relation to the protection and enforcement of intellectual property rights, is a new feature of the free trade agreements concluded after 2006. Such conditions were not formulated in trade policy documents prior to the "Global Europe" strategy. However, even though "managed globalization" did not define priority countries, the IP obligations demanded in "old generation" bilateral agreements were differentiated according to the relationship of the country with the EU. "Global Europe", on the other hand, asks for equally high standards of intellectual property protection and enforcement in agreements with priority countries and other countries, including developing countries.

The "Enforcement Strategy in Third Countries" was the first policy document that mentioned the need to identify priority countries for the enforcement of intellectual property rights. Accordingly, a survey was to be conducted periodically among relevant European stakeholders; it would form the basis for creating and updating a list of "priority countries" to which the activities set out in the "Enforcement Strategy in Third Countries" should be applied.221 Such a list of priority countries is very similar to what the United States has been doing for more than twenty years under the so-called "Special 301" process of Section 301 of the Trade Act of 1974.222 Accordingly, the USTR lists "priority foreign countries" that deny adequate and effective protection of intellectual property rights. These countries will be further investigated and ultimately may be subject to unilateral trade sanctions. ${ }^{223}$

The first Survey on enforcement of intellectual property rights in third countries, ${ }^{224}$ carried out in 2003 by the European Union, identified the following countries as most problematic in terms of copyright and trade mark infringement: China, Thailand, Ukraine, Russia, Brazil, Turkey and South Korea. Those were also presented as the priority countries for the enforcement of intellectual property rights in the "Global Europe" strategy. ${ }^{225}$ According to the latter strategy, the Commission will reinforce the customs

221 See ibid., p. 4. The Strategy presents a list of activities that shall be applied to the identified countries. See footnote 134 of section 4.3 .4 of this book for an overview of the individual activities.

Trade Act of 1974 (Pub. L. No. 93-618, 88 Stat. 2011), codified as amended at 19 U.S.C.

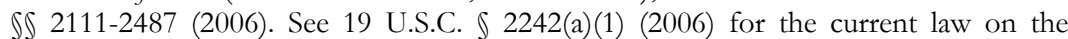
"Special 301" process. For a detailed analysis of this process, see section 1.6.4.2 of this book. See European Commission, "Press Release Memo/04/255: EU strategy to enforce Intellectual Property Rights in third countries - facts and figures" (Brussels, 10 November 2004); see also European Commission, Survey on Enforcement of Intellectual Property Rights in Third Countries (2003), available at <http://trade.ec.europa.eu/doclib/docs/2010/february/tradoc_145794.pdf $>$ accessed on 15.11.2012. 
cooperation with these countries, create and strengthen IPR dialogues, reinforce the EU's presence on the ground, allocate more resources to support right holders and build awareness of IPR issues among EU companies. ${ }^{226}$ Bilateral trade agreements are also briefly mentioned in this context; however, the selection of potential partners for future free trade agreements, which also deal with intellectual property issues, is set out in more detail elsewhere. ${ }^{227}$

The priority countries for future FTAs presented by the "Global Europe" strategy are ASEAN Member States, Mercosur and South Korea; India, Russia and the Gulf Co-operation Council are also of direct interest to the European Union. ${ }^{228}$ Absent from the list of priority countries is China. ${ }^{229}$ Whether there is a hierarchy among the listed countries (the order in which they appear or the first group above the second group of countries) is not clear. Judging from the FTA negotiations already launched and/or concluded, considerable progress has been made with regard to the negotiations with South Korea (FTA concluded), certain ASEAN Member States (Singapore and Malaysia), India and Mercosur. ${ }^{230}$ In contrast, the negotiations with Russia and the Gulf Cooperation Council have not yet been started or continued. ${ }^{231}$ The trade component of the latest "Europe 2020" Strategy emphasizes that the completion of the current agenda of FTAs remains a priority; it specifically highlights the importance of ASEAN Member States and suggests Vietnam ${ }^{232}$ as a possible next partner. ${ }^{233}$

The potential partner countries for future FTAs as set out in the "Global Europe" strategy were selected on a case-by-case basis according to a number of criteria: 1) the market potential in terms of the market's economic size and growth, 2) the level of protection against EU export interests through both tariff and non-tariff barriers, 3) ongoing negotiations between a potential partner and EU competitors and its likely impact on the EU's markets and economies, and 4) the risk that the preferential access to EU markets currently enjoyed by its developing country partners may be eroded. ${ }^{234}$ This last criterion ties in with a fifth issue mentioned some paragraphs further down the document, namely the FTA's possible impact on development,

226 See ibid.

227 See section 4.2 ii) of ibid., p. 11

228 See ibid., p. 11.

229 See below for China's role in the "Global Europe" strategy.

230 See European Commission, Report on progress achieved on the Global Europe strategy, p. $6 \mathrm{ff}$.

231 Negotiations with Russia have been opened in 2008 but have not yet led to rounds of negotiations. Its accession to the WTO in August 2012, however, is expected to boost the negotiations. See European Commission, Bilateral relations. Negotiations with the Gulf Cooperation Council have been suspended since the end of 2008 mainly due to outstanding issues on the treatment of export subsidies. See European Commission, Report on progress achieved on the Global Europe strategy, p. 10.

Negotiations for a FTA have been launched on 26 June 2012, see European Commission, "Press release: EU and Vietnam launch negotiations for a comprehensive Free Trade Agreement".

233 See European Commission, Trade, Growth and World Affairs, p. 10. Next to the listed FTA partners, "Europe 2020" wishes to focus the EU's trade policy on the United States, China, Russia, Japan, India and Brazil because of their strategic dimension. However, no FTAs so far are envisaged with the United States, China and Japan. See European Commission, Trade, Growth and World Affairs, p. 11. 
both on the potential developing country partner to the FTA and on other countries. ${ }^{235}$ These factors make clear that the European Union wishes to focus primarily on the dynamically developing world regions and emerging markets, such as ASEAN, South Korea, India, Brazil and Russia. ${ }^{236}$

Four out of the seven countries that were identified as having most problems with the enforcement of IP rights are also priority countries for FTA negotiations. ${ }^{237}$ China is not mentioned as a potential partner for an FTA, even though "Global Europe" states that it fulfills many of the criteria of selection. Instead, a separate approach is suggested by the strategy due to the many opportunities and risks. According to the strategy, China is the

“single greatest test of Europe's capacity to make globalisation an opportunity for jobs and growth." 238

Simon Evenett offers another point of view. He argues that China (and Japan for that matter) are not suggested for FTA negotiations in the "Global Europe" strategy because bilateral trade agreements with such large trading nations would diminish their interest in the multilateral system's rules and therefore threaten the support for the WTO. ${ }^{239}$ Other reasons for not suggesting a free trade agreement with China could be political and economic frictions that have arisen since 2004, ${ }^{240}$ fears of Chinese competition, ${ }^{241}$ or a strategy based on diverse tools such as a high-level form of dialogue and the negotiation of a comprehensive Partnership and Cooperation Agreement. ${ }^{242}$

While the countries set out in the "Global Europe" strategy indeed seem to be priority countries for the European Union, other countries have also been approached for negotiations of comprehensive and competitiveness-driven bilateral

235 See section 4.6 of this book for a more detailed analysis of how development concerns are represented in the new generation FTAs.

236 See European Commission, Annex to Global Europe: Competing in the World (Brussels, 4 October 2006) [SEC(2006)1230], p. 11; Evenett, “'Global Europe': An Initial Assessment", p. 379.

237 Thailand belongs to the group of ASEAN Member States and Brazil is a crucial member of Mercosur. South Korea and Russia are mentioned in both groups of priority countries. Note that Turkey's enforcement problems are addressed in the context of accession negotiations.

238 European Commission, Global Europe, p. 12.

239 See Evenett, “'Global Europe': An Initial Assessment”, p. 386.

240 See P. Messerlin and J. Wang, Redesigning the European Union's Trade Policy Strategy towards China (Joint ECIPE-GEM Working Paper, 2008) [No. 04/2008], p. 8-10.

241 See R. Sally, Looking East: The European Union's New FTA Negotiations in Asia (European Centre for International Political Economy, Jan Tumlir Policy Essays, 2007) [No. 03/2007], p. 9.

242 In April 2008, the EU-China High Level Economic and Trade Dialogue was launched. This dialogue provides a tool to address issues of mutual concern in the trade-related areas, such as investment and intellectual property rights protection. The negotiations of the comprehensive Partnership and Cooperation Agreement were started in January 2007; however, positions remain far apart on many important chapters. See European Commission, China (2012), available at <http://ec.europa.eu/trade/creatingopportunities/bilateral-relations/countries/china/> accessed on 15.11.2012. 
trade agreements. In fact, since the launch of the "Global Europe" strategy, three full (opposed to interim) trade agreements have been concluded with other countries than those put forward in the strategy. The European Union has signed agreements with the CARIFORUM region in 2007 and with Colombia-Peru and Central America in 2010.243 However, Caribbean, Andean and Central American countries are developing countries, which, according to "Global Europe", do not fall under its set of priority countries for FTAs; agreements with these countries aim at promoting development rather than trade and therefore fall under a different set of tools. ${ }^{244}$

The chapter on the protection of intellectual property rights in the agreements signed with CARIFORUM, the Andean Community and Central America countries contains very similar features to the agreements signed and negotiated with key priority countries of "Global Europe". Each IP chapter in the respective agreements follows a prototype developed by the European Union, with adaptations made where partner countries have crucial interests. ${ }^{245}$ Even though this prototype may have been developed for the agreements with emerging economies, it is also used in bilateral negotiations that supposedly focus on development rather than competitiveness. ${ }^{246}$

As a result, it has to be concluded that the content and scope of the obligations contained in IP chapters in "new generation" bilateral trade agreements does not make a significant difference according to whether agreements with priority country partners are at issue or agreements are negotiated with other developing country partners. ${ }^{247}$ The list of priority countries therefore might be relevant for the choice of which country to approach next for negotiations. It does not seem to define the countries that are asked to adhere to the high level of intellectual property protection set out in recent policy documents and agreements. ${ }^{248}$ Extending the application of the IP policy proposed by "Global Europe" beyond the countries listed in that strategy is an aggressive feature of the EU's new external IP policy. It also constitutes a shift away from the trade policy "managed globalization" where IP protection and enforcement in bilateral agreements were differentiated according to the partner countries.

See European Commission, Bilateral relations. Canada, a country that has not been identified in the "Global Europe" strategy, is also negotiating a free trade agreement with the European Union.

The European Commission claims that these agreements try to promote "asymmetric trade liberalisation and attention to sustainability considerations rather than reciprocal trade opening." European Commission, Annex to Global Europe, p. 11. Interview with a member of DG Trade, March 2010, Brussels (available on request). See also Heron and Siles-Brügge, "Competitive Liberalization and the 'Global Europe' Services and Investment Agenda: Locating the Commercial Drivers of the EU-ACP Economic Partnership Agreements".

It has to be noted that the IP chapters in the agreements concluded with the CARIFORUM region, Colombia and Peru and Central American countries do reflect a stronger development component than the IP chapter in the FTA with South Korea and the one proposed to India and Canada. See section 4.6 of this book. See section 4.5 of this book. 


\subsection{DEVELOPMENT CONCERNS IN EU's EXTERNAL IP POLICY}

Development concerns are relevant to any trade policy that is likely to affect developing countries. According to the Treaty of Lisbon, the Union shall

"take account of the objectives of development cooperation in the policies $[\ldots]$ which are likely to affect developing countries." 249

However, the most recent trade policy "Global Europe" including the external IP policy and in particular its application in relation to developing countries raise concerns with regard to their impact on developing countries. Arguably, a shift in the importance attributed to development concerns has occurred since Pascal Lamy's "managed globalization" was abandoned.

\subsubsection{Strong Concern for Development under "Managed Globalization"}

The trade policy applied under Pascal Lamy had a strong concern for development. The policy was based on the premise that market opening needs to be balanced by a redistribution of its costs and benefits. ${ }^{250}$ Such a redistribution of benefits was not only applied internally but importantly at the global level with a view of improving the economic development of the least advanced countries. ${ }^{251}$ Several trade initiatives under Lamy's tenure were started to improve the development prospects of developing countries. For example, according to Pascal Lamy,

"the priority given to development in the Doha Agenda, or the agreement on medicines are evidence of the pivotal European role." 252

In addition, Pascal Lamy personally initiated and carried out the "Everything But Arms" policy in $2001^{253}$ and the new Generalized System of Preferences ${ }^{254}$ for developing countries adopted in 2005.255

249 See Article 208.1 subparagraph 2 of the TFEU. See also Articles 205 and 207.1 of the TFEU for the full scope of the obligation in relation to trade policy. See also section 4.2.2 of this book. Note that former Articles 177 and 178 of the TEC (Treaty of Nice) also required the European Union (back then the European Community) to take into account development objectives in any policy that is likely to affect developing countries.

250 See European Commission, Trade policy in the Prodi Commission, p. 3.

251 See Meunier, "Managing Globalization?”, p. 915.

252 European Commission, Trade policy in the Prodi Commission, p. 4. The "agreement on medicines" refers to the Declaration on the TRIPS Agreement and Public Health, which WTO Members have agreed to in 2001. See WTO Ministerial Conference, Doha Declaration on Public Health.

253 The Council Regulation (EC) 416/2001 grants duty-free access to imports of all products from LDCs, except arms and ammunitions, without any quantitative restrictions (with the exception of bananas, sugar and rice for a limited period). See Council Regulation (EC) 416/2001 of 28 February 2001 amending Regulation (EC) 2820/98 applying a multiannual scheme of generalised tariff preferences for the period 1 July 1999 to 31 December 2001 so as to extend duty-free access without any quantitative restriction to products originating in the least developed countries (OJ L 60 of 28 February 2001, p. 43).

254 The GSP scheme adopted in 2005 introduced a new "GSP Plus" scheme for especially vulnerable countries with special development needs. It requires the beneficiaries to 
Also the IP chapter of "old generation" bilateral trade agreements with developing countries that do not fall under the categories candidate, potential candidate or neighbouring countries reflected development concerns. As explained above, the IP obligations in bilateral trade agreements concluded with developing countries such as Mexico, Chile, South Africa and the ACP Group of States are rather modest and generally formulated, leaving considerable policy space for those countries to make appropriate choices as to what particular protection to provide. ${ }^{256}$ In addition, "old generation" agreements mainly adhered to the TRIPS standard of protection, the exception being the agreements on trade in wine and spirits. The TRIPS Agreement tries to balance development concerns with the entitlements granted to right holders; Article 7 and 8 of the TRIPS Agreement reflect this balance. ${ }^{257}$

\subsubsection{Little Concern for Development since "Global Europe"}

While development concerns played a significant role in the trade policy "managed globalization", their importance has decreased since then. An evaluation report of the "Enforcement Strategy in Third Countries" commissioned by the European Commission in 2010 came to the conclusion that already the "Enforcement Strategy in Third Countries" did not take much account of the emerging development agenda. ${ }^{258}$ Accordingly, one of the main activities proposed by the "Enforcement Strategy in Third Countries", namely the list of priority countries, has led to the dissipation of the European Union's goodwill in terms of IP enforcement. ${ }^{259}$ The latter list was perceived to constitute a move towards a hard line, which pushes third countries into a defensive position. ${ }^{260}$ Seemingly, the Strategy's proposal of promoting and extending technical cooperation programmes with priority countries $^{261}$ did not mitigate the general perception by developing countries that the EU has taken on a hard stance with little concern for development needs.

The trend initiated by the "Enforcement Strategy in Third Countries" is continued in the "Global Europe" strategy. One could question why "Global Europe" should be concerned with development issues at all since it focuses on emerging economies whose interests clearly go beyond that of development. The answer is simple: the European Union is under an obligation to take into account development concerns in

ratify and effectively apply twenty-seven key international conventions on sustainable development and good governance. See Council Regulation (EC) 980/2005 of 27 June 2005 applying a scheme of generalised tariff preferences (OJ L 169 of 30.06.2005, p. 1).

See Meunier, "Managing Globalization?”, p. 915.

See section 4.4.1 of this book.

See section 2.3.1 of this book on the general provisions and basic principles of the TRIPS Agreement.

See Analysis for Economic Decisions, Evaluation of the Intellectual Property Rigths Enforcement Strategy in Third Countries (European Commission, Louvain la Neuve, 2010), p. ii.

The European Union had built up a strong reputation on IP enforcement issues through a holistic and cooperative approach in previous years. Examples for this are the ECAPII (EC-ASEAN Project on the Protection of IPRs) which ran from 2000 until 2007 and the EU-China Project on the Protection of IPRs carried out from 2007 until 2011. See ibid., p. 29.

See ibid., p. 29.

See European Commission, Enforcement Strategy in Third Countries, p. 7. 
activities which are likely to affect developing countries. ${ }^{262}$ As argued above, even though the "Global Europe" strategy does not target (other) developing country partners, comprehensive free trade agreements as one of the main activities suggested by the strategy are in fact signed with developing countries such as Caribbean states, Colombia and Peru and Central American countries. The agreements demand, among others, high levels of intellectual property protection and enforcement, which arguably have a strong impact on countries' ability to promote development.

Since "Global Europe", on its face, is not a strategy drafted for trade with vulnerable developing countries, development concerns do not receive much attention therein. In fact,

"Sustainable development is clearly not the overriding concern of Global Europe."263

This conclusion was reached by a recent report on the relationship between the new "Global Europe" strategy and sustainable development. "Global Europe" is primarily about increasing the competitiveness of Europe and about delivering growth and jobs; development concerns of third countries receive little attention.

Admittedly, the strategy announces that development objectives will remain a core function of EU's trade policy. ${ }^{264}$ Accordingly, "Global Europe" is part of an integrated and coherent approach to domestic and global challenges. This approach also incorporates the instrument entitled "EU's renewed Strategy for Sustainable Development"265 which aims at developing actions that will improve the sustainability in seven key priority areas, most of which are predominantly environmental. ${ }^{266}$ The only concrete reference to development needs is in the section on free trade agreements where the "Global Europe" strategy claims to take into account the development needs of the EU's partners and the potential impact of any agreement on other developing countries when assessing the impact of launching FTA negotiations. ${ }^{267}$

Despite the declared respect for development concerns in "Global Europe", the IP chapter in recent free trade agreements signed with developing countries does not focus on development concerns. Even though the IP chapters reflect certain See Articles 205, 207.1 and 208.1 subparagraph 2 of the TFEU. See Andersson, Global Europe and Sustainable Development, p. 21. See European Commission, Global Europe, p. 2.

The seven priority areas are: 1) climate change and clean energy, 2) sustainable transport, 3) sustainable consumption \& production, 4) conservation and management of natural resources, 5) public health, 6) social inclusion, demography and migration, and 7) global poverty and sustainable development challenges. See Council of the European Union, Review of the EU Sustainable Development Strategy (EU SDS) - Renewed Strategy (Brussels, 26 June 2006) [10917/06].

266 See European Commission, Global Europe, p. 2. By referencing the latter strategy, the Commission seemingly wishes to claim that "Global Europe" in itself does not deal and does not need to deal with development concerns; other complementary instruments address them sufficiently.

See ibid., p. 12.
} 
elements that can be described as "development-friendly", ${ }^{668}$ the general hard line of demanding partner countries to grant high levels of protection and enforcement beyond the TRIPS-standard dominates in each of the agreements. The facts that 1) it is the Directorate General for Trade that leads the IP negotiations in the context of trade agreements with developing countries and that 2) the Directorate General for Development is not involved in the negotiations on IP issues, ${ }^{269}$ further reinforces the conclusion that IP provisions are not deemed relevant for development needs.

Also the most recent "Europe 2020" Strategy does not grant more importance to development concerns in bilateral IP obligations. ${ }^{270}$ It clearly states that the EU should aim at offering identical levels of IPR protection to that existing in the EU in the IPR clauses of future bilateral trade agreements. ${ }^{271}$ This obligation leaves no flexibility for developing countries' priorities in the various areas of IP protection. Arguably, the stated objective is limited by the notion of

"while taking into account the level of development of the countries concerned."

However, no further explanation or examples are given in which way the level of development will matter for deviating from the stated goal. It does not seem to establish any additional obligation for the Union to give development concerns more importance compared to "Global Europe".

In conclusion, a shift in the level of importance dedicated to development concerns in the most recent trade and IP policy can be observed since the abandoning of Pascal Lamy's “managed globalization”. As a matter of fact, the activities proposed

268 For an analysis of development-friendly provisions in the IP chapter of the CARIFORUM-EC EPA, see section 5.3, and in particular section 5.3.1.5, which identify the provisions that leave policy space for partner countries to balance all interests involved. Two specific examples in the CARIFORUM-EC EPA are Article 149.1 on farmers' rights as an exception to plant breeders' rights and the general exception applicable to the entire agreement in Article 224. See sections 5.3.2.7 and 5.4 of this book. For an analysis of development-friendly provisions in the draft IP chapter of the India-EU BTLA, see sections 6.2.1 on the link between innovation and intellectual property protection, section 6.2 .3 on the transfer of technology, section 6.3.6 on the protection of plant varieties, section 6.3.7 on the protection of genetic resources and traditional knowledge, and partly in section 6.4 on enforcement matters. In the IP negotiations on the CARIFORUM-EC EPA, DG Development was included in the negotiations only on the request of the negotiating team of CARIFORUM States, rather than on the EU's own initiative. Interview with Malcolm Spence, Senior Coordinator Intellectual Property, Science and Technology Issues in the Office of Trade Negotiations, formerly CRNM; Alternate Lead Negotiator on Trade Related Issues in the CARIFORUM-EC EPA, 8 April 2010, Bridgetown, Barbados (available on request).

270 It has to be noted that the "Europe 2020" Strategy does elaborate more on the development goals of the Union than "Global Europe". In its section 2.2, it provides an overview of the measures undertaken by the European Union to address development issues, such as the EU's Generalized System of Preferences, the envisaged development of a Communication on trade and development and the goals with regard to green growth and climate change. See European Commission, Trade, Growth and World Affairs, p. 8. 
by the "Enforcement Strategy in Third Countries", the "Global Europe" and "Europe 2020" strategies are equally used for emerging economies and (other) developing countries. In view of the focus of these strategies, being increasing competitiveness rather than promoting development, the relatively low importance given to development concerns is worrying. It leads me to the conclusion that the EU's approach on IP issues towards developing countries has become aggressive with the launch of the "Global Europe" strategy.

\subsection{CONCLUSIONS}

The analysis of how the European Union's trade and IP policy with third countries, in particular developing countries, has developed over the last fifteen years shows a shift towards a tough approach. Even though several aggressive features have been identified in the analysis above, there remain certain differences compared with the approach used by the United States which make the EU's approach, even though tough, not yet as aggressive as the US approach. ${ }^{272}$ The shift has occurred at four levels. First, on a policy level, the EU has abandoned the informal moratorium on concluding new bilateral trade agreements introduced under Pascal Lamy, when the latter was EU Trade Commissioner. Since the launch of the "Global Europe" strategy, the European Commission has promoted a "new generation" of competitiveness-driven FTAs as a cornerstone of its new external trade policy, rather than focusing solely or primarily on the multilateral forum, the WTO.

Second, the level of intellectual property protection in these FTAs has increased considerably compared with agreements concluded before the launch of the "Global Europe" strategy. While "old generation" bilateral agreements included rather general and modest obligations that adhere to the TRIPS-standard of protection, "new generation" agreements with third countries stipulate detailed obligations that provide TRIPS-plus standards of protection equivalent to the level of protection set in European legislation.

Third, on the face of it, the "Enforcement Strategy in Third Countries" and the "Global Europe" strategy focus on certain priority countries which can be described as emerging economies. However, the suggested activities such as incorporating the highest standards of IPR protection and enforcement in comprehensive FTAs are equally applied to certain (other) developing countries. Therefore, a shift has occurred in the countries addressed by the trade policy: whereas "managed globalization" differentiated its IP obligations in bilateral agreements according to the partner country, the practice apparent since the launch of the "Global Europe" strategy applies the same model provisions on IP issues to emerging economies and (other) developing countries. Differences in final agreements are the result of trading partners' interests rather than proposed by the EU. ${ }^{273}$

272 The extent of patent protection required by United States agreements, and its effects on public health, as well as the manner in which negotiations have been carried out are especially aggressive features of the US approach not found in recent agreements concluded by the European Union.

273 Note that Chapter 7 : Legal Comparison of the CARIFORUM-EC EPA with the India-EU $B T I A$ provides one further specification of this analysis: while most of the model IP chapter is apparent in all "new generation" agreements, there seems to be a 
Fourth, development concerns have decreased in their importance since the trade policy "managed globalization" introduced by Pascal Lamy was replaced by "Global Europe". Next to launching a number of initiatives to the benefit of developing countries, "managed globalization" also adapted the IP obligations included in agreements to the level of development of their partners. Even though the "Global Europe" and "Europe 2020" strategies claim to take into account development concerns, they do not further specify how these concerns will influence the overall objectives of concluding FTAs which provide for identical levels of protection and enforcement as those existing in the European Union. The provisions proposed by the European Union in recent BTAs hardly reflect different approaches according to the level of development of the partner countries.

The question as to whether or not these shifts indicate a revolution in the Union's thinking has been the subject matter of a scholarly debate. ${ }^{274}$ The general consensus seems to be that "Global Europe" is more a reassessment of the short-term policies set out by "managed globalization" rather than a revolution of the long-term goals. The diminished influence of the European Union in the WTO and the rise of bilateral trade agreements concluded between competitors of the EU and emerging economies left the EU with no other option than to pursue market opening through comprehensive FTAs. ${ }^{275}$

However, the conditions under which developing country partners negotiate bilateral trade agreements with the European Union have changed considerably. They must be prepared to deal with a tough approach of including high levels of IP protection with little regard for their development concerns. The agreements signed so far with developing countries do not reflect many deviations from the model IP chapter which has also been used in the agreements with South Korea or the draft texts of the India-EU BTIA and EU-Canada CETA.

The provisions in the IP chapter included in two recent bilateral trade agreements are analyzed in greater detail in the following chapters. These agreements are the Economic Partnership Agreement between CARIFORUM States and the European Community, which was signed in December 2007, and the draft IP chapter (July 2011) of the Broad-based Trade and Investment Agreement between India and the EU, which is still being negotiated. The EPA with CARIFORUM States is the first bilateral trade agreement concluded by the European Union after the launch of the "Global Europe" strategy. The legal analyses will focus on the TRIPS-plus standards of the various areas of intellectual property protection covered. Such standards are the most significant features of the "new" external IP policy of the European Union.

development of increasing the standard of protection asked from partner countries. For example, the protection asked from CARIFORUM States in certain areas of IP protection was not yet as elaborate and strong as identified in the draft IP chapter of the India-EU BTLA. See section 7.11 of this book.

274 See Meunier, “Managing Globalization?”, p. 918 ff; see Evenett, “'Global Europe’: An Initial Assessment", p. 10; see Andersson, Global Europe and Sustainable Development, p. 20. 
Comparing the IP provisions of these two agreements with each other provides a precise account of what obligations the European Union demands from CARIFORUM States, a sub-group of the ACP Group of States on the one hand, and India on the other hand. The analysis allows for an exact judgment as to whether the European Union takes the development needs of its partner countries into account when concluding trade agreements with them. According to the European Union, the EPA is a tool of improving the opportunities of development for Caribbean countries, whereas the agreement with India is primarily concerned with improving European firms' market access to that market. 



\section{Chapter 5 : Legal Analysis of the CARIFORUM-EC Economic Partnership Agreement}

The Economic Partnership Agreement concluded between the States of the Caribbean Forum of African, Caribbean and Pacific States (CARIFORUM) ${ }^{1}$ and the European Community is the first bilateral trade agreement in which the explicit TRIPS-plus mandate of the "Global Europe" strategy" has been incorporated. The agreement contains many new features not yet used in the bilateral trade agreements concluded before 2006. These attributes of the CARIFORUM-EC EPA mark a significant shift in the EU's policy of intellectual property protection required from bilateral trading partners: it moved from a rather defensive approach towards an offensive strategy of demanding more and further-reaching standards of IP protection. This new strategy shows strong similarities with the approach that the United States has adopted in its free trade agreements. At the same time, it shows significant efforts by CARIFORUM States to incorporate provisions that aim at enlarging the domestic policy space in tailoring the IP regime to domestic needs. This chapter provides a background to the CARIFORUM-EC EPA and its negotiations, presents the main characteristics of the new legal method used by the European Union and analyzes in depth the substantive provisions of the CARIFORUM-EC EPA, with a particular focus on the TRIPS-plus provisions.

\subsection{BACKGROUND}

The CARIFORUM group is one of the six regional groupings of the seventy-six ACP Member States with which the European Union has been negotiating Economic Partnership Agreements since September 2002. The mandate for these negotiations was already included in the Cotonou Agreement. ${ }^{3}$ According to its Article 36.1, the parties agree to conclude WTO-compatible trading arrangements and to remove existing barriers to trade. The trading regime established under the Cotonou Agreement did not comply with the rules of the GATT 1994 due to trading preferences between the EU and the ACP Group. ${ }^{4}$ This non-compliance was temporarily remedied by a waiver, which had been granted by the WTO Ministerial Conference in November 2001. ${ }^{5}$ The waiver allowed the European Communities and the participating ACP States to

1 CARIFORUM is the grouping that links the Caribbean Community (CARICOM) with the Dominican Republic. The Caribbean Community is an organization made up of fifteen Caribbean nations. All its Member States are also included in the CARIFORUM, except for Montserrat, which is a territory of the United Kingdom. Since its revised founding document, the Treaty of Chaguaramas from 2001, the CARICOM Single Market and Economy has been established.

2 See European Commission, Global Europe.

See Article 37.1 of the Cotonou Agreement.

The MFN treatment obligation of Article I.1 of the GATT 1994 obliges WTO Members to treat like products from any WTO member in the same way. The European Union is therefore under an obligation to extend the preferences granted on certain products from ACP Member States to like products from any other WTO Member. The EU did not extend these preferences to other WTO Members and therefore failed to comply with the MFN treatment obligation. These preferences were aimed at improving the standard of living and economic development of the ACP States.

5 See WTO Ministerial Conference, European Communities - The ACP-EC Partnership Agreement (Doha, 14 November 2001) [WT/MIN(01)/15]. 
maintain preferential trading relations under the Cotonou Agreement until 31 December 2007.

With this deadline in mind, the European Union started negotiating individual bilateral agreements with six regional groupings of ACP States, four in Africa, one in the Pacific and one in the Caribbean region. By the end of December 2007, only the CARIFORUM group had agreed to a comprehensive EPA, including trade in goods, trade in services, e-commerce, capital movement, trade-related matters such as investment, competition, innovation and intellectual property, trade-unrelated matters such as public procurement, environment, social aspects, the protection of personal data, and dispute settlement provisions. The other five groups of ACP States initialled interim agreements dealing with trade in goods only. The interim agreements provide the basis for the continuing negotiations of subsequent full EPAs.

The fifteen governments of the CARIFORUM regional grouping first initialled the CARIFORUM-EC EPA on 16 December 2007. Thirteen out of the fifteen States signed the agreement on 15 October $2008 .{ }^{6}$ Guyana hesitated signing the agreement because it had reservations with regard to non-trade-in-goods provisions. It eventually signed the agreement on 20 October 2008, emphasizing the "role that the 'imminent threat of GSP sanctions' played in its final decision to sign the EPA."? During the negotiations, the European Commission had exercised considerable pressure on CARIFORUM States. They were threatened that if they failed to sign the EPA, they would fall back to the standard Generalised System of Preferences (GSP) regime. ${ }^{8}$ GSP duties provide far lower preferences than those enjoyed by ACP States under the Cotonou Agreement. Guyana would have been affected severely, with standard GSP tariffs applying to 21.8 percent of its goods and services. ${ }^{9}$ Haiti, the only least-developed country in the CARIFORUM, had asked for more time to review the agreement and eventually signed the EPA on 11 December $2009 .{ }^{10}$ As an LDC, Haiti benefits from duty-free market access to European markets under the "Everything But Arms" initiative"11 for all products except for arms. In terms of market access, signing the EPA did not offer Haiti more benefits.

6 These States include Antigua and Barbuda, the Bahamas, Barbados, Belize, Dominica, the Dominican Republic, Grenada, Jamaica, Saint Lucia, Saint Vincent and the Grenadines, Saint Christopher and Nevis, Suriname, and Trinidad and Tobago.

7 Technical Centre for Agricultural and Rural Cooperation, "Caribbean-EU EPA negotiations" Agritrade Executive brief (Wageningen, October 2008), p. 3. See E. Jones and T. Hormeku, A Matter of Political Will: How the European Union Can Maintain Market Access for African, Caribbean and Pacific Countries in the Absence of Economic Partnership Agreements (TWN Africa, Oxfam International, Brighton, 2007), p. 1. See R. Sanders, Africa Right to Hold out for Better European Deal (2009), available at <http://www.sirronaldsanders.com/viewarticle.aspx?ID=15> accessed on 21.11.2012. See the information provided by the Caribbean Regional Negotiating Machinery, CRNM, Office of Trade Negotiations (2012), available at <www.crnm.org> accessed on 15.11.2012.

11 See Article 11.1 and 11.2 of EC Council Regulation 732/2008 of 22 July 2008 (OJ L 211/1 of 6.08.2008). 


\subsection{LEGAL APPROACH}

The legal approach adopted in the CARIFORUM-EC EPA differs considerably from the approach pursued in previous bilateral trade agreements, and mainly for three reasons. First, the scope of the chapter addressing IP has become much more extensive than before. Chapter 2 on "Innovation and intellectual property" is subdivided into two subsections. ${ }^{12}$ Section 1 deals with "Innovation" and Section 2 focuses on "Intellectual property". Together, Section 1 and 2 incorporate thirty-four articles over twelve pages. Compared to an average of one or two articles and one annex in previous agreements, ${ }^{13}$ this increase is remarkable. However, it does not yet reach the extent and level of detail displayed in the US-South Korea FTA, whose provisions extend over thirty-one pages.

Second, whereas the European Union was clearly following the multilateral approach in previous bilateral agreements, the CARIFORUM-EC EPA introduces a mixed approach. On the one hand, the European Union continues to require the accession to or compliance with several multilateral treaties. On the other hand, these requirements are supplemented by detailed provisions on the protection of individual intellectual property regimes. In this regard, the CARIFORUM-EC EP $A$ resembles the free trade agreements of the United States. The latter also require parties to accede to or ratify specific multilateral treaties and, in addition, address each area of intellectual property covered individually, by asking for detailed rules to be complied with.

Third, important provisions in the CARIFORUM-EC EPA are transplants of EU legislation. In particular the Articles on the protection of industrial designs and enforcement matters have been transposed literally from internal EU rules into the bilateral agreement. They are lengthy, detailed and leave hardly any room for implementing such obligations into national legislation. In this respect, EPA provisions again appear like US-provisions, which have also been characterized as being "legislation-like". In the following, the legal provisions addressing the protection of intellectual property of the CARIFORUM-EC EPA are analyzed. The analysis mainly concentrates on the new features not yet contained in previous agreements concluded by the European Union and highlights those provisions that go beyond the level of protection foreseen by the TRIPS Agreement. In addition, the new EU approach is compared with the US approach adopted in the respective field.

\subsection{CHAPTER 2 ON INNOVATION AND INTELLECTUAL Property}

The new approach towards intellectual property protection followed by the EU is already reflected in the structure of the CARIFORUM-EC EPA: the provisions on the protection of intellectual property are embedded in Chapter 2 entitled "Innovation and intellectual property". In previous EU bilateral trade agreements, there has never been a separate chapter on (innovation and) intellectual property. The

12 Chapter 2 of the CARIFORUM-EC EPA belongs to Part II on "Trade and traderelated matters" and Title IV on "Trade-related issues".

13 The agreements previously concluded with (potential) candidates for accession, particular developing countries and ACP States (the Cotonou Agreement) have been analyzed in section 3.3. 
chapter can be subdivided into three parts: two overarching articles on context and objectives, Section 1 on Innovation and Section 2 on Intellectual property.

The rationale of combining the two Sections in one chapter is incorporated in Article 131 of the CARIFORUM-EC EPA. Accordingly, the contracting parties agree that the protection and enforcement of intellectual property plays a key role in fostering innovation and creativity. Innovation and creativity, in their turn, are crucial in achieving improved competitiveness and sustainable development. The EPA, therefore, pretends that development concerns have driven the Chapter on Innovation and Intellectual Property. The development concerns incorporated in the EPA have been analyzed below. This analysis sheds some more light on how they can influence the interpretation of the IP obligations in the EPA. ${ }^{14}$

Section 1 on "Innovation" covers six Articles. ${ }^{15}$ No previous bilateral agreement concluded by the European Union contained a separate Section dealing with innovation. For the purpose of this thesis, it is not necessary to analyze its provisions in detail, as the focus is on the substantive provisions addressing intellectual property. ${ }^{16}$ Nevertheless, an important characteristic of the commitments made in the Section on Innovation is that they are mostly of a non-binding, declaratory nature. ${ }^{17}$ As noted by Sisule Musungu, President of the Geneva-based civil society organization IQSensato, the areas of cooperation addressed in this Section are ambitious but fail

\footnotetext{
"to translate the laudable aspirations to promote innovation and competitiveness, science and technology, information society, ICTs, eco-innovations and renewable energy into operational language and specific obligations." 18
}

This is in sharp contrast with Section 2 on "Intellectual property". Instead of being limited to best endeavour cooperation activities, Section 2 contains hard law obligations with regard to the protection of intellectual property. Articles 139 until 164 contain provisions that address three types of matters: 1) general provisions, 2) provisions addressing individual intellectual property regimes, and 3) enforcement provisions. These three parts will be examined in the following.

\subsubsection{General Provisions}

The Chapter on "Innovation and intellectual property" of the CARIFORUM-EC $E P A$ contains six general elements. These are a) the scope of protection, b) the definition of IP, c) the principle of minimum protection and freedom of implementation, d) transfer of technology, e) development concerns and f)

$14 \quad$ See section 5.3.1.5 of this chapter.

15 See Articles 133 until 138 of the CARIFORUM-EC EPA.

16 Certain provisions of Section 1 of the CARIFORUM-EC EPA are addressed nevertheless in section 5.3.1.5 of this book on development concerns.

17 See also South Centre, Comments on "Innovation and Intellectual Property", Chapter 2 Part II, Title IV of the Draft Cariforum-EC EPA dated November 22, 2007 (South Centre, Geneva, 2007), p. 1.

18 S.F. Musungu, Cariforum EPA and Beyond: Recommendations for Negotiations on Services and Trade Related Issues in EPAs (Gesellschaft für Technische Zusammenarbeit, Eschborn, 2008), p. 17. 
transitional periods. The range of topics addressed is much larger than in previous European bilateral agreements; the only common general element is the definition of intellectual property, which in itself has not changed considerably. Concerning the differences, previous agreements used to include an obligation to comply with the MFN treatment obligation and required the accession to various multilateral agreements as a general obligation, rather than dealing with each area of IP individually. The provision dealing with the scope of protection used to be the only stipulation that specified the substantive level of protection for all areas of intellectual property. In the CARIFORUM-EC EPA, obligations as to the accession to or compliance with certain multilateral treaties are not included as a general matter, but form part of the sections dealing with each intellectual property area separately. The provision on the scope of protection is addressed merely as a general obligation; the EPA provides for detailed obligations in the various areas of IP covered.

\subsubsection{Scope of Protection}

Article 139.1 of the CARIFORUM-EC EPA requires the parties to ensure

"an adequate and effective implementation of the international treaties dealing with intellectual property to which they are parties and of the Agreement on Trade-related Aspects of Intellectual Property [...]".

Compared with Article 46.1 of the Cotonou Agreement, it is much clearer with which standards the Caribbean countries and the EU have to comply. They are under an obligation to implement the international treaties to which they are already parties and the TRIPS Agreement in an adequate and effective manner. In contrast, the Cotonou Agreement did not specify with which "international standards" the parties had to comply. ${ }^{19}$ The scope of protection covered by the CARIFORUM-EC EPA, therefore, is identical to that of the TRIPS Agreement.

All but one CARIFORUM States are WTO Members; the Bahamas only enjoys observer status. Even though not a WTO Member, the Bahamas is under a bilateral obligation towards the European Union to implement the TRIPS Agreement. For all other CARIFORUM States, and for the Member States of the European Union, this obligation already stems from their membership to the WTO which also requires them to comply with the TRIPS Agreement. However, the obligation of an "adequate and effective implementation" creates an additional layer of obligation for all contracting parties to the EPA. The TRIPS Agreement itself does not address the method of implementation of its provisions, ${ }^{20}$ which is addressed by this EPA obligation. In case of a conflict between EPA parties as to whether a party has implemented the obligations stemming from the TRIPS Agreement adequately and effectively, the bilateral dispute settlement system, rather than the multilateral WTO Dispute Settlement System, would have to determine whether this standard of adequateness and effectiveness has been met. ${ }^{21}$

19 See section 3.3.5 of this book.

20 See Article 1.1 of the TRIPS Agreement.

21 The dispute settlement system established by the EPA is dealt with in Part III on Dispute avoidance and settlement, Articles 202 until 223 of the CARIFORUM-EC EPA. 


\subsubsection{Definition of Intellectual Property}

Intellectual property, as referred to in the CARIFORUM-EC EPA, must be understood according to the definition in paragraph 3 of Article 139. The components included therein are basically identical to those covered by the definition in Article 46.5 of the Cotonou Agreement. In this regard, there are no new obligations imposed on Caribbean countries compared with what the Cotonou Agreement required. However, the areas dealt with in the IP chapter of the CARIFORUM-EC EPA go beyond the TRIPS Agreement in three ways. First, the EPA stipulates rules on utility models. The TRIPS Agreement only covers the protection of patents and does not address utility models. ${ }^{22}$

Second, the definition in Article 139.3 includes the protection for databases as one area of intellectual property protection. Even though no concrete rules on how to protect such databases are set out in the Chapter, they have been included in the definition of intellectual property and are therefore covered when provisions generally refer to intellectual property rights. Examples are the enforcement provisions, which often apply to all areas of IP protection covered by the EPA. Internationally, the protection for non-original databases has not yet been accepted. The European Union is the major proponent of such protection and has included this protection in its recent bilateral trade agreements. The usefulness of protecting investment rather than creativity has been subject to much debate and is questionable when required from developing countries. ${ }^{23}$

Third, the CARIFORUM-EC EPA integrates the protection of genetic resources, traditional knowledge and folklore into the IP chapter. ${ }^{24}$ So far, no multilateral solution on how to protect these issues has been agreed upon. As part of the Doha Development Agenda, the TRIPS Council is currently discussing an amendment of the TRIPS Agreement under the mandate of Article 27.3(b) of the TRIPS Agreement. ${ }^{25}$ The proposed Article 29bis could oblige WTO Members to disclose the country of origin or source of the biological resources and/or associated traditional knowledge when applying for a patent. ${ }^{26}$ In addition, the WIPO Intergovernmental Committee on Intellectual Property and Genetic Resources, Traditional Knowledge and Folklore has been conferring about the different multilateral options on how to protect traditional knowledge for several years.

See Article 148 of the CARIFORUM-EC EPA. Section 5.3.2.6 of this book analyses the rules on utility models in depth.

See also Christian Aid and Oxfam, The EU's approach to Free Trade Agreements: Intellectual Property (ActionAid International, EU FTA Manual Briefing 8, London, 2008), p. 3.

See Article 150 of the CARIFORUM-EC EPA.

See Doha Development Agenda, WTO Ministerial Conference, Doba Ministerial Declaration, paragraph 19.

See WTO General Council, Trade Negotiations Committee and Council for TradeRelated Aspects of Intellectual Property Rights, Doba Work Programme, p. 2. See for the latest submission on this matter, WTO Trade Negotiations Committee, Draft Decision to Enbance Multual Supportiveness between the TRIPS Agreement and the Convention on Biological Diversity, Communication from Brazil, China, Colombia, Ecuador, India, Indonesia, Peru, Thailand, the ACP Group, and the African Group (Geneva, 19 April 2011) [TN/C/W/59]. See section 5.3.2.8 for a more detailed analysis of the proposed amendment. 
To sum up, while the required protection for data bases can be regarded as a clear TRIPS-plus feature, the inclusion of rules on utility models and on the protection of genetic resources, traditional knowledge and folklore seem to provide developing countries with additional tools to address their domestic development needs. These rules are assessed in more detail in section 5.3.2.6 and 5.3.2.8 of this chapter.

\subsubsection{Principle of Minimum Protection and Freedom of Implementation}

For the first time, the European Union has incorporated two important principles from the TRIPS Agreement into a bilateral agreement. ${ }^{27}$ These principles are stipulated in Article 1.1 of the TRIPS Agreement. Its first sentence allows, but does not oblige, parties to implement more extensive protection than required by the agreement, provided that such protection does not contravene the provisions of the Agreement. This principle is referred to as minimum protection. It allows parties to the respective agreement to conclude successive agreements that will establish more extensive protection than the TRIPS Agreement. Peter Drahos has classified this principle as one of the three necessary elements for the global intellectual property ratchet to work. ${ }^{28}$ By incorporating ever more extensive standards in successive agreements, global intellectual property protection is ratcheted up. As these agreements do not stipulate a principle of maximum protection, there is no limit to the extensiveness of IP protection. In contributing to this international trend, the European Union aligns itself with the United States which has also included the principle of minimum standards in all its free trade agreements. ${ }^{29}$

The second part of Article 1.1 of the TRIPS Agreement grants members the freedom to determine the appropriate method of implementation. ${ }^{30}$ This is an important freedom that should prevent matters of IP protection from being regulated in such a detailed fashion that parties would be left without any freedom to determine how to implement these matters into their national systems. Although the inclusion of this principle into the EPA is a positive development with regard to preserving flexibility in implementing its provisions, its strength is significantly diminished by the incorporation of legislation-like provisions in the areas of industrial design protection and enforcement matters. ${ }^{31}$ It seems difficult to argue that this principle is not violated by integrating such provisions. US free trade agreements, in contrast, have not repeated the second part of Article 1.1 of the TRIPS Agreement. In brief, while the principle of minimum protection emphasizes the possibility of concluding subsequent agreements with more extensive IP protection, the principle on the freedom of implementation aims at safeguarding the necessary domestic policy space for contracting parties to integrate all relevant interests in the implementation process. However, the latter principle seems to be at stake in view of legislation-like provisions.

\footnotetext{
$27 \quad$ Article 139.5 and 139.4 last sentence of the CARIFORUM-EC EPA literally reproduce Article 1.1 of the TRIPS Agreement.

28 See Chapter 1 : The International System of Protecting Intellectual Property preTRIPS.

29 See section 3.2.3 of this book.

30 Article 139.4 of the CARIFORUM-EC EPA literally repeats this principle.

31 See sections 5.3.2.4 and 5.3.3 of this book.
} 


\subsubsection{Transfer of Technology}

Technology transfer is a prominent issue in the CARIFORUM-EC EPA, much more so than in previous European bilateral trade agreements. CARIFORUM States have made an attempt to incorporate provisions on technology transfer that cater for their interests. This attempt has been criticized for not being specific enough and merely including soft obligations, for example the exchange of views, the sharing of information and using language such as "promoting" and "facilitating" incentives. ${ }^{32}$ On the other hand, CARIFORUM States' effort needs to be appreciated for going beyond TRIPS obligations: it allows CARIFORUM firms to participate in support programmes made available by the European Union, tries to establish an obligatory forum to exchange information and work out specific actions in the future, and applies the obligation to provide incentives to all CARIFORUM States instead of only least-developed countries.

Technology transfer is addressed in four provisions. Arguably the most important provision on technology transfer, Article 142 of the CARIFORUM-EC EPA, is a new rule compared to previous European bilateral trade agreements and stipulates some clear obligations for the contracting parties. The three other provisions address objectives, participation of CARIFORUM firms in framework programmes and facilitated cooperation and support. Arguably, they provide the context on how to interpret Article 142 of the CARIFORUM-EC EPA and are primarily relevant for the implementation of Article 142.

\subsection{Article 142: Transfer of Technology}

According to Article 142.1 of the CARIFORUM-EC EPA, contracting parties have an obligation to exchange views and information on their practices and policies affecting transfer of technology. ${ }^{33}$ In contrast, the TRIPS Agreement does not create a mandatory forum for discussing policies. Such a forum allows CARIFORUM States to put the issue of technology transfer on the agenda and should be evaluated as a positive development since it can give rise to concrete and specific measures.

A second obligation contained in this provision requires EPA parties to take measures to prevent or control certain licensing practices or conditions pertaining to intellectual property rights. ${ }^{34}$ The licensing practices that are meant to be controlled are those that may adversely affect the international transfer of technology, and may constitute an abuse of intellectual property rights by right holders, or an abuse of obvious information asymmetries in the negotiation of licenses. According to Malcolm Spence, the technical negotiator of IP issues during the EPA negotiations,

32 See Third World Network, EU EPAs: Economic and Social Development Implications: the case of the CARIFORUM-EC Economic Partnership Agreement (2009), available at <www.twnside.org.sg> accessed on 21.11.2012, p. 72; D. Shabalala, Intellectual Property in European Union Economic Partnership Agreements with the African, Caribbean and Pacific Countries: What way Forward after the Cariforum EPA and the interim EPAs? (CIEL, Geneva, 2008), p. 9.

34 See Article 142.2 of the CARIFORUM-EC EPA. This wording is taken from Article 40.1 of the TRIPS Agreement. The obligation to take measures is a TRIPS-plus element as Article 40.2 of the TRIPS Agreement only foresees the right of a Member to adopt such measures. 
this provision should avoid certain situations that have arisen in the past in CARIFORUM States. Small firms in developing countries found themselves in situations in which licensing agreements had already been concluded before the product was protected by a form of intellectual property in CARIFORUM States' markets. Another scenario was that licensing agreements had still been concluded even though the product was running out of protection and was about to enter into the public domain. ${ }^{35}$

Furthermore, CARIFORUM States were eager to prevent agreements in which innovations made by the licensee become the property of the right holder. ${ }^{36}$ To a certain extent this goal has been achieved as parties are obliged to prevent and control these practices and because the provision addresses the issue of information asymmetries. This mandatory requirement is an improvement compared with the equivalent TRIPS provision: Article 40.2 of the TRIPS Agreement merely establishes a voluntary possibility for WTO Members to install measures against abusive licensing practices and does not yet talk about information asymmetries. On the other hand, the provision has been criticized because it fails to set up specific rules on how to address the issue. ${ }^{37}$ Nevertheless, even though the rules are not clearly defined yet, they provide room to address specific actions in the future.

Finally, the European Union shall promote and facilitate the use of incentives for technology transfer to all CARIFORUM States. ${ }^{38}$ While the technical negotiator of IP issues Malcolm Spence stresses that it has been an interest of CARIFORUM States to 1) extend the use of incentives, rather than incentives as such, to 2) all CARIFORUM States, ${ }^{39}$ rather than to least developed countries only, ${ }^{40}$ the provision loses some of its strength because of the type of obligation agreed upon: the EU shall "promote" and "facilitate" the use of such incentives and is not obliged to provide them. ${ }^{41}$

\subsection{Context for Interpreting Article 142}

The context for interpreting Article 142 is provided for by three provisions which address a) objectives, b) the participation of CARIFORUM firms in framework programmes, and c) facilitated cooperation and support. Among the stated objectives of the Chapter on Innovation and intellectual property, one can find the promotion of technological innovation and the transfer and dissemination of technology and know-how as well as the production and commercialization of innovative and creative products between the parties. ${ }^{42}$ While the former objective is clearly related

35 Interview with Malcolm Spence, 8 April 2010, Bridgetown.

36 See M. Spence, Negotiating Trade, Innovation and Intellectual Property: Lessons from the CARIFORUM EPA experience from a Negotiator's Perspective (UNCTAD-ICTSD Project on IPRs and Sustainable Development, Policy Brief No. 4, 2009), p. 5-6.

37 See S.F. Musungu, "Innovation and Intellectual Property in the EC-CARIFORUM EPA: Lessons for other ACP Regions” IQsensato Studies, 2009, Vol. 1, 1-45, p. 26.

38 See Article 142.3 of the CARIFORUM-EC EPA.

39 See Spence, Negotiating Trade, Innovation and Intellectual Property, p. 6.

40 See Article 66.2 of the TRIPS Agreement, which applies this obligation to leastdeveloped countries only.

41 See the mandatory language of Article 66.2 of the TRIPS Agreement, which the CARIFORUM-EC EPA does not contain.

42 See Article 132(c) and 132(e) of the CARIFORUM-EC EPA. 
to technology transfer, the second may be as well. If the production and commercialization of innovative and creative products addresses local production, technology transfer is needed to accomplish this goal and provides a discussion point on how to implement the technology transfer provided for in Article 142.

One of the very concrete and meaningful obligations agreed upon by the parties is their commitment in Article 134 of the CARIFORUM-EC EPA to facilitate and promote the participation of CARIFORUM States in existing and future framework programmes, specific programmes and other activities of the European Union. ${ }^{43}$ So far, no other bilateral partner country was able to obtain access to such programmes for its firms. In addition, it identifies the relevant programmes clearly enough for CARIFORUM firms to rely on them. This obligation has to be read in conjunction with the caveat that such access is granted only in so far as it is permitted by each party's internal rules governing the access to these programmes and activities.

The programmes that would come under this provision are the so-called Seventh Framework Programmes (FP7). These are support programmes that are aimed at encouraging greater innovation. Only firms established in disadvantaged and outermost regions of the European Union, as well as those established in neighbouring states which participate in the European Neighbourhood Policy, are eligible for participation. ${ }^{44}$ As Malcolm Spence pointed out during the negotiations, CARIFORUM States indeed are neighbouring states to the French Caribbean Overseas Regions and other EU territories in the Caribbean. Their firms should therefore also be entitled to participate in these programmes. ${ }^{45}$ As the first breakthrough in the negotiations on the CARIFORUM side, CARIFORUM firms were granted access under these programmes; Article 134 of the CARIFORUM-EC $E P A$ is a reflection of this result. ${ }^{46}$

Surely less concrete than the previous commitment but nevertheless more specific than some of the cooperation efforts declared in previous European bilateral trade agreements, CARIFORUM and EU Member States agree to cooperate and facilitate support for technical assistance and to promote partnerships for research and development activities in CARIFORUM States, with the goal of improving local innovation systems. ${ }^{47}$ Although it has to be seen how these provisions will be operationalized in practice, they provide a starting point and legal basis for discussing such possibilities among the parties. All of the presented activities can contribute to the transfer of technology.

See Article 134 of the CARIFORUM-EC EPA.

These programmes are the so-called Lisbon agenda programmes. See European Commission, Seventh Framework Programme (FP7) (2011), available at $<$ http://cordis.europa.eu/fp7/understand_en.html> accessed on 04.10.2012; European Commission, Competitiveness and Innovation Framework Programme (CIP) (2011), available at <http://ec.europa.eu/cip/> accessed on 04.10.2012.

See M. Spence, Innovation and Intellectual Property, paper presented at the conference "The CARIFORUM-EC Economic Partnership Agreement One Year On: Regional Integration and Sustainable Development" in Barbados (University of West Indies, 22 April 2010), paragraph 18.

See section 10.1.2 for a more detailed account of the negotiations.

See Article 135(d) and (f) of the CARIFORUM-EC EPA. 
In conclusion, the rules on the transfer of technology present a first, appreciated effort by CARIFORUM States to bring this important issue of transferring technology to developing countries into the bilateral arena. However, it would have benefited from more mandatory and specific obligations.

\title{
5.3.1.5. Development Concerns
}

Arguably, the CARIFORUM-EC EPA incorporates a number of provisions that clearly express a commitment to an integrated and differentiated approach when implementing EPA obligations related to the protection of intellectual property. These are a) the principle of sustainable development, b) the specific context and objectives of the Innovation and intellectual property chapter, and c) the reference to Article 8 and parts of Article 7 of the TRIPS Agreement.

One of the very first principles set out in the CARIFORUM-EC EPA addresses sustainable development. ${ }^{48}$ According to the European Commission,

"sustainable development is the presiding principle governing the whole agreement." 49

The parties understand this principle as a commitment that:

\begin{abstract}
"the application of this Agreement shall fully take into account the human, cultural, economic, social, health and environmental best interests of their respective population and of future generations;" 50
\end{abstract}

Furthermore, the contracting parties reaffirm the commitment to apply and integrate the principle at every level of their economic partnership. ${ }^{51}$ In other words, when interpreting and implementing the provisions on intellectual property protection, this treaty objective of sustainable development shall play a crucial role. ${ }^{52}$

In addition to this overarching principle, the specific context and objectives of the Innovation and intellectual property chapter call for a balanced understanding of intellectual property protection which integrates all affected interests. Article 131.1 and 131.2 of the CARIFORUM-EC EPA stipulate that the promotion of creativity, innovation and competitiveness are a means for achieving the goal of sustainable development; an essential tool in achieving this goal is the protection of intellectual property. In this line of thinking, when setting higher standards of intellectual property protection, the standards must always be appropriate to the parties' levels of development. ${ }^{53}$ This statement acknowledges the need for differentiated levels of protection which take into account different levels of development. However, the substantive provisions on the protection of IP in the remainder of Chapter 2 on "Innovation and intellectual property" do not always reflect this differentiated

48 See Article 3 of the CARIFORUM-EC EPA.

49 European Commission, Information Paper: CARIFORUM-EU Economic Partnership Agreement: An Overview (Brussels, 2008).

50 See Article 3.2(a) of the CARIFORUM-EC EPA.

51 See Article 3.1 of the CARIFORUM-EC EPA.

52 See Grosse Ruse-Khan, Sustainable Development in International Intellectual Property Law, p. 5 .

53 See Article 131.2 of the CARIFORUM-EC EPA. 
approach. Academic scholars have therefore pleaded for a more explicit statement on the need of flexibility. ${ }^{54}$

Similarly, the objective to "achieve an adequate and effective level of protection and enforcement" of intellectual property rights emphasizes the need to tailor IP protection to domestic development needs. ${ }^{55}$ The term "adequate" implies a case-bycase assessment of the individual situations in each country. "Effective" should be understood as efficient, successful or as having an effect, ${ }^{56}$ in relation to the objectives that IP protection in the CARIFORUM-EC EPA aims to achieve. As addressed above, the objective of the IP chapter is to foster innovation and creativity; IP protection shall be conducive to these goals.

An important provision that sets out the principles applying to the intellectual property section is contained in Article 139.2 of the CARIFORUM-EC EPA. It stipulates the main horizontal obligation on the integration of intellectual property interests on the one hand, and other social interests on the other hand. Two obligations stand out. First, it requests that the interpretation of its bilateral provisions is subject to the principles set out in Article 8 of the TRIPS Agreement. The latter Article addresses the need to

\footnotetext{
"adopt measures necessary to protect public health and nutrition, and to promote the public interest in sectors of vital importance to their socio-economic and technological development, provided that such measures are consistent with the provisions of this Agreement." 57
}

Article 8 of the TRIPS Agreement, usually together with Article 7 of the TRIPS Agreement, can play an important role when interpreting TRIPS obligations in a way that integrates all relevant social, economic and environmental interests at stake. One important caveat is that measures must always be consistent with the TRIPS Agreement, which preempts the Article from functioning as an exception. Hence, also obligations stemming from the IP chapter of the CARIFORUM-EC EPA cannot be justified by the equivalent Article. The CARIFORUM-EC EPA only refers directly to Article 8 of the TRIPS Agreement, not Article 7. Some of the objectives of Article 7 of the TRIPS Agreement, such as the balance of rights and obligations, are mentioned in Article 139.2 of the CARIFORUM-EC EPA. However, the important element of Article 7 , that IP protection and enforcement should be conducive to social and economic welfare, is missing in the EPA. ${ }^{58}$

Second, Article 139.2 allows the contracting parties

\footnotetext{
$54 \quad$ See Musungu, Cariforum EP $A$ and beyond, p. 16.

55 See Article 132(d) of the CARIFORUM-EC EPA.

56 See Grosse Ruse-Khan, Sustainable Development In International Intellectual Property Law, p. 11.

$57 \quad$ Article 8 of the TRIPS Agreement.

58 Henning Grosse Ruse-Khan argues that the missing element "in a manner conducive to social and economic welfare" is arguably covered by the substantively similar phrase to "promote the public interest in sectors of vital importance to their socio-economic and technological development" of Article 8 of the TRIPS Agreement, which has been incorporated in Article 139.2 of the CARIFORUM-EC EPA. See Grosse Ruse-Khan, Sustainable Development In International Intellectual Property Law, p. 11.
} 
"to protect public health and nutrition. Nothing in this Agreement shall be construed as to impair the capacity of the Parties and the Signatory CARIFORUM States to promote access to medicines."

This provision addresses measures that protect public health and nutrition and that do not have to be consistent with the provisions on IP protection. Compared to the equivalent provision in Article 8.1 of the TRIPS Agreement, this Article enables an interpretation of the individual IP obligations that allows domestic measures protecting public health to take effect. ${ }^{59}$ To interpret the provision as an exception that could justify breaches of individual IP obligations would, however, be contrary to the general exception provision in Article 224 of the CARIFORUM-EC EPA which provides a possibility to except measures that are "necessary to protect human, animal or plant life or health." ${ }^{60}$

The purpose and objectives of the EPA, and of the IP chapter in particular, can play an important role when interpreting the substantive provisions on innovation and intellectual property, which are laid down in Articles 133 until 164. The object and purpose, together with the ordinary meaning of specific provisions, provide a good faith interpretation of the treaty. ${ }^{61}$ Even though both the ordinary meaning and the object and purpose of the treaty are equally important in the interpretation of the treaty, if a legal obligation includes very clear language, the room for the object and purpose to inform the interpretation is rather small. The assessment of the substantive provisions will show where there is room for an interpretation that takes development concerns into account. ${ }^{62}$

In conclusion, the overarching principle of sustainable development, the context and objectives of the chapter on "Innovation and intellectual property" as well as the principles applying to the intellectual property section show a genuine effort to create international obligations on intellectual property rights, which are driven by development concerns. The principles provide considerable policy space to address domestic development needs in the implementation process. The provisions reflect a balanced and integrated approach towards intellectual property protection, which should enable policy makers to integrate the social, economic and environmental interests at stake. Their value will have to be demonstrated in the implementing phase of the substantive IP provisions into national law. The following analysis in section 5.3.2 points out where substantive provisions leave some policy space to give effect to these principles.

\subsubsection{Transitional Periods}

All parties to the agreement, except for least-developed countries, shall give effect to the provisions of the section addressing intellectual property by 1 January $2014 .{ }^{63}$ This rule is subject to the decisions made by the CARIFORUM-EC Trade and

\footnotetext{
59 See ibid., p. 13.

60 See Article 224.1(b) of the CARIFORUM-EC EPA. See also section 5.4 of this book.

61 See Article 31.1 of the Vienna Convention on the Law of Treaties, signed at Vienna on 23 May 1969, entered into force 27 January 1980, 1155 U.N.T.S. 331 (1980) [hereinafter Vienna Convention on the Law of Treaties].

62 See section 5.3.2 of this book on Individual Intellectual Property Provisions.

63 See Article 139.4 first sentence of the CARIFORUM-EC EPA.
} 
Development Committee (TDC) ${ }^{64}$ The Committee may deviate from this period, after having taken the development priorities and levels of development of the signatory CARIFORUM States into account. The transitional period will apply to all signatories of the agreement, except for Haiti, which is the only LDC among the CARIFORUM States.

Haiti has until 1 January 2021 to apply the obligations concerning intellectual property rights (Subsection 2 of Chapter 2) and enforcement of intellectual property rights (Subsection 3 of Chapter 2). ${ }^{65}$ They incorporate the substantive provisions addressing individual intellectual property regimes and enforcement matters discussed in the remainder of this chapter. Also this deadline can be adjusted by the TDC. ${ }^{66}$ The CARIFORUM-EC EPA does, however, require LDCs to give effect to the obligations under the TRIPS Agreement according to the relevant decisions of the TRIPS Council or the WTO General Council. This obligation merely reiterates the multilateral obligation of contracting parties under the TRIPS Agreement to implement the Agreement in accordance with the transitional periods established by the TRIPS Agreement or by the TRIPS Council.

\subsubsection{Interim Conclusions}

The general provisions included in the Chapter on "Innovation and intellectual property" of the CARIFORUM EC-EPA contain different elements that seem to stress the development component of the agreement. The inclusion of the protection of utility models and genetic resources, traditional knowledge and folklore in the IP chapter show an effort to make IP protection more useful for developing countries. CARIFORUM States, and in particular Haiti as the only LDC, have received a rather broad transitional period. The principles governing the EPA in general and the IP section in particular emphasize contracting parties' freedom of implementation, the need to make the transfer of technology to developing countries more operational and to safeguard enough domestic policy space in order to integrate all relevant social interests. These general principles should be particularly useful in the implementation of substantive IP provisions.

\subsubsection{Individual Intellectual Property Provisions}

The individual standards concerning intellectual property rights are set out for the different areas of intellectual property protection covered by the EPA. These areas are copyright and related rights, trade marks, geographical indications, industrial designs, patents, utility models, plant varieties and genetic resources, traditional knowledge and folklore. Instead of an article-by-article analysis of the IP chapter, the provisions that a) go beyond the level of protection foreseen in the TRIPS Agreement or b) are different from the EU's old approach included in previous bilateral trade agreements are discussed in detail. In addition, the obligations are compared with

According to Article 230 of the CARIFORUM-EC EPA, the CARIFORUM-EC Trade and Development Committee assists the Joint CARIFORUM-EC Council in the performance of its duties. The Council is the highest political body that meets at ministerial level, whereas the Committee is composed of senior officials from the parties.

65 See Article 140 of the CARIFORUM-EC EPA.

66 See Article 140(b) of the CARIFORUM-EC EPA. 
United States' FTAs and assessed in how far they provide domestic policy space to take into account development concerns.

\subsubsection{Provisions Relating to Access to Information in the Digital Environment}

The first area of intellectual property protection addressed in the CARIFORUM-EC $E P A$ is copyright protection granted to digital products. Article 143.A.1 of the CARIFORUM-EC EPA requires parties to "comply with" the WIPO Copyright Treaty and the WIPO Performances and Phonograms Treaty. These treaties are the two main multilateral instruments regulating the access to information on the Internet. The socalled WIPO Internet treaties extend the application of rules governing copyright to works on the Internet and in the digital media. ${ }^{67}$ In addition, they also create new rights for right holders by requiring parties to adopt legal protection and remedies against the circumvention of technological protection measures or the alteration of digital rights management information. ${ }^{68}$ Protecting the use of TPMs has been criticized because not only copyright infringers are barred from accessing the protected information; also consumers that want to use this information for legitimate purposes, such as for education, libraries or the visually impaired cannot do so. ${ }^{69}$ Protection for TPMs and DRM information allows right holders to determine themselves the terms of access to their materials without respecting public interest exceptions. $^{70}$

The obligation "to comply with" these treaties is an increase in the level of protection compared with the Cotonou Agreement and the TRIPS Agreement: both agreements do not establish rules against the circumvention of TPMs and the alteration of DRM information. Previous European bilateral agreements "merely" include the obligation "to accede to" the WCT and WPPT in several agreements. ${ }^{71}$ The same is true for the United States which has included this requirement in all its FTAs as well as detailed standards of protection taken from US legislation. ${ }^{72}$ However, the obligation "to comply with" the WIPO Internet treaties contained in the CARIFORUM-EC EPA is different. Compliance concerns the substantive fulfillment of the obligations established under the multilateral treaty. Accession, in contrast, requires a state to officially become a party to that treaty; it does not touch upon the substantive fulfillment of its rules. Although the multilateral treaty also requires that its contracting parties comply with the rights and obligations set out therein, a dispute on such matters would be dealt with under the multilateral framework only. If the bilateral treaty requires compliance, another party to the bilateral agreement could start a dispute settlement procedure under the EPA, ${ }^{73}$ claiming non-compliance with

See section 3.2.5 of this book for a general discussion on these treaties.

See Articles 11 and 12 of the WIPO Copyright Treaty.

See Christian Aid and Oxfam, The EU's Approach to Free Trade Agreements: Intellectual Property, p. 3.

See Shabalala, What Way Forward after the Cariforum EPA and the Interim EPAs?, p. 9.

Albania had to accede to the WCT, not the WPPT (Article 73.3 juncto Annex V of the EC-Albania SAA). Bosnia and Herzegovina, Algeria and Chile were all required to accede to the WCT and the WPPT (Article 38 juncto Annex VI of the EC-Bosnia and Herzegovina IA; Article 44.2 juncto Annex 6 of the EC-Algeria EuroMed AA, and Article 170(b) of the EC-Chile AA.

See sections 3.2.3 and 3.2.5 of this book.

See Articles 202 until 223 of the CARIFORUM-EC EPA. 
the multilateral treaty. In this respect, the obligation "to comply with" goes further than accession as it concerns substantive fulfillment of the multilateral obligations.

On the other hand, compliance does not necessarily require a country to become a contracting party to the treaty. Even without being a party to the WCT and WPPT, a country can comply with its rules. So far, only four out of the fifteen CARIFORUM States have acceded to the WCT and five out of fifteen to the WPPT. ${ }^{74}$ However, whether they comply with the provisions set out in the treaties is a different matter. Jamaica, for example, has become a member to the WIPO Internet treaties in 2002 but is yet to implement its obligations. ${ }^{75}$

Another new feature of the CARIFORUM-EC EPA is a provision on the cooperation between collecting societies on the access to and delivery of licenses in order to facilitate the adequate reward to right holders. ${ }^{76}$ The cooperation in this area has been noted positively by some scholars as it will help the Caribbean countries to foster the flow of royalty revenues to their cultural industries. ${ }^{77}$ Overall, the protection of digital works is achieved through the required compliance with the WCT and WPPT. Compliance is a strong obligation which goes beyond the TRIPS standard. At the same time, the provisions in the WIPO Internet Treaties with regard to the protection of TPMs and DRM information leave more freedom of implementation than the detailed obligations contained in United States FTAs. Cooperation with collecting societies may enhance the flow of royalty payments to artists in CARIFORUM States.

\subsubsection{Provisions Relating to Trade Marks}

The rules relating to trade marks deal with issues that have so far not been included in European bilateral trade agreements, and only in few aspects in US free trade agreements. ${ }^{78}$ They concern a) the procedural requirements for the registration of trade marks, b) well-known marks, the protection of marks and signs on the Internet, and trade mark licenses, c) international agreements and d) exceptions to the rights. These issues do not pose major concerns and will be discussed briefly.

First, the CARIFORUM-EC EPA includes several procedural requirements for the registration of trade marks. The final decision on registering a trade mark must be reasoned and in writing. ${ }^{79}$ Furthermore, applicants shall have a possibility to contest

74 Up until October 2012, the Dominican Republic, Jamaica, Saint Lucia and Trinidad and Tobago have acceded to the WCT and WPPT, and Saint Vincent and Grenadines to the WPPT.

See D. Daley, "Intellectual Property in the EPA: Broad Scope, Huge Impact - Parts I, II, III" Jamaica Observer (9 July 2008), part I.

78 These rules have been taken up in Article 144 of the CARIFORUM-EC EPA.

79 As the term final was not yet included in the EC non-paper, CARIFORUM States were able to limit this procedural requirement to final decisions only. See Article 8.1 of the EC non-paper CARIFORUM-EC EPA, Elements for a Section on IPRs from November 2006. See bilaterals.org, Draft EU-Caribbean EPA - IPR non-paper (Nov 2006) 
the refusal to register and third parties shall have a possibility to object the registration of a trade mark after its publication. ${ }^{80}$ The obligation to put in place an opposition procedure is a TRIPS-plus requirement as the TRIPS Agreement leaves it to the Member States' discretion to establish an opposition procedure or not. ${ }^{81}$ Article 144.A of the CARIFORUM-EC EPA furthermore requires parties to set up an electronic database of trade mark applications and registrations, which must be publicly available. Such a database is not required by the TRIPS Agreement and puts an additional administrative and financial burden on Caribbean countries. In the EC non-paper, presented to CARIFORUM States in November 2006, ${ }^{82}$ this was one of the provisions in square brackets, suggesting that discussion on these points was required. Finally, the provision was kept in.

Second, parties must endeavour to apply three WIPO Joint Recommendations on trade marks. These recommendations concern the protection of well-known marks, trade mark licenses and the protection of marks and signs on the Internet. ${ }^{83}$ In a nutshell, the recommendation on well-known marks specifies concepts relevant for well-known marks already provided for by the TRIPS Agreement. The recommendation dealing with trade mark licenses sets out requirements that a WIPO Member State may demand in the request for the recordal of a license. Finally, the recommendation on the protection of marks and signs on the Internet establishes rules dealing with the use, acquisition and maintenance of rights in signs on the Internet. These specifications are TRIPS-plus obligations. At least with regard to the determination of well-known marks, United States' FTAs provide for rules that include stricter requirements compared with the catalogue of criteria offered by the recommendation. ${ }^{84}$

"Best endeavour" obligations are rather soft obligations: parties should strive for applying the above-mentioned recommendations. However, if a party does not achieve this goal, it is not necessarily in violation of its obligation under the EPA. Should a party be challenged on this point, it is the complainant who has to prove that the defendant failed to endeavour to apply the recommendations. This could be

(2006), available at <http://www.bilaterals.org/spip.php?article6496\&lang=en> accessed on 12.11.2012 [hereinafter EC non-paper November 2006].

80 See Article 144.A of the CARIFORUM-EC EPA.

81 See Article 15.5 of the TRIPS Agreement.

82 See Article 8.1 of the EC non-paper November 2006.

83 See Assembly of the Paris Union for the Protection of Industrial Property and General Assembly of the World Intellectual Property Organization, Joint Recommendation Concerning Provisions on the Protection of Well-Known Marks (Geneva, 20-29 September 1999) [Publication 833E] [hereinafter WIPO Joint Recommendation on well-known marks]; Assembly of the Paris Union for the Protection of Industrial Property and General Assembly of the World Intellectual Property Organization, Joint Recommendation Concerning Provisions on the Protection of Marks, and other Industrial Property Rights in Signs, on the Internet (Geneva, 24 September-3 October 2001) [Publication 845E] [hereinafter Joint Recommendation on the protection of marks and signs on the internet]; Assembly of the Paris Union for the Protection of Industrial Property and General Assembly of the World Intellectual Property Organization, Joint Recommendation Concerning Trademark Licenses (Geneva, 25 September-3 October 2000) [Publication 835E].

$84 \quad$ See section 3.2.6.2 of this book. 
rather difficult to prove. The integration of such soft obligations was at the heart of CARIFORUM States' negotiation catalogue because the original proposal by the European Union still foresaw that the parties "will apply" or "will $[\ldots]$ use" the recommendations. ${ }^{85}$ Thus, the language has been weakened significantly.

Third, another "best endeavour" obligation pertains to international agreements. ${ }^{86}$ The contracting parties shall endeavour to accede to the Madrid Protocol and to the revised Trade Mark Law Treaty or the Singapore Treaty. The Madrid Protocol is an international registration instrument that facilitates the registration of trade marks in multiple jurisdictions. The Singapore Treaty is a standard-setting instrument that aims at harmonizing the administrative trade mark registration procedures in the contracting parties. Up until October 2012, only Antigua and Barbuda is a party to the Madrid Protocol. Only the Dominican Republic has signed the Singapore Treaty but has yet to ratify it. Again, CARIFORUM States were successful in lowering the standard from an obligation to "ratify or accede to" these treaties to the much softer "best endeavour" obligation. ${ }^{87}$ This flexibility allows CARIFORUM States to investigate the administrative and financial costs of accession to these instruments before applying for accession. Several US FTAs require their trading partners to accede to or ratify the Madrid Protocol; 88 however, only the recent draft IP chapter of the TPP February 2011 and the US-South Korea FTA have also included the Singapore Treaty in their catalogue of multilateral treaties. ${ }^{89}$ In that respect, the EPA requires similar standards as US free trade agreements.

The fourth and final provision presents an exception to the rights conferred by a trade mark: parties must allow for the fair use of descriptive terms, including geographical indications, even if a registered trade mark exists that includes such terms.${ }^{90}$ In other words, such an exception limits the rights of trade mark owners. A geographical indication, for example, can be used alongside a registered trade mark if its use does not conflict with the legitimate interests of the owner of the trade mark and third parties. The possibility of such an exception is also foreseen in the TRIPS Agreement, ${ }^{11}$ the EPA, in contrast, obliges parties to provide for a limited exception with regard to the fair use of descriptive terms.

In summary, the provisions relating to the protection of trade marks incorporate few TRIPS-plus provisions, mainly due to the "best-endeavour" obligations with regard to the application of the WIPO Joint Recommendations and the accession to the Madrid Protocol and the Singapore Treaty. This flexibility allows CARIFORUM States to

See Article 8.2, 8.3 and 8.4 of the EC non-paper November 2006.

See Article 144.E of the CARIFORUM-EC EPA.

In fact, Article 8.5 of the EC non-paper November 2006 required the ratification of or accession to the Madrid Protocol and the Trade Mark Law Treaty, not the revised version. See Article 1.3(e) of the draft IP chapter of the TPP of February 2011; Article 18.1.3(e) of the US-South Korea FTA; Article 14.1.2(c) of the US-Babrain FTA; Article 15.1.2(c) of the US-Morocco FTA and Article 17.1.2(c) of the US-Australia FTA.

Only Article 1.3(h) of the draft IP chapter of the TPP of February 2011 requires parties to ratify or accede to the Singapore Treaty by the date of entry into force of the TPP. Article 18.1.4(c) of the US-South Korea FTA demands its negotiating parties to make all reasonable efforts to ratify or accede to the treaty. See Article 145.F of the CARIFORUM-EC EPA.

See Article 17 of the TRIPS Agreement. 
investigate the related administrative and financial costs. On the other hand, the procedural requirements for the registration of trade marks do not leave the same policy space; they require contracting parties to incur substantial costs by establishing an opposition procedure and an electronic database (if not yet provided for). The rules on trade mark protection contained in the EPA stay well behind those included in US FTAs which provide for an especially right holder-friendly level of protection.

\subsubsection{Provisions Relating to Geographical Indications}

The protection afforded to geographical indications is an important feature of the CARIFORUM-EC EPA. The European Union is the most forceful proponent of GI protection. The United States, in contrast, does not address geographical indications as a standalone area of IP protection in its free trade agreements but deals with their protection as a matter of trade mark law. Therefore, the protection included in the CARIFORUM-EC EPA goes far beyond the protection sought for GIs in US FTAs. Similar to previous European agreements on trade in wine and/or spirits, the GI protection in the CARIFORUM-EC EPA is extensive. ${ }^{92}$ However, the structure and substance of the provisions on GI protection in the CARIFORUM-EC EPA differs from that of previous agreements. Article 145 of the CARIFORUM-EC EP $A$ deals with the following issues: a) scope of protection, transitional periods and term of protection; b) level of protection; c) exceptions; d) invoking TRIPS exceptions in disputes before an EPA panel; e) the relationship between GIs and trade marks; and f) the application of the WIPO Joint Recommendation concerning the protection of marks on the Internet. These six issues contain several TRIPS-plus elements, which will be addressed in turn.

\subsection{Scope of Protection, Transitional Periods and Term of Protection}

In contrast to the agreements on trade in wine and/or spirits, the protection granted by the CARIFORUM-EC EPA is not limited to geographical indications in the area of wine and/or spirits. It covers all classes of products on which geographical indications are granted in the contracting states to the EPA. This is evident from Article 145.B, which specifies the level of protection for GIs in general. The EPA does not include a definition of geographical indications. In this respect, it differs from most previous European agreements on trade in wine and/or spirits which defined the term geographical indication. ${ }^{93}$

CARIFORUM States are obliged to establish a system of protection of geographical indications in their respective territories no later than 1 January 2014. ${ }^{94}$ In order to establish such a system, CARIFORUM States shall cooperate with the CARIFORUM-EU Trade and Development Committee (TDC) and develop geographical indications in their territories. In this respect, a list of prospective GIs originating in the CARIFORUM States must be submitted to the Committee within six months from the entry into force of the EPA. The EPA will enter into force on the first day of the month following the month in which the parties have notified

92 See section 3.3.6 of this book.

93 See section 3.3.6.1 of this book.

94 See Article 145.A.2 of the CARIFORUM-EC EPA. 
each other of the completion of their ratification procedures. ${ }^{95}$ So far, the ratification procedures in the signatory states have not been finalized and no prospective GIs have been developed so far.

It is a new feature of European bilateral trade agreements to ask partner countries to develop a list of geographical indications that will be protected in the bilateral agreement. Such a provision takes into account the reality in CARIFORUM States which did not protect geographical indications prior to the EPA negotiations. It remains to be seen what role the TDC will play in this process and whether partner countries benefit from this cooperation. ${ }^{96}$ In addition to the rules on GIs already established in Article 145, the EPA schedules negotiations on a new agreement on the protection of geographical indications to start no later than 1 January $2014 .{ }^{97}$ This is commonly referred to as a rendezvous clause. The European Commission intends to negotiate a "fully fledged agreement on GIs." 98 This suggests that the agreement will not only cover trade in wine and/or spirits but all agricultural products, similar to the EC-Switzerland Agricultural Products Agreement.

Another new feature of the CARIFORUM-EC EPA is the minimum term of protection for GIs. According to Article 145.B, protection afforded to GIs in the European Union and CARIFORUM States shall be indefinite. Footnote 1 to this paragraph clarifies that an unlimited number of renewable periods of not less than ten years shall be considered indefinite. The TRIPS Agreement does not specify a term of protection; neither do previous European agreements on trade in wine and/or spirits. The specification of the term of protection for GIs is therefore a new TRIPSplus element in European bilateral trade agreements.

Overall, the CARIFORUM-EC EPA contains a number of new elements compared to previous European agreements on trade in wine and/or spirits. The EPA stipulates rules for geographical indications for both wines and spirits and agricultural products, requires CARIFORUM States to develop a list of GIs to be protected and sets up a minimum term of protection for GIs. The last element also constitutes a TRIPS-plus feature.

\subsection{Level of Protection}

The EPA requires a level of protection that contains three core obligations:99 1) exclusive protection of geographical indications, 2) protection against misleading use and 3) "additional protection". While the second obligation reflects the general level of protection required by the TRIPS Agreement for all GIs, the first and the third obligation go beyond the standard set by the TRIPS Agreement.

These notifications must be sent to the depository of the Agreement, being the Secretary General of the Council of the European Union. See Article 243.1 and 243.2 of the CARIFORUM-EC EPA.

6 Note that so far two meetings of the TDC have taken place, the first one in Bridgetown, Barbados 9-10 June 2011, and the second in Port-of-Spain on 27 September 2012.

See Article 145.E of the CARIFORUM-EC EPA.

European Commission, Fact Sheet on Cariforum-EC EPA: Innovation and Intellectual Property (Brussels, 2008), p. 3.

See Article 145.B of the CARIFORUM-EC EPA. 
According to the first obligation, the contracting parties agreed that if a geographical indication enjoys GI protection in one signatory state, the use of that geographical indication must be

"exclusively reserved [in all signatory countries] [...] to goods originating in the geographical area concerned and that are produced in accordance with the relevant product specifications."'100

This absolute protection for geographical indications would not do justice to situations in which geographical indications carry the same name but originate in different territories if the agreement did not contain an exception for homonymous geographical indications. ${ }^{101}$ The exception in the EPA, which is identical to the relevant TRIPS rule, ${ }^{102}$ allows homonymous indications to be protected if there is sufficient distinction between the indications in practice so that consumers are not misled or deceived. Previous European agreements on trade in wine and/or spirits also maintain this flexibility.

Second, listed GIs must also be protected against misleading use. ${ }^{103}$ In other words, geographical indications may not be used in a manner that misleads consumers as to the true geographical origin of the good. ${ }^{104}$ This protection is known as the general protection granted by the TRIPS Agreement to geographical indications for all kinds of products. ${ }^{105}$ European agreements on trade in wine and/or spirits have included a slightly different obligation in which the element of misleading the consumer has been left out and therefore is clearly broader than the EPA provision. ${ }^{106}$

The third type of protection is referred to as "additional protection", as also provided for in the TRIPS Agreement. "Additional protection" requires parties to prevent the use of a GI for products that do not originate in the place indicated, even where a) the true origin is indicated, b) the GI is used in translation, or c) the GI is accompanied by terms such as "kind", "type", "style" "imitation" or "method". ${ }^{107}$ While the substantive protection granted is the same in the EPA and the TRIPS Agreement, the scope of beneficiary geographical indications differs: Article 23.1 of the TRIPS Agreement applies "additional protection" to wines and spirits only; the CARIFORUM-EC EPA, in contrast, grants it to all classes of products. It is a matter

100 Article 145.B.2 of the CARIFORUM-EC EPA.

101 See Article 145.C.3 of the CARIFORUM-EC EPA.

102 See Article 22.4 of the TRIPS Agreement.

103 Note that, so far, no lists of GIs have been submitted. Geographical indications are yet to be protected under the CARIFORUM-EC EPA. See the transitional period explained in section 5.3.2.3.1 of this book.

104 Parties are required to prohibit and prevent the use in their territory of any means of "designation or presentation of a good that indicates or suggests that the good in question originates in a geographical area other than the true place or origin in a manner which misleads the public as to the true geographical origin of the good" [emphasis added]. See Article 145.B.3(a) of the CARIFORUM-EC EPA.

105 See Article 22.2 of the TRIPS Agreement.

106 See section 3.3.6.2 of this book.

107 See Article 145.B.3(b) of the CARIFORUM-EC EPA. This protection is also required in most previous European agreements on the trade in wine and/or spirits. See section 3.3.6.2 of this book. 
of international debate whether it is justifiable that the "additional protection" in the TRIPS Agreement is limited to wines and spirits. Extending this protection to other products goes beyond the current TRIPS-standard. However, it can be argued that this extension merely remedies a birth problem of the TRIPS Agreement which does not grant the same GI protection to all sorts of products. Such an extension is also discussed as part of the Doha mandate for negotiations under the Doha Development Agenda. ${ }^{108}$

In summary, the level of protection consists of exclusive protection against misleading use and other uses of the listed GIs on all types of products protected in CARIFORUM territories and the European Union. This level of protection seems to be at odds with the following principle incorporated in the CARIFORUM-EC EPA: GIs are protected according to the parties' own legal system and practice. ${ }^{109}$ At first sight, such a principle could be interpreted as mutually recognizing the protection granted in each signatory party. However, the three obligations as to the required level of protection, which need to be integrated into the legal systems of the parties, do not seem to offer parties a choice as to whether they would like to keep their own level of protection and mutually recognize these different levels. Instead, national legal systems and practices not in line with the level of protection set out in the EPA will have to be adapted in order to comply with these obligations in the EPA. Admittedly, except for the required "exclusive" protection as well as the "additional protection" for products other than wine and spirits, the protection required by the CARIFORUM-EC EPA reflects the TRIPS standard with which CARIFORUM States have to comply anyway.

\subsection{Exceptions}

The CARIFORUM-EC EPA provides for several exceptions. ${ }^{110}$ The first exception reflects an exception contained in the TRIPS Agreement: ${ }^{111}$ It allows contracting parties to refuse protection for a geographical indication that is not protected in its country of origin. ${ }^{112}$ It has been noted that this provision puts CARIFORUM States at a disadvantage compared to the European Union. ${ }^{113}$ CARIFORUM States have yet to establish a system of identifying and registering GIs whereas the European Union already works with a highly sophisticated system of protection. However, once effective systems of GI protection have been established in CARIFORUM territories, which it was attempted to be secured through the transitional period and rendezvous clause, ${ }^{114}$ such an exception is more than logical.

See paragraph 18 juncto 12 of the WTO Ministerial Conference, Doha Ministerial Declaration. See WTO Secretariat, TRIPS: Geographical Indications - Background and the current situation (2012), available at < http://www.wto.org/english/tratop_e/trips_e/gi_background_e.htm\#protection> accessed on 23.07.2012.

See Article 145.B.1 of the CARIFORUM-EC EPA.

For an analysis of the exception for homonymous GIs, see section 5.3.2.3.2 above.

See Article 24.9 of the TRIPS Agreement.

See Article 145.A.1 of the CARIFORUM-EC EPA.

See Shabalala, What Way Forward after the Cariforum EPA and the Interim EPAs?, p. 10.

See section 5.3.2.3.1 of this book. 
Another important TRIPS exception incorporated in the EPA concerns geographical indications that have become generic in the language of a signatory state. ${ }^{115}$ If an indication is identical to the term customary in common language as the common name for a good or service, a country can deny protection for this geographical indication. ${ }^{116}$ An example is the word "champagne" which can be argued has become generic for different types of sparkling wine not necessarily originating in the French region Champagne. Its inclusion in the CARIFORUM-EC EPA can be evaluated as positive at least for two reasons. First, in view of the fact that the majority of agreements on trade in wine and/or spirits does not provide for this exception, ${ }^{117}$ its recognition in the EPA is a new feature that safeguards more flexibility compared with previous European agreements. Second, the exception is also not limited by a clawback provision: according to such an obligation, contracting parties must cease to deem particular terms customary to their common language. Such a list was still included in the EC non-paper from November $2006^{118}$ and forms part of the ECCanada Wine and Spirits Agreement, ${ }^{119}$ the only agreement on trade in wine and/or spirits that did preserve the exception for generic terms. In brief, the recognition of the exception for generic terms provides CARIFORUM States with domestic policy space to adapt the protection of geographical indications in accordance with all relevant interests.

A new exception in European bilateral trade agreements addresses the use of GIs identical to the name of a grape variety, plant variety or animal breed. Contracting states are allowed to deny protection to indications that are

"identical with the name of a grape variety, plant variety or animal breed existing in the territory of $[\ldots]$ [a signatory party]". 120

Previous agreements on trade in wine and/or spirit did not yet contain this exception which is similar to the exception in internal EU legislation on the protection of geographical indications. Article 3.2 of the EC Regulation 510/2006 reads:

"A name may not be registered as a designation of origin or a geographical indication where it conflicts with the name of a plant variety or an animal breed and as a result is likely to mislead the consumer as to the true origin of the producer."

Two differences are apparent. ${ }^{121}$ First, the internal EU rule is mandatory, whereas the CARIFORUM-EC EPA leaves it to the parties to make use of the exception or not.

115 See Article 24.6 of the TRIPS Agreement.

116 See Article 145.C.1 of the CARIFORUM-EC EPA.

117 See section 3.3.6.4 of this book for an analysis of which agreements explicitly prohibit their application, which agreements have not included this exception and what the respective consequences for contracting parties are.

See Article 9.3.2 of the EC non-paper November 2006. Note that the EC non-paper November 2006 contains two articles numbered 9.3. It is the second Article 9.3 that is referred to here.

119 See Article 12 of the EC-Canada Wine and Spirits Agreement.

120 Article 145.C.2 of the CARIFORUM-EC EPA.

121 The name "grape variety" is not included in EC Regulation 510/2006 since it only deals with agricultural products. However, EC Regulation No. 479/2008 of 29 April 2008 on the common organisation of the market in wine sets out rules on the relationship between 
Second, Article 3.2 of the EC-Regulation 510/2006 limits the application of the exception to conflicts between names that are likely to mislead the consumer as to the true origin of the producer. This limitation is not included in the CARIFORUMEC EPA and therefore makes the scope of application of the exception broader.

Interesting to note is that while most exceptions concerning geographical indications contained in the TRIPS Agreement have been taken up in the CARIFORUM-EC EPA, this is not the case for the exceptions contained in Article 24.4 and 24.8 of the TRIPS Agreement regarding the grandfathering of certain geographical indications and the use of a person's name. In most previous European agreements on trade in wine and/or spirits, the right to use one's name in the course of trade for her/his business has been preserved. ${ }^{122}$ The grandfathering of GIs as an exception has been explicitly excluded in two previous agreements on trade in wine and/or spirits. ${ }^{123}$ This is different from the EPA which does not explicitly exclude these exceptions but does not establish any rule thereon either. Omitting an exception contained in the TRIPS Agreement is a TRIPS-plus feature since the exception is not immediately available anymore in the context of the CARIFORUM-EC EPA. The question arises whether a party to the EPA and the TRIPS Agreement can nevertheless rely on the exceptions laid down in Article 24.4 and 24.8 of the TRIPS Agreement in the case that this party breaches an EPA obligation. This subject will be addressed in the next section on invoking TRIPS exceptions before an EPA panel.

Overall, the exceptions provided for in the CARIFORUM-EC EPA reflect the TRIPS level of protection. They provide more flexibility than previous European agreements on trade in wine and/or spirits. Contracting parties are able to balance the protection for GI right holders with other relevant interests.

\subsection{Invoking TRIPS Exceptions before an EPA Panel}

Can a party to the EPA and the TRIPS Agreement rely on the exception laid down in Article 24.4 and 24.8 of the TRIPS Agreement in case it breaches an EPA obligation? Let us suppose that country $\mathrm{A}$ and country $\mathrm{B}$ are bound by the CARIFORUM-EC EPA and the TRIPS Agreement. In scenario I, producer X in country B applies for the protection of a geographical indication in country A. That GI happens to be identical to a geographical indication that has been registered in good faith in country A prior to 15 April 1994. Country A decides not to prevent this similar use of the prior GI on the basis that it has been registered in good faith in its territory before 15 April 1994. It uses Article 24.4 of the TRIPS Agreement to justify this use. In scenario II, producer $\mathrm{Y}$ in country $\mathrm{B}$ applies for the protection of a GI in country $\mathrm{A}$ that happens to be identical to a person's name which this person uses in the course of trade in a non-misleading manner. Country A refuses to prevent this person from using his name on the basis of this person's right to use his name. Article 24.8 of the TRIPS Agreement provides the legal basis for this refusal.

geographical indications and grape varieties. See Article 42.3 of the EC Regulation $479 / 2008$.

See section 3.3.6.4 of this book, footnote 404. Only the EC-Switzerland Agricultural Products Agreement does not preserve this exception expressly. Agreement/EC-Switzerland Spirits Agreement. See section 3.3.6.4 of this book, footnote 409. 
As a response to both scenarios, country $\mathrm{B}$ initiates consultations with country $\mathrm{A}$ under Article 204 of the CARIFORUM-EC EPA and eventually requests the establishment of an arbitration panel. ${ }^{124}$ It claims that country A has not fulfilled its obligation under Article 145.B.2 and Article 145.B.3 of the CARIFORUM-EC EPA. Country A relies, as a defense, on Article 24.4 of the TRIPS Agreement, respectively on Article 24.8 of the TRIPS Agreement.

What will the arbitration panel adjudicate? The arbitration panel first has to determine its jurisdiction. ${ }^{125}$ Article 203.1 of the CARIFORUM-EC EPA provides that the rules on dispute settlement

"apply to any dispute concerning the interpretation and application of this Agreement."

Article 219 of the CARIFORUM-EC EPA on rules of interpretation specifies that the panels shall interpret the provisions of this Agreement in accordance with customary rules of interpretation of public international law. Furthermore,

"The rulings of the arbitration panel cannot add to or diminish the rights and obligations provided in the provisions of this Agreement."

Accordingly, if a party brings a dispute claiming that an EPA obligation has not been complied with, the panel has jurisdiction. In the case of the examples set out above, this is the case.

At the same time, Article 219 of the CARIFORUM-EC EPA contains another rule, namely one that addresses what it has competence to adjudicate on. The competence question becomes relevant for the next issue a panel needs to determine, namely the applicable law. The applicable law between two parties is first determined by the question which law binds them. In the case set out above, country $\mathrm{A}$ and country $\mathrm{B}$ are contracting parties to both the CARIFORUM-EC EPA and the WTO Agreement, hence also the TRIPS Agreement. Therefore, the rules in Article 145.B.2 and 145.B.3 of the CARIFORUM-EC EPA and the Article 24.4 and Article 24.8 of the TRIPS Agreement are relevant provisions between the parties.

The second question is: do both treaties deal with the same subject matter? Treaties on the same subject matter exist if there is an overlapping ratione materiae. This can be decided upon by undertaking an "assessment of whether the fulfillment of the obligation under one treaty affects the fulfillment of the obligation of another."126

124 See Article 206 of the CARIFORUM-EC EPA.

125 See A. Dahrendorf, "Free Trade Meets Cultural Diversity: the Legal Relationship between WTO Rules and the UNESCO Convention on the Protection of the Diversity of Cultural Expressions" in H. Schneider and P. Van den Bossche (eds.), Protection of Cultural Diversity From a European and International Perspective (Intersentia, Antwerpen, 2008) 31-83.

126 See Koskenniemi, Fragmentation of International Law: Difficulties arising from the Diversification and Expansion of International Law, paragraph 254. 
The rules of both treaties affect the protection of geographical indications. Therefore, the answer to this question is affirmative. ${ }^{127}$

In that case, the panel gets to the third question: does a true legal conflict exist between the provisions in the EPA on the one hand, and the provisions of the TRIPS Agreement on the other hand? According to Wilfred Jenks,

"A conflict of law-making treaties arises only where simultaneous compliance with the obligations of different instruments is impossible [...]. There is no conflict if the obligations of one instrument are stricter than, but not incompatible with, those of another, or if it is possible to comply with the obligations of one instrument by refraining from exercising a privilege or discretion accorded by another." ${ }^{128}$ [emphasis added]

In other words, only if both treaties set out obligations with which a party cannot comply simultaneously, a true legal conflict exists. The ILC Report on the Fragmentation of International Law on the other hand takes a different approach. It suggests a wide notion of conflict. Accordingly, a conflict also exists where a treaty frustrates the goals of another treaty without there being any strict incompatibility between their provisions. ${ }^{129}$ An example of a broad conflict exists where an obligation in one agreement prohibits what a right in another agreement permits. It is the judicial body addressed that has to determine which definition of legal conflict will prevail in the case before it.

Looking at the provisions at issue in scenario I and II, it is clear that Article 145.B.2 and Article 145.B.3 of the CARIFORUM-EC EPA are hard obligations. Article 24.4 of the TRIPS Agreement, on the other hand, states that "Nothing in this Section shall require a Member to prevent continued and similar use." This means that W'TO Members can prevent but do not have to prevent continued and similar use. In scenario I, according to the narrow definition of conflict, a legal conflict between Articles 145.B.2 and 145.B.3 of the CARIFORUM-EC EPA and Article 24.4 of the TRIPS Agreement can be avoided if country A does not apply the TRIPS rule. Following the narrow definition of conflict, the outcome of scenario I will most likely be that country A has to disregard the possibility offered by Article 24.4 of the TRIPS Agreement and apply the protection in accordance with Articles 145.B.2 and 145.B.3 of the CARIFORUM-EC EPA. When applying the broad definition of conflict, one would find a legal conflict nevertheless.

Scenario II differs from scenario I in that Article 24.8 of the TRIPS Agreement on the use of a person's name is not permissive but mandatory.

"The provisions in this Section shall in no way prejudice the right of any person to use, in the course of trade, that person's name" [emphasis added].

This is in line with the observations made in the ICL Report: the requirement of the "same subject-matter" is already fulfilled where the two treaties point in different directions on one legal question. See ibid., paragraph 23.

129 See Koskenniemi, Fragmentation of International Law: Difficulties arising from the Diversification and Expansion of International Law, paragraph 24. 
As a consequence, compliance with both obligations is not possible as Article 24.8 of the TRIPS Agreement requires the continued use of a persons' name in the course of trade, whereas Articles 145.B.2 and 145.B.3 of the CARIFORUM-EC EPA require the exclusive protection of geographical indications against different uses. Here, under both definitions of conflict, a legal conflict clearly exists.

For scenario II, and in the case of applying the broad definition of legal conflict also for scenario I, the arbitration panel will have to apply conflict rules of international law in order to decide to which of the provisions it should give effect. The first source of conflict rules are the agreements themselves. The TRIPS Agreement provides for a conflict rule in the second sentence of Article 1.1. It authorizes members to grant more extensive protection than the TRIPS Agreement requires, with the qualification that such protection "does not contravene the provisions of the Agreement." 'This last sub-sentence limits WTO Members' ability to introduce more extensive IP protection: TRIPS-plus rules must not contravene the TRIPS Agreement. ${ }^{130}$ Arguably, a TRIPS-plus provision can contravene the TRIPS Agreement if one can point to conflicts with a mandatory TRIPS provision instead of an optional one.

Also the CARIFORUM-EC EPA contains a rule that defines its relationship with the WTO Agreement and its Annexes. This rule is a lex specialis to the general conflict rule in Article 1.1 of the TRIPS Agreement and therefore its result prevails over the result flowing from the application of the more general TRIPS conflict norm. ${ }^{131}$ Article 242 of the CARIFORUM-EC EPA sets out:

"The Parties agree that nothing in this Agreement requires them or the Signatory CARIFORUM States to act in a manner inconsistent with their WTO obligations" [emphasis added].

Even though the language used could be interpreted to mean that EPA parties are allowed, but not required, to breach WTO obligations, the purpose of this provision seems to be that parties are also prohibited from acting in a manner inconsistent with their WTO obligations. This conflict rule, therefore, seems to indicate that the provisions of the CARIFORUM-EC EPA do not change the obligations between the parties stemming from the WTO Agreement, including its Annexes.

The consequence of the application of this rule suggests that in scenario I, if the broad notion of legal conflict was followed, EPA parties are only prohibited from acting in a manner inconsistent with WTO obligations; they may act in a manner inconsistent with their WTO rights. In other words, since Article 24.4 of the TRIPS Agreement does not constitute a WTO obligation but an optional right, the EPA may require its parties to disregard such WTO rights or flexibilities. The outcome for scenario II is different. Article 24.8 of the TRIPS Agreement is a mandatory TRIPS obligation. According to the conflict rule of Article 242 of the CARIFORUM-EC $E P A$, this mandatory TRIPS exception remains unchanged and therefore still governs the relationship between the two parties. Country A can rightly rely on that

130 See Grosse Ruse-Khan, "The International Law Relation between TRIPS and Subsequent TRIPS-plus Free Trade Agreements", p. 346.

131 See ibid., p. 350. 
article in order to justify a breach of Articles 145.B.2 and 145.B.3 of the CARIFORUM-EC EPA.

This outcome for scenario II would be possible if the competence of arbitration panels under the EPA did allow them to apply a WTO rule to a dispute before them. Article 219 of the CARIFORUM-EC EPA, mentioned above, also deals with the competence of arbitration panels.

"The rulings of the arbitration panel cannot add to or diminish the rights and obligations provided in the provisions of this Agreement."

The provision contains similar language as Article 3.2 of the Dispute Settlement Understanding which has been interpreted very narrowly. Accordingly, panels cannot apply other rules than those provided for in the EPA. In cases of legal conflicts between a rule in the EPA and a rule in another agreement, for example the TRIPS Agreement, the arbitration panel would have to apply conflict rules. However, the outcome of such rules has the effect that if the EPA rule does not prevail, this would add to or diminish the rights and obligations of EPA parties.

Another relevant article for the competence of panels is Article 222 of the CARIFORUM-EC EPA on the relation with WTO obligations. According to paragraph 1 of this provision,

"Arbitration bodies set up under this Agreement shall not adjudicate disputes on each Party or Signatory CARIFORUM States' rights and obligations under the Agreement establishing the WTO."

Similarly to the previous provision, a panel is prohibited from applying a TRIPS rule in the case that it has established that the TRIPS rule prevails over the EPA rules because of conflict rules.

As a result, even though the conflict rule would benefit the party that wants to apply a mandatory TRIPS exception, the FTA panel most likely cannot adjudicate on the matter and jurisdiction because of a lack of competence to adjudicate the matter before it.

\subsection{Relationship between Geographical Indications and Trade Marks}

The relationship between geographical indications and trade marks is regulated according to three rules. The first rule addresses posterior trade marks, the second prior marks and the third rule applies to well-known trade marks. First, in the case that 1) a trade mark is applied for after the entry into force of the EPA or after the date of application of the GI, and 2) is identical to, similar to or contains a geographical indication protected in a signatory country, such a trade mark must be refused or, in case of already registered trade marks, invalidated. ${ }^{132}$ This provision resembles the obligation of Article 23.2 of the TRIPS Agreement but differs in certain aspects. The scope of trade marks covered by the EPA, namely those that are "identical with, similar to or containing", is drafted in a broader way than the TRIPS 
standard which covers only trade marks that "contain or consist of" a GI. ${ }^{133}$ Hence, the category of similar trade marks is added to the scope of application of the EPA.

In addition, the TRIPS Agreement limits the posterior trade mark rule to cases where the product carrying the trade mark does not have the origin of the geographical indication. This limitation in the TRIPS Agreement ensures that only trade marks that are registered in bad faith are affected by the rule. The CARIFORUM-EC EPA, on the other hand, does not contain this balancing element, similarly to certain previous European agreements on trade in wine and/or spirits. ${ }^{134}$ Hence, even if a product, carrying an identical trade mark, originates from the location for which the GI has been registered, the trade mark has to be refused or invalidated. In summary, the rule on posterior marks is broader than in the TRIPS Agreement.

The second rule addresses prior trade marks. Prior marks refer to marks that have been registered before the date of application of the WTO obligations in that state, or before the date of application for protection of the GI in the respective territory. If a trade mark has been registered in good faith before one of those dates, the trade mark

"may continue to be used notwithstanding the registration of the geographical indication". 135

In other words, the trade mark and the geographical indication will be used alongside each other, provided that no grounds for the invalidity or revocation of the trade mark exist. This rule strongly resembles Article 24.5 of the TRIPS Agreement which excepts trade marks registered in good faith from being refused or invalidated according to Article 23.2 of the TRIPS Agreement. The inclusion of this conflict rule in the CARIFORUM-EC EPA again proves to leave more policy space to CARIFORUM States than granted to contracting parties in previous European agreements on trade in wine and/or spirits: contracting parties of those agreements cannot make use of this rule. ${ }^{136}$

The third rule applies to well-known marks, in which case the application for the registration of a geographical indication shall be refused or invalidated. If a trade mark has a strong reputation and is renowned and has been used for some time, a geographical indication shall not be registered if it is liable to mislead the consumer as to the true identity of the product. ${ }^{137}$ In other words, only if the legal authority responsible for registering geographical indications is convinced that its use "is liable

133 When comparing the wording with Article 8.5.1 of the Negotiating Group Report, November 2006, the TRIPS wording had been incorporated in the first place and was changed again in the final text.

See Article 7 of Annex V and VI of the EC-Chile AA; Article 7.8(a) of the EC-South Africa Wine Agreement and 5.8(a) of the EC-South Africa Spirits Agreement. See also section 3.3.6.3 of this book.

135 See Article 145.D.4 of the CARIFORUM-EC EPA.

136 For agreements that have prohibited its use, see Article 4.4 of the EC-Mexico Spirits Agreement, Article 5.7 of Annex 7 of the EC-Switzerland Agricultural Products Agreement, Article 5.4 of Annex 8 of the EC-Switzerland Spirits Agreement. The other agreements on trade in wine and/or spirits do not stipulate the rule and make it non-applicable in a dispute between the parties. See section 3.3.6.4 of this book. 
to" mislead the consumer, in light of the well-known trade mark, the geographical indication must be refused or invalidated. Such a provision is neither contained in the TRIPS Agreement, nor in previous European agreements on trade in wine and/or spirits. It will be up to the relevant authorities to decide how much evidence must be presented in order to prove the future existence or possibility of deception.

In brief, the rules on the relationship between trade marks and geographical indications offer, with minor deviations, a similar standard of protection as the TRIPS Agreement. The rule on posterior trade marks is slightly broader than the equivalent TRIPS standard. Prior trade marks are treated equally in the CARIFORUM-EC EPA and the TRIPS Agreement. The obligation to invalidate geographical indications that would mislead the consumer in view of a well-known trade mark even limits the protection granted to geographical indications more than the TRIPS Agreement.

\subsection{WIPO Joint Recommendation Concerning the Protection of Marks and Signs on the Internet}

Sixth, according to Article 145.F of the CARIFORUM-EC EPA, parties to the agreement shall endeavour to apply the WIPO Joint Recommendation concerning the protection of marks and signs on the Internet. Primarily dealing with the use of signs and trade marks on the Internet, the WIPO recommendation can also play a role in the determination of and infringement of geographical indications. For example, it establishes that the use of a sign on the Internet shall be taken into consideration for determining whether a right, such as a geographical indication, has been infringed. ${ }^{138}$ The application of the recommendation has already been endeavoured in the trade marks section and was classified as being a rather soft obligation. ${ }^{139}$

\subsection{Interim Conclusions}

The protection for geographical indications provided for in the CARIFORUM-EC EPA contains some TRIPS-plus elements while most other provisions reflect the TRIPS standard. The TRIPS-plus elements therein are the extension of the GI protection to other products than wines and spirits, the minimum term of protection and the omission of exceptions granted by the TRIPS Agreement. Other provisions dealing with the level of protection, the exceptions and the relationship between GIs and trade marks overall reflect the TRIPS standard, with minor deviations. Remarkably, the exception for generic terms is maintained in full. Overall, the level of protection seems to be a bit lower than in previous European agreements on trade in wine and/or spirits. Therefore, contracting parties have preserved the domestic policy space to balance the protection for GI right holders with other relevant interests. 


\subsubsection{Provisions Relating to Industrial Designs}

The rules pertaining to the protection of industrial designs present a new feature in European bilateral agreements. No bilateral agreement before contained substantive provisions on industrial designs; neither do United States free trade agreements. ${ }^{140}$ The elements of protection go beyond the TRIPS Agreement in some aspects. While building upon the provisions of the TRIPS Agreement, the protection is inspired by EU legislation in the harmonized area of design protection. In fact, several provisions from the Council Directive on the Legal Protection of Designs ${ }^{141}$ have almost literally been copied. As argued above, ${ }^{142}$ incorporating legislation-like provisions into bilateral agreements seems to be at odds with the principle of freedom of implementation contained in the general provisions of this agreement. ${ }^{143}$ Contracting parties are effectively denied the freedom to choose the appropriate method of implementation. Although it is true that the provisions of a European Union Directive leave some discretion to EU Member States to implement them into national law, the same is not true for third countries. Directives are drafted in a way that addresses the needs of the European internal market, not the internal markets of CARIFORUM States. The limited freedom of implementation for CARIFORUM States has been noted with concern. ${ }^{144}$

The elements of protection for design rights are a) the accession to the Geneva Act of the Hague Agreement, b) requirements for protection, c) exclusive rights and exceptions thereto, and d) the term of protection. ${ }^{145}$ Compared with the EC nonpaper of November 2006, certain elements have been dropped, such as detailed rules on disclosure (Article 10.2 of the EC non-paper), grounds for invalidity or refusal of a registration (Article 10.7 of the EC non-paper) and a provision securing protection for textile designs (Article 10.4 of the $\mathrm{EC}$ non-paper). ${ }^{146}$ In that respect, CARIFORUM States were able to limit the catalogue of obligations to core areas. On the other hand, the language in most provisions of the EC non-paper from November 2006 does not differ much from the final agreement. This suggests that CARIFORUM States had limited input on the formulation of the remaining obligations.

First, the CARIFORUM-EC EPA requires parties to endeavour to accede to the Geneva Act from 1999 of the Hague Agreement. ${ }^{147}$ The Hague Agreement is a multilateral registration instrument for industrial designs. So far, Belize and Suriname have

140 This is with exception to the requirement to make best efforts to accede to multilateral agreements in this field. For an overview of the requirements to accede to the Geneva Act of the Hague Agreement, see section 3.2.3 of this book for the US FTAs and section 3.3.4.2 for the EU BTAs concluded before 2006.

Council Directive 98/71/EC of the European Parliament and of the Council of 13 October 1998 on the legal protection of designs (OJ L 289 of 28.10.1998, p. 0028-0035) [hereinafter EC Directive 98/71].

See section 5.3.1.3 of this book. See also Musungu, Cariforum EPA and beyond, p. 23.

See Musungu, Cariforum EPA and beyond, p. 23.

See Article 146 of the CARIFORUM-EC EPA.

That provision is identical to Article 25.2 first sentence of the TRIPS Agreement.

See Article 146.A of the CARIFORUM-EC EPA. Note that the EC non-paper from November 2006 still included an obligation to ratify or accede to the agreement. See Article 10.9 of the EC non-paper November 2006. 
acceded to the Hague Act from 1960 and to the Complementary Act of Stockholm from 1967, but not to the Geneva Act from 1999. ${ }^{148}$ The European Union requires countries to accede to the Geneva Act because nationals of a party can only designate their signs to be protected in countries that have also signed up to the same act. As the European Union is only a party to the 1999 Geneva Act, it is essential that its partner countries sign up to the Geneva Act. For example, now nationals from France cannot designate their applications to the Hague system to Belize or Suriname as the latter did not become parties to the Geneva Act.

CARIFORUM States have incurred a rather soft obligation of making best efforts to accede to that treaty. The TRIPS Agreement does not refer to the Hague Agreement. Neither can the requirement to endeavour acceding to the Geneva Act of the Hague Agreement be found in previous European bilateral agreements; only Bosnia and Herzegovina undertakes to accede to the Geneva Act. ${ }^{149}$ However, all (draft) agreements concluded or negotiated after 2006 contain at least a "best endeavour" obligation with regard to this treaty. ${ }^{150}$ European Union agreements have aligned themselves in this respect with the obligations contained in United States free trade agreements which also require the contracting parties to make "best efforts" to accede to the Geneva Act. ${ }^{151}$ The European Union itself acceded to the Geneva Act of the Hague Agreement in January 2008.

In order to benefit from industrial design protection, certain conditions need to be fulfilled. These requirements resemble the TRIPS standard: Article 146.B.1 of the CARIFORUM-EC EPA requires parties to protect independently created industrial designs that are "new or original", and have "individual character". While "new or original" is also an element in Article 25.1 of the TRIPS Agreement, the requirement "individual character" is new. "Individual character" according to Article 146.B.3 of the CARIFORUM-EC EPA exists if

\footnotetext{
"the overall impression [a design] [...] produces on the informed user differs from the overall impression produced on such a user by any design which has been made available to the public."
}

This provision is identical to Article 5.1 of EC Directive 98/71 and seems to fit the proposed definition of "new or original" given by the TRIPS Agreement in Article 25.1 second sentence. Industrial design protection is granted upon registration. ${ }^{152}$ However, also unregistered designs enjoy the same exclusive rights, although only against copying of the protected design. ${ }^{153}$ The TRIPS Agreement does not distinguish between the protection of registered or unregistered designs. Overall, the requirements for protection set out in the CARIFORUM-EC EPA limit the freedom left by the TRIPS Agreement considerably. CARIFORUM States have given up

\footnotetext{
148 Suriname has become a party to the London Act from 1934.

149 See Article 38.4 juncto paragraph 1 of Annex VI of the EC-Bosnia and Herzegovina IA.

150 See section 6.3.4.1 of this book for an account of the obligations in the draft IP chapter of the India-EU BTLA as well as other European "new generation" bilateral trade agreements.

151 See section 3.2.3 this book.

152 See Article 146.B.4 first sentence of the CARIFORUM-EC EPA.

153 See Article 146.B.4 second sentence of the CARIFORUM-EC EPA.
} 
domestic policy space on how to define concepts such as "new or original" as well as whether to grant protection also to unregistered design rights.

Turning to the exclusive rights conferred by design protection, right holders are allowed

"to prevent third parties not having the owner's consent from making, offering, selling, importing, stocking or using articles bearing or embodying the protected design when such acts are undertaken for commercial purposes or unduly prejudice the normal exploitation of the design or are not compatible with fair trade practice". ${ }^{154}$

The rights protected by the CARIFORUM-EC EPA are broader than those protected by the TRIPS Agreement in two aspects. First, the acts protected by Article 26.1 of the TRIPS Agreement do not include the acts of offering, stocking or using products in the list of exclusive rights. Second, the TRIPS Agreement stipulates that right holders are protected against the acts of making, offering, selling, etc. only when they are undertaken for commercial purposes. ${ }^{155}$ The EPA adds two other situations in which protection is offered: the acts unduly prejudice the normal exploitation of the design or they are not compatible with fair practices. This definition covers more situations of alleged infringement and therefore increases the protection for design right holders compared with the TRIPS standard.

Under the EPA, owners of unregistered designs are granted the same rights. However, they are only protected against wilful copying. If the contested use

"results from an independent work of creation from a designer who may be reasonably thought not to be familiar with the design made available to the public by the holder,"156

such use does not result in an infringement of the unregistered design rights.

The analyzed exclusive rights can be limited by exceptions and exemptions. The CARIFORUM-EC EPA offers contracting parties, similarly to the TRIPS Agreement, 157 a framework that allows parties to implement specific exceptions into their national laws. According to Article 146.C.1 of CARIFORUM-EC EPA, four conditions must be fulfilled. First, an exception must be bound to limited cases. Second, it may not unreasonably conflict with the normal exploitation of protected industrial designs. Third, exceptions may not unreasonably prejudice the legitimate interests of the owner of the protected design. Finally, the legitimate interests of third parties must be taken into account. Consequently, exceptions for fair use, educational purposes, library use and research will most likely fall under the ambits of these requirements for exceptions. ${ }^{158}$

154 See Article 146.D.1 of the CARIFORUM-EC EPA.

155 See Article 26.1 of the TRIPS Agreement.

156 See Article 146.D.2 of the CARIFORUM-EC EPA.

157 See Article 26.2 of the TRIPS Agreement.

158 Article 13 of the TRIPS Agreement constitutes a similar provision under copyright and has been interpreted by a WTO panel. It has provided some guidelines about how to assess each condition mentioned. See United States - Section 110(5) of the US Copyright Act 
Furthermore, the EPA exempts designs dictated essentially by technical or functional considerations from design protection in general. ${ }^{159}$ In this regard, the parties agreed to make use of the option given by the TRIPS Agreement in Article 25.1 last sentence, and to deny such designs protection. A last exemption from design protection addresses designs that are contrary to public policy or to accepted principles of morality. ${ }^{160}$ Protection for such designs is denied. The TRIPS Agreement does not stipulate such an exception; however, measures allowing for protecting public morals are well known from the GATT 1994 and GATS context, ${ }^{161}$ and are likely to fulfill the four conditions of the general framework provision for national exceptions.

With regard to the term of protection, the CARIFORUM-EC EPA does not increase the protection granted by the TRIPS Agreement either. However, the language used is different. While the TRIPS Agreement requires a minimum period of ten years of protection, ${ }^{162}$ Article 146.E. 1 of the CARIFORUM-EC EPA sets out a mandatory initial duration of protection of at least five years which must be renewable for one or more periods of five years but not exceeding twenty-five years from the date of filing. The same protection is contained in EC Directive $98 / 71 .{ }^{163}$ The EPA provision is in line with the TRIPS standard since the minimum required is a period of five years that must be renewable with at least one period of five years. Therefore, also a law such as Jamaica's Designs Act of 1937, which grants a period of fifteen years of protection to registered designs, ${ }^{164}$ meets the required protection.

In conclusion, the protection of designs required by the CARIFORUM-EC EPA is a new area included in European bilateral trade agreements that goes beyond the TRIPS Agreement, however not in a substantial manner. The obligation to endeavour to accede to the Geneva Act of the Hague Agreement is a soft obligation which leaves certain discretion to the contracting parties. The requirements that designs have to fulfill in order to be protected and the exclusive rights set out in the CARIFORUMEC EPA go beyond the TRIPS standard. Specifying concepts and rights in the EPA limit the freedom of contracting parties granted by the TRIPS Agreement considerably. In contrast, the available exceptions and term of protection required in the TRIPS Agreement are preserved in the EPA, even though with slightly different language.

\subsubsection{Provisions Relating to Patents}

Compared to previous European bilateral agreements, the provisions on patents included in the CARIFORUM-EC EPA have not changed considerably; they mainly follow the multilateral approach of requiring the accession to or best efforts to accede to multilateral treaties, as observed in most previous agreements. In this, the CARIFORUM-EC EPA differs significantly from the patent provisions contained in US FTAs: the latter importantly require specific protection through legislation-like

[WT/DS160/R] (WTO Panel Report, 15 June 2000). See also section 6.3.1.5 of this book for an overview of the facts of this case. See Article 146.C.2 of the CARIFORUM-EC EPA. See Article 146.C.3 of the CARIFORUM-EC EPA.

See Article XX a) of the GATT 1994 and Article XIV a) of the GATS. See Article 26.3 of the TRIPS Agreement.

See Article 10 of Directive 98/71.

See Section 7.1 of the The Designs Act No. 32 of 1937, 15 July 1937, amended by Act No. 9 of 1975. 
provisions. ${ }^{165}$ The level of protection required in the EPA is also different from the level of patent protection stipulated in the Cotonou Agreement and the TRIPS Agreement. accession to the listed multilateral treaties is not required in the latter agreements. There are four types of obligations concerning patent protection included in the EPA. All of them address the accession to certain multilateral agreements. It is interesting to note that a distinction has been made between the obligations of European Union Member States and those undertaken by CARIFORUM States. This has not been done in respect of obligations in other areas of IP.

First, the European Union is required to comply with the Patent Cooperation Treaty (PCT), the Patent Law Treaty (PLT) and the Budapest Treaty. ${ }^{166}$ The PCT and the Budapest Treaty are registration instruments. The Patent Cooperation Treaty allows patent protection to be sought for inventions simultaneously in the contracting parties of the PCT by filing a single international patent application. The Budapest Treaty provides for an international depositary authority with which patent applicants can deposit a microorganism once for the purposes of patent procedures in all contracting parties. The Patent Law Treaty, on the other hand, does not provide a point of registration but represents a standard-setting instrument that aims at harmonizing and streamlining the formal procedures in respect of national and regional patent applications. In other words, new standards of procedural patent law are set at the multilateral level which need to be implemented in each contracting party to the PLT. In order to comply with these three treaties, the Member States of the European Union decided to become contracting parties to each of the three treaties. Not all EU Member States are contracting parties of the Patent Law Treaty and the Budapest Treaty yet. ${ }^{167}$

Second, CARIFORUM States are obliged to accede to the PCT and the Budapest Treaty. ${ }^{168}$ These obligations go beyond the TRIPS standard as the TRIPS Agreement does not address the accession to the PCT or the Budapest Treaty. Requiring the accession to these treaties is in line with previous European bilateral agreements which either demand accession to, the confirmation of the importance of that treaty or the continuation of ensuring an adequate and effective implementation of their obligations. ${ }^{169}$ As of October 2012, ten CARIFORUM States are already parties to the PCT and two have also acceded to the Budapest Treaty. ${ }^{170}$ All other contracting parties are under an obligation to accede to these treaties, although no time limit is indicated in the EPA. The PCT system has been criticized for not being very beneficial for developing countries: it facilitates a patent registration system in which

\footnotetext{
165 See section 3.2.4 of this book.

166 See Article 147.A.1 of the CARIFORUM-EC EPA.

167 As of October 2012, the majority of EU Member States has not yet ratified the PLT. Only two countries have not yet signed nor ratified the Budapest Treaty, being Cyprus and Malta. See WIPO, WIPO-Administered Treaties.

168 See Article 147.A.2 of the CARIFORUM-EC EPA.

169 See section 3.3.4.2 of this book.

170 The CARIFORUM States already parties to the PCT are: Antigua and Barbuda, Barbados, Belize, Dominica, the Dominican Republic, Grenada, Saint Lucia, Saint Vincent and the Grenadines, Saint Christopher and Nevis, and Trinidad and Tobago. The Dominican Republic and Trinidad and Tobago have also acceded to the Budapest Treaty. See WIPO, WIPO-Administered Treaties.
} 
developing countries do not participate much. ${ }^{171}$ The advantages that the PCT offers are primarily relevant for countries in which firms or individuals want to register large quantities of patents: they can obtain patent protection in many countries in a relatively simple manner. In addition, developing countries may face problems in objecting to patent applications within the required period of time: they face constraints in dealing with high volumes of applications. ${ }^{172}$ The consequence of not objecting in time is the default acceptance of the patent application and ultimately the granting of a patent.

A third obligation regards the accession of CARIFORUM States to the Patent Law Treaty: they shall endeavour to accede to that treaty. ${ }^{173}$ Even though a soft obligation has been agreed upon, it goes beyond the TRIPS Agreement which does not refer to the PLT. As of October 2012, only Haiti has already signed the PLT but has yet to ratify the treaty. As observed also in other areas of IP, the soft "endeavour" obligation is a common element of this EPA. CARIFORUM States are free to determine whether, when and how to become a member to the PLT. This language seems to take into account the nature of this rather young international treaty: it is a standard-setting instrument opposed to the other two multilateral patent treaties which are registration instruments. Countries that want to become contracting parties will have to amend their national laws in order to comply with the procedural standards required.

The last obligation with regard to patent protection addresses the Doba Declaration on the TRIPS Agreement and Public Health: $:{ }^{174}$ parties recognize its importance, as well as the importance of the General Council Decision of 30 August 2003, ${ }^{175}$ and agree to accept the Protocol amending the TRIPS Agreement, annexed to the General Council Decision of 6 December 2005. This confirmation is new compared to previous European bilateral agreements. Also recent US FTAs have included a commitment to the Doha Declaration on the TRIPS Agreement and Public Health. ${ }^{176}$ The declaration and the protocol address the need to preserve the flexibilities of the TRIPS Agreement in relation to patents on pharmaceutical products. They establish clear rules about the freedom of countries to issue compulsory licenses in order to import essential medicines into countries with insufficient manufacturing capacities. While emphasizing the significance of these instruments is very important from a political point of view, it does not add any further legal obligation or commitment than those already undertaken on the multilateral level.

See Santa Cruz, Intellectual Property Provisions in European Union Trade Agreements, p. 27.

See Christian Aid and Oxfam, The EU's approach to Free Trade Agreements: Intellectual Property, p. 3.

See Article 147.A.3 of the CARIFORUM-EC EPA.

See Article 147.B of the CARIFORUM-EC EPA.

WTO General Council, Implementation of Paragraph 6 of the Doba Declaration on the TRIPS Agreement and Public Health: Decision of 30 August 2003 (Doha, 2 September 2003) [WT/L/540] [hereinafter General Council Decision of 30 August 2003].

See Article 15.12 of the US-Panama TPA and Article 16.13 of the US-Peru TPA. Also in the draft IP chapter of the TPP contains a placeholder for a provision on the understanding regarding certain public health measures. Note that the US-South Korea FTA does not provide for such a provision. 
To sum up, the obligations incurred by CARIFORUM States with regard to the PCT, PLT, the Budapest Treaty and the public health instruments are TRIPS-plus obligations. Particularly the accession to the PCT and the PLT will require significant efforts from CARIFORUM States (at least those that are not yet parties to both treaties) in order to adjust their registration systems and procedural laws to the standards set out therein. While the obligation to endeavour to accede to the PLT is a soft obligation and grants considerable leeway as to the 'if, when and how', the obligation to accede to the PCT is a hard commitment relevant for five countries that have not yet acceded to this treaty. The acceptance of the Protocol amending the TRIPS Agreement, on the other hand, is a development-friendly provision as it preserves important flexibilities with regard to the issuing of compulsory licenses in case of a public health crisis. The standards of protection in the EPA on patents stay behind those relating to public health in US FTAs. The latter go far beyond the TRIPS standard and have significant effects on generic producers.

\subsubsection{Provisions Relating to Utility Models}

A striking new element in European bilateral trade agreements are the standards on utility models. Previous European bilateral agreements, United States free trade agreements, and the TRIPS Agreement have not regulated the protection of utility models. Even the EC non-paper from November 2006 did not yet include this section. The rules integrated into the CARIFORUM-EC EP $A$ are very much aligned to the international substantive standards for patent protection as incorporated in the TRIPS Agreement. This becomes very clear in Article 148.C.1 of the CARIFORUMEC EPA, which makes all other conditions and flexibilities in section 5 of the TRIPS Agreement, dealing with patent protection, applicable mutatis mutandis. ${ }^{177}$ However, a major difference with the patent rules in the TRIPS Agreement is that none of the EPA rules on utility models are mandatory. Parties are free to determine whether they want to incorporate the protection for utility models as specified in the EPA in their national laws or not. ${ }^{178}$

While this flexibility leaves considerable freedom to contracting parties, it has also been criticized that the protection of utility models could have been strengthened by including mandatory minimum requirements of protection. ${ }^{179}$ Usually, utility models are regarded as better suited to the needs of developing countries which find it easier to reach the lower hurdle of utility model protection than the strict patentability criteria. ${ }^{180}$ On the other hand, any other commitment than a voluntary one would not

The conditions referred to are those that have not yet been incorporated in the earlier paragraphs of the EPA but are provided for in the TRIPS Agreement.

This is apparent from the word "may" in Article 148.A.1, 2 and 3 of the CARIFORUM-EC EPA.

See Musungu, Cariforum EPA and beyond, p. 25.

For a discussion on the benefits and disadvantages of utility models for developing countries, see U. Suthersanen, Utility Models and Innovation in Developing Countries (UNCTAD-ICTSD Project on IPRs and Sustainable Development, Geneva, 2006) [Issue Paper No. 13]. 
have been conceivable for the European Union which has tried to harmonize utility model protection in the European Union, however with little success. ${ }^{181}$

The substantive standards for obtaining utility models are almost identical to the patent protection requirements specified in Article 27 of the TRIPS Agreement: protection may be available for a) any products or processes in any field of technology, b) provided that they are new, c) involve some degree of non-obviousness and d) are capable of industrial application. ${ }^{182}$ The only requirement that slightly differs from the TRIPS standard is the third element regarding "some degree of nonobviousness". The equivalent element in the TRIPS Agreement is "inventive step", which clearly involves a higher level of invention than the standard of "some degree of non-obviousness" does. To what extent an invention needs to be non-obvious in order to meet the threshold for utility protection must be filled in by the implementing legislation of each party and/or, eventually, by a tribunal competent to decide upon the compliance of national law with the standard in the bilateral agreement.

Prescribing substantive standards that inventions need to meet in order to enjoy utility model protection removes parties' ability to determine for themselves which inventions should be protected. It has been argued that the strong dependence on patent standards has led to excessively strict standards for the availability of utility models. ${ }^{183}$ However, this concern can be remedied by the fact that the provisions on the standards of protection are not mandatory, i.e. contracting states cannot only choose whether or not to protect utility models but also whether they want to grant utility models on the basis of the standards agreed upon. The EPA further allows excluding products and processes from protection if it is necessary to protect public order or morality, human animal or plant life or health or to avoid serious prejudice to the environment. ${ }^{184}$ The same is true for diagnostic, therapeutic and surgical methods for the treatment of humans or animals, and plants and animals other than micro-organisms. ${ }^{185}$ These exceptions are identical to Articles 27.2 and 27.3 of the TRIPS Agreement which apply to patent protection.

In summary, the protection on utility models included in the EPA is entirely new compared to previous international agreements, both those concluded by the European Union and the United States. Also the TRIPS Agreement does not provide any rules on this subject matter. At the same time, the rules for utility models in the EPA are heavily based on the TRIPS rules on patent protection. What makes the EPA rules particular is that no contracting party is obliged to protect utility models as they are under no obligation to do so. The protection is not mandatory, which has

See Amended proposal for a European Parliament and Council Directive approximating the legal arrangement for the protection of inventions by utility model (Brussels, 12.07.1999) [COM(1999) 309 final/2]. For the follow-up of the proposal and the end of the European Commission's effort to introduce legislation on this matter, see Directorate General for Internal Market, Summary report of replies to the questionnaire on the impact of the Community utility model with a view to updating the Green Paper on protection by the utility model in the internal market (European Commission, Brussels, 1 March 2002) [SEC(2001) 1307]. 
also been interpreted as a weakness. It "only" provides guidelines to CARIFORUM States and EU Member States on how to use the system of utility model protection as a manner to foment innovation. Even though the effort as such must be welcomed from a developing country point of view, the heavy reliance on patent rules might limit other possible options.

\subsubsection{Provisions Relating to Plant Varieties}

Another new section in European bilateral trade agreements are the rules on the protection of plant varieties. Previous European bilateral trade agreements do not contain specific rules thereon but used the multilateral approach in order to oblige partner countries to accede to the UPOV Convention, Act 1991.186 The Cotonou Agreement did not contain such an obligation, but by reference to the TRIPS Agreement, ${ }^{187}$ ACP States were required to comply with the TRIPS standard incorporated in Article 27.3(b) of the TRIPS Agreement. According to this article, WTO Members shall protect plant varieties either by patents or by an effective sui generis system. The CARIFORUM-EC EPA confirms this standard of protection ${ }^{188}$ and further specifies it in two ways. One specification concerns the obligation to consider acceding to the UPOV Convention, Act 1991. ${ }^{189}$ The obligation to consider accession to the UPOV Convention, Act 1991 (instead of the obligation to endeavour to accede) is the weakest formulation compared with the other references to multilateral treaties contained in the EPA. It reflects the CARIFORUM States' hesitance to commit themselves to the standards of protection contained in the Convention.

It has been a matter of debate during the final stages of the TRIPS negotiations in the Uruguay Round what an "effective sui generis system" under Article 27.3.b of the TRIPS Agreement would mean. It is generally recognized that the rules of the UPOV Convention, Act 1991 fulfill this standard. However, as noted in Chapter 1:: The International System of Protecting Intellectual Property pre-TRIPS, ${ }^{190}$ the then Director-General of the GATT, Peter Sutherland, assured developing countries during the negotiations of the Uruguay Round that the UPOV Convention, 1978 Act provides the minimum standards that would be expected from a sui generis system and not the UPOV Convention, Act 1991. This view has so far neither been supported nor rejected by a WTO Panel or the Appellate Body.

Arguably, the soft obligation "to consider acceding" contained in the EPA preserves the option for CARIFORUM States to establish a sui generis system of plant variety protection that complies with the minimum standards of the UPOV Convention, 1978

186 Not all agreements require the accession to the UPOV Convention, Act 1991. All agreements with (potential) candidates for accession and neighbouring countries do. The obligations in the agreements with particular developing countries vary between an obligation to continue ensuring an adequate and effective implementation of obligations arising from that agreement (Chile), the obligation to endeavour to accede to that agreement (Bangladesh) as well as the obligation to confirm the importance of the obligations arising from that multilateral treaty (South Africa). See section 3.3.4.2 of this book.

187 See Article 46.2 of the Cotonou Agreement.

188 See Article 149.2 first sentence of the CARIFORUM-EC EPA.

189 See Article 149.2 second sentence of the CARIFORUM-EC EPA.

190 See section 2.3.2 on TRIPS substantive provisions. 
Act. ${ }^{191}$ The difference between the UPOV Convention, 1978 Act and the 1991 Act is important insofar as the protection of plant breeders' rights is significantly expanded in the 1991 Act. ${ }^{192}$ When parties consider acceding to the UPOV Convention, Act 1991, they should ascertain whether such expanded plant breeders' rights are in their national interest. According to a study involving five developing countries, there is no conclusive evidence of what the effects of plant variety protection both in developed and developing countries are. ${ }^{193}$ So far, only the Dominican Republic and Trinidad and Tobago are Members to the UPOV Convention, Act 1991.

The UPOV Convention, Act 1991, or a sui generis system of plant variety protection for that matter, protects the rights of plant breeders with respect to a protected variety. Certain acts regarding propagating material of the protected variety need the authorization of the breeder. Under the UPOV Convention, Act 1991, they cover the production or reproduction, conditioning for the purpose of propagation, offering for sale, selling or other marketing, exporting, importing, and stocking for any of the mentioned purposes. ${ }^{194}$ Such acts are not only protected in respect of the propagating material of the protected variety but also with regard to the harvested material, ${ }^{195}$ products directly made from harvested material, ${ }^{196}$ varieties that are essentially derived from a protected variety, ${ }^{197}$ varieties which are not clearly distinguishable from the protected variety, ${ }^{198}$ and varieties whose production requires the repeated use of the protected variety. ${ }^{199}$

There are two provisions that limit these breeders' rights. First, Article 15.1 of the UPOV Convention, Act 1991 exempts certain acts from the scope of protection. These are acts done privately and for non-commercial purposes, acts done for experimental purposes, and acts done for the purpose of breeding other varieties. All Members to the UPOV Convention, Act 1991 are under an obligation to make these exemptions available. The second limitation addresses the farmers' privilege, which is contained

It is interesting to see that the EC non-paper from November 2006 required compliance with the UPOV Convention, Act 1991, not leaving parties the choice as to whether or not to accept UPOV 1991 standards. See Article 12.1 of the EC non-paper November 2006.

For a discussion of the differences between the UPOV Convention, 1978 Act and the UPOV Convention of 1991, see Stewart (ed.), The GATT Uruguay Round: The End Game, p. 530; C. Heath, "Plant Varieties, Biodiversity and Access Rights" in C. Heath and A. Kamperman Sanders (eds.), Industrial Property in the Bio-Medical Age: Challenges for Asia (Kluwer Law International, The Hague, Netherlands, 2003) 3-34, p. 13, 15 and 17; GRAIN, "The End of Farm-saved Seed? Industry's Wish List for the Next Revision of UPOV" GRAIN briefing, 2007, p. 4; Christian Aid and Oxfam, The EU's Approach to Free Trade Agreements: Intellectual Property, p. 3.

See N. Louwaars et al., Impacts of Strengthened Intellectual Property Rights Regime on the Plant Breeding Industry in Developing Countries - A Synthesis of Five Case Studies (The World Bank, Wageningen, 2005), p. 39. 
in the UPOV Convention, Act 1991, but further specified by the EPA. According to the latter agreement, all contracting parties shall have the right

"to provide for exceptions to exclusive rights granted to plant breeders to allow farmers to save, use and exchange protected farm-saved seed or propagating material." 200

Parties may implement such exceptions in their national legislation, they do not have to do so. This optional nature is identical to the equivalent provision in the UPOV Convention, Act 1991: Article 15.2 thereof grants UPOV Members the right to permit farmers to use the product of their harvest, the protected variety or certain other varieties on their own holding for propagating purposes. The UPOV exception applies to the harvest, the variety itself and certain other varieties as they are also covered by the protection granted to breeders in the UPOV Convention, Act 1991.

Apart from the common optional nature, the two provisions differ substantively in the following way: Article 149.1 of the CARIFORUM-EC EPA includes the actions "saving", "using" and "exchanging" of protected material whereas Article 15.2 of the UPOV Convention, Act 1991 merely addresses the "use" of farm-saved seed. The latter even adds two other conditions: the seed must have been harvested on the farmer's own holding and the seed may be used for propagating purposes on its own holdings only. The last condition clearly excludes the action of "exchanging" which Article 149.1 of the CARIFORUM-EC EPA explicitly includes into the exception. In this regard, the EPA leaves discretion to parties as to whether or not to adopt such exceptions in their national legislation but also as to whether or not to apply the expanded scope of the exception in the EPA. While countries such as European Union Member States have applied the farmers' privilege only to particular crops, ${ }^{201}$ the exception in the EPA gives contracting parties the possibility to grant farmers such rights for all crops, including important crops frequently used in the particular country.

In conclusion, the obligations set out by the CARIFORUM-EC EPA with regard to the protection of plant varieties grant contracting parties considerable freedom to determine whether they want to accede to the UPOV Convention, Act 1991 and whether they prefer to expand the farmers' privilege to additional uses not covered by the UPOV Convention, Act 1991. The obligation "to consider acceding" to the latter Convention is a very soft obligation. It preserves the TRIPS flexibility of choosing an appropriate sui generis system of protecting plant varieties, which is in stark contrast to several United States FTAs: the latter either require patent protection for plants, or best efforts to provide patent protection. ${ }^{202}$

\subsubsection{Provisions Relating to Genetic Resources and Traditional Knowledge}

The last section of the CARIFORUM-EC EPA, dealing with substantive standards of intellectual property, is dedicated to rules addressing genetic resources, traditional knowledge and folklore. So far, no similar rules have been integrated into previous

200 Article 149.1 of the CARIFORUM-EC EPA.

201 See the listed crops in Article 14.2 of the Council Regulation 2100/94 of 27 July 1994 on Community plant variety rights (OJ L 227 of 01.09.1994).

202 See section 3.2.7 of this book. 
European bilateral trade agreements, neither in United States FTAs. The Cotonou Agreement merely included a provision requiring adherence to the Convention on Biological Diversity. ${ }^{203}$ At the heart of these rules lies the relationship between intellectual property rules, as laid down by the TRIPS Agreement, and the rules on the protection of biodiversity in the CBD. This relationship has been the focus of negotiations since 2000, both in the WIPO Intergovernmental Committee on Intellectual Property and Genetic Resources, Traditional Knowledge and Folklore, and at the WTO as part of the Doha Development Agenda. ${ }^{204}$ The CARIFORUMEC EPA refers to these multilateral discussions by stating that the parties agree to regularly exchange views and information thereon. ${ }^{205}$ This section of the EPA deals with three issues: a) a general obligation to protect traditional knowledge, b) the support for an international instrument, and c) the mutually supportive implementation of the patent provisions and the CBD.

First, the general obligation in the CARIFORUM-EC EPA with regard to the protection of traditional knowledge reiterates Article 8(j) of the Convention on Biological Diversity: the parties

"respect, preserve and maintain knowledge, innovations and practices of indigenous and local communities embodying traditional lifestyles $[\ldots]$ and the sustainable use of biological diversity $[\ldots] " .{ }^{206}$

What the article does not reiterate, however, is the nature of this obligation as stated in the chapeau of Article 8 of the CBD: "Each Contracting Party shall, as far as possible and as appropriate: [...] j) respect [...]" [emphasis added]. As this part is missing in the EPA, it is not clear what the concrete obligation for parties to the EPA with regard to respecting, preserving and maintaining these types of knowledge is. Nevertheless, even without a "shall obligation", the language in the EPA seems to indicate that parties are under a hard obligation to respect, preserve and maintain such knowledge. This interpretation is also supported by the fact that all EPA parties are also parties to the $\mathrm{CBD}$ and therefore have accepted the hard obligation of its Article $8 .^{207}$

Next to the respect for traditional knowledge, the parties commit themselves to working towards an internationally agreed sui generis model for the legal protection of traditional knowledge. ${ }^{208}$ The wording "internationally agreed sui generis model" deserves some further explanation. The discussions in the WIPO Intergovernmental Committee on Intellectual Property and Genetic Resources, Traditional Knowledge and Folklore, inter alia, have focused on the nature of the international instrument that should regulate the legal protection of traditional knowledge. The spectrum of

203 See Article 46.2 of the Cotonou Agreement.

204 See WTO Ministerial Conference, Doba Ministerial Declaration, paragraph 19.

205 Also, the rules established in the EPA will be reviewed in the light of the results of such multilateral discussions. See paragraphs 5 and 6 of Article 150 of the CARIFORUM-EC EPA.

206 Article 150.1 of the CARIFORUM-EC EPA.

207 See Convention on Biological Diversity, List of Parties to the Convention on Biological Diversity (2012), available at < http://www.cbd.int/convention/parties/list/> accessed on 22.10.2012. 
possibilities reaches from a binding international instrument to a non-binding statement, guidelines, an authoritative interpretation or a political declaration. ${ }^{209}$ The wording "internationally agreed sui generis model" is vague enough to encompass all possibilities discussed in the ICG. At the same time, it is close enough to the position of the European Union in the ICG, which prefers the

"development of international sui generis models, or other non-binding options, for the legal protection of TK." 210

With this formulation, the EU achieved to preserve the necessary room to negotiate at the multilateral level while implicitly providing for its own preferred option.

Third, the contracting parties of the CARIFORUM-EC EPA agree to implement the patent provisions of the EPA and the Convention on Biological Diversity in a mutually supportive way. ${ }^{211}$ This agreement to a mutually supportive implementation gives the impression that all parties of the EPA regard the relationship between patent protection for inventions based on biological resources and traditional knowledge on the one hand, and the preservation of biological diversity according to the CBD on the other hand as a matter of implementation rather than as a matter of a real international legal conflict. However, such an agreement does not exist at the international level: a significant group of States, including the Group of ACP States, classifies this relationship as a real legal conflict. For that reason, it supports the proposed amendment of the TRIPS Agreement by inserting a new Article 29bis, which would require 1) the disclosure of the country of source and, as known after reasonable inquiry, the country of origin of the biological resources and/or the associated traditional knowledge, 2) evidence of compliance with the applicable legal requirements of the source country as to prior informed consent for access and 3) evidence of compliance with the requirements for fair and equitable benefit-sharing arising from commercial utilization of the biological resources or the traditional knowledge. ${ }^{212}$

While the proposed TRIPS amendment would be of an obligatory nature, the CARIFORUM-EC EPA addresses the disclosure of biological resources in a voluntary manner: parties may require, as a necessary aspect of the administrative requirements for a patent application, the identification of the sources of the biological material used by the applicant. ${ }^{213}$ The possibility to require such disclosure, however, is not disputed. The legal problem with regard to the relationship between the TRIPS Agreement and the CBD is about whether countries are under an obligation to adopt such procedures as a binding international obligation. In this respect, the

209 See WIPO Secretariat, Summary of Options for the International Dimension of the Committee's work (Geneva, 29 April 2009) [WIPO/GRTKF/IC/14/6], paragraph 3.

210 WIPO Secretariat, Draft Report (Intergovernmental Committee on Intellectual Property and Genetic Resources, Traditional Knowledge and Folklore, Fourteenth Session, Geneva, 26 August 2009) [WIPO/GRTKF/IC/14/12 Prov. 2], paragraph 18.

211 See Article 150.3 of the CARIFORUM-EC EPA.

212 See WTO General Council, Trade Negotiations Committee and Council for TradeRelated Aspects of Intellectual Property Rights, Doha Work Programme, p. 2. See for the latest submission on this matter, WTO Trade Negotiations Committee, Draft Decision to Enhance Multual Supportiveness between the TRIPS Agreement and the CBD. 
provision in the CARIFORUM-EC EPA does not contribute to the international debate; it rather draws attention from the crucial points of discussion to issues that are not disputed anymore. These attempts of political gamesmanship have been criticized by observers for shifting the focus of the debate away from the essential points. ${ }^{214}$

To conclude, the CARIFORUM-EC EPA is the first European bilateral trade agreement that deals with the relationship between patent protection and the protection for genetic resources traditional knowledge and folklore. Other agreements concluded and negotiated thereafter have even based some of their provisions on those provisions agreed upon in the EPA. ${ }^{215}$ At the same time, the language included does not reveal true commitments to one solution to the problem. The contracting parties merely reiterate commitments from the Convention on Biological Diversity, promise to work towards an international solution on how to protect traditional knowledge and allow each other to require the identification of the sources of the biological material used in a patent application. Overall, the EPA succeeded in providing a precedence of bilateral commitments on this important issue.

\subsubsection{Interim Conclusions}

The CARIFORUM-EC EPA is the first European bilateral trade agreement that deals with each area of intellectual property protection individually and includes specific commitments thereon. Some of these commitments go beyond the standard established in the TRIPS Agreement. However, many provisions still leave considerable domestic policy space to the contracting parties to balance the relevant interests when implementing EPA obligations.

TRIPS-plus provisions are primarily incorporated in the provisions on the protection of digital works, geographical indications, design rights and patents. In particular, the CARIFORUM-EC EPA requires the compliance with the WIPO Copyright Treaty and the WIPO Performers and Phonograms Treaty, the accession to the Patent Cooperation Treaty and Budapest Treaty, and efforts to accede to the Patent Law Treaty and the Geneva Act of the Hague Agreement. In the area of geographical indications, the EPA extends GI protection to other products than wines and spirits, it establishes a minimum term of protection and omits exceptions granted by the TRIPS Agreement. Nevertheless, with the exception of the protection for geographical indications and design rights, EPA obligations do not provide more extensive protection than the free trade agreements concluded by the United States which contain remarkably high standards of protection for digital products and patents.

At the same time, the areas dealing with the protection of trade marks, utility models, plant variety protection and the protection of plant genetic resources and traditional knowledge in the EPA reflect an effort to preserve contracting parties' freedom to make use of certain TRIPS flexibilities and to implement EPA obligations in a way that balances the interests of right holders with those of users of intellectual property. Important examples are the "best-endeavour obligations" with regard to the 
accession to the Madrid Protocol, Singapore Treaty and the UPOV Convention, Act 1991. This flexibility allows CARIFORUM States to investigate the administrative and financial costs related to accession. The EPA is the first agreement to set out protection on utility models, genetic resources and traditional knowledge. It provides guidelines to EPA parties on how to use a system of utility model protection in a manner that foments innovation. Furthermore, the EPA makes a good effort in establishing useful language on the different issues related to the protection of biological diversity and traditional knowledge.

\subsubsection{Enforcement Provisions}

Thirteen articles of the CARIFORUM-EC EPA address the enforcement of intellectual property rights. Previous European bilateral trade agreements made do with the enforcement requirements contained in multilateral agreements, such as the TRIPS Agreement, the WCT and the WPPT. ${ }^{216}$ This new trend of expanding enforcement protection beyond the TRIPS standard is a reflection of a larger strategy used by developed countries to seek stronger enforcement in various forums, such as exemplified by the negotiation of the Anti-Counterfeiting Trade Agreement ${ }^{17}$ and the provisions contained in United States free trade agreements. ${ }^{218}$ To this end, the European Union has adopted a document entitled 'Strategy for the Enforcement of Intellectual Property Rights in Third Countries". One of the goals of this strategy is to revisit the approach towards enforcement provisions in bilateral agreements. ${ }^{219}$ As a source of inspiration, the strategy proposes to use the Enforcement Directive 2004/48. ${ }^{220}$ The aim of this Directive was to harmonize the national laws of the Member States of the European Union in accordance with the rules of the TRIPS Agreement (Articles 41-50 and Article 61) and to incorporate "best practice" measures. ${ }^{221}$

It is precisely from this Directive that certain provisions have been literally copypasted into the enforcement section of the CARIFORUM-EC EPA; other provisions have been left out. This approach has received mainly two kinds of criticism: first, mirroring the wording of certain provisions of the Directive in the EPA does exactly what the strategy intends not to do: proposing a one-size-fits-all approach. ${ }^{222}$ Second, the CARIFORUM-EC EPA hardly copy-pastes any provision of the Directive that deals with guarantees and balances. Only the provisions granting rights to right holders are identical to those contained in the Directive. Leaving out important safeguards for users and competitors increases the imbalance between right holders, competitors and users of intellectual property.

\footnotetext{
216 See section 3.3.7 of this book.

217 See section 3.1 .4 of this book.

218 See section 3.2 .8 of this book.

219 See European Commission, Enforcement Strategy in Third Countries, p. 5.

220 This Directive aims at harmonizing Community legislation with regard to civil enforcement mechanisms for all types of intellectual property.

221 See M. Veddern, "The Enforcement Directive 2004/48/EC - A Further Step in the Harmonisation of IP Laws in Europe" IPR Helpdesk Bulletin, 2004, Vol. 16, 4-5. Musungu, Cariforum EP $A$ and beyond, p. 29.
} 
At the heart of the first criticism is that the European Union's approach of copypasting parts of its internal legislation (Articles 151 until 163 of the CARIFORUMEC EPA almost entirely mirror the wording of the Directive) into an international trade agreement does not reflect its declared goal of taking into account different needs, levels of development and countries' main problems in terms of intellectual property protection. ${ }^{223}$ Detailed provisions are prone to affect CARIFORUM States' freedom to determine the appropriate method of implementation, as stated above. ${ }^{224}$ This criticism is even more justified when having in mind the heated debate within the European Union about the adequateness of the Directive which arose when the first proposal for the Directive was launched. ${ }^{225}$ The debate focused on the observed shift of balance in favour of the rights of the incumbents and to the detriment of competitors. ${ }^{226}$ As a result of this debate, the Directive's first draft had to be amended. Nevertheless, also the final provisions of the Directive reflect this imbalance.

The appropriateness of requiring CARIFORUM States to implement enforcement provisions that mainly benefit IP right holders is disputable for another reason. Strong enforcement rules shift the burden of enforcing private IP rights from right holders to state authorities. ${ }^{27}$ Providing specific state authorities with this task requires resources, both of financial and human nature. These are notoriously scarce in developing countries, such as CARIFORUM States. One risks a deviation of scarce resources from other areas of public policy to the enforcement of intellectual property rights. This is particularly so as the EPA does not explicitly state that its rules do not create any obligation to put in place a judicial system for the enforcement of IPRs distinct from that for the enforcement of law in general, as the TRIPS Agreement does. ${ }^{228}$

The second criticism relates to the types of provisions that are copy-pasted and those that are not taken up in the EPA at all. The provisions of the CARIFORUM-EC $E P A$ that are almost identical to the original provisions in the Directive are those that grant rights to title holders. In order to balance the rights of right holders, the Directive also contains provisions that limit right holders' entitlements and establish rights of their competitors and users of IPR protected goods. ${ }^{229}$ However, the latter checks and balances are mostly left out completely or incorporated in different

See European Commission, Enforcement Strategy in Third Countries.

See section 5.3.1.3 of this chapter. For the criticism, see Christian Aid and Oxfam, The EU's Approach to Free Trade Agreements: Intellectual Property, p. 4.

See H. MacQueen, C. Waelde and G. Laurie, Contemporary Intellecutal Property - Law and Policy (Oxford University Press, Oxford, 2008), p. 912.

See R. Anderson, The Draft IP Enforcement Directive - A Threat to Competition and to Liberty (Foundation for Information Policy Research, Cambridge, 2004), available at $<$ http://www.fipr.org/copyright/draft-ipr-enforce.html> accessed on 12.11.2012, p. 1. See H. Grosse Ruse-Khan, IP Enforcement Beyond Exclusive Rights (Max Planck Institute for Intellectual Property, Competition \& Tax Law Research Paper Series No. 08-09, München, 2008), p. 5.

See Article 41.5 of the TRIPS Agreement. See section 5.3.3.1 below.

See X. Seuba, "Checks and Balances in the Intellectual Property Enforcement Field: Reconstructing EU Trade Agreements" in C. Geiger (ed.), Constructing European Intellectual Property: Achievements and New Perspectives (European Intellectual Property Institutes Network series, Edward Elgar Publishing, Camberley, 2012) 409-431, p. 414. 
wordings in the CARIFORUM-EC EPA. This approach by the European Union to export deconstructed proposals has been criticized and raises the question as to whether or not the European Union complies with the obligation to negotiate treaties in good faith. ${ }^{230}$ The partner countries to European bilateral trade agreements must be aware when implementing the enforcement rules to integrate the public-interest balancing provisions similar to those contained in the Enforcement Directive 2004/48.

The enforcement provisions in the CARIFORUM-EC EPA cover a variety of issues. Many of these provisions are of a TRIPS-plus nature and therefore considerably increase the level of enforcement compared with the TRIPS Agreement. In the following, the most important enforcement provisions contained in the CARIFORUM-EC EPA will be analyzed according to three main groups. The first group deals with general obligations, including rules on entitled applicants (Article 151 and152 of the CARIFORUM-EC EPA). The second group addresses civil enforcement measures which are subdivided into five subsections. The first subsection assesses the rules on evidence and measures for preserving evidence (Articles 153 and 154). Subsection two focuses on the right of information (Article 155) and subsection three deals with provisional and precautionary measures (Article 156). The three available remedies of corrective measures, injunctions and pecuniary compensation (Articles 157-159) are addressed in subsection four. Damages and legal costs are at issue in the fifth subsection (Articles 160-161). The final group of enforcement measures deals with border measures (Article 163).

\subsubsection{General Obligations}

A general obligation that parties to the EPA have agreed upon is to ensure that their national enforcement measures are fair and equitable, not unnecessarily complicated or costly, or entail unreasonable time-limits. ${ }^{231}$ Furthermore, the measures must be effective, proportionate and dissuasive, and they must be applied in a manner to avoid the creation of barriers to legitimate trade. ${ }^{232}$ The first obligation is an important provision taken from the TRIPS Agreement, ${ }^{233}$ which can also be found in the Enforcement Directive 2004/48. ${ }^{234}$ However, in contrast to the TRIPS Agreement, the EPA provision does not refer to the understanding contained in Article 41.5 of the TRIPS Agreement. Accordingly, the enforcement obligations shall

"not create any obligation to put in place a judicial system for the enforcement of intellectual property rights distinct from that for the enforcement of law in general".

Together with Article 1.1 of the TRIPS Agreement, this provision has often been used by developing countries in the TRIPS Council to safeguard their national policy space with regard to enforcement matters. ${ }^{235}$ The omission of this principle seems to imply that developing countries do not need the freedom to determine how to enforce

$230 \quad$ See ibid.

231 See Article 151.1 of the CARIFORUM-EC EPA.

232 See Article 151.2 of the CARIFORUM-EC EPA.

233 See Article 41.2 of the TRIPS Agreement.

234 See Article 3.1 of the Enforcement Directive 2004/48. Note that paragraph 2 of Article 151 of the CARIFORUM-EC EPA is a copy of Article 3.2 of the Enforcement Directive 2004/48, which is not found in the TRIPS Agreement.

235 See Santa Cruz, Intellectual Property Provisions in European Union Trade Agreements, p. 30. 
intellectual property rights in view of their limited resources, which is at least doubtful. The vast majority of US FTAs goes even so far as to require that the distribution of resources cannot be used as an excuse for non-compliance with the provisions on enforcement of the FTA. ${ }^{236}$

However, the absence of this TRIPS rule does not necessarily mean that it cannot be applied in an EPA context. EPA parties are also Members to the WTO and therefore bound by the obligations and exceptions of the TRIPS Agreement.237 This is emphasized by the reference to the TRIPS Agreement in Article 139 of the CARIFORUM-EC EPA which states that parties are bound to implement the TRIPS Agreement adequately and effectively. However, honouring the commitments under the EPA, as well as making use of the flexibility created by Article 41.5 of the TRIPS Agreement, in reality might be very difficult: it is very expensive in terms of human (judges, customs officers) and institutional (registration offices, judicial remedies) infrastructure and knowledge to implement the detailed and specific enforcement provisions set out in the EPA. ${ }^{238}$ As a consequence, the choice implicit in Article 41.5 of the TRIPS Agreement might already have become redundant.

Another provision that clearly shifts the balance in favour of right holders is Article 152 of the CARIFORUM-EC EPA which addresses entitled applicants. It establishes the right to initiate legal proceedings for four distinct groups: right holders, licensees, collective rights management bodies representing right holders and professional defence bodies, such as trade associations. ${ }^{239}$ The provision goes beyond the TRIPS standard in two important aspects. First, the list of entitled applicants is expanded. Article 42 of the TRIPS Agreement merely entitles right holders to initiate civil judicial procedures. Footnote 12 specifies that right holders include federations and associations that have legal standing to assert such rights. The TRIPS Agreement does not address third parties in this context; it has left this matter up to Member States to decide. The CARIFORUM-EC EPA includes also third parties that are legally authorized to exercise the rights of right holders in the list of entitled applicants. Also US FTAs refer to licensees in this respect. ${ }^{240}$ Note that Article 152 of the CARIFORUM-EC EPA, however, only addresses third parties authorized by the right holder; it fails to deal with the rights of interested third parties, such as consumers of high technology products. ${ }^{241}$

The second aspect in which the provision on entitled applicants in the CARIFORUM-EC EPA expands the TRIPS mandate is the scope of measures

See Article 17.11.2 of the US-Chile FTA; Article 15.11.2 of the US-CAFTA-DR; Article 16.11.4 of the US-Peru TPA; Article 15.11.2 of the US-Panama TPA. Note that the USAustralia FTA and the US-Jordan FTA do not include this provision. See also section 3.2.8.1 of this book. One exception are the Bahamas, which are not a WTO Member. See Seuba, "Checks and Balances in the Intellectual Property Enforcement Field", p. 417.

239 Article 152 of the CARIFORUM-EC EPA is identical to Article 4 of the Enforcement Directive 2004/48.

$240 \quad$ See section 3.2.8.1 of this book.

241 See S.M. Kierkegaard, "Taking a Sledgehammer to Crack the Nut: The EU Enforcement Directive" Computer Law \& Security Report, 2005, Vol. 21 (6), 488-495, p. 491. 
applicants can request. Article 42 of the TRIPS Agreement deals with the right of right holders to request civil judicial procedures. The CARIFORUM-EC EPA, on the other hand, addresses

"measures, procedures and remedies referred to in this Section and in Part III of the TRIPS Agreement."”242

The section, also referred to as Part III of the TRIPS Agreement, covers both civil judicial procedures as well as border measures. Hence, the list of entitled applicants is also applicable in the context of customs procedures. Even US FTAs do not require other proceedings than civil judicial proceedings to be available to the listed applicants. ${ }^{243}$

To sum up, the general provisions in the CARIFORUM-EC EPA go beyond the TRIPS standard insofar as the important TRIPS freedom to determine how to enforce intellectual property rights is not guaranteed by the EPA. Furthermore, compared to the TRIPS Agreement, the provision on entitled applicants adds third parties to the list of applicants and entitles the listed applicants to request not only civil judicial measures but also border measures, the latter not being included in the TRIPS rule. Both TRIPS-plus aspects are contained in internal EU legislation and are similar to US FTAs.

\subsubsection{Evidence}

One of the important civil enforcement measures are the rules on evidence. Rules on protecting evidence aim at protecting evidence that is under the control of the alleged infringer, for judicial proceedings. The CARIFORUM-EC EPA provides two rules in this regard. First, judicial authorities must have the power to order the communication of relevant documents during legal proceedings. Second, judicial authorities must be able to order provisional measures before proceedings have started in order to preserve evidence. Both the TRIPS Agreement and the EU Enforcement Directive 2004/48 address the same subject matters; however, they also include certain mandatory procedural safeguards, which the CARIFORUM-EC EPA does not repeat.

First, according to Article 153 of the CARIFORUM-EC EPA, judicial authorities must be able to order the communication of banking, financial or commercial documents in case of an infringement committed on a commercial scale. ${ }^{244}$ The TRIPS Agreement does not provide for such a specific rule; it merely sets out the more general rule that judicial authorities may order the opposing party to produce evidence of any sort which lies in its control. 245 The specification of the type of evidence that may be ordered by judicial authorities is taken from the Enforcement Directive 2004/48. Article 6.2 of the Directive is identical to Article 153 of the CARIFORUM-EC EPA. However, the EPA only reflects the specific rule of the second paragraph of Article 6 of the Directive and does not provide for the general rule contained in the first paragraph

\footnotetext{
242 Article 152 of the CARIFORUM-EC EPA.

243 See Article 15.11 .6 of the US-Panama TPA.

244 See Articles 153 of the CARIFORUM-EC EPA.

245 See Article 43.1 of the TRIPS Agreement.
} 
of Article 6, which is identical to the TRIPS rule. According to the general rule, judicial authorities may only order the opposing party to produce evidence if two conditions are fulfilled. First, the claiming party must have presented reasonably available evidence which is sufficient to support its claims. Second, that party must also have specified the evidence that lies within the control of the opposing party. ${ }^{246}$ The CARIFORUM-EC EPA lacks this general rule with the two caveats and contains merely the specific rule.

Apart from the measures to produce evidence for judicial proceedings, national authorities may also take provisional measures to preserve relevant evidence before the commencement of proceedings. ${ }^{247}$ Again, the authority to take provisional measures to preserve evidence as set out in Article 154 of the CARIFORUM-EC EPA is identical to the equivalent provision in the Enforcement Directive 2004/48.248 In particular, such measures may include the detailed description or the physical seizure of infringing goods, and, where appropriate, the materials and implements used in the production or distribution of these goods. This rule is subject to a number of procedural guarantees. These safeguards relate to a) the presentation of reasonably available evidence that supports the claim that an infringement has been or is about to take place; and b) to the nature of the measures, which must be prompt and effective. The corresponding TRIPS rule ${ }^{249}$ also requires WTO Members to grant judicial authorities the power to order prompt and effective provisional measures. However, it does not specify which measures could be covered. Therefore, the specification contained in the CARIFORUM-EC EPA is a TRIPS-plus feature which can also not be found in the equivalent provision in US FTAs. ${ }^{250}$

Another TRIPS-plus element is reflected in the omission of a number of balancing provisions, which have been left out of the EPA-provision on the preservation of evidence, even though they have been included in the Enforcement Directive 2004/48. Article 50 of the TRIPS Agreement and Article 7 of the Enforcement Directive 2004/48 foresee at least three other safeguards which specify conditions under which the measures taken to preserve evidence must be revoked. First, if the applicant does not institute proceedings that will lead to a decision on the merits, within a reasonable period of time, the measures taken must be revoked or must cease to have effect upon request of the defendant. ${ }^{251}$ Second, where the measures to preserve evidence are revoked or where it is found that there has been no infringement of an IP right, the judicial authorities shall order the applicant to compensate the defendant for the injury caused. ${ }^{252}$ And third, in order to ensure compensation in the latter case, the measures taken to preserve evidence may be subject to the lodging of an adequate security by the applicant. ${ }^{253}$ US FTAs have incorporated the first and second

The third caveat, which requires that the protection of confidential information must be ensured when judicial authorities order the production of evidence, is provided for in Article 153 of the CARIFORUM-EC EPA. See Article 154 of the CARIFORUM-EC EPA. See Article 7.1 of the Enforcement Directive 2004/48. See Article 50.1 of the TRIPS Agreement. See Article 15.11.18 of the US-Panama TPA and the US-Morocco FTA; Article 14.10.18 of the US-Babrain FTA.

251 See Article 7.3 of the Enforcement Directive 2004/48.

252 See Article 7.4 of the Enforcement Directive 2004/48. 
procedural safeguards in its provision on preserving evidence through provisional measures. ${ }^{254}$

The absence of the procedural safeguards in the presented rules on evidence denies competitors and users of IP-protected products the necessary guarantees to ensure a balanced enforcement of the rights of title holders. If not supplemented by similar balancing provisions in the implementing laws of CARIFORUM States, the rules of evidence as contained in the EPA

"run the risk of being used by right holders to engage in fishing expeditions to hunt for evidence even before the nature of any potential infringement has been established." 255

Since these procedural guarantees are lacking in the EPA text, it is up to the parties to implement similar guarantees in their national laws. In fact, many of these safeguards are mandatory under the TRIPS Agreement and have to be implemented in WTO Members' national laws, regardless of their absence in the CARIFORUM-EC EPA. ${ }^{256}$ While it is beneficial for contracting parties to determine for themselves how to implement procedural safeguards in accordance with their approach to fairness, equity and fundamental freedoms, developing countries are likely to face problems in terms of resources to develop such laws. They often have not yet included procedural and substantive guarantees into their national laws and would have to prioritize their development. By merely requiring the transposition of enforcement rights, to the exclusion of necessary procedural safeguards, CARIFORUM States run the risk of not prioritizing the implementation of possible safeguards and ending up with an even stricter enforcement regime than that applied in the EU context.

In brief, the rules on the protection of evidence incorporated in the CARIFORUMEC EPA go beyond the protection foreseen in the TRIPS Agreement and also in the equivalent European legislation. Even United States FTAs do not expand the rights of right holders with regard to evidence to the same extent as the CARIFORUM-EC EPA. EPA provisions specify in detail which measures judicial authorities must be able to take, specifications that are not integrated in the TRIPS Agreement. Furthermore, the CARIFORUM-EC EPA omits important balancing provisions that grant rights to the supposed infringing party. CARIFORUM States run the risk of not prioritizing the implementation of the absent balancing provisions together with the implementation of the EPA obligations dealing with evidence.

\subsubsection{Right of Information}

In judicial proceedings, national authorities are able to order the infringer to provide information on the persons involved in the infringement and the distribution

254 See Article 15.11 .18 of the US-Panama TPA and the US-Morocco FTA; Article 14.10.18 of the US-Babrain FTA.

255 Kierkegaard, "Taking a Sledgehammer to Crack the Nut: The EU Enforcement Directive", p. 492.

256 See also Article 151 of the CARIFORUM-EC EPA, which specifies that the enforcement obligations shall not prejudice parties' rights and obligations under the TRIPS Agreement. 
channels. This right of information has been dealt with in remarkable detail in the CARIFORUM-EC EPA compared to the TRIPS Agreement.

"The EC Party and the Signatory CARIFORUM States shall ensure that, in the context of proceedings concerning an infringement of an intellectual property right and in response to a justified and proportionate request of the claimant, the competent judicial authorities may order that information on the origin and distribution networks of the goods or services which infringe an intellectual property right be provided by the infringer and/or any other person[...]"257

who was found in possession of, using, or providing the infringing goods or services on a commercial scale. The types of information that can be obtained include names and addresses of producers, manufacturers, distributors, suppliers and the quantities and price of these goods or services. ${ }^{258}$ The provision also foresees certain guarantees with regard to the prevalence of other statutory provisions above the specified rules on the right to information. ${ }^{259}$

The mandatory nature of Article 155 of the CARIFORUM-EC EPA, the preciseness of the information required and the omission of an important safeguard constitute TRIPS-plus elements. Article 47 of the TRIPS Agreement leaves WTO Members a choice as to whether or not to grant judicial authorities the power to order certain information. EPA parties are obliged to provide this power. The mandatory nature of the provision is identical to US FTAs in this regard. ${ }^{260}$ Furthermore, the TRIPS rule does not specify in detail what types of information can be obtained or who can be ordered to provide that information. Article 47 of the TRIPS Agreement merely allows judicial authorities to order the infringer to inform the right holder of the identity of third persons involved in the production as well as the channels of distribution. Even US FTAs do not contain a similarly detailed list of what information may be ordered as the CARIFORUM-EC EPA; the former, however, also broaden the scope of persons who can be ordered to provide the information. ${ }^{261}$ Finally, an important TRIPS safeguard is absent in the EPA provision. According to Article 47 of the TRIPS Agreement, authorities may only order information as long as this is in proportion to the seriousness of the infringement. Also recent US FTAs have omitted this balancing provision. ${ }^{262}$

A consequence of this new TRIPS-plus provision in the CARIFORUM-EC EPA is that right holders' work to enquire who the infringers are is rendered considerably easier at the cost of state authorities. The right of information regulated in the CARIFORUM-EC EPA follows European internal legislation and goes considerably

Article 155.1 of the CARIFORUM-EC EPA. See also Article 8 of the Enforcement Directive 2004/48. The latter article has been subject to discussion among many stakeholders during the debate on the Directive within Europe. See Veddern, "The Enforcement Directive 2004/48/EC". See Article 155.2 of the CARIFORUM-EC EPA.

For example, the use of such information in civil and criminal proceedings shall be governed by the relevant statutory provisions. See Article 155.3(b)-(e) of the CARIFORUM-EC EPA. 
beyond the equivalent TRIPS rule. Similar to the rules on preserving evidence, the EPA provisions set out a level of protection that is higher than that required in US FTAs.

\subsubsection{Provisional and Precautionary Measures}

Provisional and precautionary measures are an essential tool of national authorities to avoid that irreparable harm is caused to right holders and can be ordered even before an infringement has been found. Article 156 of the CARIFORUM-EC EPA contains the same three types of provisional measures as foreseen in Article 9 of the Enforcement Directive 2004/48. These are a) interlocutory injunctions, b) the seizure or delivery up of allegedly infringing goods, and c) the seizure of movable and immovable property of the alleged infringer. Compared to the general rule on provisional measures contained in Article 50.1 of the TRIPS Agreement, the level of detail in which the EPA specifies the measures and the relevant conditions is remarkable. At the same time, Article 156 of the CARIFORUM-EC EPA omits the procedural safeguards guaranteed by the TRIPS Agreement, as well as the Enforcement Directive 2004/48, which are aimed at avoiding the abuse of provisional measures. ${ }^{263}$

As regards interlocutory injunctions, judicial authorities shall have the power 1) to issue interlocutory injunctions in order to prevent any imminent infringement, 2) to forbid the continuation of an alleged infringement by making it subject to recurring penalty payments, or 3) to subject such continuation to the lodging of guarantees that will ensure the compensation of the right holder. ${ }^{264}$ At the request of the applicant, an injunction can also be directed against an intermediary whose services are used by a third party to infringe an intellectual property right. ${ }^{265}$ The notion of any intellectual property right even goes beyond European Union law as the Directive only requires the use of such injunctions against intermediaries where third parties make use of their services to infringe a copyright or related right. ${ }^{266}$ The TRIPS rule, on the other hand, does not specify what types of provisional measures must be available. It generally requires WTO Members to grant judicial authorities the power to order prompt and effective provisional measures in order to prevent an infringement of any intellectual property right from occurring and, in particular, to prevent the entry into the channels of commerce of the relevant goods. ${ }^{267}$

Secondly, authorities are permitted to order the seizure or delivery up of suspected goods to prevent their entry into or movement within the channels of commerce. ${ }^{268}$ Under the TRIPS Agreement, the seizure of suspected goods is only explicitly mentioned in the context of criminal proceedings. ${ }^{269}$ This suggests that the TRIPS Agreement does not foresee this type of provisional measure in the context of civil

263 See Seuba, "Checks and Balances in the Intellectual Property Enforcement Field", p. 425.

See Article 156.1 of the CARIFORUM-EC EPA. The provision is identical to Article 9.1(a) of the Enforcement Directive 2004/48.

265 See Article 156.1 of the CARIFORUM-EC EPA.

266 See Article 9.1(b) of the Enforcement Directive 2004/48.

267 See Article 50.1 of the TRIPS Agreement.

268 See Article 156.2 of the CARIFORUM-EC EPA. The provision is identical to Article 9.1(b) of the Enforcement Directive 2004/48.

269 See Article 61 of the TRIPS Agreement. 
proceedings. The EPA follows the rules contained in United States FTAs in this regard which grant judicial authorities the power to order the seizure of alleged infringing goods, materials and implements. ${ }^{270}$ Lastly, in the case that an infringement has been committed on a commercial scale and the applicant is able to demonstrate circumstances likely to endanger the recovery of damages, a third type of measure is available to the judicial authorities under the EPA: they may order the precautionary seizure of movable and immovable property, including blocking bank accounts and other assets, as well as the communication of bank, financial or commercial documents. ${ }^{271}$ No equivalent rule can be found in the TRIPS Agreement, nor in US free trade agreements.

What has not been incorporated into the EPA are four provisions of the TRIPS Agreement and the Enforcement Directive 2004/48 that are meant to prevent the abuse of provisional measures. First, an important guarantee is that authorities can require the applicant to provide "any reasonably available evidence" that proves "with a sufficient degree of certainty" that the applicant is the right holder and that his right is being infringed or that such infringement is imminent. ${ }^{272}$ This safeguard represents a basic requirement of justice: a provisional or precautionary measure can only be taken against a defendant if it stands up to a proper trial. ${ }^{273}$ The requirements permit the parties to adopt a high threshold for taking provisional and precautionary measures, which can be different for each category of IP. ${ }^{274}$

Second, judicial authorities shall have the power to order the applicant to provide a security in order to protect the defendant and to prevent abuse. ${ }^{275} \mathrm{~A}$ third safeguard allows the defendant to request the revocation of provisional measures if the applicant has not started proceedings on the merits within a reasonable period of time. ${ }^{276}$ Furthermore, in case the measures are revoked or it is found that there was no infringement of an IP right, the judicial authorities can also order the applicant to provide the defendant appropriate compensation for the injury caused by the

270 See section 3.2.8.3 of this book for a more detailed analysis of the provisions on provisional measures in US FTAs.

271 See Article 156.3 of the CARIFORUM-EU EPA. The provision is identical to Article 9.2 of the Enforcement Directive 2004/48.

272 See Article 50.3 of the TRIPS Agreement and Article 9.3 of the Enforcement Directive 2004/48.

273 See C. Heath, "Comparative Overview and the TRIPS Enforcement Provisions" in C. Heath and L. Petit (eds.), Patent Enforcement Worldwide: Writings in Honour of Dieter Stauder (2nd edn, IIC Studies Vol. 23, Hart Publishing, Oxford, 2005) 5-65, p. 28.

274 See Seuba, "Checks and Balances in the Intellectual Property Enforcement Field", p. 425.

275 See Article 50.3 of the TRIPS Agreement and Article 9.6 of the Enforcement Directive 2004/48.

276 See Article 50.6 of the TRIPS Agreement and Article 9.5 of the Enforcement Directive 2004/48. 
measure. ${ }^{277}$ Where such safeguards are absent from the EPA rule, CARIFORUM States run the risk of not prioritizing the implementation of such laws. ${ }^{278}$

In summary, the provisions on provisional measures contained in the CARIFORUMEC EPA considerably go beyond the TRIPS standard, as well as beyond European Union law on enforcement matters. The level of detail with which the EPA provision specifies which types of provisional measures may be ordered and under which circumstances is not comparable with the general rule contained in the TRIPS Agreement. The same is true for US FTAs, which also stay well behind the level of detail incorporated in the EPA. At the same time, procedural safeguards foreseen in both the TRIPS Agreement and the Enforcement Directive 2004/48 have not been incorporated. This approach of omitting procedural and substantive safeguarding provisions has already been observed in the previously analyzed parts of the enforcement section of the EPA. It shifts the balance in favour of rights of title holders and to the detriment of competitors and users of IP-protected products.

\subsubsection{Remedies}

Remedies are applied after an infringement has been found by the judicial authority. They are stipulated in Articles 157-159 of the CARIFORUM-EC EPA and equal the provisions of Articles 10-12 of the Enforcement Directive 2004/48. Accordingly, judicial authorities can a) order corrective measures, b) issue injunctions or c) order pecuniary compensation. The equivalent TRIPS rule in Article 46 only sets out two corrective measures; the provisions in the CARIFORUM-EC EPA enlarge judicial authorities' competences by adding additional remedies.

There are three corrective measures that, according to the CARIFORUM-EC EPA, competent judicial authorities can take in relation to goods that are found to be infringing an intellectual property right: they can order 1) the recall of infringing goods, 2) their definitive removal from channels of commerce, or 3) their destruction. ${ }^{279}$ Article 46 of the TRIPS Agreement only sets out two corrective remedies: their disposal outside of the channels of commerce, or their destruction. It furthermore adds the condition that when considering such requests, judicial authorities need to secure proportionality with the seriousness of the infringement as well as the interests of third parties. This TRIPS safeguard is not incorporated in the CARIFORUM-EC EPA.

The rules on corrective measures stay well behind those taken up in the United States free trade agreements. US FTAs generally require the destruction of infringing goods as the first option, without providing for the accompanying TRIPS safeguard. Furthermore, US FTAs also allow that materials and implements used in the manufacture or creation of infringing goods can be ordered to be destroyed. Materials and implements are not addressed by the EPA rule. While judicial authorities maintain the

277 See Article 50.7 of the TRIPS Agreement and Article 9.7 of the Enforcement Directive 2004/48.

278 For the same argument, see section 5.3.3.2 on the rules addressing the preservation of evidence.

279 See Article 157 of the CARIFORUM-EC EPA. 
power to decide if and which remedy to apply under the EPA, US FTAs oblige authorities to apply a remedy upon the request of the right holder. ${ }^{280}$

The second measure judicial authorities can issue are injunctions. These are aimed at prohibiting the infringer from continuing the infringement. ${ }^{281}$ The EPA rule stipulates that where domestic law generally provides for the possibility to subject non-compliance with an injunction to a recurring penalty payment, parties are obliged to make them available to judicial authorities. In addition, right holders must be able to apply for an injunction against an intermediary whose services are used by a third party to infringe an intellectual property right. No equivalent provision is contained in US FTAs, nor in the TRIPS Agreement.

Finally, according to Article 159 of the CARIFORUM-EC EPA, parties may grant judicial authorities the power to order the infringer to pay pecuniary compensation to the injured party. Making use of pecuniary compensation is possible if certain requirements are met. First, pecuniary compensation can only be used as an alternative for applying the measures in Part III of the TRIPS Agreement or in this Chapter. The measures referred to seem to include all corrective measures and injunctions. Second, authorities will only make use of this measure in appropriate cases and at the request of the infringer. Third, the infringer must have acted unintentionally and without negligence. Fourth, the execution of the measures in question would cause him disproportionate harm. Lastly, the pecuniary compensation must appear reasonably satisfactory. These conditions are identical to those of Article 12 of the Enforcement Directive 2004/48. The TRIPS Agreement does not provide for the remedy pecuniary compensation.

In brief, the remedies set out by the CARIFORUM-EC EPA offer a broader array of measures than the equivalent TRIPS rule. The provision on corrective measures lacks the important TRIPS safeguard of securing proportionality between the seriousness of the infringement, third parties' interests and the measure to be taken, even though the equivalent rule in the Enforcement Directive 2004/48 contains this proportionality test. In view of the obligation not to prejudice the rights and obligations under the TRIPS Agreement, ${ }^{282}$ it can be argued that EPA parties are still under an obligation to adopt this proportionality test. The corrective measures required by the US set out an even higher level of enforcement than the EPA. However, the second and third remedy on injunctions and pecuniary compensation are not regulated in the TRIPS Agreement, nor in US FTAs.

\subsubsection{Damages and Legal Costs}

The last civil measures discussed here are the payment of damages and the reimbursement of legal costs. They do not go beyond the TRIPS standard in significant aspects. With regard to damages, judicial authorities have the power to award, in addition to remedies, damages to the applicant. Article 160 of the CARIFORUM-EC EPA distinguishes between a knowing infringer and one that did not know. In that, it follows the approach set out in the TRIPS Agreement. For the 
case that the infringer knew or had reasonable grounds to know that (s)he was engaging in an infringing activity, a clear choice has been made to require the infringer to pay civil damages appropriate to the actual prejudice suffered as a result of the infringement. ${ }^{283}$ The same is true for the Enforcement Directive 2004/48 and the TRIPS Agreement.284

The aspect that goes beyond internal EU law and TRIPS obligations is that the EPA rule specifies in detail how judicial authorities shall set damages: either by taking into account all appropriate aspects, such as lost profits, unfair profits made by the infringer or moral prejudice caused to the right holder, ${ }^{285}$ or by fixing damages as a lump sum based on the royalties or fees normally due when demanding authorization. ${ }^{286}$ United States FTAs use pre-established or statutory damages for cases of copyright and related rights' infringement and trade mark counterfeit. ${ }^{287}$ For the case that the infringer did not know or did not have reasonable grounds to know, the parties may provide the authorities with the power to order the recovery of profits or the payment of pre-established damages. ${ }^{288}$ In this, the EPA rule clearly follows the TRIPS standard incorporated in Article 45.2 which grants WTO Members the option to provide their authorities with such powers. US FTAs, however, have turned this option into an obligation. ${ }^{289}$

With regard to legal costs, EPA parties agreed that domestic law contains measures that will generally require the unsuccessful party to bear the legal costs, unless equity requires the costs to be allocated otherwise. ${ }^{290}$ It does not specify what these costs involve and where the limits lie. In this, the provision deviates from European internal law, which clearly states that, as a general rule, the expenses of the successful party will be borne by the unsuccessful party insofar as the legal costs are reasonable and proportionate. ${ }^{291}$ The TRIPS rule, on the other hand, orders the infringer to pay the right holder expenses, which may also include appropriate attorney's fees. ${ }^{292}$ It does not distinguish between the winning and losing party, which must not necessarily be the same as the right holder and infringer. However, Article 45.2 of the TRIPS Agreement neither specifies which types of expenses are covered and up to what limit. To sum up, the provisions on damages and legal costs are considerably more specific than the TRIPS standard. Where the TRIPS Agreement contains rather general obligations and therefore grants flexibility to WTO Members on how to interpret them, EPA rules fill the gaps with concrete rules and take away the TRIPS flexibility. US FTAs go beyond the protection set out in the EPA regarding the award of damages. These are regulated in Article 160 of the CARIFORUM-EC EPA.

284 See Article 13 of the Enforcement Directive 2004/48 and recital 26 thereof and Article 45.1 of the TRIPS Agreement.

289 See section 3.2.8.5 of this book.

290 See Article 161 of the CARIFORUM-EC EPA.

291 See Article 14 of the Enforcement Directive 2004/48.

292 See Article 45.2 of the TRIPS Agreement.
} 


\subsubsection{Border Measures}

After having assessed the most important civil enforcement procedures contained in the CARIFORUM-EC EPA, another crucial tool available to enforce intellectual property rights are border measures. Border measures are applied by customs authorities at the border of their territory when goods under their supervision are suspected of infringing a form of intellectual property. According to Article 163 of the CARIFORUM-EC EPA, right holders must be able to apply to customs authorities to suspend the release into free circulation or the retention of goods in case they are suspected of infringing an intellectual property right and have been imported, exported, re-exported or are exiting of the respective customs territory.

This obligation contains two elements that go beyond the TRIPS standard in Article 51. First, customs authorities are empowered to suspend the release of goods that are imported, exported, re-exported, in exit or placed under a suspensive procedure, a customs free zone or a customs free warehouse. Article 51 of the TRIPS Agreement merely obliges this power to be granted in respect of imported products, and makes it optional for countries to apply them also to goods destined for exportation. Free trade agreements concluded by the United States also expand customs authorities' power beyond the TRIPS standard, but not to the same extent as the EPA. US FTAs include imported, exported, goods in transit and merchandise in free trade zones; they do not explicitly list re-exported goods, goods in exit or those placed under a suspensive procedure or in a customs free warehouse. In that, the CARIFORUM-EC EPA provision addressing border measures goes beyond the level of the TRIPS Agreement and US FTAs.

Second, according to Article 163.2 of the CARIFORUM-EC EPA, customs authorities can suspend the release of "goods that infringe an intellectual property right". Footnote 2 to this Article specifies what kinds of goods are covered by "goods infringing an intellectual property right". They include "counterfeiting goods" and "pirated goods" (both of which are defined precisely in the footnote), and "designs" and "geographical indications". It is in two aspects that this provision goes beyond what Article 51 of the TRIPS Agreement requires: first, Article 51 merely obliges countries to grant this power in respect of counterfeit trade mark goods and pirated copyright goods, not for designs or geographical indications. Second, Article 51 of the TRIPS Agreement does not contain such a detailed definition of counterfeit trade mark goods and pirated copyright goods. The definition in Footnote 2 is mainly identical to the European Union's definition of such goods incorporated in Article 2 paragraph 1 sub a and b of the EC Customs Regulation 1383/2003. Adding such a precise definition that will be applied in all parties to the EPA is problematic in view of the territorial nature of intellectual property rights ${ }^{293}$ and the freedom of each member to determine for itself the appropriate method of implementation.

Free trade agreements concluded by the United States still go a bit further than the EPA rule. They grant customs authorities the power to apply border measures also to confusingly similar trade mark goods. ${ }^{294}$ This power has been criticized for interfering with normal trading relationships and normal competitive behaviour. The 
CARIFORUM-EC EPA applies border measures to counterfeit products only. To sum up, the border measures required by the CARIFORUM-EC EPA clearly go beyond the TRIPS standard. Not only do they apply to more customs statuses of possibly infringing goods than the TRIPS Agreement, the EPA rule also requires customs authorities to apply border measures to goods infringing a broader range of intellectual property rights than those set out in Article 51 of the TRIPS Agreement. In the former aspect, the CARIFORUM-EC EPA requires border measures to be applied to a broader range of goods in customs than US FTAs.

\subsubsection{Interim Conclusions}

The enforcement provisions in the CARIFORUM-EC EPA are an entirely new feature of European bilateral trade agreements. No bilateral trade agreement concluded by the European Union up until then has seen this extensive amount of enforcement provisions dealing with general matters, civil enforcement and border measures. Most of these provisions set an enforcement standard that goes considerably beyond the equivalent TRIPS rules. The level of detail and the omission of important balancing safeguards in certain parts even goes beyond the level set in internal European Union legislation as well United States free trade agreements. Without doubt, the enforcement section of the intellectual property chapter is the most far-reaching part of the Chapter on "Innovation and intellectual property" when compared to the other areas, in particular in terms of the TRIPS-plus nature of its provisions, as well as compared to European internal legislation and US FTAs. It indicates the importance the European Union started to dedicate to the improvement of intellectual property enforcement in third countries, as evidenced by the 2004 "Strategy for the Enforcement of Intellectual Property Rights in Third Countries".

The enforcement provisions go beyond the TRIPS Agreement in three ways: 1) by enlarging the scope of rights or the list of beneficiaries to the rights; 2) by setting out in greater detail what a right entails; and 3) by omitting important TRIPS safeguards and flexibilities. Examples of provisions that have expanded the scope of rights considerably compared to the TRIPS Agreement are the provisions dealing with entitled applicants, the right of information, corrective measures and border measures. The standards set for the right of information and partly also for border measures grant right holders even more rights than United States free trade agreements. Broadening the rights of right holders makes it easier for the latter to enquire who the infringers are and to request judicial measures to be taken at the cost of state authorities.

Other provisions in the CARIFORUM-EC EPA elaborate in detail which rights or measures are covered by certain enforcement actions. These are particularly the rules on the protection of evidence, the right of information and provisional measures. The provisions on all three enforcement aspects go far beyond the enforcement standard incorporated in the TRIPS Agreement and also well beyond the level of detail applied in equivalent provisions in free trade agreements concluded by the United States. CARIFORUM States will find it difficult to provide for the detailed enforcement measures required by the EPA if they do not yet comply with that level. It requires financial and human resources to establish the necessary infrastructure and to train state authorities in applying the new rules. 
Finally, a number of important TRIPS flexibilities and safeguards have been omitted from the CARIFORUM-EC EPA when compared with the TRIPS Agreement. These are the general principle on freedom of implementation, the safeguards relevant to rules on preserving evidence, provisional and corrective measures. Except for the general principle on the freedom of implementation, all of those rules are based on the equivalent provisions in the Enforcement Directive 2004/48. However, even though the internal rules incorporate TRIPS flexibilities and safeguards, the CARIFORUMEC EP $A$ has omitted them. In this respect, the EPA is even stricter than European Union law. Where balancing provisions are omitted, EPA parties arguably still are under an obligation with regard to or benefit from the right to use the flexibilities due to Article 151.1 of the CARIFORUM-EC EPA. ${ }^{295}$ The latter article specifies that the rights and obligations under the TRIPS Agreement are not affected by the enforcement rules set by the EPA. Nevertheless, even though the flexibilities are not taken away from EPA parties, CARIFORUM States run the risk of not prioritizing the implementation of absent balancing provisions together with the implementation of the EPA obligations as regards evidence, provisional and corrective measures.

\subsection{GENERAL EXCEPTION}

After having analyzed the substantive provisions contained in the intellectual property chapter of the CARIFORUM-ECEPA in detail, one provision still deserves particular attention. Article 224 of the CARIFORUM-EC EPA provides general exceptions that apply to any Chapter contained in the EPA, including Chapter 2 on "Innovation and intellectual property". In other words, where a breach of an obligation contained in the intellectual property chapter is claimed, the respondent may resort to this Article in order to justify that breach in accordance with one of the policy objectives mentioned and the chapeau requirements. This is a completely new and unique feature of European bilateral trade agreements (concluded or in drafting stage $)^{296}$ and, to my knowledge, of any international treaty dealing with intellectual property protection. Even the TRIPS Agreement lacks a possibility to generally except measures in breach of obligations in any of the covered areas of IP for commonly accepted societal values, such as those integrated in the GATT 1994 and the GATS. Before exploring in some depth in which circumstances this provision could be used by EPA parties in a dispute involving intellectual property rights, a short summary of the Article is presented.

295 Whether there is an obligation to make a flexibility or safeguard available under national law depends on whether the individual TRIPS provision at issue contains mandatory or optional language.

Other European bilateral trade agreements have provided for general exceptions in the context of other chapters, but not to be applicable for disputes in the area of intellectual property protection. Article 167 of the EU-Colombia-Peru FTA is only applicable to trade in services, establishment, trade in commerce, current payments and capital movements. Article 158 of the EU-Central America FTA applies Article XX of the GATT 1994 to trade in goods in the FTA context and Article 203, which repeats language incorporated in Article XVI of the GATS applies to trade in services, establishment and electronic commerce. Article 2.15 of the EU-South Korea FTA refers to Article XX of the GATT 1994 and applies only to the trade in goods chapter of the FTA. 
In fact, this Article is very similar to Article XX of the GATT 1994 and Article XIV of the GATS. The exceptions in Article 224 of the CARIFORUM-EC EPA allow EPA parties, under specific conditions, to adopt and maintain legislation or measures that protect specific societal values and interests, even though this legislation or these measures are in conflict with substantive disciplines imposed by the EPA. The Article sets out a two-tiered test in order to determine whether a measure, which is otherwise EPA-inconsistent, can be justified under Article 224 of the CARIFORUM-EC EPA: first, the measure must be provisionally justifiable under one of the specific exceptions under paragraph (a) to (h). If this is the case, secondly, the application of the measure must meet the requirements of the chapeau of Article 224.

The most important specific exceptions listed in Article 224.1 of the CARIFORUMEC EPA, which are relevant for breaches of obligations contained in the 'Innovation and intellectual property' Chapter, address a) public security and public morals, b) human, animal or plant life or health, c) securing compliance with laws or regulations which are not inconsistent with the provisions of this Agreement, among others those relating to customs enforcement or the protection of intellectual property protection, e) the protection of national treasures of artistic, historic or archaeological value, and f) the conservation of exhaustible natural resources. ${ }^{297} \mathrm{~A}$ measure has to meet one of these policy objectives, the interpretation of which has been developed in the WTO context. In addition, the measure must also be necessary ${ }^{298}$ to meet the policy objective of a) protecting public security and public morals, b) protecting human, animal or plant life or health, c) securing compliance with certain laws or regulations and e) protecting national treasures. In the case of exhaustible natural resources, the measure must relate $t^{299}$ their conservation.

Measures provisionally justified under one of the specific exceptions must subsequently meet the requirements of the chapeau of Article 224. The purpose of the chapeau is to avoid abuse or misuse of the exceptions: the application of the measure may not constitute a) an arbitrary or unjustifiable discrimination between countries where the same conditions prevail; or b) a disguised restriction on international trade. ${ }^{300}$ Overall, the chapeau tries to guarantee an equilibrium between the right of Members to pursue legitimate societal values and the right of other Members to trade.

It is entirely new terrain to hypothesize about the way this Article could be used in EPA disputes involving a breach of an obligation in the Innovation and intellectual property chapter of the CARIFORUM-EC EPA. Three scenarios will be sketched to illustrate possible ways of applying this article as well as open questions. In all scenarios, country $\mathrm{A}$ and country $\mathrm{B}$ are parties to the CARIFORUM-EC EPA and to the WTO Agreement.

\footnotetext{
297 For a comprehensive analysis of most of these different policy objectives, see Van den Bossche, The Law and Policy of the World Trade Organization, p. $621 \mathrm{ff}$ and $655 \mathrm{ff}$.

298 For a comprehensive analysis of the concept of necessary in the WTO context, see ibid., p. $623 \mathrm{ff}$.

299 For an analysis of the concept of "relating to" in the WTO context, see ibid., p. $635 \mathrm{ff}$

300 For a comprehensive analysis of these concepts in the WTO context, see ibid., p. 643.
} 
In scenario 1, country A refuses to grant patents on products that are derived from biological material or traditional knowledge present in its country. Country B claims that this is in breach of Article 27 of the TRIPS Agreement. Country A argues that such a breach can be justified by Article $224.1 \mathrm{~b}$ ) and e) of the CARIFORUM-EC $E P A$, which allow EPA parties to adopt measures that are necessary to protect plant life or health and national treasures of artistic, historic or archaeological value. The question arises whether the EPA general exception in Article 224 can be invoked in a dispute involving a TRIPS obligation. Several reasons exclude this possibility. First, Article 224.1 restricts its application to this Agreement, referring to the CARIFORUM-EC EPA. Second, the TRIPS Agreement is a separate agreement and contains its own system of obligations, rights and exceptions thereto. Using an exception from a different context interferes with the system of rights and obligations established by the TRIPS Agreement and is liable to add to or diminish the rights and obligations of all WTO Members. In a dispute before a WTO Panel, the Panel would be prohibited from issuing a ruling to that effect because of Article 3.2 of the Dispute Settlement Understanding. Third, Article 242 of the CARIFORUM-EC $E P A$ sets out that nothing in the EPA requires parties to act in a manner inconsistent with their WTO obligations. This conflict rule seems to indicate that the provisions of the CARIFORUM-EC EPA do not change the obligations between the parties stemming from the WTO Agreement, including its Annexes. As a consequence, where TRIPS obligations are not reiterated in the CARIFORUM-EC EPA, the general exception provision of the EPA cannot be used to justify a breach of the TRIPS obligation.

In scenario 2, country A has not adopted procedures that enable right holders of pharmaceutical products to enforce their trade mark rights against imported, exported and in transit goods. Country B claims that this behaviour is in breach of Article 163 of the CARIFORUM-EC EPA. As a defense, country A invokes Article $224.1 \mathrm{~b}$ ) of the CARIFORUM-EC EPA as a means to justify this breach. It argues that suspending counterfeit generic medicine is necessary to protect the public health of its own (importation) and other countries' (in transit) citizens. Should that the measure meet this policy objective and its application fulfills the requirements of the chapeau, such a scenario seems to be possible. Article 224 of the CARIFORUM-EC EPA can be applied to breaches of EPA obligations. It does not matter whether the EPA obligation is a reiterated TRIPS obligation (in the case of imported goods), a TRIPS-plus obligation (in the case of in-transit goods) or a flexibility not yet provided for in the TRIPS Agreement. However, the question arises whether country A, by invoking Article 224 in a case where a breach of an EPA obligation is involved that constitutes a reiterated TRIPS obligation, breaches that TRIPS obligation. However, the WTO Member that would claim a breach of the TRIPS obligation would be country B, which is party to the EPA dispute and could have brought the claim that this TRIPS obligation is breached to the WTO Dispute Settlement System in the first place. It therefore seems unlikely that such a WTO claim would be made. Overall, where the breach of an EPA obligation is claimed, the general exception Article can be used to justify such a breach. This is possible in cases where the obligation contains a reiterated TRIPS obligation, a TRIPS-plus obligation or a flexibility not yet provided for in the TRIPS Agreement.

In the third scenario, country A refuses to grant protection to a geographical indication on a herbal drink that has the effect of leading to a miscarriage and which 
originates in country B. Country B claims that this refusal breaches Article 145.B.3 of the CARIFORUM-EC EPA. As a defense, country A relies on Article 224.1 a) of the CARIFORUM-EC EPA: it is necessary to deny such a drink the protection of its geographical indication in order to protect the public morals of this very religious country and to maintain public order. Should the measure meet this policy objective and its application fulfills the requirements of the chapeau, such a scenario seems to be possible. A breach of an EPA obligation can be justified by an exception available under the EPA framework. The fact that the section on the protection of geographical indications in the CARIFORUM-EC EPA already contains specific exceptions (such as Article 145.A.1, Article 145.C.1-4 of the CARIFORUM-EC $E P A)$ relevant to the protection of geographical indications cannot prevent a party from relying, in addition to such specific exceptions, on the general exception provision of Article 224 if it grants different grounds to justify a measure. This is the case here. As a consequence, even though the intellectual property chapter of the CARIFORUM-EC EPA provides for specific exceptions relevant to obligations with regard to different intellectual property rights, the general exception article provides additional possibilities for justification.

In summary, Article 224 of the CARIFORUM-EC EPA is a surprising new and still unique feature in a bilateral trade agreement in that it applies to conflicts involving intellectual property rights. The provision allows, under certain conditions, a variety of specific policy objectives to be protected. Its usefulness in specific situations involving the breach of an EPA obligation in the area of intellectual property rights still has to be shown. The above three scenarios have provided some indications as to how the provision might be used. It is important to keep in mind, however, that the "necessary" requirement in many specific exceptions is a difficult test to pass. Together with the requirements of the chapeau, it will not be easy for an EPA party to make successful use of the Article in a dispute involving intellectual property rights, regardless of the political willingness of parties to do so.

\subsection{CONCLUSION}

The chapter dealing with intellectual property protection in the CARIFORUM-EC $E P A$ is new in many ways. The obligations contained therein are new obligations for CARIFORUM States. They used to be bound by the standards of the TRIPS Agreement and the Cotonou Agreement, the CARIFORUM-EC EPA has expanded these standards considerably. It contains important TRIPS-plus provisions, particularly in the area of the protection of digital works, geographical indications, design rights, patents and enforcement matters. At the same time, the EPA shows a considerable amount of effort to adapt the intellectual property obligations to the needs of CARIFORUM States, the majority of which are developing countries. This effort is primarily visible in the principles set out in the IP chapter as well as in substantive provisions, such as those addressing the transfer of technology, the protection of utility models and the protection of genetic resources and traditional knowledge. However, the usefulness of these principles and substantive provisions is questionable in view of the fact that the language used therein is mostly optional and declaratory in nature, whereas provisions, such as those contained in the enforcement section, are legislation-like and leave hardly any room for weighing different interests in the implementation process. 
The legal approach adopted by the European Union and CARIFORUM States in the intellectual property chapter shows important new features. The scope of the chapter has become much more extensive than "old generation" European bilateral trade agreements. Section 1 and 2 incorporate thirty-four articles over twelve pages. These provisions introduce the mixed approach: protection of intellectual property is sought by requiring its parties to accede to or comply with certain multilateral treaties as well as by stipulating detailed standards of protection in the individual areas of intellectual property protection. The rules in the individual areas of intellectual property protection are often transplants from EU legislation. Overall, the new legal approach used by the EU in the IP chapters of its bilateral trade agreements has become very similar to United States free trade agreements.

In the legal analysis of the substantive IP provisions contained in the EPA, four issues were addressed. First, particular attention has been paid to the question as to whether the protection sought goes beyond the level of protection foreseen in the TRIPS Agreement. Second, differences with previous European bilateral trade agreements under the EU's old approach were discussed in detail. Third, where appropriate and relevant, the standard of protection has been compared to the equivalent obligations included in United States' FTAs. Finally, the provisions were assessed as to how far they provide domestic policy space to take into account development concerns.

TRIPS-plus provisions are primarily incorporated in the provisions on the protection of digital works, geographical indications, design rights and patents, and the enforcement provisions. In particular, the CARIFORUM-EC EPA requires compliance with the WIPO Copyright Treaty and the WIPO Performers and Phonograms Treaty, the accession to the Patent Cooperation Treaty and Budapest Treaty, and best efforts to accede to the Patent Law Treaty and the Geneva Act of the Hague Agreement. All of these obligations are new features of the CARIFORUM-EC EPA compared to previous European bilateral trade agreements. In the area of geographical indications, the EPA extends GI protection to other products than wines and spirits; it establishes a minimum term of protection and omits exceptions granted by the TRIPS Agreement. Nevertheless, with the exception of the protection for geographical indications and design rights, the EPA obligations do not provide more extensive protection than the free trade agreements concluded by the United States, which contain remarkably high standards of protection for digital products and patents.

At the same time, the areas dealing with the protection of trade marks, utility models, plant variety protection, the protection of plant genetic resources and traditional knowledge and the transfer of technology in the EPA reflect an effort to preserve contracting parties' freedom to make use of certain TRIPS flexibilities and to implement the EPA obligations in a way that balances the interests of right holders with those of users of intellectual property. Such balancing provisions are new compared to previous European bilateral trade agreements. Important examples are the "best-endeavour obligations" with regard to the accession to the Madrid Protocol, Singapore Treaty and the UPOV Convention, Act 1991. This flexibility allows CARIFORUM States to investigate the administrative and financial costs related to accession. The EPA is the first agreement to set out protection on utility models, genetic resources and traditional knowledge. It provides guidelines on how to use a system of utility model protection in a manner that foments innovation, and makes a 
good effort in establishing useful language on the different issues related to the protection of biological diversity and traditional knowledge. The free trade agreements concluded by the United States have not shown a similar effort of including enough policy space for its partner countries to take development concerns into account.

Without doubt, the enforcement section of the intellectual property chapter is the most far-reaching part of the chapter when compared with the other areas. It contains many TRIPS-plus provisions and often equals the level of enforcement set out in European internal legislation and US FTAs. The enforcement provisions go beyond the TRIPS Agreement in three ways: 1) by enlarging the scope of rights or the beneficiaries to the rights; 2) by setting out in greater detail what a right entails; and 3) by omitting important TRIPS safeguards and flexibilities. This is true for the general provisions, the provisions on civil judicial enforcement and those dealing with border measures. In most cases, they are copied from the Enforcement Directive 2004/48; where EPA obligations omit safeguarding provisions also contained in the Directive, the enforcement level set out in the CARIFORUM-EC EPA even goes beyond the standard of protection required within the European Union. Also the free trade agreements of the United States often do not contain a similar level of detail or the same broad scope of enforcement as the CARIFORUM-EC EPA does.

Complying with the detailed enforcement standards will be difficult for countries that do not yet comply with that level. Such a high level of IP enforcement requires financial and human resources to establish the necessary infrastructure and to train state authorities in applying the new rules. The broadened rights of right holders have shifted the burden of enquiring who the infringers are into the direction of state authorities, who are paid by public funds. Another problem that could occur is that CARIFORUM States will not prioritize the implementation of the absent balancing provisions together with the implementation of the EPA obligations. Overall, the enforcement chapter of the CARIFORUM-EC EPA can be categorized as an aggressive feature of the agreement.

Since this chapter has demonstrated that the coverage, scope and nature of the provisions concerning intellectual property protection have changed tremendously compared to previous European bilateral agreements, it is crucial to provide some closer analysis and research into the negotiating history and interests of the parties involved in the negotiations of the CARIFORUM-EC EPA. For the purpose of this thesis, the areas of the intellectual property relevant for the protection of agricultural products and foodstuffs will be at the centre of Part D of this research project. In particular, the protection of geographical indications, trade marks, plant varieties, plant genetic resources and traditional knowledge, as well as enforcement matters, will be relevant in this context. As concluded in the previous section, in almost all of these areas, the CARIFORUM-EC EPA establishes new standards compared to previous European bilateral agreements, TRIPS-plus obligations or additional policy space to address development concerns. The protection of foodstuffs is of high relevance for the European Union. It is the aim of the subsequent research to carefully analyze what the interests of CARIFORUM States are in these fields of IP protection. This will be done by a stakeholder analysis in one of the major countries in the CARIFORUM region, Jamaica. 
Before turning to the study on the influence of non-state actors on the policy-making process during the negotiations of the intellectual property chapter of the CARIFORUM-EC EPA, the detailed analysis of the provisions of another draft intellectual property chapter negotiated after the conclusion of the strategy "Global Europe" will be presented. The draft Broad-based Trade and Investment Agreement has been negotiated since June 2007 between India and the European Union; its conclusion is envisaged for 2013. It will contain a chapter on the protection of intellectual property protection, of which drafts have been circulated, the most recent one in July 2010. The analysis of this agreement adds another example of the new European Union legal approach to intellectual property protection in its bilateral trade agreements with third countries. India is a very different trading partner than CARIFORUM States: it represents one of the biggest emerging economies that has a strong interest in protecting intellectual property at the level that benefits the Indian society. Also multilaterally, India has been very active in preserving flexibilities set out in the TRIPS Agreement. A detailed analysis of the proposals made by both parties in the India-EU BTIA promises to shed some further light on India's interests and how the EU so far has reacted to them. 


\section{Chapter 6 : Legal Analysis of the Draft India-EU Broad-based Trade and Investment Agreement}

India is a very different actor from the small Caribbean island states which form part of the CARIFORUM region. It is one of the priority countries of the European Union's new trade strategy with third countries. ${ }^{1}$ According to the European Union, India is a dynamically developing world region with a large market potential and a high level of protection against EU exports. ${ }^{2}$ The driving force of the negotiations on the Broad-based Trade and Investment Agreement between India and the European Union (India-EU BTLA), hence, is to gain market access. Furthermore, it is the European Union's ambition to conclude a substantial and comprehensive agreement that covers a broad range of areas. ${ }^{3}$ It aims at achieving a high level of intellectual property protection in the relationship with India. At the same time, India is an important developing country with strong interests of its own, in particular with regard to an adequate system of intellectual property protection. An in-depth analysis of the proposed rights and obligations in the various areas of intellectual property protection contained in the BTIA negotiations promises to reveal a balanced approach which reflects the interests of both parties.

The draft IP chapter of the India-EU BTIA is still under negotiation. From June 2007 until October 2012, the two partners have held fifteen negotiation rounds, the last EU-India Summit taking place on 10 February 2012 in New Delhi. ${ }^{4}$ The negotiating parties expect to sign the agreement by the end of 2012.5 The latest draft IP chapter dates from July 2010 and presented the consolidated version of the IPR text in preparation for the discussions during the New Delhi talks of 12-14 July 2010. ${ }^{6}$ It still contains the propositions made by both parties in many areas but also indicates where the parties have already agreed to one text. It illustrates what the European Union's priority areas are and where India has offensive interests.

This chapter analyzes the proposed IP provisions of both parties contained in the latest draft IP chapter of the India-EU BTIA from July 2010. The analysis assesses where the proposed protection goes beyond the TRIPS standard and compares the suggested standards of protection with European internal rules and the IP chapters

See European Commission, Global Europe, p. 11.

See ibid., p. 11.

See EU-India High Level Trade Group, Report of the EU-India High Level Trade Group to The EU-India Summit (13 October 2006), available at <http://trade.ec.europa.eu/doclib/docs/2006/september/tradoc_130306.pdf> accessed on 15.11.2012, p. 11. The High Level Trade Group (HLTG) recommended the European Commission to include nine areas: trade in goods, trade in services, investment, trade facilitation, government procurement, technical regulations, intellectual property and GIs, competition policy and dispute settlement. See EU-India High Level Trade Group, Report of the EU-India High Level Trade Group to The EU-India Summit, Chapter 3.

$4 \quad$ For an updated status of these negotiations, see European Commission, Bilateral relations.

$5 \quad$ See "Belgium hopes talks on India-EU FTA will conclude by year end" The Economic Times (New Delhi, 3 August 2012), available at <http://articles.economictimes.indiatimes.com/2012-08-03/news/33020033_1_export-low-cost-drugs-india-eu-ftaindia-and-european-union $>$ accessed on 12.11.2012.

6 See Aisola, "New Release of IPR Chapter of India-EU Free Trade Agreement". 
of other European bilateral trade agreements that have been or will most likely be concluded after the launch of the "Global Europe" strategy. These include the CARIFORUM-EC EPA, the EU-South Korea FTA, the EU-Colombia-Peru FTA, the EU-Central America $A A$, and the draft EU-Canada CETA, which is still being negotiated. ${ }^{7}$ The analysis identifies suggested TRIPS-plus elements and how the intellectual property standards contained in European bilateral trade agreements have developed, not only in relation to the CARIFORUM-EC EP A, but also in respect to the other bilateral agreements that have been recently concluded or are still under negotiation. This comparison is meant to indicate whether different standards included in various agreements reflect the interests of the different negotiating partners of the European Union, or whether the European Union was generally successful in achieving similar levels of protection, with all of its partners, which are similar to its own standards of protection. In addition, it will be assessed in how far the proposed provisions provide domestic policy space to take development concerns into account. The structure of this chapter follows the structure of the draft IP chapter. It deals with a) general provisions, b) the detailed rules in the individual areas of intellectual property protection, and c) enforcement issues.

\subsection{LEGAL APPROACH}

The draft IP chapter of the India-EU BTIA still contains the propositions of both the European Union and India in many areas. There is not one legal approach yet that can be identified in the chapter. Rather, there are two approaches apparent in the provisions suggested by each party.

The provisions suggested by India clearly relate to the standard provided for in the TRIPS Agreement. India has proposed provisions that either repeat the language contained in the latter agreement or that refer to its articles directly. Hence, the standard of protection suggested by India hardly goes beyond the TRIPS Agreement. Furthermore, India has used the CARIFORUM-EC EPA as a source of inspiration for the provisions suggested on innovation, the transfer of technology, and the protection of traditional knowledge and genetic resources. Many of these provisions have been copy-pasted and even developed further by India. Finally, India has hardly inserted any identical provisions of its relevant internal legislation.

The European Union, on the other hand, seems to adhere to the already analyzed approach displayed in the CARIFORUM-EC EPA. The proposed provisions use the mixed approach: they require accession to or compliance with multilateral treaties and set out detailed rules in each area. Many provisions are transplants from internal European legislation. ${ }^{8}$ At the same time, one observes a turn-around by the European Union: it is willing to give up some of its standard provisions and to accept the suggestions made by India, particularly in the area of enforcement provisions. With the exception of the EU-Central America $A A$, the European Union has so far not given up much of its proposed language in recent European "new generation" bilateral trade agreements to the benefit of the trading partner's proposals.

\footnotetext{
$7 \quad$ The negotiations of the draft EU-Canada CETA have been launched in May 2009 and are expected to last until end of 2012. See European Commission, Bilateral relations. See section 5.2 of this book for a detailed analysis of these three features.
} 


\subsection{GENERAL Provisions}

The first section of the draft IP chapter of the India-EU BTLA addresses general provisions relevant for intellectual property protection. Different from the CARIFORUM-EC EPA, it does not set out the relationship between innovation and intellectual property in detail. The general provisions contained in the draft IP chapter of the India-EU BTLA can be summarized according to three subject matters: a) the context and a definition of intellectual property, b) objectives and scope of protection, and c) the transfer of technology and exhaustion.

\subsubsection{Context and Definition of Intellectual Property}

The negotiating parties have agreed to set out the context of the draft IP chapter in Article 2.1 in the following way:

"1. The parties agree that fostering innovation and creativity improves competitiveness and is a crucial element in their economic partnership, in achieving sustainable development and promoting mutually beneficial trade between them."

The proposal for this provision came from India. ${ }^{9}$ It has copied the almost identical provision from the CARIFORUM-EC EPA, which places intellectual property in the context of innovation, creativity and competitiveness. ${ }^{10}$ This was a novelty in the EPA, on which CARIFORUM States had insisted. Accordingly, innovation and creativity shall promote mutually beneficial trade. No other "new generation" bilateral trade agreement recently concluded by the European Union contains a similar provision.

In addition, Article 2.2 of the draft IP chapter of the India-EU BTLA recognizes that intellectual property, when protected and enforced in a manner appropriate to and justified by parties' level of development, promotes creativity, innovation and competitiveness. The element of "justified by" the parties' level of development has been suggested by India and is new compared with the CARIFORUM-EPA. ${ }^{11}$ If accepted by the European Union, it can provide a flexible ceiling to the level of intellectual property protection foreseen by the India-EU BTLA. The parties would then agree that standards of IP protection, which go beyond the level of development of the parties, will not enhance innovation and competitiveness and therefore are not desirable. This provision could be used when interpreting and implementing the obligations of the India-EU BTLA, similar to the role Articles 7 and 8 of the TRIPS Agreement have played in the TRIPS context. ${ }^{12}$ No other recently concluded European bilateral trade agreement provides for a similar provision.

9 See Article 1.1 of the draft IP chapter of the India-EU BTLA from April 2010, as proposed by India.

10 See Article 131 of the CARIFORUM-EC EPA.

11 See Article 131.2 of the CARIFORUM-EC EPA.

12 See section 2.3.1 of this book. The WTO Panel in Canada-Pharmaceuticals noted that Articles 7 and 8 have some interpretative force, but shall not be read to alter the negotiated balance of the TRIPS Agreement. In other words, although Articles 7 and 8 cannot add rights or diminish obligations set out in the TRIPS Agreement, they still play a role in the interpretation of flexibilities such as Article 30 of the TRIPS Agreement. See Canada-Pharmaceutical Patents, paragraph 7.26. 
With regard to the definition of intellectual property in Article 1 of the draft IP chapter of the India-EU BTLA, India and the EU have proposed quite different provisions; however, the elements covered by each definition are very similar. India proposed that the term "intellectual property" refers to all categories of IP that are protected in the TRIPS Agreement. ${ }^{13}$ This is in contrast to the European Union's suggestion: the proposed definition does not relate to the TRIPS Agreement, but lists one by one each category of rights that should be covered. ${ }^{14}$ Overall, the EU's proposed definition is similar to the one contained in other EU bilateral trade agreements ${ }^{15}$ and, in fact, includes the same categories as those covered by the TRIPS Agreement. This is different from the definition used in the CARIFORUM-EC EP $A,{ }^{16}$ which also included the sui generis protection for non-original databases, a TRIPS-plus element. ${ }^{17}$ That element was still contained in the first draft IP chapter of the IndiaEU BTLA of November $2008^{18}$ but has been omitted by the Parties.

Although neither definition of IP goes beyond the TRIPS standard, the elements dealt with in the chapter show that the protection of traditional knowledge and genetic resources has been added to the list of issues addressed in the IP chapter. To conclude, India seems to succeed in providing a provision on the context of intellectual property protection in the IP chapter of the India-EU BTIA. It has used the CARIFORUM-EC EPA as a source of inspiration. If India's proposition is followed by the European Union, Article 2 can inform the interpretation of the substantive provisions in a development-friendly manner. As regards the definition, the propositions made by India and the EU do not deviate from the TRIPS standard.

\subsubsection{Objectives and Scope of Protection}

Another set of general provisions addresses objectives and the nature and scope of protection. The parties are far from agreeing on a common text and therefore the proposed texts of Article 3 and 4 of the draft IP chapter of the India-EU BTLA are analyzed separately. Overall, India's efforts to draft detailed provisions that reflect its interests is remarkable.

\subsubsection{Provisions Suggested by India}

The provisions dealing with objectives and scope of protection suggested by India are quite numerous: twelve provisions have been proposed. The overall impression conveyed by them is that India wishes to stay as close as possible to the standards of the TRIPS Agreement. This is evidenced by the references to Articles 1.1, 7 and 8 of

See Article 1 of the draft IP chapter of the India-EU BTLA, as proposed by India. Note that Article 1.2 of the TRIPS Agreement itself defines "intellectual property" as all categories of IP addressed in sections 1 through 7 of Part II of the TRIPS Agreement. See Article 1 of the draft IP chapter of the India-EU BTLA, as proposed by the EU. See Article 10.2.2 of the EU-South Korea FTA; Article 196.5 of the EU-Colombia-Peru FTA; Article 229.3(a) of the EU-Central America AA. Note that the recent draft IP chapter of the EU-Canada CETA from February 2012 has eliminated the paragraph that previously contained a proposal for a definition of intellectual property. See Article 139.3 of the CARIFORUM-EC EPA.

17 See section 5.3.1.2 of this book on the definition of intellectual property in the CARIFORUM-EC EPA.

18 See Article 2.2 of the draft IP chapter of the India-EU BTLA of November 2008, as proposed by the European Union. 
the TRIPS Agreement, as well as to its preamble. In addition, it expresses its concerns with the not fully harmonized IP legislation of the European Union.

First, according to India, the parties shall maintain the freedom to determine the appropriate method of implementing the provisions of the IP chapter within their own legal system. ${ }^{19}$ This freedom of implementation is an important provision of the TRIPS Agreement ${ }^{20}$ which prevents issues of IP protection from being regulated in such a detailed fashion that parties would be left without any freedom to determine how to implement these matters into their national legal systems. The equivalent provision in the CARIFORUM-EC EPA has introduced this principle in EU bilateral trade agreements for the first time. Article 139.5 of the CARIFORUM-EC EP $A$ also includes the principle of minimum protection, which is not incorporated in the provisions of the draft IP chapter of the India-EU BTLA, as suggested by India. It is not surprising that India does not propose the right of each party to conclude more extensive agreements on IP protection because India is not pursuing intellectual property protection that goes beyond the TRIPS Agreement, neither internationally nor at the bilateral level.

Second, India suggests achieving the objectives and principles of Article 7 and 8 of the TRIPS Agreement. ${ }^{21}$ It does so by citing their provisions verbatim. ${ }^{22}$ No other recently concluded European bilateral trade agreement includes verbatim citations of these articles, except for the EU-Colombia-Peru FTA, which also uses elements from Article $7 .{ }^{23}$ Article 7 together with Article 8 of the TRIPS Agreement play an important role in the context of interpreting the obligations in the TRIPS Agreement in a development-friendly way, although their force in altering the negotiated balance reflected in the provisions is limited. ${ }^{24}$ In particular, India emphasizes the balance of rights and obligations, the protection of public health concerns and India's development needs and the need to avoid that intellectual property protection and enforcement become a disguised restriction on trade..$^{25}$

Third, apart from the references to the TRIPS Agreement, India has introduced a provision that expresses India's concerns with the EU's not fully harmonized intellectual property legislation. It requests that each party shall harmonize its intellectual property laws within its territories so that various Member States do not

19 See Article 4.2 of the draft IP chapter of the India-EU BTLA, as proposed by India.

20 See Article 1.1 of the TRIPS Agreement.

21 See Article 3(a) and 4.10 of the draft IP chapter of the India-EU BTLA, as suggested by India. The European Union seems to agree to provision 4.10 of the draft IP chapter of the India-EU BTLA as Article 8.2 of the draft IP chapter of the India-EU BTLA of April 2010 identifies this language as not being disputed anymore. However, in the latest draft of July 2010, this language is clearly marked as India's suggestion. See Articles 195(b) and 196.3 of the EU-Colombia-Peru FTA.

See section 2.3.1 of this book. See also footnote 12 of section 6.2 .1 of this book on the interpretation given by the WTO Panel in Canada - Pharmaceuticals.

See Article 4.9 of the draft IP chapter of the India-EU BTLA, as suggested by India; Article 3(b) of the draft IP chapter of the India-EU BTLA, as proposed by India; Article 4.6 of the draft IP chapter of the India-EU BTIA, as proposed by India. 
impose different IP laws on the same intellectual property. ${ }^{26}$ For the case where harmonization is not achieved within the entire territory, each party needs to make sure that the products covered by the intellectual property laws can circulate freely. ${ }^{27}$ To sum up, India's main goal is to emphasize important principles already set out in the TRIPS Agreement. These are the freedom of implementation, the principles set out in Article 7 and 8 of the TRIPS Agreement as well as the prohibition to abuse enforcement provisions. If India is successful in maintaining these provisions, it would guarantee some policy space for both parties when interpreting and implementing BTIA provisions. India would also like to see a commitment by the European Union to complete the harmonization of IP legislation within its entire territory.

\subsubsection{Provisions Suggested by the European Union}

While India clearly takes the TRIPS Agreement as a reference point, the European Union suggests objectives that are unrelated to the TRIPS Agreement. It uses two objectives also listed in the CARIFORUM-EC EPA: ${ }^{28}$ facilitation of the production and commercialization of innovative and creative products, and an adequate and effective level of protection and enforcement of IPRs. It is remarkable how the two parties have chosen to emphasize opposite sides of the balance of rights and obligations as objectives: India accentuates the development-friendly interpretation of intellectual property protection, such as enabling transfer of technology, whereas the European Union stresses the commercial benefits of strong IP protection.

Compared to India's rather detailed list of provisions describing the scope of obligations, the EU has so far only suggested the following obligation:

"The provisions of this chapter shall complement and further specify the rights and obligations between the Parties beyond those under the TRIPS Agreement and other international treaties in the field of intellectual property to which they are parties." 29

The European Union has chosen for a new definition of the scope of obligations compared to its earlier bilateral trade agreements. It clearly sets the standard beyond the TRIPS Agreement and other international agreements on IP: the bilateral agreement shall complement existing rights and obligations and, hence, add new rules. India on the other hand, ${ }^{30}$ as well as the CARIFORUM-EC EP $A,{ }^{31}$ focused on the already established framework of IP protection: India suggests that the parties shall ensure an appropriate (in the case of the EPA adequate) and effective implementation of the international IP treaties to which they are parties, including the TRIPS Agreement. ${ }^{32}$ To summarize, India emphasizes the status quo of IP protection

\footnotetext{
26 See Article 4.7 of the draft IP chapter of the India-EU BTLA, as proposed by India.

27 See Article 4.8 of the draft IP chapter of the India-EU BTLA, as proposed by India.

28 See Article 132(c) and (d) of the CARIFORUM-EC EPA.

29 See Article 4.1 of the draft IP chapter of the India-EU BTIA, as proposed by the European Union.

30 See Article 4.1 of the draft IP chapter of the India-EU BTLA, as proposed by India.

31 See Article 139.1 of the CARIFORUM-EC EPA.

32 As noted earlier, such a bilateral obligation of adequate/appropriate and effective implementation of the mentioned treaties is an addition to the already existing obligation under the respective multilateral treaties to comply with them: appropriate
} 
as established through the various international agreements to which India and the EU are parties, whereas the EU wishes to complement existing protection by adding new rights and obligations. The EU's proposal on the level of enforcement follows the same line. ${ }^{33}$

\subsubsection{Transfer of Technology and Exhaustion}

Two other general provisions of the draft IP chapter of the India-EU BTLA deal with the transfer of technology and the principle of exhaustion. The EU and India are in agreement to exchange views and information on policies and practices affecting the transfer of technology and to ensure that legitimate interests of right holders are protected. ${ }^{34}$ Not yet agreed upon are three provisions suggested by India. The first requires the European Union to pay attention to the training and development of human capital in order to enable transfer of technology to India. ${ }^{35}$ A similar provision has been suggested by the EU in previous drafts, ${ }^{36}$ making an agreement between the parties on the issue likely. The other two provisions proposed by India are literally taken from the CARIFORUM-EC EPA: ${ }^{37}$ they grant India the ability to take measures to control licensing and other contractual practices under certain circumstances ${ }^{38}$ and oblige the EU to facilitate and promote the use of incentives for institutions and enterprises to engage in transfer of technology in India. ${ }^{39}$ The transfer of technology is a prime example of the influence of the text agreed in the CARIFORUM-EC EPA on India's position in the negotiations with the European Union. Not only India has used the CARIFORUM-EC EPA as a source of inspiration; also the EU-South Korea FTA and the EU-Central America $A A$ have included similar provisions. ${ }^{40}$ Nevertheless, India has not proposed similarly concrete commitments as CARIFORUM States or Central American countries. ${ }^{41}$

and effective implementation goes further than compliance. A bilateral party to the India-EU BTLA or the CARIFORUM-EC EPA that doubts whether the other party effectively implements certain provisions of the trade agreement would have to bring this claim to the bilateral dispute settlement system. See section 5.3.1.1 of this book on the scope of protection agreed upon in the CARIFORUM-EC EPA.

See section 6.4.1 of this book.

See Article 5.1 and 5.4 of the draft IP chapter of the India-EU BTLA.

See Article 5.1 second sentence of the draft IP chapter of the India-EU BTLA, as suggested by India.

Previous drafts already included the following provision suggested by the EU: "Particular attention shall be paid to the conditions necessary to create an adequate enabling environment for technology transfer in the host countries, including issues such as the relevant legal framework and development of human capital." See Article 3 of the draft IP chapter of the India-EU BTIA of November 2008, Article 9 of the draft IP chapter of the India-EU BTLA of April 2010. This suggestion is almost identical to Article 142.1 last sentence of the CARIFORUM-EC EPA and has also been taken up in Article 231.1 of the EU-Central America AA and Article 10.3.1 of the EU-South Korea FTA.

See Article 142.2 and 142.3 of the CARIFORUM-EC EPA.

See Article 5.2 of the draft IP chapter of the India-EU BTLA, as proposed by India. See Article 5.3 of the draft IP chapter of the India-EU BTLA, as proposed by India. See Article 10.3.2 of the EU-South Korea FTA; Article 231.3 und 231.4 of the EUCentral America AA.

The latter refers to concrete programmes in which their respective nationals or firms wish to participate. 
Finally, the last general provision acknowledges one of the important TRIPS flexibilities: parties are free to establish the system of exhaustion that they deem to be appropriate. ${ }^{42}$ In other words, BTIA parties are free to adopt the national exhaustion principle, and therefore prevent parallel imports, or the principle of international exhaustion, which allows parallel imports to the country where, for example, a patent has been granted. Enabling pharmaceuticals first marketed in another country to be imported to India can have important public health benefits. This provision is not contested by any of the parties. It is also commonly contained in "new generation" European bilateral trade agreements, ${ }^{43}$ with the exception of the CARIFORUM-EC $E P A$. In brief, the provisions on the transfer of technology proposed by India include useful commitments by the parties, in particular the European Union. They are taken from the CARIFORUM-EC EPA, even though they are not as concrete as the latter's provisions. Safeguarding the principle of international exhaustion can benefit India's health care system.

\subsubsection{Interim Conclusions}

The general provisions proposed in the draft IP chapter of the India-EU BTIA are not very different from the CARIFORUM-EC EPA and other recently concluded European bilateral trade agreements. The CARIFORUM-EC EPA has been used as a source of inspiration for the provisions on the relationship between innovation and intellectual property rights as well as the transfer of technology provisions, suggested by India. As regards principles and objectives, India emphasizes the status quo of IP protection as established by the TRIPS Agreement, whereas the EU wishes to complement existing protection by adding new rights and obligations. Nevertheless, both parties have already agreed to maintain the freedom to choose the principle of exhaustion.

\subsection{INDIVIDUAL INTELLECTUAL PROPERTY PROVISIONS}

The individual standards concerning intellectual property rights are set out for the different areas of intellectual property protection covered by the draft IP chapter of the India-EU BTLA. These areas are the protection of copyright and related rights, trade marks, geographical indications, designs, patents, plant varieties and genetic resources and traditional knowledge. Instead of an article-by-article analysis of the IP chapter, the provisions that a) go beyond the level of protection foreseen in the TRIPS Agreement or b) are different from the CARIFORUM-EC EPA or from other "new generation" European bilateral trade agreements are discussed in detail. These include the EU-South Korea FTA, the EU-Colombia-Peru FTA, the EU-Central America $A A$, and the draft EU-Canada CETA, which is still being negotiated. In addition, the obligations are compared with relevant European legislation and assessed in how far they provide domestic policy space to take into account development concerns. the TRIPS Agreement.

43 See Article 10.4 of the EU South Korea FTA; Article 200 of the EU-Colombia-Peru FTA; Article 232 of the EU-Central America AA; Article 4 of the draft IP chapter of the EUCanada CETA, as proposed by Canada. 


\subsubsection{Provisions Relating to Access to Information in the Digital Environment}

The protection of copyright and related rights takes an important place in the draft IP chapter of the India-EU BTLA, mainly on the request of the European Union. ${ }^{44}$ Compared to the CARIFORUM-EC EPA, the copyright section of the draft IP chapter has been expanded considerably: the former only contained two provisions on copyright protection, one dealing with the compliance with international treaties and the other with the cooperation between collecting societies. ${ }^{45}$ The requests made by the European Union seem to be the Union's new standard of protection as they have also been incorporated in the (proposed) "new generation" bilateral trade agreements with South Korea and Canada. This Section covers five themes that contain TRIPS-plus elements: a) compliance with international treaties, b) the protection against the circumvention of technical protection measures and the alteration of rights management information, c) the duration of authors' and related rights, d) the cooperation with collective management of rights and e) particular rights and exceptions.

\subsubsection{Compliance with International Treaties}

The European Union requires India to comply with four international treaties: the Berne Convention, the Rome Convention, the WIPO Copyright Treaty and the WIPO Performances and Phonograms Treaty. ${ }^{46}$ The requests made by the European Union with regard to the Rome Convention, the WCT and the WPPT have so far not been accepted by India. While India is a party to the Berne Convention and the Rome Convention already, this is not the case for the WCT and the WPPT. Although accession is not a necessary condition for a country to be in compliance with an international treaty, it is a good indication as to whether the domestic law has been adapted to the requirements of that international treaty. Compliance is a strong obligation which enables the other BTIA party to claim under the bilateral dispute settlement that a particular law is not in compliance with the rules of the WCT and WPPT. Normally, such compliance questions are addressed in the multilateral dispute settlement system agreed to by the parties to these treaties.

The WIPO Internet Treaties require protection against the circumvention of technical protection measures and against the alternation of rights management information. ${ }^{47}$ Such protection is not required by the TRIPS Agreement. So far, India has not yet included protection for TPMs and RMI in its Copyright Act 1957, as last amended by Act No. 49 of 1999. If India accepts these requirements, it will have to adjust its copyright rules in order to address works on the Internet and in the digital media. The same rule has been included in other "new generation" European bilateral trade agreements. ${ }^{48}$

\footnotetext{
$44 \quad$ Most provisions included in the draft agreement have been suggested by the European Union and have subsequently been amended with the suggestions made by India.

45 See Article 143 of the CARIFORUM-EC EPA.

46 See Article 7.1 of the draft IP chapter of the India-EU BTIA, as suggested by the European Union.

$47 \quad$ See Articles 11 and 12 of the WCT.

48 See Article 10.5 of the EU-South Korea FTA; Article 215.2 of the EU-Colombia-Pern FTA; Article 233 of the EU-Central America $A A$ and Article 5.1.1 of the draft IP
} 


\subsubsection{The Protection of Technical Protection Measures and Rights Management Information}

The protection against the circumvention of TPMs and against the alteration of RMI is furthermore regulated individually in the copyright section of the draft IP chapter of the India-EU BTLA. Articles 7.7 and 7.8 as proposed by the EU are identical to the standard of protection that the European Union has adopted for all Member States internally, namely through the Information Society Directive. ${ }^{49}$ The Information Society Directive is meant to implement the obligations stemming from the WCT and the WPPT, and therefore adapt European copyright law to the Internet, new communications technologies, the growth of e-commerce as well as harmonizing certain substantive copyright law aspects across the board..$^{50}$ Copy-pasting provisions from this Directive into the India-EU BTIA suggests that India will implement the WCT and the WPPT in the exact same way as the European Union internally. The implementation of the WCT and the WPPT through the Information Society Directive has been criticized by several authors for having been highly influenced by lobbying groups and going considerably beyond the standard required by the WCT. ${ }^{51}$

Circumscribing precisely how the WCT and the WPPT need to be implemented contravenes the principle of freedom of implementation confirmed in Article 4.2 of the draft IP chapter of the India-EU BTLA. Furthermore, such detailed rules severely limit India's domestic policy space to balance all interests involved. For this reason, India should insist on dropping Articles 7.7 and 7.8 of the draft IP chapter of the India-EU BTIA, as suggested by the European Union. Moreover, the draft agreement already contains the obligation to comply with the WCT and WPPT, which in itself provides a guideline on how to protect TPMs and RMI. So far, India has not yet agreed to the protection suggested by the European Union. The same provisions have been included in the EU-South Korea FTA, however not in the CARIFORUMEC EPA, the EU-Colombia-Peru FTA and the EU-Central America AA. ${ }^{52}$

\subsubsection{Duration of Author's and Related Rights}

The parties have agreed to grant authors protection for their lifetime plus at least fifty years. ${ }^{53}$ A lifetime plus at least fifty years is unexpected as this term of protection is

chapter of the EU-Canada CETA. Article 143.A of the CARIFORUM-EC EPA also requires compliance with the WCT and WPPT but merely asks "best endeavours" to be made to accede to the Rome Convention.

See Articles 6 and 7 of the Information Society Directive.

See B. Hugenholtz, "Editorial, Why the Copyright Directive is Unimportant, and Possibly Invalid” EIPR, 2000, Vol. 22 (11), 499-505, p. 499.

51 See M. Hart, "The Copyright in the Information Society Directive: An Overview" EIPR, 2002, Vol. 24 (2), 58-64, p. 58 and 61 ff; Hugenholtz, "Editorial, Why the Copyright Directive is Unimportant, and Possibly Invalid", p. 501 and 499; M. Kretschmer, "Digital Copyright: The End of an Era" EIPR, 2003, Vol. 25 (8), 333-341, p. 334.

See Article 10.12 and 10.13 of the EU-South Korea FTA; note that Articles 221 and 222 of the EU-Colombia-Peru FTA merely refer to the relevant provisions in the WCT and WPPT in this respect.

3 See Article 7.2 of the draft IP chapter of the India-EU BTLA. 
below the domestic standard of both parties. In earlier drafts of the IP chapter, ${ }^{54}$ the EU had suggested a protection for authors of a lifetime plus sixty years, a proposal which seemed to have already anticipated India's domestic situation, which offers a protection for a lifetime plus sixty years. ${ }^{55}$ This in fact is ten years less than what the EU has asked for and has agreed to in other European "new generation" bilateral trade agreements, and applies at home. ${ }^{56}$ Nevertheless, this request went beyond the TRIPS standard, which sets the term of protection at a lifetime plus fifty years. ${ }^{57}$ India, in reply to the suggestion made by the EU, has offered a term of fifty years after the death of the author, which is in line with the TRIPS Agreement. ${ }^{58}$ It is not evident why India would persist on fifty years while its domestic law ${ }^{59}$ already fulfills the proposed standard by the EU. One reason could be that India wants to keep the option of changing its own copyright law in the future. The agreed protection for a lifetime plus fifty years will apply to authors of literary or artistic works as well as to co-authors and anonymous works.

As far as the rights of performers, producers of phonograms, producers of movies and broadcasting organizations are concerned, the EU has suggested a term of protection of fifty years from the date of performance, publication of the phonogram, first fixation of the movie and first transmission of a broadcast. ${ }^{60}$ This is identical to the term of protection proposed to Canada, received from Colombia, Peru and Central American countries, and provided for in EU legislation. ${ }^{61}$ India has agreed to the fifty years of protection for performers and producers of phonograms, but requests sixty years for producers of movies and twenty-five years for broadcasting organizations. India's offer is almost identical to the protection India grants to these different groups under its domestic law. ${ }^{62}$ It is unclear whether the

$54 \quad$ See Article 5.2.1 of the draft IP chapter of the India-EU BTLA of November 2008; Article 11.2 of the draft IP chapter of the India-EU BTLA of April 2010.

55 See Article 22 of the consolidated Indian Copyright Act of 1957, amended by Act No. 49 of 1999, published in the Gazette of India (Extraordinary Part II - Section 3) dated 21 January 1957 [hereinafter Copyright Act of 1957]. See Article 5.2 of the draft IP chapter of the EU-Canada CETA from January 2010, as proposed by the EU (the most recent draft does not contain all Articles); Article 10.6 of the EU-South-Korea FTA; Article 218.1 of the EU-Colombia-Peru FTA; Article 234 of the EU-Central America AA. See Article 1 of the EEC Council Directive 93/98/EEC of 29 October 1993 harmonizing the term of protection of copyright and certain related rights (OJ L 290 of 24.11.1993) [hereinafter Directive 93/98/EEC on the term of protection].

57 See Article 12 of the TRIPS Agreement.

58 See Article 7.2 of the draft IP chapter of the India-EU BTIA.

59 Note that Indian law dealing with intellectual property issues is regulated in federal laws and therefore applicable to the entire territory of India rather than to only one substate.

60 See Article 7.3 of the draft IP chapter of the India-EU BTLA. Related rights in the EU are protected for the same duration, see Article 3 of the Directive 93/98/EEC on the term of protection.

61 See Article 5.3 of the draft IP chapter of the EU-Canada CETA; Article 219 of the EUColombia-Peru FTA; Article 235 of the EU-Central America AA. See Article 3 of the Directive 93/98/EEC on the term of protection. Note that the suggestion for broadcasting organizations is also identical to Article 10.7.1 of the EU-South-Korea FTA.

62 See Article 26, 37.2 and 38.2 of the Indian Copyright Act of 1957, as consolidated. Note that the protection for phonograms is sixty years, see Article 27 of the Indian Copyright Act of 1957 . 
European Union will accept the sixty years for movie producers since it would require an amendment of European Union law. ${ }^{63}$ Both the sixty years for producers of movies and the twenty-five years for broadcasting organizations go beyond the TRIPS standard. ${ }^{64}$ Another difference between the Indian and the EU proposal prevails in relation to the moment when the protection for producers of films should start. The EU suggests this moment to be the first fixation of a film, whereas India prefers its first "publication".

To sum up, the parties have agreed to protect the rights of authors of literary or artistic works for the lifetime of the author plus fifty years. This is in line with the TRIPS Agreement but stays behind the protection applied in Indian and European Union domestic law. The protection for producers of movies and broadcasting organizations, on the other hand, goes beyond the TRIPS Agreement. India has demanded a period of protection of sixty years for movies and twenty-five years for broadcasts. This is the only example in the draft IP chapter of the India-EU BTLA where India is a TRIPS-plus demandeur.

\subsubsection{Cooperation on the Collective Management of Rights}

India and the EU agree to cooperate on the collective management of rights. ${ }^{65}$ Accordingly, they shall facilitate arrangements between their collecting societies to ensure easier access, delivery of content and mutual transfer of royalties. This obligation is similar to the equivalent standard contained in the CARIFORUM-EC EPA, the EU-South Korea FTA and the draft EU-Canada CETA. ${ }^{66}$ In addition, the EU proposes to take reasonable measures to achieve rationalization and transparency in executing collecting societies' tasks, a provision to which India has not yet agreed. India's system of collecting societies is well established with three registered Indian copyright societies ${ }^{67}$ and legislative control mechanisms in place. ${ }^{68}$

\subsubsection{Particular Rights and Exceptions}

The European Union has suggested including the following rights in the IP chapter: the reproduction right, the right of broadcasting and communication to the public, and the resale right. India has not yet agreed to any of them. The three rights have

63 See Article 3.3 of the Directive 93/98/EEC on the term of protection, which sets out a term of protection of fifty years.

64 See Article 12 and 14.5 of the TRIPS Agreement require at least fifty years for the protection of cinematographic movies and Article 14.5 of the TRIPS Agreement at least twenty years for the protection granted to broadcasting organizations.

65 See Article 7.4 of the draft IP chapter of the India-EU BTIA.

66 This provision is similar to Article 143.B of the CARIFORUM-EC EPA; Article 10.8 of the EU-South Korea FTA and Article 5.5 of the draft IP chapter of the EU-Canada CETA, as proposed by the EU. A minor difference regards the language of taking "such reasonable measures as may be available to them to facilitate" instead of "endeavour to facilitate/achieve". The former language proposed by the EU in Article 7.4 of the draft IP chapter of the India-EU BTLA has not yet been accepted by India. Compared with the European Union, where each Member States has several collecting societies, the Indian system is much simpler than the EU system.

68 See P. Ishwara Bhat, "The Role of Collective Bodies in Protection of Intellectual Property Rights in India" Journal of Intellectual Property Rights, 2009, Vol. 14, 214-225, p. 219 and 221. 
been copy-pasted from European legislation: the first two are taken from the Information Society Directive and the latter right is a copy of Article 1 of the Directive $2001 / 84 / E C$ on the resale right. ${ }^{69}$ The provisions of both directives go beyond the TRIPS standard. The Information Society Directive deals with digital technologies that have not yet been addressed in the TRIPS Agreement. ${ }^{70}$ Directive 2001/84/EC on the resale right specifies how the right to control the resale of the product protected by copyright needs to be implemented. The Berne Convention does not set out whether or how to implement the resale right in national legislation. ${ }^{71}$ Therefore, the three rights proposed for the draft IP chapter of the India-EU BTIA are TRIPS-plus elements.

The right of reproduction, as proposed by the European Union in the draft IP chapter of the India-EU BTLA, ${ }^{72}$ and contained in the Information Society Directive, ${ }^{73}$ covers the right to authorise any reproduction, including temporary reproductions, by any means and in any form. The right applies to authors as well as to performers, phonogram producers, producers of films and broadcasting organizations. So far, no other European bilateral trade agreement sets out this right, except for the EU proposal made to Canada. ${ }^{74}$ At the same time, the European Union proposes to include an exception for temporary reproductions into the draft IP chapter of the India-EU BTLA. Temporary reproductions would be exempted from the reproduction right if they are 1) transient or incidental, 2) represent an essential part of a technological process, and 3) have as their sole purpose the transmission by an intermediary or the lawful use of a work without any economic significance. ${ }^{75}$ This exception is identical to Article 5.1 of the Information Society Directive and would be needed in order to balance the all-encompassing reproduction right set out in Article 7.4bis of the draft IP chapter of the India-EU BTLA, as proposed by the European Union. India's Copyright Act of 1957, as amended, does not yet contain such a broad reproduction right for all beneficiaries listed in the BTIA. Temporary reproductions are, for example, not covered by the reproduction right in the Act. ${ }^{76}$ This might be one reason why India has neither accepted the broad reproduction right nor the exception for temporary reproductions.

The second right proposed by the EU pertains to the right of broadcasting and communication to the public. They cover the same content but apply to two different groups of beneficiaries: the first applies to performers, phonogram producers,

69 EC Directive 2001/84/EC of the European Parliament and of the Council of 27 September 2001 on the resale right for the benefit of the author of an original work of art (OJ L. 272/32 of 13.10.2001) [hereinafter EC Directive on the resale right].

70 See section 6.3.1.2 for a summary of the issues dealt with in the Information Society Directive.

$71 \quad$ See Article 14 ter.2 of the Berne Convention.

72 See Article 7.4 bis of the draft IP chapter of the India-EU BTIA, as suggested by the EU.

73 See Article 2 of the Information Society Directive.

74 See Article 5.10 of the draft IP chapter of the EU-Canada CETA, as proposed by the European Union.

75 See Article 7.9.2 of the draft IP chapter of the India-EU BTIA, as proposed by the European Union.

76 See Article 14(a)(1) of the Indian Copyright Act of 1957, as amended. 
producers of films and broadcasting organizations; the second applies to authors. ${ }^{77}$ They cover the right to authorize any communication or broadcast of protected works to the public, by wire or wireless means, in such a way that the public may access the work from a place and at a time chosen by them. In addition to the verbatim text of Article 3 of the Information Society Directive, the European Union proposes to add yet two related rights: one for broadcasting organizations and one for phonogram users.

According to the proposed paragraph 1 of Article 7.5bis of the draft IP chapter, broadcasting organizations should also have the right to authorize the re-transmission of their broadcast. Subparagraph 2 of Article 7.5bis adds the right of phonogram users to only pay a single equitable remuneration when phonograms are used for broadcasting or any communication to the public. Both rights have also been proposed to Canada and were agreed upon in the EU-South Korea FTA. ${ }^{78}$ Should India agree to the proposed rights, some changes to its domestic law would be required. India recognizes the right of authorizing the re-broadcast by wire or wireless means but without specifying that the public can have access against payment of an entrance fee. ${ }^{79}$ The right of a single equitable remuneration for phonogram users is not specified in the Indian Copyright Act of 1957.

The last right proposed by the European Union is the resale right which so far has not been included in any European "new generation" bilateral trade agreement. ${ }^{80}$ Accordingly, any author of an original work benefits from the resale right, which applies to acts of resale by sellers, buyers, intermediaries or dealers in works of art. The right only applies to resale prices above a certain minimum amount, which is up to the discretion of the parties to the agreement. ${ }^{81}$ The European Union applies a minimum amount of EUR 10,000 and India a threshold of 10,000 rupees, which is about EUR 150.82 The European and Indian legislation on this right do not contradict each other, although the European Union's framework is clearly more elaborate compared with that of India. However, the European Union has proposed another provision in the India-EU BTLA which seems to accommodate some of the

See Article 7.5 of the draft IP chapter of the India-EU BTLA, as proposed by the European Union.

78 See Article 10.9.3 and 10.9.5 of the EU-South Korea FTA; Article 5.8.2 and 5.8.3 of the draft IP chapter of the EU-Canada CETA from January 2010, as proposed by the European Union. However, the new draft from February 2012, in which the parties have agreed upon the text of the Article addressing broadcasting and the communication to the public, does not anymore include the right to authorize the retransmission of their broadcast. Note that Article 220 of the EU-Colombia-Peru FTA and Article 237 of the EU-Central America $A A$ also address the same right, however in a quite different form than the equivalent proposed to India. However, the right of phonogram users to only pay a single equitable remuneration is included also in the latter two.

See Article 37.3(a) jo. 2 (dd) of the Indian Copyright Act of 1957, as amended.

80 See Article 7.6 of the draft IP chapter of the India-EU BTLA, as proposed by the European Union. Note that only the draft IP chapter of the EU-Canada CETA contains a similar proposal, see Article 5.6 as proposed by the EU. 
differences in the approaches chosen by the EU and India. Article 7.6.5 of the draft IP chapter of the India-EU BTIA allows the parties to determine for themselves the conditions under which such protection can be claimed.

According to the European Union's proposal, parties are allowed to provide for exceptions to these three rights. These national exceptions have to fulfill three conditions known as the "minor exception doctrine", which has been developed and interpreted in the context of Article 9.2 of the Berne Convention and Article 13 of the TRIPS Agreement. ${ }^{83}$ Accordingly, parties need to make sure that their exceptions are 1) limited to certain special cases, 2) do not conflict with a normal exploitation of the work and 3) do not unreasonably prejudice the legitimate interests of the right holder, in accordance with conventions and international treaties to which they are parties. ${ }^{84}$ Since the last sub-sentence alludes to the before mentioned international treaties, the jurisprudence developed by the WTO Dispute Settlement Body will be relevant when interpreting this obligation. Of major importance in this context is the Panel Report on US-Section 110, ${ }^{85}$ which assessed the meaning and application of each criterion of the three-step test. It did so in the context of two US rules exempting establishments that used home-style equipment and those that fell below a certain size from paying royalties for the music played there. If India accepts the mentioned rights, it is crucial that India develops exceptions that limit these rights in the case of, for example, teaching material.

In summary, the European Union wishes to include three rights into the India-EU BTIA that so far have hardly been included in other "new generation" bilateral trade agreements. These rights are the reproduction right, the right to broadcasting and communication to the public, and the resale right. Only the right to broadcasting and communication to the public has been contained in a similar manner in the EU-South Korea FTA. The three rights go beyond the standard set by the TRIPS Agreement and are copied from internal European legislation. Such legal transplants leave little policy space for India to implement the rights in accordance with its domestic preferences. If accepted by India, changes to its copyright law are necessary in order to accommodate the broad reproduction right and the remuneration for phonogram users. Equally important for India is the development of national exceptions that limit these rights, for example the exception addressing temporary reproductions.

\subsubsection{Interim Conclusions}

Most of the provisions addressing the protection of digital products, which have been proposed by the European Union, have not yet been accepted by India. This is particularly so as regards compliance with the Rome Convention, the WCT and WPPT, the protection against the circumvention of TPMs and against the alternation of RMI, and the provisions regarding the rights of reproduction, broadcasting and communication to the public and resale. Except for the requirement to comply with the Rome Convention, they are all TRIPS-plus elements, which in most cases would also

83 Both articles provide a framework for national exceptions, Article 9.2 of the Berne Convention in the context of the right of reproduction only and Article 13 of the TRIPS Agreement generally for all rights addressed in the copyright Section.

84 See Article 7.9.1 of the draft IP chapter of the India-EU BTLA, as proposed by the EU.

85 See WTO Panel Report, US-Section 110(5) Copyright Act. 
require changes to Indian copyright law. While compliance with the WCT and WPPT has also been included in other European "new generation" bilateral trade agreements, this is not the case for the detailed rules on the protection of TPMs and RMI, the reproduction or the resale right. The proposed rules have been heavily inspired by European internal legislation. Legislation-like provisions do not leave much discretion to implement the obligations from the BTIA in a way that takes the different domestic interests into account. If India accepts the proposed provisions, its domestic policy space would be reduced considerably.

On the other hand, with regard to the duration of the rights of producers of movies and broadcasting organizations, India is a TRIPS-plus demandeur: it has proposed sixty years of protection for producers of movies and twenty-five for broadcasting organizations. The sixty years of protection for movie producers also goes beyond the standard of protection required from European Union trading partners and provided for in European Union legislation. It is therefore unlikely that the EU will accept the sixty years of protection for movie producers.

\subsubsection{Provisions Relating to Trade Marks}

With only four provisions, the section dealing with the protection of trade marks in the draft IP chapter of the India-EU BTIA is by far the shortest. The issues dealt with are not new compared with the CARIFORUM-EC EPA and other EU bilateral trade agreements. They concern a) the compliance with international agreements, b) the registration procedure, c) well-known marks and d) exceptions to the rights conferred by a trade mark.

\subsubsection{Compliance with International Agreements}

While India does not want to commit to any obligation addressing international agreements, the European Union proposed that the parties shall accede to the Madrid Protocol and comply with the Trademark Law Treaty. ${ }^{86}$ They shall also make reasonable efforts to comply with the Singapore Treaty. India is not (yet) a party to any of the agreements. None of the agreements is prescribed by the TRIPS Agreement, therefore, these obligations go beyond the TRIPS standard. However, already since a couple of years, India is making efforts to accede to the Madrid Protocol in order to benefit from the quick, efficient and cost-effective extension of national registrations to all the Member States of the Madrid system. ${ }^{87}$ India therefore might be willing to accept the obligation with regard to the latter Protocol. The same is not true for the Trademark Law Treaty and the Singapore Treaty: India has not shown any intention to apply the rules of these treaties in its domestic law. These treaties aim at streamlining national trade mark registration procedures, the latter treaty focusing on updating those procedures to the new communication technologies. One compromise solution could be that the obligations are reduced to "best endeavour" commitments, similar to

See Article 8.1 of the draft IP chapter of the India-EU BTLA, as proposed by the European Union. Note that India has indicated that the Article needs to be deleted.

Even though India has enacted the Trademark (Amendment) Act, 2010, it has not yet notified the Act to the WIPO. In absence of such notification, the proposed Act has no applicability in India. See Perry4Law, "Implementation of The Madrid Protocol in India" Corporate Laws of India, 2012, available at <http://corporatelawsforindia.blogspot.nl> accessed on 20.11.2012. 
what CARIFORUM States, Colombia and Peru, Central American countries and Canada were able to achieve. ${ }^{88}$ Such a soft obligation would enable India to determine whether accession to and/or compliance with these international treaties is in its best interest.

\subsubsection{The Registration Procedure}

As regards the registration procedure, the EU has proposed the identical text on registration requirements as used in recent bilateral trade agreements with CARIFORUM States, South Korea, Colombia and Peru and Canada. ${ }^{89}$ These contain four requirements: 1) each final decision by a trade mark authority, including the refusal to register, shall be reasoned and in writing; 2) applicants must have an opportunity to contest and appeal against the refusal before a court; 3) the parties shall introduce an electronic database of trade mark applications and registrations as well as 4) an opposition procedure..$^{90}$ The TRIPS Agreement either does not deal with such procedural issues or leaves it to Member States' discretion whether they want to establish, for example, an opposition procedure. ${ }^{91}$ At least the requirements to set up an electronic database and an opposition procedure are TRIPS-plus elements. India has not yet accepted them but proposed its own provision, which nevertheless includes the same elements as suggested by the EU, namely an opposition procedure, written and reasoned communication with the applicant, an appeals procedure and a database. In fact, Indian trade mark law seems to comply with these requirements already, ${ }^{92}$ including the availability of a public search in earlier trade marks. ${ }^{93}$ Therefore, agreement between the two parties could be within reach.

\subsubsection{Protection of Well-known Marks}

The protection of well-known marks is primarily defined by referring to multilateral agreements within the WIPO framework. The European Union suggests that parties commit themselves to provide effective protection for well-known marks, as referred

88 See Article 144.E of the CARIFORUM-EC EPA. Canada was even able to drop the Trademark Treaty from the list entirely. See Article 6.1 of the draft IP chapter of the EUCanada CETA. Colombia, Peru and Central American countries were able to drop the Singapore Treaty from the list of commitments. See Article 202.3 of the EU-Colombia-Peru FTA and Article 238 of the EU-Central America AA. Note that Article 10.16 of the EUSouth Korea FTA contains the hard obligations.

89 See Article 144.A of the CARIFORUM-EC EPA; Article 10.15 of the EU-South Korea FTA; Article 204.2 of the EU-Colombia-Peru FTA; Article 139 of the EU-Central America $A A$; and Article 6.2 of the draft IP chapter of the EU-Canada CETA.

$90 \quad$ See Article 8.2 of the draft IP chapter of the India-EU BTIA.

91 Article 15.5 of the TRIPS Agreement leaves the choice to WTO Members as to whether they want to provide for an opposition procedure or not.

92 Regarding the opposition procedure, see Article 21 of the Indian Trade Marks Act of 1999, as amended by Act No. 47 of 1999, published in Gazette of India Extraordinary (Part II, Section 2) dated 30 December 1999 [hereinafter Trade Marks Act of 1999]. Concerning the communication with the applicant, see rule 40 of the Indian Trade Marks Rules 2002, published in the Gazette of India Extraordinary (Part II, Section 3, sub-Section (i)), dated 26 May 2002. See Article 91 jo. 83 of the Indian Trade Marks Act of 1999, as regard the intellectual property appellate board.

93 See Indian Controller General of Patents Design \& Trade Marks, Public Search of Trade Marks (2012), available at <http://ipindiaservices.gov.in/tmrpublicsearch/frmmain.aspx> accessed on 16.11.2012. 
to in Article 6bis of the Paris Convention and Article 16.2 and 16.3 of the TRIPS Agreement. ${ }^{44}$ Similar protection has also been agreed upon in some European "new generation" bilateral trade agreements. ${ }^{95}$ According to the EU, the parties shall apply the WIPO Joint Recommendation on well-known marks. This recommendation sets out criteria for determining whether a trade mark is well known and defines concepts contained in the TRIPS Agreement, for example "relevant sector of the public". ${ }^{96}$ Such defining elements are of a TRIPS-plus nature. Although India has not agreed to apply the WIPO Recommendation, it seems to already apply most of its concepts in its national trade mark law, in particular the criteria for well-known trade marks as well as the concept of relevant sector of the public. ${ }^{97}$ In brief, the parties do not appear to be too far removed from each other on the issue of well-known marks in order for them to agree.

\subsubsection{Exceptions}

According to the European Union's proposal, parties shall allow as a limited exception the fair use of descriptive terms. ${ }^{98}$ Furthermore, they may establish other limited exceptions, provided that they take account of the legitimate interests of the owner of the trade mark and third parties. The obligation to provide for the fair use of descriptive terms goes beyond the level of protection granted by the TRIPS Agreement, as the latter only grants the option to provide for such an exception. ${ }^{99}$ The EU proposal follows the equivalent provision in the CARIFORUM-EC EPA and other "new generation" agreements. ${ }^{100}$ India has not accepted the EU's proposal and suggested adopting the optional TRIPS standard. Indian trade mark law does not yet allow for the fair use of descriptive terms, other than in the context of the honest and concurrent use of a trade mark. ${ }^{101}$ If the parties agree to leave it to the parties whether to provide for the fair use of descriptive terms, India can balance the relevant stakeholders' interests before introducing such an exception.

See Article 8.3.1 of the draft IP chapter of the India-EU BTLA, as proposed by the European Union.

Article 205 of the EU-Colombia-Peru FTA is identical to Article 8.3.1 of the draft IP chapter of the India-EU BTLA, as proposed by the European Union. The European Union had also suggested the identical provision to Canada, Article 6.3 of the draft IP chapter of the EU-Canada CETA of January 2010, as proposed by the European Union. However, the latest draft does not contain that provision anymore. Article 240 of the EU-Central America AA only repeats the protection of Article 6bis of the Paris Convention but does not refer to Article 16.2 and 16.3 of the TRIPS Agreement. The provision is entirely absent from the EU-South Korea FTA.

See Articles 2 and 3 of the WIPO Joint Recommendation on well-known marks.

See Article 11.6-11.10 of the Indian Trade Marks Act of 1999, as amended.

See Article 8.4 of the draft IP chapter of the India-EU BTLA, as proposed by the European Union.

See Article 17 of the TRIPS Agreement.

See Article 144.F of the CARIFORUM-EC EPA. See also Article 6.3 of the draft IP chapter of the EU-Canada CETA; Article 10.16 of the EU-South Korea FTA; Article 206.1 of the EU-Colombia-Peru FTA. Note that Article 241 of the EU-Central America $A A$ merely repeats the TRIPS standard.

See Article 12 of the Indian Trade Marks Act of 1999, as amended. 


\subsubsection{Interim Conclusions}

The provisions dealing with the protection of trade marks are not new in comparison with other "new generation" bilateral trade agreements concluded or negotiated by the European Union. Even though not new, India has not yet agreed to any of the propositions made by the EU. Particularly the compliance with international agreements and the WIPO Joint Recommendation on the protection of well-known trade marks seem to be issues India does not want to compromise on. Together with some elements of the registration procedure, these are also the main TRIPS-plus elements in the EU proposals. With the exception of the compliance with international agreements, it seems quite possible that the parties will agree on common language since India often already complies in its domestic law with the requests made by the European Union. In order to maintain the largest possible policy space, India could strive for a best-endeavour obligation with regard to compliance with the international agreements and for adopting an optional commitment to introduce the fair use of descriptive terms.

\subsubsection{Provisions Relating to Geographical Indications}

Reaching agreement on the provisions addressing the registration and protection of geographical indications seems to be very difficult. Both the European Union and India have a strong interest in the protection of GIs: together they concentrate the world largest number of GIs. ${ }^{102}$ The rules agreed upon in the draft IP chapter of the India-EU BTLA will therefore have an impact on a considerable number of registered geographical indications. Similar to the copyright and trade mark sections, it is the European Union that has proposed detailed language on the protection of GIs, often copied from its domestic legislation, the EC Regulation 510/2006. These provisions go beyond the TRIPS Agreement on most issues, one of them being the proposed equal treatment of GIs on agricultural products and GIs on wines and spirits. In its proposal, the European Union does not follow closely the model set in the CARIFORUM-EC EPA: while the scope and level of protection are similar, the draft IP chapter of the India-EU BTIA differs from the CARIFORUM-EC EPA in so far as it does not address the term of protection and the use of geographical indications on the Internet. ${ }^{103}$ The issues discussed are: a) the recognition of geographical indications, b) the scope and level of protection, c) exceptions, and d) the relationship with trade marks. ${ }^{104}$

\subsubsection{Recognition of Geographical Indications}

While parties are in agreement on recognizing each other's geographical indications, they have not yet accepted one text defining the conditions attached to recognition. India wishes to register those geographical indications that have also been registered by the other party in accordance with its relevant laws, without specifying them in a

102 Clearly, the European Union is the world leader with 5674 registered GIs in 2008. India had registered 146 GIs by October 2010.

103 The latter issue has been deleted from Article 9.12 of the draft IP chapter of the IndiaEU BTIA from January 2010, even though it was still part of the draft IP chapter of the India-EU BTIA from April 2010.

104 Institutional provisions are also addressed in the draft IP chapter but will be finalized at a later stage. See Article 9.11 of the draft IP chapter of the India-EU BTLA. 
list. ${ }^{105}$ The European Union, on the other hand, proposes that the parties recognize the geographical indications listed in Annex III and IV to the draft IP chapter of the India-EU BTLA. ${ }^{106}$ These annexes do not yet contain lists of specific GIs but clearly indicate that they will contain GIs pertaining to agricultural products and foodstuffs, as well as to wines and spirits. At least for the European Union, it can be expected that its lists for wines and spirits and agricultural products and foodstuffs will look very similar to the one stipulated in the EU-South Korea FTA (and previous agreements on trade in wines and spirits), including indications such as Bordeaux, Rioja, Ouzo, Tiroler Speck, Roquefort, Feta and Prosciutto di Parma. ${ }^{107}$

Furthermore, according to the EU's proposal, recognition is made dependant on 1) a completed objection procedure and 2) an examination of the proposed GIs. ${ }^{108}$ The same requirements would apply to new geographical indications, which are added to the list of GIs protected by both parties later. ${ }^{109}$ First, the criteria for the objection procedure proposed by the EU are set out in detail in Annex II. They address procedural requirements, such as time limits and mandatory information on the product class, and substantial requirements, such as the admissibility of statements of objection. ${ }^{110}$ The TRIPS Agreement does not require the establishment of an objection procedure; setting out in detail elements of this procedure goes beyond the TRIPS standard. India suggests a similar opposition procedure to the one proposed by the EU: the procedure shall fulfill the conditions set out in the respective legislation of the parties. ${ }^{111}$ In fact, India's GI Act of 1999112 already provides for an opposition procedure that can be regarded as an objection procedure. However, the procedure does not set out the same grounds of opposition that would be required under the objection procedure under Annex II proposed by the European Union; these elements might have to be added to India's GI legislation if the parties agreed upon the European Union's proposal.

The requirement of completing an objection procedure is beneficial for the parties: they can check whether the GIs registered in the other party comply with their own rules and do not conflict with already existing GIs. At the same time, setting out

See Article 9.2.1 and 9.2.2 of the draft IP chapter of the India-EU BTLA, as proposed by India.

See Article 9.2 of the draft IP chapter of the India-EU BTLA, as proposed by the EU. See Annex 10-B of the EU-South Korea FTA.

See Article 9.2.3 and 9.2.4 of the draft IP chapter of the India-EU BTLA, as proposed by the EU.

See Article 9.3 of the draft IP chapter of the India-EU BTLA, as proposed by the EU. The criteria set out in Annex II shall be included in the objection procedure: the names proposed for protection shall be listed, information about the product class shall be given, an invitation for any person to lodge statements shall be published, objections shall be forwarded within two months and the admissibility shall be limited to particular statements of objection which shall be evaluated in relation to the territory where the rights are protected. Admissible statements of objection address one of the following situations: the GI conflicts with a plant variety, a homonymous name which misleads the consumer, a renowned and reputed trade mark, a prior trade mark or generic names.

See Article 9.2.1 of the draft IP chapter of the India-EU BTIA, as proposed by India. See Article 14 of The Geographical Indications of Goods (Registration and Protection) Act, 1999, enacted by Act No. 48 of 1999, published in Gazette of India Extraordinary (Part II, Section 1) [hereinafter GI Act of 1999]. 
detailed requirements that such a procedure needs to fulfill reduces the policy space of the parties considerably: they are not able to fill in the procedure in accordance with their domestic preferences. India's proposal, however, would preserve this discretion. Not all "new generation" bilateral trade agreements require the completion of an objection procedure: the bilateral trade agreements with South Korea and Canada do not provide for a similar standard. ${ }^{113}$

The second condition for recognition according to the EU's proposal pertains to an examination of the listed geographical indications. ${ }^{114}$ It is not entirely clear what exactly should be examined. It may be that the parties assess whether the registered GIs are consistent with that party's GI legislation. The GI legislation of both parties, in fact, must meet certain criteria, which are set out in the draft IP chapter of the India-EU BTLA.115 Those criteria are listed in Annex I part B and require, for example, to provide a register listing GIs protected in the territory and an administrative process to verify the GI's identity. ${ }^{116}$ These requirements are new features of EU bilateral trade agreements as the CARIFORUM-EC EPA did not yet contain similar obligations; so far, only the EU-South Korea FTA and the EU-Central America $A A$ contain almost identical elements. ${ }^{117}$ India has not yet agreed to these provisions, which prescribe in a very detailed fashion what administrative, control, enforcement and substantive criteria domestic law has to fulfill. As the TRIPS Agreement does not address such conditions, the EU goes beyond the TRIPS standard in its request. Also here, setting out specific elements that the laws of the parties need to incorporate is highly prescriptive and reduces domestic policy space significantly.

To sum up, India and the European Union still considerably differ on the level of detail with which the recognition of each other's registered geographical indications needs to be regulated. India simply suggests recognizing the registered geographical indications in accordance with each party's relevant laws. The European Union, on the other hand, wishes to list the geographical indications to be registered. Furthermore, according to the EU, recognition is made dependent on two

113 See Article 10.18.3 and 10.18.4 of the EU-South Korea FTA and Article 7.1 of the draft IP chapter of the EU-Canada CETA, as proposed by the EU. However, the requirement of completing an objection procedure has been included in Article 208 of the EU-Colombia-Peru FTA and Article 245 of the EU-Central America AA.

114 See Article 9.2.3 and 9.2.4 of the draft IP chapter of the India-EU BTIA, as proposed by the EU.

115 See Article 9.2.1 and 9.2.2 of the draft IP chapter of the India-EU BTIA, as proposed by the EU.

116 The criteria listed in Annex I part B cover a register listing GIs, an administrative process to verify the GI's identity, a requirement that a registered name corresponds to a specific product, the existence of control provisions on production, enforcement of registered names, the right of operators conforming to the specification to use the GI and an objection procedure. Furthermore, Annex I part B lists certain obligations already covered by the agreement, such as the protection against commercial use, misuse, false or misleading use and any other practice, the rule that protected names cannot become generic, provisions concerning the registration of homonymous terms and the relationship between trade marks and GIs.

117 The first set of elements listed in the previous footnote is identical to the ones included in Article 10.18.6 of the EU-South Korea FTA and Article 244.2 of the EU-Central America $A A$, whereas the EU has not suggested such elements in the draft IP chapter of the EU-Canada CETA, the EU-Colombia-Peru FTA and the CARIFORUM-EC EPA. 
procedures: an objection and an examination procedure. For both procedures, specific criteria are set out. These specific requirements go beyond the TRIPS standard and have also been included in some recent "new generation" European bilateral trade agreements. If India accepts the EU's proposal, it gives up considerable policy space to determine the domestic interests with regard to the content of such procedures.

\subsubsection{Scope and Level of Protection}

The level of protection is the same for all geographical indications included in the Annexes. In that respect, no distinction is made between the level of protection for GIs on wines and spirits on the one hand, and GIs on agricultural products and foodstuffs on the other. ${ }^{118}$ This equal treatment is in line with a trend that started with the CARIFORUM-EC EPA and which is continued in recent European bilateral trade agreements. ${ }^{119}$ Not only the European Union is a strong supporter of equal treatment of all GIs, India has promoted an amendment of the TRIPS Agreement in that respect for many years. ${ }^{120}$ Currently, the TRIPS Agreement applies a different level of protection for GIs on wines and spirits compared with GIs on agricultural products and foodstuffs.

The level of protection proposed by the European Union can be distinguished into three categories of protection: 1) protection against commercial use, 2) "additional protection", and 3) protection against unfair competition. These forms of protection are identical to the protection set out in the EC Regulation 510/2006, which applies to the protection of GIs on agricultural products and foodstuffs within the European Union. Protecting GIs according to these categories is a new feature in European bilateral trade agreements: the protection agreed upon in the recently concluded free trade agreements with the CARIFORUM States, South Korea and Central American countries still included the TRIPS standard as explained below. ${ }^{121}$ However, the new approach of the three-tiered protection seems to be Europe's preferred approach for future agreements: it has also been included in the agreement with Colombia and Peru and proposed to Canada. ${ }^{122}$ India has not yet accepted the proposed level of protection and suggests following the standard of protection set out in the TRIPS Agreement.

See Article 9.1 of the draft IP chapter of the India-EU BTIA.

See Article 145 of the CARIFORUM-EC EPA; Article 10.18 of the EU-South Korea FTA; Article 242.1 of the EU-Central America $A A$ and Article 7.1 of the draft IP chapter of the EU-Canada CETA, as suggested by the EU. An exception is the EUColombia-Peru FTA where GIs on wines and spirits are treated differently from GIs on agricultural products and foodstuffs, in accordance with the level prescribed by the TRIPS Agreement. See Article 210 of the EU-Colombia-Peru FTA and Article 23 of the TRIPS Agreement.

See WTO Secretariat, Communication from Bulgaria, Cuba, Cyprus, the Czech Republic, the European Communities and their Member States, Georgia, Hungary, Iceland, India, Kenya, Liechtenstein, Malta, Mauritius, Pakistan, Romania, the Slovak. Republic, Slovenia, Sri Lanka, Switzerland, Thailand and Turkey (Geneva, 24 June 2002) [IP/C/W/353].

See Article 145.B.3 of the CARIFORUM-EC EPA; Article 10.21.1 of the EU-South Korea FT; Article 246.1 of the EU-Central America AA.

See Article 210.1 of the EU-Colombia-Peru FTA and Article 7.4.1 of the draft IP chapter of the EU-Canada CETA, as proposed by the EU. 
First, the EU suggests that geographical indications are protected against:

"any direct or indirect commercial use of a protected name:

for comparable products not compliant with the product specification of the protected name, or

in so far as such use exploits the reputation of a geographical indication;"123

Such protection goes beyond the protection afforded by the TRIPS Agreement in two aspects. First, Article 22.2(a) of the TRIPS Agreement protects GIs against their use for goods that originate in an area other than the true place of origin and where such use misleads the public as to the origin of that good. This latter element of misleading the public, which needs to be fulfilled under the TRIPS Agreement, is lacking in the draft IP chapter of the India-EU BTLA. Second, the draft IP chapter of the India-EU BTLA covers a situation of infringing use that is not contained in the TRIPS Agreement, namely the exploitation of the GI's reputation. Therefore, the EU proposal classifies more situations as infringing use than the TRIPS Agreement does and hence broadens the rights of right holders. India, on the other hand, suggests that parties to the draft IP chapter of the India-EU BTIA adhere to the level of protection of the TRIPS Agreement. ${ }^{124}$ This is in line with its national GI Act of 1999 which applies the same protection as specified in Article 22.2 of the TRIPS Agreement. ${ }^{125}$

Second, in addition to the protection against commercial use, the EU suggests that all GIs listed are also protected against misuse, imitation or evocation, even if the true origin of the product is indicated, translated or accompanied by "style", "type", "method", "imitation", "flavour", "like" or "similar". ${ }^{26}$ This level of protection can be classified as "additional protection". In contrast to the EU's proposal, the TRIPS Agreement grants this protection only to wines and spirits. ${ }^{127}$ India, on the other hand, proposes to follow the TRIPS regime, ${ }^{128}$ even though its domestic GI Act of 1999 does not limit "additional protection" to wines and spirits but makes it available to any product, under the condition that they have been specified by the Central Government. ${ }^{129}$ In other words, India's Central Government has the discretion to declare which GIs shall benefit from "additional protection". This broad discretion

Article 9.4(a) of the draft IP chapter of the India-EU BTLA, as proposed by the EU, and also Article 13.1(a) of EC Regulation 510/2006.

See Article 9.4 of the draft IP chapter of the India-EU BTLA, as proposed by India. See Article 22.1 (a) of the Indian GI Act of 1999.

See Article 9.4(b) of the draft IP chapter of the India-EU BTIA, as protected by the EU. Note that this protection is again identical to the respective protection in Article 13.1(b) of the EC Regulation 510/2006.

See Article 23.1 of the TRIPS Agreement. Note that also in Article 203.1 of the EUColombia-Peru FTA, only GIs for wines and spirits are granted additional protection. This is not the case for the CARIFORUM-EC EPA, the EU-South Korea FTA, the EUCentral America $A A$ and the draft IP chapter of the EU-Canada CETA, which reflect equal protection. See Article 145.B.3 of the CARIFORUM-EC EPA; Article 10.21.1 of the EU-South Korea FTA; Article 246.1(b) of the EU-Central America AA and Article 7.4.1(b) of the draft IP chapter of the EU-Canada CETA, as proposed by the EU. See Article 9.4 of the draft IP chapter of the India-EU BTLA, as proposed by India. See Articles 22.3 juncto 22.2 of the Indian GI Act of 1999. 
of the Central Government could, in fact, also be used to grant only valued Indian GIs "additional protection" rather than all GIs for agricultural products and foodstuffs from anywhere in the world. ${ }^{130}$ Making the level of protection conditional upon the Central Government's approval does not seem to fulfill the required equal protection between GIs for wines/spirits and agricultural products/foodstuffs as foreseen by Article 9.4(b) of the draft IP chapter of the India-EU BTIA, as proposed by the EU. This might be one reason why India has not accepted the suggestion made by the European Union.

Third, the EU further proposes to protect the listed GIs against all practices that are liable to mislead the consumer as to the product's origin. ${ }^{131}$ The protection extends to:
"Any false or misleading indication as to the provenance, origin, nature or essential qualities of the product, on the inner or outer packaging, advertising material or documents relating to the product concerned and the packing of the product in a container liable to convey a false impression as to its origin;"'132

Such protection might be regarded as an equivalent to the protection against any act of unfair competition within the meaning of Article 10bis of the Paris Convention, which has been incorporated into the TRIPS Agreement by reference. ${ }^{133}$ According to Article 10bis of the Paris Convention, any act contrary to honest practices constitutes an act of unfair competition. Examples of such behaviour are (1) the creation of confusion with or the discreditation of the establishment, goods or industrial or commercial activities of a competitor by making false allegations, ${ }^{134}$ or (2) the use of indications in the course of trade that mislead the public as to the nature, manufacturing process, characteristics, suitability or the quantity of the goods. ${ }^{135}$

Despite these examples, the Paris Convention grants countries considerable discretion in determining what behaviour is covered by "contrary to honest practices". India also specifies which acts constitute acts of unfair competition under the Indian GI Act of 1999. ${ }^{136}$ However, the list of acts is not exhaustive and gives enough freedom to add other acts. Taking this broad scope of interpretation into consideration, it is fair to say that the interpretation proposed by the European Union in the draft IP

See K. Das, "Select Issues and Debates around Geographical Indications with Particular Reference to India" Journal of World Trade, 2008, Vol. 42 (3), 461-507, p. 485. An exception are the geographical indications for wines and spirits, which must be granted additional protection due to the TRIPS standard. See Article 9.4(c) and (d) of the draft IP chapter of the India-EU BTIA, as proposed by the EU. These provisions are identical to Article 13.1(c) and (d) of the EC Regulation $510 / 2006$.

See Article 9.4(c) of the draft IP chapter of the India-EU BTLA.

See Article 22.2(b) of the TRIPS Agreement. Article 145.B.3(a) of the CARIFORUM-EC EPA; Article 10.21.1(c) of the EU-South Korea FTA and Article 246.1(c) of the EUCentral America $A A$ also refer to Article 10bis of the Paris Convention. Only the EU proposal in the draft IP chapter of the EU-Canada CETA, together with the EU proposal in the draft IP chapter of the India-EU BTLA, do not refer to the Paris Convention explicitly but introduce the new third element of protection as cited above. 
chapter of the India-EU BTIA could limit India's freedom of implementation. At the same time, India could argue that its current law on the matter already fulfills the standard required by the European Union since it is even broader.

In conclusion, the level of protection for geographical indications in the draft IP chapter of the India-EU BTLA has not yet been agreed upon. While India suggests protecting GIs according to the TRIPS standard, the European Union has proposed a three-tiered type of protection that contains some TRIPS-plus features. Most importantly, the EU proposes to protect all geographical indications equally, no matter whether they indicate the origin of wines or spirits, or agricultural products. Also the protection of commercial use is broader than the TRIPS standard. In view of the fact that India has supported an amendment of the TRIPS Agreement to achieve equal protection for all GIs, it seems likely that the parties will find a common solution. Whether it will contain the three-tiered protection proposed by the EU or follow the language of the TRIPS Agreement remains to be seen.

\subsubsection{Exceptions}

The European Union also suggests a number of exceptions that should limit the scope of protection outlined above; however, the proposed exceptions do not cover all exceptions contained in the TRIPS Agreement. In contrast, India suggests applying the protection afforded by the TRIPS Agreement; therefore all TRIPS exceptions would be applicable. ${ }^{137}$ This is also in accordance with the Indian GI Act of 1999 which adheres to the TRIPS standard in that respect. ${ }^{138}$ There are two exceptions that have been omitted from the EU proposal: the right of a person to use her/his name in the course of trade and the use of generic terms. ${ }^{139}$ As regards the latter exception, the European Union requires that names once registered cannot anymore become generic in the language of a party. ${ }^{140}$ However, the exception in the TRIPS Agreement applies to both new and existing GIs. Thereby, the draft IP chapter of the India-EU $B T L A$ limits the application of the exception to new GIs, to the detriment of registered GIs. ${ }^{141}$ This seems to be at odds with the purpose of the exception, which arguably is most relevant for GIs that have been used (and often registered) for a number of years.

Where the draft IP chapter of the India-EU BTLA omits a TRIPS exception, it is not anymore immediately available in the context of the India-EU BTLA and hence constitutes a TRIPS-plus feature. Whether parties can still rely on the omitted TRIPS exception as a defence in a dispute involving a breach of a rule of the India-EU BTLA

See Article 9.4 of the draft IP chapter of the India-EU BTIA, as proposed by India. See for example Article 26.2 of the GI Act of 1999 for generic names.

See Article 24.8 and Article 24.6 of the TRIPS Agreement.

This rule also applies to the European Union's internal protection of geographical indications, see Article 13.2 of the EC Regulation 510/2006 and has also been proposed to Canada and included in the EU-Colombia-Peru FTA and the EU-Central America AA. See Article 7.4.3 of the draft IP chapter of the EU-Canada CETA, as proposed by the EU; Article 207(h) of the EU-Colombia-Peru FTA, and Article 246.3 of the EU-Central America $A A$. Interestingly enough, the CARIFORUM-EC EP $A$ still includes the full TRIPS exception, whereas the EU-South Korea FTA was the first agreement to leave out the equivalent exception. See Article 145.C.1 of the CARIFORUM-EC EPA.

See Article 24.6 of the TRIPS Agreement. 
depends on the specific provision at issue (whether the exception is for the use of a person's name or for the use of generic terms) and the conflict rule established by the India-EU BTIA, the TRIPS Agreement or public international law. ${ }^{142}$ Even if the omitted TRIPS exceptions cannot be used as a defence in disputes involving the India-EU BTLA, prior agreements to which both partners are parties, such as the WTO Agreement, can play a role in the interpretation of FTA rules. However, if the India-EU BTLA does not contain such an exception, interpretation cannot help in making the TRIPS exception available for the parties to the BTIA. The same is true if an exception is explicitly denied for a certain category of GIs; it will be difficult to come to a different interpretation by taking the TRIPS exception into account.

The first exception included in the European Union's proposal pertains to homonymous geographical indications. These are geographical indications that consist of the same name but refer to two different locations. According to this provision, homonymous GIs shall be protected simultaneously if they 1) have been used in good faith, 2) practical conditions of use have been agreed upon under which the homonymous GIs will be differentiated from each other, and 3) their use is not misleading for the consumer. ${ }^{143}$ This protection is almost identical to the TRIPS exception of Article 23.3 juncto Article 22.4 of the TRIPS Agreement, which India has suggested to adhere to. The only difference between the EU proposal and the TRIPS standard is that the TRIPS Agreement does not include the first requirement, the use of both GIs in good faith; neither does the Indian GI Act of 1999.144 Hence, the proposed exception by the EU is stricter than the TRIPS standard as it asks for an additional condition to be fulfilled. Moreover, the EU suggests that in the case of negotiations with third countries, the other party shall be informed about homonymous geographical indications and given the opportunity to comment before the name is protected. ${ }^{145}$ This is a new TRIPS-plus obligation which has also been included in some "new generation" bilateral trade agreements. ${ }^{146}$ It is however unclear what the legal nature of the possibility to comment entails, other than political pressure.

The European Union proposes another exception that is identical to the respective TRIPS exception. It addresses the parties' ability to terminate the protection of geographical indications that are not or cease to be protected in their country of

For a detailed analysis of the questions that the judiciary body will have to address, see section 3.3.6.5 of this book on invoking TRIPS exceptions in the context of agreements on trade in wine and/or spirits and section 5.3.2.3.4 of this book for the CARIFORUM-EC EPA context.

See Article 9.4.3 of the draft IP chapter of the India-EU BTIA, as proposed by the EU. See Article 10 of the Indian GI Act of 1999.

See Article 9.4.4 of the draft IP chapter of the India-EU BTLA, as proposed by the EU. See Article 7.4.9 of the draft EU-Canada CETA, as proposed by the EU, and Article 210.2 of the EU-Colombia-Peru FTA. Article 145.C.3 of the CARIFORUM-EC EPA and Article 10.21.3 of the EU-South Korea FTA does not include this addition. Note that the EU-Central America $A A$ neither includes the exception for homonymous GIs, nor the obligation to inform the other party in case of negotiations with third countries include homonymous geographical indications. 
origin. ${ }^{147}$ Other European bilateral trade agreements have also included this exception. ${ }^{148}$

Two other exceptions proposed by the European Union are not taken from the TRIPS Agreement but from the EC Regulation 510/2006. These address names of plant varieties or animal breeds and the rights of operators. The first exception suggests that parties can exclude those GIs from protection that are identical to the name of a plant variety or animal breed and, as a result, are likely to mislead the consumer. ${ }^{149}$ Since the CARIFORUM-EC EP $A,{ }^{150}$ this exception figures in most recent European bilateral trade agreements. ${ }^{151}$ India has not agreed to it yet; neither the Indian GI Act of 1999 nor the GI Rules of $2002^{152}$ contain the prohibition to issue a GI for the name of plant varieties or animal breeds if this registration would result in misleading the consumer.

Even if India accepted the provision, it would be under no obligation to adapt its domestic law because the draft IP chapter of the India-EU BTLA does not prescribe the exception but grants parties discretion to implement it into their national laws. However, Indian collective bodies, that want to apply for GI protection in the EU, would need to make sure that the name of the geographical indication is not identical to the name of a plant variety or an animal breed if that would mislead the consumer. This requirement does not seem to cause many problems as the name of a plant variety or animal breed often involves a technical classification which usually is not chosen to be used as the GI. An example is Basmati: if the word Basmati was to be registered as a GI in Europe, it would include a description of which varieties of the Basmati rice could benefit from this protection, for example Basmati 217, Kasturi, Pusa Basmati. ${ }^{153}$ A GI therefore usually displays a general common name rather than the specific name of a plant variety. At the same time, it can be beneficial for countries to protect a plant by the two forms of protection: plant variety protection protects the plant material whereas a GI protects the produce of such plants. ${ }^{154}$

The second exception proposed by the European Union and taken from EC Regulation $510 / 2006^{155}$ is the right of an operator, who markets agricultural products,

147 See Article 9.4.5 of the draft IP chapter of the India-EU BTLA, as proposed by the European Union. See also Article 24.9 of the TRIPS Agreement.

148 See Article 10.21.4 of the EU-South Korea FTA; Article 212.2 of the EU-Colombia-Peru FTA and Article 7.4.8 of the draft IP chapter of the EU-Canada CETA, as proposed by the EU. Note that the CARIFORUM-EC EPA and the EU-Central America AA do not provide for this exception. See Article 9.3.2 of the draft IP chapter of the India-EU BTLA, as proposed by the EU. See Article 145.C.2 of the CARIFORUM-EC EPA.

151 See Article 10.24.3 of the EU-South Korea FTA and Article 7.6.3 of the draft IP chapter of the EU-Canada CETA.

152 See The Geographical Indications of Goods (Registration and Protection) Rules, 2002, Ministry of Commerce \& Industry New Delhi, 8 March 2002 [hereinafter GI Rules of 2002].

153 See M.-V. Delphine, "From Plant Variety Defintion to Geographical Indication Protection: A Search for the Link Between Basmati Rice and India/Pakistan" Journal of World Intellectual Property, 2008, Vol. 11 (4), 321-344, p. 328. 
foodstuffs, wines, aromatised wines or spirit drinks, to use the protected name if the products fulfill the corresponding specifications. ${ }^{156}$ This right of an operator is not contained in the TRIPS Agreement. It limits the scope of rights granted to the registered owner of the geographical indication as it allows for the use of the GI by operators that otherwise would have to ask the owner for permission. The European Union has proposed the same right to Canada and included it in the agreement with South Korea but not in the agreements with CARIFORUM States, Colombia and Peru and Central American countries. ${ }^{157}$ India, instead, suggests that the use of geographical indications shall be governed by the laws of the parties. ${ }^{158}$

In summary, India and the European Union have clearly different views on which exceptions should be available to GI owners. India wishes to follow the scope of protection as set out in the TRIPS Agreement. The proposal forwarded by the European Union, on the other hand, specifies in detail which TRIPS exceptions shall be applicable in the relationship between the EU and India. This means that certain TRIPS exceptions have been omitted from the draft IP chapter of the India-EU $B T I A$ as proposed by the EU. This is a TRIPS-plus feature as these provisions are not immediately available to the parties in a dispute involving the breach of a BTIArule. Similarly, the exceptions taken from internal EU legislation also go beyond the TRIPS standard. India should establish their usefulness for its domestic context before accepting them and investing in amending its national GI system. The exceptions included in the bilateral agreement differ considerably among the European "new generation" bilateral trade agreements. This could indicate that the exceptions included can indicate very well the preferences and bargaining power of the partner countries of the European Union.

\subsubsection{The Relationship with Trade Marks}

There are three rules suggested by the European Union that pertain to the relationship between geographical indications and trade marks: one addressing posterior trade marks, a second dealing with prior trade marks, and a third rule creating an exception to the rule on prior trade marks. These rules stem from the EC Regulation 510/2006 159 and are similarly provided for in the TRIPS Agreement as well as in recent and future European bilateral trade agreements, however with certain differences in terminology. They also come close to the Indian GI Act of 1999. Nevertheless, India has not yet accepted the European proposal and offers its own provisions.

According to the first rule suggested by the European Union, a trade mark that is applied for after a geographical indication has been granted (a posterior trade mark) will not be registered or, in case of already registered trade marks, will be invalidated. ${ }^{160}$ This rule applies to trade marks that fulfill the following cumulative conditions: a) the application date for the trade mark is after the application date of

\footnotetext{
156 See Article 9.5.1 of the draft IP chapter of the India-EU BTIA, as proposed by the EU.

157 See Article 7.3.1 of the draft IP chapter of the EU-Canada CETA, as proposed by the EU; Article 10.20 of the EU-South Korea FTA.

158 See Article 9.3 of the draft IP chapter of the India-EU BTLA, as proposed by India.

159 See Article 14 of the EC Regulation 510/2006.

160 See Article 9.7.1 juncto 9.7.2 juncto 9.7.3 of the draft IP chapter of the India-EU BTLA, as proposed by the EU.
} 
the geographical indication (a posterior trade mark); ${ }^{161} \mathrm{~b}$ ) the use of the trade mark refers to one of the three situations mentioned in Article 9.4.1 of the draft IP chapter of the India-EU BTLA, as suggested by the EU; and c) the trade mark is applied for like products. As regards the second criterion, the three situations are: 1) the trade mark incorporates the protected name of the GI and makes commercial use of it, 2) it misuses the GI even though the true origin is indicated, or 3) it makes other misleading use of the GI. ${ }^{162}$ These situations are identical to the proposed three levels of protection available for GIs under the draft IP chapter of the India-EU BTLA. ${ }^{163}$ Hence, if a trade mark interferes with the protection foreseen for GIs, the trade mark will not be registered.

It has to be noted that it is a new feature in European bilateral trade agreements to refer to the three levels of protection as a condition for applying the posterior trade mark rule. ${ }^{164}$ The CARIFORUM-EC EPA still stipulated that the trade mark needed to be identical with, similar to or contain the GI. ${ }^{165}$ This previous approach was more in line with the TRIPS standard, which also applies the criteria of consisting of or containing a GI. ${ }^{166}$ The TRIPS Agreement stipulates another element which the draft IP chapter of the India-EU BTIA does not include: the products for which the trade mark is applied do not have the origin to which the GI refers. With the last condition, the TRIPS Agreement ensures that only trade marks that are registered in bad faith are affected by the rule. In that respect, the draft IP chapter of the India-EU $B T L A$, as proposed by the EU, is broader in its scope than the TRIPS Agreement because it covers trade marks registered in bad and good faith. The Indian GI Act of 1999 closely follows the TRIPS standard. ${ }^{167}$ Surprisingly, India has not proposed any rule relating to posterior trade marks in the draft IP chapter of the India-EU BTLA; the provisions suggested seem to have as their primary purpose the coexistence of

161 Paragraphs 2 and 3 of Article 9.7 of the draft IP chapter of the India-EU BTLA, as proposed by the EU, specify the application date for established and new GIs further. See Article 9.4.1 of the draft IP chapter of the India-EU BTIA, as proposed by the EU.

163 See section 6.3.3.2 of this book.

164 Since its first introduction, this rule applying to posterior trade marks has found its way into the agreements with South Korea, Central American countries and Colombia and Peru, and has also been suggested to Canada. See Article 10.23.1 and 2 of the EU-South Korea FTA; Article 248.1 of the EU-Central America AA; Article 211.1 of the EUColombia-Peru FTA, and Article 7.4 .4 of the draft IP chapter of the EU-Canada CETA, as proposed by the EU.

165 See Article 145.D.2 of the CARIFORUM-EC EPA.

166 See Article 23.2 of the TRIPS Agreement.

167 See Article 25(a) of the GI Act of 1999. Note that this Article adds another element that needs to be fulfilled: the consumer must be mislead or confused by the concurrent use of the trade mark and the GI. According to Article 22.1(a) of the GI Act of 1999, the Indian rule is only applicable to GIs protected under the general protection against commercial use; once dealing with a GI that enjoys additional protection according to Article 22.3 juncto 22.2 of the GI Act of 1999 , all trade marks shall be refused or invalidated, regardless of whether they are registered in good faith or whether they mislead the public (Article 25(b) of the GI Act of 1999). Nevertheless, according to Article 26.4 of the GI Act of 1999, an exception applies to these rules: if five years have passed since the date that the infringement or the registration of the trade mark has become known to the GI proprietor, then no action will be taken against that trade mark anymore. 
trade marks and geographical indications. ${ }^{168}$ However, it has to be noted that the rules suggested by India are not yet treaty-like provisions and therefore lack the precision of what trade marks the respective provision refers to.

According to the European Union's proposal, the second conflict rule addresses prior trade marks, which shall be treated differently from posterior ones. A prior trade mark may be used next to the protected geographical indication if a) the trade mark has been applied for, registered or established by use before the date of application for protecting the GI, b) the use of the trade mark refers to one of the situations in Article 9.4.1 of the draft IP chapter of the India-EU BTIA, as proposed by the EU, and c) no grounds for invalidating or revoking the trade mark apply. ${ }^{169}$ Two remarkable differences with equivalent provisions in other agreements can be noted. ${ }^{170}$ The first difference again pertains to the second criterion, which refers to the protection for GIs that neither the TRIPS Agreement, European bilateral trade agreements nor the Indian GI Act of 1999 provide for. The meaning of this condition is not entirely clear as it seems counterintuitive to require that the trade mark, which will be used simultaneously with the GI, actually interferes with the protection that the GI enjoys. It would be expected that the rule would require that none of the three uses applies. However, in light of the purpose of the provision, which is supposedly similar to the rule foreseen in the TRIPS Agreement, even trade marks that interfere with the protection of GIs (in TRIPS terminology that are identical or similar to a GI) can be protected if no ground for revocation or invalidity exists. For clarity purposes, this provision might best be revised in order for it to express what it intends to say.

The second difference with the equivalent rule in the TRIPS Agreement, the EC Regulation 510/2006, the Indian GI Act of 1999 and several European bilateral trade agreements is that the draft IP chapter of the India-EU BTLA has omitted the element of good faith: according to the former agreements and legislative acts, only trade marks applied for, registered or established by use in good faith may be continued to be used parallel to the protected GI. ${ }^{171}$ It could be argued that the grounds for invalidity and revocation, incorporated by the third requirement, might already filter out trade marks registered in bad faith. However, also EC Regulation 510/2006 includes the good faith element in addition to the grounds for invalidity and revocation. This implies that the two elements are not redundant. India does not propose a precise rule for prior trade marks but generally favours the laws of the parties to govern the concurrent use of GIs and relevant trade marks. ${ }^{172}$

\footnotetext{
168 See Article 9.7 of the draft IP chapter of the India EU BTIA, as proposed by India.

169 See Article 9.7.5 of the draft IP chapter of the India-EU BTIA, as proposed by the EU.

170 Note that the EU-Central America $A A$ does not contain this second rule on the relationship between GIs and trade marks.

171 See Article 24.5 of the TRIPS Agreement, Article 14.2 of the EC Regulation 510/2006; Article 26.1 of the Indian GI Act of 1999; Article 145.D.4 of the CARIFORUM-EC EPA and Article 10.21 .5 of the EU-South Korea FTA. Interesting to note is that the EU-Colombia-Peru FTA does not stipulate this rule.

See Article 9.7 of the draft IP chapter of the India-EU BTIA, third rule suggested by India.
} 
The third rule on the relationship between geographical indications and trade marks deals with well-known or reputed marks. It presents an exception to the general rule addressing prior trade marks and applies where protection is liable to mislead consumers. ${ }^{173}$ In that case, the registered geographical indication does not have to be protected. This last rule proposed by the EU is not included in the TRIPS Agreement, nor in the Indian GI Act of 1999, but surprisingly has also been suggested by India in the draft IP chapter of the India-EU BTLA. ${ }^{174}$

To conclude, the relationship between geographical indications and trade marks would be addressed in the draft IP chapter of the India-EU BTLA by three rules if India accepts the European Union proposal. India's own suggestions are still too vague to be considered as future BTIA rules. The rules on posterior and prior trade marks proposed by the EU follow the ones provided for by the TRIPS Agreement, even though with certain differences. The language used by the European Union has been copied from internal legislation; however, at least in the case of prior trade marks, revision is recommended in order to clarify the conditions. Some elements that are incorporated in the TRIPS rules have been dropped from the EU proposal. In the case of posterior trade marks, this means that more trade marks will have to be denied registration or must be invalidated. For prior marks, it has the effect of enlarging the group of trade marks that will benefit from their coexistence with geographical indications. The third rule suggested by the EU is not contained in the TRIPS Agreement but has also been suggested by India. It addresses well-known trade marks and presents an exception to the rule addressing prior trade marks.

\subsubsection{Interim Conclusions}

The rules on the protection of geographical indications are clearly one of the most important areas of the draft IP chapter of the India-EU BTIA. Similar to other European bilateral trade agreements, including the agreements on trade in wines and spirits, the provisions suggested by the European Union are very detailed and mostly copy equivalent provisions from internal legislation which deals with the protection of geographical indications. Legislation-like provisions have the disadvantage of creating legal transplants into Indian law that are prone to creating problems in terms of implementation and enforcement. In view of the fact that India wishes to adhere to the TRIPS standard and that its proposed provisions are rather vague, India would be well advised to provide for language that is not as prescriptive as the EU proposal and that leaves enough domestic policy space.

As far as the European Union proposal is concerned, a number of elements go beyond the standard set in the TRIPS Agreement. Most importantly, according to the $\mathrm{EU}$, the India-EU BTIA will provide equal protection to GIs on wines and spirits and agricultural products. Also the criteria that need to be met by the objection and examination procedures (those that the parties need to provide when registering geographical indications) are set out in detail. This specification is a feature not found in the TRIPS Agreement. Furthermore, the omission of certain TRIPS exceptions and the additional rule on the relationship between well-known trade marks and GIs

173 See Article 9.7.4 of the draft IP chapter of the India-EU BTIA, as proposed by the EU.

174 See Article 9.7 of the draft IP chapter of the India-EU BTLA, first rule suggested by India. 
constitute TRIPS-plus features. It is to be expected that the proposal by the European Union will have to be adapted in several parts. However, overall, India also has an interest in a strong protection for geographical indications which should put agreement on the most important provisions within reach.

\subsubsection{Provisions Relating to Designs}

The rules pertaining to the protection of industrial designs present a relatively new feature in agreements negotiated by the European Union: it is only since the CARIFORUM-EC EPA that substantive provisions on industrial designs are part of such agreements. Also US FTAs do not deal with this subject matter. India and the EU have not yet been able to agree on most provisions of this section. The EU has proposed almost identical language to its internal EC Directive 89/71, which was also integrated in recent trade agreements with CARIFORUM States, South Korea, Colombia and Peru, Central American countries and Canada. In this area of IP, India has shown its ability to integrate its interests into the provisions suggested by the EU: India is unwilling to protect unregistered designs (Article 12.3.1) and it opposed criteria for the invalidity or refusal of registration (Article 12.7), certain requirements for protection (Article 12.3) and some exceptions (Article 12.4). On the other hand, the draft IP chapter of the India-EU BTLA contains considerably more provisions that define concepts such as "new", "identical" and "making available" to the public than other recent bilateral trade agreements. It is particularly with regard to these detailed concepts that this section goes beyond the TRIPS standard. The elements of protection addressed are a) the accession to the Geneva Act of the Hague Agreement and the definition of design, b) requirements for protection, c) the rights conferred and the term of protection and d) exceptions.

\subsubsection{Accession to the Geneva Act of the Hague Agreement and Definition of Industrial Design}

The European Union proposes that BTIA parties accede to the 1999 Geneva Act of the Hague Agreement. ${ }^{175}$ Accession to the Geneva Act of the Hague Agreement is a TRIPS-plus provision since the TRIPS Agreement does not demand accession or compliance with that agreement. India is not yet a party to any of the acts of the Hague Agreement and it apparently also does not want to do so because it proposed to delete this provision. The Hague Agreement provides an instrument for registering industrial designs; however, registration in another country is dependent on the fact whether that country has signed up to the same act as one's own country. As the European Union is a party to the Geneva Act of 1999, this is the act which the EU has also asked other trading partners to accede to. ${ }^{176}$ So far, all of the latter were able or are trying to negotiate a "best endeavour" or "reasonable efforts" obligation. It is not yet clear whether India is willing to compromise on a soft obligation.

The draft IP chapter of the India-EU BTLA is the first European "new generation" agreement that includes a definition of designs. Also, the TRIPS Agreement does not define the concept of "design". Even though the agreements with the CARIFORUM

175 See Article 12.1 of the draft IP chapter of the India-EU BTLA, as proposed by the EU.

176 See Article 146.A of the CARIFORUM-EC EPA; Article 224 of the EU-Colombia-Peru FTA; Article 251 of the EU-Central America $A A$ and Article 8.1 of the draft IP chapter of the EU-Canada CETA. 
States, South Korea, Colombia and Peru and Central American countries already contain provisions on the protection of industrial designs, they do not set out a definition for designs. ${ }^{177}$ The definition agreed upon is almost identical to the equivalent provision in the EC Directive 98/71:178

"For the purpose of this Agreement 'design' means in particular the appearance of the whole or a part of a product resulting from the features of, in particular, the lines, colours and/or the shape of the product itself and/or its ornamentation." ${ }^{179}$ [emphasis added].

India had proposed a definition that was much more specific, including elements such as two or three dimensional shapes or manual, mechanical or chemical processes, which is identical to the definition used in its Designs Act of 2000. ${ }^{180}$ Having given up its own proposition, India managed to add "in particular" to the European definition, indicating that this list of elements is not exhaustive. The TRIPS Agreement does not define industrial designs.

In brief, the European Union requires the accession to the Geneva Act of the Hague Agreement. Even though India seems to be unwilling to accept this TRIPS-plus provision, it may eventually compromise on a "best endeavour" obligation to that effect, similar to what other trading partners of the European Union have done. With regard to the definition of a "design", both parties are in agreement to define designs rather broadly, by not providing an exhaustive list of elements. The proposal mainly follows the definition used by the European Union internally and goes beyond the TRIPS standard.

\subsubsection{Requirements for Protection}

In order to benefit from protection for industrial designs, certain conditions need to be fulfilled. The parties have agreed that applicants must fulfill two main requirements: a) designs need to be "new or original", ${ }^{181}$ and b) the design has to be registered. Regarding the first criteria, independently created designs need to be "new or original". ${ }^{182}$ This is identical to the TRIPS standard which India has implemented into its internal legislation. ${ }^{183}$ Both parties agree that a design is considered to be "new" if no identical design has been made available to the public before the date of filing for registration or before the priority date. ${ }^{184}$ The parties have made an effort to

177 Note that the draft IP chapter of the EU-Canada CETA, as proposed by the EU, contains an almost identical definition of "design" in its Article 8.2.1.

178 See Article 1(a) of the EC Directive 98/71.

179 See Article 12.2 of the draft IP chapter of the India-EU BTLA.

180 See Article 2(d) of the Indian Designs Act of 2000, published in Gazette of India (Extraordinary Part II - Section I) dated 12 May 2000.

181 The EU proposes to add another element: each party may also require "individual character" of the design in order to qualify for protection. The element "individual character" is also required by Article 3.2 juncto 5 of the EC Directive 98/71 and has been added in recent and future bilateral trade agreements. However, India has not agreed to this possibility yet.

182 See Article 12.3.1 of the draft IP chapter of the India-EU BTIA.

183 See Article 25.1 first sentence of the TRIPS Agreement and Article 4(a) of the Designs Act of 2000 .

184 See Article 12.3.2 of the draft IP chapter of the India-EU BTLA. 
define what "identical" means and under which conditions one "makes a design available to the public". According to India's proposal,

"Designs shall be deemed to be identical if they are not significantly distinguishable from known designs or combinations of known designs." 185

This definition comes close to the TRIPS definition of "new or original" designs, ${ }^{186}$ which the EU has accepted in the EU-Central America $A A .{ }^{187}$ Even though the EU currently suggests slightly different language (namely that the features differ only in "immaterial details"), ${ }^{188}$ the precedent of the EU-Central America $A A$ might present an opportunity for India to get its proposal accepted, certainly in view of the fact that the two proposals do not differ much content-wise; they merely display a preference by both parties to use the language of their internal legislations. ${ }^{189}$

The draft IP chapter of the India-EU BTIA also sets out a definition for "making available to the public". The parties have agreed to take over the rule of EC Directive 98/71: a design is made available to the public if it has been published, exhibited or used in trade or otherwise disclosed before the date of filing or the date of priority. ${ }^{190}$ Defining what "making available to the public" means is a TRIPS-plus feature; the TRIPS Agreement does not use this concept in its text. Furthermore, the parties have agreed that certain situations do not make the design available to the public. One situation addresses the disclosure in good faith: if the disclosed information enables another person, 1) in consequence of the breach of good faith, 2) to use, publish, exhibit or disclose such a design 3) in the normal course of business 4) to circles specialized in the sector 5) operating within the territory 6) before the date of filing of the registration or date of priority, then the design has not been made available. ${ }^{191}$ This exception has clearly been inspired by the similar provision in EC Directive $98 / 71.192$

The second exception agreed upon is also taken from EC Directive 98/71 and deals with the disclosure to another person under explicit or implicit conditions of confidentiality: this type of disclosure will not make the design available to the public. ${ }^{193}$ India has proposed a third exception which is foreseen in its own design law: ${ }^{194}$ designs exhibited at an industrial or other exhibition within six months before

See Article 12.3 .3 of the draft IP chapter of the India-EU BTLA, as proposed by India. According to Article 25.1 last sentence of the TRIPS Agreement, "designs are not new or original if they do not significantly differ from known designs or combinations of known designs."

See Article 252.2 of the EU-Central America AA. The CARIFORUM-EC EPA, the EUSouth Korea FTA and the EU-Colombia-Peru FTA do not contain definitions of the concepts "identical" and "made available to the public".

See Article 12.3.3 of the draft IP chapter of the India-EU BTIA, as proposed by the European Union.

See Article 4(c) of the Indian Designs Act of 2000; Article 4 of the EC Directive 98/71.

See Article 12.3.2 and 12.3.4 of the draft IP chapter of the India-EU BTLA.

See Article 12.3.4 of the draft IP chapter of the India-EU BTLA.

See Article 6.1 of the EC Directive 98/71.

See Article 12.3.5 of the draft IP chapter of the India-EU BTLA and Article 6.1 of the EC Directive 98/71.

See Article 21 of the Indian Designs Act of 2000. 
the date of registration shall not prevent the design from being registered. ${ }^{195}$ However, the EU has not yet agreed to this exception, even though the rule in Article 6.2(b) of EC Directive 98/71 comes down to an even more extensive exception, namely a designer's right to make his/her design public during a twelve month period before the filing date without destroying its novelty.

Besides being "new or original", industrial designs must also have been registered to confer exclusive rights upon their holders. ${ }^{196}$ The European Union did not succeed in convincing India to also regulate the protection of unregistered designs and therefore its suggested that provisions on unregistered designs are not included in the BTIA. In this respect, other European "new generation" agreements are broader since they do set out rights for unregistered designs. ${ }^{197}$ The TRIPS Agreement does not address the issue of registration. To sum up, the parties have already been able to agree on a number of issues concerning the requirements for protection. Above all, designs need to be "new or original" and must be registered. When it comes to the specific concepts of "identical" and "making available to the public", the proposals of both parties are not far removed from each other, bringing agreement thereon within reach. The definition of "making available to the public", as well as the exceptions thereto, constitute TRIPS-plus features. Overall, the provisions already agreed upon and those proposed by the European Union are copies of European Union law.

\subsubsection{Rights Conferred and Term of Protection}

If a design is protected under the draft IP chapter of the India-EU BTLA, the right holder will be entitled to at least the following right: he can prevent third parties from making, offering, putting on the market, importing or stocking a product in which the design is incorporated or to which it is applied. ${ }^{198}$ This is subject to the condition that the right holder has not given his consent and that the use made of the design is of a commercial nature. The list of actions covered by the right is a compromise between the European Union and India: the latter was not willing to accept "exporting" or "using" the product to be added to the Article.

Contrary to European Union law, Indian design law merely provides for copyright protection for registered designs. ${ }^{199}$ Accordingly, it is unlawful for any person other than the copyright owner to apply the design to any article belonging to the same class of products as the design for the purpose of sale, to import such articles for the purposes of sale or to know that such articles are published or exposed for sale. ${ }^{200}$ The Indian Designs Act of 2000 does not seem to cover all actions listed in the draft IP chapter of the India-EU BTLA, such as "putting on the market" or "stocking". These

195 See Article 12.3.4 of the IP chapter of the India-EU BTLA, as proposed by India.

196 See Article 12.3.6 of the draft IP chapter of the India-EU BTIA.

197 See Article 146.B.4 of the CARIFORUM-EC EPA; Article 10.29 of the EU-South Korea FTA and Article 252.3 of the EU-Central America AA. Note that the EU-Colombia-Peru FT $A$ and the EU proposal of the draft IP chapter of the EU-Canada CETA also limits protection to registered designs, see Article 229.1 of the EU-Colombia-Peru FTA and Article 8.3.1 last sentence of the draft IP chapter of the EU-Canada CETA, as proposed by the EU.

198 See Article 12.5 of the draft IP chapter of the India-EU BTLA.

199 See Article 11.1 of the Indian Designs Act of 2000.

200 See Article 22.1 of the Designs Act of 2000. 
actions are also not covered by the TRIPS standard. ${ }^{201}$ Having compromised on the described standard of protection, the European Union was not able to secure the standard of protection applied internally and in several European bilateral trade agreements. $^{202}$

With regard to the term of protection, India was clearly able to secure its own interests. According to the draft IP chapter of the India-EU BTLA, industrial designs will be protected for at least ten years, ${ }^{203}$ which equals the term of protection established by the TRIPS Agreement and that of the Indian Designs Act of 2000. ${ }^{204}$ This period of time, however, is significantly below the standard applied by the European Union in its own legislation and in several other trade agreements. ${ }^{205}$ Accordingly, designs shall be protected for one or more periods of five years, up to a total term of twenty-five years from the date of filing. ${ }^{206}$ In other words, protection is guaranteed for twenty-five years, as long as the registered design still fulfills the requirements and a renewal fee is paid every five years.

In brief, India and the European Union have already agreed upon the rights conferred on design right holders and the term of that protection. The rights listed go beyond the TRIPS standard and therefore also beyond Indian design law, by adding two actions ("putting on the market" or "stocking"), which are not yet protected. This represents a compromise between the European Union and India as the EU has given up the actions "exporting" and "using" the product from being included in the list of rights. The term of protection is set at ten years of protection, which equals the TRIPS standard and Indian law; it differs considerably from European protection. However, the EU has also made this concession in two other recent "new generation" agreements.

\subsubsection{Exceptions}

The draft IP chapter of the India-EU BTLA establishes merely two exceptions to the protection of designs; compared with recent bilateral trade agreements, internal EU legislation and the TRIPS Agreement, at least one exception is missing, namely the

See Article 26.1 of the TRIPS Agreement, which only mentions making, selling or importing as being forbidden.

See Article 12.1 of the EC Directive 98/71; Article 10.28 of the EU-South Korea FTA; Article 226.1 of the EU-Colombia-Peru FTA; Article 8.4 of the draft IP chapter of the EU-Canada CETA, as proposed by the EU. The CARIFORUM-EC EPA differs from the ones listed as CARIFORUM States have resisted the inclusion of the action "exporting" articles that bear a protected design, see Article 146.D.1 of the CARIFORUM-EC EPA. Also Article 254.1 of the EU-Central America AA does not include the protection of designs as applied internally; it reproduces the TRIPS standard of forbidding merely the actions of making, selling and importing. See Article 12.6 of the draft IP chapter of the India-EU BTLA. See Article 26.3 of the TRIPS Agreement, Article 11.1 of the Designs Act of 2000. See Article 146.E of the CARIFORUM-EC EPA; Article 8.6 of the draft IP chapter of the EU-Canada CETA, as proposed by the EU. Article 10.30 .1 of the EU-South Korea FTA obliges parties to protect designs for at least fifteen years. Note that Article 227 of the EU-Colombia-Peru FTA and Article 255.1 of the EU-Central America AA contain the same term of protection (ten years) as the draft IP chapter of the India-EU BTLA and the TRIPS Agreement. 
exemption of designs dictated essentially by technical or functional considerations. ${ }^{207}$ The EU has worked out the details of this exemption in most other trade agreements as well as in its own legislation. ${ }^{208}$ However, it was not successful in incorporating the same exception into the draft IP chapter of the India-EU BTLA due to India's opposition. ${ }^{209}$ The TRIPS Agreement leaves it up to WTO Members to determine whether they want to apply such an exception. India, in its Designs Act of 2000, has chosen not to do so and apparently would like to preserve this flexibility.

The two exceptions that have been agreed upon in the draft IP chapter of the IndiaEU BTIA regard limited exceptions, on the one hand, and designs that are contrary to public policy or public morality, on the other hand. ${ }^{210}$ The provision on limited exceptions is literally taken from Article 26.2 of the TRIPS Agreement. ${ }^{211}$ It establishes four conditions that national exceptions have to fulfill: 1) national exceptions need to be limited, 2) they must not unreasonably conflict with the normal exploitation of the work, 3) they may not unreasonably prejudice the legitimate interests of the right holder, and 4) the legitimate interests of third parties need to be taken into account. $^{212}$ This rule so far has not yet been interpreted by a W'TO Panel or Appellate Body. However, it is similar to the TRIPS "three-step test" enshrined in Article 13 of the TRIPS Agreement, which has been interpreted by a WTO Panel in the context of copyright protection. ${ }^{213}$ This case law might also be relevant when determining whether a specific national exception fulfills the criteria of Article 26.2 of the TRIPS Agreement and possibly also Article 12.4 of the draft IP chapter of the India-EU BTLA. ${ }^{214}$

An example of a limited exception could be the second exception contained in the draft IP chapter of the India-EU BTIA: designs that are contrary to public policy or

See Article 25.1 of the TRIPS Agreement.

See Article 7 of the EC Directive 98/71; Article 186.C.2 of the CARIFORUM-EC EPA; Article 10.31.2 of the EU-South Korea FTA; Article 228.2 and 228.3 of the EU-ColombiaPeru FTA; Article 253.2 of the EU-Central America AA; Article 8.7.2 of the draft IP chapter of the EU-Canada CETA, as proposed by the EU.

From earlier drafts, it is evident that India has ruled this exception out. See Article 8.4.2 of the draft IP chapter of the India-EU BTLA of November 2008, as proposed by the EU; Article 16.4.2 of the draft IP chapter of the India-EU BTLA of April 2010, as proposed by India.

These exceptions have also been included in other "new generation" agreements, see Article 146.C.1 and 146.C.3 of the CARIFORUM-EC EPA; Article 228.2 and 228.4 of the EU-Colombia-Peru FTA; Article 253.1 and 253.3 of the EU-Central America AA; Article 8.7.1 and 8.7.4 of the draft IP chapter of the EU-Canada CETA, as proposed by the EU.

See Article 26.2 of the TRIPS Agreement.

See Article 12.4 of the draft IP chapter of the India-EU BTLA.

See WTO Panel Report, US-Section 110(5) Copyright Act. See also section 6.3.1.5 of this book for an overview of the facts of this case.

Note that the first condition is slightly different in Article 13 than in Article 26.2 of the TRIPS Agreement: it specifies that exceptions must be confined to certain special cases rather than merely requiring that the exceptions have to be limited. The relevance of WTO case-law for bilateral disputes on the BTIA provision is difficult to predict. The judiciary body would have to determine in how far it takes the WTO panel's interpretation into consideration when interpreting the BTIA provision. 
to accepted principles of morality are excluded from protection. ${ }^{215}$ The TRIPS Agreement does not contain this specific exception itself but, from the justifications accepted under the GATT 1994 and the GATS, such an exception is likely to meet the "limited exception" standard. India has also incorporated such an exception into its national design law: designs which comprise or contain scandalous or obscene matter shall not be registered. ${ }^{216}$

To conclude, the provisions dealing with exceptions to design rights contain very few TRIPS-plus features. The only one is the omission of the TRIPS exception for designs dictated solely by technical or functional consideration. However, since the draft IP chapter of the India-EU BTLA contains the provision that allows for limited national exceptions, one could argue that the omitted TRIPS exception would fulfill the conditions set out in the latter and would therefore be allowed. In addition, the parties have agreed to add an exception regarding designs contrary to public policy or accepted principles of morality. The latter is not contained in the TRIPS Agreement, however, if applied to special and limited cases, this exception arguably also fulfills the standard of the limited national exceptions.

\subsubsection{Interim Conclusions}

The protection of industrial designs seems to be one of the less problematic areas of intellectual property protection included in the draft IP chapter of the India-EU BTIA. Many provisions have already been agreed upon, such as the definition of designs, rights conferred on right holders, the exceptions thereto and the term of protection. The core requirements for protection are also agreed upon; however, the specific concepts contained therein are still under negotiation. The TRIPS-plus features are importantly found in the definition of these concepts, the definition of industrial designs, the broadened scope of the rights and the omission of one TRIPS exception. Agreeing to detailed definitions of specific concepts limits the freedom of India to adapt the requirements for protection to its domestic preferences.

Similar to the sections addressing the protection of copyright and geographical indications, the provisions on the protection of designs rely heavily on the standards applied internally in the European Union. The section on the protection of industrial designs is not always coherent with the standards asked from other trading partners of the European Union. For example, with regard to the rights conferred and the exceptions thereto, the EU could not achieve the standard usually asked for. On the other hand, the parties are discussing a definition of industrial designs, which is a feature not yet included in other European bilateral trade agreements.

\subsubsection{Provisions Relating to Patents}

Rules on patent protection are still a new feature of European bilateral trade agreements: the CARIFORUM-EC EPA and the EU-Central America $A A$ do not include detailed patent standards, other than obligations to comply with or accede to certain multilateral patent treaties. ${ }^{217}$ The EU-South Korea FTA, ${ }^{218}$ EU-Colombia-Peru 
FTA and the draft IP chapter of the EU-Canada CETA, as proposed by the EU, however, incorporate detailed patent standards on the duration of patent rights and data exclusivity protection. Those standards even go beyond the level of protection under negotiation in the draft IP chapter of the India-EU BTLA. India has not been an easy negotiating partner on patent protection as it is particularly opposed to the provisions on data exclusivity which have slowed down the negotiations of the entire agreement considerably.

The proposed chapter deals with three issues: a) compliance with international agreements, b) patents and public health, and c) data exclusivity. It is interesting to note that the extension of the patent term, a provision that is part of the EU-South Korea FTA and the draft IP chapter of the EU-Canada CETA, as proposed by the $\mathrm{EU}, 219$ is not anymore included in the IP chapter of the India-EU BTLA. Previous drafts suggest that the European Union asked for an effective term of protection that takes into account delays in the administrative or registration procedure before the product is put on the market. ${ }^{220}$ Accordingly, the patent term of twenty years could have been extended by a maximum of five years in compensation for the period between the filing of the application for a patent and the first authorization to place the product on the market. Such protection is equivalent to the European internal rule. ${ }^{221}$ It differs from the TRIPS standard insofar as the latter suggests a nominal term of protection of twenty years, which is not adapted in case of delays. As indicated in a note in the draft IP chapter of the India-EU BTLA of April 2010, this provision was going to be explored further with Indian authorities. These explorations have obviously resulted in the European Union giving up their demand in the latest draft of July 2010.

\subsubsection{Compliance with International Treaties}

Both parties have agreed to comply with Articles 1-51 of the Patent Cooperation Treaty and with Articles 2-9 of the Budapest Treaty. ${ }^{222}$ Even though these obligations are of a TRIPS-plus nature, they seem to be relatively unproblematic as India and European Union Member States have already become contracting parties to these treaties.223 However, as noted before, ${ }^{224}$ having acceded to certain treaties does not necessarily mean that they also comply with or fulfill the substantive obligations of the multilateral treaties. While it is usually the multilateral framework itself that aims at

218 See Article 10.33-10.38 of the EU-South Korea FTA.

219 See Article 10.35 .2 of the EU-South Korea FTA and Article 9.2 of the draft IP chapter of the EU-Canada CETA, as proposed by the EU.

220 See Article 9.3 of the draft India-EU BTLA of November 2008, as proposed by the EU, and Article 17.3 of the draft India-EU BTLA of April 2010, as proposed by the EU. See Article 13 of the Council Regulation No.1768/92 of 18 June 1992 concerning the creation of a supplementary protection certificate for medicinal products (OJ L 182 of 02.07.1992).

See Article 13.1(a) and (b) of the draft IP chapter of the India-EU BTLA. Under the PCT, patent applicants can seek patent protection for inventions simultaneously in the contracting parties of the PCT by filing one single international patent application. The Budapest Treaty established an international depositary authority with which patent applicants can deposit a microorganism once in order to facilitate national patent procedures in all contracting parties.

223 See WIPO, WIPO-Administered Treaties.

224 See section 5.3.2.1 of this book on access to digital products under the CARIFORUMEC EPA. 
ensuring compliance with the multilateral treaty, incorporating such a complianceobligation into a bilateral treaty gives both parties an additional option to claim noncompliance with the incorporated multilateral treaties under the bilateral dispute settlement procedure. Although it is not clear yet whether parties will use that option, it sets the stage for choosing bilateral procedures over multilateral ones. This development adds to the fragmentation of international law, particularly if this is pursued in several bilateral trade agreements. ${ }^{225}$

A final obligation relating to international agreements addresses a third treaty, the Patent Law Treaty: the European Union has proposed to make all reasonable efforts to comply with its Articles 1-16.226 India has not yet agreed to this proposal, even though the obligation is a soft one. India might be concerned about the fact that the PLT is a standard-setting treaty which tries to harmonize and streamline formal procedures of national and regional patent applications, while the PCT and the Budapest Treaty are registration instruments. It thereby touches upon important elements of national procedural requirements which countries seemingly do not wish to adapt. So far only twenty-seven States have become contracting parties to the PLT, among which several European Union' Member States. ${ }^{227}$ India is not yet a party. The European Union is trying to entice more of its trading partners to become parties to the PLT through the same or similar provisions in bilateral trade agreements. ${ }^{228}$ However, it also needs to be kept in mind that becoming a member to the treaty is not a prerequisite for complying with it: as long as domestic laws implement the substantive obligations of the treaty, compliance would be fulfilled. The requirement of making "best endeavour" efforts to comply with the PLT goes beyond the level of protection set out in the TRIPS Agreement.

\subsubsection{Patents and Public Health}

The second commitment agreed upon by both parties addresses the Doha Declaration on the TRIPS Agreement and Public Health: parties recognize its importance and agree to contribute to the implementation of the General Council Decision of 30 August 2003 on paragraph 6 of the Doha Declaration, as well as the Protocol amending the TRIPS Agreement annexed to the General Council Decision of 6 December 2005.229 This confirmation is relatively new compared with previous European bilateral trade agreements but has also been included in recent and future agreements since the CARIFORUM-EC EPA. ${ }^{230}$ The two instruments address the need to preserve the

The CARIFORUM-EC EPA requires EU Member States to comply with the PCT, PLT and the Budapest Treaty, see Article 147.A.1 of the CARIFORUM-EC EPA. The EU-Colombia-Peru FTA and the EU-Central America $A A$ require compliance with the Budapest Treaty, see Article 230.1 of the EU-Colombia-Peru FTA and Article 258.1 of the EU-Central America AA.

See Article 13.1(c) of the draft IP chapter of the India-EU BTLA, as proposed by the EU.

See WIPO, WIPO-Administered Treaties.

See Article 147.A.3 of the CARIFORUM-EC EPA; Article 10.33 of the EU-South Korea FTA; Article 230.2 of the EU-Colombia-Peru FTA; Article 258.2 of the EU-Central America $A A$ and Article 9.1 of the draft IP chapter of the EU-Canada CETA.

See Article 13.2 of the draft IP chapter of the India-EU BTLA.

See Article 147.B of the CARIFORUM-EC EPA; Article 10.34 of the EU-South Korea FTA; Article 197.2 of the EU-Colombia-Peru FTA; Article 229.2 of the EU-Central America $A A$, and Article 3 of the draft IP chapter of the EU-Canada CETA. Note that 
flexibilities of the TRIPS Agreement with regard to patents on pharmaceutical drugs and establish clear rules with regard to the freedom of countries to issue compulsory licenses in order to import essential medicines into countries with insufficient manufacturing capacities. While emphasizing the significance of these instruments is very important from a political point of view, it does not add any further legal obligation or commitment than those already incurred at the multilateral level.

\subsubsection{Data Exclusivity}

The final issue set out in the patent section of the draft IP chapter of the India-EU $B T L A$ deals with the protection of undisclosed information or data exclusivity. This part is probably one of the most controversial provisions of the entire IP chapter. The controversial nature is reflected, among others, by the note "to be further discussed". 231 The text contained in the last draft is the result of several rounds of negotiations on the extensive proposal submitted by the European Union. India has been unwilling to compromise on elements of the proposal; in contrast, it has proposed to ensure protection through the parties' domestic laws and regulations. ${ }^{232}$ In view of the importance of this provision, it is worthwhile to analyze the European Union's proposal. Before doing so, a short introduction into the matter is provided. ${ }^{233}$

Data exclusivity intends to protect the information submitted by a company that proves the safety and efficacy of a new chemical entity, being a drug or a plant essence. This data is submitted to regulatory authorities and is kept undisclosed. In order to protect the data of originators, the TRIPS Agreement requires in Article 39.3 that WTO Members must protect undisclosed test data on pharmaceutical products against unfair competition. The rationale behind this provision is the protection against unfair commercial use, not against any use by third parties. However, the European Union has proposed data exclusivity, meaning that no use of the data whatsoever can be made for a specific period of time by subsequent applicants. This interpretation of Article 39.3 of the TRIPS Agreement follows the approach also pursued by the United States in its FTAs. ${ }^{234}$ Hence, not only unfair commercial use is prohibited but also any other use.

The general obligation suggested by the European Union for both pharmaceutical and plant protection products is stipulated in Articles 14 and 15 of the draft IP chapter of the India-EU BTLA: generic producers of new pharmaceutical or plant protection products cannot rely on the undisclosed data submitted by the originator in order to receive marketing authorization for their bio-equivalent product, unless proof of the explicit consent by the originator is provided. ${ }^{235}$ This protection exists regardless of whether the product received patent protection or not. The period

recent US free trade agreements also affirm the parties' commitment to the Doha Declaration. See Article 15.12 of the US-Panama TPA; Article 16.13 of the US-Peru TPA.

231 See Articles 14 and 15 of the draft IP chapter of the India-EU BTLA, as proposed by India.

232 Ibid.

233 See also section 3.2.4.1 of this book.

234 Ibid.

235 See Articles 14.2(a) and 15.2 second sentence of the draft IP chapter of the India-EU $B T I A$, as proposed by the European Union. 
during which the data is exclusively protected varies according to the type of product, being either pharmaceutical products or plant protection products.

For pharmaceutical products, a distinction is made between a) the period in which the generic producer cannot apply for market authorization if (s)he wants to rely on the originator's test data, and b) the period in which the generic producer will not be able to market his product. ${ }^{236}$ Although the exact number of years for both periods is still blank in the draft IP chapter of the India-EU BTLA, the rule as such is identical to European Union legislation on data protection for pharmaceutical products: while a subsequent applicant can rely on the originator's data for her/his application for market authorization after eight years, market protection lasts for a period of ten years from first authorization. . $^{37}$ In other words, even though a generic producer can apply for authorization of his/her drug after eight years from the authorization of the originator's drug, (s)he will have to wait another two years before (s)he can market the generic product. This period of ten years can be extended to a maximum of eleven years if during the first eight years the originator has obtained an authorization for a new therapeutic indication. ${ }^{238}$ India and the EU could deviate from these periods by reducing the respective number of years. Examples are the EU-South Korea FTA and the EU-Colombia-Peru FTA, where only one period of protection of five years was agreed upon. ${ }^{239}$

For plant protection products, only one period of data protection has been proposed by the EU which starts at the date of first authorization. The number of years is also left blank but from the equivalent internal EU legislation, as well as from other bilateral agreements, it can be inferred that ten years would be envisaged by the European Union. ${ }^{240}$ Special rules apply for data that involves tests and studies with vertebrate animals. The purpose of these rules is to avoid duplicative testing. ${ }^{241}$ Accordingly, the new applicant and the holder of the relevant authorization shall try

See Article 14.2(a) and (b) of the draft IP chapter of the India-EU BTIA, as proposed by the European Union.

See Article 14.11 of Regulation (EC) No. 726/2004 of the European Parliament and of the Council of 31 March 2004 laying down Community procedures for the authorisation and supervision of medicinal products for human and veterinary use and establishing a European Medicines Agency (OJ L 136 of 30.4.2004) [hereinafter Regulation 726/2004]; amended Article 10.1 first and second subparagraph of Directive 2001/83 on the Community code relating to medicinal products for human use, as amended by Directive 2004/27/EC of the European Parliament and of the Council of 31 March 2004 (OJ L 136 of 30.4.2004) [hereinafter Directive 2001/83].

See Article 14.11 of Regulation 726/2004 and amended Article 10.1 fourth subparagraph of Directive 2001/83.

See Article 10.36.1 of the EU-South Korea FTA and Article 231.2 of the EU-ColombiaPeru FTA.

See Article 59.1 fourth subparagraph of Regulation (EC) No. 1107/2009 of the European Parliament and of the Council of 21 October 2009 concerning the placing of plant protection products on the market and repealing Council Directives 79/117/EEC and 91/414/EEC (OJ L 209 of 24.11.2009); Article 10.37.3 of the EU-South-Korea FTA; Article 231.2 of the EUColombia-Peru FTA; Article 11 of the draft IP chapter of the EU-Canada CETA, as proposed by the EU.

241 See Article 15.7 of the draft IP chapter of the India-EU BTLA, as proposed by the European Union. 
to share the tests and studies data as well as the costs. ${ }^{242}$ However, if that is not possible, the new applicant shall inform the party where (s)he is seeking protection. For the European Union side, the European Medicines Agency (EMEA) is the relevant contact point. EMEA can then decide whether it will use the originator's data for the purpose of the application by the new applicant without the consent of the former. ${ }^{243}$ These special rules on duplicative testing are a new feature of European bilateral trade agreements which so far have only been proposed to Canada, however in a slightly different way. ${ }^{244}$

\subsubsection{Interim Conclusions}

Protection of patents is still a very new feature of European bilateral trade agreements. Only a few European "new generation" bilateral trade agreements deal with specific obligations on that matter; others merely require compliance with certain multilateral treaties. So far, the parties to the draft IP chapter of the India-EU $B T L A$ have agreed to undertake obligations concerning the compliance with the PCT and Budapest Treaty and the recognition of the importance of the Declaration on the TRIPS Agreement and Public Health and the General Council Decision of 30 August 2003. The obligations regarding compliance with the multilateral treaties are of a TRIPSplus nature but seem to be relatively unproblematic for both parties that are contracting parties of these treaties. Primarily the proposed provisions on data exclusivity for pharmaceutical and plant protection products are contested and still under negotiation. The EU has proposed similar provisions as those included in its internal legislation, even though the term of data exclusivity is still left blank. They contain strong TRIPS-plus elements and provide similarly strong protection as United States free trade agreements. If India accepts the Union's proposal, the effect on producers of generic medicines in India may be significant.

\subsubsection{Protection of Plant V arieties}

The draft IP chapter of the India-EU BTLA briefly deals with the protection of plant varieties. The European Union and India agree to cooperate in promoting and reinforcing the protection of plant varieties according to their applicable laws and the international agreements to which both parties are signatories. ${ }^{245}$ This protection does not contain any TRIPS-plus elements. Compared with recent bilateral trade agreements, it is surprising that the European Union does not intend to require accession to or compliance with the UPOV Convention, Act 1991.246 India is not a

242 See Article 15.8 of the draft IP chapter of the India-EU BTLA, as proposed by the European Union.

243 See Article 15.10 of the draft IP chapter of the India-EU BTIA.

244 See Article 11.6 and 11.7 of the draft IP chapter of the EU-Canada CETA, as proposed by the European Union. Note that the draft chapter does not set out an obligation to inform its own Party.

245 See Article 16 of the draft IP chapter of the India-EU BTLA.

246 The accession to or compliance with the UPOV Convention, Act 1991 are elements in the CARIFORUM-EC EPA (Article 149), the EU-South Korea FTA (Article 10.39), the EU-Colombia-Peru FTA (Article 232) and the draft IP chapter of the EU-Canada CETA, as proposed by the EU (Article 12). Note that Article 259 of the EU-Central America $A A$ does not require accession or compliance with the UPOV Convention, Act 1991. 
party to the Convention yet. ${ }^{247}$ In fact, India's Protection of Plant V arieties and Farmers' Rights Act (PPVFRA) of $2001^{248}$ combines elements of protection for breeders of plant varieties, as set out in the UPOV Convention, Act 1978 and Act 1991, with the farmers' rights drawn from Resolutions of the United Nations Food and Agricultural Organization and the International Treaty on Plant Genetic Resources for Food and Agriculture $^{249}$ (ITPGRFA).250 India's system of plant variety protection is very interesting and differs in important aspects from the protection required by the UPOV Convention, Act 1991.251

India protects three categories of plant varieties: new and essentially derived varieties, farmers' varieties and extant varieties. Farmers' varieties are defined as a variety which

“i) has been traditionally cultivated and evolved by the farmers in their fields; or ii) is a wild relative or land race of a variety about which the farmers possess the common knowledge"252

They also form a sub-category of extant varieties, being varieties about which there is common knowledge or which are in the public domain. 253 The UPOV Convention, Act 1991, however, does not recognize farmers' varieties and extant varieties as protected varieties. In order to protect a variety under the UPOV Convention, Act 1991, breeders have to show that a variety is new, distinct, uniform and stable. ${ }^{254}$ Farmers' and extant varieties would not fulfill the criteria of novelty. For that reason, the registration requirements in the Indian PPVFRA of 2001 for farmers' and extant varieties differ from the UPOV conditions: farmers' and extant varieties merely have to meet the conditions of distinctiveness, uniformity and stability. ${ }^{255}$ It is unclear whether farmers can fulfill these conditions when their breeding efforts occur in situ,

247 According to Christoph Antons, India is determined to join the UPOV Convention in the near future. See C. Antons, "Sui Generis Protection for Plant Varieties and Traditional Agricultural Knowledge: The Example of India" European Intellectual Property Review, 2007, Vol. 29 (12), 480-485, p. 485.

The Protection of Plant Varieties and Farmers' Rights Act, 2001, enacted by Act No. 53 of 2001, published in Gazette of India Extraordinary (Part II, Section 1) dated October 30, 2001 [hereinafter PPVFRA of 2001]. International Treaty on Plant Genetic Resources for Food and Agriculture, adopted 3 November 2001 in Rome, entered into force on 29 June 2004, FAO/RES/3 (2001). See FAO Resolutions 4/89 and 5/89 and Article 9.2 and 9.3 of the ITPGRFA. For an analysis of the protection required by the UPOV Convention, Act 1991 and Act 1978, see section 5.3.2.7 of this book on an analysis of the obligation regarding plant varieties under the CARIFORUM-EC EPA. See Section 2 (l) of the PPVFRA of 2001. See Section 2(j), (i), (iii), (iv) of the PPVFRA of 2001.

See Article 5.1 of the UPOV Convention, Act 1991. Also the Indian PPVFRA of 2001 requires these conditions for new and essentially derived varieties, see Section 15.1 of the PPVFRA of 2001.

See Section 15.2 of the PPVFRA of 2001. 
without full control of the agro-ecological conditions. ${ }^{256}$ The benefit for farmers therefore seems to be primarily of a symbolic nature. ${ }^{257}$

Once a variety is registered, the certificate of registration enables the owner to produce, sell, market, distribute, import or export the variety. ${ }^{258}$ The owner can be the breeder or, in the case of extant varieties, the Central Government. ${ }^{259}$ The rights of breeders, however, are limited by the farmers' privilege, which allows farmers to save, use, sow, re-sow, exchange, share and sell their farm produce, including the seeds. ${ }^{260}$ The so-called farmers' privilege is also contained in the UPOV Convention, Act 1991, however in a more restrictive manner, ${ }^{261}$ and not to be confused with the farmers' right. ${ }^{262}$ Farmers' rights are protected under Article 9 of the ITPGRFA and have been made available to Indian farmers through the PPVFRA of 2001. Accordingly, a farmer who is engaged in the conservation of genetic resources and their improvement is entitled to recognition and reward from the Gene Fund if the material so conserved has been used as donors of genes in varieties registrable under the Act. ${ }^{263}$ The exact reward is determined by the Protection of Plant Varieties and Farmers' Rights Authority. ${ }^{264}$ In addition, farmers, as any other group, can make a further compensation claim on the basis of their contribution to the evolution of a plant variety. ${ }^{265}$ If their claim satisfies the Authority, the breeder of the variety deposits the granted compensation in the Gene Fund and the Authority will distribute the money to the farmers. ${ }^{266}$ It still remains to be seen whether traditional communities and farmers see sufficient value in this centralized system of compensation. ${ }^{267}$

To sum up, the protection of plant varieties agreed upon by the parties merely contains a cooperation obligation in order to promote and reinforce plant variety protection according to the parties' domestic laws and international agreements, to which both parties are signatories. Since India is not a party to the UPOV Convention, Act 1991, the standards of protection included therein do not govern the relationship

256 See S.K. Verma, "Plant Genetic Resources, Biological Inventions and Intellectual Property Rights: The Case of India" in B. Ong (ed.), Intellectual Property and Biological Resources (Marshall Cavendish Academic, Singapore, 2004), 128-162, p. 149. See Antons, "Sui Generis Protection for Plant Varieties and Traditional Agricultural Knowledge: The Example of India", p. 485.

258 See Section 28.1 of the PPVFRA of 2001.

259 See Section 18.1 of the PPVFRA of 2001.

260 See Section 39.1(iv) of the PPVFRA of 2001.

261 According to Article 15.2 of the UPOV Convention, Act 1991, farmers are permitted to use, for propagating purposes, on their own holdings, the product of the harvest which they have obtained by planting, on their own holdings, the protected variety. This clearly excludes the exchange, sharing and sale of the farm produce.

The farmers' right is a concept introduced into the International Undertaking on Plant Genetic Resources as an agreed interpretation by the FAO Conference Resolutions 4/89 and 5/89 and the ITPGRFA, which has also been included in the Indian PPVFRA of 2001.

263 See Section 39.1(iii) of the PPVFRA of 2001.

264 See Section 26.5 of the PPVFRA of 2001.

265 See Section 41.1 of the PPVFRA of 2001.

266 See Section 41.4 of the PPVFRA of 2001.

267 See Antons, "Sui Generis Protection for Plant Varieties and Traditional Agricultural Knowledge: The Example of India", p. 485. 
between them. This cooperation obligation does not go beyond the TRIPS Agreement and stays well behind the standard included in other European "new generation" agreements. At the same time, Indian law sets out substantial standards for protecting plant varieties: it protects new varieties, farmers' varieties and extant varieties.

\subsubsection{Provisions Relating to Genetic Resources and Traditional Knowledge}

The protection of plant genetic resources and associated traditional knowledge is certainly one of the most important parts of the IP chapter for India. In contrast with the provisions dealing with copyright, trade marks and geographical indications, it is India that has proposed detailed provisions to the European Union. ${ }^{268}$ If agreed upon, they would be the most far-reaching rules on this topic so far included in a European bilateral trade agreement, maybe even in any North-South free trade agreement. However, the parties have not yet shown any signs of their willingness to compromise.

At the heart of the protection of genetic resources and traditional knowledge lies the conflict that has arisen in the past between the implementation of TRIPS patent rules and the rules on the protection of biodiversity in the Convention on Biological Diversity. The conflict becomes evident when companies use biological material or traditional knowledge as the basis for new inventions on which they are granted patent protection. The countries of origin of this genetic material or traditional knowledge feel that it is unjust that foreign companies can obtain property rights on such inventions without displaying the origin of the material, having asked for approval or sharing the benefits with them. In lack of an internationally agreed solution, the final provisions that will be included in the agreement can be of significant value for future multilateral negotiations currently ongoing in WIPO and the WTO. ${ }^{269}$

Where the CARIFORUM-EC EPA still fell short of stipulating real commitments with regard to the treatment of genetic resources and traditional knowledge, ${ }^{270}$ the text asked for by India promises to push the European Union further into accepting stronger commitments regarding the mandatory disclosure of origin or source, evidence of prior informed consent for access and fair and equitable sharing of benefits. Although the issues contained in the proposed text by India are primarily defensive in nature, ${ }^{271}$ agreement thereon is urgently needed, even though this means

268 See the draft IP chapter of the India-EU BTLA from November 2008 where the European Union had left a blank for India to fill in its proposal on the Convention of Biological Diversity.

269 See the WIPO Intergovernmental Committee on Intellectual Property and Genetic Resources, Traditional Knowledge and Folklore and the Doha Development Round, WTO Ministerial Conference, Doha Ministerial Declaration, paragraph 19.

Article 150 of the CARIFORUM-EC EPA reiterates Article 8(j) of the CBD, contains soft obligations with regard to requiring the disclosure of the source, and suggests exchange of views on the multilateral discussions in the WTO and WIPO. It therefore does not establish any hard obligation.

271 This is true for the provisions addressing domestic patent laws, see K. Venkataraman, "Intellectual Property Rigths, Traditional Knowledge and Biodiversity of India" Journal of Intellectual Property Rights, 2008, Vol. 13, 326-335, p. 334; S. Swarna Latha, "Biopiracy and Protection of Traditional Medicine in India" European Intellectual Property Review, 2009, Vol. 31 (9), 465-477, p. 475. 
postponing multilateral discussions on the establishment of a system of sui generis protection for traditional knowledge. An agreement between these two parties would mean that countries from opposite groups in the international debate would consent on one solution. Such a common text could be the basis for further discussions in WIPO and the WTO. It is therefore worthwhile carefully analyzing the different propositions made by India and the European Union.

Four issues are addressed: a) the definition of traditional knowledge; b) provisions reiterating the $\mathrm{CBD}$; c) new commitments with regard to disclosure, prior informed consent, sharing of benefits and the related consequences of non-compliance; and d) procedural commitments by patent offices.

\subsubsection{Definition of Traditional Knowledge}

India is the first partner country of the European Union to propose a definition of traditional knowledge in a bilateral trade agreement. Although the CARIFORUM-EC EPA already contained provisions on the protection of genetic resources and traditional knowledge, it did not attempt to stipulate a definition. Even in the FTA with Colombia and Peru, a definition is lacking in the otherwise elaborate provision on the protection of TK. ${ }^{272}$ The definition of traditional knowledge suggested by India encompasses a diverse array of existing applied knowledge and information. Examples listed include cultural expressions, such as literature, music and designs, and medicinal and agricultural forms of knowledge, such as methods of treatment, knowledge about the use of plants, seeds and other living species. ${ }^{273}$ These forms of knowledge must be known and used by members of the community for generations; knowledge used by individuals or in secret is explicitly excluded. Furthermore, it is recognized that such knowledge is evolving.

Although there is no internationally accepted definition of traditional knowledge, a frequently used definition has been developed by WIPO. It introduces a general distinction between traditional knowledge and traditional cultural expressions or folklore. The first category focuses on the

\footnotetext{
"Use of knowledge such as traditional technical know-how, or traditional ecological, scientific or medical knowledge. This encompasses the content or substance of traditional know-how, innovations, information, practices, skills and learning of TK systems such as traditional agricultural, environmental or medicinal knowledge."274 [emphasis added]
}

The second category addresses traditional cultural expressions or expressions of folklore, such as songs, narratives and designs. ${ }^{275}$ The knowledge systems, creations, innovations and cultural expressions in both categories must also be "traditionbased":

\footnotetext{
272 See Article 201 of the EU-Colombia-Peru FTA.

273 See the chapeau of Article 10 of the draft IP chapter of the India-EU BTLA, as proposed by India.

274 See WIPO, Booklet No. 2 on Intellectual Property and Traditional Knowledge (Geneva, 2009), p. 4.

275 See ibid., p. 4.
} 


\begin{abstract}
"they have generally been transmitted from generation to generation; are generally regarded as pertaining to a particular people or its territory; and are constantly evolving in response to a changing environment." 276
\end{abstract}

In comparison, both definitions are rather broad and have elements in common, such as the categories of knowledge, passing on the knowledge from generation to generation and the requirement that traditional knowledge constantly evolves. A clear emphasis in the Indian definition seems to be the knowledge on the use of seeds, plants and other living species, highlighting the environmental and agricultural aspect of traditional knowledge.

\title{
6.3.7.2. Provisions Reiterating the CBD
}

The following provisions proposed by India reiterate certain principles of the Convention on Biological Diversity. Consequently, the language of these rules is often declarative rather than standard setting. For example, India suggests that the parties reaffirm the sovereign rights over natural resources and the rights and obligations stemming from the CBD with regard to access to genetic resources and fair and equitable sharing of benefits. ${ }^{277}$ They shall also recognize the importance of the value of biological diversity and traditional knowledge. ${ }^{278}$ An obligation that goes slightly beyond the CBD standard relates to the prior informed consent: parties shall take all measures to ensure that access to genetic resources is subject to prior informed consent. ${ }^{279}$ The equivalent provision in the CBD merely states that access shall be subject to prior informed consent ${ }^{280}$ rather than obliging members to take all measures to ensure this.

As regards the sharing of benefits, India proposes that the parties shall take measures to guarantee the fair and equitable sharing of benefits arising from the use of genetic resources or traditional knowledge. ${ }^{281}$ Also here, India proposes a broader obligation than the one in the CBD which only applies this rule to the use of genetic resources, not to the use of traditional knowledge. ${ }^{282}$ The European Union has not yet agreed to these proposals. It has put forward two paragraphs, one of which is identical to the equivalent rule in the CAFIRORUM-EC EPA and the other is identical to the rule in the EU-Colombia-Peru FTA. ${ }^{283}$ They contain less constraining wording but equally address the promotion of the prior informed consent and the encouragement of the equitable sharing of benefits arising from the utilization of genetic resources. ${ }^{284}$ In

276 See WIPO Secretariat, Intellectual Property Needs and Expectations of Traditional Knowledge Holders: WIPO Report on Fact-Finding Missions on Intellectual Property and Traditional Knowledge (1998-1999) (Part one, Geneva, 2001), available at <http://www.wipo.int/$\mathrm{tk} / \mathrm{en} / \mathrm{tk} / \mathrm{ffm} / \mathrm{report} / \mathrm{final} /$ index.html $>$ accessed on 25.10.2012, p. 25. See Article 10.1 second sentence of the draft IP chapter of the India-EU BTIA, as proposed by India. This is similar to Article 15.1 of the CBD. See Article 10.2 of the draft IP chapter of the India-EU BTIA, as proposed by India. Ibid.

280 See Article 15.5 of the CBD.

See Article 15.7 of the CBD. CBD, and Article 201.4 of the EU-Colombia-Peru FTA. the EU. 
brief, India has suggested a number of provisions that reiterate principles already incorporated into the CBD. These obligations have been broadened compared to the CBD and could provide concrete rights for indigenous and local communities. The EU, however, has not yet agreed to them.

\subsubsection{New Commitments with Regard to Disclosure, Prior Informed Consent,} Sharing of Benefits and the Related Consequences of Non-compliance

In addition to the references to the $\mathrm{CBD}$, India proposes new obligations. They importantly address the origin or source of genetic material, prior informed consent, the sharing of benefits and the consequences of non-compliance. Accordingly, patent applications must contain a mandatory declaration of the origin or source of the genetic resource and traditional knowledge. ${ }^{285}$ Furthermore, applicants shall produce evidence of prior informed consent for access and for fair and equitable sharing of benefits. The consequences of non-disclosure or wrongful disclosure shall be set out in the national patent regime and the act addressing biological diversity. ${ }^{286}$ In particular, India wants to require the parties to provide for legal means to revoke patents granted in cases of non-compliance. ${ }^{287}$ Making such an obligation mandatory suggests that India regards the disclosure of origin, prior informed consent and equitable sharing of benefits as substantive conditions rather than formal ones. Therefore, non-compliance will have an effect on the granting of a patent rather than incurring civil or criminal sanctions that do not affect the granting of the patent.

The legal effect of non-compliance with such requirements has also been subject to significant debate in the framework of the WTO and WIPO. During this debate, the European Union has made clear that it regards the requirements as formal requirements, ${ }^{288}$ whereas Brazil and India propose substantive sanctions, such as the suspension of the patent application or revocation of the patent, as well as other consequences, such as transfer of rights, narrowing the scope of the claims, and criminal and/or administrative sanctions. ${ }^{289}$ This approach is in line with India's own patent and biodiversity laws, which contain the following obligations: mandatory disclosure of the source and geographical origin of biological material, ${ }^{290}$ prior approval by the National Biodiversity Authority (NBA) for access to the genetic

285 See Article 10.5 of the draft IP chapter of the India-EU BTLA, as proposed by India.

286 Ibid.

287 See Article 10.6 of the draft IP chapter of the India-EU BTIA, as proposed by India.

288 See European Communities and their Member States, Review of the Provisions of Article 27.3(b) of the TRIPS Agreement: Communication from the European Communities and their member States (Geneva, 13 June 2001) [IP/C/W/254], Section 22; European Community and its Member States, Disclosure of Origin or Source of Genetic Resources and Associated Traditional Knowledge in Patent Applications (Geneva, 17 May 2005) [WIPO/GRTKF/IC/8/11], Section 5 and 6.

289 See Section IV of WTO Secretariat, Elements of the Obligation to Disclose the Source and Country of Origin of the Biological Resources and/ or Traditional Knowledge Used in an InventionSubmission from Brazil, Cuba, Ecuador, India, Pakistan, Peru, Thailand, and Venezuela (Geneva, 27 September 2004) [IP/C/W/429/Rev.1]; Section 5 of WTO Secretariat, The Relationship Between the TRIPS Agreement and the Convention on Biological Diversity (CBD) and the Protection of Traditional Knowledge - Elements of the Obligation to Disclose Evidence of Prior Informed Consent under the relevant National Regime - Submission from Bolivia, Brazil, Cuba, Ecuador, India, Pakistan, Peru, Thailand and Venezuela (Geneva, 10 December 2004) [IP/C/W/438].

290 See Section 10(d)(ii)(D) of the Indian Patent Amendment Act of 2002. 
resources and for acquiring an intellectual property right, ${ }^{291}$ compliance with the benefit sharing fee or royalty demanded by the NBA, ${ }^{292}$ and making non-compliance with these requirements grounds for opposition and revocation. ${ }^{293}$ The TRIPS Agreement does not address these matters. India's propositions can be interpreted as constituting additional elements of the disclosure requirement under patent law. ${ }^{294}$ Arguably, this information is necessary to enable a proper novelty evaluation. ${ }^{295}$

The European Union's reply to India's suggestion in the draft IP chapter of the India$E U$ BTLA is unequivocal: it proposes that the parties acknowledge the usefulness of requiring the disclosure of the origin or source of genetic resources and associated traditional knowledge. ${ }^{296}$ It is not willing to accept a mandatory disclosure element and even less so the two additional elements of prior informed consent and equitable sharing of benefits; it reduces parties' commitment from a hard obligation to an acknowledgment of its usefulness, without creating any obligation for parties. The same is true for its response to the requirement of having the consequences of noncompliance included in substantive patent law: the European Union merely suggests that the domestic law of the parties will provide for the consequences of noncompliance. ${ }^{297}$ These suggestions made by the EU are identical to the ones proposed, and ultimately accepted, in the EU-Colombia-Peru FTA. ${ }^{298}$

Overall, India's propositions on a mandatory disclosure of origin, prior informed consent, equivalent sharing of benefits and consequences for non-compliance show a strong determination to protect traditional knowledge and genetic resources appropriately. The required protection is in line with India's own law but goes beyond the TRIPS Agreement. The European Union is clearly opposed to India's suggestions, particularly when it comes to the mandatory obligations.

\subsubsection{Procedural Commitments by Patent Offices}

Besides substantive obligations, India proposes certain procedural commitments. First, patent offices and national biodiversity authorities shall take appropriate administrative action to ensure that traditional knowledge in the territory of the

See Sections 6 and 18.3 and 18.4 of the Indian Biological Diversity Act of 2002. However, it has to be noted that it is up to applicants to ask for prior approval by the NBA and that the NBA cannot monitor whether IP applications concerning TK and biological resources are granted without the approval. See Swarna Latha, "Biopiracy and Protection of Traditional Medicine in India", p. 474. See Article 6.2 of the Indian Biological Diversity Act of 2002. See Sections 25.1(j) and 25.2(j) of the Indian Patent Amendment Act of 2006 for the grounds for pre- and post-grant opposition; see Section 64.1(p) and (q) of the Indian Patent Amendment Act of 2002 for the grounds of revocation. See Article 29 of the TRIPS Agreement.

Note that an amendment of the TRIPS Agreement is currently being negotiated in the WTO framework which would address the relationship between patent rules and these requirements and make disclosure of origin obligatory for all WTO Members. See section 5.3.2.8 of this book for a detailed analysis of the elements of the proposed Article 29 bis of the TRIPS Agreement. See Article 10 of the draft IP chapter of the India-EU BTIA, as proposed by the EU. Ibid.

See Article 201.8, 201.7, 201.4 and 201.3 of the EU-Colombia-Peru FTA. 
parties is not misappropriated. ${ }^{299}$ Furthermore, the parties shall ensure that the Traditional Knowledge Digital Library (TKDL) developed by India is accessed and utilized in order to screen patent applications for prior art. ${ }^{300}$ The TKDL is a database developed by the Government of India in order to prevent the patenting of inventions that are based on Indian traditional knowledge. As of September 2012, it contained information on more than 250,000 medical formulations and 1,490 Yoga concepts, postures and terminology. ${ }^{301}$ The TKDL acts as a

"bridge between the traditional knowledge existing in local languages and the patent examiners at various international patent offices." 302

The database solves the problem of lack of access to documentation on India's traditional medicine due to language barriers. Its content is transcribed into English, French, German, Japanese and Spanish. ${ }^{303}$ The EU, however, does not seem to be willing to accept the obligation to ensure that the TKDL is accessed and screened for prior art searches; on the contrary, it proposes to recognize the usefulness of such databases rather than committing to using them. ${ }^{304}$ The European Patent Office, in fact, has concluded an access agreement in February 2009 with the Indian Council of Scientific and Industrial Research on the use of the TKDL. ${ }^{305}$ It is not clear, however, whether the TKDL is consulted in each prior art search and whether the desired effect of avoiding misappropriation of biological material or traditional knowledge is safeguarded through such an agreement. As Swarna Latha recognizes, the instances of granting intellectual property rights on prior art have increased despite the availability of the TKLD to international patent examiners. ${ }^{306}$ On the other hand, the official website of the TKLD lists several instances in which the claims of applications have been amended due to information provided in the TKLD. ${ }^{307}$

Another more procedural requirement relates to third party observations, which shall be facilitated before the grant of a patent at no cost and without time limits. ${ }^{308}$ Where India already fulfills these requirements, ${ }^{309}$ the European Patent Convention, to which the Members States of the European Union are parties, only provides for a post-grant opposition period of nine months, which also entails costs for the parties involved in

See Article 11.1 of the draft IP chapter of the India-EU BTLA, as proposed by India. See Article 11.2 of the draft IP chapter of the India-EU BTLA, as proposed by India. See Government of India, Traditional Knowledge Digital Library (2010), available at <http://www.tkdl.res.in/tkdl/langdefault/common/Abouttkdl.asp?GL=Eng> accessed on 16.11.2012.

See ibid.

See R. Chakravarty, "Preserving traditional knowledge: Initiatives in India" International Federation of Library Associations and Institutions, 2010, Vol. 36 (4), 294-299, p. 296.

See Article 11 of the draft IP chapter of the India-EU BTIA, as proposed by the EU. See European Patent Office, India's Traditional Knowledge Digitnal Library (TKDL): A powerful tool for patent examiners (2009), available at <http://www.epo.org/topics/issues/traditional.html> accessed on 09.02.2011.

See Swarna Latha, "Biopiracy and Protection of Traditional Medicine in India", p. 467. See Government of India, Traditional Knowledge Digital Library.

See Article 11.3 of the draft IP chapter of the India-EU BTLA, as proposed by India. See Article 25.1(j) and (k) and Article 25.2(j) and (k) of the Indian Patent Amendment Act of 2005. 
opposition proceedings. ${ }^{310}$ Finally, India asks the European Union to create a mechanism to review and revoke, outside of the opposition system, all cases where patents concerning Indian medicine have wrongfully been granted, due to the absence of a comprehensive prior art search. ${ }^{311}$ In other words, India demands that the EU undertake a review of all granted patents based on medicinal knowledge to determine wrong examinations of prior art. This would require a large amount of work for the EPO as they would have to assess these patents without a claimant who points the EPO to allegedly wrongfully granted patents.

To sum up, India has proposed procedural commitments for the European Union. They mainly address the use of the Traditional Knowledge Digital Library in prior art searches, providing an opportunity for third party observations and the revocation of wrongfully granted patents. The European Union so far has not agreed to any of them. These provisions clearly show India's desire to make the TKDL a success, which is visible in the patents granted by foreign patent offices, such as the EPO.

\subsubsection{Interim Conclusions}

The protection of genetic resources and traditional knowledge could become a crucial part of the draft IP chapter of the India-EU BTIA if the European Union accepts important provisions that have been proposed by India. The TRIPS Agreement does not stipulate any rules on such protection. However, in view of the fact that the obligations with regard to mandatory disclosure of origin, prior informed consent, equivalent sharing of benefits and consequences for non-compliance, as well as the procedural requirements from the EPO, go further than any other international treaty text on the issue so far, it is rather unlikely that the provisions as analyzed here will be incorporated in the final India-EU BTLA. No other European bilateral trade agreement contains similar provisions, apart from the reiteration of some provisions contained in the Convention on Biological Diversity.

\subsubsection{Interim Conclusions}

The draft IP chapter of the India-EU BTLA strongly reflects the interests of both negotiating partners. It is difficult to conclude a general tendency followed in the agreement because the controversial areas are not yet agreed upon and it seems difficult to give an indication of what could be a possible compromise between the parties. Nevertheless, this analysis has revealed important insights on the areas that are still under negotiation, where TRIPS-plus elements have been included, in how far the trend set out in recent European "new generation" agreements is being followed, where legislation-like provisions have been proposed by the European Union and in how far India was able to preserve sufficient domestic policy space. Overall, the IP chapter of this agreement reflects negotiations between equal partners. India has often proposed its own language on areas that constitute offensive interests for India. Whether these provisions will be included in the final agreement remains to be seen.

Many provisions in the different areas are still under negotiations. This is the case for the protection sought for digital products, the protection of trade marks, the

$310 \quad$ See Articles 99.1 and 104.1 of the European Patent Convention.

311 See Article 11.4 of the draft IP chapter of the India-EU BTIA, as proposed by India. 
protection of geographical indications, the provisions on data exclusivity and the protection of genetic resources and traditional knowledge. Only the protection of designs, the relationship of patents and public health and the protection of plant varieties are relatively undisputed. In many areas, the European Union has suggested text to be included in the draft IP chapter of the India-EU BTLA. However, India has proposed its own text for the term of duration of related rights, the protection of trade marks and geographical indications, and importantly the protection of genetic resources and traditional knowledge.

The protection sought in the draft IP chapter is clearly of a TRIPS-plus standard. Mainly the protection proposed by the European Union goes beyond the TRIPS Agreement. Important examples of proposed TRIPS-plus provisions are incorporated in the following areas: copyright protection for digital products, protection of trade marks, geographical indications, industrial designs and patents. Only the protection of plant varieties does not go beyond the TRIPS standard. In one area, India is also a TRIPS-plus demandeur: India has asked for a longer term of protection for related rights than the TRIPS Agreement requires. In all other areas where India has suggested provisions, it mainly wishes to adhere to the TRIPS standard. The protection for genetic resources and traditional knowledge represents a different case: India proposes to agree on specific standards of protection, which would limit the grant of patents to those that fulfill these requirements. If agreed upon, they would add additional conditions that patent applicants need to fulfill.

When comparing the suggested provisions in the IP chapter of the India-EU BTLA with the equivalent chapters of other European "new generation" agreements, the majority of propositions made by the European Union follow the trend observed in the other agreements. This is particularly so with regard to the provisions on the protection of digital products, trade marks and geographical indications. The protection of industrial designs and plant varieties, on the other hand, in many aspects stays behind the level of protection achieved by the European Union in other agreements. The India-EU BTLA also contains elements in the IP chapter that are new compared with other agreements. The protection of data exclusivity and the detailed obligations required by India with respect to the protection of genetic resources and traditional knowledge have hardly been integrated in other European "new generation" agreements.

It is still unclear whether the India-EU BTIA will allow India to preserve sufficient domestic policy space in order to balance domestic interests and take into account development concerns when implementing the provisions of the agreement. The draft IP chapter of the India-EU BTLA as proposed by the European Union does not seem to leave much space to do so. In the areas of copyright protection, protection for geographical indications, industrial designs and data exclusivity, the provisions suggested by the European Union have been copied from internal EU legislation. In addition, the EU requires compliance with international agreements, particularly in the areas of copyright and trade mark protection, instead of allowing for softer "best endeavour" obligations. India, on the other hand, proposes to adhere to the TRIPS standard in many areas. It already was able to convince the European Union to accept these standards in the areas of design right protection and plant variety protection. Arguably, the TRIPS standard is generally accepted as the international 
standard that preserves the balance between rights and obligations and takes the development needs of WTO Members into account.

\subsection{ENFORCEMENT PROVISIONS}

The European Union was the first of both parties to propose a text for the enforcement section in the draft IP chapter of the India-EU BTLA. This proposal by the European Union contains the same structure and content as adopted in other bilateral trade agreements with CARIFORUM States, South Korea, Peru and Colombia, Central American countries and Canada. ${ }^{312}$ The suggested language has been borrowed from Articles of the Enforcement Directive 2004/48 and the Customs Regulation 1383/2003. It is primarily the provisions therein that grant rights to the title holders that have been transposed; the provisions that balance these rights against those of competitors and users of IP protected products have been mostly left out or changed considerably.

The draft IP chapter of the India-EU BTIA of July 2010 still reflects the structure of the proposal made by the European Union in September 2008; 313 the content of the provisions, however, has been revised extensively by India. The European Union seems to agree with most of India's revisions and has given up its own language for many subject matters. This is surprising as the EU has not compromised much on these provisions in other bilateral trade agreements so far. It appears that India was able to achieve different language by drafting detailed provisions itself to counter the proposals made by the European Union. Often, India's propositions do not cover the whole range of requirements envisaged by the European Union. They integrate a good deal of the safeguards left out by the European Union and offer some flexibility in terms of how to implement the rules in domestic law.

The enforcement section deals mainly with three areas: a) general provisions, b) civil enforcement measures and c) border measures. Not addressed in the following analyses are the proposed provisions on the liability of intermediary service providers. The European Union has envisaged a Section thereon that is similar to the one included in the EU-South Korea FTA, the EU-Colombia-Peru FTA and the draft EUCanada CETA. ${ }^{314}$ However, India wishes to delete this Section. ${ }^{315}$ The draft IP chapter of the India-EU BTLA does not address criminal sanctions: the European Union failed to propose such rules in the draft IP chapter of the India-EU BTLA. It is surprising that a proposal on criminal enforcement measures is lacking in the most recent draft from July 2010 because the European Union had included such measures

312 See draft IP chapter of the India-EU BTLA of September 2008.

313 See Articles 12-29 of the draft IP chapter of the India-EU BTIA of November 2008.

314 See Article 10.62-66 of the EU-South Korea FTA; Article 242 of the EU-Colombia-Peru FTA, and Article 29 of the draft IP chapter of the EU-Canada CETA, as proposed by the EU. Note that the CARIFORUM-EC EPA and Article 272 of the EU-Central America $A A$ do not contain any (new) obligations on the matter. 
in earlier drafts, ${ }^{316}$ the EU-South Korea FTA and the Anti-Counterfeiting Trade Agreement. ${ }^{317}$

Two reasons can be put forward which may explain why criminal sanctions were left out of the last draft IP chapter of the India-EU BTLA. First, the EU has difficulties agreeing to criminal enforcement rules internally, as illustrated by the failed proposal for a criminal enforcement directive. ${ }^{318}$ The lack of agreement thereon within the European Union has most recently been demonstrated by the European Parliament's rejection of ACTA, among others because of the fact that ACTA provides for criminal measures. ${ }^{319}$ Second, and maybe more importantly, India does not seem to have any interest in committing to criminal enforcement measures in an international treaty, even though some of its laws do foresee criminal sanctions for particular IP infringements. ${ }^{320}$ It is not a signatory party of ACTA and it has rejected such provisions in the BTIA negotiations.

\subsubsection{General Provisions}

Two general provisions have been included in the draft IP chapter of the India-EU BTIA. Article 17 incorporates by reference the commitments under the TRIPS Agreement: the parties agree that they reaffirm these commitments. It is not yet clear what additional measures the parties want to undertake. India and the EU have not yet agreed on whether the measures in the enforcement section of the India-EU BTIA are merely meant to meet their obligations under the TRIPS Agreement or whether they will complement TRIPS measures. ${ }^{321}$ The first option has been proposed by India, while the EU wishes to go beyond that level. Choosing one option over the other can have an impact on the interpretation of the substantive enforcement provisions: general obligations are taken into account as the context and purpose of the agreement, which will be considered together with the wording of substantive provisions.

In addition, the European Union proposes copying Article 41.2 of the TRIPS Agreement. Accordingly, the measures adopted shall be fair and equitable, not unnecessarily complicated or costly, nor shall they entail unreasonable time-limits. ${ }^{322}$ In other words, the enforcement measures shall be necessary, fair and simple. India has not yet agreed to this provision. This would be a pity since such a clause provides

316 See Article 25 of the draft IP chapter of the India-EU BTLA of November 2008 and Article 34 of the IP chapter of the draft India-EU BTLA of June 2010.

317 See Articles 23-26 of ACTA and Article 10.54-10.61 of the EU-South Korea FTA.

318 See Proposal for a European Parliament and Council Directive on criminal measures aimed at ensuring the enforcement of intellectual property rights (COM(2005) 276 final of 12.7.2005).

319 See Pinsent Masons, "ACTA rejected by European Parliament".

320 India provides for criminal offences for copyright infringements (Chapter XIII of the Indian Copyright Act of 1999), certain trade mark infringements (Chapter XII of the Indian Trade Mark Act of 1999) and certain GI infringements (Chapter VIII of the Indian GI Act 1999).

321 See Article 17.1 of the draft IP chapter of the India-EU BTLA.

322 See Article 17.2 of the draft IP chapter of the India-EU BTIA. Note that the same provision has been included in Article 151.1 of the CARIFORUM-EC EPA; Article 10.41.2 of the EU-South Korea FTA; Article 234.3 of the EU-Colombia-Peru FTA; Article 260.1 second sentence of the EU-Central America AA; Article 13.1 of the draft IP chapter of the EU-Canada CETA. 
a certain procedural ceiling to enforcement measures. Neither party has proposed the important safeguard of Article 41.5 of the TRIPS Agreement. the assurance that the enforcement measures do not create an obligation to put in place a judicial system for the enforcement of IP rights distinct from the enforcement of law in general. ${ }^{323}$ Its omission constitutes a TRIPS-plus feature: in the relationship between the EU and India, parties cannot rely on the clear absence of an obligation on the matter. In view of India applying general enforcement laws, as well as special enforcement provisions for copyright, trade marks and geographical indications, India could benefit from this safeguard in a way that allows it to maintain a general enforcement system.

The second general provision addresses entitled applicants and has already been agreed upon. Accordingly, holders of intellectual property rights, ${ }^{324}$ licensees and professionals who have a right to represent holders of IPRs are entitled to seek the application of specified measures and procedures, in line with the applicable domestic law. ${ }^{325}$ It is clear from earlier drafts ${ }^{326}$ that the European Union has given up its own language, which added the category of colleting societies to the list of entitled applicants. ${ }^{327}$ On the other hand, India succeeded in extending the category of professional defense bodies to the more general term "professionals having a right to represent right holders". This presumably allows parties to cover different types of professional groups. For example, the European Union might be able to cover collective rights-management bodies under this category.

The provision goes beyond the TRIPS standard in two aspects. First, the list of entitled applicants covers more persons than the TRIPS rule. According to Article 42, only right holders may initiate civil judicial measures. ${ }^{328}$ Second, according to Article 18 of the draft IP chapter of the India-EU BTLA, entitled applicants may seek the application of measures, procedures and remedies. The types of measures are not specified, whereas the TRIPS Agreement limits this right to the initiation of civil judicial measures. Therefore, border measures would be covered under the India-EU BTLA. To sum up, the general provisions contained in the draft IP chapter of the India-EU $B T L A$ are similar to other European "new generation" agreements. India and the European Union have already agreed upon the omission of an important TRIPS safeguard and the list of entitled applicants. Both contain certain TRIPS-plus

The same is true for the CARIFORUM-EC EPA, the EU-South Korea FTA, the EUCentral America $A A$ and the draft IP chapter of the EU-Canada CETA. The provision has been, however, included in Article 234.4 of the EU-Colombia-Peru FTA.

For that purpose, the parties agree that for copyright or related right holders, the name of the person on the work is presumed to be the first owner of rights. However, this is not the case for cinematograph movies and sound recordings. See Article 29 of the draft IP chapter of the India-EU BTLA. See Article 18 of the draft IP chapter of the India-EU BTLA. See Article 13 of the draft IP chapter of the India-EU BTLA of September 2008 and Article 22 of the draft IP chapter of the India-EU BTIA of April 2010. The provision is identical to Article 4 of the Enforcement Directive 2004/38 and Article 152 of the CARIFORUM-EC EPA; Article 10.42 of the EU-South Korea FTA; Article 228 of the EU-Colombia-Peru FTA and Article 14 of the draft IP chapter of the EUCanada CETA.

See section 5.3.1 of this book on general provisions in the CARIFORUM-EC EPA for a more detailed analysis of this aspect. 
elements. Still under negotiation is the provision referring to the TRIPS Agreement and the TRIPS-safeguard with regard to the cost- and time-effectiveness of the measures.

The next part of the enforcement section of the India-EU BTLA addresses civil enforcement measures. They constitute by far the largest part of the enforcement section. Nine Articles address rules on a) evidence, b) the right of information, c) provisional and precautionary measures, d) remedies and e) damages and legal costs. Thanks to India's efforts of suggesting its own language and the EU's willingness to embrace them, most provisions are not as detailed as the equivalent rules in other European trade agreements.

\subsubsection{Evidence}

One of the important civil enforcement measures are the rules on evidence. Rules on protecting evidence are aimed at protecting evidence that is under the control of the alleged infringer for judicial proceedings. The draft IP chapter of the India-EU BTLA provides two rules in this regard. First, judicial authorities must have the power to order the communication of evidence during legal proceedings. Second, judicial authorities must be able to order provisional measures before proceedings have started in order to preserve evidence. Both provisions are identical to the equivalent TRIPS rules and have been agreed upon by both parties.

According to Article 19 of the draft IP chapter of the India-EU BTIA, judicial authorities may order the opposing party to produce specified evidence that lies in its control. ${ }^{329}$ This obligation is subject to three caveats, which are also set out in the TRIPS Agreement and the Enforcement Directive 2004/48. ${ }^{330}$ First, the claiming party must have presented reasonably available evidence that is sufficient to support its claims. Second, that party must also have specified the evidence that lies within the control of the opposing party. Third, when judicial authorities order the production of evidence, the protection of confidential information must be ensured. The three caveats have not been included in most other European "new generation" bilateral trade agreements. ${ }^{331}$ The only other agreement in which the caveats are also included is the EU-Central America AA. ${ }^{332}$ Both Central American countries and India successfully rejected the provision proposed by the EU, which omitted the procedural safeguards. ${ }^{333}$

Also on the rules applying to provisional measures preserving evidence, India and the $\mathrm{EU}$ are almost in agreement: the judicial authorities can order (EU: at any time) appropriate provisional measures to preserve relevant evidence. ${ }^{334}$ No examples are

329 See Article 19 of the draft IP chapter of the India-EU BTIA.

330 See Article 43.1 of the TRIPS Agreement and Article 6 of the Enforcement Directive 2004/48.

331 See Article 153 of the CARIFORUM-EC EPA; Article 10.43 of the EU-South Korea FTA; Article 229 of the EU-Colombia-Peru FTA and Article 15 of the draft IP chapter of the EU-Canada CETA. The provision is identical to Article 6.2 of the Enforcement Directive 2004/48 applying to infringements on a commercial scale.

332 See Article 262 of the EU-Central America $A A$.

333 See Article 19 of the draft IP chapter of the India-EU BTIA, as proposed by the European Union.

334 See Article 20 of the India-EU BTIA. 
given of what such measures could entail, as for instance were proposed by the EU: taking samples, seizing infringing goods and materials used. ${ }^{335}$ The provision is identical to Article 50.1(b) of the TRIPS Agreement. The broad power of judicial authorities enables them to order any provisional measure that the court thinks is appropriate. The procedural and substantive safeguards set out in Article 50.2-50.8 of the TRIPS Agreement are absent from the draft IP chapter.

Where the draft IP chapter of the India-EU BTIA omits a TRIPS exception, it is not anymore immediately available in the context of the India-EU BTLA and hence constitutes a TRIPS-plus feature. Whether parties can still rely on the omitted TRIPS exception as a defence in a dispute involving a breach of a rule of the India-EU BTLA depends on the specific provision at issue and the conflict rule established by the India-EU BTLA, the TRIPS Agreement or public international law. ${ }^{336}$ In fact, many of the procedural safeguards guaranteed by Article 50 of the TRIPS Agreement are mandatory and have to be implemented in WTO Members' national laws, regardless of their absence in the India-EU BTLA.

In brief, the rules on evidence have already been agreed upon and are identical to the equivalent provisions in the TRIPS Agreement. India was very successful in rejecting the proposals made by the European Union which would have contained several TRIPS-plus aspects. The agreed text, therefore, stays far behind the standard of protection agreed upon in most European "new generation" agreements and included in internal legislation, and preserves a considerable amount of flexibility for parties to take due account of their domestic preferences.

\subsubsection{Right of Information}

In judicial proceedings, national authorities may have the power to order the infringer to provide information on the identity of third persons involved in producing or distributing infringing goods and their channels of distribution. ${ }^{337}$ This authority is subject to one caveat: the order may not be out of proportion to the seriousness of the infringement. Both parties agree on the substance of this right. Agreement is still lacking on the type of obligation connected thereto. India has proposed that countries may grant this power to judicial authorities. This would be identical to Article 47 of the TRIPS Agreement. The European Union, on the other hand, has proposed to oblige parties to grant this power. Either way, the flexibility enshrined in the provision gives both parties the freedom to put in place specific rules on what information the judicial authorities may order to be released, by whom and under which procedural and substantive conditions.

See Article 20 of the draft IP chapter of the India-EU BTIA, as proposed by the EU. This provision is identical to Article 7.1 of the Enforcement Directive 2004/48 and to the provisions included in Article 154 of the CARIFORUM-EC EPA; Article 10.44.1 of the EU-South Korea FTA; Article 230 of the EU-Colombia-Peru FTA and Article 16.2 of the draft IP chapter of the EU-Canada CETA.

336 For a detailed analysis of the questions that the judiciary body will have to address, see section 3.3.6.5 on invoking TRIPS exceptions in the context of agreements on trade in wine and/or spirits and section 5.3.2.3.4 for the CARIFORUM-EC EPA context. 
Compared with earlier drafts, the provision agreed upon differs considerably from the proposal made by the European Union, which is similar to the rules contained in the agreements with CARIFORUM States, ${ }^{338}$ South Korea ${ }^{339}$ and Colombia and Peru. ${ }^{340}$ The language therein is taken from the Enforcement Directive 2004/48 and sets out in detail which persons can be ordered to provide what types of information, while omitting the proportionality test provided for in the TRIPS Agreement. 341 Hence, it contains several TRIPS-plus elements. One agreement also deviates from the European Union standard: Central American countries ${ }^{342}$ were able to incorporate the TRIPS obligation in the same way as India has proposed for the draft IP chapter of the India-EU BTLA.

In conclusion, also for the right of information, India succeeded in preserving the TRIPS standard rather than adopting the specific rules suggested by the European Union, which would have been similar to the rules contained in most other European bilateral trade agreements and identical to the relevant provision in the Enforcement Directive 2004/48. Only the nature of the obligation is still disputed: India has suggested keeping the voluntary nature whereas the European Union wishes to oblige parties to provide their judicial authorities with the power to order the infringer to provide information on the persons and distribution channels involved in the infringing activity. If the parties agree to insert a hard obligation, it would be the only TRIPS-plus element.

\subsubsection{Provisional and Precautionary Measures}

Provisional and precautionary measures are an essential tool of national authorities to avoid that irreparable harm is caused to the right holder; these measures can be ordered even before an infringement has been found. The provision dealing with provisional and precautionary measures included in the draft IP chapter of the IndiaEU BTI $A$ is not yet agreed upon. The parties' proposals still stand next to each other; no efforts on compromising language are visible yet. The EU and India suggest rules that focus on very different aspects of provisional measures: while the EU emphasizes measures that can be used against the alleged infringer, India focuses on safeguard mechanisms that aim at avoiding abuse of provisional measures and that have been provided for in the TRIPS Agreement, the Enforcement Directive 2004/48 and partly also in ACTA. ${ }^{343}$

To start with, the European Union proposes the same three types of provisional measures that are foreseen in Article 9 of the Enforcement Directive 2004/48 and have also been incorporated in most other recent bilateral trade agreements. At the same time, the European Union chooses to omit the procedural safeguards contained in its own internal law.

338 See Article 155 of the CARIFORUM-EC EPA.

339 See Article 10.45 of the EU-South Korea FTA.

340 See Article 239 of the EU-Colombia-Peru FTA.

341 See Article 21 of the draft IP chapter of the India-EU BTLA, as proposed by the EU and Article 8 of the Enforcement Directive 2004/48. See also section 5.3.3.3 of this book on the regulation of the right of information in the CARIFORUM-EC EPA.

342 See Article 264 of the EU-Central America AA.

343 See Article 22.3-22.7 of the draft IP chapter of the India-EU BTIA, as suggested by India. 
The first type of measures proposed by the European Union are interlocutory injunctions. Judicial authorities shall have the power to 1) issue interlocutory injunctions in order to prevent any imminent infringement, 2) forbid the continuation of an alleged infringement by making it subject to recurring penalty payments, 3) to subject such continuation to the lodging of guarantees that will ensure the compensation of the right holder, or 4) to issue interlocutory injunctions against an intermediary whose services are being used by a third party to infringe an intellectual property. ${ }^{344}$ These four powers set out in detail the specific measures that must be available. ${ }^{35}$ The TRIPS Agreement, on the other hand, merely requires judicial authorities to order prompt and effective provisional measures. ${ }^{346}$ In addition, its Articles 50.2-50.8 stipulate important procedural safeguards, which are also taken up in the Enforcement Directive 2004/48,347 however not in the proposal made by the EU. ${ }^{348}$ In fact, many of these safeguards are mandatory under the TRIPS Agreement and have to be implemented in WTO Members' national laws, regardless of their absence in the India-EU BTIA. ${ }^{349}$

The second type of measures proposed by the European Union regards the authority to order the seizure or delivery up of suspected goods in order to prevent their entry into or movement within the channels of commerce. ${ }^{350}$ Under the TRIPS Agreement, the seizure of suspected goods is only explicitly mentioned in the context of criminal proceedings. ${ }^{351}$ This suggests that the TRIPS Agreement does not foresee this type of provisional measure in the context of civil proceedings. Lastly, in the case that an infringement has been committed on a commercial scale and the applicant is able to demonstrate circumstances likely to endanger the recovery of damages, a third type

344 See Article 22.1 of the draft IP chapter of the India-EU BTIA, as proposed by the EU. The provision is identical to Article 9.1(a) of the Enforcement Directive 2004/48; Article 156.1 of the CARIFORUM-EC EPA; Article 10.46 .1 of the EU-South Korea FTA; Articles 232.1 and 232.2 of the EU-Colombia-Peru FTA and Article 18.1 of the draft IP chapter of the EU-Canada CETA. Note that Article 265.1 of the EU-Central America $A A$ does neither include the possibility to make the continuation of the alleged infringement subject to recurring penalty payments or to the lodging of guarantees, nor to issue injunctions against intermediaries. See section 5.3.3.4 of this book on the provisional measures contained in the CARIFORUM-EC EPA for a detailed assessment of the TRIPS-plus features. See Article 50.1(a) of the TRIPS Agreement. See Article 9.3-9.7 of the Enforcement Directive 2004/48.

The EU has not proposed such guarantees to any of its negotiating partners; only in the EU-Central America $A A$, parties have agreed to include two of these safeguards, being the power to require reasonably available evidence and a reasonable security by the applicant, see Article 265 of the EU-Central America AA.

For a detailed analysis of the relationship between TRIPS exceptions and bilateral trade agreements, see section 6.4.2 and the section invoking TRIPS exceptions before wine agreement arbitrators and section 5.3.2.3.4 for the CARIFORUM-EC EPA context. See Article 22.2 of the draft IP chapter of the India-EU BTLA, as proposed by the EU. The provision is identical to Article 9.1(b) of the Enforcement Directive 2004/48; Article 156.2 of the CARIFORUM-EC EPA; Article 10.46 .2 of the EU-South Korea FTA; Article 18.2 of the draft IP chapter of the EU-Canada CETA; Article 240.2 of the EUColombia-Peru FTA. Note that Article 265 of the EU-Central America $A A$ does not include this second type of measures in its provision on provisional and precautionary measures. 
of measure is available to judicial authorities: they may order the precautionary seizure of movable and immovable property, including blocking bank accounts and other assets, as well as the communication of bank, financial or commercial documents. ${ }^{352}$ No equivalent can be found in the TRIPS Agreement.

India's proposal, on the other hand, has copy-pasted the entire Article 50 of the TRIPS Agreement in the draft IP chapter of the India-EU BTIA. It contains a general obligation for judicial authorities to adopt provisional measures and sets out a series of general guarantees in order to avoid the abuse of these measures. ${ }^{353}$ The general obligation does not prescribe interlocutory measures or the seizure of goods, but requires judicial authorities to command prompt and effective provisional measures to prevent an infringement and the entry into the channels of commerce. The authority to order provisional measures can also be used inaudita altera parte, without having heard the defendant party in case of likely irreparable harm or a demonstrable risk of evidence. ${ }^{354}$

When it comes to the guarantees foreseen by the Indian proposal, it provides for all seven provisions stipulated in the TRIPS Agreement and the Enforcement Directive 2004/48. So far, only Central American countries were able to integrate two out of the six safeguards into a bilateral agreement with the EU; 355 other agreements do not contain any of them. First, India proposes an important guarantee which permits authorities to require the applicant to provide "any reasonably available evidence" which proves "with a sufficient degree of certainty" that the applicant is the right holder and that his right is being infringed or that such infringement is imminent. ${ }^{356}$ Second, judicial authorities shall have the power to order the applicant that (s)he must provide a security in order to protect the defendant and to prevent abuse. ${ }^{357}$ Third, when measures are taken without having heard the defendant party, the parties affected have to be given notice without delay after the execution of the measures at the latest. ${ }^{358}$

See Article 22.3 of the draft IP chapter of the India-EU BTIA, as proposed by the EU. The provision is identical to Article 9.2 of the Enforcement Directive 2004/48; Article 156.3 of the CARIFORUM-EC EPA; Article 10.46 .3 of the EU-South Korea FTA (with the exception of the communication of bank, financial or commercial documents) and Article 18.3 of the draft IP chapter of the EU-Canada CETA. Note that the EUColombia-Peru FTA and the EU-Central America $A A$ do not provide for this third type of measure.

353 See Article 22.1 of the draft IP chapter of the India-EU BTIA, as proposed by India.

354 See Article 22.2 of the draft IP chapter of the India-EU BTLA, as proposed by India. Note that also Article 9.4 first sub sentence of the European Enforcement Directive 2004/48 contains this obligation, as well as Article 12.2 of ACTA. These safeguards include the power to require reasonably available evidence and a reasonable security by the applicant, see Article 265 of the EU-Central America AA. See Article 22.3 of the draft IP chapter of the India-EU BTIA, as proposed by India. See also Article 50.3 of the TRIPS Agreement, Article 9.3 of the Enforcement Directive 2004/48 and Article 12.4 of ACTA.

357 See Article 22.3 of the draft IP chapter of the India-EU BTLA, as proposed by India. See also Article 50.3 of the TRIPS Agreement, Article 9.6 of the Enforcement Directive 2004/48 and Article 12.4 of ACTA.

See Article 22.4 of the draft IP chapter of the India-EU BTIA, as proposed by India. See also Article 50.4 of the TRIPS Agreement and Article 9.4 second sentence and 
India further requires that the judicial authorities may require the applicant to supply other information necessary for the identification of the goods concerned. ${ }^{359}$ A fifth safeguard suggested by India allows the defendant to request the revocation of provisional measures if the applicant has not started proceedings on the merits within a reasonable time. ${ }^{360}$ Sixth, in case the measures are revoked or it is found that there was no infringement of an IP right, the judicial authorities can also order the applicant to provide the defendant with appropriate compensation for the injury caused by the measure. ${ }^{361}$ Finally, where provisional measures can be ordered as a result of administrative procedures, these procedures shall conform to principles equivalent in substance to those set forth in this Article. ${ }^{362}$

Overall, the provision on provisional measures is one of the few provisions where the parties were not yet able to find a common text. India emphasizes the rights of defendants. For that, it has copied provisions from the TRIPS Agreement, language that has also been incorporated into the European Union's own internal instrument as well as ACTA, to which it is not a party. It contains important procedural safeguards that are meant to avoid the abuse of provisional and precautionary measures. Nevertheless, the European Union does not seem to be inclined to accept these provisions in the India-EU BTLA. So far, it has almost never done so in other bilateral trade agreements. What it has proposed to insert in the draft IP chapter of the India-EU BTIA, however, are three specific types of provisional measures that are also required in the Enforcement Directive 2004/48. They contain important TRIPS-plus provisions.

\subsubsection{Remedies}

Remedies are applied after an infringement has been found by the judicial authority. The draft IP chapter of the India-EU BTIA sets out three types of remedies that judicial authorities have at their discretion. They can order a) corrective measures, b) issue an injunction aimed at prohibiting the infringer from continuing the infringement, or c) order pecuniary compensation. All provisions are already agreed upon. As regards the first two types of measures, India was able to defend its own proposal. In respect of pecuniary compensation, both parties agreed to a common text.

The provision stipulating the authority to take corrective measures is a copy of Article 46 of the TRIPS Agreement. It classifies the available corrective measures according to the types of goods that are made subject to such measures. In the case of infringing goods, judicial authorities may order two kinds of actions: they may be

paragraph 2 of the Enforcement Directive 2004/48. Note that Indian Code of Civil Procedure of 1908, Order XXXIX, Section 3 and addition [390] provide for a similar rule. the TRIPS Agreement.

360 See Article 22.6 of the draft IP chapter of the India-EU BTLA, as proposed by India. See also Article 9.5 of the Enforcement Directive 2004/48.

361 See Article 22.7 of the draft IP chapter of the India-EU BTLA, as proposed by India. See also Article 50.7 of the TRIPS Agreement, Article 9.7 of the Enforcement Directive 2004/48 and Article 12.5 of ACTA. 
disposed of outside the channels of commerce or they can be destroyed. ${ }^{363}$ In that, the parties have adopted the text suggested by India and disregarded the EU's proposal. The European proposal would have permitted three actions for such goods, namely the recall from channels of commerce, their definitive removal or their destruction. ${ }^{364}$ The additional corrective measure of recalling from commerce is not very intrusive and therefore the difference between the two provisions is relatively small.

In the case of materials and implements used in the creation of infringing goods, authorities may order that such materials are disposed of outside the channels of commerce in order to minimize the risks of further infringement; hence, they may not be destroyed. ${ }^{365}$ Here, the agreed text differs from the original European proposal: it suggested that competent authorities may order, if appropriate, the destruction of such materials and implements. ${ }^{366}$ In other words, the European proposal did not foresee the disposal of materials and implements outside the channels of commerce, but merely relied on destruction. Such a provision has also been included in various "new generation" agreements, with the exception of the CARIFORUM-EC EPA and the EU-Central America AA, which grant the authority to order destruction as well as disposal of outside the channels of commerce. ${ }^{367}$

If corrective measures are applied to materials and implements, judicial authorities must take into account a proportionality test, which requires a balance between the seriousness of the infringement, the remedies ordered and third parties' interests. ${ }^{368}$ The TRIPS Agreement, the Enforcement Directive 2004/48 and some European "new generation" bilateral agreements contain the equivalent provision. ${ }^{369}$

The second remedy available is injunctions. According to the provision agreed upon by both parties, injunctions can be issued in order to prohibit the continuation of the

See Article 23 of the draft IP chapter of the India-EU BTLA.

See Articles 23 and 24 of the draft IP chapter of the India-EU BTLA, as proposed by the EU. This is identical to Article 10.1 of the Enforcement Directive 2004/48 and integrated in Article 157.1 of the CARIFORUM-EC EPA; Article 10.47.1 of the EUSouth Korea FTA (which only lists destruction and other appropriate measures that definitively remove goods as allowed actions); Article 241.1 of the EU-Colombia-Peru FTA; Article 266.1 of the EU-Central America $A A$ (which only covers pirated or counterfeit products and lists destruction and other appropriate measures to definitively remove goods as allowed actions) and Article 19.1 of the draft IP chapter of the EU-Canada CETA, as suggested by the EU.

See Article 23 of the draft IP chapter of the India-EU BTIA.

See Article 23 of the draft IP chapter of the India-EU BTLA, as proposed by the EU.

The CARIFORUM-EC EPA did not yet cover materials and implements. The EUCentral America $A A$ grants both the authority to order destruction or disposal outside the channels of commerce, see Article 266.2 of the EU-Central America AA. Other recently concluded agreements in fact only provide for the destruction of such materials if appropriate. See Article 10.47.1 of the EU-South Korea FTA; Article 241.1 second sub sentence of the EU-Colombia-Peru FTA; and Article 19.1 second sentence of the draft IP chapter of the EU-Canada CETA.

See Article 23 of the draft IP chapter of the India-EU BTIA.

See Article 46 of the TRIPS Agreement and Article 10.3 of the Enforcement Directive 2004/48. See also Article 10.47.3 of the EU-South Korea FTA; Article 266.1(b) of the EU-Central America AA. 
infringement of an intellectual property right. ${ }^{370}$ There are considerable differences compared to the EU proposal. Notably, the European Union had also included the authority to apply injunctions to intermediaries as well as the option for parties to make non-compliance with an injunction subject to a recurring penalty payment, if provided for by domestic law. ${ }^{371}$ The TRIPS Agreement, however, does not deal with this matter.

Another optional measure agreed concerns the power of judicial authorities to order pecuniary compensation to be paid to the injured party. ${ }^{372}$ Judicial authorities can make use of pecuniary compensation if certain conditions are fulfilled. First, authorities will only make use of this measure in appropriate cases and at the request of the infringer; second, if the infringer acted unintentionally and without negligence; and third, the measures must be permitted under the applicable law of the parties. Three conditions that need to be fulfilled to order pecuniary compensation under other bilateral agreements are missing: 1) pecuniary compensation can only be used as an alternative to the measures mentioned above; 2) the execution of the measures in question would cause the infringer disproportionate harm; and 3) the pecuniary compensation must appear reasonably satisfactory. ${ }^{373}$ Therefore, the order of pecuniary compensation would seem to be available in a broader range of cases. The possibility to order pecuniary compensation is not provided for by the TRIPS Agreement.

In brief, while the provision agreed upon on corrective measures is identical to the TRIPS rule, the two other remedies allowing for injunctions and pecuniary compensation are not covered by the TRIPS Agreement. They are copies of the relevant provisions from the Enforcement Directive 2004/48 as well as European "new generation" agreements. However, the possibility of ordering pecuniary measures is subject to fewer conditions than in the Enforcement Directive 2004/48. Judicial authorities, therefore, have more discretion to apply this remedy.

\subsubsection{Damages and Legal Costs}

The last civil measures to be discussed here are the payment of damages and the reimbursement of legal costs. While parties have agreed on the payment of damages, this is not the case for the reimbursement of legal costs. The parties agree that the infringer may be ordered to pay the right holder damages adequate to compensate his injury. ${ }^{374}$ This provision is identical to Article 45.1 of the TRIPS Agreement. Once

See Article 24 of the draft IP chapter of the India-EU BTLA.

See Article 24 of the draft IP chapter of the India-EU BTLA, as proposed by the EU. See also Article 11 of the Enforcement Directive 2004/48. The same provision has been agreed upon in Article 158 of the CARIFORUM-EC EPA; Article 10.48.2 of the EUSouth Korea FTA and Article 242 of the EU-Colombia-Peru FTA. The EU-Central America $A A$ and the draft IP chapter of the EU-Canada CETA are silent on that matter. See Article 25 of the draft IP chapter of the India-EU BTLA.

See Article 159 of the CARIFORUM-EC EPA; Article 10.49 of the EU-South Korea FTA; Article 243 of the EU-Colombia-Peru FTA. See also Article 12 of the Enforcement Directive 2004/48. Note that the EU-Central America $A A$ and the draft IP chapter of the EU-Canada CETA do not deal with pecuniary compensation.

See Article 26 of the draft IP chapter of the India-EU BTLA. 
more, the European Union has accepted the proposal made by India and has given up its own text.

The reimbursement of legal costs, on the other hand, is still under negotiation. The European Union proposes as a general rule that the unsuccessful party shall bear the reasonable and proportionate legal costs and other expenses incurred by the successful party, unless equity does not allow this. ${ }^{375}$ India, on the other hand, adheres to the TRIPS standard, and suggests that judicial authorities shall have the power to order the infringer to pay the right holder expenses, which may include appropriate attorney's fees. ${ }^{376}$ Furthermore, judicial authorities may order, in appropriate cases, the recovery of profits or the payment of pre-established damages, even where the infringer did not knowingly, or with reasonable grounds to know, engage in infringing activities. Interesting to note is that the TRIPS Agreement makes the infringer subject to the specified payments, whereas the EU proposal obliges the unsuccessful party to pay such costs.

In summary, the negotiating parties have already agreed to follow India's proposal on the payment of damages and to dismiss the detailed rules proposed by the European Union on how authorities shall set damages exactly. 377 The agreed text is identical to the TRIPS rule. Compared with the rules applying in the European Union, as well as those integrated in recent European bilateral trade agreements, ${ }^{378}$ the India-EU BTLA leaves considerably more discretion to the parties on how to calculate damages. Parties have not yet found a compromise on the reimbursement of legal costs: again India wishes to follow the TRIPS standard and the European Union its own rules. ${ }^{379}$

\subsubsection{Border Measures}

After having assessed the most important civil enforcement procedures proposed in the India-EU BTLA, another crucial tool available to enforce intellectual property rights are border measures. Customs authorities apply such measures at the border of their territory when goods under their supervision are suspected of infringing a form of intellectual property protection. The negotiations on Article 31 of the draft IP chapter of the India-EU BTLA addressing border measures has to be seen in the light

375 See Article 27 of the draft IP chapter of the India-EU BTIA, as proposed by the EU.

376 See Article 27 of the draft IP chapter of the India-EU BTLA, as proposed by India. Note that the same provision is also contained in Article 26.2 of the draft IP chapter. See also Article 45.2 of the TRIPS Agreement.

377 See Article 13.1 of the Enforcement Directive 2004/48.

378 Recent bilateral trade agreements contain overall similar obligations as the Enforcement Directive 2004/48 contains. See Article 160 of the CARIFORUM-EC EPA; Article 10.50 of the EU-South Korea FTA and Article 244 of the EU-Colombia-Peru FTA. Note that Article 267 of the EU-Central America $A A$ reflects the TRIPS standard. Note that Article 21 of the draft IP chapter of the EU-Canada CETA is not similar to the European rule but contains language that seems to have been proposed by Canada.

379 See Article 10.51 of the EU-South Korea FTA; Article 245 of the EU-Colombia-Peru FTA; Article 268 of the EU-Central America AA. Note that Article 161 of the CARIFORUM-EC EPA does not stipulate that only the reasonable and proportionate legal costs and expenses must be borne by the unsuccessful party, but costs in general. Note that the draft IP chapter of the EU-Canada CETA is not identical to the provision contained in other agreements. See also Article 14 of the Enforcement Directive $2004 / 48$. 
of the vivid debate that has evolved around these measures: certain countries, among which the European Union, are applying them in a broad manner, affecting international trade of suspected goods that are in transit in the European Union. This has caused strong concerns with countries such as India and Brazil, which have requested consultations at the WTO after several incidents of generic products originating from India and destined for Brazil being seized by Dutch customs authorities. ${ }^{380}$ The European Union is also making efforts to broaden the scope of application of border measures through plurilateral and bilateral agreements, as evidenced by the provisions on border measures included in ACTA and recent bilateral trade agreements. It is therefore not surprising that critical elements of the provision dealing with border measures in the draft IP chapter of the India-EU BTIA have not yet been agreed upon.

According to Article 31 of the draft IP chapter of the India-EU BTIA, right holders shall have the right to apply to customs authorities for suspending the clearance of goods that are a) imported [EU: or exported] and b) are suspected of infringing a trade mark or a copyright, [EU: a design right or a geographical indication]. ${ }^{381}$ Compared with the respective Article in the TRIPS Agreement, India follows the TRIPS standard in limiting border measures to imported goods that are suspected of infringing either a trade mark or a copyright. The EU clearly wishes to go beyond that standard by adding the exportation of goods as well as other forms of intellectual property rights, in particular designs and geographical indications.

Either way, the EU stays well behind its equivalent provisions in recent and future European bilateral trade agreements: not only imported and exported goods, but also re-exported goods, goods in customs transit, transshipment or placed under a suspensive procedure, a customs free zone or a customs free warehouse are covered in most other European "new generation" trade agreements. ${ }^{382}$ In addition, other European bilateral trade agreements also include more forms of intellectual property: while the trade agreements with Colombia and Peru, Central American countries and the proposal by Canada, ${ }^{383}$ similar to India's proposal, allow border measures for

See WTO Delegation of India, European Union and A Member State - Seizure of Generic Drugs in Transit: Request for Consultations by India (Geneva, 19 May 2010) [WT/DS408/1]; WTO Delegation of Brazil, European Union and A Member State - Seizure of Generic Drugs in Transit: Request for Consultations by Brazil (Geneva, 19 May 2010) [WT/DS409/1]; N. Basu, "India to Move WTO Panel against EU" Business Standard (New Delhi, 1 October 2010), available at <http://www.business-standard.com/india/news/india-tomove-wto-panel-against-eu/409835/> accessed on 12.11.2012. See Article 31.1 of the draft IP chapter of the India-EU BTLA. These are the cases covered in Article 163.1 of the CARIFORUM-EC EPA; Article 10.67.1 of the EU-South Korea FTA and Article 273.2 of the EU-Central America AA. The European Union had also proposed these extensive lists of customs statuses to India, but has given up that suggestion. See Article 31.1 of the draft IP chapter of the India-EU BTLA, as proposed by the EU. Note that Article 249.1 of the EU-ColombiaPeru FTA merely covers goods under importation, exportation and transit. Article 25.1 of the draft IP chapter of the EU-Canada CETA, as proposed by India, merely covers imported goods, and if the parties agree to the EU's proposal, only exportation would be added.

383 See Article 241 of the EU-Colombia-Peru FTA; Article 273.2 of the EU-Central America $A A$, and Article 25.2 of the draft IP chapter of the EU-Canada CETA, as proposed by India. 
counterfeit trade mark and pirated copyright goods only, the agreement with the CARIFORUM States and the EU's proposal to Canada additionally include designs and geographical indications (as is the case for the European Union's proposal to India). ${ }^{384}$ The agreement with South Korea encompasses all forms of IP, including patents. ${ }^{385}$

Although the EU does not meet the standards of protection agreed upon in previous bilateral trade agreements, the EU's proposal to India is in line with ACTA. ${ }^{386}$ That is also the case with regard to the EU proposal for goods in transit: parties should be able to take measures for the detention of suspected goods in transit, and if they do, they have to ensure that legitimate trade in generic medicines is not hindered. ${ }^{387}$ India, on the other hand, has suggested ensuring that goods in transit are not subject to any enforcement procedures. ${ }^{388}$ Arguably, both propositions made with regard to transit goods seem to reflect the sensitivity of the issue in the international sphere. However, it must be clear that if parties can apply such measures, international trade could be hindered and that is clearly not what India or Brazil want. Nevertheless, the provision suggested by the European Union is in line with the TRIPS Agreement, which states that there is no obligation to apply border measures to goods in transit. ${ }^{389}$ In other words, there is no obligation to not apply border measures to intransit goods either. In view of the overall debate around the issue, this provision might very well be one of the most difficult on which to come to an agreement.

To sum up, the provision dealing with border measures touches upon a subject matter that has been intensively discussed, both at the WTO, in the European Union and India. Reaching agreement on the enforcement of infringing in-transit goods is without doubt one of the most contentious issues. While India does not want border measures to be applied to any in-transit goods, the EU would like to see them being covered, under the caveat that such measures may not hinder legitimate trade in generic medicines. As regards goods under importation (and exportation), the parties also disagree as to whether or not border measures should also be applied to exported goods and as to which types of intellectual property infringements should be covered. If the European Union is successful in its demands, the latter aspects would be TRIPS-plus issues. Most other European "new generation" bilateral trade agreements cover in-transit goods as well as more types of IP infringements than the Indian proposal.

\subsubsection{Interim Conclusions}

Most remarkable about the enforcement section of the draft IP chapter of the IndiaEU BTLA is the fact that the European Union has compromised its own proposals on several subject matters and accepted the provisions suggested by India. In no

384 See Article 163.1 footnote 2 of the CARIFORUM-EC EPA and Article 25.1 of the draft IP chapter of the EU-Canada CETA, as proposed by the EU.

385 See Article 10.67.1 of the EU-South Korea FTA.

386 See Article 13, footnote 6, and Article 16.1 of ACTA.

387 See Article 31.2 of the draft IP chapter of the India-EU BTIA, as suggested by the EU. Article 16.2 of ACTA also grants countries this option, without forcing other countries to do so.

388 See Article 31.2 of the draft IP chapter of the India-EU BTIA, as suggested by India.

389 See Article 51, footnote 14 of the TRIPS Agreement. 
other area of IP protection has India, so far, been equally successful in maintaining its own language. This is even more surprising as the first to propose very detailed provisions on each subject matter was the EU. The proposals made by the EU were in many cases identical to the equivalent rules proposed to other European trading partners and contained in European internal law.

The parties have already agreed to adhere to the TRIPS standard with regard to the rules on evidence, the right to information, corrective measures and damages. For all four provisions, the European Union had suggested language identical to its internal legislation and the rules suggested to most other European trading partners. Nevertheless, India succeeded in bringing these demands back to the level of enforcement included in the TRIPS Agreement. The TRIPS standard arguably allows both parties to take development concerns into account and to balance domestic interests when implementing the rights and obligations agreed upon.

The TRIPS standard has also been suggested by India for the general level of enforcement, provisional and precautionary measures, the reimbursement of legal costs and border measures. So far, India was not yet able to convince the European Union to also give up its own language on these subject matters. They are still under negotiation, and certainly for the areas of provisional and precautionary measures and border measures, reaching agreement seems to be very difficult.

Where the agreed text differs from the TRIPS standard is with regard to entitled applicants and the remedies injunctions and pecuniary compensation. The parties will apply measures that go beyond the standard of enforcement guaranteed by the TRIPS Agreement. In other words, the draft IP chapter of the India-EU BTLA also covers third parties in the list of entitled applicants, and allows for injunctions and pecuniary compensation, remedies not foreseen in the TRIPS Agreement. Whereas the first provision is a compromise between the EU and India, the provisions on injunctions and pecuniary compensation are identical to the equivalent rules in the Enforcement Directive 2004/48.

Another conclusion about the enforcement section concerns the proposal made by the European Union, in particular with regard to provisional and precautionary measures, and in other European "new generation" agreements also in respect of corrective measures for materials and implements used in the production of infringing goods. The European Union has not proposed or included important balancing provisions, including a proportionality test, which are foreseen by the TRIPS Agreement and equally contained in European internal law, the Enforcement Directive 2004/48. In other words, in recent European Union bilateral trade agreements, the European Union goes even beyond the standard of enforcement applied internally.

\subsection{CONCLUSIONS}

The analysis of the draft IP chapter of the India-EU BTIA reveals a process of negotiation between two rather equal negotiating partners. Almost in each area under negotiation, both parties have proposed text that reflects their interests. In some areas, the European Union or India have already accepted the proposal of the other party. For example, the European Union has preserved its own proposals with regard 
to the definition of industrial designs, certain requirements for design protection, the obligations with regard to the compliance with international patent treaties, the provision on patents and public health as well as the remedies injunctions and pecuniary compensation. India, on the other hand, was able to do the same in respect of some design rights, plant variety protection and several enforcement matters.

Apart from these particular provisions, agreement is still lacking in many areas. Therefore, it is difficult to draw final conclusions on the general nature of the agreement. Nevertheless, I can present some conclusions with regard to the proposals made by both parties. I have analyzed the approach followed by each party, the TRIPS-plus elements contained in the proposed provisions, the relationship of the draft IP chapter of the India-EU BTLA with other European bilateral trade agreements, in particular with the CARIFORUM-EC EPA, and how much policy space is preserved if the agreement adopts one of the two proposals.

The legal approach apparent in the provisions suggested by India differs considerably from that used by the European Union. India's proposals are almost exclusively based on and do not deviate from the standard of IP protection included in the TRIPS Agreement. India either proposes to insert language identical to particular provisions of the TRIPS Agreement or wishes to incorporate particular Articles by reference. There are two exceptions to this general observation. First, the term of protection for related rights proposed by India, in particular those of producers of movies and broadcasting organizations, goes beyond the term of protection foreseen by the TRIPS Agreement. Second, and most importantly, India suggests incorporating commitments with regard to the protection of traditional knowledge and genetic resources, an area of protection that is not (yet) addressed in the TRIPS Agreement.

The European Union, on the other hand, has used a very similar legal approach as adopted in other "new generation" agreements and therefore fits very well in the development of provisions in European bilateral trade agreements since the launch of the "Global Europe" strategy. According to the European Union, the scope of the draft IP chapter will be very extensive. The EU proposes to adopt the mixed approach, where commitments on the application of multilateral treaties are complemented with detailed provisions on the protection of individual intellectual property rights. The latter provisions often are transplants from European directives and regulations.

In addition, the proposed provisions often equal the rules agreed upon in the CARIFORUM-EC EPA, the EU-South Korea FTA, the EU-Colombia-Peru FTA and the draft IP chapter of the EU-Canada CETA, as proposed by the European Union. The EU-Central America $A A$, on the other hand, in many cases forms an exception to the list of European agreements: Central American countries managed to preserve the TRIPS standard of protection, particularly in the enforcement section, but also with regard to the commitments in the field of plant varieties, design rights and data exclusivity. As the association agreement was only signed in June 2012, it might be that India will still take the achievements of Central American countries into consideration when revisiting its own proposals or areas of compromise.

While India proposes the TRIPS standard in many areas as the general rule, the European Union often has included TRIPS-plus elements. Such elements are 
contained in the proposals made by the EU in the areas of copyright, trade mark, geographical indications and design rights protection, the protection of undisclosed data, provisional and precautionary measures and border measures. India has not yet agreed to include these provisions in the draft IP chapter. There are four TRIPS-plus obligations suggested by the European Union that India has already accepted. These are the compliance with the PCT and the Budapest Treaty, the definition of "making available" in the context of design protection and the two remedies injunctions and pecuniary compensation.

Overall, the draft IP chapter of the India-EU BTLA, as proposed by the European Union, does not leave much space to take into account development concerns when implementing the provisions of the agreement. Importantly, the TRIPS-plus elements and legislation-like provisions in the areas of copyright, geographical indications and industrial designs protection, data exclusivity and enforcement matters contained in the EU proposals limit the flexibility granted by the TRIPS Agreement to balance the interests of right holders and users of intellectual property rights. In addition, the European Union requires compliance with international agreements, particularly in the areas of copyright and trade mark protection, instead of allowing for softer "best endeavour" obligations. If India accepts such detailed and hard rules, the policy space to balance the domestic interests properly is considerably reduced.

India, on the other hand, seems to strive towards maintaining as much discretion as possible. It proposes to adhere to the TRIPS standard in many areas, in particular with regard to the protection of trade marks, geographical indications, design rights, data exclusivity and plant varieties, as well as enforcement matters (except for injunctions and pecuniary compensation). So far, it has been successful in convincing the European Union to accept these standards in the areas of design right protection, plant variety protection and several enforcement matters.

Another important conclusion is that India has been inspired by the CARIFORUMEC EP $A$ in certain areas, such as the innovation policy, transfer of technology and the protection of traditional knowledge and genetic resources. The latter agreement is the first bilateral agreement concluded between the European Union and a trading partner that reflects the "Global Europe" strategy standard. Already in the CARIFORUM-EC EPA, a special effort has been made by CARIFORUM States, and in particular the negotiator, to include as many development-friendly provisions as possible, most of them newly created. These provisions haven't gone unnoticed in India and have been used to develop certain standards of protection even further, such as those on the protection of traditional knowledge.

Even though this chapter has already presented a first comparison of the provisions of the CARIFORUM-EC EPA and the draft IP chapter of the India-EU BTLA, the following chapter aims at juxtaposing all obligations contained in the IP chapters of both agreements in a table and comparing the nature and scope of the main obligations with each other. It will provide a deeper insight into the areas where CARIFORUM States have been more successful in preserving domestic policy space and their interests than India and vice versa. Such a comparison is limited in so far as the final provisions of the India-EU BTIA are not yet agreed upon and the proposals made by both parties are taken as reference points. 


\section{Chapter 7 : Legal Comparison of the CARIFORUM-EC EPA with the India-EU BTIA}

The preceding chapters have presented a deep legal analysis of the IP chapter included in the CARIFORUM-EC Economic Partnership Agreement and the draft IP chapter of the India-EU Broad-based Trade and Investment Agreement. The CARIFORUM-EC EPA is the first bilateral trade agreement concluded after the launch of the "Global Strategy". Since then, three other agreements have been negotiated and concluded with South Korea, Colombia and Peru, and Central American countries. The BTIA is one of the most recent European bilateral trade agreements which is still being negotiated with an important developing country, namely India. This chapter aims at providing a clear and concise comparison of the IP obligations undertaken by CARIFORUM States and those under negotiation with India.

In particular, the comparative analysis focuses on the features that are common to the new approach adopted by the European Union in the "new generation" agreements. As defined in section 4.4.2 of Chapter 4 : The European Union's Intellectual Property Policy in Third Countries since the TRIPS Agreement: A Shift towards a Tough Approach, these are 1) the use of legal transplants in the diverse areas of IP protection regulated in the bilateral agreements; 2) the use of TRIPS-plus elements; and 3) the presence or absence of sufficient policy space to balance the different domestic interests when implementing the provisions of the bilateral agreements and to take development concerns into consideration. By comparing these elements with each other, it will become apparent in which areas both trading partners, the CARIFORUM States and India, were able to preserve their own interests. While it is difficult to make final observations for the draft IP chapter of the India-EU BTLA, which is still under negotiation, the analysis of the legal provisions allows some indications to be given on the bargaining power of the negotiators of India and CARIFORUM States in the different areas.

The following analysis is presented in the form of a table, which lists the relevant article numbers under analysis in the CARIFORUM-EC EPA and the draft IP chapter of the India-EU BTLA. It sets out the main elements of the provisions and provides a comparative analysis of the two respective provisions. In that comparison, particular attention is paid to the commonalities and differences, the TRIPS-plus nature of their elements, and the origin of the (proposed) provisions. Each section of the IP chapters addressed in the table is complemented with a summary of these aspects, as well as an overall assessment in how far domestic policy space is safeguarded so that the different interests can be balanced in the implementation process and development concerns can be taken into account. The sections addressed are a) general provisions, b) copyright protection in the digital environment, c) trade mark protection, d) the protection of geographical indications, e) design protection, f) patent protection, g) the protection of utility models, $h$ ) the protection of plant varieties, i) the protection of genetic resources and traditional knowledge, and j) enforcement matters. 


\subsection{GENERAL PROVISIONS}

\section{Table 6: General provisions}

\begin{tabular}{|c|c|c|c|c|c|}
\hline 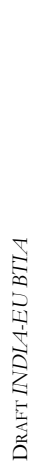 & 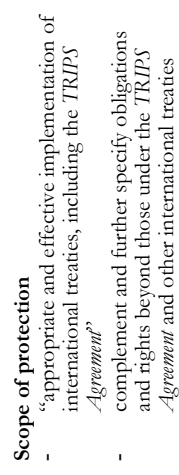 & 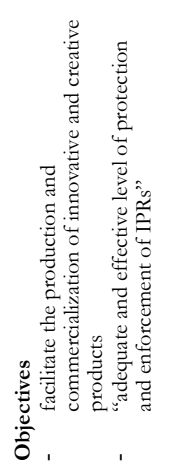 & 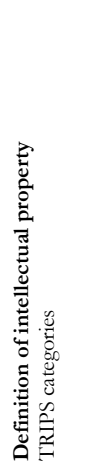 & 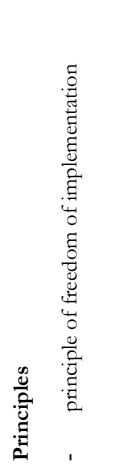 & 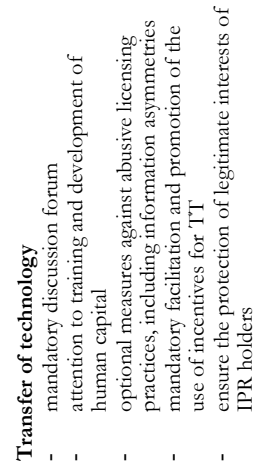 \\
\hline 尊 & 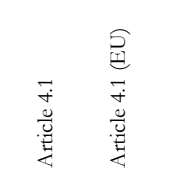 & 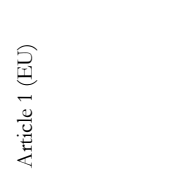 & $\overrightarrow{\breve{u}}$ & 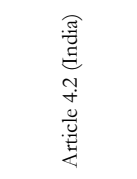 & 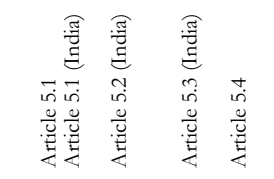 \\
\hline 商 & 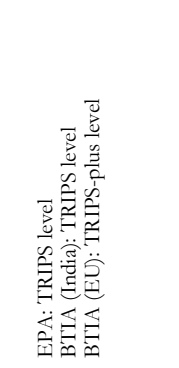 & 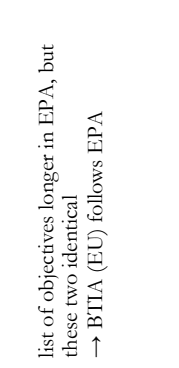 & 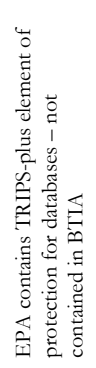 & 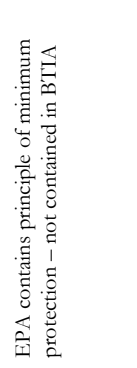 & 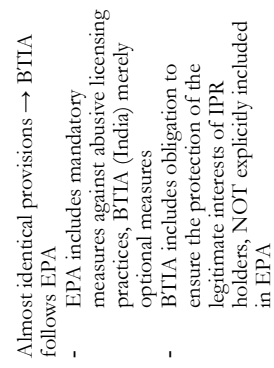 \\
\hline 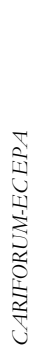 & 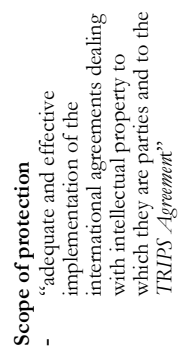 & 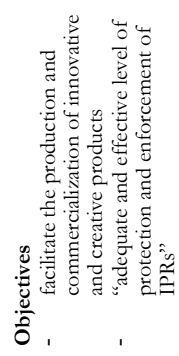 & 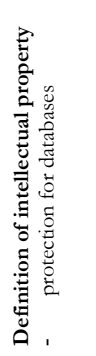 & 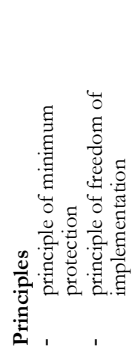 & 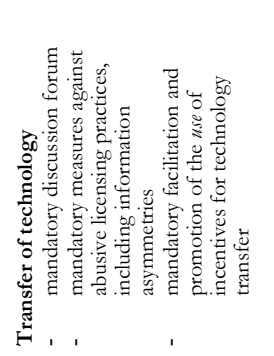 \\
\hline 鱼 & 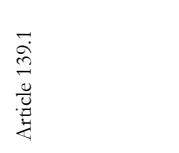 & 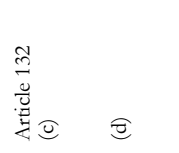 & 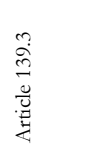 & 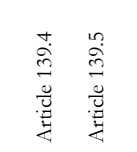 & $\frac{\sqrt{4}}{\frac{\pi}{g}}$ \\
\hline
\end{tabular}




\begin{tabular}{|c|c|c|c|}
\hline 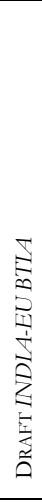 & 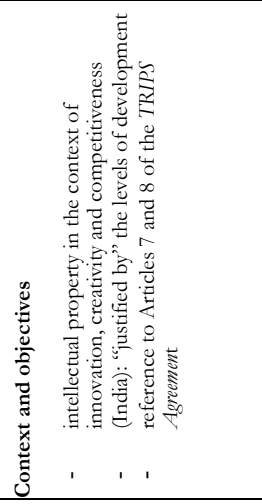 & & 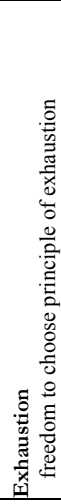 \\
\hline 递 & 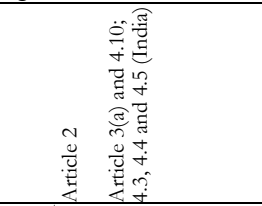 & & 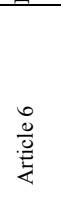 \\
\hline 育 & 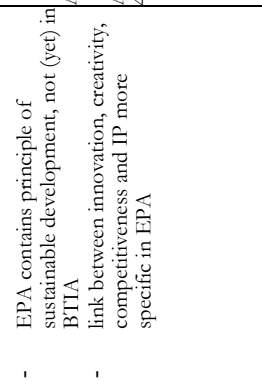 & 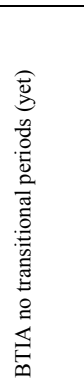 & 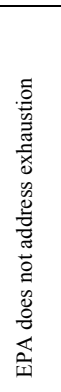 \\
\hline 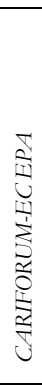 & 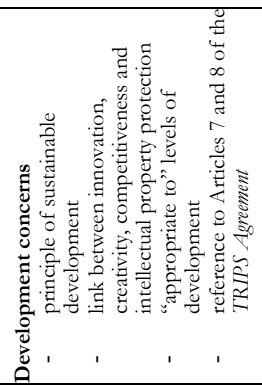 & 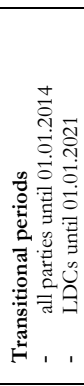 & \\
\hline 畐 & 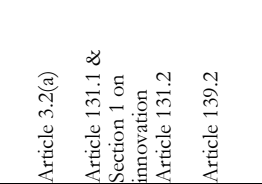 & 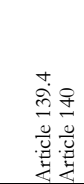 & \\
\hline
\end{tabular}


The section that deals with the general provisions contains very few TRIPS-plus features. One TRIPS-plus element is contained in the CARIFORUM-EC EPA: it includes the sui generis protection for databases in the definition of intellectual property, which is not provided for in the TRIPS Agreement. Another TRIPS-plus feature has been proposed by the European Union in the India-EU BTLA: the scope of protection shall complement and further specify the obligations and rights beyond those contained in the TRIPS Agreement and other international treaties. This general provision would set the tone for the substantive provisions contained in the future India-EU BTLA and indicate that its rules are meant to go beyond the standard of protection agreed to in the TRIPS Agreement. The general provisions proposed by the European Union in neither the EPA nor the BTIA include rules to those in internal legislative instruments.

As a consequence of the few TRIPS-plus features and the absence of legislation-like provisions, development concerns can be given due consideration when implementing the general provisions of both the EPA and the BTIA. Both agreements contain explicit references to the link between innovation, creativity, competitiveness and intellectual property protection and to IP protection that takes into account development concerns, to Articles 7 and 8 of the TRIPS Agreement. The agreements contain commitments with regard to the transfer of technology (BTIA as proposed by India) and provide for the principle of freedom of implementation (BTIA as proposed by India). If compared to each other, the CARIFORUM-EC EPA provides a stronger link between development concerns and intellectual property protection in the general provisions than the India-EU BTLA. The former agreement contains generous transition periods, is governed by the general principle of sustainable development, provides for more concrete obligations with regard to transfer of technology and limits the scope of protection to the standards provided for in the TRIPS Agreement and other international treaties.

It must be pointed out that some general provisions in the draft IP chapter of the IndiaEU BTLA are very similar to the ones included in the CARIFORUM-EC EPA. It seems that the provisions on transfer of technology and objectives have served as a source of inspiration for the proposals made by India and the EU in the India-EU BTIA. Overall, the bargaining power of both CARIFORUM States and India has been strong on the general provisions. They have proposed their own language and were/might be able to preserve their proposals in the final agreements. 


\subsection{Copyright PRotection In the Digital ENVIRONMENT}

Table 7: Copyright Protection in the Digital Environment

\begin{tabular}{|c|c|c|c|c|c|}
\hline 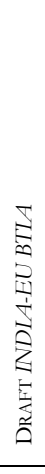 & 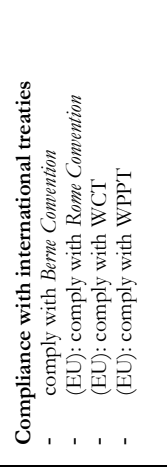 & 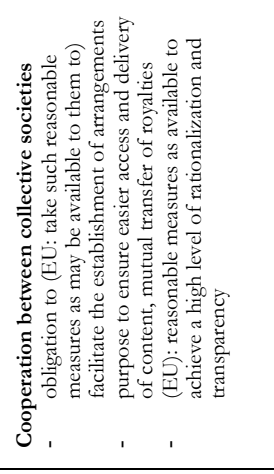 & 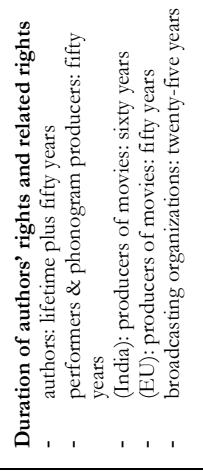 & 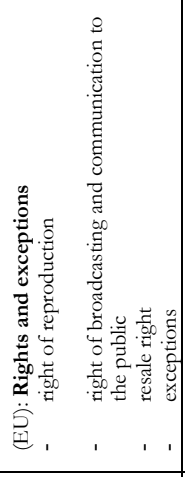 & 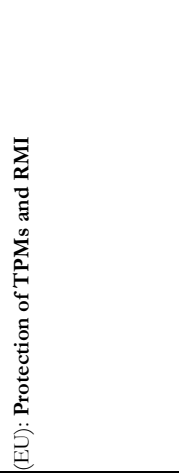 \\
\hline 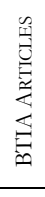 & 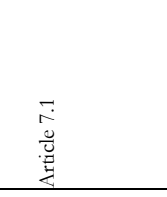 & 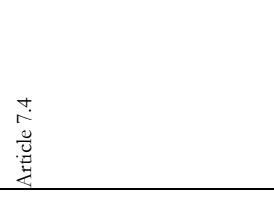 & 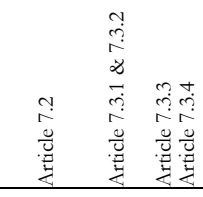 & 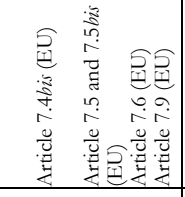 & 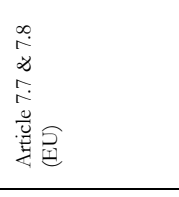 \\
\hline 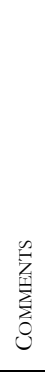 & 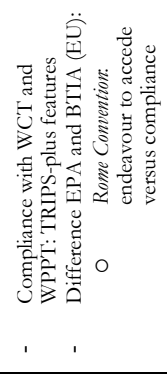 & 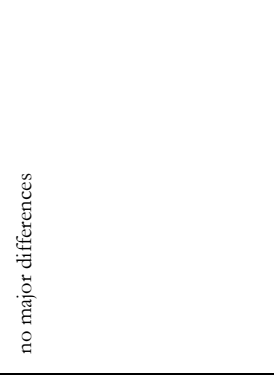 & 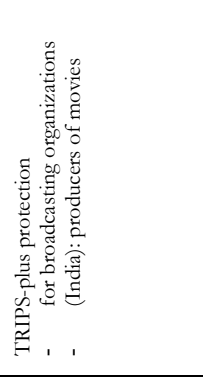 & 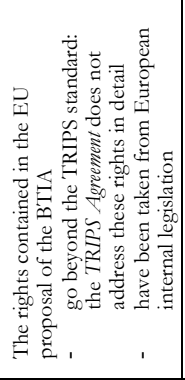 & 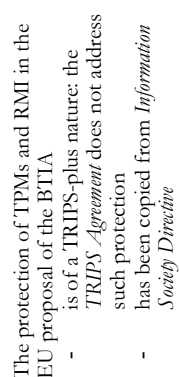 \\
\hline 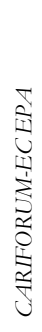 & 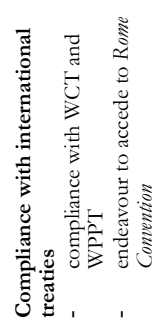 & 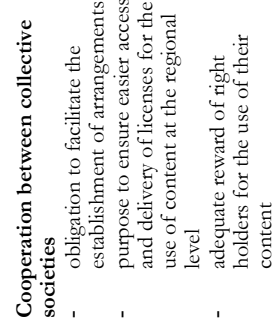 & & & \\
\hline 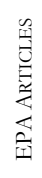 & 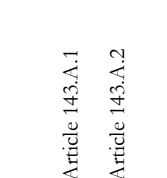 & 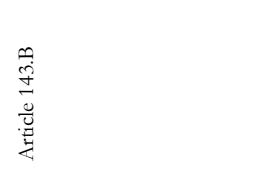 & & & \\
\hline
\end{tabular}


The protection of copyright products included in both agreements differs considerably. The CARIFORUM-EC EPA merely contains one TRIPS-plus feature, namely the requirement to comply with the WIPO Copyright Treaty and the WIPO Performers and Phonograms Treaty. In the draft IP chapter of the India-EU BTLA, as proposed by the European Union, the protection for digital products is one of the strongest TRIPS-plus sections of the draft IP chapter. The European Union has proposed to comply with the WCT and the WPPT, to grant copyright holders certain rights and corresponding exceptions in the digital environment, as well as to protect the circumvention of technical protection measures and rights management information. Also India has proposed a TRIPS-plus feature: producers of movies shall be granted a term of protection of sixty years and broadcasting organizations for twenty-five years, whereas the TRIPS Agreement stipulates fifty years for the former and twenty years for broadcasting organizations.

In addition, some of the proposed provisions by the European Union are legal transplants from internal EU legislation. In particular, the rights and exceptions as well as the protection for TPMs and RMI proposed by the European Union have been copied from the Information Society Directive and the Directive 2001/84/EC on the resale right. Since the EPA lacks these provisions, it does not contain any legal transplant. When considering the scope of TRIPS-plus elements. as well as the proposed detail of provisions, the policy space for devising national legislation that reflects domestic interests would be considerably smaller for India than for CARIFORUM States should India agree to the EU proposals. Particularly the protection against the circumvention of TPMs and RMI is not needed as the requirement to comply with the WCT and WPPT already set out general obligations in that regard. The fact that the European Union has not yet given up its proposals could indicate that the EU has a strong interest in keeping the provisions and that India's bargaining power might be weak. CARIFORUM States, on the other hand, were not asked to protect the same rights, exceptions and TPMs and RMI. 
7.3. Trade Mark Protection

Table 8: Trade Mark Protection

\begin{tabular}{|c|c|c|c|c|}
\hline 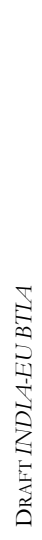 & 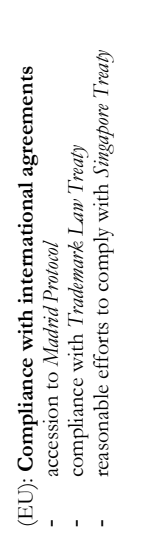 & 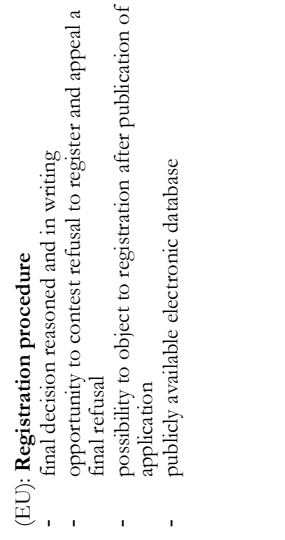 & 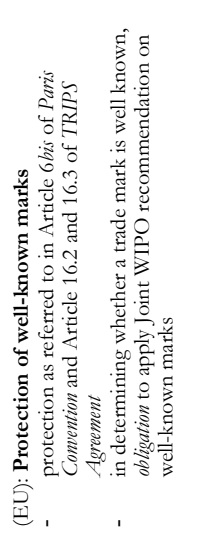 & \\
\hline 柕 & 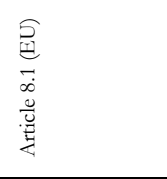 & 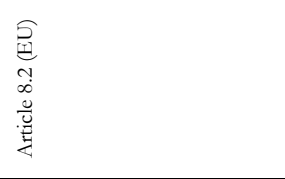 & 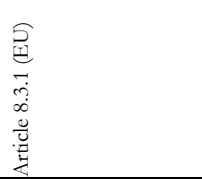 & \\
\hline 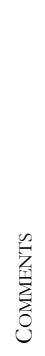 & 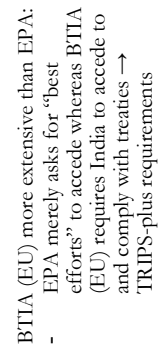 & 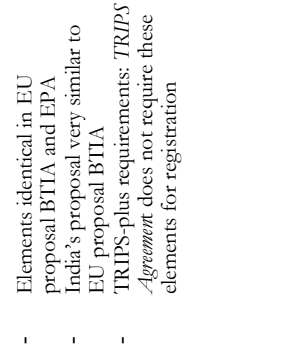 & 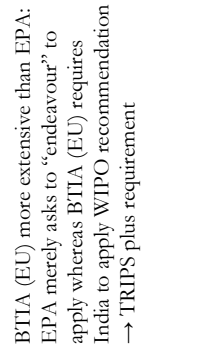 & 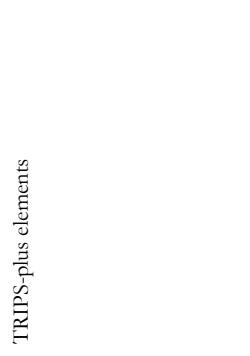 \\
\hline 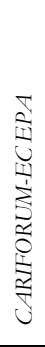 & 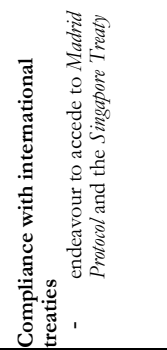 & 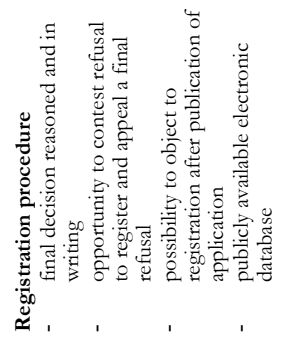 & 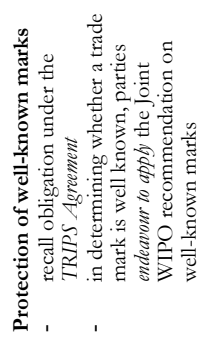 & 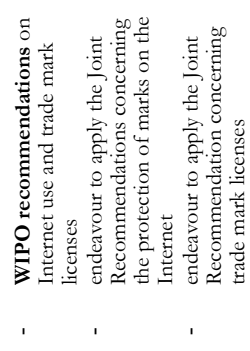 \\
\hline 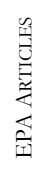 & 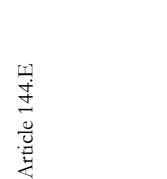 & 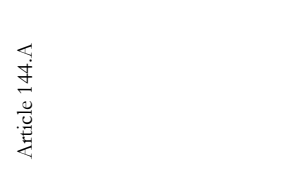 & 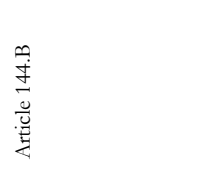 & 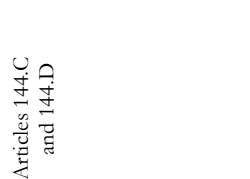 \\
\hline
\end{tabular}


Why Jamaica WANTS to Protect Champagne

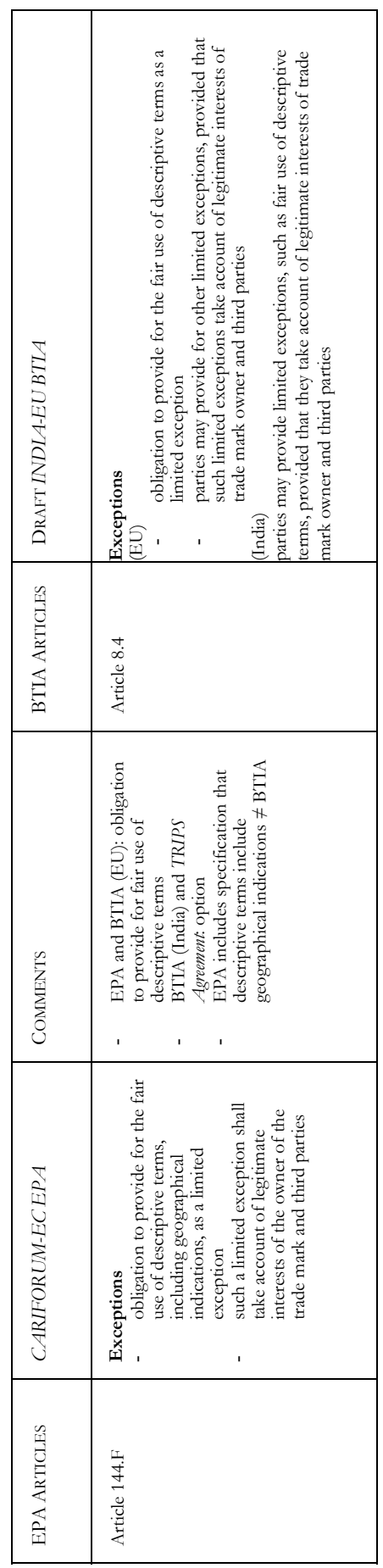


The protection of trade marks is regulated in a similar manner in both agreements, however with clear differences as to the nature of the obligations, if the EU proposal in the India-EU BTIA is followed. This difference relates to the soft obligations contained in the CARIFORUM-EC EPA, which are not (yet) integrated in the India-EU BTIA. CARIFORUM States were able to achieve soft obligations for the commitment to accede to the Madrid Protocol and the Singapore Treaty and the commitment to apply the Joint WIPO recommendation on well-known trade marks: they have to "endeavour" to accede and apply. In contrast, the European Union requires India to make hard commitments as to the accession, compliance and application of these international instruments. Both the soft and hard obligations are TRIPS-plus elements. Other TRIPS-plus elements in the BTIA as proposed by the EU is the obligation to provide for the fair use of descriptive terms as an exception to trade mark protection and the procedural requirements for registration. Also the CARIFORUM-EC EPA contains TRIPS-plus features: CARIFORUM States also have to provide for the same procedural requirements as asked from India, and will have to endeavour to apply the WIPO recommendations on the use of trade marks on the Internet and trade mark licenses. No provision on the protection of trade marks in either agreement has been copied from internal EU legislation.

Overall, the soft obligations in the EPA as well as the optional nature of the fair use exception give CARIFORUM States considerable discretion to weigh the benefits and disadvantages of the usefulness of such provisions for their national systems. Merely the procedural requirements when registering a trade mark are rather detailed and prescribe main elements. If India accepts the hard obligations suggested by the European Union as to international instruments and registration procedures, India will have considerably less domestic policy space to determine whether the obligations in the international instruments and the registration procedure are beneficial to CARIFORUM States. The proposal of the European Union to India seems to take little account of the development concerns of India. The soft obligations contained in the CARIFORUM-EC EPA reflect a relatively strong bargaining power of CARIFORUM States. 
7.4. PROTECTION OF GEOGRAPHICAL INDiCATIONS

Table 9: Protection of Geographical Indications

\begin{tabular}{|c|c|c|c|c|c|}
\hline 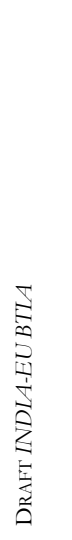 & 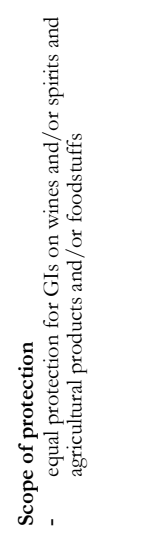 & 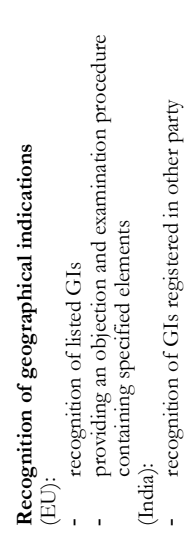 & & & 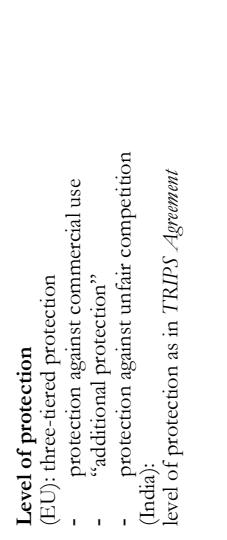 \\
\hline 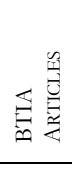 & $\begin{array}{l}\overrightarrow{\overline{0}} \\
\vec{u} \\
\overrightarrow{\underline{E}}\end{array}$ & 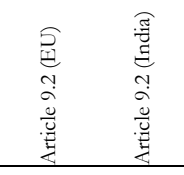 & & & 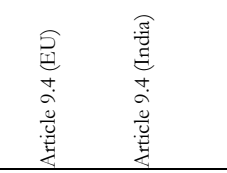 \\
\hline 点 & 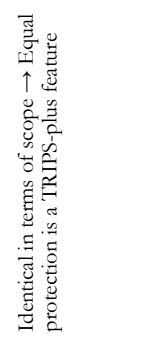 & 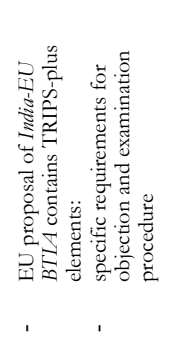 & 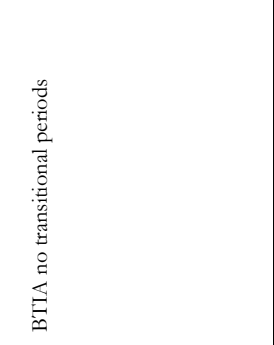 & 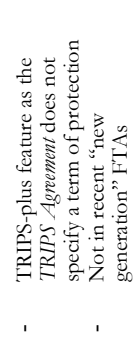 & 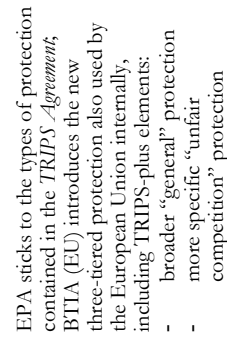 \\
\hline 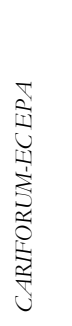 & 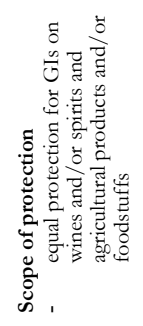 & & 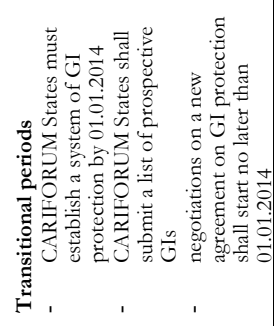 & 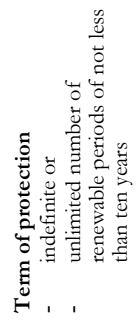 & 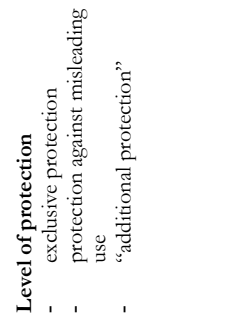 \\
\hline 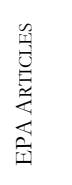 & 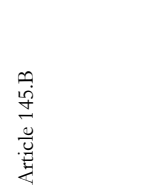 & & 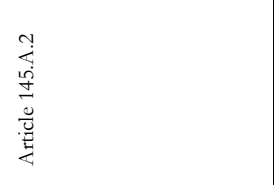 & 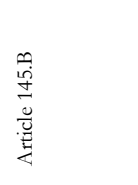 & 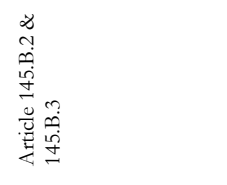 \\
\hline
\end{tabular}




\begin{tabular}{|c|c|c|}
\hline 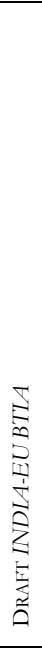 & 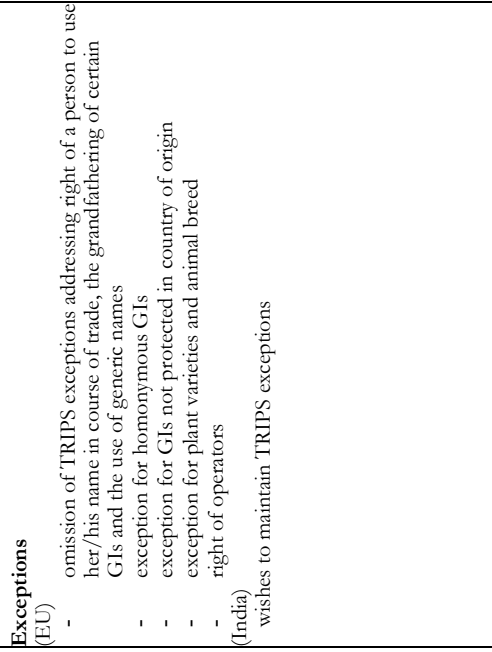 & 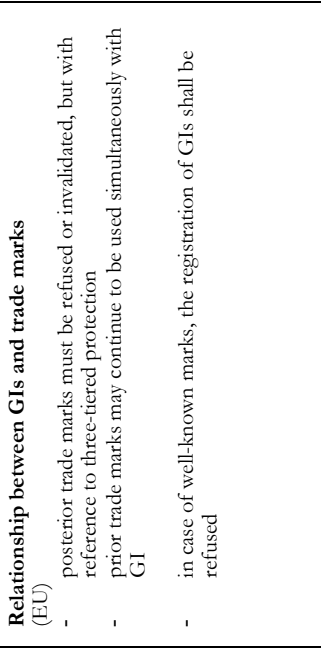 \\
\hline 留 & 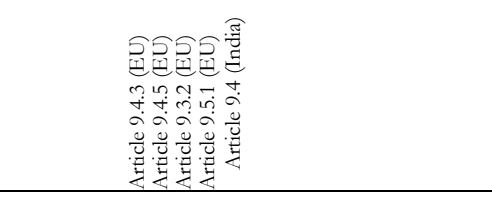 & 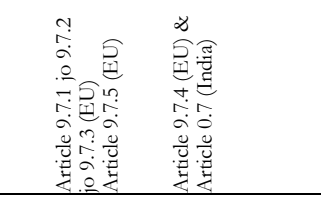 \\
\hline & 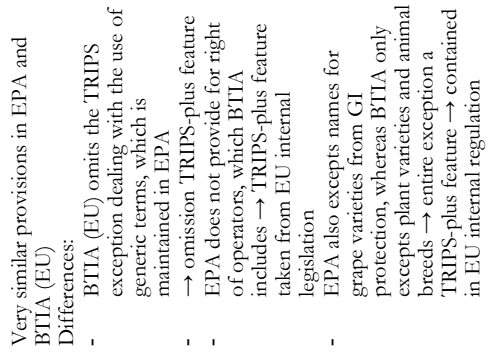 & 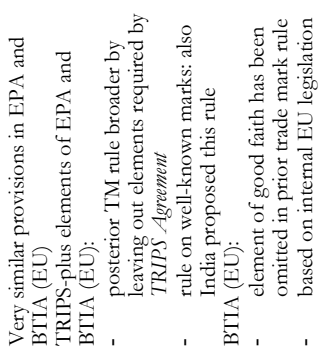 \\
\hline 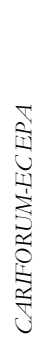 & 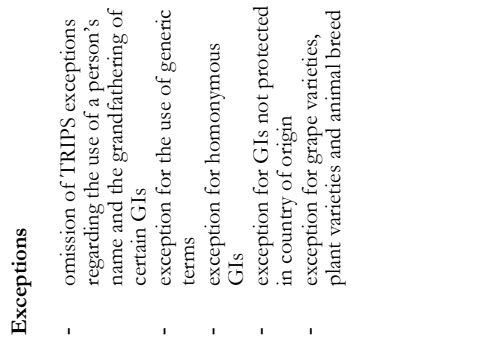 & 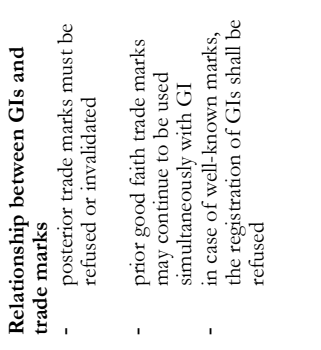 \\
\hline 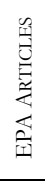 & 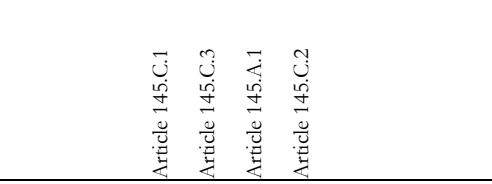 & 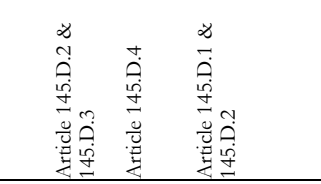 \\
\hline
\end{tabular}


The protection of geographical indications is one of the more detailed sections of the IP chapters of both agreements. The provisions therein contain several TRIPS-plus features, the main elements of which are similar in both agreements. One of the most important common TRIPS-plus elements is the equal protection for wines, spirits, agricultural products and foodstuffs. Also in the draft IP chapter of the India-EU BTLA, this protection has been agreed upon. Other TRIPS-plus elements are contained in the section on exceptions: the EPA and the BTIA as proposed by the European Union omit certain TRIPS exceptions (even though not the same) and add exceptions also contained in European internal legislation, which are not provided for in the TRIPS Agreement.

In addition, the India-EU BTIA as suggested by the European Union contains three other TRIPS-plus features. First, the EU has asked for a three-tiered type of protection for geographical indications, which the European Union also uses internally. It goes beyond the TRIPS Agreement where it provides for broader "general" protection and more specific protection against unfair competition. Second, the provisions proposed by the EU on the scope of protection in the India-EU BTLA set out specific requirements for an objection and examination procedure that are not required by the TRIPS Agreement. Third, the relationship between geographical indications and trade marks is regulated according to three rules that have been based on the TRIPS Agreement, however the EU proposes to omit certain elements required by the TRIPS Agreement.

The CARIFORUM-EC EPA contains one other TRIPS-plus element not asked for in the India-EU BTLA: CARIFORUM States are required to protect geographical indications indefinitely, whereas the TRIPS Agreement does not require a certain period of protection. On the other hand, CARIFORUM States were successful in receiving substantial transitional periods.

As already mentioned, some proposals made by the European Union in the draft IP chapter of the India-EU BTLA are based on internal EU legislation. This is particularly so with regard to the level of protection, certain exceptions and the relationship between geographical indications and trade marks. Overall, the protection for geographical indications in both agreements leaves relatively little domestic policy space to the parties when it comes to implementing the provisions required. They are very detailed, in the case of the BTIA as proposed by the EU even legislation-like. CARIFORUM States were able to preserve the TRIPS standard with regard to the level of protection and they obtained generous transitional periods. In that respect, their bargaining power seems to have been strong. 


\subsection{Industrial DeSign PROTECTION}

Table 10: Industrial Design Protection

\begin{tabular}{|c|c|c|c|}
\hline 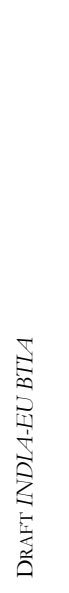 & 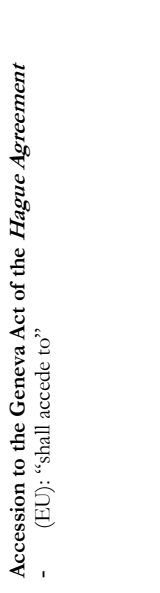 & 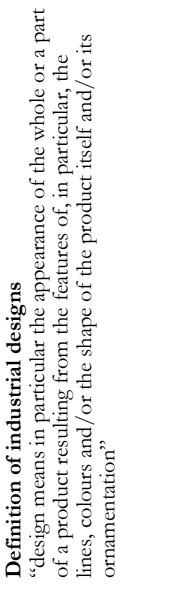 & 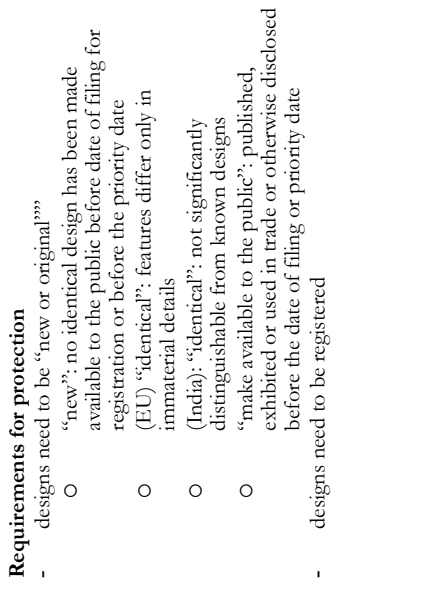 \\
\hline 崌兽 & 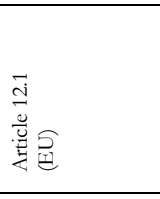 & & 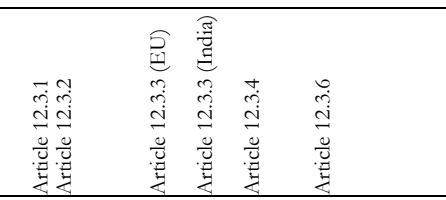 \\
\hline 商 & 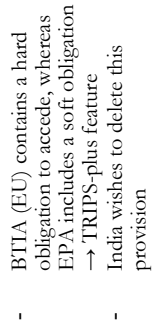 & 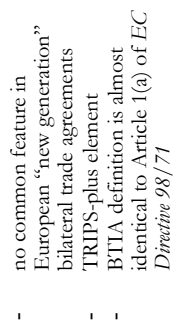 & 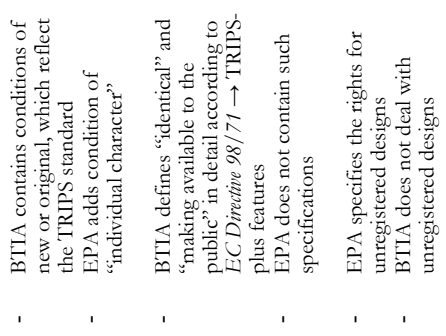 \\
\hline 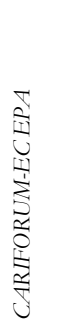 & 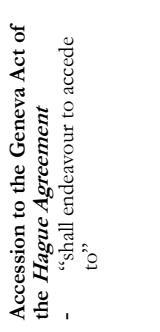 & & 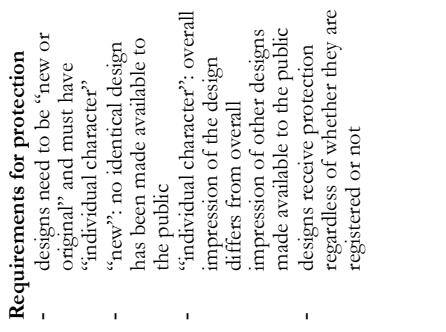 \\
\hline 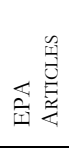 & 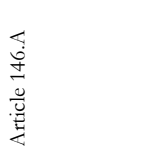 & & 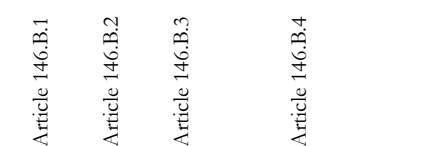 \\
\hline
\end{tabular}


Why JAMAICA WANTS TO PROTECT CHAMPAGNE

\begin{tabular}{|c|c|c|c|}
\hline 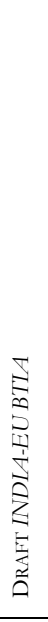 & 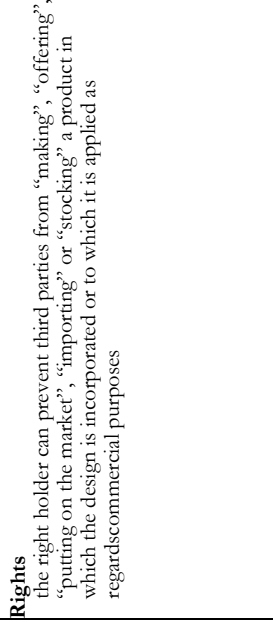 & 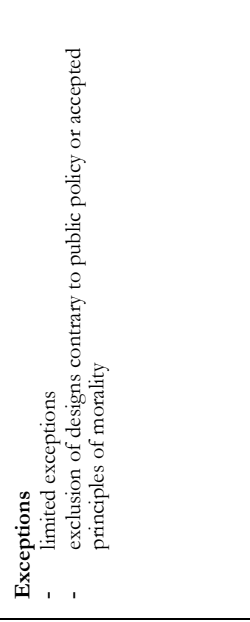 & 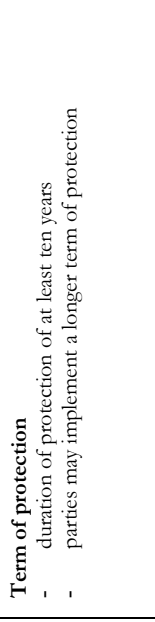 \\
\hline 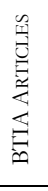 & 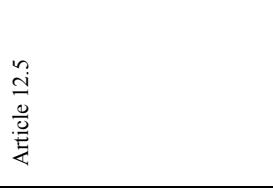 & 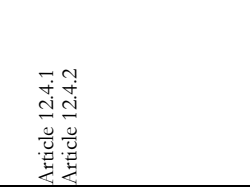 & 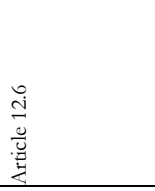 \\
\hline 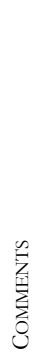 & 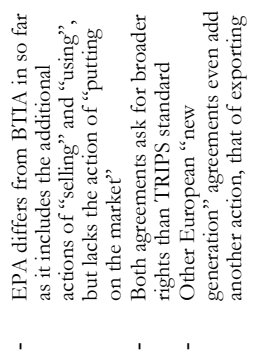 & 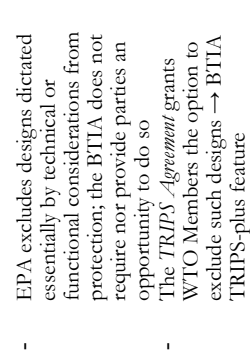 & 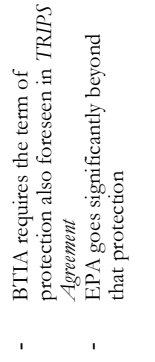 \\
\hline 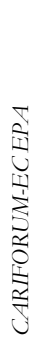 & 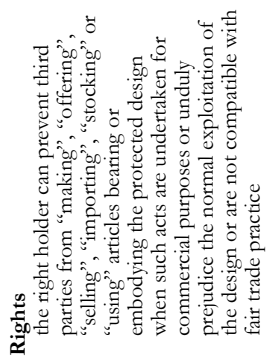 & 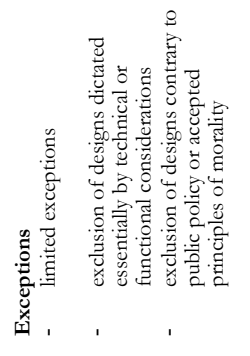 & 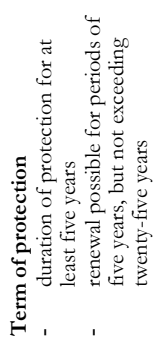 \\
\hline 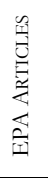 & 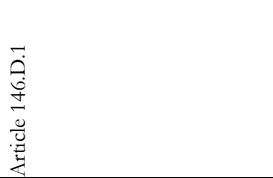 & 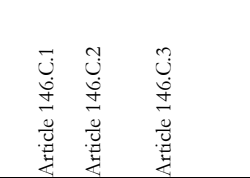 & 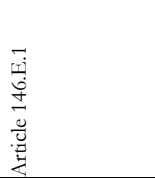 \\
\hline
\end{tabular}


The protection of industrial designs agreed upon in the CARIFORUM-EC EPA differs in some respects from the draft IP chapter of the India-EU BTIA. It is less strict with regard to the obligation to accede to the Geneva Act of the Hague Agreement than the EU proposal of the BTIA: the EPA requires its parties to endeavour to accede to the Geneva Act whereas the European Union wishes to insert a hard obligation. Both obligations are TRIPS-plus features. Furthermore, the CARIFORUM-EC EPA does not specify in similar detail as the India-EU BTLA how the concepts "making available to the public" and "identical" (as proposed by the EU) need to be understood and does not provide for a definition of industrial designs. These definitions in the draft IP chapter of the India-EU BTLA go beyond the TRIPS standard. Finally, the EPA has incorporated a TRIPS exception that the BTIA does not provide. Where the BTIA omits a TRIPS exception, it goes beyond the TRIPS standard.

The EPA contains TRIPS-plus elements with regard to the scope of rights, which are broader than the rights conferred through the TRIPS Agreement: the latter agreement does not include the actions of "selling" and "using". The BTIA does not add "selling" and "using" to the rights of design right holders, but the action of "putting on the market", which is also not included in the TRIPS Agreement. Lastly, the CARIFORUMEC EPA requires a term of protection that goes beyond the TRIPS standard, whereas the BTIA provides for the same duration as the TRIPS Agreement. Overall, both agreements contain several TRIPS-plus features.

The European Union has used the EC Directive $98 / 71$ as a source of inspiration in both agreements. In the CARIFORUM-EC EPA, the definition of the concept "individual character" and the term of protection have been copied from the relevant provisions of the Directive. In the draft IP chapter of the India-EU BTLA, the definitions of an industrial design and of the concept "making available to the public" are similarly contained in European internal law. Defining concepts and rights in detail beyond the TRIPS standard considerably limits the implementing freedom of contracting parties granted by the TRIPS Agreement. As regards the term of protection and the scope of rights, the bargaining power of India seems to have been relatively strong: the protection in the India-EU BTLA stays considerably behind the protection agreed upon with CARIFORUM States. The latter's bargaining power seemingly was weaker on these aspects; at the same time, they obtained a soft obligation with regard to the accession to the Geneva Act of the Hague Agreement, showing a relatively strong bargaining power there. 
7.6. Patent Protection

Table 11: Patent Protection

\begin{tabular}{|c|c|c|c|}
\hline 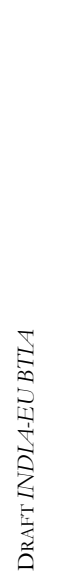 & 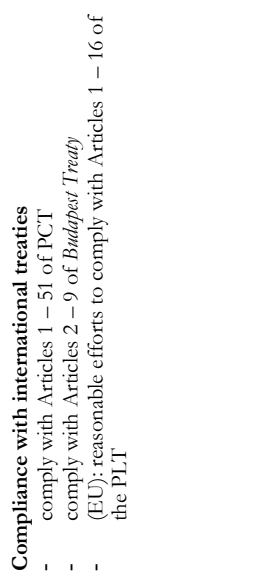 & 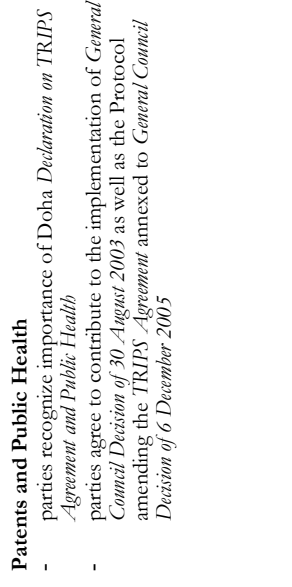 & 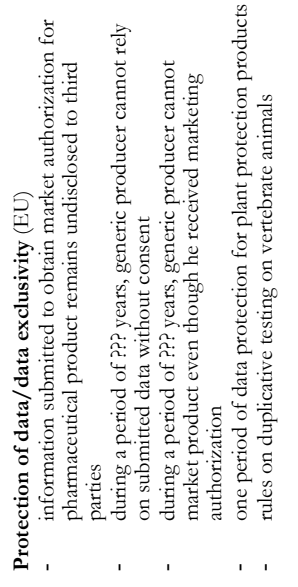 \\
\hline 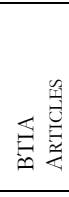 & 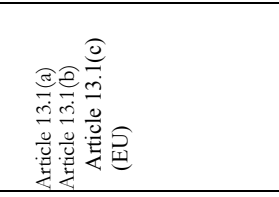 & 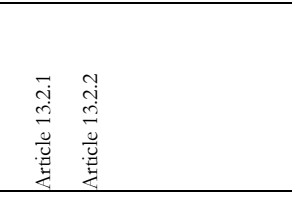 & 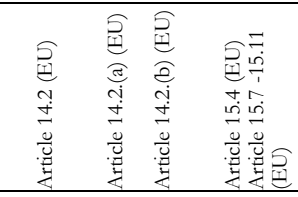 \\
\hline & 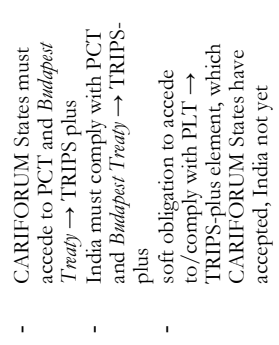 & 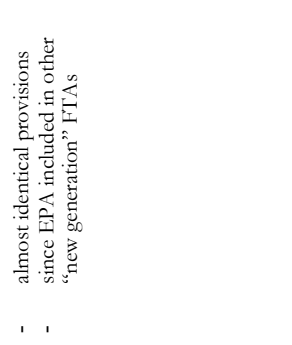 & 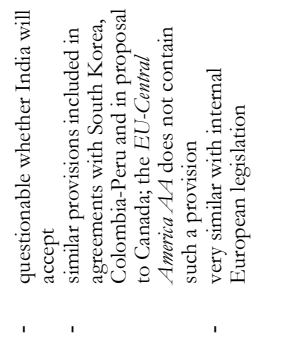 \\
\hline 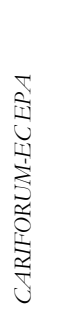 & 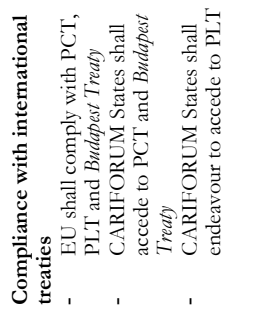 & 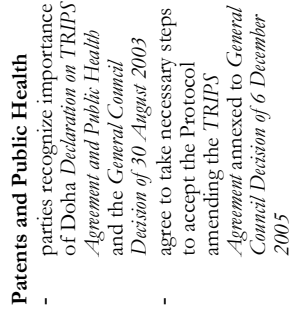 & \\
\hline 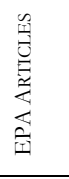 & 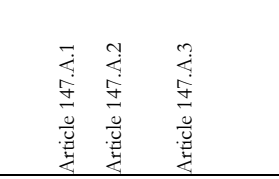 & 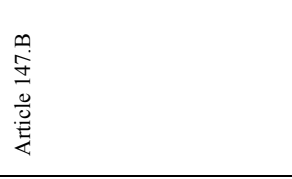 & \\
\hline
\end{tabular}


The protection for patents agreed upon in the CARIFORUM-EC EPA is limited to two commitments. First, CARIFORUM States agreed to accede to the Patent Cooperation Treaty and the Budapest Treaty and endeavour to accede to the Patent Law Treaty. Such requirements are TRIPS-plus elements. Second, EPA parties recognize the importance of the Doba Declaration on TRIPS Agreement and Public Health and the General Council Decision of 30 August 2003 and agree to take the necessary steps to accept the Protocol amending the TRIPS Agreement annexed to General Council Decision of 6 December 2005. The content of these documents emphasizes the flexibilities incorporated in the patent section of the TRIPS Agreement.

Almost identical is the commitment of the European Union and India in the draft IP chapter of the India-EU BTIA. The latter agreement contains two TRIPS-plus features. India and the EU have agreed to comply with the PCT and the Budapest Treaty. The EU has proposed additionally to make reasonable efforts to comply with the PLT. The other TRIPS-plus provision concerns data exclusivity, which goes far beyond the protection sought in the TRIPS Agreement and is highly contested in India. In brief, if India agrees to the data exclusivity provision suggested by the EU, the patent section of the India-EU BTLA will contain considerably more TRIPS-plus features than the respective section of the CARIFORUM-EC EPA.

In the India-EU BTIA, the European Union has proposed provisions on the protection of data that are identical to European Union legislation on data protection for pharmaceutical products. Even though the number of years during which the data should be protected is currently still blank, such concrete levels of protection would significantly limit India's ability to enable generic producers entering the market quickly. India has an important generic drug industry which would be considerably harmed by such protection. Judging from the continuous resistance of India to accept such data exclusivity rules, it seems that its bargaining power thereon is relatively strong. CARIFORUM States managed to limit the patent section to one TRIPS-plus feature. Whether they had a strong bargaining power in this area is difficult to assess since they were not asked to protect undisclosed data according to European standards. 
Why JAMAICA WANTS TO PROTECT CHAMPAGNE

\subsection{PRotection OF UTILITY MODELS}

Table 12: Protection of Utility Models

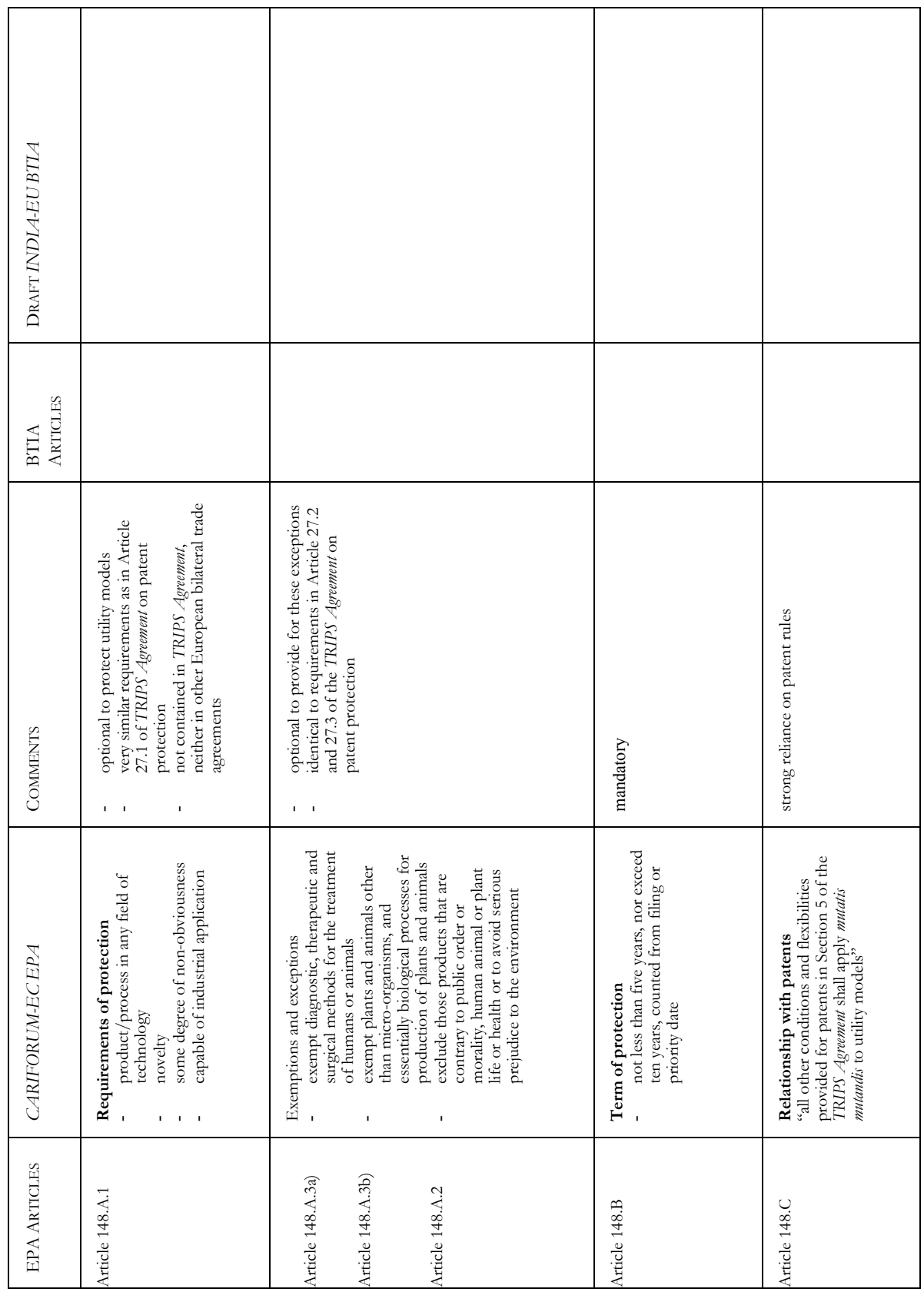


Only the CARIFORUM-EC EPA contains provisions on the protection of utility models; this type of intellectual property protection has not been proposed by either party in the India-EU BTLA. Since this protection is not regulated in the TRIPS Agreement, the standards proposed therein go beyond the level of protection agreed upon in the TRIPS Agreement. None of the provisions included in the CARIFORUMEC EPA are based on internal European legislation; it is rather the provisions of the TRIPS Agreement on patent protection that have served as a source of inspiration.

The protection of utility models offers protection to technical inventions that do not meet the high threshold of "inventive step" required for patent protection. As such, it is a type of protection that could benefit countries that are not yet at the level of development where its domestic products are highly innovative. It offers a protection beyond the TRIPS standard that CARIFORUM States can choose to adopt. Therefore, it leaves maximum freedom to CARIFORUM States to balance domestic interests in that respect. Seemingly, the bargaining power of CARIFORUM States has been relatively strong in this area. It seems probable that the European Union did not have strong interests with regard to the utility model protection. 
Why JAMAICA WANTS TO PROTECT CHAMPAGNE

7.8. Plant VARIETy PRotection

Table 13: Plant Variety Protection

\begin{tabular}{|c|c|c|c|}
\hline 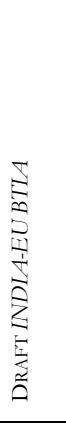 & 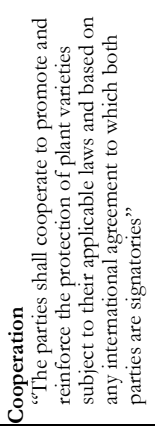 & & \\
\hline 甭兽 & 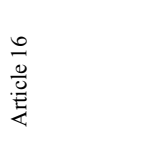 & & \\
\hline 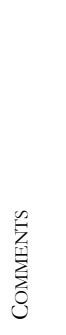 & 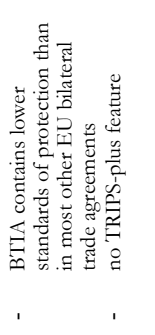 & 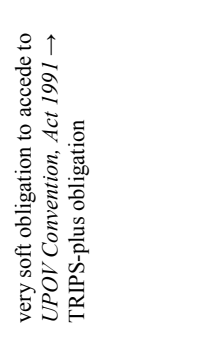 & 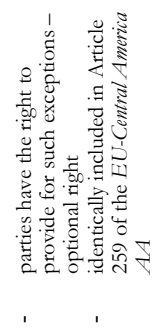 \\
\hline 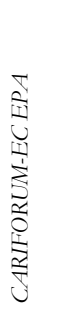 & & 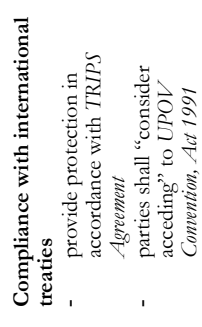 & 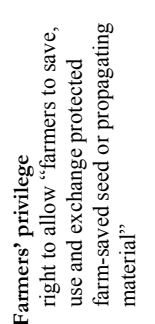 \\
\hline 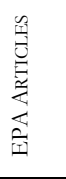 & & 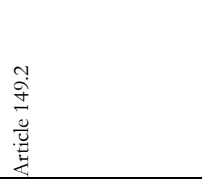 & 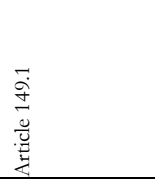 \\
\hline
\end{tabular}


In the area of plant variety protection, both CARIFORUM States and India have been able to preserve much freedom as to which system of plant variety protection to adopt domestically. India has even been able to avoid any commitment with regard to the accession to the UPOV Convention, Act 1991. The only obligation included in the draft IP chapter of the India-EU BTLA regards a cooperation commitment to promote and reinforce the protection of plant varieties based on any international agreement to which both India and the EU are signatories. India is not a contracting party to any of the acts of the UPOV Convention. None of the provisions are based on EU internal legislation. Compared to the protection usually sought in other European bilateral trade agreements, India's bargaining power in this area has been particularly strong.

CARIFORUM States were also successful in bringing down the obligation to accede to the UPOV Convention, Act 1991 to a very soft commitment: they will "consider acceding" to the Convention. Nevertheless, also this soft commitment goes beyond the TRIPS standard and makes it a TRIPS-plus element. A second provision that also goes beyond the TRIPS Agreement is the specification of the farmers' privilege: the scope of this right of farmers is broadened compared to the UPOV Convention, Act 1991. It increases the flexibility of CARIFORUM States to preserve its farmers' rights to save, use and exchange farm-saved seeds. In brief, CARIFORUM States were able to display a strong bargaining power in this area of IP protection. 
7.9. Protection of Genetic Resources and Traditional KNOWLEDGE

Table 14: Protection of Genetic Resources and Traditional Knowledge

\begin{tabular}{|c|c|c|c|}
\hline 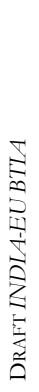 & 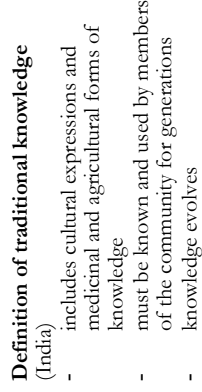 & 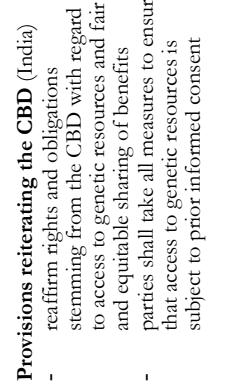 & \\
\hline 䱛 & 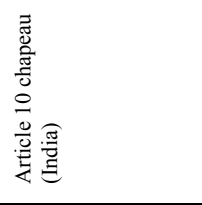 & 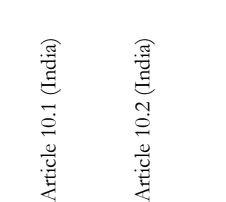 & \\
\hline 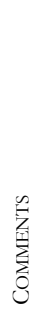 & 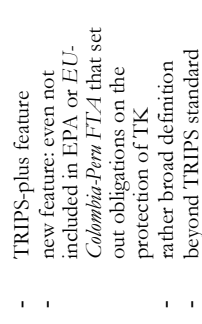 & 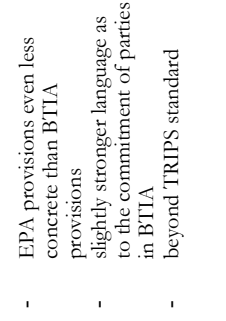 & \\
\hline 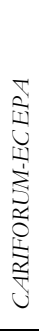 & & 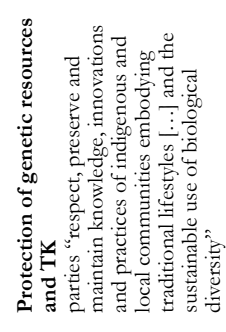 & 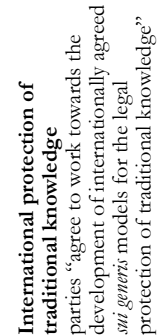 \\
\hline 通 & & 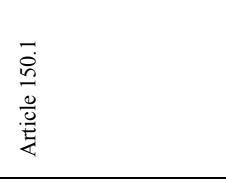 & 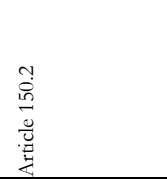 \\
\hline
\end{tabular}




\begin{tabular}{|c|c|c|}
\hline 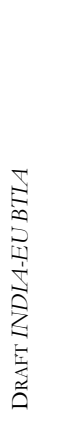 & 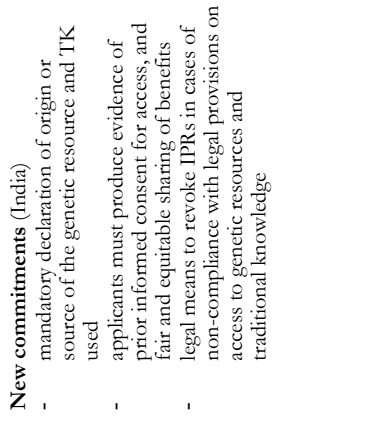 & 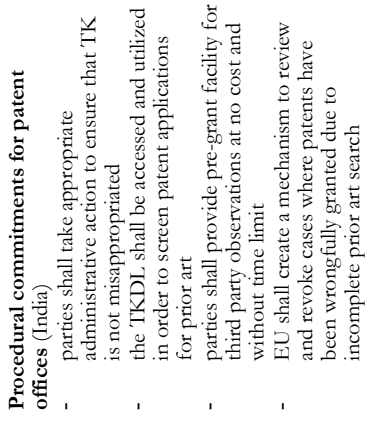 \\
\hline 震兽 & 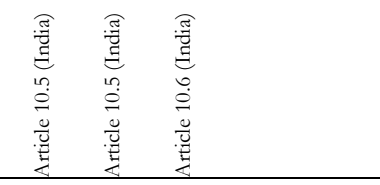 & 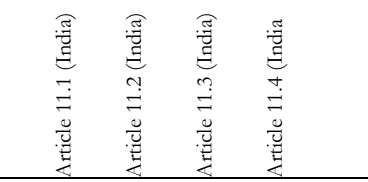 \\
\hline 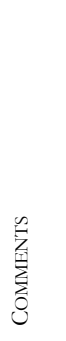 & 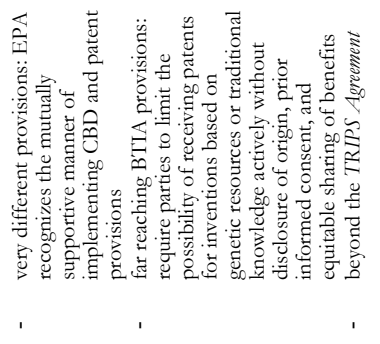 & 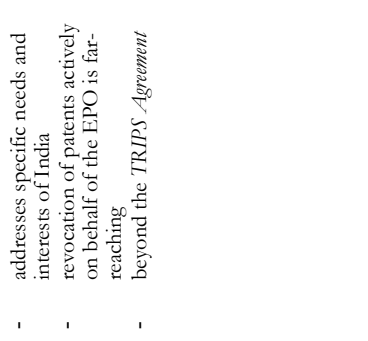 \\
\hline 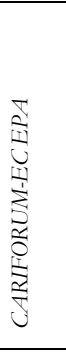 & 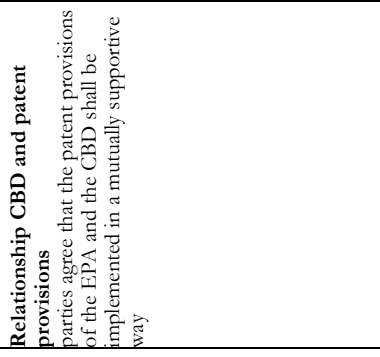 & \\
\hline 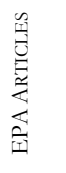 & 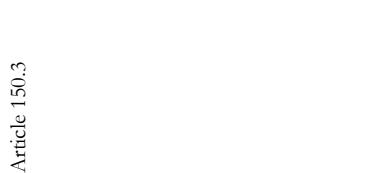 & \\
\hline
\end{tabular}


The protection of traditional knowledge and genetic resources is an area of protection that has been inserted or proposed by the trading partners of the European Union, namely the CARIFORUM States and India, and therefore not by the European Union. The European Union has not yet agreed to the provisions suggested by India and it seems that the commitments proposed by India go considerably beyond what the EU is willing to concede to. They include the most far-reaching commitments included in any North-South agreement up until now. The issue of protection for genetic resources and traditional knowledge is highly contested at the international level and has not been addressed in the TRIPS Agreement. Therefore, all commitments included in the CARIFORUM-EC EPA and in the final India-EU BTLA go beyond the TRIPS standard.

The provisions contained in both agreements are not based on European internal legislation, but have been proposed by CARIFORUM States and India. India seems to have used some of the EPA provisions as a source of inspiration for the commitments included in its proposal to the EU. The language incorporated is very strong and urges the European Union to take measures in order to prevent the misappropriation of genetic resources and traditional knowledge. The CARIFORUM-EC EPA was the first agreement to include language on this matter, which indicates that CARIFORUM States had strong bargaining power in this area. The commitments therein are not as strong as in the proposal made by India. However, it remains to be seen how much of that language will be included in the final India-EU BTIA. If India manages to preserve most of it, its bargaining power would have been very strong. 


\subsection{ENFORCEMENT PROVISIONS}

\section{Table 15: Enforcement provisions}

\begin{tabular}{|c|c|c|}
\hline 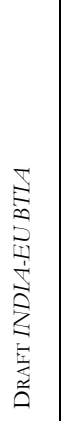 & 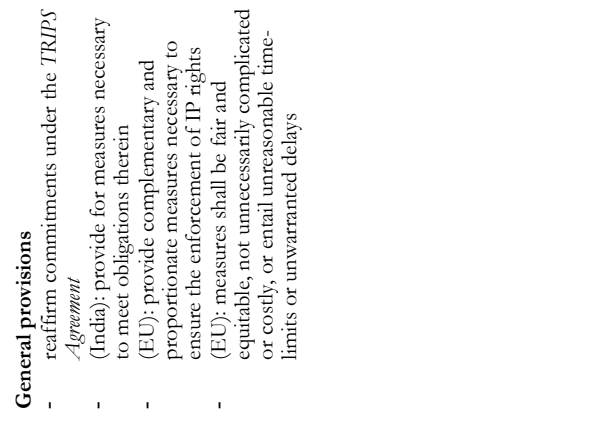 & 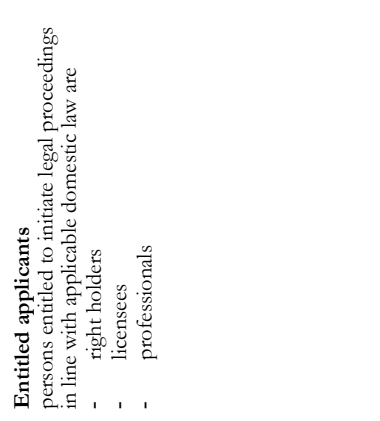 \\
\hline 㕝兽 & 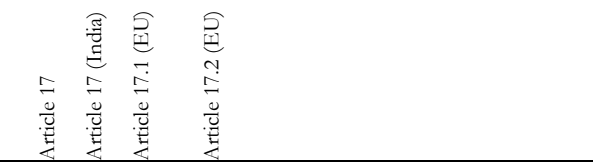 & 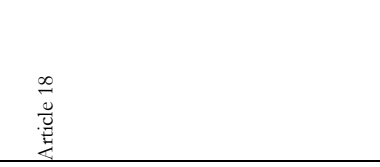 \\
\hline & 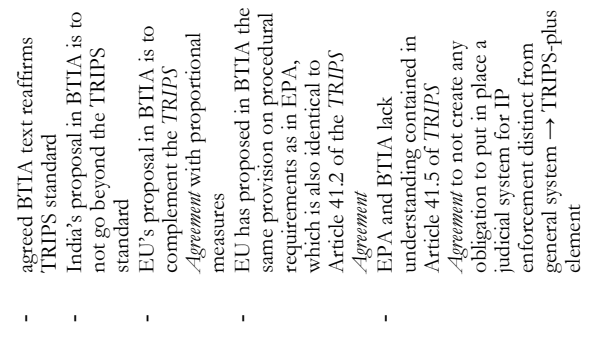 & 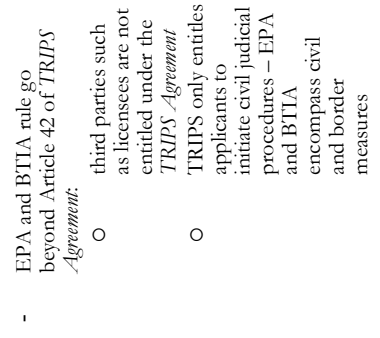 \\
\hline 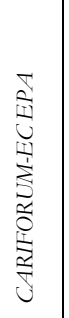 & 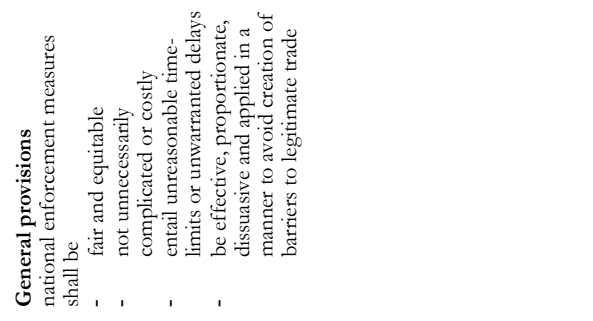 & 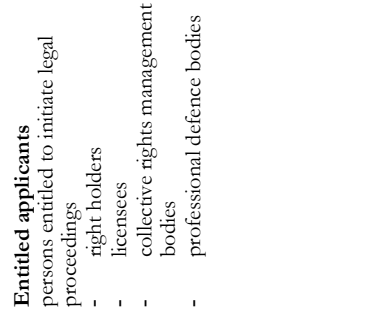 \\
\hline 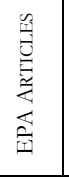 & 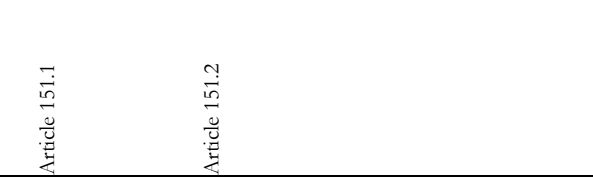 & 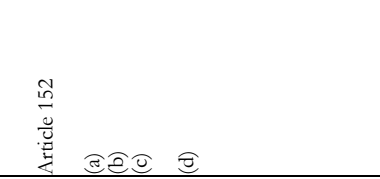 \\
\hline
\end{tabular}




\begin{tabular}{|c|c|c|c|c|c|c|c|c|c|c|c|}
\hline 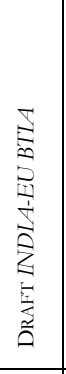 & 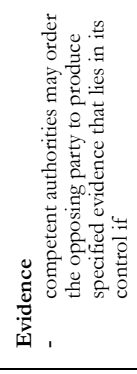 & 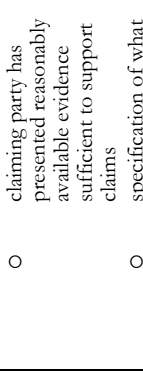 & 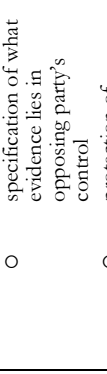 & 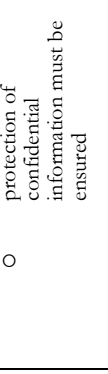 & 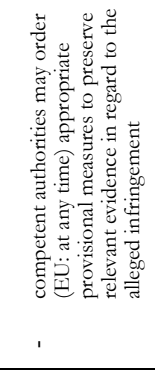 & 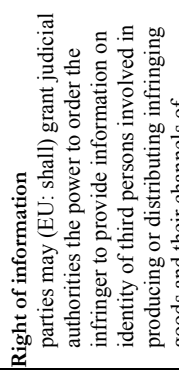 & $\begin{array}{l} \\
\end{array}$ & & & & \\
\hline 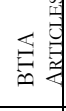 & $\frac{a}{\frac{u}{\underline{E}}}$ & & & & 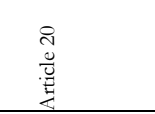 & $\begin{array}{l}\vec{N} \\
\stackrel{U}{\vec{E}} \\
\vec{E}\end{array}$ & & & & & \\
\hline 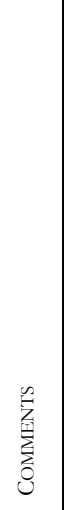 & 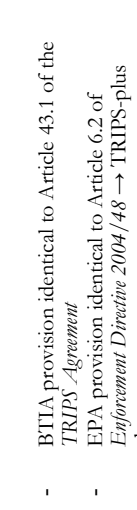 & 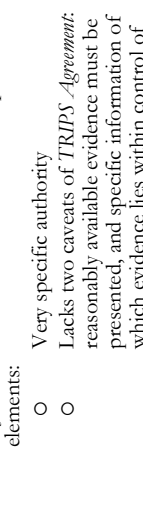 & 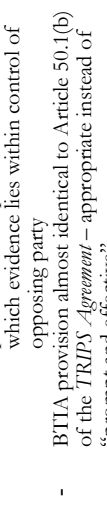 & 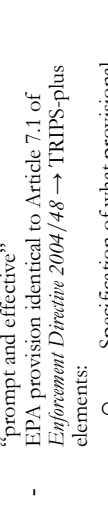 & 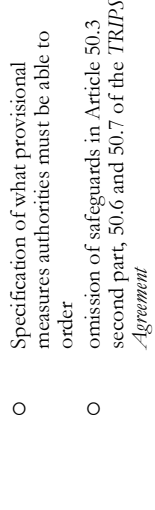 & 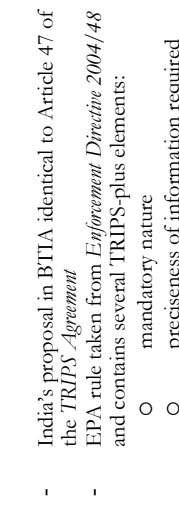 & 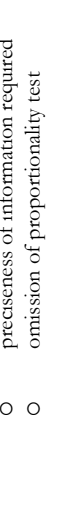 & & & & \\
\hline 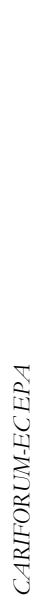 & 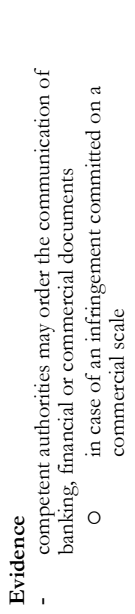 & \multicolumn{4}{|c|}{ 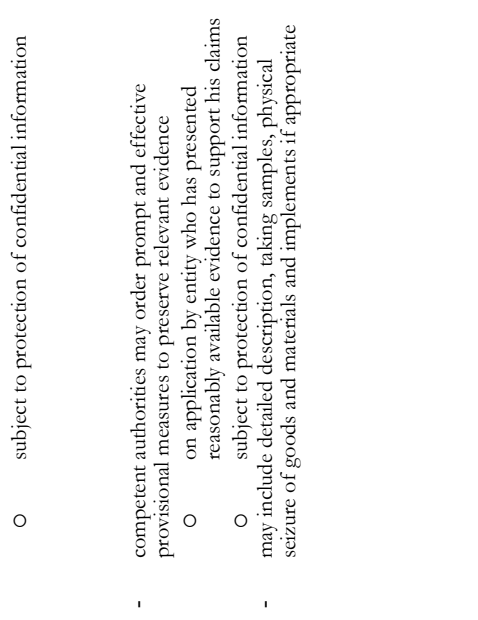 } & \multicolumn{3}{|c|}{ 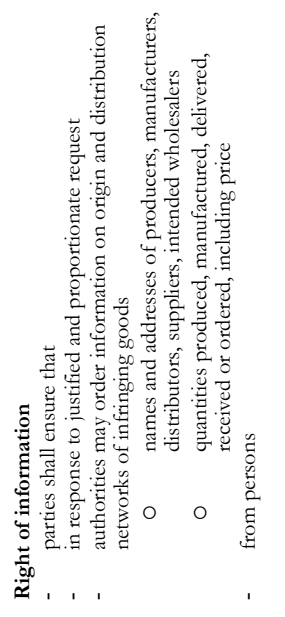 } & 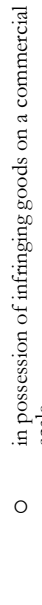 & & 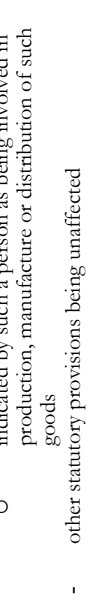 \\
\hline 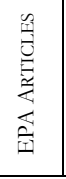 & 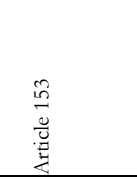 & 党 & 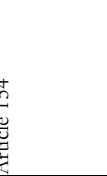 & & & 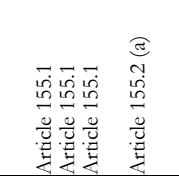 & 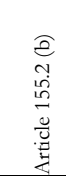 & 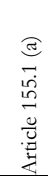 & 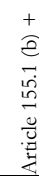 & & 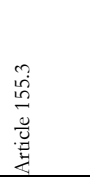 \\
\hline
\end{tabular}




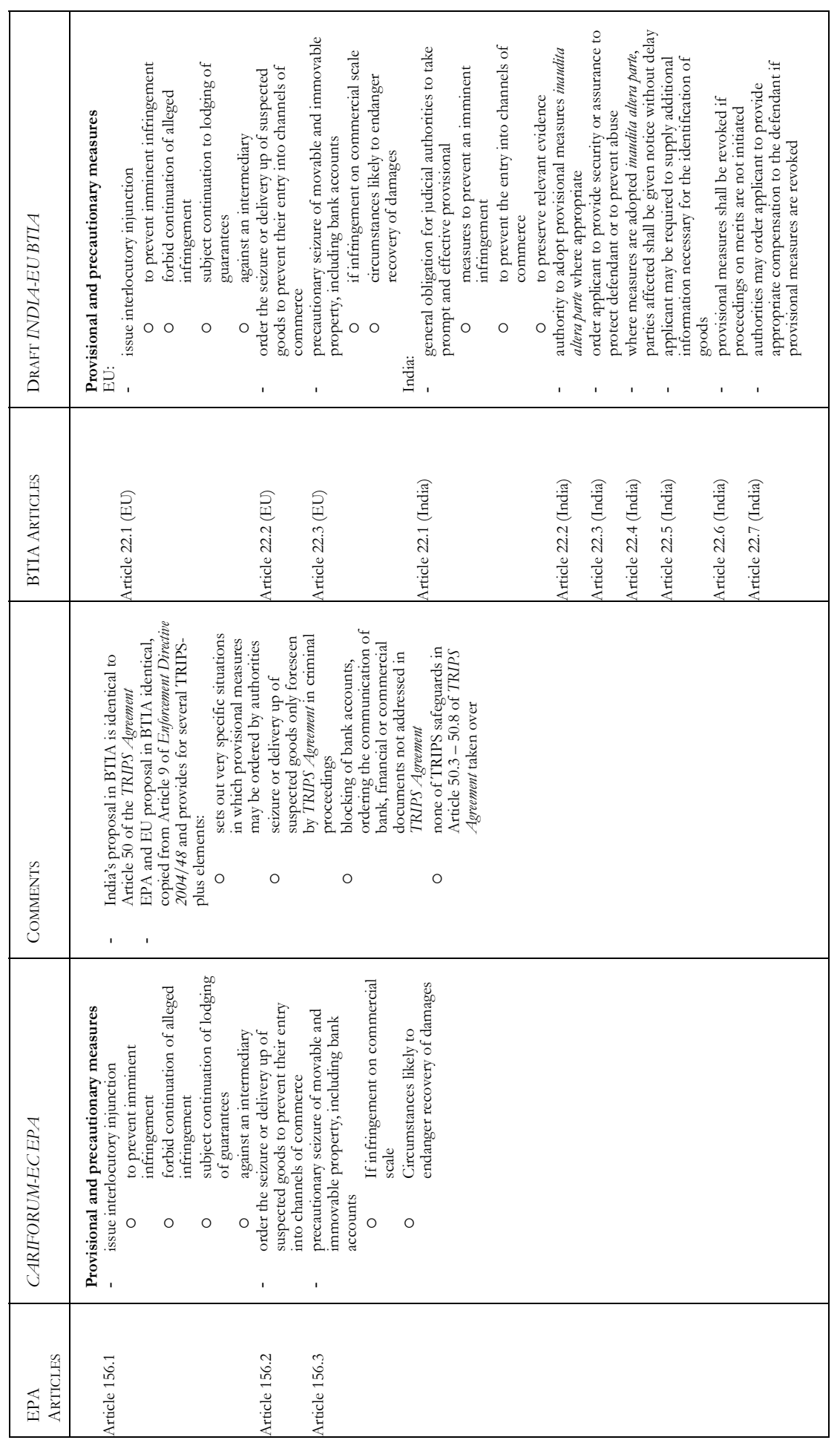




\begin{tabular}{|c|c|c|c|}
\hline 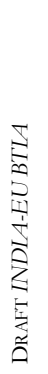 & 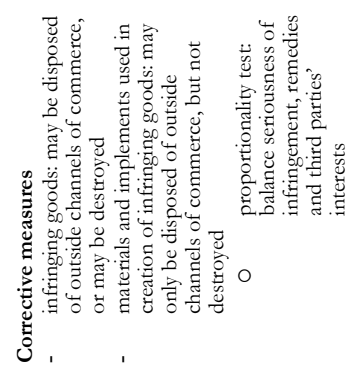 & 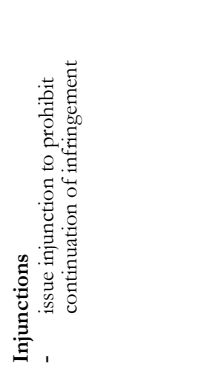 & 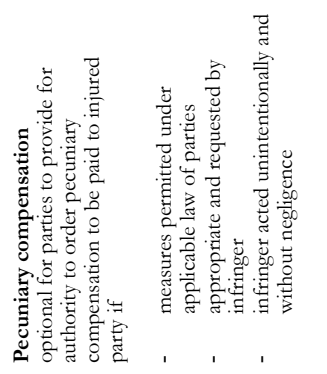 \\
\hline 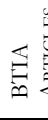 & 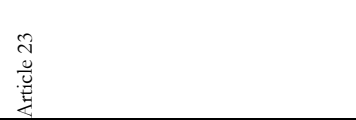 & $\begin{array}{l}\stackrel{+}{N} \\
\stackrel{0}{\underline{E}} \\
\end{array}$ & 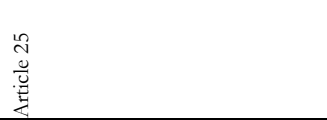 \\
\hline $\begin{array}{l}\text { 号 } \\
\text { 兽 } \\
\text { 总 }\end{array}$ & 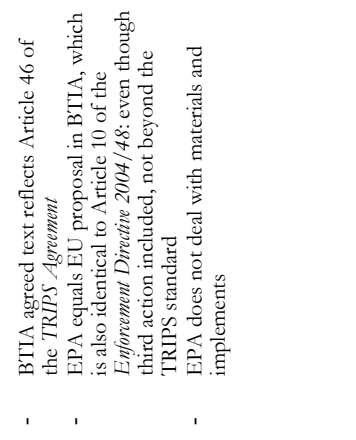 & 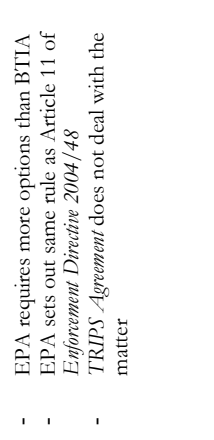 & 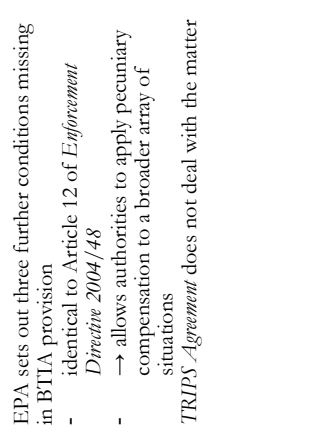 \\
\hline 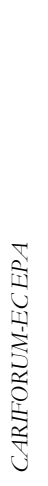 & 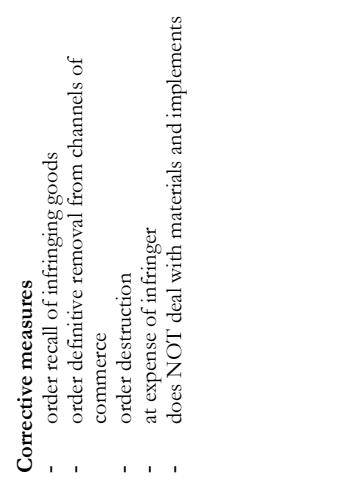 & 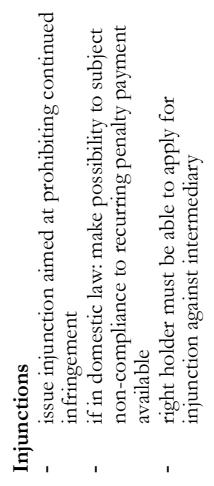 & 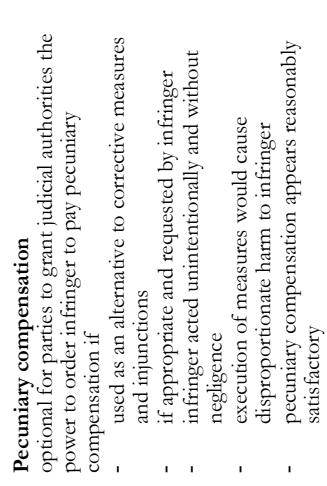 \\
\hline 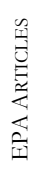 & 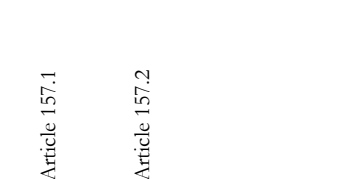 & 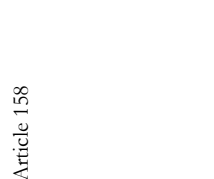 & 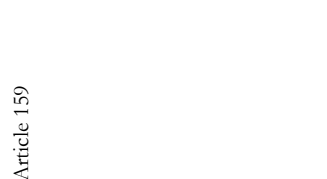 \\
\hline
\end{tabular}




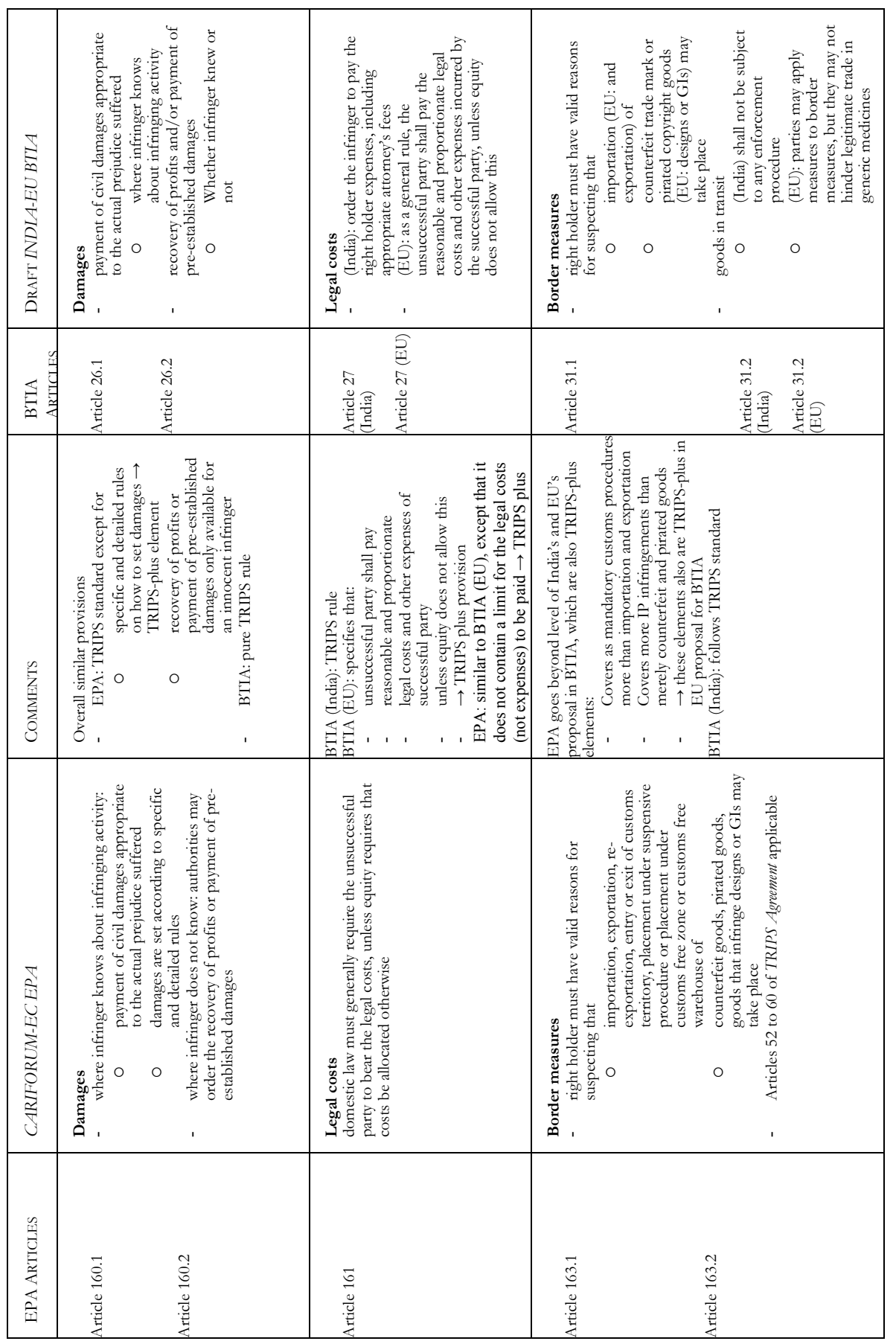


The section dealing with the enforcement of intellectual property rights is a strong element of European "new generation" agreements. Since the CARIFORUM-EC EPA, European agreements provide TRIPS-plus elements in each of the enforcement measures addressed. A number of areas therein are based on internal EU legislation (the rules on evidence, provisional and precautionary measures, and corrective measures). The draft IP chapter of the India-EU BTIA forms a surprising exception in the list of recent European bilateral trade agreements. The European Union has abandoned its own suggestion in respect of many enforcement measures and adopted the protection proposed by India.

India has generally proposed the TRIPS standard. As a consequence, BTIA parties have already agreed to reflect the TRIPS standard in four enforcement measures (rules on evidence, the right of information, corrective measures and damages). In four other areas (general level of enforcement, provisional and precautionary measures, the reimbursement of legal costs and border measures), India has also proposed the TRIPS standard, but the EU has not yet accepted them. Certainly in the area of provisional and precautionary measures, as well as border measures, reaching agreement seems to be difficult. So far, three enforcement measures that have been agreed upon reflect TRIPS-plus elements. These are entitled applicants, and the remedies are injunctions and pecuniary compensation. Even though the two remedies have been copied from European internal legislation, all three elements do not reflect a very high standard of protection. India, therefore, is still able to take into account its domestic preferences when implementing these standards into its national legislation.

While the domestic policy space of India seems to stay rather big with regard to the implementation of enforcement measures, CARIFORUM States have incurred strong TRIPS-plus commitments, which have to be transposed in national law if not yet complied with. Legislation-like provisions and the omission of procedural safeguards otherwise provided for in the TRIPS Agreement limit CARIFORUM States' ability to properly balance the rights of right holders against those of alleged infringers. Compared to the provisions contained in the draft IP chapter of the India-EU BTLA and in view of the numerous TRIPS-plus elements in the EPA, CARIFORUM States' bargaining power has been relatively weak. The opposite seems to be true for India, which already has shown to have had considerable bargaining power in this area.

\subsection{CONCLUSION}

The comparative analysis of the legal provisions contained in the CARIFORUM-EC $E P A$ and the draft IP chapter of the India-EU BTIA has provided important conclusions with regard to two questions. First, it has been examined whether both agreements contain the defining features of the new approach taken by the European Union since the launch of the "Global Europe" strategy with regard to the intellectual property protection its seeks from its trading partners. The three aspects assessed were 1) the nature of the obligations, whether they contain TRIPS-plus features or not, 2) the origin of the legislation, whether it copies European internal legislation or not, and 3) the presence or absence of sufficient policy space to balance the different domestic interests when implementing the provisions of the bilateral agreements and to take development concerns into consideration. The second research question addressed the bargaining power of the EU's trading partners in the various areas: it has been examined whether the results obtained for the defining features of the new EU 
approach indicate that CARIFORUM States and India are able to preserve their interests and therefore whether they have a strong bargaining power in the diverse areas of IP protection.

In several areas of IP protection, the conditions for India have stayed equally beneficial as for CARIFORUM States to preserve sufficient domestic policy space to balance the various interests involved. In both agreements, the general provisions, the provisions on patent protection (if India succeeds in limiting the data exclusivity protection), the protection of plant varieties, and the protection of genetic resources and traditional knowledge (if the EU accepts the provisions suggested by India) contain few TRIPSplus features, are not based on internal EU legislation and leave enough discretion to the EU's trading partners to take development concerns into consideration when implementing the provisions into national law. Rather than concluding that the European Union's new approach, as defined in section 4.3 and section 4.4, does not apply in these areas, I argue that these areas of IP protection were 1) not introduced by the European Union but by the other negotiating party, or 2) the trading partners have been particularly successful in adapting the proposals made by the European Union. In brief, the proposals made by the EU still reflect the new tough approach of the European Union.

The areas where the level of IP protection has increased considerably in the India-EU $B T L A$ compared to the CARIFORUM-EC EPA is with regard to copyright protection, the protection of trade marks and geographical indications. This analysis is true if the proposals made by the European Union will prevail in the final India-EU BTIA. The EPA also contained certain TRIPS-plus provisions in these areas, which were based on internal EU legislation and therefore left little domestic policy space to the parties to balance the relevant interests. However, the provisions proposed by the EU to India could further limit India's discretion in the implementation process considerably. In relation to these three areas, the European Union wishes to increase the protection in the India-EU BTLA, when compared to the level of protection agreed upon in the CARIFORUM-EC EPA.

Merely with regard to the protection of industrial designs and enforcement measures, the provisions already agreed upon in the India-EU BTI $A$ indicate that the protection will be significantly less than in the CARIFORUM-EC EPA, with less TRIPS-plus features and less provisions based on internal EU legislation. Even though not all enforcement measures have been agreed upon yet, chances that India will achieve further deviations from the strong enforcement approach displayed in the CARIFORUM-EC EPA are likely. Therefore, the policy space of India to balance the rights of right holders against the rights of users of design rights and alleged infringers is likely to be significantly higher than that of CARIFORUM States.

The analysis of the TRIPS-plus features, the origin of provisions and the domestic policy space left to India and CARIFORUM States has provided some insights into the bargaining power of both parties in the analyzed areas. India so far has shown relatively strong bargaining power in the negotiations of the general provisions, design protection, the protection of plant varieties, genetic resources and traditional knowledge, and, maybe most importantly, in the negotiations on the enforcement provisions. CARIFORUM States' bargaining power has been substantial in the negotiations of the general provisions and the protection of plant varieties, genetic 
resources and traditional knowledge. The final provisions in the areas of copyright protection, the protection of trade marks, geographical indications, patents and utility models also preserve important interests of the region. However, it is questionable whether the reasons for these relatively soft obligations is the strong bargaining power of CARIFORUM States or a still milder approach by the European Union, which has not yet asked for the same protection as asked from India and other trading partners.

One other conclusion can be drawn from the comparison of the legal provisions contained in the IP chapter of the CARIFORUM-EC EPA and the draft IP chapter of the India-EU BTLA. The provisions on transfer of technology, objectives, the relationship between intellectual property protection and innovation, and the protection of genetic resources and traditional knowledge in the CARIFORUM-EC EPA have served as a source of inspiration for the proposals made by India in the India-EU BTLA. They are evidence of a practice that the trading partners of the European Union are well-advised to make best use of in the negotiations in order to increase their bargaining power. The European Union will find it difficult to deny a lower level of protection to a trading partner if it already has accepted that same level in previous bilateral agreement with another trading partner. India could make further use of this technique as regards soft obligations to comply with international agreements. CARIFORUM States have for example achieved a soft obligation with regard to the accession to the Madrid Protocol. So far, India has been hesitant to commit to a hard obligation; the soft obligation could be an acceptable compromise, to which the European Union has agreed before. 
PART D: CASE STUDY JAMAICA:

AN ANALYSIS OF THE PREFERENCES

AND INFLUENCE OF NON-STATE

ACTORS ON THE IP POLICY POSITION OF

JAMAICA AND THE CARIFORUM REGION 

Previous chapters of this book have focussed on the analysis and interpretation of the intellectual property provisions included in European "new generation" bilateral trade agreements, one of them being the CARIFORUM-EC EPA. The remainder of this book will address another side of the same coin, namely the policy-making process that is at the heart of policy choices made in the context of bilateral trade negotiations. In particular, Part D assesses how non-state actors in Jamaica and in the Caribbean Forum of African, Caribbean and Pacific States region with an interest in the regulation of IP in general and specifically in the EPA negotiations have influenced the national and regional IP policy positions. The study also addresses the non-state actors and the policy position of the CARIFORUM region because Jamaica has coordinated its foreign trade policy with the countries in the region. Nevertheless, the main focus is on Jamaica as the largest, independent, English-speaking state in the Caribbean region. ${ }^{1}$ It is an island nation with a current population of approximately 2.9 million inhabitants. ${ }^{2}$ In order for the study of non-state actors' influence on IP policy-making to be of value, it was necessary to choose a country where certain minimum conditions were fulfilled: a certain degree of public debate on intellectual property protection, the existence of public and private groups with an interest in IP policy-making and a certain degree of public and private stakeholders involvement in the policy-making process. Jamaica is known in the region for being one of the more advanced countries on all three factors. ${ }^{3}$

Chapter 8 of this part sets out the research design used to carry out the case study. Chapter 9 provides an overview of Jamaica's trade policy and trade patterns. It also contains a brief analysis of Jamaica's intellectual property legislation before and after the entering into force of the TRIPS Agreement. Chapter 10 assesses the policy-making process with regard to intellectual property matters during the EPA negotiations. Particular attention is paid to 1) the phases of negotiations, 2) the national and regional state and non-state actors involved in the policy-making process and the negotiation of the IP commitments in the EPA negotiations, and 3) the interaction between state and non-state actors through consultations at the regional and national level. Chapter 11 presents an investigation of the influence non-state actors have had on the IP negotiations in the EPA. In this context, the role of the technical negotiator on intellectual property issues is further examined. Chapter 12 highlights the main findings and conclusions.

\footnotetext{
1 See B.A. Lehman, Modernizing Jamaica's Intellectual Property System (International Intellectual Property Institute, 2000), p. 6.

2 See US Central Intelligence Agency, Jamaica: The World Factbook (Washington, 2012), available at <https://www.cia.gov/library/publications/the-world-factbook/geos/jm.html $>$ accessed on 15.11.2012.

3 Interview with Malcolm Spence, 8 April 2010, Bridgetown.
} 



\section{Chapter 8 : Research Design: Methodology and Theoretical Framework}

\subsection{SCOPE OF THE RESEARCH}

\subsubsection{Research Questions}

TRIPS-plus provisions are increasingly incorporated in recent bilateral trade agreements. This is primarily the case for the agreements to which one of the major actors, the United States and the European Union, is a party. ${ }^{1}$ These agreements are negotiated with developed countries, emerging economies and developing countries alike. Increasing the protection of intellectual property in various areas has an effect on the social and economic welfare of a country. It is therefore crucial that such decisions are subject to a transparent process, in which the interests of all parties in society are taken into account. This study aims at providing the reader with detailed information on what the preferences of non-state actors in developing countries are in that respect, whether they have been involved in the decision-making process and what their influence was on the final policy decision to adopt TRIPS-plus provisions in international agreements. ${ }^{2}$

In the area of intellectual property protection, studies in developed countries, such as in the United States and the European Union, have shown that mainly small, singleissued and resource-intensive non-state actors, in particular industry organizations and companies, have been very successful in influencing the intellectual property policy position of their state at the international level. ${ }^{3}$ However, there is a lack of research that addresses the influence of non-state actors in developing countries on the policy decision whether to accept or resist TRIPS-plus provisions in bilateral negotiations. This research adds to the scientific discourse in international relations, collective action and negotiation theory by providing a deep analysis of the case of a developing country, Jamaica and the CARIFORUM region. ${ }^{4}$

It is far from evident why certain developing countries agree to TRIPS-plus issues in particular areas of intellectual property protection in bilateral trade agreements. These decisions, as diverse as the context for different developing countries may be, have in common that they are the result of a domestic decision-making process. The outcome of this process is the position that the developing country's chief negotiator adopts in international trade negotiations. In other words, in order to investigate why

1 Up until now, no pure South-South agreement has been identified to include TRIPSplus provisions. See R. Newfarmer, Trade, Regionalism, and Development (The World Bank, Global Economic Prospects, Washington, 2005), p. 99; Kampf, “TRIPS and FTAs: A World of Preferential or Detrimental Relations", p. 105.

$2 \quad$ For a definition of social relevance, see Lehnert, Miller and Wonka, "Increasing the Relevance of Research Questions (2007)", p. 25 ff.

$3 \quad$ M.P. Pugatch, The International Political Economy of Intellectual Property Rights (Edward Elgar Publishing Ltd., Northampton, 2004); Sell, Private Power, Public Law; Heron and SilesBrügge, "Competitive Liberalization and the 'Global Europe' Services and Investment Agenda: Locating the Commercial Drivers of the EU-ACP Economic Partnership Agreements".

$4 \quad$ For a definition of theoretical relevance, see Lehnert, Miller and Wonka, "Increasing the Relevance of Research Questions (2007)", p. $23 \mathrm{ff}$. 
a certain policy position is chosen by a developing country partner in bilateral or multilateral negotiations, one needs to examine the "structure of domestic preferences". ${ }^{5}$

It is understood that the negotiation of intellectual property issues cannot be isolated from the negotiation of other areas of trade in a trade agreement, whether at the multilateral level (the WTO) or the bilateral level (bilateral trade agreements). An important aspect of international trade negotiations is the possibility of making tradeoffs for a key interest in one area of trade by a concession in another area under negotiation. In this context, developing countries often see the protection of intellectual property as a concession made in exchange for commitments in other areas of trade, such as market access in trade in goods.

Even though the above observation may be true for most developing countries, it would be unsatisfactory as an explanation for detailed policy choices made by developing countries. Such policy choices address specific issues, such as the question which IP rights to protect to what degree in which international forum. Based on the theoretical understanding that policy choices at the international level are informed by domestic preferences of both state and non-state actors, the main research question addressed in this thesis is the following: What influence can domestic non-state actors have on the final IP policy position adopted by a developing country in bilateral trade negotiations through participation in consultative processes? In particular, do they influence the country's policy choice to engage in bilateral negotiations instead of, or in addition to, multilateral negotiations on matters of intellectual property protection?

\subsubsection{Specification of Concepts}

The concept of influence is notoriously difficult to specify and to operationalize. Despite the fact that particular aspects of the concept might not be given enough importance, I chose a pragmatic approach towards defining influence, following other scholars in this field. ${ }^{6}$ Accordingly, influence of non-state actors must be understood as control over political outcomes, derived from the broader concept of power, ${ }^{7}$ which is being understood as control over outcomes, resources or actors. Actors are powerful or influential if they succeed in affecting policy outcomes in a way that brings them closer to their ideal points. In other words, when policy outcomes reflect their preferences, they have been influential. It is therefore the effect of power rather than the concept of power itself that is analyzed. ${ }^{8}$ This

5 For a definition of the term "structure of domestic preference", see section 8.2.1 of this book. For a general discussion, see also R.D. Putnam, "Diplomacy and domestic politics: the logic of two-level games” International Organization, 1988, Vol. 42 (3), 427460 .

6 See A. Dür and D. De Bièvre, "The Question of Interest Group Influence” Journal of Public Policy, 2007, Vol. 27 (1), 1-12, p. 3.

7 There is a widespread disagreement on how the term power should be understood. However, Robert Dahl's "intuitive idea of power", according to which "A has power over B to the extent that he gets B to do something that B would not otherwise do", has been widely accepted as a basic definition of power. See R. Dahl, "The Concept of Power" Behavioural Science, 1957, Vol. 2, 201-215, p. 202-203; S. Lukes, Power: A Radical View (2nd expanded edn, Macmillan, London, 1974), p. 30.

8 See Dür and De Bièvre, “The Question of Interest Group Influence”, p. 3. 
definition contains another concept, being that of policy outcome. Policy outcome can be understood in two ways: 1) the official position taken by public authorities, and 2) the actual implementation of the policy.

The main research question focuses primarily on the first element of policy outcome, the policy position. It is not straight forward to analyze the second element, the implementation of an international agreement into domestic law. To relate the preferences of domestic societal actors on IP issues in an international agreement with the implementation of the obligations of the final agreement is farfetched: these two processes are too remote from each other to study the effect of one on the other. ' There are at least two other processes, in addition to that of domestic preference formation, which have an effect on the implementation of the policy as determined in the international agreement. First, the domestic policy position (which has been formed through domestic preference formation) is subject to the complex process of international negotiations (negotiating theory), where other actors' preferences and various factors have an impact on the final agreement. Second, also the implementation of the final agreement into domestic policy represents yet another political process, in which the preferences of domestic societal actors are only one factor out of many. Therefore, influence should be understood as control over the policy position as the outcome, rather than the implementation of the international agreement. The underlying assumption of the control over outcomes approach is that actors have clear preferences over outcomes.

The concept of non-state actors encompasses a broad group of actors. They include all actors that do not belong to a state institution, perform public tasks or are financed mainly by the state. Following Duncan Matthews, ${ }^{10}$ non-state actors can be usefully categorized in five groups: public action NGOs, industry associations, right holders groups, professional associations and the academic community.

Special attention is paid to the preferences of domestic (national and regional) nonstate actors and their influence on regulating IP protection. International non-state actors are not at the core of this research mainly for two reasons. One reason is that international non-state organizations are already addressed by a body of literature that examines their involvement in developing countries' IP policy-making when these countries are negotiating in multilateral organizations. ${ }^{11}$ Another reason is that I have

9 Of course a study of preferences of societal actors during the negotiations of an international agreement may, and in this case also did, provide certain insights on the preferences of societal actors in the implementation phase of the obligations stemming from the international agreement. Having used these insights for certain conclusions on the implementation of EPA obligations (see section 12.1), the argument made here tries to emphasize that the formation of a policy position for the negotiations of an international agreement and the implementation of obligations in that international agreement are two separate processes and therefore the choice has been made to study only the former.

10 See Matthews, NGOs, Intellectual Property Rights and Multilateral Institutions, p. 5.

11 For an account of the influence of international non-state actors on the negotiations of the TRIPS Agreement, see Menescal, "Those behind the TRIPS Agreement". For an account of the influence of international civil society organizations in the aftermath of the TRIPS Agreement, see Drahos, "Developing Countries and International Intellectual Property Standard Setting", p. 26 ff; Sell and Prakash, "Using Ideas Strategically". For 
a specific interest in the domestic non-state actors' situation which, from a democratic and pluralistic point of view, should be determinative for the policy choice made by the developing country.

Arguably, the negotiations of international agreements constitute the phase in which the obligations, which will be undertaken by both parties to the agreement, can best and most directly be influenced by interest groups. In addition, some attention is devoted to the implementation process of the EPA and the involvement of interest groups therein. The way an international agreement is implemented is most relevant to its citizens because they rely on the national law in order to derive rights.

The policy preferences of non-state actors on IP matters in Jamaica and the Caribbean region are at the heart of the study. The concept of "preferences" needs to be differentiated from the concept of "interests". According to Helen Milner, policy preferences of actors involved in the policy-making process derive from their basic interests; interests in that sense are fundamental goals such as maximizing one's income. ${ }^{12}$ Whereas interests do not differ much from one actor to the other, preferences do. They refer to specific policy choices made in a particular situation and policy area. ${ }^{13}$ This thesis aims at identifying the preferences of non-state actors in the policy area of intellectual property protection in general and more specifically in the context of the EPA negotiations. However, the word "interest" has been used in its common sense way when interviewing state and non-state actors, reflecting the fact that they are interested in a particular matter and have a stake therein. Therefore, when the concept "interests" is used in this thesis, it refers to its common sense meaning of having an interest in IP regulation in general and specifically in the context of the EPA negotiations.

While not only the preferences in the regulation of a particular IP right are assessed, this research also tries to identify whether non-state actors have a preference for the bilateral or multilateral level to regulate international intellectual property protection and whether this preference was reflected in the final policy position adopted by Jamaica and the CARIFORUM region. The question of forum choice posed to the interviewed non-state actors aims at establishing whether the decision to conclude a full EPA, which included an IP chapter, was influenced by the preferences of nonstate actors.

While there are multiple channels for non-state actors to be involved in the policymaking process, this analysis focuses on the arguably most important form of

an account of the relations between international civil society organizations and groups in the Global South, see D. Matthews, Intellectual Property, Human Rights and Development: The Role of NGOs and Social Movements (Edward Elgar, Cheltenham, 2011), p. 4. Matthews also notes here that most literature on NGO engagement with intellectual property rights issues tend to focus on the role of international NGOs. See Matthews, Intellectual Property, Human Rights and Development, p. 3.

12 The fundamental interests of actors are captured by the utility function, which they aim to maximize. For non-state actors, Helen Milner notes that their interest is to maximize income whereas political actors would be interested in remaining in office. See H. Milner, Interests, Institutions, and Information: Domestic Politics and International Relations (Princeton University Press, Princeton, 1997), p. 33. 
interaction between policy makers and non-state actors: non-state actors' participation in the institutionalized consultations organized by regional and national policy makers. This choice for the channel of direct lobbying through consultations has been made for two reasons: first, none of the other possible ways of interaction (such as through influencing the public opinion, influencing the selection of decision makers or wielding structural power) has been identified by the interviewees, neither by policy makers nor non-state actors, as having been used. ${ }^{14}$ One exception is the contact between the West Indies Rum and Spirits Association and Malcolm Spence, which the latter identified as having been informal rather than formal. ${ }^{15}$ Second, information and documentation on informal contacts between state and non-state actors was not reasonably available. ${ }^{16}$

\subsubsection{Delimitations}

The case study only assesses non-state actors' preferences that relate to IP protection that is relevant to protect agricultural products and foodstuffs. Compared with the two important issue areas of 1) the impact of the IP regime on access to medicines and 2) its impact on access to knowledge, securing food security has not received an equal amount of attention by non-state actors. ${ }^{17}$ This relative neglect makes it necessary to focus research and non-state actors' attention on the protection of intellectual property in agricultural and food products. In addition, many developing countries, among which Jamaica and the CARIFORUM States, are important exporters of food products; the protection of the relevant IP aspects also abroad is a crucial condition for the success of their products. The same is true for the European Union, which is their partner in the EPA negotiations and has shown a keen interest in protecting forms of IP that are relevant for their agricultural products and foodstuffs, for example geographical indications. The IP areas that this research addresses in particular are the protection of geographical indications, trade marks, plant varieties protection, genetic resources and traditional knowledge, and the enforcement of these rights.

\subsection{THEORETICAL FraMEWORK}

The theoretical framework used in this thesis argues that policy choices at the international level are informed by domestic preferences of both state and non-state actors (liberal theories of international relations). Societal actors may form groups only if they have a crucial interest in common and if certain conditions for overcoming collective action problems are fulfilled (logic of collective action). Groups with different preferences compete with each other for the most influence on the policy makers. The nature and constellation of domestic preferences has an impact on the negotiator's autonomy in international negotiations as well as on her/his bargaining power (logic of two-level games). Being bound by the outcomes that are acceptable to the domestic constituency, the negotiator has either a large or small autonomy to compromise; the degree of negotiating autonomy, in turn, has an

14 Only state actors, such as Jamaica Promotions Corporation and the Scientific Research Council, reported to have used written submissions in addition to the consultations as a lobbying tool.

15 Email correspondence with Malcolm Spence, 29 April 2012.

$16 \quad$ See also section 8.3.2.1.1 of this book.

17 See Matthews, NGOs, Intellectual Property Rights and Multilateral Institutions, p. 9. 
effect on his bargaining power. Strategic behaviour as well as the relative strength of the negotiating partners will further influence the outcome of the international negotiations (negotiation theory).

The theories used here can be categorized into five fields: 1) the impact of domestic preferences on international negotiations; 2) the conditions under which societal actors organize themselves; 3 ) the relation between domestic preferences, negotiating autonomy and bargaining power; 4) the study of the process of international negotiations; and 5) factors that influence the choice of one forum over another. Even though these theories have been developed on the basis of research mostly carried out in developed countries, they are applied here to the situation of a developing country, Jamaica and the CARIFORUM region. The study aims at adding to the scientific discourse in international relations, collective action and negotiation theory by providing a deep analysis of this case study.

\subsubsection{Liberal Theories of International Relations}

Liberal approaches to international relations emphasize that the preferences of domestic actors are crucial to explain why countries coordinate their policies on specific issues at certain times. In particular, this research focuses on the societycentred theories, which stress the pressure from domestic social groups on the state. According to Helen Milner,

\footnotetext{
"cooperation among nations is affected less by fears of other countries' relative gains or cheating than it is by the domestic distributional consequences of cooperative endeavours. $[\ldots]$ The internal struggle between these groups shapes the possibility and nature of international cooperative agreements." 18
}

Liberal institutionalists, such as Helen Milner, oppose the view held by realists that states are unitary actors, with a single actor at the top making final decisions. ${ }^{19}$ Helen Milner argues that states are not hierarchically organized but are composed of actors with varying preferences, who share power over decision making. ${ }^{20}$ Therefore, it is the structure of domestic preferences that can explain the likelihood and the terms of cooperation among nations. ${ }^{21}$

Three factors are decisive to define the "structure of domestic preferences": 1) the policy preferences of domestic actors; 2) the institutions that define how power is shared when making decisions; and 3) the distribution of information among domestic actors. ${ }^{22}$ Relevant domestic actors are those that participate in the legislative process. Helen Milner names three categories: the legislature, the executive and social interest groups. ${ }^{23}$ The preferences of all participating actors are aggregated through the process that the political institutions shape. ${ }^{24}$ The distribution of information

18 Milner, Interests, Institutions, and Information, p. 9.

19 See K. Waltz, Theory of International Politics (1st edn, Addison-Wesley, Reading, Massachusetts, 1979), p. 88.

20 See Milner, Interests, Institutions, and Information, p. 11.

$21 \quad$ See ibid., p. 7 and 17.

22 See ibid., p. 11.

23 See ibid., p. 12.

24 See ibid., p. 18. 
among domestic actors affects the decision-making process by creating uncertainty as well as political advantage. If an actor possesses more relevant information, (s)he is likely to be more dominant in the domestic policy-making process. ${ }^{25}$

In contrast to Helen Milner's view of including the state into the definition of domestic actors, the liberal conception of domestic politics as described by Andrew Moravscik does not see the state as an actor only, but as a representative institution. ${ }^{2}{ }^{6}$ According to Andrew Moravscik, representative institutions and practices translate the preferences of individuals and groups into state policy. In other words, the government acts as a broker, who weighs the interests of different non-state actors and puts together a domestic win-set. ${ }^{27}$ Andrew Moravscik does not adopt a narrowly pluralist view of domestic politics, in which all individuals and groups have equal influence on state policy. ${ }^{28}$ Rather, government and political institutions are captive to special interest groups and will create a bias in favour of certain actors and particular preferences. ${ }^{29}$ It is this conceptualization of the state (or chief negotiator) as an aggregator of the preferences of non-state and state actors that will be used in the context of this research.

Preferences of domestic actors are likely to conflict and it is a matter of domestic politics to determine which preferences of which actors will prevail in the final policy choices on particular issues. ${ }^{30}$ As noted by Andrew Moravcsik,

"The fundamental actors in international politics are individuals and private groups, $[\ldots]$ who organize exchange and collective action to promote differentiated interests under constraints imposed by material scarcity, conflicting values and variations in societal influence." 31

In other words, societal actors exploit the social incentives for exchange and collective action in order to promote their respective preferences. Hence, groups of actors will engage in the policy-making process.

It is useful to understand that domestic actors are unlikely to form coalitions along the lines of state and non-state actors' boundaries, but rather along policy issues. ${ }^{32}$ According to Paul Sabatier and Hank Jenkins-Smith, particular combinations of government officials, interest groups, academics and journalists form "advocacy coalitions" because they share the same policy objectives. The concept of "advocacy coalition" challenges the general assumption often made by political scientists that

25 See ibid., p. 21.

26 See A. Moravcsik, "Taking Preferences Seriously: A Liberal Theory of International Politics” International Organization, 1997, Vol. 51 (4), 513-553, p. 518.

27 See Von Braun, The Domestic Politics of Negotiating International Trade: Intellectual Property Rights in US-Colombia and US-Peru Free Trade Agreements, p. 30.

28 See Moravcsik, "Taking Preferences Seriously", p. 518.

29 See Milner, Interests, Institutions, and Information, p. 18; see also S. Meunier, Trading Voices: The European Union in International Commercial Negotiations (Princeton University Press, Princeton, 2007), p. 45.

$30 \quad$ See Meunier, Trading Voices, p. 45.

31 See Moravcsik, "Taking Preferences Seriously", p. 516.

32 See S. Princen, "Advocacy Coalitions and the Internationalization of Public Health Policies" Journal of Public Policy, 2007, Vol. 27 (1), 13-33, p. 18. 
"legislators, administrative agency officials, interest group leaders, researchers and journalists" 33 are fundamentally different from each other. For the purpose of policymaking, it has been observed by several authors that coalitions or networks of public and private actors compete with each other in a policy area in order to determine the policy outcome in a given field. ${ }^{34}$

\subsubsection{Logic of Collective Action}

Liberal theories of international relations emphasize the importance of domestic actors' preferences in explaining a state's policy position in international negotiations. What they do not analyze, however, is under which conditions certain domestic actors form coalitions and successfully influence the decision-making process. This research aims at linking the conditions for domestic coalitions to have influence with the final policy position of a state to engage in international cooperation. This link has already been demonstrated in the context of earlier research in developed countries; ${ }^{35}$ however, so far, such research has not been carried out for developing countries' policy positions on intellectual property protection to be included in a bilateral trade agreement.

Mancur Olson was the first scholar to develop a theory about the conditions under which individuals form groups in order to provide a collective good. ${ }^{36}$ A collective good is defined by Mancur Olson as a good that cannot be withheld from other group members if any person in the group consumes it. ${ }^{37}$ In other words, if the good is provided to any member of the group, the other members cannot be excluded from using it. ${ }^{38}$ The "Logic of Collective Action" is relevant to this research as it can

33 P.A. Sabatier and H.C. Jenkins-Smith, "The Advocacy Coalition Framework: An Assessment" in P.A. Sabatier (ed.), Theories of the Policy Process (1st edn, Westview Press, Boulder, 1999) 117-166, p. 127.

34 See Matthews, Intellectual Property, Human Rights and Development, p. 6-7; see G.C. Shaffer, Defending Interests: Public-Private Partnerships in WTO Litigation (Brookings Institution Press, Washington, 2003), p. 13; P. Drahos, "Four Lessons For Developing Countries From The Trade Negotiations Over Access To Medicines" Liverpool Law Review, 2007, Vol. 28 (1), 11-39, p. 35-36.

35 See M. Olson, The Logic of Collective Action (Harvard University Press, Cambridge, 1965); P. Bernhagen and T. Bräuninger, "Structural Power and Public Policy: A Signaling Model of Business Lobbying in Democratic Capitalism" Political Studies, 2005, Vol. 53 (1), 43-64; J. Beyers, "Voice and Access: Political Practices of European Interest Associations" European Union Politics, 2004, Vol. 5 (2), 211-240.

36 Note that Mancur Olson uses the words public good, common good and collective good synonymously. However, the terms "common" or "public" good can also have a normative meaning of being a general benefit to everybody in society, not only to the group of actors that provides it. Since this normative use of these terms is not appropriate in the context of this theory, I will use the term "collective good" to indicate a good that a group of actors derives a benefit from (and not necessarily everybody in society).

37 See Olson, The Logic of Collective Action, p. 14.

38 In the literature, the terminology of excludable and non-excludable goods has been used. In reality, these two concepts are not dichotomous. There is a grey area, a continuum between these two extremes. An example is the collective good of a subsidy that is available for apple growers of a particular size. However, if the law makes the grant of the subsidy contingent on the application of each apple grower individually, 
provide insights on the characteristics of coalitions of domestic actors who are likely to engage in collective action and who tend to be successful in lobbying the domestic negotiator for their preferences with regard to international rules of intellectual property protection. ${ }^{39}$ The collective good, in the context of this thesis, is a particular degree of international regulation of intellectual property rights, which is sought by the group of people that uses or will potentially make use of these IP rights. Even though Mancur Olson's assumption of rational, self-interested individuals has been criticized as not reflecting reality, ${ }^{40}$ his theory is the basis of many interest group studies conducted today.

According to the logic of collective action, group size is, in part, a cause for whether a group will be successful in providing the collective good or not. ${ }^{41}$ In large groups, the risk of one member free-riding on the expenses of the other members is substantial. When a group has many members, the contribution or lack of contribution by a single individual has no perceptible effect to the group as a whole or to the benefits or burden of its members. ${ }^{42}$ Because of the risk of free-riding behaviour, a member of a large group will not invest any costs in advancing the common goal: (s)he will have no incentive to pay for the collective good if no one notices her or his lack of contribution. ${ }^{43}$ Since each member feels this disincentive, large groups are unlikely to engage in collective action without any external inducement or selective incentive.

On the other hand, in small groups the risk of free-riding is relatively small. ${ }^{44}$ In a group of few members, each individual is so significant for the group as a whole that her/his contribution or lack of contribution has a noticeable effect on the costs or benefits of the others in the group. ${ }^{45}$ Since the risk of free-riding is relatively low, a small group is much more likely to provide the collective good than large groups.

Mancur Olson further elaborates that the likelihood of small groups to provide the collective good is greatest if there is a considerable degree of inequality among its

then only those that know about this possibility and have the relevant information to complete the application will be able to enjoy the collective good. which he has elaborated upon in his later work "The Rise and Decline of Nations", but which he has not explained. See M. Olson, The Rise and Decline of Nations: Economic Growth, Stagflation, and Social Rigidities (Yale University Press, New Haven, 1982).

40 See E. Ostrom, "Collective Action and the Evolution of Social Norms" The Journal of Economic Perspectives, 2000, Vol. 14 (3), 137-158, p. 142.

41 See T. Sandler, Collective Action: Theory and Applications (Harvester Wheatsheaf, Herfordshire, 1992), p. 8.

42 See Olson, The Logic of Collective Action, p. 44.

43 Olson explains that "the larger the group, the less the likelihood that the contribution of any one will be perceptible." See ibid., p. 35 and 44.

$44 \quad$ Olson also tries to explain that small groups are more likely to provide the collective good by referring to the share an individual gets from the group benefit. This would be substantial in a small group, therefore exceed the associated costs and induce members to get organized. See ibid., p. 34. However, in case of the collective good being a certain degree of intellectual property protection, the benefit cannot be translated into shares for each member that would differ depending on the size of the group. Therefore, that rationale is not being used here. 
members. ${ }^{46}$ Where members have different sizes or different extents of interest in the collective good, there is a tendency towards an arbitrary sharing of the burden that comes with providing the collective good. ${ }^{47}$ The largest member or the member with the strongest interest bears a disproportionate share of the burden to satisfy his or her own collective good demand. Smaller members are likely to have their demands satisfied by the amount of the collective good already provided for by the largest member and therefore will not contribute to the costs of providing the collective good. ${ }^{48}$ In the most extreme case, that member pays the entire costs of providing the good and acts like a hegemon. ${ }^{49}$ Next to the impact of a hegemon on the group, another form of increasing the likelihood for small groups to provide the collective good is through institutional arrangements, which the group itself sets up. Such arrangements could be forms of group advertising or specific monitoring mechanisms..$^{50}$

Another distinction of groups that impacts the likelihood of them to provide the collective good is that of concentrated and diffuse interests. The provision of a collective good can entail large benefits and/or costs for a particular group of actors, while it produces only diffuse benefits and/or cost for other groups of actors. If a group can derive a large benefit from the good being provided, the group has a concentrated interest in providing the good. The same is true for goods that produce high costs for a group: that group has a concentrated interest in avoiding the provision of the collective good. On the other hand, if a group only derives a small benefit from a good or has to incur small costs for its provision, that group has diffuse interests.

In the literature, large groups are often referred to as having diffuse interests. While it is true that often large groups indeed have diffuse interests and small groups concentrated ones, the concepts of concentrated and diffuse interests are in fact unrelated to the size of a group. A potential large group of consumers, for example, can have a concentrated interest in avoiding the costs of paying higher royalties for using copyright products for a longer period of years. The same is true for a small group of plant breeders for whom an additional exception to their rights is relatively unimportant and therefore only represents a diffuse interest.

Even though the terminology of concentrated and diffuse interests has not been used by Mancur Olson, the consequences are compatible with his theory. Accordingly, diffuse interests find it more difficult to get organized than concentrated interests: ${ }^{51}$ since the benefits or costs are only tiny for each member of the group, it is not worthwhile for any of them, and hence for the entire group, to become active. The opposite is true for concentrated interests: where actors can derive a substantial

\footnotetext{
$46 \quad$ See ibid., p. 34.

$47 \quad$ See ibid., p. 35.

48 See Sandler, Collective Action: Theory and Applications, p. 54.

49 One could argue that this form of behaviour, where one individual member provides the collective good by himself, is individual action, which leads to the provision of the collective good to all members of the group.

$50 \quad$ See Olson, The Logic of Collective Action, p. 45, footnote 67.

51 See Dür and De Bièvre, "The Question of Interest Group Influence”, p. 6.
} 
benefit or cost from providing a collective good, they are likely to engage in collective action.

\subsubsection{Logic of Two-level Games}

Having described the theoretical conditions for groups to engage in collective action and lobby the policy-maker in accordance with their interests, the link needs to be made between the structure of domestic preferences, negotiating autonomy and bargaining power. The analytical framework that allows us to make this connection is Robert Putnam's logic of two-level games. The logic can be best illustrated by a metaphor of two separate tables that symbolize the interaction between domestic politics and international negotiations. When a negotiator is at the international table bargaining with her/his foreign counterparts, he can only give as much as the constituents at the domestic table will accept. At the same time, any amendment made at the domestic table must be signed by all negotiators at the international table.

According to the two-level game logic, the international negotiator is determined by his so-called "domestic win-set". The domestic win-set is defined as the set of all possible international agreements that can gain the necessary majority among the domestic constituents. ${ }^{52}$ A large domestic win-set incorporates many possible agreements accepted by domestic actors, whereas a small win-set only allows particular solutions to pass the domestic ratification procedure. Its size depends on a number of factors ${ }^{53}$ probably the most important determinants are the distribution of power, the intensity of preferences and possible coalitions at the domestic table. ${ }^{54}$

Two aspects of the two-level game logic need to be emphasized. First, the size of the domestic win-set determines the likelihood of an international agreement. Second, the size of the domestic win-set determines the degree of negotiating autonomy, which in itself has an impact on the bargaining power of the negotiator. In that respect, the following findings are significant.

\section{1) Large win-sets make an international agreement more likely, ceteris paribus. ${ }^{55}$}

An international agreement is only possible where the domestic win-sets of all negotiating parties overlap. The bigger their sizes, the more likely it is that they overlap. The win-set is not a static concept but can alter during the conduct of negotiations. Reasons for such alterations are changes in domestic actors' preferences, impacts from the process of the international negotiations or external factors, such as an economic crisis. The following Scheme 1 illustrates the effects of a change in the win-set size.

52 See Putnam, "Diplomacy and Domestic Politics: The Logic of Two-level Games", p. 437. Domestic constituents are political parties, social classes, non-state actors, legislators, public opinion and elections. See Putnam, "Diplomacy and Domestic Politics: The Logic of Two-level Games", p. 432.

53 Robert Putnam elaborates three factors that determine a win-set: 1) domestic preferences and coalitions, 2) domestic political institutions, and 3) strategies used by the international negotiators. See Putnam, "Diplomacy and Domestic Politics: The Logic of Two-level Games", p. 442.

54 See ibid., p. 442.

$55 \quad$ See ibid., p. 437. 
Scheme 1: Effects of reducing win-set size

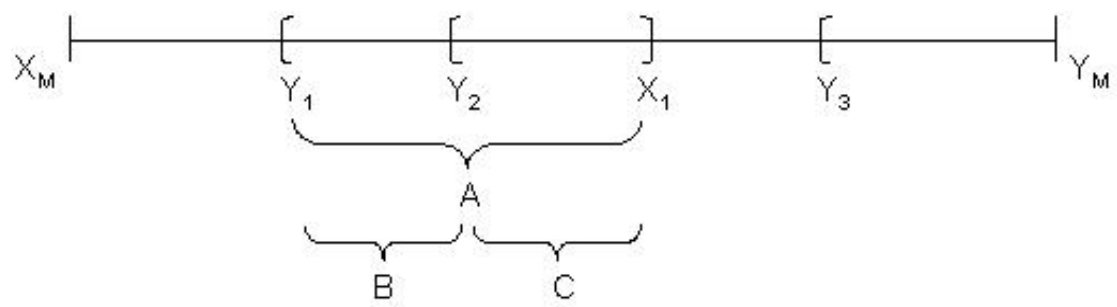

Source: Putnam 1988, p. 441 (adapted by the author).

In the case of two negotiating partners, the optimal (maximum) outcome of the negotiations for country $\mathrm{X}$ lies on the left side of the spectrum $\left(\mathrm{X}_{\mathrm{M}}\right)$ and for country $\mathrm{Y}$ on the right side $\left(\mathrm{Y}_{\mathrm{M}}\right)$. The possibilities for compromise are situated in between these extreme points. For negotiator $\mathrm{X}$, everything between $\mathrm{X}_{\mathrm{M}}$ and $\mathrm{X}_{1}$ is within his domestic win-set. $\mathrm{X}_{1}$ is referred to as the resistance point of country $\mathrm{X}$ and reflects the point where a non-agreement becomes more valuable than an agreement. ${ }^{56}$ The win-set of negotiator $\mathrm{Y}$, on the other hand, is a dynamic one: its size decreases during the course of the negotiations. At the beginning, his domestic win-set is largest, describing the area between $\mathrm{Y}_{1}$ and $\mathrm{Y}_{\mathrm{M}}$. At that point, the area of overlap is A. Later in the negotiations, the reservation point of negotiator $\mathrm{Y}$ moves to $\mathrm{Y}_{2}$, leaving the area of overlap C. Ultimately, the win-set of negotiator $\mathrm{Y}$ becomes so small that no area of overlap exists $\left(\mathrm{Y}_{3}\right)$.

The point of resistance is highly dependent on the alternatives available to an agreement with the negotiating partner. If the best available alternative is a good alternative in the negotiator's eyes, his or her resistance point will be higher and the likelihood of agreement lower. ${ }^{57} \mathrm{~A}$ negotiating party with an unsatisfactory alternative, on the other hand, can be expected to yield on issues in conflict. ${ }^{58}$

It is a challenging task for a negotiator to calculate his domestic win-set. (S)he needs to have full information on the preferences of all actors involved as well as her/his own and the other party's resistance points. In that context, the negotiator must have information about the other negotiating partner's "real" win-sets, opposed to the "perceived" ones. ${ }^{59}$ This difference becomes important where negotiators choose to provide strategic misinformation about their domestic win-sets in order to move the

See J.S. Odell, Negotiating the World Economy (Cornell University Press, Ithaca and London, 2000), p. 26; W.R. Clark et al., "Domestic and International Asymmetries in United States-European Union Trade Negotiations" International Negotiation, 2000, Vol. 5 (1), 69-95, p. 76. Note that some authors also refer to this point as Best Alternative To a Negotiated Agreement (BATNA). See N. Bayne and S. Woolcock, The New Economic Diplomacy: Decision-making and Negotiation in International Economic Relations (The G8 and Global Governance Series, Ashgate Publishing Limited, Hampshire, 2003), p. 37.

$57 \quad$ See Odell, Negotiating the World Economy, p. 27.

58 See ibid., p. 28.

59 See H. Raiffa, The Art and Science of Negotiation: How to Resolve Conflicts and Get the Best out of Bargaining (Harvard University Press, Cambridge, 1982), Chapter 4. 
area of overlap more to their countries' preferred direction (for negotiator $\mathrm{Y}$, an agreement in area $\mathrm{C}$ is more desirable than in area $\mathrm{B}$, see figure 1 ).

2) The smaller the win-set and the negotiating autonomy of a negotiator, the bigger her/his bargaining power. ${ }^{60}$

This principle refers to the "Schelling conjecture", which states that

"the power of a negotiator often rests on a manifest inability to make concessions and meet demands." 61

In other words, a small domestic win-set ties the negotiator to the few acceptable outcomes for an agreement. Since (s)he cannot compromise much, her/his small negotiating autonomy can be a bargaining advantage at the international table, even though this finding may be counterintuitive at first sight. If the other negotiating party's win-set is big enough to compromise on one of the few acceptable outcomes and no better alternatives are available to the latter, the former negotiator can exercise a strong bargaining power over outcomes.

On the other hand, where the domestic win-set and the negotiator's autonomy are large, her/his bargaining power will be small. Even though the negotiator has much more autonomy as to which tactics and strategies to apply in the international negotiations, the large negotiating autonomy allows the other party to push her/him around by asking several concessions. If the negotiator cannot misrepresent the size of his win-set, her/his large negotiating autonomy will result in a low bargaining power.

This "paradox of weakness" is presented here as a structural argument: the structure of domestic preferences determines the negotiator's autonomy and therefore also his bargaining power. Robert Putnam, however, framed this argument in his 1988 article on "Diplomacy and domestic politics: the logic of two-level games" in a strategic and intentional manner. He emphasized that the negotiator can make use of the strategy of "tying hands" in order to induce the other country's negotiator to compromise at a point closer to his or her preferences. ${ }^{62} \mathrm{He}$ cites the example of American negotiators who use the domestic constraint of winning congressional ratification in the United States as a bargaining tool in order to achieve an agreement closer to the United States Trade Representative's preferences. ${ }^{63}$ However, the argument is made here that a negotiator with a small domestic win-set has not a lot of leeway to make effective use of tactics and strategies and therefore is confronted with a structural constraint.

60 See Putnam, "Diplomacy and Domestic Politics: The Logic of Two-level Games", p. 440.

61 T.C. Schelling, The Strategy of Conflict (Harvard University Press, Cambridge, Massachusetts, 1960), p. 19.

62 See A. Moravcsik, "Integrating International and Domestic Theories of International Bargaining" in P.B. Evans, H.K. Jacobson and R.D. Putnam (eds.), Double-Edged Diplomacy: International Bargaining and Domestic Politics (University of California Press, Berkeley, 1993) 3-42, p. 28.

63 See Putnam, "Diplomacy and Domestic Politics: The Logic of Two-level Games", p. 440. 


\subsubsection{Negotiation Theory}

When domestic preferences leave the international negotiator some negotiating autonomy, (s)he can make use of strategies that are meant to increase her/his bargaining power. One example is the strategy of "tying hands", which can be used in case the domestic win-set is large and the negotiator chooses to provide strategic misinformation on the size of the win-set. At the same time, such a strategy runs the risk of provoking a stalemate if the pretended point of resistance goes beyond the ability of the other to concede. ${ }^{64}$ In practice, little evidence exists that this strategy is used effectively by governments. ${ }^{65}$ One of the few examples where the strategy is successfully used is the case of European Union negotiators, which have been reported to increase their bargaining power by referring to their complicated structure of competences. ${ }^{66}$

Apart from the strategy "tying hands", negotiators have a variety of strategies at their disposal. Strategy in that sense means

"a set of behaviours or tactics that are observable in principle and associated with a plan to achieve some objective through negotiation." 67

Two broad categories of strategies can be distinguished: value-creating strategies (seek a common solution to the problem at hand) and value-claiming strategies (actions that place little or no emphasis on joint gains). In most cases, negotiators use a mixed strategy, which consists mainly of value-creating and mild value-claiming elements. Examples of value-creating actions are sharing information relatively openly, proposing to exchange concessions, or the agreement to treat partial agreements as provisional until all issues are settled. ${ }^{68}$ Examples of value-claiming elements are high demands, refusing all concessions, exaggerating one's minimum needs, manipulating information or making threats. ${ }^{69}$

Issue linkage and the making of side payments is a frequently used course of action, which can be both value creating and value claiming. Linking issues to each other is not a strategy in itself. Rather, it is found in every strategy and negotiation because there are very few agreements that pertain to only a single issue. ${ }^{70} \mathrm{~A}$ prominent example of an issue linkage in the area of intellectual property protection is the inclusion of the TRIPS Agreement into the framework of the WTO. The United States

See Schelling, The Strategy of Conflict, p. 28.

See P.B. Evans, "Building an Integrative Aprroach to International and Domestic Politics: Reflections and Projections" in P.B. Evans, H.K. Jacobson and R.D. Putnam (eds.), Double-Edged Diplomacy: International Bargaining and Domestic Politics (University of California Press, Berkeley, 1993), 397-430, p. 399. Peter Evans concludes that the eleven case studies, which were supposed to explore Putnam's two-level game logic further, provided evidence that the strategy of "tying hands" "is infrequently attempted and usually not effective."

See Meunier, Trading Voices, p. 53.

See J.S. Odell (ed.), Negotiating Trade: Developing Countries in the WTO and NAFTA (Cambridge University Press, Cambridge, 2006), p. 15.

See ibid., p. 16; Odell, Negotiating the World Economy, p. 34.

See Odell (ed.), Negotiating Trade, p. 32.

See Odell, Negotiating the World Economy, p. 37. 
used a clearly value-claiming strategy to include international standards of intellectual property protection. Particularly developing countries only accepted this inclusion in return for the liberalization of trade restrictions on textiles and clothing exports from developing countries. ${ }^{71}$

\subsubsection{Forum Selection}

This research focuses particularly on the preferences of non-state actors with regard to the choice of forum for international negotiations of intellectual property protection. Forum selection or forum choice refers either to the "choice of venue for negotiating specific issues or to the choice of forum for more broadly-based international trade negotiations", ${ }^{72}$ which include intellectual property issues. This thesis is not concerned with the question as to whether intellectual property issues should be negotiated in one forum or in another. Neither does this focus imply that governments usually make choices between mutually exclusive venues. Rather, the research aims at clarifying the preferences of non-state actors with regard to alternative venues for government-led negotiations and whether they have (successfully) influenced the national policy decision on the question as to which alternative to pursue.

Scholars so far have almost exclusively focussed on assessing different venues for trade negotiations from the perspective of governments. ${ }^{73}$ Only one contribution, the edited volume of Ann Capling and Patrick Low that assembles case studies of eight developing countries, has tried to assess non-state actors' preferences on forum choice and whether they try to influence these choices by governments. ${ }^{74}$ This analysis was carried out in the trade context, with the multilateral forum being the WTO and the regional forum being preferential trade agreements. In other words, it looked at preferential trade agreements in general, rather than one particular area, and analyzed the preferences of non-state actors in terms of a preference for liberalization and market access, rather than a specific level of intellectual property protection in specific areas.

The outcome of the various case-studies has provided some insights on non-state actors' preferences in trade negotiations. These findings might also be relevant for negotiations on intellectual property issues at the multilateral (WTO) and bilateral (FTA) level, which are the focus of this research. It becomes clear that the objectives

71 See Bayne and Woolcock, The New Economic Diplomacy, p. 39.

72 A. Capling and P. Low, "The Domestic Politics of Trade Policy-making: State and Non-state Actor Interactions and Forum-choice" in A. Capling and P. Low (eds.), Governments, Non-state Actors and Trade Policy-Making (Cambridge University Press, Cambridge, 2010) 9-28, p. 16.

73 Ann Capling and Patrick Low have summarized these studies. See ibid., p. 17.

74 They themselves are not aware of any other empirical studies that have investigated the question of forum selection. See Capling and Low (eds.), Governments, Non-State Actors and Trade Policy-Making, p. 326. They also refer to a journal article authored by Edward Mansfield and Helen Milner from 1999 which points out that there is a lack of empirical evidence of "which domestic groups support regional trade agreements, whose interests these agreements serve, and why particular groups prefer regional to multilateral liberalization." See Mansfield and Milner, "The New Wave of Regionalism", p. 604. 
of governments to conclude preferential trade agreements ${ }^{75}$ are not the same for nonstate actors. Rather, the case studies highlight that non-state actors have shown very little involvement in trade-policy making at the multilateral level. In comparison with preferential trade agreements, non-state actors' preferences can be summarized in three rules. ${ }^{76}$

i. The WTO is too remote and too big for effective direct influence.

ii. What happens in the WTO is less important to non-state actors' influence than the outcomes of preferential trade negotiations.

iii. In a systemic sense, the WTO is a better option than preferential trade agreements. It is more protective of developing country interests, especially when it comes to preferential trade agreements involving a developed country.

That non-state actors tend to focus on preferential or bilateral negotiations instead of multilateral ones can be explained by the argument that Andrew Moravcsik makes in relation to bargaining among different countries: the possibilities for cooperation among countries are constraint by the preferences of the least forthcoming government. ${ }^{77}$ In other words, agreements will only reflect the lowest common denominator among the group of negotiating parties. Where there are many parties involved, a larger diversity of preferences exists and agreements tend to be less farreaching since they reflect the preferences of the party that is closest to the status quo. By contrast, bilateral negotiations are likely to be more ambitious in content and scope and therefore either effectively or potentially more important for non-state actors. In addition, with fewer parties, and therefore preferences, involved, non-state actors have more space to realize their preferences in bilateral negotiations.

\subsubsection{Theoretical Hypotheses}

When combining the theoretical frameworks presented above, two main theoretical hypotheses and six sub-hypothesis can be formulated. These hypotheses provide the basis for the research design and the research questions. ${ }^{78}$

75 The authors assembled four objectives that are economically and political motivated and identified six factors that are perceived to be less attainable in a multilateral setting. The former four are: 1) protection from foreign competition; 2) smaller regional agreements as a stepping stone; 3) political consolidation at the regional level; and 4) enhancing bargaining power. The latter six include the following: 5) more efficient negotiations with fewer parties; 6) absent subject matter at the multilateral level; 7) speed of negotiations; 8) domestic policy lock-in; 9) reducing policy uncertainty; and 10) fear of exclusion. See Capling and Low, "The Domestic Politics of Trade Policymaking”, p. 22-23.

76 See Capling and Low (eds.), Governments, Non-State Actors and Trade Policy-Making, p. 326327.

77 See A. Moravcsik, "Preferences and Power in the European Community: A Liberal Intergovernmentalist Approach" Journal of Common Market Studies, 1993, Vol. 31 (4), 473-524, p. 501.

78 See below. 
1) The size of groups and the intensity of their preferences determine whether their preferences are reflected in the outcome.

- Small groups with concentrated interests are more likely to see their preferences reflected in the outcome.

- Small groups with diffuse interests are less likely to see their preferences reflected in the outcome.

- Large groups with concentrated interests are less likely to see their preferences reflected in the outcome.

- Large groups with diffuse interests are less likely to see their preferences reflected in the outcome.

2) The size of the domestic win-set determines the negotiating autonomy of the negotiator.

- Negotiators with a narrow domestic win-set have only little negotiating autonomy.

- Negotiators with a large domestic win-set have a considerable degree of negotiating autonomy.

\subsection{METHODOLOGICAL FRAMEWORK}

\subsubsection{Case Selection}

The research question introduced above does not allow a large number of cases to be examined. There are two main reasons for this. First, the data properties limit the possible cases to a) developing countries that b) have already concluded or currently are negotiating a bilateral trade agreement with the European Union, ${ }^{79}$ which includes TRIPS-plus provisions. Second, since systemic data sets do not exist on the issue of policy preferences on intellectual property protection of domestic non-state actors in developing countries and their influence on the decision-making process during international negotiations, new data needed to be collected. The application of different data sources to one issue (so-called triangulation) is time-consuming and therefore opts for a small-n design.$^{80}$ Third, the main method used, namely process tracing, requires the case studies to be carried out in a very detailed manner. In these cases, small-n research is often employed. ${ }^{81}$

This research uses a single case study. A case study is a detailed description and analysis of a delineated phenomenon as it manifests itself in (social) reality. ${ }^{82}$ Most authors choose this established method because it allows adding accurate observations and descriptions of the phenomenon under investigation. When

79 This book focuses on the European Union as the main actor in setting TRIPS-plus standards through bilateral trade agreements. See the introduction to Part C of this book for an explanation why this choice has been made.

80 See D. Leuffen, "Case Selection and Selection Bias in Small-n Research" in T. Gschwend and F. Schimmelfennig (eds.), Research Design in Political Science: How to Practice What They Preach (Palgrave MacMillan, New York, 2007) 145-160, p. 149.

81 See ibid., p. 149.

82 For a detailed discussion of the crucial elements for defining the concept 'case study', See P. Swanborn, Case Study Research: What, Why and How? (Sage Publications, London, 2010), p. 13. 
studying processes, it is a prerequisite to have accurate description and analysis in order to arrive at valid explanations and generalizations. ${ }^{83}$ The research seeks to generate inductively some conclusions and possible hypotheses that may provide a starting point for further investigation and use in other cases.

The choice of the country/region for the case study is based on two criteria. The first criterion is that the country is a developing country. This is determined according to the World Bank country classification system, based upon the gross national income of that country. ${ }^{84}$ Jamaica is classified as an upper-middle-income economy, just as most other members of the region CARIFORUM. ${ }^{85}$ The second criterion is that the developing country already has concluded or is still negotiating a bilateral agreement with the European Union, which contains TRIPS-plus provisions. The CARIFORUM region was the first group of countries that has agreed to an IPchapter that includes important TRIPS-plus provisions. In the meantime, also other countries, such as Peru, Colombia and Central American countries have concluded bilateral trade agreements with the European Union, which also contain TRIPS-plus provisions; India, Singapore, Malaysia and Vietnam are still negotiating such agreements. However, at the time when the choice for the case study was made, only the IP chapter of CARIFORUM-EC EPA was available for analysis; no draft chapters of any of the other agreements had been published yet. Since it was important for the choice of questions asked to relevant state and non-state actors to have an indication of what TRIPS-plus provisions would be included in the bilateral agreement, Jamaica and the CARIFORUM region have been selected as the case study. Due to time constraints, no other case study could be carried out.

\subsubsection{Operationalization}

The case study of Jamaica and the CARIFORUM region is concerned with the influence of domestic and regional non-state actors on the final IP policy position chosen by Jamaica and the region in the EPA negotiations. Influence is understood as the attainment of preferences in the policy outcome, as reflected in the theoretical hypothesis presented above. ${ }^{86}$ In the following, the variables contained therein are operationalized into measurable indicators.

\subsubsection{First Hypothesis}

The size of groups and the intensity of their preferences determine whether their preferences are reflected in the outcome.

This main hypothesis has been specified in four sub-hypotheses, illustrating the different combinations of the variables as well as the relevant outcome. ${ }^{87}$ There are

83 See Odell (ed.), Negotiating Trade, p. 8.

84 The World Bank classifies economies according to income, see The World Bank, Country and Lending Groups (2011), available at <http://data.worldbank.org/about/country-classifications/country-and-lending-groups $>$ accessed on 21.11.2012.

85 Nine out of fifteen CARIFORUM States fall in the category of upper-middle-income country. Three of the fifteen are categorized high-income economies, two lowermiddle-income economies and one is classified as low-income economy. See section 9.1.1 of this book.

86 See section 8.2.6 of this book.

87 See section 8.2.6 of this book. 
three variables contained in this hypothesis: 1) group size, 2) intensity of preferences and 3) preference attainment. The hypothesis relates the variables group size and intensity of preferences to the outcome, being preference attainment. Whether groups attain their preferences depends on the variations that group size and intensity of preferences can take. For that reason, preference attainment is called the dependent variable, which depends on the two independent variables of group size and intensity of preferences.

\subsection{Group Size}

The independent variables describe characteristics of groups of relevant non-state actors. In order to determine these characteristics, first, relevant regional and national non-state actors are identified that have some interest in the international regulation of intellectual property in general and in particular in its regulation in the CARIFORUM-EC EPA. It is enough for an actor to have shown some interest in an area of IP protection relevant for protecting food products to be included in the list of relevant non-state actors.

A general condition for all non-state actors is that they participated in any of the institutionalized consultative processes in either Jamaica and/or at the regional CARIFORUM level. This choice has been made in view of the fact that I found it impossible to study informal contacts comprehensively. Where other forms of contact with the negotiating team were mentioned (for example in the case of the regional West Indies Rum and Spirits Association, which had informal contacts with the technical negotiator for IP, Malcolm Spence, at several occasions), these were taken into consideration. In fact, apart from that one case, no other instances of contacts outside the consultations were reported. ${ }^{88}$

The first independent variable group size is measured by counting the constituting members of a group. In relation to all other identified groups, an organization is classified as large or small or as being an individual person or an undertaking. It is not possible to indicate a clear dividing line between large and small groups, but in the case study of Jamaica and the CARIFORUM region, the categorization is straight forward in view of the few non-state actors with an interest in IP. Relative to the other actors in the region, the differences in their sizes are clear enough to classify them in either a large or small group, or an individual actor.

\subsection{Intensity of Preferences}

The second independent variable is the intensity of preferences with regard to intellectual property protection in general and in particular in its regulation in the CARIFORUM-EC EPA. The intensity of actors' preferences is measured according to 1) the importance that actors give to the matter at issue (in general in their work and specifically in the context of the EPA negotiations), 2) the knowledge they have on the subject matter, and 3) whether or not they have formed a specific position on the matter. These three indicators have proven to be essential in the case study of Jamaica and the CARIFORUM region as the existence of those attributes is a 
prerequisite for the actors to have an impact on the final IP policy position chosen by Jamaica and the region.

Overall, three categories have been created to distinguish different degrees of intensity of preferences: preferences can be marginal, general or specific. An actor is labelled to have a marginal interest in IP if (s)he does not or hardly deal with intellectual property issues in her/his work and also lacks the necessary knowledge on the subject matter. An actor has a general interest in IP if (s)he has a general understanding of the different forms of IP protection, including its regulation at the international level, and the issue is part of her/his work, even though not as a major topic. If an actor has 1) specific knowledge on intellectual property issues, in particular on its regulation at the international level, 2) deals with these matters as an important part of her/his work and 3) has formed a specific policy position on such matters (including a preference for the choice of forum), the actor is categorized as having specific preferences on certain issues of intellectual property protection. The categorization is carried out based on the information provided by the actors themselves. The indicators of marginal and general preferences translate into diffuse interests, whereas the indicator of specific preferences would classify as concentrated interests.

\subsection{Preference Attainment}

Having determined the indicators for the two independent variables, I will now turn to the operationalization of the dependent variable, being the question as to whether or not the analyzed actors were able to see their preferences reflected in the final IP policy position that Jamaica and CARIFORUM have adopted during the EPA negotiations. In other words, the variable is limited to the IP policy position adopted by the regional negotiator in the negotiations; it does not encompass the final outcome of the EPA negotiations. Two concepts need to be distinguished: first, the policy position of Jamaica and the CARIFORUM region in the particular areas of IP in the EPA negotiations and second, preference attainment.

The policy position in the particular areas of IP in the EPA negotiations is analyzed separately for the Jamaican case and for the region CARIFORUM. Each area of intellectual property protection relevant for food products is examined individually (protection of geographical indications, protection for traditional knowledge, the protection of plant variety protection, enforcement matters). Particular attention is paid to the question as to whether or not the protection sought in those areas is of a TRIPS-plus nature. In addition, the policy position of Jamaica and the CARIFORUM region is identified in relation to the forum choice.

In order to analyze whether non-state actors were able to attain their preferences in the final IP policy positions, one main method is used: process tracing.

Process tracing can be defined as the 
"method [that] attempts to identify the intervening causal process - causal chain and causal mechanisms - between an independent variable (or variables) and the outcome of the dependent variable". 89

The goal of the process tracing approach is to unravel the steps by which the preferences of relevant non-state actors have affected the final IP policy position.

This thesis does not aim at identifying all relevant factors and steps that might have been relevant in the determination of the final IP policy position of Jamaica and the region. The project's main subject of research is to discover the role of non-state actors in the policy-making process. As it is very difficult to find information on the entire causal chain between non-state actors' preferences and the final IP policy position, many researchers underestimate the influence of interest groups since they do not have conclusive proof of non-state actors' influence. ${ }^{90}$ Even though this empirical problem still remains, I try to complement and correct the results from the process tracing analysis by using two complementary methods: a) the degree of preference attainment, and b) self and peer assessment.

The first complementary method of determining the influence of non-state actors on the final IP policy position is an assessment of the degree of preference attainment by the non-state actors analyzed. This involves a comparison of the final policy positions on specific IP issues adopted by Jamaican and regional policy makers with the preferences (or ideal points) of the non-state actors. The distance between these two factors, in principle, reflects the influence of the actor analyzed. ${ }^{91}$ If the final IP policy position adopted by Jamaican and regional policy makers reflects the preferences of an actor who was active on the issue, the conclusion can be drawn that the group had some influence. Admittedly, this method does not test for alternative factors that could explain a coincidence between the preferences and the IP policy positions. For example, the policy maker could already have chosen that same position in the first place and therefore the actor's influence was limited. ${ }^{92} \mathrm{Or}$ other actors than domestic non-state actors could have influenced the policy position. However, I have tried to examine alternative explanations in cases where preferences and outcomes coincided but the influence was not conclusive.

The second method investigates the self and peer assessment of the analyzed nonstate actors and state-actors on two issues. First, non-state actors assess whether they believe to have influenced the final IP policy position adopted by Jamaican and regional policy makers in the EPA negotiations. Second, state and non-state actors report which actor or factor they believe to have been most determinative in the IP policy choice. Often, state and non-state actors' own perceptions on a) whether their preferences mattered to the final IP policy position adopted by relevant policy

89 A.L. George and A. Bennet, Case Studies and Theory Development in the Social Sciences (MIT Press, Cambridge, MA, 2005), p. 206.

90 The study of influence by interest groups on policy-outcomes faces serious problems. Each method has advantages and drawbacks, which are tried to be outweighed by using three different methods. See A. Dür, "Measuring Interest Group Influence in the EU: A Note on Methodology" European Union Politics, 2008, Vol. 9 (4), 559-576.

91 See ibid., p. 566.

92 The policy makers' initial policy positions before or when entering into the EPA negotiations could not be determined by the author. 
makers and b) which actor or factor was influential, offer insights into the policymaking processes that are not revealed when purely identifying the ideal position of non-state actors and their involvement in certain consultative processes. It needs to be emphasized that this method assesses perceptions of influence rather than actual influence.

\subsubsection{Second Hypothesis}

The size of the domestic win-set impacts the negotiating autonomy of the negotiator.

The second hypothesis has been worked out into two sub-hypotheses, illustrating how a large or small win-set determines the degree of negotiating autonomy. ${ }^{93}$ The two variables contained in this hypothesis are the following: 1) the size of the domestic win-set, and 2) the degree of negotiating autonomy.

\subsection{Size of Domestic Win-set}

The independent variable "size of the domestic win-set" is measured by analyzing the preferences of domestic non-state actors involved in the policy-making process. If there are a variety of specific and conflicting preferences, the domestic win-set is classified as being small. If there are only a few (conflicting) preferences of relevant non-state actors and their preferences are mostly general or marginal, the domestic win-set may be categorized as a large win-set.

\subsection{Degree of Negotiating Autonomy}

The dependent variable of negotiating autonomy of the negotiator can vary from a high degree of autonomy to a low one. The negotiating autonomy is small if some of the following situations prevail: clear negotiating mandates for each area of IP exist, the negotiating team does not develop parts of the negotiating position itself and a lot of control is exerted on the negotiator by the principals. The autonomy of the negotiator is large if the reverse is true: clear negotiating mandates for some areas of IP are lacking, the negotiating team has an important role in developing the regional policy position and little control is exerted on the negotiator.

\subsubsection{Sources}

Most of the empirical data on the influence of non-state actors in the policy-making process was derived from interviews with Jamaican and regional non-state actors, policy makers and negotiators.

In Kingston, interviews were conducted with representatives from the Jamaican Ministry of Foreign Affairs and Foreign Trade and the Ministry of Agriculture, a former negotiator of intellectual property issues in the negotiations of the Free Trade Agreement of the Americas, representatives of the Jamaica Intellectual Property Office, Jamaica Promotions Corporation and the Scientific Research Council, the Coffee Industry Board, business and industry associations, a consultancy firm, coffee producers, law firms dealing with intellectual property cases and academic experts at the University of the West Indies. 
In Bridgetown, interviews were carried out with the chief negotiator on IP issues in the EPA negotiations for the CARIFORUM region, a representative from the Barbados Ministry of Foreign Affairs and Foreign Trade, regional and Barbadian civil society organizations, a regional industry association for rum and spirits, the regional sugar cane breeding station and an academic expert at the University of the West Indies.

In Geneva and Brussels, the study benefited from interviews conducted with an official from the Directorate General for Trade of the European Commission, a member of the former Caribbean Regional Negotiation Machinery (CRNM), ${ }^{94}$ a diplomat of the Permanent Mission of Jamaica in Geneva and the Jamaican Mission to the European Union in Brussels, an official of the WTO Secretariat, a representative of international civil society organization and a journalist.

Apart from primary sources, use has also been made of secondary sources that reported on the negotiations. These include articles on intellectual property issues and/or the EPA negotiations published in newspapers and news services in Jamaica and the CARIFORUM region. Also academic articles and papers written about the issue of intellectual property protection in the EPA negotiations as well as publications produced by civil society organizations and other non-state actors have been included in the analysis. Finally, publications by state institutions in Jamaica, CRNM and the European Commission were used. Each section in the Jamaica, CARIFORUM case study refers to the specific sources used.

\subsubsection{Methodology}

The study mainly relies on the data collected through thirty-one semi-structured interviews with relevant state and non-state actors. Most interviews were held in March and April 2010 on a face-to-face basis. Five out of thirty-one interviews were conducted by phone and three interviewees filled in a questionnaire. Most of the interviews by phone and the questionnaires were held between May 2010 and April 2012. Some interviewees also added information in writing after the interview had taken place. In addition, interviewees were given the opportunity to clarify and comment on the information revealed in this study in May 2012. Only a few of them have used this possibility.

All of the interviews for this study were held on an attributable basis. Only two interviewees wished to remain anonymous. Interviews were recorded with the permission of the interviewees and notes were taken in cases where consent was lacking. The recorded interviews were transcribed verbatim. The analysis of the data collected through the interviews was undertaken simultaneously with the data collection. This allowed for adapting interview questions and filling in gaps during the interviewing process.

94 As explained in section 10.1.3.4.1, in 2009, the name of this machinery was changed into the Office of Trade Negotiations (OTN). At the same time, its institutional position in the CARICOM Secretariat was re-organized. However, since at the time of the negotiations this body was called CRNM, I will refer to it as CRNM rather than its new name OTN. 
The persons interviewed were selected by a purposive sampling method. The purpose was not to get a random or representative sample but to interview representatives from various sectors and institutions, such as international and regional organizations, government institutions, negotiating teams, producers and industry associations, law firms, academics and civil society organizations. They all met the criteria of having some relation with the international negotiation on intellectual property matters involving developing countries, in particular the EPA negotiations between the European Union and CARIFORUM States. Several persons interviewed were identified through in depth research on the Internet. Most interviewees, however, were referred to me by those already interviewed. In some cases, they even facilitated the respective introduction, which often led to further interviews.

While most interviewees enjoyed reflecting on their experiences in the EPA negotiations, others gave the impression that they were frustrated at not being able to answer certain interview questions. This was particularly so when conducting interviews with non-state actors in Jamaica and the CARIFORUM region, some of whom were not readily willing to be interviewed. In fact, approximately twenty-five actors approached did not react to my request for an interview or stated that they had not been involved in intellectual property protection in the EPA negotiations.

All of the interviews were carried out as semi-structured interviews. The nature of the interview questions varied, depending on the interviewee. Generally, two different interview guides were used for interviews with, on the one hand, state actors, negotiators and policy makers, and on the other hand non-state actors. They indicated the specific topics to be covered but were adapted according to the replies by the interviewees. The two general interview guides are attached in Appendix 2 and Appendix 3; the topics addressed cover the following issues.

State actors, negotiators and policy makers were asked about their role in the EPA negotiations dealing with IP, their relationship with other state entities, defining moments of the negotiations, negotiating strategies, the place of IP relative to all other areas negotiated in the EPA, the way they developed the domestic policy position on various IP issues, which consultations with non-state actors were organized and which preferences were brought forward by which actors, and finally on whether they prefer either the bilateral or the multilateral forum for negotiating the international regulation of intellectual property protection.

Non-state actors were asked to give information about their organization, in how far they deal with the regulation of IP issues at the national, regional and/or multilateral level, their preferences with regard to the IP issues negotiated in the EPA, their and other non-state actors' participation in consultations, their perception of how much influence they and other non-state actors had on the final IP policy position, and whether they have a preference as to whether the multilateral or the bilateral level is more beneficial for Jamaica and the region when negotiating the regulation of intellectual property issues. 


\subsubsection{Limitations of the Research}

This case study is not used to criticize existing schools of thought on the nature of collective action or the interaction between domestic pressures and international negotiations. It rather presents a study of an important empirical phenomenon which provides a better understanding of the underlying domestic policy dynamics in bilateral negotiations involving IP issues and, in particular, the influence of non-state actors on the final policy position.

The study has focussed on the influence of non-state actors on the IP policy position of Jamaica and the CARIFORUM region during the EPA negotiations, not on their influence on the process of implementing these obligations into national law. While the latter process is crucial for determining the concrete obligations for each country, it went beyond the scope of this book to also assess non-state actors' involvement and influence on that process. Moreover, most IP obligations arising from the EPA have not yet been implemented in CARIFORUM States.

This case study focuses on Jamaica as one of the important and, in matters of intellectual property protection, most advanced countries of the CARIFORUM region. It does not provide an in-depth analysis of the influence of non-state actors on the IP policy position developed in the other countries of the CARIFORUM region. Nevertheless, the process in Jamaica is compared to other countries in the region where interviewees provided that information. The assessment of the regional non-state actors has also provided me with enough information to draw certain conclusions in relation to the region as a whole, rather than to any of the other CARIFORUM countries individually.

Methodologically, the study suffered from a low response rate by non-state actors and sometimes imprecise information provided by the interviewees, which could not be verified through other sources. These methodological problems can be explained by the time gap between the EPA negotiations and the interviews (approximately three years), and the general lack of interest in intellectual property protection by non-state actors. The low number of interested non-state actors and the complete absence of civil society organizations also prevented me from arriving at detailed conclusions on the first hypothesis. 



\section{Chapter 9 : Jamaica's Economic Development and Intellectual Property Legislation}

\subsection{JAMAICA'S ECONOMIC DEVELOPMENT}

\subsubsection{Development Indicators}

In 2011, Jamaica had a gross national income per capita (atlas method) of US\$4,980. ${ }^{1}$ It has been classified by the World Bank as an upper-middle-income economy. ${ }^{2}$ Compared to the countries in the region, only three out of the other fourteen CARIFORUM States have a lower GNI per capita than Jamaica. In terms of classification, the Bahamas, Barbados and Trinidad and Tobago are ranked highincome economies. Antigua and Barbuda, St. Kitts and Nevis, Grenada, St. Lucia, St. Vincent and the Grenadines, Dominica, the Dominican Republic and Suriname fall in the same classification of upper-middle-income economies as Jamaica, with Jamaica having the lowest GNI per capita among them. Belize and Guyana are classified lower-middle-income economies, and Haiti, as the only LDC, falls in the category of low-income economy.

According to the UN Human Development Index of 2011,3 Jamaica is ranked $79^{\text {th }}$ out of 182 countries; it therefore belongs to the high-human-development countries. ${ }^{4}$ In comparison to the countries in the region, eight out of the fourteen countries are ranked below Jamaica, namely Belize, Dominica, Dominican Republic, Guyana, Haiti, Saint Lucia, Saint Vincent and the Grenadines and Suriname. ${ }^{5}$

With regard to the achievement of the UN Millennium Goals, the World Bank has classified Jamaica a "country in green", which means that it is "likely" to achieve the goals. ${ }^{6}$ Significant achievements have been made in poverty reduction and primary education enrolment; however, Jamaica is lagging far behind in relation to improving maternal health and reducing child mortality. ${ }^{7}$

1 See The World Bank, Open Data of 2011: Jamaica (2011), available at <http://data.worldbank.org/country/jamaica> accessed on 25.10.2012.

2 The World Bank classifies economies according to income, see The World Bank, Country and Lending Groups.

3 The Human Development Index is a way of "measuring development by combining indicators of life expectancy, educational attainment and income." See United Nations Development Programme, Human Development Report 2011 (2011).

4 See ibid. Note that in 2009, Jamaica was still ranked $100^{\text {th }}$ out of 182 countries. See ibid.

See United Nations Development Programme, Millennium Development Goals: Jamaica (2004), available at <http://www.jm.undp.org/files/MDG_final_report_Jamaica.pdf> accessed on 21.11.2012, p. 3.

7 See United Nations Development Programme, Jamaica's Progress Towards the MDGs (2009), available at <http://www.jm.undp.org/millenium-development-goals/japrogress-toward-the-mdgs $>$ accessed on 26.10.2012. 
In $2007,14.4$ percent of Jamaica's population lived below the US $\$ 2$ per day poverty line. ${ }^{8}$ Unemployment has fallen in recent years to 12.6 percent in $2011 .{ }^{9}$ A great social challenge that Jamaica faces is homicidal violence: in 2008, the murder rate amounted to 60 per 100,000 persons. ${ }^{10}$ The characteristics of the violence are male on male, poor on poor, and youth on youth.

\subsubsection{Form of Government}

Jamaica gained independence in 1962 and since then has been a member of the British Commonwealth. Jamaica's form of government is based on the system of separation of powers and constitutes a constitutional parliamentary democracy. ${ }^{11}$ The Jamaican Parliament is comprised of a bicameral system, the House of Representatives and the Senate. The two houses together make laws according to the Jamaican Constitution of 1962. ${ }^{12}$ Both ministers and Members of Parliament may introduce bills.

The Jamaican Constitution of 1962 is the supreme law with which all secondary laws need to comply. International agreements need to be implemented into domestic law in order to have effect. The domestic law that implements international agreements will have to be in compliance with the Jamaican Constitution of 1962.

The Executive in Jamaica consists of the Cabinet which is led by the Prime Minister. The Cabinet assembles at least eleven ministers who manage and have responsibility for the portfolio assigned to them by the Prime Minister. The Cabinet initiates government policies and programmes, gives direction to the government and controls it. The judicial system of Jamaica is based on the British system. Its highest domestic court is the Court of Appeal whereas the final Court of Appeal of Jamaica is the Judicial Committee of the Privy Council in England. By October 2012, Jamaica had not yet accepted the appellate jurisdiction of the Caribbean Court of Justice, which would replace the Privy Council for final appeal cases. ${ }^{13}$

According to the Corruption Perception Index of Transparency International, Jamaica is perceived to have shown more corrupt practices since 2002: the index fell from 4.0 in 2002 to 3.0 in 2009 and increased to 3.3 in 2011 again. This score

8 See K. Watkins, Human Development Report 2007/2008. Fighting Climate Change: Human Solidarity in a Divided World (United Nations Development Programme, New York, 2007), p. 239.

9 See Planning Institute of Jamaica, Economic Sector Indicators: Overview 2011 (2011), available at <http://www.pioj.gov.jm/ResearchandData/EconomicSectorIndicators/tabid/124/Default.aspx > accessed on 26.10.2012.

10 See Planning Institute of Jamaica, National Report of Jamaica on Millennium Development Goals (United Nations, UN Economic and Social Council Annual Ministerial Review, Geneva, 2009), p. 8.

11 See D. Daley, "Jamaica: Intellectual Property" in H. Vanhees (ed.), International Encyclopedia for Intellectual Property (Kluwer Law International, the Netherlands, 2008), 1328 , p. 20 f.

12 The Jamaica (Constitution) Order in Council 1962, No. 1550, made on 23.07.1962, entered into operation on 25.07.1962, Kingston, Jamaica [hereinafter Jamaican Constitution of 1962].

13 See C. Summer, "Jamaica's London Appeal Court Dilemma" BBC News (3 August 2012). 
indicates a rather high level of perceived corrupt practices in Jamaica. ${ }^{14}$ It ranks Jamaica at 86 out of 180 countries. $^{15}$

\subsubsection{Trade Policy}

Being a small island country with a narrow resource base, Jamaica is highly dependent on trade, as most CARIFORUM States are. This also means that it is vulnerable to external shocks, such as the terrorist attacks of 11 September 2001 or the global economic crisis from 2007. This is even more the case as the region, including Jamaica, relies on the United States as its major trading partner: in 2011, 49.6 percent of Jamaica's exports were destined for the US and the US was the country of provenance of 35.9 percent of Jamaica's imports. ${ }^{16}$ Trade between the EU and Jamaica in the same year accounted for 13.4 percent of Jamaican exports entering the EU while only 6.8 percent of Jamaican imports came from the EU.

For these reasons, Jamaica has chosen a proactive and progressive trade policy. ${ }^{17}$ The new trade policy was designed by former Minister of Foreign Trade Anthony Hylton. In 2001, he proposed a trade policy that focuses on the creation and diversification of exports, the displacement of imports (i.e. the steady reduction of the share of imports relative to outputs) and an increased flow of net positive returns from foreign investment.

" $[T]$ he adjusted trade policy seeks to enhance the capacity to export by going beyond the narrow focus on market access issues to promoting measures for facilitating market penetration."18

Jamaica has worked hard to achieve this openness of its economy to multinational corporations and international capital. The successes of these efforts were reflected in the UNCTAD World Investment Report 2010: Jamaica could double the inward flow of foreign direct investment (FDI) into the country compared to five years before. In the years 1995-2005, the annual average of inward FDI was approximately 25 percent of gross fixed capital formation. In 2009, the annual average of inward FDI increased

14 Note that the index is given on a scale from 0 to 10 . Countries with a score of ten are perceived to be "very clean" in terms of corrupt practices in the public and private sector. Countries with a score of zero are perceived to by highly corrupt. A score of 3.3 therefore indicates a rather high level of perceived corruption for Jamaica.

15 Jamaica shares this rank with Bulgaria, Panama, Serbia and Sri Lanka. See Transparency International, Corruption Perceptions Index 2011 (2011), available at <http://cpi.transparency.org/cpi2011/results/> accessed on 26.10.2012.

16 See WTO Secretariat, Trade Profile Jamaica (2012), available at <http://stat.wto.org/> accessed on 23.11.2012.

17 Jamaica's economy used to be based on import-substitution strategies until the late 1980s. It is only since then that the country began to liberalize and deregulate trade through unilateral reform and regional and multilateral trade initiatives. See A. Jessen and C. Vignoles, Jamaica: Trade, Integration and the Quest for Growth (INTAL - ITD, Occasional Paper 30, Buenos Aires, 2005), p. 39.

18 See A. Hylton, Jamaica's New Trade Policy - 2001 (Jamaica Ministry of Foreign Affairs and Foreign Trade, Kingston, 29 October 2001) [Ministry Paper No. 69/2001], p. 3. 
to more than 40 percent. ${ }^{19}$ However, with the financial and economic crisis, Jamaica's inward flow of FDI has decreased to merely 6.8 percent in 2011.20

The most recent trade policy was published in 2009 and entitled "Vision 2030 Jamaica - Planning for a Secure \& Prosperous Future". It is Jamaica's declared goal to achieve developed country status by 2030. ${ }^{21}$ Vision 2030 introduces a new paradigm which will move from dependence on the "lower forms of capital", such as tourism and agricultural commodities, to the development of "higher forms of capital", being cultural, human knowledge and institutional capital stocks. ${ }^{22}$

At the same time, the new trade policy recognizes that one of the major challenges for the Jamaican Government is the public debt ratio, which is one of the highest in the world: it represented 142.3 percent of GDP in $2010 .{ }^{23}$ The high level of public debt as well as persistent high fiscal deficits have been dominant factors in Jamaica's economy for the last two decades and are a source of macroeconomic instability. The situation is aggravated by the fact that Jamaica is a net goods importing country, that is to say Jamaica's imports amount to 46 percent of the GDP while exports account for 17.5 percent. ${ }^{24}$ Vision 2030 aims at addressing these problems under its goal of creating a stable economy..$^{25}$

\subsubsection{Sectoral Performance}

The main foreign revenue earner in Jamaica is services. ${ }^{26} 63$ percent of the GDP in 2007 were derived from the services sector. ${ }^{27}$ The tourism industry is by far Jamaica's most important service: 77.1 percent of all exported services in 2011 were in the area of travel..$^{28}$ Not only Jamaica's economy depends to a large extent on the service

See UNCTAD, World Investment Report 2010: Investing in a Low-Carbon Economy, Country fact sheet: Jamaica (UNCTAD, 2010).

See UNCTAD, Country fact sheet: Jamaica (World Investment Report 2012: Towards a New Generation of Investment Policies, 2012), available at <www.unctad.org/wir> accessed on 26.10.2012.

See Planning Institute of Jamaica, Vision 2030 Jamaica: National Development Plan (Kingston), p. XXII.

See ibid., p. XXIII.

See K. Grenade, "Who is Afraid of Fiscal Adjustment?" Journal of Business, Finance \& Economics in Emerging Economies, 2011, Vol. 6 (2), 1-33, p. 4.

See WTO Secretariat, Trade Policy Review Report by Jamaica (Geneva, 15 December 2004) [WT/TPR/G/139], paragraph 13.

See National Outcome No. 7: A Stable Macroeconomy in Planning Institute of Jamaica, Vision 2030 Jamaica: National Development Plan, p. 127 ff.

See WTO Secretariat, Trade Policy Review Jamaica (Geneva, 9 March 2005) [WT/TPR/S/139/Rev.1], paragraph 75.

Industry and agriculture accounted for 31 percent and 5 percent respectively of GDP. See OECD, "Aid For Trade at a Glance 2009: Jamaica" 2009, available at <www.oecd.org/dataoecd/15/58/43191213.pdf> accessed on 16.11.2012.

See WTO Secretariat, Trade Profile Jamaica. Transportation services constitute the second most important services exported in 2011 with 11.2 percent. 
industries, but also the majority of Jamaican workers: 64.6 percent of the Jamaican labour force is employed in the services sector. ${ }^{29}$

Besides services, Jamaica has important industries in primary goods: the mining and agricultural sectors produced almost 90 percent of all merchandise exports in 2008, with a clear dominance of exported bauxite and alumina products over agricultural exports. ${ }^{30}$ This reflects Jamaica's large dependency on commodities.

Agriculture remains a crucial sector for Jamaica, even though it constituted only 5.6 percent of real GDP in 2009. ${ }^{31}$ Agricultural exports, including processed food, accounted for 25.9 percent of all exports in 2009.32 In addition, 18.2 percent of Jamaica's workers are employed in the agricultural sector. ${ }^{33}$ It is these workers that are the poorest of Jamaican society: 80 percent of the poor persons in Jamaica live in rural areas ${ }^{34}$ and are dependent on the agricultural sector as their means of existence. The alleviation of rural poverty therefore depends to a large extent on the successful export of agricultural products, in particular food products and processed food. Intellectual property protection is one important tool to establish and foster the success of niche agricultural products.

Three different sub-sectors of the Jamaican agriculture can be distinguished. ${ }^{35}$ The most important sector comprises traditional export products such as sugar, bananas, coffee, cocoa, citrus and pimento. ${ }^{36}$ Sugar and bananas were the main revenue earners $^{37}$ under the system of preferences as agreed upon in the Cotonou Agreement. ${ }^{38}$

29 See Labour Market Information System, The Jamaican Economy: An Overview 2008 (2008), available at <http://www.lmis-ele.org.jm/Jamaica_Economy.aspx $>$ accessed on 30.09.2010.

30 See WTO Secretariat, Trade Profiles 2009 (WTO Publications, Geneva, 2009), p. 88. Jamaica's mining sector, dominated by bauxite and aluminia production, is by far the largest export product. 76.1 percent of Jamaica's total exports in 2008 constituted fuels and mining products, whereas agricultural products and manufactured goods accounted for 13.1 percent and 10.1 percent respectively.

31 See WTO Secretariat, Trade Policy Review Jamaica (WTO Trade Policy Review Body, Geneva, 22 February 2011) [WT/TPR/S/242/Rev.1], paragraph 7.

32 See ibid., paragraph 7.

33 See United Nations Statistics Division, Jamaica (United Nations, Department of Economic and Social Affairs, World Statistics Pocketbook 2009, No. 34, 2010). The industrial sector employs 17.7 percent of the labour force.

34 See WTO Secretariat, TPR Jamaica 2011, paragraph 7.

35 A fourth sub-sector is livestock products such as poultry, beef and pork.

36 See D. McGlashan et al., "Jamaica: Country Report to the FAO International Technical Conference on Plant Genetic Resources for Food and Agriculture" 2008, available at <http://www.pgrfa.org/gpa/jam/jamaica2.pdf> accessed on 16.11.2012, p. 10. See D. Prévost, Balancing Trade and Health in the SPS Agreement: The Development Dimension (Wolf Legal Publishers, Nijmegen, 2009), p. 259 f. Note that coffee is Jamaica's second largest export crop which achieves very high prices in its export market Japan. Coffee is not dependant on a preference system and therefore is not affected by the preference erosion for bananas and sugar.

38 The Partnership Agreement Between the Members of the African, Caribbean and Pacific Group of States of the One Part, and the European Community and its Member States, of the Other Part, signed in Cotonou, Benin on 23 June 2000, entered into force on 1 April 2003, revised in 2005 and 2010 [hereinafter Cotonou Agreement]. The Cotonou Agreement has replaced 
With the phasing out of these preferences, the currently still fragmented and weak agricultural products for the domestic market - the second subsector of the Jamaican agriculture - are increasing in importance. ${ }^{39}$ Domestic crops include vegetables, fruits, yams, other tubers, potatoes, and condiments. ${ }^{40}$ The third subsector of the Jamaican agriculture relates to processed food products which mainly occur in canned goods, flour, sauces and beverages. The agro-processing subsector constitutes one of Jamaica's most important industries. ${ }^{41}$

\subsubsection{Trade Relations}

Jamaica is actively involved in trade liberalization agreements at the multilateral, regional and bilateral stage. The three levels of international trade relations will be addressed successively by describing their main components. At the multilateral level, Jamaica's trade relations, in particular related to intellectual property, are governed by the WTO Agreement, including its annexes, on the one hand, and the agreements administered by the World Intellectual Property Organization on the other hand. ${ }^{42}$ The main regional components are Caribbean Community (CARICOM), Caribbean Forum of African, Caribbean and Pacific States (CARIFORUM) and Association of Caribbean States (ACS). At the bilateral level, Jamaica has bilateral trade agreements with several Latin American countries, Canada, the United States and the European Union.

\subsubsection{The WTO Agreement}

Jamaica became a WTO Member in March 1995, having been a contracting party to the GATT 1947 since its independence in 1962. Market access for goods has increased significantly through Jamaica's membership to the WTO: its applied average most-favoured-nation tariff fell to 7.5 percent in 2007. However, the average MFN tariff applied on most agricultural products is still between 15 and 30 percent, with a maximum tariff of 100 percent applied on some animal products and fruits and vegetables. ${ }^{43}$ Jamaica has bound all its tariff lines, which increases predictability of its trade regime. This is not to say that the tariff actually applied is close to the bound tariff: the gap between applied and bound tariff remains significant for most product groups. ${ }^{44}$

Market access for services is defined by the commitments that Jamaica has made in its Schedule of Specific Commitments (hereinafter services schedule) annexed to the GATS. According to its services schedule, Jamaica made market access commitments - with some limitations - with regard to business services, such as professional services, computer related services, research and development and real estate services;

the Lomé Convention between the EU and ACP States. The Cotonou Agreement has been amended by EC Council Decision 2005/599/EC of 21.06.2005 (OJ L 209 of 11.08.2005). 
telecommunication services; educational services; insurance-related services; healthrelated services; tourism; recreational services and maritime transport services. ${ }^{45}$

With regard to Jamaica's participation in the different bodies of the WTO, Jamaica has been particularly active in promoting special and differential treatment (S\&D treatment) for developing countries. For example, it has pushed S\&D treatment to be an integral element of the negotiations in the Doha Development Agenda. ${ }^{46}$ Jamaica has also strongly supported that developing countries are granted S\&D treatment in WTO disputes. ${ }^{47}$ More recently, it has focused its attention on the areas of rules, in particular fisheries subsidies, and intellectual property. ${ }^{48}$ To date, Jamaica has not been a plaintiff or defendant in any case before the Dispute Settlement Body; it has participated as a third party in several cases, mainly in the area of agriculture.

Jamaica is a member of several groupings of countries that have common positions in different bodies of the WTO. Countries form groups for several reasons: they belong to the same geographical region, have similar socio-economic conditions at home or share common interests in a specific area. As a Caribbean country, Jamaica belongs to the group of African, Caribbean and Pacific States. Being an ACP State, it forms part of the G-90, which is made up by ACP States, the African Group and least-developed countries.

Jamaica is also a member of the group of small, vulnerable economies (SVEs). According to different thematic issues, certain SVEs have formed groups based on being sponsors of particular proposals. Jamaica is a member of the group of SVEs interested in non-agricultural market access and the group interested in rules (fisheries subsidies). ${ }^{49}$ The groups are made up of nineteen and fourteen WTO Members from the Caribbean and Pacific region and Central America respectively.

In the area of agriculture, Jamaica has joined forces with another forty-five developing countries and formed the group G-33, which is also called "Friends of Special Products" in agriculture. This coalition of Caribbean, Central and South American, African, Central European and Asian countries, which includes India and China, presses for flexibility for developing countries to undertake limited market opening in agriculture.

With regard to intellectual property issues, Jamaica is one of the 109 WTO Members that supports the proposal $\mathrm{TN} / \mathrm{C} / \mathrm{W} / 52$ for modalities in the context of the Doha

45 See WTO Secretariat, Services Database (2011), available at $<$ http://tsdb.wto.org/> accessed on 19.08.2011.

46 Jamaica is a strong proponent of the creation of a special safeguard mechanism for developing countries as an essential element of S\&D treatment. See WTO Secretariat, Summary Report on the Eighteenth Meeting of the Committee on Agriculture Special Session (Committee on Agriculture, Geneva, 18 July 2003) [TN/AG/R/8], p. 39.

47 See WTO Secretariat, TPR Jamaica 2005, p. 26.

48 See Jamaica' membership of several groups at the WTO below.

49 See WTO Secretariat, Small, Vulnerable Economies (SVEs) - Statement on Key Aspects of Article III of the Fisheries Subsidies Annex (Geneva, 22 September 2008) [TN/RL/W/226/Rev5]. 
Development Agenda. ${ }^{50}$ The group of "W52" sponsors assembles ACP States, the EU, the African Group, India and China. In July 2008, they called for a procedural decision to negotiate three intellectual property issues in parallel. These issues are 1) the establishment of a register open to geographical indications (GI) for wines and spirits, 2) the extension of the higher level of protection in Article 23 of the TRIPS Agreement to GIs for all products, and 3) the mandatory requirement for patent applicants to disclose the origin of genetic resources or traditional knowledge used in their inventions. The purpose was to open up the way for negotiations through modality texts; however, WTO Members remain divided over this idea.

\subsubsection{Treaties Administered by WIPO}

Jamaica became a member of the World Intellectual Property Organization (WIPO) in 1978 as one of the first Commonwealth Caribbean countries. Jamaica is a contracting party to six standard-setting treaties in the area of copyright, which are administered by WIPO: the Berne Convention (since January 1994), the Rome Convention (since January 1994), the Geneva Convention (since January 1994), the Brussels Convention (since January 2000), the WIPO Copyright Treaty and the WIPO Performances and Phonograms Treaty (since June 2002). In the area of industrial property, Jamaica has signed three treaties: the Paris Convention (in December 1999), the Nice Agreement and the Vienna Agreement (in February 2006). ${ }^{51}$ While the Paris Convention sets out substantive and procedural rules in the major areas of industrial property, the latter two merely concern classification systems in the area of trade marks.

Jamaica participates regularly, however not always, in meetings of different WIPO bodies, such as the Standing Committee on Copyright and Related Rights, the Committee on Development and Intellectual Property, the Standing Committee on the Law of Patents, the Standing Committee on the Law of Trade Marks, Industrial Designs and Geographical Indications (SCT), and the Intergovernmental Committee on Intellectual Property and Genetic Resources, Traditional Knowledge and Folklore. Usually, it is the Permanent Mission of Jamaica to the United Nations Office and Other Specialized Institutions in Geneva that represents Jamaica in these bodies. ${ }^{52}$ For specific meetings, such as the First Intersessional Working Group of the Intergovernmental Committee in June 2010 or the twenty-third session of the SCT, representatives of Jamaica Intellectual Property Office (JIPO) have participated. ${ }^{53}$

Next to the general meetings of WIPO bodies, Jamaica, in particular JIPO, cooperates with WIPO actively. This collaboration has resulted in, inter alia, several workshops, regional expert meetings, roundtable discussions, training programmes,

This document sets out the parameters for discussing the three TRIPS related issues in parallel, in terms of process, and in terms of substance.

Note that Jamaica has also signed the Nairobi Treaty in March 1984, which protects the Olympic Symbol.

See section 10.1.5.2 of this book.

See WIPO Secretariat, Second provisional list of participants (Geneva) [WIPO/GRTKF/IWG/1/INF/1 Prov.2] see also WIPO Secretariat, Summary of Options for the International Dimension of the Committee's work; WIPO Secretariat, Draft Report (WIPO Standing Committee on the Law of Trademarks, Industrial Designs and Geographical Indications Twenty-Third Session, Geneva, 13 July 2010) [SCT/23/7 Prov.]. 
symposia. These activities address, in particular, the protection of copyright, the protection of traditional knowledge, folklore and genetic resources, technology licensing, national branding, amongst others. ${ }^{54}$

\subsubsection{The Caribbean Community and the Caribbean Forum}

Jamaica is one of the founding fathers of the Caribbean Community (CARICOM) which includes the Caribbean Common Market and has been established in 1973 under the Treaty of Chaguaramas..$^{55}$ The other fourteen Members of CARICOM are Antigua and Barbuda, the Bahamas, ${ }^{56}$ Barbados, Belize, Dominica, Grenada, Guyana, Haiti, Montserrat, Saint Lucia, Saint Vincent and the Grenadines, Saint Christopher and Nevis, Suriname, and Trinidad and Tobago. In order to negotiate the Economic Partnership Agreement with the European Union, CARICOM Member States formed part of the Caribbean Forum of African, Caribbean and Pacific (APC) countries, known as CARIFORUM. ${ }^{57}$ CARIFORUM is one of the six regional groupings of the seventy-six ACP States with which the EU has been negotiating EPAs since September 2002. It consists of fourteen CARICOM Member States, the Dominican Republic and Cuba (see Scheme 2). ${ }^{58}$ The British dependent territory Montserrat is not part of CARIFORUM. ${ }^{59}$

54 See WIPO, Conferences, Meetings and Seminars (2012), available at <http://www.wipo.int/meetings/en/index.jsp> accessed on 21.11.2012.

55 See Caribbean Community (CARICOM) Secretariat, The Caribbean Community (2011), available at <http://www.caricom.org/jsp/community/community_index.jsp?menu=community $>$ accessed on 15.11.2012.

56 The Bahamas are not a member of the Common Market.

57 CARIFORUM was established in 1992 and aims to improve coordination of EU support and to further regional integration and cooperation. See Daley, "Jamaica: Intellectual Property”, p. 25; A. Dunlop, S. Szepesi and K. Van Hove, Organising Trade Negotiating Capacity at Regional Level: A Case Study of Jamaica, Barbados and the Caribbean Region (ECDPM, Discussion Paper No. 54, 2004), p. 6.

58 Note that Cuba is not a party to the CARIFORUM-EC EPA.

$59 \quad$ Note that the scheme does not list Montserrat. 
Scheme 2: CARIFORUM-EC EPA configuration and overlapping regional and sub-regional economic integration groupings

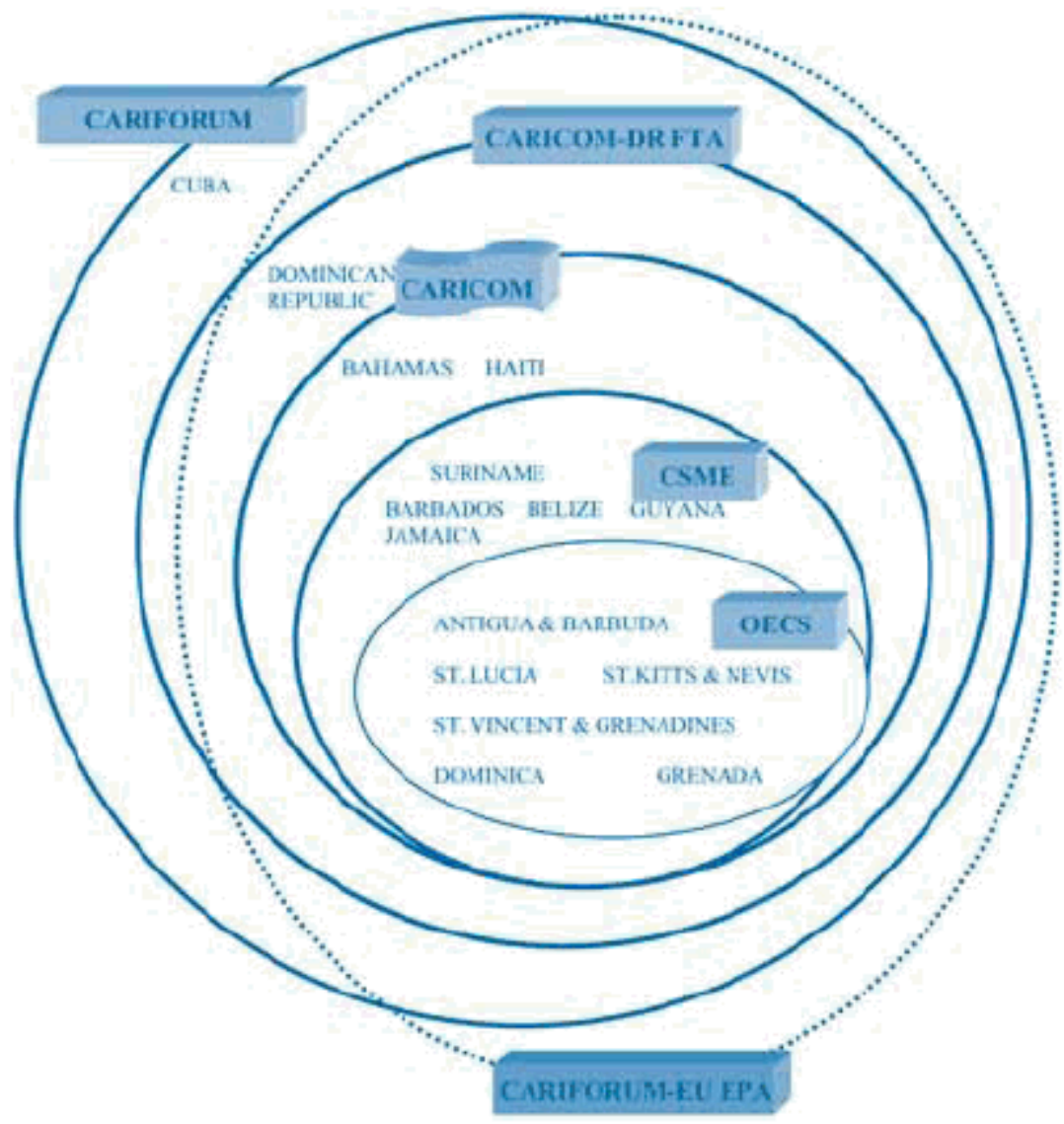

Source: ECDPM 2006, p. 5.

In any other context than the EPA negotiations, it is in the framework of CARICOM rather than CARIFORUM that Caribbean countries coordinate their external trade policy. CARICOM represents the deepest form of integration in the region. Since its establishment, it has developed from a common market into a single market. In 2001, its Member States created the CARICOM Single Market and Economy (CSME) when revising the founding treaty. ${ }^{60}$ So far only the Single Market has been implemented. It provides for the free movement of goods, services and capital, the free movement of certain types of labour, a common CARICOM passport and the harmonization of laws in several areas, such as intellectual property. ${ }^{61}$ Furthermore, it

Not all fifteen countries participate in the CSME: Montserrat, as a dependent territory of the United Kingdom, is seeking permission to become part of the single market, Haiti did not join because of its internal political situation and the Bahamas are opposed to joining due to local opposition to the free movement of skilled workers. been achieved. 
contains a similar institutional set-up as that of the European Union:62 a CARICOM Secretariat, CARICOM Heads of Governments, the Community Council, and a Caribbean Court of Justice which settles disputes on the functioning of the CSME. ${ }^{63}$ The Single Economy, which is intended to harmonize the macroeconomic, fiscal and monetary policies of all Member States and to establish a CARICOM Monetary Union, has not yet been implemented. Full implementation is envisaged to be completed in phases, the second and final phase lasting until 2015. When it comes to external economic and trade matters, CARICOM ministers of trade coordinate their trade policies in the CARICOM Council for Trade and Economic Development (COTED). It has been noted that the slow progress has hindered CARICOM Member States in defining a sound regional trade strategy before entering into trade negotiations; instead, the group committed itself to other partners without having finalized the regional process first. ${ }^{64}$

\subsubsection{The Association of Caribbean States}

Besides CARICOM, Jamaica is also a Member of the Association of Caribbean States (ACS), which promotes consultation, cooperation and concerted action among all countries in the Caribbean. ${ }^{65}$ ACS was established in July 1994 in Port of Spain and consists of all CARICOM Member States plus Colombia, Costa Rica, Cuba, the Dominican Republic, El Salvador, Guatemala, Honduras, Mexico, Nicaragua and Venezuela. Due to its mainly consultative character, it does not provide for a farreaching trade agenda. ${ }^{66}$ It rather fulfills the diplomatic function of engaging the Caribbean countries on the continent with CARICOM Member States in order to widen the region's geopolitical position. ${ }^{67}$ This political cooperation in the ACS is complemented by free trade agreements between five out of the ten continental Caribbean countries and CARICOM.

\subsubsection{Bilateral Trade Agreements with Latin American Countries}

CARICOM has signed bilateral trade agreements with Venezuela (October 1992), Colombia (July 1994), the Dominican Republic (August 1998), Cuba (July 2000) and Costa Rica (March 2004). The first two agreements are limited in scope as they provide preferential access only for a few selected CARICOM products. ${ }^{68}$ The latter three agreements reflect the new approach of CARICOM Member States to negotiate

62 This does not infer that the tasks, competences and composition of both regional integration forms are also similar.

63 This Court also acts as the final appellate court for CARICOM Member States that are Members of the CSME.

64 See Dunlop, Szepesi and Van Hove, Organising Trade Negotiating Capacity at Regional Level, p. 7.

65 See Planning Institute of Jamaica, Vision 2030 Jamaica: National Development Plan, p. 142.

66 See Jessen and Vignoles, Jamaica: Trade, Integration and the Quest for Growth, p. 45; Dunlop, Szepesi and Van Hove, Organising Trade Negotiating Capacity at Regional Level, p. 6.

67 See V. Lewis, Trinidad and Tobago-Eastern Caribbean Integration Initiative Task Force Report (Trinidad and Tobago Office of the Prime Minister, Vol. 2, Port of Spain, 2009), p. 333.

68 The Agreement on Trade, Economic and Technical Cooperation between the CARICOM and the Government of the Republic of Colombia, signed on 24 July 1994, entered into force on 1 January 1995, was amended in May 1998 to provide for reductions on imports from Colombia. See WTO Secretariat, TPR Jamaica 2005, p. 29. 
enhanced bilateral trade agreements that are based on the principle of reciprocity and a list of exemptions. ${ }^{69}$ However, they are only effective in some CARICOM Member States. ${ }^{70}$ The new agreements also cover rules on services, investment and government procurement; the most recent agreement with Costa Rica enlarges the scope of issues beyond those three areas to competition policy, sanitary and phytosanitary measures and anti-dumping provisions. ${ }^{71}$ None of these agreements deals with intellectual property protection. Despite these preferential trade agreements, Jamaica does not trade much with Latin American countries. ${ }^{72}$

\subsubsection{CARICOM - Canada Free Trade Negotiations}

Since July 2007, CARICOM has been negotiating a Trade and Development Agreement with Canada. Currently, trade between CARICOM Member States and Canada is governed by the Caribbean-Canada Trade Agreement, a non-reciprocal preferential trade agreement, which is due to expire in December 2013.73 The new agreement will cover a wide range of issues, such as market access for agricultural and non-agricultural products, trade in services, e-commerce, trade facilitation, investment and trade-related issues, such as intellectual property, government procurement and competition policy. ${ }^{74}$

\subsubsection{Caribbean Basin Initiative}

Jamaica enjoys preferential access to the US market under the Caribbean Basin Initiative (CBI) since 1984. The framework governing the CBI has been revised in 2000 to provide additional duty-free access for most goods from the CBI beneficiary countries. ${ }^{75}$ Jamaica benefits from this preferential treatment as long as no free trade

69 See OECS Secretariat, "Recent Trends in CARICOM Trade Relations: An Analysis with Special Attention to the Western Hemisphere" OECS Trade Policy Brief, Vol. 14, p. 3 .

70 The Agreement establishing the Free Trade Area between Caribbean Community and the Dominican Republic was signed on 22 August 1998 and entered into force for Barbados, Dominican Republic, Guyana, Jamaica, Suriname and Trinidad and Tobago [hereinafter CARICOM-DR FTA]. The Trade and Economic Co-operation Agreement Between The Caribbean Community (CARICOM) and the Government of the Rebpulic of Cuba, signed on 5 July 2000, is provisionally applied in Cuba, Belize, Guyana, Jamaica, St. Kitts and Nevis, St. Vincent and the Grenadines and Trinidad and Tobago. The Agreement between CARIFORUM and the Government of the Republic of Costa Rica was signed on 9 March 2004 and entered into force for Barbados, Costa Rica, Guyana and Trinidad and Tobago.

71 See WTO Secretariat, TPR Jamaica 2005, p. 30.

72 See Jessen and Vignoles, Jamaica: Trade, Integration and the Quest for Growth, p. 44.

73 See CRNM, CARICOM-Canada (2012), available at <www.crnm.org> accessed on 15.11.2012.

74 See ibid.

75 The Caribbean Basin Economic Recovery Act has been expanded substantially through the US-Caribbean Basin Trade Partnership Act of 2000. See Office of the United States Trade Representative, Caribbean Basin Initiative (2010), available at <http://www.ustr.gov/trade-topics/trade-development/preference-programs/caribbean-basin-initiative-cbi> accessed on 20.11.2012. 
agreement between the US and Caribbean countries has entered into force. Up until October 2012, this is not the case. ${ }^{76}$

\subsubsection{The COTONOU AGREEMENT and the ECONOMIC PARTNERSHIP AGREEMENT}

The European Union has always had special and preferential relations with the group of ACP States, Jamaica being one of them. These relations are governed by the Cotonou Agreement, which is primarily an instrument for development. The Cotonou Agreement was signed in 2000 and was concluded for a period of twenty years. However, the trading regime established under the Cotonou Agreement did not comply with the rules of the GATT 1994 due to trading preferences between the EU and ACP States. ${ }^{77}$ This incompliance was temporarily remedied through a waiver, which had been granted by the WTO in November 2001.78 The waiver allowed the European Communities and the participating ACP States to maintain preferential trading relations under the Cotonou Agreement until 31 December 2007.

With this deadline in mind, the European Union started negotiating European Partnership Agreements that would be based on reciprocal preferences and would therefore be consistent with WTO law. ${ }^{79}$ The CARIFORUM-EC EPA defines the new trading regime under which Jamaica benefits from duty-free and quota-free market access for most of its exports to the EU; this includes bananas and other agricultural products. However, for sugar, a special safeguard mechanism has been put in place. ${ }^{80}$ This arrangement is WTO-compliant since both parties have made liberalization commitments on substantially all trade in goods. The revised Cotonou Agreement of June 2010 provides the basis for cooperation in the fields of regional integration, security and fragility, food security, HIV-AIDS, sustainability of fisheries, aid for trade and aid effectiveness. ${ }^{81}$

$76 \quad$ See ibid.

77 The most-favoured-nation treatment obligation of Article I:1 of the GATT 1994 obliges WTO Members to treat like products from any WTO Member in the same way. The European Union is therefore under an obligation to extend the preferences granted on certain products from ACP States to like products from any other WTO Member. The EU did not extend these preferences to other WTO Members and therefore failed to comply with the most-favoured-nation treatment obligation. These preferences were aimed at improving the standard of living and economic development of the ACP States.

78 See WTO Ministerial Conference, European Communities - The ACP-EC Partnership Agreement.

79 The mandate for these negotiations was already included in Article 37.1 of the Cotonou Agreement. According to its Article 36.1, the parties agree to conclude WTO-compatible trading arrangements and to remove existing barriers to trade.

80 See Prévost, Balancing Trade and Health in the SPS Agreement, p. 255; European Commission, "Cariforum-EC EPA: Trade in Goods" 2008, available at <http://trade.ec.europa.eu/doclib/docs/2008/october/tradoc_140975.pdf> accessed on 26.10.2012.

81 See European Commission, The Cotonou Agreement. 


\subsection{JAMAICAN INTELLECTUAL PROPERTY LEGISLATION BEFORE AND AFTER THE TRIPS AGREEMENT}

Intellectual property protection did not play an important role in Jamaica until the country became a party to the TRIPS Agreement. As a former British colony, Jamaica's early intellectual property laws were those of the United Kingdom. The UK Copyright Act of $1911^{82}$ applied in Jamaica until it was repealed in 1993. British law was also applied in the area of trade mark and designs protection, until the Designs Act of 193783 became applicable. ${ }^{84}$ Even the current Trade Marks Act of 199985 for the most part "faithfully follows the UK Trade Marks Act of 1994." ${ }^{86}$ The current patent act dates back to 1857 and is still closely related to the British patent system: Letters Patents are granted by the Queen of England through her representative in Jamaica, the Governor General of Jamaica. ${ }^{87}$ In addition, should doubts arise when granting Letters Patents, the laws in force in England can be construed by analogy.88 Apart from these British influences on copyright, trade mark and patent law, Jamaica did not develop its own intellectual property regime any further.

It is with the obligations stemming from the TRIPS Agreement that the country started to enact legislation in all areas of intellectual property covered by the latter agreement. For example, the protection of geographical indications, plant varieties and layout-designs has only been introduced or is still being introduced because the TRIPS Agreement demands such protection. Also in other areas of intellectual property protection, amendments became necessary, particularly in the area of patent and designs law.

Jamaica has yet to implement important obligations of the TRIPS Agreement. This is not to say that Jamaica is lagging behind in all areas of intellectual property law. In fact, Jamaica is TRIPS-compliant in the areas of copyright, trade marks, geographical indications and layout-designs. However, as discussed below, the country has so far fallen short of implementing TRIPS obligations into its patent and designs law, and the protection of plant varieties.

An Act to amend and consolidate the Law relating to Copyright, royal assent given on 16 December 1911, entered into force on 1 July 1912, Geo.6 5(1911) c.46, available at http://www.legislation.gov.uk/ukpga/Geo5/1-2/46, accessed on 29.10.2012.

Designs Act of 1937, entered into force on 15 July 1937, consolidated version of an Cap. 97 as amended last by Act No. 9 of 1975 and authorized last by L.N. 60/1976, see Jamaican Ministry of Justice, Jamaican laws (2012), available at <http://www.moj.gov.jm/> accessed on 29.10.2012 [hereinafter Designs Act of 1937]. See Daley, "Jamaica: Intellectual Property", paragraph 57 for trade mark law and paragraph 54 for design law.

Trade Marks Act No. 32 of 1999, entered into force on 3 September 2001, last amended by Act No. 25 of 2001, last authorized by L.N. 112/2002, see Jamaican Ministry of Justice, Jamaican laws [hereinafter Trade Marks Act of 1999]. See Daley, "Jamaica: Intellectual Property", paragraph 58.

87 See Section 3 of the Patent Act No. 30 of 1857, consolidated version of Cap. 283 as amended last by Act No. 8 of 1975 and authorized last by L.N. 60/1976, see Jamaican Ministry of Justice, Jamaican laws [hereinafter Patent Act of 1857]. 


\subsubsection{Copyright and Related Rights}

Jamaican copyright law is regulated in the Copyright Act of 1993 which was amended in 1999.89 The 1999 amendment implemented the changes brought about by the TRIPS Agreement and some provisions of the Brussels Convention, which Jamaica was obliged to adhere to under the bilateral US-Jamaica IP Agreement. ${ }^{90}$ It may be suggested that the rather prompt amendment of the Copyright Act in 1993 demonstrates Jamaica's priorities with regard to intellectual property protection: copyright protection seems to be an urgent and relevant type of protection for the country, due to Jamaican creative industries and famous Jamaican music. ${ }^{91}$

The Copyright Act of 1993 (amended in 1999) reflect the Berne and the TRIPS standard with regard to the categories of works protected, the nature of rights, the scope of protection, the duration of rights, sanctions and penalties. ${ }^{92}$ Therein, Jamaica clearly follows the British approach to copyright protection, although there are significant differences with the UK Copyright Designs and Patents Act of $1988 .{ }^{93}$ First, Jamaican copyright law does not provide for statutory exceptions to the ownership of copyright in respect of works created in the course of employment, and second, some provisions of the Copyright Acts of 1993 and 1999 are more akin to US copyright law than to British copyright law, in particular with regard to fair dealing. ${ }^{94}$ Jamaica's accession to the WIPO Copyright Treaty and the WIPO Performances and Phonograms Treaty in 2002 is not yet reflected in its copyright law. For example, technological protection measures or rights management information are not yet protected. ${ }^{55}$ Such provisions will be incorporated by way of a Copyright (Amendment) Bill, which was prepared by a working group in 2003 and, at the time of writing, is still in the drafting stage. ${ }^{96}$ The delay suggests that intellectual property issues are not among the

89 Copyright Act No. 4 of 1993, entered into force on 1 September 1993, last amended by Act No. 29 of 1999, last authorized by L.N. 3/2002, see Jamaican Ministry of Justice, Jamaican laws [hereinafter Copyright Act of 1993].

90 Agreement concerning the Protection and Enforcement of Intellectual Property Rights between the United States of America and the Government of Jamaica, see Trade Compliance Center, Jamaica Intellectual Property Rights Agreement (1994), available at <http://tcc.export.gov/Trade_Agreements/All_Trade_Agreements/exp_005444.asp> accessed on 26.10.2012 [hereinafter US-Jamaica IPR Agreement]. Note that Jamaica became a contracting party to the Brussels Convention in January 2000.

91 Interview with Beverley Pereira, University Counsel and Head of the Legal Unit in the Office of the Vice Chancellor at the University of the West Indies (UWI), 6 April 2010, Kingston (available on request).

92 See D. Daley, IP Regime In Jamaica (2009), available at <www.fogadaley.com/laws.html> accessed on 26.10.2012.

93 See UK Copyright Designs and Patents Act of 1988 Chapter 48, 15 November 1988, as amended.

$94 \quad$ See Daley, “Jamaica: Intellectual Property”, paragraph 55.

95 See D. Daley and N. Foga, "Jamaica: Significant IP Progress ... on the Horizon" in I.A.M. Magazine (ed.), IP V alue 2006: Building and Enforcing Intellectual Property V alue (Global White Page Ltd, London, 2006), 150-153.

96 See Cabinet Office of Jamaica, Government of Jamaica Legislation Programme 2012/2013 as at June 2012 (2012a), available at <http://www.cabinet.gov.jm/files/GOJ\%20Legislation\%20Programme\%202012-2013\%20as\%20at\%20JUNE\%202012.pdf $>$ accessed on 15.11.2012, number 42. Note that none of the intellectual property bills is a priority of the Prime Minister in its legislation programme of 2012/2013. 
Jamaican Government's priority concerns. ${ }^{97}$ Similar delays are apparent with regard to the amendments of the patent and design law of Jamaica.

The rights of performers and broadcasting organizations are also governed by the Copyright Acts of 1993 and 1999. However, although Jamaica is a contracting party to the Rome Convention and the WPPT since June 2002, their rights under the latter treaty have not yet been implemented into national law. Therefore, Jamaican law only grants non-proprietary rights to performers, their entitlements being governed solely by contracts. ${ }^{98}$

\subsubsection{Trade Marks}

In the area of trade marks, Jamaica has put in place a modern system of protection. The Trade Marks Act of 1999, together with the rules promulgated there under (the Trade Marks Rules of 2001), ${ }^{99}$ are in compliance with the obligations of the TRIPS Agreement and the Paris Convention. Amendments to the current legislation have been proposed to address typographical errors and to improve the efficiency of the Trade Marks Act of 1999.100 Among others, it is proposed to expand the grounds of revocation of a trade mark. ${ }^{101}$

Protection for a trade mark is contingent upon registration. ${ }^{102}$ For a trade mark to be registered, it must fall under the definition of a trade mark as set out in section 2 paragraph 1 of the Trade Marks Act of 1999. There are three criteria. First, the trade mark must be a sign. That can involve a work, design, numeral, shape, etc. Second, the sign must be capable of being represented graphically. This is usually no problem for visual signs; it can become a problem when a smell or a sound is involved. Third, the sign must be capable of distinguishing goods and services of one undertaking from those of another undertaking. Such trade marks can also be collective marks or certification marks. ${ }^{103}$

In addition to fulfilling the definition of a trade mark, the sign must not constitute an absolute ground for refusal. Section 11 of the Trade Marks Act of 1999 specifies a number of situations that would disqualify a trade mark from being registered. One such requirement is that the trade mark must have a distinctive character. ${ }^{104}$ Other criteria are that the trade mark may not be descriptive nor must it consist of a generic indication. ${ }^{105} \mathrm{~A}$ trade mark may also be refused if it consists exclusively of a shape, or

Interview with Beverley Pereira, 6 April 2010, Kingston.

See Daley and Foga, "Jamaica: Significant IP Progress ... on the Horizon".

The rules have not been officially published yet. However, they are in effective as of 3 September 2001 and can be found on the website of JIPO, available at http://www.jipo.gov.jm/sites/default/files/PDF_Files/TradeMarksRules.pdf, accessed on 29.10.2012. See Cabinet Office of Jamaica, Government of Jamaica Legislation Programme 2012/2013 as at June 2012, number 46.

See Daley and Foga, "Jamaica: Significant IP Progress ... on the Horizon".

See Section 4, paragraph 1 of the Trade Marks Act of 1999.

See Section 3 and schedules 1 and 2 of the Trade Marks Act of 1999.

See Section 11.1(b) of the Trade Marks Act of 1999.

See Section 11.1(c) and (d) of the Trade Marks Act of 1999. 
if it is contrary to public policy, registered in bad faith or deceives the public as to the quality, nature or origin. ${ }^{106}$

Furthermore, applications for trade marks can be denied based on their close relationship with earlier trade marks based on the so-called relative grounds of refusal. This is the case if the sign of a trade mark is identical or similar to the earlier trade mark, and the goods or services for which the trade mark is applied are identical or similar to those for which the earlier trade mark is registered. ${ }^{107}$ In case of similarity, trade marks will only be denied if there exists a likelihood of confusion of the public. In case of an earlier well-known trade mark, the public is assumed to be confused. ${ }^{108}$ However, the registrar will not refuse registration if the applicant satisfies the registrar that there has been honest concurrent use of the trade mark with an earlier trade mark. ${ }^{109}$

When it comes to earlier trade marks, the filing date of the trade mark determines which trade mark is an earlier mark. Under the Paris Convention, applicants for trade marks in one party can rely on a six months priority period during which the proprietor can register the same trade mark in other contracting States. ${ }^{110}$ The latter States will register the trade mark with the same filing date as it has been registered in the first contracting State. Jamaica has become a contracting party to the Paris Convention in 1999. In contrast to the patent and design law of Jamaica, its Trade Marks Act of 1999 does recognize prior applications in the contracting States to the Paris Convention. Therefore, trade mark applicants in Jamaica can make use of a priority period of six months during which the filing date of the first application will be the effective filing date in Jamaica. ${ }^{111}$

Before the trade mark is registered, third parties have a chance to oppose the registration of the trade mark. Section 22.2 of the Trade Mark Act of 1999, together with Rule 12 of the Trade Mark Rules of 2001, provide for the possibility of giving a notice of opposition, indicating the grounds of opposition.

Once a trade mark meets the criteria for protection and is registered, it confers exclusive rights on the proprietor; he or she may authorize any use of the trade mark. ${ }^{112}$ These rights are granted for an initial period of ten years and can be renewed for successive ten-year periods upon application and payment. ${ }^{113}$

Jamaica is not a contracting party to the Madrid Agreement or to the Madrid Protocol. In recent years, a vivid debate has evolved in Jamaica about the benefits and disadvantages of becoming a party to the Madrid Protocol.114 The Jamaican Bar

\footnotetext{
106 See Section 11.3 and 11.4 of the Trade Marks Act of 1999.

107 See Section 13.1 and 13.2 of the Trade Marks Act of 1999.

108 See Section 13.3 of the Trade Marks Act of 1999.

109 See Section 15 of the Trade Marks Act of 1999.

110 See Article 4(C)(1) of the Paris Convention.

111 See Section 19 of the Trade Marks Act of 1999.

112 See Section 5.1 and Section 9 of the Trade Marks Act of 1999.

113 See Section 8 juncto Section 40 of the Trade Marks Act of 1999.

114 For an in-depth discussion of the debate around the issue of accession to the Madrid Protocol, see section 10.2.1.4.1 of this book.
} 
Association has been very vocal on the perceived disadvantages, such as a huge administrative burden for a system which is mainly used by foreigners and through which the pool of domestic trade marks could shrink. ${ }^{115}$ On the other hand, private sector companies, represented by the Private Sector Organization of Jamaica, would like to enjoy the benefits of the system, one of which is a single fee for the registration of the trade mark in several countries. ${ }^{116}$ The CARIFORUM-EC EPA obliges signatory parties to endeavour to accede to the Madrid Protocol. ${ }^{117}$ However, the lobbying pressure by the legal fraternity against accession seems to be the inhibiting factor for Jamaica becoming a contracting party soon. ${ }^{118}$

\subsubsection{Geographical Indications}

Apart from copyright protection, significant steps have also been made in the area of geographical indications: Jamaica passed the Protection of Geographical Indications Act ${ }^{19}$ in 2004, which implements the two-tiered approach of protecting geographical indications as required by the TRIPS Agreement. ${ }^{120}$ The two-tiered approach protects geographical indications on wines and spirits to a higher degree than geographical indications on foodstuffs. This strict implementation of the TRIPS standard is surprising as Jamaica has expressed a preference for the equal protection of geographical indications for wines and spirits and foodstuffs. The country is also a member of the multilateral group of friends of GIs in the WTO debate that supports the extension of the level of GI protection for wines and spirits to other products. Jamaica has also agreed to equal protection for wines and spirits and other products in the EPA, which creates an obligation for Jamaica to adjust the protection no later than 1 January 2014. ${ }^{121}$ Therefore, Jamaica is expected to amend its GI Act of 2004 to reflect the equal protection of wines and spirits and other products. ${ }^{122}$

The GI Act of 2004 entered into force only in June 2009 and became effectively operational in September 2009, when the GI Regulations of $2009^{123}$ were promulgated. Section 3 of the GI Regulations of 2009 sets out the criteria of an application for the registration of a geographical indication: first, the full name and address of the applicant, second, the geographical area, and third, the quality, reputation or other

115 Interview with Dianne Daley, Head of IP Department of FogaDaley, 31 March 2010, Kingston (available on request).

116 Interview with Dianne Daley, 31 March 2010, Kingston.

117 See Article 145.E of the CARIFORUM-EC EPA.

118 Interview with Kai-Saran Davis, Trade Marks and Industrial Designs Director at JIPO, 31 March 2010, Kingston (available on request).

119 The Protection of Geographical Indications Act (Act 5 of 2004) (Jamaica Gazette Supplement: Proclamations, Rules and Regulations, Kingston, 2 June 2009 [CXXXII No. 45] [hereinafter GI Act of 2004].

See Section 3.1(c) of the GI Act of 2004; see Articles 22 and 23 of the TRIPS Agreement. See Article 145.A.2 of the CARIFORUM-EC EPA.

Interview with Loreen Walker, former Legal Officer of the Coffee Industry Board and former Executive Director of JIPO, 31 March 2010, Kingston (available on request). See also Jamaican Ministry of Industry Investment \& Commerce, Ministerial Report for Jamaica Intellectual Property Office on Performance for Financial Year 2008/09 and Focus for Financial Year 2009/2010 (Kingston) p. 2.

123 The Protection of Geographical Indications Regulations (The Jamaica Gazette Supplement: Proclamations, Rules and Regulations, Kingston, 9 September 2009 [Vol CXXXII No. 78] [hereinafter GI Regulations of 2009]. 
characteristics of the goods must be revealed. The latter criteria is fulfilled if information is provided as to how the GI serves to designate the goods originating from the particular territory and what the quality, reputation or other characteristics of the goods are that are attributable essentially to their geographical origin.

In addition, local producer groups, industry associations and regulatory authorities still need to agree on codes of practice for each particular product that may qualify for protection as a geographical indication. ${ }^{124}$ The codes of practice will form the basis for granting the respective geographical indication, as well as the regulation and monitoring of its use. ${ }^{125}$ A certification body that oversees the observance of procedures and standards is still in the process of being set up. ${ }^{126}$

The Swiss Federal Institute of Intellectual Property (IPI) has made a crucial contribution to the establishment of a system to protect geographical indications in Jamaica. On request of Jamaica, the cooperation project "Geographical Indications Project Jamaica - Switzerland" between IPI and JIPO started in July 2008 and lasted for nearly three years. IPI has allocated financial and human resources worth CHF $928,000^{127}$ to the project in order to effectuate the following activities: advisory and institutional support for the establishment of an effective legal system for GIs, capacity building for officials of the public sector, training for representatives of producers' groups of potential GIs, marketing support for enhancing and building public awareness on GIs as well as research support for the monitoring of the economic impact of introducing GIs. ${ }^{128}$ Switzerland is a country well renowned for its record of protecting GIs. ${ }^{129}$ The Swiss Federal Institute for Intellectual Property has the mandate to provide international cooperation to partner countries; its

124 Interview with Lilyclaire Bellamy, Deputy Director and Legal Counsel for JIPO, 12 April 2010, Kingston (available on request). At the moment, the products considered as a geographical indication are Blue Mountain Coffee, Jamaican rum and Jamaican jerk. Interview with Sara-Ruth Allen, Local Expert working on the "Geographical Indications Project Jamaica-Switzerland”, 31 March 2010, Kingston (available on request).

See D. Daley, “A Balancing Act: Weighing Patents and Geographical Indications: The Implementation of the TRIPS Agreement in Jamaica" Latin American World Focus 2008, 2008, 17-19, p. 19.

126 Interview with Lilyclaire Bellamy, 12 April 2010, Kingston. According to Lilyclaire Bellamy, such a body would consist of a representative of the Ministry of Agriculture, a representative of the Jamaica Intellectual Property Office, a person with relevant interest and knowledge (such as an agriculturalist), an ordinary person and a person with knowledge on accreditation and standards.

See B. Bridier, Geographical Indications Project Jamaica - Switzerland (GIJA): Summary of the final evaluation (2010), available at <https://www.ige.ch/fileadmin/user_upload/Juristische_Infos/e/summary_external_evaluation_Jamaika.pdf $>$ accessed on 12.11.2012, p. 2.

See Jamaica Intellectual Property Office and Swiss Federal Institute of Intellectual Property, Memorandum of understanding between The Swiss Federal Institute of Intellectual Property and The Jamaica Intellectual Property Office on the "Geographical Indications Project Jamaica - Switzerland" (GIJA) (Kingston), p. 3.

See D. Daley and N. Foga, "Jamaica: Protecting Geographical Indications" in J. Moore and L. Rutherford-Johnson (eds.), IP Value 2011: Building and Enforcing Intellectual Property Value - An International Guide for the Boardroom (Globe White Page, London, 2011) 90-93, p. 93. 
objectives are to contribute to the improvement of the partner country's economic situation and the worldwide protection of intellectual property. ${ }^{130}$ As a parallel process, Jamaica and Switzerland have been negotiating a bilateral agreement on the mutual protection of GIs, which still remains to be concluded. ${ }^{131}$

\subsubsection{Layout-Designs or Topographies}

The Layout-Designs Act of 1999132 has come into force in 1999 in order to comply with Jamaica's TRIPS obligations in this area of intellectual property protection. The law is based on the requirements of the IPIC Treaty ${ }^{133}$ and the additional standards in Articles 36-38 of the TRIPS Agreement. It introduces a right for the creator of an original $^{134}$ layout design for ten years ${ }^{135}$ to authorize the reproduction, import, distribution or otherwise commercial exploitation of the layout-design. ${ }^{136}$ Creators do not have to register with an authority to benefit from the protection; there is no registration requirement. Before 1999, Jamaica did not have such legislation, probably because the country did and does not have any layout-design or semiconductor chip manufacturing industry that could benefit from the rights offered under the new law. ${ }^{137}$ It is not clear whether the system has been used so far. The fact that no civil action has been brought under the act and that no implementing regulations have been promulgated indicate that there is a lack of domestic interested parties using the system. ${ }^{138}$ The promulgation of the Layout-Designs Act of 1999 therefore seems to be driven by a pure preference for compliance with the TRIPS Agreement.

\subsubsection{Patents}

In contrast to its copyright, geographical indications and layout-designs laws, Jamaica is seriously lagging behind in implementing its TRIPS obligations in the area of patents. The country currently operates under an "archaic"139 Patent Act of 1857, which has not yet been replaced. This is the result of a severe delay in enacting the draft Patent and Designs Bill, which has been pending and revised several times since 1999. This delay is partly due to the comprehensive nature of the bill, encompassing patent and design law, the new developments surrounding the Doba Declaration on the

130 See Swiss Federal Institute of Intellectual Property, International Cooperation (2011), available at <www.ige.ch/en/legal-info/international-cooperation.html> accessed on 22.11.2012.

See Jamaica Intellectual Property Office, Geographical Indications - Jamaica \& Switzerland (2009), available at <http://www.jipo.gov.jm/?q=node/162> accessed on 16.11.2012. See the Layout-Designs (Topographies) Act No. 30 of 1999, entered into force on 3 September 1999, last authorized by L.N. 3/2001, see Jamaican Ministry of Justice, Jamaican laws [hereinafter Layout-Designs Act of 1999].

Treaty on Intellectual Property in Respect of Integrated Circuits, adopted in Washington on 26 May 1989, 28 I.L.M. 1477 (1989) [hereinafter IPIC Treaty]. Note that the IPIC Treaty has not entered into force. 
TRIPS Agreement and Public Health that needed to be incorporated, significant interest from both policy makers and local stakeholders and a lengthy revision process. ${ }^{140}$

The two most striking features of Jamaica's current patent law regard the nonrecognition of priority filings abroad, ${ }^{141}$ and the concept of local novelty. First, the system of priority has been established under the Paris Convention. Under this system, patent applicants that have applied for a patent earlier in one contracting State are able to rely on the same date of filing when applying for a patent in another party. However, although Jamaica is a party to the Paris Convention, it does not fulfill its obligations in this respect. It is therefore not possible for patent applicants in Jamaica to rely on a prior filing date in another contracting State to the Paris Convention in order to be recognized as the date of filing also in Jamaica. The draft bill on patents and designs will remedy this situation by implementing the Patent Cooperation Treaty, which offers a unified procedure for filing patent applications in the contracting parties to the PCT. ${ }^{142}$ Although not a party to the PCT yet, Jamaica's accession to the treaty has been under discussion for a while ${ }^{143}$ and also has become an obligation under the CARIFORUM-EC EPA. ${ }^{144}$

Second, Jamaican patent examiners rely on local novelty when determining whether an innovation is new. ${ }^{145}$ Hence, one can apply for a patent in Jamaica even though the same invention is already part of the state of the art in another country. This is in contrast to a system of universal novelty that most countries have implemented, among others the United States, the European Union and Japan. Once an invention has become public anywhere in the world, it is not new anymore and will therefore not fulfill the requirements for getting a patent in those countries. As the TRIPS Agreement does not define the concept of novelty further, local novelty as applied currently in Jamaica is not inconsistent with the TRIPS Agreement. Furthermore, a Jamaican Letter Patent is granted for a period of fourteen years and can be extended for another seven years. ${ }^{146}$ The Jamaican patent act does not provide for compulsory licensing of patents but allows parallel imports. ${ }^{147}$

\subsubsection{Designs}

It is also only with the draft Patents and Designs Bill that the TRIPS standard will be introduced in Jamaica in the field of design protection. Similarly to the area of patents, the current Designs Act of 1937 falls short of Jamaica's international obligations, in particular those of the TRIPS Agreement and the Paris Convention. Under the Designs Act of 1937, and its implementing Design Rules of 1937, ${ }^{148}$ an industrial design (which is a design applied to a manufactured product or any natural or

\footnotetext{
140 See Daley, “A Balancing Act”, p. 18.

141 See Daley, “Jamaica: Intellectual Property”, paragraph 53.

142 See ibid., paragraph 53.

143 See Daley, "Intellectual Property in the EPA", Part III.

144 See Article 147.A.2 of the CARIFORUM-EC EPA.

145 See Section 3 of the Patent Act of 1857.

146 Ibid.

147 See WTO Secretariat, TPR Jamaica 2005, paragraphs 183 and 184.

148 Designs Rules of 1937, adopted on 16 December 1937, last amended by Act No. 66 of 1999 and last authorized by L.N. 102/2001, see Jamaican Ministry of Justice, Jamaican laws [hereinafter Designs Rules of 1937].
} 
artificial substance ${ }^{149}$ receives protection if it is original and novel in Jamaica. ${ }^{150}$ As is the case with patents, JIPO relies on local novelty in order to decide whether a design is new. ${ }^{151}$ A design therefore must not have already been published in Jamaica; whether that is the case in other parts of the world is not relevant. Another similarity with the Patents Act of 1857 is that the Designs Act of 1937 does not recognize priority filings of designs in the contracting parties of the Paris Convention. ${ }^{152}$ This inconsistency with the latter convention and the TRIPS Agreement will be remedied once the draft Patents and Designs Bill is enacted. ${ }^{153}$

Protection is contingent upon registration of the design in one of sixteen classes. ${ }^{154}$ Jamaica is not yet a party to the Locarno Agreement, which establishes an international system for classifying industrial designs and provides for a far broader range of classes than the current sixteen in Jamaica. ${ }^{155}$ Once protected, the owner of the design has the right to authorize any making, selling or importing of articles that bear a design that is (substantially) a copy of the protected design if such acts are undertaken for commercial purposes. ${ }^{156}$ These rights last for a period of fifteen years. ${ }^{157}$ With regard to the rights and the duration thereof, Jamaican design law meets the requirements of Article 26 of the TRIPS Agreement.

\subsubsection{Plant Varieties}

Also in the area of protecting new varieties of plants, Jamaica is not TRIPScompliant. The TRIPS Agreement requires Jamaica to offer protection to new varieties of plants, either through patent protection or an effective sui generis system. ${ }^{158}$ Currently, Jamaica does not offer protection for plant varieties, neither under the Patent Act of 1857, nor under any other law. In contrast to the other areas of intellectual property protection, where a draft law is awaiting to be enacted, JIPO has not yet started drafting the instructions for a future plant variety protection law, ${ }^{159}$ even though cabinet approval for the promulgation of a law on the protection of the rights of breeders of new varieties of plants was already given in 2004. ${ }^{160}$

\footnotetext{
149 See Section 2 of the Designs Act of 1937.

$150 \quad$ See Section 5.1 of the Designs Act of 1937.

151 Ibid.

152 See Daley, IP Regime in Jamaica.

153 See Daley, "Jamaica: Intellectual Property", paragraph 54.

$154 \quad$ See Section 5 and third schedule of the Designs Rules of 1937.

155 The system provides for thirty-two broad classes with several subclasses. See WIPO, International Classification for Industrial Designs under the Locarno Agreement (2012), available at <http://www.wipo.int/classifications/locarno/en/index.html> accessed on 21.11.2012.

See Section 7.1 of the Designs Act of 1937. Note that the Article refers to the rights granted under copyright. See Daley, IP Regime in Jamaica.

$157 \quad$ See Section 7.1 of the Designs Act of 1937.

158 See Article 27.3(b) of the TRIPS Agreement.

159 Interview with Lilyclaire Bellamy, 12 April 2010, Kingston.

160 See Ministry of Industry Investment \& Commerce, Ministry Paper No. 45: Performance of the Jamaica Intellectual Property Office (JIPO) for the Financial Year 2004/2005 and Focus for the Financial Year 2005/2006 (Kingston), p. 3.
} 
The lack of activity in this area of protection seems to be the result of an absence of parties in Jamaica that could benefit from protection for new varieties of plants. ${ }^{161}$ According to JIPO, there are only a few breeders of flowers (in particular orchids) that might benefit from plant variety protection; ${ }^{162}$ in agriculture, plant breeders' rights primarily benefit individuals and entities that can create new strains through scientific means - and to date there seem to be very few in Jamaica. ${ }^{163}$ However, it needs to be noted that there have been a few efforts so far to raise awareness among possible stakeholders about plant variety protection. ${ }^{164}$

As to the content of the future law on plant variety protection, Jamaica envisages to implement the UPOV Convention, Act 1991. Jamaica has been in contact with the Office of the International Union for the Protection of New Varieties of Plants (UPOV) since 2004 with a view to developing legislation in line with the UPOV Convention. ${ }^{165}$ In this context, the Executive Director of JIPO visited the Office of UPOV in September 2004 in order to discuss the usefulness of enacting such legislation in Jamaica. In November 2004, JIPO and UPOV staged a seminar together on the protection of new plant varieties for Jamaican stakeholders. ${ }^{166}$ More recently, representatives from JIPO and the Ministry of Agriculture participated in a regional seminar on "New Plant Variety Protection" under the UPOV Convention in Port of Spain (Trinidad and Tobago), organized by UPOV together with the US Patent and Trade Mark Office. ${ }^{167}$ This choice for a law based on the UPOV Convention, Act 1991,168 rather than developing a tailor-made sui generis system of protection for the Caribbean region, seems to be informed by the fact that most developing countries rely on technical assistance from WIPO, which proposes a system of protection according to the UPOV Convention, Act 1991. ${ }^{169}$ Also the CARIFORUM-EC EPA requires its parties to "consider acceding" to the UPOV Convention, Act $1991 .{ }^{170}$ In this respect, Jamaica needs to be wary when implementing

Interview with Michelle Walker, Head of the Legal Unit of the Jamaican Ministry of Foreign Affairs and Foreign Trade, 13 April 2010, Kingston (available on request).

Interview with Lilyclaire Bellamy, 12 April 2010, Kingston. Interview with Beverley Pereira, 6 April 2010, Kingston.

Raising awareness for plant variety protection is still on JIPO's work plan and has not yet been started. Interview with Lilyclaire Bellamy, 12 April 2010, Kingston.

See GRAIN, PVP in the South: caving in to UPOV (2004), available at <www.grain.org> accessed on 29.10.2012.

The stakeholders that participated were the Ministry of Commerce, Science and Technology, the Ministry of Agriculture, the University of the West Indies, the Scientific Research Council, the Coffee Industry Board January, the Sugar Industry Authority, the herbal industry, the National Consumers League, and law firms. See Ministry of Industry Investment \& Commerce, Ministry Paper No. 45: Performance of the Jamaica Intellectual Property Office (IIPO) for the Financial Year 2004/2005 and Focus for the Financial Year 2005/2006, p. 5.

See UPOV Council, Report on activities during the first nine months of 2009 (International Union for the Protection of New Varieties of Plants, Forty-Third Ordinary Session, Geneva, 09 October 2009) [C/43/3], paragraph 17.

Interview with Michelle Walker, 13 April 2010, Kingston, and interview with KerriGaye Rushton, Legal Officer at the Ministry of Agriculture and Fisheries, 29 March 2010, Kingston (available on request).

Interview with Michelle Walker, 13 April 2010, Kingston.

See Article 149.2 second sentence of the CARIFORUM-EC EPA. 
the farmers' privilege ${ }^{171}$ provided for in Article 15.2 of the UPOV Convention, Act 1991, as the EPA itself defines the rights of farmers covered there under in greater detail. ${ }^{172}$

\subsubsection{Protection of Genetic Resources and Traditional Knowledge}

Protection for traditional knowledge is not required under the TRIPS Agreement. Having no national legislation that sets out protection for

"knowledge, innovations and practices of indigenous and local communities embodying traditional lifestyles [...] and the sustainable use of biological diversity"173

does not make Jamaica TRIPS-noncompliant. However, Jamaica is a contracting party to the Convention of Biological Diversity, which obliges each party, as far as possible and as appropriate, to respect these types of knowledge. This is also what the CARIFORUM-EC EPA reiterates, even though without connecting a clear obligation to this protection. ${ }^{174}$

The international debate at the W'TO and WIPO basically involves the introduction of three elements into a countries' patent application procedures: 1) the mandatory disclosure of origin or source of the biological resource or traditional knowledge from which the product to be patented is derived; 2) evidence of prior informed consent for access from the indigenous community; and 3) evidence of fair and equitable sharing of benefits. So far, these three elements have not yet been incorporated into a multilateral agreement to which countries can become contracting parties. However, an amendment of the TRIPS Agreement has been proposed, which would incorporate these requirements into WTO Members' national patent application procedures. ${ }^{175}$

Even without an international agreement, states are free to introduce these elements into their national legislation, as has been done by some countries. ${ }^{176}$ Although Jamaica supports the proposed amendment by Article 29 bis of the TRIPS Agreement, it has not yet enacted a national law to that effect. According to Lilyclaire Belamy, Legal Counsel at JIPO, the Caribbean region is trying to find out what exactly it can do in order to protect the traditional knowledge of the region. ${ }^{177}$ Both setting up a sui generis system of traditional knowledge protection as well as amending their patent laws are options that are being considered. Apart from choosing a system of protection, the

The farmers' privilege provides an exception to the exclusive rights granted to plant breeders. Accordingly, farmers may use protected farm-saved seed or propagating material if certain conditions are fulfilled. See section 5.3.2.7 of this book on the plant variety protection included in the CARIFORUM-EC EPA. See Article 149.1 of the CARIFORUM-EC EPA. See also section 5.3.2.7 of this book. See Article 150.1 of the CARIFORUM-EC EPA. Note that this provision is identical to Article $8 j$ of the CBD.

Note that the "shall respect" obligation is missing in Article 150.1 of the CARIFORUM-EC EPA.

See section 5.3.2.8 for an analysis of the proposed amendment.

India provides for these and other elements in its patent and biodiversity laws. See section 6.3.7.3 of this book.

Interview with Lilyclaire Bellamy, 12 April 2010, Kingston. 
region faces the major problem that many of the products identified as being "traditional knowledge" exist in various legislations of the region, even though under different names; it would be almost impossible to identify the origin of such products if origin must be limited to a particular group of the community in one Caribbean country only. ${ }^{178}$

While Jamaica and the Caribbean countries have not yet advanced much in devising a suitable solution for the conflict between patent law and the preservation of biodiversity and traditional knowledge, biological resources and traditional knowledge are protected by several national laws. ${ }^{179}$ For example, the Natural Resources Conservation Authority issues permits to those who want to undertake specific categories of enterprise, construction or development on the island of Jamaica. ${ }^{180}$ When considering an application, the Authority will have regard to material considerations, including

"the effect on the environment generally, and in particular on any national resources in the area concerned." 181

However, the Natural Resources Conservation Authority Act of 1991 falls short in regulating and enforcing access to genetic resources and traditional knowledge, and fair and equitable sharing of benefits arising out of the utilization of genetic resources or traditional knowledge. ${ }^{182}$ An analysis of other Jamaican laws addressing the protection of the environment, such as the Wild Life Protection Act of $1945^{183}$ and The Endangered Species Act of 2000, as well as the laws protecting intellectual property, such as the Patent Act of 1875 and the Institute of Jamaica Act of 1978, ${ }^{184}$ reveals that the results are the same as for the Natural Resources Conservation Authority Act of 1991: the regulation of access to genetic resources does not comply with the obligations

$178 \quad$ Ibid.

179 For a detailed analysis of the various laws potentially regulating access to genetic resources, see M. Goffe, Jamaica's Compliance with the Convention on Biological Diversity: An Intellectual Property Assessment of the Relevant Laws, Policies and Procedures Regulating Access and Benefit Sharing with Respect to Genetic Resources and Traditional Knowledge (30 May 2010) [UNDP/NEPA/IOJ].

180 See Section 9 of the Natural Resources Conservation Authority Act No. 9 of 1991, entered into force on 5 July 1991, reprinted version of Act No. 9 of 1991 as authorized last by L.N. 90/1993, see Jamaican Ministry of Justice, Jamaican laws [hereinafter Natural Resources Conservation Authority Act of 1991]. The Natural Resources (Prescribed Areas) (Prohibition of Categories of Enterprise, Construction and Development) Order, 1996 was passed pursuant to section 9.1 of the Natural Resources Conservation Authority Act of 1991. It provides that the entire island of Jamaica is a prescribed area and lists, in column A, the categories of enterprise that require a permit.

181 See Section 9.5(b) of the Natural Resources Conservation Authority Act of 1991.

182 See Goffe, Jamaica's Compliance with the Convention on Biological Diversity, p. 21.

183 The Wild Life Protection Act, entered into force on 20 September 1945, consolidated version of a Cap. 413 as amended last by Act No. 33 of 1991 and authorized last by L.N. 111/2005, see Jamaican Ministry of Justice, Jamaican laws.

184 The Insitute of Jamaica Act, entered into force on 28 March 1978, as amended last by Act No. 8 of 1995 and authorized last by L.N. 95/1997, see ibid. 
Why JAMAICA WANTS TO PROTECT CHAMPAGNE

stemming from the CBD. Jamaican law also does not fulfill the CBD requirements as to benefit sharing and the protection of traditional knowledge. ${ }^{185}$

185 See Goffe, Jamaica's Compliance with the Convention on Biological Diversity, p. 39, 61 and 103. 


\title{
Chapter 10 : Policy-making Processes on Intellectual Property Matters in CARIFORUM, in Particular Jamaica
}

\author{
10.1. STATE ACTORS INVOLVED IN POLICY-MAKING AND INTERNATIONAL \\ Negotiations on INTELLECTUAL Property MATTERS IN CARIFORUM, \\ IN PARTICULAR JAMAiCA
}

State actors play a crucial role in the policy-making on international intellectual property matters. International agreements such as the CARIFORUM-EC EPA are negotiated by governmental entities. At the same time, they are the actors that interact with non-state parties, who would like to make sure that their interests with regard to the international negotiations are taken into consideration by the relevant bodies. This analysis therefore forms the first part of the broader research as to the question what the influence of non-state actors was on CARIFORUM's, in particular Jamaica's, policy position with regard to IP protection in the EPA negotiations. Having determined the role and involvement of these state actors in the policymaking and negotiating process is a prerequisite for the research to proceed to examine the role and involvement of non-state actors at the regional and national level in these processes and to finally determine their influence on the policy position adopted in the negotiating process.

In order to answer the questions which state actors represent Jamaica's interests in international trade negotiations on IP issues and which state actors are involved in determining Jamaica's policy position for these negotiations, different regional and national governmental institutions and bodies are assessed. The first regional actor assessed is the ACP Group of States, which historically represented all ACP States in negotiations with other countries. Also in the negotiations of the CARIFORUM-EC EPA, the ACP Group of States played a role.

The second set of actors analysed are the relevant bodies in the regional grouping of CARIFORUM to which Jamaica is a party. CARIFORUM is the subgroup of ACP States that negotiated the CARIFORUM-EC EPA with the European Union. Particular attention is paid to the following CARIFORUM actors: the EPA College of Negotiators, the CARIFORUM Council of Ministers, the Caribbean Regional Negotiation Machinery, the Technical Working Groups and the Regional Preparatory Task Force. However, before analyzing the relevant CARIFORUM actors, a short overview of the political negotiating phases of the CARIFORUM-EC EPA, with particular attention to intellectual property issues, is presented.

A final set of state actors analyzed are the national Jamaican Governmental bodies, which are responsible for determining the policy and negotiating international trade agreements, such as the EPA negotiations. Special attention is paid to Jamaican state actors that are particularly concerned with the policy on the protection of intellectual property in such agreements. Finally, this section will address the question as to whether the analyzed regional and national state actors fulfill different roles when it comes to IP policy making at the multilateral level, such as the WTO and WIPO, compared to the bilateral EPA level.

When negotiating international trade agreements, Jamaica often is not the negotiating partner. Historically, ACP States have formed one group that presented all ACP 
States in international negotiations. ${ }^{1}$ In the case of the EPA negotiations, the ACP States were split up in subgroups in order to negotiate separately with the European Union. Jamaica formed part of the group of CARIFORUM that represented by the Caribbean Regional Negotiation Machinery in the EPA negotiations. The CRNM falls under the ambit of CARICOM, the regional organization to which Jamaica is also a Member. In fact, all CARIFORUM States are parties to that organization, with the exception of the Dominican Republic. However, the British dependent territory Montserrat, which is a Member of CARICOM, does not form part CARIFORUM. Because of this multi-layered structure of organizations, this section outlines which regional and national governmental actors had which function in the negotiations of the CARIFORUM-EC EPA, in particular in the field of the protection of intellectual property rights.

\subsubsection{ACP Group of States}

Under the four Lomé Conventions ${ }^{2}$ and the Cotonou Agreement with the European Community and its Member States, the African, Caribbean and Pacific Group of States $(\mathrm{ACP})^{3}$ incurred the same rights and obligations for each of its Member States since all of them signed and ratified the same treaties. This was different in the EPA negotiations where the ACP Group of States did not negotiate as one entity but separately in six regional groupings. The agreements that each group has signed or will sign therefore differ from each other. The splitting up of the ACP Group of States was subject to intense discussions among ACP States and the European Commission, that negotiated the EPAs on behalf of the European Community and its Member States. In the following, the role of the ACP Group of States as a whole during the negotiations is analyzed.

As foreseen in the Cotonou Agreement of 2000, its parties were to negotiate economic partnership agreements or new trading arrangements. However, the Agreement did not clearly indicate who the negotiating parties on the ACP side would be. ${ }^{4}$

"Article $37[\ldots]$

5. Negotiations of the economic partnership agreements will be undertaken with ACP States which consider themselves in a position to do so, at the level they consider appropriate and in accordance with the procedures agreed by the ACP Group, taking into account regional integration process within the ACP."

In 2001, already before the negotiations started in September 2002, the European Commission had made clear that it had a preference to negotiate with the main ACP regional groupings. The ACP Group of States, on the other hand, was divided about

An example is the Cotonou Agreement.

The first Lomé Convention was signed in 1975, the second in 1980, the third in 1985 and the fourth in 1990. The number of signatory countries from the ACP Group of States rose from forty-six for the first Lomé Convention to seventy for the fourth Lomé Convention.

This organization was created by the Georgetown Agreement in 1975 and consists of seventy-nine Member States, all of them, except for Cuba, being signatories to the Cotonou Agreement [hereinafter ACP Group of States].

$4 \quad$ See Article 37.5 of the Cotonou Agreement. 
whether to prefer negotiations that would be conducted by each regional ACP grouping separately or negotiations with the entire ACP Group of States, which would lead to an all-ACP Agreement, establishing the same rights and obligations for all ACP States..$^{5}$ In October 2002, the parties acknowledged that it was up to the ACP Groups of States to decide within which regional setting they wished to negotiate and to agree on procedures to apply throughout the negotiation of EPAs. ${ }^{6}$ They agreed that the negotiations were to be conducted in two phases, the first phase taking place at the all-ACP level and the second phase at the regional levels.

\subsubsection{Phase One: All-ACP Level}

During the first phase, negotiations took place at an all-ACP level. The ACP Group of States was represented by the ACP Council of Ministers at the ministerial level and by the ACP Committee of Ambassadors at the ambassadorial level. ${ }^{7}$ The ACP Secretariat coordinated the technical preparations within the ACP Group of States. ${ }^{8}$ In addition, dedicated meetings took place on specific issues, such as legal issues, the development dimension, market access, trade-related issues, inter alia. ${ }^{9}$ The negotiations dealt with objectives and principles of EPAs and issues of common interest to all ACP States. ${ }^{10}$ The original idea was to conclude an all-ACP-EC Agreement at the end of phase one to provide guidelines for phase two of the negotiations. However, agreement between the parties was not within reach when phase one ${ }^{11}$ was coming to an end. Consequently, they decided that the Joint Report on the all-ACP-EC phase of EPA negotiations of October $2003^{12}$ would serve as a point of reference for the second phase of the negotiations. ${ }^{13}$ It was also agreed upon that an all-ACP mechanism should be maintained during the whole process of negotiations, particularly in phase two of the negotiations. This mechanism was meant to ensure the circulation of information, facilitate dialogue and consultation and to give any advice or recommendations on "all-ACP" issues and negotiating strategies. ${ }^{14}$

\subsubsection{Phase Two: Regional Phase}

The second regional phase started merely two days after the adoption of the Joint Report on 4 October 2003 with the launch of the regional negotiations with the Central African Economic and Monetary Community, the regional grouping in

$5 \quad$ See S. Bilal, "Who Will Negotiate with the EU? In Search of an ACP-EU Negotiating Framework" Trade Negotiations Insights, 2002, Vol. 1 (1), 5-7, p. 5-6.

6 See ACP Secretariat, ACP-EC EPA negotiations: Joint Report on the all-ACP-EC phase of EPA negotiations (Brussels, 2 October 2003) [ACP/00/118/03 Rev.1], p. 11.

$7 \quad$ See ibid., p. 10.

8 See ibid., p. 16.

9 See ibid., p. 16.

10 See ACP Secretariat, ACP Guidelines for the negotiations of Economic Partnership Agreements (Brussels, 5 July 2002) [ACP/61/056/02 [FINAL]], p. 4.

11 See ACP Secretariat, ACP-EC EPA negotiations: Joint Report on the all-ACP-EC phase of EPA negotiations, p. 12.

12 See ibid.

13 See M. Julian, "EPA Negotiations Update: Start of Regional Negotiations" Trade Negotiations Insights, 2004, Vol. 3 (1), 6-7, p. 6.

14 See ACP Secretariat, ACP-EC EPA negotiations: Joint Report on the all-ACP-EC phase of EPA negotiations, p. 12 and 94. 
Central Africa. ${ }^{15}$ In parallel to the regional negotiations with the individual ACP groupings, the ACP Group of States was still involved in the negotiations, in particular through the establishment of the ACP Technical Follow-up Group. This Group comprised the principal negotiator and a representative from each of the six ACP regions, a representative of relevant regional organizations, the SecretaryGeneral of the ACP Group, the Troika of the Committee of Ambassadors and a representative of the Group of Senior Experts. ${ }^{16}$ Its role was to review the progress achieved in the negotiations and to formulate recommendations for enhancing effectiveness of the approaches and strategies. It would assist and prepare meetings of the ACP Council of Ministers, which reviewed the advancement of the negotiations and ensured their conformity with the ACP Group's principles of unity and solidarity.

The ACP Technical Follow-up Group met for the first time in January 2004 where it was agreed upon that the issues to be discussed at the all-ACP-EC level would be limited to trade-related issues (excluding so-called "Singapore issues"), ${ }^{17}$ rules of origin, dispute settlement and the non-execution clause. ${ }^{18}$ For example, with regard to rules of origin, ACP States decided to negotiate one set of rules of origin common to all EPAs at the all-ACP level in order to treat goods from all ACP regions in the same way; eventually, this decision was revoked and the matter was delegated to the regional levels. ${ }^{19}$ The discussions on the non-execution clause focussed on the question whether one country's non-compliance with EPA rules could give rise to EU trade sanctions for an entire ACP region under an EPA dispute settlement system. ${ }^{20}$ This controversy was finally solved for the CARIFORUM region by recognizing each CARIFORUM state as a party to EPA. ${ }^{21}$

Early on, tensions arose in the ACP Technical Follow-up Group between the representatives of the regions on matters such as placing all-ACP conditionalities on regional level negotiations. ${ }^{22}$ As a consequence of these tensions, the Group did not pass the stage of discussing mainly procedural aspects rather than substantive ones: it devoted attention to the general progress of negotiations and common problems, such as the lack of EU commitment on how to deal with the development dimension of EPAs, the pressure by the EU to include issues that some ACP regions were not

15 See Julian, "EPA Negotiations Update: Start of Regional Negotiations", p. 6.

16 See ACP Secretariat, ACP-EC EPA negotiations: Joint Report on the all-ACP-EC phase of EPA negotiations, p. 94.

17 See footnote 117 of section 4.3 .2 of this book.

18 See M. Julian, "EPA Negotiations Update: State of Play of the Negotiations March 2004" Trade Negotiations Insights, 2004, Vol. 3 (2), 6-7, p. 6.

19 See M. Pearson, "Agreeing EPA rules of origin: a strategy unfolds" Trade Negotiations Insights, 2007, Vol. 6 (4), 6-8, p. 6.

20 See M. Julian, "EPA Negotiations Update: State of Play of the Negotiations July 2004" Trade Negotiations Insights, 2004, Vol. 3 (4), 6-7, p. 6.

21 See M. Julian, "EPA Negotiations Update September 2007” Trade Negotiations Insights, 2007, Vol. 6 (5), 14-15, p. 15.

22 See Julian, "EPA Negotiations Update: State of Play of the Negotiations March 2004", p. 6. 
ready to discuss and the EU's refusal to allow for variable geometry when granting Special and Differential Treatment to least-developed countries. ${ }^{23}$

The ACP Technical Follow-up Group was not the only ACP body involved in phase two; at a political level, the ACP Council of Ministers played an important role, in particular its Ministerial Trade Committee. ${ }^{24}$ Similar to the Follow-up Group, the Council occupied itself with the more general aspects of EPA negotiations, rather than with specific negotiation areas. In its several meetings, both on its own and with the EU, the main issues discussed were the EU financial support to strengthen ACP's negotiating capacity and implementation efforts, the development dimension of EPAs, regional integration priorities and the modalities of a review mechanism. ${ }^{25}$

Malcolm Spence, technical negotiator of the CARIFORUM region on IP, confirmed that the all-ACP phase was a great disappointment to the Caribbean region as their expectations to deal with the common issues at that level were not met. ${ }^{26} \mathrm{He}$ felt that the individual regions were largely left alone to construct a complete agreement by themselves. According to him, the reason for the inability of the all-ACP phase to contribute more was that other ACP regions in Africa and the Pacific were not as negotiation-ready as CARIFORUM, due to the latter's experience gained during the negotiations of the Free Trade Agreement of the Americas (FTAA). ${ }^{27}$ The consequence of this frustration was that regional representatives started exchanging information informally and coordinating and collaborating on the preparations and

See M. Julian, “TNI EPA Update June 2006” Trade Negotiations Insights, 2006, Vol. 5 (3), 6-7, p. 6.

Note that also other bodies of the ACP Group of States were involved during the second phase of negotiations. The ACP-EU Joint Parliamentary Assembly, established under the Cotonou Agreement Article 17 and jointly composed of Members of the European Parliament and national ACP parliaments met twice a year to discuss matters pertaining to the ACP-EU Partnership and adopted resolutions or made recommendations to the Council of Ministers. The Committee of Ambassadors publicly presented the ACP Group of States' concerns on the development dimension and the regional integration priorities in the EPA negotiations during a hearing in the European Parliament's International Trade Committee in September 2005, see M. Julian, “EPA Negotiations Update, October 2005" Trade Negotiations Insights, 2005, Vol. 4 (5), 6-7, p. 6. In addition, an all-ACP-EC Technical Monitoring Committee was established to ensure the free flow of information and promote the dialogue between the different ACP regional groupings and between them and the EU. It met in October 2004 and December 2005. They primarily discussed funding for capacity building and the rapid delivery of trade-related technical assistance. See M. Julian, "EPA Negotiations Update, February 2006” Trade Negotiations Insights, 2006, Vol. 5 (1), 6-7, p. 6.

25 See M. Julian, "EPA Negotiations, Update August 2005" Trade Negotiations Insights, 2005, Vol. 4 (4), 6-7, p. 6; M. Julian, "EPA Negotiations, Update December 2005" Trade Negotiations Insights, 2005, Vol. 4 (6), 6-7, p. 6; Julian, "EPA Negotiations, Update February 2006", p. 6; M. Julian, "EPA Negotiations, Update August 2006" Trade Negotiations Insights, 2006, Vol. 5 (4), 6-7, p. 6; M. Julian, "EPA Negotiations, Update April 2007” Trade Negotiations Insights, 2007, Vol. 6 (2), 10-11, p. 10.

26 Interview with Malcolm Spence, 8 April 2010, Bridgetown, Barbados; see S. Bilal and V. Roza, "Sharing Information: A Survival Tool for EPA Negotiations" Trade Negotiations Insights, 2005, Vol. 4 (2), 4-5, p. 5; Spence, Innovation and Intellectual Property, p. 4.

27 Interview with Malcolm Spence, 8 April 2010, Bridgetown. 
strategic approaches towards the EPA negotiations. ${ }^{28}$ An example of such informal meetings are the "Workshop on EPA Negotiating Arrangements, Process and Issues" organized by United Nations Development Programme (UNDP) and the ACP Secretariat in Brussels on 15-16 February 2005, which dealt in particular with regional integration and the development agenda of ACP States. ${ }^{29}$ The Caribbean regional grouping, for example, has benefited tremendously from the technical and strategic work of other ACP regions. ${ }^{30}$

\subsubsection{Interim Conclusions}

To summarize, even though the ACP Group of States fulfilled a certain function in the EPA negotiations, its contribution to the negotiations on substantive matters ${ }^{31}$ was limited. Several shortcomings of the all-ACP mechanism inhibited the ACP Group as a whole from having more influence.

First, phase one ended without having reached an agreement among all ACP States on the common issues and without having prepared sufficiently for the technical issues of common interest. ${ }^{32}$ Second, tensions arose in the newly established Technical Follow-up Group between the different ACP regions, which led to informal consultations among certain regional groupings; the discussions in the allACP Technical Follow-up Group were limited to procedural aspects. Third, issues first dealt with by the all-ACP mechanism were delegated to the regional levels due to a lack of agreement among ACP regions. For example, it was decided that the review mechanism would be carried out at regional levels, with an opportunity for inputs from the all-ACP level. ${ }^{33}$ Also, regional groupings were left to negotiate the rules of origin with the EU. ${ }^{34}$ As a consequence, the regional negotiations became the most important part of the EPA negotiations in which substantive matters were decided.

28 See Julian, "EPA Negotiations Update: State of Play of the Negotiations March 2004", p. 6; see M. Julian, "EPA Negotiations, Update: State of Play of the Negotiations May 2004" Trade Negotiations Insights, 2004, Vol. 3 (3), 6-7, p. 7. See CRNM, "EPA Workshop Enables ACP Regions to Share Experiences" RNM Update 0503, 2005.

See J. Lodge, "Launch of CARIFORUM-EC Negotiations of an Economic Partnership Agreement" Trade Negotiations Insights, 2004, Vol. 3 (3), 1-3, p. 3. Negotiations Update: State of Play of the Negotiations March 2004", p. 6. See Bilal and Roza, "Sharing Information: A Survival Tool for EPA Negotiations", p. 5.

33 See Julian, "EPA Negotiations Update February 2006", p. 6; M. Julian and D. Makhan, "EPA Negotiations, Update October 2006" Trade Negotiations Insigbts, 2006, Vol. 5 (5), 6-7, p. 6; European Council, Main results of the ACP-EC Joint Council of Ministers: trade and financial issues (Brussels, 25 May 2007) [1005/07 (Presse 120)], paragraph 1.2.

See Pearson, "Agreeing EPA Rules of Origin: A Strategy Unfolds", p. 6; European Council, Main results of the ACP-EC Joint Council of Ministers: trade and financial issues, paragraph 2.7 . 
Table 16: Schedule for negotiations on the CARIFORUM-EC EPA

\begin{tabular}{|l|l|l|l|l|}
\hline Phase & Dates & Content of Negotiations & Launching event & Concluding event \\
\hline I & $\begin{array}{l}\text { 16 April 2004 - } \\
12 \text { November 2004 }\end{array}$ & $\begin{array}{l}\text { Establishing the Priorities } \\
\text { of EPA Negotiations }\end{array}$ & $\begin{array}{l}\text { Launch of } \\
\text { Negotiations }\end{array}$ & $\begin{array}{l}\text { Second Meeting of } \\
\text { Principal Negotiators }\end{array}$ \\
\hline II & $\begin{array}{l}12 \text { November 2004 - } \\
30 \text { September 2005 }\end{array}$ & $\begin{array}{l}\text { Convergence on strategic } \\
\text { approach to } \\
\text { CARIFORUM regional } \\
\text { integration }\end{array}$ & $\begin{array}{l}\text { Second Meeting of } \\
\text { Principal Negotiators }\end{array}$ & $\begin{array}{l}\text { Fourth Meeting of } \\
\text { Principal Negotiators }\end{array}$ \\
\hline III & $\begin{array}{l}30 \text { September 2005- } \\
30 \text { November 2006 }\end{array}$ & $\begin{array}{l}\text { Structuring and } \\
\text { consolidating EPA } \\
\text { negotiations }\end{array}$ & $\begin{array}{l}\text { Fourth Meeting of } \\
\text { Principal Negotiators }\end{array}$ & $\begin{array}{l}\text { Third EU- } \\
\text { CARIFORUM } \\
\text { Ministerial Meeting }\end{array}$ \\
\hline IV & $\begin{array}{l}30 \text { November 2006 - } \\
16 \text { December } 2007\end{array}$ & Finalization & $\begin{array}{l}\text { Third EU- } \\
\text { CARIFORUM } \\
\text { Ministerial Meeting }\end{array}$ & $\begin{array}{l}\text { Initialling of } \\
\text { comprehensive EPA }\end{array}$ \\
\hline
\end{tabular}

10.1.2.1. Phase One: April 2004-November 2004

The negotiations of the CARIFORUM-EC EPA were divided into four phases, ${ }^{35}$ as planned and set out in the "Plan and Schedule for CARIFORUM EC Negotiations". ${ }^{36}$ The initial phase started with the launch of EPA negotiations in Kingston, Jamaica on 16 April 2004, and ended in November 2004. During this phase, the focus lay on establishing the scope and priority areas for the EPA negotiations and to agree on timetables and phasing for the negotiations. ${ }^{37}$ This was mainly achieved during the first meeting of Principal Negotiators in July 2004 when also the modalities for the functioning of a Joint Regional Preparatory Task Force (RPTF) were agreed upon. ${ }^{38}$ The latter body was meant to act as a nexus between EPA negotiations and the development support component of the Cotonou Agreement. It therefore played an important role in supporting the building of negotiationcapacity in the Caribbean with resources from the European Development Fund. ${ }^{39}$

35 See ACP Group of States and Council of the European Union, ACP-EU Economic Partnership Agreement Negotiations Cotonon Agreement Article 37.4 Review (Brussels, 31 May 2007) [ACP-CE 2116/07], p. 11.

36 See European Commission, Plan and Schedule for CARIFORUM EC Negotiation of an Economic Partnership Agreement (Brussels).

37 See ibid., p. 4.

38 See Lodge, "Launch of CARIFORUM-EC Negotiations of an Economic Partnership Agreement", p. 2.

39 See European Commission, Plan and Schedule for CARIFORUM EC Negotiation of an Economic Partnership Agreement, p. 4. 


\subsubsection{Phase Two: November 2004-September 2005}

The second phase began in November 2004 when the second meeting of the CARIFORUM-EC Principal Negotiators took place. ${ }^{40}$ The focus was shifted from the scope and timing of negotiations to identifying the priorities for support of CARIFORUM regional integration through the EPA negotiations. At this stage of the negotiations, it was necessary to define the economic entity that would assume commitments under the EPA. ${ }^{41}$ This importantly included an exchange of information and views between CARIFORUM States and the European Commission on 1) the CARICOM integration process as related to the CARICOM Single Market and Economy, and 2) the CARICOM-DR FTA. The European Commission required clarification on which core elements of the CSME would be signed off by CARICOM Member States in 2005 and what the exact position of the Dominican Republic was in the regional integration context. ${ }^{42}$ Just before the meeting of CARIFORUM-EC Principal Negotiators, the first meeting of the Joint RPTF took place. It had prepared a Memorandum on the Internal Organization of the Joint RPTF, which the Principal Negotiators signed. Accordingly, the Task Force was going to be guided by the decision of CARIFORUM-EC Principal Negotiators and would first build an inventory of studies and donor-funded programmes currently and recently carried out. ${ }^{43}$

It was also during this phase that the first technical negotiating sessions took place, such as on market access (including sanitary and phytosanitary measures and technical barriers to trade), services and investment, and trade-related issues (including intellectual property, competition policy and government procurement). ${ }^{44}$ In particular, the technical negotiations on intellectual property started at the end of 2004, beginning of 2005 with discussions on the links between specific development interests of CARIFORUM and the most relevant intellectual property rights. ${ }^{45}$ It was in this phase that the first breakthroughs for CARIFORUM States on IP issues were already reached.

At the beginning of the technical negotiations with the European Commission, the CARIFORUM technical negotiator for intellectual property issues, Malcolm Spence, introduced a concept note on "Trade and Innovation", which was further developed

40 The Second Meeting of CARIFORUM-EC Principal Negotiators took place on 12 November 2004. See CRNM, "CARIFORUM and EC Advance Regional Integration Elements of EPA Negotiations" RNM Update 0418, 2004.

41 See M. Julian, "EPA Negotiations, Update January 2005” Trade Negotiations Insights, 2005, Vol. 4 (1), 6-7, p. 7 and M. Julian, "EPA Negotiations, Update June 2005" Trade Negotiations Insights, 2005, Vol. 4 (3), 6-7, p. 7.

See CRNM, "CARIFORUM and EC Advance Regional Integration Elements of EPA Negotiations".

43 See ibid.

44 The second technical session on market access issues was held in March, the technical session on services and investment was convened in April 2005 and the technical session on trade-related issues was held in May 2005. See Julian, "EPA Negotiations Update June 2005", p. 7; CRNM, "CARIFORUM-EC EPA Talks on Track, Say Principal Negotiators" RNM Update 0509, 2005.

$45 \quad$ See Spence, Innovation and Intellectual Property, paragraph 17. 
in a note on "Innovation and Intellectual Property". ${ }^{46}$ This concept note was based on the idea that national and regional innovation systems are prerequisites to benefit from increasing trade. Following this idea, it proposed to address the following three issues in the EPA: 1) creating relevant innovative products (encompassing creative, scientific and technical products), 2) market access conditions and 3) intellectual property rights protection. ${ }^{47}$ Accordingly, intellectual property protection would not stand alone but be contextualized in a broader framework, that of trade and innovation.

In order to operationalize these ideas, the note required the EU to consider CARIFORUM firms eligible for relevant support programmes which are aimed at encouraging greater innovation. These programmes are available to European firms in disadvantaged and outermost regions and to those established in neighbouring states that participate in the European Neighbourhood Policy. ${ }^{48}$ Malcolm Spence pointed out that the EU Neighbourhood Policy

"is targeted at supporting its continental neighbouring States [...]. Its implementation appeared not to have considered the CARIFORUM States as having similar neighbouring status to the French Caribbean Overseas Regions (FCORs) and other EC territories in the Caribbean, as indeed they do." 49

According to Malcolm Spence, at first, it seemed to be difficult for the EU to agree to the participation of CARIFORUM firms in the suggested programmes. Therefore, it constituted a major breakthrough for CARIFORUM States when DirectoratesGeneral of the European Commission other than DG Trade participated in the negotiations: DG Enterprise and Industry and DG Regional Policy brought the relevant expertise on the suggested programmes to the negotiating table. These broadened discussions had as a result that the EU agreed to let CARIFORUM firms participate in the suggested programmes..$^{50}$

The link between innovation and intellectual property protection suggested by Malcolm Spence was innovative in itself: no other bilateral trade agreement until then contained a chapter where the protection of intellectual property was integrated in a

46 Interview with Malcolm Spence, April 7, Bridgetown, Barbados. It is not entirely clear when the concept notes have been introduced in the negotiations. However, it appeared from the interview with Malcolm Spence and his conference paper that the first concept note was submitted end of 2004, beginning of 2005, and that both concept notes were developed before the beginning of 2006. See ibid., paragraph $20-$ 32. One source suggests that both notes were submitted in 2006. See South Centre and CIEL, "Intellectual Property in European Partnership Agreements with the African, Caribbean and Pacific Group of Countries" Intellectual Property Quarterly Update, 2006, Vol. Fourth Quarter 2006, p. 4.

47 This concept note is not publicly available but was shared with me by the technical negotiator for IP, Malcolm Spence.

48 These programmes are the so-called Lisbon agenda programmes. See European Commission, Seventh Framework Programme (FP7); European Commission, Competitiveness and Innovation Framework Programme (CIP).

$49 \quad$ Spence, Innovation and Intellectual Property, paragraph 18.

$50 \quad$ Interview with Malcolm Spence, 7 April 2010, Bridgetown, Barbados. 
broader approach of fostering innovation. This seems to explain the European Union's initial hesitation to the approach of linking IP with innovation.

The second phase was concluded by the Ministerial meeting in September 2005 where 1) CARIFORUM regional integration priorities were identified as being market access, services, investment and trade-related issues, 2) the Joint Report on Phase II negotiations was adopted, ${ }^{51}$ and 3) CARIFORUM States raised concerns about the European Union's focus on demand-side issues rather than supply-side constraints. ${ }^{52}$

\subsubsection{Phase Three: September 2005-November 2006}

Phase three constituted the main substantive phase. The structure of the EPA was defined, the outcome of discussions on the priority issues for CARIFORUM regional integration consolidated and the approach to trade liberalization determined. ${ }^{53}$ It also was the longest phase, lasting from 30 September 2005 until 30 November 2006. In six technical negotiating rounds, all areas finally included in the CARIFORUM-EC $E P A$ were discussed: market access, including agricultural and non-agricultural goods, sanitary and phytosanitary measures and technical barriers to trade, customs legislation, trade facilitation and trade defence mechanisms; services and investment; trade-related issues; and legal and institutional issues. ${ }^{54}$ Although the negotiations on each of these issues advanced well, increasing divergence in positions arose on key issues, namely the development dimension of the EPA, 55 the commitment of resources for EPA-related projects, ${ }^{56}$ and the Caribbean regional integration process. ${ }^{57}$

In the September 2006 meeting of CARIFORUM-EC Principal Negotiators, consensus was reached on the inclusion of a development chapter in the EPA. ${ }^{58}$ The two parties initially had advocated different approaches on how to incorporate development into the EPA; they eventually concurred on a two-pronged approach:

That meeting took place on 30 September 2011. See Julian, "EPA Negotiations Update December 2005", p. 7. See CRNM, "CARIFORUM-EU Launch Crucial Phase of Trade and Development Talks" RNM Update 0514, 2005. See Julian, “EPA Negotiations Update December 2005”, p. 7. See Delegation of the European Commission in Barbados and the Eastern Caribbean, "The EU and CARIFORUM approach third phase of trade negotiations" e-Newsletter, 2005, Vol. 13.

See ACP Group of States and Council of the European Union, ACP-EU Economic Partnership Agreement Negotiations Cotonou Agreement Article 37.4 Review, p. 11; M. Julian, "EPA Negotiations Update March 2006" Trade Negotiations Insights, 2006, Vol. 5 (2), 6-7, p. 7; Julian, "EPA Negotiations Update August 2006", p. 7.

Caribbean Trade Ministers have expressed their concern at the failure of the EU to give meaningful expression to the development dimension in EPA talks. See CRNM, "Caribbean Ministers Deeply Disappointed with EU Approach to EPA Negotiations" RNM Update 0608, 2006; Julian, “TNI EPA Update June 2006”, p. 7. See Julian, "EPA Negotiations Update August 2006", p. 7; CRNM, "Billie Miller: "EPAs in Danger of Becoming Unfulfilled Promises and Expectations"' RNM Update 0612, 2006.

See CRNM, "Billie Miller: 'EPAs in Danger of Becoming Unfulfilled Promises and Expectations"”.

58 See M. Julian, "EPA Negotiations Update January 2007" Trade Negotiations Insights, 2007, Vol. 6 (1), 6-7, p. 7. 
first, to include a development chapter into the EPA and second, to set out the region's sect oral development needs in each subject-specific chapter, ${ }^{59}$ especially on capacity building and technical assistance. ${ }^{60}$

Regarding the negotiations on intellectual property issues, this phase did not present major controversies: the negotiations "went rather smoothly" once the innovation context had been agreed upon. ${ }^{61}$ By the beginning of 2006, CARIFORUM States were willing to adopt the EU's approach to include various trade-related aspects of intellectual property rights. Until then, the group had refused to discuss IP independently, without linking each IP obligation to a concrete area of developmental interest to CARIFORUM. The EU introduced a non-paper in order to reflect the joint discussions. According to Malcolm Spence, the most problematic aspects of the non-paper were the provisions on multilateral IP treaties that the EU requested CARIFORUM parties to comply with without providing for asymmetry in these obligations. ${ }^{62}$ This problem was solved by allowing CARIFORUM States to use their best endeavours to implement these treaties without fixing a time limit. Also the language on enforcement, which the EU proposed only later in 2006, was not controversial. Even though it drew heavily on the EU's Enforcement Directive 2004/48, ${ }^{63}$ CARIFORUM States considered that much of the prescribed rules were already common practice in their individual states; the little that appeared to go beyond that practice was modified without major discussions. ${ }^{64}$ This method of agreeing to certain rules are commonly known as low adaptation costs and allows for the adoption of rules in an easy way and without much political cost. ${ }^{65}$

The third phase culminated in the EU-CARIFORUM Ministerial on 29-30 November 2006 in Brussels where trade ministers agreed upon the general structure and scope of the EPA and on consolidating texts that would serve as the basis for the final phase of negotiations. In particular, the negotiations in the trade-related areas had advanced considerably well: similar to the chapter on "Innovation and Intellectual Property", the negotiations of other issue areas had resulted in almost finished consensus texts. ${ }^{66}$ The parties also reached agreement on establishing an EPA Council that would implement and review the EPA. ${ }^{67}$ Further negotiations were still required on financial commitments beyond the European Development Fund, on tariff liberalization and the thereto applicable transitional periods. ${ }^{68}$

\footnotetext{
59 See E. Humphrey, Reflections on the Cariforum-EC EPA (Committee on International Trade of the European Parliament, Brussels, 2008).

60 See CRNM, "Progress of Trade Negotiations" RNM Update 0701, 2007.

61 Phone interview with a senior official from a CARIFORUM State, March 2010.

62 See Spence, Innovation and Intellectual Property, paragraph 35.

63 See EC Directive 204/48 of the European Parliament and of the Council of 29 April 2004 on the Enforcement of Intellectual Property Rights (OJ L 157 of 30.04.2004) [hereinafter Enforcement Directive 2004/48].

$64 \quad$ See Spence, Innovation and Intellectual Property, paragraph 37.

65 See also section 11.2.1.3 of this book.

66 See CRNM, "Progress of Trade Negotiations".

67 See Julian, "EPA Negotiations Update January 2007”.

68 See ibid.
} 


\subsubsection{Phase Four: December 2006-December 2007}

The final phase started in December 2006, after the third EC-CARIFORUM Ministerial was finished on 30 November 2006. During that phase, particular focus was paid to the negotiations of market access in both goods and services and the precise implementation of development aspects into the legal provisions of the EPA. ${ }^{69}$ At the beginning of this phase, in April 2007, the EU had announced its dutyfree quota-free market access offer to all the ACP regions. ${ }^{70}$ However, in June 2007, Caribbean countries made clear that commitments on market access and trade facilitation on their behalf would be conditional upon the provision of additional funding for EPA-related adjustment matters by the EU.71 This prompted the EU Development Commissioner to outline additional resources for funding in October 2007. ${ }^{72}$ Also, provisions on financial cooperation were integrated in the EPA. ${ }^{73}$ Even with these commitments, the main subject of disagreement remained the issue of tariff liberalization until the end of the negotiations. ${ }^{74}$ Already in September 2007, it became clear that CARIFORUM States internally could not agree on a marketliberalization offer for goods to the EU. ${ }^{75}$ It was only in early December 2007 when CARIFORUM Heads of Government improved their previous offer and enabled CARIFORUM negotiators to continue negotiations with the European Commission in the final round of 14-16 December 2007. ${ }^{76}$

As concerns the specific technical negotiations in the other areas of the EPA, the various Technical Negotiating Groups on trade-related issues, services, investment and legal issues held several meetings in June, July, September, October and November 2007 in order to come to a final agreement. The negotiations on intellectual property remained mostly uncontroversial, with the exception of the

69 These issues were discussed by the Heads of State of Caribbean states and by the Caribbean-EU Joint Regional Preparatory Task Force in February 2007. See Julian, "EPA Negotiations Update April 2007", p. 11.

See "Chronology - CARIFORUM/EPA Agreement" Jamaica Gleaner (Kingston, 20 July 2008), available at <http://jamaica-gleaner.com/gleaner/20080720/lead/lead8.html> accessed on 12.11.2012.

The CARIFORUM-EC Technical Negotiating Groups met from May 29 until June 1, 2007, in Brussels. See M. Julian, "EPA Negotiations Update August 2007" Trade Negotiations Insights, 2007, Vol. 6 (4), 14-15, p. 15.

During the Special Meeting of CARIFORUM Heads of Government in October 2007, EU Development Commissioner Louis Michel had outlined the sources of funding available to the Caribbean in addition to the European Development Fund, see CARICOM Secretariat, "Press release 228/2007: Remarks by Louis Michel, EU Commissioner, on the Occasion of the Special Meeting of CARIFORUM Heads of Government on EPA Related Issues" (Montego Bay, 5 October 2007), available at <http://www.caricom.org/jsp/pressreleases/pres228_07.jsp> accessed on 15.11.2012. See CRNM, "Contextualizing EPA Provisions on Development and Development Cooperation" RNM Update 0802, 2008.

See CRNM, "The EPA Negotiations at a Critical Stage" RNM Update 0715, 2007; M. Julian and D. Makhan, "EPA Negotiations Update November 2007" Trade Negotiations Insights, 2007, Vol. 6 (7), 14-15, p. 15; D. Jessop, "All or Nothing: The Caribbean EPA" Trade Negotiations Insights, 2008, Vol. 6 (8), p. 14. See "Chronology - CARIFORUM/EPA Agreement".

76 See Speech by B. Golding (Kingston, 10 December 2007), The Status of Negotiations Towards an Economic Partnerbsip Agreement Between CARICOM and the European Commission, paragraph 4. 
protection of geographical indications. According to Malcolm Spence, the agenda point geographical indications was held back by the European Commission until $2007,{ }^{77}$ a strategy already used in previous negotiations with Chile and Mexico and therefore anticipated by CARIFORUM States. ${ }^{78}$

The EU pushed hard for an agreement on protecting a list of specific geographical indications, the so-called "clawback list" of GIs. ${ }^{79}$ However, because of the halt of the negotiations on market access for goods between September and December 2007, the EU did not push further in the GI negotiations and, towards the end of the overall negotiations, accepted to postpone the negotiations on the protection of geographical indications for seven years, allowing CARIFORUM States to develop their own list of GIs first. CARIFORUM States were not acquainted with the protection of geographical indications at the time of negotiations as they used trade marks to protect indications of localities in the course of trade. They feared to be overwhelmed administratively and in terms of economic harm by the large number of EU GIs. ${ }^{80}$

For the GI debate, the slow progress in the market-access negotiations for goods worked to the advantage of CARIFORUM States as it allowed them to keep a strong stance and wait for the EU to concede on that matter. This was not the case for other areas of the negotiations where the influence of the liberalization of market access for goods proved to be a real hindrance to advancing the negotiations. ${ }^{81}$ This is also true with regard to the other areas of IP in which CARIFORUM States were not able to push for more flexibility because the EU's position had hardened as a matter of the stalemate in the trade in goods negotiations. ${ }^{82}$

Finally, although agreement has come later than originally scheduled, CARIFORUM States initialled a comprehensive EPA on 16 December $2007 .{ }^{83}$ It was the only ACP regional grouping to do so as no other ACP region at that time and until October 2012 has agreed to sign a comprehensive EPA.

\subsubsection{Caribbean Forum of African, Caribbean and Pacific States (CARIFORUM): Regional State Actors}

At the regional Caribbean level, Caribbean countries, including the Dominican Republic, formed the group CARIFORUM in order to negotiate with the European Union during the CARIFORUM-EC EPA negotiations. CARIFORUM's institutional structure is based on that of the Caribbean Community (CARICOM) which represents the deepest form of integration in the Caribbean region. Although the Member States of both organizations are not identical (Dominican Republic is part of CARIFORUM but not of CARICOM, the British dependent territory Montserrat is

\footnotetext{
$77 \quad$ See Spence, Innovation and Intellectual Property, paragraph 43.

78 Interview with Malcolm Spence, 7 April 2010, Bridgetown, Barbados.

79 Ibid.

$80 \quad$ See Spence, Innovation and Intellectual Property, paragraphs 43, 44 and 45.

81 See Speech by Golding (The Status of Negotiations Towards an Economic Partnerhsip Agreement Between CARICOM and the European Commission), paragraph 3.

82 Interview with Malcolm Spence, 7 April 2010, Bridgetown, Barbados.

83 See CRNM, “The EPA Negotiations Completed” RNM Update 0716, 2007.
} 
part of CARICOM, but not of CARIFORUM), ${ }^{84}$ the CARIFORUM-EC EPA negotiations were coordinated and carried out by several bodies of CARICOM; representatives of the Dominican Republic were invited to the meetings of relevant CARICOM institutions in order for the interests of all CARIFORUM States to be represented. The regional institutions that had a crucial function during the EPA negotiations were the EPA College of Negotiators, the CARIFORUM Council of Ministers, the Prime Ministerial Sub-Committee (PMSC) on External Negotiations and the Caribbean Heads of Government, the Caribbean Regional Negotiation Machinery and the technical working groups.

\subsubsection{Methodology}

The information presented below has been identified through a literature study of a number of sources. In particular, the website of the Caribbean Regional Negotiation Machinery, ${ }^{85}$ which serves to share information with relevant sectors of society and to gather information and analytical assessments. In addition, the accounts of CRNM staff Richard Bernal ${ }^{86}$ and Junior Lodge ${ }^{87}$ have also been consulted. Press articles in Caribbean newspapers as well as the papers written by Adam Dunlop ${ }^{88}$ and others, such as Norman Girvan ${ }^{89}$ and Keste Miller $^{90}$ provided additional background information.

\subsubsection{The EPA College of Negotiators: Conduct of Technical Negotiations}

The CARIFORUM-EC EPA negotiations on the Caribbean side took place at three tiers: the Ministerial, the Principal Negotiator and the subject-specific technical negotiators. While all three levels had a role to play, the actual technical negotiations were conducted at the second and third tier of negotiations by the EPA College of Negotiators (see Scheme 2). ${ }^{91}$ The College of Negotiators was led by the Principal Negotiator Richard Bernal who served at the time as Director General of CRNM and represented the second tier of negotiations.

Apart from the Principal Negotiator, the College was comprised of eighteen individuals with expertise in the various negotiating areas, many of whom had also

Note that Cuba is a Member of CARIFORUM but did not participate in the CARIFORUM-EC EPA negotiations.

See CRNM, Office of Trade Negotiations.

See R. Bernal, "CARIFORUM-EU Economic Partnership Agreement Negotiations: Why and How" Journal of Eastern Caribbean Studies, 2008, Vol. 33 (2), 1-23.

See Lodge, "Launch of CARIFORUM-EC Negotiations of an Economic Partnership Agreement".

See Dunlop, Szepesi and Van Hove, Organising Trade Negotiating Capacity at Regional Level. See N. Girvan, The Caribbean EPA Affair: Lessons for the Progressive Movement, paper presented at the conference "Remembering the Future: The Legacies of Radical Politics in the Caribbean" in Pittsburgh (Centre of Latin American and Caribbean Studies, 3-4 April 2009).

See K.O. Miller, Paradigms in Caribbean Trade Diplomacy: Negotiating the CARIFORUMEC Free Trade Agreement (University of Westminster, Westminster, 2010).

See Bernal, "CARIFORUM-EU Economic Partnership Agreement Negotiations", p. 12. 
been involved in the FTAA negotiation process..$^{92}$ Members of the College were approved by the CARIFORUM Council of Ministers and included senior officials and ambassadors from CARIFORUM States, the Dominican Republic, representatives from the CARICOM Secretariat, regional experts and CRNM staff members. ${ }^{93}$ These individuals served either as lead or alternate lead negotiators in one negotiating area. The four negotiating areas were 1) market access, 2) services and investment, 3) trade-related issues and 4) legal and institutional issues; one representative of the CARICOM Secretariat held the position of special advisor on the Caribbean Single Market and Economy (see Scheme 3).94 The Principal Negotiator Richard Bernal and his alternate Errol Humphrey, Ambassador of Barbados to Belgium and the EU, served as Dean and Vice-Dean of the EPA College of Negotiators.

The composition of the bodies carrying out the technical negotiations, namely the EPA College of Negotiators as well as the Principal Negotiator, gives a good impression of the important coordinating role that CRNM had in the technical negotiations. At least six staff members of CRNM were part of the EPA College of Negotiators, with at least one of them being represented in each subject area and level of negotiation (see Scheme 3). In fact, the CRNM is being referred to as the face of CARIFORUM States that carried out the negotiations. ${ }^{95}$ According to Junior Lodge, at the time Technical Coordinator of the EPA negotiations for CRNM in Brussels, the choice to draw heavily on CRNM's experience for carrying out the technical negotiations recognized 1) the highly complex and technical nature of the EPA negotiations, and 2) "the imperative of achieving coherence in all spheres of the region's trade negotiations." 96 While CRNM was well represented at the second and third tier of negotiations, its actions were always subject to and supervised by the first tier of negotiations, the Ministerial tier.

92 See Lodge, "Launch of CARIFORUM-EC Negotiations of an Economic Partnership Agreement", p. 2.

93 See CRNM, EPA College of Lead and Alternate Lead Negotiators (2009), available at $<$ http://www.crnm.org/index.php?option $=$ com_content\&view $=$ article\&id=49\&Itemi $\mathrm{d}=99 \& 0872 \mathrm{a} 8 \mathrm{~d} 70 \mathrm{c} 6252 \mathrm{~b} 77261 \mathrm{~d} 45 \mathrm{~b} 4779477 \mathrm{~d}=9 \mathrm{e} 61 \mathrm{c} 804 \mathrm{~b} 7002 \mathrm{~b} 34 \mathrm{ec} 4611 \mathrm{dbfe} 6 \mathrm{~d} 2 \mathrm{dd} 2$ $>$ accessed on 15.11.2012.

94 This was Mr. Ivor Carryl, Programme Manager in the CSME Unit in Bridgetown, Barbados.

95 Phone interview with a senior official from a CARIFORUM State, March 2010.

96 Lodge, "Launch of CARIFORUM-EC Negotiations of an Economic Partnership Agreement", p. 2. 
Scheme 3: EPA College of Negotiators

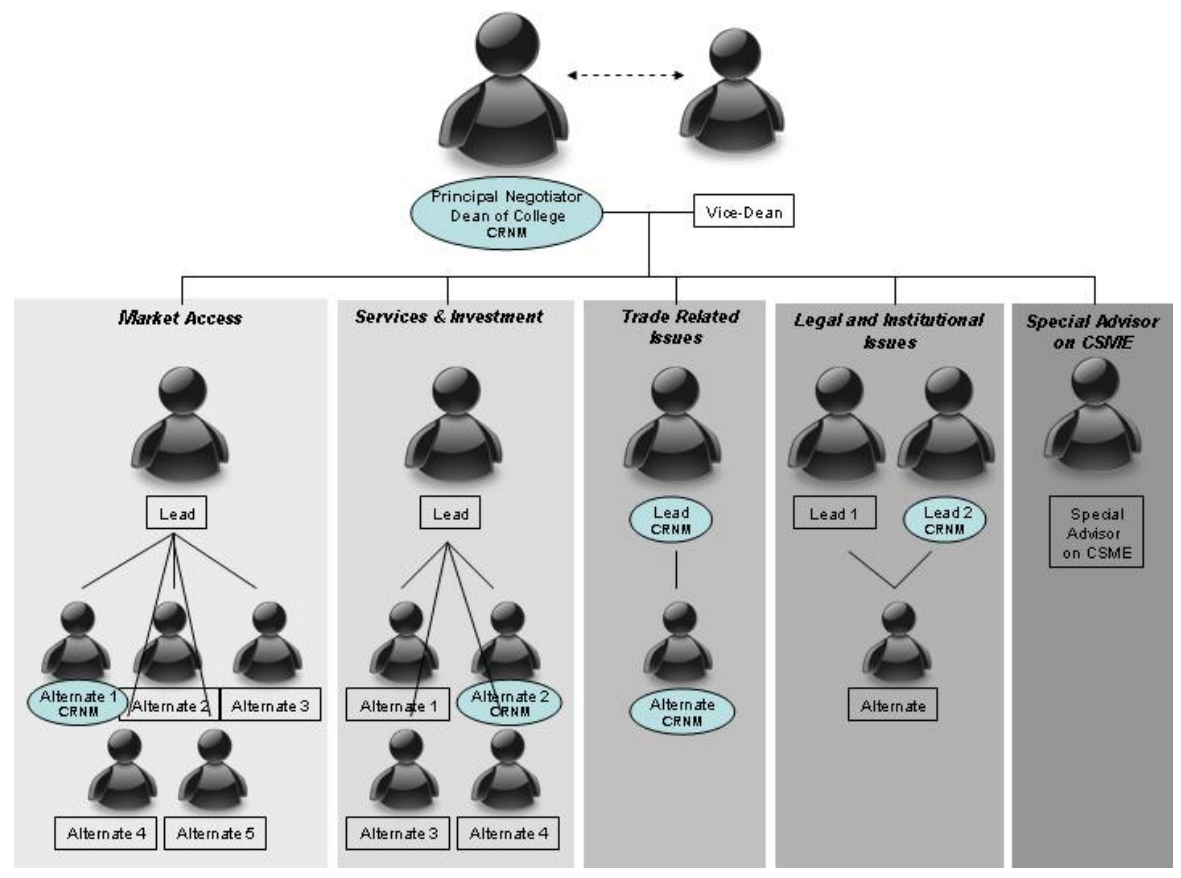

10.1.3.3. CARIFORUM Council of Ministers: Political Direction of the Negotiations

Ministerial supervision of the negotiating positions was carried out by the CARIFORUM Council of Ministers, which consists of the CARICOM Council for Trade and Economic Development (COTED) and the ministerial representative of the Dominican Republic. ${ }^{97}$ The EPA College of Negotiators had to refer its strategy recommendations and negotiating positions to the CARIFORUM Council of Ministers for review and approval. Even though the latter's recommendations were subject to review by the Heads of Government (see below), it was COTED (together with the minister from the Dominican Republic) that "determined the negotiating mandate with the authority of Caribbean Heads of Government." 98

In addition to reporting to the CARIFORUM Council, the Principal Negotiator was also directly responsible to the Caribbean Heads of Government through the Prime Ministerial Sub-Committee (PMSC) on External Negotiations (see Scheme 4). ${ }^{99}$ The PMSC is the forum that is mid-way between the Ministers of the region and the Heads of Government. ${ }^{100}$ The Principal Negotiator reported regularly on the state of negotiations to the PMSC on External Negotiations; according to CRNM, it also

97

See Bernal, "CARIFORUM-EU Economic Partnership Agreement Negotiations", p. 12.

See ibid., p. 14.

See CRNM, "Press Release: From CRNM to OTN" (Kingston, 9 July 2009).

See scheme Governance in Office of Trade Negotiations, About the OTN: Structure, Functions \& Governance (2009), available at <http://www.slideshare.net/CRNM/otngeneralseptember-24-2009> accessed on 20.11.2012, slide 3 . 
served as a quick consultation mechanism when deadlocks or urgent matters in the negotiations needed to be addressed. ${ }^{101}$ This direct line to the Prime Ministers who dealt with external negotiations, however, allowed the Principal Negotiator to bypass the CARIFORUM Council of Ministers, which was perceived "as an affront to the trade ministers". ${ }^{102}$ It deprived the ministers of fulfilling their role in determining the external trade policy position of CARIFORUM as foreseen by the first reporting mechanism.

Although the CARIFORUM Council of Ministers and the PMSC on External Negotiations fulfilled in fact an important role, the highest level of oversight was maintained by the Caribbean Heads of Government. They had the final say on strategy and final positions adopted in the negotiations; their approval of the recommendations issued by the CARIFORUM Council of Ministers was necessary to move on in the regions external trade negotiations. ${ }^{103}$

\subsubsection{Caribbean Regional Negotiation Machinery (CRNM): Coordination of Technical Negotiations}

CRNM was established in April 1997 by CARICOM Heads of Government with the aim

"to develop, coordinate and execute an overall negotiating strategy for various external trade negotiations in which the region was involved."104

With the launch of the FTAA negotiations in 1994 and the conclusion of the Uruguay Round in 1995, Caribbean States realized that they should use the limited human and financial resources in the region in an effective and efficient way in order to benefit from global trade negotiations in the best way possible. The mandate of CRNM therefore was to develop a cohesive and effective framework to coordinate and manage the Caribbean's external trade negotiating resources and expertise. ${ }^{105}$ The programme areas of CRNM, which are detailed in the RNM Strategic Plan 2003/4$2007 / 8,106$ consist of 1) carrying out consultations with national and regional interest groups, 2) formulating regional negotiating positions, 3) representing its Member States in the main negotiating forums, such as the WTO, EPAs and bilateral negotiations, for example with Canada, 4) building regional negotiating capacity, 5) providing advice through technical research and analysis and 6) mobilize human and financial resources to strengthen the technical and professional capacity of CRNM and Member States. ${ }^{107}$ According to these prescribed tasks, CRNM assumed different roles in the negotiating process of the CARIFORUM-EC EPA, as elaborated below. CRNM is financed through two major sources: 1) Member States' contributions

\footnotetext{
101 See CRNM, "Press Release: From CRNM to OTN".

102 See Miller, Paradigms in Caribbean Trade Diplomacy: Negotiating the CARIFORUM-EC Free Trade Agreement, p. 368.

103 See Lodge, "Launch of CARIFORUM-EC Negotiations of an Economic Partnership Agreement", p. 2.

104 Office of Trade Negotiations, The Office of Trade Negotiations - Its Function, Structure and Mandate (2012), available at <www.crnm.org > accessed on 20.11.2012.

105 See ibid.

106 See Office of Trade Negotiations, About the OTN: Structure, Functions \& Governance.

107 See ibid.
} 
constituting the core financing, and 2) donor contributions that fund programme activities and some staff members. ${ }^{108}$

\subsection{From CRNM to OTN}

Even though CRNM was set up by CARICOM Heads of Government, it was not incorporated into the CARICOM institutional framework. Originally, CRNM was established as a programme, not as an institution; ${ }^{109}$ however, it soon developed into a regional intergovernmental organization of its own, different from CARICOM. ${ }^{110}$ Its membership not only comprised CARICOM Member States, but also the Dominican Republic and Cuba. This organizational set-up ${ }^{111}$ as well as its name was changed in 2009: CARICOM Heads of Government decided to incorporate CRNM into the CARICOM Secretariat as a Specialized Department and to alter the name of the machinery into the Office of Trade Negotiations (OTN). ${ }^{12}$ This re-organization was carried out because of the criticism by Guyana's President Bharrat Jagdeo who disapproved of CRNM's work during the EPA negotiations. ${ }^{113}$ Seemingly, CARICOM Member States felt that it was necessary to provide a stronger link with existing CARICOM institutions in order to establish more stringent governance structures.

The governance structures during the EPA negotiations had been organized in a twotiered way: the College of Negotiators reported 1) to the CARIFORUM Council of Ministers and 2) directly to the Prime Ministerial Sub-Committee (PMSC) on External Negotiations (see Scheme 4). The latter reporting line served as a quick consultation mechanism whenever negotiations had reached a deadlock and an urgent decision was needed. ${ }^{114}$ It is this mechanism that has been eliminated from the new governance structure of OTN, for purposes of guaranteeing "proper oversight," 115 as a regional journalist noted. OTN will now report only to CARICOM Council of Ministers and, by extension, to the Heads of Government through the Secretary General of the CARICOM Secretariat. ${ }^{116}$ It is these two bodies (and not the

Donors have been the Canadian International Development Agency, the Deutsche Gesellschaft für Internationale Zusammenarbeit, the Department for International Development and Cooperation of the United Kingdom, United States Agency for International Development, the Caribbean Development Bank, the Commonwealth Secretariat, the European Commission, the Inter-American Development Bank, the Organization of American States. See ibid; Dunlop, Szepesi and Van Hove, Organising Trade Negotiating Capacity at Regional Level, p. 16. See Dunlop, Szepesi and Van Hove, Organising Trade Negotiating Capacity at Regional Level, p. 15.

110 See Office of Trade Negotiations, About the OTN: Structure, Functions \& Governance. The re-organization did not affect its membership: OTN still represents CARICOM Member States, the Dominican Republic and Cuba. See CRNM, "Press Release: From CRNM to OTN". See Stabroek, "Gail Mathurin to head regional negotiating office" Stabroek News, 2009. See CRNM, "Press Release: From CRNM to OTN".

Kaieteur News, "CRNM renamed OTN, has new Director General" Kaieteur News Online (Georgetown, Guyana, 18 November 2009), available at <http://www.kaieteurnewsonline.com/2009/11/18/crnm-renamed-otn-has-newdirector-general/> accessed on 16.11.2012. 
PMSC) that will provide policy guidance to and approve the work programme and budget of OTN. ${ }^{117}$ In addition, its mandate was extended to include all external trade negotiations, rather than assuming responsibility for selected trade-related issues only. ${ }^{118}$ OTN undertakes the same programme activities within the various negotiation forums as CRNM did previously, although there are plans to expand the original six programme areas. ${ }^{119}$

The name change was decided upon in order to reflect the function of CRNM better: while the name regional negotiating machinery suggested that CRNM negotiated everything for CARICOM, the name Office of Trade Negotiations now correctly identifies that the office only deals with trade-related matters. ${ }^{120}$

Scheme 4: Governance structure of CRNM during the EPA negotiations

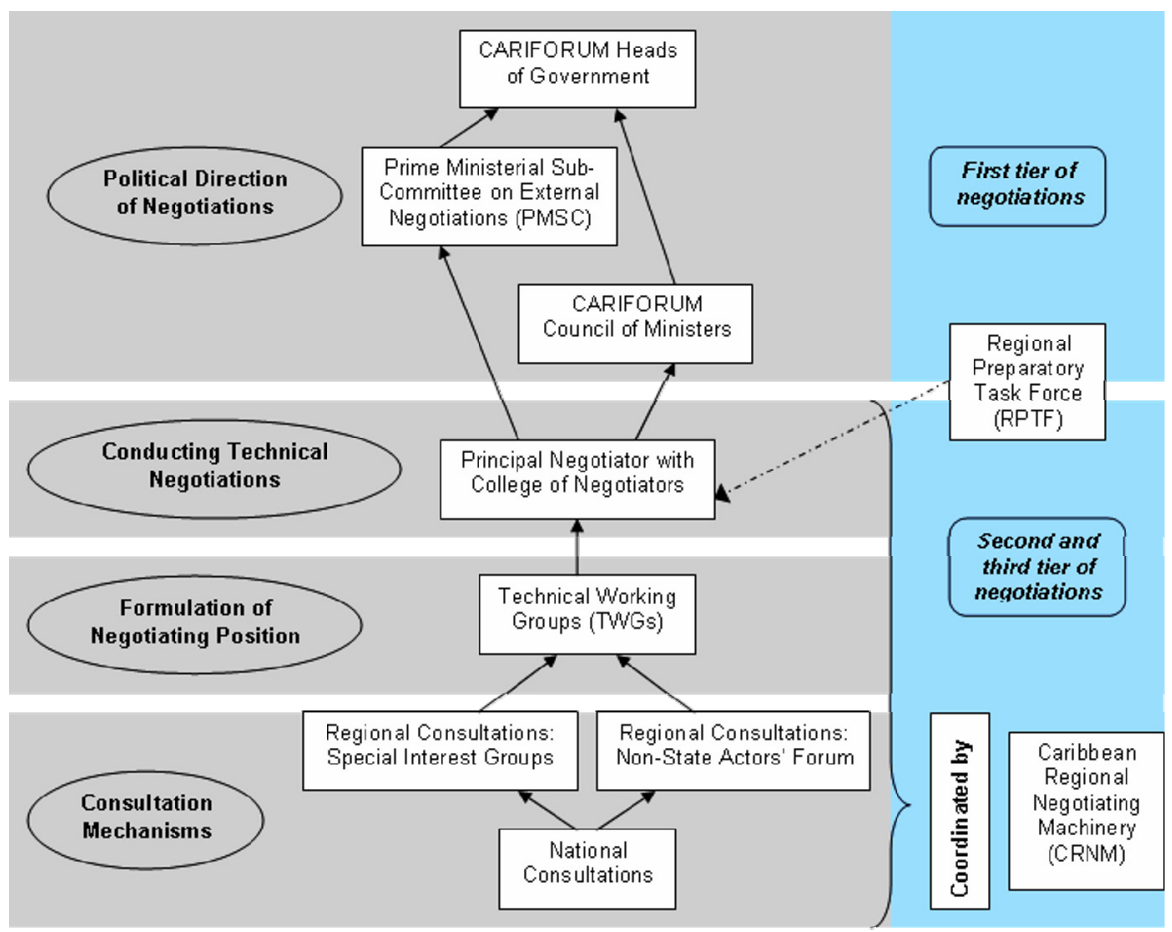

CARIFORUM States, OTN will report to the CARIFORUM Council of Ministers (COTED enlarged by the Minister of the Dominican Republic) and, by extension, to the CARIFORUM Heads of Government.

117 See Office of Trade Negotiations, About the OTN: Structure, Functions \& Governance.

118 See Kaieteur News, "CRNM renamed OTN, has new Director General".

119 See Office of Trade Negotiations, About the OTN: Structure, Functions \& Governance.

120 See Kaieteur News, "CRNM renamed OTN, has new Director General". 


\subsection{Difficult role of CRNM}

The organizational changes to CRNM undertaken by CARIFORUM States reflect that the role of CRNM during the EPA negotiations and its institutionalization has created tensions among CARICOM Member States. CRNM staff members were exposed to considerable criticism during and particularly after the EPA negotiations. ${ }^{121}$ As stated above, ${ }^{122}$ part of the unhappiness of CARICOM Member States had to do with the reporting structure in which CRNM was able to address the Heads of Government directly, bypassing the CARIFORUM Council of Trade Ministers. However, another problem constituted the way in which the negotiations were conducted. ${ }^{123}$ To understand what CRNM tried to achieve during the negotiations, it is important to analyze the various roles CRNM was supposed to fulfill during the negotiations.

First, CRNM formed part of the group of technical negotiators that carried out the negotiations in each subject area. Its Director General even assumed the post of Principal Negotiator. In that role, CRNM represented the interests of CARIFORUM States and therefore was also bound by their views. Even though CARIFORUM States have been present during actual negotiations, ${ }^{124}$ CRNM was the contact point for the European Commission, which it addressed for negotiations. In that capacity, CARIFORUM States needed to trust and rely on the work and attitude of CRNM.

Second, CRNM had a supportive and coordinating role. Its staff members advised CARIFORUM States on negotiating positions; they provided technical analysis of relevant subject matters, facilitated stakeholder consultations and coordinated the meetings of negotiators. In this role, CRNM often acted as chair in consultative, deliberative or preparatory meetings.

Third, CRNM was also a key stakeholder with its own opinion on which direction the negotiations should go. In fact, it assembled some of the most skilled experts in the various areas of trade negotiations in the region. They wanted to contribute their knowledge to the formulation of the negotiating positions.

See Miller, Paradigms in Caribbean trade diplomacy: Negotiating the CARIFORUM-EC Free Trade Agreement, p. 390. Although the interviewees in Jamaica and Barbados, particularly the senior officials, did not express this criticism in the interviews, one interviewee from the Private Sector Organization of Jamaica, Omar Chedda, confirmed that it was felt that CRNM went beyond its mandate in negotiating for the entire region. Interview with Omar Chedda, Trade and Environment Manager of the Private Sector Organization of Jamaica, 12 April 2010, Kingston, Jamaica (available on request); see Girvan, The Caribbean EPA Affair, p. 14. See section 10.1.3.4.1 of this book.

Among others, the then President of Guyana, Bharrat Jagdeo, had led the criticism of the CRNM over the manner in which the EPA had been concluded. See Stabroek, "Gail Mathurin to head regional negotiating office"; "Guyana - Jagdeo says negotiating mechanism flawed" Jamaica Gleaner (Kingston, 13 July 2009), available at $<$ http://jamaica-gleaner.com/gleaner/20090113/carib/carib1.html> accessed on 12.11.2012.

Phone interview with a senior official of CARIFORUM State, March 2010. 
Separating these roles from each other depending on the forum they were in constituted a difficult task for CRNM. This was particularly so as their conviction on how to approach the negotiations did not coincide and sometimes even contradicted those of officials from CARIFORUM States. ${ }^{125}$ According to Junior Lodge, at the time Technical Coordinator of the EPA negotiations for CRNM in Brussels, CARIFORUM States felt uneasy about the profile and attitude CRNM had towards the trade negotiations. According to them, during the negotiations, CRNM took on its own views as a stakeholder, which CARIFORUM States perceived to be closer aligned to the EU position than to their own. ${ }^{126}$ Their views and opinions, they felt, were not correctly reflected in the negotiations. In particular, it was perceived that CRNM had operated with a significant degree of autonomy, which promoted a disconnect from the CARICOM integration process and facilitated an alignment with the negotiating agenda of the European Commission. ${ }^{127}$ While this difficult relationship constituted a challenge to the negotiating team, these observations seem to be comparable to similar situations where the negotiating team (agent) is not identical to the principal. A well-documented example is the context of the European Union Member States and their relationship with the Trade Policy Committee. ${ }^{128}$

Another factor that played into this tense relationship was the asymmetry in technical knowledge; CRNM staff was clearly more skilled in most areas under negotiation in the EPA than CARIFORUM States, in particular with regard to intellectual property issues. Beverley Pereira noted that in many CARICOM Member States that form part of the CARIFORUM group, there was limited knowledge and experience concerning intellectual property rights. ${ }^{129}$ As a result, it was often difficult for negotiators to obtain information on national positions on various intellectual property issues under negotiation. Small countries tend to have skills in other, more traditional areas of trade. They were not informed enough to question technical propositions on IP made by the negotiating team. Many CARICOM Member States had the impression that CRNM was pushing them beyond their capacity with respect to various negotiating areas. This might have left them with an uneasy feeling that CRNM took technical decisions rather independently.

\subsubsection{Technical Working Group (TWGs): Formulation of Negotiating Positions}

Also in the formulation of negotiating positions for the EPA College of Negotiators, CRNM played an important coordinating role. Through a number of consultation

125 Interview with Junior Lodge, Technical Coordinator of the EPA negotiations for CRNM in Brussels, 3 March 2010, Geneva (available on request).

126 See ibid.

127 See Girvan, The Caribbean EPA Affair, p. 14.

128 Several scholars have addressed the principal-agent framework in the context of trade policy in the European Union. See T. Delreux and B. Kerremans, "How Agents Weaken their Principals' Incentives to Control: The Case of the EU Negotiators and EU Member States in Multilateral Negotiations" Journal of European Integration, 2010, Vol. 32 (4), 357-374, p. 364; M. Pollack, "Delegation, Agency, and Agenda Setting in the European Community" International Organization, 1997, Vol. 51 (1), 99-134; B. Kerremans, "What Went Wrong in Cancun? A Principal-Agent View on the EU's Rationale Towards the Doha Development Round" European Foreign Affairs Review, 2004, Vol. 9 (3), 363-393.

129 Interview with Beverley Pereira, 6 April 2010, Kingston. 
processes with various stakeholders and experts at the regional and the national level, ${ }^{130} \mathrm{CRNM}$ collected information in order to develop negotiating positions for the different subject areas. It then proposed a negotiating position to officials at the technical level and invited them for discussion to technical working group meetings. ${ }^{131}$ It is in these technical working groups on each subject area that the negotiating positions were discussed in detail. The discussions led to the adoption of regional positions that were subsequently sent as recommendations to the CARIFORUM Council of Ministers for approval (see Scheme 4). ${ }^{132}$ This procedure also has strong similarities with the specialized working groups in the European Union Council of Ministers.

TWGs comprised officials and experts from CARIFORUM States, officials from regional secretariats, such as the OECS Secretariat and CARICOM Secretariat, regional private sector organizations, ${ }^{133}$ labour organizations, ${ }^{134}$ the University of the West Indies ${ }^{135}$ and technical experts from the CRNM. These working groups were formed for specific subjects, being market access, agriculture, services and investment, legal and institutional issues, and trade-related issues. ${ }^{136}$ They met before and after each negotiating session. ${ }^{137}$ From the official launch of the regional negotiations in April 2004 until their finalization, in total at least twenty-nine meetings of TWGs were convened, ${ }^{138}$ among which at least six TWGs on traderelated issues, which included the protection of intellectual property. ${ }^{139}$

The technical working groups fulfilled a crucial role in the generation of regional negotiating positions and in providing a forum in which the technical negotiators (in the form of CRNM) met major stakeholders, in particular CARIFORUM States' officials, to discuss issues, ask questions and seek clarifications where necessary. ${ }^{140} \mathrm{It}$ was through this process that consensus among various stakeholders was built and

4

See section 10.2.2 and 10.2.3 of this book.

See C. Preville, Mid-Term Review of the Negotiation of an Economic Partnership Agreement (EPA) between CARIFORUM and the EC: Implications for Agriculture and Farmers of the Windward Islands (9 November 2006), p. 22.

See Miller, Paradigms in Caribbean trade diplomacy: Negotiating the CARIFORUM-EC Free Trade Agreement, p. 127.

"Private sector organizations" is understood as a synonym for industries, businesses and producers as well as the associations assembling them. See section 10.2.1 of this book.

Labour organizations are otherwise referred to as trade unions and present associations of workers. An example from the Caribbean region is the Caribbean Congress of Labour which represents thirty individual trade union and coalitions in Caribbean countries. See A.D. Montoute, Civil Society Participation in Trade Negotiations: A Caribbean Case Study (University of the West Indies, St. Augustine, 2009), p. 153.

See ibid., p. 418.

See Bernal, "CARIFORUM-EU Economic Partnership Agreement Negotiations", p. 14.

See Miller, Paradigms in Caribbean trade diplomacy: Negotiating the CARIFORUM-EC Free Trade Agreement, p. 380.

See Bernal, "CARIFORUM-EU Economic Partnership Agreement Negotiations", p. 14.

See CRNM, "News Briefs" RNM Update 0610, 2006; CRNM, "Upcoming events" RNM Update 0713, 2007; CRNM, "News Briefs" RNM Update 0711, 2007.

Phone interview with a senior official from a CARIFORUM State, March 2010. 
that information was disseminated and exchanged with the private sector and civil society in general. ${ }^{141}$

\subsubsection{The Regional Preparatory Task Force (RPTF)}

Although not a formal entity in the negotiating structure, the Regional Preparatory Task Force ${ }^{142}$ played an important role in connecting the CARIFORUM-EC EPA negotiations with the development support component of the Cotonou Agreement. ${ }^{143}$ The RPTF was mandated under Articles 1, 18, 20 and 35 of the Cotonou Agreement and was put in place shortly after the regional negotiations had started. ${ }^{144}$ Its mandate was to

"translate needs for support identified in the course of the negotiations into operational ideas for trade-related and other development assistance". ${ }^{145}$

The task force was guided by the decisions of the CARIFORUM-EC Principal Negotiators, as agreed upon at its first meeting in November 2004. ${ }^{146}$ Its activities encompassed the pre-identification of new initiatives and sources to finance them as well as assisting CARIFORUM negotiators in assessing existing research activities or projects and identifying key state and non-state stakeholders, which should be consulted during the preparatory phase. ${ }^{147}$

According to Malcolm Spence, however, the background work by RTFP to inform regional negotiating positions in different areas was not completed in time for the negotiations. The task force had used most of its time to discuss what work should be done rather than actually carrying out the work. ${ }^{148}$ Consequently, its main task has

See Montoute, Civil Society Participation in Trade Negotiations, p. 419.

The RPTF consists of the CARIFORUM Regional Authorizing Officer (who co-chairs the RPTF together with a representative of the EU); National Authorizing Officers; representatives of the OECS, the CARICOM Secretariat, the Caribbean Development Bank and the CRNM; a CARIFORUM member of the ACP Development Finance Committee; non-state actors and universities; and representatives of the European Commission (DG Trade, DG Development, EuropeAid and an EU Delegation based in the Caribbean). See Bernal, "CARIFORUM-EU Economic Partnership Agreement Negotiations", p. 18; European Commission and CARIFORUM, Terms of Reference for CARIFORUM-EC Regional Preparatory Task Force (August 2004), available at $<$ http://www.delbrb.ec.europa.eu/en/epa/epa_docs/RPTF_ToRs_Adopted_version _August_2004.pdf $>$ accessed on 19.05.2011, p. 3.

See European Commission, Plan and Schedule for CARIFORUM EC Negotiation of an Economic Partnership Agreement, p. 4.

The first meeting of the RPTF took place on 11 November 2004 in Barbados. See European Commission and CARIFORUM, Terms of Reference for CARIFORUM-EC Regional Preparatory Task Force, p. 2.

See CRNM, "CARIFORUM and EC Advance Regional Integration Elements of EPA Negotiations".

See European Commission and CARIFORUM, Terms of Reference for CARIFORUM-EC Regional Preparatory Task Force.

Interview with Malcolm Spence, 6 April 2010, Bridgetown, Barbados. While it seems true that the negotiators were not much helped by the work of the RTPF, note that, for example, during the second phase of the regional negotiations, RTPF did identify priority areas that needed to be supported by the EPA. It submitted eleven proposals 
become to evaluate the costs of implementation, which the RTFP only started to deal with after the negotiations had been completed.

\subsubsection{Interim Conclusions}

The regional institutions presented above played rather distinct roles in the negotiations of the CARIFORUM-EC EPA. Four phases of the negotiations have been distinguished in order to illustrate each actor's function in this process: 1) the formulation of the regional negotiating position, 2) the political direction of the negotiations, 3) the conduct of the technical negotiations, and 4) the coordination of the negotiations. Several conclusions can be drawn from this analysis.

First, the formulation of the regional negotiating position was informed by the input from 1) national and regional consultations with public and private stakeholders, 2) research and studies undertaken by CRNM staff and 3) the, although limited, results provided by the RPTF. These results were taken up in the deliberations of the technical working groups that formulated the regional negotiating positions for each area under negotiation in the EPA.

Second, the regional negotiating positions formulated by the Technical Working Groups were subject to the approval by political CARICOM institutions, enlarged by the respective representative of the Dominican Republic. The ministers of the region supervised the decisions taken by the TWGs and submitted them to the Heads of Government for final review. The Prime Ministerial Sub-Committee on External Negotiations could also guide the negotiations through its regular contact with the Principal Negotiator.

Third, based on the decisions taken by the political organs of the region, the EPA College of Negotiators carried out the technical negotiations for the region. It was led by a Principal Negotiator and assembled experts from the region for each area under negotiation in the EPA. With the Principal Negotiator and at least five other members of the College being CRNM staff, the important role of the latter in the College becomes evident.

Fourth, the negotiations were coordinated by CRNM. This regional negotiation machinery constituted a unique feature in the ACP region during the EPA negotiations: it assembled experts from the Caribbean region who were highly involved in the negotiations. CRNM facilitated the regional consultations, provided technical knowledge and advice on the negotiation areas, chaired technical working group meetings and was prominently represented in the EPA College of Negotiators. Hence, it fulfilled three kinds of roles: a coordinating, negotiating and advisory role. This institutional set-up as well as the relative asymmetry in technical expertise between CRNM staff and CARIFORUM States made CRNM a very influential actor for the determination of the regional negotiating position as well as for the conduct of the technical negotiations. This has caused severe tensions between CARIFORUM States and CRNM, which ultimately led to an institutional re-organization of this body.

for strengthening regional integration to the European Union. See CRNM, "CARIFORUM-EU Launch Crucial Phase of Trade and Development Talks". 


\subsubsection{Jamaica: National State Actors}

Next to the regional institutions involved in the negotiations of the CARIFORUMEC EPA, CARIFORUM States determine their national policy positions on the issues under negotiation and thereby inform the regional negotiating position. In this process of determining national policy positions, relevant national actors are involved. These Jamaican actors are 1) the Jamaican Parliament, 2) the Ministry of Foreign Affairs and Foreign Trade, 3) the Jamaican Intellectual Property Office (JIPO), 4) Jamaica Promotions Corporation (JAMPRO), 5) the Scientific Research Council (SRC) and 6) the Coffee Industry Board (CIB).

Particular attention is paid to the institution's function in international trade negotiations, their tasks with regard to intellectual property protection and their role during the EPA negotiations. JAMPRO, the SRC and the CIB take up a special position in this regard. They constitute government bodies that provide services to particular groups of stakeholders and often represent these groups' interests towards the Jamaican Government. In relation to these three bodies, the analysis also addresses the following issues: 1) which stakeholders are represented by them, 2) what were the stakeholders' and the agencies' interests in intellectual property protection in respect of EPA negotiations, 3) what were the agencies' activities to further these interests and 4) how did they perceive that their interests were treated by the Ministry of Foreign Affairs as the main Jamaican policy maker on IP issues negotiated in international trade agreements.

\subsubsection{Methodology}

Although there are more government bodies involved in international trade negotiations, the choice of actors presented below has been made based on their particular involvement in the determination of policy positions on intellectual property protection. These actors have been identified through a literature study (WTO Trade Policy Review reports, the report by Jessen and Vignoles and the paper by Dunlop and others) and interviews carried out with officials from the Ministry of Foreign Affairs and Foreign Trade and the Jamaican Intellectual Property Office. ${ }^{149}$ The Jamaican Parliament has been included due to its important role in the policymaking process in general.

The information presented below is mainly derived from interviews with at least one official from each institution; ${ }^{150}$ an exception is the Jamaican Parliament where no Member of Parliament could be interviewed. Also the interview with Douglas Graham was informative for the section on the Coffee Industry Board. Other

149 The Rural Agricultural Development Authority has been identified as another important actor in the area of food products which has also been a member of the GI working group. Interview with Stacian Bennett, Legal Officer and Board Secretary of the Coffee Industry Board, 7 April 2010, Kingston (available on request). However, contact could not be established with the Authority and the interviews with two officials from the Ministry of Agriculture, under whose direction the Authority falls, did not reveal enough information on the Rural Agricultural Development Authority.

150 Interviews with four institutions were conducted in person in March/April 2010; the interview with an official of JAMPRO was conducted on the phone in September 2010. 
sources consulted are, among others, press articles, online information available on the institutions' websites and the constituting acts of the institutions.

\subsubsection{Jamaican Parliament}

The Jamaican Parliament, consisting of the House of Representatives and the Senate, de jure and de facto had no role to play during the negotiations of the EPA negotiations. Its involvement during the process of signature and ratification of the EPA was also very limited; only a few discussions took place on the state of negotiations.

Concerning the negotiation of trade agreements, the Parliament is not involved in this process. Moreover, the Jamaican Constitution of 1962 does not contain any obligation for the Executive to keep the Parliament informed about the state of international trade negotiations. However, the lack of such an obligation did not preclude the Executive from, occasionally, informing Members of Parliament about the EPA negotiations. For example, in January 2007, the then Minister of Foreign Affairs and Foreign Trade Anthony Hylton gave a speech to the Jamaican Senate in which he emphasized that Jamaica is not forced to

"adhere to a timeline if we are not satisfied that we have negotiated the best possible agreement for stakeholders in Jamaica and the wider CARIFORUM". ${ }^{151}$

One news article from March 2007 indicates that, seemingly as a consequence of this speech, discussions took place in the Jamaican Parliament on the implications of a possible non-conclusion of the EPA by the 2007 deadline. ${ }^{152}$ Next to the Minister of Foreign Affairs and Foreign Trade, on 9 October 2007 the Prime Minister also gave a report in the House of Representatives on the results of the meeting of the PMSC on External Negotiations on 4-5 October 2007 in Montego Bay. ${ }^{153}$

While the Executive "voluntarily" provided incidental updates to the Parliament during the EPA negotiations, the Parliament could also seek information on its own initiative. For example, it disposes of a Parliamentary Sub-Committee on International Relations which could monitor the process of trade negotiations. ${ }^{154}$ In addition, Members of the House of Representatives can ask questions of the

151 See "Unusually strident Hylton warns Europe" Jamaica Observer (Kingston, 28 January 2007), available at <http://www.jamaicaobserver.com/news/118410_Unusuallystrident-Hylton-warns-Europe $>$ accessed on 12.11.2012.

See Technical Centre for Agricultural and Rural Cooperation, "Joint report of the seventh meeting of principal negotiators" Agritrade News Update (Wageningen, 28 February 2007).

See "CARIFORUM Heads Committed to Concluding EPA Negotiations by Year End - Golding" Jamaica Information Service (Kingston, 10 October 2007), available at $<$ http://www.jis.gov.jm/news/archive/13214-officePM-cariforum-heads-committedto-concluding-epa-negotiations-by-year-end-g $>$ accessed on 29.10.2012. Note that in September 2007, a new Government was selected in Jamaica. The Minister of Foreign Affairs and Foreign Trade became Dr. Kenneth Baugh and the Prime Minister Portia Simpson-Miller was succeeded by Bruce Golding. from this source, no other reference to the work of the sub-committee could be found and no information could be obtained on whether the committee has been involved in discussions on the EPA. 
Government. According to a senior official from the Ministry of Foreign Affairs and Foreign Trade, the spokesperson of the opposition on Foreign Affairs has asked some questions of the Government on the EPA from time to time. ${ }^{155}$ While these ways of keeping abreast with the developments of trade negotiations exist and have been used sometimes, the Parliament does not have an active role to play in the process of negotiating trade agreements. It is not involved in the process of making policies for international trade agreements.

Also in the phase of signing international agreements, the Jamaican Parliament has no active role. Under the Jamaican Constitution of 1962, neither its assent nor its consultation is required; it is sufficient that the Executive, in form of the Cabinet, approves the signature of the agreement by consensus. ${ }^{156}$ In the case of the EPA, the Prime Minister exceptionally took the political decision to involve the House of Representatives in the process of signature: ${ }^{157}$ it approved the signature of the EPA on 2 September 2008.158 The Parliament was informed about the content of the EPA through a paper by the Ministry of Foreign Affairs and Foreign Trade, which contained a summary of the EPA and its full text. ${ }^{159}$ Even though the positive vote reflects that the majority of the House's Members were in favour of the EPA in general, it was noted that the opposition People's National Party (PNP) walked out during the vote as it particularly opposed the most-favoured-nation treatment obligation included in the EPA. ${ }^{160}$

The MFN treatment obligation obliges CARIFORUM States to accord European exporters the same favourable treatment that they provide to other major trading economies in free trade agreements. ${ }^{161}$ In other words, by way of the MFN treatment obligation, CARIFORUM States immediately extend benefits agreed with other countries to the European Union. Criticism with regard to the MFN clause in the EPA had also been raised by Brazil in the WTO General Council Meeting in February 2008 since it believed that the MFN clause would provide a disincentive for CARIFORUM States to negotiate agreements that contain more favourable market access conditions than the European Union and thereby undermine South-South trade. ${ }^{162}$

What the legal status of the vote by the House of Representatives on the signature of the EPA is and whether a negative vote would have prevented the agreement from

155 Ibid.

156 Ibid.

$157 \quad$ Email correspondence with Michelle Walker, 26 May 2011.

158 See D. Luton, "EPA Vote Widens Bitter Divide" Jamaica Gleaner (Kingston, 04 September 2008).

159 See "Chronology - CARIFORUM/EPA Agreement".

160 See Luton, "EPA Vote Widens Bitter Divide".

161 The most-favoured-nation treatment obligation is contained in Article 19 of the CARIFORUM-EC EPA for trade in goods and Articles 70 and 79 of the CARIFORUM-EC EPA for trade in services. According to these articles, Major trading economies are defined as any country or territory accounting for a share of world merchandise exports above 1 percent in the year before the entry into force of the free trade agreement between CARIFORUM and that country.

162 See CRNM, The Cariforum-EC Economic Partnership Agreement: Highlights on the MostFavoured Nation (MFN) clause in the EPA (2008) [3200.2/EPA-04 [08]]. 
being signed is unclear. Bearing in mind that the House's involvement in the process of signature was a voluntary choice by the Prime Minister, it can be concluded that Parliament cannot exercise much influence during the phase of signature.

The final legal requirement for an international agreement to enter into force is ratification. Also at this point, the Jamaican Parliament is not involved in the approval process that authorizes ratification. Ratification takes place by the Prime Minister, the Minister of Foreign Affairs and Foreign Trade or another Minister to whom that power is delegated; they can only do so after approval by the Cabinet, which takes decisions by consensus. ${ }^{163}$ No role is foreseen for the Parliament at this stage. As a Member of CARICOM, Jamaica is bound by Article 80 of the Revised Treaty of Chaguaramas, ${ }^{164}$ which stipulates that CARICOM Member States cannot enter into trade agreements unilaterally. The EPA therefore can only enter into force for Jamaica after all CARICOM Member States have ratified the agreement and have notified this ratification to the CARICOM Secretariat. ${ }^{165}$

The phase during which Parliament can have an impact is after the agreement has been negotiated, signed and ratified, namely in the implementation phase. In case the current laws do not yet foresee all rights and obligations stipulated in the EPA, these rules that are lacking will need to be implemented into national law either by creating new implementing legislation or by amending existing laws. Both Houses of Parliament are actively involved in passing bills for new legislation. After the Executive has introduced a bill in either House of Parliament, the bill goes through the first and second reading by the House of Representatives and subsequently through the Committee and reporting stage until it is accepted or rejected in the third reading. ${ }^{166}$ When the House of Representatives has passed the bill it is placed before the Senate for a similar procedure.

It is in the phase of implementation that the details of the obligations undertaken in the EPA are interpreted and formulated as they will apply in Jamaica. This process gives Parliament an important role. However, despite its strong involvement in this phase, Parliament does not get to discuss the rules of the EPA at the level of their substance at a moment when these rules can still be amended or taken out of the agreement. Also, the value of Parliament's role in implementing the EPA must not be overestimated as several of its provisions are already legislation-like obligations, as exemplarily identified for the chapter on intellectual property protection. ${ }^{167}$ Even though these provisions still need to be implemented in national law, legislation-like

See Advocates for International Development, Ratification of EPAs: the process required in each ACP state (London, 2008) [LONDON-4518122.1], available at $<$ http://www.normangirvan.info/epa-ratification-procedures-in-acp-states-byadvocates-for-international-development/> accessed on 12.11.2012, p. 41. CARICOM Secretariat, Revised Treaty of Chaguaramas Establishing the Caribbean Community Including the CARICOM Single Market and Economy, signed on 5 July 2001 in Nassau and entered into force on 4 February 2002, 2259 U.N.T.S. 293 [hereinafter Revised Treaty of Chaguaramas.

See Advocates for International Development, Ratification of EPAs: the process required in each ACP state. See WTO Secretariat, TPR Jamaica 2005, paragraph 9. Agreement. 
language in a trade agreement does not leave much space for the implementation process in determining the precise content of the agreed rules: this content is already detailed in the EPA.

\subsubsection{Ministry of Foreign Affairs and Foreign Trade (MoFAFT)}

International trade issues fall under the competence of the Ministry of Foreign Affairs and Foreign Trade. It is the Foreign Trade department of this Ministry that has primary responsibility for the formulation and implementation of foreign trade policy as well as the negotiation of foreign trade agreements. In particular, this encompasses the negotiations of trade agreements concluded at the multilateral, regional or bilateral level, such as the Economic Partnership Agreement negotiated with the European Union and its Member States. This responsibility extends to intellectual property matters in international relations.

As trade agreements are very complex and comprehensive in nature, MoFAFT works closely together with other ministries and agencies. One forum of collaboration with partner ministries and agencies is the cabinet-level International Relations and Trade Committee that the Minister of Foreign Affairs and Foreign Trade chairs together with the Prime Minister. ${ }^{168}$ With regard to international negotiations, the Committee reviews the recommendations put forward by the MoFAFT in order to ensure that negotiating positions benefit from the expertise and know-how present in other ministries. ${ }^{169}$

When it comes to the formulation of foreign trade policy, MoFAFT plays an important role in coordinating the policy-making process. It is through the consultative mechanism Jamaica Trade Adjustment Team (JTAT) that positions on, among others, IP matters are generated. JTAT is a task force that brings together state and non-state actors and is chaired by a Senior Trade Official of the MoFAFT. ${ }^{170}$ Its composition and role during the EPA negotiations is elaborated below. ${ }^{171}$ In addition, the MoFAFT is supported by the work of the eighteen Jamaican diplomatic missions and consulates in the world. ${ }^{172}$ For the formulation of specific policies, such as in the area of intellectual property protection, MoFAFT relies heavily on the work of government agencies such as the Jamaica Intellectual Property Office (JIPO), the Jamaica Promotions Authority (JAMPRO) and the Scientific Research Council (SRC) (see Scheme 5). For example, specific consultations with private stakeholders on intellectual property and innovation issues in the EPA debate were organized together with JIPO. ${ }^{173}$

\footnotetext{
168 See WTO Secretariat, TPR Jamaica 2011.

169 See Cabinet Office of Jamaica, Cabinet Committees (2008), available at <http://www.cabinet.gov.jm/files/Cabinet $\% 20$ Committees $\% 20$ Membership $\% 20$ and \%20TORs \%20as\%20at \%20October\%202012.pdf $>$ accessed on 15.11.2012.

170 JTAT succeeded the Trade Coordination and Policy Committee with a view of widening and deepening the consultative process. See Jessen and Vignoles, Jamaica: Trade, Integration and the Quest for Growth, p. 52.

171 See section 10.2.3.2 of this book.

172 See Jamaican Ministry of Foreign Affairs \& Foreign Trade, Overview (2006), available at <http://www.mfaft.gov.jm/?q=overview-0> accessed on 16.11.2012.

173 See section 10.1.4.4 of this book.
} 
Scheme 5: Jamaican state actors involved in policy-formulation

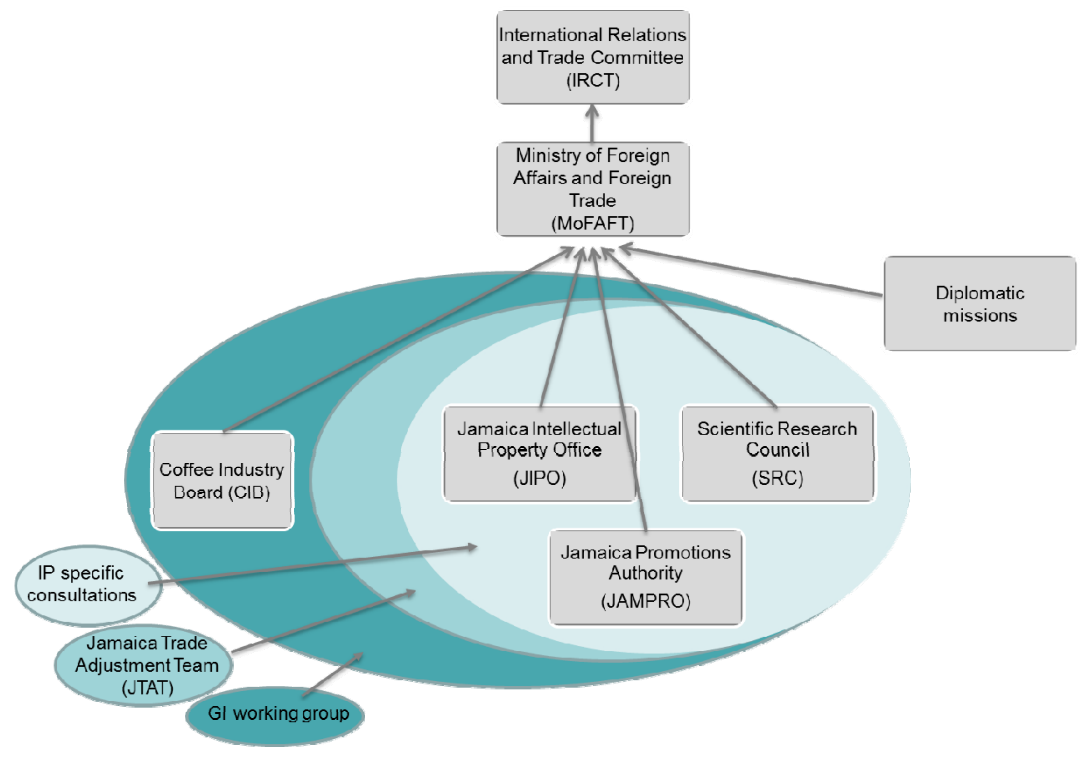

As far as the negotiations of international trade agreements are concerned, MoFAFT is responsible for carrying out the negotiations with Jamaica's trading partners. While this gives the impression that MoFAFT sits at the negotiation table and leads the discussions on behalf of Jamaica, this is only the case where Jamaica is not negotiating international trade agreements within the group of CARICOM Member States. With the Revised Treaty of Chaguaramas, Jamaica has agreed to coordinate its negotiation efforts with the other countries in the region and is therefore bound by the collective foreign trade efforts of CARICOM Member States. ${ }^{174}$ In these cases, it will not necessarily be the MoFAFT of Jamaica that leads negotiations but a regional negotiator who can be appointed from any CARICOM Member State. In the case of the EPA negotiations, it was CRNM that acted as the negotiator on behalf of CARICOM Member States and the Dominican Republic. The MoFAFT has a close working relationship with CRNM; during the EPA negotiations, it often sent its own national representative to the negotiations to work alongside CRNM officers. ${ }^{175}$ This was necessary when certain nuances in the negotiations arose that needed to be addressed by CARIFORUM States on the spot.

Concerning the implementation of foreign trade policy, MoFAFT fulfills an important coordinating role. In the case of the EPA implementation process, it regularly convenes and chairs the "Technical Working Group on the EPA Implementation", which was set up by the International Relations and Trade Committee in March

175 See Jessen and Vignoles, Jamaica: Trade, Integration and the Quest for Growth, p. 53; interview with a Jamaican senior official, March 2010. 
2008. ${ }^{176}$ This working group brings together state actors from relevant ministries and governmental agencies as well as business and industry associations; its mandate is "to expand the capacity of domestic stakeholders to exploit the benefits"177 of the EPA. In this working group, intellectual property protection is also discussed. In particular, one focus area currently is the protection of geographical indications. ${ }^{178}$

In view of MoFAFT's important role in the negotiations of international trade agreements, it is one of the most decisive actors in determining Jamaica's national policy position, also in respect of intellectual property protection in the CARIFORUM-EC EPA. This national body takes the final decision and presents it to the other CARIFORUM States as well as to the regional negotiators.

\subsubsection{Jamaica Intellectual Property Office (JIPO)}

The administration of intellectual property falls under the responsibility of the Ministry of Industry, Investment and Commerce; ${ }^{179}$ however, it does not deal with the daily administration of intellectual property itself but has established in 2001, to that end, the Jamaica Intellectual Property Office, which holds the status of a government statutory body. ${ }^{180}$ JIPO does not only administer the various IP statutes and provides the relevant registration services thereunder, ${ }^{181}$ it also makes recommendations on the development of intellectual property policies in Jamaica ${ }^{182}$ and advises the Minster of Industry, Investment and Commerce on matters relating to the administration of the IP laws. ${ }^{183}$

With regard to international aspects of intellectual property protection, JIPO fulfills an important function. When requested by other agencies, JIPO advises on technical aspects of IP and cross-sector issues, such as international trade. ${ }^{184}$ In international trade negotiations that include IP, for instance during the EPA negotiations, the MoFAFT relied upon JIPO (see Scheme 5) as a source of expertise and advice and, in addition, as the contact point for private stakeholders. Together with MoFAFT, JIPO convened specific IP consultations with relevant stakeholders in order to inform them about the IP content of the EPA negotiations as well as to receive their

176 Interview with Michelle Walker, 13 April 2010, Kingston.

177 See Shridath Ramphal Centre for International Trade Law, EPA Implementation Stakeholder Analysis: The CARIFORUM Context (German Technical Cooperation, Project: Support to regional institutions in the implementation of the Economic Partnership Agreement in the Caribbean, Santo Domingo, 2009), p. 20.

178 Interview with Michelle Walker, 13 April 2010, Kingston.

179 See Ministry of Industry Investment \& Commerce, The Ministry's Portfolio (2010), available at <http://www.miic.gov.jm/portfolio.php> accessed on 16.11.2012.

180 See Jamaica Intellectual Property Office Act No. 25 of 2001, entered into force on 1 February 2002, last authorized by L.N. 88/2003, see Jamaican Ministry of Justice, Jamaican laws [hereinafter JIPO Act of 2001]. A statutory body is an entity set up by a public law and entrusted with specific, circumscribed "public" powers. In the case of JIPO, one example is the registration of IP rights.

181 See Section 4(a) of the JIPO Act of 2001.

182 See Section 4(b) of the JIPO Act of 2001.

183 See Section 4(c) of the JIPO Act of 2001.

184 See Jamaica Intellectual Property Office, Responsibilities of JIPO (2009), available at <http://www.jipo.gov.jm/?q=node/35> accessed on 16.11.2012. 
feedback. ${ }^{185}$ As a regular member of the meetings of the Jamaica Trade Adjustment Team during the EPA negotiations, JIPO made sure that the relevant non-state actors' feedback on IP issues was considered when formulating Jamaica's policy position.

Currently, JIPO spearheads the establishment of a system of GI protection in Jamaica. In 2006, JIPO started to convene a public-private sector working group on geographical indications (hereinafter GI working group) in order to make recommendations for developing such a system. ${ }^{186}$ During the EPA negotiations, the working group was committed to devising a policy position on GI protection for Jamaica; with MoFAFT and JIPO being part of this group, its proposals were determinative for Jamaica's GI position (see Scheme 5). Shortly after the initialling of the EPA, a two-year technical assistance project "Geographical Indications Project Jamaica-Switzerland" was set up in July 2006 between JIPO and the Swiss Federal Intellectual Property Institute. ${ }^{187}$ The aim of the project was to build up the necessary knowledge and institutional structure for a system of GI protection to work. Therefore, training was given to the producers of potential GIs, including specific workshops to the producers of the three targeted products, being coffee, jerk ${ }^{188}$ and rum. ${ }^{189}$

In brief, JIPO has played a crucial role in the determination of Jamaica's policy position. It advises MoFAFT on IP issues, convened specific IP consultations and the GI working group and functioned as the contact point for relevant stakeholders. JIPO's regular participation in the meetings of the Jamaica Trade Adjustment Team ensured that the results of these consultations as well as JIPO's expertise were taken up in the formulation of Jamaica's national IP policy position.

\subsubsection{Jamaica Promotions Corporation (JAMPRO)}

Jamaica Promotions Corporation is another government agency under the direction of the Ministry of Industry, Investment and Commerce. It was established in 1988 to serve as Jamaica's investment and export promotion agency. ${ }^{190}$ Its mission is twofold: 1) promoting Jamaica's exports of goods and services, including the facilitation of business linkages between local suppliers and investment projects; and 2) facilitating investment opportunities in Jamaica, which requires oftentimes assisting firms in

Interview with Michelle Walker, 13 April 2010, Kingston. See section 10.2.3.3 of this book.

186 See Daley, "Jamaica: Intellectual Property". For a more detailed description of the working group's activities and role during the EPA process, see section 10.2.3.4 of this book.

See IPI and JIPO, Memorandum of Understanding between The Swiss Federal Institute of Intellectual Property (IPI) and The Jamaica Intellectual Property Office (IIPO) on the Geographical Indications Project Jamaica-Switzerland (Kingston, 28 May 2008). Jerk is a Jamaican type of spice that is applied to meat. Interview with Stacian Bennett, 7 April 2010, Kingston. Note that no specific actors were identified by the interviewee. See IPI and JIPO, Memorandum of Understanding between The Swiss Federal Institute of Intellectual Property (IPI) and The Jamaica Intellectual Property Office (IIPO) on the Geographical Indications Project Jamaica-Switzerland. The Jamaica Promotions Corporation Act No. 7 of 1990, entered into force on 26 April 1990, last authorized by L.N. 5/1992, see Jamaican Ministry of Justice, Jamaican laws. 
accessing the necessary licenses, permits and incentives. ${ }^{191}$ In fulfilling these tasks, it focuses on several target sectors. On the investment side, target sectors are the information and communications technology industry, tourism, manufacturing, mining and agriculture sectors. Special emphasis is also placed on the creative industries (including film, music and fashion). Relating to exporting enterprises, JAMPRO targets similar industries with regard to investment, including agroprocessing industries (in particular juices and sauces), fashion and handicrafts. ${ }^{192}$ The corporation's clientele profile is representative of the various target sectors.

Intellectual property protection forms part of the facilitation services provided by JAMPRO, although it predominantly refers such matters to JIPO. ${ }^{193}$ The proportion of queries relating to intellectual property protection made to the agency is small; market access issues, standards and requirements raised by regulatory authorities are priority areas that JAMPRO's clients are interested in. Among JAMPRO's clients, the creative industries and those in agro-processing tend to be the most involved in intellectual property issues. ${ }^{194}$ Their interest lies primarily in the protection of copyright, trade marks and geographical indications. These are also the areas of IP that JAMPRO focuses on when organizing workshops for its clients or when lobbying for their preferences with the Jamaican Government. ${ }^{195}$ One of its recent clients is the coffee industry. It is highly interested in GI protection for Blue Mountain coffee; JAMPRO has organized workshops addressing the issue and is part of the GI working group (see Scheme 5).

During the negotiations of the CARIFORUM-EC EPA, JAMPRO was highly involved in national and regional consultations. It was part of several JTAT meetings as well as specific consultations on IP (see Scheme 5); it also attended technical working group meetings at the regional level. ${ }^{196}$ In addition, it used written submissions to the Ministry of Foreign Trade and Foreign Affairs as a lobbying tool where it outlined the issues of concern to its clients. JAMPRO's position on intellectual property protection regulated by the EPA concurred with that of JIPO and the negotiating team: they wanted to ensure sufficient IP protection for agroprocessed products as well as the creative industries. JAMPRO had a preference for achieving a high level of GI protection for coffee, protection for trade marks and copyright and enforcement of IP rights. Cheronne Allen, Manager in Planning \& Policy Development of JAMPRO, believes that international IP negotiations at any forums are beneficial for Jamaica; she did not mention a preference for a particular forum or concerns with regard to a particular forum. In Cheronne Allen's view, JAMPRO's comments were treated seriously by MoFAFT. 197

\footnotetext{
191 See Jamaica Promotions Corporation, About JAMPRO (2012), available at $<$ http://www.jamaicatradeandinvest.org/aboutjti> accessed on 16.11.2012.

192 Phone interview with Cheronne Allen, Manager in Planning and Policy Development of JAMPRO, 10 September 2010 (available on request).

193 Phone interview with Cheronne Allen, 10 September 2010.

194 Many of Jamaican producers that are JAMPRO's clients are still not fully aware of intellectual property protection. Phone interview with Cheronne Allen, 10 September 2010.

195 Phone interview with Cheronne Allen, 10 September 2010.

196 Ibid.

197 Ibid.
} 


\subsubsection{Scientific Research Council (SRC)}

The third government agency established under the responsibility of the Ministry of Industry, Investment and Commerce is the Scientific Research Council. ${ }^{198}$ Its main task is to foster and coordinate scientific research and to promote the application of its results. ${ }^{199}$ With an extensive expertise in technology transfer and innovation, the agency has been heavily involved in advising the government on questions of technology transfer and intellectual property protection during the EPA negotiations.

The Scientific Research Council is not involved in intellectual property protection on a daily basis but has an interest in IP to the extent that it relates to innovation and technology transfer. It fulfills different functions, one being product research and development and another being the collection, analysis and dissemination of technological know-how. The Council is an actor in its own interest as it seeks IP protection for the products developed by SRC;200 it does not represent the interests of clients or other actors in Jamaica.

Concerning product development, SRC develops products based on science and technology research and that are market driven, particularly in the field of agricultural/agro-processing sectors. In this function, SRC has an interest in intellectual property protection in so far as the products developed can be protected by certain forms of IP, such as patents or possibly future plant breeders' rights. Its interest stemming from this role is, however, limited to that of a user rather than a policy maker. ${ }^{201}$ With regard to technology transfer, the Research Council identifies, organizes and disseminates technological know-how to individuals and businesses. This information enables the latter to apply a technology to a domestic need or an industrial application. ${ }^{202}$ SRC is also involved in setting up a system of GI protection in Jamaica. In this process, it tries to establish itself as the organization that will provide certificates of analysis of the products that are applied for GI protection. ${ }^{203}$ Such certificates of analysis will be based on a molecular and chemical screening as well as an analysis of where a particular plant originates from. ${ }^{204}$

The expertise developed in delivering these information services has established SRC as an important actor for the making of policies in the field of IP and technology transfer. It is heavily relied upon by JIPO or the Ministry of Foreign Affairs and

The Scientific Research Council Act, entered into force on 16 June 1960, last amended by Act 3 of 2007, last authorized by L.N. 11/2010, see Jamaican Ministry of Justice, Jamaican laws.

See Scientific Research Council, Scientific Research Council (2003), available at <www.srcjamaica.org/> accessed on 21.11.2012.

Interview with Audia Barnett, Executive Director of Scientific Research Council, 6 April 2010, Kingston (available on request). Products developed by SRC are, among others, extracted and processed essential oils, identified active ingredients in medicinal and other local plants, high protein fish feed or peas soup made from local raw materials and spices. Ibid.

Interview with Audia Barnett, 6 April 2010, Kingston.

See Scientific Research Council, Scientific Research Council.

Interview with Audia Barnett, 6 April 2010, Kingston. It has already been approached by the coffee industry to provide such an analysis.

Interview with Stacian Bennett, 7 April 2010, Kingston. 
Foreign Trade as was also the case during the EPA negotiations. ${ }^{205}$ For instance, SRC regularly participated in the meetings of the Jamaica Trade Adjustment Team, was consulted on technology transfer issues in specific meetings convened by JIPO and MoFAFT and is a member of the GI working group (see Scheme 5).

According to Audia Barnett, Executive Director of the Scientific Research Council, the Council's main interest in intellectual property protection during the EPA negotiations was to get some more attention for the promotion of innovation; in its view, innovation can be fostered by "decent" pieces of legislation in the different fields of IP. ${ }^{206}$ Obligations in the field of IP protection need to strike a balance between Jamaica's limitations (in terms of an immaturity of the culture to use IP) and protecting the products with some value. On the question of forum choice, Audia Barnett did not feel she was informed enough to state a preference for one level; however, she noted that at the international level, Jamaica could benefit from the experience of other countries such as India. ${ }^{207}$ Overall, SRC could find its preferences well reflected in the positions taken by JIPO and the MoFAFT. That is why it believes that its input in the negotiations was taken seriously.

Also after the conclusion of the EPA negotiations, the Scientific Research Council has preserved an important role in fostering technology transfer with the European Union: it became the national contact point for applications to the European Union's Seventh Framework Programme for Research and Technological Development. The programme finances research grants for projects in different thematic areas, from which also CARIFORUM activities can benefit if they collaborate with institutions from EU countries. The SRC raises awareness among Jamaican SMEs for the possibilities that the FP7 Programme offers, advises on administrative and legal issues and assists with the application process. ${ }^{208}$ This task is highly relevant for Jamaica as participating in research collaborations with European institutions has a great potential for promoting innovation in Jamaica.

\subsubsection{Coffee Industry Board (CIB)}

Although not directly entrusted with intellectual property issues, the Coffee Industry Board played an important role during the EPA negotiations, in particular in relation to geographical indications. Its function is even more important in view of the fact that the Ministry of Agriculture and Fisheries, under whose responsibility it falls, has hardly been involved in the formulation of a policy position on intellectual property issues for the EPA negotiations. This lack of involvement in IP matters has to be understood in the context of the capacity constraints the Ministry is faced with: there is only one International Trade Specialist who is responsible for all international trade negotiations. ${ }^{209}$ For the EPA negotiations, this person mainly focussed on market access negotiations rather than on the negotiations including IP issues. The interests of the Ministry of Agriculture and Fisheries with regard to, for example, geographical indications were represented by MoFAFT.

\footnotetext{
205 Interview with Audia Barnett, 6 April 2010, Kingston.

206 Ibid.

207 Ibid.

208 See Scientific Research Council, Scientific Research Council.

209 Karl Hyatt, International Trade Specialist, Ministry of Agriculture and Fisheries.
} 
The Coffee Industry Board was established in 1948 by the Ministry of Agriculture and Fisheries under the Coffee Industry Regulations Act of $1948^{210}$ as one of the seven commodity boards in Jamaica. ${ }^{211}$ Its mission is to encourage the development of the Jamaican coffee industry, to promote the welfare of persons engaged in that industry and to protect the quality and integrity of Jamaican coffee..$^{212}$ It does so through a strict licensing and certification process in which coffee dealers, coffee works and coffee nurseries need to take part. ${ }^{213} \mathrm{CIB}$ is also the owner of two important certification marks, the Jamaica Blue Mountain and the Jamaica High Mountain Supreme. These trade marks are registered in sixty-one countries, including the European Union. ${ }^{214}$

With regard to the protection of intellectual property rights, the Coffee Industry Board represents the interests of the coffee producers in Jamaica. They themselves hardly get involved in matters concerning the protection of trade marks, GIs or plant varieties, one exception being the company Blue Mountain Coffee Ventures Limited, which is one of the larger coffee farms in the Blue Mountain region that occasionally has been in contact with the CIB on IP matters. ${ }^{215}$ Generally, Jamaican coffee producers trust that the Coffee Industry Board will take due care of their interests in IP protection and enforcement and therefore they have little interest in becoming active themselves. ${ }^{216}$ The knowledge and information coffee producers have about IP derives from consultation sessions organized by the CIB. ${ }^{217}$

It has to be noted that the involvement of the Coffee Industry Board in intellectual property matters is limited to the protection and enforcement of trade marks and geographical indications; their interests in the area of protecting plant varieties seems to be marginal. The reasons for this lack of interest are not very clear. However,

Coffee Industry Regulations Act of 1948, entered into force on 9 December 1948, last amended by Act 14 of 1998, last authorized by L.N. 146/1999, see Jamaican Ministry of Justice, Jamaican laws.

The other six commodity boards are the Banana Board, Cocoa Industry Board, Coconut Industry Board, Dairy Development Board, Export Division (Pimento) and the Sugar Industry Authority. See Jamaican Ministry of Agriculture \& Fisheries, Commodity Boards (2008), available at <http://www.moa.gov.jm/AboutUs/index.php> accessed on 16.11.2012.

See The Coffee Industry Board of Jamaica, Mission, Vision and Values (2012), available at <www.ciboj.org/cib/general/mission.html> accessed on 16.11.2012. See Section 7(d) of the Coffee Industry Regulations Act of 1948.

See L. Walker, Jamaica Blue Mountain: Quality and Geographical Origin, paper presented at the conference "Workshop on the Challenges relating to GIs for ACP Countries" in Montpellier (Technical Centre for Agricultural and Rural Cooperation, 24-27 March 2009).

According to the legal officer of the CIB, this coffee producer has been the only one who called sometimes to talk about IP issues. Interview with Stacian Bennett, 7 April 2010, Kingston. Unfortunately, no contact could be established with this coffee producer, see section 10.2.1.1.2 of this book.

216 Interview with Graham Douglas, Owner of Greenwich Mountain Estate and independent coffee producer, 30 March 2010, Kingston (available on request); email correspondence with Jack Minott, Managing Director of Jamaica Standard Product, Co., Limited which produces the coffee Wallenford Blue, 21 April 2010 (available on request). 
some circumstances contribute to the lack of activity. First, there are no commercial coffee breeders in Jamaica that have voiced an interest in protecting specific varieties. Jamaican coffee producers are relatively small and do not have the capacity to engage in commercial breeding. They rather save the seeds of their plants and re-use them the next year. ${ }^{218}$ This type of self-selecting the "best" coffee plants has led to satisfying results in terms of quality. Before the late 1990s, CIB used to run a nursery itself where the Board produced seedlings; with the deregulation of the coffee industry in the late 1990s, the Coffee Industry Board stopped doing that. ${ }^{219}$ Hence, the CIB itself has no interest in protecting certain plant varieties, neither do the coffee producers. 220

Second, there is no specific coffee bean variety that is special to Jamaica. Since hurricane Gilbert in 1988, the coffee producers learned that the best coffee plant for the Jamaican climate and soil is the Arabica typica plant variety, a variety which comes very close to the variety originally grown in Jamaica, the East African Islands variety. ${ }^{221}$ Hybrid coffee varieties bred by Portuguese and Central American, such as Colombian, coffee producers, which were more productive and disease-resistant, were torn out of the ground by the hurricane. Since then, the decision was made to standardize the use of the coffee variety Arabica typica. ${ }^{22}$ That variety, however, does not come under plant variety protection as it has been used for many years and was not bred by Jamaican coffee producers. Nevertheless, it seems as if legislation on plant variety protection might be of use to protect the specific deviations of the Arabica typica that exist on the different premises of the coffee farmers. However, no inventarization or study in that direction has been launched.

The area of intellectual property protection, which has been most relevant to the coffee producers in the last couple of years is the protection of geographical indications. The industry has even contacted Jamaica Promotion Corporation to support them in making best use of GI protection abroad. ${ }^{223}$ The CIB is strongly involved in the GI working group convened by the Jamaica Intellectual Property Office and the Ministry of Foreign Affairs and Foreign Trade (see Scheme 5). Blue Mountain Coffee is currently the most developed national product that is likely to benefit from GI protection in the near future. Next to the GI working group, the CIB participated in the "Geographical Indications Project Jamaica-Switzerland" with the Swiss Federal Intellectual Property Institute. ${ }^{224}$ The project aimed at establishing an institutional structure that comprises three distinct bodies, being an association assembling all coffee producers and farmers, a management body and a certification body. In this respect, two problems have been encountered. First, the project could

\footnotetext{
218 Interview with Douglas Graham, 30 March 2010, Kingston.

219 Ibid.

220 Even though the CIB and coffee producers have no interest in protecting certain plant varieties, they are also not opposed to protecting them. Rather, they are indifferent as to whether such protection exists in Jamaica or not, probably due to a lack of knowledge of the benefits and disadvantages of such a system.

221 Ibid.

222 Ibid.

223 Phone interview with Cheronne Allen, 10 September 2010.

224 See IPI and JIPO, Memorandum of Understanding between The Swiss Federal Institute of Intellectual Property (IPI) and The Jamaica Intellectual Property Office (JIPO) on the Geographical Indications Project Jamaica-Switzerland.
} 
not finalize the inventorization and registration of all coffee farmers and producers. They do not seem to be united enough to form a collective. Second, currently, the CIB fulfills both the management and certification role, which need to be fulfilled by separate bodies in order to safeguard impartiality. The CIB could continue its role as a certification and licensing body if it relinquished its management task; however, there seems to be a lack of political will to amend the Coffee Industry Regulations Act of 1948 in that respect. ${ }^{225}$ Stacian Bennett, the Legal Officer and Board Secretary of the Coffee Industry Board, feels that CIB's position is very much relied upon by the MoFAFT's in the area of GI protection; in fact, according to her, JIPO together with CIB are driving Jamaica's policy position in this field of IP rather than the Ministry of Foreign Affairs and Foreign Trade. ${ }^{226}$

On the question which international forum is more beneficial for Jamaica to engage in negotiations on IP, Stacian Bennett feels that there is a difference between agreements including the protection of GIs and those that protect trade marks. She is of the opinion that GI protection is better negotiated at the multilateral level for two reasons: first, Jamaica can benefit from other countries' experiences in terms of GI protection. Second, there are a number of multilateral agreements and networks (Organization for an International Geographical Indications Network) on the protection of geographical indications in which Jamaica is interested.227 When it comes to the protection of trade marks, Stacian Bennett favours bilateral agreements since they can be tailor-made for the countries and products relevant for Jamaica. She has no concern with regard to bilateral negotiations on IP.

From the research results, it is not clear whether the Coffee Industry Board was part of the specific consultations organized by the Ministry of Foreign Affairs and Foreign Trade and Jamaica Intellectual Property Office in preparation for the IP negotiations under the EPA. ${ }^{228}$ Its possible non-involvement, however, would be surprising as CIB and JIPO have a very good working relationship, to the extent that they have written position papers together to the Ministry of Industry, Investment and Commerce, the Prime Minister or MoFAFT, an example being the policy paper on the accession to the Madrid Protocol. ${ }^{229}$ As an alternative explanation, it is likely that the CIB's preferences are clearly communicated to MoFAFT through its active role in the GI working group, which also occupied itself with the EPA negotiations.

\subsubsection{Interim Conclusions}

When determining Jamaica's policy position in the area of intellectual property protection, diverse actors are involved. The actors presented here fulfill different roles in this process. While MoFAFT and JIPO are clearly key actors, the three specialized agencies identified provide expert knowledge for specific IP issues and

\footnotetext{
225 Email correspondence with Sara-Ruth Allen, 9 October 2012, (available on request).

226 Interview with Stacian Bennett, 7 April 2010, Kingston.

227 Ibid.

228 The person working at the CIB at the time of the EPA negotiations who was in charge of legal issues, among others IP issues, could not remember being involved in any consultations on IP issues in the EPA negotiations. Interview with Loreen Walker, former Legal Officer of the Coffee Industry Board, 31 March 2010, Kingston. 
therefore give important input into the policy-making process. The Jamaican Parliament, on the other hand, is hardly involved in this process.

First, the Jamaican Parliament has no role to play in the preparation or during the negotiations of the EPA; its influence in the process of formulating a Jamaican policy position for each subject-area under negotiation in the EPA is marginal. Where the Parliament can have an impact is on the laws that implement new obligations established by the EPA through its important role in the legislative process. However, with the provisions of the EPA containing legislation-like language, the space left to interpret these rules in national legislation is rather limited.

Second, the Ministry of Foreign Affairs and Foreign Trade has the main competence for international trade agreements. It chairs the meetings of the Jamaica Trade Adjustment Team, where national policy positions are formulated, leads or assists regional negotiators in the technical negotiations and regularly convenes a technical working group that addresses EPA implementation issues. Despite having the leading role in the negotiations, it relies heavily on the expertise of several governmental agencies for each subject area under negotiation. The key state actor in the area of intellectual property protection is JIPO. It is through JIPO's contacts that relevant stakeholders were addressed on particular IP issues during the EPA negotiations. JIPO's regular participation in JTAT meetings ensured that the results of these consultations as well as JIPO's expertise were taken up in the formulation of Jamaica's national IP policy position. Separately, it convenes the GI working group and has coordinated the GI technical assistance project between Jamaica and Switzerland.

Third, Jamaica Promotions Corporation and the Scientific Research Council were significant actors in Jamaica's policy-formulation process on IP issues dealt with in the EPA: they took part in several JTAT meetings and specific consultations on IP issues and are members of the GI working group. JAMPRO also attended some technical working group meetings at the regional level. Bringing intellectual property issues to the attention of Jamaican policy makers is part of both government agencies' mandates. In the case of JAMPRO, its activities do not go further than its clients' interests in IP issues, the latter being rather limited. Its lobbying activities include writing reports or submissions. According to both organizations, their positions were treated seriously by Jamaican IP policy makers.

When involved in IP policy making, Jamaica Promotions Corporation represents the interests of the exporting industry, in particular those in agro-processing, the creative industries and the coffee industry. The SRC does not represent particular groups of society; it develops special products that can benefit from IP protection themselves. Both JAMPRO and the SRC have built up a considerable amount of expertise on particular issues of IP protection. The SRC strives for a balanced protection of IP whereas JAMPRO clearly favours a high level of intellectual property protection; neither agency is concerned that a too high level of IP protection might harm Jamaica's businesses or industries. Jamaica Promotions Corporation focuses on the protection of GIs, trade marks and copyright as well as enforcement issues. The Scientific Research Council is specialized in IP regulation relating to technology transfer and innovation; more generally, it aims at introducing good legislation on IP issues. 
Fourth, the Coffee Industry Board was also an important actor in the formulation of Jamaica's policy position on GI protection. The Board is a key actor in the GI working group as well as in the GI technical assistance project between Jamaica and Switzerland. Although it did not become clear whether the CIB participated in specific consultations on IP, it can be suggested that its involvement in the GI working group was sufficient to have an influence on the formulation of Jamaica's GI policy position in the EPA. The Coffee Industry Board represents the interests of coffee producers in Jamaica; the latter do not participate in the policy process because they trust the Board to take good care of their interests in all fields, including intellectual property protection. CIB's own preference on IP protection is to have a strong level of IP protection, particularly in the field of GIs and trade marks and their enforcement; it is not concerned that a high level of IP protection could harm its interests.

Fifth, all three government agencies, Jamaica Promotions Corporation, the Scientific Research Council and the Coffee Industry Board, felt that their preferences coincided with those of the Jamaican IP policy makers, being the Ministry of Foreign Affairs and the Jamaica Intellectual Property Office. They also felt that their positions on IP issues in the EPA negotiations were treated seriously and have generally been influential to the national policy positions in the various areas of IP. In particular for GI protection, CIB believes that it was a leading actor, together with JIPO.

Sixth, on the question of forum choice, a common answer by Jamaica Promotions Corporation and the Coffee Industry Board was that both the bilateral and the multilateral level can be beneficial for Jamaica when negotiating IP issues. In particular, Stacian Bennett from the CIB favours multilateral forums for negotiations on GI protection and bilateral negotiations when trade mark protection is at issue. Audia Barnett from the Scientific Research Council did not feel informed enough to have a preference for one over the other forum.

\subsubsection{Differences between EPA Negotiations and Multilateral Negotiations}

Although no in depth analysis of past or ongoing negotiations in the field of intellectual property at the multilateral level has been carried out as part of this research project, it is worthwhile to compare the findings briefly with regard to the actors involved in IP policy making for the EPA negotiations with those involved in IP policy making in multilateral negotiations, in particular negotiations at WIPO and in the TRIPS Council. A distinction will again be made between regional CARICOM actors and Jamaican national actors.

\subsubsection{Regional Actors}

Regional actors are involved in the policy making during multilateral negotiations where CARICOM Member States have coordinated their policy. One coordinated policy area is that of external trade. Therefore, when multilateral trade agreements are negotiated, CARICOM institutions, next to the national bodies of each member, are involved in determining the common policy of CARICOM Member States. One important multilateral organization where trade agreements are negotiated is the WTO. Negotiations on trade-related aspects of intellectual property protection form part of the WTO framework and are therefore also coordinated among CARICOM Member States. This situation is different at WIPO where no trade negotiations but 
negotiations addressing various matters of IP protection are addressed. Negotiations at WIPO do not fall under the concept of "trade negotiations" and are therefore not part of CARICOM coordinated policies.

As regards the question which CARICOM institutions are involved in multilateral negotiations in the field of IP, the institutional framework analysed under the EPA negotiations is the same for any other type of trade negotiations, including multilateral negotiations. Hence, the CARICOM Council for Trade and Economic Development (COTED) together with the Prime Ministerial Sub-Committee on External Negotiations and the Heads of Government are the decisive political organs that make decisions as to negotiation strategies and preferred outcome of negotiated agreements. A major difference with the EPA negotiations is that no "College of Negotiators", similar to the EPA College of Negotiators, has been formed for multilateral trade negotiations. In principle, CARICOM Member States speak for themselves in the WTO and WIPO, unless they entitle representatives of other countries or the group to do so. ${ }^{230}$ As a consequence, only one of the analyzed regional actors is actually involved in the technical negotiations, the new Office of Trade Negotiations (OTN) of the CARICOM Secretariat (former CRNM).

In the context of the IP negotiations taking place in the WTO, the Office of Trade Negotiations is responsible for the coordination, development and execution of negotiating strategies for CARICOM Member States. To this end, staff members of the OTN in Geneva attend relevant meetings of the TRIPS Council and follow the negotiations. They prepare reports on the regular and special sessions of the TRIPS Council, channel information back to the Members and give technical advice. ${ }^{231}$ Despite the OTN's substantive involvement in the work taking place at the TRIPS Council, it does not represent CARICOM Member States views there. In other words, OTN does not speak on behalf of one individual country of CARICOM at the Council's meetings. ${ }^{232}$ CARICOM Member States will present their views themselves through the diplomatic staff working in the missions in Geneva.

This limited involvement of OTN in the TRIPS Council and in the WTO in general has been further clarified in the aftermath of the EPA negotiations: during the EPA negotiations, CARICOM Member States realized that OTN (the former CRNM) can have a policy position of its own, which is not necessarily the same as those of its Member States. In order to prevent the body from misrepresenting the views of certain CARICOM Member States, they decided that its role should be more limited compared to its involvement during the EPA negotiations, where the then CRNM was heavily involved in the negotiations itself. ${ }^{233}$ OTN therefore does not represent CARICOM Member States' interests at the WTO but serves as an advising, facilitating and coordinating body.

To summarize, OTN is not involved in negotiations on IP matters undertaken at WIPO. In the TRIPS Council of the WTO, OTN fulfills a coordinating and advisory

230 See section 9.1.5.1 of this book for an account of the groups formed within the WTO of which Jamaica is a member.

231 Interview with Junior Lodge, 3 March 2010, Geneva.

232 Ibid.

233 See section 10.1.3.3 of this chapter. 
role; it does not represent CARICOM Member States at the WTO. In negotiations taking place at both organizations, CARICOM Member States' preferences are represented by the national diplomatic staff working in the missions in Geneva.

\subsubsection{National Actors}

The national Jamaican actors involved in multilateral negotiations on IP matters are the same institutions as those analyzed for the EPA negotiations; one other body is added to the ones described, being the Permanent Mission of Jamaica to the United Nations and Other Specialized Agencies at Geneva [hereinafter Permanent Mission of Jamaica in Geneva]. As explained above, ${ }^{234}$ the Ministry of Foreign Affairs and Foreign Trade is in charge of international trade matters, which also cover multilateral negotiations on IP matters. It coordinates consultations with relevant stakeholders and collaborates with other ministries and agencies. When it comes to negotiations in the field of IP, one such agency is JIPO upon which MoFAFT relies to a great extent. While MoFAFT often also negotiates the trade agreements for Jamaica, this is not always possible for multilateral negotiations due to financial and human constraints. It will therefore also rely on the Permanent Mission of Jamaica in Geneva, which is part of the MoFAFT.

The Permanent Mission of Jamaica in Geneva is entrusted with the representation of Jamaica's preferences with regard to all matters concerning IP in all international organizations in Geneva, including the WTO and WIPO.235 The Mission is supported by JIPO, which is in charge of Jamaica's national IP portfolio and Jamaica's multilateral IP policy and positions. ${ }^{236}$ MoFAFT also plays a crucial role by assisting JIPO in the process of shaping and formulating Jamaica's multilateral IP policy and position. The Mission therefore maintains contact on IP issues with both entities. However, all final decisions on IP matters are taken by JIPO.237

An officer of the Mission represents Jamaica's interests in the regular and special sessions of the TRIPS Council as well as in relevant WIPO meetings. JIPO assists the Mission in its representational duties by sometimes sending an officer of JIPO to Geneva to participate in the technical legal discussions at WIPO. ${ }^{238}$ JIPO's capacity to do so is subject to both funding and capacity constraints.

At the WTO, the officer of the Permanent Mission of Jamaica to Geneva works alongside the staff of OTN, which is instructed to observe and report back to the CARICOM Secretariat on issues that affect the Caribbean's regional IP policies and agenda. OTN may also provide CARICOM Member States with technical assistance and analyses on issues of importance that arise under the agenda of the TRIPS

\footnotetext{
$234 \quad$ See section 10.1.4.2 of this chapter.

235 Email correspondence with Richard Brown, First Secretary of the Permanent Mission of Jamaica in Geneva, 22 July 2011 (available on request).

236 See Jamaica Intellectual Property Office, Responsibilities of JIPO.

$237 \quad$ Email correspondence with Richard Brown, 22 July 2011.

238 See WIPO Secretariat, Second provisional list of participants. See also WIPO Secretariat, Summary of Options for the International Dimension of the Committee's Work; WIPO Secretariat, Draft Report.
} 
Council. ${ }^{239}$ It does not, however, represent CARICOM Member States at the WTO, as noted in the previous section. OTN has no role to play in WIPO.

In conclusion, in order to determine which actors represent Jamaica at multilateral forums dealing with IP issues, one needs to distinguish between the WTO and WIPO. In the WTO, external trade policy is at issue, which has been coordinated by CARICOM Member States. OTN therefore plays a role in reporting on the issues that affect the regional IP policy and, if desired, provide technical assistance and analysis on issues of importance. The work of WIPO does not form part of a coordinated policy within the CARICOM region; OTN staff therefore does not work alongside national actors. International IP negotiations at both the WTO and WIPO fall under the responsibility of JIPO and are also mostly attended by the Permanent Mission of Jamaica.

\subsubsection{Conclusions}

The ACP Group of States' contribution to the negotiations on substantive matters was limited. Several shortcomings of the all-ACP mechanism inhibited the ACP Group as a whole from having more influence. As a consequence, the regional negotiations became the most important part of the EPA negotiations in which substantive matters were decided.

The state actors involved at the regional level were classified in political organs on the one hand and technical working groups and negotiators on the other. While the former took the final decisions as to which negotiating strategy to choose, the regional positions were prepared and formulated by the latter. The technical working groups assembled state and non-state actors from the region; they used the input from regional and national consultations, research papers and studies to formulate CARIFORUM's negotiating positions. These deliberations were coordinated by staff members of CRNM, which played a crucial role in the determination of the regional policy positions due do their institutional involvement in the regional bodies as well as their expert knowledge in the areas of trade under negotiation. This has caused tensions with CARIFORUM States.

The key Jamaican state actors responsible for determining the Jamaican policy positions in the various areas of IP protection under negotiation in the EPA were the Ministry of Foreign Affairs and Foreign Trade and Jamaica Intellectual Property Office. MoFAFT has the main competence for international trade agreements; it relies on the expertise and contacts of JIPO to devise national policy positions. Three government agencies have been significant actors in the formulation of Jamaica's preferences on different areas of IP: Jamaica Promotions Corporation, the Scientific Research Council and the Coffee Industry Board. Because of their expertise in particular areas of innovation and IP, they felt that their input in the EPA negotiations was treated seriously and has generally been influential to the national policy positions in the various areas of IP.

International IP negotiations at both the WTO and WIPO fall under the responsibility of JIPO and are mostly attended by the Permanent Mission of Jamaica 
in Geneva. The regional actor OTN reports on issues affecting CARICOM IP policy that are negotiated at the WTO. This is not the case for the negotiations carried out at WIPO since intellectual property issues outside of trade agreements do not form part of a coordinated policy of the region CARICOM.

\subsection{STATE - NON-STATE ACTORS INTERACTION}

After having analyzed relevant regional and Jamaican state actors, the question as to how non-state actors in the CARIFORUM region, in particular in Jamaica, could participate in the policy-making and negotiation process of IP issues in the CARIFORUM-EC EPA is addressed. In answering this question, the research focuses on non-state actors that have preferences on issues of intellectual property protection which are relevant for protecting food products. In particular, the focus areas are the protection for geographical indications, trade marks, plant breeders' rights, the protection of traditional knowledge and enforcement issues. In this context, the analysis addresses these areas of IP protection in general as well as specific to the protection discussed in the EPA negotiations.

First, an analysis of the CARIFORUM and Jamaican non-state actors that have an interest in one of the areas of IP protection in general, and in particular in the context of the EPA negotiations, is presented. It focuses on their institutional set-up as well as their objectives in the various areas of IP which are related to food products and have been negotiated under the EPA. Particular attention is paid to their preference of regulating IP protection at the bilateral level and/or at the multilateral level. Second, this section contains an investigation of the institutional structures for consultations between state and non-state actors during the EPA negotiations. Here, regional and national consultation processes are analyzed. Finally, a comparison is drawn between the structures of consultations on IP issues that were used during the EPA negotiations and those used when multilateral negotiations are carried out by international organizations.

The information presented is mainly collected from interviews conducted with relevant state and non-state actors in March/April 2010. Each section below will discuss individually which interviews were instrumental for the analysis and which constraints were encountered. The literature used in order to investigate non-state actors and consultation processes during the EPA negotiations was very limited. Literature addressing the role of Caribbean non-state actors in domestic and regional intellectual property policy making in international agreements is non-existent. One thesis has been found that addresses regional Caribbean and/or national non-state actors with an interest in trade issues in general. ${ }^{240}$ That thesis was also relevant for the analysis of the regional consultation mechanisms, together with the RNM updates during the EPA negotiations, ${ }^{241}$ a journal article by Richard Bernal ${ }^{242}$ and a paper by

240 For an account of the Caribbean private and civil society organizations that participated in the FTAA negotiations and/or the EPA negotiations, see Montoute, Civil Society Participation in Trade Negotiations.

241 See CRNM, RNM Updates available at <http://www.crnm.org/index.php?option=com_sectionex\&view $=$ category\&id $=13 \&$ Itemid $=126>$ accessed on 15.11.2012. Bernal, "CARIFORUM-EU Economic Partnership Agreement Negotiations". 
Clive Thomas. ${ }^{243}$ For the analysis of the national consultation processes, a paper commissioned by the Institute for the Integration of Latin America and the Caribbean, ${ }^{244}$ a study conducted by the European Centre for Development Policy Management ${ }^{245}$ as well as the Trade Policy Review Report of Jamaica by the WTO Secretariat were used primarily. ${ }^{246}$ Overall, I was confronted with a situation where only very few relevant writings were available. This made it necessary to rely heavily on the data collected from the interviews.

\subsubsection{Non-state Actors and Forum Choice}

Before describing the possibilities for regional and national non-state actors to be involved in the consultation processes at the regional and national level, an assessment of which non-state actors at both levels have an interest in IP protection in general and its regulation through the CARIFORUM-EC EPA is presented. A choice has been made to limit the research to national and regional non-state actors, to the exclusion of international actors. Three reasons explain this choice. 1) The scope of the research needed to be limited. Therefore, the project tries to identify whether and what kind of organizations exist locally (Jamaica and the region) that have an interest in the protection of intellectual property and to what extent they could have an influence on the policy-making process. 2) International non-state organizations are already addressed by a body of literature that examines their involvement in developing countries' IP policy making when these countries are negotiating in multilateral organizations. ${ }^{247}$ 3) I have a particular interest in the domestic non-state actors' situation which, from a democratic and pluralistic point of view, should be determinative for the policy choices made by a developing country. For these reasons, this research project focuses on national and regional non-state actors. Even though international non-state actors are excluded from the research, a short overview is given of which organizations were involved, and in what way, in the process of policy making and negotiating the IP chapter of the CARIFORUM-EC EPA.

Regional and national non-state actors are presented by addressing their institutional make-up (subject matter, members, financing) and their objectives in the EPA negotiations. Attention is also paid to their preferences with regard to the choice of

243 C. Thomas, "Reflections on the CARIFORUM-EC, Economic Partnerhsip Agreement: Implications for CARICOM" in M. Chuck-A-Sang and K.Hall (eds.), CARICOM: Policy Options for International Engagement (Ian Randle Publishers, Kingston, 2009) 258-290.

244 Jessen and Vignoles, Jamaica: Trade, Integration and the Quest for Growth.

245 Dunlop, Szepesi and Van Hove, Organising Trade Negotiating Capacity at Regional Level.

246 W'TO Secretariat, TPR Jamaica 2011.

$247 \quad$ For an account of the influence of international non-state actors on the negotiations of the TRIPS Agreement, see Menescal, "Those behind the TRIPS Agreement". For an account of the influence of international civil society organizations in the aftermath of the TRIPS Agreement, see Drahos, "Developing Countries and International Intellectual Property Standard Setting", p. 26 ff; Sell and Prakash, "Using Ideas Strategically". For an account of the relations between international civil society organizations and groups in the Global South, see Matthews, Intellectual Property, Human Rights and Development, p. 4. Duncan Matthews also notes here that most literature on NGO engagement with intellectual property rights issues tends to focus on the role of international NGOs. See Matthews, Intellectual Property, Human Rights and Development, p. 3. 
forum between the regional and multilateral level to regulate IP protection. The nonstate actors presented will be organized according to the grouping in which they can be categorized. Following Duncan Matthews, ${ }^{248}$ non-state actors can be usefully categorized into five groups: public action NGOs, industry associations, right holders groups, professional associations and the academic community. Adapted to the landscape of non-state actors in Jamaica, this thesis uses the following four categories, which in essence equal those identified by Duncan Matthews, with the exception of right holders groups which are not represented in Jamaica: 1) business/industry associations and producers, ${ }^{249}$ 2) civil society organizations, 3) lawyers and 4) the academic community. Before presenting the analysis of these organizations, the methodology used is set out.

\subsubsection{Methodology}

The non-state actors analyzed have been identified through information gathered from interviews with mostly public bodies (see sections 10.1.3 and 10.1.4 of this book) and non-state actors. Finding relevant non-state actors that were willing to answer the author's questions on IP issues in the EPA negotiations was difficult, primarily due to the general low interest in the subject matter.

Although this thesis has put the focus on regional and domestic non-state actors, international non-state and para-state actors were mentioned by regional and national negotiators interviewed as having been involved in the policy-making process by submitting relevant documents and studies. This information will be presented; however, it could not be further substantiated. ${ }^{250}$

A distinction is made between international non-state actors on the one hand and regional and domestic non-state actors on the other. Generally, international nonstate actors are organizations that 1) have an international reach, and 2) are formally established in developed countries, with their head offices there. ${ }^{251}$ The distinction between regional and domestic non-state actors is similarly defined. Regional organizations have a regional reach and are established in one or more of the countries in the Caribbean region. Domestic non-state actors rather operate exclusively in the Jamaican context and are established in Jamaica.

\subsection{Regional Non-state Actors}

The following analysis investigates four regional non-state actors. Two actors fall under the category business associations (the industry association West Indies Rum \& Spirits Producers' Association Inc and the West Indies Central Sugar Cane Breeding Station in Barbados), one under civil society organizations (the Caribbean Policy

See Matthews, NGOs, Intellectual Property Rights and Multilateral Institutions, p. 5.

Note that in the remainder of this chapter, business and industry associations as well as their members will also be referred to as the "private sector". The latter expression shall therefore be understood as a synonym for industries, businesses and producers as well as the associations assembling them.

For example, the author's attempt to contact the South Centre, one of the important international civil society organizations mentioned by some interviewees, failed.

See for a similar definition Matthews, Intellectual Property, Human Rights and Development, p. 11. 
Development Centre), and the fourth actor under academic community (Norman Girvan from the Graduate Institute of International Relations of the University of the West Indies, St. Augustine campus).

Another regional academic was approached for an interview since both Malcolm Spence and the managing director of the Barbadian civil society organization Policy NetWorks International Inc., Wendy Hollingsworth, had suggested that he was a regional stakeholder involved in discussions on IP on a regional and national Barbadian level. This academic was the Pro-Vice Chancellor for Research, Wayne Hunte, of the University of the West Indies (UWI), Cavehill Campus, who was not available for an interview. In addition, the Director of the Sir Shridath Ramphal Centre for International Trade Policy at UWI Cavehill Campus, Keith Nurse, was also approached without success.

The information presented is mainly derived from interviews with the technical negotiator on IP, Malcolm Spence (CRNM), CRNM's technical coordinator of the EPA negotiations in Brussels, Junior Lodge, the chairperson of West Indies Rum \& Spirits Producers' Association Inc, Frank Ward, the director of West Indies Central Sugar Cane Breeding Station, Anthony Kennedy, the managing director of the Barbadian civil society organization, Wendy Hollingsworth (Policy NetWorks International Inc.), the senior programme officer of the regional civil society organization, Shantal Munro-Knight (Caribbean Policy Development Centre) and the regional academic, Norman Girvan (Graduate Institute of International Relations of the University of the West Indies, St. Augustine campus).

\subsection{National Non-state Actors}

With regard to the national non-state actors, seven domestic institutions with an interest in IP protection were interviewed in Jamaica and are presented here. These are two private sector organizations, one consultancy firm, two coffee producers, two law firms and one academic. More institutions have been contacted on the basis of information received by state and non-state actors interviewed. These were the Jamaica Exporters' Organization, Lascelles DeMercado \& Company Limited (the major company distributing local and international wines and spirits), Grace Kennedy Group (one of the largest companies which comprises a network of subsidiaries and companies, among others in food manufacturing and food retail), the National Consumers' League (civil society organization in consumer advocacy), the Jamaica Agricultural Society (an independent organization which represents the interests of farmers in Jamaica), Jamaica's Coffee Exporters' Association (which assembles coffee exporting producers), Blue Mountain Coffee Ventures Limited (one of the larger coffee farms in the Blue Mountain region), and the law firm DunnCox. None of these actors reacted to my queries.

In addition, contact was sought with the para-state actors Friedrich-Ebert Foundation in Jamaica (a non-profit German political foundation committed to democracy promotion and international dialogue) and USAID in Jamaica (the principal US government agency that extends assistance to foreign countries). Both USAID and Friedrich-Ebert Foundation replied that they have not worked in the area of IP for quite some time. 
The analysis of relevant non-state actors is based on the information collected from interviews with representatives of each of the institutions investigated as well as with Jamaican state actors presented in the previous section. ${ }^{252}$ It is remarkable that no national civil society organization with an interest in IP protection relevant for food products and in the context of the EPA negotiations could be identified. One civil society organization, the Association of Development Agencies, was indicated by Mrs. Munro-Knight from Caribbean Policy Development Centre as being part of Jamaica Trade Adjustment Team. ${ }^{253}$ In the government report submitted by Jamaica for the 2011 WTO Trade Policy Review, this link is confirmed. ${ }^{254}$ However, I did not get any reply on several emails sent to the director of the association, neither was it possible to obtain more information on the association's activities and preferences via the Internet because its website does not exist (anymore). ${ }^{255}$

Following these methodological notes, the regional and national non-state actors identified will be presented, starting with business/industry associations and producers and continuing with civil society organizations, lawyers and the academic community.

\subsubsection{Business/industry Associations and Producers}

Only two regional business or industry associations were identified as having an interest in the areas of IP protection related to protecting food products, as suggested by CRNM staff. ${ }^{256}$ These are the West Indies Rum \& Spirits Producers' Association Inc. and the West Indies Central Sugar Cane Breeding Station. Another possible regional industry group, the coffee industry of CARIFORUM States, had not approached the CRNM at the time with particular IP requests, neither were its representatives involved in consultations at the regional level..$^{257}$

At the national Jamaican level, a number of business associations, companies and producers have been found to have an interest in intellectual property protection relevant for food products. Not all but most have, to a certain degree, also communicated their preferences to the national policy makers during the EPA negotiations. In the following, two regional and two Jamaican business associations, one consultancy firm and two coffee producers are presented.

See section 10.1.4 of this book.

Phone interview with Shantal Munro-Knight, Senior program officer of Caribbean Policy Development Centre, 13 May 2010 (available on request).

See WTO Secretariat, Trade Policy Review: Report by Jamaica (Trade Policy Review Body, Geneva, 7 December 2010) [WT/TPR/G/242], paragraph 43.

For some information about this organization's activities, see an overview by USAID, Directory of Governmental, Non-Governmental and Community Based Organizations, Associations and Social Safety Net Programmes in Jamaica (Washington), available at <http://usaidcomet.org/reports/FINAL\%20Social\%20Services\%20Directory\%20June\%2008.pdf> accessed on 21.11.2012, p. 46.

Note that the entertainment and creative industries in Jamaica and other CARICOM Member States was also mentioned by CRNM staff as having been active on IP issues during the EPA negotiations. However, the protection of copyright falls outside the scope of this book and has therefore not been further investigated. Interview with Malcolm Spence, 7 April 2010, Bridgetown and Junior Lodge, 3 March 2011, Geneva. Interview with Junior Lodge, 3 March 2011, Geneva. 


\subsection{West Indies Rum \& Spirits Producers’ Association Inc. (WIRSPA)}

The West Indies Rum \& Spirits Producers' Association Inc. assembles the national rum associations of thirteen CARIFORUM States. ${ }^{258}$ The largest producers by volume are the Dominican Republic, Jamaica, Guyana, Trinidad \& Tobago and Barbados. Individual rum producers are not members of WIRSPA but of the national associations. WIRSPA represents the interests of its member associations by providing trade facilitation and advocacy. Its trade advocacy includes collaboration with organizations such as the CARICOM Secretariat, CARIFORUM and Caribbean governments. ${ }^{259}$ The association's primary goal is the development of Caribbean rum as a "premium category". ${ }^{260}$

To that end, WIRSPA owns the Authentic Caribbean Rum Marque, a certification trade mark, which has been widely registered. ${ }^{261}$ Key international markets are the United Kingdom, Spain and Italy. WIRSPA is also interested in the protection of Caribbean rum through geographical indications. However, it recognizes that such protection must be put in place through legislation at the national level first. Therefore, at present, GI protection is not an urgent matter of attention for WIRSPA, neither for its members nor individual rum producers. Nevertheless, WIRSPA supports any initiatives to establish a system of GI protection for rum for all of its members. ${ }^{262}$

WIRSPA followed the negotiations of the CARIFORUM-EC EPA, also on intellectual property issues. According to WIRSPA's chairperson Frank Ward, the main focus of the association was on market access and rules of origin issues; intellectual property issues discussed during the EPA negotiations were only of peripheral importance to WIRSPA. With regard to the protection of geographical indications, WIRSPA made its interest in the possibility of a geographical indication for Caribbean rum known to Malcolm Spence on several occasions. ${ }^{263}$ This contact was of an informal nature, as clarified by Malcolm Spence. ${ }^{264}$

In summary, WIRSPA represents the interests of national rum and spirits organizations of twelve Caribbean countries, including IP issues. The association can be described as a large organization (thirteen national organizations with individual members). WIRSPA's interest in IP protection (which is a preference for establishing a system for GI protection in all Caribbean States) is of a marginal nature; the same is

These are Antigua \& Barbuda, the Bahamas, Barbados, Belize, Dominican Republic, Grenada, Guyana, Haiti, Jamaica, St Lucia, St Vincent \& the Grenadines, Suriname, Trinidad \& Tobago.

WIRSPA is also a partner member of The European Spirits Organisation, which represents the interests of all European spirits producers, and a member of the World Spirits Alliance, which represents spirits producers' interests in North America, Europe, Japan, Australia, New Zealand and the Caribbean. See West Indies Rum \& Spirits Producers' Association Inc., About WIRSPA (2010), available at <http://www.wirspa.com/about-wirspa.html> accessed on 21.11.2012.

261 Email correspondence with Frank Ward, Chairperson of WIRSPA, 27 March 2012 (available on request).

262 Note that, so far, only the Dominican Republic has a GI for rum.

263 Email correspondence with Malcolm Spence, 29 April 2012 (available on request).

264 Ibid. 
true for its involvement in consultation processes on such matters during the EPA negotiations.

WIRSPA had informal contact with the negotiating team. Its chairperson did not convey his view on a preference with regard to the bilateral or multilateral forum when negotiating intellectual property issues.

\subsection{West Indies Central Sugar Cane Breeding Station (WICSCBS)}

The West Indies Central Sugar Cane Breeding Station in Barbados is the only breeder of sugar cane varieties or any other plant variety in the region. ${ }^{265}$ It employs eighteen staff members and is owned and funded by the Sugar Association of the Caribbean, which assembles the six main sugar companies of the Caribbean States Barbados, Belize, Guyana, Jamaica, Trinidad and Tobago and St. Kitts. WICSCBS's mandate is to breed superior varieties of sugarcane in order to cater to the needs of the sugar industry. As far as sugar cane varieties are concerned, the Breeding Station represents the interests of the Caribbean sugar industry assembled in the Sugar Association of the Caribbean.

The Breeding Station has a strong interest in an effective system of plant variety protection in CARICOM Member States. ${ }^{266}$ At the same time, WISCBS does not make use of the plant variety protection available in Barbados, Belize and Trinidad and Tobago or elsewhere in the world. ${ }^{267}$ There are four reasons that can explain the current reluctance. First, the Breeding Station is the only sugar cane variety breeder in the Caribbean; there are no competitors against whom they would have to protect themselves. Also the farmers growing sugar cannot infringe any possible breeding rights because they are the owners of the varieties. ${ }^{268}$ Second, instead of protection through public law, the Station has concluded private contracts with receiving companies all over the world. These contracts set out obligations about the use, modification and the possibility of passing on the provided varieties. ${ }^{269}$ Third, Caribbean countries that have put in place laws to protect plant varieties have not yet implemented these laws. Hence, the institutional set-up for registration and certification is still missing. Fourth, in countries where there is an effective system of plant variety protection outside the region, the costs of applying, providing and certifying the material are prohibitive for the Station.

Phone interview with Anthony Kennedy, Director of the WICSCBS, 17 April 2012 (available on request).

Ibid. Note that the Sugar Cane Breeding Station is not concerned with any other area of intellectual property protection.

So far, only these three countries of the CARICOM region have enacted plant variety protection in 2002, 2000 and 1997 respectively.

The Sugar Association of the Caribbean assembles all sugar producers in the Caribbean. Since the Association mandates and funds the activities of WICSCBS, it is the sugar farmers themselves that own the varieties. and which serves his purpose well. It is primarily a sales contract but specifies some of the rights of the breeder. However, the rights specified are far less specific and comprehensive than those specified in the UPOV Convention, Act 1991. 
Even though the Station currently does not use plant variety protection to protect its sugar cane varieties, it has a strong preference for establishing an effective system of plant variety protection in the Caribbean region. In particular, Anthony Kennedy, Director of the WICSCBS, believes that different Caribbean countries could benefit from a system of plant variety protection if they started breeding programmes for crops such as hot peppers, sweet potatoes, peas and beans. ${ }^{270}$ Since Caribbean countries dispose of various plant varieties that are of commercial interest to other countries, such as the European Union, exporting these seeds could be a lucrative business opportunity, which at the same time would contribute to maintaining the traditional agriculture and hence food security. Protecting these varieties both in the Caribbean region and abroad would be crucial for this endeavour.

Anthony Kennedy is also in favour of establishing a regional system of plant variety protection, where registration in one country would lead to protection in the entire region of CARICOM, similar to the system of the European Union. According to him, membership to the UPOV Convention, Act 1991 is not required to achieve this goal. He does not see a direct advantage of becoming a signatory as long as the individual countries have not enacted or implemented plant variety protection legislation. Membership does not confer additional rights but involves significant costs. At the same time, he appreciates that an international obligation to become a party to the Convention could create an additional incentive for Caribbean States to implement an effective system of plant variety protection along the lines of the UPOV rules. ${ }^{271}$

During the negotiations of the EPA, the Station was not involved in any consultations or discussions with the CRNM on the issue of plant variety protection. ${ }^{272}$ Anthony Kennedy, in fact, did not know about the existence of an IP chapter in the EPA before the signature of the agreement. ${ }^{273}$ Even though he did not participate in consultations in the context of the EPA, he did have intensive discussions with Malcolm Spence and the CARICOM Secretariat on the benefits of establishing a system of plant variety protection several years ago. This was at a regional seminar organized by the Ministry of Legal Affairs of Trinidad and Tobago, UPOV and WIPO in April 1998. ${ }^{274}$ Malcolm Spence, at that time employee of the Ministry of Legal Affairs of Trinidad and Tobago, was the principal organizer of this

270 None of these crops is subject to a breeding programme yet. Note that pees and beans are landrace varieties (traditional local varieties) and as such would not meet the constitutive criterion of novelty. However, they could be diversified into pesticideresistant varieties, which then would qualify for plant variety protection. Phone interview with Anthony Kennedy, 17 April 2012.

271 Phone interview with Anthony Kennedy, 17 April 2012.

272 Note that Anthony Kennedy cannot exclude that a member of the board of directors of the Sugar Association of the Caribbean, Kusha Haraksingh, represented the interests of the sugar industry in consultations with the CRNM. This person is also a member of the government of Trinidad \& Tobago and was involved in the EPA negotiations in the latter capacity. Phone interview with Anthony Kennedy, 17 April 2012.

273 Anthony Kennedy did not receive any information about the protection of intellectual property in the EPA and was not invited to any meeting thereon. He also was not aware of any meetings or consultation organized by the then CRNM on the matter. Phone interview with Anthony Kennedy, 17 April 2012.

274 Email correspondence with Anthony Kennedy, 20 April 2012 (available on request). 
seminar, which aimed at promoting the accession of CARICOM Member States to the UPOV Convention. ${ }^{275}$ Anthony Kennedy was invited as one of the few active plant breeders in the Caribbean region by the Ministry of Legal Affairs. ${ }^{276}$ At that seminar, he declared his support for an effective system of plant variety protection in the region and discussed the possibility of a regional system of plant variety protection with representatives of the CARICOM Secretariat. According to Malcolm Spence, the Station was the most influential non-state actor on CARIFORUM's policy position on plant variety protection in the EPA negotiations. ${ }^{277}$

As to the choice of forum, Anthony Kennedy made clear that he cannot express a preference as to the forum of negotiations for intellectual property protection in general. For the area of plan variety protection, he thinks bilateral negotiations might be the better option to find adequate arrangements. However, he mentioned two caveats to this preference. First, he is not knowledgeable enough to recommend this option in terms of process: he cannot judge the benefits and drawbacks of multilateral versus bilateral negotiations. Second, arrangements of protecting the exclusively tropical crops grown in the Caribbean with, for example, European countries, does not make much sense since none of the crops can be grown in Europe. ${ }^{278}$

To sum up, WICSCBS is the only plant breeder in the Caribbean region and represents the interests of the sugar industry in the Caribbean region on the issue of plant variety protection. The organization can be classified as a small organization, representing six companies. Even though not involved in consultations during the negotiations of the EPA, Anthony Kennedy has expressed his preferences with regard to a system of plant variety protection to Malcolm Spence in 1998. WICSCBS has a strong interest in an effective system of plant variety protection in the region, which would be available for any possible crop. He also favours a regional system of protection. Accession to the UPOV Convention, Act 1991 is not necessary to achieve this goal.

\subsection{The Private Sector Organization of Jamaica (PSOJ)}

The Private Sector Organization of Jamaica is the biggest umbrella organization of private sector associations, companies and individuals in Jamaica. Out of its approximately 330 members, ${ }^{279}$ some important association members of PSOJ are Jamaica Exporters' Association, Jamaica Manufacturing Association and the Jamaica Chamber of Commerce. Diverse industries are covered by its membership, such as agro processing, manufacturing, financial/professional services, etc. The organization's financing is assured by managing different projects, fundraising and,

Phone interview and email correspondence with Anthony Kennedy, 17 and 20 April 2012.

The seminar was directed at the Ministries of Agriculture and Legal Affairs of CARICOM Member States, most of which also participated. According to Anthony Kennedy's account, he was the only practicing plant breeder present. Interview with Malcolm Spence, 8 April 2010. Phone interview with Anthony Kennedy, 17 April 2012. See USAID, Directory of Governmental, Non-Governmental and Community Based Organizations, Associations and Social Safety Net Programmes in Jamaica, p. 302. 
above all, through membership subscriptions, which are calculated according to the gross annual returns per member. ${ }^{280}$

Its objective is to influence national policy making that is relevant for economic growth and development. This includes a wide range of issues, such as education, corporate governance, national security and trade policy. One can classify PSOJ therefore as a multi-issued organization. Concerning trade policy, PSOJ's objectives go beyond keeping abreast with various trade policies and agreements. It aims at submitting well-researched negotiating positions to the Government, ensuring that the private sector is well represented at major trade negotiating meetings and forging alliances with other private sector interests in other trading blocs. ${ }^{281}$

In order to achieve its goals, it maintains close contact with Jamaica's Government and the opposition as well as with major multilateral and bilateral agencies. This proactive participation of PSOJ in policy making is to a large extent carried out through the work of the Trade Policy Committee. The Committee comprises not only stakeholders from the private sector, but also from the public sector as well as academia. ${ }^{282}$ It aims at facilitating greater understanding of trade issues by its members as well as to formulate private sector's position in relation to regional and international trade matters. ${ }^{283}$ PSOJ hopes that through liaising with the Government in the Committee as well as by participating in relevant negotiating forums, it is able to preserve the preferences of local enterprises. ${ }^{284}$

Intellectual property protection is also an issue that is discussed in the Trade Policy Committee. PSOJ's preference, in that regard, is to ensure that IP protection does not raise the costs of business in Jamaica and, at the same time, to protect Jamaica's own intellectual property. ${ }^{285}$ Omar Chedda, Trade and Environment Manager of PSOJ, however noted that IP protection usually is not an important issue for the organization's members. ${ }^{286}$ This is also exemplified by the kind of IP preferences identified by PSOJ which are more general than specific to certain areas of intellectual property protection. Many of PSOJ's members are not yet aware of protecting their innovative products with IP measures; they are more concerned about the day-to-day business, which focuses on short-term concerns. ${ }^{287}$ IP seems to fall outside the range of PSOJ's members' immediate interest.

As regards the inclusion of certain IP provisions into the CARIFORUM-EC EPA, PSOJ tried to promote its general preferences on issues of IP protection: to continue access to information and technology and to protect innovative products present in

280 Interview with Omar Chedda, 12 April 2010, Kingston.

281 See Private Sector Organization of Jamaica, The Private Sector Organization of Jamaica (2008), available at <http://www.psoj.org> accessed on 20.11.2012. See ibid.

283 It is, however, via JTAT that ideas and interests of non-state actors find expression in national policies. So far, there is no close collaboration between TPC and JTAT. See Dunlop, Szepesi and Van Hove, Organising Trade Negotiating Capacity at Regional Level, p. 9.

284 Private Sector Organization of Jamaica, The Private Sector Organization of Jamaica.

285 Interview with Omar Chedda, 12 April 2010, Kingston.

286 Ibid.

287 Ibid. 
Jamaica. The organization is represented in the consultations of the Jamaica Trade Adjustment Team (JTAT) organized by the Ministry of Foreign Affairs and Foreign Trade (MoFAFT) and in the GI working group; this is where the organization made its preferences heard. According to Omar Chedda, PSOJ's views on IP protection in the EPA were supported by most people present in JTAT meetings.

When asked whether PSOJ had a preference for negotiating IP at the multilateral level instead of the bilateral level, Omar Chedda replied that he supported the view of the MoFAFT in that Jamaica should not bind itself to higher standards than the TRIPS Agreement. It did not become clear whether he believes that, in order to stick to the TRIPS standard, the multilateral setting is more beneficial for Jamaica than the bilateral setting. He noted that he is not up-to-date with current developments at the multilateral level. 288

To conclude, PSOJ is the largest business association in Jamaica. It has the necessary resources and connections with the Government to develop and communicate its preferences. Nevertheless, PSOJ's interest in IP protection in general and in the CARIFORUM-EC EPA in particular is of a marginal nature. Since PSOJ represents the interests of a large number of business and industry associations in Jamaica, it must be noted that its members have an equally low interest in the various forms of intellectual property protection as the association itself. Due to this general lack of interest, PSOJ has formed a specific position on neither the issue of the appropriate level of IP protection through the EPA, nor on the issue of preference for a forum.

\subsection{The Jamaica Chamber of Commerce (JCC)}

Jamaica Chamber of Commerce comprises large, medium-sized and small businesses and professionals from various sectors of the economy. They are involved in retailing, manufacturing, finance, law, distribution, food services, inter alia. ${ }^{289} \mathrm{~A}$ number of its members are exporting companies such as coffee, rum and cotton producers. Compared to the PSOJ, JCC does not assemble associations in its membership and is considerably smaller. However, the Chamber can still be classified as a large group of firms. The Chamber finances itself through membership fees. ${ }^{290}$

Its main objective is to ensure the most favourable environment for an effective and profitable operation of Jamaica's businesses. In particular, it aims at advocating and promoting the free market system and attracting investments. In view of this wide range of interests in different fields of commerce, the Chamber is clearly a multiissued organization. In order to promote these goals, it, among others, advises its members on trade regulations, trade matters and governmental policies, and lobbies the Government on such issues. ${ }^{291}$ Its contact with the Government is primarily achieved through its membership in JTAT as well as in the Trade Policy Committee of PSOJ.

288 Interview with Omar Chedda, 12 April 2010, Kingston.

289 See Jamaica Chamber of Commerce, The Chamber (2011), available at <http://www.jamaicachamber.org.jm/about_chamber.asp > accessed on 28.07.2011.

$290 \quad$ See ibid.

$291 \quad$ See ibid. 
Only a few of its members have a preference for certain IP matters. ${ }^{292}$ These are the businesses which are exporting products such as coffee, rum and cotton. They are mainly concerned with trade mark protection and enforcement, although a preference for a system of GI protection and plant variety protection has been noted. ${ }^{293}$ In order to support these few members, Jamaica Chamber of Commerce is alert to possible cases of trade mark infringement and reports them to JIPO in order for them to take action. JCC's interest seems to be of a purely defensive nature rather than an interest in strengthening or adapting the trade mark policy of Jamaica. This conclusion is supported by fact that the Chamber is not actively involved in policy making in any area of IP policy making, even though it is a member of the JTAT group.

With regard to the CARIFORUM-EC EPA negotiations, the Chamber has not formulated a position on the IP issues discussed therein. ${ }^{294}$ However, when asked for the preferred forum to negotiate intellectual property protection, an officer of the Jamaica Chamber of Commerce, who had previously worked with the CRNM, said that her personal view is that multilateral negotiations are more beneficial for Jamaica because the country has more leverage in multilateral settings than in bilateral negotiations. ${ }^{295}$ She believes that this is also the general view among JCC's members.

To sum up, Jamaica Chamber of Commerce only has a marginal interest in the regulation of IP in general and in the context of the CARIFORUM-EC EPA negotiations in particular. As a membership-based organization, JCC's activities are limited to the preferences of its members of which only a few exporting businesses are interested in trade mark protection and its enforcement. The Chamber did not formulate a position on IP issues discussed during the EPA negotiations. A preference for the multilateral forum was stated by an internationally experienced officer of the JCC.

\subsection{The Competitiveness Company Limited (CC)}

The Competitiveness Company is a subsidiary of Jamaica Exporters' Association, which has been set up by the latter as a centre of expertise in order to increase and enhance the competitiveness of Jamaican firms. The services it offers to the private and public sector are the coordination of companies involved in the production of a high-quality product, strategy coaching, market research and opportunity identification and policy research. ${ }^{296}$ It acts as a consultancy firm that advises companies. In fact, its services are mostly carried out in the context of projects paid for by international donors. This is also how CC finances itself. Some of the donors

292 When the Chamber has organized meetings together with JIPO staff to inform its members on how certain forms of IP protection could be of interest to them, only a few JCC members have shown an interest.

293 Interview with Anthony Gomes, Director of Jamaica Chamber of Commerce, 6 April 2011, Kingston (available on request).

294 Interview with Anthony Gomes, 6 April 2011, Kingston.

295 Interview with Teisha Mattison, Officer at Jamaica Chamber of Commerce, 6 April 2010, Kingston (available on request).

296 See Jamaica Exporters' Organization, The Competitiveness Company (2008), available at $<$ http://www.exportjamaica.org/start/index.php?option=com_k2\&view $=$ item\&layout $=$ item\&id=7\&Itemid $=111>$ accessed on 16.11.2012. 
are the Inter-American Development Bank and the UK Department of International Development. ${ }^{297}$ It therefore is financially independent from Jamaica Exporters' Association and does not represent its members.

The companies that benefit from the Competitiveness Company's services are selected based on the projects that the Company is carrying out. Mostly, they are active along the value chain of high-quality products whose competitiveness needs to be increased. For example, in the case of West Indian Sea Island Cotton, CC's clients are the primary producers of sea island cotton (farmers) as well as its processors and distributors, market specialists and those who are willing to finance the marketing. ${ }^{298}$ The same categories of companies are involved in the clusters for other products. However, it has to be stressed that the Competitiveness Company does not represent any of these firms but merely works together with them.

In its work as a consultancy firm, the Competitiveness Company has been involved in matters of copyright and trade mark protection. With regard to the latter, one of the projects carried out by CC (the Private Sector Development Project) was to develop five certification marks (honey, processed ackees, scotch bonnet peppers and sauces, jerk seasoning and sauces, and a generic food certification mark) and to manage four collective marks for the Jamaica Exporters Association (wearable art, visual arts, fresh produce and boutique agri-business). ${ }^{299}$ Because of the work that the Competitiveness Company does in relation to intellectual property protection, it has also been invited to participate in the GI working group established by JIPO. Apart from that involvement, the Company is hardly concerned with IP policy making. Its interest in the international regulation of intellectual property rights is limited. ${ }^{300}$ That is also why it did not find out about the content of the IP chapter in the CARIFORUM-EC EPA before its signature.

Even though the Competitiveness Company was hardly involved in the discussions on IP protection in the context of the EPA (with the exception of the GI working group), the Company holds the view that the strongest IP regime possible is favourable for Jamaica; the higher the protection Jamaica can get, the better for the country. ${ }^{301}$ Margaret Mais, the Coordinator of Projects of the Competitiveness Company, referredin particular, to copyright and trade mark protection, the areas of IP in which they have been active so far. She is convinced that everyone in Jamaica, including public and private actors, shares the same preference since she has not heard of other opinions opposing high protection for copyright and trade marks. ${ }^{302}$ In view of the fact that Jamaica still faces the important challenge of becoming TRIPS-compliant, Margaret Mais also noted that there has to be financial and

Interview with Margaret Mais, Coordinator of Projects of the Competitiveness Company Limited, 30 March 2010, Kingston (available on request).

See "Competitiveness Company Working with Local Firms to Ensure Viability and Sustainability" Jamaica Information Service (Kingston, 21 January 2007), available at $<$ http://www.jis.gov.jm/news/archive/11062-commerce_science-competitivenesscompany-working-with-local-firms-to-ensure-viability-and > accessed on 12.11.2012. Interview with Margaret Mais, 30 March 2010, Kingston. Ibid. Ibid. Ibid. 
technical support from international organizations to support the implementation of an IP system. When asked about the Competitiveness Company's preference with regard to regulating international IP issues in bilateral or multilateral agreements, Margaret Mais explained that it is more beneficial for Jamaica to conclude bilateral negotiations on intellectual property issues, which in the past have proven to be successful in solving problems. ${ }^{303}$

To summarize, the Competitiveness Company is a somewhat unique actor in the Jamaican non-state actors' landscape as it has a special focus on intellectual property protection in its work. No other business/industry association or firm in the analysis of Jamaican non-state actors has been identified as having a focus on particular areas of IP protection. Probably due to its close contact with IP protection in its daily work, it holds the strong view that a system of IP protection of a high standard is favourable for Jamaica, if supported adequately. CC has a preference for the bilateral regulation of international IP issues since bilateral agreements have proven successful in the past. Nevertheless, its interest in policy making in the area of IP protection, in particular in the EPA negotiations, has been very limited.

\subsection{Greenwich Mountain Estate}

Greenwich Mountain Estate is a coffee estate which produces Greenwich Blue coffee. It is one of the smaller coffee producers in Jamaica, with 109 acres of land. The coffee farm is fully integrated in the sense that it grows its own seedlings, produces all the coffee cherries that it processes and sells it in retail packs. ${ }^{304}$ As a family business, the farm is run by Douglas Graham independently of the bigger coffee producers or cooperatives. Greenwich Mountain Estate is a member of the Jamaican Coffee Exporters' Association, which is linked to the Coffee Industry Board (CIB). ${ }^{305}$ The farm holds a license from CIB to produce coffee in Jamaica.

Douglas Graham has a limited interest in the protection of intellectual property. This is regardless of the fact that he has registered the trade mark Greenwich Blue for his coffee. In terms of IP policy making, he trusts that the Coffee Industry Board (the governmental commodity board under the responsibility of the Ministry of Agriculture) represents the preferences of coffee producers in the area of IP protection. ${ }^{306}$ This was also the case for the EPA negotiations, which he did not follow personally. This trust has been built up over several years as the CIB is the governmental organization that regulates the industry and the quality of the coffee. The only interest Douglas Graham mentioned is a better enforcement of intellectual property rights, in particular trade marks, both domestically and abroad. ${ }^{307}$ With regard to the issue of forum choice, Douglas Graham did not have a preference.

In brief, the preferences of the individual coffee producer Douglas Graham on intellectual property issues are very limited, with the exception of a strong

\footnotetext{
303 Email correspondence with Margaret Mais, 2 August 2011 (available on request).

304 See Greenwich Mountain Estate, Greenwich Blue (2003), available at <http://www.greenwichblue.com/> accessed on 16.11.2012.

305 No further information could be retrieved on Jamaica's Coffee Exporters' Association.

306 Interview with Douglas Graham, Owner of Greenwich Mountain Estate, 30 March 2011, Kingston.

307 Interview with Douglas Graham, 30 March 2011, Kingston.
} 
enforcement regime for trade mark infringements. He did not follow the IP issues being discussed in the EPA negotiations; he does not have a preference for a particular forum either. In fact, coffee producers such as Douglas Graham are assembled and represented by the Coffee Industry Board, the governmental commodity board under the responsibility of the Ministry of Agriculture. Coffee producers trust that their preferences with regard to IP protection are properly represented by CIB and therefore do not get involved in the process of policy making on IP themselves. Since the CIB is a state actor, no private sector organization exists that assembles coffee producers or coffee farmers. ${ }^{308}$

\subsection{Jamaica Standard Products Company (JSP)}

The coffee that Jamaica Standard Products Company produces is sold under the trade mark Wallenford Blue coffee. It is the only Jamaican coffee to carry the international ISO 9001:2008 standard, which is given to coffee with an outstanding quality. JSP is also one of the few coffee businesses in Jamaica that is licensed by the CIB to export its coffees to foreign markets. ${ }^{309}$

The conclusions reached for the small coffee producer Greenwich Mountain Estate are also true for the big coffee conglomerate Jamaica Standard Products Company. Jack Minott, owner of JSP, has hardly any interest in the regulation of intellectual property protection, not in general or in particular during the EPA negotiations. He also feels that the CIB properly represents the preferences of the coffee industry and therefore sees no need to get in touch with national IP policy makers. His connection with IP protection is the registration of his trade mark Wallenford Blue and his membership in the GI working group. In the working group, he is in favour of protecting Jamaica Blue Mountain coffee as a geographical indication, similar to his colleagues in the coffee industry. ${ }^{310}$ As regards the question of forum choice, Jack Minott has no preference for one level over another to negotiate intellectual property protection.

\subsection{Interim Conclusions}

Almost all businesses and private sector organizations interviewed lack a genuine interest in IP policy making. With the exception of Jack Minott being a member of the GI working group, the coffee producers interviewed are not involved in IP policy making because they trust that CIB will represent their preferences on IP issues adequately. Even the Competitiveness Company, which seems to hold the unique position of being an informed consultant company, has hardly been involved in Jamaican IP policy making. The participation of some interviewed actors (Private Sector Organization of Jamaica, Jamaica Chamber of Commerce, the Competitiveness Company, Jamaica Standard Products Company) in the GI working group indicates a growing awareness for GI protection; however, none of the actors

\footnotetext{
308 No information could be retrieved on Jamaica's Coffee Exporters' Association, which was mentioned by Douglas Graham in the interview.

309 See Jamaica Standard Co. LTD, Wallenford Blue (2009), available at <http://www.wallenfordblue.com/> accessed on 16.11.2012.

310 Jack Minott mentions in his email three other coffee producers, Jablum, City of Refuge and Greenwich Mountain Estate. Email correspondence from Jack Minott, Owner of Jamaica Standard Products Company, Limited, 22 April 2010 (available on request).
} 
seems to be very active in that group. If the members of the associations presented here have a preference for some form of intellectual property protection, it is in the protection and enforcement of the IP rights relevant for Jamaican products (the Competitiveness Company, Jamaica Chamber of Commerce, coffee producers), which is mainly through trade marks, geographical indications and copyright protection.

These conclusions tend to be true for the private sector at large, as confirmed by Michelle Walker from the Ministry of Foreign Affairs and Foreign Trade who notices a general lack of interest on IP. ${ }^{311}$ Also Peter Goldson, Partner in the Jamaican law firm Myers, Fletcher \& Gordon, and Anthony Gomes confirmed a limited interest by the business community in general. ${ }^{312}$

This lack of interest by the businesses and industry associations is primarily explained by a lack of knowledge on the issue of IP as well as a set of business priorities, which does not include intellectual property protection. Omar Chedda noted that the members of Private Sector Organization of Jamaica (PSOJ) do not have too much of an understanding of IP; they rather focus on issues such as market access, for example for agricultural products. ${ }^{313}$ Margaret Mais from the Competitiveness Company (CC) confirmed that most businesses do not understand the importance of IP and therefore do not attend meetings organized by industry associations or the government addressing IP issues. ${ }^{314}$ The Jamaica Chamber of Commerce has had the same experience when only a handful of its members attended a meeting on IP protection organized by Jamaica Intellectual Property Office in February 2010; even if they attend, they do not react as it might be the first time they really think about IP. ${ }^{315}$ According to Peter Goldson, the business community does not seem to be aware that IP protection will affect them very soon. ${ }^{316}$

Another important conclusion, which can be drawn from these interviews, is that there is very little concern on the part of businesses and industry associations as to whether the level of protection agreed upon in the EPA is too high for Jamaica and could have detrimental effects for Jamaican users and economy. However, this lack of concern does not necessarily mean that there is no reason for businesses to be alarmed; alone, the stakeholders' lack the necessary insight to assess the provisions critically. As Audia Barnett from the Scientific Research Council puts it, most people are not aware of the need to strike a balance between, on the one hand, offering enough protection for innovative and creative products Jamaica has and, on the other hand, limiting the protection to the necessary in order to avoid overprotection. ${ }^{317}$ There was basically no public debate on the pros and cons of the protection of IP in the EPA. ${ }^{318}$ From the businesses and associations interviewed, only the PSOJ made

\footnotetext{
311 Interview with Michelle Walker, 13 April 2010, Kingston.

312 Interview with Peter Goldson, Partner in Myers, Fletcher \& Gordon, 31 March 2010, Kingston (available on request).

313 Interview with Omar Chedda, 12 April 2010, Kingston.

314 Interview with Margaret Mais, 30 March 2010, Kingston.

315 Interview with Anthony Gomes, 6 April 2011, Kingston.

316 Interview with Peter Goldson, 31 March 2010, Kingston.

317 Interview with Audia Barnett, 6 April 2010, Kingston.

318 Interview with Beverley Pereira, 6 April 2010, Kingston.
} 
clear that it supported the position held by the Jamaican Ministry of Foreign Affairs and Foreign Trade. Their position is that Jamaica should not agree to IP protection which goes beyond the TRIPS standard and that the access to information and technology needed to be safeguarded. The Competitiveness Company can be placed at the other side of the spectrum: it clearly favours the highest possible level of IP protection; it is not concerned that strong IP protection could potentially have harmful effects for producers. ${ }^{319}$ This informed strong view in favour of a high level of protection voiced by the CC, however, must be classified as the exception rather than the rule: the majority of private sector undertakings has no view on the matter and therefore cannot critically assess the IP protection suggested in the EPA.

Concerning the issue of forum choice, most businesses and industry associations interviewed cannot say whether they have a preference for a particular forum to negotiate the protection of intellectual property. The reason is a lack of interest for regulating intellectual property protection at the multilateral level as well as a lack of awareness of the advantages and disadvantages of the multilateral versus the bilateral level. Two interviewees voiced their, interestingly opposing, preferences by using rather different motivations. An officer of the Jamaica Chamber of Commerce, who had previously worked with the CRNM, said to favour multilateral negotiations above bilateral ones due to a higher leverage. ${ }^{320}$ The Competitiveness Company, on the other hand, favours bilateral negotiations because they have proven successful in removing problems that had occurred in the past. ${ }^{321}$ The preference for the bilateral level seems to be the result of the positive experience when solving particular problems through bilateral arrangement; it does not seem to be an informed general preference for the bilateral level regarding any kind of negotiations on a variety of IP issues.

\subsubsection{Civil Society Organizations (CSO)}

Only one civil society organization with an interest in intellectual property protection and some involvement in the EPA negotiations has been identified. This is the Caribbean Policy Development Centre (CPDC) which is active at the regional CARIFORUM level. At the Jamaican national level, no civil society organization could be found that deals with intellectual property protection. This is similar in other CARIFORUM States, such as Barbados, where the CPDC and its national members encompass the CSOs with an interest in IP protection. ${ }^{322}$ An officer at the Jamaica Intellectual Property Office and Beverley Pereira from University of the West Indies noted that a couple of civil society organizations, such as consumer organizations, do exist in Jamaica; however they are not involved in or knowledgeable on intellectual property issues. ${ }^{323}$ Hence, I conclude that no national CSO has been in contact with Jamaican policy makers on IP matters during the EPA negotiations.

\footnotetext{
319 Interview with Margaret Mais, 30 March 2010, Kingston.

$320 \quad$ Interview with Teisha Mattison, 6 April 2010, Kingston.

321 Email correspondence with Margaret Mais, 2 August 2011.

322 Interview with Wendy Hollingsworth, Managing Director and Consultant of Policy Networks International Inc., 8 April 2010, Bridgetown (available on request); phone interview with Shantal Munro-Knight, 13 May 2010. 


\subsection{Caribbean Policy Development Centre (CPDC)}

Caribbean Policy Development Centre is a coalition of Caribbean civil society organizations that is concerned with devising a development strategy for the Caribbean region. It is an umbrella organization that represents major national and regional civil society organization networks in the Caribbean. ${ }^{324}$ According to a senior program officer, the Centre has between forty and fifty contact persons in various Caribbean States; the members listed on its website, however, do not exceed twenty CSOs. ${ }^{325}$ These civil society organizations are national networks that assemble individual members themselves, allowing CPDC to be classified as a large organization. Without doubt, CPDC is the largest civil society organization in the Caribbean and, as noted above, the only civil society organization found in the Caribbean region that has some affinity with intellectual property protection. It receives funding from international organizations, such as Oxfam and ActionAid, for carrying out particular projects. ${ }^{326}$

\section{Caribbean Policy Development Centre's primary goal is to}

"sensitize [...] [CSOs] and the general public on key policy issues and to impact policymakers on decisions which put the interests of Caribbean people at the center of the Caribbean development strategy." 327

Key issues that CPDC is interested in are sustainable development, trade liberalization, governance and participation, and capacity building. This makes the organization a multi-issued one, with intellectual property protection coming under trade liberalization. In these areas of interest, it organizes seminars and conferences, lobbies and advocates policy makers, organizes marches or sponsors petitions. ${ }^{328}$

Caribbean Policy Development Centre does not focus on policy making in intellectual property protection, but it is aware of some IP issues because of its work on WTO and bilateral trade negotiations, and because of the ongoing discussions at the regional CARICOM level on the harmonization of IP regulation. In the context of trade negotiations, IP is seen and treated as only one part of the overall agreement; it is clearly not at the forefront of CPDC's activities. ${ }^{329}$ Its members are not very interested in IP protection either: they are not knowledgeable on specific IP rights and only know about IP in the context of the overall subject matter of trade liberalization. In discussions on the efforts to harmonize IP regulation at the

\footnotetext{
324 See Caribbean Policy Development Centre, CPDC (2011), available at <http://www.cpdcngo.org/cpdc/> accessed on 15.11.2012.

325 Examples of those networks are the Hope Foundation in Barbados, the Belize Enterprise For Sustainable Technology, the Bureau of NGOs in Suriname and the Caribbean Network For Integrated Rural Development in Trinidad and Tobago, and regional networks such as the Caribbean Organization of Indigenous People, the Caribbean Conference of Churches, the Windward Islands Farmers' Association and the Caribbean Youth Environment Network. See ibid.

326 Phone interview with Shantal Munro-Knight, 13 May 2010.

327 See Caribbean Policy Development Centre, CPDC.

328 See N. Girvan, Civil Society and the EPA (2007), available at <www.normangirvan.info> accessed on 16.11.2012.

329 Phone interview with Shantal Munro-Knight, 13 May 2010.
} 
CARICOM level, Caribbean Policy Development Centre held the view that IP processes and legislation need to be strengthened at the national level first. ${ }^{330}$ One example of national legislation that according to CPDC is needed before harmonization takes place is the protection of cultural diversity.

Despite this general interest in intellectual property as part of the broader trade package, Caribbean Policy Development Centre's senior programme officer Shantal Munro-Knight acknowledges that CPDC lacks specific knowledge on IP. 331 That is also why the organization was not able to come up with a precise position on the relevant IP issues during the EPA negotiations. Its basic position entailed that the Caribbean countries should limit the IP chapter to the TRIPS standard; it also supported the notion of innovation brought up by the technical negotiator, Malcolm Spence.

The lack of specific knowledge on IP also impacted the organization's level of activity in making its views on IP heard during the EPA negotiations: its officers felt they lacked the level of expertise to speak comfortably on behalf of society. ${ }^{332}$ For that reason, they were neither part of national nor regional consultations on IP issues during the EPA negotiations. They also did not choose to lobby the CRNM. What CPDC, however, tried to do is to encourage national groups such as the cultural sector, small business people and rural groups, to lobby their governments on important trade issues, among which also IP protection. ${ }^{333}$ They do not advise these groups what position to takebut try to build awareness among them.

Caribbean Policy Development Centre clearly is in favour of the multilateral forum for negotiating IP issues. ${ }^{334}$ Their key message at the outset of the EPA negotiations was not to go beyond the standards of the WTO. ${ }^{335}$ In other words, CPDC has an interest in preserving the flexibilities contained in the TRIPS Agreement, these flexibilities arguably allow WTO Members to adopt a standard of intellectual property protection that reflects their level of development. The reason why CPDC strongly favours multilateral agreements above bilateral ones is the increased leverage small countries have in multilateral negotiations. According to Shantal Munro-Knight, bilateral agreements primarily entail disadvantages for developing countries, particularly if concluded with a developed country. ${ }^{336}$

In conclusion, the Caribbean Policy Development Centre is the only civil society organization identified in the CARIFORUM region with some interest in IP. However, its preferences in intellectual property protection must be classified as being marginal. CPDC is the largest network of CSOs in the Caribbean region. It was not involved in consultations at the time of EPA negotiations but was in favour of limiting the IP provisions to the TRIPS standard as well as linking them to the

\footnotetext{
$330 \quad$ Ibid.

$331 \quad$ Ibid.

332 Phone interview with Shantal Munro-Knight, 13 May 2010.

333 Ibid.

334 Phone interview with Shantal Munro-Knight, 13 May 2010.

335 See chapter 5 of this book for a comprehensive analysis of the TRIPS-plus provisions contained in the CARIFORUM-EC EPA. Ibid.
} 
concept of innovation. It also thinks that it is more beneficial for the Caribbean region to carry out negotiations on international IP standards at the multilateral rather than at the bilateral level.

\subsubsection{Lawyers}

Individual lawyers have been important non-state actors in the policy-making process in Jamaica. The Jamaican lawyers interviewed were Peter Goldson from the law firm Myers, Fletcher \& Gordon, and Dianne Daley from FogaDaley. Contact was also sought with another law firm, DunnCox; however, I did not receive a reply. At the regional level, no similar involvement by the lawyers' community could be identified. Therefore no regional law firm is presented here.

\subsection{Dianne Daley}

Dianne Daley can probably be best described as an expert in the field of intellectual property protection in Jamaica. She holds different positions, her main occupation being the head of the IP department of the law firm FogaDaley. Importantly, she also is the chair person of the IP Committee of the Jamaican Bar Association. The IP Committee assembles a group of interested IP lawyers in Jamaica. It provides, among others, feedback and guidance to JIPO on amended or new IP legislation. ${ }^{337}$ The Committee also keeps track of international agreements that cover IP issues and that are being negotiated, such as the CARIFORUM-EC EPA. Besides her work as a lawyer, Dianne Daley is the director of the Intellectual Property Service Centre which is a private sector organization representing IP right holders and users of their works. However, the Centre does not seem to be much involved in IP policy making in Jamaica as no further information on its activities could be retrieved. ${ }^{338}$ Before holding these positions, Dianne Daley has worked, among others, as Acting Chairperson of the Advisory Board of the Jamaica Intellectual Property Office between January 2006 and September 2007,339 a period which falls within the negotiation phase of the CARIFORUM-EC EPA. In the last years, Dianne Daley has also published considerably about intellectual property protection in Jamaica in international journals and books, among others, on the content of the IP Chapter of the CARIFORUM-EC EPA. ${ }^{340}$

Dianne Daley's preferences on issues of intellectual property protection mainly concentrate on the areas of patent and trade mark protection. These are also the areas of IP in the CARIFORUM-EC EPA which she was concerned about. Her concerns addressed Jamaica's accession to multilateral treaties in those areas of IP protection:

See Jamaican Bar Association, Report of the Council of the Jamaican Bar Association: For the Period July 2007 - May 2008 (Kingston, 2008), available at <http://www.jambar.org/Council_Report_07-08.pdf> accessed on 16.11.2012.

Note that the Intellectual Property Service Centre has no website which provides further information on its activities. Neither could other sources of information be identified.

339 Email correspondence with Dianne Daley, 14 April 2010 (available on request).

340 See Daley, "Intellectual Property in the EPA"; D. Daley, "IP Rights Obligations under New EU-CARIFORUM Economic Partnership Agreement" Newsletter of the International Law Office, 2008; D. Daley, "Jamaica Takes Control" Managing Intellectual Property, 2008, Vol. 179, 133-135; Daley, "Jamaica: Intellectual Property”; Daley, “A Balancing Act". 
she had the feeling that no long-term assessment was made when accepting those commitments. In her opinion, the implications of acceding to each treaty under discussion should be critically assessed. First, during the negotiations of the EPA, she felt uneasy about the proposed obligations to sign the Patent Cooperation Treaty and the Patent Law Treaty. This would increase Jamaica's current obligations and would not be very useful for Jamaica as its citizens are primarily users of patented products that do not benefit from a simplified patent registration system such as the PCT. ${ }^{341}$

Second, she also had concerns with regard to the proposed obligation to become a member to the Madrid Protocol. ${ }^{32}$ This is a concern that the legal community of Jamaica had voiced several times before; ${ }^{343}$ the Jamaican Bar Association had even put forward a position paper to the Government on the matter. ${ }^{344}$ Dianne Daley believes that the Madrid system is primarily useful for foreign trade mark holders who want to register their trade marks in Jamaica. ${ }^{345}$ National trade mark holders are much less likely to use the system. She is of the opinion that if Jamaica becomes a member to the Madrid Protocol, this will result in an extra administrative burden with little added value for Jamaican society. On this issue, private companies with large trade mark portfolios in Jamaica, as well as Jamaica Intellectual Property Office, have opposite preferences compared to IP lawyers. The former favour Jamaica's membership to the system as it would make international trade mark registration much easier and cheaper. ${ }^{346}$ However, from the interviews conducted with the legal community, it seems as if these opposed opinions did not come up in the EPA negotiations; the debate was mainly led before but might have had an influence on the negotiations. The "best endeavour" obligation in the EPA gives Jamaica currently enough flexibility to further postpone its accession to the Madrid Protocol. ${ }^{347}$

Due to the manifold positions Dianne Daley held or continues to hold, it is not always clear in what capacity Dianne Daley was involved in the policy making on IP issues during the EPA negotiations. Clearly, her contacts to the Government were very close due to her former position as Acting Chairperson on the Advisory Board of JIPO. However, she emphasized that she did not directly advise the government on the draft IP chapter of the CARIFORUM-EC EPA. ${ }^{348}$ But also, as the chairperson of the IP Committee of the Jamaican Bar Association as well as because of her publications, her views on certain IP issues would have been available to the Government. According to her own account, she participated in specific

341 Interview with Dianne Daley, 31 March 2010, Kingston.

342 See Article 144.E of the CARIFORUM-EC EPA. Note that the finally agreed obligation is a soft obligation, indicated by asking CARIFORUM States to "endeavour to accede" to the Madrid Protocol.

In relation to the Madrid Protocol, some lawyers perceived that membership might be inimical to their financial interest. Interview with Beverley Pereira, 6 April 2010, Kingston.

Interview with Dianne Daley, 31 March 2010, Kingston. Also Kai-Saran Davis noted that the legal community has lobbied the Government intensively on not signing the Madrid Protocol. Their lobbying efforts were well organized and strong, which so far has made them successful. Interview with Kai-Saran Davis, 31 March 2010, Kingston. 
consultations on IP organized for the cluster of businesses and industry organizations, including the legal community during 2006 and 2007. In the specific consultations, participants looked at the draft IP text of the EPA and commented on the provisions. ${ }^{349}$ In these meetings, Dianne Daley felt that her input on the IP chapter was heard by the Ministry of Foreign Affairs and Foreign Trade and communicated to CRNM. In fact, she believes that her concerns in relation to the accession to the PLT and the Madrid Protocol led to best endeavour obligations in the final agreement. ${ }^{350}$

On the question of forum choice, Dianne Daley differentiates between areas of IP where there is a multilateral agreement and those where there is none. In the area of biodiversity, for example, she feels it is useful to join existing multilateral treaties. ${ }^{351}$ However, as there is no protection, for example, for traditional knowledge at the multilateral level, she thinks that bilateral agreements should be favoured to no international protection at all. In addition, according to Dianne Daley, there are good reasons to conclude bilateral agreements with countries which have markets where Jamaican products, protected by certain forms of IP, are exploited. ${ }^{352}$ An example is Switzerland which is a potential market for Jamaican export products that might be protected by geographical indications in the future. A bilateral cooperation agreement with these countries, in her opinion, is useful. Accordingly, the EU is also an interesting market for Jamaica in terms of accepting reciprocity for the protection of traditional knowledge and geographical indications. Even though Dianne Daley sees the benefits of bilateral agreements in the above stated cases, she also has concerns with regard to the asymmetrical relationship between the partners in bilateral negotiations. This is particularly so when the agreement is wide in scope, such as the EPA, and intellectual property protection can become sidetracked and a bargaining tool for other areas under negotiation. ${ }^{353}$ However, this concern does not seem to outweigh her view on the general benefit of concluding a bilateral agreement with the EU.

To sum up, Dianne Daley has a strong interest in the regulation of IP issues in the EPA negotiations. As the head of the IP department of the law firm FogaDaley, she has a preference for avoiding any obligation under which Jamaica has to accede to one of the following international agreements: the Patent Law Treaty, Patent Cooperation Treaty and the Madrid Protocol. Dianne Daley does not have a general preference for one particular forum when negotiating international agreements on the regulation of intellectual property. In the case of the EPA, she noted that it is useful to agree on reciprocal protection of traditional knowledge and geographical indications through a bilateral agreement; her concern that IP protection could become a bargaining tool in this wide agreement did not seem to have outweighed her general take on the bilateral nature of the agreement.

\footnotetext{
349 Ibid. and email correspondence with Dianne Daley, 14 April 2010. See also section 10.2.3.3 of this chapter.

350 Interview with Dianne Daley, 31 March 2010, Kingston. These "best endeavour" obligations are contained in Articles 147.A.3 and 144.E of the CARIFORUM-EC EPA.

351 Interview with Dianne Daley, 31 March 2010, Kingston.

352 Ibid.

353 Ibid.
} 


\subsection{Peter Goldson, Myers, Fletcher \& Gordon}

Peter Goldson is a partner at the law firm Myers, Fletcher \& Gordon, which is the largest in Jamaica. The law firm's services include the entire spectrum of legal fields, including intellectual property. In the area of IP protection, it deals with trade mark and copyright protection as well as patent registrations. The firm's interest in policy making on IP protection goes as far as their clients' interests. According to Peter Goldson, the business community's interest in IP is rather limited (with the exception of larger companies) as they are not yet aware that intellectual property protection will affect them very soon. ${ }^{354}$

Because of the limited interest of its clients in IP issues, the law firm Myers, Fletcher \& Gordon was not involved in the IP policy-making process during the EPA negotiations. They were not consulted and they did not contribute to any discussions. ${ }^{355}$ Even on the issue of the accession to the Madrid Protocol, the law firm did not voice its opinion during the EPA negotiations. According to Peter Goldson, the soft obligation to "endeavour to accede" to the Protocol for Jamaica was presented to them as a fait accompli. ${ }^{356}$ On that issue, the law firm's view is identical to the one described by Dianne Daley: it has opposed any obligation under which Jamaica would have to accede to the Madrid Protocol in previous discussions with Jamaican IP policy makers.

Even though neither Peter Goldson nor any other lawyer of the law firm was involved in the policy-making process on IP issues during the EPA negotiations, he holds a strong view on the IP chapter in the EPA. He found it "scandalous" that MoFAFT agreed to an extensive IP chapter in the EPA. ${ }^{357}$ In his view, the trade ministers in the Caribbean primarily see the trade benefits but have limited appreciation for the implications on intellectual property protection. From his work with clients, he finds that they are not yet ready to embrace intellectual property protection as part of their business strategy. ${ }^{358}$ They are primarily users of intellectual property rather than brand owners. An extensive IP chapter does not correspond with this reality. On the question of forum choice, Peter Goldson has no particular preference as his law firm is not involved in international agreements.

To conclude, the law firm Myers, Fletcher \& Gordon is interested in intellectual property protection since it deals with trade mark, copyright and patent registration issues as part of its daily work. However, the law firm's interests in IP regulation do not go further than its clients' interests. Hence, the firm has not been involved in the policy-making process on IP issues during the EPA negotiations. It also has not developed an opinion with regard to which forum would be preferable for Jamaica to negotiate international IP standards.

$\begin{array}{ll}354 & \text { Interview with Peter Goldson, } 31 \text { March 2010, Kingston. } \\ 355 & \text { Ibid. } \\ 356 & \text { Ibid. } \\ 357 & \text { Ibid. } \\ 358 & \text { Ibid. }\end{array}$




\subsection{Interim Conclusions}

The legal community is involved in Jamaican IP policy making when a matter is at issue that is in their immediate interest. This has been the case for discussions on the accession to the Madrid Protocol, which took place before the EPA negotiations started. In view of their strong lobbying efforts to avoid the accession to the Protocol, it is rather surprising that Jamaican IP lawyers did not make their views known during the EPA negotiations. An exception is Dianne Daley who was involved in specific consultations on IP with the MoFAFT due to her manifold positions and good contacts within the Government. According to Peter Goldson, law firms do not get involved in matters that their clients are not yet interested in. IP issues would be such an area.

Overall, IP lawyers in Jamaica are concerned about far-reaching IP protection, the implications of which have not been thoroughly assessed. This was the feeling the two interviewees got from the policy-making process during the EPA negotiations. They think that most stakeholders, partly including the Government, are not aware of the implications of increased IP protection.

\subsubsection{Academic Community}

Policy makers regularly draw upon the expertise of academics from the University of the West Indies to inform their policy choices. Some of the academics affiliated with the University were also involved in the debate about the Economic Partnership Agreement. One example is Norman Girvan, a professor emeritus of the UWI in St. Augustine, Trinidad \& Tobago who has a strong interest in trade negotiations that the region is involved in, including IP as part of such negotiations. His views and involvement are presented below as a regional actor. Although not part of the policy making or the negotiations of the EPA, the other interviewee presented here was involved in IP negotiations of prior trade agreements and disposes of a considerable body of experience in that field. Beverley Pereira is currently employed as University Counsel and Head of the Legal Unit in the Office of the Vice Chancellor at the University of the West Indies, Jamaica. As a Jamaican, her views are assessed as a national actor. Two other academics from Cavehill Campus, Wayne Hunte and Keith Nurse, were approached but could not be interviewed. No information was available to assess their preferences and involvement in the policy making on IP during the EPA negotiations.

\subsection{Norman Girvan, University of the West Indies St. Augustine, Trinidad \& Tobago}

Norman Girvan is a professor emeritus at the University of the West Indies. He has a strong research interest in the political economy of development in the Caribbean region and has published extensively on that matter. ${ }^{359}$ Next to his work as an academic, he served as a Board Member and Vice-Chairperson of the South Centre. Importantly, Norman Girvan was one of the authors of the memorandum "Renegotiate the EPA" submitted to the Reflections Group of the CARICOM 
Council of Trade and Economic Development for their meeting of 27 February $2008,{ }^{360}$ which has provoked some debate among the negotiators.

Norman Girvan's interest in IP is not specific; he does not focus on IP issues in his work. However, he has a general interest in the role of IP in stimulating or retarding innovation. ${ }^{361}$ This is also how far his comments went in the public debate on the IP provisions in the EPA, which he only communicated after the agreement had been initialled in December 2007. ${ }^{362}$ His core criticism of the IP chapter was that the negotiators accepted intellectual property provisions that went beyond the level of TRIPS in return for provisions on EU support for the development of innovation capacities. However, according to Norman Girvan, this trade-off was not in CARIFORUM's advantage as the provisions on EU support lack sufficiently concrete, specific and time-bound language whereas the TRIPS-plus provisions ${ }^{363}$ are very precise. ${ }^{364}$ Apart from this criticism, he was also concerned with the fact that commitments on IP issues have been made to the European Union while the CARICOM region has not yet completed a regional IP regime.

His opinion was in line with that of the South Centre, which had also commented on the IP chapter. ${ }^{365}$ In view of Norman Girvan's involvement in the organization South Centre and their common interests, it is fair to say that both actors have supported each other. Norman Girvan has not confirmed to have formed a coalition with similarly interested parties. 366

In addition, Norman Girvan has criticized the approach of CRNM. He held the view that CRNM, and in particular the negotiators drawn from that group, accepted the neo-liberal framework of the European Union. According to him,

See Speech by H. Brewster, N. Girvan and V. Lewis (23 March 2008), Renegotiate the $E P A$, available at <www.normangirvan.info/renegotiate-epa/> accessed on 12.11.2012.

Email correspondence with Norman Girvan, 22 April 2010 (available on request). According to him, he had only learnt about the IP chapter in the EPA end of October, early November 2007, less than two months from the initialling. Email correspondence with Norman Girvan, 22 April 2010.

The TRIPS-plus provisions in the CARIFORUM-EC EPA have been identified in Chapter 5: Legal analysis of the CARIFORUM-EC Economic Partnership Agreement. Examples of clear TRIPS-plus provisions are the obligation in Article 143.A.1 to comply with the WIPO Copyright Treaty and the WIPO Performers and Phonograms Treaty; the exclusive and additional protection of geographical indications for wines, spirits and other products in Article 145.B; the requirement to accede to the Patent Cooperation Treaty in Article 147.A.2; the enforcement provisions in the CARIFORUM-EC EPA are very detailed on specific requirements, taking away the policy space left by the TRIPS Agreement.

Email correspondence with Norman Girvan, 22 April 2010.

See Speech by Innovation and Access Programme of the South Centre (Geneva, 3 December 2007), Comments on "Innovation and Intellectual Property", Chapter 2 Part II, Title IV of the Draft CARIFORUM-EC EPA dated November 22, 2007, available at $<$ www.normangirvan.info $>$ accessed on 16.11.2012. 
"they were intellectually convinced that it would be good to bind the government policies in 'market-friendly' ways as that would encourage foreign investment." 367

Also, CRNM used the concessions made by the European Union on EU support for innovation capacities as a justification for signing the final agreement, reasons with which Norman Girvan did not agree.

Norman Girvan made these views known through writing memoranda, sharing information on his website, speaking on conferences, participating in marches and sponsoring petitions. ${ }^{368}$ Junior Lodge, at the time Technical Coordinator of the EPA negotiations for CRNM in Brussels, said he was surprised to learn about Norman Girvan's criticism only after the initialling of the agreement and that he had not contacted CRNM earlier. ${ }^{369}$ Due to the fact that Norman Girvan only got involved after the EPA negotiations had been concluded, it is fair to say that his influence on the IP provisions in the agreement has been non-existent.

On the question of forum choice, Norman Girvan indicates a preference for multilateral negotiations. As reasons, he mentions the stronger bargaining power and negotiation strength for Caribbean countries when being part of groups such as the G77 or that of small and vulnerable economies. The outcome of bilateral negotiations, where the formation of groups is not possible, is more likely to be weighted in favour of the developed country partner. ${ }^{370}$

To sum up, Norman Girvan has a general interest in intellectual property protection as part of international trade agreements. His criticism of the IP chapter in the CARIFORUM-EC EPA mainly addressed the precise TRIPS-plus concessions made by CARIFORUM. He clearly favours the multilateral forum above the bilateral one. Since he only made his views known after the EPA negotiations had been concluded, his influence on the negotiations of the IP chapter must have been non-existent.

\subsection{Beverley Pereira, UWI Mona Campus Jamaica}

Although Beverley Pereira is not currently occupied with IP matters, she has fulfilled several positions in the recent past that have provided her with valuable insights on IP policy making in Jamaica. Currently, she holds the position of University Counsel and Head of the Legal Unit in the Office of the Vice Chancellor at the University of the West Indies in Jamaica. Before that, she held the position of Deputy Chief Parliamentary Counsel in the Office of the Parliamentary Counsel, Ministry of Justice (the Office responsible for drafting the laws). As Parliamentary Counsel, she drafted IP legislation for Jamaica, including the Copyright Act of 1993, related regulations and the Trade Marks Act of 1999. She was also the chairperson of the Copyright Tribunal of Jamaica for six years. ${ }^{371}$ After the TRIPS Agreement entered into force, Beverley Pereira became more involved in IP policy making in Jamaica. She was part of the Interministerial Committee, which assessed the legal changes that needed to be made in view of the TRIPS obligations. Shortly after that, she was on the negotiating team

\footnotetext{
$367 \quad$ Ibid.

368 See Girvan, Caribbean Political Economy.

369 Interview with Junior Lodge, 3 March 2010, Geneva.

370 Email correspondence with Norman Girvan, 17 August 2011.

371 Interview with Beverley Pereira, 6 April 2010, Kingston.
} 
for the US-Jamaica IPR Agreement and later became the lead negotiator on behalf of CARICOM Member States for intellectual property provisions in the FTAA negotiations. Overall, Beverley Pereira's extensive experience in negotiations and the subject matter of international IP negotiations justifies her inclusion in this section, even though she was not involved in national or regional policy-making processes during EPA negotiations on IP issues. ${ }^{372}$

Beverley Pereira is of the opinion that when negotiating intellectual property provisions with international partners, the CARIFORUM region in general and Jamaica in particular needs to be aware that they are mainly users of intellectual property. ${ }^{373}$ The ability to take on IP protection to her seems to be a function of the level of industrial development of a country. In the case of the Caribbean, this level is still not high, even in the area of music and entertainment where copyright protection could be useful but, in general, lacks an efficient administration of rights by right holders organizations. With regard to the EPA, she is mostly concerned about the fact that it includes a number of TRIPS-plus provisions. ${ }^{374}$ In view of past experiences of how intellectual property protection has developed at the international level, she is worried that the United States will approach the Caribbean region and/or Jamaica to accept standards of IP protection that go beyond the ones agreed to by Chile and the CAFTA-DR region. ${ }^{375}$ Since they accepted the EPA with a comprehensive IP chapter, the US might request their approval of the standards put forward by the United States.

In reply to the question in which forum she thinks it is more beneficial for Jamaica or the CARIFORUM region to conduct negotiations on IP protection, Beverley Pereira feels that Jamaica and CARIFORUM should be concerned about the bilateral setting where the flexibilities of the TRIPS Agreement are thoroughly eroded. ${ }^{376}$ By way of the most-favoured-nation treatment obligation in the TRIPS Agreement, countries immediately multilateralize bilateral obligations which might not prove to be in their interest. At the same time, she acknowledges that signing up to bilateral TRIPS-plus standards has become a political reality. It is a political choice for governments to determine which areas of the agreement are absolute musts and which areas can be sacrificed; IP protection usually belongs to the latter ones. ${ }^{377}$ This is also true for Jamaica or the CARIFORUM region, which are not IP demandeurs and will therefore not put a priority on the protection of intellectual property. She has developed this opinion from her experiences in previous IP negotiations; whether that is how it went in the EPA, she cannot say.

In brief, Beverley Pereira is an experienced IP expert currently employed by the University of the West Indies, Jamaica Campus. She is concerned with the IP chapter in the CARIFORUM-EC EPA because it contains TRIPS-plus provisions that have to be multilateralized and, at the same time, erode TRIPS flexibilities. In order to

\footnotetext{
372 Beverley Pereira stated that she has been consulted by neither the Jamaican Government nor CRNM. Interview with Beverley Pereira, 6 April 2010, Kingston.

373 Interview with Beverley Pereira, 6 April 2010, Kingston.

374 Ibid.

375 Ibid.

$376 \quad$ Ibid.

377 Ibid.
} 
avoid global standard setting through bilateral agreements, she feels that negotiations on IP matters at the multilateral level are more beneficial for Jamaica and the region. When it comes to Beverley Pereira's involvement the IP policy making in the context of the EPA negotiations, it has to be noted that she was not part of any consultations.

\subsection{Interim Conclusions}

Norman Girvan and Beverley Pereira are academics with a general interest in intellectual property issues negotiated in international trade agreements. Although neither of them has been directly involved in the negotiations of the EPA or in consultations thereon, both have been concerned with the level of commitment that the region was willing to accept in the area of IP protection: to go beyond the TRIPS standard in certain areas of IP. They prefer negotiations at the multilateral level above those carried out at the bilateral for different reasons. Norman Girvan believes that the region can have a greater leverage in a multilateral setting whereas Beverley Pereira emphasizes the danger of eroding multilateral flexibilities when concluding bilateral agreements.

\subsubsection{International Non-state and Para-state Actors}

A short overview is given of the role of international non-state and para-state actors $^{378}$ that are mostly based in Geneva and have had some interest in the regulation of intellectual property issues in the CARIFORUM-EC EPA. Although their involvement in the policy-making or negotiation process was not at the heart of this research, some information has been gathered, which allows for a few general remarks.

Since the negotiations of the TRIPS Agreement, a number of international non-state and para-state actors have been involved in the debate on international intellectual property standard setting, in particular reflecting the point of view of developing countries. ${ }^{379}$ Some examples ${ }^{380}$ of international civil society organizations are Oxford Committee for Famine Relief International, 381 Medecines sans Frontieres, 382 International Centre for Trade and Sustainable Development, ${ }^{383}$ Center for

378 The concept of para-state actors refers to actors that are not completely independent from a government, be it regarding their financing or input on their policy-agenda. However, their work is similar to that of a non-state actor in that it tries to provide independent policy advice.

See Drahos, "Developing Countries and International Intellectual Property Standard Setting", p. 26 ff. and 29; Sell and Prakash, "Using Ideas Strategically".

380 Those have been mentioned by the interviewees to be relevant in the international intellectual property arena.

381 Oxfam is a confederation of fifteen affiliates who work together to enable people to exercise their rights and manage their own lives.

382 Medecines sans Frontieres is an international, independent, medical humanitarian organization.

383 ICTSD is an independent, non-profit and non-governmental organization that serves as a leading source of knowledge and information on trade policy and sustainable development. 
International Environmental Law, ${ }^{384}$ Third World Network, ${ }^{385}$ and Quaker United Nations Office. ${ }^{386}$ Two para-state actors mentioned by interviewees were the Gesellschaft für Internationale Zusammenarbeit ${ }^{387}$ and South Centre. ${ }^{388}$

There seems to be a consensus that, under certain conditions, international non-state and para-state actors can and have been successful in influencing international policy outcomes in the field of IP where multilateral forums are at issue. Less clarity exists about their role and contribution to policy decisions taken by developing country state actors at the national and regional level. The data collected from the interviews conducted for this research allows adding some observations, in particular on whether international non-state and para-state actors also focus on IP decision making at the national and regional developing country level, and in how far their expertise is taken up by developing countries.

For that purpose, Sisule Musungu's views on the possible influence of international non-state and para-state actors are presented in detail. Sisule Musungu is the President of the Geneva-based civil society organization IQSensato. IQsensato is a not-for-profit organization which aims at providing high-quality research and policy advice to stimulate a well-informed policy debate. Its main area of focus so far has been intellectual property protection and innovation; the organization is involved in various projects, carries out studies and publishes newsletters. ${ }^{389}$

According to Sisule Musungu, international non-state and para-state actors have an important role to play in international IP policy making. They make developing countries aware of particular problems and provide the necessary expertise and understanding of the issues under discussion, knowledge that the developing country cannot dispose of at home. ${ }^{390}$ According to him, there are some conditions that make their influence on developing countries' policy decisions more likely. One such factor is whether the developing country's negotiator is located in Geneva, close to

Center for International Environmental Law is a public interest, non-profit environmental organization that is committed to strengthening and using international law and institutions to protect the environment, promote human health and ensure a just and sustainable society.

Third World Network is an independent non-profit international network of organizations and individuals involved in issues relating to development, developing countries and North-South affairs.

Quaker United Nations Office is a non-governmental organization that represents Friends at the international level.

Gesellschaft für Internationale Zusammenarbeit is a federal enterprise that supports the German Government in achieving its objectives in the field of international cooperation for sustainable development. The services it offers follow a holistic approach and are guided by the concept of sustainable development. In this respect, its services are comparable with those of international civil society organizations. The South Centre is an intergovernmental policy think tank that interfaces with both developing countries and non-state actors. The work they produce is similar to that of a civil society organization as it functions as an independent policy think tank, which provides policy-oriented research and analysis.

See IQsensato, Publications (2011), available at <http://www.iqsensato.org/index.php/publications/> accessed on 16.11.2012. Interview with Sisule Musungu, President of IQSensato, 4 March 2010, Geneva (available on request). 
international CSOs in the field. The Geneva-based delegates are more inclined to listen to the advice from international non-state and para-state actors than national governments back home. ${ }^{391}$ Second, there is a discrepancy between smaller developing countries and the bigger ones: the latter countries such as India, Brazil, Kenia or Chile are less likely to rely on the services of international non-state and para-state actors, such as reports or advisory papers, than the smaller countries. ${ }^{392}$

Third, the area of expertise of a civil society organization matters considerably in whether an international CSO is influential on domestic policy making or not. Foreign trade issues, including the protection of intellectual property, are issues for which developing countries are more likely to turn to international non-state and para-state actors than to domestic ones. ${ }^{393}$ Fourth, the fact whether trade negotiations take place at the multilateral, regional or bilateral level is not a criterion that international non-state and para-state actors consider when determining their involvement: to his knowledge, most international actors that provide policy advice on intellectual property issues focus on all levels of negotiations as the issues addressed tend to be the same.

Comparing Sisule Musungu's general observations with the case study CARIFORUM, in particular Jamaica, most of his observations seem to be true for the case of Jamaica, a small developing country, during the EPA negotiations. For the regional level, the technical negotiator Malcolm Spence, although located in the CARIFORUM region, was in contact with some of the Geneva-based non-state and para-state actors as a matter of his personal contacts. Center for International Environmental Law and Quaker United Nations Office were particularly relevant for the development of a policy position on transfer of technology as well as the enforcement provisions in the CARIFORUM-EC EPA. Next to the direct contact he had with some of the international non-state and para-state actors, the South Centre and the Third World Network supposedly have been in contact with the regional civil society organization Caribbean Policy Development Centre. ${ }^{394}$ This information has not been confirmed by CPDC.

Regarding the national level, Malcolm Spence reported that the Jamaican Permanent Mission in Geneva has received all the publications published by the South Centre and the Third World Network. ${ }^{395}$ Michelle Walker from the Ministry of Foreign Affairs and Foreign Trade confirmed that the reports and papers published by South Centre, Third World Network and International Centre for Trade and Sustainable Development were assessed by the Jamaican Ministry of Foreign Affairs. ${ }^{396}$ The conclusions of such reports and papers were also presented in the consultations with stakeholders and therefore taken on board in the policy-making process. However, neither the Permanent Mission nor the Ministry of Foreign Affairs and Foreign Trade

$\begin{array}{ll}391 & \text { Ibid. } \\ 392 & \text { Ibid. } \\ 393 & \text { Ibid. } \\ 394 & \text { Interview with Malcolm Spence, } 6 \text { April 2011, Bridgetown. } \\ 395 & \text { Ibid. } \\ 396 & \text { Interview with Michelle Walker, } 13 \text { April 2011, Kingston. }\end{array}$


commissioned a special impact assessment study or a report from one of the international non-state and para-state actors. ${ }^{397}$

To conclude, international non-state and para-state actors have been in contact with Jamaican policy makers and the regional technical negotiator through reports, studies and, for the latter, personal contacts. One conclusion therefore is that a number of the international CSOs focus on IP matters also in bilateral negotiations. Another conclusion is that both the national as well as the regional policy makers took their suggestions into account when determining their policy.

\subsubsection{Conclusions}

The analysis of non-state actors' preferences and involvement in the IP policy making during the EPA negotiations has provided considerable insights in the nonstate actor's landscape in Jamaica and the CARIFORUM region. Table 17 summarizes the results for each non-state actor presented according to the categories size, heterogeneity of members in terms of endowments, their interest in intellectual property issues, their involvement in the policy making during the EPA negotiations and their position towards the question which forum is more beneficial for Jamaica/the CARIFORUM region to regulate IP at an international level.

For the category size, three varieties have been noted: either an organization was classified as large (with at least twenty members), ${ }^{398}$ small (with less than twenty members) or the actor was an individual person or an undertaking. In the category "Interest in IP", a distinction was made between two factors. The first factor addresses the range of issues an organization deals with. An actor either solely or primarily targeted intellectual property protection, or (s)he had a preference for different subjects, one of which was IP protection. The second factor specifies what kind of interest an actor had in intellectual property protection. Here, an actor could have a marginal, general or specific interest in IP. An actor was labelled as having a marginal interest in IP if that actor does not or hardly deals with intellectual property issues in her/his work and also lacked the necessary knowledge on the subject matter. An actor was labelled as having a general interest in IP if (s)he had a general understanding of different forms of IP protection, including its regulation at the international level, and the issue is part of her/his work, even though not as a major topic. If an actor had specific knowledge on intellectual property issues, in particular on its regulation at the international level, dealt with these matters as an important issue in her/his work and had formed a preference on such matters, the actor was categorized as having specific preferences on certain issues of intellectual property protection. The last two categories list the consultations that actors participated in and the preference for the bilateral or multilateral forum.

Ibid.

The boundary of twenty members has been chosen on the basis of the data collected in the CARIFORUM region. The Caribbean Policy Development Centre assembles approximately twenty national networks of civil society organizations. However, since these networks have individual members themselves, this organization needs to be classified as large. See section 10.2.1.3.1 of this book. 
Table 17: Non-state actors' preferences and involvement in IP policy making during EPA negotiations

\begin{tabular}{|c|c|c|c|c|c|}
\hline $\begin{array}{l}\text { CATEGORY NON- } \\
\text { STATE ACTOR }\end{array}$ & $\begin{array}{l}\text { NAME NON- } \\
\text { STATE ACTOR }\end{array}$ & SIZE & $\begin{array}{l}\text { PREFERENCES } \\
\text { IN IP }\end{array}$ & $\begin{array}{l}\text { INVOLVEMENT IN IP } \\
\text { POLICY MAKING }\end{array}$ & FORUM CHOICE \\
\hline \multicolumn{6}{|c|}{ Business/industry associations and producers } \\
\hline Regional & $W I R S P A$ & $\begin{array}{l}\text { Large } \\
\text { association }\end{array}$ & $\begin{array}{l}\text { Multi-issued } \\
\text { and marginal }\end{array}$ & Informal contacts & No preference \\
\hline Regional & WICSCBS & $\begin{array}{l}\text { Small } \\
\text { association }\end{array}$ & $\begin{array}{l}\text { Multi-issued } \\
\text { and specific }\end{array}$ & Informal contacts & Bilateral forum \\
\hline National & PSOJ & $\begin{array}{l}\text { Large } \\
\text { association }\end{array}$ & $\begin{array}{l}\text { Multi-issued } \\
\text { and general }\end{array}$ & $\begin{array}{l}\text { TTAT consultations } \\
\text { GI working group }\end{array}$ & No preference \\
\hline National & JCC & $\begin{array}{l}\text { Large } \\
\text { association }\end{array}$ & $\begin{array}{l}\text { Multi-issued } \\
\text { and general }\end{array}$ & JTAT consultations & Multilateral forum \\
\hline National & $C C$ & $\begin{array}{l}\text { Individual } \\
\text { consultancy } \\
\text { firm }\end{array}$ & $\begin{array}{l}\text { Multi-issued } \\
\text { and specific }\end{array}$ & GI working group & Bilateral forum \\
\hline National & $\begin{array}{l}\text { Greenwich } \\
\text { Mountain Estate }\end{array}$ & $\begin{array}{l}\text { Individual } \\
\text { coffee } \\
\text { producer }\end{array}$ & $\begin{array}{l}\text { Multi-issued } \\
\text { and marginal }\end{array}$ & No involvement & No preference \\
\hline National & JSP & $\begin{array}{l}\text { Individual } \\
\text { coffee } \\
\text { producer }\end{array}$ & $\begin{array}{l}\text { Multi-issued } \\
\text { and general }\end{array}$ & GI working group & No preference \\
\hline \multicolumn{6}{|c|}{ Civil society organizations } \\
\hline Regional & $C P D C$ & $\begin{array}{l}\text { Large } \\
\text { network of } \\
\text { CSOs }\end{array}$ & $\begin{array}{l}\text { Multi-issued } \\
\text { and marginal }\end{array}$ & No involvement & Multilateral forum \\
\hline \multicolumn{6}{|l|}{ Lawyers } \\
\hline National & Dianne Daley & $\begin{array}{l}\text { Individual } \\
\text { lawyer }\end{array}$ & $\begin{array}{l}\text { Single-issued } \\
\text { and specific }\end{array}$ & $\begin{array}{l}\text { Specific IP } \\
\text { consultations }\end{array}$ & $\begin{array}{l}\text { Depends on area } \\
\text { of IP and partner } \\
\text { country }\end{array}$ \\
\hline National & Peter Goldson & $\begin{array}{l}\text { Individual } \\
\text { lawyer }\end{array}$ & $\begin{array}{l}\text { Multi-issued } \\
\text { and general }\end{array}$ & No involvement & No preference \\
\hline \multicolumn{6}{|l|}{$\begin{array}{l}\text { Academic } \\
\text { community }\end{array}$} \\
\hline Regional & Norman Girvan & $\begin{array}{l}\text { Individual } \\
\text { academic }\end{array}$ & $\begin{array}{l}\text { Multi-issued } \\
\text { and general }\end{array}$ & No involvement & $\begin{array}{l}\text { Multilateral } \\
\text { forum }\end{array}$ \\
\hline National & Beverley Pereira & $\begin{array}{l}\text { Individual } \\
\text { academic }\end{array}$ & $\begin{array}{l}\text { Single-issued } \\
\text { and specific }\end{array}$ & No involvement & $\begin{array}{l}\text { Multilateral } \\
\text { forum }\end{array}$ \\
\hline
\end{tabular}

First, twelve non-state actors have been presented that have an interest in intellectual property protection in the CARIFORUM-EC EPA. This relatively low number of groups is partly a result of methodological problems of establishing contact with nonstate actors. ${ }^{399}$ However, and more importantly, it also shows that there are very few non-state actors with an interest in the regulation of IP issues in trade agreements. Even including the non-state actors identified and contacted but not interviewed (actors contacted but not interviewed were approximately twenty-five actors), the number of actors is still very low, even for a small developing country such as Jamaica and the region CARIFORUM. In addition, and as will be elaborated further in the fifth conclusion hereunder, the majority of the actors presented are not knowledgeable on the protection of intellectual property rights in general and on its regulation in the EPA.

Second, out of the twelve non-state actors presented, four are regional. This very low number of regional actors can lead to the following two conclusions: 1) there is merely a limited number of groups with some affinity for IP protection that operate at a regional level due to a relatively low level of regional integration (the region CARICOM) in the area of intellectual property protection; and 2) only a few regional 
actors are interested in intellectual property protection in the context of trade agreements that the region CARIFORUM concludes. Overall, more non-state actors' activity in the area of IP can be constituted at the national level than at the regional level.

Third, out of the twelve non-state actors presented, five are groups or associations. The majority are individual persons or companies. This lower number of groups compared to individual actors could suggest two conclusions: 1) there are not enough individual actors with an interest in the field of IP in order to form a group that will further their collective interest; ${ }^{400} 2$ ) there is not enough collective interest in the field of IP of a number of individual actors to build a group with a focus on this issue. Clearly, the first conclusion is supported by the fact that there is a general lack of non-state actors with an interest in IP. Chances that the few non-state actors with an interest in IP will form a group to further their collective goal are rather small since they originate from very different groupings of society (such as the business sector, professional organizations and academia). In addition, as the second conclusion explains, those few non-state actors also need to have common preferences in an area of IP to form a group. An example of such common preferences could be the promotion or resistance to the accession to the Madrid Protocol. 401 However, the process of group forming could not be observed during the EPA negotiations.

Fourth, out of the five groups identified, four were large groups, ranging from 20 to 330 members, ${ }^{402}$ and one a small organization.

Fifth, there are only very few actors that are actually informed about intellectual property issues and interested in their regulation. The majority of the actors presented are not knowledgeable enough on IP protection to have formed preferences. They mainly focus on other areas of trade and only have a marginal or general interest in IP protection. The few actors with specific preferences on IP issues in general are WICSCBS, the Competitiveness Company (although it does not have preferences with regard to the international regulation of IP), Dianne Daley and Beverley Pereira. It can be observed that only one of the four actors is a group of actors; also, none of them falls under the category of civil society organization. The latter two actors both have a strong background in IP policy making in Jamaica due to their previous functions. Their preferences in the field of IP can also be understood as those of partial state actors rather than pure non-state actors.

Sixth, only six of the presented non-state actors have been involved in the IP policymaking process during the EPA negotiations. Out of these six, one non-state actor is

It does not seem to be feasible that the individual actors that could form a group are so many that they face collective action problems.

This debate indeed took place before the EPA negotiations where the legal community, on the one hand, and the private businesses together with JIPO, on the other hand, formed groups.

402 Twenty members may sound like a rather small number of members. However, the Caribbean Centre of Policy Development, for which twenty members could be identified, assembles national civil society organizations which themselves assemble various numbers of individual members. Therefore, the judgment of calling the CPDC a large organization seems to be adequate. 
Dianne Daley, a lawyer and expert in IP protection. She has specific preferences on IP matters and was the only non-state actor involved in the specific IP consultations convened by the Ministry of Foreign Affairs and Foreign Trade of Jamaica and JIPO. Another actor with specific preferences on IP matters was WICSCBS, the only sugar cane breeder in the region. Even though not involved in consultations, the Breeding Station had informal contact with the regional negotiator. The other four actors belong to the group of producers, businesses and business and industry associations; these are Private Sector Organization of Jamaica, Jamaica Chamber of Commerce, the Competitiveness Company and Jamaica Standard Products Company. Jamaica Chamber of Commerce participated in the consultations of the Jamaica Trade Adjustment Team; the Competitiveness Company and Jamaica Standard Products Company were part of the GI working group. The Private Sector Organization of Jamaica was involved in both forums.

Among these four actors, the Competitiveness Company is the only one that has been identified as having specific preferences on matters of IP protection; however, also CC's preferences do not incorporate the regulation of intellectual property in international trade agreements. According to the other three actors' own accounts, their interests in IP are of a general nature and of little importance to its members. Due to these four actors' limited interest in IP protection in the EPA, their participation in the national consultation mechanisms can be qualified as rather passive; this is in contrast to Dianne Daley's participation, which can be classified as active. 403

A seventh conclusion that can be made is that almost no public debate emerged in the CARIFORUM region on the IP provisions in the CARIFORUM-EC EPA. Some interviewees mentioned as a reason the lack of a culture of IP in their society. 404 Non-state actor groups are not concerned with the protection of intellectual property; their priorities are clearly in other areas of trade. It seems to be generally accepted that the struggle to obtain preferred positions on IP matters in trade negotiations should not be at the expense of other aspects of trade that are considered to be vital to the economies of these states. ${ }^{405}$ Part of the problem is also that possible stakeholders are not educated in IP protection: they do not know what the implications of certain policy choices are. ${ }^{406}$ Governments first have to teach them what particular provisions in a trade agreement mean before a group can form a position on whether they think this is in their interest or not. JIPO clearly is trying to inform Jamaican stakeholders about IP protection in general; however, the success is limited and certainly did not reach so far as to foment positions by non-state actors in the debate on IP provisions during the EPA negotiations.

Lastly, in view of the above stated conclusions, it also becomes clear that the question of forum choice, in many cases, went beyond the level of understanding of most non-state actors interviewed. This is also reflected by the answer of five

\footnotetext{
403 See section 10.2.3 of this book.

404 Interviews with Dianne Daley, 31 March 2010, Kingston, and Beverley Pereira, 6 April 2010, Kingston.

405 Interview with Beverley Pereira, 6 April 2010, Kingston.

406 Phone interview with Shantal Munro-Knight, 13 May 2010, and interview with Dianne Daley, 31 March 2010, Kingston.
} 
interviewees who stated that they have no opinion on which forum to prefer as they are not concerned with the multilateral level of regulating intellectual property rights. Four out of the other seven interviewees mentioned a preference for the multilateral level. For three of those (Jamaica Chamber of Commerce, Caribbean Policy Development Centre and Norman Girvan), the increased leverage of Jamaica/the region in multilateral forums was determinative in that choice. The other proponent of the multilateral level (Beverley Pereira) argued that the erosion of TRIPS flexibilities as well as the immediate multilateralization of bilateral standards through the MFN treatment obligation in the TRIPS Agreement are important reasons why CARIFORUM States should be careful in agreeing to IP standards at the bilateral level. The important and interesting advantage of the multilateral level that Jamaica could benefit from the experience of other countries such as India was not mentioned by any non-state actor; only Audia Barnett from the public agency Scientific Research Council raised this point. ${ }^{407}$

Dianne Daley distinguished in her choice different areas of IP and different partner countries. She favours bilateral agreements for those areas of IP where there is no multilateral agreement (for example traditional knowledge) and where partner countries have important markets that can be exploited by Jamaican products. At the same time, she is concerned about the asymmetrical relationship between bilateral partners and agreements of a wide scope where IP issues can become bargaining tools for other areas under negotiation.

Finally, two actors with a preference for the bilateral level were West Indies Central Sugar Breeding Station and the Competitiveness Company. While WICSBS preferred the bilateral level only for plant variety protection and purely based on reasons of content (rather than process), CC felt that bilateral agreements for IP regulation have proven to be successful in solving problems that occurred in the past. Of the actors with specific preferences on issues of IP protection, Anthony Kennedy, Beverley Pereira and Dianne Daley appreciate the advantages and disadvantages of negotiations at both forums. The Competitiveness Company, however, seems to merely focus on the short term benefits of a bilateral solution without seeing possible dangers of conducting bilateral negotiations.

The insights from the analysis of regional and Jamaican non-state actors with an interest in IP issues will be taken up in Chapter 1 : The International System of Protecting Intellectual Property pre-TRIPS. The purpose there is to show how much influence these actors had through their involvement in consultations on the determination of the national and regional policy positions on IP issues discussed during the EPA negotiations. Before this assessment can be made, the next sections 10.2.2 and 10.2.3 investigate the regional and national consultative processes between state and non-state actors held during the EPA negotiations.

\subsubsection{Regional Consultative Processes, Organized by CRNM}

The regional consultations were an important part of the consultative processes during the EPA negotiations since they took place in parallel and added to the national consultations organized in each CARIFORUM State individually. The scope 
and timeliness of the national consultations differed considerably from country to country. Even in the larger countries where consultations went reasonably well, the results were not delivered to the regional level in time for the negotiators to use them during the negotiations. ${ }^{408}$ When this challenge became obvious to CRNM, it started to facilitate and coordinate regional consultations, primarily with business and industry associations whose input they felt was critical to the formulation of the negotiating agenda and strategy of the CARIFORUM region during the EPA negotiations.

CRNM's efforts encompassed three main activities through which consultations with non-state actors were carried out: 1) consultations in the technical working groups; 2) the Private Sector Outreach Programme (PSOP); and 3) the Caribbean Non-State Actor (NSA) Network. While the consultations with non-state actors in the technical working groups involved regional private sector organizations, such as business and industry associations, the PSOP targeted national business and industry associations, and the NSA Network mainly civil society organizations at the national and regional level.

Not only did the three initiatives involve different kinds of non-state actors, they also fulfilled different functions in the formulation of regional negotiating positions. The technical working groups served as a forum where negotiating positions were formulated by coordinating the views of national and regional non-state actors with those of the officials from Member States, regional secretariats and the negotiating team. ${ }^{409}$ While the TWG coordinated the regional negotiating positions just before the actual negotiations, the second and third initiative took place prior to TWGs' meetings and informed their work. As shown in Scheme 6 published by CRNM, ${ }^{410}$ the results of national and regional consultative processes, such as the Private Sector Outreach Programme and the Non-State Actor Network, fed into the discussions in the TWGs. ${ }^{411}$ This section aims at establishing what forums of consultation existed at the regional level, what activities they included, which actors they addressed and whether they dealt with intellectual property protection in general as well as in the context of the EPA negotiations.

408 Interview with Malcolm Spence, 6 April 2010, Bridgetown.

409 See section 10.1.3.5 of this book.

410 See CRNM, "Diagram of the CARIFORUM EPA Negotiating Structure" RNM Update 0801, 2008.

411 Note that the scheme also mentions consultations with special interest groups. From the interviews conducted and the information collected from other sources, meetings with special interest groups were not seen as a distinct category of activities but would rather fall under the Private Sector Outreach Programme. This is why this group of activities are not treated separately from the PSOP. 
Scheme 6: CARIFORUM Negotiating Structure Update 0801

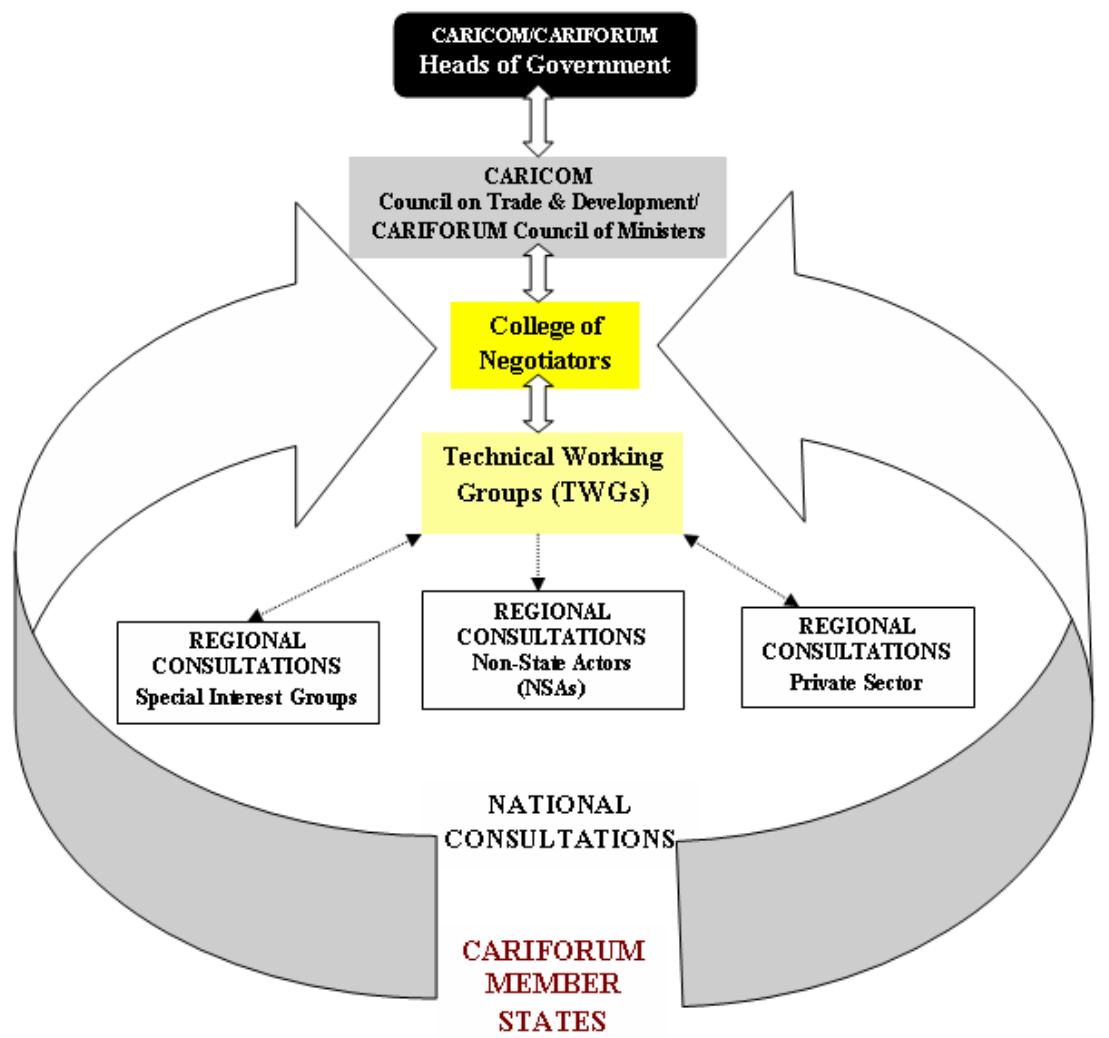

Source: CRNM "CRNM EPA Reflections" 2008

\subsubsection{Methodology}

The analysis presented in this section relies mainly on the detailed information available on the website of the former CRNM, in particular the RNM Updates, as well as the account published by Richard Bernal. In addition, information from the interviews conducted with Malcolm Spence, Junior Lodge and Shantal Munro-Knight helped to clarify certain issues. In relation to the Non-State Actor Network, difficulties were encountered in finding relevant sources that described the exact scope and amount of activities organized under the NSA Network. Here, the information provided by PricewaterhouseCoopers' report on a workshop on building sustainable development in the Caribbean region ${ }^{412}$ as well as the final declaration of

412 PricewaterhouseCoopers, Final Report of the conference "Caribbean Workshop on Building Sustainable Development Issues into Economic Partnership Agreements (EPA)" in Montego Bay, Jamaica (sponsored by European Commission, 24-25 July 2006). 
a seminar for European and ACP economic social interest groups ${ }^{413}$ were informative.

\subsubsection{Technical Working Groups}

The main purpose of the technical working groups was to formulate regional negotiating positions and to build consensus among CARIFORUM States. In assembling various actors at one table, TWG meetings also fulfilled an important consultation role. The composition of the groups differed depending on the subject matter addressed. Intellectual property protection came under the scope of the technical working group on trade-related issues. The TWG on trade-related issues mainly comprised technical experts from CRNM, officials from CARIFORUM States and regional secretariats. ${ }^{414}$ In addition to these state actors, information on the preferences and objectives of relevant non-state actors was needed in order to formulate the regional negotiating positions. While the preferences of national nonstate actors (expressed in the national consultations, the Private Sector Outreach Programme and the Non-State Actor Network) were brought to the table by the officials from CARIFORUM States and CRNM staff, there was a need to engage regional non-state actors also. Those are the actors that are organized at the level of CARIFORUM or CARICOM and who were not addressed by national consultations and the PSOP.

In particular, non-state actors invited to the technical working groups were regional private sector organizations that had the opportunity to share their views directly with the negotiating team and the officials from CARIFORUM States. They were socalled participant observers without voting rights when decisions were made. ${ }^{415}$ According to Malcolm Spence, only one such industry association with an interest in intellectual property protection actually attended TWG meetings on trade-related issues, namely the regional rum and spirits producers' organization (WIRSPA). ${ }^{416}$ WIRSPA itself classified its involvement in IP issues during the EPA negotiations as peripheral. ${ }^{417}$ Next to business and industry organizations, civil society organizations reportedly should also have participated in the TWGs; ${ }^{418}$ however, in the area of

$413 \quad$ European Economic and Social Committee, Final Declaration of the conference "9th Regional Seminar of ACP-EU Economic and Social Interest Groups" in Bridgetown, Barbados (14-16 May 2007).

414 Interview with Junior Lodge, 3 March 2010, Geneva.

415 Interview with Malcolm Spence, 7 April 2010, Bridgetown.

416 Also other regional private sector organizations were identified by Malcolm Spence as having been present at TWGs meetings. However, they have primarily been involved and interested in market access and other areas rather than IP. These organizations were the Sugar Association of the Caribbean, the Caribbean Poultry Association, the Caribbean Breweries Association and the Caribbean Rice Association. Interview with Malcolm Spence, 7 April 2010, Bridgetown.

417 Email correspondance with Frank Ward, 23 March 2010 and 27 March 2012 (available on request).

418 See CRNM, “The EPA: Fact vs. Fiction” EPA Fact vs Fiction Series, 2008, (Issue 2), available at <www.crnm.org $>$ accessed on 21.11.2012. 
trade-related issues, no civil society organization could be identified as having been a participant in the technical working group. ${ }^{419}$

In brief, the technical working group mainly served as a mechanism to coordinate the views of national and regional state and non-state actors. At the same time, it constituted the consultation forum for regional businesses and industries which participated in the TWGs meetings as observers. In TWG meetings on trade-related aspects, which included intellectual property protection, no civil society organizations and only one business and industry association participated. Compared to the other consultation activities organized at the regional level, the TWG was not of major importance as a consultation tool.

\subsubsection{Private Sector Outreach Programme (PSOP)}

In addition to inviting regional business and industry associations directly to TWG meetings, CRNM also engaged national businesses and industries. ${ }^{420}$ This had become necessary because the private sector in the individual CARIFORUM States was not sufficiently involved in the national consultation processes; these businesses did not feel that EPA negotiations were really important to them. ${ }^{421}$ The Private Sector Outreach Programme was meant to stimulate businesses' and industry sectors' participation in national consultative processes. By directly providing them with timely information on the EPA negotiations, the CRNM wanted to trigger their feedback and therewith distil the objectives of importers and exporters in the various fields of trade affected by the EPA.422 The information obtained from the national businesses was communicated back to trade ministry officials from CARIFORUM States and CRNM staff made sure that this information was reflected in the TWG meetings. ${ }^{423}$ Although this was not a comfortable situation for CRNM staff, they felt it was a practical approach to remedy the lack of stakeholders' involvement; in fact, most CARIFORUM officials appreciated this approach as it supplemented their own efforts. $^{424}$

The activities under the PSOP were manifold. They can be classified in two groups of activities according to their main goal. The first group of activities were primarily aimed at providing information on different aspects of the EPA negotiations. These were the "Caribbean TradeBeat and TradeBeat Extra Radio Programmes" 425 and the

419 Interview with Malcolm Spence, 7 April 2010, Bridgetown; phone interview with Shantal Munro-Knight, 13 May 2010. Annita Montoute, in her thesis, also finds a general bias towards private sector organizations at the detriment of civil society organizations in the consultations regarding in all areas of trade. See Montoute, Civil Society Participation in Trade Negotiations, p. 151. See Bernal, "CARIFORUM-EU Economic Partnership Agreement Negotiations", p. 15. Interview with Malcolm Spence, 6 April 2010, Bridgetown. See Bernal, "CARIFORUM-EU Economic Partnership Agreement Negotiations", p. 15. Interview with Malcolm Spence, 6 April 2010, Bridgetown. Ibid.

See CRNM, Office of Trade Negotiations: Caribbean Community (CARICOM) Secretariat (2011), available at < http://www.crnm.org/> accessed on 15.11.2012. 
CRNM "Private Sector Trade Briefs". ${ }^{426}$ The protection of intellectual property was, however, only marginally covered by these activities: only three radio broadcasts ${ }^{427}$ (out of one hundred) and two trade briefs ${ }^{428}$ (out of twenty-six) addressed intellectual property protection in general, in the context of innovation or in relation to creative industries.

A second group of activities focussed on providing training and opportunities for discussions. They included the capacity-building workshops called "Trade Power Dialogues"429 and "Trade Negotiation Boot Camps"430 as well as interactive meetings such as town-hall meetings, ${ }^{431}$ consultations with business associations, ${ }^{432}$ in-country research and consultation missions ${ }^{433}$ and sector-specific workshops in individual CARIFORUM States. ${ }^{434}$ Together, the activities were meant to constitute a systematic opportunity for national businesses and industries to take part in the policy-making process. ${ }^{435}$ Neither the workshops ${ }^{436}$ nor the interactive meetings ${ }^{437}$ addressed intellectual property issues to a significant extent.

\subsubsection{Regional Consultations with Non-State Actors (NSAs)}

The third component of consultations that should feed into the technical working groups (next to the Private Sector Outreach Programme and national consultations) were those with civil society organizations. The Regional Non-State Actor (NSA)

See CRNM, "Expanding the CRNM Private Sector Outreach" CRNM Private Sector Trade Brief, 2005, Vol. 1, p. 1.

See broadcast 34 on "Trade and Innovation", broadcast 42 on "Ideas plus Innovation equals Trade Power" and broadcast 105 on "The Caribbean at the movies". See CRNM, Office of Trade Negotiations: Caribbean Community (CARICOM) Secretariat.

See CRNM, "Fostering Innovation Through Trade Agreements" CRNM Private Sector Trade Brief, 2007, Vol. 26, 1-6; CRNM, "Developing The Potential of Creative Industries" CRNM Private Sector Trade Brief, 2006, Vol. 16, 1-5.

See CRNM, "Private Sector Perspectives on Trade Agreements" CRNM Private Sector Trade Brief, 2007, Vol. 27, 1-8.

See ibid. See CRNM, "Press Release: CRNM Private Sector Boot Camps Series Labelled a Success" (Kingston, 19 March 2009).

See CRNM, "Private Sector Perspectives on Trade Agreements".

Taking Jamaica as an example, Director General of CRNM Richard Bernal participated in 2007 in discussions with Jamaican business associations about the business implications of the EPA. See CRNM, "CRNM DG Updates the Jamaican Private Sector on the EPA" RNM Update 0714, 2007.

As an example, the in-country research and consultation mission visited Jamaica in 2006. See CRNM, "RNM Convenes Market Access Country Mission in Jamaica" RNM Update 0610, 2006.

An example is the workshop entitled "Promoting Creative Industries: A Trade and Investment Strategy", which took place in October 2006 in Barbados. See CRNM, "Progress of Trade Negotiations".

See Bernal, "CARIFORUM-EU Economic Partnership Agreement Negotiations", p. 15.

See CRNM, "Private Sector Perspectives on Trade Agreements".

In how far consultations and meetings dealt with intellectual property issues in general and specific to the EPA depended on the interests of participating stakeholders. From the recollection of Malcolm Spence, Jamaican stakeholders were interested in copyright and GI protection as well as to some extent in enforcement rules. Interview with Malcolm Spence, 7 April 2011, Bridgetown. 
Network was launched in November 2004 as a consultative body to interact with trade unions, civil society organizations (CSOs) and private sector groups. ${ }^{438}$ The network aimed at facilitating the effective contribution of regional civil society stakeholders to the negotiations. ${ }^{439}$ However, with some exceptions, very little documentation could be found about activities that took place under the network.

Richard Bernal makes reference to the exchange of positions with civil society organizations through proposals and research papers, such as papers submitted by the University of the West Indies in the area of higher education services. ${ }^{440}$ Another reported activity was a workshop hosted by CRNM and the Friedrich-Ebert Foundation in Jamaica in June 2006. The workshop addressed civil society and community groups, and aimed at providing an understanding of issues discussed at the WTO and in the EPA negotiations.

Criticism has been voiced by various groups of civil society organizations about the lack of meaningful interaction between CRNM and non-state actors. ${ }^{441}$ They felt that the EPA negotiation process was not transparent and only little information was provided to them. ${ }^{442}$ Similar criticism was voiced by the ACP-EU economic and social interest groups ${ }^{443}$ in the final declaration of the conference "9th Regional Seminar of the ACP-EU Economic and Social Interest Groups":

"The ACP-EU economic and social interest groups regret the insufficient information available to non-state actors on the negotiations, the inadequate consultations and limited capacity of economic and social interest groups to participate in the process." 444

CRNM itself acknowledges in its own reflections on the EPA process that there is room to improve:

See PricewaterhouseCoopers, Final Report, p. 14. Note that the NSA Network initially indeed was meant to also involve private sector groups. However, with the establishment of the PSOP, those were mainly targeted by the latter programme, leaving the NSA Network for interaction with primarily civil society organizations.

See European Commission, Plan and Schedule for CARIFORUM EC Negotiation of an Economic Partnership Agreement, p. 4. Note that in this early document also private sector umbrella groupings should come under the scope of the network. This however became the focus of the PSOP.

See Bernal, "CARIFORUM-EU Economic Partnership Agreement Negotiations", p. 16.

Participants of the workshop mentioned in the previous paragraph called for more active involvement of CSOs in identifying the negotiating priorities and positions of countries in the negotiations. See CRNM, "RNM/FES Workshop Advances Civil Society Engagement" RNM Update 0610, 2006.

This was the view of the participants of a workshop organized by PricewaterhouseCoopers on behalf of the European Commission in Jamaica in July 2006. See PricewaterhouseCoopers, Final Report, p. 13.

These included representatives of employers, trade unions, farmers, consumer organizations and civil society organizations from fifteen countries.

See European Economic and Social Committee, Final Declaration, paragraph 29. 
"CRNM $[\ldots]$ must find ways to improve the efficiency and efficacy of interaction and dialogue with Non-State Actors (NSAs) because their improved participation is critical to consensus building." 445

At the same time, CRNM staff also felt that there was a lack of organization on behalf of CSOs that prevented them from responding to issues in negotiations. ${ }^{446}$

Overall, the interaction between CRNM and the civil society organizations cannot be called a success in light of the few events reported to have taken place and the criticism voiced by several CSOs.

\subsubsection{Interim Conclusions}

The analysis of the regional consultations with non-state actors allows for two major conclusions of relevance to this thesis. The first conclusion is that only a few activities organized by CRNM addressed the issue of intellectual property protection in the EPA negotiations. Merely three broadcasts of the TradeBeat Radio Programme and two trade briefs were identified as dealing with intellectual property protection in general or with one area of IP protection, such as copyright protection, specifically. Reportedly, the Trade Power Dialogues, Boot Camps, consultations and workshops organized by the CRNM only marginally dealt with IP issues relevant to the EPA negotiations; participants hardly brought up the issue.

A second conclusion is that CRNM, in its efforts to consult with relevant stakeholders, was clearly geared towards involving business and industry representatives rather than civil society organizations. This strong divergence in treatment by CRNM is evident from the manifold initiatives directed at the private sector under the Private Sector Outreach Programme compared to the few events that could be identified for the NSA Network. A bias towards business and industry associations could also be recognized in the technical working groups, which only involved regional private sector organizations. ${ }^{447}$ CRNM's technical coordinator of the EPA negotiations in Brussels, Junior Lodge, also felt that the private sector was highly involved in the negotiation process due to CRNM reaching out to them through the PSOP; civil society organizations, however, were not involved to the same extent. ${ }^{448}$

It has to be stated that the second conclusion is made with regard to the consultations conducted by CRNM on all issues of the EPA negotiations, rather than intellectual property protection in particular. As noted above, even in the numerous activities organized for regional and national businesses, intellectual property issues played only a minor role. In other words, a lack of consultations on IP issues could be constituted for both businesses and civil society organizations alike. The difference between the level of involvement of businesses and industries compared to civil society organizations, therefore, is not as big for the area of IP as it is for

445 Confirmed by Junior Lodge in interview, 3 March 2010, Geneva. See CRNM, "CRNM EPA Reflections" RNM Update 0801, 2008.

446 See ibid.

447 This bias has been confirmed by the research conducted by Annita Montoute, see Montoute, Civil Society Participation in Trade Negotiations, p. 151.

448 Interview with Junior Lodge, 3 March 2010, Geneva. 
trade issues in general. Incorporating the findings of the previous section of this chapter, this low amount of interaction between regional policy makers and non-state actors on IP is partly due to a general low interest in IP on the part of non-state actors. At the same time, it has also been acknowledged that the consultative processes conducted at the regional level could have been improved in that respect, certainly for the involvement of civil society organizations.

\subsubsection{National Consultative Processes: Jamaica}

The regional consultative processes described above, ${ }^{449}$ organized by CRNM, were mainly instigated due to insufficient and untimely results from the national consultative processes in some CARIFORUM States. While this was less of a problem in the bigger countries such as Barbados, Jamaica and Trinidad and Tobago, CRNM staff still felt that they were lacking important information from national non-state actors all over the region. 450 This initially intended subsidiary role of the regional consultations also shows that the main interaction between state and nonstate actors was meant to take place at the national level. In the following, the institutional structures for policy makers' interaction with non-state actors in Jamaica will be analyzed, with an emphasis on the role of different institutions in the discussions on issues of intellectual property protection during the EPA negotiations.

Jamaica held different kinds of consultations prior to and during the EPA negotiations. There are three forums in which state actors interacted with non-state actors in determining the policy position of Jamaica on issues dealt with in the EPA, including intellectual property protection. First, the Jamaica Trade Adjustment Team (JTAT) is the main consultative mechanism through which policies for trade negotiations are developed. It also includes the policy making on intellectual property issues insofar as they are part of trade negotiations. Second, the Ministry of Foreign Affairs and Foreign Trade together with Jamaica Intellectual Property Office instigated specific consultations on intellectual property issues in which state and non-state stakeholders analyzed and debated the draft EPA negotiation texts on IP protection. Third, the GI working group provided a forum in which suggestions on the development of a system of GI protection could be discussed. With JIPO and the MoFAFT being members of the working group, the issues discussed were taken into consideration when developing Jamaica's policy position on GI protection in the $C A R I F O R U M-E C E P A$. Although not directly relevant for the negotiations of the EPA, finally, a short oversight is given of the consultations held after the conclusion of the EPA, which focus on the implementation of the EPA.

Apart from consultations, no other ways of interaction on IP issues between domestic state and non-state actors could be identified. International non-state and para-state actors, however, were in contact with the Ministry of Foreign Affairs and Foreign Trade of Jamaica. Michelle Walker mentioned that the Ministry consulted several studies done by international civil society organizations such as the South Centre, Third World Network and International Centre for Trade and Sustainable Development; ${ }^{451}$ it was also in contact with other WTO Members through informal

\footnotetext{
449 See section 10.2.2 of this book.

$450 \quad$ Interview with Malcolm Spence, 6 April 2010, Bridgetown.

451 See section 10.2.1.6 of this book on international non-state and para-state actors.
} 
dialogues during WTO meetings. ${ }^{452}$ However, the contact with international state and non-state actors is not further analyzed here due to the focus of this thesis on domestic stakeholders.

\subsubsection{Methodology}

The information presented below has been derived from a study of available literature (mainly Government sources and newspaper articles) as well as to a large extent from interviews conducted with Jamaican state and non-state actors. Most important in this context was the information obtained from Michelle Walker from the MoFAFT, Omar Chedda from Private Sector Organization of Jamaica and Dianne Daley from FogaDaley. However, it has to be stated that particularly on the specific consultations organized by JIPO, it was very difficult to obtain reliable data as some of the information provided by some interviewees was not supported by other interviewees and consultations were referred to by using different names. In addition, only three actors were interviewed that reported to have been present at these specific consultations..$^{453}$

Particular problems were encountered in determining the exact composition of participants of the specific consultations and how many meetings took place. That is partly due to the fact that the interviewed staff member of JIPO only joined the government agency shortly before the initialling of the CARIFORUM-EC EPA.454 Also, the other actors had difficulties recalling the composition of the group due to the time that had elapsed between these consultations and the interview (approximately two and a half years). As mentioned above, ${ }^{455}$ Dianne Daley fulfilled several positions at the time of the EPA negotiations. She found it difficult to identify which meetings she attended in which capacity.

\subsubsection{Jamaica Trade Adjustment Team (JTAT)}

Jamaica Trade Adjustment Team is a consultative mechanism that brings together state and non-state actors. ${ }^{456}$ It is an institutionalized taskforce which was established in the year 2000 with a view of performing two major tasks. First, it provides a mechanism for coordinating international trade policies, such as in trade negotiations. In this capacity, JTAT plays a vital role in formulating and implementing trade policies, such as Jamaica's intellectual property policy. Although this first task is of crucial importance to the policy-making process in the area of trade, it is the second task of JTAT that is of main interest for an assessment of the interaction between state and non-state actors. As a second task, JTAT facilitates the cooperation between state and non-state actors. This interaction serves to share information with

\footnotetext{
452 Interview with Michelle Walker, 13 April 2010, Kingston.

453 These were Dianne Daley from FogaDaley, Audia Barnett from the Scientific Research Council and Cheronne Allen from JAMPRO.

$454 \quad$ Interview with Lilyclaire Bellamy, 12 April 2010, Kingston.

455 See section 10.2.1.4.1 of this book.

456 JTAT succeeded the Trade Coordination and Policy Committee with a view of widening and deepening the consultative process. See Jessen and Vignoles, Jamaica: Trade, Integration and the Quest for Growth, p. 52.
} 
relevant sectors of society as well as to gather information and carry out an analytical assessment. ${ }^{457}$

Overall, meetings of the Jamaica Trade Adjustment Team take place once a month and when the need arises. ${ }^{458}$ In preparation of and during the negotiations of the CARIFORUM-EC EPA, JTAT meetings were held continuously every month between April 2004 and December 2007.459 According to Michelle Walker, the Jamaica Trade Adjustment Team convened general consultations, which mainly addressed priority issues under discussion in the EPA negotiations. ${ }^{460}$ Such priority areas included market access for goods, the regulation of services and anti-dumping mechanisms; intellectual property protection was discussed to a lesser degree. ${ }^{461}$

The agenda of JTAT meetings generally is determined according to the response by its members; if they do not express an interest in intellectual property issues, the discussion will focus on other items. The IP issues under discussion during the EPA negotiations mainly focussed on copyright protection, the protection of software, the protection of geographical indications and the enforcement of these rights. ${ }^{462}$ Plant variety protection or patent protection for plants did not feature greatly in the discussions. ${ }^{463}$

In general, approximately thirty people attend meetings of the Jamaica Trade Adjustment Team. These are members from different categories of state and nonstate actors, for example government officials, businesses and industries, local authorities, civil society organizations and CRNM staff. ${ }^{464}$ The actors from each group invited to a JTAT meeting differ according to the issue under discussion: only organizations with an interest in the particular matter will be approached. ${ }^{465}$

Participating actors of JTAT meetings organized during the negotiations of the EPA were: 466 a majority of state actors ${ }^{467}$ (the Ministry of Industry, Investment and Commerce, Jamaica Intellectual Property Office, Scientific Research Council, CRNM and Jamaica Promotions Corporation), some business and industry associations (Private Sector Organization of Jamaica, Jamaica Exporters' Association, Jamaica

See Hylton, Jamaica's New Trade Policy - 2001, p. 11.

See Montoute, Civil Society Participation in Trade Negotiations, p. 193, footnote 47.

See "Chronology - CARIFORUM/EPA Agreement"; also interview with Lilyclaire Bellamy, 12 April 2010, Kingston.

Interview with Michelle Walker, 13 April 2010, Kingston.

Ibid. Cheronne Allen from JAMPRO noted that only a few minutes were dedicated to IP in a JTAT meeting. Phone interview with Cheronne Allen, 10 September 2010.

Interview with Omar Chedda, 12 April 2010, Kingston; phone interview with Cheronne Allen, 10 September 2010. Note that due to the focus of this book on intellectual property rights that can protect food products, copyright protection and the protection of software was not at the heart of interests investigated in this book. Phone interview with Cheronne Allen, 10 September 2010.

See Hylton, Jamaica's New Trade Policy - 2001, p. 10-11.

See Montoute, Civil Society Participation in Trade Negotiations, p. 193, footnote 47.

Interview with Michelle Walker 13 April 2010, Kingston; interview with Lilyclaire Bellamy, 12 April 2010, Kingston; interview with Omar Chedda, 12 April 2010, Kingston.

Interview with Omar Chedda, 12 April 2010, Kingston. 
Manufacturers' Association, Jamaica Chamber of Commerce), few businesses (software industry, entertainment industry), and a few trade unions and civil society organizations (women groups, environmental entities). ${ }^{468}$ Only a few of these actors were interested in IP protection; exceptions constituted the software and entertainment industry as well as government officials from the Ministry of Foreign Affairs and Foreign Trade, CRNM and the Jamaica Promotions Corporation. ${ }^{469}$

From this assessment of the tasks and composition of the Jamaica Trade Adjustment Team, it is evident that intellectual property issues were not extensively discussed in the general consultations of JTAT. Only a few Jamaican businesses and industries were interested in intellectual property protection and have pushed IP in trade negotiations in general and in the EPA negotiations in particular. ${ }^{470}$ Note that no civil society organization was reported to have been an active participant of JTAT on IP issues. In order to determine Jamaica's IP policy position in the EPA negotiations, MoFAFT has relied mainly on specific IP consultations with relevant stakeholders that were carried out together with the government agency Jamaica Intellectual Property Office. $^{471}$

\subsubsection{Specific Consultations on IP}

Specific consultations that dealt with intellectual property issues were convened by MoFAFT together with JIPO. They were organized in separate meetings with different groups from society. For example, government bodies were assembled in one group, businesses and industry organizations in another. Only three of the actors interviewed were present at such meetings and able to report on the participants of those groups as well as the discussions carried out. According to Dianne Daley, she participated in the meetings organized for the cluster of businesses and industry organizations, which also included the legal community. Other participants in that group supposedly were Jamaica Manufacturing Association and Jamaica Exporters' Association. ${ }^{472}$ Audia Barnett from the Scientific Research Council and Cheronne Allen from Jamaica Promotions Corporation participated in meetings where primarily other government actors were present. The key actors there were JIPO and the Scientific Research Council. ${ }^{473}$

468 In addition, generally a Senior Trade Official of the Ministry of Foreign Affairs and Foreign Trade is present in JTAT meetings, who acts as the chair of the Jamaica Trade Adjustment Team, a senior trade policy analyst, researchers who carry out substantive analytical work related to trade policy, and the coordinators of the advisory groups and working groups.

469 Interview with Omar Chedda, 12 April 2010, Kingston.

470 Interview with Michelle Walker, 13 April 2010, Kingston; phone interview with Cheronne Allen, 10 September 2010.

471 Interview with Michelle Walker, 13 April 2010, Kingston.

472 Interview with Dianne Daley, 31 March 2010, Kingston.

473 Interview with Michelle Walker, 13 April 2010, Kingston. Note that Cheronne Allen from JAMPRO recalled that detailed discussions on intellectual property issues took place in subcommittees of JTAT. She did not refer to these meetings as specific consultations convened by JIPO, but as subcommittees of JTAT. Phone interview with Cheronne Allen, 10 September 2010. 
These consultations served to discuss the draft EPA text on the protection of IP, to formulate a position on specific IP issues in the proposed text and to report the participants' views back to MoFAFT. ${ }^{474}$ According to Audia Barnett, the Scientific Research Council's input focussed on the provisions dealing with technology transfer. ${ }^{475}$ Dianne Daley reported that their discussions primarily dealt with the accession to international treaties in the field of trade marks and patents, and the proposed equal protection on GIs for products other than wines and spirits. ${ }^{476}$ According to both interviewees, enforcement matters, plant variety protection and the protection of genetic resources and traditional knowledge did not take up an important part in the discussions. ${ }^{477}$

To conclude, it seems as if the specific consultations were most relevant for determining Jamaica's policy position on IP issues in the EPA negotiations as they carried out a thorough analysis of the draft texts and discussed the most controversial IP issues in detail. From the actors that were reported to be present in the different meetings, one can constitute a dominance of state actors over non-state actors.

\subsubsection{The GI Working Group}

The third forum where state and non-state actors met to discuss one area of IP specifically, the protection of geographical indications, is the GI working group. The working group was started by JIPO in 2006 with the aim of making recommendations for developing a system of GI protection in Jamaica and overseeing projects on the development of such a system. ${ }^{478}$ With this mandate, the group's work was highly relevant for the EPA negotiations as the protection that the parties agreed upon in the agreement would set the conditions for establishing Jamaica's future system of GI protection. Although the GI working group was not explicitly mentioned by interviewees as a decisive consultation forum in preparation of the EPA negotiations, it is believed to have played a major role for determining Jamaica's policy position on GI protection in the negotiations.

First, many interviewees stressed its important role for determining Jamaica's GI policy position in general. The working group, in fact, brings together a considerable amount of Jamaican state and non-state stakeholders in the field of GI protection. Among the state actors, Jamaica Intellectual Property Office acts as the chair of the working group and the Coffee Industry Board is strongly involved; ${ }^{479}$ the Ministry of Foreign Affairs and Foreign Trade, the Ministry of Agriculture, the Scientific

\footnotetext{
$474 \quad$ Phone interview with Cheronne Allen, 10 September 2010.

475 Interview with Audia Barnett, 6 April 2010, Kingston.

476 Interview with Dianne Daley, 31 March 2010, Kingston.

477 Interview with Dianne Daley, 31 March 2010, Kingston, and Audia Barnett, 6 April 2010, Kingston.

478 See Daley, "Jamaica: Intellectual Property". For a more detailed description of the working groups' activities and role during the EPA process, see section 10.1.3.5 of this chapter.

479 Interview with Stacian Bennett, 7 April 2010, Kingston; interview with Loreen Walker, Kingston.
} 
Research Council, ${ }^{480}$ Jamaica Promotions Corporation, ${ }^{481}$ the Rural Agricultural Development Authority ${ }^{482}$ and the Bureau of Standards are also represented. ${ }^{483}$

Among the non-state actors that participate in the working group are the Private Sector Organization of Jamaica, ${ }^{484}$ Lascelles DeMercado \& Company Limited, which is the major Jamaican company distributing local and international wines and spirits and the producer of Appelton Jamaica Rum, ${ }^{485}$ some jerk producers, the Jamaica Exporters' Association, the Competitiveness Company, ${ }^{486}$ and Jamaica Standard Product Co. Limited. ${ }^{487}$ Among the participating non-state actors, no civil society organization could be identified. While a wide range of non-state actors participated in the group's activities (workshops and discussion groups), they were reported to have had rather little input on the development of the national GI policy; state actors clearly are the driving force.

Second, with MoFAFT and JIPO being part of the GI working group, the group's proposals were directly available to key Jamaican policy makers on IP issues. Michelle Walker from MoFAFT declared that for the policy position on GI protection in the EPA negotiations, the Coffee Industry Board was rather influential. ${ }^{488}$ As CIB was not present in any other forum than the GI working group, it is most likely that CIB has put forward its preferences with regard to GI protection to MoFAFT in this working group.

Third, none of the other forums was reported to have held specific discussions on GI protection. It is believed that discussions in these forums were not necessary since Jamaican policy makers were provided with the views of the main stakeholders in GI protection through their participation in the GI working group.

To sum up, even though it has not been reported that the draft text of the GI provisions in the EPA were discussed in the GI working group, this group had an important consultative role for preparing Jamaica's policy position in the field of GI protection. In included all major state and non-state stakeholders in the area; the results of the discussion were directly available to Jamaican policy makers in the field of intellectual property protection.

480 Interview with Stacian Bennett, 7 April 2010, Kingston; interview with Audia Barnett, 6 April 2010, Kingston.

481 Phone interview with Cheronne Allen, 10 September 2010.

482 The Rural Agricultural Development Authority falls under the authority of the Ministry of Agriculture and is primarily occupied with enhancing the development of farming in Jamaica.

483 The Bureau of Standards is a government agency under the responsibility of the Ministry of Industry, Investment and Commerce, which promotes, certifies and inspects standardization in relation to commodities, processes and practices. See Government of Jamaica, Bureau of Standards Jamaica (2009), available at $<$ http://bsj.org.jm/> accessed on 21.05.2013.

484 Interview with Stacian Bennett, 7 April 2010, Kingston; interview with Omar Chedda, 12 April 2010, Kingston.

485 Interview with Stacian Bennett, 7 April 2010, Kingston.

486 Interview with Margaret Mais, 30 March 2010, Kingston.

487 Email correspondence with Jack Minott, 22 April 2010.

488 Interview with Michelle Walker, 13 April 2010, Kingston. 


\subsubsection{Involvement during the Implementation Phase}

Having described the consultation processes during the EPA negotiations, a short overview is given on the possibilities for interaction between state and non-state actors in the implementation phase. While all CARIFORUM States face severe challenges in the implementation of the EPA, Jamaica is relatively advanced in its efforts to implement the obligations arising from the EPA and tries to involve nonstate actors in this process. As noted by Errol Humphrey,

"[while] the small OECS countries are struggling to make any meaningful progress [...], Barbados and Jamaica are making slow, but steady progress." $" 489$

In his report, he particularly refers to the progress made in terms of setting up implementation units for trade agreements in the trade ministries. ${ }^{490}$ One of the initiatives started by the implementation unit was the establishment of the "Technical Working Group on the EPA Implementation".

The TWG on the EPA implementation was established in March 2008 and brings together state actors from relevant ministries and governmental agencies as well as business and industry associations. ${ }^{491}$ One of its tasks is to sensitize and build awareness of the EPA, as well as to ensure dialogue with major stakeholders. ${ }^{492}$ This is particularly important in the situation

"that in many of the [CARIFORUM] countries only a very small number of companies understand the provisions of the EPA or are able to utilise them to access the EU market," 493

E. Humphrey, Implementing the Economic Partnership Agreement: Challenges and Bottlenecks in the CARIFORUM Region (ECDPM, Discussion Papers, No. 117, Maastricht, 2011), p. 9. According to the European Commission Directorate General for Development and Cooperation, Jolita Butkeviciene, Guyana seems to have taken the lead in the implementation process. See "Guyana leading Caribbean in EPA implementation, says EU regional director" caribbeannewsnowcom (Georgetown, 25 April 2012), available at $<$ http:/ / www.caribbeannewsnow.com/guyana.php?news_id=10645\&start=80\&catego ry_id=13> accessed on 27.09.2012.

See Humphrey, Implementing the Economic Partnership Agreement, p. 9.

The TWG on EPA Implementation brings together public and private stakeholders. The non-state stakeholders include representatives of the Jamaica Exporters' Association, the Private Sector Organization of Jamaica, Competitiveness Company, the University of the West Indies, the African, Caribbean Institute of Jamaica and the law firm FogaDaley. The stakeholders from ministries and government agencies are the Ministry of Agriculture, the Ministry of Industry, Investment and Commerce, the Attorney General's Chamber and the Broadcasting Commission. Email correspondence with Michelle Walker from 16 April 2010. Also interview with Michelle Walker, 13 April 2010, Kingston.

492 See Economic Commission for Latin America and the Caribbean, Report of the Expert Group Meeting on the CARIFORUM-EU Economic Partnership Agreement (Port of Spain, 23 June 2009) [LC/CAR/L.196/Rev.1], p. 10; see Shridath Ramphal Centre for International Trade Law, EPA Implementation Stakeholder Analysis, p. 20. Partnership" Huntingtonnewsnet (16 July 2011), available at <www.huntingtonnews.net/5275> accessed on 21.11.2012. 
as was noted by Sir Ronald Sanders, a former Caribbean diplomat. In the TWG on the EPA implementation, EPA obligations in relation to intellectual property protection are also discussed. In that respect, one focus area currently is the protection of geographical indications. ${ }^{494}$ However, not more information could be obtained on the detail and scope of the working group's work on IP issues.

\subsubsection{Interim Conclusions}

The analysis of the various consultations that were convened by Jamaican policy makers prior to the conclusion of the EPA has led to three main conclusions.

First, certainly in comparison with other CARIFORUM States, ${ }^{495}$ Jamaican policy makers have made use of the institutional structures to consult with non-state actors on relevant issues under discussion in the EPA negotiations. In this context, the permanent Jamaica Trade Adjustment Team was used for general consultations with actors from all fields of society. The specific consultations and the GI working group, in contrast, particularly addressed IP issues. However, it was only the specific consultations that have been reported to analyze EPA draft texts on IP in detail.

Second, the composition of non-state actors participating in the forums addressing IP issues did not cover all fields of society. Civil society organizations and members of academia were not represented in any of the consultations analyzed. The non-state actors represented in the specific consultations on IP and the GI working group were business/industry associations, producers or lawyers. Among these two forums, the GI working group assembled considerably more actors from the business and industry sector than the specific IP consultations. Also in the JTAT meetings, the private sector was represented most strongly. However, among JTAT actors, merely the software and entertainment industry were reported to have been interested in IP protection.

Third, there is a clear dominance of government actors in the consultations on IP issues. Even though members of business and industry associations were consulted on IP issues, it has been reported that they provided little feedback on substantive IP issues due to a fundamental weakness in the consultative process on IP issues: ${ }^{496}$ the IP culture has been developing relatively slowly in Jamaica; many non-state actors lack a full understanding and knowledge on IP issues; and the creative industries, in particular music, as well as the agro-processing sub-sector are generally more aware of IP issues based on the nature of their business. ${ }^{497}$ As a consequence, the consultations were structured in a way that government agencies and ministries informed businesses and industries about the relevant IP issues without being able to initiate informed discussions on the question as to which policy position Jamaica

494 Interview with Michelle Walker, 13 April 2010, Kingston.

495 Note that Shantal Munro-Knight acknowledged that Jamaica and Trinidad and Tobago are to be classified as exceptions in terms of national consultations carried out in the CARIFORUM region. The other countries do not possess similar institutional structures to convene consultations with non-state actors. Phone interview with Shantal Munro-Knight, 13 May 2010.

496 Interview with Dianne Daley, 31 March 2010, Kingston.

497 Interview with Michelle Walker, 13 April 2010, Kingston; phone interview with Cheronne Allen, 10 September 2010. 
should favour. Consequently, ministries and government agencies were the main drivers of the discussions on IP issues.

Fourth and more generally, where a country lacks knowledgeable and interested parties on a particular subject and international negotiations are conducted thereon, it is likely that the other negotiating party will be able to fill that vacuum of domestic preferences with international rules that it has a substantive interest in. ${ }^{498}$ This seems to have been the case for Jamaica and the CARIFORUM region in the EPA negotiations on several matters of intellectual property protection. This conclusion is confirmed by the analysis of the national and regional policy position on the IP matters: at least the areas of intellectual property protection in which Jamaica and the region clearly had only defensive interests have been subject to the importation of international rules strongly favoured by the European Union. 499

\subsubsection{Differences between EPA Negotiations and Multilateral Negotiations}

Although past or ongoing negotiations in the field of intellectual property at the multilateral level were not an important part of this research project, a brief comparison between the findings of the consultative processes held during the EPA negotiations and those for multilateral negotiations is presented. A distinction is again made between regional and Jamaican consultative processes.

As far as regional consultations are concerned, the level of interaction between the staff of CRNM and non-state actors in the context of the WTO negotiations during the Doha Development Round ${ }^{500}$ has been considerably less than the consultations organized during the EPA negotiations. CRNM's activities to engage non-state actors in determining the region's policy position in the Doha Development Round have been limited to information sharing via its website. In particular, it publishes regular updates on the issues under discussion at the WTO as well as documents released by the WTO. The updates rarely touch upon IP issues; ${ }^{501}$ two of the published W'TO documents address the negotiations on the extension of the additional GI protection to other products than wines and spirits as well as the multilateral system of notification and registration of GIs for wines and spirits. ${ }^{502}$ However, this relative lack of information on intellectual property issues discussed in the Doha Development Round is not surprising since IP is not one of the important Doha issues. No consultations, workshops or seminars similar to those launched during the

See also section 6.2.2. of this chapter where it is also concluded that the results of the self and peer assessment of non-state actors' influence also suggest that Jamaica was the receiver of international rules.

These were the protection of plan varieties and the enforcement of IP rules. See section 11.1.1.3 of this book.

The negotiations of the Doha Development Agenda are the only multilateral negotiations that the CRNM so far has been engaged in as it was set up in 1997 and since then has primarily dealt with regional and bilateral trade agreements. Among the multilateral forums, only the WTO falls under the competence of the CRNM.

See CRNM, RNM Updates.

See CRNM, WTO Documents on Intellectual Property (2011), available at $<$ http://www.crnm.org/index.php?option=com_docman\&task=cat_view\&gid=138\& Itemid $=120>$ accessed on 15.11.2012. 
EPA negotiations have been organized for business/industry associations or other non-state actors.

With regard to Jamaican consultative processes, Jamaica Trade Adjustment Team is the main forum for consultations between state and non-state actors also for multilateral negotiations: together, they formulate policy positions for all levels of negotiations in all fields of trade. The non-state actors involved in JTAT meetings generally cover the same range of societal sectors as those that participated during the EPA negotiations. Although the meetings in Jamaica Trade Adjustment Team deal with foreign trade issues and therefore are concerned with any type of international trade negotiations, it is suspected that multilateral negotiations in the area of intellectual property protection do not get the same level of attention as EPA negotiations did. Only a few of the non-state actors interviewed reported that they follow developments at the multilateral level, in particular in the area of intellectual property protection. ${ }^{503}$ Therefore, the extent of consultations on intellectual property protection at the multilateral level in JTAT is believed to be even lower than in the case of EPA negotiations.

Specific national consultations on intellectual property issues discussed at the multilateral level have taken place in the past and are believed to be organized by JIPO when the need arises. A prominent example of multilateral negotiations that has been mentioned several times by interviewees was Jamaica's accession to the Madrid Protocol. Some interviewees have reported that consultations have been initiated by JIPO in order to discuss the benefits and disadvantages of becoming a party to the Protocol with business and industry associations as well as the legal community. ${ }^{504}$ In those consultations, the Jamaican Bar Association and Private Sector Organization of Jamaica were the key non-state actors involved. ${ }^{505}$ The question as to whether or not it is beneficial for Jamaica to accede to the Madrid Protocol has provoked a, for an IP issue, exceptionally intense debate. However, it seems as if JIPO, in cooperation with the Ministry of Foreign Affairs and Foreign Trade, would also convene specific consultations on other IP issues dealt with in multilateral negotiations at WIPO or the WTO. The GI working group addresses, among others, the negotiations on the protection of geographical indications, which are held at the WTO in the context of the Doha Development Round. 506

\subsubsection{Conclusions}

Three main themes have been discussed in this section. First, I have presented nonstate actors with an interest in intellectual property protection relevant to protecting food products in general and in particular to the EPA negotiations. Second, I have analyzed the institutional structures for consultations between state and non-state actors at the regional and national level. Third, similarities and differences were identified between the structures for consultations on IP issues in the EPA

\footnotetext{
503 The few actors that do follow international developments are Dianne Daley, Beverley Pereira and Teisha Mattison. Interviews with Dianne Daley, 31 March 2010, Kingston; Beverley Pereira, 6 April 2010, Kingston; Teisha Mattison, 6 April 2010, Kingston.

504 Interview with Peter Goldson, 31 March 2010, Kingston; interview with Kai-Saran Davis, 31 March 2010, Kingston.

505 Interview with Dianne Daley, 31 March 2010, Kingston.

506 Interview with Michelle Walker, 13 April 2010, Kingston.
} 
negotiations and for multilateral negotiations at international organizations that address intellectual property issues.

Starting with a methodological conclusion, only very few sources of literature were available to carry out the three above-stated analyses. This made it necessary to rely heavily on the new set of data retrieved through interviews with stakeholders in Jamaica, Barbados, Geneva and Brussels. Even though approximately thirty interviews could be conducted, information is lacking on non-state actors that were mentioned by other interviewees as having had some form of interest in the IP negotiations in the context of the EPA but with whom I could not establish contact (approximately twenty-five). Therefore, the results of this case study need to be understood with this methodological note in mind.

Probably the most important conclusion of this section is that there are only a few non-state actors at the regional and national level that have some interest in IP protection in general and in its regulation through the EPA in particular. Also the state actor Jamaica Promotions Corporation and the Coffee Industry Board noted that their clients, which are private businesses, have only a limited interest in the matter. Among the few non-state actors analyzed, only one regional civil society organization with some interest in IP regulation in general and in the context of the EPA negotiations could be identified, none in Jamaica. It can be concluded that more businesses/industry associations and lawyers have some interest in IP than civil society organizations.

Second, the few non-state actors identified do not have a specific interest in the regulation of IP issues in general and in the EPA negotiations in particular. In fact, only two national and one regional non-state actors were identified as having specific preferences on issues dealt with in the IP negotiations in the context of the EPA. The other non-state actors had little knowledge and interest in the international regulation of intellectual property issues.

Third, the lack of interest in IP protection in general and its regulation through the EPA in particular is primarily a result of the lack of knowledge and preoccupation with the matter in non-state actors' daily work. Other issues of trade dominate most non-state actors' daily agendas. Jamaica and other Caribbean countries are rather young economies that had not dealt with the protection of intellectual property rights other than trade marks and copyright before the signature of the TRIPS Agreement in 1993. This is confirmed by another result established through this study: there was hardly any public debate in Jamaica and in the Caribbean region on the question as to how much IP protection Jamaica and the region want to agree to in the EPA. The Jamaican and regional society clearly are not occupied with this issue.

Fourth, on the question of forum choice, the answers given by the interviewed nonstate actors are not conclusive. An important observation is that four out of ten nonstate actors, and even one out of three state actors, could not state a preference for one forum over the other as they are not concerned with the multilateral level of regulating intellectual property rights. Four out of six non-state actors that gave an answer mentioned a preference for the multilateral level, mainly because of an increased leverage. The lawyer Dianne Daley thought that both levels of negotiating IP issues can be beneficial for Jamaica and the region. A preference for one over the 
other was stated for cases where only the protection of GIs, traditional knowledge or trade marks was at issue. Only one non-state actor had a clear preference for the bilateral level, the Competitiveness Company.

Fifth, among the few non-state actors that were identified as having some interest in IP protection in general and its regulation in the EPA in particular, only a few groups of actors could be found. This has led to the conclusions that a) there are not enough individual actors with an interest in IP protection in general and its regulation in the EPA that could form a group, and b) there is a lack of a common interest in the regulation of IP in the EPA. These conclusions can also explain a related finding of this study: no coalition building has occurred among regional or Jamaican non-state actors in the context of the EPA negotiations on IP issues. If individual actors have not formed groups around a common interest, it is also unlikely that they would form coalitions with each other.

Sixth, Jamaica's consultations encompassed three different forums: Jamaica Trade Adjustment Team, specific IP consultations and the GI working group. However, in fact, only the specific IP consultations have been reported to analyze EPA draft texts on IP in detail. The non-state actors that participated in the specific consultations were business/industry associations, producers or lawyers. Civil society organizations and members of academia were not represented in any forum of national consultations. Also, in regional consultations, they were rather absent from consultative processes addressing intellectual property protection.

Seventh, state actors clearly dominated (Jamaica Promotions Corporation, the Scientific Research Council and the Coffee Industry Board) the consultative processes in Jamaica. Only a few non-state actors were involved in any of the consultative forums; even then, their involvement was not active but rather passive due to a lack of knowledge on the issue of IP protection. As a consequence, the consultations were structured in a way that government agencies and ministries informed businesses and industries about the relevant IP issues without being able to initiate informed discussions on the question as to which policy position Jamaica should favour. An exception is Dianne Daley, who was actively involved in the specific consultations on IP issues. Also, in regional consultations, it has been reported that non-state actors were only marginally interested in the protection of intellectual property through the EPA.

The final conclusion addresses the differences between consultations held during the EPA negotiations and multilateral negotiations. As far as regional consultations are concerned, the level of interaction between former CRNM staff and non-state actors in the context of the WTO negotiations during the Doha Development Round has been considerably less than the consultations organized during the EPA negotiations. With regard to the Jamaican consultative processes, JTAT is also the main forum for consultations between state and non-state actors for multilateral negotiations. The non-state actors involved in JTAT meetings generally cover the same range of societal sectors as those that participated during the EPA negotiations. The extent to which consultations on intellectual property protection at the multilateral level take place in JTAT is believed to be even lower than in the case of EPA negotiations. Specific national consultations on intellectual property issues discussed at the 
Why JAMAICA WANTS TO PROTECT CHAMPAgNE

multilateral level have taken place in the past and are believed to be organized by JIPO when the need arises. 


\section{Chapter 11 : Influence of Non-state Actors on the IP Policy Position during the EPA Negotiations}

The following analyses have already been carried out: 1) the identification of relevant regional and national non-state actors, 2) their interest in intellectual property protection in general and in particular in its regulation in the CARIFORUM-EC $E P A$, and 3) their involvement in the policy-making processes during the EPA negotiations. While these analyses have provided important results on which nonstate actors exist that have an interest in intellectual property protection and were involved in consultative processes, this thesis also aims at determining whether the results can be linked to the final IP policy position adopted by Jamaica and the CARIFORUM region during the EPA negotiations. The relationship between the involvement of these non-state actors in the policy-making process and the final IP policy position is referred to, in this thesis, as "influence". In other words, an answer is sought to the question as to whether or not the identified non-state actors could have some sort of influence on the final IP policy position adopted by Jamaica and the CARIFORUM region by participating in the consultative processes. In order to assess this influence, the first section will define the final IP policy position of Jamaica as well as the negotiating position of the region. The second section introduces the methodology used and subsequently presents the results of the main method of process tracing and the two complementary methods of preference attainment and self and peer assessment. In the third section, the role of the regional negotiator on IP is further examined.

\subsection{Final Policy Positions in the Area of IP Protection}

When analyzing the final policy positions for the different areas of intellectual property protection that are relevant for protecting food products, a distinction is made between the regional negotiating position adopted by the regional technical negotiator for intellectual property, Malcolm Spence, and the policy position adopted by Jamaican policy makers, namely the Ministry of Foreign Affairs and Foreign Trade and JIPO. Since the CARIFORUM-EC EPA was negotiated by the region CARIFORUM on behalf of its Member States, the final regional negotiating position can differ from the final policy position adopted by Jamaica. Differences can occur in cases where a) other CARIFORUM States have clear preferences in areas of intellectual property protection where Jamaica did not have offensive preferences and the region adopted these preferences, b) the preferences of various Member States did not coincide and had to be reconciled in a regional compromise policy position, or c) where the regional negotiating position was determined by other factors, such as results of studies carried out, personal contacts or the personal conviction of the regional negotiators and the EU negotiators.

\subsubsection{Regional Negotiating Position}

The regional negotiating position of CARIFORUM for the area of intellectual property protection has been explained on different occasions by the technical negotiator for intellectual property issues, Malcolm Spence. ${ }^{1}$ The position of the

1 See Spence, Negotiating Trade, Innovation and Intellectual Property; Spence, Innovation and Intellectual Property; interviews with Malcolm Spence, 7/8 April 2010, Bridgetown. 
region can be subdivided into three general objectives for the area of intellectual property protection, three objectives in specific areas of IP and two positions developed as a reaction to the proposals made by the European Union.

\subsubsection{General Objectives}

Three general objectives were identified and adopted by the region during the EPA negotiations on IP issues. The first key preference was to minimize changes to the level of protection agreed upon in the TRIPS Agreement. According to Malcolm Spence, there was a general understanding that the countries of the region significantly underutilize the obligations stemming from the TRIPS Agreement. ${ }^{2}$ Adding obligations on top of the TRIPS Agreement therefore did not seem to be an option. Furthermore, CARIFORUM States believed that the TRIPS Agreement provides "more than ample protection for intellectual property within its scope". 3

The second general objective of the region was to introduce the concept of "innovation" into the negotiations, to which the protection of intellectual property would be inherently linked. According to CARIFORUM States, the concept of innovation had to be understood as a broad concept which includes the creative industries in addition to science and technology. ${ }^{4}$ The region therefore did not agree with the EU's reading of innovation to just encompass science and technology. Next to securing this understanding of innovation, the main objective in relation to innovation was to discuss IP protection only in the framework of and as a quid pro quo for improving the levels of innovation in specific areas of development interests to CARIFORUM States through concrete measures. ${ }^{5}$ For example, the protection for designs was to be countered with a provision on the establishment on design centres; commitments to comply with the WIPO Internet Treaties were to be tied to market access in the area of services to enable the small entertainer to benefit. ${ }^{6}$ In other words, their goal was

\footnotetext{
"to ensure an appropriate balance between the level of protection granted to intellectual property rights and the level of development of CARIFORUM economies, in particular the level of innovation."
}

It was until the beginning of 2006 that the regional negotiator continued to resist the inclusion of intellectual property "as a stand-alone section in the EPA" ${ }^{8}$ However, Malcolm Spence noted three reasons that convinced the CARIFORUM region to agree to the inclusion of various trade-related aspects of intellectual property protection. ${ }^{9}$ 1) One Member State of CARIFORUM, the Bahamas, is not a WTO Member and therefore does not have to comply with the obligations of the TRIPS Agreement. 2) The ministerial mandate allowed the region to agree to a full IP chapter.

See Spence, Negotiating Trade, Innovation and Intellectual Property, p. 2.

See Spence, Innovation and Intellectual Property, paragraph 12.

References to the creative industries in the innovation section were imperative for Jamaica. Interview with Malcolm Spence, 7 April 2010, Bridgetown.

See Spence, Innovation and Intellectual Property, paragraph 17.

See Spence, Negotiating Trade, Innovation and Intellectual Property, p. 2.

See ibid., p. 2.

Spence, Innovation and Intellectual Property, paragraph 32.

See ibid., paragraph 32. 
3) CARIFORUM was persuaded by the European Union that innovative products should have the full range of IP protection available.

As a third general objective, the region wanted to be granted access to support programmes and activities under the Lisbon Agenda of the European Union in order to establish innovation systems in the Caribbean. ${ }^{10}$ Funding as well as the necessary knowledge was crucial for the concept of innovation to work. The EU was believed to have built up sufficient experience in its own region to be able to provide this support. ${ }^{11}$ The first CARIFORUM concept note on "Trade and Innovation", therefore, proposed for a given area of economic activity the necessary support for CARIFORUM firms in order to increase its level of innovation. ${ }^{12}$ One natural priority area identified was the creative industries, for which the development of innovation systems should be strengthened. ${ }^{13}$

\subsubsection{Offensive Interests}

Next to these three general objectives, the CARIFORUM region identified three specific areas of intellectual property protection in which they had offensive interests. One such area was the protection of traditional knowledge, folklore and genetic resources, the second the development of a system of protection for geographical indications and the third to include a concrete transfer of technology clause.

The "paucity of protection for traditional knowledge and folklore through the TRIPS Agreement" was expressed as an early concern in the regional discussions. ${ }^{14}$ Although the countries in the region have not yet developed a system of protection for traditional knowledge themselves, the region wanted to take up some aspects of the multilateral discussions into the EPA. ${ }^{15}$ One clear priority was to include the disclosure requirement in the context of patent applications. Such a requirement would oblige any patent applicant to disclose the origin or source of the biological resource or traditional knowledge from which the patented product "to-be" is derived. Even though the region is still trying to devise a workable system of protection for itself, ${ }^{16}$ they wanted to keep all options open in the EPA. As a second objective, CARIFORUM States aimed at introducing an obligation that would require the European Union to support the final language of a possible future multilateral agreement on the matter. ${ }^{17}$ Third, the region strove for preserving the freedom to

10 See section 5.3.1.4.2 on the provisions on the transfer of technology included in the CARIFORUM-EC EPA.

11 Interview with Junior Lodge, 3 March 2010, Geneva.

12 See Spence, Innovation and Intellectual Property, paragraph 17.

13 See Spence, Negotiating Trade, Innovation and Intellectual Property, p. 3.

$14 \quad$ Spence, Innovation and Intellectual Property, paragraph 12.

15 Interview with Junior Lodge, 3 March 2010, Geneva.

16 This requirement would clearly benefit indigenous groups in Caribbean countries also to benefit from the royalties earned by a patented product that is mainly based or derived from a biological resource or traditional knowledge preserved by them. However, as was noted by Lilyclaire Bellamy from the Jamaica Intellectual Property Office, the region is not sure how to attribute such knowledge or biological resources to one community within one Caribbean country. Interview with Lilyclaire Bellamy, 12 April 2010, Kingston.

17 Interview with Malcolm Spence, 7 April 2010, Bridgetown. 
develop a future system of protection that is adjusted to their needs. Since concrete elements of such a system are still lacking, the final provisions were aimed to be rather vague. ${ }^{18}$

The second specific offensive interest of the CARIFORUM region regarded the development of a system of GI protection. In particular, the region had a strong preference for improving the protection for geographical indications of products other than wines and spirits. ${ }^{19}$ The products for which protection was sought were coffee, rum, pimento, jerk, patties and sugar. ${ }^{20}$ At the same time as seeking increased protection for those products, CARIFORUM stakeholders had a considerable fear of "being overwhelmed administratively." 21 They were also concerned about "the economic harm from a large number of EU GIs."22 To alleviate these fears, the region aimed at obtaining a transitional period in which it could develop a list of products that would be protected by geographical indications. At the same time, CARIFORUM States tried to postpone the protection of EU geographical indications in their countries until the region had developed such a list. ${ }^{23}$

As a final offensive preference, the CARIFORUM negotiating team intended to introduce a broader transfer of technology clause than the one included in the TRIPS Agreement. ${ }^{24}$ Their goal was to remedy an observed problem of the TRIPS clause: technology owners so far have not been stimulated to transfer technology. ${ }^{25}$ The region therefore strove for three changes compared to the TRIPS clause. First, the obligation was to be extended to all CARIFORUM States rather than limiting its scope to least-developed countries. ${ }^{26}$ Second, the region was eager to define an incentive as

"a measure that actually results in the successful transfer of technology". ${ }^{27}$

Third, a critical CARIFORUM objective in this context was to avoid abusive contractual licensing arrangements that had arisen due to information asymmetries between the Caribbean licensee and the right holder. In the past, licensing agreements had been concluded on products that either would enter the public domain soon after the contract was concluded, or that were not protected in the jurisdiction of the licensee ${ }^{28}$ and did not need to be licensed at all.

18 Interview with Malcolm Spence, 7 April 2010, Bridgetown.

19 See Spence, Innovation and Intellectual Property, paragraph 43. In particular, Jamaica, the regional rum industry and at a cautious level also Barbados had expressed their vested interest in including GI protection for other products than wine and spirits into the EPA. Interview with Malcolm Spence, 7 April 2010, Bridgetown.

$20 \quad$ Email correspondence with Norman Girvan, 22 April 2010.

21 See Spence, Innovation and Intellectual Property, paragraphs 43-44.

22 See ibid., paragraphs 43-44.

23 Interview with Malcolm Spence, 7 April 2010, Bridgetown.

$24 \quad$ See Article 66.2 of the TRIPS Agreement.

25 See Spence, Innovation and Intellectual Property, paragraph 4.

26 Interview with Malcolm Spence, 7 April 2010, Bridgetown.

$27 \quad$ Spence, Innovation and Intellectual Property, paragraph 28. This has already been proposed in CARIFORUM's second concept note entitled "Trade and Innovation".

28 See Spence, Negotiating Trade, Innovation and Intellectual Property, p. 5-6. 
Although not identified by the technical negotiator of CARIFORUM as an offensive preference, the protection of utility models was taken up in the negotiation agenda on CARIFORUM's behalf rather than on that of the EU. In particular, the government of Trinidad \& Tobago sought this protection for the very reason that utility models offer protection for innovative products at an early stage of development; the region's level of development would benefit clearly from this early protection. ${ }^{29}$ CARIFORUM's position, in this respect, was derived from the proposal already made in the FTAA negotiations.

\subsubsection{Defensive Interests}

In contrast, in two other areas of IP protection, the CARIFORUM region had no proactive preferences that it put on the table. Rather, it reacted to what the EU had proposed. One such area was the protection of plant varieties. CARIFORUM States were not willing to include plant variety protection into the EPA; they were clearly opposed to a provision that would require them to become a party to the UPOV Convention, Act 1991.30 According to Malcolm Spence, this conviction had been adopted by CARIFORUM States due to information received from international para-state and non-state actors, such as Third World Network and the South Centre. $^{31}$ In fact, only Trinidad and Tobago and the Dominican Republic are countries that have already acceded to the UPOV Convention, Act 1991. The regional negotiator's position seemed to deviate from CARIFORUM's preferences in that respect: Malcolm Spence personally was convinced that CARIFORUM States should implement a system of plant variety protection, preferably a regional system. ${ }^{32}$ It is fair to conclude that the preferences of CARIFORUM States and the regional negotiator were divided on this issue.

Another challenging aspect of the negotiations constituted the discussions on enforcement provisions; ${ }^{33}$ also for this area of IP protection, the region had no offensive preferences itself. The EU proposal was prescriptive and drew heavily on the Enforcement Directive 2004/38. Although the region was hesitant to agree to such prescriptive language in a free trade agreement, it sought to determine

"how much of the document described what was already practice in their respective States." 34

Three factors determined CARIFORUM's negotiating position on the proposed enforcement issues. First, the result of the determination by CARIFORUM States indicated that much of the EU proposal was already common law practice in their

29 Interview with Malcolm Spence, 7 April 2010, Bridgetown.

30 Ibid. Note that Jamaica is in the process of becoming a party to the UPOV Convention, Act 1991. Interview with Michelle Walker, 13 April 2010, Kingston. Its opposition to an obligation to accede to the UPOV Convention, Act 1991, therefore, was not significant.

31 Interview with Malcolm Spence, 7 April 2010, Bridgetown.

32 Interview with Junior Lodge, 3 March 2010, Geneva.

33 See Spence, Negotiating Trade, Innovation and Intellectual Property, p. 6.

$34 \quad$ Spence, Innovation and Intellectual Property, paragraph 37. 
jurisdictions. ${ }^{35}$ This conclusion is commonly known as low adaptation costs since it makes the adoption of rules easy and without much political cost. Second, two issues were of concern to the region: a) the proposals to secure evidence for prosecuting infringement cases, ${ }^{36}$ and b) the broad scope of border measures. ${ }^{37}$ Third, the regional and national entertainment/copyright industries in Jamaica, Barbados and Trinidad \& Tobago welcomed the rather prescriptive language as they had experienced challenges in enforcing their copyright in the past. ${ }^{38}$ As a result of these factors, CARIFORUM was not opposed to discussing the EU proposal, with the exception of the noted areas of concern to its Members.

\subsubsection{Forum Choice}

On the issue of forum choice, Malcolm Spence and Junior Lodge reported that the CARIFORUM region did not have concerns to negotiate a trade agreement at the bilateral level. Having no concern, however, does not mean that they prefer this level: the region's preferred approach, according to them, would always be multilateral negotiations. ${ }^{39}$ Nevertheless, the region felt well prepared for negotiations with the European Union at the bilateral level, mainly for three reasons. First, CARIFORUM had obtained sufficient experience in the FTAA negotiations to be able to handle pressure used in bilateral negotiations. Second, the negotiators were seizing the opportunity to insert issues in a bilateral agreement that could not be achieved at the multilateral level. Third, it was felt that CARIFORUM's position was not too far removed from the position adopted by the European Union. ${ }^{40}$

For the analysis of how much influence interested non-state actors could have had on the region's IP policy position in the EPA negotiations, not only the regional policy position is relevant. National (Jamaica) and regional (CARIFORUM) non-state actors were able to interact with both regional as well as national policy makers and could therefore have influenced either the regional or the national policy position, or both. In addition, even if a national non-state actor only interacted with the national policy maker, (s)he could still have influenced the regional policy position through the national policy maker, who successfully put forward the former's concerns. For these reasons, the Jamaican IP policy position is presented in the following.

\subsubsection{Jamaican Policy Position}

The Jamaican policy positions for the different areas of intellectual property protection overall coincided with those adopted by the regional negotiator. However,

The lawyers at the national level (Trinidad, Barbados, Jamaica) did not find many differences from the EPA to the common practice already existing in the CARIFORUM region. Interview with Malcolm Spence, 7 April 2010, Bridgetown. The rules on evidence and measures for preserving evidence included in the CARIFORUM-EC EPA are analyzed in section 5.3.3.2 of this book.

The border measures included in the CARIFORUM-EC EPA go beyond the TRIPS standard in that they broaden their mandatory application to include designs and geographical indications in addition to counterfeit trade mark goods and pirated copyright goods. It also includes precise definitions of what constitutes counterfeit trade mark goods and pirated copyright goods. See section 5.3.3.7 of this book. Interview with Malcolm Spence, 7 April 2010, Bridgetown.

Ibid.

Ibid. 
for some areas of IP, Jamaica's policy position could not be identified clearly. One reason certainly is that the policy positions have mainly been derived from interviews with relevant Jamaican policy makers from MoFAFT (Michelle Walker) and JIPO (Lilyclaire Belamy, Kai-Saran Davis), without the benefit of verifying or complementing that information with written accounts. Another explanation for the lack of a specific position in certain areas is the lack of a genuine interest of Jamaica in those areas.

Also for Jamaica, three general preferences in regulating IP through the EPA could be identified. First, Jamaica aimed at not committing to standards that go beyond the level of protection foreseen by the TRIPS Agreement. While this was an important objective, at the same time, the country realized that it would be difficult to sustain this position as most recent bilateral trade agreements concluded worldwide contain higher protection. ${ }^{41}$ Second, for those areas of IP that go beyond the level of the TRIPS Agreement, Jamaica sought to obtain as long transitional periods of implementation as possible. Their main concern was that Jamaica only agrees to commitments it will be able to live up to. ${ }^{42}$ A third key objective was to link the concept of "innovation" to the protection of intellectual property protection in the way that the regional negotiator Malcolm Spence had proposed. ${ }^{43}$ With these general objectives, Jamaica was very much in line with the position adopted by the regional negotiators.

The area of IP in which Jamaica had a genuine interest was the protection of geographical indications. As a member of the group of "Friends of GIs" in the WTO, Jamaica was eager to agree on equal protection for food products and wines and spirits. ${ }^{44}$ This position implies that Jamaica is also willing to change its own legislation, which still stipulates a non-equal level of protection for wines and spirits versus other products. Also for this area, Jamaica's position clearly coincided with that of the regional negotiating team.

Furthermore, Jamaica has a preference for establishing a system of protection for traditional knowledge, folklore and genetic resources; however, within the region, Jamaica was not the country to push the matter on the regional negotiating agenda. Suriname, Belize and Guyana were the CARIFORUM States with a genuine interest. In fact, Jamaica has not yet developed a clear position on what system and form of protection it favours. So far, it supports an international mandatory requirement of prior informed consent; it also has a preference for a sui generis model of protection opposed to a solution within the patent system only. However, the CARICOM region faces the problem of having many traditional products in common and therefore being unable to identify one indigenous group in one country which is the "owner" of the relevant traditional knowledge. ${ }^{45}$ Therefore, Jamaica and other CARICOM Member States currently look into harmonizing a future system of protection for traditional knowledge at the regional level. From this account, it becomes obvious that Jamaica did not push for including the protection of traditional

41 Interview with Michelle Walker, 13 April 2010, Kingston.

42 Interview with Lilyclaire Bellamy, 12 April 2010, Kingston.

43 Interview with Michelle Walker, 13 April 2010, Kingston.

44 Ibid.; interview with Lilyclaire Bellamy, 12 April 2010, Kingston.

45 Interview with Lilyclaire Bellamy, 12 April 2010, Kingston. 
knowledge into the EPA but was also not opposed to relatively vague language that would allow the region to determine their preferred system of protection in the future.

Plant variety protection did not form part of Jamaica's areas of interest. Michelle Walker from MoFAFT believes that the country does not have products that can benefit from such protection. ${ }^{46}$ During the consultations in Jamaica, no discussions took place on the question as to whether or not it is beneficial for Jamaica to agree to a specific level of protection for plant varieties. Despite this apparent lack of interest among its economy, Jamaica did not insist on dropping the issue from the EPA negotiations because the country has already committed itself to join the UPOV Convention, Act 1991 and started the process of becoming a member to the Convention. ${ }^{47}$

No specific interests could be identified for Jamaica in the following areas of IP: the protection of trade marks, patents, technology transfer, utility models and enforcement standards.

Regarding the question as to which type of agreement is most beneficial for Jamaica and the CARIFORUM region, Jamaica slightly differed from the position held by the regional negotiating team. Michelle Walker and Lilyclaire Belamy clearly favour multilateral agreements over bilateral ones. One reason is that the multilateral arena gives countries such as Jamaica better opportunities to negotiate in a group in which they can strengthen their voice. ${ }^{48}$ Even taking the need to compromise in such a group into consideration, this constellation will eventually bring the country closer to its preference. ${ }^{49}$ In bilateral arrangements with a partner country of a considerably different size, Jamaica is at a disadvantage: because of the different leverage, the smaller country often has no choice than giving more than it has agreed upon at the multilateral level..$^{50}$ Another reason why Jamaica favours multilateral protection is that Jamaican right holders have suffered from misappropriation in the areas of biodiversity, traditional knowledge and plant varieties worldwide. The only way to remedy this problem, in Lilyclaire Belamy's view, is to achieve multilateral protection rather than concluding bilateral agreements with countries in which their rights are potentially misappropriated. ${ }^{51}$

\subsubsection{Interim Conclusions}

Overall, the Jamaican policy positions in the different fields of intellectual property protection are reflected in the negotiating positions adopted by the region. In terms of general objectives, Jamaica had formulated the same objectives as the region in respect of 1) minimizing changes to the TRIPS level of protection and 2) with regard to the link between intellectual property protection and the concept of innovation. One general objective of the region and one Jamaican objective were not identical.

$\begin{array}{ll}46 & \text { Interview with Michelle Walker, } 13 \text { April 2010, Kingston. } \\ 47 & \text { Ibid. } \\ 48 & \text { Ibid. } \\ 49 & \text { Ibid. } \\ 50 & \text { Interview with Lilyclaire Bellamy, } 12 \text { April 2010, Kingston. } \\ 51 & \text { Ibid. }\end{array}$


The regional negotiator did not report to have striven for long transitional periods which represented a Jamaican general objective. On the other hand, Jamaican policy makers did not mention the access to support programmes of the European Union to be an important objective.

Objectives in specific areas of intellectual property protection coincided particularly in the area of geographical indications. Both Jamaican policy makers and the regional negotiator had a strong preference for achieving equal protection for wines and spirits and other products. Also with regard to establishing a system of protection for traditional knowledge, folklore and genetic resources, Jamaica is interested as much as the region in rather vague language that will allow CARIFORUM States to develop a future system of protection appropriate for the region.

In the field of plant variety protection, the regional and national policy positions were not identical. Jamaica was indifferent as to whether or not the region agreed to an obligation of becoming a party to the UPOV Convention, Act 1991. In contrast, opposing this obligation was a defensive preference of the region. With regard to the regional objectives to achieve a broader transfer of technology clause, utility model protection and enforcement standards, no specific preferences could be established in Jamaica. This suggests that Jamaica was rather indifferent about the protection agreed to in these areas.

Interesting to note is that neither any of the Jamaican policy makers interviewed, nor any of the regional negotiators, wereconcerned with the fact that CARICOM Member States have not yet agreed upon a common regional policy on intellectual property protection within the region. Michelle Walker from MoFAFT and Lilyclaire Belamy from JIPO are convinced that most of the protection for IP in the region is already harmonized since CARICOM Member States fall back on each others' legislation when developing new legislation. ${ }^{52}$ Moreover, CARICOM Member States have relied on technical assistance from WIPO in developing relevant IP laws; since the model laws used by WIPO are standardized, their legislation is very similar. ${ }^{53}$ In view of the fact that CARIFORUM as the only ACP region has agreed to a comprehensive IP chapter in the EPA, it can be suggested that most CARIFORUM States as well as the regional negotiators were not too concerned about entering into commitments vis-à-vis the European Union while the region CARICOM has not yet finished harmonizing its own IP laws.

Finally, as to the question which forum is more beneficial for Jamaica/CARIFORUM, Jamaican policy makers unconditionally favoured the multilateral forum over the bilateral one. The regional position also reflected a preference for the multilateral forum; at the same time, the region had relatively few concerns about negotiating a bilateral agreement with the European Union, for which they felt well prepared. Jamaican policy makers, on the other hand, were quite concerned about bilateral negotiations. The views by regional negotiators and Jamaican policy makers on the forum-choice issue, therefore, did not coincide.

52 Interview with Lilyclaire Bellamy, 12 April 2010, Kingston.

53 Interview with Michelle Walker, 13 April 2010, Kingston. 


\subsection{PROCESS TRACING}

In order to determine whether certain non-state actors have had some influence on the policy-making process at the Jamaican and/or regional level, the most important necessary prerequisite is that they have participated in any of the consultation processes outlined above. ${ }^{54}$ According to the assumptions for this research project, if a non-state actor has not contributed to the policy formulation in a consultative forum, (s)he could not have influenced the final IP policy position. ${ }^{55}$ Therefore, only the actors identified in section 10.2.1, which have been involved in one of the various forms of consultations, will be further assessed in this section. An exception to this is the West Indies Central Sugar Cane Breeding Station, which did not participate in consultations during the EPA negotiations but seemed to have influenced the regional decision-making process through a workshop that took place in 1998.

Five actors were identified to have been involved in consultations during the EPA negotiations and one in a workshop on plant variety protection in 1998. The five actors involved in the consultations during the EPA negotiations were national actors; the actor involved in the 1998 workshop was a regional actor. These non-state actors encompass one lawyer/expert in IP (Dianne Daley) and five businesses, producers and business and industry associations (Private Sector Organization of Jamaica, Jamaica Chamber of Commerce, the Competitiveness Company, Jamaica Standard Products Company and West Indies Central Sugar Cane Breeding Station). Among these actors, three have been assessed to have specific preferences on issues of intellectual property protection in general; these are WICSCBS, Dianne Daley and the Competitiveness Company. While WICSCBS and Dianne Daley had specific preferences in the international regulation of IP (through bilateral or multilateral agreements), this is not the case for the Competitiveness Company, which focuses on the national regulation of IP rights. The Competitiveness Company therefore must be classified as a non-state actor with a marginal or general interest in the regulation of IP issues through the CARIFORUM-EC EPA.

This latter conclusion is also true for the other three non-state actors involved in consultations during the EPA negotiations. According to their own accounts, Private Sector Organization of Jamaica, Jamaica Chamber of Commerce and Jamaica Standard Products Company only have a general or marginal interest in IP protection in general as well as in the EPA in particular. Also the members of Private Sector Organization of Jamaica or Jamaica Chamber of Commerce have no specific interest in this area.

Only Dianne Daley participated in the specific consultations on IP protection organized by Ministry of Foreign Affairs and Foreign Trade and Jamaica Intellectual Property Office. Because of Dianne Daley's expertise in the field, her contacts with the Jamaican policy makers and her own assessment, ${ }^{56}$ her participation in that group

$54 \quad$ See sections 10.2.2 and 10.2.3 of this book.

55 Note that this research has focussed on the institutionalized forms of interaction between state and non-state actors, being the consultations organized by the former, due to the fact that no other forms of interaction were named by the interviewees. In addition, information on informal contacts was not readily available.

56 Interview with Dianne Daley, 31 March 2010, Kingston; also interview with Peter Goldson, 31 March 2010, Kingston. 
can be classified as active and substantial. WICSCBS did not participate in any consultations during the EPA negotiations, but was a key participant in a workshop on plant variety protection in 1998. The other four organizations participated in the two non-IP specific consultations: the consultations in the Jamaica Trade Adjustment Team (Private Sector Organization of Jamaica and Jamaica Chamber of Commerce) and the GI working group (Private Sector Organization of Jamaica, the Competitiveness Company, Jamaica Standard Products Company). The Private Sector Organization of Jamaica was the only actor that participated in both forums.

The involvement of the four organizations in these groups on the issue of intellectual property protection in the EPA has been rather passive for two reasons: first, these organizations merely have a marginal or general interest in intellectual property protection; second, Jamaica Trade Adjustment Team (JTAT) and the GI working group have not addressed IP issues in the EPA in detail. JTAT members only discussed IP issues when brought up by one of its members; since IP was not a priority area, this rarely happened. Although the regulation of GI protection through the EPA was dealt with in the GI working group, the three non-state actors that participated therein were not at the forefront of its activities; ${ }^{57}$ JIPO and the CIB were the key players in this group..$^{58}$

In brief, it has been determined that five non-state actors were involved in national consultative processes and one regional actor in a workshop on plant variety protection in 1998. Out of the six actors, only two had specific preferences on the regulation of IP protection through the CARIFORUM-EC EPA. First, Dianne Daley was the only national actor with specific preferences. She was also the only actor out of the six that has participated in the specific IP consultations, which were most determinative for Jamaica's national policy position on IP matters. Second, the regional actor WICSCBS had specific preferences in the area of plant variety protection and participated in a workshop thereon in 1998. The other four national actors Private Sector Organization of Jamaica, the Jamaica Chamber of Commerce, the Competitiveness Company and Jamaica Standard Products Company had only a general or marginal interest in the IP regulation in the EPA and were involved in the two non-IP specific consultative processes of the JTAT framework and the GI working group.

\subsubsection{Preference Attainment}

The aim of this section is to assess whether an actor that participated in one of the consultation forums was able to attain his preferences with regard to IP protection in the EPA. The method preference attainment uses the actors' preferences in the various areas of intellectual property protection and compares them to the relevant

$57 \quad$ Omar Chedda from PSOJ stated that he attends the GI working group sometimes. The $\mathrm{CC}$ has been active in the area of the protection of geographical indications and has attended all meetings convened. Margaret Mais thinks it is important that the CC continues to be represented in the group, largely due to its impact on the CC's work and the importance of IP at the national and international level. Email correspondence with Margaret Mais, 8 May 2012 (available on request). Jack Minott stated that he attended three meetings of the GI working group. Email correspondence with Jack Minott, 22 April 2010.

58 Interview with Stacian Bennett, 7 April 2010, Kingston. 
national and regional policy positions. Although none of the five actors participated in consultations at the regional level, it could be that their views were accepted by Jamaica and taken to the regional level, which could have also influenced the regional policy position.

In the following, the method preference attainment will be applied to the actors WICSCBS, Dianne Daley, Private Sector Organization of Jamaica, Jamaica Chamber of Commerce, the Competitiveness Company and Jamaica Standard Products Company. In this respect, it needs to be noted that WICSCBS's and Dianne Daley's preferences will be assessed in greater detail than those of the other four non-state actors. The latter have hardly developed specific policy positions on the various issues of IP protection which could be assessed in terms of preference attainment. They have mainly stated general preferences about IP protection in the EPA. In addition, they have not been active actors in the non-IP specific consultative processes.

\subsubsection{WICSCBS}

The director of WICSCBS, Anthony Kennedy, expressed a clear preference for the establishment of an effective system of plant variety protection in Caribbean States. This preference also includes the option of a regional system of plant variety protection, similar to the one in the European Union. WICSCBS' preferences, however, did not encompass becoming a contracting party to the UPOV Convention, Act 1991. Anthony Kennedy does not see the value of membership where individual CARICOM Member States have not yet enacted or implemented national or regional plant variety legislation. However, he acknowledges that the international obligation to adhere to the UPOV system could be an extra incentive for countries to set up an effective system of plant variety protection in the near future. ${ }^{59}$

Compared with the regional policy position, there are strong similarities with the regional negotiator's position on plant variety protection. Both have an interest in establishing an effective system of plant variety protection in the Caribbean region. Where the regional negotiator's policy position differs from Anthony Kennedy's interest is on the question of membership to the UPOV Convention, Act 1991: Anthony Kennedy does not see the value of becoming a contracting party to the Convention if individual countries have not yet enacted or implemented legislation on plant variety protection. Malcolm Spence, on the other hand, seemed willing to undertake an obligation in the EPA to become a member to the UPOV Convention, Act 1991. The fact that the final EPA includes a soft "best-endeavour" obligation to "consider becoming" a contracting party can be explained both as a result of CARIFORUM States' reluctance to undertake a harder obligation and the Breeding Station's general preference for a plant variety protection system. ${ }^{60}$ WICSCBS's slight preference for concluding a bilateral agreement on the protection of plant variety protection does not seem to have influenced the regional negotiating position at all. The caveats mentioned by Anthony Kennedy (no preference for IP in general and not in terms of process) indicate that the WICSCBS has not communicated its preference thereon to the regional negotiator.

59 Phone interview with Anthony Kennedy, 17 April 2012.

60 Interview with Malcolm Spence, 8 April 2010, Bridgetown. 


\subsubsection{Dianne Daley}

Dianne Daley's preferences in the IP chapter of the CARIFORUM-EC EPA as identified in section 10.2.1.4.1 can be summarized as follows. ${ }^{61}$ First, she opposed any commitment that would put Jamaica under a hard obligation to become a member to the Patent Corporation Treaty and the Patent Law Treaty as well as to the Madrid Protocol. Second, Dianne Daley found it useful to include intellectual property protection in the bilateral agreement with the European Union, in particular in view of agreeing to reciprocal protection for traditional knowledge and GIs; her concern that IP protection can become a bargaining tool did not outweigh her general positive take on the bilateral nature of the agreement.

Compared to the Jamaican national policy positions held by the Ministry of Foreign Affairs and Foreign Trade and JIPO, there are certain differences with Dianne Daley's preferences. First, Jamaican policy makers did not mention a preference of becoming a member to or abstaining from signing any of the multilateral treaties under discussion, being the PCT, the PLT or Madrid Protocol. The policy makers did, however, declare that they had the general objective of safeguarding as much flexibility in terms of obligations for Jamaica as possible. It can be argued that Dianne Daley's preference for not signing any of the three treaties was acceptable to Jamaica as it fell under their general objective of safeguarding flexibility for most commitments. "Best endeavour" obligations could achieve both Jamaica's policy makers' and Dianne Daley's preference as Jamaica would preserve its freedom to decide whether and when to become a party to the treaties.

Second, the Ministry of Foreign Affairs and Foreign Trade and Jamaica Intellectual Property Office had strong concerns with regard to negotiating IP protection at the bilateral level; they have a clear preference for multilateral negotiations in this regard. Although Dianne Daley shares these concerns with regard to IP negotiations at the bilateral level, particularly when the agreement is wide in scope, she sees advantages in bilateral IP negotiations, which MoFAFT and JIPO have not mentioned. Overall, Dianne Daley's preferences only partly coincided with the national policy position.

In comparison with the regional policy position, Dianne Daley's preferences corresponded slightly more with the region's policy-agenda than the national policy position. First, her resistance to the obligations of becoming a member to the PCT, PLT and the Madrid Protocol were not part of the region's offensive preferences. Even though the region ultimately insisted to include "best endeavour" obligations in the final EPA text, ${ }^{62}$ according to the technical negotiator Malcolm Spence, this was not attributable to Jamaica's or Dianne Daley's positions but the result of the resistance by other CARIFORUM States, in particular Guyana and Suriname, to take on greater

61 Note that these were the interests particularly mentioned and addressed by Dianne Daley in the interview; this does not exclude the fact that Dianne Daley has provided suggestions to Jamaican policy makers on other areas of IP protection addressed in the CARIFORUM-EC EPA. However, since I have no information on other views expressed by Dianne Daley, the interests mentioned here are treated as her exclusive interests.

62 This was the case for the obligations to become a party to the PLT and the Madrid Protocol. 
commitments. ${ }^{63}$ In Malcolm Spence's experience, CARIFORUM States with limited capacities have chosen the side of caution when they were confronted with ambitious policy positions; this is why the region eventually has put a less ambitious negotiating position to the EU where the EPA text now contains "best endeavour" obligations.

Second, the regional negotiators' and Dianne Daley's preferences coincided on the issue of concluding a bilateral agreement including IP issues with the EU: both parties saw value in the bilateral regulation of intellectual property protection. Dianne Daley found it useful for CARIFORUM States to obtain reciprocity in the protection of geographical indications and traditional knowledge. The regional negotiators embraced bilateral negotiations with the EU because they hoped to achieve regulation of matters where there is no multilateral agreement yet, an example being traditional knowledge. Also, they felt that the EU's position was not too far removed from that of the CARIFORUM region; GI protection would be a clear example of this.

These comparisons show that Dianne Daley's preferences did coincide with but were not exactly identical to the national and regional policy makers' IP positions. Neither the national nor the regional policy makers had a similar preference for abstaining from signing the suggested multilateral treaties as Dianne Daley. The national policy maker had not formulated this specific objective but generally aimed at preserving as much flexibility in commitments as possible. According to Malcolm Spence's account, the fact that the final EPA text provides for "lighter" commitments was not attributable to Jamaica's or Dianne Daley's interventions. Therefore, although Dianne Daley's preference and the regional policy position ultimately were the same, it is doubtful whether Dianne Daley has influenced that outcome.

Including IP issues in the bilateral agreement with the EU was clearly not in Jamaica's policy makers' interest; regional policy makers were more in line with Dianne Daley's preferences in this respect, however for slightly different reasons. In view of the fact that Dianne Daley did not participate in regional consultations and had to rely on Jamaican policy makers to communicate preferences that are opposed to their own at the regional level, it is not obvious that Dianne Daley has influenced the regional decision to conclude a bilateral agreement that contains IP standards.

\subsubsection{Others}

The other four actors that participated in one of the three consultative processes were the Private Sector Organization of Jamaica, the Jamaica Chamber of Commerce, the Competitiveness Company and the Jamaica Standard Products Company. None of the four has formulated specific preferences with regard to any of the areas of IP protection dealt with in the EPA negotiations. Therefore, only a few can be related to the objectives of the national and/or regional policy makers' policy positions.

Private Sector Organization of Jamaica stated that its preferences in IP protection in general are the continuation of access to information and technology and the improvement of the protection for innovative products present in Jamaica. ${ }^{64}$ It has

63 Interview with Malcolm Spence, 7 April 2010, Bridgetown.

64 Interview with Omar Chedda, 12 April 2010, Kingston. 
no preference for the bilateral or multilateral level when regulating IP issues internationally. These were also the objectives they pursued in the context of the EPA negotiations. Compared with the objectives pursued by the national policy makers, PSOJ's preferences seem to be reflected in the Jamaican policy position in so far as Jamaica did not want to commit to anything more than what the TRIPS Agreement prescribes. Also the regional policy position reflects this preference: to minimize changes to the TRIPS level of protection. Arguably, the TRIPS Agreement provides a balanced protection for the main areas of intellectual property protection that grants important flexibilities to safeguard access by the users of technological and creative knowledge. ${ }^{65}$ Nevertheless, even though PSOJ's preferences would be satisfied by not going beyond the TRIPS Agreement, PSOJ did not bring this specific preference forward in the national consultative processes. ${ }^{66}$

The second actor involved in the Jamaican policy-making process was the Jamaica Chamber of Commerce. The Chamber has not formulated a position on IP issues discussed during the EPA negotiations, even though it took part in the JTAT consultations. A preference for the multilateral forum was stated by an internationally experienced officer of JCC. This latter preference on the choice of forum cannot clearly be attributed to the organization itself; it was rather the personal opinion of one officer who, nevertheless, believed that most people would agree with her. Since JCC's preferences are either non-existent (specific areas of intellectual property protection) or too generally formulated (forum choice), their preference attainment cannot be assessed.

The Competitiveness Company has a very limited interest in the international regulation of intellectual property issues; in fact, it has not developed a position with regard to certain aspects of the IP chapter in the EPA, neither before nor after its signature. Its participation in the GI working group in general and specifically with regard to the GI protection in the EPA can be classified as being passive, even though it attends all meetings. Despite this obvious non-involvement in IP matters concerning the EPA, the company holds the strong view that a system of IP protection of a high standard, particularly for the areas of copyright and trade mark protection, is favourable for Jamaica, if supported adequately by the necessary resources and knowledge. CC also has a preference for the bilateral regulation of international IP issues. To sum up, due to its passive participation in the GI working group and the lack of a position on the regulation of IP in the EPA, no preference attainment can be established for the Competitiveness Company.

The final actor involved in one form of the Jamaican consultative processes, the GI working group, is Jamaica Standard Products Company. The coffee producer's preference in relation to the regulation of intellectual property in the EPA was the

Article 7 of the TRIPS Agreement sets out the objectives of the agreement and highlights that the protection and enforcement of IP rights should contribute to the mutual advantage of producers and users of technological knowledge. Although it can be argued that the agreement does not fulfill this objective, it is the only recent multilateral agreement to which both developed and developing countries have agreed. It therefore has been acknowledged to provide enough protection and flexibilities to satisfy the different needs of producers and users.

66 Interview with Omar Chedda, 12 April 2010, Kingston. 
reciprocal protection of "Jamaica Blue Mountain" coffee as a geographical indication by the European Union. Comparing this preference with the objectives that formed part of the national and regional policy position, his preference clearly coincided with that of national and regional policy makers. They aimed at achieving equal protection for products other than wines and spirits, among others for coffee. JSP has no preference for the forum where intellectual property protection is regulated. Since Jamaica Standard Products Company did not face costs of collective action and his preferences were identical to the national and regional policy position, it could be concluded that JSP influenced the national policy position on GI protection. However, it seems more likely that the coffee producer merely had the same preferences as the policy makers. The preference for achieving an equal level of GI protection for other products than wines and spirits was one of the least controversial ones. Actors that have been dominant in promoting this interest were JIPO and the Coffee Industry Board.

\subsubsection{Interim Conclusions}

To conclude, WICSCBS's preferences mainly coincided with those of the regional negotiator. It can be concluded that WICSCBS attained its preferences. Dianne Daley's preferences partly coincided with those of the national and regional policy positions. However, they were not so similar to the relevant positions as to allow for the judgement that she has attained her preferences by her own involvement. With regard to the other four organizations, only Private Sector Organization of Jamaica and Jamaica Standard Products Company have attained their preferences when compared to the national and regional policy position on IP matters in the EPA negotiations. However, it is doubtful whether this attainment in fact is an indication of influence that has taken place.

In terms of preferences for the bilateral or multilateral forum for IP negotiations, Dianne Daley's and the Competitiveness Company's preference for concluding a bilateral agreement on IP issues with the EU coincided with those reflected in the regional policy position: they all saw value in regulating different IP issues in a bilateral agreement. While the region's concerns with regard to bilateral IP negotiations were also reflected in Dianne Daley's preferences, the Competitiveness Company did not have the same concerns. The view of one officer of the Jamaica Chamber of Commerce that multilateral negotiations are more beneficial for Jamaica as such is not reflected in the regional negotiating position.

\subsubsection{Self and Peer Assessment}

By using the method of self and peer assessment, it is established how the non-state actors under analysis perceive 1) their own and 2) other non-state actors' influence on Jamaica's and the regional policy position in different IP areas. The method draws on these non-state actors' own assessment of the question as to whether they themselves or other non-state actors have influenced the national and regional policy outcome. Finally, the interviewed state and non-state actors disclosed 3) which state actors or other factors they perceived as having considerably influenced relevant policy makers' positions.

The self-assessment by the director of the West Indies Central Sugar Cane Breeding Station, Anthony Kennedy, conveyed that he thinks that he influenced the regional 
policy position on the matter of plant variety protection. He felt that the CRNM took his comments seriously and thought to have influenced the regional policy position. ${ }^{67}$

Dianne Daley also thinks that she influenced Jamaica's and the regional policy position. According to her, the Jamaican policy makers (in particular Michelle Walker) heard her concerns with regard to avoiding commitments in the area of patent and trade mark protection by not accepting a hard obligation for Jamaica to become a member to the PCT, PLT and the Madrid Protocol. Dianne Daley believes that Michelle Walker communicated that position to the regional negotiators who have adopted these concerns in the form of the "best endeavour" obligations, at least in respect of the PLT and the Madrid Protocol. ${ }^{68}$

The other four actors analyzed did not perceive themselves or any other non-state actor as having influenced the Jamaican or regional policy positions on IP matters in the EPA negotiations. Jamaica Chamber of Commerce stated that it did not have a specific role in the EPA negotiations on IP matters and therefore would not have influenced the policy outcome. The Competitiveness Company feels that its comments are generally taken very seriously by the Government. However, during the consultations on IP issues in the EPA, its role was so limited that it does not believe that it influenced the Jamaican policy position. Jamaica Standard Products Company and Private Sector Organization of Jamaica did not provide an answer to this question.

These results concur to a certain extent with the results of most self-assessment studies. They reveal that non-state actors usually think that what they said or did only had a marginal impact on policy makers; Anthony Kennedy's and Dianne Daley's self assessment is very exceptional in this regard. This assessment can be explained by the fact that where there are many other non-state actors, the impact of one actor is almost not felt. An analogy is the individual voter who does not feel (s)he has an impact. However, this result would not have been expected for a situation where there are only very few participating actors in the policy process (rather than a plural civil society). The normal expectation would have been that few players would be able to feel at least some marginal preference attainment. This study shows that even in a situation with few players, the majority's perception is that they had no or hardly any influence on the policy-making process on the IP issues dealt with in the EPA.

The reasons for this result can be explained by the fact that almost all non-state actors in Jamaica and in the CARIFORUM region are "receivers" of international rules. This means that they have just reacted to proposals of IP rules that were made by the European Union or the regional negotiators rather than proposing such rules by themselves. Even though a few non-state actors have been involved in the policy process, they were not in a position to influence the choice of international rules. This vacuum of preferences was filled by the rules proposed by the European or the regional negotiators. ${ }^{69}$

67 Phone interview with Anthony Kennedy, 17 April 2012.

68 Interviews with Dianne Daley, 31 March 2010, Kingston.

69 See section 10.2.3.6 of this chapter where a lack of domestic preferences was noted and linked to the conclusion that the European Union most likely has filled this vacuum of 
Apart from the non-state actor's perception of their own influence on Jamaican or regional policy makers, both state and non-state actors were asked to assess which state actor or factor they perceived to have been most influential in the determination of the regional and/or Jamaican policy position on IP matters. The answers provided by the interviewees indicate that they emphasize rather different factors to have been determinative for the final policy choice.

Starting with the six non-state actors analyzed above, four actors (WICSCBS, the Competitiveness Company, Dianne Daley and Private Sector Organization of Jamaica) answered this question; Jamaica Chamber of Commerce and Jamaica Standard Products Company did not provide their opinion on this issue. Anthony Kennedy felt that the costs of becoming a party of the UPOV Convention, Act 1991 must have been most determinative for the regional policy choice of leaving some discretion to CARIFORUM States as to whether or not to accede to the Convention. The Competitiveness Company emphasized that JIPO and MoFAFT have been the most influential actors for Jamaica's IP policy position. The factor that was most determinative, according to the $\mathrm{CC}$, was the proliferation of goods that infringe Jamaica's goods protected by intellectual property rights (in particular copyright and trade marks infringements).

Dianne Daley stressed that it was a solid analysis of the costs and gains for Jamaica in the various areas of IP that determined the Jamaican Government's policy choices. To her knowledge, JIPO made cost-benefit analyses for each area of intellectual property protection negotiated in the EPA. Those were passed on to MoFAFT and, according to Dianne Daley, were most influential on the final policy decisions by the Jamaican policy makers. ${ }^{70}$

Private Sector Organization of Jamaica believes that the regional negotiators in the area of IP mainly influenced the regional policy position. CRNM has expert knowledge on the IP issues under discussion, which CARIFORUM States were dependant on. Other sources of knowledge, such as the consultations organized with non-state actors at the national level, according to Omar Chedda, were not influential for the very reason that non-state actors are not informed enough on IP issues to communicate a meaningful opinion. ${ }^{71} \mathrm{He}$ experienced the consultations to be onesided in the way that JIPO and MoFAFT provided information on the IP issues and possible policy positions, and non-state actors listened without giving meaningful feedback. Since the view of the regional negotiating team of CRNM and of the technical negotiator on IP issues, Malcolm Spence, was mentioned by several actors as being critical to the final regional policy position, ${ }^{72}$ it will be examined in further detail in the following section 11.3.

preferences in Jamaica and the CARIFORUM region by proposing international rules of intellectual property protection in the EPA negotiations. could not be verified by the author.

71 Interview with Omar Chedda, 12 April 2010, Kingston.

72 Interview with Beverley Pereira, 6 April 2010, Kingston. Interview with Junior Lodge, 3 March 2010, Geneva. Phone interview with a senior official from a CARIFORUM State, March 2010. Interview with Michelle Walker, 13 April 2010, Kingston. 
Before turning to CRNM and Malcolm Spence in particular, it is worthwhile to present some other factors that other interviewed actors have mentioned to have been determinative for the final national and regional policy positions in the various areas of IP. Beverley Pereira is of the opinion that intellectual property protection in a trade agreement is often sacrificed for other priorities of trade. Hence, when making choices in the area of IP protection, these choices are mostly informed by the benefits in other areas of trade rather than necessarily in the area of IP. In her opinion, the link made in the EPA between intellectual property protection and the concept of innovation enabled Malcolm Spence to put IP higher on the regional negotiating-agenda since innovation is crucial for successful trade and most national policy makers prioritize trade issues. ${ }^{73}$

Also staff members of CRNM, in particular Malcolm Spence, have indicated quite clearly which actors and factors have influenced the regional negotiating positions in each area of intellectual property protection. As CRNM staff is the main regional policy maker in the context of the EPA negotiations, their perception of which actors and factors have influenced them most will be presented according to each area of IP protection focussed on in this research project. These are the following areas: the protection of traditional knowledge, geographical indications, technology transfer, plant variety protection and enforcement rules.

According to Malcolm Spence, three CARIFORUM States particularly insisted on including the protection of traditional knowledge in the EPA negotiations. These were Belize, Dominica and Suriname. ${ }^{74}$ However, they did not provide him with information on which elements they would like to see back. Therefore, Malcolm Spence felt that it was rather a bilateral effort between him and the European Union negotiator to find a placeholder that would enable the region to use a mechanism of protecting traditional knowledge that the international discussions will eventually determine. $^{75}$

With regard to the issue of GI protection, CARIFORUM's negotiating position was influenced mainly by three factors. First, two studies published in 2002 were made available to CRNM staff and informed their thinking in the area of GI protection. ${ }^{76}$ In one of them, Carlos Correa raised the challenge for CARICOM Member States of being unable to identify products that might be susceptible for the use of geographical indications. Second, the rum industry, in particular, the West Indies Rum \& Spirits Producers' Association Inc., had expressed its preference for having

73 Interview with Beverley Pereira, 6 April 2010, Kingston.

$74 \quad$ Interview with Malcolm Spence, 7 April 2010, Bridgetown.

75 Ibid.

76 One was authored by Carlos Correa and the other by Paolo Bifani. See C.M. Correa, Protection of Geographical Indications in CARICOM Countries (Inter-American Development Bank, Georgetown, Guyana, 2002), available at <http://www.iadb.org/intal/intalcdi/PE/2009/03454.pdf $>$ accessed on 15.11.2012. The other study commissioned in the context of the FTAA negotiations dealt with CARICOM's interests in relation to biodiversity and intellectual property rights. See P. Bifani, CARICOM Interests in Relation to Biodiversity and Intellectual Property Rights in the Context of FTAA Negotiations (InterAmerican Development Bank, 2001) [ATN/JF/SF-6158-RG], available at $<$ http://www.crnm.org/index.php?option=com_docman\&task=cat_view\&gid $=109 \&$ Itemid $=81>$ accessed on 12.11.2012. 
Caribbean rum recognized as a trans-national geographical indication in the region. ${ }^{77}$ Third, CARIFORUM negotiators were able to bargain a convenient solution for the protection of geographical indications. With only a few market access issues being still unresolved in the final negotiating phase of the CARIFORUM-EC EPA, CARIFORUM negotiators could push the discussions on GI protection in the direction of a mutually convenient solution in exchange for movement on the market access side. ${ }^{78}$ The solution in geographical indications was to postpone the negotiation of protection for some years. ${ }^{79}$

On the issue of determining the regional negotiating position on an appropriate technology-transfer clause, Malcolm Spence stated that the international civil society organizations Quaker United Nations Office and Center for International Environmental Law were particularly relevant. ${ }^{80}$

For the area of plant variety protection, Malcolm Spence indicated that the Central Sugar Cane Breeding Station in Barbados was most influential on him as the technical negotiator by encouraging the greater consideration of plant breeding and the need for this work to be protected. ${ }^{81}$ In addition, according to Malcolm Spence, participation in the UPOV Convention, Act 1991 was not critical for commercial success in trade in target markets, many of which already protect plant varieties. In view of the costs of membership, a best endeavour obligation was most feasible. ${ }^{82}$ According to Junior Lodge, it was Malcolm Spence's view on the protection of plant varieties that primarily informed the regional negotiating position. ${ }^{83}$ In fact, all CARIFORUM States were hesitant regarding membership to the UPOV Convention, Act 1991; Malcolm Spence eventually was able to convince the national ministries of the importance of this type of IP protection. ${ }^{84}$

Finally, concerning the enforcement of intellectual property rights, Malcolm Spence found the input of Quaker United Nations Office and Center for International Environmental Law to have been particularly relevant. ${ }^{85}$

It is remarkable that CRNM staff, in particular Malcolm Spence, did not mentioned CARIFORUM States' input in the policy-making process to be most influential for the regional negotiating positions on IP issues. An exception is the area of the protection of traditional knowledge where Belize, Dominica and Suriname were named as having insisted on the inclusion of a clause that would allow for the

Interview with Malcolm Spence, 7 April 2010, Bridgetown. See section 10.2.1.2.1 of this book.

See section 10.1.2.4 of this book.

See Spence, Innovation and Intellectual Property, paragraph 45.

Interview with Malcolm Spence, 7 April 2010, Bridgetown. Note that this analysis has not focused on the influence of international non-state actors on the regional and national policy positions in the area of IP. See section 10.2.1 of this book.

Ibid. See section 10.2.1.2.2 of this book.

Email correspondence with Malcolm Spence, 8 October 2012 (available on request).

Interview with Junior Lodge, 3 March 2010, Geneva.

Ibid.

Interview with Malcolm Spence, 7 April 2010, Bridgetown. 
protection of traditional knowledge. This conclusion will be further discussed below. ${ }^{86}$

\subsubsection{Interim Conclusions}

Summarizing the actors' assessment of which actors and factors were influential, no clear-cut answer can be provided as to which actors or factors were most determining for the national and regional policy positions in the different areas of IP. In fact, very different actors and factors have been brought up by the various interviewees. However, there are some conclusions that can be made with regard to the influence on a) the Jamaican policy positions and b) the regional negotiating positions.

Starting with the conclusions for the Jamaican policy positions, Dianne Daley is the only non-state actor who assessed her own influence on the Jamaican policy maker as having been important. Furthermore, she believes that the most influential factor in the Jamaican policy-making process on the question as to whether or not a particular standard of protection in an area of intellectual property protection is embraced is a positive cost-benefit analysis made by Jamaica Intellectual Property Office. Domestic non-state actors, therefore, were not mentioned by her as a determining factor for the Jamaican IP policy position.

The conclusions for the influence on the regional negotiating positions are rather different. First, West Indies Central Sugar Cane Breeding Station believed to have influenced the regional policy position in the area of plant variety protection. Its director also believed that the costs of becoming a member might have been determining for not engaging a hard obligation of becoming a party to the UPOV Convention, Act 1991.

Second, Private Sector Organization of Jamaica as well as several other actors interviewed had the strong feeling that the preferences of the regional negotiating team, hence CRNM, were most determinative for the negotiating position adopted at the regional level. Third, the technical negotiator on IP mentioned two regional nonstate actors as well as two international civil society groups as having been relevant for the regional policy positions in particular areas of intellectual property protection. In addition, he referred to two external studies, his contact with the European Union negotiator and the negotiating process to have influenced the regional negotiating positions. In other words, domestic non-state actors were hardly perceived as influential on the regional IP negotiating position by any interviewee.

\subsection{ROLE OF CRNM AND THE TECHNICAL NEGOTIATOR ON IP}

As observed in the previous section, Malcolm Spence did not perceive CARIFORUM States' influence on the regional IP negotiating position as determinative. Not only the technical negotiator on IP felt this way. The relatively limited input from CARIFORUM States, compared to regional policy makers, has been noted by various sources. ${ }^{87}$ This is not an unfamiliar result in a regional

$86 \quad$ See section 11.3 of this book.

87 See Bilal and Roza, "Sharing Information: A Survival Tool for EPA Negotiations", p. 4 , for a critical assessment of the negotiation structures in the six ACP groupings. Also interview with Malcolm Spence, 6 April 2010, Bridgetown. Interview with Beverley 
organization: also in the European Union, Member States feel that they have little input on the trade policy of the Union.

The regional negotiators were perceived to have taken the lead role in the determination of regional negotiating positions. ${ }^{88}$ To speak in the words of one interviewee,

"the CRNM was the one that was cooking the soup. They put all the ingredients in the soup, they stirred it and allowed it to get where they wanted it to go." 89

Accordingly, the CRNM team did not merely act as a broker. It was a stakeholder with its own views, which its members also promoted in the technical working group meetings. ${ }^{90}$ If these positions were well argued and backed up with evidence, CARIFORUM States did not have any other option "than coming around to their line of thinking." 91 Also the Jamaican policy maker Michelle Walker from MoFAFT felt that CRNM generated regional policy positions in the area of IP. CRNM staff members advanced their preferred negotiating positions drawn from previous negotiations at the WTO, WIPO and in the internal CARICOM discussions, and then consulted CARIFORUM States on whether this would be acceptable to them. ${ }^{92}$ Overall, the process was felt to have been "CRNM-driven", with the CRNM putting forward a clear agenda. ${ }^{93}$

There are several reasons that can explain the perceived dominance of the CRNM team and in particular of the technical negotiator on IP issues, Malcolm Spence, in the formulation of the regional IP policy position. Three reasons are of outstanding importance: 1) an asymmetrical distribution of knowledge, 2) CRNM's philosophy, and 3) Malcolm Spence's personality and know-how.

\subsubsection{Asymmetrical Distribution of Knowledge}

It was a common acknowledgment by most interviewees that the countries in the CARIFORUM region still lack a solid knowledge on the protection of intellectual property in general as well as in particular for each area of IP. Dianne Daley and Audia Barnett from the Scientific Research Council speak about the lack of a culture of intellectual property protection in the region. ${ }^{94}$ Caribbean actors, including government actors, are still primarily occupied with other trade issues; intellectual

Pereira, 6 April 2010, Kingston. Interview with Junior Lodge, 3 March 2010, Geneva. Phone interview with a senior official from a CARIFORUM State, March 2010. Phone interview with Shantal Munro-Knight, Senior program officer of Caribbean Policy Development Centre, 13 May 2010.

88 Interview with Junior Lodge, 3 March 2010, Geneva.

89 Phone interview with a senior official from a CARIFORUM State, March 2010.

$90 \quad$ Note that it has been explained earlier that CRNM fulfilled three roles during the EPA negotiations: they were part of the EPA negotiating team, they coordinated regional preparatory discussions and they were stakeholders themselves. See section 10.1.3.4 of this chapter.

91 Phone interview with a senior official from a CARIFORUM State, March 2010.

92 Interview with Michelle Walker, 13 April 2010, Kingston.

93 Phone interview with Shantal Munro-Knight, 13 May 2010.

94 Interview with Dianne Daley, 31 March 2010, Kingston. Interview with Audia Barnett, 6 April 2010, Kingston. 
property protection is a new set of rights that has not yet been fully embraced by state and non-state actors in the region. ${ }^{55}$ According to Beverley Pereira, most countries in the region have skills and competencies in trade matters. However, there is an absence of expertise in IP, which has meant that little or no guidance is given to regional negotiators on IP policy or IP negotiating positions. These have to be developed by regional negotiators considered as experts in the field. ${ }^{96}$

While the actors interviewed are predominantly drawn from Jamaican society, the perceived lack of knowledge on IP issues has been noted for the entire region. In fact, the three larger countries Barbados, Jamaica and Trinidad and Tobago have been mentioned by many interviewees as the countries in the region that are most knowledgeable on and interested in IP issues. ${ }^{97}$ The less-advanced countries on IP issues are for example Guyana and Suriname; their understanding of intellectual property issues, supposedly, is even less than that established for Jamaica. With this comparison in mind, the views of Jamaican actors on how limited the knowledge on IP issues is in the region already presents the views of actors from a more advanced society in terms of IP knowledge.

The relative lack of involvement of CARIFORUM States in the area of intellectual property protection is also reflected in the results established in this study on nonstate actors' preferences and influence on national policy makers in the area of IP protection. It has been established that there are only very few non-state actors in Jamaica and the region that are knowledgeable and interested in the issue of intellectual property protection. If non-state actors hardly understand the importance of IP protection and are unable or unwilling to make their preferences known to national policy makers, it is not surprising that state actors also do not possess the information that would inform a detailed policy position on how to regulate the protection of intellectual property internationally. However, the case study has also revealed that Jamaican state actors have stronger preferences and involvement in IP issues dealt with in the EPA than Jamaican non-state actors.

To summarize, in the context of the EPA negotiations, CARIFORUM States were not in a position to give detailed instructions to the negotiating team due to the relative absence of a solid understanding or much experience in the areas of IP protection under negotiation. ${ }^{98}$ CRNM staff, and in particular Malcolm Spence, had to rely on their own judgment as well as other sources of information ${ }^{99}$ in order to devise an IP negotiating position that would be as favourable to the region as possible. ${ }^{100}$ Since this reality is a generally accepted one, most state and non-state

Interview with Peter Goldson, 31 March 2010, Kingston. Interview with Loreen Walker, 31 March 2010, Kingston.

$96 \quad$ Interview with Beverley Pereira, 6 April 2010, Kingston.

97 Interview with Malcolm Spence, 6 April 2010, Bridgetown. Interview with Beverley Pereira, 6 April 2010, Kingston. Interview with Loreen Walker, 31 March 2010, Kingston. Interview with Junior Lodge, 3 March 2010, Geneva. Phone interview with a senior official from a CARIFORUM State, March 2010.

98 Interview with Loreen Walker, 31 March 2010, Kingston. Interview with Beverley Pereira, 6 April 2010, Kingston.

$99 \quad$ See section 11.3.3 on the contacts Malcolm Spence established.

100 Interview with Omar Chedda, 12 April 2010, Kingston. 
actors in Jamaica felt at ease with the fact that the approach suggested by the experts in the field has mostly been transferred into the regional negotiating position. ${ }^{101}$

\subsubsection{CRNM's Philosophy}

According to Junior Lodge from CRNM,

"CRNM consists of highly opiniated trade negotiators who have a view of the world and how the Caribbean fits into this world as well as of what is required to achieve this [state]." 102

CRNM did not merely coordinate the technical EPA negotiations in the various areas of trade, including intellectual property protection. Their role was threefold: 1) as part of the EPA College of Negotiators, they conducted technical negotiations; 2) CRNM coordinated the formulation of the negotiating positions in the technical working groups; and 3) they were stakeholders themselves with their own view. As Junior Lodge asserts, CRNM had a philosophy in which its staff members strongly believed and which they were willing to embrace as much as possible during the EPA negotiations. ${ }^{103} \mathrm{He}$ also stated that in fact this philosophy was highly influential on the regional negotiating position finally adopted by the region.

In a nutshell, CRNM staff members were convinced that the Caribbean countries, a region that consists of small developing countries, needs to engage in economic reform in order to foment more trade. Since they felt that this economic reform would not be homegrown, they believed that the region would do well in committing themselves to certain reforms and timelines through international trade agreements. The reforms that they envisaged can probably best be described as market-friendly reforms. ${ }^{104}$ While Caribbean countries were averse to binding themselves internationally through trade agreements, CRNM welcomed the opportunity of the EPA negotiations. This motivation for accepting certain obligations in bilateral trade agreements is also known as the "lock-in domestic reform" strategy. ${ }^{105}$ They included areas where the Caribbean did not yet have capacity, for example in the area of innovation and intellectual property protection. ${ }^{106}$ In Junior Lodge's view, being experts in the various areas of trade and civil servants who are free to express their views independently from political agendas of the Member States, CRNM staff

101 Phone interview with a senior official from a CARIFORUM State, March 2010. Interview with Dianne Daley, 31 March 2010, Kingston. Interview with Stacian Bennett, 7 April 2010, Kingston. Interview with Omar Chedda, 12 April 2010, Kingston. Interview with Audia Barnett, 6 April 2010, Kingston. Interview with Karl Hyatt, 29 March 2010, Kingston (available on request). Interview with Junior Lodge, 3 March 2010, Geneva.

Ibid.

Email correspondence with Norman Girvan, 22 April 2010.

See C. Damro, "The Political Economy of Regional Trade Agreements" in L. Bartels and F. Ortino (eds.), Regional Trade Agreements and the WTO Legal System (Oxford University Press, Oxford, 2006), 23-42, p. 36 ff.

Beverley Pereira confirms that in her view, CRNM staff used the opportunity of the EPA negotiations to advance the regional integration process, which in the area of intellectual property protection is not yet at an advanced stage yet. Interview with Beverley Pereira, 6 April 2010, Kingston. 
members were in a position to communicate their views clearly and try to obtain an outcome in the EPA negotiations that would meet their objectives. ${ }^{107}$

In brief, CRNM staff strongly believed in the philosophy that economic reform can be enhanced by concluding international trade agreements. Bearing the asymmetrical information distribution in mind, CRNM was able to achieve a regional negotiating position that was driven by that philosophy.

\subsubsection{Malcolm Spence}

As stated above, ${ }^{108}$ the technical negotiator for intellectual property protection, Malcolm Spence, was named by important interviewees as having been crucial to the formulation of the regional negotiating position. ${ }^{109}$ According to Junior Lodge, the combination of Malcolm Spence's personality and his technical know-how made him the strongest factor in the regional policy-making process: there are very few experts on intellectual property issues in the region that could have challenged him. ${ }^{110}$ Also the European Union negotiator on IP issues perceived Malcolm Spence to be a very active counterpart who has contributed to the final IP chapter about fifty percent. ${ }^{111}$ CARIFORUM States were confident in his ability to meet the European Union "head to head on all aspects of IP." 112

Malcolm Spence is from Trinidad and Tobago. He has been educated as a patent examiner and agricultural engineer in the United Kingdom. He has worked as national counterpart consultant for industrial property, in particular patent protection, to the World Intellectual Property Organization. Through the relationship with WIPO, he received several trainings of six weeks in the British, Swedish, German and Canadian patent offices and by WIPO. He was then involved in establishing the Trinidad and Tobago Intellectual Property Office and system. As an employee of the Trinidad and Tobago IP Office, he already participated in the FTAA negotiations. In 2001, he started to work for CRNM. Malcolm Spence is one of the few Caribbean nationals that has a strong background in various areas of intellectual property protection who has been trained in Europe, Canada and by WIPO, and who has gained much experience in negotiating the FTAA with the countries in the broader region of the Americas.

It is clear that Malcolm Spence's background has helped him in many ways to carry out the intellectual property negotiations in the EPA as well as coordinating the regional policy-making process in this area. Being aware of the limitations of the region in terms of knowledge of IP issues as well as the limited response by non-state actors through national consultative processes, Malcolm Spence often resorted to personal contacts. These involved contacts with local enterprises, IP administrators,

107 Interview with Junior Lodge, 3 March 2010, Geneva.

108 See section 11.2.2 of this book.

109 Interview with Michelle Walker, 13 April 2010, Kingston.

110 Interview with Junior Lodge, 3 March 2010, Geneva. Also the senior official from a CARIFORUM State confirmed his expert knowledge in the area. Interview in March 2010.

111 Interview with a member of the European Union negotiating team, 18 March 2010, Brussels (available on request).

112 Phone interview with a senior official from a CARIFORUM State, March 2010. 
the Copyright Music Organisation of Trinidad \& Tobago, etc. ${ }^{113} \mathrm{He}$ was also in contact with international civil society organizations, such as Quaker United Nations Office and Center of International Environmental Law, which advised him on certain issues under discussion in the EPA negotiations on IP. Another important line of communication of the CRNM was the contact with European Union negotiators. ${ }^{114}$ Overall, Malcolm Spence was able to benefit from his personal contacts in order to help inform the regional policy-making process.

\subsection{CONCLUSIONS}

This section has addressed the question as to whether or not the identified non-state actors had some influence on the final IP policy position adopted by Jamaica and the CARIFORUM region by participating in the consultative processes. First, the regional negotiating positions and the Jamaican policy positions in the various areas of IP protection were defined. Second, the influence of the non-state actors was assessed by using three methods: 1) the policy tracing of the non-state actors' involvement in the consultative processes; 2) a comparison of their preferences with the regional and national policy positions in the various areas of IP; and 3) the self and peer assessment by non-state actors of their own influence on the policy positions as well as an assessment of the most influential actor or factor. Third, the role of CRNM and in particular that of the technical negotiator on IP, Malcolm Spence, have been highlighted specifically due to their important role in the determination of the regional negotiating position.

Overall, the Jamaican policy positions in the different fields of intellectual property protection are reflected in the negotiating positions adopted by the region. Concerning the general objectives, Jamaica had formulated mainly the same objectives as the region. The objectives in specific areas of intellectual property protection coincided particularly in the area of geographical indications. In the field of plant variety protection, the regional and national policy positions were not identical.

In terms of policy-tracing, it has been determined that five non-state actors (Dianne Daley, Private Sector Organization Jamaica, Jamaica Chamber of Commerce, Competitiveness Company and Jamaica Standard Products Company) were involved in national consultative processes and one regional non-state actor (West Indies Central Sugar Cane Breeding Station) in a regional workshop on plant variety protection in 1998. Out of the six actors, only two had specific preferences on the international regulation of IP protection through bilateral or multilateral agreements. These actors were WICSCBS and Dianne Daley. Dianne Daley was the only actor out of the six who participated in the specific national IP consultations, which were most determinative for Jamaica's policy position on IP matters.

113 Interview with Malcolm Spence, 6 April 2010, Bridgetown.

114 See CRNM, CRNM Note on CARIFORUM Economic Partnership Agreement: What Europe is Offering Africa: the Pros and Cons of EPAs (Overseas Development Institute, London, 2008), available at <http://www.odi.org.uk/events/docs/1974.pdf> accessed on 11.01.2012. 
The assessment of whether non-state actors attained their preferences established that WICSCBS preferences on plant variety protection clearly coincided with those of the regional negotiator for IP. It can be concluded that WICSCBS attained its preferences. Dianne Daley's preferences were partly the same as the objectives of the national and regional policy makers. However, her preferences were not so similar to the relevant policy makers' positions as to allow for the conclusion that she has attained her preferences by her own involvement. With regard to the other four organizations, only Private Sector Organization of Jamaica and Jamaica Standard Products Company attained their preferences when compared to the national and regional policy positions on IP matters in the EPA negotiations. However, it is doubtful whether this attainment has in fact been caused by their involvement in the consultative mechanisms.

The actors' assessment has not provided a clear-cut answer as to which actors or factors were most determining for the national and regional policy positions in the different areas of IP. Concerning the influence on the regional negotiating position, WICSCBS believed that it has influenced the regional position on plant variety protection during the EPA negotiation. However, Anthony Kennedy thought that the costs of joining the UPOV Convention, Act 1991 would have been determinative for the final regional policy position on plant variety protection. As to the influence on the Jamaican policy positions, Dianne Daley, as the only national non-state actor, assessed her influence on the Jamaican policy maker as having been important. According to her, the most influential factor, however, in the Jamaican policy-making process was a positive cost-benefit analysis made by Jamaica Intellectual Property Office. The conclusions for the influence on the regional negotiating positions are rather different. Several actors interviewed had the strong feeling that the preferences of the regional negotiating team, hence CRNM, were most determinative on the negotiating position adopted at the regional level.

When reading the three methods together, it becomes evident that non-state actors in general were not determinative for the IP policy position chosen by Jamaican and regional policy makers. Most influence on the regional policy maker could be attributed to WICSCBS with regard to the policy position on the protection of plant varieties. Apart from that, even Dianne Daley, who had specific preferences on IP issues and was actively involved in the specific consultations on IP, did not have a significant influence on the regional negotiating position on IP. Although she was successful in voicing her concerns with regard to accepting commitments in the areas of patent and trade mark protection to the Jamaican policy makers, the final negotiating position taken by the regional negotiator was not influenced by Jamaica's or her own interventions but by other CARIFORUM States.

Instead of regional and national non-state actors, it was the regional negotiating team that was perceived by non-state actors to have taken the lead role in the determination of the regional negotiating positions. Three explanations were put forward to clarify their crucial role. First, CARIFORUM States were not in a position to give detailed instructions to the negotiating team due to the relative absence of a solid understanding in the areas of IP protection under negotiation. Second, CRNM staff adhered to the philosophy that economic reform can be enhanced by concluding international trade agreements. This philosophy informed their thinking and activities. Bearing the asymmetrical information distribution in mind and even 
though CARIFORUM States did not always want to commit to reforms, CRNM was able to achieve a regional negotiating position that was driven by that philosophy. Third, the combination of Malcolm Spence's personality and his technical know-how made him the strongest factor in the regional policy-making process on determining the final negotiating positions in the various areas of intellectual property protection. 


\section{Chapter 12 : Main Findings and Conclusions}

The study on the influence of non-state actors in the Caribbean and in particular in Jamaica on the national and regional policy-making process in the area of IP protection during the EPA negotiations has provided important results.

\subsection{MAIN FINDINGS}

The most significant conclusion is the importance of the regional negotiating team CRNM and in particular of the technical negotiator on IP, Malcolm Spence, for the regional negotiating position on IP in the EPA negotiations. Three factors were instrumental for CRNM's dominant position in the determination of the regional negotiating position in IP: CRNM's anchorage in regional policy-making forums (as discussed in section 10.1.3), an asymmetry of knowledge between CRNM and CARIFORUM States (as discussed in section 0) and the personality and technical know-how of Malcolm Spence (as discussed in section 11.3).

First, CRNM fulfilled several roles in the process of formulating the regional negotiating position as well as negotiating with the European Union. CRNM was instrumental for the technical input that informed the regional negotiating positions and in setting up regional consultations, in particular with regional industry and businesses from the entire region. In addition, CRNM coordinated the technical working group meetings in which the negotiating positions were actually formulated. Finally, it was also dominantly represented in the EPA College of Negotiators, which carried out the technical negotiations with the European Union. In particular, the CRNM staff member Malcolm Spence was in charge of the technical negotiations in the area of IP.

Second, CRNM assembled regional experts in the various fields of trade. Their knowledge in the respective areas was of such an expert level that national policy makers in the CARIFORUM States were hardly in a position to propose and defend alternative choices for the trade aspects under negotiation. In the regional technical working groups, therefore, CRNM staff has dominated the process due to their relative supremacy in knowledge on the issues under discussion. They were able to achieve a regional negotiating position that was strongly influenced by their arguably market-friendly philosophy.

Third, Malcolm Spence was able to convince most CARIFORUM States of his views on the different subjects of IP protection due to his personality, eloquence and know-how. He institutionalized collegial discussions with national policy makers and stakeholders, in which he was able to steer the outcome by providing convincing arguments, evidence and concrete examples. Combined with a clear view of what reforms were necessary for the region to prosper, he became a crucial factor for the final regional policy positions on IP issues.

The strong influence of CRNM, and in particular of Malcolm Spence, on the regional IP policy positions was facilitated by the limited involvement of national and regional non-state actors. The research has shown that only very few non-state actors have an interest in the international protection of intellectual property matters, the reason being that they lack the necessary knowledge and prioritize other trade issues above IP protection. As a consequence, only three out of twelve non-state actors were 
identified to have specific interests in the regulation of intellectual property in the EPA. Out of those three actors, merely one also participated in national consultations that addressed IP protection in detail. As a consequence of these results, the influence of non-state actors on the national and regional policy-making process was very low; at most two non-state actors can be concluded to have (partially) influenced Jamaica's and the region's IP policy position in the EPA negotiations.

Where state actors hardly receive any information on non-state actors' preferences with regard to the regulation of intellectual property matters, a vacuum of policy preferences is left. Such a vacuum could have been filled by state actors. This has only rarely happened in the case of Jamaica. Also Jamaican policy makers' knowledge and experience in all matters of intellectual property protection was found to be limited. The vacuum left enough space for the regional negotiating team to fill the gaps with their own expertise, experience and beliefs. However, in the areas of IP protection in which the regional negotiating team also lacked strong policy preferences, the European negotiators were able to insist on their preferred level of protection. One example is the area of enforcement of IP rights, which did not reflect offensive interests of the CARIFORUM region but was a priority for the European Union.

These results show that the case study of Jamaica is an example of a substantial disconnect between the technical experts who carried out the IP negotiations on the EPA on the one hand and national non-state actors as well as policy makers of CARIFORUM States on the other hand. Not only is there a disconnect between the persons involved; also the issues of IP protection dealt with in international trade negotiations are far removed from the reality in CARIFORUM States. Jamaican nonstate actors, and to a lesser extent national state actors too, are not aware of many issues that have been negotiated as part of the IP chapter in the EPA. It must therefore be concluded that the IP chapter in the EPA does not reflect the preferences of non-state actors in the region, who had rather undefined preferences. This generalization from Jamaica to the region is valid since Jamaican non-state actors are known to be one of the most advanced in terms of awareness and involvement with IP issues compared to the non-state actors in other CARIFORUM States.

Because of this disconnect between the content of the IP chapter and the IP knowledge of non-state actors, the implementation of the obligations of the EPA is already causing and will cause serious problems. Very little has been done by Jamaica so far in terms of implementing laws in the area of IP. When they do so, it is of eminent importance that the obligations are carefully translated into meaningful legislation that takes national specificities into account. An example is the enforcement provisions of the IP chapter in the EPA which, if not countered by checks and balances, can shift the balance of rights and obligations towards the advantage of IP right holders and to the disadvantage of users of IP, as illustrated in Chapter 5: Legal analysis of the CARIFORUM-EC Economic Partnership Agreement. In order to draft useful legislation, relevant policy makers need to be trained on the obligations in the final IP chapter of the CARIFORUM-EC EPA as well as on the policy space that they leave for national choices. 


\subsection{LIMITATIONS}

This research aimed at establishing how much influence various non-state actors at the regional and national level had on relevant policy makers. While it was possible to present results as to 1) the identity of non-state actors with an interest in IP regulation in general and in particular in the context of the EPA negotiations, 2) their specific preferences in IP regulation in the EPA, and 3) their involvement in different consultative processes, it was hardly possible to assess the influence of more than five non-state actors due to certain limitations.

The most important inhibiting factor was the fact that only very few non-state actors with some interest in the regulation of IP in general, and in particular in the context of the EPA negotiations, could be identified. While the methodological problem of establishing contact with non-state actors certainly played a role in this outcome, it became clear that there is a lack of interested non-state actors. Due to this lack of actors, it was not possible to carry out an analysis that would involve the definition of different coalitions with competing preferences.

The second inhibiting factor addresses the knowledge on IP issues present among non-state actors in the Caribbean region. Very few non-state actors have specific preferences on the regulation of intellectual property in general; even less have preferences with regard to the international regulation of IP through trade agreements and a preference for the forum in which IP negotiations should take place. Many questions that I aimed to discuss with non-state actors went beyond their understanding of the regulation of intellectual property.

The third inhibiting factor regarded the consultations that addressed IP matters dealt with in the EPA negotiations. Only very few national and regional consultations were concerned with the issue of intellectual property protection in the EPA. Merely one national forum of consultations, the specific consultations on IP, discussed draft texts of the IP issues under negotiations in detail. These consultations involved a relatively small number of non-state actors, which made it difficult to retrieve concrete information on the number of meetings, their agenda and the roles played by the participating actors.

Due to the limited knowledge on IP issues and international developments, Jamaican and regional non-state actors were hardly in a position to state their preference regarding the forum where international IP negotiations should take place. Only the preferences of three non-state actors could be compared to those of the regional and national policy makers since the other actors did not formulate a preference. It was therefore not possible to have a meaningful discussion of whether such preferences were reflected in the final regional and national policy positions on IP.

\subsection{THEORETICAL IMPLICATIONS}

This study also aimed at providing insights into some theoretical questions developed from the collective action logic, the two-level game logic, negotiation theory and the choice of forum framework. Two hypotheses have been formulated; their applicability for the case of Jamaica and the CARIFORUM region is addressed first. In addition, this section also sheds some light on whether the conclusions forwarded 
by Ann Capling and Patrick Low on the issue of forum choice hold true for the Jamaican/ CARIFORUM case.

\subsubsection{First Hypothesis}

The first hypothesis reads as follows: The size of groups and the intensity of their preferences determine whether their preferences are reflected in the outcome. Due to the limitations analyzed above, the actors and groups analyzed have been very few. Any attempt to provide an answer to the question as to whether this hypothesis is true for the analyzed case must be done with a lot of caution since it is based only on a very small number of groups.

Bearing this caution in mind, the information gathered provided a number of interesting findings. First, on the variable group size, the six non-state actors for whom preference attainment was analyzed were two large organizations, one small organization and three individual actors. Out of these six actors, the two actors who were assessed as having been (partially) influential on the national and regional IP policy position were the small organization West Indies Central Sugar Cane Breeding Station and the individual actor Dianne Daley. It has been concluded that even though Private Sector Organization Jamaica and Jamaica Standard Products Company did attain their preferences, their own assessment and other factors indicated that their preference attainment can probably not be explained by influence that has taken place.

Second, on the variable intensity of preferences, out of the six non-state actors under examination, three actors (WICSCBS, Competitiveness Company, Dianne Daley) had specific interests and three actors (Private Sector Organization Jamaica, Jamaica Chamber of Commerce, Jamaica Standard Products Company) had general interests. The actors that were assessed to have (partially) influenced the national and regional IP policy positions were two actors with specific interests, being WICSCBS and Dianne Daley. ${ }^{1}$

These results allow for the following conclusions in relation to the first hypothesis. First, the two non-state actors that were found to have attained their preferences as a consequence of influence were a small organization and an individual non-state actor, both with specific preferences. The first sub-hypothesis, which stated that small groups with concentrated interests are likely to see their preferences reflected in the outcome, seems to hold true for the Jamaica and CARIFORUM region case study. Second, the small organization with diffuse (general) interests Jamaica Standard Products Company was assessed as not having attained its preferences. This is in accordance with the second sub-hypothesis: small groups with diffuse interests are not likely to see their preferences reflected in the outcome. Third, no organization was identified in the Jamaica case study that had a large group size and at the same time specific interests. Therefore, the validity of the third hypothesis (Large groups with concentrated interests are not likely to see their preferences reflected in the outcome) could not be tested. Fourth, two organizations with a large

1 It has been concluded that even though Private Sector Organization Jamaica and Jamaica Standard Products Company did attain their preferences, their own assessment and other factors indicated that their preference attainment can probably not be explained by influence that has taken place. 
group size and diffuse (general) interests did not attain their interests. This finding is in accordance with the fourth sub-hypothesis that large groups with diffuse interests are not likely to see their preferences reflected in the outcome.

\subsubsection{Second Hypothesis}

While the results for the first hypothesis have to be evaluated with some caution due to the low number of actors analyzed, the data collected in the case study was enough to examine the second hypothesis. The size of the domestic win-set determines the negotiating autonomy of the negotiator. In particular, and as elaborated in the two sub-hypotheses, negotiators with a small domestic win-set have only little negotiating autonomy, whereas negotiators with a large domestic win-set have large negotiating autonomy.

The case study of Jamaica and the CARIFORUM region has provided an example of a large domestic win-set. It has been defined ${ }^{2}$ that a domestic win-set is large if there are only a few (conflicting) preferences of relevant non-state actors and their preferences are mostly general or marginal. The analysis of non-state actors' preferences on IP protection in the EPA has provided a clear picture: first, there were only very few non-state actors that had an interest in intellectual property issues regulated through the EPA; second, out of the twelve identified actors, only five had specific interests in various fields of IP protection relevant to food products. These interests mostly did not conflict with each other.

On the degree of negotiating autonomy, the study has also provided an unambiguous result. According to the factors that have been developed earlier to indicate a large or small degree of negotiating autonomy, ${ }^{3}$ the autonomy of the negotiator is large if clear negotiating mandates for some areas of IP are lacking, if the negotiating team had an important role in developing the regional policy position and little control was exerted on the negotiator. In the case study, it has been argued that the role of the negotiator and the negotiating team has been crucial to the development of the regional policy position in many areas of intellectual property protection. In short, the reasons forwarded included a lack of non-state actors' preferences on IP issues, a strong reliance on the expertise of the negotiating team in all stages of the policymaking process, an asymmetry of knowledge between the experts in the negotiating team and CARIFORUM officials, and a strong personality of the technical negotiator for IP issues. These insights unequivocally support the finding that the negotiator for IP issues had a large negotiating autonomy.

These results allow us to draw certain conclusions in relation to the second hypothesis, and in particular to the second sub-hypothesis, which deals with large domestic win-sets. The case study of Jamaica and the CARIFORUM region validates the second sub-hypothesis: negotiators with a large domestic win-set also have a large degree of negotiating power. Since no example of a small domestic win-set was assessed, I cannot provide any conclusion on whether negotiators with a small domestic win-set have a small degree of negotiating power.

$2 \quad$ See section 8.3.2.2.1 of this book.

3 See section 8.3.2.2.2 of this book. 


\subsubsection{Forum Choice}

Another aim of this study was to provide some results on the question as to which forum non-state actors prefer for the regulation of international intellectual property issues. Ann Capling and Patrick Low ${ }^{4}$ have provided the following rule: in a systemic sense, the WTO is a better option than preferential trade agreements. It is more protective of developing country interests, especially when it comes to preferential trade agreements involving a developed country.

Also in Jamaica and the CARIFORUM region, more non-state actors favoured the multilateral venue of negotiating intellectual property protection over the bilateral. However, no common explanation was given that could clarify this preference; the more protective nature of the multilateral forum for developing countries' interests was not mentioned by any interviewee as such. Rather, three non-state actors (out of six who stated a preference for a forum) explained that the leverage of a country like Jamaica or the CARIFORUM region would be higher at the multilateral forum than in bilateral negotiations.

Another important result of the case study was that the preference of the CARIFORUM region to engage in negotiations on intellectual property matters in the bilateral negotiations of the EPA was not derived from the preferences of nonstate actors, which hardly had a preference at all. It was rather the beliefs and philosophy followed by the negotiating team as well as the context of the international negotiations that induced the region to engage in bilateral negotiations on intellectual property matters.

$4 \quad$ They are the authors of the book Capling and Low (eds.), Governments, Non-State Actors and Trade Policy-Making. 


\section{PART E: CONCLUSIONS AND SUMMARY}





\section{Chapter 13 : Conclusions and Summary}

\subsection{The International System of Intellectual Property Protection PRE-TRIPS}

At the starting point of this research was the recent proliferation of bilateral trade agreements that include intellectual property protection beyond the level agreed upon in the TRIPS Agreement. This phenomenon has occurred since the entering into force of the TRIPS Agreement on 1 January 1995. While the coverage and scope of the chapters addressing IP protection contained in recent BTAs is exceptional, the existence of bilateral trade agreements regulating the international protection of intellectual property is not.

Already prior to the entering into force of the TRIPS Agreement, the international system of intellectual property protection has been marked by alternating phases of bilateral, multilateral and unilateral regulation of intellectual property matters. The first form of international protection of intellectual property was a comprehensive network of bilateral copyright conventions among European and Latin American countries. Also in the field of industrial property, European states started cooperating internationally through bilateral treaties. However, due to a lack of uniformity, these bilateral treaties were complemented by multilateral pillars. The Paris Convention and the Berne Convention marked the first multilateral phase. Many further multilateral initiatives took place in the framework of the Secretariat administering the Paris and Berne Conventions, and later within the context of the World Intellectual Property Organization. The IP-reliant industries in the United States and in European states, however, were not satisfied with the still fragmented international system of IP protection. They started using bilateral investment treaties and unilateral legislation, such as the different forms of the Section 301 process, to achieve a higher level of intellectual property in other countries. Overall, the international system of IP protection shows a dialectic development, in which bilateral phases of protection are followed by multilateral phases and the other way around.

The alternating phases of bilateral, multilateral and unilateral protection of intellectual property reveal a process of forum shifting. When dissatisfaction with existing forms of international IP regulation increased, certain members addressed other regulating forums, where the institutional structures or membership seemed to be more favourable for dealing with IP protection. The TRIPS Agreement itself has become one of the most important examples of the successful use of the strategy of forum shifting. The United States and European states, together with the support of Japan, have promoted the incorporation of IP regulation into the framework of the then GATT 1947, which on 1 January 1995 became the World Trade Organization. These countries perceived the strong trade framework to have clear advantages compared with the enforcement mechanisms in place at WIPO and the fragmented approach of bilateral investment treaties concluded between several countries.

The TRIPS Agreement reached an unprecedented scope of substantive intellectual property protection, membership and level of enforcement. It addresses principles and objectives of intellectual property protection, the protection for the individual areas copyright, trade marks, geographical indications, industrial designs, patents, layout-designs of integrated circuits and undisclosed information, dispute settlement 
provisions, enforcement measures, transitional periods and rules on the transfer of technology. Certainly due to the significant commitments made by developing countries during the long and controversial negotiations, there was an expectation by developing countries that the TRIPS standard would remain the main international standard for the protection of intellectual property, with which the majority of trading nations has to comply. However, immediately after the conclusion of this significant agreement, a new bilateral phase was started by the United States, and with some time lag followed by the European Union, to conclude bilateral trade agreements that go beyond the level of protection agreed upon in the TRIPS Agreement.

\subsection{The International System of Intellectual Property ProteCtion POST-TRIPS}

Since the establishment of the TRIPS Agreement, bilateral trade agreements concluded by the main actors United States, the European Union, the European Free Trade Association and Japan have been especially successful in setting TRIPS-plus provisions. This is particularly so when compared with the setting of TRIPS-plus norms at the multilateral and the plurilateral level. Except for the WIPO Copyright Treaty and the WIPO Performers and Phonograms Treaty, few successful multilateral or plurilateral treaties have been concluded that address the protection and/or enforcement of intellectual property rights. Among the major actors that conclude bilateral TRIPS-plus norms, the United States is by far the most aggressive actor. Not only the content of the IP chapter in its free trade agreements, but also its style of conducting negotiations and the legal approach used for the IP chapter are not comparable with the approach of any of the other major actors.

The IP chapter contained in US FTAs sets out the highest international standards of IP protection in almost all areas of IP covered by the TRIPS Agreement, no other international agreement, not even the plurilateral Anti-Counterfeiting Trade Agreement or the multilateral WIPO Internet Treaties, reach this standard. An exception is the area of geographical indications, in which the European Union sets the highest standards. US FTAs, and in particular the protection for patents and copyright agreed upon, have been critizised of severely impacting the availability and affordability of generic medicines and the legal access of users to digital works. The provisions on data exclusivity, extension of the patent term and the restrictions on compulsory licenses prevent competitive drug pricing and the affordability of essential medicines for citizens of developing countries. The protection of technological protection measures and rights management information, as well as the specific enforcement measures required, do not only impede non-infringing use of digital works but also affect a country's capacity to spend their (scarce) resources on the enforcement of law in general.

What also makes the United States an aggressive actor in negotiations on intellectual property protection is the way in which they negotiate. IP standards are negotiated in secrecy, outside of pre-established institutional structures and without a possibility for obtaining advice from third parties. If negotiations take place outside of institutional structures, rules on a balanced involvement of interest groups or transparency considerations are lacking. If certain non-state actors are prevented from making their concerns known, they cannot influence outcomes during the 
negotiations. Many actors even lack the necessary information on the content of the FTA, which is kept secret until the agreement is signed. Furthermore, the United States employs a clear value-claiming strategy: it pressures its (developing) negotiating partners to accept high standards of IP protection and enforcement in exchange for rules on access to US markets of, for example, textiles and agriculture, which constitute absolute priorities for many developing countries.

Moreover, the legal approach employed by the United States contains strong aggressive elements. The IP chapter in US FTAs is based on a model IP chapter, which in itself is derived from domestic legislation. In other words, (developing) negotiating partners are asked to provide for the exact same standards of protection as set out in US law. Such legal transplants create severe problems when they need to be implemented in a different legal system. Balancing provisions provided for in US competition or privacy laws may not exist in the partner countries' legal system. Furthermore, no agreement deviates from the standard of protection obtained in other free trade agreements; the protection is even scaled up in more recent agreements. Finally, the United States even preserves itself a say on how the implementing laws of the partner country should look. Through the "certification" process, the executive branch determines whether the laws are satisfactory before the FTA will enter into force.

Compared with the linear US approach that has been aggressive since the beginning, the European Union's approach has changed considerably during the last decennium. Before 2006, only a few provisions on intellectual property protection were taken up in bilateral trade agreements, which reflect a modest level of IP protection. They refer to standards of protection indirectly, by setting out a list of multilateral agreements, with which negotiating partners need to comply or accede to. In pre-2006 bilateral agreements, trading partners are required to adhere to merely very few TRIPS-plus provisions, such as the protection of databases and utility models, and the requirement to accede to the WCT, the WPPT and the UPOV Convention, Act 1991. One important exception are the agreements on trade in wine and spirits, which seek to protect geographical indications beyond the level set out in the TRIPS Agreement.

With the launch of the "Global Europe" strategy in 2006, the European Union's approach towards protecting intellectual property protection in third countries has shifted from a soft to a tough approach. The IP protection required in recent European bilateral trade agreements is similarly strong as that set out in US FTAs, even though in different areas and through different standards. Hence, the United States is not the only TRIPS-plus demandeur anymore; the European Union has followed suit.

Having concluded that the international development of intellectual property protection has been dialectic and that bilateral phases have been followed by multilateral ones and vice versa, it could be argued that the most recent phase of bilateral trade agreements fits well in this development. However, there are at least two reasons why I suggest that the latest phase of bilateral agreements is exceptional and will most probably not be followed by a multilateral phase. First, the standards contained in recent BTAs are not coherent; the major actors have developed different TRIPS-plus provisions, which in certain cases even conflict with each other. Finding a multilateral solution that accommodates the conflicting approaches of the 
major actors seems very difficult. Second, the geographical extent and the material scope of the bilateral agreements suggest that major trading nations have a preference for quick and tailor-made commitments, and that they are not willing to compromise on one multilateral approach. While plurilateral agreements could still serve countries' needs, multilateral agreements seem to become ever more difficult to be concluded.

\subsection{The EU'S INTELLECTUAL PROPERTy POLICY TOWARDS THIRD COUNTRIES}

Mainly two strategies have initiated a shift with regard to the intellectual property protection sought by the European Union in third countries, both on a policy level as well as in practice. These are the "Enforcement Strategy in Third Countries" published in November 2004 and the "Global Europe: competing in the world" strategy launched in October 2006. The new trade policy described therein presents the external agenda of the Lisbon Strategy, according to which Europe should become the most competitive and dynamic knowledge-based economy in the world. The two policy documents paved the way for a new generation of competitivenessdriven free trade agreements as an important cornerstone of the EU's new external trade policy. They set out standards of protection that go beyond current WTO disciplines. Intellectual property protection became a centerpiece of these agreements. The sole or primary focus on the multilateral forum, the WTO, has been abandoned.

Intellectual property protection in third countries is now sought through detailed obligations in bilateral trade agreements, which often go beyond the level of protection set in the TRIPS Agreement and equal the level of protection contained in European Union legislation. Even though the strategy "Global Europe" differentiates in its policy document between emerging economies on the one hand and developing countries on the other hand, the countries involved in recent agreements and the provisions proposed to them and agreed upon do not reflect a distinction. The recent agreements concluded with South Korea, CARIFORUM States, Colombia and Peru, and Central American countries, and the proposals made to Canada and India, are all based on the same model IP chapter, with minor differences. The proposed provisions have not been adapted according to the level of development of the partner countries. Where there are differences in the final agreements, they are mostly the result of the trading partners' interests and bargaining power. Therefore, development concerns are not a priority when concluding "new generation" FTAs; their importance has decreased considerably compared to the agreements concluded before 2006, under the trade policy "managed globalization". Next to launichng a number of initiatives to the benefit of developing countries, "managed globalization" also adapted the IP obligations included in agreements to the level of development of their partners.

The detailed legal analysis of the CARIFORUM-EC EPA and the draft IP chapter of the India-EU BTLA have confirmed the existence of the defining elements of the new approach adopted by the European Union since the launch of the "Global Europe" Strategy: many IP provisions in the EPA and the BTIA as proposed by the European Union 1) contain important TRIPS-plus features, 2) are often based on EU internal legislation, and 3) provide little space to balance domestic interests in the implementation process or to take development concerns into account. The areas of IP protection where these features are most dominant are the protection of copyright 
in a digital environment, trade marks and geographical indications. Also the protection of designs and enforcement measures reflect a tough approach; however, the draft IP chapter of the India-EU BTLA will (most probably) contain less TRIPSplus elements in those areas than the CARIFORUM-EC EPA due to a strong bargaining power of India.

The CARIFORUM-EC EPA is the first agreement in which features of the European Union's "new generation" FTAs are included in the chapter on intellectual property protection. Already the scope of the chapter is much more extensive than previous agreements: thirty-four articles deal with innovation and intellectual property. Compared with only one or two provisions in "old generation" agreements, this is a considerable increase. The detailed IP provisions set out TRIPS-plus standards with regard to the protection of digital works, geographical indications, design rights and patents, and importantly enforcement provisions. The enforcement section is without doubt the most far-reaching part of the chapter. The provisions equal the level of protection set out in EU internal legislation and US FTas. They go beyond the TRIPS Agreement in three ways: 1) by enlarging the scope of rights or the beneficiaries to the rights; 2) by setting out in greater detail what a right entails; and 3) by omitting important TRIPS safeguards and flexibilities.

Also the draft IP chapter of the India-EU BTLA will be very extensive, according to the European Union's proposal. The EU has suggested TRIPS-plus provisions in several areas, such as the protection of copyright, trade marks, geographical indications, design rights, undisclosed data, provisional and precautionary measures and border measures. If India accepts many of these proposals, the agreement will not leave much space to take into account development concerns when implementing the provisions of the agreement. Legislation-like provisions and the hard obligations to comply with international agreements (compared with many best endeavour obligations in the CARIFORUM-EC EPA) considerably reduce the policy space to balance domestic interests. However, India has already convinced the European Union to accept the TRIPS standard for many enforcement provisions and the provision on plant variety protection.

While the highlighted IP provisions provide much evidence of the new approach of the European Union, both agreements analyzed also reflect important interests of the EU's trading partners. CARIFORUM States and India were able to preserve considerable domestic policy space to take development concerns into account. In both agreements, the provisions on the link between innovation and intellectual property, transfer of technology, patent protection (if India succeeds in limiting the data exclusivity protection), the protection of plant variety protection, and the protection of genetic resources and traditional knowledge (if the EU accepts the provisions suggested by India) contain few TRIPS-plus features and are not based on internal EU legislation. Rather than concluding that the European Union's new approach does not apply in these areas, I argue that these areas of IP protection were 1) not introduced by the European Union but by the other negotiating party, or 2) the trading partners have been particularly successful in adapting the proposals made by the European Union. In brief, the proposals made by the EU still reflect the new tough approach of the European Union. 
The protection identified in the CARIFORUM-EC EPA and in the draft IP chapter of the India-EU BTLA has importantly indicated that the outcome in these agreements is also a consequence of the bargaining power a country has vis-à-vis the European Union. The extent to which the European Union is willing to make concessions in various areas strongly depends on the bargaining power of its negotiating partner. The bargaining power of CARIFORUM States, for example, must have been especially strong with regard to the unprecedented link made between innovation and intellectual property protection, the concrete commitments concerning the transfer of technology, the protection of plant varieties, genetic resources and traditional knowledge. It is more difficult to make inferences about the bargaining power of India because the final provisions of the IP chapter of the IndiaEU BTLA are not yet agreed upon. Nevertheless, India has already shown to have a relatively strong bargaining power in the same areas in which also CARIFORUM States could preserve enough policy space to take development concerns into account; in addition, its bargaining power might be even stronger in the area of design protection and, most importantly, with regard to several enforcement measures.

Overall, the conditions under which developing country partners nowadays have to negotiate bilateral trade agreements with the European Union have changed considerably compared with a few years ago. They must be prepared to deal with a tough approach of including high levels of IP protection, based on European Union legislation and with little regard for their development concerns. The possibility to adapt the EU's requests according to partner countries' preferences will depend greatly on the latters' bargaining power. Overall, India seems to be able to use a stronger bargaining power vis-à-vis the EU than CARIFORUM States. One way to increase one's bargaining power is to base its own proposals on the commitments already made by the European Union in other agreements. This is a strategy that seems to work well for India, who has used several provisions fought for by CARIFORUM States in the negotiations on the CARIFORUM-EC EPA and developed the language therein even further. It is well advised to do the same with certain provisions of the EU-Central America $A A$, which seems to include even more concessions by the European Union than so far made in the CARIFORUM-EC EPA or the draft IP chapter of the India-EU BTLA.

\subsection{JAMAICA CASE STUDY}

Bilateral agreements with ever more and ever more stringent TRIPS-plus provisions would not exist if the developing countries involved had not agreed to them. These countries, and in particular all actors that participated in the domestic policy-making process, decided to accept strong intellectual property protection and enforcement standards. The case study carried out in Jamaica and the CARIFORUM region provides an analysis of the preferences that determined these countries to sign up to the intellectual property chapter of the CARIFORUM-EC EPA. It presents a study of the interests of domestic non-state actors in Jamaica and the CARIFORUM region, and their influence on the policy-making process of determining Jamaica's and the region's IP policy position during the EPA negotiations. In particular, the preferences of non-state actors with regard to protecting the intellectual property in agricultural and food products have been assessed. I have obtained relevant 
information that shows in how far relevant IP provisions in the EPA reflect the interests of Jamaican non-state actors and those of the region.

The case study is primarily based on data collected through face-to-face or phone interviews with approximately thirty state and non-state actors based in Jamaica, Barbados, Brussels and Geneva. The interviews provided data on 1) the identity of non-state actors in Jamaica and the CARIFORUM region with some interest in IP protection, 2) their preferences with regard to the regulation of IP protection in the EPA, 3) their involvement in national and regional consultative processes, and 4) their influence on the national and regional policy position. However, due to several limitations, the data available was very limited and hardly allowed a proper analysis of the influence of non-state actors to be carried out. The main limitation was that I could only identify few non-state actors that 1) had some interest in intellectual property protection in general or in the context of the EPA in particular, and 2) that participated in relevant consultative processes. Therefore, the conclusions regarding the influence of non-state actors in the case study have to be understood with these limitations in mind.

This research has importantly shown that there are only very few non-state actors at the regional and national level that have some interest in IP protection in general and in its regulation through the EPA in particular. The interest that these few non-state actors have can hardly be classified as a specific interest. In fact, only three out of the twelve identified non-state actors were classified to have specific preferences on issues dealt with in the IP negotiations in the context of the EPA. In other words, merely three actors have specific knowledge on relevant intellectual property issues, in particular on its regulation at the international level, and deal with these matters as a significant part of their work. Most importantly, they have formulated specific preferences with regard to which level of protection should be agreed upon in the EPA; none of the other nine actors were able to indicate such preferences, even though four of them had a general interest in IP protection. The main reason for this result seems to be that only very few actors are actually informed and knowledgeable about intellectual property protection. Their daily life is occupied with other areas of trade than IP issues.

Furthermore, only one of these actors actually participated in consultative processes that addressed the national and/or regional IP policy position in the EPA negotiations in detail. This was the lawyer Dianne Daley who participated in the national specific IP consultations organized by Jamaica Intellectual Property Office and the Ministry of Foreign Affairs and Foreign Trade. As a consequence, national consultations dealing with intellectual property issues in the CARIFORUM-EC EPA were largely dominated by state actors. The other national consultative processes that addressed the EPA in general did include more non-state actors. In fact, five out of the twelve analyzed actors took part in the meetings of the Jamaica Trade Adjustment Team and the GI working group. However, these groups have been reported to merely discuss IP protection in general and certainly not the draft texts of the proposed IP provisions in the EPA. At the regional level, only a few consultations addressed the protection of intellectual property in detail. One actor that had specific interests in the protection of plant varieties, the West Indies Central Sugar Cane Breeding Station, had informal contact with the regional negotiator, outside of the consultative processes. 
Another conclusion is that intellectual property protection negotiated at the multilateral level, such as at the WTO or WIPO, is not an important area of interest for national and domestic non-state actors either. The actors analyzed as having had some interest in the regulation of IP through the EPA generally also have an interest in multilateral regulation of IP. Hence, very few non-state actors are concerned with the multilateral protection of IP. There is, however, a difference with regard to the consultative processes when comparing the consultations organized on multilateral IP issues and those organized in relation to the IP issues addressed in the CARIFORUM-EC EPA negotiations: the national and regional consultations dedicate less attention to the IP negotiations in the Doha Development Round than in the CARIFORUM-EC EPA. One reason is clearly that IP issues are not a priority in the Doha Development Round. But also for the negotiations at WIPO, hardly any IP consultations in Jamaica or in the region take place.

A specific area of attention of the research regarded the question of which forum national and regional non-state actors prefer when regulating the protection of intellectual property internationally. The results are not clear-cut, partly because the question of forum choice, in many cases, went beyond the level of understanding of most non-state actors interviewed. While Ann Capling and Patrick Low have suggested that non-state actors would prefer the WTO above preferential trade agreements because it is more protective of developing country interests, the data collected in Jamaica and the CARIFORUM region showed a preference for the multilateral venue, however not because of the explanation given by them. The argument raised by most non-state actors with a preference for the multilateral forum was that Jamaica or small Caribbean islands have an increased leverage in a multilateral rather than a bilateral context.

The overall influence of national and regional non-state actors on the Jamaican and CARIFORUM policy position on IP matters has been examined to be very little. Most non-state actors had no influence at all due to their lack of specific interests and participation in the consultations on the regulation of IP in the EPA. At most two actors can be qualified as having (partially) influenced the Jamaican or the regional policy position. The regional actor West Indies Central Sugar Cane Breeding Station had a significant influence on the regional policy position in the area of plant variety protection. The lawyer Dianne Daley, who was the only national actor that had a specific interest in international IP regulation and who participated in specific consultations on IP issues, was able to influence the national policy position with regard to accepting international commitments in the area of trade mark and patent protection. However, she did not influence the regional negotiating positions in these areas.

The actor that was most determinative for the final IP policy position chosen by CARIFORUM States was the Caribbean Regional Negotiation Machinery, and in particular the technical negotiator on IP, Malcolm Spence. First, CRNM staff was anchored in each of the policy-making forums of the region. It was instrumental in the internal determination of the regional negotiating positions as well as in the negotiations with the European Union. Second, due to a clear asymmetry of expertise and knowledge between CRNM and national policy makers, the latter were not in a position to defend their choices properly during the process of determining the regional policy position. Third, the technical negotiator for intellectual property 
protection, Malcolm Spence, was able to convince national policy makers and stakeholders of his philosophy and policy choices because of his personality, eloquence and technical know-how.

In addition to the factual conclusions, the data obtained in the Jamaica and the CARIFORUM region case study allows some empirical conclusions to be added with regard to the two theoretical hypotheses set out. The first hypothesis ('The size of groups and the intensity of their preferences determine whether their preferences are reflected in the outcome') could only be assessed for a low number of non-state actors analyzed; therefore, the conclusions that can follow from that analysis are limited. Overall, the hypothesis was verified in the Jamaica and the CARIFORUM region case study since the two actors that have (partially) influenced the national and regional policyposition were small groups with specific preferences. For the hypothesis ('The size of the domestic win-set determines the negotiating autonomy of the negotiator'), a result could only be provided for the second sub-hypothesis formulated ('Negotiators with a large domestic win-set have a considerable degree of negotiating autonomy'). The case study of Jamaica and the CARIFORUM region clearly presented an example of a large domestic win-set (with only a few and mainly general or marginal preferences of relevant non-state actors) and also of a negotiator with a large degree of negotiating autonomy. Therefore, the second hypothesis in the case of large domestic win-sets has also been verified in the case study carried out.

According to the logic of two-level games, the second hypothesis does not stop there, but a link between the negotiating autonomy of the negotiator and his bargaining power can be made. Robert Putnam has suggested the following hypothesis: The smaller the win-set and the negotiating autonomy of a negotiator, the bigger her/his bargaining power.' However, this link between negotiating autonomy and bargaining power has not formed part of the Jamaica and the CARIFORUM region case study. The relative bargaining power of one party in the negotiations can only be assessed if the policymaking and negotiating process has been analyzed on both sides. However, in the present research, this process has merely been assessed for CARIFORUM States and not for the European Union.

Nevertheless, the legal analyses of the provisions in the CARIFORUM-EC EPA have given some indications on the bargaining power of CARIFORUM States, judging from the final provisions included in the EPA. According to the assessment of the final provisions, CARIFORUM States have been successful in preserving their interests with regard to the link of innovation and intellectual property, the transfer of technology, the protection of plant varieties, genetic resources and traditional knowledge. Its bargaining power supposedly has been particularly weak in the areas of design protection and enforcement matters. These results are not entirely in conformity with the expectations derived from the above-cited hypothesis. Since the domestic win-set of the negotiator was large in general, one would have expected a small bargaining power in general.

The strong bargaining power in the areas innovation, transfer of technology and the protection of genetic resources and traditional knowledge cannot be explained by the negotiating autonomy of the negotiator. The negotiating autonomy in these areas has in fact been rather large because of a lack of domestic preferences. Therefore, what could explain the strong bargaining power of the negotiator are his new and 
innovative concepts, which the European Union had not expected. The strong bargaining power in the area of plant variety protection, on the other hand, may be explained by the preferences and influence of the West Indies Central Sugar Cane Breeding Station, who was the only non-state actor that has communicated his specific and strong preferences to the regional negotiating team. Finally, the weak bargaining power in the area of enforcement standards is one example in which the hypothesis as formulated for the Jamaica case study seems to fit: very few preferences existed in the area of enforcement, therefore the negotiator's negotiating autonomy was large and his bargaining power small.

When compared with the draft IP chapter of the India-EU BTLA, it may be concluded that the bargaining power of CARIFORUM States may not have been as strong as that of India in areas such as enforcement matters, the protection of genetic resources and traditional knowledge and design protection, at least when judging from the last draft IP chapter of the India-EU BTLA from July 2010. However, for being the first trading partner with whom the European Union has used its new tough approach, the results achieved by CARIFORUM States are remarkable. Even though no similarly deep analysis has been carried out for the EU-Central America $A A$, it seems as if the bargaining power of Central American countries might have been even stronger than that of CARIFORUM States and India on the protection of industrial designs and patents. According to Robert Putnam's hypothesis on the link between bargaining power and the negotiator's negotiating autonomy, the strong bargaining power of Central American countries suggests a strong mandate of important domestic constituencies in these areas of IP protection.

\subsection{FINAL WORDS}

Bilateral trade agreements are likely to continue to be the preferred option for the major trading nations to regulate, among others, intellectual property protection. This book has presented a first comprehensive analysis of the legal approaches used by the United States and the European Union for regulating intellectual property protection through BTAs. In view of the agreements that are still under negotiation and are envisaged to be concluded in the future, it is important to continue analyzing in detail what the obligations entail, how they differ from each other and where they conflict with each other. Developing countries, which are important partner countries to these agreements, will be able to use such research to prepare properly for the IP negotiations with the United States and/or the European Union.

This book also presents a first attempt of analyzing the domestic policy-making process in Jamaica and the CARIFORUM region, which informed the negotiations of and the final agreement to the IP provisions in the CARIFORUM-EC EPA. The case study addresses the lacuna in the political-scientific literature on domestic policy making of international intellectual property regulation. For a subject as allencompassing and relevant as intellectual property protection, in particular with regard to the protection of agricultural and food products, political-scientists should dedicate their research much more to the processes through which standards of intellectual property protection are set in developing countries. It provides great insight on the relevance of IP protection in these countries and indicates the prospects of such protection being used and enforced by its citizens and institutions. 


\section{Chapter 14 : Conclusies en Samenvatting}

\subsection{HET INTERNATIONAAL SYSTEEM VAN IE BESCHERMING PRE-TRIPS}

Het beginpunt van dit onderzoek was de recente uitbreiding van bilaterale handelsovereenkomsten (BHOs) die intellectueel eigendom (IE) boven het niveau van het TRIPS Verdrag beschermen. Dit fenomeen is ontstaan nadat het TRIPS Verdrag op 1 januari 1995 in werking trad. Ondanks dat de reikwijdte van de bescherming van intellectuele eigendom in recente BHOs exceptioneel is, is het bestaan van bilaterale handelsovereenkomsten die intellectueel eigendom (IE) beschermen niet exceptioneel.

Al voordat het TRIPS Verdrag in werking trad kende het internationale systeem voor de bescherming van intellectueel eigendom alternerende fasen die intellectueel eigendom bilateraal, multilateraal en unilateraal reguleerden. De eerste vorm van internationale IE bescherming was het alomvattende netwerk van bilaterale auteursrechtelijke conventies tussen Europese en Latijns-Amerikaanse landen. Ook op het gebied van industrieel eigendom waren Europese landen de eerste die door middel van bilaterale overeenkomsten internationaal coöpereerden. Desalniettemin, als gevolg van het ontbreken van uniformiteit, wilde de internationale gemeenschap de bilaterale verdragen met multilaterale pilaren complementeren. Het Verdrag van Parijs en de Berner Conventie markeerden de eerste multilaterale fase. Het secretariaat verantwoordelijk voor het beheer van het Verdrag van Parijs en de Berner Conventie, initieerde vele andere multilaterale verdragen, later ook in de context van de Wereldorganisatie voor de Intellectuele Eigendom (WIE). De IE afhankelijke industrieën in de Verenigde Staten en Europa waren echter niet tevreden met het nog steeds gefragmenteerde internationale systeem van IE bescherming. Ze begonnen dan ook bilaterale investeringsverdragen en unilaterale wetten te gebruiken, zoals de verschillende vormen van het 'Sectie 301 proces', met als doel een hoger niveau van IE bescherming te bereiken. In het algemeen zien we een dialectische ontwikkeling van het internationale systeem van IE bescherming een, in welke bilaterale fasen multilaterale opvolgen en andersom.

De alternerende fasen van bilaterale, multilaterale en unilaterale bescherming van intellectueel eigendom openbaren een proces van 'forum-shifting'. Wanneer de ontevredenheid met de bestaande vormen van internationale IE bescherming toenam, richteden zich bepaalde landen op andere forums; de institutionele structuren of lidmaatschap van die instellingen leek deze landen geschikter voor de regulering van internationaal eigendom. Het TRIPS Verdrag zelf is één van de belangrijkste voorbeelden voor het succesvolle gebruik van de 'forum-shifting' strategie. De Verenigde Staten en een aantal Europese landen, gesteund door Japan, wilden IE bescherming in de Algemene Overeenkomst over Tarieven en Handel van 1947 (GATT 1947) integreren omdat ze ervan overtuigd waren dat de reguleringsmechanismen van de GATT 1947, die op 1 januari 1995 in de Wereldhandelsorganisatie (WHO) zou opgaan, duidelijke voordelen hadden vergeleken met de handhavingmechanismes van de WIE enerzijds en het gefragmenteerde netwerk van bilaterale investeringsverdragen anderzijds. Zoals bekend zijn ze hierin geslaagd. 
De reikwijdte van het TRIPS Verdrag met betrekking tot materiële intellectueel eigendomsbescherming, lidmaatschap en handhaving is ongekend. Het bevat algemene bepalingen en beginselen met betrekking tot normen betreffende de individuele gebieden van IE, zoals het auteursrecht en naburige rechten, handelsmerken, geografische aanduidingen, tekeningen en modellen van nijverheid, octrooien, topografieën, bepalingen over de bescherming van niet openbaar gemaakte informatie, de handhaving van IE rechten, de voorkoming en beslechting van geschillen, overgangsregelingen en bepalingen betreffende de transfer van technologie. Mede omdat ontwikkelingslanden tijdens de lange en controversiële onderhandelingen belangrijke toezeggingen hebben gemaakt, verwachtten ze dat de TRIPS-standaard de voornaamste internationale standaard voor de bescherming van intellectueel eigendom zou blijven. Desalniettemin, meteen naar het sluiten van het TRIPS Verdrag, zagen we het begin van een nieuwe bilaterale fase. De Verenigde Staten, en met enige vertraging ook de Europese Unie, begonnen BHOs te sluiten die intellectuele eigendom boven het TRIPS-niveau beschermen (TRIPS-plus).

\subsection{HET INTERNATIONAAL SYSTEEM VAN IE BESCHERMING POST-TRIPS}

Sinds de inwerkingtreding van het TRIPS Verdrag zijn de bilaterale handelsovereenkomsten, die door de hoofdactoren Verenigde Staten, de Europese Unie, de Europese Vrijhandelsassociatie en Japan zijn gesloten, bijzonder succesvol in het vaststellen van TRIPS-plus bepalingen. Dit is voornamelijk het geval in vergelijking met de TRIPS-plus normen in multilaterale en plurilaterale verdragen. Behalve het WIPO Auteursrechtverdrag en het WIPO Naburige Rechtenverdrag zijn er weinig succesvolle multilaterale en plurilaterale verdragen gesloten, die de bescherming van intellectuele eigendom reguleren. Van de hoofdactoren die bilaterale TRIPS-plus normen in hun BHOs opnemen, zijn de Verenigde Staten verreweg de meest agressieve actor. Niet alleen de inhoud van de hoofdstukken betreffende IE in de vrijhandelsovereenkomsten (VHOs) is uniek; ook de manier van onderhandelen en de juridische aanpak in de IE hoofdstukken is niet vergelijkbaar met de aanpak van andere actoren.

Het IE hoofdstuk in VS vrijhandelsovereenkomsten bevat de hoogste internationale standaards betreffende IE bescherming op bijna alle IE gebieden;geen ander internationaal verdrag, zelfs niet de plurilaterale Handelsovereenkomst ter bestrijding van namaak (ACTA) of de WIPO Internet Verdragen, bereikt deze standaards. Een uitzondering is de bescherming van geografische aanduidingen; hier stelt de Europese Unie de hoogste standaards vast. VS vrijhandelsovereenkomsten, en in het bijzonder de bescherming van octrooien en auteursrechten daarin, worden bekritiseerd voor hun belangrijke invloed op de beschikbaarheid en betaalbaarheid van generieke geneesmiddelen en de legale toegang voor gebruikers tot digitale werken. De bepalingen betreffende de exclusiviteit van data, de verlenging van de duur van een octrooi en de beperkingen betreffende dwanglicencies voor octrooien hebben een negatief effect op competitieve prijzen van medicijnen en de toegankelijkheid van essentiële medicijnen voor patiënten in ontwikkelingslanden. De bescherming van technische voorzieningen, informatie betreffende het beheer van rechten en desbetreffende specifieke handhavingmechanismen verhinderen niet alleen het gebruik van digitale werken maar ook de capaciteit van een land hun schaarse middelen voor de handhaving van recht in het algemeen in te zetten. 
Wat de VS bovendien tot een agressieve actor in de onderhandelingen over IE bescherming maakt is de manier waarop zij onderhandelen. IE standaards worden onder absolute geheimhouding onderhandeld, buiten bestaande institutionele structuren en zonder een mogelijkheid voor hun onderhandelingspartners om advies van derde partijen te ontvangen. Als onderhandelingen buiten institutionele structuren plaats vinden zijn regels over een evenwichtige deelname van belangengroepen of transparantie niet van toepassing. Indien niet-overheidsactoren geen mogelijkheid krijgen hun belangen bekend te maken kunnen zij de uitkomsten van de onderhandelingen ook niet beïnvloeden. Bovendien kunnen vele actoren hun belangen niet ontwikkelen als ze de nodige informatie over de inhoud van VHOs missen. De Verenigde Staten hanteren ook een 'value-claiming' strategie: ze zetten hun onderhandelingspartners (dus ook ontwikkelingslanden) onder druk om hoge IE en handhaving standaards te accepteren en in ruil voor hoge IE normen wordt hun toegang tot de VS markten voor bijvoorbeeld textiel en landbouw gegarandeerd. Toegang tot zulke markten zijn absolute prioriteiten voor veel ontwikkelingslanden.

Daarnaast bevat de juridische aanpak van de Verenigde Staten in bilaterale overeenkomsten bijzonder agressieve elementen. Het IE hoofdstuk in VS vrijhandelsovereenkomsten is gebaseerd op IE standaards die hun oorsprong in VS wetgeving vinden. Met andere woorden, onderhandelingspartners worden gevraagd om exact dezelfde standaards aan IE bescherming beschikbaar te stellen als de VS in hun eigen wetgeving doet. Zulke juridische transplantaten kunnen gewichtige problemen opleveren als deze in een ander juridisch systeem omgezet moeten worden. Bepalingen in VS wetten over mededingen of de bescherming van de privésfeer, die de effecten van hoge IE standaards afwegen, ontbreken vaak in de juridische systemen van onderhandelingspartners en hebben ongewild negatieve effecten tot gevolg. Ten tweede wijkt geen overeenkomst van de IE standaards af die in eerdere VHOs zijn voorzien; de IE bescherming in recente overeenkomsten gaat zelfs omhoog. Ten slotte houdt de VS zich het recht voor over de uitvoerende wetgeving van de onderhandelingspartner te oordelen en aanpassingen te eisen. Door het 'machtigingsproces' kan de uitvoerende macht van de VS beslissen of de wetten van onderhandelingspartners de normen in de VHO tevredenstellend omzetten; pas na instemming van de VS treedt de VHO in werking.

Vergeleken met de lineaire aanpak van de Verenigde Staten, die van begin af aan agressief was, is de aanpak van de Europese Unie tijdens het laatste decennium duidelijk verandert. Voor 2006 bevatten de bilaterale handelsovereenkomsten van de Europese Unie weinig bepalingen over de bescherming van intellectueel eigendom; het beschermingsniveau was bescheiden. Ze verwezen indirect naar IE standaards: de BHOs bevatten lijsten met multilaterale verdragen die door hun onderhandelingspartners getekend moesten worden of waaraan zij moesten voldoen. Pre-2006 BHOs omvatten slechts enkele TRIPS-plus bepalingen, bijvoorbeeld de bescherming van databases en gebruiksmodellen en de verplichtingen het WIPO Auteursrechtverdrag, het WIPO Naburige rechtenverdrag en het UPOV Verdrag van 1991 te tekenen. Een belangrijke uitzondering zijn de overeenkomsten inzake de handel in wijn en gedistilleerde dranken. Deze eisen bescherming voor geografische aanduidingen boven het TRIPS-niveau.

Met de lancering van de strategie 'Global Europe' in 2006 is de aanpak van de Europese Unie betreffende de bescherming van intellectueel eigendom in derde 
landen veranderd van een zachte tot een harde aanpak. De IE bescherming in recente bilaterale handelsovereenkomsten van de EU is vergelijkbaar hoog met die in VS vrijhandelsovereenkomsten, alhoewel op verschillende gebieden en door middel van andere standaards. Derhalve zijn de Verenigde Staten niet meer de enige TRIPS-plus demandeur; de Europese Unie is hun voorbeeld gevolgd.

Met het oog op de eerder gemaakte conclusies betreffende de dialectische internationale ontwikkeling van IE bescherming zou gesteld kunnen worden dat de meest recente fase van bilaterale overeenkomsten daar deel van uitmaakt en derhalve ook door een multilaterale fase opgevolgd zal worden. Er zijn echter tenminste twee redenen waarom ik stel dat de laatste fase van bilaterale overeenkomsten exceptioneel is en waarschijnlijk niet door een multilaterale fase opgevolgd zal worden. Ten eerste zijn de standaards in recente BHOs niet coherent; de hoofdactoren hebben verschillende TRIPS-plus bepalingen ontwikkeld die in bepaalde gevallen zelfs met elkaar in conflict zijn. Een multilaterale oplossing, die aan deze verschillende aanpakken voldoet, lijkt zeer moeilijk te bewerkstelligen. Ten tweede is de geografische uitbreiding en de materiële reikwijdte van bilaterale overeenkomsten een duidelijk teken dat de meeste handelsnaties een voorkeur hebben voor snelle en op maat gemaakte toezeggingen. Het sluiten van multilaterale overeenkomsten vereist dat landen een compromis willen sluiten vanwege het multilaterale karakter van de overeenkomst. De wil een compromis te bereiken lijkt op dit moment niet aanwezig te zijn. Plurilaterale overeenkomsten bieden soms een tussenweg, maar zijn ook niet eenvoudig te bereiken. Het sluiten van multilaterale overeenkomsten daarentegen lijkt bijna onmogelijk geworden.

\subsection{HET BELEID VAN DE EU BETREFFENDE DE BESCHERMING VAN INTELLECTUEEL EIGENDOM IN DERDE LANDEN}

Er zijn voornamelijk twee strategieën die een verschuiving in het beleid en de praktijk van de Europese Unie betreffende IE bescherming in derde landen hebben bevorderd. Dit zijn de 'Strategie voor de handhaving van intellectuele eigendomsrechten in derde landen', die in november 2004 gepubliceerd werd, en de 'Global Europe: concurreren in de wereld' strategie, die in oktober 2006 werd uitgebracht. De nieuwe handelsstrategie, die in beide documenten beschreven wordt, stelt de externe agenda van de Strategie van Lissabon voor. Volgens de Strategie van Lissabon moet de EU de meest concurrerende en dynamische kenniseconomie ter wereld worden. De twee beleidsstukken hebben het pad voor een nieuwe generatie van concurrentiegerichte vrijhandelsovereenkomsten geëffend. Zulke vrijhandelsovereenkomsten zijn een belangrijke steunpilaar van het nieuwe externe handelsbeleid van de EU geworden. Intellectuele eigendomsbescherming speelt een hoofdrol in deze overeenkomsten. Ze bevatten beschermingsstandaards voor intellectueel eigendom die boven de bestaande TRIPS-standaards gaan. De Europese Unie richt zich niet meer uitsluitend of voornamelijk op het multilaterale forum, de Wereldhandelsorganisatie, maar vooral op de nieuwe VHOs.

De bescherming van intellectueel eigendom in derde landen wordt nu door gedetailleerde verplichtingen in bilaterale handelsovereenkomsten bereikt. De IE normen daarin zijn vaak hoger dan de bescherming in het TRIPS Verdrag; ze evenaren veelal de bescherming in EU wetgeving. De strategie 'Global Europe' makkt in zijn beleidsdocument een onderscheid tussen opkomende economieën aan 
de ene kant, en ontwikkelingslanden aan de andere kant. De praktijk geeft echter geen blijk van dit verschil: onderhandelingen over nieuwe concurrentiegerichte overeenkomsten worden ook met ontwikkelingslanden gevoerd. Zo zijn de (concept) IE hoofdstukken in de overeenkomsten met Zuid Korea, de CARIFORUM landen, Colombia en Peru, Centraal Amerikaanse landen, Canada en India allemaal op hetzelfde modelhoofdstuk betreffende IE bescherming gebaseerd, met kleine verschillen. De voorgestelde bepalingen zijn niet aan het ontwikkelingsniveau van de onderhandelingspartners aangepast. Waar verschillen in de definitieve overeenkomsten voorkomen hebben deze meestal hun oorsprong in de belangen van de handelspartner en zijn onderhandelingspositie. Met andere woorden, belangen omtrent ontwikkeling zijn geen prioriteit in de nieuwe generatie van vrijhandelsovereenkomsten; het belang van ontwikkeling in de nieuwe overeenkomsten is klein vergeleken met de overeenkomsten die voor 2006 onder het handelsbeleid 'beheerste globalisering' zijn gesloten. Het oude handelsbeleid 'beheerste globalisering' had naast het uitbrengen van een aantal initiatieven ten voordele van ontwikkelingslanden ook de IE standaards in bilaterale handelsovereenkomsten aan het ontwikkelingsniveau van hun partners aangepast.

De gedetailleerde juridische analyse van het CARIFORUM-EC EPA en het concept IE hoofdstuk van het India-EU BTIA bevestigd dat de nieuwe aanpak van de Europese Unie, sinds het uitbrengen van de 'Global Europe' strategie, drie kenmerken voorwijst: vele IE-bepalingen in het EPA en BTIA die door de Europese Unie zijn voorgesteld, 1) bevatten belangrijke TRIPS-plus elementen, 2) zijn vaak op interne EU wetgeving gebaseerd, en 3) bieden weinig mogelijkheden om nationale belangen in de omzettingsprocedure af te wegen en ontwikkelingsbelangen in aanmerking te nemen. Deze kenmerken komen het meest dominant in de bescherming van auteursrechten in de digitale omgeving, merkenrechten en geografische aanduidingen voor. Ook de bescherming van modellen en handhavingmaatregelen laten een harde aanpak zien; desondanks lijkt het alsof het concept India-EU BTLA waarschijnlijk minder TRIPS-plus elementen in deze gebieden zal bevatten dan het CARIFORUM-EC EPA, vooral te wijten aan een sterkere onderhandelingspositie van India.

Het CARIFORUM-EC EPA is de eerste overeenkomst die de kenmerken van de nieuwe generatie vrijhandelsovereenkomsten in het IE hoofdstuk behelst. Al de omvang van het hoofdstuk is veel breder dan eerdere overeenkomsten: vierendertig bepalingen behandelen innovatie en intellectueel eigendom. Vergeleken met één of twee bepalingen in de oude generatie overeenkomsten is dat een significante verbreding. De gedetailleerde IE bepalingen bevatten TRIPS-plus elementen, met name in de bescherming van digitale werken, geografische aanduidingen, modelrechten en octrooien, en handhavingmaatregelen. De sectie die handhaving behandelt, is zonder twijfel het meest verreikende onderdeel van het IE hoofdstuk in het CARIFORUM-EC EPA. De bepalingen erin evenaren het beschermingsniveau in interne EU wetgeving en VS vrijhandelsovereenkomsten. Ze gaan boven het beschermingsniveau van het TRIPS Verdrag op drie aspecten: 1) door de omvang van de rechten te vergroten of de kring aan begunstigden uit te breiden; 2) door nauwkeuriger aan te geven wat een bepaald recht inhoudt; en 3) door belangrijke TRIPS waarborgen weg te laten. 
Afgaand op het voorstel van de Europese Unie zal ook het concept IE hoofdstuk van het India-EU BTLA zeer uitgebreid zijn. De EU heeft TRIPS-plus bepalingen op verschillende gebieden voorgesteld, zoals de bescherming van auteursrechten, merkenrechten, geografische aanduidingen, modellenrechten, niet openbaar gemaakte data, voorlopige maatregelen en maatregelen aan de grens. Als India vele van deze voorstellen accepteert zal de overeenkomst weinig mogelijkheden bieden om met ontwikkelingsbelangen rekening te houden wanneer India de BTIA normen in wetgeving zal moeten omzetten. Bepalingen in het BTIA die gelijk zijn aan EU wetgeving of die concrete verplichtingen uiteenzetten (zoals de verplichting aan bepaalde internationale verdragen te voldoen in plaats van inspanningsverplichtingen zoals 'streven naar'), laten weinig ruimte om nationale belangen af te wegen. Echterheeft India de Europese Unie al overtuigt om de relatief flexibele TRIPSstandaard voor vele handhavingbepalingen en de bescherming van kwekersrechten aan te houden.

Alhoewel de IE bepalingen in recente bilaterale handelsovereenkomsten de nieuwe aanpak van de Europese Unie duidelijk doet uitkomen, weerspiegelen beide overeenkomsten ook de belangen van de handelspartners van de EU. De CARIFORUM landen en India konden belangrijke bepalingen waarborgen die het hun mogelijk maken ontwikkelingsbelangen in aanmerking te nemen. Dit zijn met name de bepalingen betreffende de connectie tussen innovatie en IE bescherming, de overdracht van technologie, octrooibescherming (als India de exclusiviteit van data tot een minimum kan beperken), de bescherming van kwekersrechten en de bescherming van genetische hulpbronnen en traditionele kennis (als de EU de bepalingen accepteert die India naar voren heeft gebracht). Deze bevatten weinig TRIPS-plus elementen en zijn niet gebaseerd op interne EU wetgeving. Ook behouden beide overeenkomsten deze flexibelere bepalingen, de nieuwe aanpak van de EU is op deze gebieden toch van toepassing. Ik stel dat deze gebieden van IE bescherming 1) niet door de Europese Unie maar door de andere onderhandelingspartner zijn voorgesteld, of 2) dat de handelspartners bijzonders succesvol waren de voorstellen van de EU aan te passen. In het kort, de voorstellen die de Europese Unie heeft gemaakt, spiegelen nog steeds de nieuwe harde aanpak van de EU weer.

Het CARIFORUM-EC EPA en het concept India-EU BTLA laten duidelijk zien dat de definitieve IE bescherming in de bilaterale handelsovereenkomst een gevolg van de onderhandelingspositie van de handelspartner is. De mate waarin de Europese Unie bereid is concessies op verschillende gebieden te doen hangt sterk van de onderhandelingspositie van haar onderhandelingspartner af. De onderhandelingspositie van de CARIFORUM landen, bijvoorbeeld met betrekking tot ongekende connectie tussen innovatie en IE bescherming, moet bijzonder sterk zijn geweest. Ook de concrete toezeggingen betreffende de overdracht van kennis, de bescherming van kwekersrechten, genetische hulpbronnen en traditionele kennis zijn een teken van een sterke onderhandelingspositie. In het geval van India is het moeilijker om conclusies te trekken aangezien de definitieve bepalingen in het concept IE hoofdstuk van het India-EU BTIA nog niet overeen zijn gekomen. Desalniettemin heeft India reeds laten zien dat ze een relatief sterke onderhandelingspositie heeft, vooral op die gebieden waar de CARIFORUM landen al bepalingen konden waarborgen en die het mogelijk maken om met ontwikkelingsbelangen rekening te houden. Bovendien lijkt India's onderhandelingspositie met betrekking tot 
modelrechten en vooral met betrekking tot handhavingmechanismen zelfs nog sterker te zijn.

Samenvattend zijn de voorwaarden waaronder ontwikkelingslanden bilaterale handelsovereenkomsten met de Europese Unie onderhandelen duidelijk verandert vergeleken met een aantal jaar geleden. Ze moeten zich op een hardere aanpak instellen: de EU eist hoge IE standaards die op interne EU wetgeving gebaseerd zijn en weinig mogelijkheid laten om ontwikkelingsbelangen in aanmerking te nemen. Of een onderhandelingspartner vorderingen van de EU aan zijn eigen belangen kan aanpassen zal sterk van zijn onderhandelingspositie afhangen. Over het algemeen lijkt India een sterkere onderhandelingspositie vis-à-vis de EU geldend te kunnen maken vergeleken met de CARIFORUM landen. Een strategie die de onderhandelingspositie kan versterken, is de eigen voorstellen op toezeggingen baseren die de EU al in andere overeenkomsten heeft gemaakt. Deze strategie lijkt voor India goed te werken: ze heeft al verschillende bepalingen voorgesteld die de CARIFORUM landen van de $\mathrm{EU}$ in de onderhandelingen van het CARIFORUM-EC EPA hebben afgedwongen, en zelfs de taal nog verder aan haar eigen wensen aangepast. India zou er dan ook goed aan doen dezelfde strategie met betrekking tot bepaalde bepalingen uit het EU-Centraal Amerika $A A$ te gebruiken. De Europese Unie heeft daarin toezeggingen gedaan die zelfs nog verder reiken dan die in het CARIFORUM-EU EPA of het concept IE hoofdstuk van het India-EU BTLA.

\subsection{CASESTUdy JAMAica}

Bilaterale overeenkomsten met altijd meer en altijd striktere TRIPS-plus bepalingen zouden niet bestaan als betrokkene ontwikkelingslanden er niet mee hadden ingestemd. Deze landen, en in het bijzonder alle actoren die in het nationale beleidsvormingsproces deel hebben genomen, hebben besloten om striktere IE bescherming en handhavingmaatregelen te accepteren. De casestudy, die in Jamaica en de CARIFORUM regio is uitgevoerd, verschaft een analyse van de belangen die bepalend waren voor het tekenen van het IE hoofdstuk in het CARIFORUM-EC $E P A$. Het is een studie over de belangen van nationale niet-overheidsactoren in Jamaica en de CARIFORUM regio, alsmede van hun invloed op het beleidsvormingsproces dat het IE beleid van Jamaica en de regio tijdens de EPA onderhandelingen heeft gevormd. In het bijzonder zijn de belangen van nietoverheidsactoren met betrekking tot de bescherming van IE in landbouw- en voedselproducten onderzocht. Ik heb informatie verzamelt die laat zien in hoeverre relevante IE bepalingen in het EPA de belangen van Jamaicaanse en regionale nietoverheidsactoren weerspiegeld.

De casestudy is primair op data gebaseerd die door rechtstreekse interviews of telefooninterviews met ongeveer dertig overheids- en niet-overheidsactoren in Jamaica, Barbados, Brussel en Genève is verzameld. De interviews leverden data over 1) de identiteit van niet-overheidsactoren in Jamaica en de CARIFORUM regio die enige belangstelling voor IE bescherming hebben, 2) hun belangen met betrekking tot de regulering van IE bescherming in het EPA, 3) hun betrokkenheid in nationale en regionale raadplegingsprocessen, en 4) hun invloed op de nationale en regionale beleidspositie. De beschikbare data was echter vanwege bepaalde omstandigheden beperkt en liet een grondige analyse van de invloed van niet-overheidsactoren amper toe. De belangrijkste beperking was dat ik maar enkele niet-overheidsactoren kon 
identificeren die 1) enige belangstelling voor IE bescherming in het algemeen of in de context van het EPA hadden, en 2) aan relevante raadplegingsprocessen hebben deelgenomen. Derhalve moeten de conclusies betreffende de invloed van nietoverheidsactoren dan ook met deze beperkingen in het achterhoofd worden gelezen.

Dit onderzoek heeft duidelijk kunnen aantonen dat er maar enkele nietoverheidsactoren op regionaal en nationaal niveau zijn die enige belangstelling voor IE bescherming in het algemeen en in het bijzonder in de regulering van IE door het EPA hebben. Hun belangstelling houdt amper specifieke belangen in. Slechts drie van de twaalf geïdentificeerde niet-overheidsactoren hadden specifieke belangen in de kwesties die in de IE onderhandelingen van het EPA aan de orde kwamen. Met andere woorden, slechts drie actoren hadden specifieke kennis van relevante IE kwesties, in het bijzonder de regulering van IE op internationaal niveau, en gebruiken die kennis ook in hun dagelijks werk. Deze drie actoren hebben ook specifieke belangen ten aanzien van de beschermingsomvang die in het EPA zou moeten opgenomen worden; geen van de andere negen actoren had zulke concrete belangen, alhoewel vier van de negen actoren wel algemene belangstelling voor IE bescherming hadden. De hoofdreden hiervoor lijkt te zijn dat slechts enkele actoren inderdaad informatie en kennis op het gebied van intellectueel eigendomsbescherming hebben. De anderen houden zich vooral met andere handelsaspecten dan IE bescherming bezig.

Verder heeft er maar één van de geanalyseerde niet-overheidsactoren in de raadplegingsprocessen deelgenomen die Jamaica's IE beleidspositie in de EPA onderhandelingen tot onderwerp hadden: de advocaat Dianne Daley. Over het algemeen hebben maar weinig niet-overheidsactoren aan de Jamaicaanse raadplegingsprocessen deel genomen waarin ook IE bescherming aan de orde kwam. Als gevolg daarvan werden de raadplegingsprocessen grotendeels door overheidsactoren gedomineerd. Andere nationale raadplegingsprocessen, die het EPA in het algemeen behandelden, hebben volgens verschillende bronnen de bescherming van intellectuele eigendom nauwelijks besproken; de concept teksten van het IE hoofdstuk zijn hier niet behandeld. Één actor met specifieke belangen in de bescherming van kwekersrechten, de West Indies Central Sugar Cane Breeding Station, heeft informeel contact gehad met de regionale onderhandelaar, buiten officiële raadplegingsprocessen.

Een andere conclusie is dat intellectueel eigendomsbescherming op het multilaterale niveau, zoals in de WHO of WIE, ook niet van groot belang voor regionale en nationale niet-overheidsactoren is. De actoren die in mijn analyse belang hadden in de regulering van IE door het EPA zijn ook in de multilaterale regulering van IE geïnteresseerd. Dit zijn er echter maar enkele. Desalniettemin bestaat er een verschil tussen de raadplegingsprocessen die IE bescherming in het EPA hebben behandeld, en zulke die multilaterale IE kwesties ter discussie stellen: nationale en regionale raadplegingsprocessen hebben minder aandacht aan de DOHA onderhandelingen over IE bescherming besteedt dan aan de IE onderhandelingen van het CARIFORUM-EC EPA. Een reden daarvoor is dat IE bescherming geen prioriteit van de Doha Ontwikkelingsronde is. Het resultaat is echter hetzelfde voor de onderhandelingen in de WIE: zij staan amper ter discussie in de raadplegingen in Jamaica en andere de CARIFORUM landen. 
Een bijzonder aandachtspunt van dit onderzoek was de vraag aan welk forum nationale en regionale niet-overheidsactoren de voorkeur geven voor de internationale regulering van intellectueel eigendomsbescherming: het regionale of het multilaterale. De bevindingen op dit punt zijn niet duidelijk, deels omdat de vraag naar de forum keuze in vele gevallen boven de kennis van de geïnterviewde nietoverheidsactoren ging. Ann Capling en Patrick Low hebben voorgesteld dat nietoverheidsactoren de voorkeur aan de Wereld Handelsorganisate, boven regionale handelsovereenkomsten, geven omdat de WHO de belangen van ontwikkelingslanden beter zou beschermen. De verzamelde data in Jamaica en de CARIFORUM landen hebben ook een voorkeur voor multilaterale forums aangegeven, maar niet voor dezelfde reden als Capling en Low. De reden die de meeste nietoverheidsactoren met een voorkeur voor het multilaterale forum hebben genoemd, is dat Jamaica of kleine Caribische eilanden meer macht in een multilaterale dan in een bilaterale setting hebben.

Over het algemeen was de invloed van nationale en regionale niet-overheidsactoren op Jamaica's en CARIFORUM's IE onderhandelingspositie zeer gering. De meeste niet-overheidsactoren hadden überhaupt geen invloed omdat zij ook geen specifieke belangen in IE kwesties hadden en ook niet in relevante raadplegingsprocessen hebben deel genomen. Mijn onderzoek heeft uitgewezen dat hoogstens twee actoren de Jamaicaanse en regionale beleidspositie (gedeeltelijk) beïnvloedt hebben. De regionale actor West Indies Central Sugar Cane Breeding Station heeft substantieel invloed uitgeoefend op de regionale onderhandelingspositie met betrekking tot kwekersrechten. De advocaat Dianne Daley, de enige nationale actor die specifieke belangen in de internationale regulering van IE had en ook in de specifieke raadplegingsprocessen over IE bescherming heeft deelgenomen, kon de nationale beleidspositie op het aangaan van internationale verplichtingen betreffende merkenen octrooirechten beïnvloeden. Ze heeft echter geen invloed op de regionale onderhandelingspositie uitgeoefend.

De actor die de meeste invloed op de definitieve IE onderhandelingspositie van de CARIFORUM landen had, was de overheidsactor 'Caribbean Regional Negotiation Machinery' (CRNM), en in het bijzonder de onderhandelaar voor intellectueel eigendom kwesties, Malcolm Spence. Ten eerste waren leden van het CRNM in elk regionaal beleidsvormingsproces vertegenwoordigd. Dit orgaan was instrumenteel voor interne beslissingen betreffende de regionale onderhandelingspositie als ook in de onderhandelingen met de Europese Unie. Ten tweede nam het CRNM het voortouw ten opzichte van nationale politici: vanwege een sterke asymmetrie in expertise en kennis waren nationale beleidsmakers nauwelijks in een positie om hun standpunten in het beleidsvormingsproces tegenover de leden van het CRNM te verdedigen. Ten derde wist de onderhandelaar voor intellectueel eigendom bescherming, Malcolm Spence, door zijn persoonlijkheid, eloquentie en technische kennis, nationale politici en niet-overheidsactoren van zijn filosofie en beleidkeuzes te overtuigen.

Naast de feitelijke conclusies heeft de casestudy over Jamaica en de CARIFORUM regio data opgeleverd die enige empirische conclusies met betrekking tot de twee theoretische hypotheses mogelijk maakt. De eerste hypothese ('De grote van groepen en de intensiteit van hun belangen zijn beslissend voor de vraag of bun belangen in het resultaat terug te vinden zijn) kon slechts voor een kleine hoeveelheid van niet-overheidsactoren 
geanalyseerd worden; de conclusies zijn daarom ook beperkt. In het algemeen kon de hypothese met betrekking tot de casestudy Jamaica en de CARIFORUM regio geverifieerd worden. De twee actoren die (gedeeltelijk) invloed hebben gehad op de nationale en regionale beleidspositie waren kleine groepen met specifieke belangen. Voor de hypothese De grote van het nationale win-set is beslissend voor de onderbandelingsautonomie van de onderhandelaar' kon slechts voor de tweede sub-hypothese een uitkomst geformuleerd worden ('Onderhandelaars met een grote nationale win-set bebben een aanzienlijke mate aan onderhandelingsautonomie'). De casestudy van Jamaica en de CARIFORUM regio is een duidelijk voorbeeld van een groot nationaal win-set (met slechts enkele en vooral algemene of marginale belangen van relevante nietoverheidsactoren) en een onderhandelaar met een grote mate aan onderhandelingsautonomie. Om die reden is dan ook de tweede hypothese voor het geval van een groot nationaal win-set door de casestudy geverifieerd.

Volgens de 'logic of two-level games' gaat de tweede hypothese verder in dat het een connectie tussen de onderhandelingsautonomie van de onderhandelaar en zijn onderhandelingspositie (negotiating power) aanduidt. Robert Putnam heeft de volgende hypothese voorgesteld: 'Hoe kleiner de win-set en de onderhandelingsautonomie van de onderhandelaar, hoe groter zijn/haar onderhandelingspositie.' Deze connectie tussen onderhandelingsautonomie en onderhandelingspositie maakt echter geen deel uit van de casestudy over Jamaica en de CARIFORUM regio. De relatieve onderhandelingspositie van een partij in onderhandelingen kan namelijk slechts worden beoordeeld als de beleidsvorming- en onderhandelingsproces aan beide kanten onderwerp van de analyse is. Dit was in dit onderzoek niet het geval; slechts de CARIFORUM landen zijn geanalyseerd en niet de Europese Unie.

Desalniettemin heeft de juridische analyse van het IE hoofdstuk van het CARIFORUM-EC EPA aanwijzingen gegeven over de mate van onderhandelingspositie van de CARIFORUM landen in de verschillende IE gebieden. Uitgaande van de analyse van de definitieve bepalingen zijn de CARIFORUM landen erin geslaagd hun belangen betreffende de connectie tussen innovatie en intellectueel eigendomsbescherming, de transfer van technologie, de bescherming van kwekersrechten, genetische hulpbronnen en traditionele kennis te bewaren. Hun onderhandelingspositie was schijnbaar bijzonders zwak wat de bescherming van modellen en de handhaving van IE betreft. Deze uitkomsten zijn niet geheel conform aan de verwachtingen uit de boven genoemde hypothese. Aangezien de nationale win-set van de onderhandelaar over het algemeen groot was had men ook een zwakke mate aan onderhandelingspositie in de meeste onderdelen van het IE hoofdstuk kunnen verwachten.

De sterke onderhandelingspositie betreffende innovatie, de transfer van technologie en de bescherming van genetische hulpbronnen en traditionele kennis kan niet door de onderhandelingsautonomie van de onderhandelaar worden verklaard. De onderhandelingsautonomie voor deze gebieden van IE bescherming was groot omdat er nauwelijks nationale belangen aanwezig waren. Een verklaring voor de sterke onderhandelingspositie op deze gebieden zijn de nieuwe en innovatieve concepten die het CRNM heeft voorgesteld en die de Europese Unie niet had verwacht. De sterke onderhandelingspositie met betrekking tot de bescherming van kwekersrechten kan aan de hand van de belangen en de invloed van de West Indies Central Sugar Cane Breeding Station worden verklaard. Deze actor was de enige niet- 
overheidsactor die specifieke en sterke belangen betreffende de bescherming van kwekersrechten aan het regionale onderhandelingsteam had gecommuniceerd. Ten slotte is de zwakke onderhandelingspositie van de CARIFORUM landen op het gebied van handhaving een voorbeeld waar de geformuleerde hypothese voor de casestudy Jamaica wel van toepassing is: in Jamaica en de CARIFORUM regio existeerden maar weinig belangen met betrekking tot handhaving, wat de onderhandelingsautonomie van de onderhandelaar groot maakte en zijn onderhandelingspositie relatief zwak.

Vergeleken met het concept IE hoofdstuk in het India-EU BTLA kan vastgesteld worden dat de onderhandelingspositie van de CARIFORUM landen op de gebieden van handhaving, de bescherming van genetische hulpbronnen en traditionele kennis, en modelbescherming niet zo sterk was als die van India, ten minste als men uitgaat van het laatste concept IE hoofdstuk van juli 2010. Hoe dan ook, gezien het feit dat de CARIFORUM landen de eerste handelspartners waren tegenover wie die de Europese Unie zijn nieuwe harde aanpak heeft gebruikt, zijn de uitkomsten die de CARIFORUM landen hebben bereikt, aanzienlijk. Ondanks dat ik geen evenzo diepe analyse voor het EU-Centraal Amerika $A A$ heb doorgevoerd, lijkt het alsof de onderhandelingspositie van Centraal Amerikaanse landen met betrekking tot de bescherming van modellen en octrooien nog sterker was dan die van India en de CARIFORUM landen. Volgens de hypothese van Robert Putnam over de connectie tussen onderhandelingspositie en onderhandelingsautonomie van de onderhandelaar, geeft de sterke onderhandelingspositie van Centraal Amerikaanse landen aan dat ze op deze gebieden van IE bescherming een sterk mandaat van belangrijke nationale actoren hadden.

\subsection{AFSLUITENDE WOORDEN}

Het is waarschijnlijk dat bilaterale handelsovereenkomsten de prefereerde optie voor de grote handelsmachten blijven om, inter alia, intellectueel eigendomsbescherming op internationaal niveau te reguleren. Dit boek heeft een eerste algehele analyse gepresenteerd hoe de Verenigde Staten en de Europese Unie de bescherming van intellectueel eigendom door middel van BHOs reguleren. Met zicht op de overeenkomsten die nog onderhandeld worden en die in de toekomst gesloten zullen worden, is het belangrijk dat de verplichtingen erin in detail onderzocht worden, in hoe ver zij van elkaar afwijken en waar ze met elkaar in conflict zijn. Ontwikkelingslanden die belangrijke partners van zulke overeenkomsten zijn, kunnen dit onderzoek gebruiken om zich op de IE onderhandelingen met de Verenigde Staten en/of de Europese Unie voor te bereiden.

Dit boek presenteert ook een eerste poging het nationale en regionale beleidsvormingsproces in Jamaica en in de CARIFORUM regio te analyseren, welke voor en tijdens de onderhandelingen over de definitieve bepalingen betreffende IE bescherming in het CARIFORUM-EC EPA plaats hebben gevonden. De casestudy behandelt een lacune in de politiekwetenschappelijke literatuur over nationale beleidsvormingsprocessen, waarin de internationale regulering van intellectueel eigendom centraal staat. Voor een onderwerp dat zo alomvattend en relevant is als de bescherming van intellectueel eigendom, in het bijzonder betreffende de bescherming van landbouw- en voedselproducten, zouden politieke wetenschappers meer onderzoek naar de processen moeten doen die IE standaards in ontwikkelingslanden 
WHY JAMAICA WANTS TO PROTECT CHAMPAGNE

meebepalen. Zulk onderzoek kan inzichtelijk maken hoe relevant IE bescherming in deze landen is en hoe waarschijnlijk het zal zijn dat de beschermingsregels door hun burgers en instellingen gebruikt en gehandhaafd zullen worden. 


\section{Bibliography}

\section{GATT Panel Reports}

United States - Imports of Certain Automotive Spring Assemblies [BISD 30S/107] (GATT Panel Report, 26 May 1983).

Japan - Customs Duties, Taxes and Labelling Practices on Imported Wines and Alcoholic Beverages [BISD 34S/83] (GATT Panel Report, 10 November 1987).

\section{W'TO Panel Reports}

Canada - Patent Protection of Pharmaceutical Products [WT/DS114/R] (WTO Panel Report, 7 April 2000).

United States - Section 110(5) of the US Copyright Act [WT/DS160/R] (WTO Panel Report, 15 June 2000).

EC - Trademarks and Geographical Indications [DS174] (WTO Panel Report, 15 March 2005).

China - Measures Affecting the Protection and Enforcement of Intellectual Property Rights [WT/DS362/R] (WTO Panel Report, 26 January 2009).

\section{CRNM and Jamaican documents}

CRNM, The Cariforum-EC Economic Partnership Agreement: Highlights on the Most-Favoured Nation (MFN) clause in the EPA (2008) [3200.2/EPA-04 [08]].

A. Hylton, Jamaica's New Trade Policy - 2001 (Jamaica Ministry of Foreign Affairs and Foreign Trade, Kingston, 29 October 2001) [Ministry Paper No. 69/2001].

IPI and JIPO, Memorandum of Understanding between The Swiss Federal Institute of Intellectual Property (IPI) and The Jamaica Intellectual Property Office (JIPO) on the Geographical Indications Project Jamaica-Switzerland (Kingston, 28 May 2008).

Jamaica Intellectual Property Office and Swiss Federal Institute of Intellectual Property, Memorandum of understanding between The Swiss Federal Institute of Intellectual Property and The Jamaica Intellectual Property Office on the "Geographical Indications Project Jamaica - Switzerland" (GIJA) (Kingston).

Jamaican Ministry of Industry Investment \& Commerce, Ministerial Report for Jamaica Intellectual Property Office on Performance for Financial Year 2008/09 and Focus for Financial Year 2009/2010 (Kingston).

Ministry of Industry Investment \& Commerce, Ministry Paper No. 45: Performance of the Jamaica Intellectual Property Office (JIPO) for the Financial Year 2004/2005 and Focus for the Financial Year 2005/2006 (Kingston).

Planning Institute of Jamaica, Vision 2030 Jamaica: National Development Plan (Kingston).

\section{European Union documents}

Council of the European Union, Council Conclusions following the Commission's Communication "Global Europe: Competing in the World" (Brussels, 13 November 2006).

Council of the European Union, Review of the EU Sustainable Development Strategy (EU SDS) - Renewed Strategy (Brussels, 26 June 2006) [10917/06].

Council of the European Union, Anti-Counterfeiting Trade Agreement (Brussels, 23 August 2011) [2011/0166 (NLE)]. 
Directorate General for Internal Market, Summary report of replies to the questionnaire on the impact of the Community utility model with a view to updating the Green Paper on protection by the utility model in the internal market (European Commission, Brussels, 1 March 2002) [SEC(2001)1307].

European Commission, Annex to Global Europe: Competing in the World Brussels, 04 October 2006) [SEC(2006)1230].

European Commission, Communication on the External Dimension of the Lisbon Strategy for Growth and Jobs (Brussels, 16 December 2008) [COM(2008)874 final].

European Commission, Report on progress achieved on the Global Europe strategy, 2006-2010 (Brussels, 03 March 2010) [SEC(2010)1269].

European Commission, Trade policy in the Prodi Commission 1999-2004: An assessment (Brussels, 19 November 2004).

European Commission, Plan and Schedule for CARIFORUM EC Negotiation of an Economic Partnership Agreement (Brussels).

European Commission, Strategy for the Enforcement of Intellectual Property Rights in Third Countries (Brussels, 10 November 2004) [OJ C 129 of 26.05.2005, p. 3].

European Commission, Working together for growth and jobs: A new start for the Lisbon Strategy (Brussels, 2 February 2005) [COM(2005) 24 final].

European Commission, Global Europe: competing in the world (Brussels, 4 October 2006).

European Commission, Europe 2020: A strategy for smart, sustainable and inclusive growth (Brussels, 03 March 2010) [COM(2010)2020].

European Commission, Trade, Growth and World Affairs: Trade policy as a core component of the EU's 2020 Strategy (DG Trade, Brussels, 2010) [COM(2010)612].

European Commission and CARIFORUM, Terms of Reference for CARIFORUM-EC Regional Preparatory Task Force (August 2004), available at <http://www.delbrb.ec.europa.eu/en/epa/epa_docs/RPTF_ToRs_Adopted_version_August_2004.pdf $>$ accessed on 19.05.2011.

European Council, Presidency Conclusions (Lisbon, 23 and 24 March 2000).

European Council, Main results of the ACP-EC Joint Council of Ministers: trade and financial issues (Brussels, 25 May 2007) [1005/07 (Presse 120)].

\section{GATT/ WTO documents}

Chairman Lars Anell, Status of Work in the Negotiating Group (1 October 1990) [Ref. No. 2341].

Chairman Lars Anell, Status of Work in the Negotiating Group, Chairman's Report to the GNG (23 July 1990) [MTN.GNG/NG11/W/76].

Council for Trade-Related Aspects of Intellectual Property Rights, Decision of the Council of TRIPS of 19 February 2003 on the Implementation of Article 66.2 of the TRIPS Agreement (Geneva, 20 February 2003) [IP/C/28].

European Communities and their Member States, Review of the Provisions of Article 27.3(b) of the TRIPS Agreement: Communication from the European Communities and their member States (Geneva, 13 June 2001) [IP/C/W/254].

GATT, Ministerial Declaration on the Uruguay Round (Punta del Este, 20 September 1986) [MIN.DEC].

GATT Council, Decision of 28 November 1985 on Establishment of the Preparatory Committee Doc. No. L/5925].

GATT Delegation of India, Standards and Principles Concerning the Availability Scope and Use of Trade-Related Intellectual Property Rights, Communication from India (10 July 1989) [MTN.GNG/NG11/W/37]. 
GATT Delegation of Japan, Main Elements of a Legal Text for TRIPs, Communication from Japan (15 May 1990) [MTN.GNG/NG11/W74].

GATT Delegation of Switzerland, Draft Amendment to the General Agreement on Tariffs and Trade on the Protection of Trade-Related Intellectual Property Rights, Communication from Switzerland (14 May 1990) [MTN.GNG/NG11/W73].

GATT Delegation of the European Community, Draft Agreement on Trade-Related Aspects of Intellectual Property Rights, Communication from the European Community (29 March 1990) [MTN.GNG/NG11/W68].

GATT Delegation of the United States, Draft Agreement on the Trade-Related Aspects of Intellectual Property Rights, Communication from the United States (11 May 1990) [MTN.GNG/NG11/W70].

GATT Preparatory Committee, Draft Ministerial Declaration, Revision (16 July 1986) [PREP.COM(86)W/41/Rev.1].

GATT Trade Negotiations Committee, Agreement on Trade Related Aspects of Intellectual Property Rights, Including Trade in Counterfeit Goods (Annex III), Draft Final Act Embodying the Resultus of the Uruguay Round of Multilateral Trade Negotiations (20 December 1991) [MTN.TNC/W/FA].

GATT Trade Negotiations Committee, Agreement on Trade Related Aspects of Intellectual Property Rights, including Trade in Counterfeit Goods, Draft Final Act Embodying the Results of the Uruguay Round of Multilateral Trade Negotiations (3 December 1990) [MTN.TNC/W/35/Rev.1].

GATT Trade Negotiations Committee, Meeting at Ministerial Level (Montreal, 9 December 1988) [MTN.TNC/7(MIN)].

GATTT Trade Negotiations Committee, Mid-Term Meeting (Geneva, 21 April 1989) [MTN.TNC/11].

WTO Delegation of Brazil, European Union and A Member State - Seizure of Generic Drugs in Transit: Request for Consultations by Brazil (Geneva, 19 May 2010) [WT/DS409/1].

WTO Delegation of India, European Union and A Member State - Seizure of Generic Drugs in Transit: Request for Consultations by India (Geneva, 19 May 2010) [WT/DS408/1].

WTO General Council, Implementation of Paragraph 6 of the Doha Declaration on the TRIPS Agreement and Public Health: Decision of 30 August 2003 (Doha, 2 September 2003) [WT/L/540].

WTO General Council, Doha Work Programme, Decision adopted by the General Council on 1 August 2004 (2 August 2004) [WT/L/579].

WTO General Council, Trade Negotiations Committee and Council for TradeRelated Aspects of Intellectual Property Rights, Doha Work Programme - The Outstanding Implementation Issue on the Relationship Between the TRIPS Agreement and the Convention on Biological Diversity, Communication from Brazil, China, Colombia, Cuba, India, Pakistan, Peru, Thailand and Tanzania (Geneva, 5 July 2006) [IP/C/W/474].

WTO Ministerial Conference, Implementation-Related Issues and Concerns, Decision of November 2001 (Doha, 20 November 2001) [WT/MIN(01)/17].

WTO Ministerial Conference, Declaration on the TRIPS Agreement and Public Health (Doha, 20 November 2001) [W'T/MIN(01)/DEC/2].

WTO Ministerial Conference, Doba Ministerial Declaration (Doha, 20 November 2001) [W'T/MIN(01)/DEC/1].

WTO Ministerial Conference, European Communities - The ACP-EC Partnership Agreement (Doha, 14 November 2001) [WT/MIN(01)/15]. 
WTO Secretariat, Communication from Argentina, Brazil, Chile, China, Colombia, Cuba, Egypt, India, Nigeria, Peru, Tanzania and Uruguay (Geneva, 14 May 1990) [MTN.GNG/NG11/W71].

WTO Secretariat, Report of the Working Party on the Accession of Cambodia (Geneva, 15 August 2003) [WT/ACC/KHM/21].

WTO Secretariat, Report of the Working Party on the Accession of the Kingdom of Saudi Arabia to the World Trade Organization (Geneva, 1 November 2005) [WT/ACC/SAU/61].

WTO Secretariat, Report of the Working Party on the Accession of Tonga to the World Trade Organization (Hong Kong, 2 December 2005) [WT/ACC/TON/17].

WTO Secretariat, Report of the Working Party on the Accession of Ukraine to the World Trade Organization (Geneva, 25 January 2008) [WT/ACC/UKR/152].

WTO Secretariat, Summary Report on the Eighteenth Meeting of the Committee on Agriculture Special Session (Committee on Agriculture, Geneva, 18 July 2003) [TN/AG/R/8].

WTO Secretariat, Trade Policy Review Jamaica (WTO Trade Policy Review Body, Geneva, 22 February 2011) [WT/TPR/S/242/Rev.1].

WTO Secretariat, Communication from Bulgaria, Cuba, Cyprus, the Czech Republic, the European Communities and their Member States, Georgia, Hungary, Iceland, India, Kenya, Liechtenstein, Malta, Mauritius, Pakistan, Romania, the Slovak Republic, Slovenia, Sri Lanka, Switzerland, Thailand and Turkey (Geneva, 24 June 2002) [IP/C/W/353].

WTO Secretariat, Elements of the Obligation to Disclose the Source and Country of Origin of the Biological Resources and/or Traditional Knowledge Used in an Invention - Submission from Brazil, Cuba, Ecuador, India, Pakistan, Peru, Thailand, and Venezuela (Geneva, 27 September 2004) [IP/C/W/429/Rev.1].

WTO Secretariat, The Relationship Between the TRIPS Agreement and the Convention on Biological Diversity (CBD) and the Protection of Traditional Knowledge - Elements of the Obligation to Disclose Evidence of Prior Informed Consent under the relevant National Regime - Submission from Bolivia, Brazil, Cuba, Ecuador, India, Pakistan, Peru, Thailand and Venezuela (Geneva, 10 December 2004) [IP/C/W/438].

WTO Secretariat, Trade Policy Review Report by Jamaica (Geneva, 15 December 2004) [WT/TPR/G/139].

WTO Secretariat, Trade Policy Review Jamaica (Geneva, 9 March 2005) [WT/TPR/S/139/Rev.1].

WTO Secretariat, Report of the Working Party on the Accession of Viet Nam (Geneva, 2006) [WT/ACC/VNM/48].

WTO Secretariat, Small, Vulnerable Economies (SVEs) - Statement on Key Aspects of Article III of the Fisheries Subsidies Annex (Geneva, 22 September 2008) [TN/RL/W/226/Rev5].

WTO Secretariat, Trade Policy Review: Report by Jamaica (Trade Policy Review Body, Geneva, 7 December 2010) [WT/TPR/G/242].

WTO Secretariat, World Trade Report 2011 (Geneva, 2011).

WTO Trade Negotiations Committee, Draft Decision to Enhance Multual Supportiveness between the TRIPS Agreement and the Convention on Biological Diversity, Communication from Brazil, China, Colombia, Ecuador, India, Indonesia, Peru, Thailand, the ACP Group, and the African Group (Geneva, 19 April 2011) [TN/C/W/59].

\section{WIPO documents}

Assembly of the Paris Union for the Protection of Industrial Property and General Assembly of the World Intellectual Property Organization, Joint Recommendation 
Concerning Provisions on the Protection of Well-Known Marks (Geneva, 20 - 29 September 1999) [Publication 833E].

Assembly of the Paris Union for the Protection of Industrial Property and General Assembly of the World Intellectual Property Organization, Joint Recommendation Concerning Trademark Licenses (Geneva, 25 September - 3 October 2000) [Publication 835E].

Assembly of the Paris Union for the Protection of Industrial Property and General Assembly of the World Intellectual Property Organization, Joint Recommendation Concerning Provisions on the Protection of Marks, and other Industrial Property Rights in Signs, on the Internet (Geneva, 24 September - 3 October 2001) [Publication 845E].

European Community and its Member States, Disclosure of Origin or Source of Genetic Resources and Associated Traditional Knowledge in Patent Applications (Geneva, 17 May 2005) [WIPO/GRTKF/IC/8/11].

WIPO Secretariat, Draft Report (Intergovernmental Committee on Intellectual Property and Genetic Resources, Traditional Knowledge and Folklore, Fourteenth Session, Geneva, 26 August 2009) [WIPO/GRTKF/IC/14/12 Prov. 2].

WIPO Secretariat, Draft Report (WIPO Standing Committee on the Law of Trademarks, Industrial Designs and Geographical Indications Twenty-Third Session, Geneva, 13 July 2010) [SCT/23/7 Prov.].

WIPO Secretariat, Intellectual Property Needs and Expectations of Traditional Knowledge Holders: WIPO Report on Fact-Finding Missions on Intellectual Property and Traditional Knowledge (1998-1999) (Part one, Geneva, 2001), available at <http://www.wipo.int/tk/en/tk/ffm/report/final/index.html> accessed on 25.10.2012.

WIPO Secretariat, Summary of Options for the International Dimension of the Committee's work (Geneva, 29 April 2009) [WIPO/GRTKF/IC/14/6].

WIPO Secretariat, Second provisional list of participants (Geneva) [WIPO/GRTKF/IWG/1/INF/1 Prov.2].

\section{Other policy documents}

ACP Group of States and Council of the European Union, ACP-EU Economic Partnership Agreement Negotiations Cotonou Agreement Article 37.4 Review (Brussels, 31 May 2007) [ACP-CE 2116/07].

ACP Secretariat, ACP Guidelines for the negotiations of Economic Partnership Agreements (Brussels, 5 July 2002) [ACP/61/056/02 [FINAL]].

ACP Secretariat, ACP-EC EPA negotiations: Joint Report on the all-ACP-EC phase of EPA negotiations (Brussels, 2 October 2003) [ACP/00/118/03 Rev.1].

Economic Commission for Latin America and the Caribbean, Report of the Expert Group Meeting on the CARIFORUM-EU Economic Partnership Agreement (Port of Spain, 23 June 2009) [LC/CAR/L.196/Rev.1].

ICANN, Uniform Domain-Name Dispute-Resolution Policy (adopted on 24 August 1999, accepted on 26 October 1999), available at <http://www.icann.org/en/help/dndr/udrp/policy> accessed on 28.06.2012.

M. Koskenniemi, Fragmentation of International Law: Difficulties arising from the Diversification and Expansion of International Law (International Law Commission of the United Nations General Assembly, Geneva, 13 April 2006) [A/CN.4/L.682].

UNCTAD, The role of the patent system in the transfer of technology to developing countries (United Nations, Geneva, 1974) [TD/B/AC.11/19].

UNCTAD, The International Patent System as an Instrument for National Development (United Nations, Geneva, 1975) [TD/B/C.6/AC.2/3]. 
UNCTAD, Intellectual Property Provisions in International Investment Arrangements (UNCTAD, Geneva, 2007) [UNCTAD/WEB/ITE/IIA/2007/1].

UNCTAD, World Investment Report 2010: Investing in a Low-Carbon Economy, Country fact sheet: Jamaica (UNCTAD, 2010).

UNCTAD, Country fact sheet: Jamaica (World Investment Report 2012: Towards a New Generation of Investment Policies, 2012), available at <www.unctad.org/wir> accessed on 26.10.2012.

United States Congress, Unfair Foreign Trade Practices, Stealing American Intellectual Property: Imitation is not Flattery (Washington) [Committee print 98-V].

United States General Accounting Office, International Trade: Strengthening Worldwide Protection of Intellectual Property Rights (Washington) [NSIAD-87-65].

United States General Accounting Office, GATT: Uruguay Round Final Act Should Produce Overall U.S. Economic Gains (Geneva, 29 July 1994) [GAO/GGD-94-83b].

United States Senate, Investment Treaty with Nicaragua (Washington, 26 June 2000) [Treaty Doc. 106-33].

\section{Literature}

"Seeds of Doubt: Assurance on 'Farmers' Privilege"' India Times (15 March 1994).

"CARIFORUM Heads Committed to Concluding EPA Negotiations by Year End Golding" Jamaica Information Service (Kingston, 10 October 2007), available at <http://www.jis.gov.jm/news/archive/13214-officePM-cariforum-headscommitted-to-concluding-epa-negotiations-by-year-end-g $>$ accessed on 29.10.2012.

"Competitiveness Company Working with Local Firms to Ensure Viability and Sustainability" Jamaica Information Service (Kingston, 21 January 2007), available at $<$ http://www.jis.gov.jm/news/archive/11062-commerce_sciencecompetitiveness-company-working-with-local-firms-to-ensure-viability-and $>$ accessed on 12.11.2012.

"Unusually strident Hylton warns Europe" Jamaica Observer (Kingston, 28 January 2007), available at <http://www.jamaicaobserver.com/news/118410_Unusuallystrident-Hylton-warns-Europe $>$ accessed on 12.11.2012.

"Chronology - CARIFORUM/EPA Agreement" Jamaica Gleaner (Kingston, 20 July 2008), available at <http://jamaica-gleaner.com/gleaner/20080720/lead/lead8.html> accessed on 12.11.2012.

"Guyana - Jagdeo says negotiating mechanism flawed" Jamaica Gleaner (Kingston, 13 July 2009), available at <http://jamaica-gleaner.com/gleaner/20090113/carib/carib1.html $>$ accessed on 12.11.2012.

"Belgium hopes talks on India-EU FTA will conclude by year end" The Economic Times (New Delhi, 3 August 2012), available at <http://articles.economictimes.indiatimes.com/2012-08-03/news/33020033_1_export-low-cost-drugs-india-eu$\mathrm{fta}$-india-and-european-union $>$ accessed on 12.11.2012.

"Guyana leading Caribbean in EPA implementation, says EU regional director" caribbeannewsnowcom (Georgetown, 25 April 2012), available at <http://www.caribbeannewsnow.com/guyana.php?news_id=10645\&start=80\&c ategory_id $=13>$ accessed on 27.09.2012.

"Press Release: Conroversial Trade Pact Text Leaked, Shows U.S. Trade Officials Have Agreed to Terms That Undermine Obama Domestic Agenda" Public Citizen (Washington), available at <http://citizen.typepad.com/eyesontrade/2012/06/controversial-trade-pact-text-leaked-shows-us-trade-officials-have-agreed-toterms-that-undermine-ob.html $>$ accessed on 12.11.2012. 
F.M. Abbott, "Protecting First World Assets in the Third World: Intellectual Property Negotiations in the GATT Multilateral Framework" Vanderbilt Journal of Transnational Law, 1989, Vol. 22 (4), 689-745.

F.M. Abbott, The Doha Declaration on the TRIPS Agreement and Public Health and the Contradictory Trend in Bilateral and Regional Free Trade Agreements (QUNO, Geneva, 2004) [Occasional Paper No. 14].

F.M. Abbott, "A New Dominant Trade Species Emerges: Is Bilateralism a Threat?" Journal of International Economic Law, 2007, Vol. 10 (3), 571-583.

Advocates for International Development, Ratification of EPAs: the process required in each ACP state (London, 2008) [LONDON-4518122.1], available at $<$ http://www.normangirvan.info/epa-ratification-procedures-in-acp-states-byadvocates-for-international-development/ > accessed on 12.11.2012.

M. Aisola, "New Release of IPR Chapter of India-EU Free Trade Agreement" The Centre for Internet \& Society, 2011, available at <http://cis-india.org/advocacy/ipr/blog/july-2010-ipr-india-eu-fta $>$ accessed on 01.10.2012.

Analysis for Economic Decisions, Evaluation of the Intellectual Property Rigths Enforcement Strategy in Third Countries (European Commission, Louvain la Neuve, 2010).

R. Anderson, The Draft IP Enforcement Directive - A Threat to Competition and to Liberty (Foundation for Information Policy Research, Cambridge, 2004), available at $<$ http://www.fipr.org/copyright/draft-ipr-enforce.html $>$ accessed on 12.11.2012.

J. Andersson, Global Europe and Sustainable Development: Implications for Climate Change and Agriculture (Swedish Society for Nature Conservation, Stockholm, 2009).

C. Antons, "Sui Generis Protection for Plant Varieties and Traditional Agricultural Knowledge: the Example of India" European Intellectual Property Review, 2007, Vol. 29 (12), 480-485.

Association of Southeast Asian Nations, Treaty of Amity and Cooperation in Southeast Asia (1976), available at <http://www.aseansec.org/5047.htm> accessed on 04.10.2012.

Australian Department of Foreign Affairs and Trade, An International Proposal for a Plurilateral Anti-Counterfeiting Trade Agreement (ACTA) (Canberra, 13 November 2007), available at <www.dfat.gov.au/trade/acta/discussion-paper.html> accessed on 13.11.2008.

T. Balasubramaniam, WIPO patent committee embarks on positive agenda (2008), available at < http://keionline.org/node/75> accessed on 12.11.2012.

N. Basu, 'India to move WTO panel against EU' Business Standard (New Delhi, 1 October 2010), available at <http://www.business-standard.com/india/news/india-to-move-wto-panel-against-eu/409835/> accessed on 12.11.2012.

N. Bayne and S. Woolcock, The New Economic Diplomacy: Decision-making and negotiation in international economic relations (The G8 and Global Governance Series, Ashgate Publishing Limited, Hampshire, 2003).

M.S. Bergman, "Bilateral Investment Protection Treaties: An Examination of the Evolution and Significance of the U.S. Prototype Treaty" New York University Journal of International Law \& Policy, 1983, Vol. 16 (1), 1-43.

R. Bernal, "CARIFORUM-EU Economic Partnership Agreement Negotiations: Why and How" Journal of Eastern Caribbean Studies, 2008, Vol. 33 (2), 1-23.

P. Bernhagen and T. Bräuninger, "Structural Power and Public Policy: A Signaling Model of Business Lobbying in Democratic Capitalism" Political Studies, 2005, Vol. 53 (1), 43-64. 
J. Beyers, "Voice and Access: Political Practices of European Interest Associations" European Union Politics, 2004, Vol. 5 (2), 211-240.

J. Bhagwati, Termites in the Trading System: How Preferential Agreements Undermine Free Trade (Oxford University Press, New York, 2008).

R. Bhala, "Competitive Liberalization, Competitive Imperialism, and Intellectual Property" Liverpool Law Review, 2007, Vol. 28, 77-105.

E.T. Biadgleng, IP Rights Under Investment Agreements: the TRIPS-plus Implications for Enforcement and Protection of Public Interest (GRAIN, Barcelona, 2006) [Research Paper No. 8].

E.T. Biadgleng and V. Muñoz Tellez, The Changing Structure and Governance of Intellectual Property Enforcement (South Centre, Research Papers 15, Geneva, 2008).

T.C. Bickham, "Protecting U.S. Intellectual Property Rights Abroad with Special 301" AIPLA Quarterly Journal, 1995, Vol. 23 (2), 195-220.

P. Bifani, CARICOM Interests in Relation to Biodiversity and Intellectual Property Rights in the Context of FTAA Negotiations (Inter-American Development Bank, 2001) [ATN/JF/SF-6158-RG], available at <http://www.crnm.org/index.php?option $=$ com_docman\&task $=$ cat_view\&gid $=109 \&$ Itemid $=81>$ accessed on 12.11.2012.

S. Bilal, "Who will negotiate with the EU? In search of an ACP-EU negotiating framework" Trade Negotiations Insights, 2002, Vol. 1 (1), 5-7.

S. Bilal and V. Roza, "Sharing Information: A Survival Tool for EPA Negotiations" Trade Negotiations Insights, 2005, Vol. 4 (2), 4-5.

bilaterals.org, Draft EU-Caribbean EPA - IPR non-paper (Nov 2006) (2006), available at $<$ http://www.bilaterals.org/spip.php?article6496\&lang=en $>$ accessed on 12.11.2012.

bilaterals.org, IPR agreements (2012), available at <http://www.bilaterals.org/spip.php?rubrique60\&lang $=$ en $>$ accessed on 12.11.2012.

BIOTHAI, "Fighting FTAs: the experience in Thailand" in bilaterals.org, BIOTHAI and GRAIN (eds.), Fighting FTAs: The growing resistance to bilateral free trade investment agreements (2008) 36-43.

M. Blakeney, "Intellectual Property in World Trade" International Trade Law and Regulation, 1995, Vol. 1 (3), 76-81.

M. Blakeney, Trade Related Aspects of Intellectual Property Rights: A Concise Guide to the TRIPs Agreement (Sweet and Maxwell, London, 1996).

M. Blakeney, "Proposals for the International Regulation of Geographical Indications" The Journal of World Intellectual Property, 2001, Vol. 4 (5), 629-652.

E.M. Braderman, "The World Intellectual Property Organization and the Administrative Reorganization of BIRPI" Patent, Trademark and Copyright Journal of Research and Education, 1968, Vol. 12, 673-689.

A.J. Bradley, "Intellectual Property Rights, Investment and Trade in Services in the Uruguay Round: Laying the Foundations" Standford Journal of International Law, 1987, Vol. 23, 57-98.

J. Braithwaite and P. Drahos, Global Business Regulation (Cambridge University Press, Cambridge, 2000).

Speech by H. Brewster, N. Girvan and V. Lewis (23 March 2008), Renegotiate the EPA, available at <www.normangirvan.info/renegotiate-epa/> accessed on 12.11.2012.

B. Bridier, Geographical Indications Project Jamaica - Switzerland (GIJA): Summary of the final evaluation (2010), available at <https://www.ige.ch/fileadmin/user_upload/Juristische_Infos/e/summary_external_evaluation_Jamaika.pdf $>$ accessed on 12.11.2012. 
M. Bungenberg, "Going Global? The EU Common Commercial Policy After Lisbon" in C. Herrmann and J.P. Terhechte (eds.), European Yearbook of International Economic Law 2010 (Springer, Heidelberg, 2010) 123-151.

Cabinet Office of Jamaica, Cabinet Committees (2008), available at $<$ http://www.cabinet.gov.jm/files/Cabinet $\% 20$ Committees $\% 20$ Membership $\% 2$ 0and $\% 20$ TORs $\% 20$ as $\% 20$ at $\% 20$ October $\% 202012$.pdf $>$ accessed on 15.11.2012.

Cabinet Office of Jamaica, Government of Jamaica Legislation Programme 2012/2013 as at June 2012 (2012a), available at <http://www.cabinet.gov.jm/files/GOJ\%20Legislation\%20Programme\%202012-2013\%20as\%20at\%20JUNE\%202012.pdf> accessed on 15.11.2012.

Cabinet Office of Jamaica, Government of Jamaica Legislation Programme 2012/2013 as at June 2012 (2012b), available at <http://www.cabinet.gov.jm/files/GOJ\%20Legislation\%20Programme\%202012-2013\%20as\%20at\%20JUNE\%202012.pdf>.

A. Capling and P. Low, "The domestic politics of trade policy-making: state and nonstate actor interactions and forum-choice" in A. Capling and P. Low (eds.), Governments, Non-state Actors and Trade Policy-Making (Cambridge University Press, Cambridge, 2010) 9-28.

A. Capling and P. Low (eds.), Governments, Non-State Actors and Trade Policy-Making: Negotiating Preferentially or Multilaterally? (Cambridge University Press, Cambridge, 2010).

Caribbean Community (CARICOM) Secretariat, The Caribbean Community (2011), available at <http://www.caricom.org/jsp/community/community_index.jsp?menu $=$ community $>$ accessed on 15.11.2012.

Caribbean Policy Development Centre, CPDC (2011), available at <http://www.cpdengo.org/cpdc/> accessed on 15.11.2012.

CARICOM Secretariat, 'Press release 228/2007: Remarks by Louis Michel, EU Commissioner, on the Occasion of the Special Meeting of CARIFORUM Heads of Government on EPA Related Issues' (Montego Bay, 5 October 2007), available at <http://www.caricom.org/jsp/pressreleases/pres228_07.jsp> accessed on 15.11.2012.

T. Carpenter, "A historical perspective on regionalism" in R. Baldwin and P. Low (eds.), Multilateralizing Regionalism (Cambridge University Press, Cambridge, 2009) 13-27.

W.R. Clark et al., "Domestic and International Asymmetries in United StatesEuropean Union Trade Negotiations" International Negotiation, 2000, Vol. 5 (1), 6995.

R. Chakravarty, "Preserving traditional knowledge: Initiatives in India" International Federation of Library Associations and Institutions, 2010, Vol. 36 (4), 294-299.

J. Chasen Ross and J. Wasserman, "Trade-Related Aspects of Intellectual Property Rights" in T.P. Stewart (ed.), The GATT Uruguay Round: A Negotiating History (1986-1992), Vol 2 (Kluwer Law and Taxation Publishers, Deventer, The Netherlands, 1993).

Christian Aid and Oxfam, The EU's approach to Free Trade Agreements: Intellectual Property (ActionAid International, EU FTA Manual Briefing 8, London, 2008).

A. Christie, S. Waller and K. Weatherall, "Exporting the DMCA through Free Trade Agreements" in C. Heath and A. Kamperman Sanders (eds.), Intellectual Property in Free Trade Agreements (Institute of European Studies of Macau Intellectual Property, Hart Publishing, Oxford, 2007) 211-243. 
CIA, Jamaica: The World Factbook (Washington, 2012), available at <https://www.cia.gov/library/publications/the-world-factbook/geos/jm.html> accessed on 15.11.2012.

CIEL, "Foreign Investment and Sustainable Development: Issue Brief for the World Summit on Sustainable Development 26 August - 4 September 2002" 2002, available at <http://www.ciel.org/Publications/investment.pdf $>$ accessed on 15.11.2012.

Commission on Intellectual Property Rights (ed.), Integrating Intellectual Property Rights and Development Policy (3rd edn, London, 2003).

Convention on Biological Diversity, List of Parties to the Convention on Biological Diversity (2012), available at <http://www.cbd.int/convention/parties/list/> accessed on 22.10.2012.

Corporate Europe Observatory, Global Europe: An Open Door Policy for Big Business Lobbyists at DG Trade (Brussels, 2008), available at <http://www.corporateeurope.org/publications/open-door-policy-big-business $>$ accessed on 15.11.2012.

C.M. Correa, Protection of Geographical Indications in CARICOM Countries (InterAmerican Development Bank, Georgetown, Guyana, 2002), available at <http://www.iadb.org/intal/intalcdi/PE/2009/03454.pdf $>$ accessed on 15.11.2012.

C.M. Correa, Bilateral Investment Agreements: Agents of new global standards for the protection of intellectual property rights? (GRAIN, 2004), available at <www.grain.org $>$ accessed on 15.11.2012.

C.M. Correa, "Bilateralism in Intellectual Property: Defeating the WTO System for Access to Medicines" Case Western Reserve Journal of International Law, 2004, Vol. 36, 79-94.

C.M. Correa, Intellectual Property in LDCs: Strategies for Enhancing Technology Transfer and Dissemination (UNCTAD, The Least Developed Countries Report, 2007) [Background Paper No. 4].

C.M. Correa, Trade Related Aspects of Intellectual Property Rights: A Commentary on the TRIPS Agreement (Oxford University Press, Oxford, 2007).

T. Cottier, "The Agreement on Trade-Related Aspects of Intellectual Property Rights" in P.F.J. Macrory, A.E. Appleton and M.G. Plummer (eds.), The World Trade Organization: Legal, Economic and Political Analysis (Springer, New York, 2005) 1041-1120.

M. Cremona, "External Relations and External Competence of the European Union: The Emergence of an Integrated Policy" in P. Craig and G. De Burca (eds.), The Evolution of EU Law (2nd edn, Oxford University Press, New York, 2011) 217268.

CRNM, RNM Updates available at <http://www.crnm.org/index.php?option= com_sectionex\&view $=$ category\&id $=13 \&$ Itemid $=126>$ accessed on 15.11.2012.

CRNM, "CARIFORUM and EC Advance Regional Integration Elements of EPA Negotiations" RNM Update 0418, 2004.

CRNM, "CARIFORUM-EC EPA Talks on Track, Say Principal Negotiators " RNM Update 0509, 2005.

CRNM, "CARIFORUM-EU Launch Crucial Phase of Trade and Development Talks" RNM Update 0514, 2005.

CRNM, "EPA Workshop enables ACP regions to share experiences" RNM Update 0503, 2005. 
CRNM, "Expanding the CRNM Private Sector Outreach" CRNM Private Sector Trade Brief, 2005, Vol. 1.

CRNM, "Billie Miller: 'EPAs in Danger of Becoming Unfulfilled Promises and Expectations'" RNM Update 0612, 2006.

CRNM, "Caribbean Ministers Deeply Disappointed with EU Approach to EPA Negotiations" RNM Update 0608, 2006.

CRNM, "Developing The Potential of Creative Industries" CRNM Private Sector Trade Brief, 2006, Vol. 16, 1-5.

CRNM, "News Briefs" RNM Update 0610, 2006.

CRNM, "RNM Convenes Market Access Country Mission in Jamaica" RNM Update 0610, 2006.

CRNM, "RNM/FES Workshop Advances Civil Society Engagement" RNM Update 0610, 2006.

CRNM, "CRNM DG Updates the Jamaican Private Sector on the EPA" RNM Update 0714, 2007.

CRNM, "The EPA negotiations at a Critical Stage" RNM Update 0715, 2007.

CRNM, "The EPA Negotiations Completed" RNM Update 0716, 2007.

CRNM, "Fostering Innovation Through Trade Agreements" CRNM Private Sector Trade Brief, 2007, Vol. 26, 1-6 .

CRNM, "News Briefs" RNM Update 0711, 2007.

CRNM, "Private Sector Perspectives on Trade Agreements" CRNM Private Sector Trade Brief, 2007, Vol. 27, 1-8.

CRNM, "Progress of Trade Negotiations" RNM Update 0701, 2007.

CRNM, "Upcoming events" RNM Update 0713, 2007.

CRNM, "Contextualizing EPA Provisions on Development and Development Cooperation" RNM Update 0802, 2008.

CRNM, "CRNM EPA Reflections" RNM Update 0801, 2008.

CRNM, CRNM Note on CARIFORUM Economic Partnership Agreement: What Europe is Offering Africa: the Pros and Cons of EPAs (Overseas Development Institute, London, 2008), available at <http://www.odi.org.uk/events/docs/1974.pdf> accessed on 11.01.2012.

CRNM, "Diagram of the CARIFORUM EPA Negotiating Structure" RNM Update 0801, 2008.

CRNM, "The EPA: Fact vs. Fiction" EPA Fact vs Fiction Series, 2008, (Issue 2), available at <www.crnm.org> accessed on 21.11.2012.

CRNM, EPA College of Lead and Alternate Lead Negotiators (2009), available at $<$ http: $/ /$ www.crnm.org $/$ index.php?option $=$ com_content\&view $=$ article\&id $=49 \&$ Itemid $=99 \& 0872 \mathrm{a} 8 \mathrm{~d} 70 \mathrm{c} 6252 \mathrm{~b} 77261 \mathrm{~d} 45 \mathrm{~b} 4779477 \mathrm{~d}=9 \mathrm{e} 61 \mathrm{c} 804 \mathrm{~b} 7002 \mathrm{~b} 34 \mathrm{ec} 4611 \mathrm{~d}$ bfe6d2dd2 > accessed on 15.11.2012.

CRNM, 'Press Release: CRNM Private Sector Boot Camps Series Labelled a Success' (Kingston, 19 March 2009).

CRNM, 'Press Release: From CRNM to OTN' (Kingston, 9 July 2009).

CRNM, Office of Trade Negotiations: Caribbean Community (CARICOM) Secretariat (2011), available at <http://www.crnm.org/> accessed on 15.11.2012.

CRNM, WTO Documents on Intellectual Property (2011), available at $<$ http://www.crnm.org/index.php?option $=$ com_docman\&task=cat_view\&gid $=$ $138 \&$ Itemid $=120>$ accessed on 15.11.2012.

CRNM, CARICOM-Canada (2012), available at <www.crnm.org> accessed on 15.11.2012. 
CRNM, Office of Trade Negotiations (2012), available at <www.crnm.org> accessed on 15.11.2012.

L. Crump, "Global Trade Policy Development in a Two-Track System" Journal of International Economic Law, 2006, Vol. 9 (2), 487-510.

R. Dahl, "The Concept of Power" Behavioural Science, 1957, Vol. 2, 201-215.

A. Dahrendorf, "Free Trade Meets Cultural Diversity: the Legal Relationship between WTO Rules and the UNESCO Convention on the Protection of the Diversity of Cultural Expressions" in H. Schneider and P. Van den Bossche (eds.), Protection of Cultural Diversity From a European and International Perspective (Intersentia, Antwerpen, 2008) 31-83.

D. Daley, "A balancing act: Weighing patents and geographical indications: the implementation of the TRIPS Agreement in Jamaica" Latin American World Focus 2008, 2008, 17-19.

D. Daley, 'Intellectual property in the EPA: broad scope, huge impact - parts I, II, III' Jamaica Observer (9 July 2008).

D. Daley, "IP Rights Obligations under New EU-CARIFORUM Economic Partnership Agreement" Newsletter of the International Law Office, 2008.

D. Daley, "Jamaica takes control" Managing Intellectual Property, 2008, Vol. 179, 133135.

D. Daley, "Jamaica: Intellectual Property" in H. Vanhees (ed.), International Encyclopedia for Intellectual Property (Kluwer Law International, the Netherlands, 2008) 1-328.

D. Daley, IP Regime In Jamaica (2009), available at <www.fogadaley.com/laws.html> accessed on 26.10.2012.

D. Daley and N. Foga, "Jamaica: Significant IP progress ... on the horizon" in I.A.M. Magazine (ed.), IP V alue 2006: Building and enforcing intellectual property value (Global White Page Ltd, London, 2006), 150-153.

D. Daley and N. Foga, "Jamaica: Protecting geographical indications" in J. Moore and L. Rutherford-Johnson (eds.), IP V alue 2011: Building and enforcing intellectual property value - An international guide for the boardroom (Globe White Page, London, 2011) 9093.

C. Damro, "The Political Economy of Regional Trade Agreements" in L. Bartels and F. Ortino (eds.), Regional Trade Agreements and the WTO Legal System (Oxford University Press, Oxford, 2006) 23-42.

K. Das, "Select Issues and Debates around Geographical Indications with Particular Reference to India" Journal of World Trade, 2008, Vol. 42 (3), 461-507.

Delegation of the European Commission in Barbados and the Eastern Caribbean, "The EU and CARIFORUM approach third phase of trade negotiations" eNewsletter, 2005, Vol. 13.

M.-V. Delphine, "From Plant Variety Defintion to Geographical Indication Protection: A Search for the Link Between Basmati Rice and India/Pakistan" Journal of World Intellectual Property, 2008, Vol. 11 (4), 321-344.

T. Delreux and B. Kerremans, "How Agents Weaken their Principals' Incentives to Control: The Case of the EU Negotiators and EU Member States in Multilateral Negotiations" Journal of European Integration, 2010, Vol. 32 (4), 357-374.

D. Demiray, "Intellectual Property and the External Power of the European Community: The New Extension" Michigan Journal of International Law, 1995, Vol. 16, 187-239.

P. Drahos, "BITs and BIPs - Bilateralism in Intellectual Property" Journal of World Intellectual Property, 2001, Vol. 4 (6), 791-808. 
P. Drahos, "Developing Countries and International Intellectual Property Standard Setting" Journal of World Intellectual Property, 2002, Vol. 5 (5), 765-789.

P. Drahos, Expanding Intellectual Property's Empire: the Role of FTAs (GRAIN, 2003), available at <www.grain.org> accessed on 15.11.2012.

P. Drahos, "Four Lessons For Developing Countries From The Trade Negotiations Over Access To Medicines" Liverpool Law Review, 2007, Vol. 28 (1), 11-39.

P. Drahos and J. Braithwaite, Information Feudalism (Earthscan Publications Ltd, London, 2002).

T. Dreier, "TRIPs and the Enforcement of Intellectual Property Rights" in F.-K. Beier and G. Schreiker (eds.), From GATT to TRIPs: the Agreement on Trade-Related Aspects of Intellectual Property Rights (International Review of Industrial Property and Copyright Law, VCH, Weinheim, 1996) 248-277.

J. Drexl, "Internationales Immaterialgüterrecht" in R. Rixecker and F.J. Säcker (eds.), Münchner Kommentar zum Bürgerlichen Gesetzbuch (5th edn, Verlag C. H. Beck, München, 2010) 1344-1491.

A. Dunlop, S. Szepesi and K. Van Hove, Organising trade negotiating capacity at regional level: A case study of Jamaica, Barbados and the Caribbean region (ECDPM, Discussion Paper No 54, 2004).

A. Dür, "Measuring Interest Group Influence in the EU: A Note on Methodology" European Union Politics, 2008, Vol. 9 (4), 559-576.

A. Dür and D. De Bièvre, "The Question of Interest Group Influence" Journal of Public Policy, 2007, Vol. 27 (1), 1-12.

G. Dutfield, Intellectual Property Rights and the Life Science Industries: a 20th century history (Ashgate Publishing Limited,Place In boek 2 def AM aangepast - overnemen 2003).

M.C. Dypski, "The Caribbean Basin Initiative: An Examination of Structural Dependency, Good Neighbor Relations, and American Investment" Journal of Transnational Law and Policy, 2002, Vol. 12, 95-136.

ECDPM, "Overview of the regional EPA negotiations" InBrief, 2006, Vol. 14C.

P. Eeckhout, EU External Relations Law (2nd edn, Oxford University Press, New York, 2011).

EFTA Secretariat, Free Trade (2012), available at <http://www.efta.int/freetrade.aspx $>$ accessed on 15.11.2012.

M. El-Said, "The Road from TRIPS-Minus, to TRIPS, to TRIPS-Plus: Implications of IPRs for the Arab World" Journal of World Intellectual Property, 2005, Vol. 8 (1), 53-65.

M. El-Said, "Editorial: Free Trade, Intellectual Property and TRIPS-plus World" Liverpool Law Review, 2007, Vol. 28, 1-9.

M. El-Said, "The European TRIPS-plus Model and the Arab World: From Cooperation to Association - A New Era in the Global IPRs Regime" Liverpool Law Review, 2007, Vol. 27, 143-174.

F. Emmert, "Intellectual Property in the Uruguay Round: Negotiating Strategies of the Western Industrialized Countries" Michigan Journal of International Law, 1990, Vol. 11 (4), 1317-1399.

A. Endeshaw, "Free Trade Agreements as Surrogates for TRIPs-Plus" European Intellectual Property Review, 2006, Vol. 28 (7), 374-380. Ook in tekst aanpassen, nog niet gezien

J.R. Enyart, "A GATT Intellectual Property Code" Les Nouvelles, Journal of the Licensing Executives Society International, 1990, Vol. 25 (2), 53-56. 
EU-India High Level Trade Group, Report of the EU-India High Level Trade Group to The EU-India Summit (13 October 2006), available at <http://trade.ec.europa.eu/doclib/docs/2006/september/tradoc_130306.pdf > accessed on 15.11.2012.

European Academics, Opinion of European Academics on Anti-Counterfeiting Trade Agreement (2011), available at <http://www.iri.uni-hannover.de/tl_files/pdf/ACTA_opinion_200111_2.pdf $>$ accessed on 15.11.2012.

European Commission, Survey on Enforcement of Intellectual Property Rights in Third Countries (2003), available at <http://trade.ec.europa.eu/doclib/docs/2010/february/tradoc_145794.pdf > accessed on 15.11.2012.

European Commission, 'Press Release Memo/04/255: EU strategy to enforce Intellectual Property Rights in third countries - facts and figures' (Brussels, 10 November 2004).

European Commission, "Cariforum-EC EPA: Trade in Goods" 2008, available at <http://trade.ec.europa.eu/doclib/docs/2008/october/tradoc_140975.pdf> accessed on 26.10.2012.

European Commission, European competitiveness (2008), available at $<$ http://ec.europa.eu/trade/creating-opportunities/trade-topics/europeancompetitiveness/index_en.htm> accessed on 15.11.2012.

European Commission, Fact Sheet on Cariforum-EC EPA: Innovation and Intellectual Property (Brussels, 2008).

European Commission, Information Paper: CARIFORUM-EU Economic Partnership Agreement: An Overview (Brussels, 2008).

European Commission, Competitiveness and Innovation Framework Programme (CIP) (2011), available at <http://ec.europa.eu/cip/> accessed on 04.10.2012.

European Commission, 'Press Release: Negotiators initial trade agreement between the EU, Colombia and Peru' (Brussels, 24 March 2011).

European Commission, Seventh Framework Programme (FP7) (2011), available at $<$ http://cordis.europa.eu/fp7/understand_en.html> accessed on 04.10.2012.

European Commission, Trade Agreement between the European Union and Colombia and Peru (2011), available at <http://trade.ec.europa.eu/doclib/press/index.cfm?id=691 $>$ accessed on 15.11.2012.

European Commission, Bilateral agreements (2012), available at <http://ec.europa.eu/agriculture/markets/wine/third/index_en.htm $>$ accessed on 15.11.2012.

European Commission, Bilateral relations (2012), available at <http://ec.europa.eu/trade/creating-opportunities/bilateral-relations/> accessed on 21.08.2012.

European Commission, China (2012), available at <http://ec.europa.eu/trade/creating-opportunities/bilateral-relations/countries/china/ $>$ accessed on 15.11.2012.

European Commission, The Cotonou Agreement (2012), available at <http:/ /ec.europa.eu/development/geographical/cotonouintro_en.cfm $>$ accessed on 15.11.2012.

European Commission, 'Notice: European Commission officially referred ACTA to the European Court of Justice' (Brussels, 11 May 2012), available at $<$ http://trade.ec.europa.eu/doclib/press/index.cfm?id=799> accessed on 15.11.2012.

European Commission, 'Press Release: EU-Central America association agreement' (Brussels, 7 August 2012).

European Commission, 'Press release: EU and Central America sign Association Agreement' (Tegucigalpa, 29 June 2012).

European Commission, 'Press release: EU and Vietnam launch negotiations for a comprehensive Free Trade Agreement' (Brussels, 26 June 2012). 
European Economic and Social Committee, Final Declaration of the conference "9th Regional Seminar of ACP-EU Economic and Social Interest Groups" in Bridgetown, Barbados (14-16 May 2007).

European Patent Office, India's Traditional Knowledge Digitnal Library (TKDL): A powerful tool for patent examiners (2009), available at <http://www.epo.org/topics/issues/traditional.html> accessed on 09.02.2011.

G.E. Evans, "Intellectual Property as a Trade Issue: The making of the Agreement on Trade-Related Aspects of Intellectual Property Rights" World Competition, 1994, Vol. 18 (2), 137-180.

P.B. Evans, "Building an Integrative Aprroach to International and Domestic Politics: Reflections and Projections" in P.B. Evans, H.K. Jacobson and R.D. Putnam (eds.), Double-Edged Diplomacy: International Bargaining and Domestic Politics (University of California Press, Berkeley, 1993), 397-430.

S. Evenett, "'Global Europe': An Initial Assessment of the European Commission's New Trade Policy" Aussenwirtschaft, 2006, Vol. 61 (4), 377-378.

J. Feather, Publishing, Piracy and Politics: An Historical Study of Copyright in Britain (Mansell, London, 1994).

C. Fink and C.A. Primo Braga, "How stronger protection of intellectual property rights affects international trade flows" in C. Fink and K.E. Maskus (eds.), Intellectual property and development: lessons from recent economic research (World Bank and Oxford University Press, New York, 2005) 19-40.

C. Fink and P. Reichenmiller, Tightening TRIPS: The Intellectual Property Provisions of Recent US Free Trade Agreements (Trade Note 20 of The World Bank Group, 07 February 2005).

R.V. Fiorentino, L. Verdeja and C. Toqueboeuf, The Changing Landscape of Regional Trade Agreements: 2006 Update (WTO, Geneva, 2007) [Discussion Paper No. 12].

Foreign Affairs and International Trade Canada, Canada's Foreign Investment Promotion and Protection Agreements (FIPAs) (2003), available at <http://www.international.$\mathrm{gc.ca} /$ trade-agreements-accords-commerciaux/agr-acc/fipaapie/index.aspx?view $=\mathrm{d}>$ accessed on 15.112012 .

G8, Reducing IPR Piracy and Counterfeiting Through More Effective Enforcement (2005), available at <www.g7.utoronto.ca/summit/2005gleneagles/ipr_piracy.pdf> accessed on 18.10.2012.

H. Gao and C.L. Lim, "Saving the WTO From the Risk of Irrelevance: The WTO Dispute Settlement Mechanism as a 'Common Good' for RTA Disputes" Journal of International Economic Law, 2008, Vol. 11 (4), 899-925.

M. Geist, ACTA Lives: How the EU \& Canada Are Using CETA as Backdoor Mechanism To Revive ACTA (2012), available at <http://www.michaelgeist.ca/content/view/6580/135/> accessed on 16.11.2012.

A.L. George and A. Bennet, Case Studies and Theory Development in the Social Sciences (MIT Press, Cambridge, MA, 2005).

D.J. Gervais, The TRIPS Agreement: Drafting History and Analysis (2nd edn, Sweet \& Maxwell, London, 1998).

M. Getlan, "TRIPs and the Future of Section 301: A Comparative Study in Trade Dispute Resolution" Columbia Journal of Transnational Law, 1996, Vol. 34, 173-218.

N. Girvan, Caribbean Political Economy (2007), available at <www.normangirvan.info> accessed on 16.11.2012.

N. Girvan, Civil Society and the EPA (2007), available at <www.normangirvan.info> accessed on 16.11.2012. 
N. Girvan, The Caribbean EPA Affair: Lessons for the progressive movement, paper presented at the conference "Remembering the Future: The Legacies of Radical Politics in the Caribbean" in Pittsburgh (Centre of Latin American and Caribbean Studies, 3 - 4 April 2009).

M. Goffe, Jamaica's compliance with the Convention on Biological Diversity: An intellectual property assessment of the relevant laws, policies and procedures regulating access and benefit sharing with respect to genetic resources and traditional knowledge (30 May 2010) [UNDP/NEPA/IOJ].

Speech by B. Golding (Kingston, 10 December 2007), The Status of Negotiations Towards an Economic Partnerhsip Agreement Between CARICOM and the European Commission.

B.K. Gordon, "Trading Up in Asia: Why the United States Needs the Trans-Pacific Partnership" Foreign Affairs, 2012, Vol. 91 (4), 17-22.

J. Gorlin, An Analysis of the Pharmacentical-related Provisions of the WTO TRIPs (Intellectual Property) Agreement (Intellectual Property Institute, London, 1998).

Government of India, Traditional Knowledge Digital Library (2010), available at <http://www.tkdl.res.in/tkdl/langdefault/common/Abouttkdl.asp?GL=Eng> accessed on 16.11.2012.

Government of Jamaica, Bureau of Standards Jamaica (2009), available at $<$ http://bsj.org.jm/> accessed on 21.05.2013.

GRAIN, PVP in the South: caving in to UPOV (2004), available at <www.grain.org> accessed on 29.10.2012.

GRAIN, "The end of farm-saved seed? Industry's wish list for the next revision of UPOV" GRAIN briefing, 2007.

GRAIN, Japan digs its claws into biodiversity through FTAs (GRAIN, Against the Grain, Geneva, 2007).

D. Greenbaum, "Determining optimal levels of intellectual property protection in developing nations: is less really more? is more really less?" Current Science, 2009, Vol. 97 (11), 1604-1620.

Greenwich Mountain Estate, Greenwich Blue (2003), available at $<$ http://www.greenwichblue.com/> accessed on 16.11.2012.

K. Grenade, "Who is afraid of fiscal adjustment?" Journal of Business, Finance \& Economics in Emerging Economies, 2011, Vol. 6 (2) 1-33.

R. Gross, IP Justice White Paper on the Proposed Anti-Counterfeiting Trade Agreement (ACTA) (2008), available at <http://ipjustice.org/wp/2008/03/25/ipj-whitepaper-acta-2008/> accessed on 18.10.2012.

H. Grosse Ruse-Khan, IP Enforcement Beyond Exclusive Rights (Max Planck Institute for Intellectual Property, Competition \& Tax Law Research Paper Series No 08-09, München, 2008).

H. Grosse Ruse-Khan, Sustainable Development In International Intellectual Property Law New Approaches From EU Economic Partnership Agreements (ICTSD, Intellectual Property and Sustainable Development Series, Issue Paper No. 29, Geneva, 2010).

H. Grosse Ruse-Khan, "The International Law Relation between TRIPS and Subsequent TRIPS-plus Free Trade Agreements: Towards Safeguarding TRIPS Flexibilities?" Journal of Intellectual Property Rights, 2011, Vol. 18 (2), 325-365.

S. Gudgeon, "United States Bilateral Investment Treaties: Comments on their Origin, Purposes, and General Treaty Standards" Berkeley Journal of International Law, 1986, Vol. 4 (1), 105-135. 
A.S. Gutterman, "International Intellectual Property: A Summary of Recent Developments and Issues for the Coming Decade" Santa Clara Computer \& High Technology Law Journal, 1992, Vol. 8, 335-405.

M. Hart, "The Copyright in the Information Society Directive: an overview" European Intellectual Property Review, 2002, Vol. 24 (2), 58-64. Ook in tekst overnemen, niet gezien

C. Heath, "Plant Varieties, Biodiversity and Access Rights" in C. Heath and A. Kamperman Sanders (eds.), Industrial Property in the Bio-Medical Age: Challenges for Asia (Kluwer Law International, The Hague, Netherlands, 2003) 3-34.

C. Heath, "Comparative Overview and the TRIPS Enforcement Provisions" in C. Heath and L. Petit (eds.), Patent Enforcement Worldwide: Writings in Honour of Dieter Stauder (2nd edn, IIC Studies Vol. 23, Hart Publishing, Oxford, 2005) 5-65.

L.R. Helfer, "Regime Shifting: The TRIPs Agreement and New Dynamics of International Intellectual Property Lawmaking" The Yale Journal of International Law, 2004, Vol. 29 (1), 1-83.

T. Heron and G. Siles-Brügge, "Competitive Liberalization and the 'Global Europe' Services and Investment Agenda: Locating the Commercial Drivers of the EUACP Economic Partnership Agreements" Journal of Common Market Studies, 2012, Vol. 50 (2), 250-266.

C. Herrmann, "Common Commercial Policy after Nice: Sisyphus Would Have Done a Better Job" Common Market Law Review, 2002, Vol. 39 (1), 7-29.

K. Heydon and S. Woolcock (eds.), The Rise of Bilateralism: Comparing American, European, and Asian Approaches to Preferential Trade Agreements (United Nations University Press, Tokyo, 2009).

B. Hugenholtz, "Editorial, Why the Copyright Directive is unimportant, and possibly invalid" European Intellectual Property Review, 2000, Vol. 22 (11), 499-505. Ook in tekst overnemen.

E. Humphrey, Reflections on the Cariforum-EC EPA (Committee on International Trade of the European Parliament, Brussels, 2008).

E. Humphrey, Implementing the Economic Partnership Agreement: Challenges and Bottlenecks in the CARIFORUM Region (ECDPM, Discussion Papers, No. 117, Maastricht, 2011).

Indian Controller General of Patents Design \& Trade Marks, Public Search of Trade Marks (2012), available at <http://ipindiaservices.gov.in/tmrpublicsearch/frmmain.aspx $>$ accessed on 16.11.2012.

Speech by Innovation and Access Programme of the South Centre (Geneva, 3 December 2007), Comments on "Innovation and Intellectual Property", Chapter 2 Part II, Title IV of the Draft CARIFORUM-EC EPA dated November 22, 2007, available at $<$ www.normangirvan.info> accessed on 16.11.2012.

International Intellectual Property Alliance, Piracy of U.S. Counterfeited Works in Ten Selected Countries (IIPA, Washington, 1985).

IQsensato, Publications (2011), available at <http://www.iqsensato.org/index.php/publications/> accessed on 16.11.2012.

P. Ishwara Bhat, "The Role of Collective Bodies in Protection of Intellectual Property Rights in India" Journal of Intellectual Property Rights, 2009, Vol. 14, 214225.

Jamaica Chamber of Commerce, The Chamber (2011), available at $<$ http://www.jamaicachamber.org.jm/about_chamber.asp $>$ accessed on 28.07.2011. 
Jamaica Exporters' Organization, The Competitiveness Company (2008), available at $<$ http://www.exportjamaica.org/start/index.php?option=com_k2\&view=item\&l ayout $=$ item\&id $=7 \&$ Itemid $=111>$ accessed on 16.11.2012.

Jamaica Intellectual Property Office, Geographical Indications - Jamaica \& Switzerland (2009), available at <http://www.jipo.gov.jm/?q=node/162> accessed on 16.11.2012.

Jamaica Intellectual Property Office, Responsibilities of JIPO (2009), available at $<$ http://www.jipo.gov.jm/?q=node/35> accessed on 16.11.2012.

Jamaica Promotions Corporation, About JAMPRO (2012), available at <http://www.jamaicatradeandinvest.org/aboutjti> accessed on 16.11.2012.

Jamaica Standard Co. LTD, Wallenford Blue (2009), available at <http://www.wallenfordblue.com/> accessed on 16.11.2012.

Jamaican Bar Association, Report of the Council of the Jamaican Bar Association: For the Period July 2007 - May 2008 (Kingston, 2008), available at <http://www.jambar.org/Council_Report_07-08.pdf> accessed on 16.11.2012.

Jamaican Ministry of Agriculture \& Fisheries, Commodity Boards (2008), available at <http://www.moa.gov.jm/AboutUs/index.php> accessed on 16.11.2012.

Jamaican Ministry of Foreign Affairs \& Foreign Trade, Overview (2006), available at $<$ http://www.mfaft.gov.jm/?q=overview-0> accessed on 16.11.2012.

Jamaican Ministry of Justice, Jamaican laws (2012), available at <http://www.moj.gov.jm/> accessed on 29.10.2012.

P. Jaszi, "A Garland of Reflections on Three International Copyright Topics" Cardozo Arts \& Entertainment Law Journal, 1989, Vol. 8 (1), 47-72.

W. Jenks, "The Conflict of Law-Making Treaties" British Year Book of International Law, 1953, Vol. 30, 401-453.

A. Jessen and C. Vignoles, Jamaica: Trade, Integration and the Quest for Growth (INTAL ITD, Occasional Paper 30, Buenos Aires, 2005).

D. Jessop, "All or nothing: the Caribbean EPA" Trade Negotiations Insights, 2008, Vol. $6(8), 14-$ ook in tekst aanpassen.

E. Jones and T. Hormeku, A Matter of Political Will: How the European Union can maintain market access for African, Caribbean and Pacific countries in the absence of Economic Partnership Agreements (TWN Africa, Oxfam International, Brighton, 2007).

M. Julian, "EPA Negotiations Update: Start of Regional Negotiations" Trade Negotiations Insights, 2004, Vol. 3 (1), 6-7.

M. Julian, "EPA Negotiations Update: State of Play of the Negotiations July 2004" Trade Negotiations Insights, 2004, Vol. 3 (4), 6-7.

M. Julian, "EPA Negotiations Update: State of Play of the Negotiations March 2004" Trade Negotiations Insights, 2004, Vol. 3 (2), 6-7.

M. Julian, "EPA Negotiations Update: State of Play of the Negotiations May 2004" Trade Negotiations Insights, 2004, Vol. 3 (3), 6-7.

M. Julian, "EPA Negotiations Update August 2005" Trade Negotiations Insights, 2005, Vol. 4 (4), 6-7.

M. Julian, "EPA Negotiations Update December 2005" Trade Negotiations Insights, 2005, Vol. 4 (6), 6-7.

M. Julian, "EPA Negotiations Update January 2005" Trade Negotiations Insights, 2005, Vol. 4 (1), 6-7.

M. Julian, "EPA Negotiations Update June 2005" Trade Negotiations Insights, 2005, Vol. 4 (3), 6-7.

M. Julian, "EPA Negotiations Update, October 2005" Trade Negotiations Insights, 2005, Vol. 4 (5), 6-7. 
M. Julian, "EPA Negotiations Update August 2006" Trade Negotiations Insights, 2006, Vol. 5 (4), 6-7.

M. Julian, "EPA Negotiations Update February 2006" Trade Negotiations Insights, 2006, Vol. 5 (1), 6-7.

M. Julian, "EPA Negotiations Update March 2006" Trade Negotiations Insights, 2006, Vol. 5 (2), 6-7.

M. Julian, "TNI EPA Update June 2006" Trade Negotiations Insights, 2006, Vol. 5 (3), 67.

M. Julian, "EPA Negotiations Update April 2007" Trade Negotiations Insights, 2007, Vol. 6 (2), 10-11.

M. Julian, "EPA Negotiations Update August 2007" Trade Negotiations Insights, 2007, Vol. 6 (4), 14-15.

M. Julian, "EPA Negotiations Update January 2007" Trade Negotiations Insights, 2007, Vol. 6 (1), 6-7.

M. Julian, "EPA Negotiations Update September 2007" Trade Negotiations Insights, 2007, Vol. 6 (5), 14-15.

M. Julian and D. Makhan, "EPA Negotiations Update October 2006" Trade Negotiations Insights, 2006, Vol. 5 (5), 6-7.

M. Julian and D. Makhan, "EPA Negotiations Update November 2007" Trade Negotiations Insights, 2007, Vol. 6 (7), 14-15.

Kaieteur News, 'CRNM renamed OTN, has new Director General' Kaieteur News Online (Georgetown, Guyana, 18 November 2009), available at $<$ http://www.kaieteurnewsonline.com/2009/11/18/crnm-renamed-otn-hasnew-director-general/> accessed on 16.11.2012.

A. Kamperman-Sanders et al., The Anti-Counterfeiting Trade Agreement (ACTA): An Assessment (Directorate-General for External Policies of the Union, Brussels, 11 July 2011) [EXPO/B/INTA/FWC/2009-01/Lot7/12].

R. Kampf, "TRIPS and FTAs: A World of Preferential or Detrimental Relations" in C. Heath and A. Kamperman Sanders (eds.), Intellectual Property in Free Trade Agreements (Institute of European Studies of Macau Intellectual Property, Hart Publishing, Oxford, 2007) 87-125.

Keionline, Draft Intellectual Property Rights Chapter of the Trans-Pacific Partnership (10 February 2011), available at <http://keionline.org/sites/default/files/tpp10feb2011-us-text-ipr-chapter.pdf $>$ accessed on 16.11.2012.

B. Kerremans, "What Went Wrong in Cancun? A Principal-Agent View on the EU's Rationale Towards the Doha Development Round" European Foreign Affairs Review, 2004, Vol. 9 (3), 363-393.

M. Khor, Bilateral and Regional Free Trade Agreements (Third World Network, Penang, 2008).

S.M. Kierkegaard, "Taking a sledgehammer to crack the nut: The EU Enforcement Directive" Computer Law \& Security Report, 2005, Vol. 21 (6), 488-495.

Y.K. Kim et al, "Appropriate intellectual property protection and economic growth in countries at different levels of development" Research Policy, 2012, Vol. 41 (2), 358-375.

M. Krajewski, "The Reform of the Common Commercial Policy" in A. Biondi, P. Eeckhout and S. Ripley (eds.), EU Law after Lisbon (Oxford University Press, New York, 2012) 292-311.

H. Krenzler and C. Pitschas, "Progress or Stagnation? The Common Commercial Policy after Nice" European Foreign Affairs Review, 2001, Vol. 6 (3), 291-313. 
M. Kretschmer, "Digital copyright: the end of an era" European Intellectual Property Review, 2003, Vol. 25 (8), 333-341. Ook in tekst aanpassen

J. Kuanpoth, "TRIPS-Plus Rules under Free Trade Agreements: An Asian Perspective" in C. Heath and A. Kamperman Sanders (eds.), Intellectual Property in Free Trade Agreements (Institute of European Studies of Macau Intellectual Property, Hart Publishing, Oxford, 2007) 28-45.

C.A. Kukkonen, "The Need to Abolish Registration for Integrated Circuit Topographies under TRIPS" IDEA: The Journal of Law and Technology, 1997, Vol. 38 (1), 105-137.

K. Kunzer, "Recent Development: Developing a Model Bilateral Investment Treaty" Law and Policy in International Business, 1983, Vol. 15, 273-A14. Dit is correct zo, er was wel een 2 teveel - graag ook in tekst aanpassen.

Labour Market Information System, The Jamaican Economy: An Overview 2008 (2008), available at <http://www.lmis-ele.org.jm/Jamaica_Economy.aspx $>$ accessed on 30.09.2010.

P.S. Ladas, The International Protection of Literary and Artistic Property (Harvard studies in international law, Macmillan, New York, 1938).

P.S. Ladas, Patents, Trademarks, and Related Rights: National and International Protection (Harvard University Press, Cambridge, 1975).

Speech by P. Lamy (Geneva, 24 September 2012), Multilateralism is struggeling, available at <http://www.wto.org/english/news_e/sppl_e/sppl244_e.htm> accessed on 27.09.2012.

D. Laohapakakul, "United States - Thailand Free Trade Agreement Negotiations: Potential Effects on Pharmaceutical Patent Protection in Thailand" Legal Electronic Document Archive, 2006.

B.A. Lehman, Modernizing Jamaica's Intellectual Property System (International Intellectual Property Institute, 2000).

M. Lehnert, B. Miller and A. Wonka, "Increasing the Relevance of Research Questions: Considerations on Theoretical and Social Relevance in Political Sience" in T. Gschwend and F. Schimmelfennig (eds.), Research Design in Political Science: How to Practice What They Preach (Palgrave MacMillan, New York, 2007) 2138.

W.W. Leirer, "Retaliatory Action in United States and European Union Trade Law: A Comparison of Section 301 of the Trade Act of 1074 and Council Regulation 2641/84" North Carolina Journal of International Law and Commercial Regulation, 1994, Vol. 20, 41-96.

S. Lester and B. Mercurio (eds.), Bilateral and Regional Trade Agreements: Case Studies (Cambridge University Press, Cambridge, 2009).

D. Leuffen, "Case Selection and Selection Bias in Small-n Research" in T. Gschwend and F. Schimmelfennig (eds.), Research Design in Political Science: How to Practice What They Preach (Palgrave MacMillan, New York, 2007) 145-160.

V. Lewis, Trinidad and Tobago-Eastern Caribbean Integration Initiative Task Force Report (Trinidad and Tobago Office of the Prime Minister, Vol. 2, Port of Spain, 2009).

N. Limão, "Are Preferential Trade Agreements with Non-trade Objectives a Stumbling Block for Multilateral Liberalization?" Review of Economic Studies, 2007, Vol. 74, 821-855.

J. Lodge, "Launch of CARIFORUM-EC Negotiations of an Economic Partnership Agreement" Trade Negotiations Insights, 2004, Vol. 3 (3), 1-3. 
N. Louwaars et al., Impacts of Strengthened Intellectual Property Rights Regime on the Plant Breeding Industry in Developing Countries - A Synthesis of Five Case Studies (The World Bank, Wageningen, 2005).

J. Love, 1997 USTR Special 301 Annual Report (2009), available at <http://www.keionline.org/ustr/1997special301> accessed on 16.11.2012.

S. Lukes, Power: A Radical View (2nd expanded edn, Macmillan, London, 1974).

D. Luton, 'EPA vote widens bitter divide' Jamaica Gleaner (Kingston, 04 September 2008).

H. MacQueen, C. Waelde and G. Laurie, Contemporary Intellecutal Property - Law and Policy (Oxford University Press, Oxford, 2008).

M. Maes, The EU's Global Europe Strategy. Where is that Strategy Today, paper presented at the conference "Building a Common Platform Between Developing Countries" in Brussels (South Centre, 4-5 December 2008).

E. Mansfield and H. Milner, "The New Wave of Regionalism" International Organization, 1999, Vol. 53 (3), 589-627.

K.E. Maskus, "Observations on the Intellectual Property Component of the European Commission's New Trade Policy" Aussenwirtschaft, 2006, Vol. 61 (4), 459-469.

D. Matthews, Globalising Intellectual Property Rights: The TRIPs Agreement (Routledge, New York, 2002).

D. Matthews, "WTO Decision on Implementation of Paragraph 6 of the DOHA Declaration on the TRIPS Agreement and Public Health: A Solution to the Access to Essential Medicines Problem?" Journal of International Economic Law, 2004, Vol. 7 (1), 73-107.

D. Matthews, NGOs, Intellectual Property Rights and Multilateral Institutions (Queen Mary Intellectual Property Research Institute, London, 2006).

D. Matthews, The Fight Against Counterfeiting and Piracy in the Bilateral Trade Agreements of the EU (European Parliament, Brussels, 2008) [EXPO/B/INTA/2008/28].

D. Matthews, Intellectual Property, Human Rights and Development: The Role of NGOs and Social Movements (Edward Elgar, Cheltenham, 2011).

C. May, "The Venetian Moment: New Technologies, Legal Innovation and the Institutional Origins of Intellectual Property" Prometheus, 2002, Vol. 20 (2), 159179.

C. May, "Why IPRs are a Global Political Issue" European Intellectual Property Review, 2003, Vol. 25 (1), 1-5. Graag ook in tekst aanpassen.

R. Mayne, Regionalism, Bilateralism, and "TRIP Plus" Agreements: The Threat to Developing Countries (United Nations Development Programme, Human Development Report, New York, 2005) [Occasional Paper No. 2005/18].

D. McGlashan et al, "Jamaica: Country Report to the FAO International Technical Conference on Plant Genetic Resources for Food and Agriculture" 2008, available at <http://www.pgrfa.org/gpa/jam/jamaica2.pdf > accessed on 16.11.2012.

S. McGuire and J. Lindeque, "The Diminishing Returns to Trade Policy in the European Union" Journal of Common Market Studies, 2010, Vol. 48 (5), 1329-1349.

A.K. Menescal, "Those behind the TRIPS Agreement: the influence of the ICC and the AIPPI on international intellectual property decisions" Intellectual Property Quarterly, 2005, Vol. 2, 155-182.

B. Mercurio, "TRIPS-Plus Provisions in FTAs: Recent Trends" in L. Bartels and F. Ortino (eds.), Regional Trade Agreements and the WTO Legal System (Oxford University Press, Oxford, 2006) 215-237. 
P. Messerlin and J. Wang, Redesigning the European Union's trade policy strategy towards China (Joint ECIPE-GEM Working Paper, 2008) [No. 04/2008].

S. Meunier, "Managing Globalization? The EU in International Trade Negotiations" Journal of Common Market Studies, 2007, Vol. 45 (4), 905-926.

S. Meunier, Trading Voices: The European Union in International Commercial Negotiations (Princeton University Press, Princeton, 2007).

K.O. Miller, Paradigms in Caribbean trade diplomacy: Negotiating the CARIFORUM-EC Free Trade Agreement (University of Westminster, 2010).

H. Milner, Interests, Institutions, and Information: Domestic Politics and International Relations (Princeton University Press, Princeton, 1997).

Ministry of Foreign Affairs of Japan, Free Trade Agreement (FTA) and Economic Partnership Agreement (EPA) (2012), available at <http://www.mofa.go.jp/policy/economy/fta/index.html $>$ accessed on 16.11.2012.

Ministry of Industry Investment \& Commerce, The Ministry's Portfolio (2010), available at <http://www.miic.gov.jm/portfolio.php> accessed on 16.11.2012.

A.D. Montoute, Civil Society Participation in Trade Negotiations: A Caribbean Case Study (University of the West Indies, 2009).

S. Moon, Does TRIPS Art. 66.2 Encourage Technology Tranfer to LDCs? (UNCTAD ICTSD Project on IPRs and Sustainable Development, Geneva, 2008).

A. Moravcsik, "Integrating International and Domestic Theories of International Bargaining" in P.B. Evans, H.K. Jacobson and R.D. Putnam (eds.), Double-Edged Diplomacy: International Bargaining and Domestic Politics (University of California Press, Berkeley, 1993) 3-42.

A. Moravcsik, "Preferences and Power in the European Community: A Liberal Intergovernmentalist Approach" Journal of Common Market Studies, 1993, Vol. 31 (4), 473-524.

A. Moravcsik, "Taking Preferences Seriously: A Liberal Theory of International Politics" International Organization, 1997, Vol. 51 (4), 513-553.

J.-F. Morin, "Tripping up TRIPs debates: IP and Health in Bilateral Agreements" International Journal of Intellectual Property Management, 2006, Vol. 1-2, 37-53.

J.-F. Morin, "Multilateralizing TRIPs-Plus Agreements: Is the US Strategy a Failure?" Journal of World Intellectual Property, 2009, Vol. 12 (3), 175-197.

S.F. Musungu, Cariforum EPA and beyond: Recommendations for negotiations on Services and Trade related Issues in EPAs (Gesellschaft für Technische Zusammenarbeit, Eschborn, 2008).

S.F. Musungu, "Innovation and Intellectual Property in the EC-CARIFORUM EPA: Lessons for other ACP Regions" IQsensato Studies, 2009, Vol. 1, 1-45.

S.F. Musungu and G. Dutfield, Multilateral agreements and a TRIPS-plus world: The World Intellectual Property Organization (WIPO) (Quakers United Nations Office, TRIPS Issues Papers 3, Geneva, 2003).

S. Nagarajan, "Geographical indications and agriculture-related intellectual property rights issues" Current Science, 2007, Vol. 92 (2), 167-171.

W. New, 'WIPO's Gurry Says 'Crisis In Multilateralism' Bringing Changes To IP' Intellectual Property Watch (17 December 2010).

R. Newfarmer, Trade, Regionalism, and Development (The World Bank, Global Economic Prospects, Washington, 2005).

J.S. Odell, Negotiating the World Economy (Cornell University Press, Ithaca and London, 2000).

J.S. Odell (ed.), Negotiating Trade: Developing Countries in the WTO and NAFTA (Cambridge University Press, Cambridge, 2006). 
OECD, "Aid For Trade At a Glance 2009: Jamaica" 2009, available at <www.oecd.org/dataoecd/15/58/43191213.pdf> accessed on 16.11.2012.

OECS Secretariat, "Recent Trends in CARICOM Trade Relations: An Analysis with Special Attention to the Western Hemisphere" OECS Trade Policy Brief, Vol. 14.

Office of Technology Assessment, Intellectual Property Rights in an Age of Electronics and Information (United States Congress, Washington DC, 1986) [OTA-CIT-302].

Office of the United States Trade Representative, 'Press Release: USTR Announces Results of Special 301 Annual Review' (1 May 1998).

Office of the United States Trade Representative, Caribbean Basin Initiative (2010), available at <http://www.ustr.gov/trade-topics/trade-development/preferenceprograms/caribbean-basin-initiative-cbi> accessed on 20.11.2012.

Office of Trade Negotiations, About the OTN: Structure, Functions \& Governance (2009), available at <http://www.slideshare.net/CRNM/otn-generalseptember-24$2009>$ accessed on 20.11.2012.

Office of Trade Negotiations, The Office of Trade Negotiations - Its Function, Structure and Mandate (2012), available at <www.crnm.org> accessed on 20.11.2012.

R. Okediji, "Back to Bilateralism? Pendulum Swings in International Intellectual Property Protection" University of Ottawa law \& Technology Journal, 2003, Vol. 1, 125-147.

R. Okediji, "The International Relations of Intellectual Property: Narratives of Developing Country Participations in the Global Intellectual Property System" Singapore Journal of International \& Comparative Law, 2003, Vol. 7, 315-385.

M. Olson, The Logic of Collective Action (Harvard University Press, Cambridge, 1965).

M. Olson, The Rise and Decline of Nations: Economic Growth, Stagflation, and Social Rigidities (Yale University Press, New Haven, 1982).

E. Ostrom, "Collective Action and the Evolution of Social Norms" The Journal of Economic Perspectives, 2000, Vol. 14 (3), 137-158.

Oxfam America, Make Trade Fair for Central America: Agriculture, Investment and Intellectual Property: Three Reasons to Say No to CAFTA (2003) [Oxfam America Briefing Note 2].

W.G. Park, "Intellectual Property Rights and International Innovation" in K.E. Maskus (ed.), Frontiers of Economics and Globalization, Intellectual Property, Growth and Trade (Elsevier, The Hague, 2008) 289-327.

W.G. Park and D.C. Lippoldt, Technology Transfer and the Economic Implications of the Strengthening of Intellectual Property Rights in Developing Countries (OECD Trade Policy Working Papers, No. 62, 2008).

M. Pearson, "Agreeing EPA rules of origin: a strategy unfolds" Trade Negotiations Insights, 2007, Vol. 6 (4), 6-8.

Perry4Law, "Implementation Of The Madrid Protocol In India" Corporate Laws of India, 2012, available at <http://corporatelawsforindia.blogspot.nl> accessed on 20.11.2012.

Pinsent Masons, "ACTA rejected by European Parliament" Out-Law, 2012, available at <http://www.out-law.com/en/articles/2012/july/acta-rejected-by-europeanparliament/> accessed on 20.11.2012.

C. Pitschas, "The Treaty of Lisbon and the "new" common commercial policy of the European Union" International Trade Law and Regulation, 2010, Vol. 16 (2), 37-43.

Planning Institute of Jamaica, National Report of Jamaica on Millennium Development Goals (United Nations, UN Economic and Social Council Annual Ministerial Review, Geneva, 2009). 
Planning Institute of Jamaica, Economic Sector Indicators: Overview 2011 (2011), available at <http://www.pioj.gov.jm/ResearchandData/EconomicSectorIndicators/tabid/124/Default.aspx $>$ accessed on 26.10.2012.

M. Pollack, "Delegation, agency, and agenda setting in the European Community" International Organization, 1997, Vol. 51 (1), 99-134.

A. Pollet-Fort, Implications of the Lisbon Treaty on EU External Trade Policy (EU Centre, Singapore, 2010) [Background Brief No. 2].

A. Porges, Guide to GATT law and practice: analytical index (6th edn, World Trade Organization, Geneva, 1995).

F.D. Prager, "A History of Intellectual Property from 1545 to 1787" Journal of the Patent Office Society, 1944, Vol. 26, 711-760.

C. Preville, Mid-Term Review of the Negotiation of an Economic Partnership Agreement (EPA) between CARIFORUM and the EC: Implications for Agriculture and Farmers of the Windward Islands (9 November 2006).

D. Prévost, Balancing Trade and Health in the SPS Agreement: The Development Dimension (Wolf Legal Publishers, Nijmegen, 2009).

PricewaterhouseCoopers, Final Report of the conference "Caribbean Workshop on Building Sustainable Development Issues into Economic Partnership Agreements (EPA)" in Montego Bay, Jamaica (sponsored by European Commission, 24-25 July 2006).

S. Princen, "Advocacy Coalitions and the Internationalization of Public Health Policies" Journal of Public Policy, 2007, Vol. 27 (1), 13-33.

Private Sector Organization of Jamaica, The Private Sector Organization of Jamaica (2008), available at <http://www.psoj.org > accessed on 20.11.2012.

M.P. Pugatch, The International Political Economy of Intellectual Property Rights (Edward Elgar Publishing Ltd., Northampton, 2004).

M.P. Pugatch, "The international regulation of IPRs in a TRIPs and TRIPs-plus worlds" Journal of World Investment and Trade, 2005, Vol. 6, 231-265.

R.D. Putnam, "Diplomacy and domestic politics: the logic of two-level games" International Organization, 1988, Vol. 42 (3), 427-460.

H. Raiffa, The Art and Science of Negotiation: How To Resolve Conflicts And Get The Best Out Of Bargaining (Harvard University Press, Cambridge, 1982).

R. Rajkumar, "The Central American Free Trade Agreement: an end run around the DOHA Declaration on TRIPS and Public Health" Albany Law Journal of Science \& Technology, 2004, Vol. 15, 433-475.

J.H. Reichman, "Compliance with the TRIPS Agreement: Introduction to a Scholarly Debate" Vanderbilt Journal of Transnational Law, 1996, Vol. 29, 363-390.

S. Ricketson, "The Birth of the Berne Union" Columbia-VLA Journal of Law and the Arts, 1986, Vol. 11, 9-32.

S. Ricketson, The Berne Convention for the Protection of Literary and Artistic Works: 18861986 (Kluwer, London, 1987).

S. Ricketson, "The Future of Traditional Intellectual Property Conventions in the Brave New World of Trade-Related Intellectual Property Rights" Intellectual Review of Industrial Property and Copyright Law, 1995, Vol. 25, 872-899.

B.A. Ringer, "The Role of the United States in International Copyright - Past, Present, and Future" Georgetown Law Journal, 1968, Vol. 56, 1050-1079.

R. Roberts and K. Mann, "Law in Colonial Africa" in R. Roberts and K. Mann (eds.), Law in Colonial Africa (Heinemann, Portsmouth, 1991) 3-58.

D. Robinson and C. Gibson, "Governing Knowledge: Discourses and Tactics of the European Union in Trade-Related Intellectual Property Negotiations" Antipode, 2011, Vol. 43 (5), 1883-1910. 
P. Roffe, Bilateral agreements and a TRIPS-plus world: the Chile-USA Free Trade Agreement (Quaker International Affairs Programme, TRIPS Issues Papers No 4, Ottawa, 2004).

D. Rose, "The E.U. Trade Barrier Regulation: An Effective Instrument for Promoting Global Harmonisation of Intellectual Property Rights?" European Intellectual Property Review, 1999, Vol. 21 (6), 313-320.

F. Rossi, "Free trade agreements and TRIPS-plus measures" International Journal of Intellectual Property Management, 2006, Vol. 1 (1/2), 150-172.

M.P. Ryan, Knowledge diplomacy: global competition and the politics of intellectual property (Brookings Institution Press, Washington, 1998).

P.A. Sabatier and H.C. Jenkins-Smith, "The Advocacy Coalition Framework: An Assessment" in P.A. Sabatier (ed.), Theories of the Policy Process (1st edn, Westview Press, Boulder, 1999) 117-166.

R. Sally, Looking East: The European Union's New FTA Negotiations in Asia (European Centre for International Political Economy, Jan Tumlir Policy Essays, 2007) [No. 03/2007].

R. Sanders, Africa right to bold out for better European deal (2009), available at $<$ http://www.sirronaldsanders.com/viewarticle.aspx?ID=15> accessed on 21.11.2012.

T. Sandler, Collective Action: Theory and Applications (Harvester Wheatsheaf, Herfordshire, 1992).

M. Santa Cruz, Intellectual Property Provisions in European Union Trade Agreements: Implications for Developing Countries (ICTSD Intellectual Property and Sustainable Development Series, Geneva, 2007) [Issue Paper No.20].

M. Schaefer, "Ensuring That Regional Trade Agreements Complement The WTO System: US Unilateralism a Supplement to WTO Initiatives?" Journal of International Economic Law, 2007, Vol. 10 (3), 585-603.

T.C. Schelling, The Strategy of Conflict (Harvard University Press, Cambridge, Massachusetts, 1960).

Scientific Research Council, Scientific Research Council (2003), available at <www.srcjamaica.org/> accessed on 21.11.2012.

S.K. Sell, Power and Ideas: North-South Politics of Intellectual Property and Antitrust (State University of New York Press, New York, 1998).

S.K. Sell, Private Power, Public Law: The Globalization of Intellectual Property Rights (Cambridge Studies in International Relations (No 88), Cambridge University Press, Cambridge, 2003).

S.K. Sell, "TRIPS-plus Free Trade Agreements and Access to Medicines" Liverpool Law Review, 2007, Vol. 28, 41-75.

S.K. Sell and A. Prakash, "Using Ideas Strategically: The Contest Between Business and NGO Networks in Intellectual Property Rights" International Studies Quarterly, 2004, Vol. 48, 143-175.

X. Seuba Hernández and J.F. García, "Intellectual Property and Public Health in the EU-CAN FTA" Bridges, 2010, Vol. 3, 15-16.

X. Seuba, Health Protection in the European and Andean Association Agreement (Health Action International, Accion Internacional para la Salud Latinoamérica \& Caribe, Amsterdam, 2009) [03-2009/02].

X. Seuba, "Checks and balances in the intellectual property enforcement field: reconstructing EU trade agreements" in C. Geiger (ed.), Constructing European Intellectual Property: Achievements and New Perspectives (European Intellectual Property Institutes Network series, Edward Elgar Publishing, Camberley, 2012) 409-431. 
D. Shabalala, Intellectual Property in European Union Economic Partnership Agreements with the African, Caribbean and Pacific Countries: What way Forward after the Cariforum EPA and the interim EPAs? (CIEL, Geneva, 2008).

G.C. Shaffer, Defending Interests: Public-Private Partnerships in WTO Litigation (Brookings Institution Press, Washington, 2003).

A. Shaw, "The Problem with the Anti-Counterfeiting Trade Agreement (and what to do about it)" Knowledge Ecology Studies, 2008, Vol. 2. Zie tekst in boek 2 def AM graag overnemen.

B. Sherman, "Remembering and Forgetting: The Birth of Modern Copyright Law" in D. Nelken (ed.), Comparing Legal Cultures (Dartmouth, Aldershot, 1997) 237-266.

Shridath Ramphal Centre for International Trade Law, EPA Implementation Stakeholder Analysis: The CARIFORUM Context (German Technical Cooperation, Project: Support to regional institutions in the implementation of the Economic Partnership Agreement in the Caribbean, Santo Domingo, 2009).

Sir Ronald Sanders, 'OP-ED: 'Time out' on the promises of European Union Partnership' Huntingtonnewsnet (16 July 2011), available at $<$ www.huntingtonnews.net/5275> accessed on 21.11.2012.

A. Slade, "Articles 7 and 8 of the TRIPS Agreement: A Force for Convergence within the International IP System" Journal of World Intellectual Property, 2011, Vol. 14 (6), 413-440.

South Centre, Intellectual property in investment agreements: The TRIPS-plus implications for developing countries (Geneva, 2005) [SC/TADP/AN/IP/5, $\mathrm{SC} / \mathrm{TADP} / \mathrm{AN} / \mathrm{INV} / 2]$.

South Centre, Comments on "Innovation and Intellectual Property", Chapter 2 Part II, Title IV of the Draft Cariforum-EC EPA dated November 22, 2007 (South Centre, Geneva, 2007).

South Centre and CIEL, "Intellectual Property in European Partnership Agreements with the African, Caribbean and Pacific Group of Countries" Intellectual Property Quarterly Update, 2006, Vol. Fourth Quarter 2006.

M. Spence, Negotiating Trade, Innovation and Intellectual Property: Lessons from the CARIFORUM EPA experience from a Negotiator's Perspective (UNCTAD-ICTSD Project on IPRs and Sustainable Development, Policy Brief Number 4, 2009).

M. Spence, Innovation and Intellectual Property, paper presented at the conference "The CARIFORUM-EC Economic Partnership Agreement One Year On: Regional Integration and Sustainable Development" in Barbados (University of West Indies, 22 April 2010).

Stabroek, "Gail Mathurin to head regional negotiating office" Stabroek News, 2009.

R.H. Steinberg, "In the Shadow of Law or Power? Consensus-Based Bargaining and Outcomes in the GATT/WTO" International Organization, 2002, Vol. 56 (2), 339374.

J. Sterling, World Copyright Law: Protection of Authors' Works, Performances, Phonograms, Films, Video, Broadcasts and published Editions in National, International and Regional Law (Sweet \& Maxwell, London, 1998).

T.P. Stewart (ed.), The GATT Uruguay Round: A Negotiating History: 1986-1992 Vol. 2 (Kluwer Law and Taxation Publishers, Deventer, 1993).

T.P. Stewart (ed.), The GATT Uruguay Round: A Negotiating History: 1986-1994 Vol. 4 (The End Game) (Kluwer Law International, Deventer, 1999).

C. Summer, 'Jamaica's London appeal court dilemma' BBC News (3 August 2012). 
P. Sutherland, The Future of the WTO - Addressing institutional challenges in the new millennium (WTO, Report by the Consultative Board to the Director-General Supachai Panitchpakdi, Geneva, 2004).

U. Suthersanen, Utility Models and Innovation in Developing Countries (UNCTAD-ICTSD Project on IPRs and Sustainable Development, Geneva, 2006) [Issue Paper No. 13].

P. Swanborn, Case Study Research: What, Why and How? (Sage Publications, London, 2010).

S. Swarna Latha, "Biopiracy and Protection of Traditional Medicine in India" European Intellectual Property Review, 2009, Vol. 31 (9), 465-477.

Swiss Federal Institute of Intellectual Property, International Cooperation (2011), available at <www.ige.ch/en/legal-info/international-cooperation.html> accessed on 22.11.2012.

T. Takahashi, South-South Trade in Asia: the Role of Regional Trade Agreements (UNCTAD Secretariat, Japan External Trade Organization, Geneva, 2008) [UNCTAD/DITC/TAB/MISC/2008/2].

Technical Centre for Agricultural and Rural Cooperation, 'Joint report of the seventh meeting of principal negotiators' Agritrade News Update (Wageningen, 28 February 2007).

Technical Centre for Agricultural and Rural Cooperation, 'Caribbean-EU EPA negotiations' Agritrade Executive brief (Wageningen, October 2008).

The Coffee Industry Board of Jamaica, Mission, Vision and Values (2012), available at $<$ www.ciboj.org/cib/general/mission.html> accessed on 16.11.2012.

The World Bank, Country and Lending Groups (2011), available at $<$ http://data.worldbank.org/about/country-classifications/country-and-lendinggroups $>$ accessed on 21.11.2012.

The World Bank, Open Data of 2011: Jamaica (2011), available at $<$ http://data.worldbank.org/country/jamaica > accessed on 25.10.2012.

Third World Network, EU EPAs: Economic and Social Development Implications: the case of the CARIFORUM-EC Economic Partnership Agreement (2009), available at $<$ www.twnside.org.sg> accessed on 21.11.2012.

C. Thomas, "Reflections on the CARIFORUM-EC, Economic Partnerhsip Agreement: Implications for CARICOM" in M. Chuck-A-Sang and K.Hall (eds.), CARICOM: Policy Options for International Engagement (Ian Randle Publishers, Kingston, 2009) 258-290.

Trade Compliance Center, Jamaica Intellectual Property Rights Agreement (1994), available at $\quad<$ http://tcc.export.gov/Trade_Agreements/All_Trade_Agreements/exp_005444.asp> accessed on 26.10.2012.

Trade Compliance Center, Nicaragua Intellectual Property Rights Agreement (2012), available at <http:/ /tcc.export.gov/Trade_Agreements/All_Trade_Agreements / exp_005869.asp $>$ accessed on 21.11.2012.

Transparency International, Corruption Perceptions Index 2011 (2011), available at < http://cpi.transparency.org/cpi2011/results/> accessed on 26.10.2012.

UNCTAD, Bilateral Investment Treaties: $1959-1999$ (United Nations, New York and Geneva, 2000).

United Nations Development Programme, Millennium Development Goals: Jamaica (2004), available at < http://www.jm.undp.org/files/MDG_final_report_Jamaica. pdf $>$ accessed on 21.11.2012. 
United Nations Development Programme, Jamaica's Progress Towards the MDGs (2009), available at <http://www.jm.undp.org/millenium-development-goals/japrogress-toward-the-mdgs $>$ accessed on 26.10.2012.

United Nations Development Programme, Human Development Report 2011 (2011).

United Nations Statistics Division, Jamaica (United Nations, Department of Economic and Social Affairs, World Statistics Pocketbook 2009, No. 34, 2010).

UPOV Council, Report on activities during the first nine months of 2009 (International Union for the Protection of New Varieties of Plants, Forty-Third Ordinary Session, Geneva, 09 October 2009) [C/43/3].

US Central Intelligence Agency, Jamaica: The World Factbook (Washington, 2012), available at <https://www.cia.gov/library/publications/the-world-factbook/geos/jm.html > accessed on 15.11.2012.

US Department of the Treasury, US/EC Wine Agreement Q\&A's (2006), available at $<$ http://www.ttb.gov/wine/itd_qas.shtml> accessed on 21.11.2012.

USAID, Directory of Governmental, Non-Governmental and Community Based Organizations, Associations and Social Safety Net Programmes in Jamaica (Washington), available at $<$ http://usaid-comet.org/reports/FINAL\%20Social\%20Services\%20Directory \% 20June\%2008.pdf $>$ accessed on 21.11.2012.

USTR, 'Press Release: Ambassador Schwab Announces US Will Seek New Trade Agreement to Fight Fakes' (12 June 2009), available at <www.ustr.gov/ambassador-schwab-announces-us-will-seek-new-trade-agreement-fight-fakes $>$ accessed on 18.10.2012.

USTR, Bilateral Investment Treaties and Related Agreements (2012), available at <http://www.state.gov/e/eb/ifd/bit/index.htm> accessed on 21.11.2012.

USTR, Free Trade Agreements (2012), available at <http://www.ustr.gov/tradeagreements/free-trade-agreements $>$ accessed on 21.11.2012.

P. Van den Bossche, The Law and Policy of the World Trade Organization: Text, Cases and Materials (2nd edn, Cambridge Publishers, Cambridge, 2008).

M. Veddern, "The Enforcement Directive 2004/48/EC - A further step in the harmonisation of IP laws in Europe" IPR Helpdesk Bulletin, 2004, Vol. 16.

K. Venkataraman, "Intellectual Property Rigths, Traditional Knowledge and Biodiversity of India" Journal of Intellectual Property Rights, 2008, Vol. 13, 326-335.

S.K. Verma, "Plant Genetic Resources, Biological Inventions and Intellectual Property Rights: The Case of India" in B. Ong (ed.), Intellectual Property and Biological Resources (Marshall Cavendish Academic, Singapore, 2004), 128-162.

A. Villarreal, US-Peru Economic Relations and the US-Peru Trade Promotion Agreement (US Congress, Congressional Research Service, 27 July 2007) [Order Code RL34108].

D. Vivas-Eugui, Regional and bilateral agreements and a TRIPS-plus world: the Free Trade Area of the Americas (FTAA) (TRIPS Issues Papers 1, Quaker United Nations Office, Geneva, 2003).

D. Vivas-Eugui and C. Spennemann, "The Evolving Regime for Geographical Indications in WTO and in Free Trade Agreements" in C.M. Correa and A. Yusuf (eds.), Intellectual Property and International Trade: The TRIPS Agreement (2nd edn, Kluwer Law International, The Hague, 2008) 163-213.

J. Von Braun, The Domestic Politics of Negotiating International Trade: Intellectual Property Rights in US-Colombia and US-Peru Free Trade Agreements (Routledge Research in International Economic Law, Taylor and Francis, London, 2011). 
L. Walker, Jamaica Blue Mountain: Quality and Geographical Origin, paper presented the conference "Workshop on the Challenges relating to GIs for ACP Countries" in Montpellier (Technical Centre for Agricultural and Rural Cooperation, 24-27 March 2009).

K. Waltz, Theory of International Politics (1st edn, Addison-Wesley, Reading, Massachusetts, 1979).

J. Watal, Intellectual Property Rights in the WTO and Developing Countries (Kluwer Law International, The Hague, 2001).

K. Watkins, Human Development Report 2007/2008. Fighting Climate Change: Human Solidarity in a Divided World (United Nations Development Programme, New York, 2007).

K. Weatherall, The Anti-Counterfeiting Trade Agreement: What's it all about? (2008), available at <http://works.bepress.com/kimweatherall/18> accessed on 18.10.2012.

West Indies Rum \& Spirits Producers' Association Inc., About WIRSPA (2010), available at <http://www.wirspa.com/about-wirspa.html> accessed on 21.11.2012.

F. Williams, "Bio-piracy' Under New Fire' Financial Times (30 November 1993).

D.I. Wilson, "A Trade Policy Goal for the 1990s: Improving the Adequacy and Effectiveness of Intellectual Property Protection in Foreign Countries" Transnational Law, 1988, Vol. 1, 421-447.

M. Wilson, "Friend or Foe? Regional Trade Agreements and the WTO" ICTSD BRIDGES Montbly Review, 2008, Vol. 12 (1), 19-20.

WIPO, Booklet No. 2 on Intellectual Property and Traditional Knowledge (Geneva, 2009).

WIPO, Conferences, Meetings and Seminars (2012), available at $<$ http://www.wipo.int/meetings/en/index.jsp> accessed on 21.11.2012.

WIPO, Draft Substantive Patent Law Treaty (2012), available at $<$ http://www.wipo.int/patent-law/en/harmonization.htm> accessed on 20.11.2012.

WIPO, International Classification for Industrial Designs under the Locarno Agreement (2012), available at <http://www.wipo.int/classifications/locarno/en/index.html> accessed on 21.11.2012.

WIPO, WIPO-Administered Treaties (2012), available at <http://www.wipo.int/. treaties/en/> accessed on 21.11.2012.

S. Woolcock, "The potential impact of the Lisbon Treaty on European Union External Trade Policy" Swedish Institute for European Policy Studies, European Policy Analysis, 2008, (Issue 8-2008).

S. Woolcock, The Treaty of Lisbon and the European Union as an actor in international trade (European Centre for International Political Economy, ECIPE Working Paper, Brussels, 2010) [01/2010].

J. Wouters, D. Coppens and B. De Meester, "The European Union's External Relations after the Lisbon Treaty" in J. Griller and J. Ziller (eds.), The Lisbon Treaty: EU Constitutionalism without a Constitutional Treaty (Springer Verlag, Wien, 2008) 143-204.

WTO Secretariat, 'Day 9: Talks collapse despite progress on a list of issues' WTO 2008 News Items (Geneva, 29 July 2008).

WTO Secretariat, Trade Profiles 2009 (WTO Publications, Geneva, 2009).

WTO Secretariat, Services Database (2011), available at <http://tsdb.wto.org/> accessed on 19.08.2011. 
WTO Secretariat, Groups in the negotiations (2012), available at <http://www.wto.org/english/tratop_e/dda_e/negotiating_groups_e.htm> accessed on 16.02.2012.

WTO Secretariat, Non-violation complaints (Article 64.2): Background and the current situation (2012), available at <http://www.wto.org/english/tratop_e/trips_e/ nonviolation_background_e.htm $>$ accessed on 23.11.2012.

WTO Secretariat, Regional Trade Agreements Information System (2012), available at $<$ http://rtais.wto.org/UI/PublicMaintainRTAHome.aspx> accessed on 27.09.2012.

WTO Secretariat, Scope of RTAs (2012), available at <http://www.wto.org/english/tratop_e/region_e/scope_rta_e.htm $>$ accessed on 09.05.2012.

WTO Secretariat, Technology transfer (2012), available at <http://www.wto.org/english/tratop_e/trips_e/techtransfer_e.htm> accessed on 15.06.2012.

WTO Secretariat, Trade Profile Jamaica (2012), available at <http://stat.wto.org/> accessed on 23.11.2012.

WTO Secretariat, TRIPS: Geographical Indications - Background and the current situation (2012), available at <http://www.wto.org/english/tratop_e/trips_e/ gi_background_e.htm\#protection> accessed on 23.07.2012.

P. Xiong, "Patents in TRIPS-Plus Provisions and the Approaches to Interpretation of Free Trade Agremeents and TRIPS: Do They Affect Public Health?" Journal of World Trade, 2012, Vol. 46 (1), 155-186.

P. Yu, "The Copyright Divide" Cardozo Law Review, 2003, Vol. 25, 331-445.

P. Yu, "Currents and Crosscurrents in the International Intellectual Property Regime" Loyola of Los Angeles Law Review, 2004, Vol. 38, 323-443.

P. Yu, "The International Enclosure Movement" Indiana Law Journal, 2007, Vol. 82, 827-907.

A. Zalik, "Implementing the Trade-Tariff Act" Les Nouvelles, Journal of the Licensing Executives Society International, 1986, Vol. XXI (4), 199-202. 


\section{Appendix 1: List of Interviewees}

Cheronne Allen, Manager in Planning and Policy Development of JAMPRO

Sara-Ruth Allen, Local Expert working on the 'Geographical Indications Project Jamaica-Switzerland'

Audia Barnett, Executive Director of Scientific Research Council

Lilyclaire Bellamy, Deputy Director and Legal Counsel for JIPO

Stacian Bennett, Legal Officer and Board Secretary of the Coffee Industry Board

Richard Brown, First Secretary of the Permanent Mission of Jamaica in Geneva

Omar Chedda, Trade and Environment Manager of the Private Sector Organization of Jamaica

David Cronin, Brussels correspondent of the Inter Press Service news agency

Dianne Daley, Head of IP Department of FogaDaley

Kai-Saran Davis, Trade Marks and Industrial Designs Director at JIPO

Graham Douglas, Owner of Greenwich Mountain Estate and independent coffee producer

Norman Girvan, Professor emeritus at the University of the West Indies St. Augustine, Trinidad \& Tobago

Peter Goldson, Partner in Myers, Fletcher \& Gordon

Anthony Gomes, Director of Jamaica Chamber of Commerce

Wendy Hollingsworth, Managing Director and Consultant of Policy Networks International Inc

Karl Hyatt, International Trade Specialist, Ministry of Agriculture and Fisheries

Anthony Kennedy, Director of the West Indies Central Sugar Cane Breeding Station Junior Lodge, Technical Coordinator of the EPA negotiations for CRNM in Brussels

Margaret Mais, Coordinator of Projects of the Competitiveness Company Limited

Julie Mapp, Consultant in Foreign Trade Division of Ministry of Foreign Affairs and Foreign Trade of Barbados

Teisha Mattison, Officer at the Jamaica Chamber of Commerce

Jack Minnott, Owner of Jamaica Standard Products Company, Limited

Shantal Munro-Knight, Senior program officer of Caribbean Policy Development

Centre

Sisule Musungu, President of IQSensato

Beverley Pereira, University Counsel and Head of the Legal Unit in the Office of the Vice Chancellor at the University of the West Indies

Kerry-Gaye Rushton, Legal Officer at the Ministry of Agriculture and Fisheries

John Malcolm Spence, Senior Coordinator Intellectual Property, Science and Technology Issues in the Office of Trade Negotiations, formerly CRNM; Alternate Lead Negotiator on Trade Related Issues in the CARIFORUM-EC EPA

Anthony Taubman, Director of the Intellectual Property Division at the WTO

Loreen Walker, Former Legal Officer of the Coffee Industry Board and former Executive Director of JIPO

Michelle Walker, Head of the Legal Unit of the Jamaican Ministry of Foreign Affairs and Foreign Trade

Frank Ward, Chairperson of West Indies Rum \& Spirits Producers' Association Inc. 



\section{Appendix 2: Interview guide used for state actors}

\section{Interviewer:}

Anke Moerland

$\mathrm{PhD}$ researcher at Institute for Globalization and International Regulation, Faculty of Law, Maastricht University, the Netherlands

Project: International Protection of Intellectual Property Rights: Multilateral versus

Bilateral Approaches

\section{Interviewee:}

[name], [organization], [date], [place]

\section{A) INTRODUCTORY REMARKS}

- I undertake research on developing countries' policy position in the field of intellectual property protection during bilateral and multilateral trade negotiations. In particular, I am interested in the IP protection relevant for food-related products, such as geographical indications, trade marks, traditional knowledge and genetic resources, plant variety protection and enforcement standards. The purpose of this research is to determine how much influence domestic non-state actors have on the negotiating policy position of a developing country. The CARIFORUM region and Jamaica in particular have been chosen as a case study due to their involvement in the CARIFORUM-EC EPA negotiations.

- Your answers will be treated with strict confidentiality. No references will be made to any specific views that you will express during the interview, unless prior and explicit approval is obtained from you.

- With permission of the respondent, the interview will be recorded with a digital voice recorder. Recording the interview will facilitate the quality and validity of response records.

\section{B) Personal information}

1. What is your position in [organization]?

2. How has your [organization] been involved in the CARIFORUM-EC EPA negotiations?

3. How long have you been working for [organization]?

4. Can you please describe your exact role in the negotiations of the IP chapter in the EPA?

\section{C) IP CHAPTER IN THE CARIFORUM-EC EPA}

5. What was [organization's] general view on discussing IP issues in the EPA negotiations with the EU?

6. What were [organization]'s key objectives with regard to the different IP areas in the chapter on intellectual property protection?

- Geographical indications

- Trade marks

- Traditional knowledge and genetic resources

- Plant varieties

- Enforcement standards 
7. How did [organization]'s objectives differ from CRNM negotiators' position towards these areas of IP? Can you give an example?

8. What was [organization]'s minimum threshold to accept the IP chapter?

9. Which part in the IP chapter would you classify as the most difficult and/or controversial part?

10. In which part of the IP chapter did you need to make concessions?

11. Can you describe different phases of negotiating the IP chapter? Has [organization]'s position changed in these phases?

\section{D) Consultations DURING THE EPA NEgotiations}

12. Can you describe the process how Jamaica determined its initial policy position in the different areas of IP part of the EPA?

- Geographical indications

- Trade marks

- Traditional knowledge and genetic resources

- Plant varieties

- Enforcement standards

13. Which actors were involved in this policy formation?

14. Did [organization] organize consultations with non-state actors?

15. Which non-state actors were part of the consultations?

16. How would you describe these consultations: did they incorporate the whole spectrum of interested parties?

17. Do you think there were enough possibilities for non-state actors to voice their opinions? Can you give some examples?

18. According to you, how much influence could non-state actors have in order to influence Jamaica's position in the EPA negotiations on IP?

19. According to you, which of these actors were most important in determining the policy position chosen by Jamaica/the CARIFORUM region? Why?

\section{E) THE PLACE OF INTELLECTUAL PROPERTY RELATIVE TO ALL OTHER AREAS} NEGOTIATED IN THE EPA

20. How important was IP protection for Jamaica/CARIFORUM relative to all other areas of the EPA?

21. Relative to other areas in the EPA, was the IP chapter a controversial/difficult negotiation area?

\section{F) Negotiating With THE EU ON IP}

22. Relative to the EU's input in the negotiations of the IP issues you were involved, what was CARIFORUM's input in these negotiations?

23. What were in your opinion the main priorities for the EU in the IP issues you were involved?

\section{G) CARIFORUM MEMBER STATES' RELATIONSHIP WITH RNM}

24. In your opinion, how did CRNM try to accommodate the different national interests?

25. Who or what would you say was the driving force behind the position that RNM took in the EPA negotiations? 


\section{H) MULTILATERAL NEGOTIATIONS}

26. What is more beneficial for Jamaica/CARIFORUM: to negotiate IP issues in bilateral negotiations or in multilateral organizations? Why?

- Resources

- Issues discussed

- Power relationship

Does [organization] in fact have a preference for negotiating with bilateral partners opposed to negotiations at multilateral organizations? 



\section{Appendix 3: Interview guide used for non-state actors}

\section{Interviewer:}

Anke Moerland

$\mathrm{PhD}$ researcher at Institute for Globalization and International Regulation, Faculty of Law, Maastricht University, the Netherlands

Project: International Protection of Intellectual Property Rights: Multilateral versus

Bilateral Approaches

\section{Interviewee:}

[name], [organization], [date], [place]

\section{A) INTRODUCTORY REMARKS}

- I undertake research on developing countries' policy position in the field of intellectual property protection during bilateral and multilateral trade negotiations. In particular, I am interested in the IP protection relevant for food-related products, such as geographical indications, trade marks, traditional knowledge and genetic resources, plant variety protection and enforcement standards. The purpose of this research is to determine how much influence domestic non-state actors have on the negotiating policy position of a developing country. The CARIFORUM region and Jamaica in particular have been chosen as a case study due to their involvement in the CARIFORUM-EC EPA negotiations.

- Your answers will be treated with strict confidentiality if you wish. No references will be made to any specific views that you will express during the interview, unless you have given explicit approval to do so.

- With permission of the respondent, the interview will be recorded with a digital voice recorder. Recording the interview will facilitate the quality and validity of response records.

\section{B) Personal information}

1. What is your precise position in [organization]?

2. How big is [organization]?

3. Whom does [organization] represent?

4. How is [organization] financed?

\section{C) ISSUE AREAS OF INTEREST TO [ORGANIZATION] AND ACTIVITIES}

5. What are the main areas of interest to [organization]?

- In which fields in general does [organization] invest time, effort and money?

- What are the objectives of [organization] in these different areas?

6. In how far does [organization] deal with intellectual property protection?

- Relative to the other areas of interest to your organization, how important would you say is IP? How much percent of [organization]'s time and money is spent on IP?

7. Which areas of IP is [organization] focusing on?

- What are your objectives in these areas of IP?

8. In how far does [organization] focus on intellectual property protection:

- At the multilateral level (WTO, WIPO, FAO) 
- At the bilateral level (EPA)

- At the national level (CARIFORUM, Member State)?

- Can you give examples of IP issues discussed at these levels in which you were involved?

9. What kind of activities does [organization] undertake in order to further your goals in the different areas of IP? Can you give some examples?

- Multilateral level (WTO, WIPO, FAO)

- CARIFORUM level and/or at Member State level

10. In your own opinion, are these activities effective in the sense that they achieve the objective of the organization? Why?

\section{D) IP CHAPTER IN THE CARIFORUM-EC EPA}

11. How did you first get to know about the IP chapter in the EPA?

12. What was [organization's position] on the IP issues that were to be discussed in the EPA negotiations with the EU?

- Geographical indications

- Trade marks

- Traditional knowledge and genetic resources

- Plant varieties

- Enforcement standards

13. How did the position of CARIFORUM negotiators differ from [organization]'s position on these IP issues? Can you give an example?

\section{E) Consultations During the EPA NEgotiations}

14. Did [organization] take part in consultations with Jamaican/CARIFORUM officials?

- Which consultations?

- What kind of (other) activities did you undertake?

- Who were the addresses of your activities?

15. Which other non-state actors took part in the consultations with the Jamaican/CARIFORUM officials?

16. Which other parties had similar interests as [organization]? Did you form any coalition? Why?

17. Which other parties had opposite interests as [organization]?

18. How would you describe these consultations: did they incorporate the whole spectrum of interested parties?

19. How serious were [organization]'s comments treated by Jamaican/CARIFORUM policy makers?

20. Do you think there were enough possibilities for non-state holders to voice their opinions? Can you give some examples?

21. According to you, how much influence could non-state actors have in order to influence Jamaica's and CARIFORUM's position in the EPA negotiations on IP?

22. According to you, which of these actors were most important in determining the policy position chosen by Jamaica/CARIFORUM region? Why? 


\section{F) Negotiating Intellectual Property in Bilateral and MUlTILATERAL AGREEMENTS}

23. According to [organization], what is more beneficial for Jamaica/CARIFORUM: to negotiate IP issues in bilateral negotiations or in multilateral organizations? Why?

In your opinion, does CARIFORUM/Jamaica in fact have a preference for negotiating with bilateral partners opposed to negotiations at multilateral organizations? 



\section{Curriculum Vitae}

Anke Moerland (born Dahrendorf) was born in Halle/Saale, Germany on 7 February 1983. Anke graduated with a Bachelor of International Relations, with a specialization in International Law, from the Technical University of Dresden, Germany in 2005. In 2006, Anke graduated with a cum laude LL.M. in International and European Law with a specialization in Globalization and Economic Regulation from the Advanced Master MIC Programme in Maastricht University. During her LL.M., Anke also worked as research assistant to Prof. dr. Peter Van den Bossche. Following her LL.M., Anke worked in the International and European Law Department of Maastricht University as lecturer teaching European Union Law courses and as researcher under the supervision of Prof. dr. Peter Van den Bossche on the project "The protection of cultural diversity". From July 2007 until October 2012, Anke worked as a $\mathrm{PhD}$ researcher in the International and European Law Department of Maastricht University conducting research towards her $\mathrm{PhD}$, teaching International Trade Law and Intellectual Property Law courses, assisting in setting up two advanced master programmes in Maastricht University and conducting research for studies commissioned by the European Parliament within the Institute for Globalization and International Regulation. In addition to her research and teaching activities, Anke completed cum laude a Bachelor of Dutch Law from Maastricht University from February 2009 until June 2011. In January 2013, Anke started working as advocaatstagiair with Boels Zanders Advocaten in Venlo. She works for the section German Desk and specializes in trade and intellectual property law. 